\title{
Short Papers in the
}

Geologic and Hydrologic

Sciences, Articles 293-435

GEOLOGICAL SURVEY RESEARCH 1961

GEOLOGICAL SURVEY PROFESSIONAL PAPER 424-D

Scientific notes and summaries of investigations prepared by members of the Geologic, Water Resources, and Conservation Divisions in the fields of geology, hydrology, and allied sciences

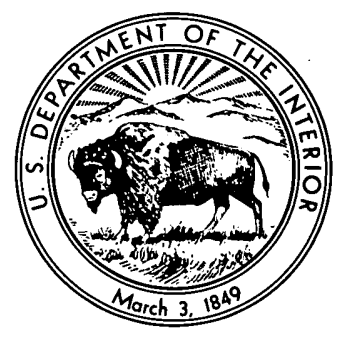

UNITED STATES GOVERNMENT PRINTING OFFICE, WASHINGTON : 1961 


\section{UNITED STATES DEPARTMENT OF THE INTERIOR STEWART L. UDALL, Secretary GEOLOGIG SURVEY \\ Thomas B. Nolan, Director}




\section{FOREWORD}

The scientific and economic results of work by the United States Geological Survey during the fiscal year 1961, the 12 months ending June 30, 1961, are summarized in 4 volumes. This volume includes 143 short papers on subjects in the fields of geology, hydrology, and related sciences, prepared by members of the Geologic, Water Resources, and Conservation Divisions of the Survey. Some are announcements of new discoveries or observations on problems of limited scope, which may or may not be described in greater detail subsequently. Others summarize conclusions drawn from more extensive or continuing investigations, which in large part will be described in greater detail in reports to be published at a later date.

Professional Paper 424-A provides a synopsis of the more important new findings resulting from work during the fiscal year. Professional Papers 424-B and 424-C contain additional short papers.like those in the present volume.

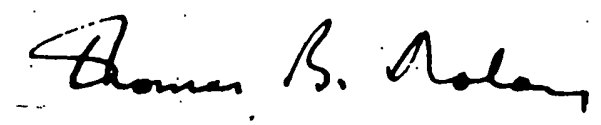

Thomas B. Nolan,

Director.

III 



\section{CONTENTS}

Foreword.

Page

III

Geology of metalliferous deposits

293. Potassic feldspathization and thorium deposition in the Wet Mountains, Colorado, by George Phair and Frances G. Fisher

294. Structural framework of the Illinois-Kentucky mining district and its relation to mineral deposits, by A. V. Heyl, Jr., and M. R. Brock

295. Possible relation between hydrogen sulfide-bearing hydrocarbons in fault-line oil fields and uranium deposits in the southeast Texas Coastal Plain, by D. Hoye Eargle and Alice D. Weeks

296. Relation of fold structures to distribution of lead and zinc mineralization in the Belmont and Calamine quadrangles, Lafayette County, Wisconsin, by Walter S. West and Harry Klemic

Hydrologic studies

297. Reservoir storage for short-period streamflow regulation, by G. N. Mesnier, R. E. Oltman, and W. B. Langbein -.--

298. Reservoir storage-general solution of a queue model, by W. B. Langbein

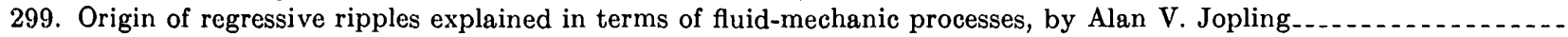

300. The significance of the fall velocity and effective fall diameter of bed materials, by William L. Haushild, Daryl B. Simons, and Everett V. Richardson.

301. Qualitative effects of temperature on flow phenomena in alluvial channels, by D. W. Hubbell and Khalid Al-Shaikh Ali

302. Dispersion-motivated fluctuations of ground-water levels in wells, by F. A. Kohout.

303. Dispersion with oscillating flow in a granular material, by Willis $\mathrm{K}$. Kulp

304. Chemical character of precipitation at Menlo Park, California, by H. C. Whitehead and J. H. Feth . . . . . ...

305. Mechanical uniform packing of porous media, by Donald A. Morris and Willis K. Kulp.

Geology and hydrology of eastern United States

306. Post-Cambrian igneous rocks of the central craton, western Appalachian Mountains and Gulf Coastal Plain of the United States, by M. R. Brock and A. V. Heyl, Jr.

307. Underseepage along Levee 30, Dade County, Florida, by Howard Klein and C. B. Sherwood........

308. Sources of water in Styx and Echo Rivers, Mammoth Cave, Kentucky, by G. E. Hendrickson .....................

309. Volcanic rocks of Ordovician age in the Mount Chase ridge, Island Falls quadrangle, Maine, by E. B. Ekren - -..--

310. Post-Carboniferous deformation of metamorphic and igneous rocks near the Northern Boundary fault, Boston

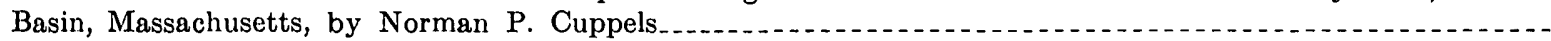
311. A regional fault in east-central Massachusetts and southern New Hampshire, by Robert F. Novotny

312. Ground water in Eocene rocks in the Jackson dome area, Mississippi, by Joseph W. Lang . . . . . . . . . . . .

313. Natural movement of ground water at a site on the Mullica River in the Wharton Tract, southern New Jersey, by S. M. Lang . .

314. Variation in temperature of two streams on Long Island, New York, by Edward J. Pluhowski.

315. Effect of Lake St. Lawrence on ground water in the Beekmantown dolomite, northern St. Lawrence County, New York, by Frank W. Trainer and Ralph C. Heath.

316. The Stokes and Surry Counties quartzite area, North Caroling- window? by Bruce Bryant and John C. Reed, Jr

317. Hydrologic processes diluting and neutralizing acid streams of the Swatara Creek basin, Pennsylvania, by E. F. McCarren, J. W. Wark, and J. R. George

318. Correlation of end moraines in southern Rhode Island, by J. P. Schafer

319. Residual sea water in the basement complex of the Fall Zone in the vicinity of Fredericksburg, Virginia, by Seymour Subitzky

Geology and hydrology of western conterminous United States

320. Suggested magmatic differences between welded "ash" tuffs and welded crystal tuffs, Arizona and Nevada, by Ralph J. Roberts and Donald W. Peterson.

321. Effects of a buried anticline on ground water in County, Arizona, by N. E. McClymonds.

322. Flattening ratios of pumice fragments in an ash-flow sheet near Superior, Arizona, by Donald W. Peterson.....

323. Landslides east of Funeral Mountains, near Death Valley Junction, California, by Charles S. Denny . . . . . . .

324. Compaction of montmorillonite-rich sediments in western Fresno County, California, by Robert H. Meade.....-

325. Surface-water hydrology of coastal basins of northern California, in relation to geology and topography, by $\mathrm{S}$. E. Rantz
$\mathrm{D}-1$

3

13

15

17

21

24

26

29

31

33

36

41

43

46

48

50

52

55

58

61

64

68

71

73

79

82

85

89

92 
Geology and hydrology of western conterminous United States-Continued

326. Central vent ash-flow eruption, western San Juan Mountains, Colorado, by Robert G. Luedke and Wilbur

327. Eight members of the Oak Spring formation, Nevada Test Site and vicinity, Nye and Lincoln Counties, Nevada, by E. N. Hinrichs and P. P. Orkild.

328. Eleana formation of Nevada Test Site and vicinity, Nye County, Nevada, by F. G. Poole, F. N. Houser, and P. P. Orkild .

329. Lake Lahontan stratigraphy and history in the Carson Desert (Fallon) area, Nevada, by $R$. B. Morrison

330. A suggested Pleistocene-Recent (Holocene) boundary for the Great Basin region, Nevada-Utah, by R. B. Morrison.

331. Hydrothermal alteration of rocks in two drill holes at Steamboat Springs, Washoe County, Nevada, by Gudmundur E. Sigvaldason and Donald E. White.

332. Correlation of the deposits of Lakes Lahontan and Bonneville and the glacial sequences of the Sierra Nevada and Wasatch Mountains, California, Nevada, and Utah, by R. B. Morrison

333. New evidence on the history of Lake Bonneville from an area south of Salt Lake City, Utah, by R. B. Morrison..--

334. New evidence of the age of Lake Bonneville from the moraines in Little Cottonwood Canyon, Utah, by G. M. Richmond.

335. Magnitude of thrust faulting in northern Utah, by Max D. Crittenden, Jr

336. Subdividing the Jordan Valley ground-water basin, Utah, by I. Wendell Marine

337. Potash-beairing evaporite cycles in the salt anticlines of the Paradox basin, Colorado and Utah, by Robert J. Hite $\ldots$. -

338. Cretaceous rocks in Lea County, New Mexico, by Sidney R. Ash and Alfred Clebsch, Jr . . . . . . . . . . . . . . .

339. Distribution of moisture in soil and near-surface tuff on the Pajarito Plateau, Los Alamos County, New Mexico, by John H. Abrahams, Jr., James E. Weir, Jr., and William D. Purtymun .

340. Structural evolution of the Valles caldera, New Mexico, and its bearing on the emplacement of ring dikes, by R. L. Smith, R. A. Bailey, and C. S. Ross

341. Hypothetical circulation of ground water around salt springs in western Oklahoma, Texas, and Kansas, by Porter E. Ward and A. R. Leonard

342. Breccia at Sierra Madera, Texas, by R. E. Eggleton and E. M. Shoemaker.....

343. John Day formation near Ashwood, north-central Oregon, by Dallas L. Peck ... . . . . . . . . . . . . . . . . . . . .

344. Differentiated gabbroic sills and associated alkalic rocks in the central part of the Oregon Coast Range, Oregon, by P. D. Snavely, Jr., and H. C. Wagner .

345. Relation between deformation, metamorphism, metasomatism, and intrusion along the northwest border zone of the Idaho batholith, Idaho, by Anna Hietanen . .

346. Deformation of the epicentral area, Hebgen Lake, Montana, earthquake of August 17, 1959-dual-basin concept, by Irving $\mathrm{J}$. Witkind.

347. Deformation accompanying the Hebgen Lake, Montana, earthquake of August 17, 1959-single-basin concept, by W. Bradley Myers and Warren Hamilton . . .

348. Stratigraphy of the Wilkins Peak member of the Green River formation, Firehole Basin quadrangle, Wyoming, by William C. Culbertson . . .

349. Chilson member of the Lakota formation in the Black Hills, South Dakota and Wyoming, by Edwin V. Post and Henry Bell III .

350. Artesian water in the Spiritwood buried valley complex, North Dakota, by C. J. Huxel, Jr . . . . . . . . . .

351. A buried valley northwest of Manhattan, Kansas, by Henry V. Beck .

352. Stratigraphy of lower and middle parts of the Pierre shale, northern Great Plains, by James R. G.d and William A. Cobban.

Geology and hydrology of Alaska and Hawaii

353. Analyses of gas and water from two mineral springs in the Copper River Basin, Alaska, by Donald R. Nichols and Lynn A. Yehle.

354. Thrust faults in the southern Lisburne Hills, northwest Alaska, by Russell H. Campbell

355. Physiographic processes of sedge meadow pool formation on Latouche Island, Alaska, by Hansford T. Shacklette-

356. Regionally metamorphosed metalliferous contact-metasomatic deposits near Nome, Alaska, by C. L. Hummel...-

357. Multiple glaciation in the headwaters area of the Delta River, central Alaska, by Troy L. Péwé.......

358. Recession of Portage Glacier, Alaska, by Ruth A. M. Schmidt.

359. Relation of discharge rate to drawdown in wells in Oahu, Hawaii, by E. R. Lubke

360. Preliminary gravity survey of Kilauea volcano, Hawaii, by H. L. Krivoy and J. P. Eaton

Extraterrestrial studies

361. Thickness of the Procellarian system, Letronne region of the Moon, by C. H. Marshall

Geology and hydrology of other countries

362. Revision of the geology of diamond districts in Bahia, Brazil, by Max G. White and Charles T. Pierson........363. Results of investigations for uranium in the Tucano basin, Bahia, Brazil, by D. D. Haynes and J. J.: Matzko.---364. Thorium and rare earths in the Poços de Caldas zirconium district, Brazil, by Helmuth Wedow, Jr. . . . . . . 365. Vegetation-free zone on dry mangrove coasts, by F. R. Fosberg. 366. Polygonal features on bedrock, north Greenland, by William E. Davies. 367. Cave deposits of phosphate rock in central Java, Indonesia, by Robert F. Johnson and Rab. Sukamto ......... 
Geology and hydrology of foreign nations-Continued

368. Pachuca mining district, Hidalgo, Mexico, by Arturo R. Geyne, Carl Fries, Jr., Kenneth Segerstrom, Robert F. Black, and Ivan F. Wilson 369. Marine phosphorites of north-central Mexico, by Cleaves L. Rogers, Eugenio Tavera Amezcua, Jesús Ojeda Rivera, Zoltan de Cserna, and Roger van Vloten.

370. Deceleration of erosion at Porícutin, Mexico, by Kenneth Segerstrom

371. The iron formation of the Surghar and western Salt Ranges, Mianwali district, West Pakistan, by Walter Danilchik

372. Ground water in the Sabi Valley, Southern Rhodesia, by P. Eldon Dennis.

Paleontology, geomorphology, and plant ecology

373. Geologic ranges of Cenozoic nonmarine diatoms, by Kenneth E. Lohman

374. Early Cretaceous (middle Neocomian) microfossils in south-central Alaska, by Harlan R. Bergquist .............

375. Late Permian ammonoids in the Inyo Range, California, and their significance, by Mackenzie Gordon, Jr., and

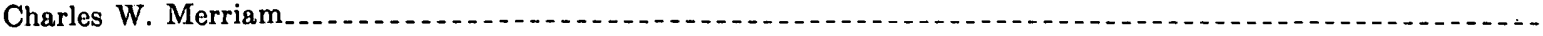

376. A stratigraphically significant association of smaller Foraminifera from western Florida, by S. M. Herrick 377. Discharge of ground water by phreatophytes in the Waianae district, Oahu, Hawaii, by C. P. Zones . . . . . . .

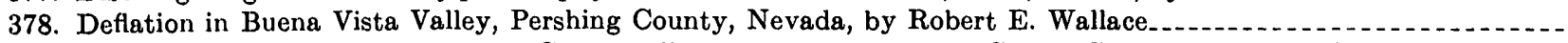
379. Ostracodes and conodonts from the Getaway limestone member of the Cherry Canyon formation (Permian), Texas, by I. G. Sohn.

380. Physical characteristics of Upper Cambrian stromatolites in western Utah, by Richard K. Hose......... 381. Pleistocene terraces on the Eastern Shore peninsula, Virginia, by Allen Sinnott and G. Chase Tibbitts, Jr........382. Stratigraphic significance of the Cretaceous fern Tempskya in the western conterminous United States, by Charles B. Read and Sidney R. Ash. .

\section{Geophysics}

383. Gravity low at Minto Flats, Alaska, by David F. Barnes.

384. Gravity survey near Tucson, Arizona, by Donald Plouff

385. Electromagnetic studies in the Twin Buttes quadrangle, Arizona, by F. C. Frischknecht and E. B. Ekren ...... 386. Geophysical exploration of wells as an aid in location of salt-water leakage, Alameda Plain, California, by R. P. Moston and A. I. Johnson.....

387. Aeromagnetic interpretation of zoned intrusions in northern Maine, by John W. Allingham. . . . .

388. Aeromagnetic, aeroradioactivity, and gravity investigations of Piedmont rocks in the Rockville quadrangle, Maryland, by Andrew Griscom and Donald L. Peterson .

389. Electrical properties of a part of the Portage Lake lava series, Houghton County, Michigan, by G. V. Keller -....-

390. Gravity anomalies, isostasy, and geologic structure in Clark County, Nevada, by Martin F. Kane and J. E. Carlson.-

391. Isostatic compensation in the Sangre de Cristo Mountains, New Mexico, by Gordon E. Andreasen and Martin F. Kane . . . . -

392. The Rio Grande trough near Albuquerque, New Mexico, by H. R. Joesting, J. E. Case, and L. E. Cordell -...--

393. Precambrian structures in the Blanding basin and Monument upwarp, southeast Utah, by J. E. Case and H. R. Joesting. . . . .

394. Use of geophysical data to interpret geology in Precambrian rocks of central Wisconsin, by John W. Allingham and Robert G. Bates . . . .

395. Some observations of the seismic-electric effect, by C. J. Zablocki and G. V. Keller

396. The significance of a group of aeromagnetic profiles off the eastern coast of North America, by Elizabeth R. King, Isidore Zietz, and William J. Dempsey

Mineralogy, geochemistry, and petrology

397. Composition of the iron-formation of Devonian age in the Christmas quadrangle, Arizona, by Ronald Willden.-.398. Chemical analyses of brines and crude oil, Cymric field, Kern County, California, by E. H. Bailey, P. D. Snavely, Jr., and D. E. White

399. Sphene in granitic gneisses of southeastern Connecticut, by Richard Goldsmith, George L. Snyder, and Nancy M. Conklin._.

400. Mineralogy of micaceous laminae in sandstones of Paleozoic age in Florida, by Dorothy Carroll.........

401. Geochemical anomalies in the upper plate of the Roberts thrust near Cortez, Nevada, by R. L. Erickson, Harold Masursky, A. P. Marranzino, and Uteana Oda

402. Radiation damage and isotopic disequilibria in some uranium-bearing asphaltite nodules in back-reef dolomites, Carlsbad, New Mexico, by Arthur P. Pierce and John N. Rosholt, Jr.

403. Regular interlayered chlorite-vermiculite in evaporite of the Salado formation, New Mexico, by Robert O. Fournier

404. Weathering of peridotite, southwest Oregon, by Preston E. Hotz 405. Geochemical surveying for gold veins in the Atlantic district, Wyoming, by Richard W. Bayley and Willard W. Janes. . . _ _ .

406. Geographic distribution of major constituents in stream waters of the western conterminous United States, by C. E. Roberson

407. Interaction of anhydrite with solutions of strontium and cesium, by Irving May, Marian Schnepfe, and Charles R. Naeser 
Mineralogy, geochemistry, and petrology-Continued Page

409. A proposal for clarifying the use of plutonic calc-alkalic rock names, by Anna Hietanen

410. Origin of mottled structure in bedded calcium sulfate, by C. F. Withington

411. Chemical basis of minor-element associations in coal and other carbonaceous sediments, by Peter Zubovic, Taisia Stadnichenko, and Nola B. Sheffey . . . . . . . .

412. Some mechanisms for cooling hydrothermal fluids, by Paul B. Barton, Jr., and Priestley Toulmin 3d.........

413. Some physical properties of bikitaite and its dehydration and decomposition products, by W. C. Phinney and D. B. Stewart . . . .

414. Ground-water sources containing high concentrations of radium, by Robert C. Scott and Franklin B. Barker . . .-

415. Chemical behavior of bicarbonate and sulfate complexes of manganese, by John D. Hem . . . . . . .

416. Overvoltage characteristics of a pyrite crystal, by Lennart A. Anderson .

Geology and hydrology applied to engineering and public health

417. Shatter cones formed by high speed impact in dolomite, by E. M. Shoemaker, D. E. Gault, and R. V. Lugn .....-

418. Geologic results of November 1960 Project Chariot high-explosive cratering experiment, Cape Thompson, Alaska, by Reuben Kachadoorian

419. Engineering geology problems in the Yukon-Koyukuk lowland, Alaska, by Florence Robinson Weber and Troy L. Péwé

420. Hydrology of radioactive-waste disposal at the Idaho Chemical Processing Plant, National Reactor Testing Station, Idaho, by Paul H. Jones..._.

421. Disposal of uranium-mill effluent near Grants, New Mexico, by S. W: West

422. Some uses of the sodium-adsorption-ratio diagram; by D. J. Cederstrom

Exploration and mapping techniques

423. Techniques for mapping of hydrochemical facies, by William Back

424. Optical current meter, by Winchell Smith

425. The effect of finite boundaries on measurement of gold-198 with a scintillation detector, by Bernard J. Frederick and Richard.G. Godfrey

426. The magnifying single-prism stereoscope, virtually a new field instrument, by T. P. Thayer

\section{Analytical and petrographic methods}

427. Trace element sensitivities, by Frank S. Grimaldi and Armin W. Helz

428. Use of releasing agents in the flame pho

429. Flame photometric determination of strontium with the use of releasing agents, by Joseph I. Dinnin ............

430. Chemical aid for distinguishing chromite, ilmenite, and magnetite, by Joseph I. Dinnin and E. G. Williams ......

431. Completeness of precipitation of selenium as the element, by Irving May and Frank Cuttitta...

432. Evaluation of hydrologic tracers, by L. L. Thatcher-

433. Gravimetric determination of silica in chromite and chrome ore, by Joseph I. Dinnin

434. Comparison of drainage data obtained by the centrifuge and column drainage methods, by R. C. Prill.........

435. Removal of manganese from solutions prior to determination of calcium and magnesium, by Lee C. Peck and Vertie C. Smith

Index

Subject.

Author

Finding list of article page numbers. 
GEOLOGICAL SURVEY RESEARCH 1961

SHORT PAPERS IN THE GEOLOGIC AND HYDROLOGIC SGIENGES, ARTICLES 293-435

GEOLOGY OF METALLIFEROUS DEPOSITS

293. POTASSIC FELDSPATHIZATION AND THORIUM DEPOSITION IN THE WET MOUNTAINS, COLORADO

By George Phatr and Frances G. Fisher, Washington, D.C.

Thorium, an element 2.4 times more abundant than uranium in the granitic rocks of the earth's crust, is rare as a hypogene constituent in hydrothermal veins, and the few hydrothermal deposits of thorium so far discovered are obviously the result of special processes. Similarities in the settings of the three largest hydrothermal districts-the Wet Mountains and Powderhorn wren in Colorado and the Lemhi Pass area in Idahoprovide clues as to what these processes may be. Each district lies in deeply reddened (hematitized) fractured siliceous Precambrian rocks within a few miles of Tertiary volcanic rocks, which are presumed to have formerly capped the thorium-bearing rocks.

In this paper a working hypothesis is presented relating thorium deposition in the Wet Mountains to potassic feldspathization of granite along weathered, oxidized fractures beneath an impervious cap of volcanic rocks. A substantial body of chemical and mineralogical information indicates that the potassic feldspathization resulted from reaction of the granite with aqueous solutions of moderate temperature but relatively high $\mathrm{pH}$. The role played by the volcanic cap must be clarified through further field work.

The work of Christman, Heyman, Dellwig, and Gott (1953), of Christman, Brock, Pearson, and Singewald (1960), and of Singewald and Brock (oral communication, 1959) has shown that the so-called veins in the Wet Mountains are sporadically metallized linear shear and breccia zones as much as 5 miles long. The composition of the ore changes along strike from sphalerite and galena in carbonate-barite-quartz matrix, to barite aggregates with or without quartz-carbonate gangue, to red K-feldspar: masses, some of which enclose the largest and highest grade thorium deposits. Thorium occurs principally as thorite and (or) thorogummite in disseminations, stringers, blebs, shoots, and pods. It also occurs, in at least one group of prospects, as a new mineral: a hydrated calcium thorium phosphate.

A working hypothesis for the origin of the thorium deposits, based on 3 months' field work and laboratory studies, is outlined in the following paragraphs.

1. Although the breccia zones cut a wide variety of igneous and metamorphic rocks, large high-grade thorium deposits are developed only in granite.

2. Such granite has undergone intensive and extensive feldspathization, resulting in vuggy aggregates of course- to fine-grained red potassic feldspar containing less than 4 percent $\mathrm{Ab}$ and having the optics of low temperature microcline.. Terminated K-feldspar crystals commonly project comb-fashion into open spaces, suggesting formation at no great depth.

3. The feldspathized zones are strongly hematitized. Early hematite impregnates coarse "relict" microcline and commonly the cores, but rarely the rims, of smaller "recrystallized" microcline laths and gives rise to the typical "red rock" of the miners.

4. During potassic feldspathization of the granite, large quantities of $\mathrm{SiO}_{2}, \mathrm{MgO}, \mathrm{CaO}, \mathrm{Na}_{2} \mathrm{O}$ and $\mathrm{BaO}$ were dissolved into the altering solutions and incorporated into the principal gangue minerals (quartz, barite, dolomite, and calcite) of fissure fillings. $\mathrm{Na}_{2} \mathrm{O}$ commonly migrated farther into the wall rocks to form replacement bodies of sodic amphibole and pyroxene.

5. Elements in which the feldspathized aggregates are enriched $\left(\mathrm{Fe}^{+3}, \mathrm{Al}, \mathrm{Th}, \mathrm{Y}\right.$, and locally $\mathrm{Nd}, \mathrm{Ce}, \mathrm{La}, \mathrm{Be}$, $\mathrm{Nb})$ are those normally concentrated in granite and syenite during magmatic differentiation. These en-

D-1 
riched elements belong to Goldschmidt's (1937) hydrolyzate group, having limited solubilities in alkalic solutions, and are thus predisposed to form residual concentrations. Because they could not be accommodated in the growing feldspar crystals, they were expelled into the adjacent spongy matrix to form an enriched protore.

6. Because part of the feldspathization involved a simple replacement of $\mathrm{K}^{+}$for $\mathrm{Na}^{+}$in the feldspar lattice, with the associated $\mathrm{Al}^{+3}$ remaining behind, the altering solutions developed a considerable excess of $\mathrm{Na}_{2} \mathrm{O}$ over that which could react with $\mathrm{Al}_{2} \mathrm{O}_{3}$ to form albite; in short they took on the compositional peculiarities prerequisite to form sodic amphiboles and pyroxenes (Ermst, 1958, p. 202). Aggregates of fibrous blue magnesio-riebeckite developed wherever such sodic solutions encountered a source of $\mathrm{MgO}$ (diabase dikes and metagabbro layers; and mafic minerals in the granite along an outer sodic "front"). Elsewhere, presumably under drier conditions (Ernst, 1960, fig. 3a), jade green acmite was the end product of sodic replacement.

7. Thorium minerals belong to a late stage in a complex paragenetic sequence, and are believed to represent a re-concentration from the enriched protore. Such short-range thorium transport as may have occurred is tentatively attributed to carbonate complexing in solutions of appropriate alkalinity.

Hemley (1959) studied the relative stability of the successive products of potassic hydrothermal alteration (clay minerals, mica, K-feldspar) in solutions of varying $\mathrm{K}^{+} / \mathrm{H}^{+}$content at temperatures ranging from $200^{\circ} \mathrm{C}$ to $500^{\circ} \mathrm{C}$ using a closed bomb technique. He found that $\mathrm{K}$-feldspar was the stable phase not only at higher temperatures but also at moderate temperatures provided only that the $\mathrm{pH}$ is maintained sufficiently high. Later Hemley (written communication, 1960) extended his experimental results to include sodic compositions; the preliminary indications are that $\mathbf{K}$-feldspar, but not albite, is stable over an intermediate range of $\mathrm{pH}$. Lacking information as to the $\mathrm{K}^{+}$and $\mathrm{Na}^{+}$content of the feldspathizing solutions in the Wet Mountains, quantitative limits cannot be placed upon this intermediate $\mathrm{pH}$ range. However, the relative stability relationships developed in the laboratory appear to be borne out in a rather striking way in the field. More recently, Morey and Fournier (1961) qualitatively confirmed Hemley's results when they succeeded in leaching the exsolved albite from coarse perthite leaving the
K-feldspar behind. This was accomplished by pumping water at a pressure of 3,000 pounds per square inch and a temperature of $300^{\circ} \mathrm{C}$ through an open system containing the feldspar.

From the evidence here summarized the origin of the thorium deposits in the Wet Mountains is reconstructed as follows:

The early-formed breccia zones served as conduits for ground waters and became deeply oxidized in their uppermost portions prior to the onset of vulcanism. Once these conduits were capped by impervious volcanic rock, the "trapped" groundwaters heated by the regional rise in the geotherms lay in contact with partly weathered silicate rocks for an appreciable length of time and acquired a relatively high $\mathrm{pH}$. The high $\mathrm{pH}$ in turn set in motion the process of potassic feldspathization, and secretion of thorium and formation of the enriched protore resulted from this process.

To an unknown extent the alkaline waters may have been augmented by (a) surface waters which took on a higin pï as they seeped downward through the partly glassy volcanic cover, and (b) hydrothermal solutions, presumably of higher temperature but lower $\mathrm{pH}$, coming from below. Scattered lead-zinc deposits are inferred to have been formed from hydrothermal solutions under more strongly reducing conditions and at greater depth than the thorium ores, but as part of a more or less continuous process. Such acid, reducing solutions rising to higher zones, would become "buffered" at a higher $\mathrm{pH}$ by the ubiquitous iron hydroxides there concentrated and eventually would become indistinguishable from the "trapped" liquid.

\section{REFERENCES}

Christman, R. A., Brock, M. R., Pearson, R. C., and Singewald, Q. D., 1960, Geology and thorium deposits of the Wet Mountains, Colorado; a progress report: U.S. Geol. Survey Bull. 1072-H, p. 491-535.

Christman, R. A., Heyman, A. M., Dellwig, L. F., and Gott, G. B., 1953, Thorium investigations, 1950-1952, Wet Mountains, Colorado: U.S. Geol. Survey Circ. 290.

Ernst, W. G., 1958, Alkali amphiboles: Carnegie Inst. Yearbook 1957-1958, p. 199-204.

1960, The stability relations of magnesio-riebeckite: Geochim. et Cosmochim. Acta, v. 19, p. 10-40.

Goldschmidt, V. M., 1937, The principles of distribution of chemical elements in minerals and rocks: Chem. Soc. [London] Jour., p. 655-673.

Hemley, J. J., 1959, Some mineralogical equilibria in the system $\mathrm{K}_{2} \mathrm{O}-\mathrm{Al}_{2} \mathrm{O}_{3}-\mathrm{SiO}_{2}-\mathrm{H}_{2} \mathrm{O}$ : Am. Jour. Sci., v. 257, p. 241-270.

Morey, G. W., and Fournier, R. O., 1961, The decomposition of microcline, albite and nepheline in hot water: Am. Mineralogist, v. 46, p. 688-699 


\section{STRUCTURAL FRAMEWORK OF THE ILLINOIS-KENTUCKY MINING DISTRICT AND ITS RELATION TO MINERAL DEPOSITS}

By A. V. HeyL, Jr., and M. R. Brock, Beltsville, Md.

The Illinois-Kentucky mining district is centered in the most complexly faulted area in the central craton of the United States. Structural studies suggest that the mineral district lies within a collapsed, blockfaulted, sliced, and partly rotated domal anticline that is located at and near the intersections of several major fault lineaments.

\section{REGIONAC FAULT LINEAMENTS}

Six major fault lineaments can be recognized in the region (fig. 294.1). (1) The New Madrid fault zone extends from near Vincennes, Ind., southwestward through and beyond New Madrid, Mo. (2) The Rough Creek-Shawneetown fault zone is traceable from the collapsed Jessamine dome of central Kentucky westward to the New Madrid fault zone, where it curves around the northwest end of the domal anticline and joins the west side of the New Madrid fault zone. (3) The Ste. Genevieve fault zone begins south of St. Louis and trends southeastward into northernmost Tennessee. (4) The Cottage Grove fault is traceable across southern Illinois to the Mississippi River, where it may end against the Ste. Genevieve system. Faults of similar westward trend are traceable through the

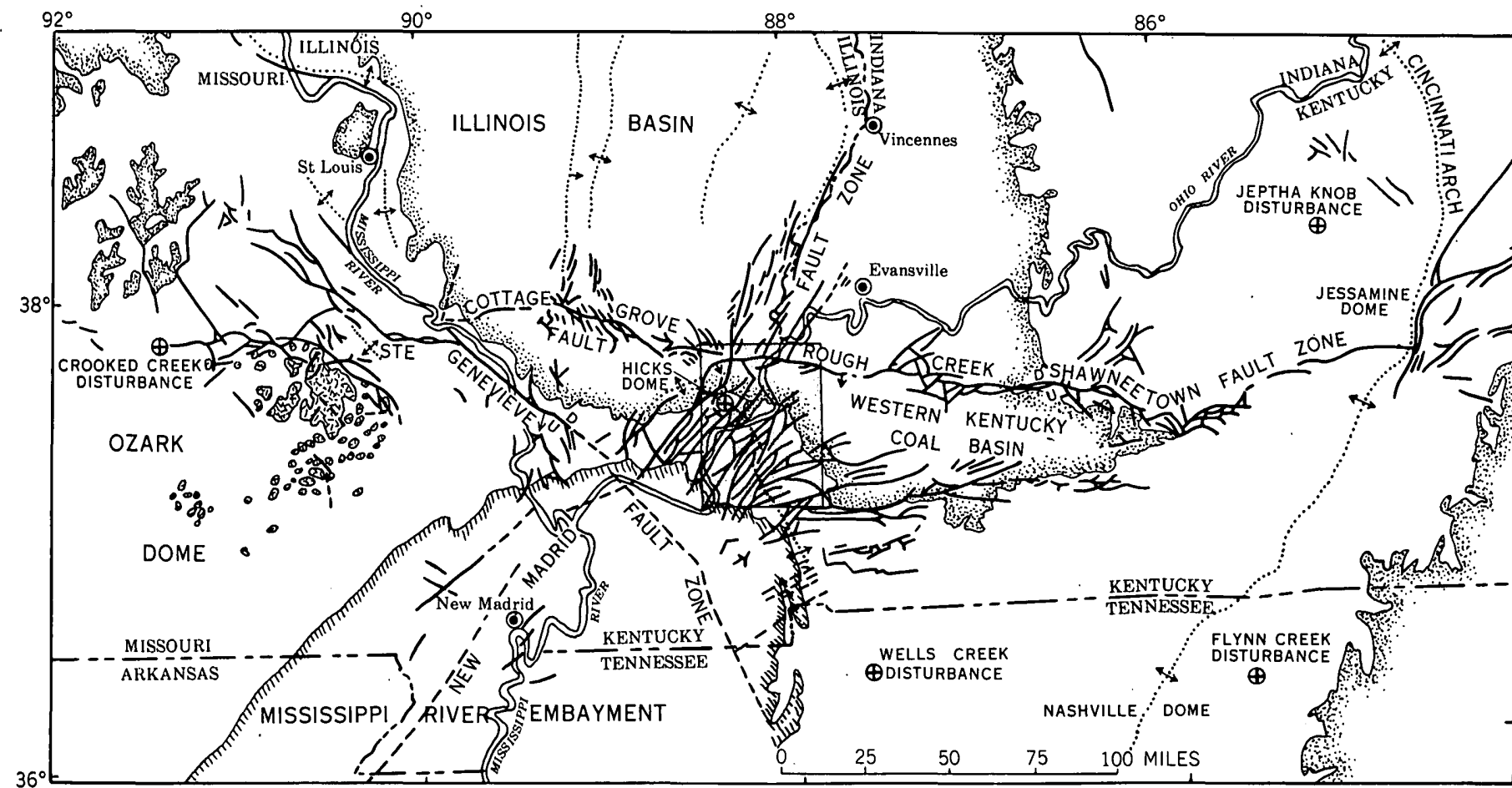

EXPLANATION
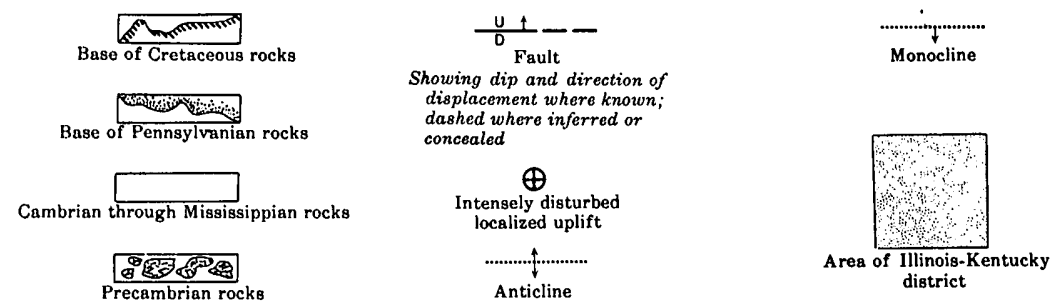

Frgure 294.1.-Major structural features near the Illinois-Kentucky mining district. Geology compiled from mary published sources by A. V. Heyl, Jr., J. J. Jolly, C. E. Wells, and M. R. Brock, 1960. 
southeast Missouri lead district to the Crooked Creek disturbance. (5) The zone of westward-trending faults along the south boundary of the western Kentucky coal basin joins the New Madrid fault zone in the southern part of the mining district. (6) Many vertical faults with a northwest trend (fig. 294.2) lie along the axis of the collapsed domal anticline of the Illinois-Kentucky district and are traceable beyond it into the southern part of the Illinois basin. The individual fractures are cut and displaced by faults of the other systems. Many fractures are filled with mafic dikes. The mafic dikes suggest that these faults are deep-seated tensional fractures that formed during the development of the domal anticline.

The north end of the Mississippi River embayment of the Coastal Plain and major parts of the channels of the Mississippi, Ohio, and Wabash Rivers in this region are very probably partly controlled by longcontinuing movements along the New Madrid and Ste. Genevieve fault systems. The largest of these two fault lineaments is the New Madrid fault zone, which has broken the rocks in the mining district into many narrow fault blocks and wedges that have a northeastward elongation. Woollard $(1958$, p. 1144) suggests that this fault zone is the southwestern part of a major structural break in the craton that extends northeastward beneath the sedimentary rocks into the St. Lawrence Valley as one of the great lineaments of North America.

The New Madrid zone, the Ste. Genevieve fault zone, and the curved west end of the Rough Creek-Shawneetown fault zone are tectonically active today. The New Madrid fault zone is one of the most active seismic areas in the country at the present time, including the wide part of the zone crossing the Illinois-Kentucky district; more than 25 earthquakes have been recorded along the zone since 1937. Several of the most violent earthquakes of historic time were in the New Madrid series of 1811 to 1813 (Fuller, 1912).

\section{STRUCTURES NEAR AND IN THE DISTRICT}

The Illinois-Kentucky mining district lies within the northern part of a collapsed north-northwest trending domal anticline. The north end of the fold terminates against the arcuate west end of the Rough CreekShawneetown fault, which in this area is a high-angle thrust fault that has over 3,000 feet of vertical displacement (fig. 294.2). A branch fault, probably of the same attitude, extends southeastward from the main fault at least as far as Saline Mines, Ill.

The main Rough Creek-Shawneetown fault system is a zone of shearing that shows evidence of being a wrench-fault system combined with a lesser high-angle thrust component of movement along steep, southward- dipping fault planes. The principal component of movement was strike slip that probably moved the north wall westward. The New Madrid fault zone apparently acted as shear-relief fractures for the Rough Creek-Shawneetown zone. The fault zone along the south boundary of the western Kentucky basin shows vertical and lateral displacements similar to the Rough Creek-Shawneetown zone.

The Cottage Grove fault is probably a weaker vertical wrench fault accompanied by scissors-type vertical displacements (Clark and Royds, 1948, p. 1748), as shown by the arrangement of the abundant subsidiary northwest-trending faults along it. The patterns of these subsidiary faults suggest that the main component of movement was strike slip, and that the rocks on the north side of the Cottage Grove fault moved eastward in relation to those south of the fault. This is the reverse of movement along the Rough Creek-Shawneetown fault. The relative alinements of the Cottage Grove and Rough Creek-Shawneetown fault systems suggest that the Cottage Grove fault may be simply a west-trending branch of the Rough Creek-Shawneetown fault.

\section{HICKS DOME}

The faulted anticline within the mining district is dominated by Hicks dome, a circular structure that has about 4,000 feet of vertical uplift and a diameter of about 9 miles. The dome contains a cluster of mineralized explosion breccias in the Devonian rocks in its center and several other explosion breccias on its flanks. Near the periphery of the dome are clusters of both radial and concentric ring faults (Weller, Grogan, and Tippie, 1952, pl. 4; Stonehouse and Wilson, 1955). Many of these fractures contain veins that have been mined for fluorite and zinc. The changes in the pattern of the northeast-trending faults in the dome area suggest that faulting is younger than doming (fig. 294. 2).

Eight altered dikes of peridotite having alkaline affinities lie within the dome. An altered northeasttrending dike just east of the center is radioactive and enriched in rare earths, barium, beryllium, niobium, gallium, and scandium similar to the fluorite-thoriumrare-earth breccias in the center of the dome. The magnetite of the dike is reported to be abnormally rich in zinc. Other dikes in the dome strike northwestward-parallel to all dikes elsewhere in the area and to the axis of the domal anticline.

Some of the central breccias have been drilled (Brown, Emery, and Meyer, 1954) and trenched, and one radioactive breccia, that of the Rose mine, has been mined for fluorite. The deepest hole, the Hamp hole, was drilled to a depth of 2,944 feet and ended in intensely brecciated Ordovician rocks. The last 1,600 


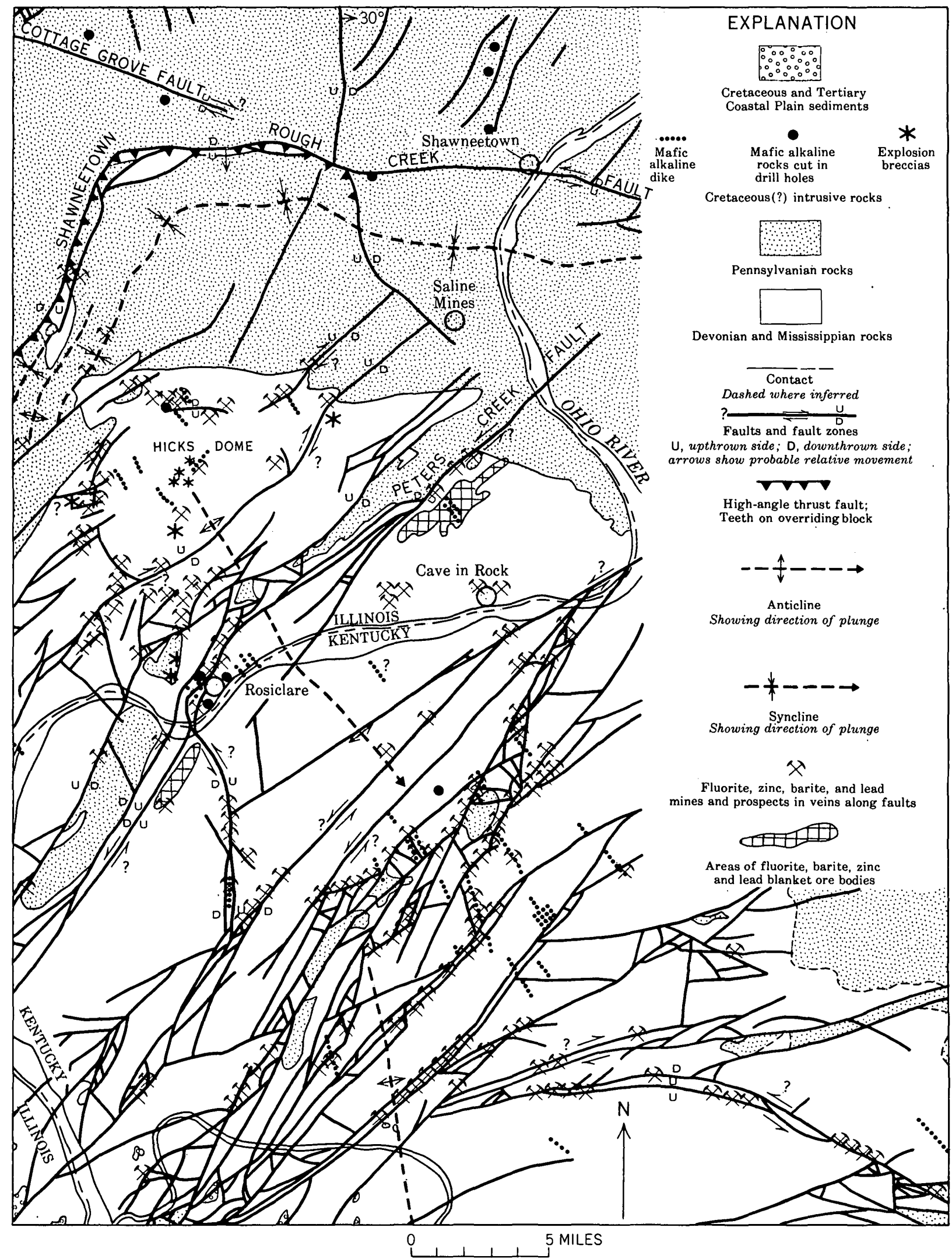

Frouri 294.2.-Structure, mineral deposits, igneous rocks, and explosion breccias of the Illinois-Kentucky mining district. Geology compiled from Weller and Sutton, 1951; Weller, Grogan, and Tippie, 1952; Clegg and Bradbury, 1956; Stonehouse and Wilson, 1955; and R. D. Trace, unpublished data, 1960. 
feet penetrated strongly mineralized breccia containing a matrix of 2 to 10 percent fluorite, much barite, quartz, calcite, and a little pyrite, sphalerite, galena, biotite, and apatite. Thorium, rare earths, beryllium, zirconium, and niobium are intimately associated with the fluorite and barite and increase in amount with these minerals. The mineralogy of the shallow drilling and trenches was studied by Trace (1960), who identified an unusual yttrium-thorium monazite and florencite. The lead- alpha age of this monazite is 90 to 100 million years, or middle Cretaceous (T. W. Stern, oral communication, 1960).

The monazite is relatively unfractionated and is of the deep-seated type that is most likely to have been deposited originally at great depth in the earth's crust (W. C. Overstreet, oral communication, 1960), thus strengthening the suggestion by Brown, Emery, and Meyer (1954) that the breccias are mineralized diatremes and Hicks dome is a cryptovolcanic structure. The presence of similar elements in both the mineralized breccias and the nearby dike, and also the abundance of fluorspar in the breccias, suggest a genetic relation between the two and to the rest of the fluorspar-zinc district. Fluorine, gallium, niobium, and barium are typical of igneous rocks of the alkaline series and are characteristic of mineral deposits closely associated with such rocks.

\section{ORIGIN OF THE DOMAL ANTICLINE}

The axis of the domal anticline from an apex at Hicks dome plunges gently southeastward into northern Kentucky, where it is apparently displaced southwestward by faulting (fig. 294.2), and extends south through western Kentucky as the Kuttawa arch; the fold flattens and dies out south of Princeton, Ky.

Unlike other domal uplifts of the region, such as the Ozark dome, the anticline formed during a relatively short period in post-Pennsylvanian time, probably middle Cretaceous, because the Pennsylvanian and older rocks are unthinned over the anticline. This domal folding probably was the result of the intrusion of a magma deep within the Precambrian basement at the intersection of several basement fault lineaments. The body was large, as is shown by the widespread extent of the satellitic dikes and explosion breccias in the area. The first tension fractures to open during uplifting were those parallel to anticlinal axes, as pro- posed by Weller and others (1927). The mafic dikes that occupy many of these are thought to be only slightly younger than the fractures. A gaseous explosion took place on the apex of the structure to form the smaller dome (Hicks dome) and its diatremes. Part of its gas and steam may have formed from the connate waters and petroleum in the heated Paleozoic rocks overlying the magma. Subsequent cooling and shrinkage of the igneous rocks partly lowered the anticline. This action was combined with a compressive forcecouple acting along the Rough Creek-Shawneetown fault zone, which compressed and rotated the north end of the fold in a counter-clockwise direction to develop the numerous northeast-trending fault blocks. Mineralized, heated solutions moved upward along the previously formed faults and breccias and selectively deposited the minerals. The Mississippi River embayment was formed in Late Cretaceous time by downwarping of the block south of the intersection of the New Madrid fault zone and the Ste. Genevieve fault zone.

\section{REFERENCES}

Brown, J. S., Emery, J. A., and Meyer, P. A., Jr., 1954, Explosion pipe in test well on Hicks Dome, Hardin County, Illinois: Econ. Geology, v. 49, no. 8, p. 891-902.

Clark, S. K., and Royds, J. S., 1948, Structural trends and fault systems in Eastern Interior Basin: Am. Assoc. Petroleum Geologists Bull., v. 32, no. 9, p. 1728-1749.

Clegg, K. E., and Bradbury, J. C., 1956, Igneous intrusive rocks in Illinois and their economic significance: Illinois Geol. Survey Rept. Inv. 197, 19 p., 1 map.

Fuller, M. L., 1912, The New Madrid earthquake: U.S. Geol. Survey Bull. 494.

Stonehouse, H. B., and Wilson, G. M., 1955, Faults and other structures in southern Illinois: Illinois Geol. Survey Circ. 195, 4 p., 1 map.

Trace, R. D., 1960, Significance of unusual mineral occurrence at Hicks Dome, Hardin County, Illinois, in Short papers in the geological sciences: U.S. Geol. Survey Prof. Paper 400-B, p. B63-B64.

Weller, J. M., Grogan, R. M., and Tippie, F. E., 1952, Geology of the fluorspar district of Illinois: Illinois Geol. Survey Bull. 76, 147 p.

Weller, Stuart, and Sutton, A. H., 1951, Geologic map of the western Kentucky fluorspar district: U.S. Geol. Survey Mineral Inv. Field Studies Map MF-2.

Weller, Stuart, and others, 1927, The geology of Hardin County, Illinois : Illinois Geol. Survey Bull. 41, $460 \mathrm{p}$.

Woollard, G. P., 1958, Areas of tectonic activity in the United States as indicated by earthquake epicenters : Am. Geophys. Union Trans., v. 39, no. 6, p. 1135-1150. 
SHORT PAPERS IN THE GEOLOGIC AND HYDROLOGIC SCIENCES, ARTICLES 293-435

\section{POSSIBLE RELATION BETWEEN HYDROGEN SULFIDE-BEARING HYDROCARBONS IN FAULT-LINE OIL FIELDS AND URANIUM DEPOSITS IN THE SOUTHEAST TEXAS COASTAL PLAIN}

By D. Hoye Eargle and Alice D. Weeks, Austin, Tex., and Washington, D.C.

Since 1954, when uranium was discovered in western Karnes County, in the Coastal Plain of southeast Texas, exploration activities for oil and gas and for uranium have been intimately associated. The uranium deposits were accidentally discovered during an airborne survey being conducted for a private oil operator on the theory that oil is associated with anomalous radioactivity. The uranium deposits were found in an area where oil has been produced for several decades from traps in comparatively shallow Tertiary sandstone beds along faults (fig. 295.1). The beds have a gentle regional dip to the southeast. The faults trend northeastward, nearly parallel to the strike of the beds, and the oil accumulations generally are located where the faults bend slightly, producing an arcuate pattern that is convex updip. The faults seem to be part of the Mexia fault system, described by A. W. Weeks (1945, p. 1734). The beds along the principal faults are upthrown to the southeast; faults with the opposite displacement lie northwest of some of the main faults. The faults are generally en echelon; individual faults may extend from 5 to 25 miles. Faulting apparently began early in Late Cretaceous time, and movement on some was intermittent until at least Miocene time (A. W. Weeks, 1945, p. 1736).

Most of the uranium deposits are slightly up dip from faults upthrown to the east (Fashing and Hobson faults) and within a grabenlike area between these faults and the Falls City fault a few miles to the west (fig. 295. 1). The host rocks in the deposits are the alternating nonmarine and shallow-marine tuffaceous rocks in the upper part of the Jackson group (late Eocene); these sediments were covered, until recent geologic time, by the nonmarine Catahoula tuff (Miocene(?)). Deposits in near-surface pits are mostly oxidized and consist of yellow uranium minerals in films on bedding planes and disseminated in the sandstone. A few small pockets of unoxidized ore are in dark-gray pyritic clay under the main ore-bearing sandstone and contain disseminated black ore minerals and minute concretionary grains of uraninite, indicating precipitation in a reducing environment.

The deposition of ore may have been brought about by a channeling of ground water into the graben-like area where there was a suitable reducing environment for precipitation of uranium (Eargle, 1958; MacKallor and Bunker, 1958). Alteration of the tuffaceous sediments by ground water may have produced heulandite and released alkalies, silica, and several trace elements including uranium (Weeks, Levin, and Bowen, 1958). The uranium was redistributed by the alkaline ground water and locally precipitated; the reducing conditions were caused by decay of plant fragments or by hydrogen sulfide, which was derived from decaying organic matter in the host rocks or derived as seepage of hydrogen sulfide gas from the deeper Edwards limestone. The amount of hydrogen sulfide seepage necessary to form the deposits would be very small compared to the amount available in the Edwards. The mechanism has been described for another uranium deposit at Palangana salt dome, Texas (Weeks and Eargle, 1960).

In 1958 a large high-pressure gas field was discovered along the Fashing fault only a few miles south-. west of the richer uranium deposits; the gas is produced from the Edwards limestone (Lower Cretaceous) and is rich in hydrogen sulfide and distillate. Several other discoveries of sulfur-rich petroleum near other uranium localities in the Karnes region have been made since 1958. In 1959 the Person oil field in northern Karnes County, producing sour gas from the Edwards limestone, was discovered in an area where a surface radioactivity anomaly and some uranium minerals have been found. The Person field is about 20 miles northeast of deposits being mined in western Karnes County. Although the fault that forms the oil trap in this field is not known to cut formations younger than Paleocene, other faults in this area may have provided access for hydrogen sulfide seepage into overlying rocks.

Three additional, widely scattered oil wells have recently been drilled along this trend from the Edwards limestone, each one a few miles down the dip from uranium prospects. The Bright and Schiff 1 Kunkel well, drilled in 1960 , is about $31 / 2$ miles south of Falls City, and is about 3 miles east of and down the dip from an uranium prospect near the San Antonio River. The Standard of Texas 1 Manka well, also drilled in 1960, about $4 \frac{1}{2}$ miles southeast of Falls City, is less than 2 


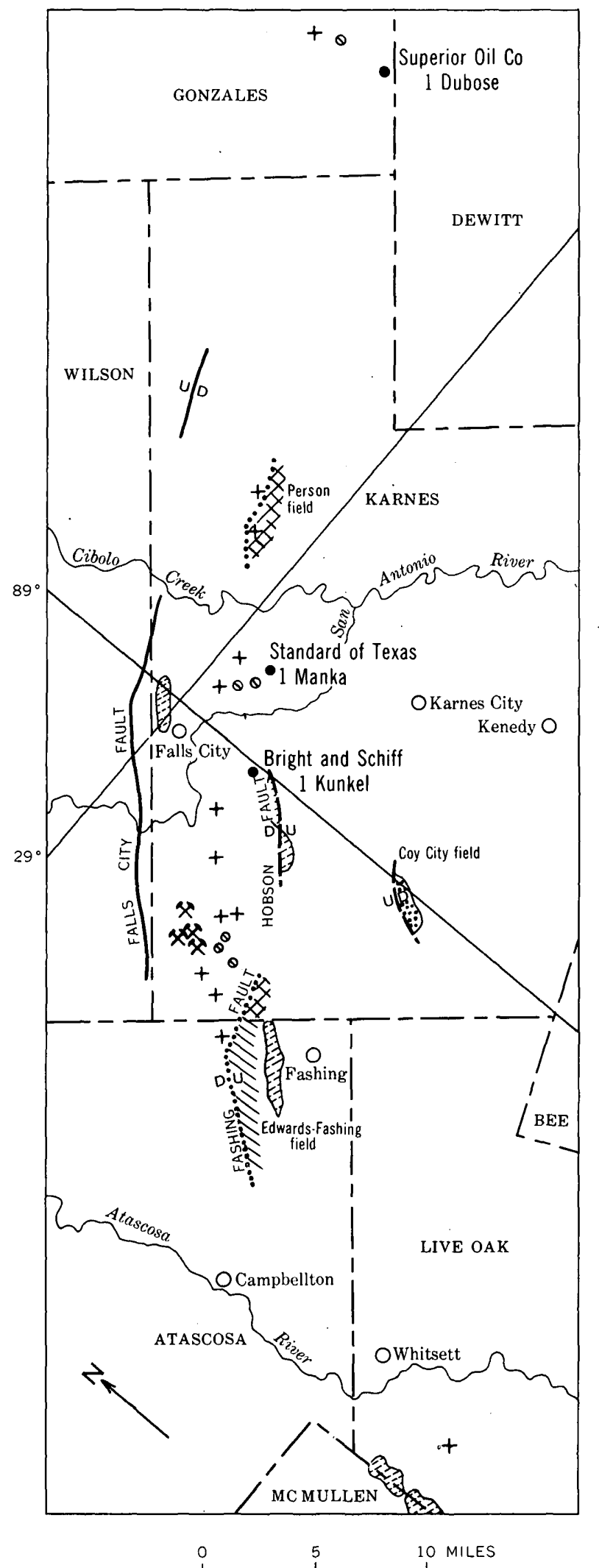

\section{EXPLANATION}

$\theta$

Well or core hole having high radioactivity anomaly

$$
+
$$

Uranium prospect

$$
x
$$

Uranium mine

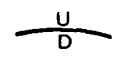

Outcropping fault

$\mathrm{U}$, upthrown side; $\mathrm{D}$, downthrown side

$$
-\frac{U}{D}-
$$

Buried fault cutting Eocene sands, projected to surface

$\mathrm{U}$, upthrown side; $\mathrm{D}$, downthrown side

$$
\text { .... U.... }
$$

Buried fault cutting Lower Cretaceous limestone, projected to surface

$\mathrm{U}$. upthrown side; $\mathrm{D}$, downthrown side

$$
\text { Q }
$$

Oil field producing from Eocene sands

$$
28
$$

Oil field producing from Lower Cretaceous limestone ?.

Gas field producing from Eocene sands

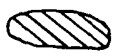

Gas field producing from Lower Cretaceous limestone

New oil discovery, Lower Cretaceous limestone

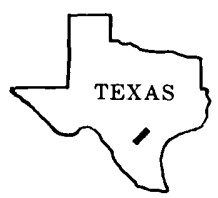

Figure 295.1.--Oil and gas fields and uranium occurrences in the Karnes County area, southeastern Texas. 
miles down the dip from two uranium prospects and is near two subsurface radioactive anomalies, found at a depth of about 100 feet by the gamma-ray logging of two wells. The Superior Oil Co. 1 Dubose well in southern Gonzales County, drilled late in 1960, is down the dip from an uranium prospect. Between the uranium prospect and the well in Gonzales County are several wells producing radioactive waters; a sample of water from one of these wells contained $10,700 \mu \mu \mathrm{c} /$ liter of radon-222 and $106 \mu \mu \mathrm{c} /$ liter of radium-226 (A. B. Tanner, written communication, 1956).

The presence of hydrogen sulfide-bearing oil and gas near the uranium occurrences suggests that hydrogel. sulfide from the oil and gas was the reducing agent that caused precipitation of the uranium.

\section{REFERENCES}

Eargle, D. H., 1958, Regional structure and lithology in relation to uranium deposits, Karnes County area, Texas [abs.] : Geol. Soc. America Bull., v. 69, no. 12, pt. 2, p. 1557.

MacKallor, J. A., and Bunker, C. M., 1958, Ore controls in the Karnes County uranium area, Texas [abs.]: Geol. Soc. America Bull., v. 69, no. 12, pt. 2, p. 1607.

Weeks, A. D., Levin, Betsy, and Bowen, R. J., 1958, Zeolitic alteration of tuffaceous sediments and its relation to uranium deposits in the Karnes County area, Texas [abs.] : Geol. Soc. America Bull., v. 69, no. 12, pt. 2, p. 1659 .

Weeks, A. D., and Eargle, D. H., 1960, Uranium at Palangana salt dome, Duval County, Texas, in Short papers in the geological sciences: U.S. Geol. Survey Prof. Paper 400-B, p. B48-B52.

Weeks, A. W., 1945, Balcones, Luling, and Mexia fault zones in Texas: Am. Assoc. Petroleum Geologists Bull., v. 29, no. 12, p. 1733-1737.

296. RELATION OF FOLD STRUCTURES TO DISTRIBUTION OF LEAD AND ZINC MINERALIZATION IN THE BELMONT AND CALAMINE QUADRANGLES, LAFAYETTE COUNTY, WISCONSIN

By Walter' S. West and Harry Klemic, Washington, D.C. and Beltsville, Md.

Work done in cooperation with the Wisconsin Geological and Natural History Survey

The Belmont and Calamine quadrangles, Lafayette County, Wis., lie wholly within the Upper Mississippi Valley zinc-lead district. Exposed in this area are Middle and Upper Ordovician rocks consisting of a few hundred feet of beds of carbonate rock and minor amounts of interbedded shale. These are underlain by as much as 340 feet of quartz sandstone, and, below this, by more than 1,000 feet of carbonate rocks, shale, and sandstone of Cambrian and Early Ordovician age (table 296.1). At many places in the Belmont and Calamine quadrangles, particularly in the latter, dolomite is prevalent in the exposed carbonate rock sequence.

The Ordovician strata have a regional dip of less than $1^{\circ} \mathrm{SSW}$ except where they have been folded. The axes of major folds and locations of domes and basins in the two quadrangles, as determined by structure contour maps of the top of the Platteville formation, are shown on figure 296.1. Most of the folds have amplitudes of only a few tens of feet; the greatest structural relief is about 190 feet on the top of the Platteville formation from the crest of the southernmost anticline in the Belmont quadrangle to the trough of the syncline in the southwestern part of the quadrangle.
Shown on figure 296.1, also, are the locations of mines, prospect pits, and drill holes in which lead and zinc minerals have been found in significant amounts. Groups of dots indicate general areas where ore was mined. Trace amounts of lead or zinc minerals were found at many localities not shown on the map, and some workings where lead was mined in early days may have been obliterated and cannot be located.

We offer the following explanation of how the ore bodies were emplaced. We suggest that limestone beds in the Platteville and Decorah formations at one time were the uppermost limestone beds beneath an erosion surface on the Galena dolomite (Du Bois, 1945) or the Maquoketa shale (Brown and Whitlow, 1960), and that meteoric waters moved through joints and fractures in the rocks, dissolving and thinning the limestone beds preferentially. Some compaction of residual material and slumping in the partly dissolved beds may have occurred late in this period. During a period of tectonism, possibly contemporaneous with the waning period of solution or perhaps distinctly later, the solution-thinned beds and some adjoining beds were brecciated, sets of inclined fractures formed, and beds overlying the zones of solution-thinning sagged into the 
TABLE 296.1.-Stratigraphic section of rocks exposed in the Belmont and Calamine quadrangles, Wis.

\begin{tabular}{|c|c|c|c|}
\hline Series & Formation & $\begin{array}{l}\text { Thickness } \\
\text { (feet) }\end{array}$ & Description \\
\hline Upper Ordovician & Maquoketa shale & $40+$ & $\begin{array}{l}\text { Shale, gray or blue, and dolomite, gray; phosphatic nodules and de- } \\
\text { pauperate fossils in thin zone near base; occurs in the northwest } \\
\text { corner of the Belmont quadrangle. }\end{array}$ \\
\hline \multirow{4}{*}{ Middle Ordovician } & Galena dolomite & $220+$ & $\begin{array}{l}\text { Dolomite, buff to grayish-orange, and numerous interbedded thin layers } \\
\text { of nodular chert in lower half; limestone in the lower part of the } \\
\text { formation locally in the west-central part of the Belmont quadrangle; } \\
\text { zinc-lead deposits in fractures in the lower part of the formation and } \\
\text { lead-zinc deposits along vertical crevices higher in the formation; } \\
\text { underlies and crops out over large areas. }\end{array}$ \\
\hline & Decorah & $30-35$ & $\begin{array}{l}\text { Dolomite and limestone, gray to buff or grayish orange; entirely } \\
\text { dolomitic at many places; underlies large areas; zinc-lead ores in } \\
\text { inclined and horizontal fractures, and in solution-thinned and brec- } \\
\text { ciated zones. }\end{array}$ \\
\hline & Platteville & $65 . \pm$ & $\begin{array}{l}\text { Dolomite in lower part, buff to pale-gray; limestone or dolomite in } \\
\text { middle part, light-gray; limestone or dolomite in upper part, pale } \\
\text { purplish gray, aphanitic or fine-grained; entire formation is dolomite } \\
\text { at many places; underlies large areas but outcrop area is small; } \\
\text { zinc-lead ores in fractured, brecciated, and solution-thinned zones in } \\
\text { upper part. }\end{array}$ \\
\hline & St. Peter sandstone & $35+$ & $\begin{array}{l}\text { Quartz sandstone, white to yellowish, crossbedded friable; iron-oxide- } \\
\text { cemented layer near top; underlies large areas but exposed only in } \\
\text { valleys. }\end{array}$ \\
\hline
\end{tabular}

voids. Still later, solutions carrying the ore elements entered the fractures, breccias, and solution-thinned zones and deposited the ore minerals.

The solutions which deposited the ore minerals probably differed considerably from those responsible for the major thinning of the host rocks, as is indicated by the following facts: (a) Some ore-cemented breccias contain angular rock fragments that show only minor solution effects. (b) The footwall sides of heavily mineralized inclined fractures show relatively extensive thinning, whereas the hangingwall sides show relatively little. This suggests that the major parts of the solution preceded the inclined fractures, which formed prior to mineralization. (c) A thin film of iron sulfide, which generally coats the host rocks of the ore, probably inhibited reaction of the ore solutions with the carbonate rocks.

Ore deposits in the dolomite of the Galena developed in somewhat similar stages as has been suggested by Bradbury (1959). Extensive solution of rock occurred along vertical joints and fractures in some beds. Interstitial calcite in beds of calcareous dolomite was dissolved preferentially, and cavernous and porous zones were produced. The remaining parts of the dolomite beds were sufficiently strong to prevent extensive col- lapsing within and above the porous and cavernous beds. Ore solutions later entered these zones and deposited the sulfides.

If the proposed sequence of events leading to the emplacement of the ore deposits is correct, then ore bodies might be found in shallow surface synclines caused by the sagging beds over solution-thinned zones.

It has been suggested that synclinal basins are favorable places in which to prospect for ore in the Upper Mississippi Valley district (Grant, 1906, p. 85 and 86; Heyl and others, 1959, p. 170-172). We suggest, however, that the widespread and possibly random distribution of mineralized sites with respect to the folds is an indication that in the Belmont and Calamine quadrangles the tectonically folded structures are not useful guides to ore deposits, and that localization of ore deposits was not controlled by these folds. All sites of lead deposits in vertical crevices in the two quadrangles are places that were pervaded by solutions capable of dissolving limestone and by solutions carrying the ore elements. If the fracture systems provided access to the underlying Decorah and Platteville formations where they contained limestone beds, it is likely that solution thinning would have occurred in the limestone layers, and collapse features would have 


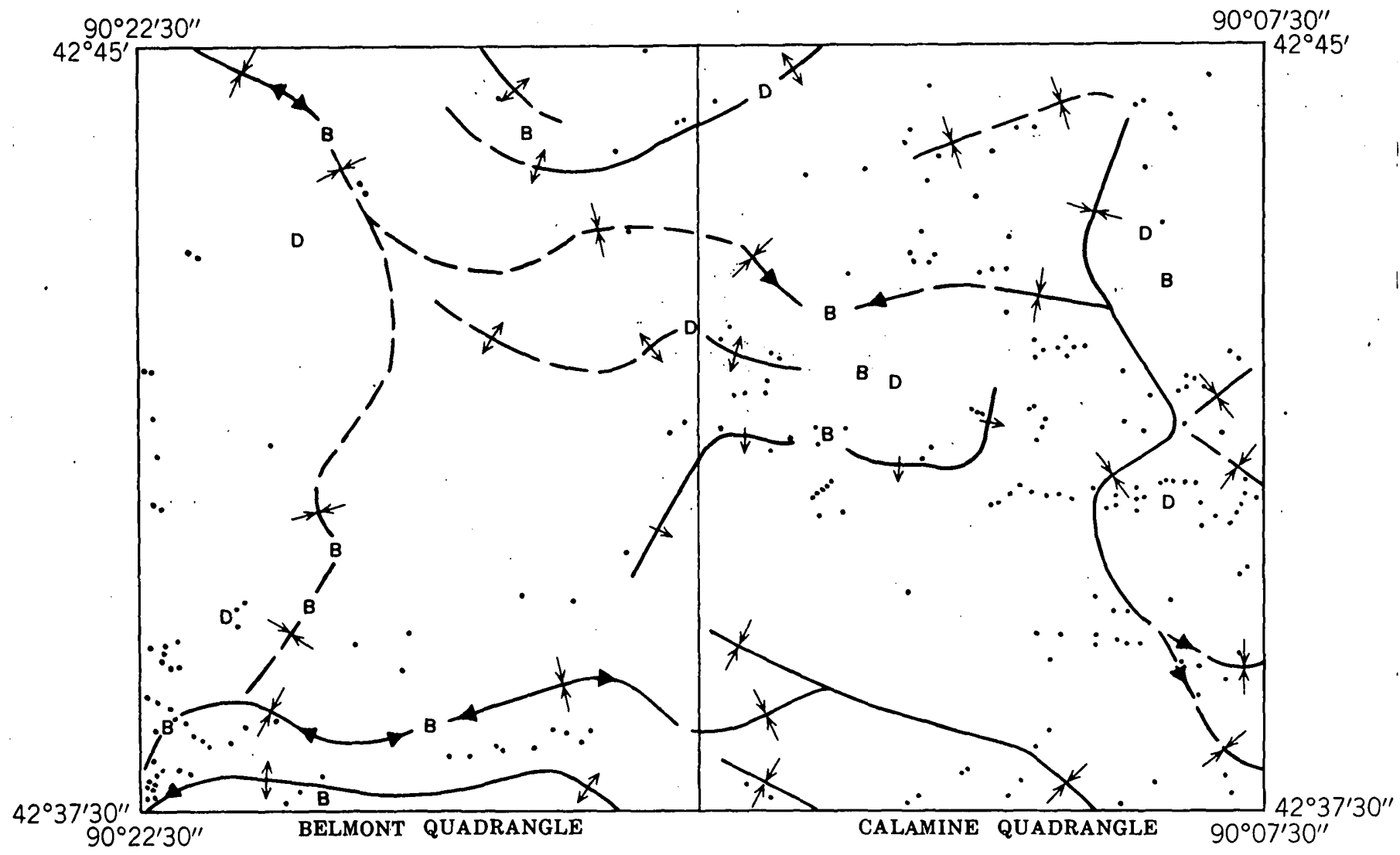

EXPLANATION

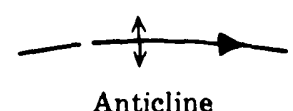

Showing bearing and plunge of axis. Dashed where approximately located

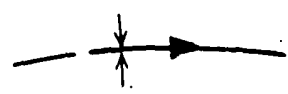

Syncline

Showing bearing and plunge of axis. Dashed where approximately located

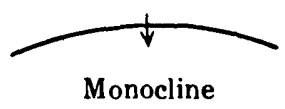

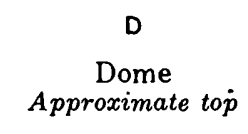

B

Basin

Approximate bottom

Old mines, prospect pits, and other occurrences of lead or zinc minerals

\section{$0 \quad 1 \quad 2$ MILES}

FraURE 296.1.-Map showing structural features and major occurrences or lead and zinc minerals in the Belmont and Calamine quadrangles, Wisconsin. 
formed in which ore deposits could have been deposited. Where the underlying rocks were dolomite, solution thinning would have been negligible. Where layers of rock bridge partly dissolved beds, ore deposits could exist with no structural expression at the surface. Such sites of mineralization may occur in the northcentral and south-central parts of the Calamine quadrangle. If the original solution thinning occurred prior to the major folding as is suggested here, there may be only a fortuitious relation between the folds and the ore deposits, regardless of whether the ore minerals were deposited before, during, or after the folding.

\section{REFERENCES}

Bradbury, J. C., 1959, Crevice lead-zinc deposits of northwestern Illinois : Illinois Geol. Survey Rept. Inv. 2100.

Brown, C: E., and Whitlow, J. W., 1960, Geology of the Dubuque South quadrangle: U.S. Geol. Survey Bull. 1123-A [1961].

DuBois, E. P., 1945, Subsurface relations of the Maquoketa and Trenton formations in Illinois: Illinois Geol. Survey Rept. Inv. 105.

Grant, U. S., 1906, Report on the lead and zinc deposits of Wisconsin, with an atlas of detailed maps: Wisconsin Geol. and Nat. History Survey Bull. 14, Econ. ser. 9, p. 85 and 86 .

Heyl, A. V., Jr., Agnew, A. F., Lyons, E. J., and Behre, C. H., Jr., 1959, The geology of the upper Mississippi Valley zinc-lead district: U.S. Geol. Survey Prof. Paper 309.

\section{HYDROLOGIC STUDIES}

\section{RESERVOIR STORAGE FOR SHORT-PERIOD STREAMFLOW REGULATION}

By G. N. Mesnier, R. E. Oltman, and W. B. Langbein, Washington, D.C.

Several graphs were prepared as part of studies for the Senate Select Committee (1960) for computation of the storage required to increase low flow of streams in major river basins. These may be of use or interest in the solution of other similar problems. The graphs, shown on figures 297.1-297.3, present generalized sets of curves expressing the relation between regulated flow and required storage. The ordinate is regulated flow expressed in ratio to the mean, the abscissa is the required storage capacity in days, and the parameter is the variability index. The variability index, as defined by Lane and Lei (1950), is the standard deviation of the common logarithms of the daily discharges. Storage capacity, reported in days, represents the volume in ratio to the mean flow of the river. Thus, a capacity of 20 days is a volume equal to a flow of 20 days at the mean rate.

Given the mean flow and the variability index characteristic of a region, an estimate may be made of the storage required to sustain flows of increasing magnitude.

Figure 297.1, showing the maximum storage required, was prepared by mass-curve analysis (Linsley and Franzini, 1955, p. 138-140) of the monthly flows of 25 different streams in the conterminous United States. Storage required for draft rates of $20,40,60$, and 80 percent of the mean was then determined by customary mass-curve techniques. The data for the several streams were then grouped in terms of their variability indices and averaged. Figure 297.1 therefore represents a rough estimate of the storage required for streamflow regulation during the most adverse or lowest sequences in a particular period of streamflow record.

Figures 297.2 and 297.3 represent the amounts of storage required, assuming that the low flows are equal to the lowest flows that occur in 1 year in 20 , and in 1 year in 5. These requirements are less stringent than the requirements assumed for figure 297.1 and therefore yield lower estimates for volumes of storage.

Two principal factors control the amount of storagethe first is variability, and the second is the sequential

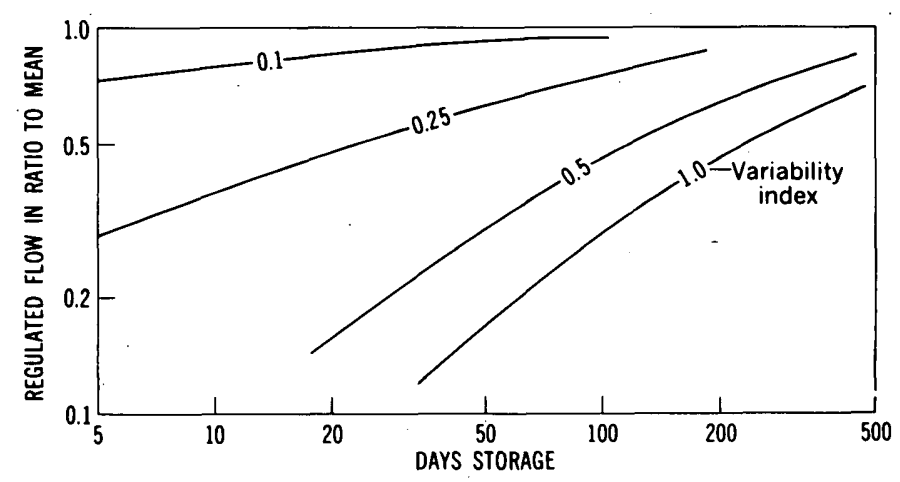

Fraure 297.1.-Storage required for streamflow regulation during periods of low flow equal to the lowest flow of record. 


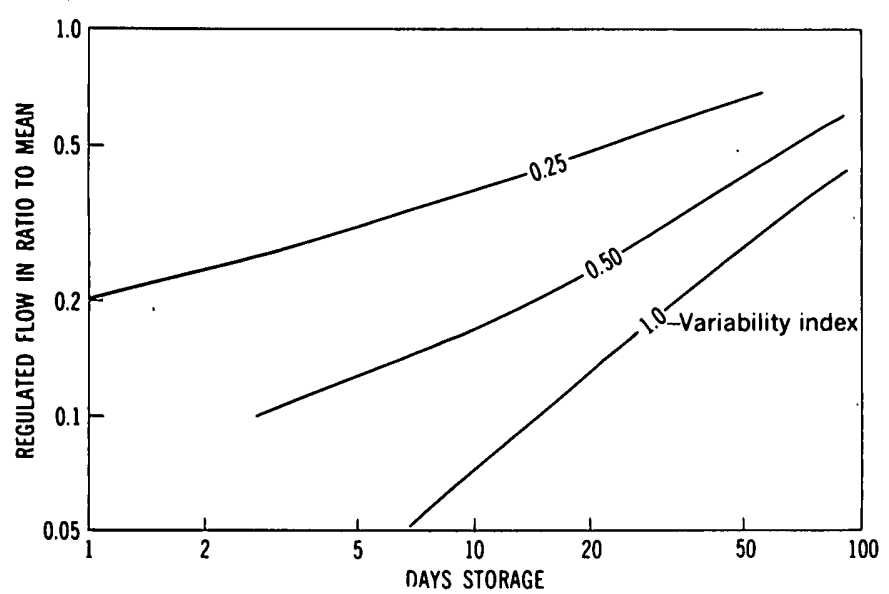

Froure 297.2.-Storage required for streamflow regulation during periods of low flow equal to the low flow of 1 year in 20.

order in which the flows occur. Variability is evaluated by the variability index, but because the index is based on the variability of daily flows it may not be representative of the variability among longer periods. The sequential order is largely controlled by the seasonal regimen; the greater the tendency for low flows to occur in a consecutive sequence, the greater the storage requirement. The sequential effects are evaluated implicitly in the graphs.

In constructing the figures, widely varying results for different streams were averaged and smooth curves constructed. Part of the differences represent inherent differences among the streams, and part is due to the behavior of each stream during the particular period of streamflow record. Different periods of record would not only indicate different amounts of storage required, but different values of the variability index as well. Figures 297.1-297.3 average out these components, and

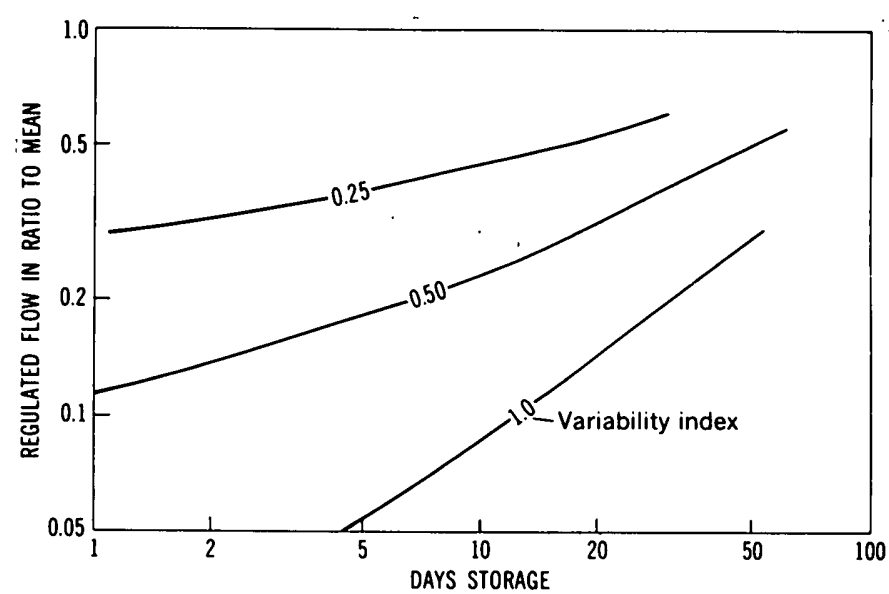

FIgURE 297.3.-Storage required for streamflow regulation during periods of low flow equal to the low flow of 1 year in 5 .

are, therefore, averages of both place and time, a fact that restricts their usefulness.

Although curves such as those shown may not be applied to any particular stream, or a particular period of years, they can be used in a general way to form estimates of storage needed for short-term regulation of streams.

The curves show that required storage increases greatly with increase in the variability index and with increase in the regulated flow.

\section{REFERENCES}

Lane, E. W., and Lei, Kai, 1950, Streamflow variability : Am. Soc. Civil Engineers Trans., v. 115, p. 1084-1134.

Linsley, R. R., and Franzini, J. B., 1955, Elements of hydraulic engineering: New York, McGraw-Hill Book Co. Senate Select Committee, 1960, National water resources and problems: Committee Print No. 3, Select Comm. on Natl. Water Resources, U.S. Senate, 86th Cong., 2nd Sess.

298. RESERVOIR STORAGE-GENERAL SOLUTION OF A QUEUE MODEL

By W. B. Langbein, Washington, D.C.

Formal application of the theory of queues to the design or operation of reservoir storage usually leads to a set or system of simultaneous linear equations that must be solved for each specific case. However, a general solution appears possible if certain approximations are made. In this example, a three-state approximate solution is described for the case when a uniform draft rate upon the reservoir is required. In the solution, it is assumed or specified that:

1. Random inflows during successive units of time are approximated by a trinomial probability distribution. The distribution supposes that the inflow in any interval of time has one of three values, $B+A, B$, and $B-A$. The value of $B$ is the draft 
rate, and the value of $A$ and of the probabilities associated with each of these quantities $B+A, B$, $B-A$, is such that their mean and standard deviations are equal to the mean $(\bar{Q})$ and standard deviation $(s)$ of the inflows as given.

2. The reservoir capacity contains $n$ integral units of volume, each equal to $A$.

3. Reservoir contents at the beginning or end of any unit of time may be in one of the $n+2$ states, which are empty, between empty and $A$, between $A$ and $2 A, \ldots \ldots$ or full.

4. Reservoir storage in a unit of time may (a) decrease one unit when inflow equals $B-A$, for which the probability is $q$; (b) remain the same when inflow equals $B$, for which the probability is $r$; or (c) increase one unit when inflow equals $B+A$, for which the probability is $p$.

5. The probability of changing more than one unit is neglected, so the alternatives above are the only possible ones. Hence,

$$
q+r+p=1.0 \text {. }
$$

These probabilities are subject to the boundary conditions imposed by an empty reservoir when a decrease in contents is not possible, or by a full reservoir when an increase in the contents is not possible. These conditions can be stated as follows:

1. When empty at a given time, the probability that the reservoir will remain empty at end of next interval of time equals the probability of inflow less than the uniform rate of draft, $B$. The probability of this occurrence is $q_{0}$.

2. When empty at a given time, the probability that at the end of the next interval of time the reservoir will be in the first storage range, between zero and $A$, is equal to the probability of inflow greater than $B$. The probability of this occurrence is $p_{v}$. By definition

$$
q_{0}+p_{0}=1.0
$$

3. When the reservoir is initially full, the probability that the reservoir will remain full at the end of the next interval of time is equal to the probability of an inflow greater than $B$. The probability of this occurrence is $p_{0}$.

4. When the reservoir is initially full, the probability that the reservoir will be in the storage range below the spillway at the end of the next interval of time is equal to the probability of inflow less than $B$. The probability of this inflow is $q_{0}$.

These statements can be expressed as a matrix, as follows:

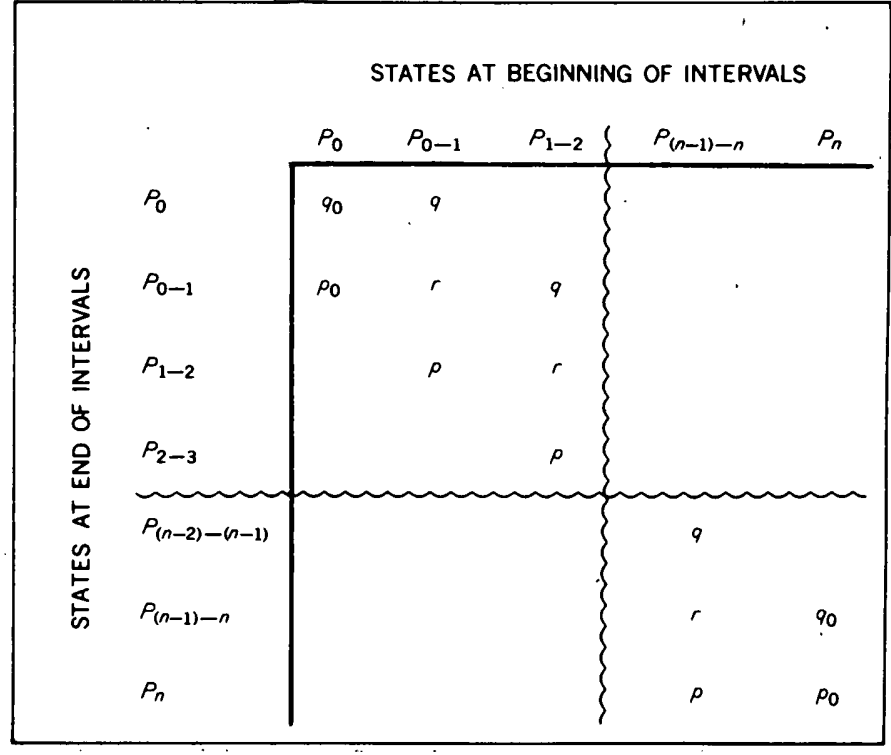

Subject to the condition that

$$
P_{0}+P_{0-1}+P_{1-2}+\ldots . P_{(n-1)-n}+P_{n}=1.0
$$

Note that the probabilities in each column total unity because these represent all possible alternatives.

The solution of this set of simultaneous equations leads to the following results for the probabilities of the reservoir spilling and of being empty:

$$
\begin{aligned}
& P_{n}=\frac{\left(\frac{p}{q_{0}}\right)}{1+\frac{p}{q_{0}}+\frac{q}{p}+\left(\frac{q}{p}\right)^{2}+\ldots \ldots\left(\frac{q}{p}\right)^{n-1}+\left(\frac{q}{p}\right)^{n-1}\left(\frac{q}{p_{0}}\right)} \\
& P_{0}=\frac{\left(\frac{q}{p}\right)^{n-1}\left(\frac{q}{p_{0}}\right)}{1+\frac{p}{q_{0}}+\frac{q}{p}+\left(\frac{q}{p}\right)^{2}+\ldots \ldots\left(\frac{q}{p}\right)^{n-1}+\left(\frac{q}{p}\right)^{n-1}\left(\frac{q}{p_{0}}\right)}
\end{aligned}
$$

where $P_{n}$ is the probability that reservoir spills, $P_{0}$ is the probability that reservoir is empty, and, $n$ is the reservoir capacity in ratio to $A$.

The number of terms in the denominator of the above fractions equals the number of storage states; that is, $n+2$. The value of $P_{0}$ is also equal to the probability of "failure"; that is, the probability that discharge from the reservoir will be less than $B$, the design rate of draft.

The values of $p, q$, and $A$ are defined by the following equations:

$$
\begin{aligned}
& p-q=y / A \\
& A=\sqrt{\frac{1+y^{2}}{1-r}} \\
& r=1-p-q \\
& y=(\bar{Q}-B) / s
\end{aligned}
$$


The values of $p_{0}$ and $q_{0}$ are read from the given distribution of reservoir inflows. The value of $p_{0}$ is the probability of inflow greater than $B$ and $q_{0}$ the probability of inflow less than $B$. The sum of $p_{0}$ and $q_{0}$ equals unity.

Calculations have been made for probability of spilling $\left(P_{n}\right)$ and of empty $\left(P_{0}\right)$ for various combinations of capacity and draft rates. The results are given nondimensional form on figure 298.1 for a normal and ran-

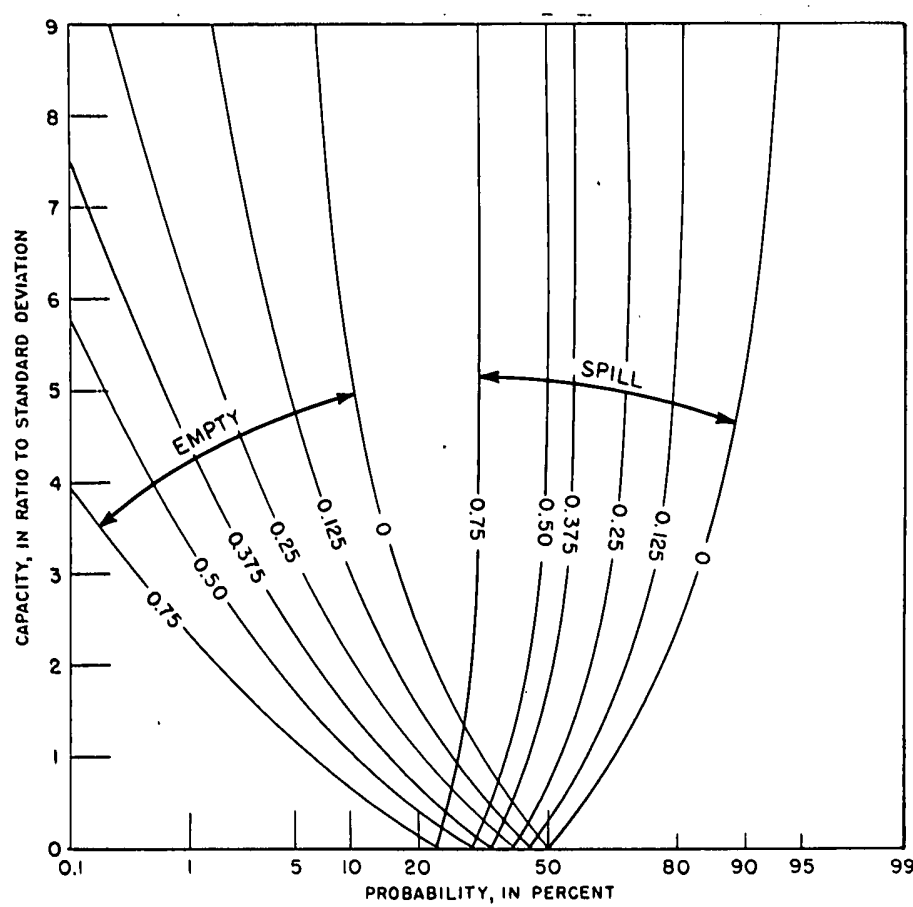

Fraure 298.1.-Probabilities of reservoir being empty or spilling, normal distribution of inflows. dom distribution of inflows and on figure 298.2 for a logarithmic normal distribution of inflows having a coefficient of skew equal to 1.0 .

The same curves can be applied to the case where the reservoir is operated so that discharge does not exceed some rate $B$. In this case, $y=(B-\bar{Q}) / s$ and the "empty" and "spill curves of figures 298.1 and 298.2 are to be interchanged.

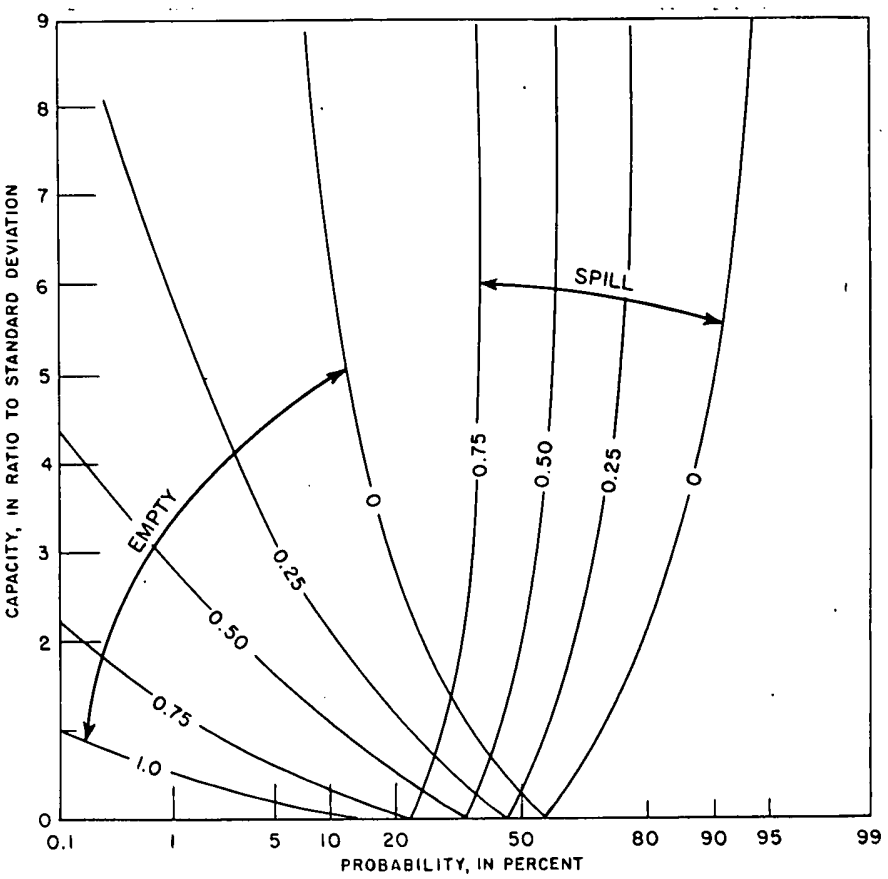

Figure 298.2.-Probabilities of reservoir being empty or spilling, logarithmic distribution of inflows, skewness $=1.0$.

\section{ORIGIN OF REGRESSIVE RIPPLES EXPLAINED IN TERMS OF FLUID-MECHANIC PROCESSES}

By Alan V. Jopling, Washington, D.C.

Work done in cooperation with Harvard University

As defined here, a regressive ripple suite refers to a sequence of asymmetric ripples oriented in the direction opposite to the general movement of current flow. Such ripples should be distinguished from the antidune ripples described by Shrock (1948) and others. Regressive ripples were recorded by $\mathrm{m}^{1}{ }^{1}$ during the course of

Jopling, A. V., 1960, An experimental study on the mechanics of bedding : Unpub. Ph. D. Thesls, Harvard Univ., 358 p. an experimental flume investigation on the mechanics of bedding. The origin of this particular type of structure is related to flow separation (Rouse, 1946, p. 232-234) that occurs when a current expands over a sharp discontinuity (such as a delta front) in a channel floor. Flow separation generates a vortex system in the lee of the discontinuity. For a deltaic transition, a reverse circulation or backflow is directed toward and 
up the foreset slope, and therefore any "normal" ripples developed as bottomset structures in response to reverse circulation are regressive only with respect to the general flow direction.

So far as the writer is aware, naturally occurring regressive ripples in the bottomset deposit of a crossbedded unit have not yet been recorded, although it seems probable that they exist.

For subcritical transitions, and for those supercritical-subcritical transitions in which the Froude number is not much in excess of one, as in most natural streams, the varied flow pattern resembles jet expansion over a finite discontinuity. The hydraulic phenomena in the immediate vicinity of the delta front are those of free-turbulence shear flow, with restrictions imposed by the boundary geometry. The hydraulic geometry and zonal terminology adopted here for the flow transition are diagrammatically illustrated on figure 299.1.

Consideration is given only to a transition characterized by a relatively low concentration of suspended sediment. A high concentration results in a gravity underflow (turbidity current) that moves along the bottomset floor, and the flow pattern assumes an entirely different character.

Based on a jet analogy, the zone of no diffusion (fig. 299.1) may be simply regarded as a vestigial phase of the upstream flow regime extending for a limited distance beyond the lip of the delta. This zone is unaffected by the eddies of lateral mixing that are developed marginal to the expanding "jet," and its velocity distribution is similar to that of the upstream flow (with a progressive, basal "truncation" in the downstream direction).

The region of mixing, on the other hand, is characterized by a rapidly altering distribution of velocity and by strong macro-turbulence activity. Hydraulic parameters such as the locus line of zero velocity and the line of no diffusion, can be designated only in a nominal sense on account of the statistical nature of the mixing processes involved.

The processes of fluid entrainment (resulting from flow expansion) and return flow (necessary to satisfy the continuity relationship) motivate a relatively stable eddy that gyrates in the toe sector of the delta. This is the eddy, already referred to, that is responsible for the development of regressive ripples. A series of measurements in a laboratory flume indicated that the maximum velocity of backflow (reverse circulation) ranged from about $1 / 6$ to $1 / 3$ that of the mean velocity of streamflow upstream from the delta front. The value depends upon the velocity of the flow, and upon the depth-ratio (ratio of depth at the lip to depth at the toe of the delta). For Reynolds numbers less than $3 \times 10^{4}$, and for a deltaic discontinuity with a 30-degree slope and a wide range of depth-ratios, most of the velocity-ratios lay between $1 / 5$ and $1 / 4$.

Theoretical considerations alone, based on a general knowledge of the hydraulic geometry of flow expansion, should suffice, therefore, to explain the occurrence of regressive ripples in a bottomset deposit.

The experimental results from a number of deltabuilding runs demonstrate that 3 types of ripples may develop in the bottomset deposits of a crossbedded unit: (a) progressive ripples that migrate in the downstream direction, (b) regressive ripples that develop within the zone of reverse circulation, and (c) hummocky, nondirectional ripples (current marks) that represent a transitional phase between (a) and (b).

The progressive ripples are "normal" current ripples that are directed downstream beyond the zone of reverse circulation. There is nothing unusual about their occurrence. However, as the delta front and the zone of backflow advance, the progressive ripples are changed-either partly or fully-into regressive ripples. Hummocky, nondirectional ripples result if the transformation is incomplete.

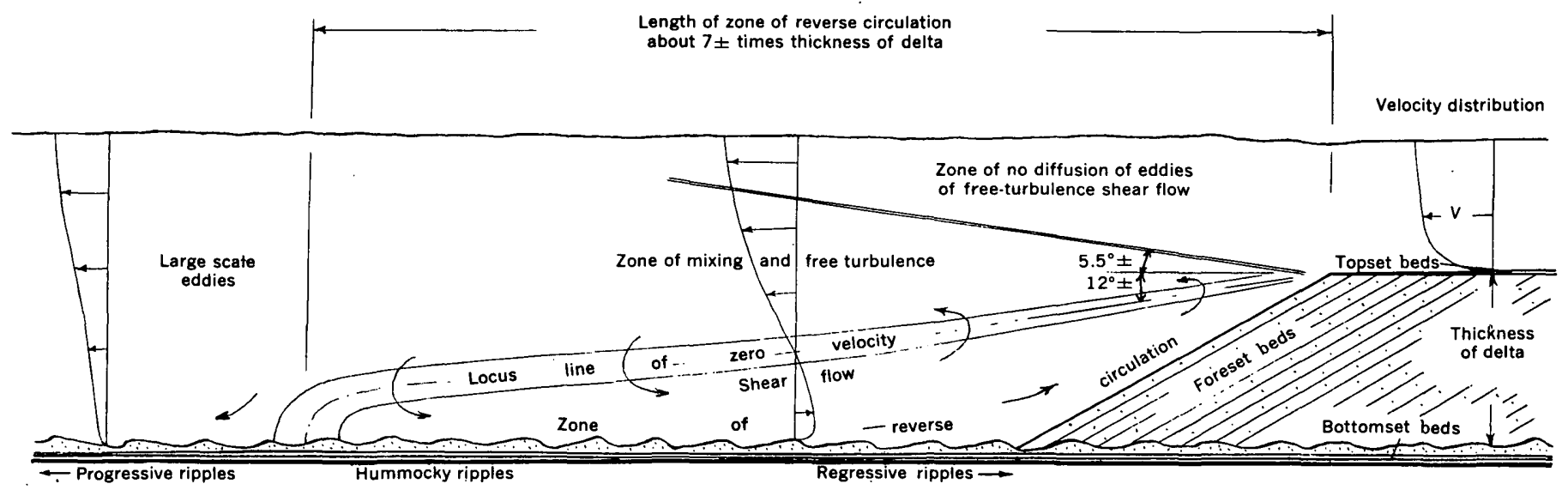

Frgure 299.1.-Schematic representation of zonal terminology for a flow transition over a delta front. 
The hummocky type of ripple characteristically forms near the diffuse termination of the zone of reverse circulation. Whether the transformation to regressive ripples is completed will depend on the velocity of the backflow, the intensity of turbulence in. the locale of the delta front, and the relative rates of foreset and bottomset deposition. Therefore, the ripples at the delta toe may be either regressive or hummocky.

The question arises concerning the probability of the burial and preservation of regressive and hummocky ripples as integral bottomset structures underlying the deltaic foresets. Flume observations demonstrated that the essential ripple-geometry could be preserved in spite of the periodic impact of slumping foreset detritus. In several delta-building runs involving the deposition of angular crossbeds, the only observable effect caused by slump was a slight to moderate distortion or puckering of the bottomset ripples, and, for the tangential type of unit, the evidence indicated that the ripples could be completely preserved.

The occurrence of regressive ripples in experimental models suggests that eventually they will be found in nature. The juxtaposition of regressively rippled bot- tomsets and deltaic foresets could conceivably pose a perplexing problem in the interpretation of paleocurrent directions. If ripple orientation were used as a diagnostic index, the conventional interpretation of current direction would be 180 degrees in error. Furthermore, the preservation of hummocky ripples could also pose an enigmatic problem in field analysis.

If regressive ripples were recognizable in a field occurrence of crossbedding, it should be possible to estimate the strength of the original current, on the assumption that the ratio of the velocity of backflow to that of the stream is roughly $1: 4$. The minimum velocity for the initiation of ripples in sandy sediments generally lies somewhere in the range $1 / 2$ to 1 foot per second, and therefore the occurrence of regressive ripples in a crossbedded sandstone unit would suggest a stream velocity of not less than 2 feet per second. The structure, therefore, may serve as a subordinate criterion in studies of environmental interpretation.

\section{REFERENCES}

Rouse, Hunter, 1946, Elementary mechanics of fluids: New York, John Wiley and Sons, $376 \mathrm{p}$.

Shrock, R. R., 1948, Sequence in layered rocks: New York, McGraẁ-Hill Book Co., 507 p.

\title{
300. THE SIGNIFICANCE OF THE FALL VELOCITY AND EFFECTIVE FALL DIAMETER OF BED MATERIALS
}

\author{
By William L. Haushimd, Daryl B. Simons, and Everett V. Richardson, Fort Collins, Colo.
}

Particle-size distribution of bed materials based upon the fall velocity of the particles will vary with the characteristics of the fluid. Results of size analyses conducted in the visual-accumulation tube for a sample of the Elkhorn River, Nebr., sand in distilled water and in 1,5 , and 10 percent by weight bentonite in distilled water are shown on figure 300.1. The distribution in distilled water is in terms of fall diameters obtained directly from the standard fall velocity; fall diameter and standard fall velocity are defined in a report of the United States Inter-Agency Committee on Water Resources (1957). The distributions in the bentonitewater dispersions are described in terms of an effective fall diameter (effective size). The effective fall diameter of a particle for a given sedimentation medium and temperature is the diameter of a quartz sphere whose standard fall velocity equals the average terminal fall velocity of a particle when it falls alone in an infinite extent of the medium at the given temperature.
The influence of effective size of particles on the mechanics of flow in alluvial channels was studied in flume experiments by changing the fall velocities of bed materials through variation of the sedimentation medium, and by using bed materials of different sizes and specific gravities. The sedimentation medium was changed by adding fine sediment (bentonite) to the flow, and by varying the temperature of clear water (Hubbell and Ali, Art. 301). Changes in the effective sizes of particle were found to change the forms of bed roughness, resistance to flow, and sediment transport.

For the fine-sediment study, the bed material used in the flumes was natural sand with median fall diameters of $0.54 \mathrm{~mm}$ and $0.47 \mathrm{~mm}$, and the fall velocity and effective fall diameter of the bed-material particles were decreased by the addition of bentonite as the fine sediment. The forms of bed roughness, resistance to flow in terms of a dimensionless form of Chezy's coefficient 


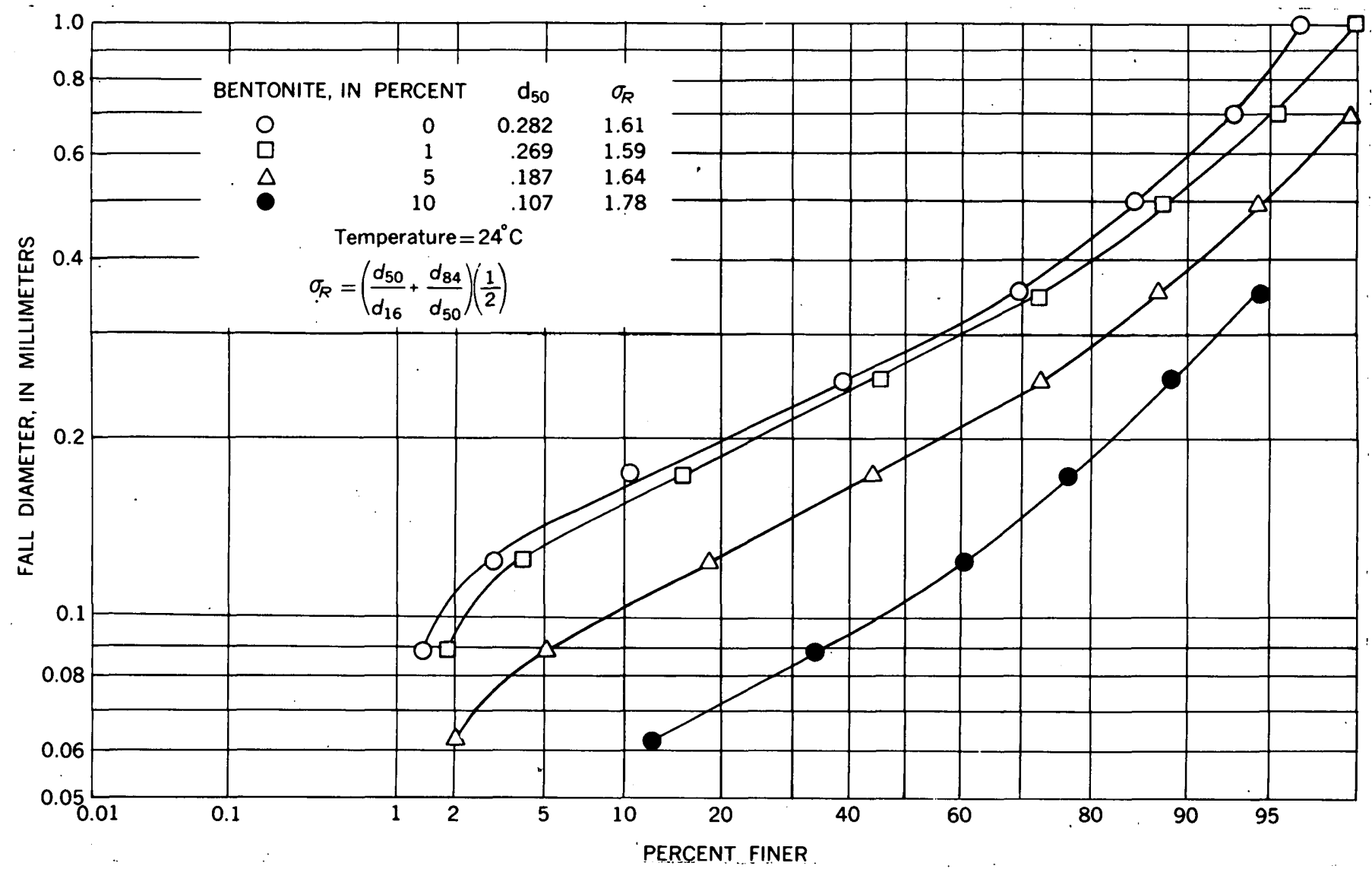

FIgure 300.1.-The particle size distribution of an Elkhorn River, Nebr., sand sample based on its fall velocity in various concentrations of bentonite dispersed in distilled water. (Analyzed in the visual-accumulation tube.)

of discharge, $C / \sqrt{g}$, and concentrations of the total bed-material transport are given in table 300.1 for the water-sand flow with bentonite and without bentonite.

When sufficient bentonite was added to the watersand mixture the resistance to flow and the total bedmaterial in transport decreased in the lower flow regime with ripples and dunes and increased in the upper flow regime with standing waves and antidunes. (See Art. 165.) The addition of bentonite changed the transition dunes to a plane bed and the flow changed from the lower to the upper regime. Also, the form of bed, resistance to flow, and bed material in transport for the water-sand flow with bentonite and a coarse bed material were similar to those developed in flume experiments using water and finer bed materials. Comparison with experiments in an 8-foot-wide flume (Simons and Richardson, 1960) shows that the median fall diameter of this finer bed material for similarity of flow and transport phenomena would be the same as the effective median fall diameter of the coarser bed material in the water-bentonite dispersion.

The use of the effective size or actual fall velocity of the bed material leads to a more thorough understand- ing and explanation of phenomena that occur in natural streams, including seasonal variations. At a nearly constant discharge, a change occurs in bed form, resistance to flow, and sediment transport between summer and winter flows in the Loup Rivers of Nebraska (Hubbell, 1960). The fall velocity and, therefore, effective size decreases with the decreasing water temperatures during the autumn and winter because viscosity increases with decreased temperature. The form of bed roughness changes during the winter to conform with the smaller effective size, and, therefore, the resistance to flow decreases and the amount of bed material in transport increases.

The fall velocity and the effective fall diameter of sediment particles decrease with increase in the viscosity of the liquid. In natural streams viscosity is increased by increase in the load of fine sediment, or by decrease in temperature. The apparent viscosity of aqueous dispersions of fine sediments depends, therefore, mainly on concentration, temperature, composition and structure of the clays, state of flocculation and neutralization--but it is complicated by many other factors. (See Bingham, 1922; Hermans, 1953; Street, 1958; and 
TABLE 300.1.-The effect of concentration of bentonite on form of bed roughness, resistance to flow, and total bed-material transport in flume studies

\begin{tabular}{|c|c|c|c|}
\hline $\begin{array}{l}\text { Flow regime and concentra- } \\
\text { tion of bentonite in the } \\
\text { water-send flow (parts } \\
\text { per mlllion) }\end{array}$ & $\begin{array}{l}\text { Form of bed } \\
\text { roughness }\end{array}$ & $\begin{array}{l}\text { Resistance } \\
\text { to flow } \\
(C / \sqrt{g})\end{array}$ & $\begin{array}{l}\text { Concentration } \\
\text { of total } \\
\text { bed-material } \\
\text { discharge } \\
\text { (parts per } \\
\text { million) }\end{array}$ \\
\hline Lower regime: & & & \\
\hline Without bentonite & Ripples_... & 10. 4 & 12 \\
\hline $4,800 \mathrm{ppm}$ bentonite & Rounded ripples_. & 14.4 & 2 \\
\hline Lower regime: & & & \\
\hline Without bentonite... & Dunes.... & 8. 5 & 1,020 \\
\hline $\begin{array}{l}63,700 \mathrm{ppm} \text { ben- } \\
\text { tonite. }\end{array}$ & $\begin{array}{l}\text { Rounded sand } \\
\text { waves. }\end{array}$ & 12.4 & 521 \\
\hline Transition: & & & \\
\hline Without bentonite... & & 8. 1 & 1,700 \\
\hline $\begin{array}{l}44,100 \mathrm{ppm} \text { ben- } \\
\text { tonite. }\end{array}$ & Plane ...... & 12. 7 & 2,960 \\
\hline $\begin{array}{l}\text { Upper regime: } \\
\text { Without bentonite.-- }\end{array}$ & Standing waves_ & 15. 7 & 3,330 \\
\hline $\begin{array}{l}58,700 \mathrm{ppm} \text { ben- } \\
\text { tonite. }\end{array}$ & Antidunes . . . . . & 12.3 & 22,300 \\
\hline $\begin{array}{l}\text { Upper regime: } \\
\text { Without bentonite...- }\end{array}$ & Antidunes & 12.5 & 9,180 \\
\hline $\begin{array}{l}51,900 \text { ppm ben- } \\
\text { tonite. }\end{array}$ & $\begin{array}{l}\text { Violent anti- } \\
\text { dunes. }\end{array}$ & 9. 0 & 50,000 \\
\hline
\end{tabular}

Wood, Granquist, and Krieger, 1955.) The apparent viscosity of $0.5-, 1-, 2-, 3-, 5-$, and 10-percent bentonite and 3-, 5-, and 10-percent kaolin (by weight) dispersions in water were measured with a Stormer Viscosimeter. At a temperature of $20^{\circ} \mathrm{C}$, the viscosity of a 5 -percent (by weight) aqueous dispersion of bentonite is about 2.5 times greater than that of distilled water and a 5-percent dispersion of kaolin is about 1.5 times more viscous than distilled water.

The visual-accumulation tube for the direct determination of the effective fall-diameter distribution was used in a number of tests. Test conditions were controlled so that the settling velocities of the three sand samples depended only on the characteristics of the sedimentation medium, which were varied by using different concentrations of aqueous dispersions of bentonite or kaolin. The variation of median effective fall diameter as determined from these tests is shown on figures 300.2 and 300.3 .

Also shown on figures 300.2 and 300.3 are the effective median fall diameters computed from the fall velocities by use of the empirical relation between the drag coefficient and the Reynolds number given in a report of the United States Inter-Agency Committee on Water Resources (1957, fig. 1). The agreement between the computed and the measured effective median fall diameters indicates that the size distributions obtained in the visual-accumulation tube closely approximated the true effective fall diameter distributions.

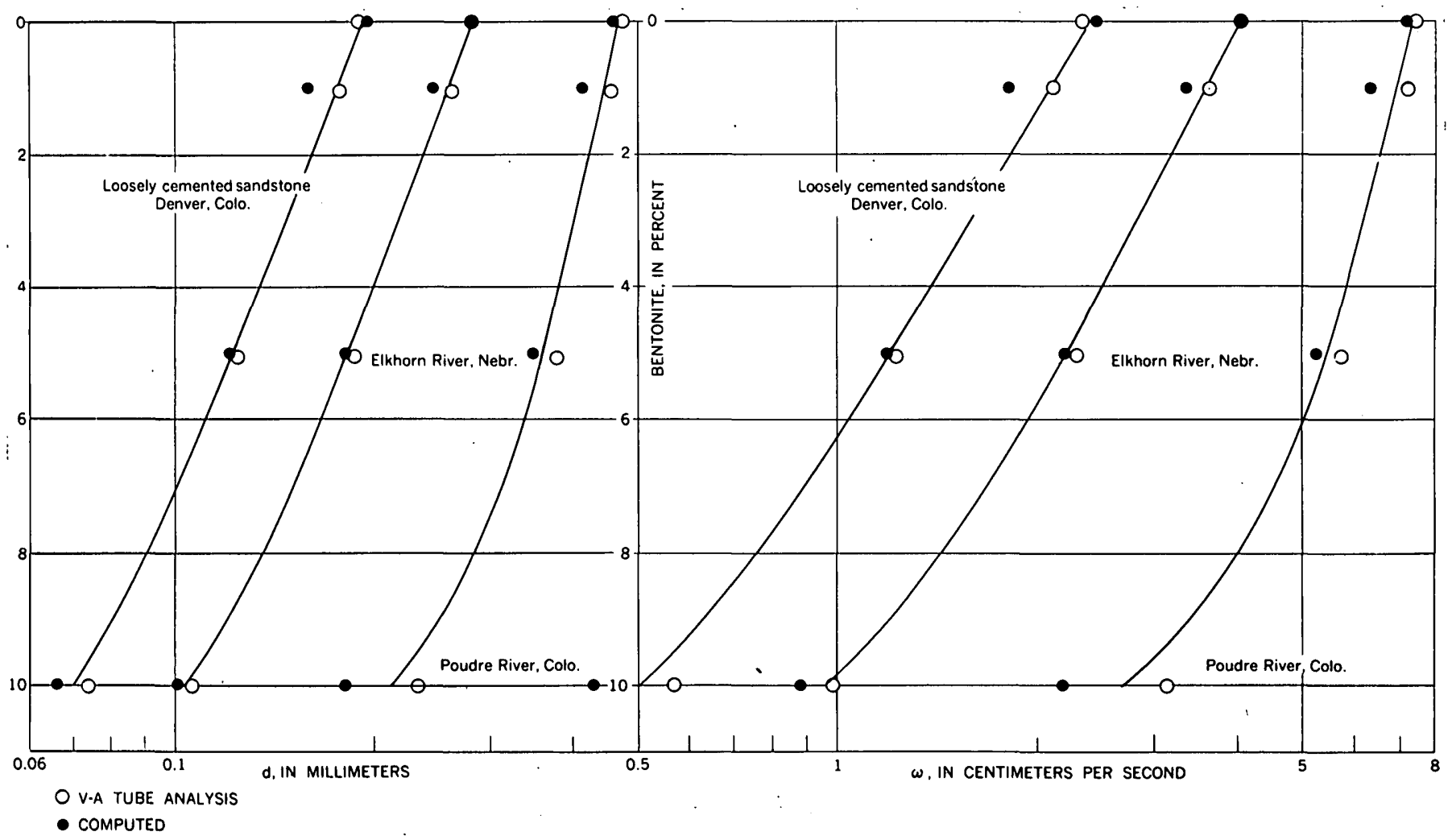

Figure 300.2.-Variation of effective fall diameter and fall velocity with change in percent of bentonite in water. 


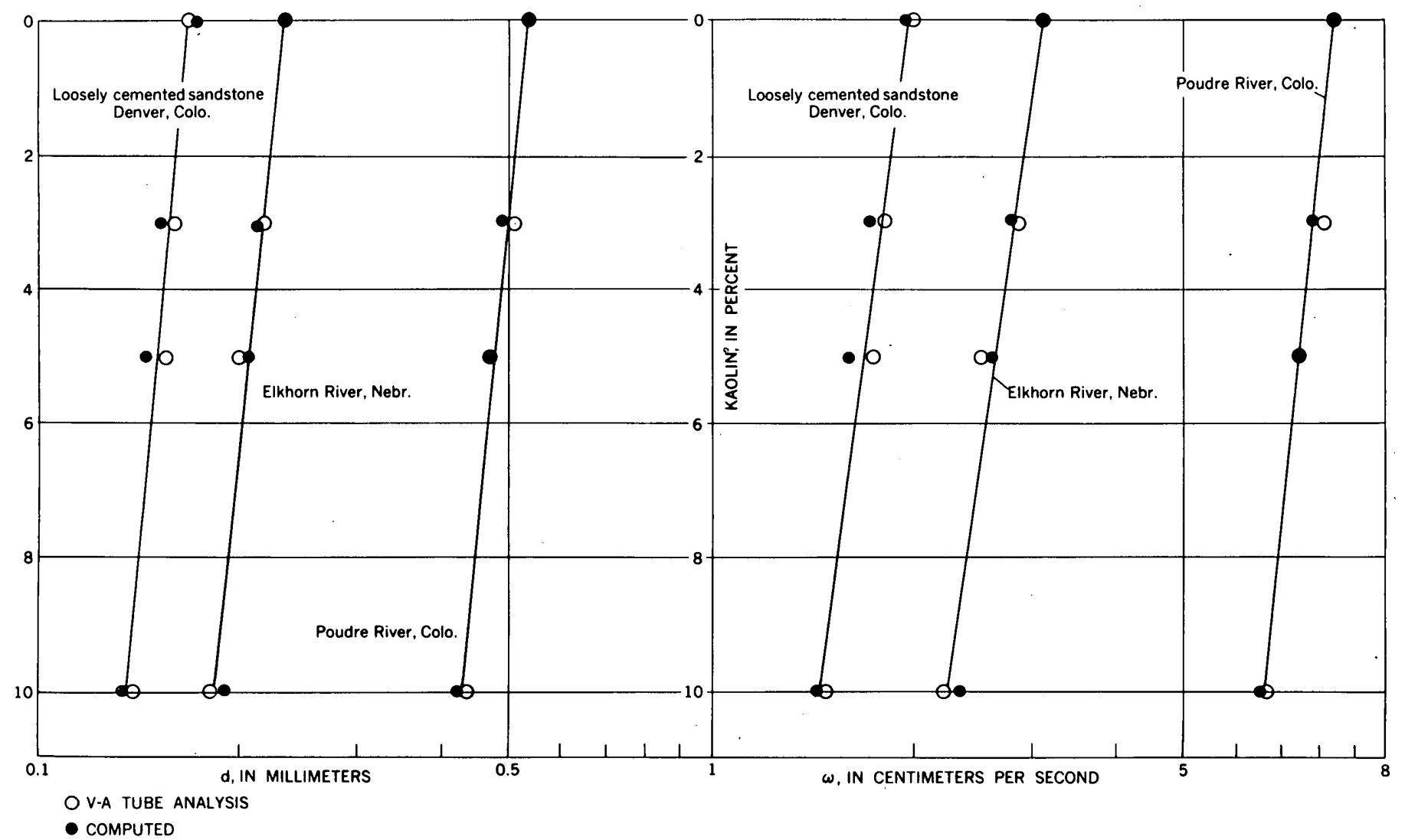

FIgURE 300.3.-Variation of effective fall diameter and fall velocity with change in percent of kaolin in water.

The influence of temperature on effective fall diameter in distilled water can be determined from the information given in the above-mentioned report. Preliminary results indicate that the particle-size distribution of light-weight bed materials in terms of effective fall diameters can be obtained directly from analyses made in the visual-accumulation tube.

\section{REFERENCES}

Bingham, E. C., 1922, Fluidity and plasticity: New York, McGraw Hill.

Hermans, J. J., 1953, Flow properties of disperse systems : New York, Inter-Science Pub., Inc.
Hubbell, D. W., 1960, Investigations of some sedimentation characteristics of sand-bed streams-Prog. Rept. No. 2: U.S. Geol. Survey open-file rept., p. 21-36.

Simons, D. B., and Richärdson, E. V., 1961, Forms of bed roughness in alluvial channels: Am. Soc. Civil Engineers Jour., v. 87, no. 3, p. 87-105.

Street, Norman, 1958, Viscosity of clay suspensions : World Oil, v. 147, p. 151-156.

United States Inter-Agency Committee on Water Resources, 1957, Some fundamentals of particle-size analysis-a study of methods used in measurement and analysis of sediment loads in streams : Rept. 12, $55 \mathrm{p}$.

Wood, W. H., Granquist, W. T., and Krieger, I. M., 1955, Viscosity studies on dilute clay mineral suspensions: Natl. Acad. Sci. Natl. Research Council, Pub. 456, p. 240-250. 


\title{
301. QUALITATIVE EFFECTS OF TEMPERATURE ON FLOW PHENOMENA IN ALLUVIAL CHANNELS
}

\author{
By D. W. Hubbell and Khalid Al-Shaikh Alr, Fort Collins, Colo.
}

Laboratory and field investigations have shown that flow phenomena can change significantly when the water temperature changes. Lane and others (1949) reported that for comparable mean daily discharges in the Colorado River, daily suspended-bed-material discharges are from two to three times greater in the winter than they are in the summer. Straub (1954) found similar increases in the Missouri River. Studies on the Middle Loup River (Hubbell and others, 1956) indicated that total bed-material discharges as measured at a turbulence flume, as well as suspended-bedmaterial discharges, are greater at low water temperatures than they are at high temperatures, and that flow resistance is the least at low temperatures. However, in laboratory studies, Ho (1939) found that total bedmaterial discharges increase as the water temperature increases, and M. G. Mostafa (written communication, 1949) concluded that a fluid having a high viscosity would in most cases transport a lower total bed-material discharge than a fluid having a low viscosity; in other words, an increase in water temperature should usually increase the total bed-material discharge.

Because of the contrary findings, a laboratory study was undertaken to examine temperature effects throughout a wide range of flow conditions. The study was conducted in a recirculation-type flume that is 2 feet wide and 60 feet long. Temperature of the watersediment mixture was controlled by adding either steam or cold water to the system. The bed material used in the study was sand from the bed of the Elkhorn River near Waterloo, Nebr.; its median fall diameter (U.S. Inter-Agency Committee on Water Resources, 1957) was $0.31 \mathrm{~mm}$. Runs for a range of flow conditions, from plane bed and no sediment movement to violent antidunes ${ }^{1}$, were made in pairs in which temperature was the only variable purposely changed. The depth of flow in the initial run of each pair was set at about 0.55 feet.

Figure 301.1 shows the differences in concentration of the total bed-material discharge, flow resistance, and bed form that occurred between the runs in each pair. In general, when the bed form was ripples or dunes with superposed ripples, the concentration of the total bed-material discharge was greatest in the high tem-

1 Simons and Richardson (1961) have described each of the various hed forms and their attendant characteristics within this range. Only the stunding wave form of bed roughness was not investigated in this study. perature run; when the bed form was dunes or plane bed, no general trend was apparent; and when the bed form was antidunes, the concentration of the total bedmaterial discharge was greatest in the low temperature run.

The concept of the change in "effective size" with temperature, and the changes in the concentration of total bed-material discharge and the flow resistance with shear provide the basis for an explanation of the effect of temperature changes on flow phenomena.

Experiments with different bed materials (D. B. Simons and E. V. Richardson, oral communication, 1960) have shown that the size of the bed material; as characterized by the median fall diameter, affects flow phenomena. Because the fall diameter is determined from fall velocity, the variations in flow phenomena that occur with different fall diameters actually reflect the effects of the fall velocity of the bed material. To illustrate this point, Haushild and others (Art. 300) in a flume experiment with a water-bentonite mixture and a bed of coarse material showed that the bed forms, flow resistance, and concentration of total bed-material discharge were similar to those developed in a flume experiment with clear water and a finer bed material. In order to express with a linear dimension the equivalency between particles having the same fall velocity, they used the term "effective fall diameter" ". By definition, whenever the viscosity of the stream liquid changes because of a temperature change, the effective median fall diameter changes. Also, two particles with different characteristics will have the same effective fall diameter if, when they fall in different liquids, their fall velocities are the same.

For a given bed material, channel shape, viscosity, and depth, flume experiments have shown that the concentration of total bed-material discharge and flow resistance vary with shear on the bed. If any of these factors change, the relations between concentration of bed material in transport and shear and flow resistance and shear change. Figure 301.2 shows concentrationshear relations for two different bed materials having median diameters of 0.28 and $0.45 \mathrm{~mm}$. The curve for the $0.28-\mathrm{mm}$ bed material is based on data collected by Simons and Richardson. (1961) in an 8-foot-wide flume;

\footnotetext{
The effective fall diameter of a particle is the diameter of a quartz sphere whose standard fall velocity equals the velocity of the particle when it falls alone in quiescent stream fluid of infinite extent and at the stream temperature.
} 


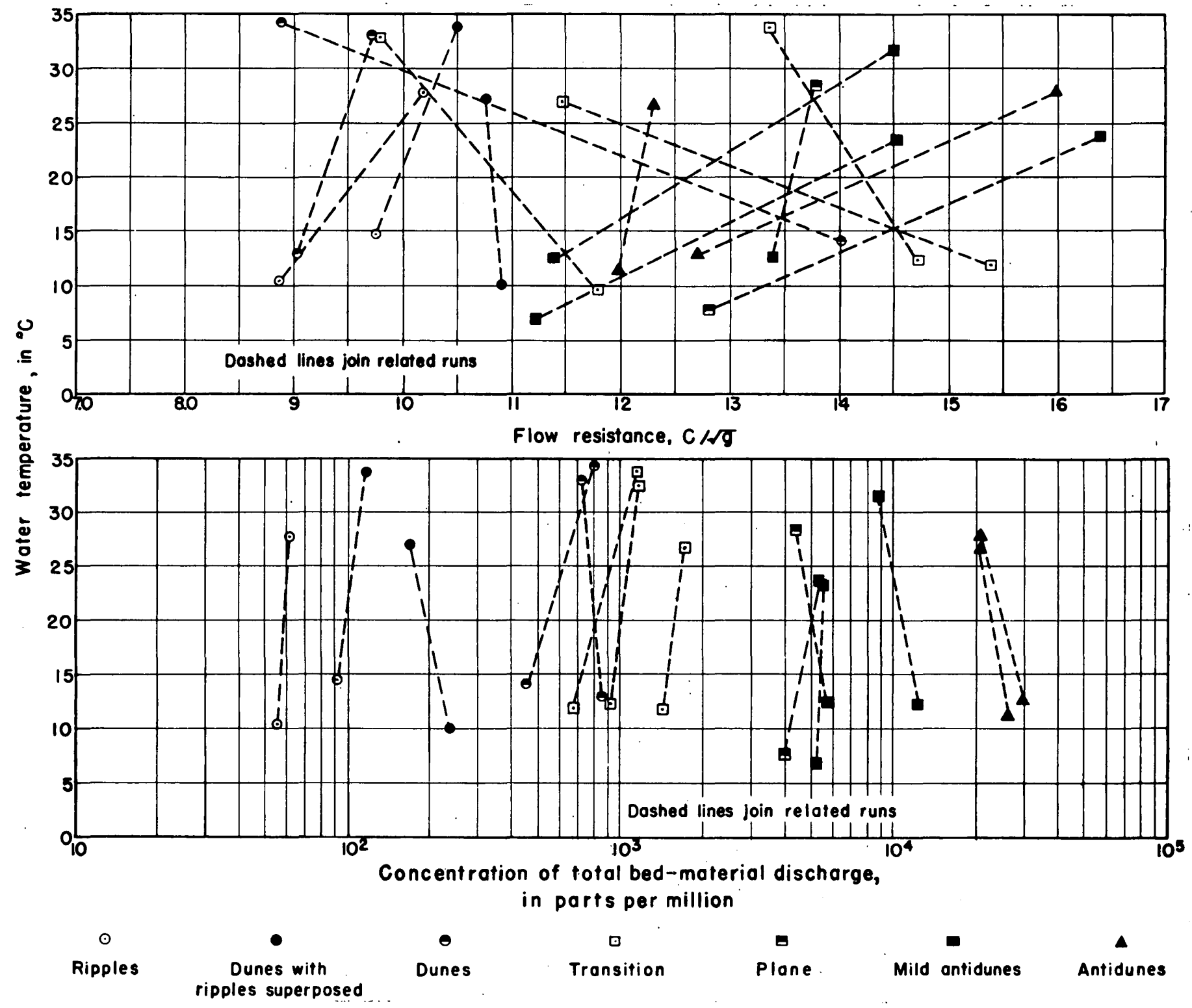

Frgure 301.1.-Change in flow resistance and concentration of the total bed-material discharge with temperature for each pair of flume runs.

the curve for the $0.45-\mathrm{mm}$ bed material is based on data collected in the same flume (Simons, Richardson, and Albertson, 1961). Both curves are defined for a depth range of 0.5 to 0.7 foot and a relatively narrow temperature range.

The implication of the effective-size and concentration-shear relations is that if the properties of the water change through a temperature change, the effective median fall diameter changes and the stream adjusts to new concentration-shear and flow resistance-shear relations. In the adjustment, the shear, the total concentration, the flow resistance, the bed form, and sometimes the flow regime change until an equilibrium is reached in which the mutual associations of all variables satisfy final concentration-shear and flow resistance-shear relations. For example, consider that in a flume experiment the initial conditions are such that the median fall diameter of the bed material is $0.36 \mathrm{~mm}$. Assume that when the water temperature is increased to $70^{\circ} \mathrm{C}$ (an extreme case) and the effective median fall diameter of the bed material changes to $0.45 \mathrm{~mm}$, the concentration-shear relation becomes that given on figure 301.2, in which value " $a$ " represents the shear. If the temperature is decreased to $0^{\circ} \mathrm{C}$, the effective median fall diameter would be reduced to $0.28 \mathrm{~mm}$ and if the slope decreased slightly because of the change, the shear would decrease slightly, say to value " $b$ ", and the concentration would decrease from 240 to $64 \mathrm{ppm}$. Or, if 


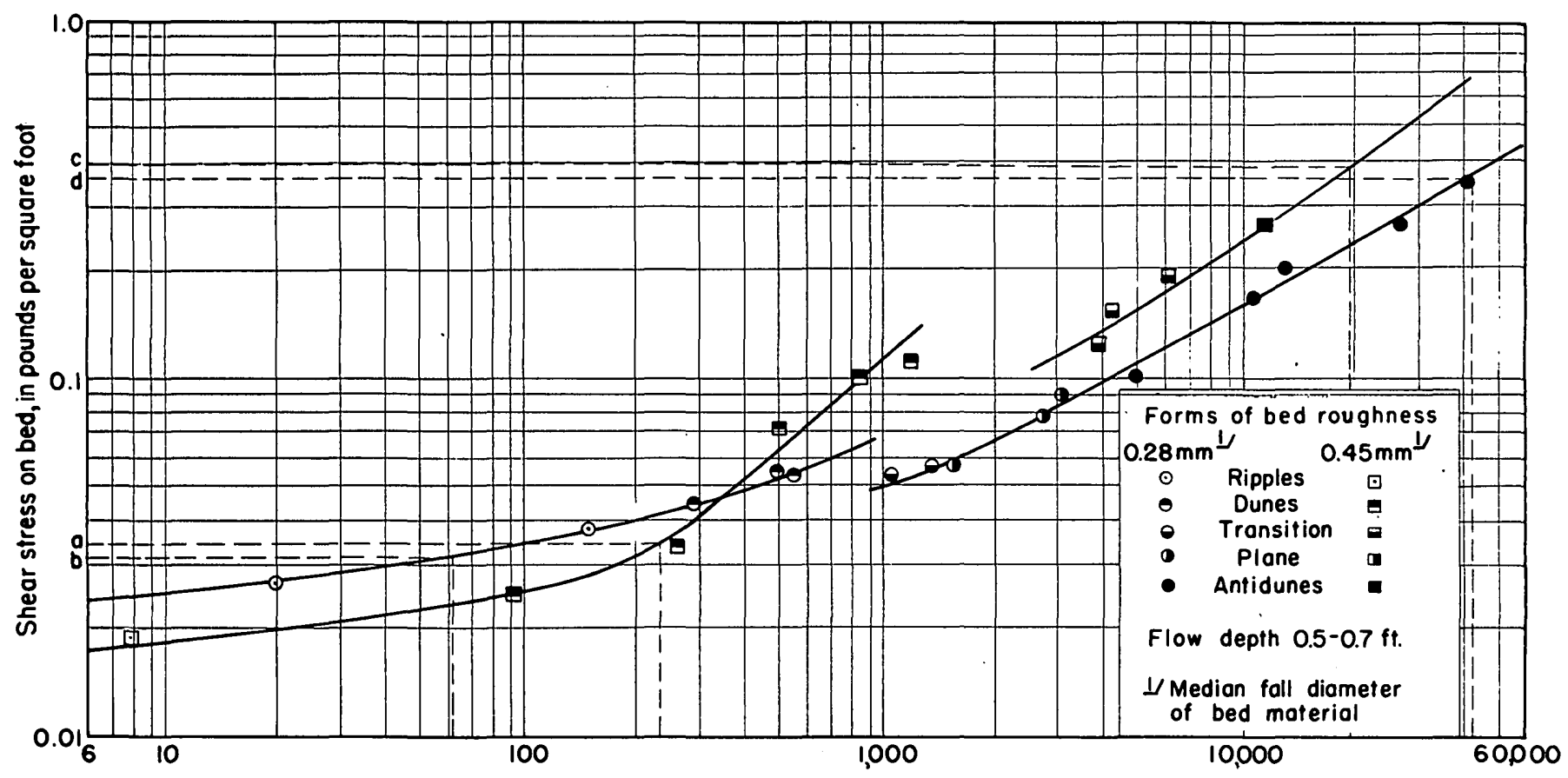

Concentration of total bed-material discharge, in parts per million

Fraure 301.2.- Relation between bed shear and concentration of total bed-material discharge in an 8-foot-wide flume for relatively constant water temperature and depth.

the shear at the hot-water temperature is given by " $c$ " and the change in slope when the temperature is decreased to $0^{\circ} \mathrm{C}$ causes a decrease in shear to " $d$ ", the concentration would increase from 20,000 to $43,000 \mathrm{ppm}$. However, if the depth also changed with the decrease in temperature, the changes in concentration could not be predicted because alterations in the other variables would cause an adjustment to a new, undefined, concentration-shear relation.

\section{REFERENCES}

Ho, Pang-Yung, 1939, Abhanglgkeit der geschiebebewegung von der kornform und der temperatur (Dependence of bed-load movement on the grain shape and the temperature) : Mittellungen der Preussischen Versuchsanstalt fur Wasser-, Erd-, und Schiffbau, Berlin, v. 37.

Hubbell, D. W., and others, 1956, Progress report number 1,
Investigations of some sedimentation characteristics of a sand-bed stream : U.S. Geol. Survey open-file report, $78 \mathrm{p}$.

Lane, E. W., Carlson, E. J., and Hanson, O. S., 1949, Low temperature increases sediment transportation in Colorado River: Givil Fng., v. 19, p. 619-620.

Simons, D. B., and Richardson, E. V., 1961, Forms of bed roughness in alluvial channels: Am. Soc. Civil Engineers Jour. v. 87 , no. 3, p. $87-105$.

Simons, D. B., Richairdson, E. V., and Albertson, M. L., 1961, Flume studies using medium sand $(0.45 \mathrm{~mm})$ : U.S. Geol. Survey Water-Supply Paper 1498-A, 76 p.

Straub, L. G., 1954, Terminal report on transportation characteristics of Missouri River sediment: University of Minnesota, Missouri River Div. of Corps of Engineers, U. S. Army, M.R.D. Sediment Series no. 4, 53 p.

U.S. Inter-Agency Committee on Water Resources, 1957, A study of methods used in measurement and analysis of sediment loads in streams; some fundamentals of particle size analysis : Rept. 12, 55 p. 


\section{DISPERSION-MOTIVATED FLUCTUATIONS OF GROUND-WATER LEVELS IN WELLS}

By F. A. Коношт, Miami, Fla.

Work done in cooperation with Dade County, Florida

There are many generally known causes of fluctuation of ground-water levels. Some of the more common are recharge by rainfall, pumping, tidal action, earthquakes, evapotranspiration, and changes in atmospheric pressure. In areas of salt-water contamination, fluctuations of water level may be caused, also, by dispersion phenomena in the casing of wells that tap the zone of diffusion between fresh and salt water (fig. 302.1). Generally, the cause of water-level fluctuations of this kind is obscure in that the fluctuations are related directly not only to changes in ground-water potential, but also to the density of water in the observation well. Thus, careful interpretation is required to insure that water-level measurements are meaningful. The purpose of this paper is to illustrate how dispersion may cause a change of water level in a well.

\section{FLUCTUATION INDUCED BY PUMPING}

In the course of routine water sampling, certain wells in the Miami area, Florida, appeared to have residual water-level drawdowns of several tenths of a foot after being pumped. Owing to the high permeability of the Biscayne aquifer in the Miami area $(50,000$ to 70,000 gallons per day per square foot) residual drawdowns of this magnitude are not expected as the result of pumping for short periods at low rates. In wells

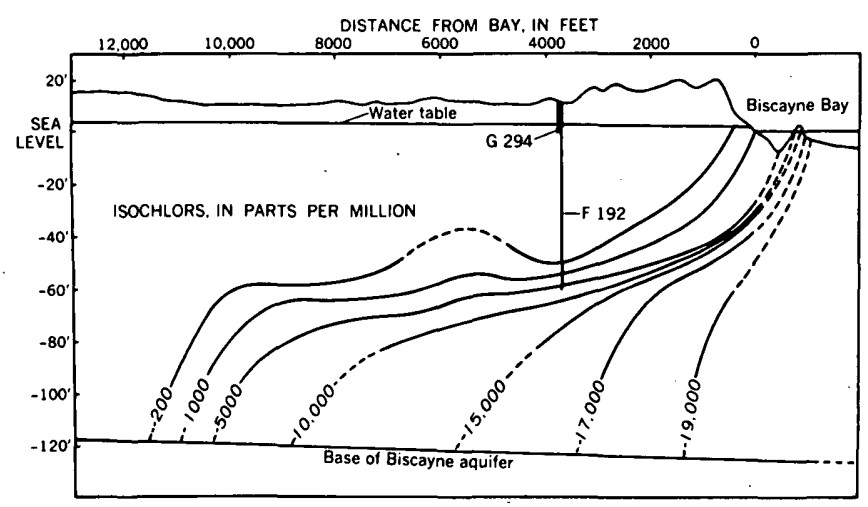

Fraure 302.1.-Cross section through the Silver Bluff area, Miami, Fla., showing the zone of diffusion, November 2, 1953. equipped with continuous water-level recorders no recovery from pumping levels occurred (fig. 302.2). After repeated pumpings (each one producing a similar drawdown), no persistent decline of water level relative to other wells was detected.

The reason for the drawdown and lack of recovery is apparent in figure 302.3 in which the water levels of wells F198 and F192 are plotted against the chloride concentration of water in the casing of well F198. Well F192 is a short distance from well F198 and is used to determine the regional fluctuations of water level. Before well F198 was pumped on March 12, its water level was 0.21 foot higher than that in well F192. After pumping stopped, the chloride content (and consequently the density) of water in the casing of well $\mathrm{F} 198$ had increased to $7,950 \mathrm{ppm}$ (parts per million) and the water level was 0.16 foot lower than that of well F192. During the afternoon of March 12 and on March 13 and 14, the water in the casing fresh-
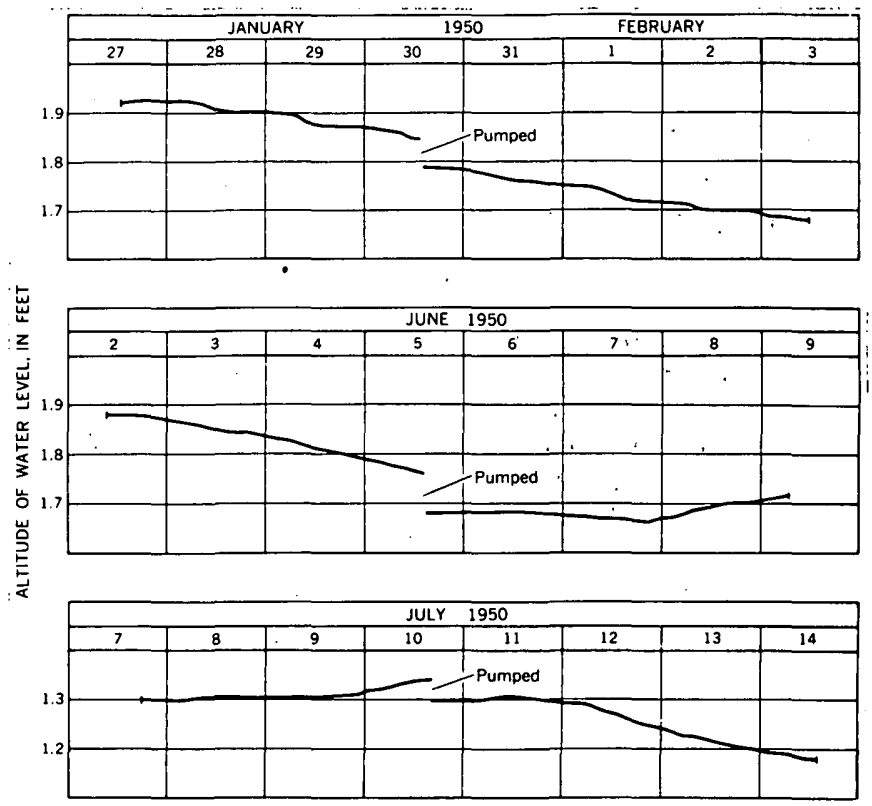

FigURE 302.2.-Hydrographs showing residual drawdown of water level caused by dispersion after pumping well G580. 


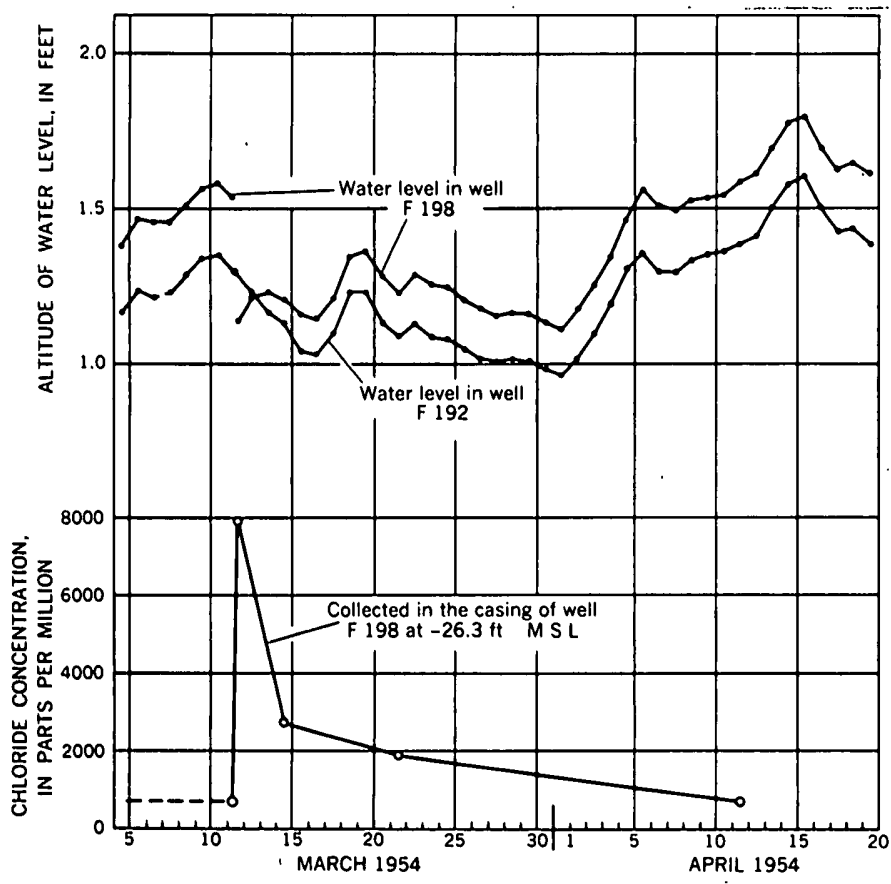

Frouke 302.3.-Density of water, drawdown, and recovery of water levels in well F198.

ened so rapidly that the daily-average water level rose in opposition to the regional decline in water level, as shown by the hydrograph of well F192. Subsequently, the hydrographs of the two wells gradually diverged as the chloride content of the water in well F198 decreased to its pre-pumping concentration.

This test clearly shows that the water level of a well fluctuates as a result of dispersion-motivated changes in the density of the water. In most wells, the recovory of water level resulting from dispersion is imperceptible from water-stage data and can be detected only by comparison with water levels in companion wells or by continuously monitoring the density of water in the well. This emphasizes that in studies of aquifers containing water of highly variable quality, considerable care must be taken to assure that observed water-level fluctuations truly represent changes in ground-water potential.

\section{WATER-LEVEL FLUCTUATIONS UNDER NATURAL CONDITIONS}

The dispersion rate shown in the test on well F198 was considered to be of significance to analysis of waterstage data, and it directed attention to whether the upward rate of dispersion in the well was as great as the downward rate. A test was devised to observe the relative rates of dispersion with and against the pull of gravity. The test consisted of collecting water samples in and below the casing of well F192 and comparing the water level of well F192 with that of another well that was not affected by the change in density. It was expected that a rapid freshening of the water in the casing would occur when the salt-water front (fig. 302.1) was pushed seaward by the high water-table conditions during the rainy season. The dispersion in this case would be downward, aided by gravity. As the water table declined below a certain critical altitude the salt-front movement would reverse, and the chloride concentration of water in the aquifer below the bottom of the casing would increase to a higher value than that of water in the casing. The dispersion in this case would oppose gravity.

On figure 302.4 (p. D-26), the changes in chloride concentration of water in and below the casing of well F192 are compared with the difference in water level between wells F192 and G294. Since well G294 is a shallow fresh-water well at the same location as F192, changes in its water level reflect true changes in groundwater potential and may be used for comparison. The difference in water level between the two wells, then, shows the fluctuation of water level caused by dispersion of salt water in the casing of well F192.

The high water levels of late September and October 1953 produced a sharp decrease in chloride content at the 60.7-foot depth in well F192. The decrease in chloride content at the 46.7-foot depth (in the casing) lagged only slightly behind. In comparison, the difference in water level between wells F192 and G294 decreased in direct relation to the freshening of the water in the casing of well F192.

Between December 1953 and May 1954, the chloride concentration below the casing gradually increased approximately $4,000 \mathrm{ppm}$; during the same period, the chloride content of the water in the casing increased less than $300 \mathrm{ppm}$. The upward rate of dispersion in the casing of well F192 apparently was much slower than the downward rate. However, the water-level difference between the wells increased in relation to the increase in chloride content of the water in the casing. This is shown by the upward trend of the difference curve from January to May 1954, before rainfall started another cycle. 'Thus, under completely natural conditions, the water level in a salty well may fluctuate by a dispersion mechanism that is not entirely dependent on changes in ground-water potentials. 

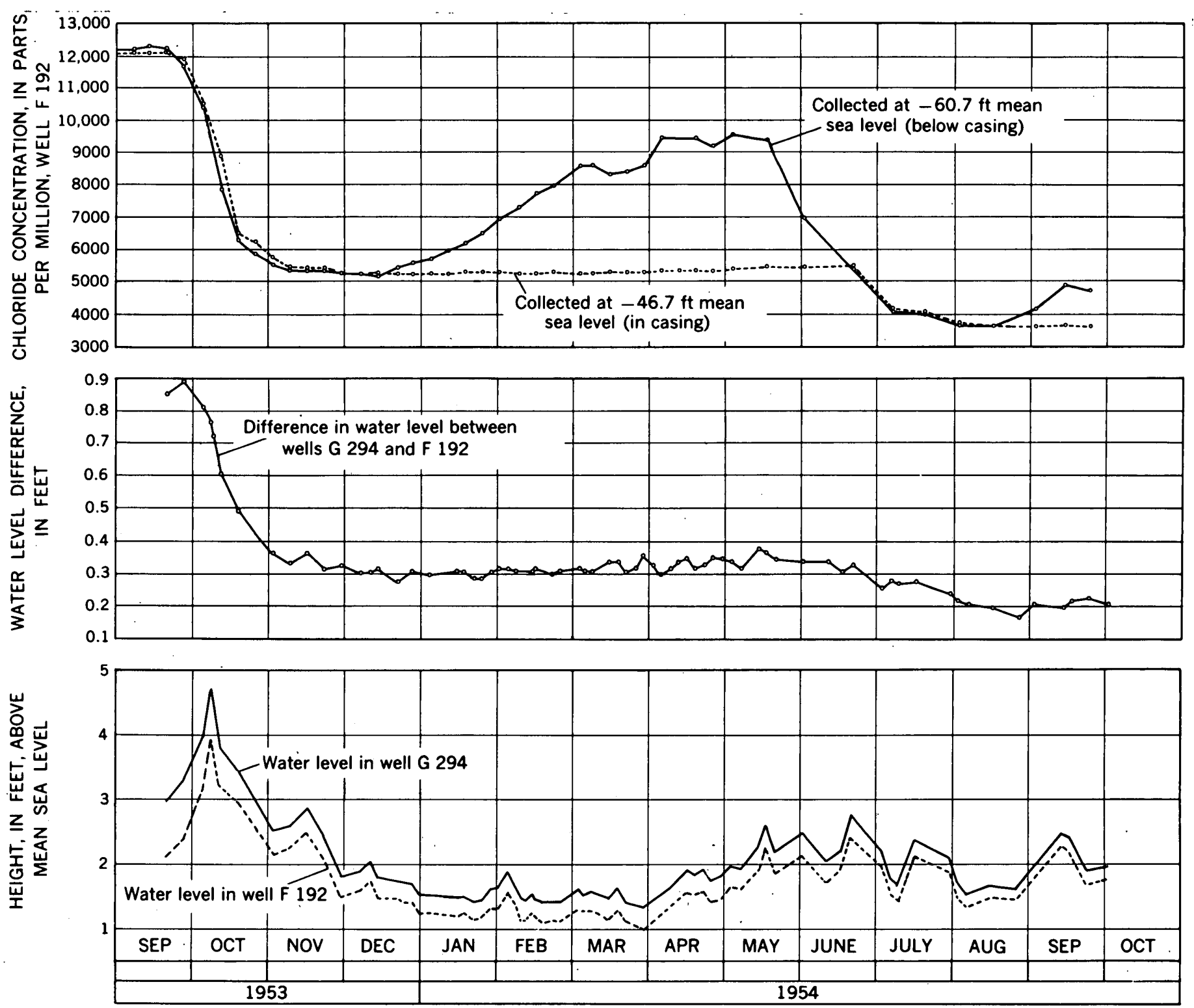

FIGURE 302.4.-Fluctuations of water level due to dispersion in well F192 for natural conditions.

303. DISPERSION WITH OSCILLATING FLOW IN A GRANULAR MATERIAL

By Wiluis K. Kulp, Denver, Colo.

To explain the discrepancy between observed and calculated intrusion of salt water into some coastal aquifers, Cooper (1959, p. 461) states that the dispersion of salts produced by oscillatory motion of the saltwater front in a coastal aquifer induces a salt-water flow from the sea floor into the zone of diffusion and back to the sea. The experiment reported here gives the coefficient of dispersion of salt at the boundary between bodies of salt and fresh water in oscillatory motion in a granular material.

A lucite column 4 inches in diameter ( $A$, fig. 303.1) was filled with Ottawa sand, a sieved sand having an 


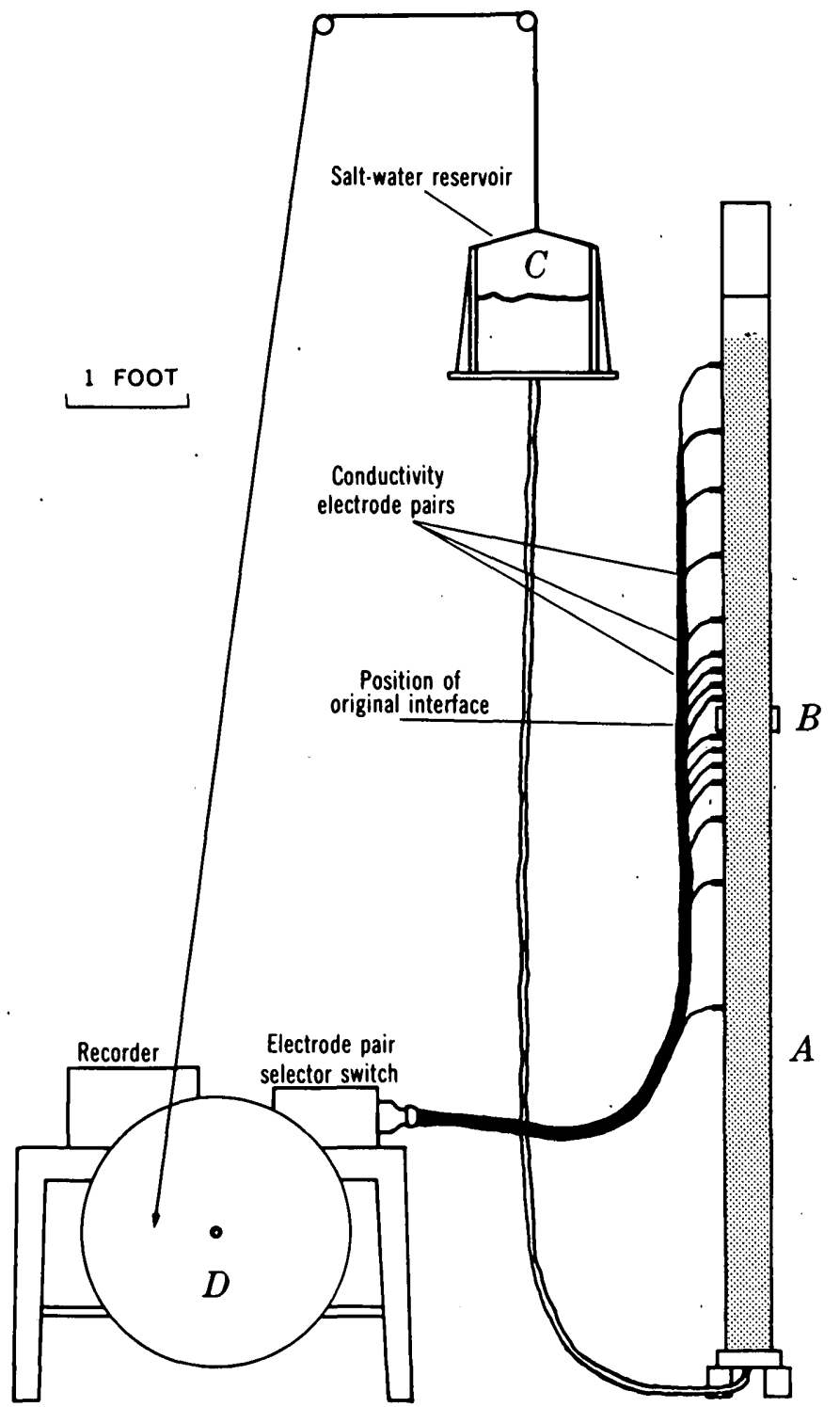

Froure 303.1.-Apparatus used to measure the coefficient of dispersion. (Letters are explained in text.)

effective grain size of $0.70 \mathrm{~mm}$, a Hazen uniformity coefficient of 1.03 , and a porosity of 36.5 percent. An interface was established near the center of the column, $B$, below which the sand was saturated with salt water containing 200 parts per million potassium chloride, and above which the sand was saturated with fresh water. The bottom of the column was connected to a salt-water reservoir, $C$, through flexible tubing. The reservoir was moved up and down by means of a cable attached to a rotating wheel, $D$, at the rate of one cycle per hour. The fresh water and salt water in the sand oscillated at the same frequency as the water level in the reservoir. The amplitude of the water in the sand was 0.63 foot, the amplitude of the reservoir water level was 0.47 foot, and the amplitude of the free water surface in the column was 0.23 foot. The time lag between water-level fluctuations in the reservoir and those in the column was determined experimentally prior to the test and the test was started with this time lag already present so dynamic equilibrium was reached instantaneously. The conductivity of this water was measured by electrode pairs spaced along the length of the column. At the end of the first, second, fourth, sixth, and eighth cycles, the movement of the interface was temporarily interrupted and conductivity profiles were observed by switching a recorder to each electrode in turn. Calibration of the electrodes permitted determination of the concentrations of salt at the electrode positions.

Figure 303.2 shows the concentration of salt in the column at the end of eight cycles. The relation is given by:

$$
1-\frac{2 C}{C_{0}}=\operatorname{erf} \frac{x}{2 \sqrt{D t}}=\operatorname{erf} u
$$

in which $x$ is the distance in feet from original interface measured positively in the direction of decreasing concentration; $D$ is the dispersion coefficient in square feet per second; $t$ is the elapsed time in seconds; $C$ is the concentration at distance $x$ in parts per million; and $C_{0}$ - is the initial concentration of salt solution in parts per million. By definition,

$$
u=x / 2 \sqrt{D t} \text {, or } D=\frac{x^{2}}{4 t u^{2}}
$$

The $u$ and $x$ values in equation 2 are the points common to curves determined by plotting $u$ versus erf $u$ and the absolute value of $x$ versus the absolute value of $1-\frac{2 C}{C_{0}}$. The latter curve is determined using concentration values for potassium chloride measured at one particular time. Figure 303.3 shows the two curves in matching position for $t=28,800$ seconds. The match-point coordinates are $u=1.02$, and $x=0.38$. These values,

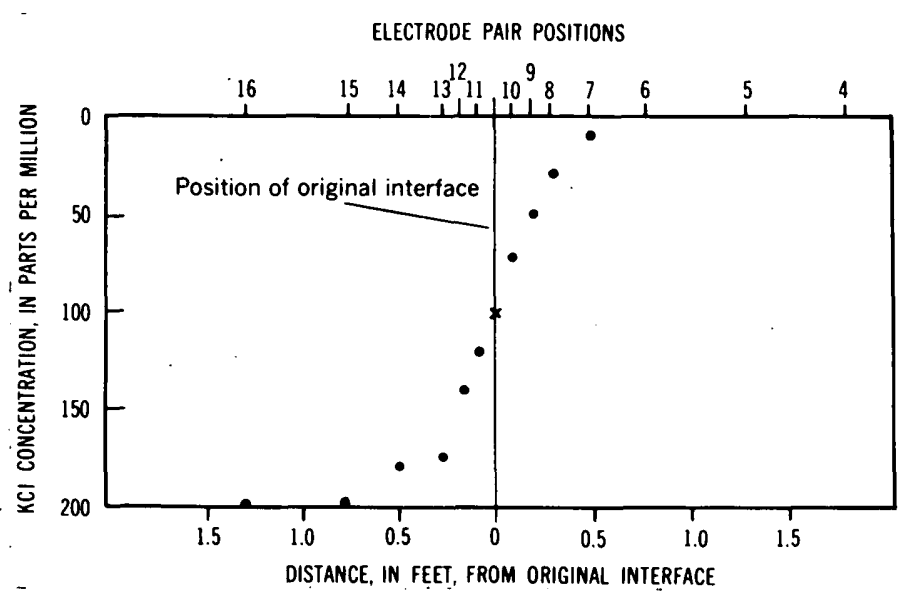

FIGURE 303.2.-Distribution of potassium chloride at the end of eight cycles. 


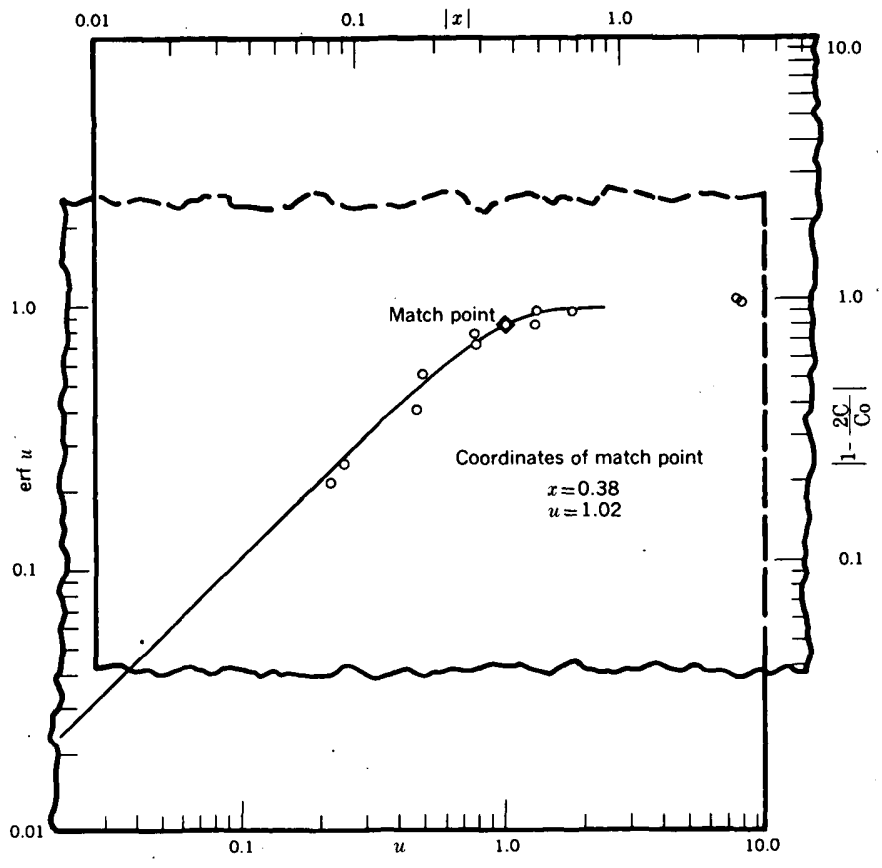

FigURe 303.3.-Matching of observed values of $|x|$ versus $\left|1-\frac{2 C}{C_{0}}\right|$ and $u$ versus erf $u$, for $t=28,800$ seconds.

substituted in equation 2 , result in a dispersion coefficient of $1.204 \times 10^{-6} \mathrm{ft}^{2}$ per second or $0.00112 \mathrm{~cm}^{2}$ per second.

The average interstitial velocity $(\bar{v})$ can be determined by the formula

$$
\bar{v}=\frac{4 x n}{t \phi}
$$

in which $x$ is the amplitude of the free water surface above the sand in centimeters; $n$ is the number of cycles; $t$ is the time, in seconds, required for $n$ cycles; and $\phi$ is the porosity. Using this formula, the average interstitial velocity for the experimental conditions is 0.213 cm per second.

Figure 303.4 compares the results of the experiment with the relation reported by Rifai and others (1956, p. 90) between the dispersion of salt and the average interstitial velocity in Ottawa sand under conditions of unidirectional flow. The effective grain size for the Ottawa sand used by Rifai and others (1956) was 0.45 $\mathrm{mm}$, which is somewhat smaller than that of the sand used in this study, but the uniformity coefficient-a much more critioal value (Orlob and Radhakrishna, 1958 , p. 656)-was 1.30 . This value is very nearly the value of 1.03 for the sand used in the present experiment. Although to date the study is inconclusive, the close comparison of results shown on figure 303.4 indicates that dispersion takes place at about the same rate in oscillatory motion as in unidirectional motion.

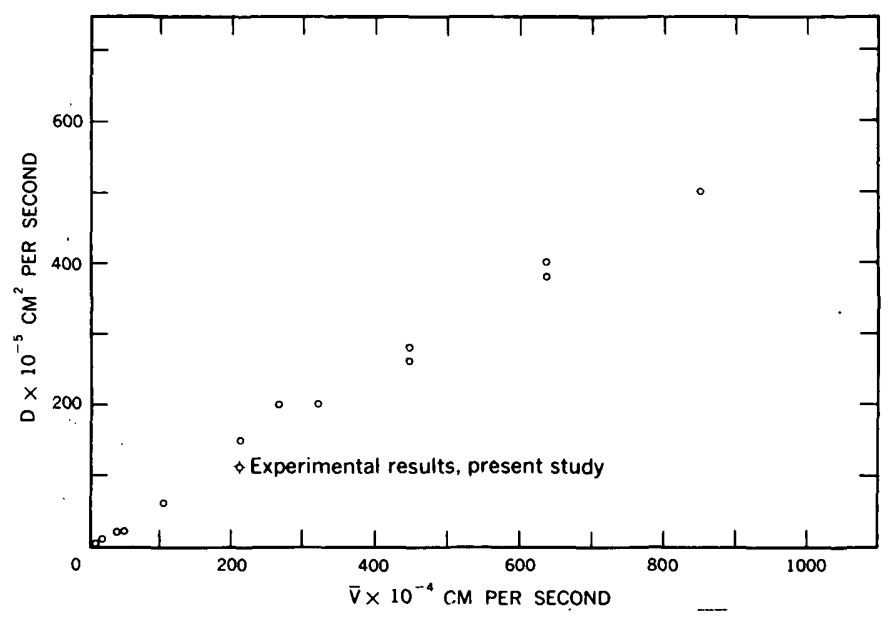

Figure 303.4.-Comparison of experimental results with data of Rifai and others (1956).

\section{REFERENCES}

Cooper, H. H., Jr., 1959, A hypothesis concerning the dynamic balance of fresh water and salt water in a coastal aquifer: Jour. Geophys. Research, v. 64, no. 4, p. 461-467.

Orlob, G. T., and Radhakrishna, G. N., 1958, The effects of entrapped gasses on the hydraulic characteristics of porous media: Am. Geophys. Union Trans., v. 39, no. 4, p. 648-659.

Rifai, M. N. E., Kaufman, W. J., and Todd, D. K., 1956, Dispersion phenomena in laminar flow through porous media: California Univ. Sanitary Eng. Research Lab. Div. Civil Eng., Prog. Rept. no. 2, 157 p.; July 1. 


\section{CHEMICAL CHARACTER OF PRECIPITATION AT MENLO PARK, CALIFORNIA}

By H. C. Whitehead and J. H. Feth, Menlo Park, Calif.

During the winters of 1957-58 and 1958-59, samples of precipitation were collected at Menlo Park, Calif., as a part of a study of the influences of precipitation on the chemical composition of surface runoff in Western Conterminous United States. Several innovations in the definitions of precipitation were instituted which are reflected in the analysis of the various precipitation phases collected. The sample collector was a sheet of semirigid polyethylene about 4 feet square supported on a wooden frame, and draining through a polyethylene funnel into a 4-liter Pyrex glass bottle. The following definitions are required to clarify the terms used in discussing the chemical character of the precipitation collected :

Precipitation Water-soluble, gaseous, liquid, and solid material that falls from the atmosphere:

Rain Precipitation that falls as liquid water, and is collected on a freshly cleaned nonreactive surface.

Dry precipitation Precipitation that falls between periods of rain. Dry precipitation consists of the water-soluble part of dust, occluded gases, and other constituents of unexplored nature that fall on the collector and are washed into the collecting bottle by distilled water. Analysis of the resulting solution has no meaning in terms of concentration, because the concentration depends on the amount of water used to wash the collector clean. The ratios of most constituents probably have significance, however.

Bulk precipitation A combination of rain and dry precipitation.

Each of the three phases of precipitation, rain, bulk, and dry precipitation, exhibits its own unique character-as was found by a comparison of the three phases collected at Menlo Park. Several interrelations were recognized and some correlations made with the physical environment. A few examples of these relations are presented below to illustrate the influences operating to produce the chemical character of the precipitation.

Menlo Park is about 30 miles southeast of San Francisco near the south end of San Francisco Bay and in the northein part of the Santa Clara Valley. This valley is one of the largest of the many valleys in the California Coast Range region, and follows the general northwest-southeast alinement of the surrounding mountains. The Santa Cruz Mountains, having a maximum altitude of about 2,000 feet, lie between Menlo Park and the Pacific Ocean to the west. The Diablo Range forms the eastern boundary of the Santa Clara Valley. The valley extends with variable width for some 60 miles, and gradually narrows to a point about 30 miles south of Menlo Park, where the Gabilan Range, the southern extension of the Santa Cruz Mountains, converges with the Diablo Range forming a funnel-shaped valley out of which the locally produced atmospheric contaminants are carried by the surface winds.

The valley is fairly well isolated from maritime winds because of the range of mountains to the west. Also, during most of the year, a temperature inversion exists along the entire Pacific Coast, having its base at an average altitude of 1,200 to 1,500 feet. This acts as a lid on the valley and contains most of the locally produced air contaminants. Of equal importance is the fact that sea salts have little direct chance to invade the valley under stable meteorological conditions and, hence, have little if any influence on the chemical composition of dry precipitation. In contrast, during the winter rainy season, the influence of sea salts is more apparent. Consequently, the chemistry of rain collected at Menlo Park reflects the influence of the sea as well as the effect of the locally produced mineral constituents.

Figures 304.1-304.3 show the general chemical character of the three types of precipitation sampled at Menlo Park during the two winters of observation. Rain and bulk precipitation are of a mixed type, with bicarbonate and chloride the dominant anions; dry precipitation is principally calcium sulfate.

The variations in the chemical composition of the rain at Menlo Park suggest that there are several factors influencing this phase. The proximity of the ocean, coupled with the fact that most of the rainstorms originate in a maritime environment, would offer a source of sodium and chloride. The inference is that the precipitation regime is composed of rain, nucleating in clouds rich in carbon dioxide and containing sodiumchloride particles derived from the ocean. The rain then falls through air, which at lower levels contains varying proportions of continental mineralization, primarily calcium and magnesium salts. Figure 304.3 indicates that the salts in the air over Menlo Park are primarily calcium sulfate.

The chemical character of dry precipitation collected at Menlo Park supports the contention that, except during rains, local continental mineralization contributes more material by direct fallout to streams in this area than do maritime sources. The contribution of the 


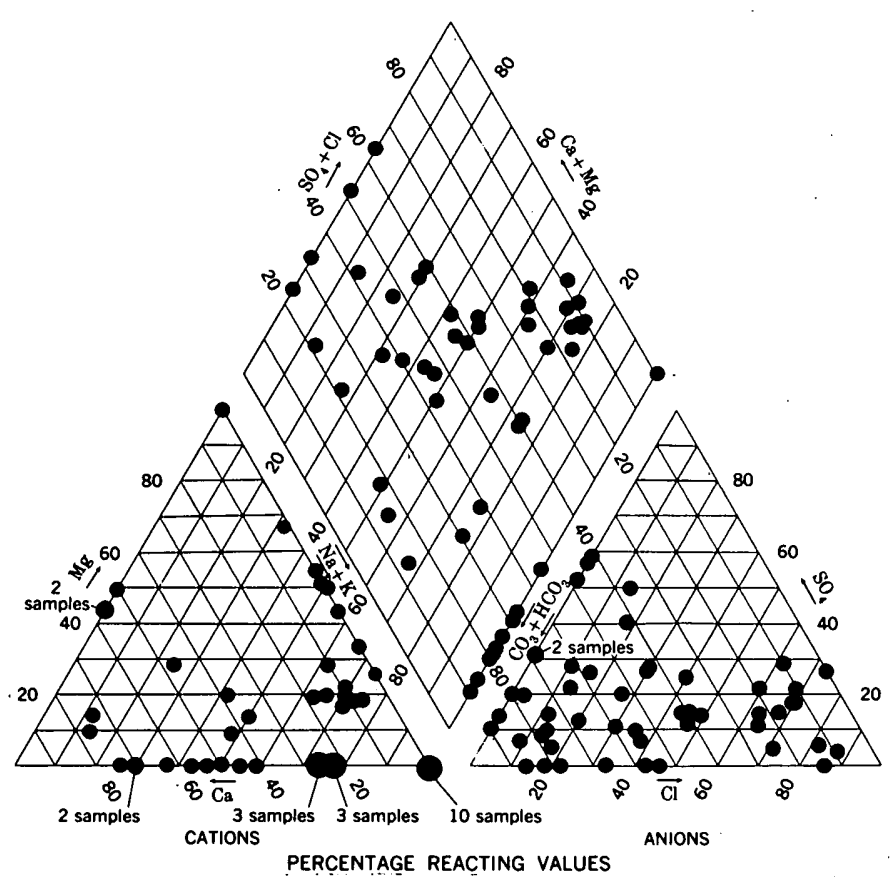

FIgúRe 304.1.-Graph showing general chemical character of rainwater collected at Menlo Park, Calif., 1957-59.

ocean, as represented by the presence of sodium and chloride, is negligible in the diagram (fig. 304.3) that illustrates the chemical character of dry precipitation.

Bulk precipitation represents a combination, in varying proportions, of rain and dry precipitation. Physi-

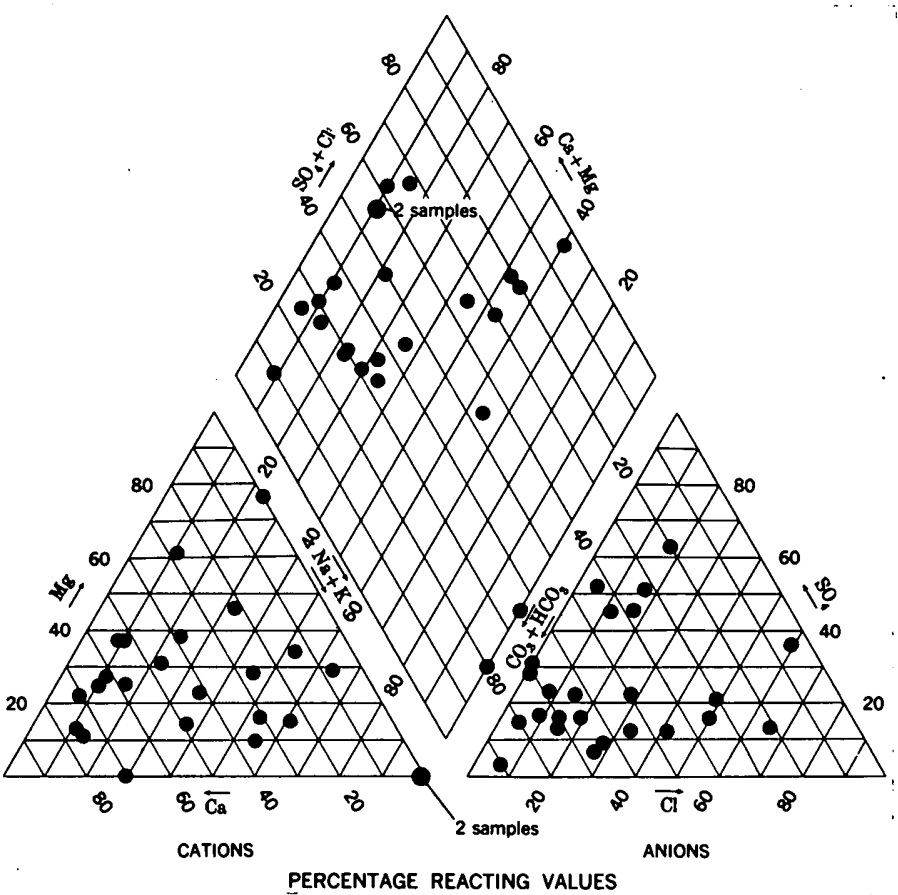

Figure 304.2.-Graph showing general chemical character of bulg precipitation collected at Menlo Park, Calif., 1957-59.

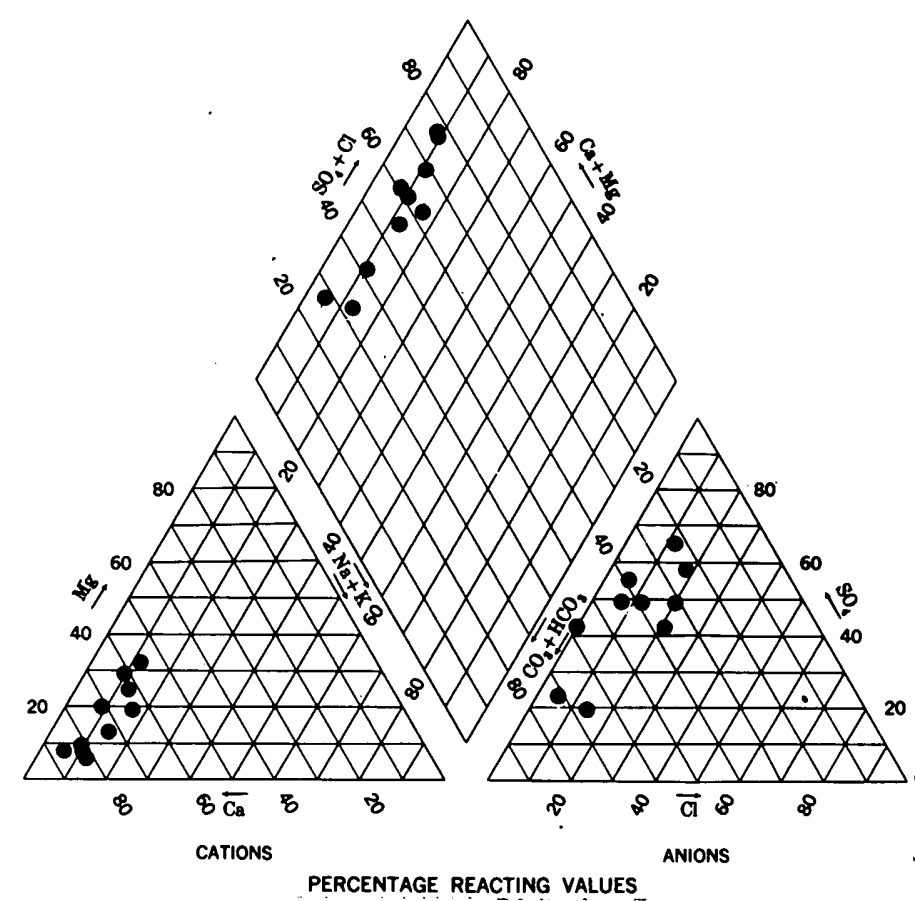

Figure 304.3.-Graph showing general chemical character of dry precipitation collected at Menlo Park, Calif., 1957-59.

cally, it is dry precipitation washed into the collecting vessel by rainwater, and as such, reflects the chemical composition of both phases to different degrees. The chemical composition of bulk precipitation is dominated largely by the bicarbonate ion. The composition of the cations is variable and is not dominated by any one ion although calcium is most abundant. In the samples collected at Menlo Park, bulk precipitation most nearly exhibits the properties of the local dry precipitation in that it tends toward a calcium-magnesium composition. However, rain in this area also is influential in affecting the chemical composition of the bulk precipitation. This is seen in the trend of some samples toward a sodium-chloride composition.

The division of precipitation into the three general categories presented here permits tentative assignment of the sources of mineralization reaching the ground and the streams in the Menlo Park area. During the winter rains, the influence is predominantly maritime, as shown by the sodium-chloride character of the available salts. During dry periods, local continental mineralization contributes the major, if not the entire part of the airborne salts. In periods of alternately wet and dry weather, the influence of both of these sources is seen. It seems, then, that bulk precipitation is a more meaningful phase of precipitation than rain when considering the contribution of atmospheric salts to the chemical character of the surface water. 


\section{MECHANICAL UNIFORM PACKING OF POROUS MEDIA}

By Donald A. Morris and Willis K. Kulp, Denver, Colo.

Work done in cooperation with California Department of Water Resources

Preliminary work during a field and laboratory study of the drainage of unconsolidated porous media indicated a nonuniform distribution of porosity in beads or sand manually packed by tapping the sides of columns with a rubber mallet. The resulting porosities ranged from 34 to 40 percent, a range considered too great for reliable experimental studies. A technique for uniform packing of glass beads or natural sand in a 60-inch segmented column has been devised that utilizes an almost noiseless vibratory packer:

Several kinds of commercial packers, including vibratory and jolting types, were tested, and the vibratory packer was selected as the most suitable. The vibratory packer chosen has a pulsating electromagnet and operates at 60 vibrations per second. A rheostat controls the vibration amplitude, which can be varied from 0.04 to $0.18 \mathrm{~cm}$.

After the operational characteristics of the packer were determined for zero-to-capacity loading (300 pounds), a study was made of the effects of amplitude, surcharge, and packing period on the uniformity of packing for both short and long columns filled with porous media.

The first tests involved filling 12 duplicate short columns, $14.6 \mathrm{~cm}$ long and $5.1 \mathrm{~cm}$ in diameter, with $0.120-\mathrm{mm}$ glass beads, and vibrating them at amplitudes ranging from 0.05 to $0.17 \mathrm{~cm}$. The resulting porosities for the samples ranged from 38.8 to 40 percent. A standard packing amplitude of $0.09 \mathrm{~cm}$ was selected arbitrarily.

The effect of surcharge was determined by comparing porosities obtained with and without a 200 -gram weight placed on the glass beads during vibration at $0.09 \mathrm{~cm}$ amplitude. A difference in porosity of only 0.8 percent was obtained. The use of a surcharge was therefore considered unnecessary.

The vibration of the columns over periods of from
5 to 200 seconds at an amplitude of $0.09 \mathrm{~cm}$ indicated that porosity was not appreciably affected by length of time of vibration within this range. To minimize sorting effects, a standard vibration period of 10 seconds was adopted.

The technique evolved for packing short columns then was extended to the packing of $0.120-\mathrm{mm}$ glass beads in columns 60 inches long and 1 to 4 inches in diameter. After packing for 10 seconds at an amplitude of $0.09 \mathrm{~cm}$, segments of the columns were separated and the porosity of each segment was determined. Figure 305.1 ( $p$. D-32) shows the distribution of porosity vertically throughout one of these columns which was 1 inch in diameter. The porosities generally ranged from about 38 to 40 percent and averaged about 39 percent. The porosity was quite uniform throughout the column and the reproducibility between columns was good. The vertical reproducibility of porosity in the 4 -inch columns was good, but the porosity ranged more widely in the 4-inch columns than in the 1-inch columns.

To test this technique further, duplicate segmented 60 -inch columns 1 inch in diameter were filled with a natural sand (commercially produced by Del Monte Corp.), 20-mesh (0.83-mm), and the same packing procedure was followed. The resulting porosities (fig. 305.2 , p. D-32) were somewhat lower (35 to 38 percent) than for glass beads, probably because of the greater range of particle sizes and shapes of the sand. The porosity was quite uniform throughout the length of the column, and again the reproducibility was consistently good.

A mechanical vibratory packer set at a vibration amplitude of $0.09 \mathrm{~cm}$ and operated for 10 seconds without a surcharge is now the standard method used in the laboratory to obtain uniform packing of porous media in long columns. 


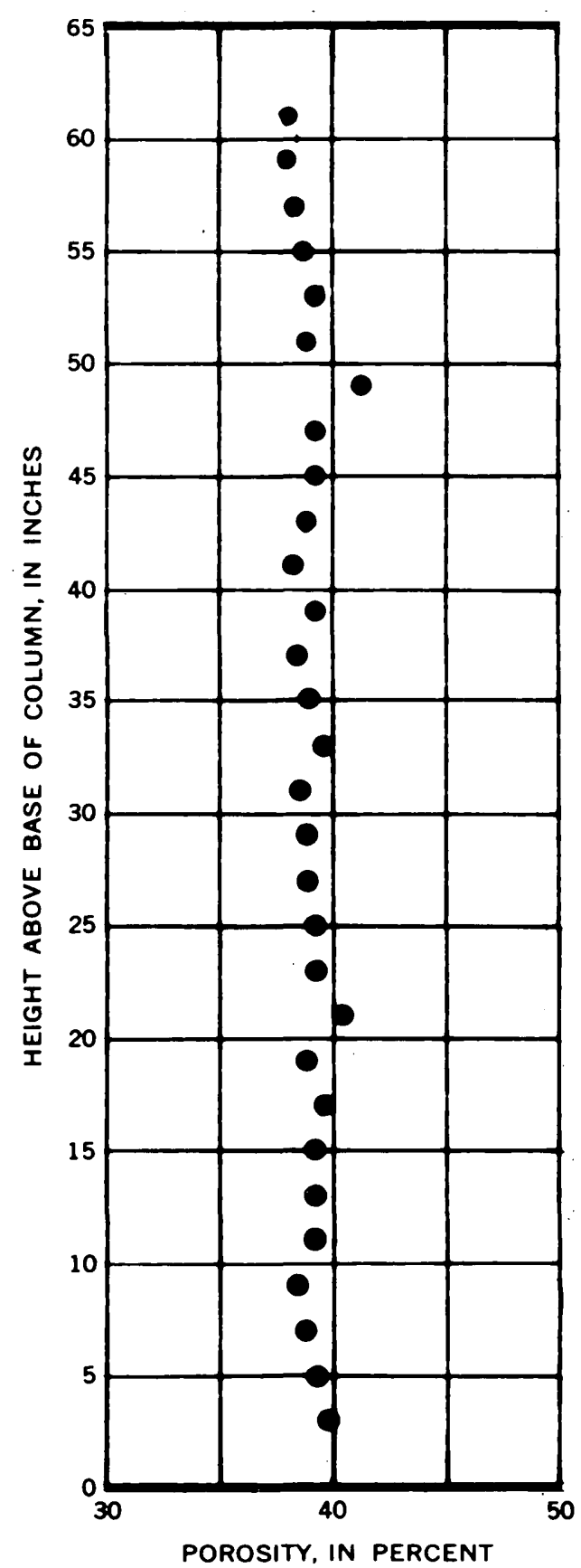

Figure 305.1.-Vertical distribution of porosity in a column of $0.120-\mathrm{mm}$ glass beads.

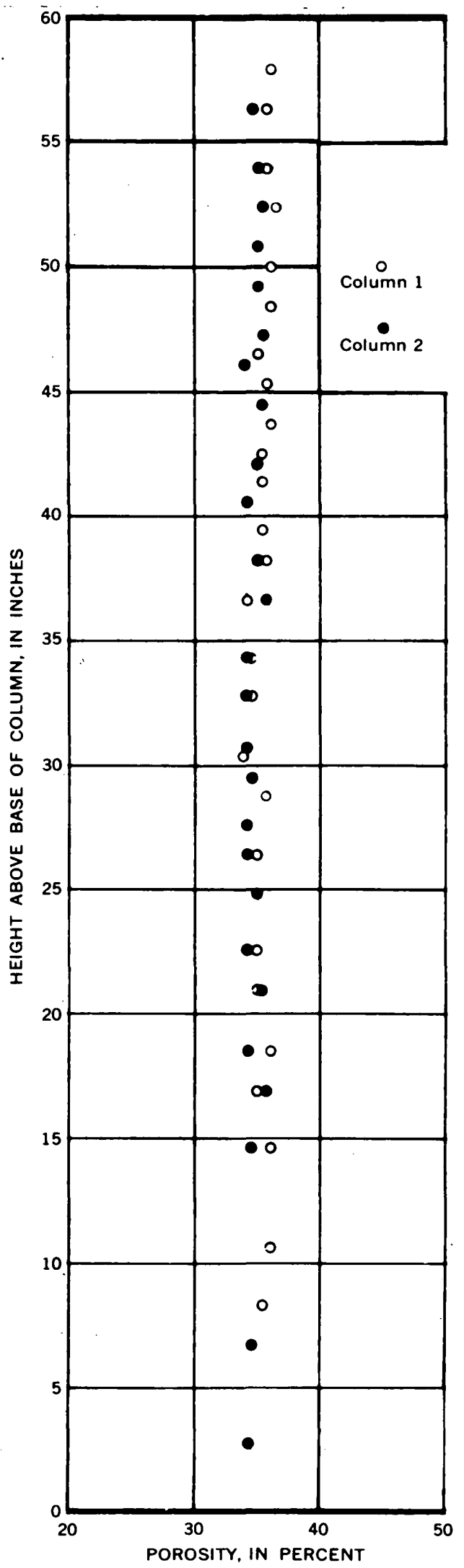

FIGURE 305.2.-Vertical distribution of porosity in columns of 20-mesh $(0.83-\mathrm{mm})$ natural sand. 
SHORT PAPERS IN THE GEOLOGIC AND HYDROLOGIC SCIENCES, ARTICLES 293-435

\section{GEOLOGY AND HYDROLOGY OF EASTERN UNITED STATES}

\section{POST-CAMBRIAN IGNEOUS ROCKS OF THE CENTRAL CRATON, WESTERN APPALACHIAN MOUNTAINS AND GULF COASTAL PLAIN OF THE UNITED STATES}

By M. R. BrocK and A. V. HeYL, Jr., Beltsville, Md.

Igneous rocks intrude Paleozoic and younger sedimentary rocks at many places in the craton of the Central and Eastern Interior, plus the Gulf Coastal Plain of the United States. Numerous intrusives discovered by drilling in recent years are not widely known. In the course of a comprehensive study of ore-deposits controls in this region, the authors have searched the literature rather thoroughly for igneous rock localities and plotted these on a map (fig. 306.1), together with the outlines of the mining districts that have produced sulfide ores, to see what correlation exists between them.

The intrusive bodies form stocks, plugs, sills, and dikes. Extensive petrographic studies by many persons show that the volume of the alkalic group predominates over the volume of the subalkalic group in this part of the country. This relation is inverse to the great preponderance of subalkalic intrusives in other parts of the continent and in general throughout the world.

The twofold division of the igneous rocks into the alkalic and subalkalic groups corresponds closely to Daly's usage (1933). The alkalic rock series is abnormally high in sodium and potassium and deficient in silica. The equivalent members in the subalkalic series are lower in alkalies and higher in silica. Each of these series has been subdivided and plotted on the map with distinctive symbols. In addition, intrusive breccias that contain igneous material are also shown.

Intermittent igneous activity in the region took place from Ordovician to Quaternary time, but most intrusive bodies are of Cretaceous age. The intrusive rocks that extend southwestward from northern New Jersey through western Virginia to northeastern Te1rnessee range in age from Ordovician to at least Triassic. Many of these have been dated only as post-Ordovician or post-Pennsylvanian, depending on the age of the rocks they cut.

Mica peridotite is sparsely distributed in western Pennsylvania and eastern Kentucky. The small stocks in eastern Kentucky are fresh kimberlite, but those in western Pennsylvania are carbonatized. These rocks are dated only as younger than the Devonian and Pennsylvanian sedimentary rocks that are intruded.
Dikes and plugs of mica periodotite and lamprophyre in the central Mississippi Valley are believed to be either late Paleozoic or Cretaceous in age. A leadalpha age on monazite from an intrusive breccia in this region suggests a Cretaceous age (oral communication, T. W. Stern, U.S. Geological Survey), and hence the closely associated lamprophyre and peridotite may also be Cretaceous.

A great variety of mostly alkalic rocks in the lower Mississippi Valley-Arkansas region intruded sediments during the Mesozoic era. Some are believed to be of Triassic age, but most are Cretaceous. The northeasttrending Balcones fault zone in Texas contains large numbers of igneous rocks assigned to both the Cretaceous and the Tertiary periods. Those in western Texas are Tertiary in age and are among several alkalic-rock subprovinces of that age along the extensive forelands east of the Rocky Mountains. Northeastern New Mexico also contains volcanic rocks of Quaternary age. Scattered intrusives between central Missouri and Colorado range in age from early Paleozoic to Cretaceous, and possibly to Tertiary. Numerous diabase rocks in Florida, Georgia, and Alabama are Triassic and Triassic(?) in age.

The many complex stocks plus transitional variations in composition within some dikes are evidence of magmatic differentiation and, to a lesser degree, of contamination through partial assimilation of wall rocks. Because of the differentiation and contamination it is hazardous to assign a specific composition to the source melt. However, studies by Kennedy and Anderson (1938) on tholeite basalt and olivine basalt show that differentiation of the first produces the range of subalkalic rocks and differentiation of the second gives the range of alkalic rocks.

Alkalic rocks are said by Beloussov (1960, p. 4136) to occur mainly in the platform regions of the world. $\mathrm{He}$, among others, considers that the upper portions of the mantle are liquid under much of the continental areas. Accordingly, the prolonged, more stable conditions under the platform regions could be expected to permit a high degree of gravitational differentiation within the melt chambers. This differentiation may proceed to the point permitting concentrations of the 


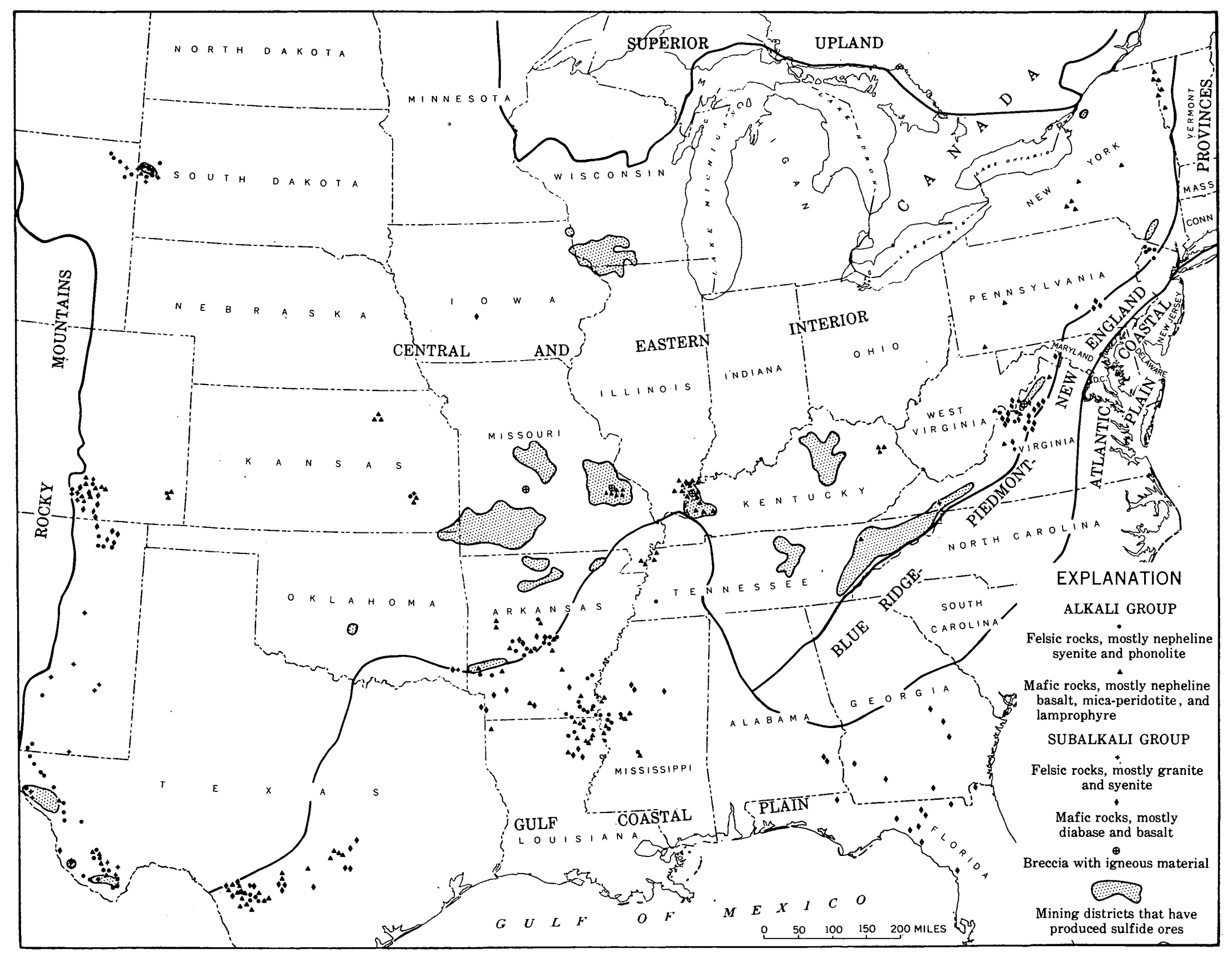


highly volatile elements, including much sodium and potassium, in the uppermost levels of the mantle and possibly within the lower parts of the crust. Breaching of the chambers by deep-seated fractures would allow exodus of the low-viscosity alkalic magma, giving rise to the alkalic suite of igneous rocks. If the release of pressure within the chamber is great and the exodus of material rapid, the result will be, in some cases, gascharged highly explosive emanations. The intrusive bodies, including explosive breccias, found along the fault zone that extends from eastern Kentucky into central Missouri may well have originated in this way. Explosive breccias and volcanic emanations are associated with alkalic rock provinces at many places in the world. At least two of the many brecciated domal structures, which are distributed over much of the craton region between the Appalachian Mountains and the Rocky Mountains and described as cryptovolcanos by Bucher (1933) and others, can be adequately explained by explosive forces originating in this way. Except for the two which contain igneous material, these brecciated domes have been omitted from figure 306.1 because of their questionable origin. However, the locations of several are shown in another paper (Heyl and Brock, Art. 294, fig. 294.1). Most of the cryptovolcanic structures of the region are located on structural highs of regional magnitude, and at least one, in central Missouri, is situated on a large fault.

Igneous rocks have been found within 8 of the 19 mining districts shown on figure 306.1. The distribution of the deposits of fluorspar-zinc-barite-lead ore and intrusive rocks in the Illinois-Kentucky mining district are better shown in another paper by Heyl and Brock, Art. 294, fig. 294.2. Other mineralized districts which are too small to show on figure 306.1 are closely associated with these intrusives in Texas, Kansas, Missouri, and Pennsylvania. Eleven mining districts, including three large producers of ores, contain no known intrusive rock.

\section{REFERENCES}

Applin, P. L., 1951, Preliminary report on buried pre-Mesozoic rocks in Florida and adjacent states: U.S. Geol. Survey Circ. 91, $28 \mathrm{p}$.

Baker, C. L., 1927, Exploratory geology of a part of southwestern Trans-Pecos, Texas: Univ. Texas Bur. Econ. Geology Bull. 2745, 70 p.
Beloussov, V. V., 1960, Development of the earth and tectogenesis: Jour. Geophys. Research, v. 65, no. 12, p. 4127-4146.

Bucher, W. H., 1933, Cryptovolcanic structures in the United States: Internat. Geol. Cong. 16th, Rept., v. 2, p. 1055-1084.

Byrne, F. E., Parish, K. L., and Crumpton, C. F., 1956, Igneous intrusions in Riley County, Kansas: Am. Assoc. Petroleum Geologists Bull., v. 40, no. 2, p. 377-387.

Clegg, K. E., and Bradbury, J. C., 1956, Intrusive rocks of Illinois and their economic significance: Illinois Geol. Survey, Rept. Inv. 197, 19 p.

Currier, L. W., 1923, Fluorspar deposits of Kentucky: Kentucky Geol. Survey Bull., ser. 6, v. 13, 198 p.

Daly, R. A., 1933, Igneous rocks and the depths of the earth: New York, McGraw-Hill Book Co., 598 p.

Goldich, S. S., and Elms, M. A., 1949, Stratigraphy and petrology of the Buck Hill quadrangle, Texas: Geol. Soc. America Bull., v. 60, no. 7, p. 1133-1182.

Gould, C. N., 1923, Crystalline rocks of the Plains: Geol. Soc. America Bull., v. 34, no. 3, p. 541-560.

Irving, J. D., 1904, Economic resources of the northern Black

- Hills: U.S. Geol. Survey Prof. Paper 26, 222 p.

Johnson, R. W., Jr., and Milton, Charles, 1955, Dike rocks of central-western Virginia [abs.] : Geol. Soc. America Bull., v. 66 , no. 12 , pt. 2 , p. 1689-1690.

Kennedy, W. Q., and Anderson, E. M., 1938, Crustal layers and the origin of the magmas: Bull. Volcanol., ser. 2, v. 3, p. $23-82$.

Knopf, Adolph, 1936, Igneous geology of the Spanish Peaks region: Geol. Soc. America Bull., v. 47, no. 11, p. 1727-1784.

Koenig, J. B., 1956, The petrography of certain igneous dikes of Kentucky: Kentucky Geol. Survey Bull., ser. 9, no. 21, $57 \mathrm{p}$.

Lonsdale, J. T., 1927, Igneous rocks of the Balcones Fault region of Texas: Univ. Texas Bur. Econ. Geology Bull. 2744, $178 \mathrm{p}$.

1940, Igneous rocks of the Terlingua-Solitario region, Texas: Geol. Soc. America Bull., v. 51, no. 10, p. 1539-1626.

Martens, J. H. C., 1923, Study of the igneous rocks of Ithaca, New York, and vicinity [abs.]: Geol. Soc. America Bull., v. 34, no. 1, p. 99.

Moody, C. L., 1949, Mesozoic igneous rocks of northern Gulf Coastal Plain: Am. Assoc. Petroleum Geologists Bull., v. 33, no. 8 , p. $1410-1428$.

Stobbe, H. R., 1949, Petrology of volcanic rocks of northeastern New Mexico: Geol. Soc. America Bull., v. 60, no. 6, p. 10411093.

Tarr, W. A., and Keller, W. D., 1933, Post-Devonian igneous intrusions in southeastern Missouri: Jour. Geology, v. 41, no. 8 , p. $815-823$.

Thomas, E. P., 1950, Mississippi structures and their relation to oil accumulation: Am. Assoc. Petroleum Geologists Bull., v. 34 , no. 7 , p. $1502-1506$.

Williams, J. F., 1890, The igneous rocks of Arkansas: Arkansas Geol. Survey Ann. Rept., v. 2, 391 p. 


\title{
307. UNDERSEEPAGE ALONG LEVEE 30, DADE COUNTY, FLORIDA
}

\author{
By Howard Klein and C. B. Sherwood, Miami, Fla.
}

Work done in cooperation with the Central and Southern Florida Flood Control District

The initial flood-control project in southern Florida was the construction of a levee west of the Atlantic Coastal Ridge, to retard the eastward overland flow of flood waters from the Everglades. The southern terminus of the levee system is shown on figure 307.1. When the flood-control system is completed, a part of the excess waters will be impounded in conservation area 3 (fig. 307.1), west of the levees.

A proposed method of flood control in area $B$, east of the levees (fig. 307.1), is to reduce ground-water storage by means of a network of canals and a series of pumping stations. The pumps will be located along the levees and will discharge water from area $B$ into conservation area 3 . Initially, it was proposed that the water stage in area $B$ be controlled at sea level to give flood protection during major storms.

In the following, determination of the underflow occurring along a section of the levee under 1960 waterlevel conditions is used to predict underflow between conservation area 3 and area $B$ for other postulated controlled conditions.

The levee area is underlain to about 50 feet below msl (mean sea level) by the Biscayne aquifer, a body of highly permeable limestone. The aquifer is floored by relatively impermeable silt.

Figure 307.2 gives details of the geology near the northern end of Levee 30. A marl and muck blanket overlies a thin layer of Miami oolite which is riddled by solution openings. Figure 307.2 shows two thin layers of hard, dense limestone from 0.5 foot above to 3.0 feet below mean sea level. These layers are relatively impermeable, and under comparable hydraulic gradients vertical flow of water through them is many times less than the horizontal flow through the deeper, more permeable rocks. The thin layers act hydraulically as a semiconfining unit that separates the ponded water in conservation area 3 from the water contained in the deeper, more permeable part of the aquifer.

The Levee 30 canal was cut through the beds of low permeability and probably intercepts all the underflow from the conservation area occurring along the northern end of Levee 30. Canal flow represents a composite of inflow from ground-water storage in adjoining areas, and seepage of ponded water through levee materials and the permeable Miami oolite.

Figure 307.3 shows water-level measurements made in a line of multiple-depth wells along a line perpendicular to Levee 30. This profile shows the relation between the pool in conservation area 3 and the piezometric surface during April 1960, and indicates, by equipotential lines, the head distribution throughout the section.

The equipotential lines show that flow through the aquifier toward the Levee 30 canal is essentially horizontal except for the section adjacent to and beneath the canal where flow has an upward component. The horizontality of the contours in the interval between 0.5 foot above and 3.0 feet below mean sea level indicates a large vertical head loss caused by vertical flow through the dense limestones. Flow through the shallower materials beneath the levee is essentially horizontal and probably occurs chiefly through the Miami oolite.

In January 1960, discharge measurements were made at 1-mile intervals in the northern end of the Levee 30 canal. Piezometric gradients in the aquifer were determined from measurements in wells on both sides of the canal and levee and are shown on figure 307.4. The following is a tabulation of the data $[\mathrm{cfs}=$ cubic feet per second $; \mathrm{mgd}=$ million gallons per day $; \mathrm{ft}$ per $\mathrm{ft}=$ feet per foot]:

A. Discharge measurements in Levee 30 canal :

Total pickup in 1-mile reach $\left(Q_{t}\right)$--- $176 \mathrm{cfs}$ (114 mgd)

Seepage visible across berm to canal

$(Q$.$) -$

Net pickup by ground-water in-

flow $\left(Q_{g}\right)$

$\left(\mathrm{Q}_{\mathrm{g}}\right)=\mathrm{Q}_{\mathrm{t}}-\mathrm{Q}_{\mathrm{s}}$

B. Gradients (I) of piezometric surface

(fig. 307.4)

Average, ponded side $0.0045 \mathrm{ft}$ per $\mathrm{ft}$

Average, southeast side $0.0010 \mathrm{ft}$ per $\mathrm{ft}$

If the aquifer is homogeneous and flow through it is laminar, the quantity of ground water discharging into the Levee 30 canal is directly proportional to the hydraulic gradient; therefore, about 80 percent of $Q_{g}$ or $86 \mathrm{mgd}$ represents underflow from the ponded side along the 1-mile canal reach. 


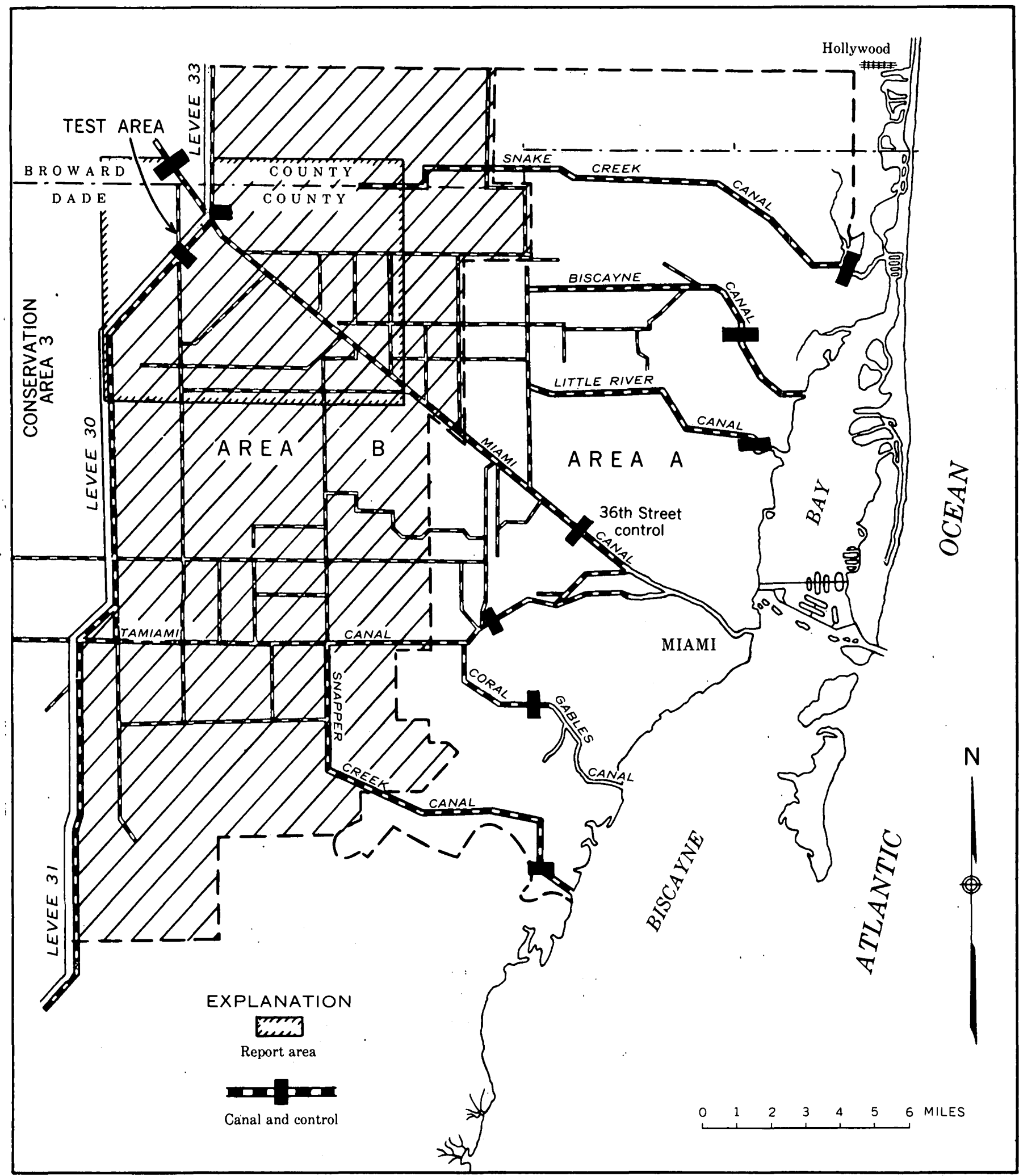

Fiaure 307.1.-Map of northern Dade County showing the area of investigation. 


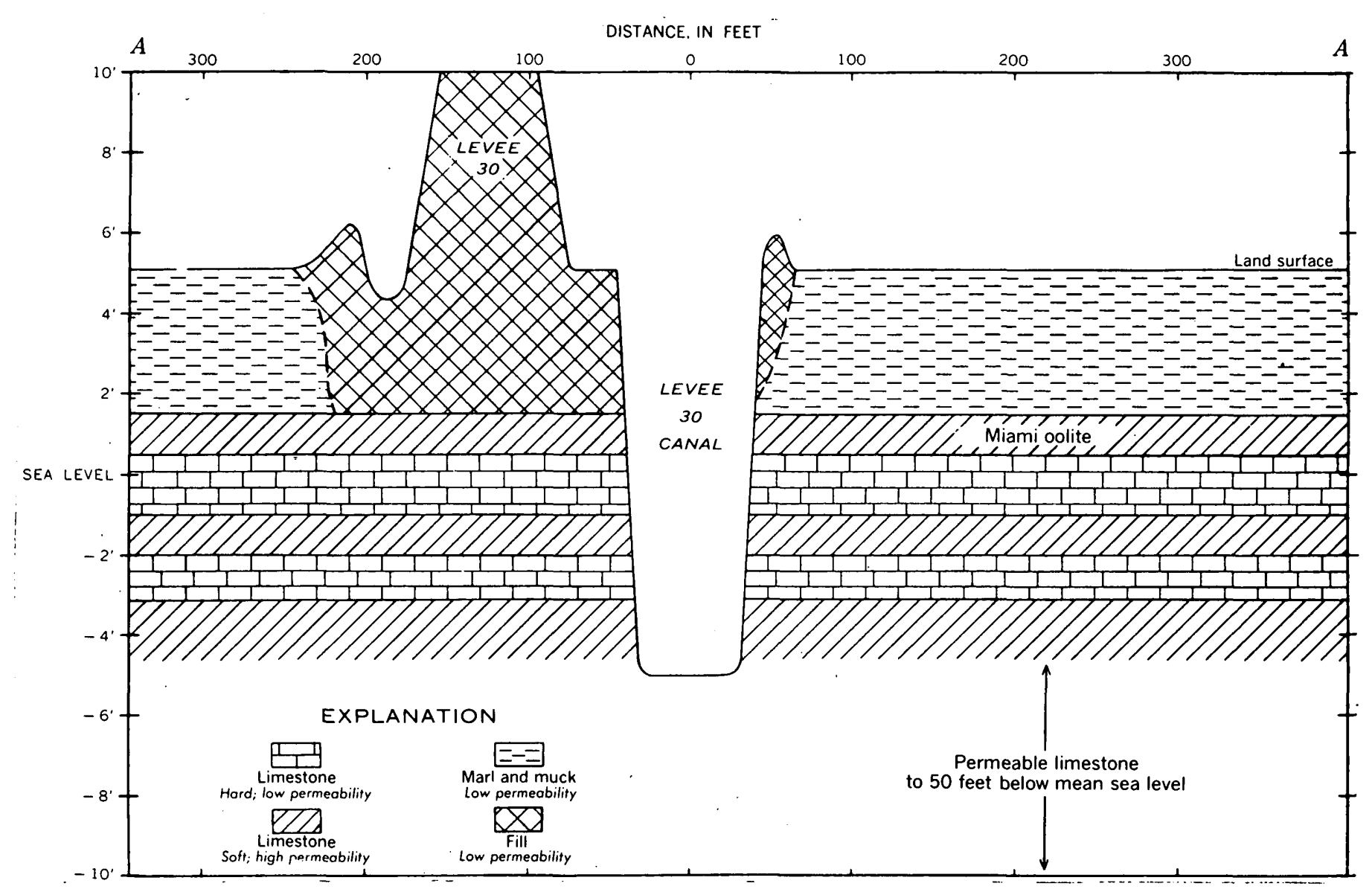

FIGURE 307.2.-Cross section showing details of the geology near the northern end of Levee 30.

Darcy's law may be expressed:

$$
Q=T I L
$$

in which $Q$ is the quantity of water in gpd (gallons per day); $T$ is the coefficient of transmissibility, in gpd for each vertical strip of the aquifer 1 -foot wide; $I$ is the hydraulic gradient, in $\mathrm{ft}$ per $\mathrm{ft}$; and $L$ is the length of the section, in feet, through which the quantity $(Q)$ flows. By substituting in the above equation the data of January 1960, a computation of the coefficient of transmissibility of the aquifer is as follows $[\mathrm{ft}=\mathrm{feet}$; gpd per $\mathrm{ft}=$ gallons per day per foot; $\mathrm{ft}^{2}$ per sec $=\mathrm{feet}^{2}$ per second; mgd per mile=million gallons per day per mile; cfs per mile=cubic feet per second per mile]:

$$
T(\operatorname{gpd} \operatorname{per} \mathrm{ft})=\frac{Q(\mathrm{gpd})}{I(\mathrm{ft} / \mathrm{ft}) \times L(\mathrm{ft})}
$$

$$
\begin{aligned}
T & =\frac{86,000,000}{0.0045 \times 5,280} \\
T & =3,600,000 \mathrm{gpd} \text { per } \mathrm{ft} \text { or } 5.6 \mathrm{ft}^{2} \text { per sec }
\end{aligned}
$$

When water control is in effect in area $B$ there may be times when the head difference between water level in the conservation pool and water surface in Levee 30 canal will be as much as 10 feet. To compute the expected maximum underseepage it is necessary to determine the relation between the head across the levee and the head differential at the toe of the levee, under different water stages. Figure 307.5 shows this relation. The projected graph indicates that if a head differential of 10 feet were held across the levee, the head differential at the toe of the levee would be 7.8 feet; thus, the gradient across the 150 -foot levee would be 2.2 feet. 
SHORT PAPERS IN THE GEOLOGIC AND HYDROLOGIC SCIENCES, ARTICLES 293-435

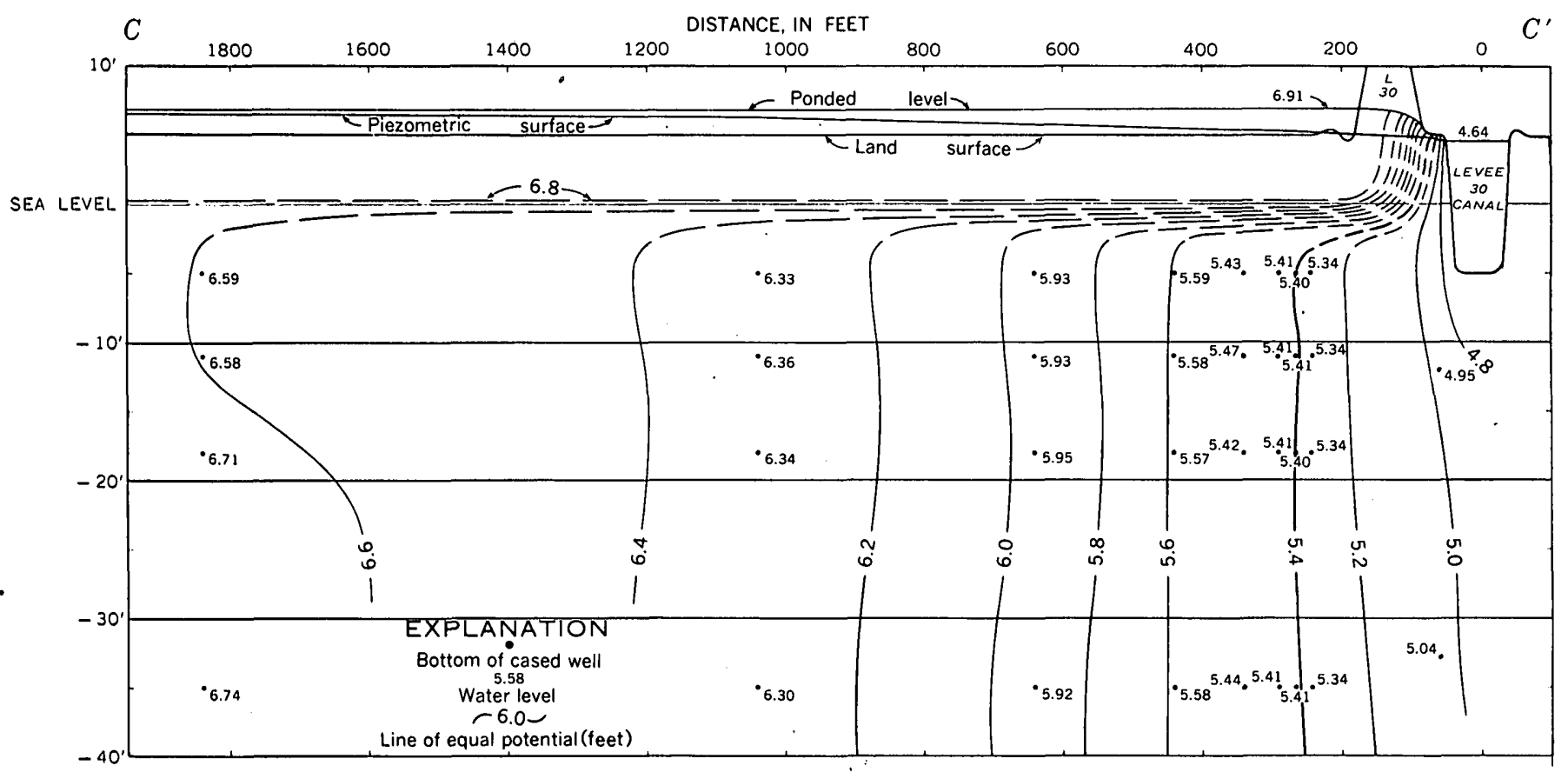

Fiaure 307.3.-Profile showing lines of equal potential adjacent to Levee 30, April 1960.

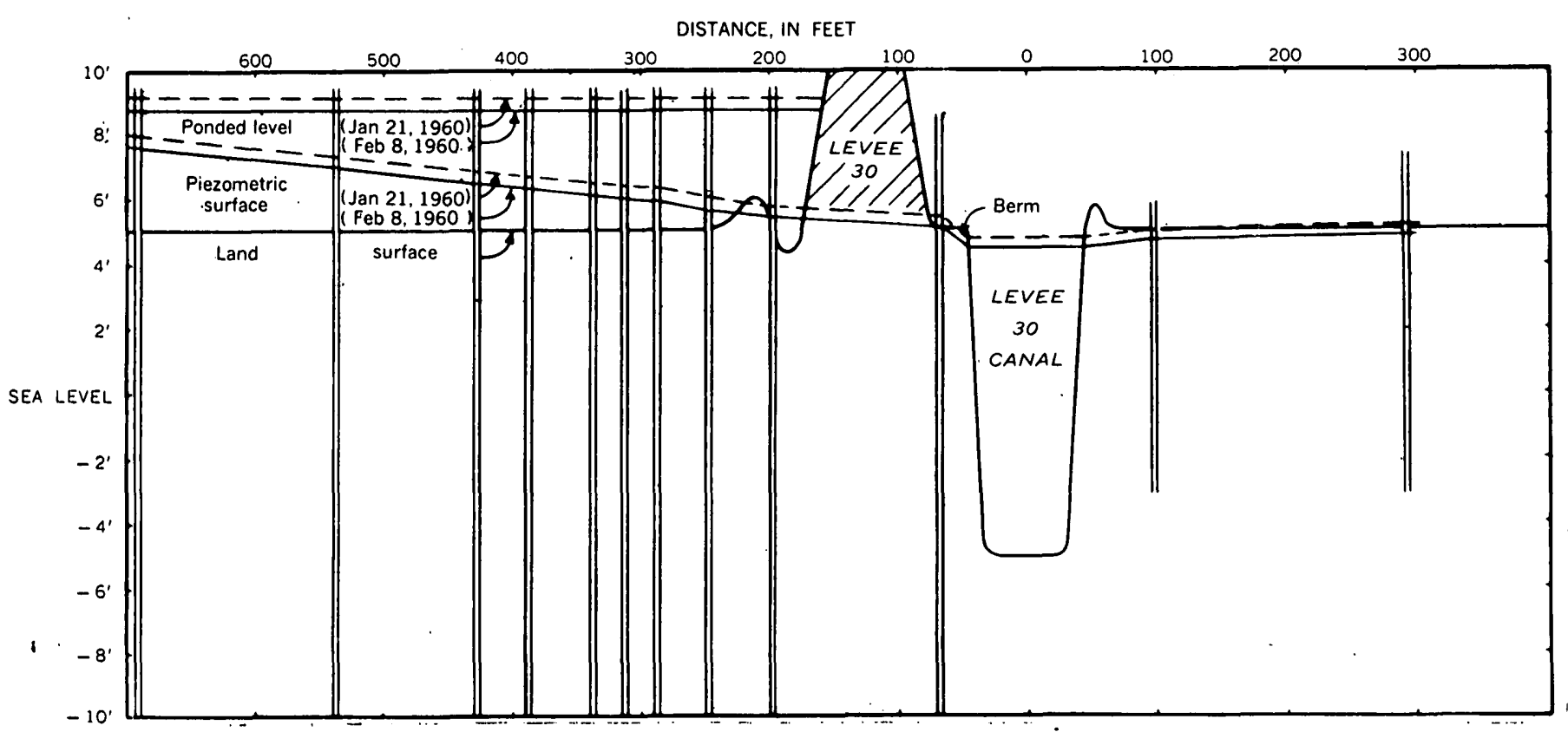

Froure 307.4.-Profile showing the relation between ponded water and the piezometric surface adjacent to Levee 30 during early 1960. 


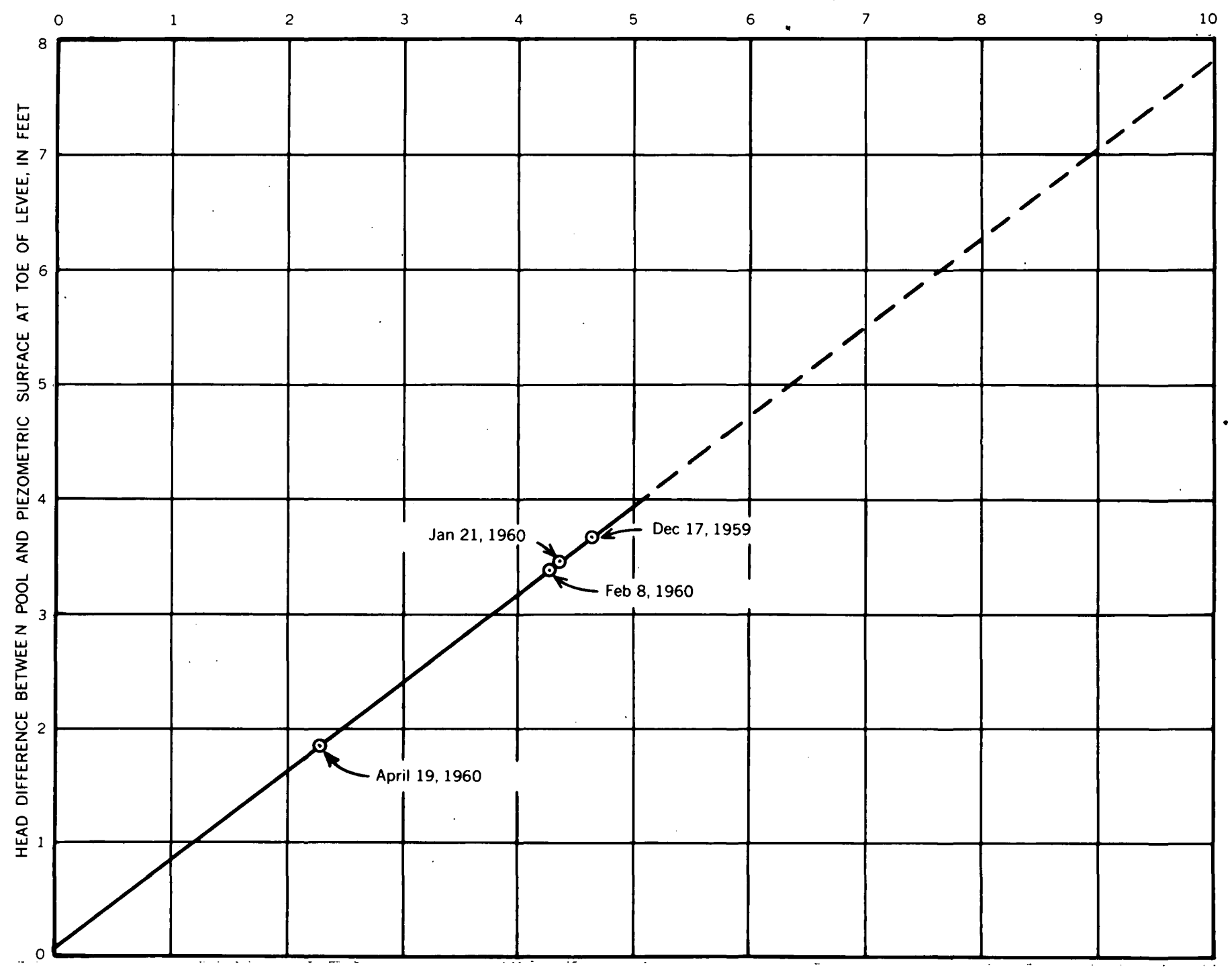

FigURE 307.5.-Graph showing the relation between the head difference across Levee 30 and the head difference between the pool and the piezometric surface at the toe of the levee.

Thus, maximum underflow from beneath the levee through the Biscayne aquifer to the canal would be:

$$
Q=3,600,000 \text { gpd per ft } \times \frac{2.2 \mathrm{ft}}{150 \mathrm{ft}} \times 5,280 \mathrm{ft}
$$

$Q=279 \mathrm{mgd}$ per mile or $432 \mathrm{cfs}$ per mile for a levee base width of 150 feet.

Consideration must be given also to the seepage through the levee materials and the layer of Miami oolite. An approximate determination of such seepage may be made using another expression of Darcy's law [gpd per $\mathrm{ft}^{2}=$ gallons per day per foot ${ }^{2}$ ]:

$$
Q=P I A
$$

using an estimated composite coefficient of permeability $(P)$ of the levee fill and oolite $=20,000 \mathrm{gpd} / \mathrm{ft}^{2}$, a length of flow section $=5,280 \mathrm{ft}$, a thickness of flow section $=10 \mathrm{ft}$, a base width of levee $=150 \mathrm{ft}$, and a head differential $=10 \mathrm{ft}$, the total seepage through the levee $(Q)$ is computed to be about

$$
\begin{aligned}
& Q=20,000 \text { gpd per } \mathrm{ft}^{2} \times \frac{10 \mathrm{ft}}{150 \mathrm{ft}} \times 5,280 \mathrm{ft} \times 10 \mathrm{ft} \\
& Q=70 \mathrm{mgd} \text { per mile, or } 108 \mathrm{cfs} \text { per mile }
\end{aligned}
$$

The total quantity that will be intercepted along the 1-mile reach from conservation area 3 is computed to be about $349 \mathrm{mgd}$ or $540 \mathrm{cfs}$. This estimate is based 
on the assumption that flow in the aquifer is laminar. For laminar flow the underflow would be directly proportional to the head difference across the levee; for turbulent flow the underflow would be approximately directly proportional to the square root of the head difference. Thus, if there is turbulence in the aquifer beneath the levee, flow to the canal will be somewhat less than $540 \mathrm{cfs}$ per mile.

\title{
308. SOURCES OF WATER IN STYX AND ECHO RIVERS, MAMMOTH CAVE, KENTUCKY
}

\author{
By G. E. Hendrickson, Louisville, Ky.
}

Work done in cooperation with the Kentucky Geological Survey and the National Park Service

The apparent sources of water in the underground streams in Mammoth Cave, Styx and Echo Rivers, are ground-water runoff from the sinkhole area to the east of the cave and surface water from the Green River. The explored reaches of the underground streams and their points of surface emergence are shown on figure 308.1. The streams come to the surface as springs and discharge into Green River.

The sources were determined by direct observation of direction of flow in the streams, comparison of gage heights on Styx, Echo, and Green Rivers, comparison of temperature of water from these streams, and sampling and analyses of waters from the various sources. Chemical analyses of waters from the Styx, Echo, and Green Rivers yielded the most reliable results because the chemical character of water from the sinkhole area is quite different from that of Green River water at all seasons of the year.

Before the development of the Greensburg oil field in 1958 (Krieger and Hendrickson, 1960), the chloride content of water from the Styx, Echo, and Green Rivers generally was less than $5 \mathrm{ppm}$ (parts per million). After the development of the oil field, however, the chloride content of water in the Green River became much greater than that of local ground-water runoff in the Mammoth Cave area, and a reasonably accurate determination of the amount of Green River water in the Styx River and Echo River became feasible.

Figure 308.2 shows the chloride content, temperature of the water, and gage height of Styx, Echo, and Green Rivers for the period February 1 through June 21, 1960 .

Because of an obstruction in the channel, the gage height of the Styx River does not fall below about 423.7 feet (mean sea level), although the gage heights of Echo River and Green River frequently are below 422 feet during the summer months. The Styx River apparently flows out of the cave into the Green River whenever the gage height of the Green River falls below about 423.7 feet. When the Green River is at stages higher than 423.7 feet, the Styx River flows in or out of the cave, depending on the amount of rainfall at Mammoth Cave, on the amount of rainfall in the Green River basin above Mammoth Cave, and in the position of the flood crest in relation to the Styx and Echo River outlets. The Styx River generally flows out of the cave into the Green River immediately following heavy rains at Mammoth Cave. Outward flow may continue for several days after the rains, but at some time near, or shortly after, the highest stage of the flood at Mammoth Cave, the flow in the Styx River reverses and water flows from the Green River through the Styx "outlet" and into the cave. The inflow in the Styx generally continues until renewed rainfall begins another cycle or until the stage of the Green River falls below 423.7 feet.

Changes in chloride content of water in the Styx River accompany the reversals in flow, and these changes give evidence of the time of the reversals. During times of inflow the chloride content of the Styx is about the same as that of the Green River at this point. During times of outflow the chloride content of the Styx generally is considerably less than that of the Green. The transition from high-chloride water during inflow to low-chloride water during outflow may be abrupt as in the period March 15-17, 1960, or gradual as during the period April 13-May 7, 1960 (fig. 308.2). Abrupt changes from high to low chloride contents are due to rapid flushing out by ground-water runoff from sinkholes during local rains, especially during the winter months when the soil is nearly saturated with water. Gradual changes are due to the slow dilution of the high-chloride water by fresh ground water from the 


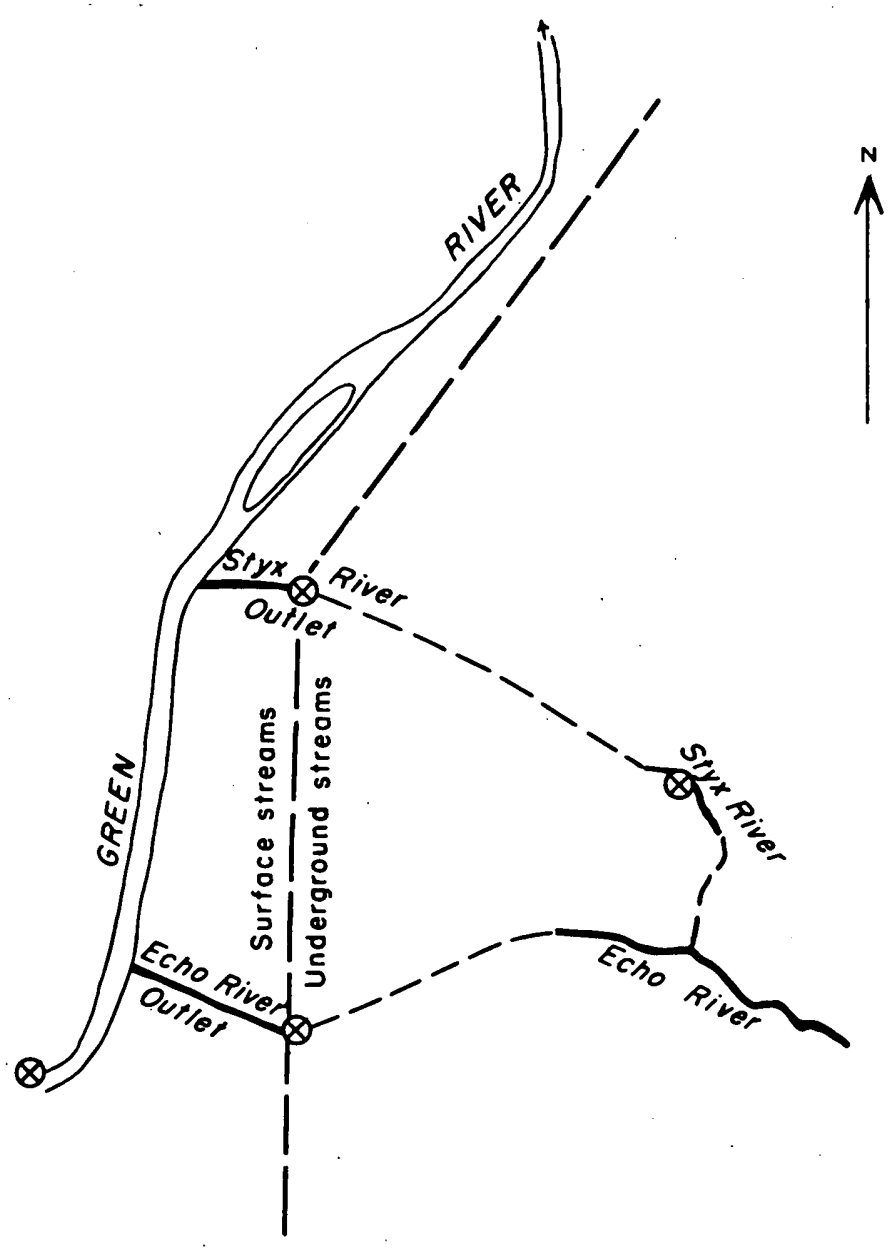

EXPLANATION

$Q$

Goging station

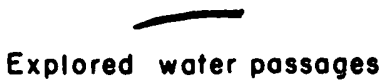

- -

Inferred water passoges

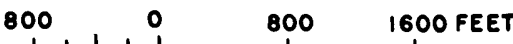

Figure 308.1.-Styx and Echo Rivers, Mammoth Cave, Ky.

sinkhole area. It is possible that some high-chloride water enters the Styx from the Green at some point upstream from the outlet, even during low stages.
National Park Service guides have reported a few observations of Echo River flowing into the cave. Sudden increases in the chloride content of water in Echo River at times when the Styx is flowing out of the cave indicate that such reversal in flow of the Echo River does occur. One such reversal occurred on May 30 (fig. 308.2), when the chlorides in Echo River increased from about $2 \mathrm{ppm}$ to $260 \mathrm{ppm}$ during a period of about 24 hours. The Styx River was flowing out at this time and had been flowing out for several days. Additional evidence of the reversal was the abrupt rise in temperature of the water from $54^{\circ}$ to $70^{\circ} \mathrm{F}$. Such reversals in flow in Echo River last only a day or two at the most.

Prolonged periods of high-chloride waters in Echo River are undoubtedly caused by Green River water entering the Styx River, flowing through the underground passages, and discharging through the Echo River outlet. Reversals in flow in the Styx are always followed by a rise in chlorides in Echo River, generally with a time lag of less than 1 day. The time required for water entering the Styx to appear at Echo River outlet was determined by dye test to be about 15 hours when the gage height at the Styx outlet was about 427 feet.

When water from the Green River flows through the Styx River into the cave and out again through Echo River the water discharged at Echo River outlet always is substantially lower in chlorides than the water entering the Styx from the Green. During the period March 8-12, 1960, chlorides in the water flowing from the Green into the cave through the Styx River averaged about $150 \mathrm{ppm}$ while water discharging at Echo River outlet contained slightly more than $60 \mathrm{ppm}$ of chlorides. Local ground-water runoff generally contains less than $5 \mathrm{ppm}$ of chlorides. Calculations show that about 40 percent of the water discharged from Echo River at this time came from the Green River and about 60 percent came from local groundwater runoff.

\section{REFERENCE}

Krieger, R. A., and Hendrickson, G. E., 1960, Effects of Greensburg oil-field brines on the streams, wells, and springs of the Upper Green River basin, Kentucky: Kentucky Geol. Survey, ser. 10, Rept. Inv. no. 2, 36 p. 

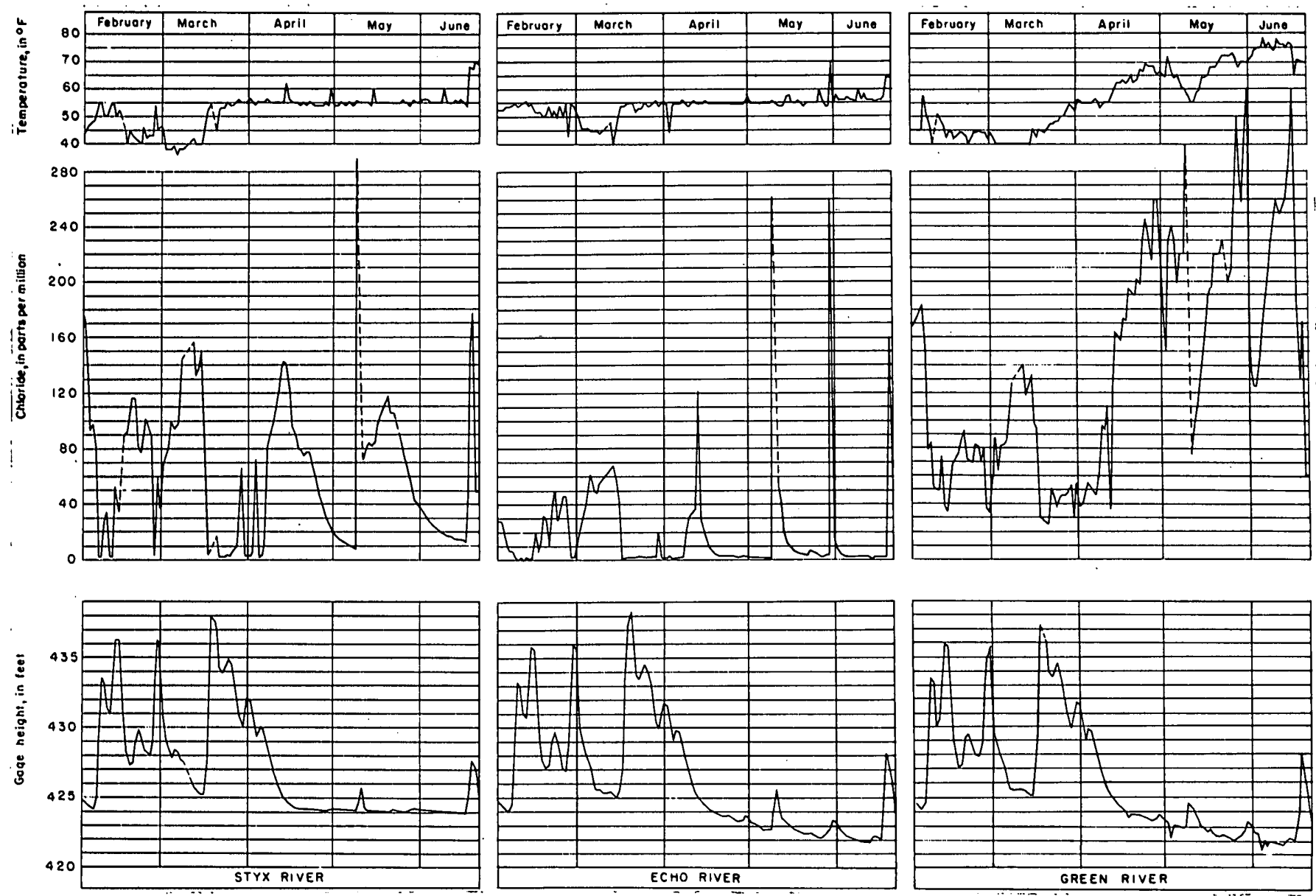

Fiquis 308.2.-Chloride content, temperature of water, and gage height in Styx, Echo, and Green Rivers, Mammoth Cave, Ky., February 1 through June 21, 1960.

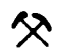
309. VOLCANIC ROCKS OF ORDOVICIAN AGE IN THE MOUNT CHASE RIDGE, ISLAND FALLS QUADRANGLE,

By E. B. Ekren, Denver, Colo.

A belt of vertically dipping volcanic rocks of Ordovician age forms a broad northeast-trending ridge from Mount Chase to Shoaler Mountain (fig. 309.1) across the Island Falls quadrangle. Similar but narrower northeast-trending belts occur north of Pleasant Lake and Rockabema Lake. Structural relations indicate that the rocks in the separate belts are part of the same stratigraphic sequence. The Mount Chase belt is continuous southwestward into the Shin Pond and Stacyville quadrangles and outlines a broad south- and southwest-plunging anticline (Neuman, 1960).

The bulk of the volcanic rock at Mount Chase is dense spilite. The spilite, interlayered with thin beds and seams of chert, is well exposed along the trail leading to the lookout tower at the peak. At places it displays poorly defined pillow structure. Eastward along the ridge spilite is relatively sparse. There, keratophyre, tuffaceous conglomerate, and sandstone make up the bulk of the sequence. Numerous sills of albite- or oligoclase-rich diabase intrude the spilite at Mount Chase and the pyroclastic and felsic rocks farther east. At places along the northwest side of the ridge, quartz porphyry crops out. These rocks appear to be parts of dikes and sills extending from a large stock of porphyritic quartz diorite (not shown on fig. 309.1). Beds of tuffaceous conglomerate and conglomeratic 


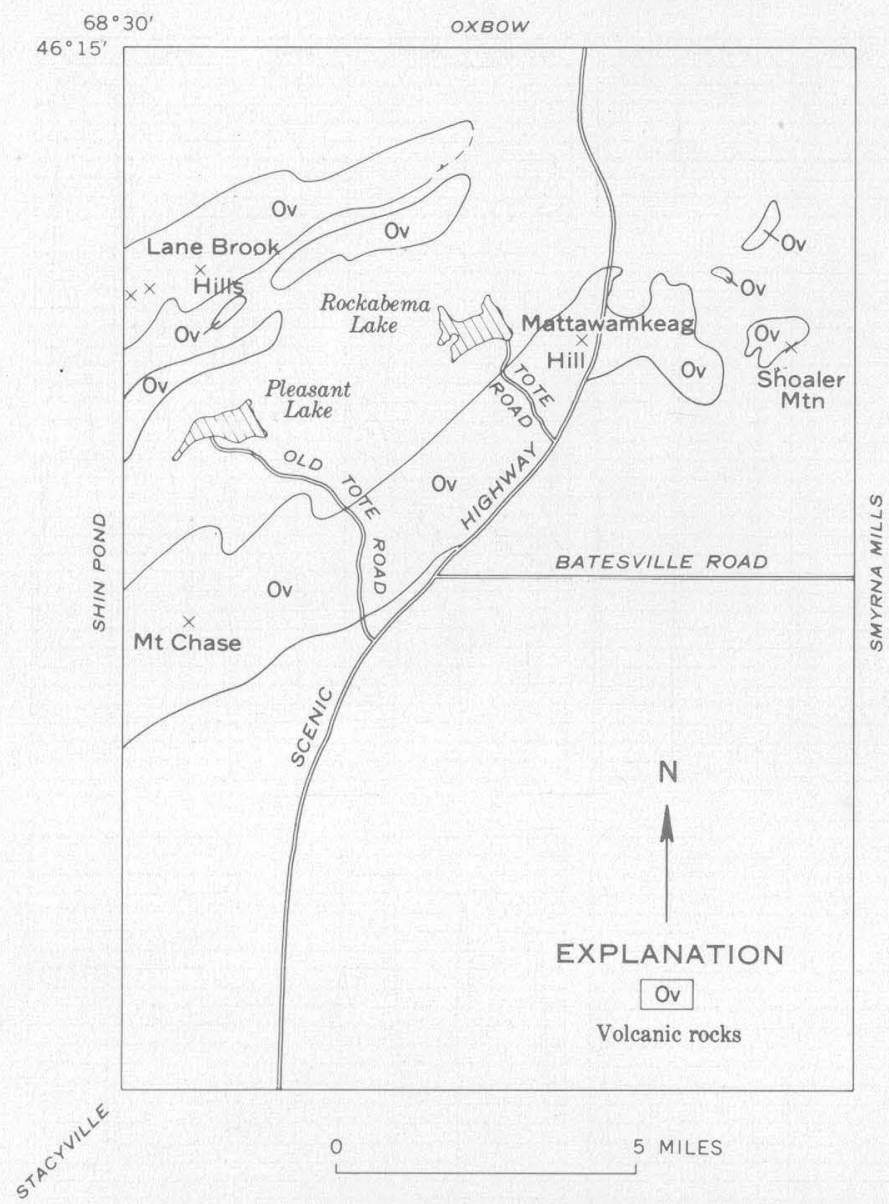

Figure 309.1. - Map of Island Falls quadrangle, Maine, showing outcrop pattern of voleanic rocks of Ordovician age.

sandstone are generally more abundant in the volcanic rocks lying northwest of Mount Chase than along any part of the Mount Chase ridge proper. Some sandstone is fossiliferous and yields brachiopods of Ordovician age (Neuman, 1960).

The Island Falls quadrangle lies in an area of lowgrade (chlorite zone) metamorphism.

Spitite.-The spilite is a dense green rock with diabasic texture (fig. 309.2) in which the plagioclase occurs mainly as twinned laths or microlites that range in composition from pure albite ${ }^{1}$ to about $\mathrm{An}_{15}$. Epidote, chlorite, sphene, and leucoxene after augite and ilmenite, fill the interstices between the plagioclase grains. The original major pyroxene, probably augite, is preserved as tiny fragments. In most specimens ilmenite or titaniferous magnetite is extensively altered to leucoxene or leucoxene-coated sphene. Tiny needles of actinolite or fibrous amphibole after pyroxene are ubiquitous; quartz is absent except in some vesicular rocks where, together with calcite, epidote, and chlorite,

\footnotetext{
1 Plagioclase compositions in most rocks were determined by comparing indices of refraction against balsam, measuring extinction angles, and determining optic sign. A few rocks were ground up and plagioclase indices determined using index oils.
}

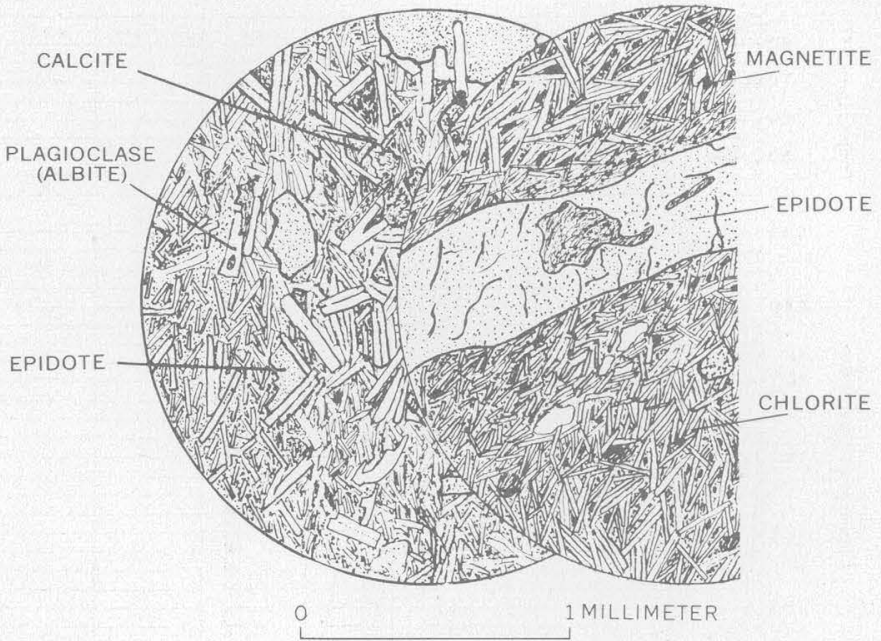

Frgure 309.2.-Spilite on trail to the lookout tower, Mount Chase. Left, Spilite showing considerable range in size of plagioclase grains; Right, Spilite consisting mostly of a dense felt of oligoclase microlites.

it fills cavities; pyrite is very abundant in some rocks but very sparse in others. The spilite appears to be partly reconstituted dense augite basalt in which the augite has been altered to epidote, chlorite, and actinolite, and the calcic plagioclase to albite or oligoclase, epidote, and calcite.

Chemical compositions calculated from modes of the spilites indicate that the average $\mathrm{Na}_{2} \mathrm{O}$ content exceeds 4 percent.

Keratophyre, keratophyre-tuff, and tuffaceous rocks.-Keratophyre, keratophyre-tuff, and sparse tuffaceous conglomerate, and conglomeratic sandstone crop out northeast of Mount Chase on the old tote roads to Rockapema and Pleasant Lakes. Slaty cleavage is well developed in these rocks and most of the fine-grained rocks are highly sheared. Common colors are light blue, green, and green gray. Most of the keratophyres in this area have flow structures; some contain rock fragments and have textures suggesting tuffs. The last named rocks are largely mylonitic, however, and shards (if they existed) have been destroyed. The conglomerate and conglomeratic sandstone contain angular to subrounded granules and pebbles of greenstone, felsite, and quartz in a chloriteand sericite-rich matrix. Some of these rocks might be termed tuff-breccias or agglomerates as they contain pumiceous boulders of greenstone, some of which are probably volcanic bombs.

Two types of keratophyre are recognized: potassic keratophyre (rare), which contains abundant phenocrysts of orthoclase and has a "glassy" groundmass, and sodic keratophyre, which contains albite phenocrysts only, and generally has a microlitic groundmass. The potassic keratophyre (fig. 309.3) contains phenocrysts 


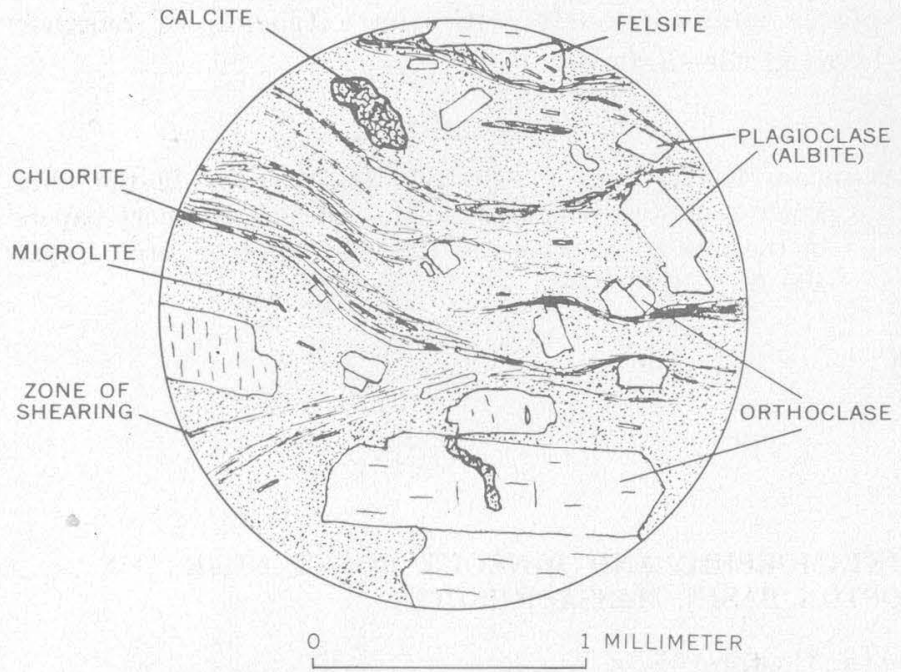

FiguRE 309.3.-Keratophyre or keratophyre-tuff rich in orthoclase. Many crystals of albite are partly altered to orthoclase. Secondary quartz occurs in patches (not visible in sketch).

of albite in addition to orthoclase and the original glassy groundmass has altered to a pale green nearly isotropic mass of chlorite, microlites of albite, quartz, a fine dust of sphene, and abundant tinty crystals of K-feldspar.

The sodic keratophyre (fig. 309.4) contains no K-feldspar as phenocrysts; staining with sodium cobaltinitrite reveals that some rocks do contain slight amounts of $\mathrm{K}$-feldspar in the groundmass. The main constituents of the groundmass are sericite, albite, quartz, and chlorite. Epidote and sphene are abundant in some rocks. The epidote probably was formed during albitization of the feldspar when abundant cal-

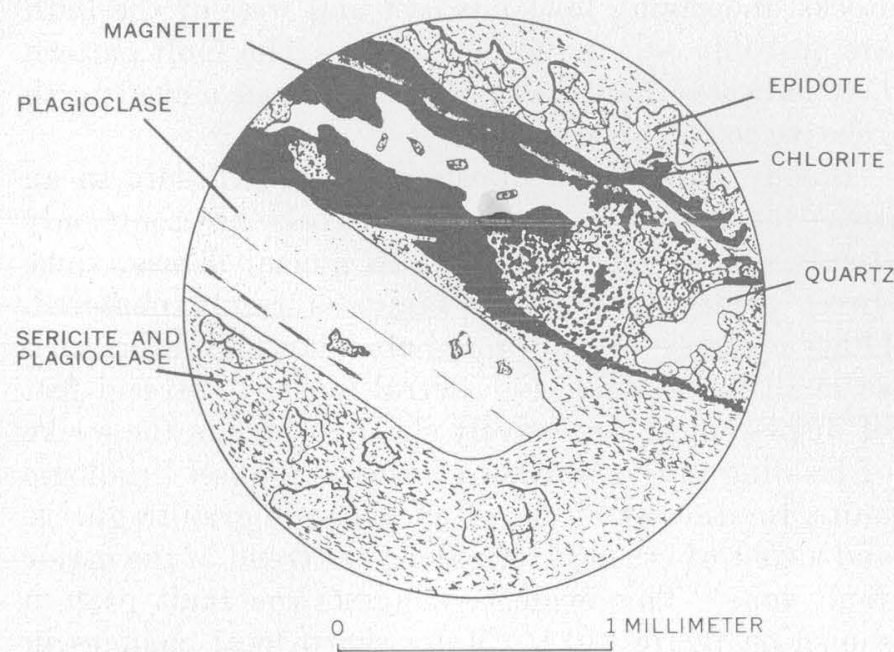

Figure 309.4.-Keratophyre rich in phenocrysts of albite. Magnetite, epidote, quartz, and chlorite occur intermixed and in alternating bands in the vein. Epidote crystals are later than the magnetite and enclose many small grains of magnetite. cium was released. Magnetite is common in tiny veinlets (fig. 309.4) as replacements in the plagioclase, and as crystals disseminated through the groundmass.

Quartz content is variable in both types of keratophyre and some rocks are quartz keratophyre. The keratophyres are altered rocks of the rhyolite and andesite-dacite clans.

Diabase.-Sills of medium-grained dark-green diabase weather to massive outcrops in many areas in the volcanic belts. The intrusive origin of the diabase is shown locally by chilled contacts and by the development of hornfels in adjacent tuffaceous sedimentary rocks.

Plagioclase shows no preferred orientation in the diabase and is generally in excess of interstitial augite (fig. 309.5). The plagioclase in most of the diabase has been saussuritized and contains epidote or zoisite. The plagioclase ranges in composition from albite to $\mathrm{An}_{25}$. Some diabase contains water-clear albite and little or no epidote or zoisite. A few rocks contain unaltered plagioclase remnants that are calcic-labradorite, and it seems probable that the original plagioclase in all the diabase was labradorite. In addition to plagioclase and augite, the diabase contains abundant actinolite, chlorite, sphene, magnetite, ilmenite, and pyrite. The actinolite and chlorite formed from the augite.

Conclusions.--The enrichment in albite in the Mount Chase volcanic rocks probably was largely independent of low-grade regional metamorphism. This conclusion is based on the fact that some of the extrusive rocks (spilites) which display pillow structure, retain

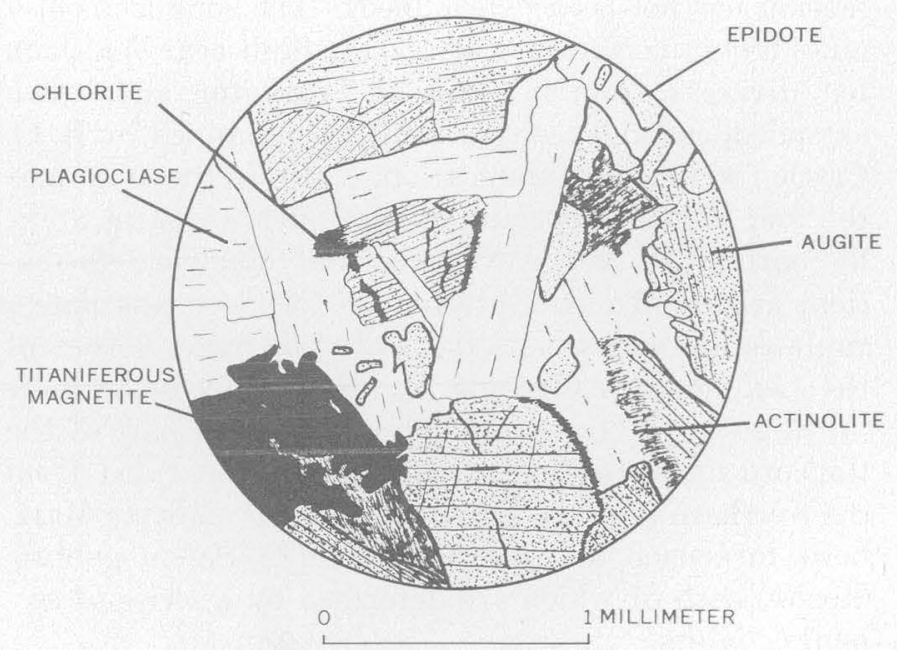

Figure 309.5.-Dark-green diabase. Augite is altered along fractures and erystal edges to pale-green actinolite and chlorite; needles of actinolite commonly extend into plagioclase crystals; plagioclase is cloudy throughout; the single crystal of titaniferous magnetite is partly altered to leucoxene. 
diabasic texture. The lack of preferred orientation of the plagioclase crystals would be unlikely if the albite originated by dynamic metamorphism.

The mineralogical similarity of the diabase to the denser spilites previously described suggests that the rocks have a common source. The diabase sills probably were intruded shortly after and possibly in some places simultaneously with the extrusion of basaltic lavas at the surface.

\section{REFERENCE}

Neuman, R. L., 1960, Pre-Silurian stratigraphy in the Shin Pond and Stacyville quadrangles, Maine, in Short papers in the geological sciences: U.S. Geol. Survey Prof. Paper $400-\mathrm{B}$, p. B166-B168.

310. POST-CARBONIFEROUS DEFORMATION OF METAMORPHIC AND IGNEOUS ROCKS NEAR THE NORTHERN BOUNDARY FAULT, BOSTON BASIN, MASSACHUSETTS

By Norman P. Cuppels, Boston, Mass.

Work done in cooperation with the Massachusetts Department of Public Works

Sedimentary rocks of Carboniferous age in the Boston Basin are separated from igneous and metamorphic rocks of Paleozoic and Precambrian(?) age north of the basin by the Northern Boundary fault (fig. 310.1). There is some evidence that the igneous and metamorphic rocks have been thrust over the sedimentary rocks along the Northern Boundary fault. Recent geologic mapping in the Concord quadrangle has revealed a fault zone of similar magnitude that may be genetically related to the Northern Boundary fault. The fault zone extends from the southwest part of the quadrangle northeastward for at least 25 miles; its southwest extension has not been determined. The zone is about 4 miles from the Northern Boundary fault near Waltham but diverges from it north of Lexington and, when extended, coincides with a fault zone mapped by $R$. $O$. Castle (written communication, 1960), in the Wilmington and South Groveland quadrangles. Stratigraphic discontinuities in the Nashoba and Marlboro formations and the Andover granite led Castle to postulate a fault zone that extends from the northwest corner of the Lexington quadrangle northeastward for 18 miles to the town of Groveland. In the eastern part of the Concord quadrangle, the fault zone is separated from the Northern Boundary fault by the Precambrian Marlboro formation and the Paleozoic(?) Salem gabbrodiorite, both of which are deformed by a series of secondary faults.

Within the Concord quadrangle, the newly mapped fault zone is best exposed in a road cut at Bloody Bluff. The center of the bluff is a medium-grained diorite containing andesine plagioclase and blebs of pink microcline. On the east side of the bluff, constituent mineral grains of the diorite are severely deformed and altered, producing a light-green rock mottled red in which grain boundaries are very hazy. A thin section of this altered rock shows sericitized and deformed plagioclase, much epidote and calcite, and no ferromagnesian minerals. Severe shattering of the rock has resulted in many closely spaced and randomly oriented fractures, in part coated with hematite. Two major fault planes 35 feet apart are exposed in the outcrop; they trend N. $25^{\circ}$ E. and $\operatorname{dip} 40^{\circ}$ to $60^{\circ} \mathrm{NW}$. Subsidiary faults, not shown on the map, have the following attitudes: strike N. $55^{\circ}$ E., $\operatorname{dip} 80^{\circ} \mathrm{NW}$.; strike N. $80^{\circ}$ E., dip $90^{\circ}$; strike E., dip $75^{\circ} \mathrm{S}$; ; and strike N. $75^{\circ}$ W., dip $90^{\circ}$. Rocks underlying lowlands east and west of the bluff are probably within the fault zone. The fault pattern here indicates that the east side of the zone moved north relative to the west side.

Bloody Bluff is an unusually good exposure in an area where thoroughly fractured rocks are commonly deeply eroded and covered with glacial debris; thus, direct evidence of major faults is rarely observed. Other evidence of faulting is abundant, however, such as small faults that have several inches to several feet of displacement, excessively sharp swings in the strike of bedding in the Marlboro formation, offset lithologic units, rotation of blocks of an alaskitic granite gneiss, and a zone of crushed rock along the trend of the major fault zone. This evidence suggests the fault pattern shown on figure 310.1. Many sharp local changes in the strike of bedding (from northeast to northwest) in the Marlboro formation occur in the area one mile south of Bloody Bluff to the sharp bend in the Northern Boundary fault near Waltham. LaForge (1932) also 


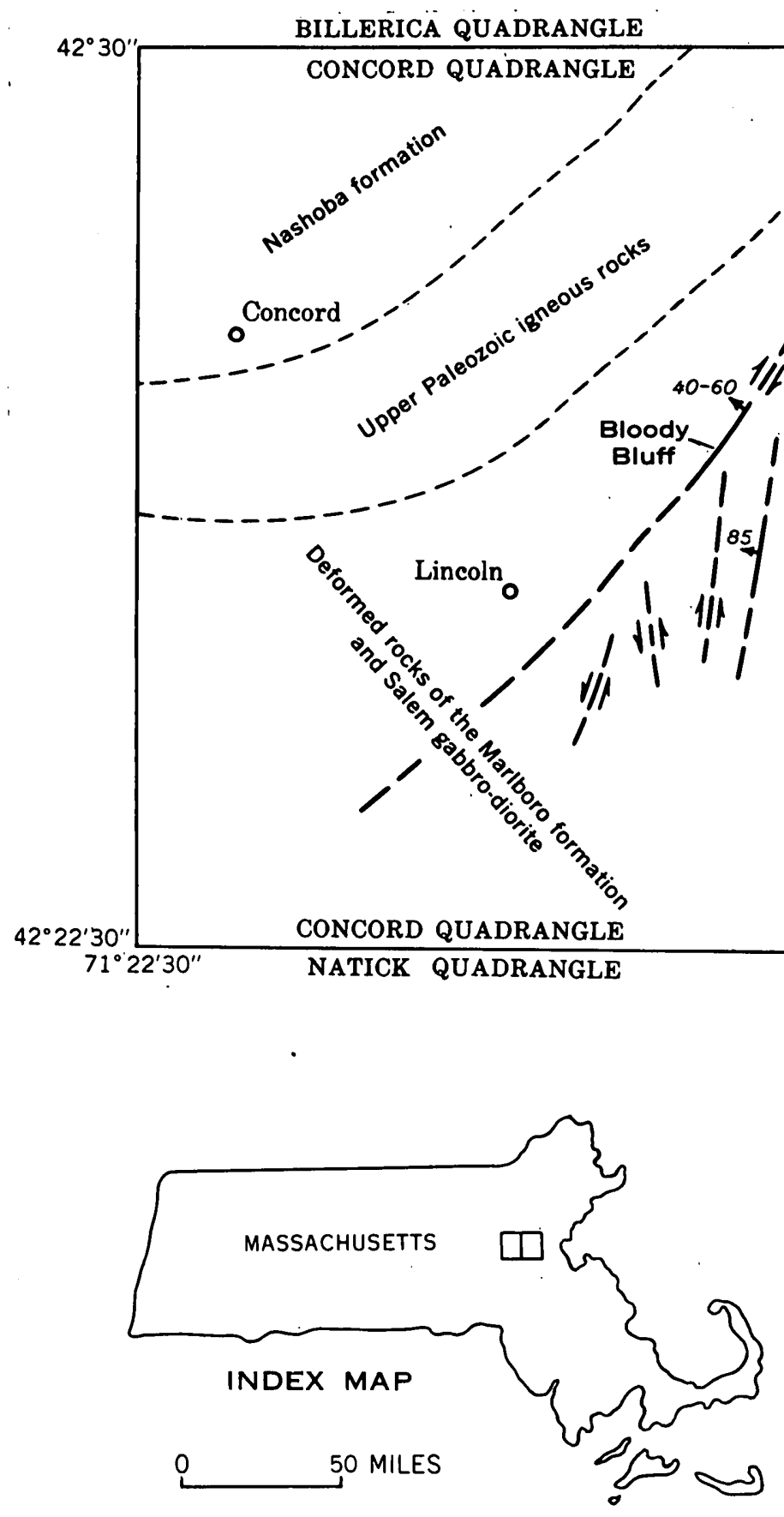

WÏLMÏNGTON QUADRANGLE 
mapped similar northwesterly strikes on an extension of this alinement of structural anomalies in the Marlboro formation near the Northern Boundary fault. The deformation which produced these fault structures is one of the youngest tectonic events in eastern Massachusetts because the faults displace Andover granite of
Carboniferous age- the youngest rock cut by the fault zone.

\section{REFERENCE}

LaForge, Laurence, 1932, Geology of the Boston area, Massachusetts: U.S. Geol. Survey Bull. 839, 105 p.

\title{
311. A REgIONAL FAULT IN EAST-CENTRAL MASSACHUSETTS AND SOUTHERN NEW HAMPSHIRE
}

\author{
By Robert F. Novotny, Boston, Mass.
}

Work done in cooperation with the Massachusetts Department of Public Works

Geological reconnaissance in east-central Massachusetts and southern New Hampshire, in conjunction with detailed bedrock mapping of the Clinton quadrangle, Massachusetts, has shown that a major fault zone extends from the Sterling quadrangle, Massachusetts, northward into Hollis township in the Milford quadrangle, New Hampshire. However, because outcrops are few, a more detailed study is necessary to trace the fault farther northward into New Hampshire. The geologic map of New Hampshire (Billings, 1955) and the geologic map of the Manchester quadrangle, New Hampshire (Sriramadas, 1955) ${ }^{1}$ show faults and zones of silicified rock that could be the northeastward extension of the fault discussed here.

The relative vertical movement on the fault shown on figure 311.1 was determined on the basis of the stratigraphic sequence found south of the Clinton quadrangle (in the Shrewsbury quadrangle). There the Worcester formation unconformably overlies the older Oakdale quartzite; both formations are of Carboniferous age or older. The trace of the fault is marked by swamps, glacial outwash, and steep-walled stream valleys. The fault plane is not exposed; however, outcrops of both the Worcester formation and the Oakdale quartzite are sufficiently abundant and are so located as to insure a reasonable degree of accuracy in establishing the position of the fault.

In the Clinton quadrangle, the fault is indicated by the juxtaposition of the Oakdale quartzite and the Worcester formation, which have noticeably divergent strikes and dips. In general, the Oakdale quartzite strikes N. $20^{\circ}$ to $30^{\circ} \mathrm{E}$. and dips $50^{\circ}$ to $70^{\circ} \mathrm{SE}$; the

\footnotetext{
${ }^{1}$ Sriramadas, Aluru, 1955, Geology of the Manchester quadrangle, New Hampshire: Unpub. Ph. D. thests, Harvard Univ., 1.42 p.
}

Worcester formation, southeast of the fault, strikes approximately north and $\operatorname{dips} 60^{\circ}$ to $70^{\circ} \mathrm{W}$.

In the Shirley and Townsend quadrangle, zones of breccia and silicified rock (fig. 311.1) mark the fault zone. The southern breccia zone consists of Oakdale quartzite which has been intensely folded, faulted, and fragmented. Axes of recumbent drag folds strike N. $55^{\circ}$ E. and $\operatorname{dip} 10^{\circ} \mathrm{NW}$.; the axial planes strike N. $75^{\circ}$ E. and dip $10^{\circ} \mathrm{NW}$. The plane of a subsidiary fault, which apparently caused the folds, strikes N. $40^{\circ}$ E. and dips $25^{\circ} \mathrm{SE}$.; sulfides have been introduced along

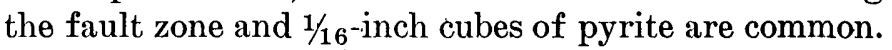
The entire outcrop in which the subsidary fault is exposed is limonite stained. The northern breccia zone (fig. 311.1) consists of Oakdale quartzite fragments in a very fine light gray-green to black matrix. Some minor silicification has also occurred in this zone.

The zone of silicified rock and large milky quartz veins completely occupies a hill 1,100 fret long and 400 feet wide in the Shirley quadrangle (fig. 311.1). The silicified angular rock fragments are pale-gray Oakdale quartzite. A rather consistent slabby parting strikes N. $20^{\circ}$ E., parallel to the orientation of the hill, and dips $79^{\circ} \mathrm{NW}$.; it may indicate a minor amount of movement after the major faulting and silicification. A single silicified zone in the Townsend quadrangle (fig. 311.1) also contains fragments of Oakdale quartzite and extensive quartz veins. This zone consists of many large outcrops of silicified rock found for a distance of about 1 mile parallel to the fault. Both of the silicified zones mentioned are on the west side of the fault, and both are bordered on the eist side by steep-walled stream valleys.

Slickensided rocks north of the Massachusetts-New Hampshire boundary, indicate the extension of the 
fuult. In this area rocks east of the fault strike N. $47^{\circ}$ E. and $\operatorname{dip} 80^{\circ} \mathrm{NW}$; and those west of the fault strike N. $26^{\circ} \mathrm{E}$. and $\operatorname{dip} 78^{\circ} \mathrm{NW}$.

Throughout most of the area examined the fault brings the Worcester formation against the Oakdale quartzite, as mapped by Emerson (1917, fig. 2). It seems possible that the fault may extend south ward into the Worcester North quadrangle and that the isolated body of Worcester formation containing the abandoned Worcester "coal" mine (fig. 311.1) may be bounded on one side by the fault.

\section{REFERENCES}

Billings, M. P., 1955, Geologic map of New Hampshire: U.S. Geol. Survey.

Emerson, B. K., 1917, Geology of Massachusetts and Rhode Island : U.S. Geol. Survey Bull. 597, 289 p.

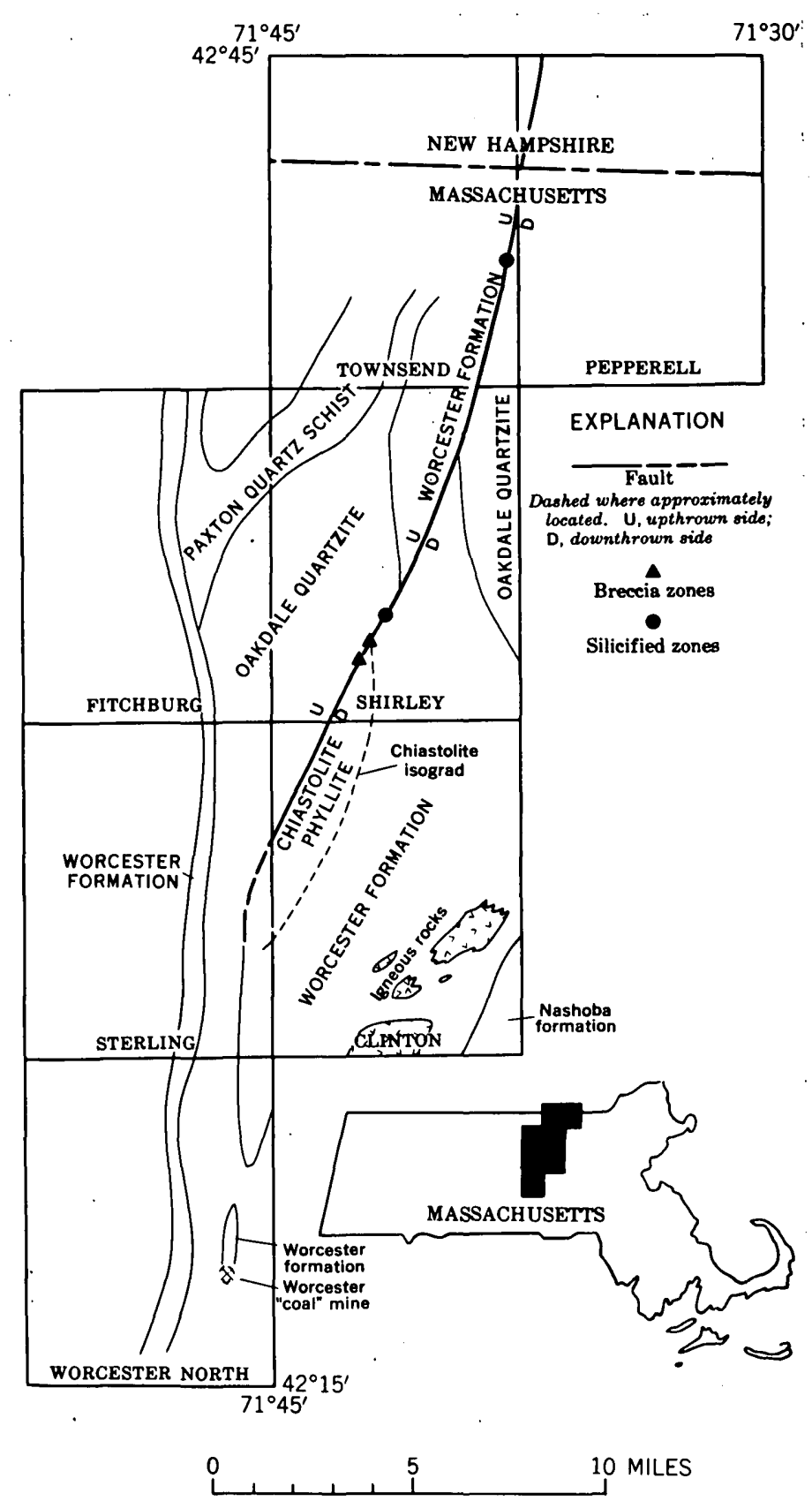

Fraure 311.1.-Generalized geologic map of part of east-central Massachusetts. Geology, except for Clinton quadrangle, modified after Emerson (1917). Names of topographic quadrangles shown in the lower parts of the quadrangles. 


\title{
312. GROUND WATER IN EOCENE ROCKS IN THE JACKSON DOME AREA, MISSISSIPPI
}

\author{
By Joseph W. Lana, Jackson, Miss.
}

Work done in cooperation with the city of Jackson, Mississippi

The Jackson dome is a large elongate fold near the center of the Gulf Coastal Plain in central Mississippi. The dome was formed in Late Cretaceous time, and folding continued into the early Tertiary. The depositional environment and structural history of the Jackson area and nearby parts of the Coastal Plain have been described by Russell (1940), Fisk (1944), Kay (1951), Monroe (1954), Bornhauser (1958), and others. In brief, during early Tertiary time great deltaic masses spread out over central Mississippi and encroached upon the Gulf of Mexico for long intervals followed by periods of less rapid sedimentation. Delta building reached a peak during early Eocene, began to slacken during middle Eocene, and had almost ceased by late Eocene. Areas on the flanks of Jackson dome sank slowly and received relatively large amounts of sediment, but the dome itself stood firm or sank relatively slowly, and formed a barrier to the sea as it advanced and retreated across the area. Lignitic beds are especially numerous in Eocene rocks on the northeastern side of the dome, and indicate that swampy conditions existed there for long periods of time.

The Eocene rocks in the Jackson dome area are assigned, from youngest to oldest, to the Wilcox, Claiborne, and Jackson groups as follows:

Jackson group (formations not listed).

Claiborne group:

Cockfield formation

Cook Mountain formation

Sparta sand

Zilpha clay

Winona sand

Tallahatta formation

Wilcox group (formations not listed).

Rocks of the Wilcox group are more than twice as thick along the Mississippi River than on Jackson dome about 30 miles to the east; the Claiborne group, which is about 2,400 feet thick along the Mississippi River, is only 1,100 feet thick on the dome.

Figure 312.1 indicates the location and size of the Jackson dome, and the source and distribution of ground-water supplies in the Jackson dome area. The aquifers commonly encountered are sandstone in the upper part of the Wilcox group, and the Sparta and Cockfield formations in the upper part of the Clai- borne group. Shallow wells in the southern part of the area find water in the Oligocene sands.

Jackson, Miss., which is on top of the dome, obtains its municipal water from the Pearl River, but about 12 million gallons of ground water a day is withdrawn from the Eocene aquifers, mostly for suburban public systems, industries, hotels, and office buildings. In addition, more than 3,000 privately owned wells in Eocene rocks supply domestic needs in surrounding rural areas.

Wells producing water from the Wilcox group are not shown on figure 312.1. Only a few wells have been drilled to the Wilcox; the water is soft, moderately mineralized, and of the sodium bicarbonate-bearing type.

The influence of the Jackson dome on the thickness of the younger Sparta and Cockfield formations is shown by the isopach maps, figure 312.2. Water is produced from the Sparta in a much smaller area than from the Cockfield, but the Sparta is present throughout the Jackson area and is an important potential source of supply. Except on the crest of the dome, the Sparta is too deep to be drilled economically; nevertheless, wells in the Sparta produce about 80 percent of the ground water in the Jackson area, and more than 75 percent of the wells are within an 8-mile radius of downtown Jackson. The Sparta thickens rapidly southwestward across the area (fig. 312.2), but the places of greatest thickness do not contain thicker or more extensive bodies of sand.

The Sparta sand consists of alternating beds of sand, silt, clay, and lignite. The sand is angular, micaceous, well sorted, fine to medium grained, and commonly more coarse in the lower part of the formation. Thick sand beds at one locality have clayey counterparts elsewhere. Variations in transmissibility (permeability times formation thickness) are large because of these local facies changes. Some beds of more permeable sand are continuous for miles in narrow sinuous bands, and these beds probably are sand-filled channels of ancient streams. A belt of coarse sand on the northern flank of the Jackson dome offers good prospects for large yields of ground water from the Sparta, whereas a few miles farther north a belt of clayey and lignitic rocks offers poor prospects. Glauconite is common in the formation and indicates a neritic or littoral deposi- 


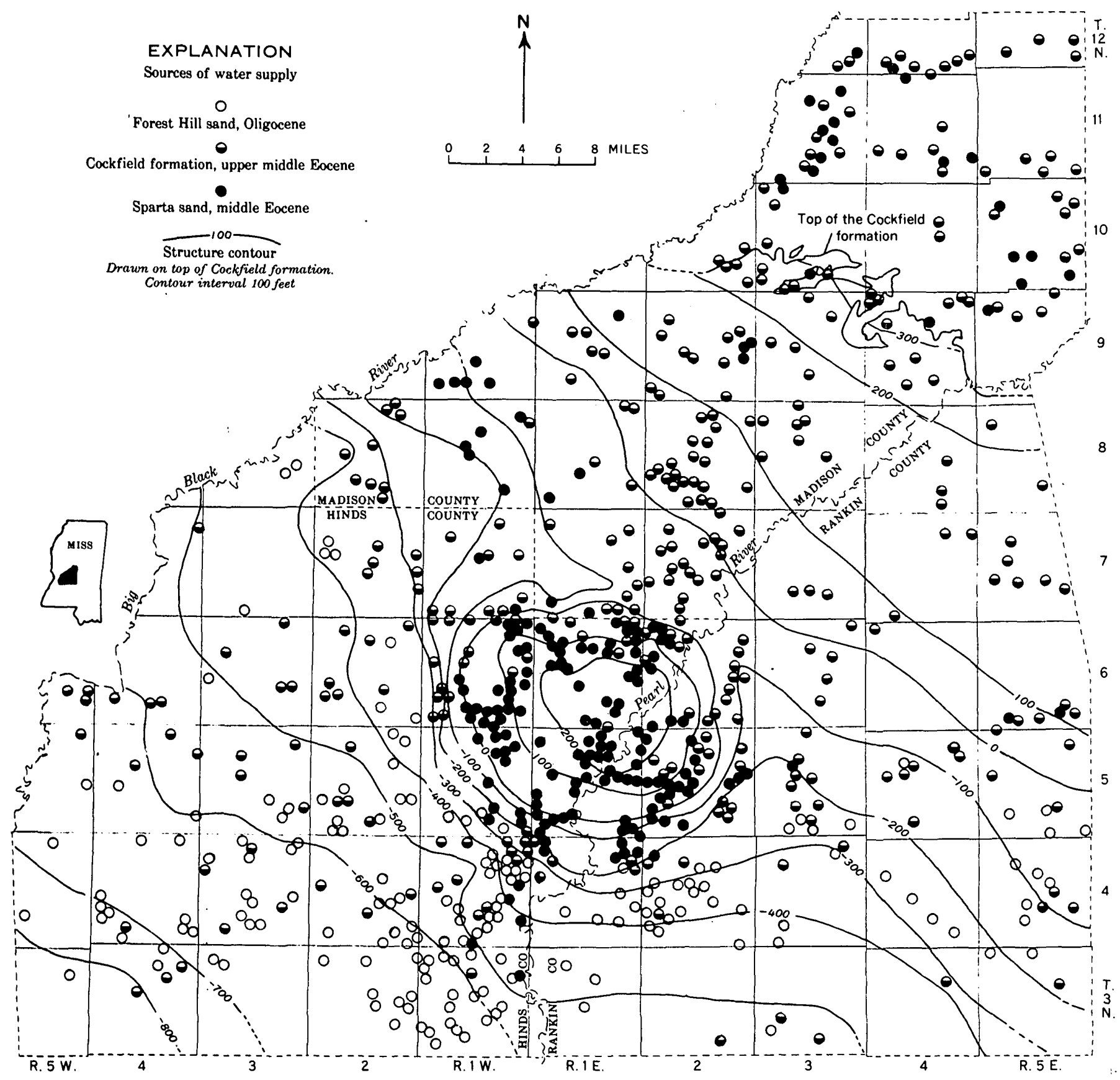

FIGURE 312.1.-Source of ground-water, Jackson area, Mississippi.

tional environment. Amber-colored ground water, particularly northeast of Jackson, indicates lignitic deposits in the sands or associated clays.

Water from the Sparta is of a soft sodium bicarbonate-bearing type, and the total dissolved solids range from 166 to $744 \mathrm{ppm}$ (parts per million). Color varies according to the amount of lignite present, and several wells have been abandoned or drilled deeper to avoid dark amber colored water. Temperature of the water averages about $80^{\circ} \mathrm{F}$ and a few wells yield water warmer than $85^{\circ} \mathrm{F}$ - the warmer waters are on the crest of the dome.

The Cockfield formation is similar to the Sparta in lithology but the Cockfield contains finer grained sands. The formation is about 200 feet thick on the Jackson dome where it crops out at a few places; it thickens rapidly on the flanks of the dome and attains a thickness of 570 feet about 25 miles southwest of Jackson. Hard water occurs at the outcrop, but base exchange downdip causes softening. Compared with water in the 

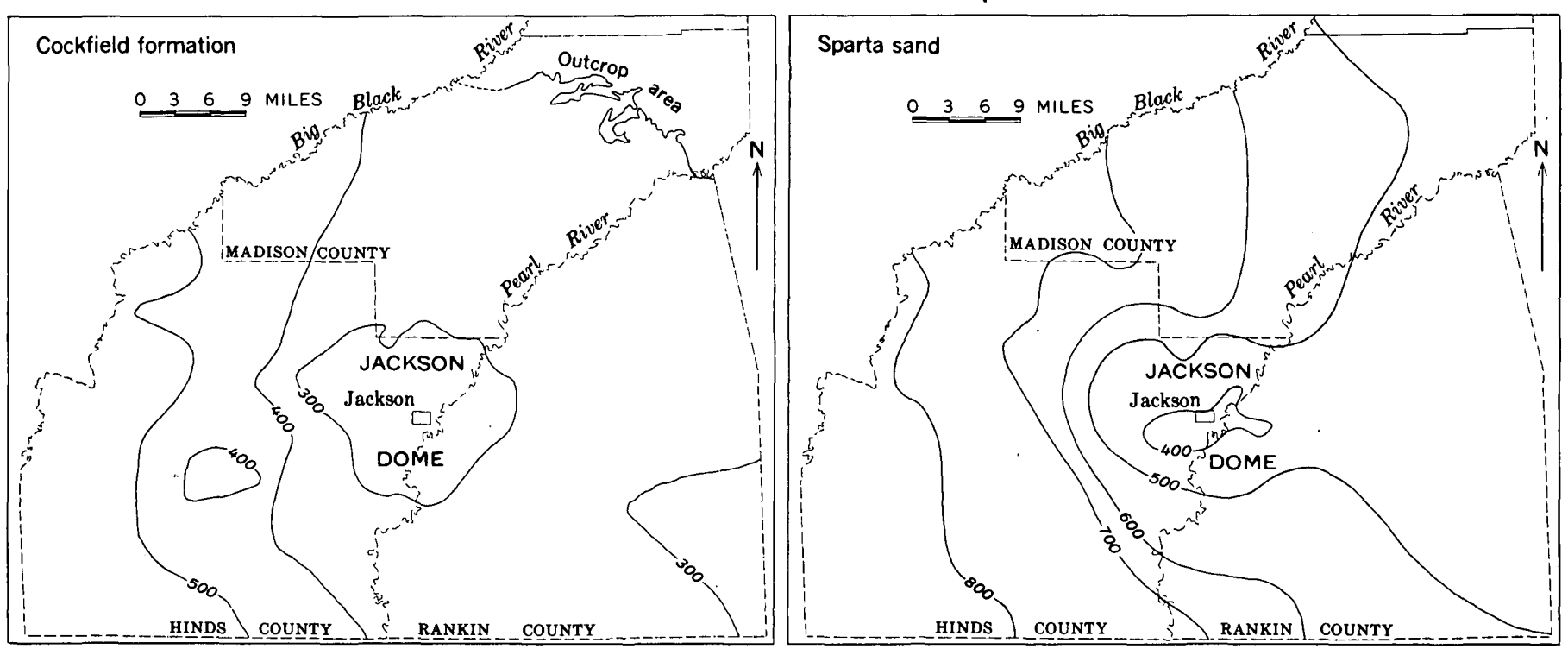

FigURE 312.2.-Isopach maps showing influence of Jackson dome on thickness of the Cockfield and Sparta formations, Jackson area, Mississippi. Thickness interval 100 feet.

Sparta formation, the amounts of sulfate, chloride, and dissolved solids in the Cockfield are high.

\section{REFERENCES}

Bornhauser, Max, 1958, Gulf Coast tectonics: Am. Assoc. Petroleum Geologists Bull., v. 42, p. 339-370.

Fisk, H. N., 1944, Geological investigation of the alluvial valley of the lower Mississippi River: Mississippi River Comm., $78 \mathrm{p}$.
Grim, R. E., 1936, The Eocene sediments of Mississippi : Mississippi Geol. Survey Bull. 30, 240 p.

Kay, Marshall, 1951, North American geosynclines: Geol. Soc. America Mem. 48, 143 p.

Monroe, W. H., 1954, Geology of the Jackson area, Mississippi : U.S. Geol. Survey Bull. 986, 133 p.

Russell, R. T., 1940, Quaternary history of Louisiana [abs.] : Geol. Soc. America Bull., v. 51, p. 1228.

\section{NATURAL MOVEMENT OF GROUND WATER AT A SITE ON THE MULLICA RIVER IN THE WHARTON TRACT, SOUTHERN NEW JERSEY}

By S. M. Lana, Trenton, N.J.

Work done in cooperation with the New Jersey Division of Water Policy and Supply

The Wharton Tract, which includes about 100,000 acres in the Pine Barrens region of southern New Jersey (fig. 313.1), was purchased by the State in 1954 for a water reserve to meet future water requirements in the Camden and Atlantic City areas. An investigation was begun in 1956 to determine the feasibility of developing the water resources of the tract by means of wells. On the basis of a reconnaissance study of the geology of the tract, a test site of about 15 acres was selected $21 / 2$ miles north of the village of Batsto.

The Mullica River, which is incised rather shallowly into the underlying sand, crosses the test site. The total relief is about 10 feet between the stream bed and the upland areas on both sides of the river. Swampy areas are present on each side, the more extensive area being along the east bank. Except during periods of high flow, the swampy tracts stand above river level; however, they are wet at all times because they are areas of ground-water seepage.

A rectangular location grid was established in the test area and the nodes of the grid were the sites of observation wells. Except for one 8 -inch well, all observation wells are $11 / 4$ inches in diameter.

The Wharton Tract is underlain by the Cohansey 


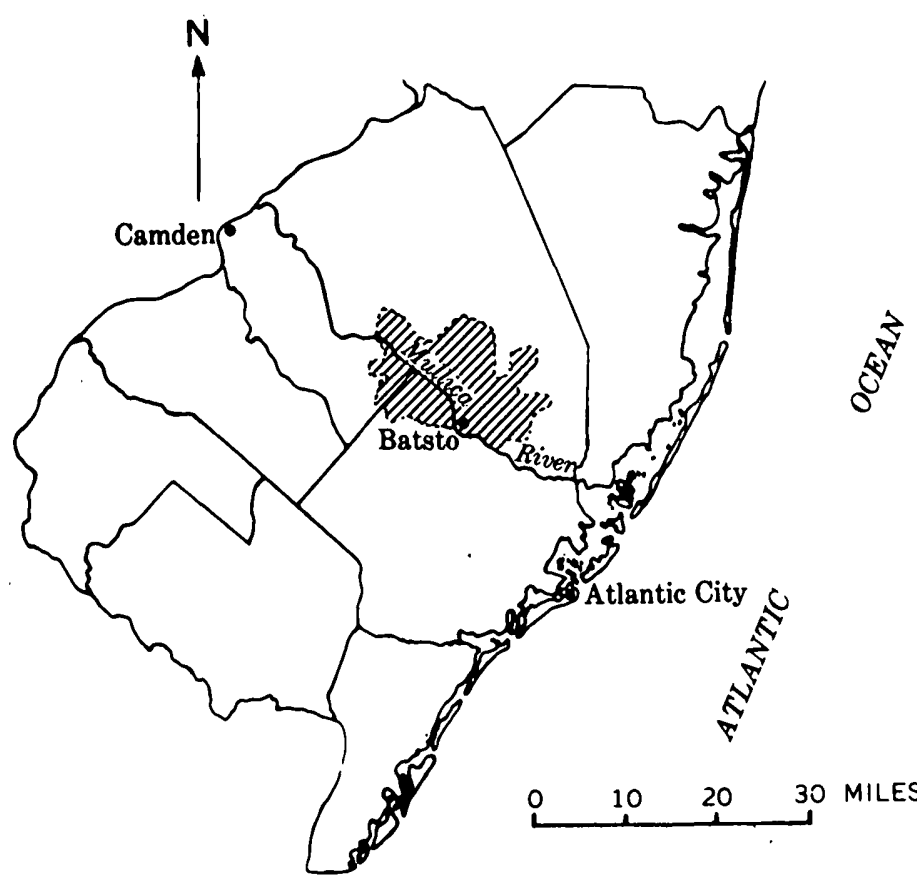

Figure 313.1.-Map of southern New Jersey showing the location of the Wharton Tract (crosshatched).

sand of Miocene(?) age which has a thickness at the test site of approximately 200 feet. The formation is water bearing and consists of laminae of fine, medium, and coarse sand and minor amounts of clay. Cores collected from one test hole indicate clay at depths ranging from 25 to 26 feet and from 82 to 88 feet below land surface; however, at the deeper level the clay occurs mostly in stringers $1 / 4$ - to $1 / 2$-inch thick, and as a coating on the sand grains. In the 8-inch observation well, clay was found at a depth of approximately 31 feet and again at a depth of 81 feet. There are also traces of clay in the interval 65 to 81 feet. At most sites a group of three wells were drilled to different depths according to the expectation that clay would be present at depths ranging from 25 to 30 feet and from 81 to 88 feet; a well about 25 feet deep was drilled above the first clay layer, a well about 50 feet deep was drilled between the clay layers, and a well about 100 feet deep below the deeper clay layer. It was found that the upper clay layer is not continuous throughout the test site and that the lower layer, although continuous, dips to the southeast. Strata to a depth of 100 feet on the upland east of the river, therefore, form a single thick water-table aquifer. The wells were developed to provide hydraulic continuity with the aquifer, and water levels were measured in the wells periodically to study the interconnection of the ground water and the river under natural conditions.

Field data indicate that each water-bearing zone has i relatively uniform flow pattern. Figures 313.2313.4 show by means of contours the shape of the piezometric surface on June 9, 1960, for each waterbearing zone. The comparison of water-level elevations at each site indicates vertical movement between the various water-bearing zones. For example, the elevations in the shallow wells along the western edge of the test site are higher than those in the medium and deep wells, indicating that this area is one of recharge from the shallow to the medium and deeper water-bearing zones. In the vicinity of the Mullica River the head relationship is reversed, indicating that the movement between units is vertically upward.

Inasmuch as the Mullica River is an effluent stream (receives water from the zone of saturation), the expected pattern of movement in the adjacent aquifer would be essentially perpendicular to the stream; water in the shallow zone would be expected to discharge directly into the stream, and the water in the deeper zones would be expected to move vertically upward to the stream. Moreover, underflow in the strata beneath the stream would be expected to move in the same direction in which the stream is flowing, which in this area is south. However, the data indicate that the hydraulic continuity between the aquifer and the stream is poor, and that the underflow moves in a direction opposite to that in which the stream is flowing.

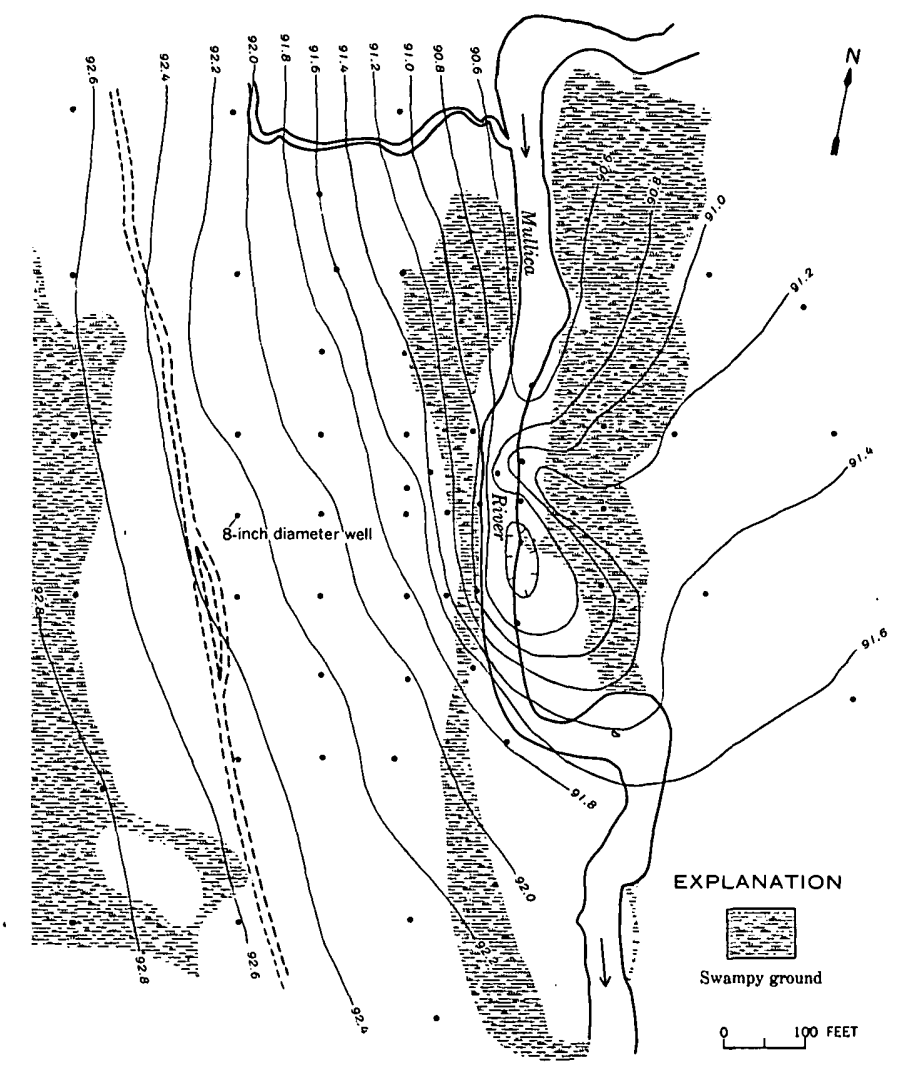

Figure 313.2.-Wharton Tract field showing location of wells and water level for the shallow water-bearing zone on June 9 , 1960. Contour. interval 0.2 foot; datum assumed. 


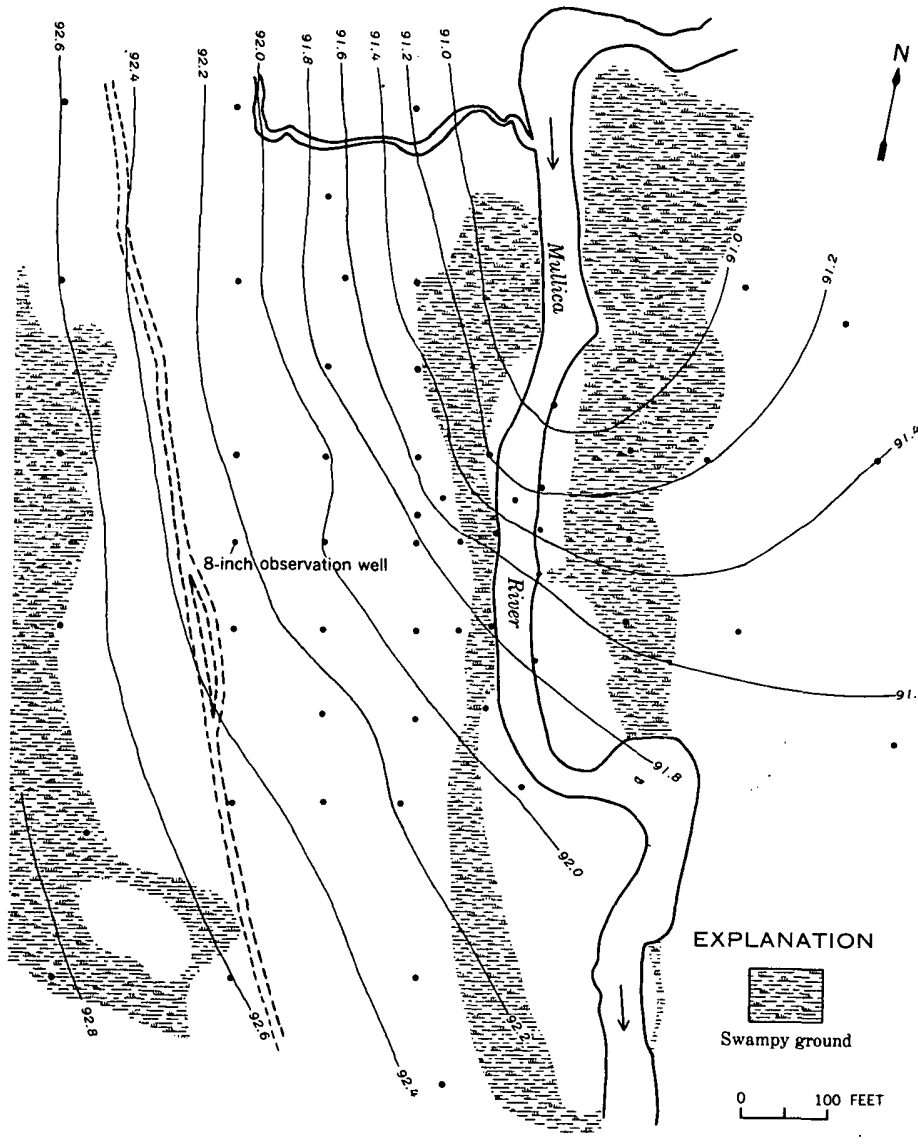

Figure 313.3.-Wharton Tract field showing location of wells and water level in intermediate water-bearing zone on June 9, 1960. Contour interval 0.2 foot; datum assumed.

Figure 313.2 indicates two areas of discharge for water in the shallow layer. One is the area outlined by the closed contour at the center of the field where the discharge is by means of vertical leakage upward into the stream. The second appears to be the major area of discharge, and is in the northern part of the area at about the confluence of the river and its tributary flowing in from the west.

Underflow in an opposite direction to that in which the stream is flowing is shown by the northerly sloping piezometric surface, illustrated by the contours, in the intermediate and deeper water-bearing layers (figs. 313.3 and 313.4); the contours show ground water moving toward the river in the northern part of the field. The lack of continuity betwen the stream and the water-bearing layers beneath is largely the result of confinement due to impervious materials in the stream bed and in the swampy areas adjacent to the stream. The impervious material is mostly bog iron ore produced by the precipitation of iron oxide in sand near the surface.

Chemical analyses of samples of ground water show iron concentrations greater than $11 \mathrm{ppm}$. Water having these high concentrations of iron moves upward from the shallow ground-water body to the stream, and the iron is oxidized and precipitates in the near-surface layer of sand. It is likely. that eventually the present stream bed will become almost impervious and ground water will seek other areas for discharge.

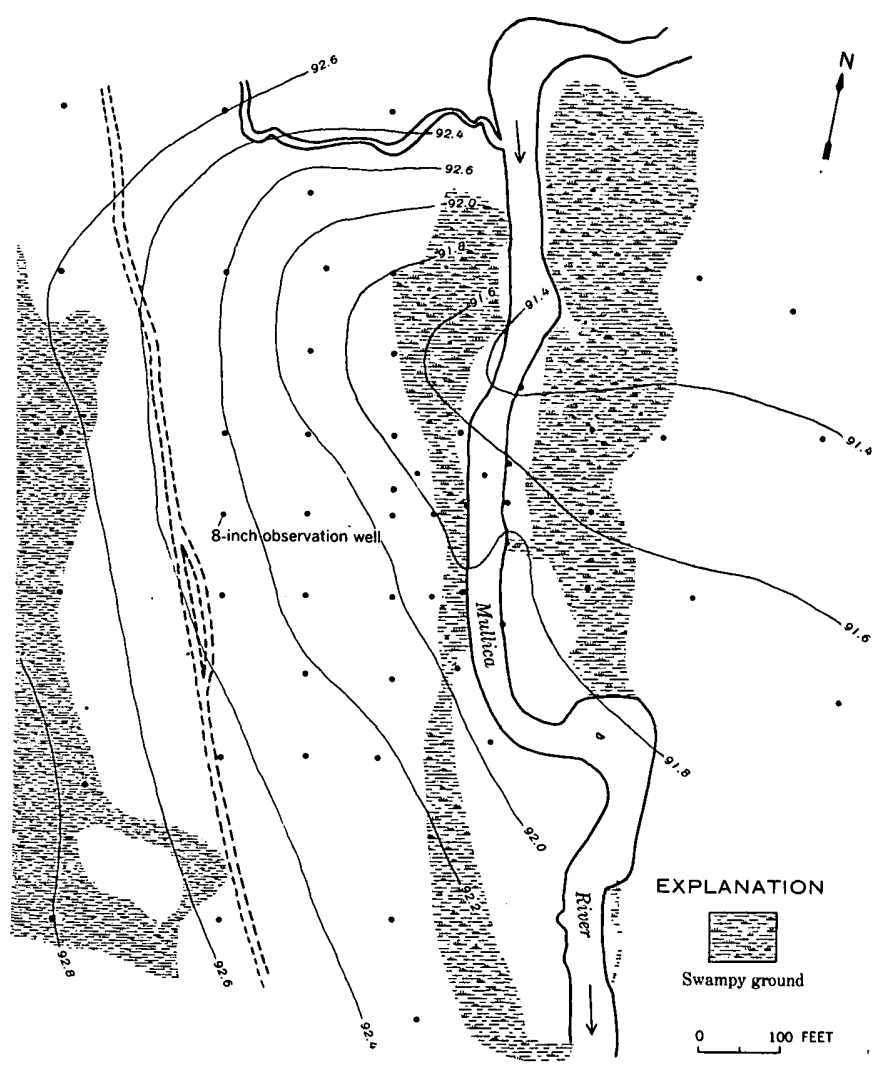

Figuke 313.4.-Wharton Tract field showing location of wells and water level in deep water-bearing zone on June 9, 1960. Contour interval 0.2 foot; datum assumed. 
SHORT PAPERS IN THE GEOLOGIC AND HYDROLOGIC SCIENICES, ARTICLES 293-435

\title{
314. VARIATION IN TEMPERATURE OF TWO STREAMS ON LONG ISLAND, NEW YORK
}

\author{
By Edward J. Pluhowski, Mineola, N.Y.
}

Work done in cooperation with Suffolk County, N.Y.

Temperatures of different streams on Long Island occiasionally vary widely on the same day, and significant temperature variations have been noted, also, between points along the sime stream. Large groundwater: inflow characterizes all streams on Long Island, and the stream temperatures are greatly influenced by ground-water temperatures. Air temperatures also have an influence. Two representative streams, Sampawams Creek at Babylon and Champlin Creek at Islip, were studied to determine the relative effects of air and ground-water temperatures on the stream temperatures.

At the Sampawams Creek gaging station a 3-element thermograph was installed to obtain air, stream, and ground-water temperatures simultaneously; at the Champlin Creek gaging station a continuous recorder was installed to obtain stream temperature and water stage. Expanded scale thermometers were used to obtain water-temperature observations manually at other sites.

The relative size and location of ponds, amount of ground-water inflow, and channel slopes of both streams are indicated on figure 314.1. On Champlin Creek, pondage is confined mainly to the lower reaches with very little pondage upstream from the gaging station. On Sampawams Creek there is one large pond and several smaller ones upstream from the gaging station, and a large one downstream at Montauk Highway. Ground-water inflow, as indicated by the increase in mean annual discharge, is small at the heads of the streams but increases in the middle reaches.

As shown by figure 314.2 , the highest and lowest stream temperatures of both streams occur in the same months as the highest and lowest air temperatures, whereas the insulating effect of soil cover causes extremes of ground-water temperature to lag by about 2 months.

A greater total area of ponds above the Sampawams Creek gage resulted in a larger variation in monthly water temperatures at that gage $\left(28^{\circ} \mathrm{F}\right)$ than at the Champlin Creek gage $\left(18^{\circ} \mathrm{F}\right)$. During the summer, ponds raise stream temperatures by absorbing solar radiation, but during the winter ponds lower the stream temperatures by increasing the rate of heat loss from the stream to the colder air.

Large ground-water inflow sharply reduces the seasonal variation of temperature along the middle reaches of both streams. This effect is shown by four series of temperature observations made on Champlin Creek (fig. 314.3). These observations indicate that the variation in temperatures is less than $20^{\circ} \mathrm{F}$ at Walnut Street and at Islip Boulevard where the rate of ground water inflow is high, and that the variation is greater upstream and downstream from these points.

Variations in solar radiation during the year cause a greater diurnal fluctuation in stream temperature in the spring and summer than in the fall and winter. In the fall and winter, when days are short and the cloud cover is at a maximum, temperature fluctuations are small. In the spring, when days lengthen and cloudiness decreases, the greater absorption of solar energy produces higher daytime stream temperatures, whereas the ground-water is still quite cold and its inflow depresses nighttime temperatures.

On a cloudy day, July 14, 1959, stream temperatures of Sampawams Creek at 2 of the 3 sites shown on figure 314.4 dropped gradually throughout the day, but at one site they increased slightly. On a sunny day, August 13, 1959, a definite warming occurred at each site between 8 a.m. and 3 p.m., followed by a gradual drop in temperature. The large variation in temperature $\left(17^{\circ} \mathrm{F}\right)$ observed at Bay Shore Road on August 13 was due to a small shallow pond just upstream. The pond is small enough to have its contents completely replaced overnight by cool ground-water inflow. During daylight hours the upper layers of the pond are rapidly heated so that its outflow produces the sharp temperature rise noted on figure 314.4.

The combination of a high rate of ground-water inflow and little or no upstream pondage tends to raise stream temperatures in winter and to lower them during the summer; low inflow and pondage produce the opposite effect. The diurnal fluctuation in stream temperature depends on the absorption of solar energy; however, ground-water inflow tends to minimize temperature fluctuation. 


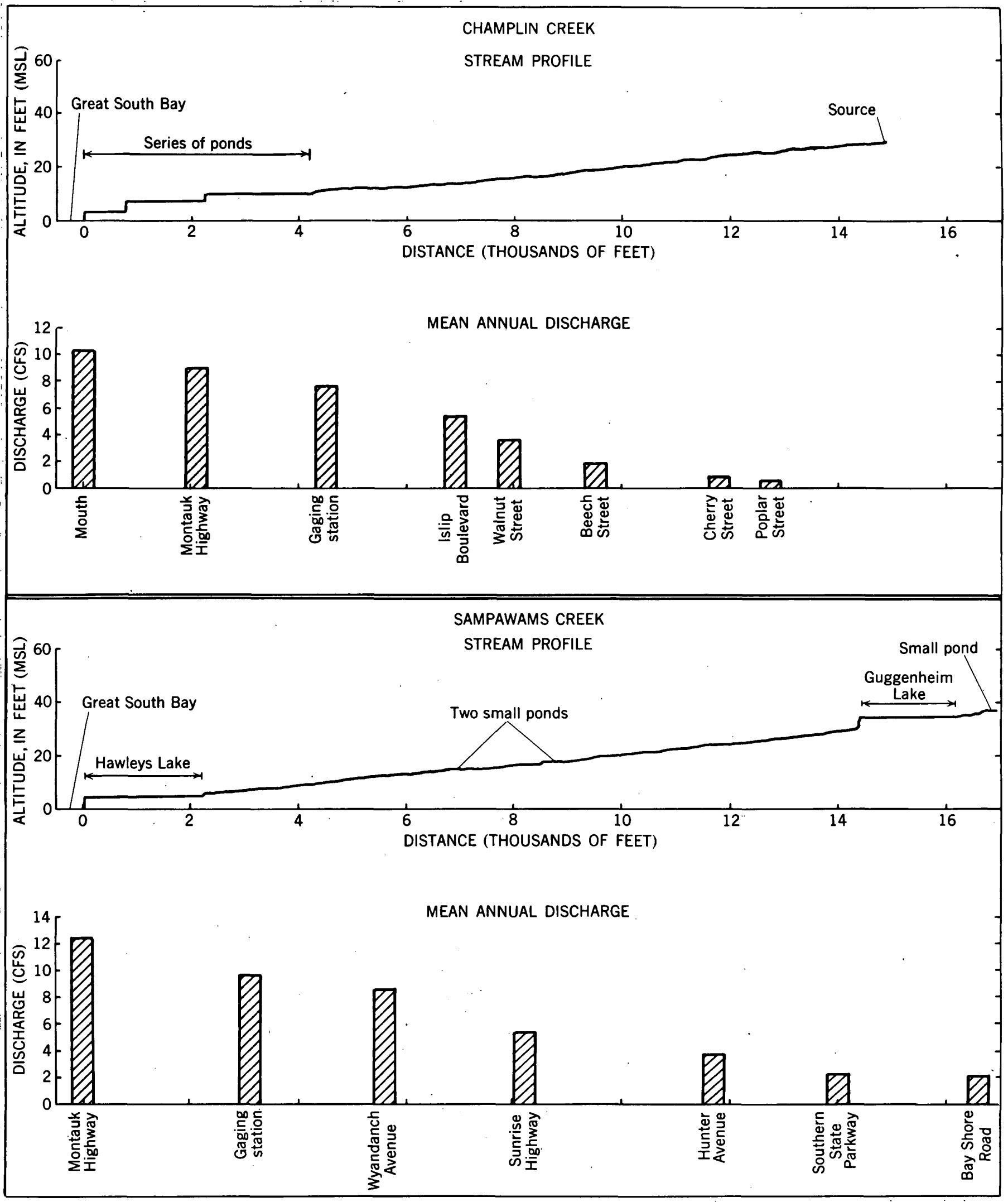

FraURe 314.1.-Stream profiles and mean annual discharge at selected sites. 


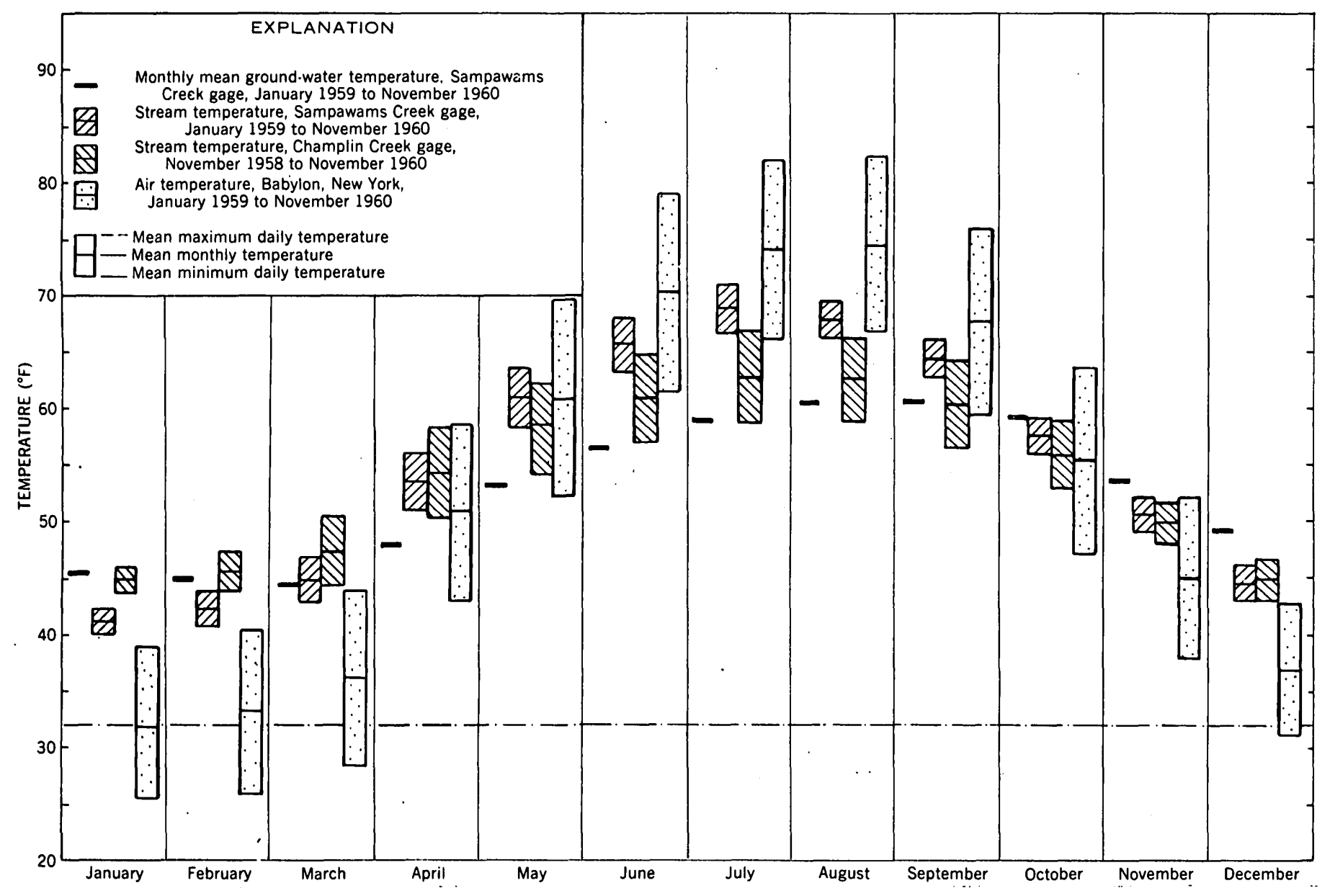

Froure 314.2.-Variation in monthly and daily temperatures of two streams on Long Island and corresponding air and ground-water temperatures. 


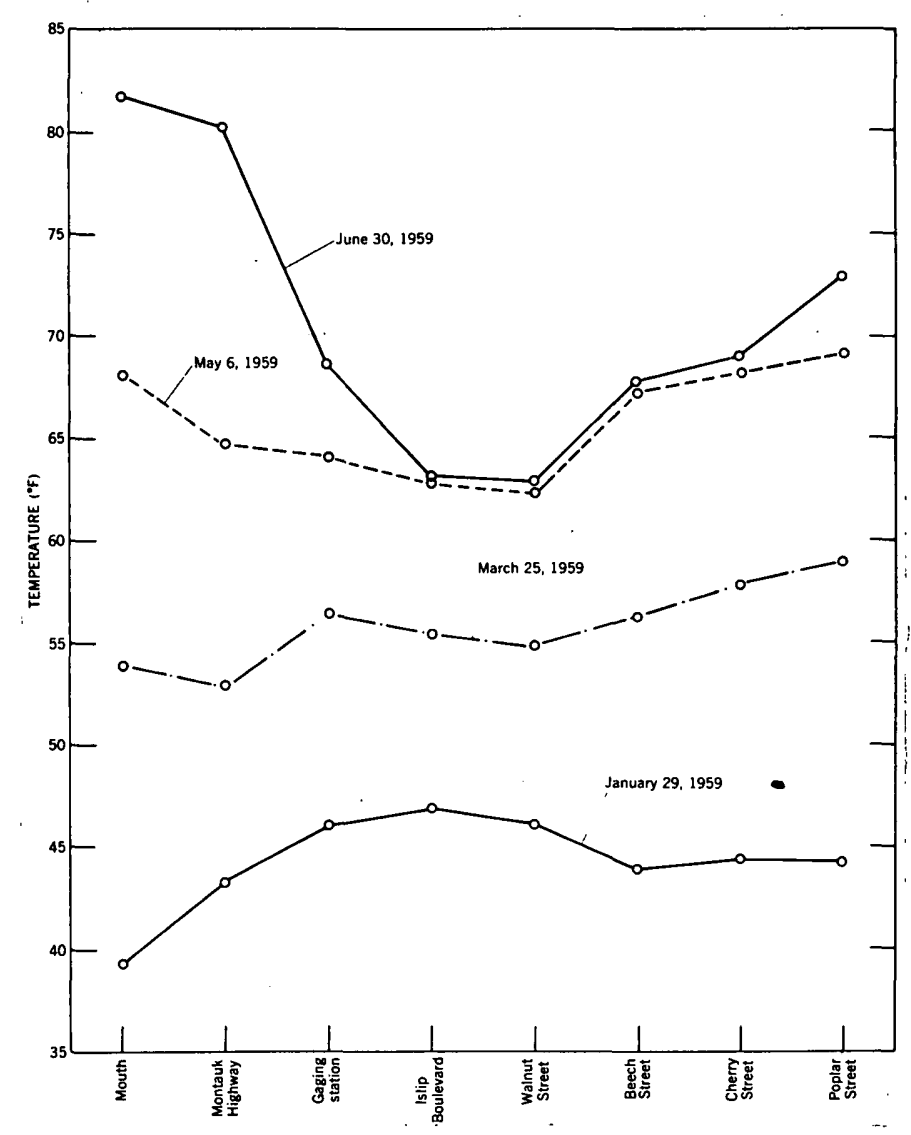

FigURE 314.3.-Stream temperature of Champlin Creek in the early afternoon on selected days.

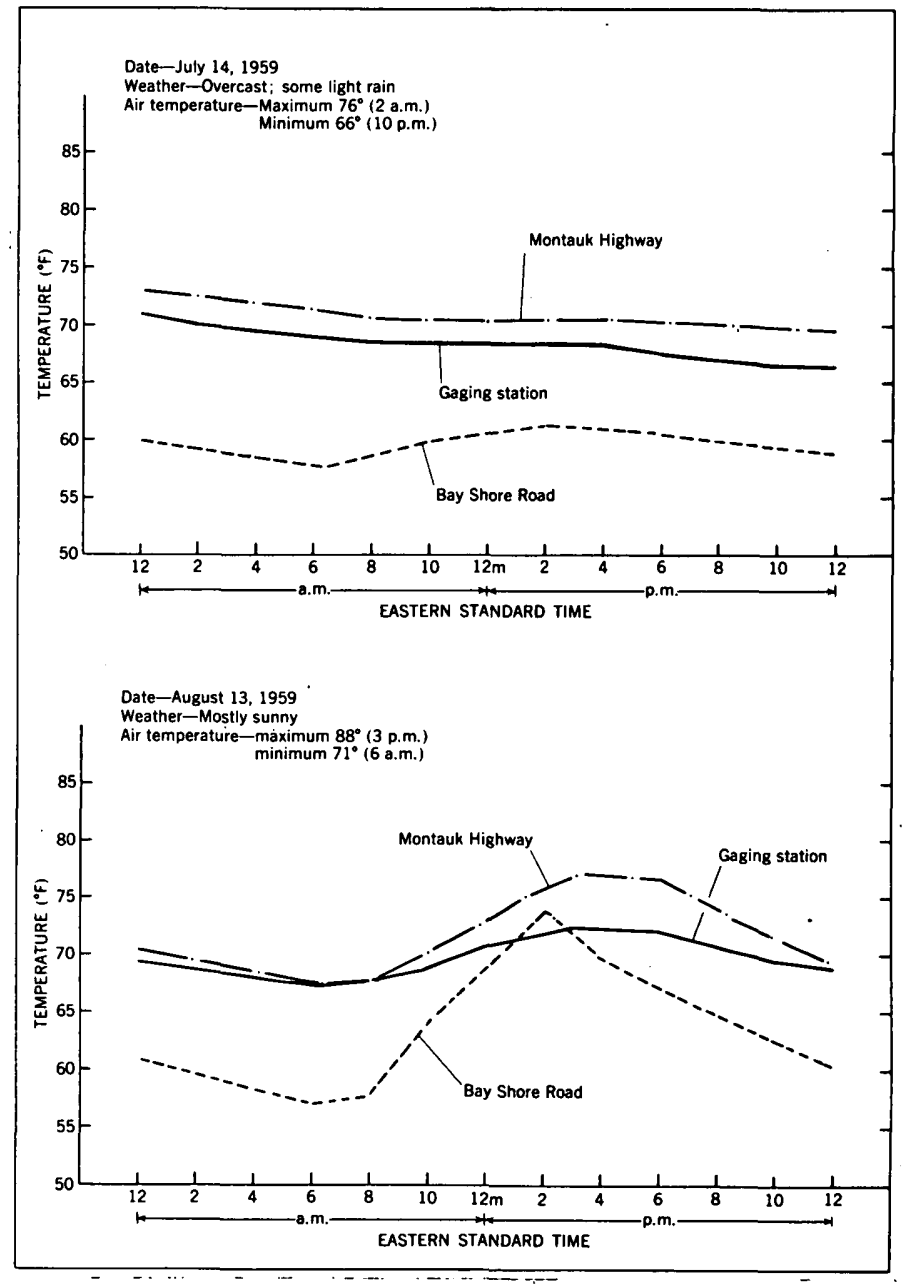

FIGURE 314.4.-Daily temperature variations of Sampawams Creek.

\section{EFFECT OF LAKE ST. LAWRENCE ON GROUND WATER IN THE BEEKMANTOWN DOLOMITE, NORTHERN ST. LAWRENCE COUNTY, NEW YORK}

By Frank W. Trainer and Ralph C. Heath, Albany, N.Y.

Work done in cooperation with the Power Authority of the State of New York and the New York Water Resources Commission

Lake St. Lawrence, a man-made lake about midway between Lake Ontario and Montreal, was formed in 1958 when the St. Lawrence River was dammed during construction of the St. Lawrence Power Project and the St. Lawrence Seaway. Filling of the lake submerged the International Rapids section of the St. Lawrence River, providing a power reservoir and facil- itating navigation of this formerly treacherous reach of the stream. The rise in water level during filling of the lake was about 80 feet at the power dam and about 20 feet at Waddington, some 25 miles upstream.

Lake St. Lawrence is in the gently rolling lowland which separates the Adirondack Mountains from the Canadian Shield. In northern St. Lawrence County 
this lowland is underlain nearly everywhere by glacial drift-chiefly interbedded till, clay, and sand-whose thickness averages 60 feet. Beneath the drift lie Lower Paleozoic dolomite, limestone, and sandstone which rest on Precambrian crystalline rocks and which are part of the southeast limb of a structural basin whose axis is in Ontario. The strata dip gently northwestward, are gently folded, and are cut by a few faults. Openings in the sedimentary rocks are chiefly fractures; there is essentially no intergrain porosity.

The upper 500 feet of bedrock in the vicinity of the St. Lawrence and Grass Rivers, near the village of Massena (fig. 315.1) is Beekmantown dolomite. The Beekmantown consists of thin strata that have moderately abundant cross fractures, interbedded with thick massive strata in which cross joints are more widely spaced. In effect, therefore, it consists of zones of relatively more permeable rock (the thin-bedded strata) alternating with zones of less permeable rock. Because fractures are much better developed parallel to the bedding than across it, the horizontal permeability of the rock is considerably greater than the vertical permeability, and the more permeable zones are poorly connected with one another. Thin-bedded or closely fractured rock in the uppermost part of the Beekmantown forms an apparently continuous permeable zone in the entire northern part of the county. Before filling of the lake, replenishment of water to this uppermost zone was almost entirely by percolation from the overlying drift. The shape of the piezometric surface in the uppermost bedrock (fig. 315.1) shows that before July 1958 recharge was chiefly in the interstream tracts, where the piezometric surface rose in broad mounds; flow was from these mounds, normal to the piezometric contours, toward the major surface streams; and the ground water was discharged from the bedrock into the streams along which the contour lines were indented upstream. The piezometric surface for water in deeper zones is believed to have been similar. This pattern of flow prevailed throughout the area except near the village of Massena, where water moved through the dolomite from the St. Lawrence River to the Grass River.

The effect, the filling of the lake had on ground water in the dolomite is shown by hydrographs for several wells (fig. 315.2). Seasonal fluctuations of groundwater level follow a regular pattern: the water level is highest in early spring and lowest in late summer, and in some years there is also a peak in late autumn. This pattern is attributed to the more effective replenish-

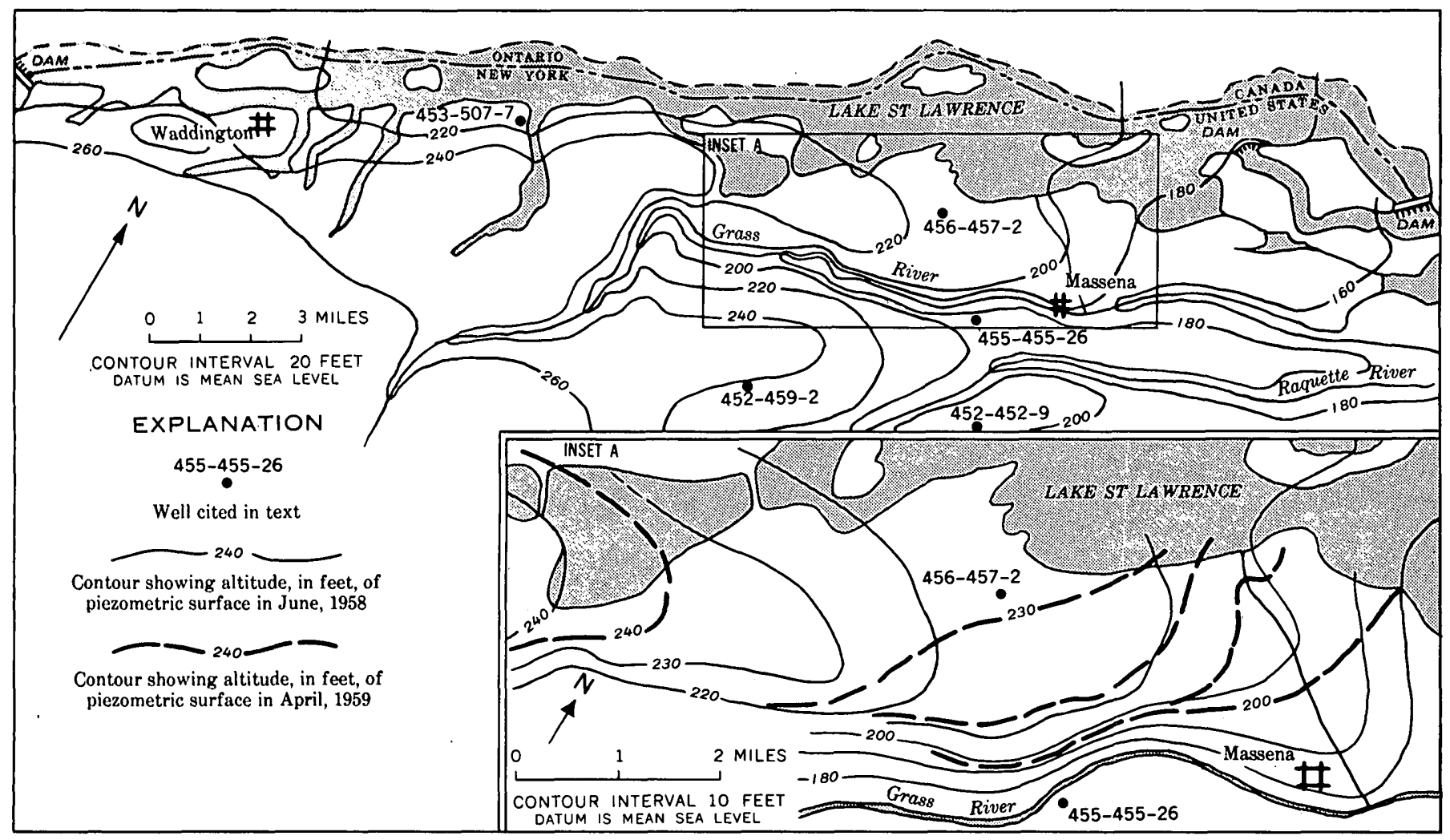

Fioure 315.1.-Configuration of piezometric surface for upper part of bedrock along south side of St. Lawrence River before filling of Lake St. Lawrence. Insert shows piezometric surface near Massena before and after filling of the lake. 


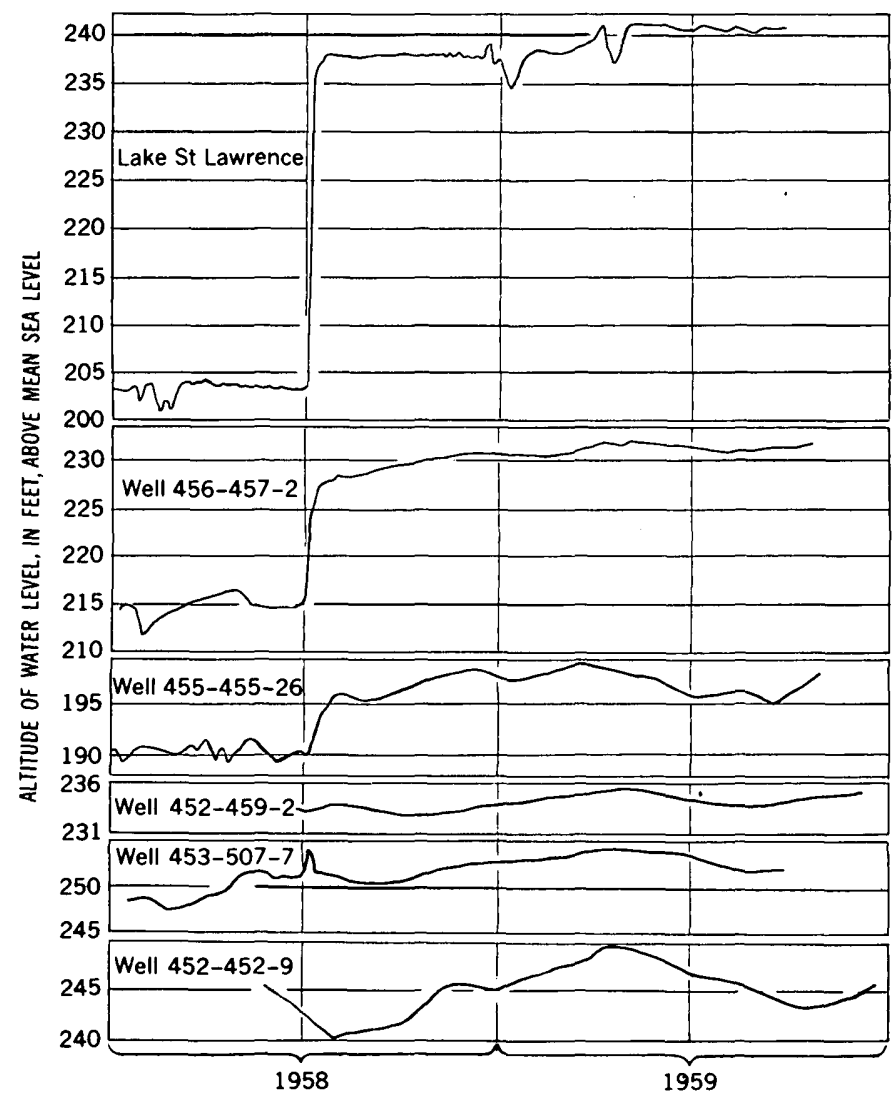

Figure 315.2.-Hydrographs for Lake St. Lawrence at a point about 21/2 miles northwest of Massena, N.Y., and for 5 wells that tap Beekmantown dolomite in northern St. Lawrence County.

ment of ground water in the glacial drift, which supplies water to the bedrock, when evaporation and transpiration rates are low and when the ground is unfrozen, and to less effective replenishment when evaporation and transpiration rates are high. At well $452-452-9$, about 3 miles south of Massena, these fluctuations continued unchanged by the filling of the lake. In most of the tract between the lake and the Grass River, however, the filling was accompanied and followed by a sharp rise in water level (fig. 315.2). In some low places the piezometric surface rose above the land surface, resulting in actual or potential artesian flow. Seasonal fluctuations in wells near the lake since have been absent or small. Near the lake the water table in the drift stands near or below the piezometric sur: face for the bedrock and little or no water moves from the drift into the bedrock; steady replenishment of water in the drift from the lake prevents large seasonal fluctuations. Farther south the water table is higher than the piezometric surface, water in the drift continues to supply the bedrock, and seasonal fluctuations of water levels occur in the dolomite.

The contour lines on figure 315.1 show the amount and areal pattern of the water-level rise after the filling. In the upper bedrock the rise reached the Grass River near Massena; it was not observed farther south and probably did not occur there because that stream is one of the principal places of discharge from the bedrock. A rise in water level was observed in two deep wells (452-459-2 and 455-455-26) south of the Grass River; both wells penetrate lower zones in the dolomite that could not drain freely into the Grass River because of the low vertical permeability of the rock. The relation between rise and distance from the lake in 18 wells (fig. 315.3 ) suggests that the effect of the filling extended 6 to 8 miles from the lake.

In well 453-507-7 the water level has remained as much as 8 feet above the lake, has continued to fluctuate seasonally, and during the filling rose and declined sharply because of the loading of the confined aquifer (Jacob, 1939). Clearly, the permeable zone tapped.by the well is separated from the lake and has a source higher than the lake. The water may have come from higher ground near the lake in New York or in Ontario, but because the Grass River, about 4 miles to the south, is lower than any potential place of discharge within 50 miles north of the lake, it appears probable that the ground water in the zone tapped by the well is flowing from Canada into the United States beneath the St. Iawrence River and Lake St. Iawrence.

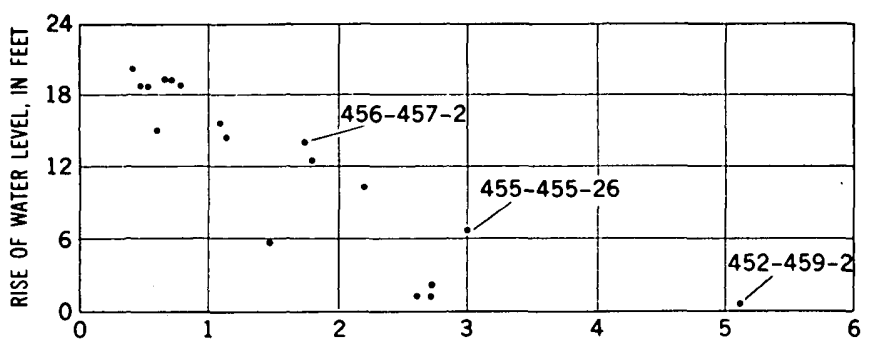

DISTANCE FROM CENTER OF ST. LAWRENCE RIVER, ALONG PROBABLE FLOW LINES, IN MILES

Figure 315.3.-Rise of water level in selected bedrock wells near Massena, in response to filling of Lake St. Lawrence. Numbers identify wells cited in the text.

\section{REFERENCE}

Jacob, C. E., 1939, Fluctuations in artesian pressure produced by passing railroad trains as shown in a well on Long Island, New York: Am. Geophys. Union Trans., pt. 4, p. $666-674$ 


\title{
316. THE STOKES AND SURRY COUNTIES QUARTZITE AREA, NORTH CAROLINA-A WINDOW?
}

\author{
By Bruce Bryant and John C. Reed, Jr., Denver, Colo.
}

Quartzite forms conspicuous cliffs on Hanging Rock Mountain, Sauratown Mountain, and Pilot Mountain, which rise abruptly 1,500 feet above the gently rolling surface of the surrounding Piedmont Plateau in Stokes and Surry Counties in north-central North Carolina (fig. 316.1).

Although quartzite is an unusual rock in this part of the Piedmont, and its occurrence here may furnish valuable clues to the regional structure, the area has received surprisingly little attention. Kerr (1875, p. 1.34) assigned the quartzite to the Huronian, mainly because of its low metamorphic grade, and recognized that it is surrounded by schist and gneiss of medium or high metamorphic grade, which he assigned to the upper Laurentian. Mundorff (1948) published a small-scale reconnaissance map including part of the aren of quartzite. His map outlines an area of "quartzite and schist" with boundaries essentially the same as the area of Huronian rocks shown by Kerr (1875). On the Geologic Map of North Carolina (North Carolina Dept. of Conserv. and Devel., 1958) the area is mapped as the Kings Mountain group and the rocks are described as quartzite, marble, conglomerate, and schist. The area of the Kings Mountain group is extended south through Yadkin County, far beyond the area of Huronian rocks mapped by Kerr. Stuckey and Conrad (1959) describe the area briefly and state that the quartzite and schist contain lenses of limestone.

During the fall of 1960 we made a reconnaissance of the quartzite area and were impressed with many similarities in lithology and structure between the rocks here and rocks in the Grandfather Mountain area 70 miles to the southwest, where we have been mapping for several years. We wish to thank Mr. Stephan G. Conrad of the North Carolina Department of Conservation and Development and Mr. Barry Centini,

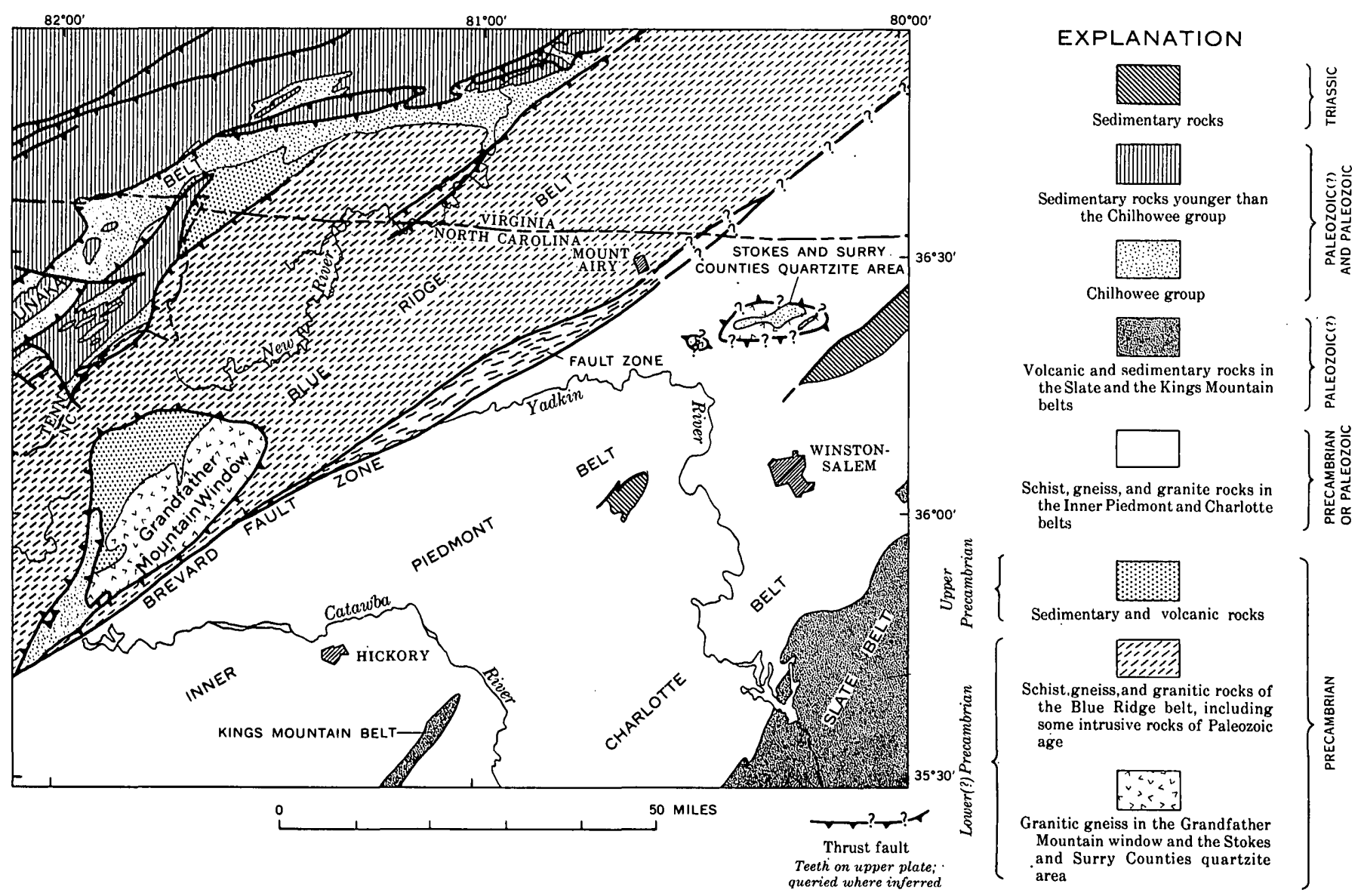

Frouks 316.1.-Generalized geologic map of northwestern North Carolina and adjacent parts of Virginia and Tennessee showing location of the Stokes and Surry Counties quartzite area. Modified from Geologic Map of North Carolina and other sources. 
graduate student at North Carolina State College, who conducted us on a field trip in the area, and our colleagues, A. M. White, W. C. Overstreet, and R. A. Laurence, who contributed data.

The prominent cliffs on the higher hills consist of massive medium- to coarse-grained sericitic quartzite and arkosic quartzite and thin layers and partings of green sericite phyllite locally containing garnet. Near the base of the quartzite, a quartz-pebble conglomerate has been reported to occur (Kerr, 1875; Barry Centini, oral communication, 1960). A bed of lustrous blue phyllite about 100 feet thick, exposed in the area northeast of Hanging Rock Mountain, apparently overlies the cliff-forming quartzite and is in turn overlain by thinly bedded quartzite and phyllite. The quartzite contains detrital rutile and tourmaline, a feature that is characteristic of rocks of the Chilhowee group in the Grandfather Mountain area and in the Unaka belt to the west.

Similarities in lithology and stratigraphic sequence strongly suggest that the quartzite-phyllite sequence in Stokes and Surry Counties, although of slightly higher metamorphic grade, is correlative with the Chilhowee group in the Grandfather Mountain window (Reed and Bryant, 1960). The rocks do not resemble the rocks of the Kings Mountain belt as described by Keith and Sterrett (1931), Kesler (1944), and Espenshade and Potter (1960) nor do they resemble rocks of the Tallulah Falls area in Georgia, which we have examined briefly.

We have found no limestone or marble in the quartzite-phyllite sequence. The marble localities described by Conrad (1960) lie well outside the quartzite area (fig. 316.2) and seem to belong with the medium- and high-grade rocks of the Inner Piedmont belt.

The quartzite-phyllite sequence rests on strongly lineated and foliated, but generally nonlayered, gratnitic biotite gneiss, and both have been metamorphosed at relatively low grade. Locally, tectonic slices of quartzite are intercalated in the gneiss. These, together with phyllonite (probably the "crumpled schist" mentioned by Mundorff, 1948) near the contact, suggest that the quartzite sequence is not everywhere in stratigraphic contact with the underlying granitic gneiss. Perhaps the quartzite sequence has been thrust over the granitic gneiss, as has been demonstrated in the Grandfather Mountain window (Bryant and Reed, 1960).

Surrounding the quartzite-phyllite sequence and granitic gneiss are mica schists and layered gneisses containing cataclastic granitic rocks and pegmatites. These rocks are widespread through the Inner Piedmont, and A. M. White has found that the nearby schists and layered gneiss contain staurolite and sillimanite and are of medium and high metamorphic grade.
The foliation and layering in the surrounding schist and gneiss of the Inner Piedmont belt form a dome, whereas the quartzite in the Hanging Rock area is synclinal (fig. 316.2). This was recognized by Mundorff (1948) although he did not point out its structural significance. In the few places where the quartzite sequence is in contact with the surrounding schists and layered gneisses, quartzite units appear to terminate abruptly and are discordant with the foliation and layering of the surrounding rocks.

Because of its lithologic character and structural relations, we believe that the quartzite-phyllite sequence of Stokes and Surry Counties is part of the Chilhowee group, and that the underlying granitic gneiss may be of early Precambrian age like the basement gneiss beneath the Chilhowee rocks in the Grandfather Mountain window. We suggest that the quartzite and the underlying gneiss are exposed in two windows beneath an overriding plate of rocks of the Inner Piedmont belt (fig. 316.2). Structural details in the Stokes and Surry Counties area are complex, and detailed geologic mapping is needed to prove or disprove our hypothesis, which, if correct, would have important implications in the interpretation of the structure of the Piedmont.

\section{REFERENCES}

Bryant, Bruce, and Reed, J. C., Jr., 1960, Road log of the Grandfather Mountain area, North Carolina : Carolina Geol. Soc. Field Trip Guidebook, 21 p.

Conrad, S. G., 1960, Crystalline limestone of the Piedmont and mountain regions of North Carolina: North Carolina Dept. Conserv, and Devel., Mineral Resources Bull. 74, 56 p.

Espenshade, G. H., and Potter, D. B., 1960, Kyanite, sillimanite and andalusite deposits of the southeastern States: U.S. Geol. Survey Prof. Paper 336, 121 p.

Keith, Arthur, and Sterrett, D. B., 1931, Description of the Gaffney and Kings Mountain quadrangles [South CarolinaNorth Carolina] : U.S. Geol. Survey Geol. Atlas, Folio 222, $13 \mathrm{p}$.

Kerr, W. C., 1875, Report of the Geological Survey of North Carolina, v. 1, Physical geography, résumé and economical geology : Raleigh, N.C., 325 p.

Kesler, T. L., 1944, Correlation of some metamorphic rocks in the central Carolina Piedmont: Geol. Soc. America Bull., v. 55, p. 755-782.

Mundorff, M. J., 1948, Geology and ground water in the Greensboro area, North Carolina: North Carolina Dept. Conserv. and Devel., Mineral Resources Bull. 55, 108 p.

North Carolina Department of Conservation and Development, 1958, Geologic map of North Carolina, scale $1: 500,000$.

Reed, J. C., Jr., and Bryant, Bruce, 1960, Lower Cambrian and late Precambrian rocks in the Grandfather Mountain window, North Carolina [abs.]: Washington Acad. Sci. Jour., v. 50, no. 7, p 3-5.

Stuckey, J. L., and Conrad, S. G., 1959, Metasedimentary rocks in Stokes, Surry, Yadkin, and Forsyth Counties, North Carolina [abs.]: Geol. Soc. America Bull., v. 70, no. 12, pt. 2, p. 1770 . 


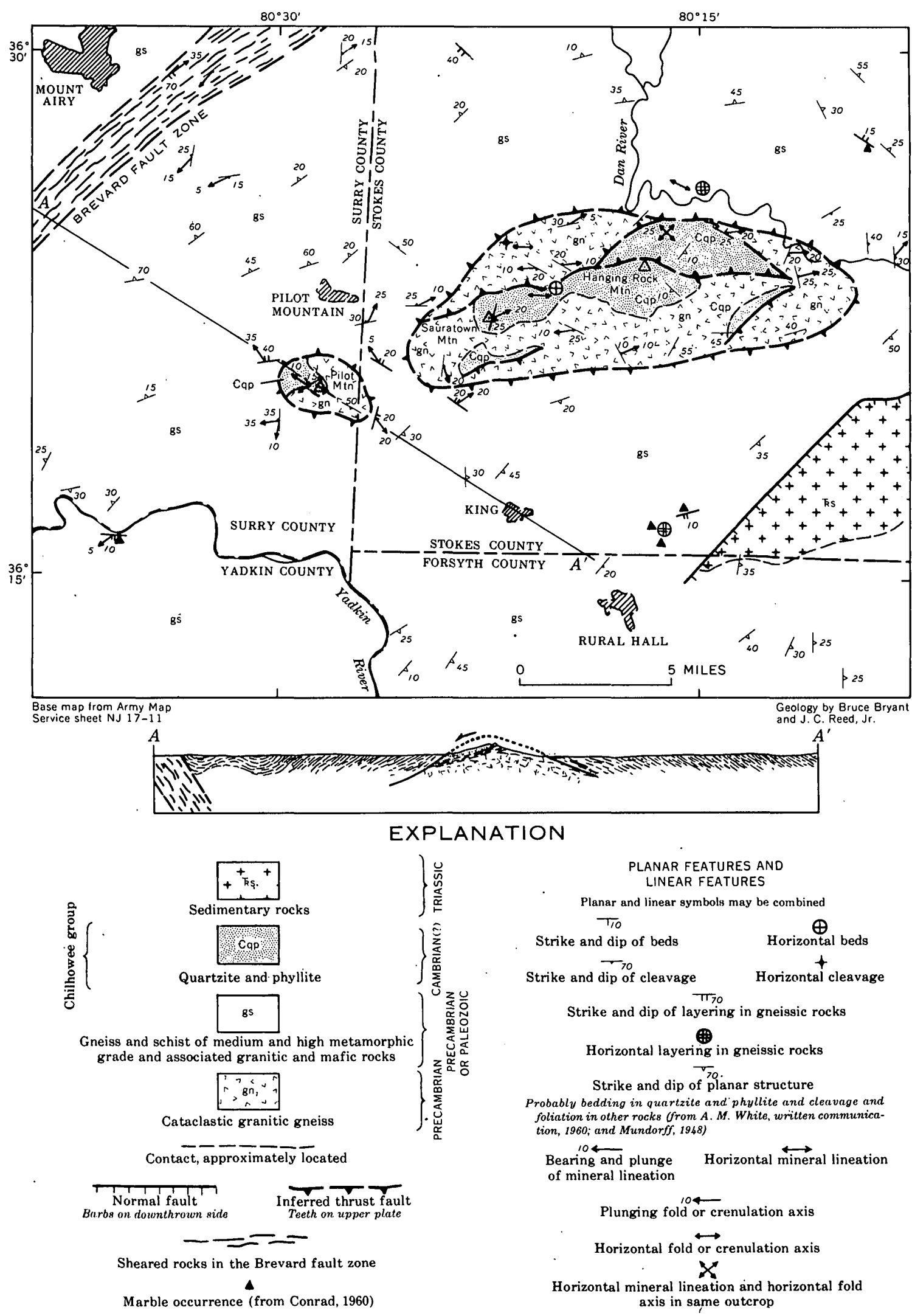

Froure 316.2.-Reconnaissance geologic map of the Stokes and Surry Counties quartzite area and vicinity. Based partly on interpretation of high-altitude aerial photographs. 


\section{HYDROLOGIC PROCESSES DILUTING AND NEUTRALIZING ACID STREAMS OF THE SWATARA CREEK BASIN, PENNSYLVANIA}

By E. F. McCarren, J. W. Wark, and J. R. George, Philadelphia, Pa.

Work done in cooperation with Pennsylvania Department of Forests and Waters

A study of water quality in the Swatara Creek basin shows how natural processes tend to dilute and neutralize acid mine drainages and retard their effects downstream.

The Swatara Creek basin of the Susquehanna River is the basin farthest downstream that drains acid wastes from anthracite coal mines in Schuylkill County, Pa. The basin drains areas of varied geology; it lies in parts of the Piedmont Plateau and Valley and Ridge provinces of the Appalachian region (fig. 317.1). In the Swatara Creek basin, mining wastes come mostly from underground pools where acidic water is impounded in the excavations of mines which are no longer worked. The rate of release of this highly mineralized acidic water (table 317.1 ) increases when water levels of pools are raised by infiltrated runoff or seepage from other underground sources, but generally the rate is uniform throughout the year. Therefore, in Swatara Creek it is possible to observe processes of dilution and the changes in chemical composition of mine overflow water and neutralization by natural means.

Acidic water of Swatara Creek is first diluted where the Upper and Lower Little Swatara Creeks flow into the main stream. Although originating in Schuylkill County, these streams are unaffected by mine wastes and are low in dissolved solids-less than $50 \mathrm{ppm}$ (parts per million). The water in these streams contains calcium bicarbonate and has a $\mathrm{pH}$ range of 6.0 to 7.0. The area drained by these streams is underlain by Silurian, Mississipian, and Pennsylvanian sandstone, shale, and conglomerate.

Jonestown is the first sampling locality where the bicarbonate ion is found most of the time. Bicarbonate ion concentration progressively increases downstream (fig. 317:2). Representative chemical composition and $\mathrm{pH}$ changes in the Swatara downstream from the headwaters are illustrated by figure 317.3 .

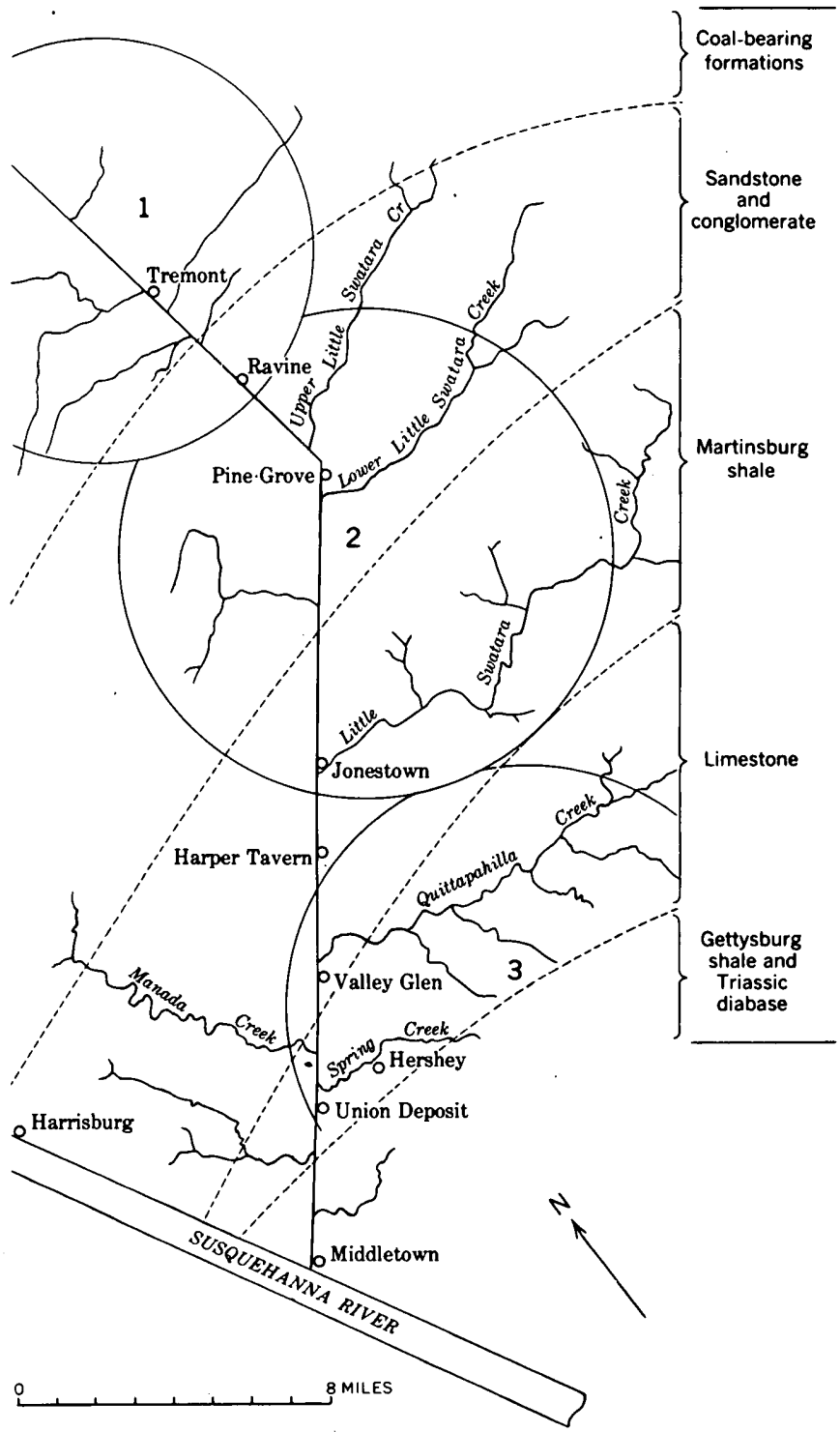

Figure 317.1-Schematic diagram of Swatara Creek basin showing major regions affecting water quality. 1, acid minedrainage region; 2 , neutral region; 3 , alkaline region. 
TАвLE 317.1.-Chemical analyses of water from anthracite coal mines in Swatara Creek basin, collected June 25,1959 [In parts per million and equivalent parts per million]

\begin{tabular}{|c|c|c|c|c|c|c|c|c|c|c|c|c|}
\hline & \multicolumn{2}{|c|}{$\underset{\text { mine }}{\text { Good Spring }}$} & \multicolumn{2}{|c|}{$\underset{\substack{\text { Middle Creek } \\
\text { mine }}}{\text { in }}$} & \multicolumn{2}{|c|}{$\begin{array}{l}\text { Colket } \\
\text { mine }\end{array}$} & \multicolumn{2}{|c|}{$\begin{array}{l}\text { New Lin- } \\
\text { coln mine }\end{array}$} & \multicolumn{2}{|c|}{$\begin{array}{l}\text { Rausch Creek } \\
\text { East Franklin } \\
\text { mine }\end{array}$} & \multicolumn{2}{|c|}{$\underset{\text { mine }}{\text { Lincoln }}$} \\
\hline & ppm & epm & $\mathrm{ppm}$ & epm & ppm & epm & pnm & epm & $\mathrm{ppm}$ & epm & ppm & epm \\
\hline \multicolumn{13}{|l|}{ Constituent: } \\
\hline Silica $\left(\mathrm{SiO}_{2}\right) \ldots \ldots$ & 13 & $\ldots$ & 16 & $\ldots$ & 15 & $\ldots$ & 8. 6 & $\ldots$ & 17 & $\ldots$ & 15 & \\
\hline Aluminum (Al) & .5 & 0.06 & 5. 6 & 0.62 & 1. 9 & 0.21 & $\ldots$ & $\ldots$ & 10 & 1. 11 & 1. 1 & 0.12 \\
\hline Iron $(\mathrm{Fe})$ & 9.0 & $\ldots$ & 9. 2 & & 10 & $\ldots$ & 5. 0 & $\ldots$ & 9.6 & $\ldots$ & 2.3 & $\ldots$ \\
\hline Iron $(\mathrm{Fe})$ in solution when analyzed $\ldots \ldots$ & .04 & .00 & 1. 7 & 06 & 1. 0 & .04 & .00 & 0.00 & 1. 3 & .05 & .02 & $\therefore 00$ \\
\hline Manganese $(M n)$ & 2. 9 & 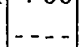 & 4. 9 & $\ldots$ & 2. 5 & 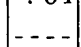 & .72 & $\left|\begin{array}{c}0.00 \\
-\ldots\end{array}\right|$ & 5. 8 & & .02 & \\
\hline Manganese $(\mathrm{Mn})$ in solution when analyzed ... & 2. 7 & .10 & 3. 0 & 11 & 1. 2 & 04 & .73 & .03 & 5. 8 & 21 & 4. 3 & 16 \\
\hline Calcium (Ca) & 41 & 2.05 & 61 & 3. 04 & 39 & 1. 95 & 4.9 & .24 & 80 & 3. 99 & 21 & 1. 05 \\
\hline Magnesium $(\mathrm{Mg})$ & 24 & 1. 97 & 48 & 3. 95 & 31 & 2.55 & 5. 6 & .46 & 56 & 4. 61 & 23 & 1. 89 \\
\hline Sodium $(\mathrm{Na})$ & 2. 0 & .09 & 2. 0 & .09 & 1.4 & .06 & 1. 4 & .06 & 1.4 & .06 & 1. 4 & .06 \\
\hline Potassium (K) $\ldots$ & 1. 8 & .05 & 1. 5 & .04 & 1. 2 & .03 & 1. 0 & .03 & 1. 5 & .04 & 1. 8 & .05 \\
\hline Carbonate $\left(\mathrm{CO}_{3}\right) \ldots \ldots$ & 0 & .00 & 0 & .00 & 0 & .00 & 0 & .00 & 0 & .00 & 0 & .00 \\
\hline Bicarbonate $\left(\mathrm{HCO}_{3}\right) \ldots \ldots \ldots$ & 0 & .00 & 0 & .00 & 0 & .00 & 12 & .20 & 0 & .00 & 0 & .00 \\
\hline Sulfate $\left(\mathrm{SO}_{4}\right) \ldots$ & 214 & 4. 46 & 427 & 8. 89 & 280 & 5. 83 & 27 & .56 & 516 & 10. 74 & 158 & 3. 29 \\
\hline Chloride $(\mathrm{Cl}) \ldots$ & 1. 2 & .03 & 3. 2 & .06 & .6 & .02 & 1. 4 & .04 & 1. 6 & .05 & .6 & .02 \\
\hline Fluoride $(\mathrm{F})$ & .3 & .02 & .3 & 02 & .3 & .02 & .2 & .01 & .4 & .02 & .3 & .02 \\
\hline Nitrate $\left(\mathrm{NO}_{3}\right) \ldots \ldots$ & .3 & .00 & .4 & .01 & .2 & .00 & .3 & .00 & 3 & .00 & .1 & .00 \\
\hline Dissolved solids . ..... & 332 & $\ldots$ & 671 & $-\ldots$ & 446 & & 62 & & 821 & & 252 & \\
\hline Hardness as $\left(\mathrm{CaCO}_{3}\right) \ldots \ldots$ & 201 & $\ldots$ & 350 & & 225 & & 35 & $-\ldots$ & 430 & & 147 & \\
\hline Noncarbonate & 201 & $\ldots$ & 350 & & 225 & $\ldots$ & 35 - & $\ldots$ & 430 & $\ldots$ & 147 & \\
\hline Specific conductance (microm hos at $25^{\circ} \mathrm{C}$ ) $\ldots \ldots$ & 533 & $\ldots$ & 1080 & $\ldots$ & 864 & -... & 92 & $-\ldots$ & 1200 & - . - & 400 & \\
\hline $\mathrm{pH}, \ldots$ & . 3.60 & $-\ldots$ & 2.95 &.- & 2.95 & $-\ldots$ & 6. 1 & $\ldots$ & 3. 00 & -.... & 3. 75 & \\
\hline Color & 1 & $\ldots$ & 1 & $\ldots$ & 2 & $-\ldots$ & 2 & $-\ldots$ & 1 & $-\ldots$ & 2 & \\
\hline Total acidity as $\mathrm{H}_{2} \mathrm{SO}_{4} \ldots \ldots$ & 59 & 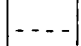 & 108 & $\ldots$ & 69 & & - & $\ldots$ & 132 & $\ldots$ & 15 & \\
\hline
\end{tabular}

Should active mining begin again in the basin, two major tributaries having neutral water low in dissolved solids will help check the effects downstream of increased acidic mine wastes. The largest of these tributaries is Little Swatara Creek, which joins the Swatara at. Jonestown. This sub-basin is underlain by Martinsburg shale. At Jonestown, the Little Swatara contains cilcium-bicarbonate water and the dissolved solids determination by chemical analyses made during the period of study did not exceed $120 \mathrm{ppm}$.

Quittapahilla Creek flows into the Swatara upstream from Valley Glen and contains predominantly alkaline water. The Quittapahilla is underlain by limestone and receives pumped ground water from limestone quarries. Although this stream is capable of neutralizing acid water, it does not perform this function at the present time because the Swatara is diluted and neutralized before reaching its confluence with the Quittapahilla. The water in the stream is calciummagnesium-bicarbonate-sulfate bearing. The concentration of calcium and magnesium is relatively high because the stream drains a limestone area. Another stream, Spring Creek, not so highly mineralized as the Quittapahilla but with characteristics for neutralizing acidity, flows into Swatara Creek just above Union deposit. Spring Creek is also located in the limestone belt of Lebanon County.

The concentrations of most solutes at Middletown are at their highest levels during the summer months and during periods of low flow; regardless of flow conditions, however, the Swatara at Middletown is not acidic when it flows into the Susquehanna River. 


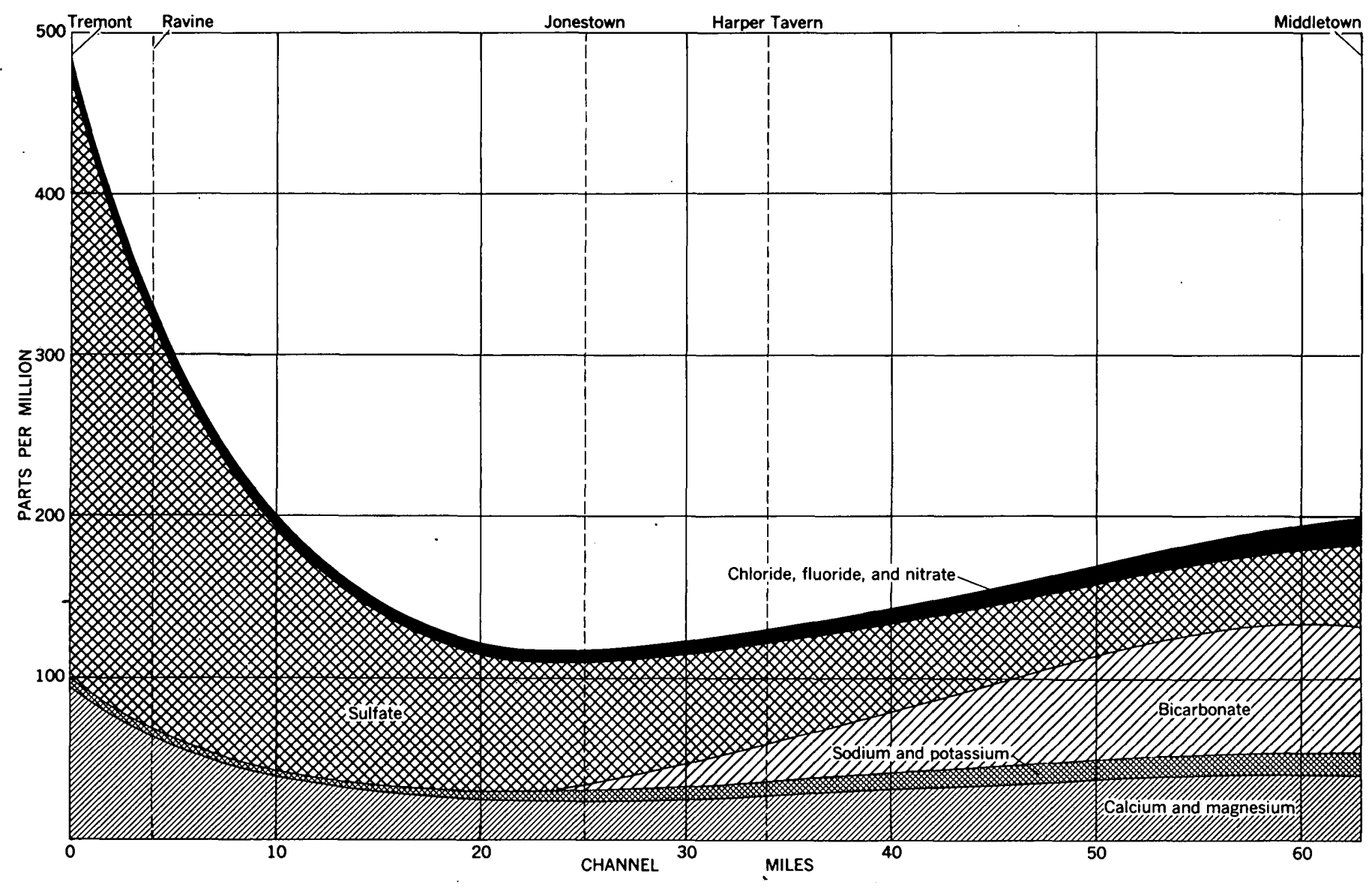

Figure 317.2.-Composition of Swatara Creek at low base flow, October, 1959.

Finding ways to correct and prevent surface pollution caused by coal mining and its related operations has become increasingly important in many regions. The Swatara Creek study shows that acid water from mines is quickly neutralized if it is diluted by streams that have suitable chemical compositions. Diverting suitable nearby streams into acid streams may be an effective and relatively economic way to counteract coal mine effluents in some areas. 
SHORT PAPERS IN THE GEOLOGIC AND HYDROLOGIC SCIENCES, ARTICLES 293-435

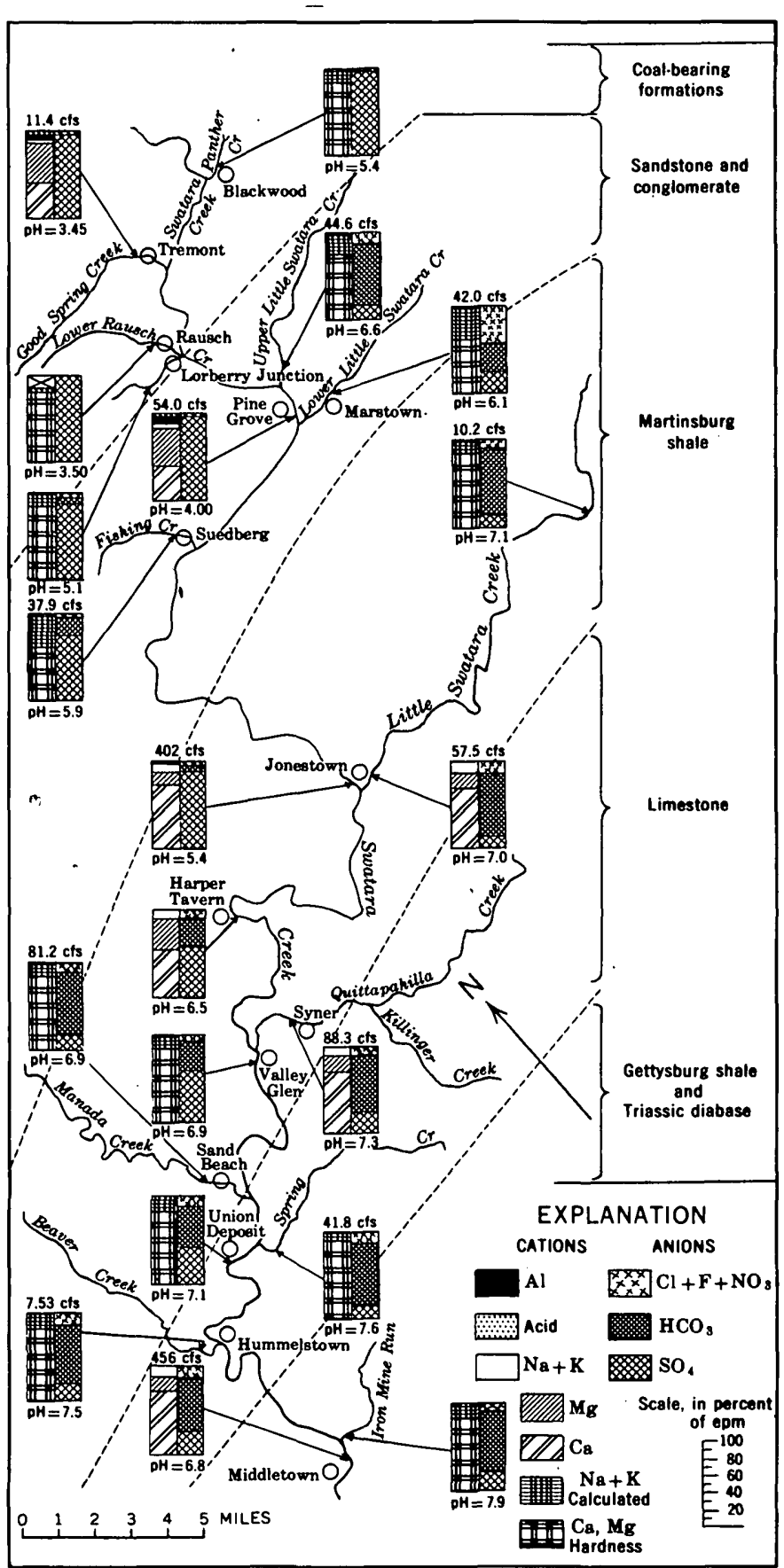

Frgure 317.3.-Chemical quality of streams in Swatara Creek basin, July 14, 16, and 17, 1958 


\title{
318. CORRELATION OF END MORAINES IN SOUTHERN RHODE ISLAND
}

\author{
By J. P. Schafer, Boston, Mass.
}

Work done in cooperation with the Rhode Island Development Council

Two prominent sets of end moraines (fig. 318.1) of Wisconsin age extend along the coastal area of southern New England (Woodworth and Wigglesworth, 1934; Fuller, 1914). Correlations have been generally assumed along these two sets of moraines. Both sets, however, are broken by Rhode Island Sound, although in some places submarine ridges suggest the positions of the moraines.

The Charlestown moraine originally was believed to bend southeast across the Point Judith peninsula (Woodworth, 1896, p. 153; Woodworth and Marbut, 1896, fig. 2). This bend was interpreted as an interlobate angle. Some later compilations have omitted this angle, and projected the Charlestown moraine directly east toward the Elizabeth Islands (for example, Flint, 1953, pl. 2). However, recent detailed mapping has shown that the Charlestown moraine at its eastern end grades into a broad area of ablation moraine (Kaye, 1960). Just to the east, the crest of the Point Judith peninsula constitutes a south-trending moraine, the Point Judith moraine (Schafer, Narragansett Pier quadrangle, 1961). These moraines define an interlobate angle of a little less than 90 degrees. The Point Judith moraine crosses the projected trend of the Charlestown moraine, and probably was deposited slightly later than the Charlestown moraine during a slight re-expansion of the ice east of the interlobate angle. On Cape Cod, the Sandwich moraine overlaps the Buzzards Bay moraine in a similar way (Mather, Goldthwait, and Thiesmeyer, 1942, p. 1147).

Recent marine-sediment studies in Rhode Island Sound (McMaster, 1960, fig. 12) have identified two belts of gravelly sediments that in some places coincide with submarine ridges, and most likely represent submerged moraines. A northern belt curves from the Point Judith moraine to the Elizabeth Islands, and a southern, less well defined, belt extends from Block Island toward Nomans Land and Martha's Vineyard. The northern belt is more strongly curved than the southern, indicating that the ice margin became more strongly lobate as it retreated. The absence of ridges along parts of these belts may be the result of filling of the original depressions behind the moraines with marine sediments.
The ice lobe whose western edge is marked by the Point Judith moraine extended eastward to the interlobate angle on western Cape Cod, and is here called the Narragansett Bay-Buzzards Bay lobe. The southward divergence of flow within this lobe is shown by glacial striations and drumlins (Flint and others, 1959) as well as by,the moraines. The boulder fan of cumberlandite, an unusual periodotite from northern Rhode Island, was spread southward in the western part of the lobe (Shaler, 1893).

The retreat of the ice front from the CharlestownCape Cod set of moraines was dominantly by stagnation zone retreat. However, the Slocum (Power, 1957) and Wickford (Schafer, 1961) quadrangles on the western side of Narragansett Bay contain five small moraines (locality 1, fig. 318.1). These moraines were built in topographically favorable places along the western margin of the shrinking Narragansett BayBuzzards Bay lobe, and are successively younger from southwest to northeast. The absence of correlative moraines on the west side of the interlobate angle indicates that the ice on the upland west of the Narragansett basin was thin and motionless at its margin. On figure 318.1, it appears that the western two of these moraines might correlate with the Point Judith moraine, but actually when they were being deposited the ice margin bent sharply eastward around an upland area, considerably north of the Point Judith moraine. Much additional information about positions of ice margins at the times of deposition of these moraines is revealed by contemporaneous ice-contact slopes of outwash deposits (not shown on figure 318.1).

The remarkable boulder masses of Cat Rocks and Queens Fort are correlated (Power, 1957) with the two western moraines of this series. (Note that the names Cat Rocks and Queens Fort apply only to the small bodies indicated on figure 318.1.) These two boulder masses once were included in the Queen's River moraine, which was described as a generally southwesttrending moraine about 10 miles long (Wood worth and Marbut, 1896). However, recent mapping (Power, 1957 ; T. G. Feininger, written communication, 1959) has shown that the Cat Rocks and Queens Fort (formerly called Queen's Kitchen) are the only morainic 


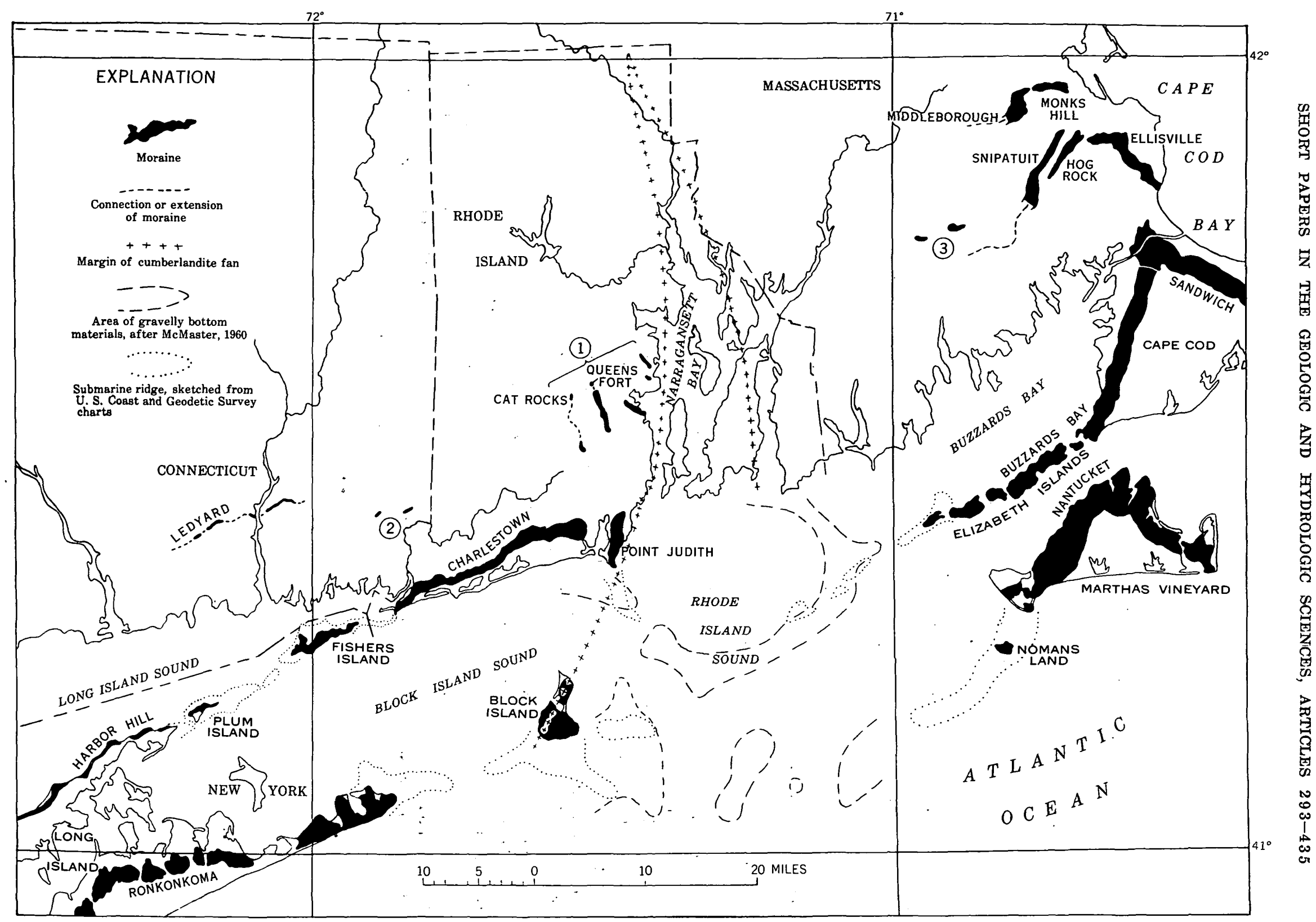

FIGURE 318.1.-End moraines in part of southern New England. Numbers for unnamed moraines are referred to in text. 
bodies along that line, and that the Queen's River moraine does not exist.

Goldsmith (1960) has suggested that the Ledyard moraine in southeastern Connecticut may be correlative with some of the western members of the series of moraines at locality 1, figure 318.1. It is doubtful, however, whether minor moraines can be correlated over such a distance, and the uncertainty is even greater for correlation across an interlobate angle such as exists between the two areas. The two small moraines in southeastern Connecticut (locality 2, fig. 318.1) are most likely slightly older than the Ledyard moraine (Schafer, written communication).

As the ice retreated northwest from the interlobate angle on Cape Cod, it built moraines at several positions of that angle (Mather, 1952). The first position is marked by the Ellisville and Hog Rock moraines, the second by the Snipatuit moraine and the possibly correlative small moraines in the southern part of the Assawompset Pond quadrangle (locality 3, fig. 318.1; Carl Koteff, oral communication, 1961), and the third by the Monks Hill and Middleborough moraines. The Snipatuit and Middleborough moraines are mapped as kame moraines (Mather, 1952), and they grade. westward into collapsed ice-contact margins of outwash.

Thus, the two main groups of moraines north of the Harbor Hill-Charlestown-Cape Cod set of moraines are those north of the Charlestown-Point Judith interlobate angle, and those northwest of the Cape Cod interlobate angle. During the early part of ice retreat, stagnation evidently occurred immediately on the broad central parts of the lobes, but the ice remained active at its margin near the interlobate angles during the first 15 to 20 miles of retreat.

\section{REF ERENCES}

Flint; R. F., 1953, Probable Wisconsin substages and late-Wisconsin events in northeastern United States and southeastern Canada: Geol. Soc. America Bull., v. 64, p. 897-919.
Flint, R. F., and others, 1959, Glacial map of the United States east of the Rocky Mountains: Geol. Soc. America.

Fuller, M. L., 1914, The geology of Long Island, New York: U.S. Geol. Survey Prof. Paper 82, 231 p.

Goldsmith, Richard, 1960, A post-Harbor Hill-Charlestown moraine in southeastern Connecticut: Am. Jour. Sci., v. 258 , p. $740-743$.

Kaye, C. A., 1960, Surficial geology of the Kingston quadrangle, Rhode Island: U.S. Geol. Survey Bull., 1071-I [1961].

McMaster, R. L., 1960, Sediments of Narragansett Bay system and Rhode Island Sound, Rhode Island: Jour. Sed. Petrology, v. 30, p. 249-274.

Mather, K. F., 1952, Glacial geology in the Buzzards Bay. region and western Cape Cod-Field Trip no. 4, p. 119-142, in Geol. Soc. America, Guidebook for field trips in New England.

Mather, K. F., Goldthwait, R. P., and Thiesmeyer, L. R., 1942, Pleistocene geology of western Cape Cod, Massachusetts : Geol. Soc. America Bull., v. 53, p. 1127-1174.

Power, W. R., Jr., 1957, Surficial geology of the Slocum quadrangle, Rhode Island: U.S. Geol. Survey Geol. Quad. Map GQ-106.

Schafer, J. P., 1961, Surficial geology of the Narragansett Pier quadrangle, Rhode Island: U.S. Geol. Survey Geol. Quad. Map GQ-140.

- 1961, Surficial geology of the Wickford quadrangle, Rhode Island: U.S. Geol. Survey Geol. Quad. Map GQ-136.

Shaler, N. S., 1893, The conditions of erosion beneath deep glaciers, based upon a study of the boulder train from Iron Hill, Cumberland, R.I. : Harvard College Mus. Comp. Zoology Bull. 16, p. 185-225.

Woodworth, J. B., 1896, The retreat of the ice-sheet in the Narragansett Bay region: Am. Geologist, v. 18, p. 150-168, 391-392.

Woodworth, J. B., and Marbut, C. F., 1896, The Queen's River moraine in Rhode Island: Jour. Geology, v. 4, p. 691-703.

Woodworth, J. B., and Wigglesworth, Edward, 1934, Geography and geology of the region including Cape Cod, the Elizabeth Islands, Nantucket, Marthas Vineyard, Nomans Land and Block Island: Harvard College Mus. Comp. Zoology Mem., v. 52, 322 p. 


\section{RESIDUAL SEA WATER IN THE BASEMENT COMPLEX OF THE FALL ZONE IN THE VICINITY OF FREDERICKSBURG, VIRGINIA}

By Seymour Subitziky, Trenton, N.J.

Work done in cooperation with the Commonwealth of Virginia ${ }^{1}$

Several wells obtain water from the basement complex crystalline rocks of the Fall Zone in the vicinity of Fredericksburg, Va. Locally, the basement complex rocks consist of granite and granite gneiss of Paleozoic(?) and Precambrian age. Water occurs chiefly in fissures and joints in these rocks at depth and in a weathered zone directly overlying the fresh rock.

Water obtained from the weathered part of the basement complex varies widely in content of dissolved mineral constituents and contains objectionable amounts of iron, but is suitable for most domestic uses. However, waters from the deeper, fractured zones of the basement complex have been reported to contain as much as 5,500 ppm (parts per million) chloride.

The saline water occurring in the basement complex within the Fall Zone is believed to be residual sea water which covered the area during Tertiary time. This hypothesis is suggested from the occurrence of Eocene and Miocene marine deposits overlying crystalline rocks of the basement complex along the eastern border of the Piedmont (Clark and Miller, 1912). Joints and fissures in the crystalline rocks provicled open channelways for entry of sea water either directly from the sea, in the area just west of the Fall Zone, or by percolation downward through the overlying Cretaceous rocks, in the area east of the Fall Zone.

The end of Tertiary time is believed to mark the last marine inundation of the area. Gradually, as the Tertiary seas receded, sea water was slowly replaced by fresh water moving from the recharge area through the ground-water reservoir. By Pleistocene time the Fredericksburg area was mantled by nonmarine terrace deposits that locally overlie the basement complex and by sands of the Patuxent formation (Lower Cretaceous). Increased precipitation provided an addi-

2 Thls paper is based on work done during a Federal-State cooperative program that was terminated in June 1957 . tional source of fresh water to enter the ground-water reservoir.

Fresh water circulates more freely within the sands of the Patuxent formation and within the uppermost part of the crystalline rocks than in less fractured crystalline rocks at depth. The deep-seated fractures, which contain Tertiary residual sea water, therefore, are less slowly flushed out. An interface between fresh water and salt water is believed to occur in the basement complex and may possibly extend into the overlying Patuxent formation.

Figure 319.1 (p. D-72) represents diagramatically the fresh-water circulation and the residual saline water. Wells 52, 72, 74, and 112, which penetrate the basement complex to considerable depths, yield water containing 550 to $5,500 \mathrm{ppm}$ of chloride. Water in well 54 , obtained from sands of the Patuxent formation, contains $112 \mathrm{ppm}$ of chloride-normal concentrations in the Patuxent are less than $20 \mathrm{ppm}$. Well 53, tapping a higher water-bearing zone within the Patuxent formation, yields water containing only $2.8 \mathrm{ppm}$ chloride. Wells 57 and 78, tapping essentially the same waterbearing zone, yield water differing considerably in chloride content. This condition is believed to reflect the irregularity of the bedrock surface and the arrangement of the interconnecting joint systems which permit some mixing of residual sea water and fresh ground water. Well 133, which penetrates 15 feet of the basement complex, yields water containing $137 \mathrm{ppm}$ of chloride, indicating the proximity of an interface between salt and fresh water.

Inasmuch as the total volume of water-bearing cracks in the basement complex is a very small percentage of the total volume of the rocks, it is likely that the salt water may be mixed with fresh water and thereby freshened by long-continued pumping of wells.

\section{REFERENCE}

Clark, W. B., and Miller, B. L., 1912, The physiography and geology of the Coastal Plain province of Virginia: Virginia Geol. Survey Bull. 4, p. 13-222. 


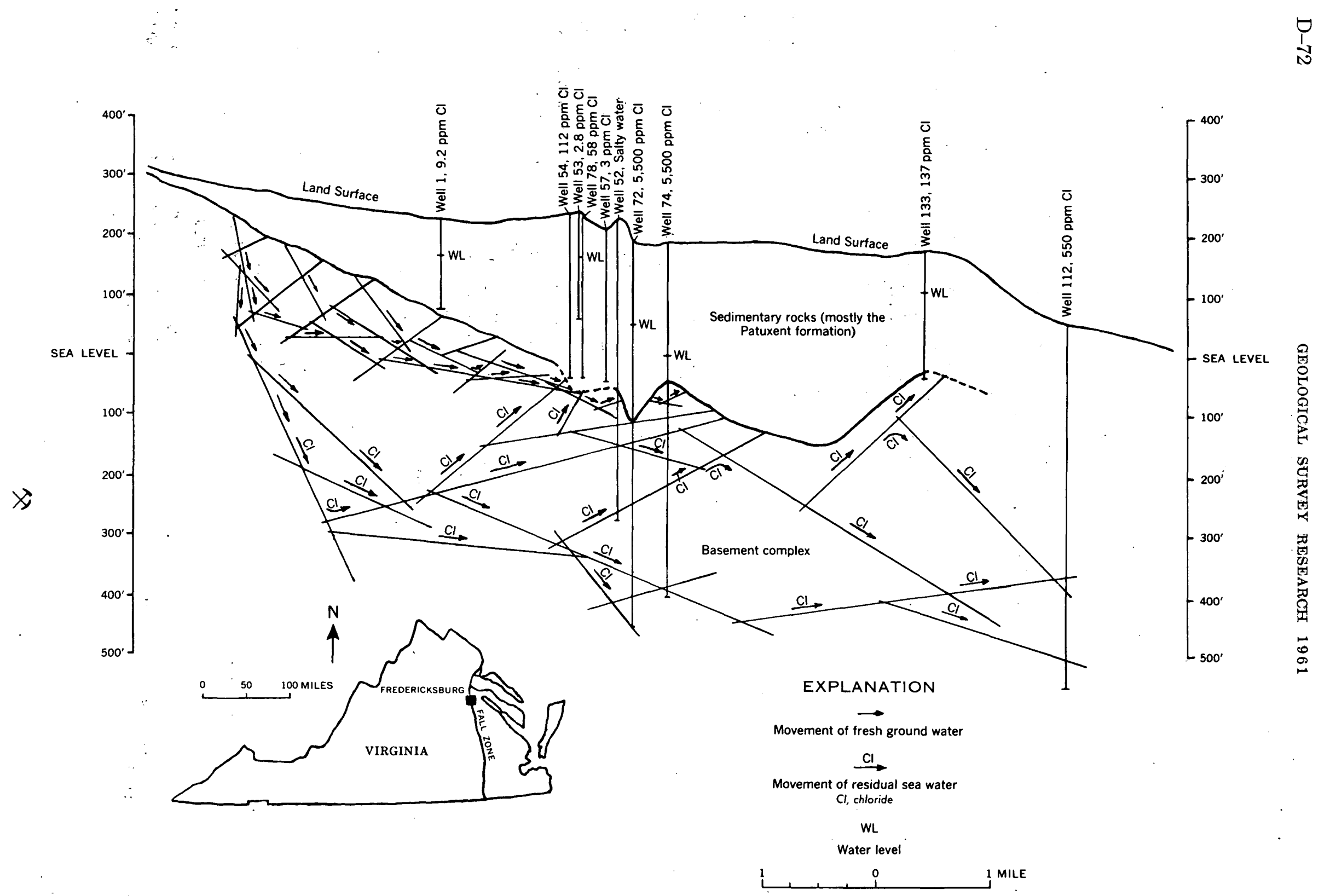

FIGURE 319.1.-Diagrammatic section showing apparent relation of fresh ground water to residual sea water in the baseme ut complex in the Fall Zone. 
GEOLOGY AND HYDROLOGY OF WESTERN CONTERMINOUS UNITED STATES

\title{
320. SUGGESTED MAGMATIC DIFFERENCES BETWEEN WELDED “ASH” TUFFS AND WELDED CRYSTAL TUFFS, ARIZONA AND NEVADA
}

\author{
By Ralph J. Roberts and Donald W. Peterson, Menlo Park, Calif.
}

During the mapping of the Antler Peak quadrangle, Nevada, in 1941-49 by Roberts, and the Haunted Canyon quadrangle, Arizona, in 1953-57 by Peterson, we independently recognized that welded tuffs of these areas are distinctly different in texture and composition from most welded tuff's previously described. Subsequent study has led us to believe that welded tuffs are of two principal types, welded "ash" tuffs and welded crystal tuft's, and that these types may be significantly related to magmatic composition and eruptive processes. Our ideas are presented here in preliminary form; additional quantitative chemical and modal information is needed to test their applicability in this and other regions.

Wo were aided in this study by the helpful criticisms of H. R. Cornwall and Dallas Peck, and suggestions by George C. Kennedy, Robert R. Coats, and Paul C. Bateman.

\section{WELDED “ASH” TUFF}

Welded "ash" tuffs are composed mainly of glass shards, rock fragments, and fragments of crystals that have been compressed and welded together. Few data on the proportions of these constitutents are available, but the crystal content is generally small. Gilbert (1938, p. 1834) described the Bishop tuff, near Bishop, Calif., which contains about 10 percent crystals; Enlows (1955, p. 1222-1225) reported that the crystal content of welded tuff's of the Chiricahua Mountains, Ariz., generally is between 2 and 25 percent; and Mansfield and Ross $(1935$, p. 320) reported a few percent to a maximum of 25 percent crystals in welded tuff from southeastern Idaho. Marshall (1935, p. 331, 341, 347) mentioned "many crystals" in certain ignimbrite units in New Zealand, but did not specify percentages; his photomicrographs show ranges in crystal content of 5 to 25 percent.

\section{WELDED CRYSTAL TUFF}

Welded arystal tuffs in Nevada and Arizona are characterized by high crystal content and fragments of lapilli size in a matrix of glass shards. The crystal content ranges from 25 to 50 percent or more and suggests long-continued intratelluric crystallization prior to eruption. Most of these tuffs are quartz latitic or dacitic in composition.
Antler Peak quadrangle, Nevada.-Welded quartz latite crystal tuffs from the Antler Peak quadrangle near the town of Battle Mountain, Nev., form extensive bodies as much as 300 feet thick. These include a basal nonwelded quartz latitic tuff that grades successively upward into densely welded quartz latitic vitrophyre and aphanitic quartz latite that comprises the major part of the deposit (Roberts, 1951). The upper unit is composed of phenocrysts and relict lapilli in a matrix of glass shards now largely recrystallized to a cryptocrystalline aggregate (fig. 320.1). All the layers are similar in composition and mineralogy ; textural differences due to variations in degree of welding and crystallization along strike were noted locally, but on the whole the layers are remarkably uniform. Phenocrysts commonly make up 35 to 50 percent of the rock in approximately the following proportions: plagioclase 33 percent, sanidine 35 percent, quartz 22 percent, and biotite and accessories 10 percent.

Globe and Superior, Arizona.-The dacitic welded tuff sheet in the vicinity of Globe and Superior, Ariz., reaches a maximum thickness of about 2,000 feet. Differences in degree of welding and crystallization of groundmass (fig. 320.2) are similar to those in the quartz latite of Antler Peak. Phenocrysts consistently make up 35 to 45 percent of the rock in the following average proportions: plagioclase 72.5 percent, sanidine 2.5 percent, quartz 10 percent, biotite 9.2 percent, magnetite 3.4 percent, hornblende 1.9 percent, and accessories 0.5 percent.

\section{COMPARISON OF CHEMICAL AND MINERALOGICAI COMPOSITION}

A comparison of chemical analyses of welded "ash" tuffs with welded crystal tuffs in the western conterminous United States reveals certain consistent differences. Most of the analyzed welded "ash" tuffs are rhyolite and have silica contents of 70 to 76 percent, whereas the welded crystal tuff's are mostly quartz latite or dacite and have silica contents of 62 to 72 percent. Table 320.1 shows chemical analyses of welded crystal tuff's (number 1 to 14) and welded "ash" tuffs (number 15 to 24 ) from the western conterminous United States. Modal data are fragmentary, but crystal content is given where available. 

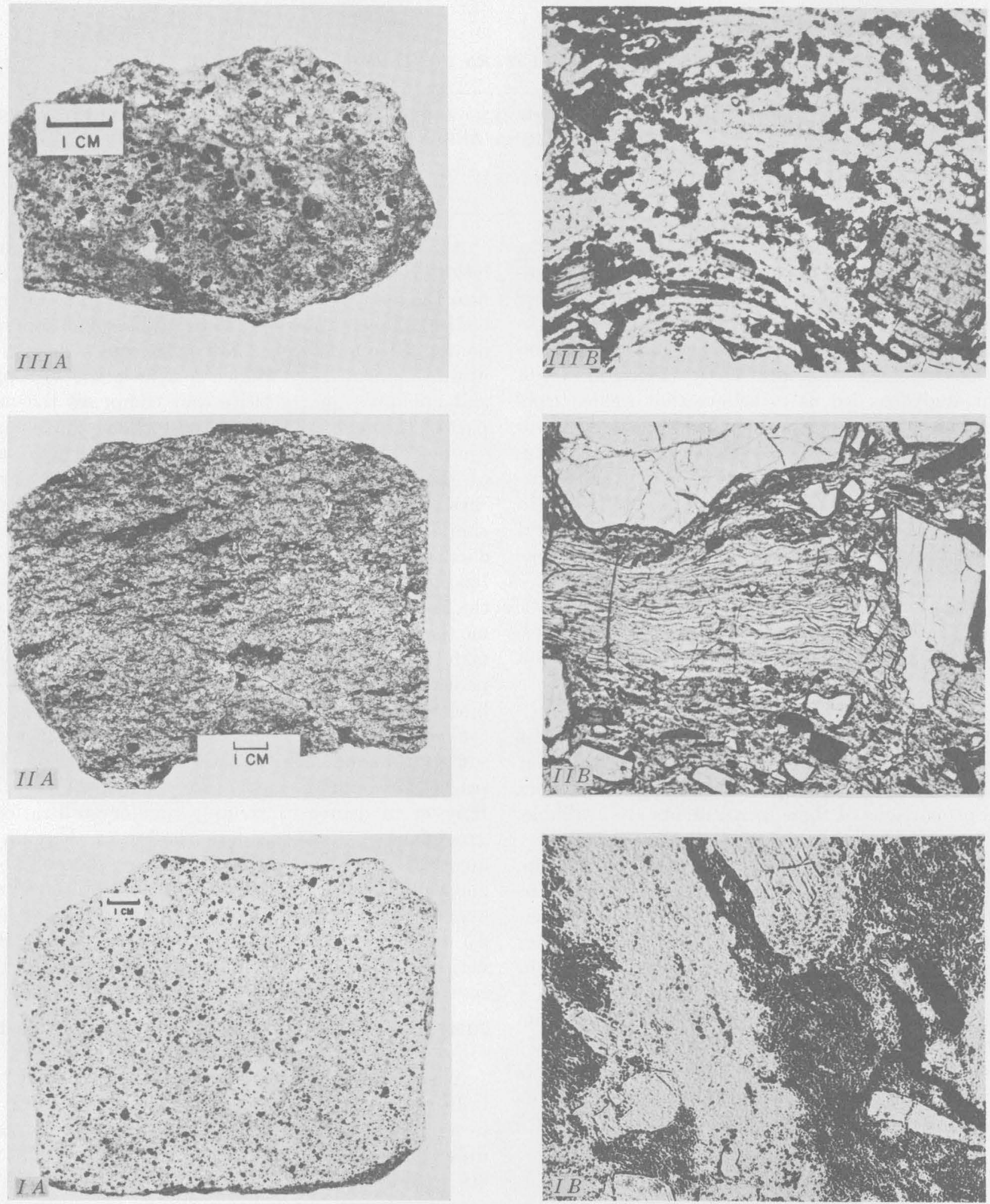

Figure 320.1.-Typical phases of quartz latite, Antler Peak quadrangle, Nevada.

I. Nonwelded quartz latitic lapilli tuff; lapilli show original pumiceous structure and are not deformed or compressed. A, Hand specimen. $B$, Photomicrograph, plane light.

II. Quartz latitic vitrophyre. Lapilli are highly compressed and deformed, forming dense rock. A, Hand specimen. Fragments are argillite from underlying units. $B$, Photomicrograph, plane light.

III. Aphanitic quartz latite showing pseudo-flow structure; lapilli intensely deformed and welded; show incipient crystallization. A, Hand specimen. $B$, Photomicrograph, plane light. 

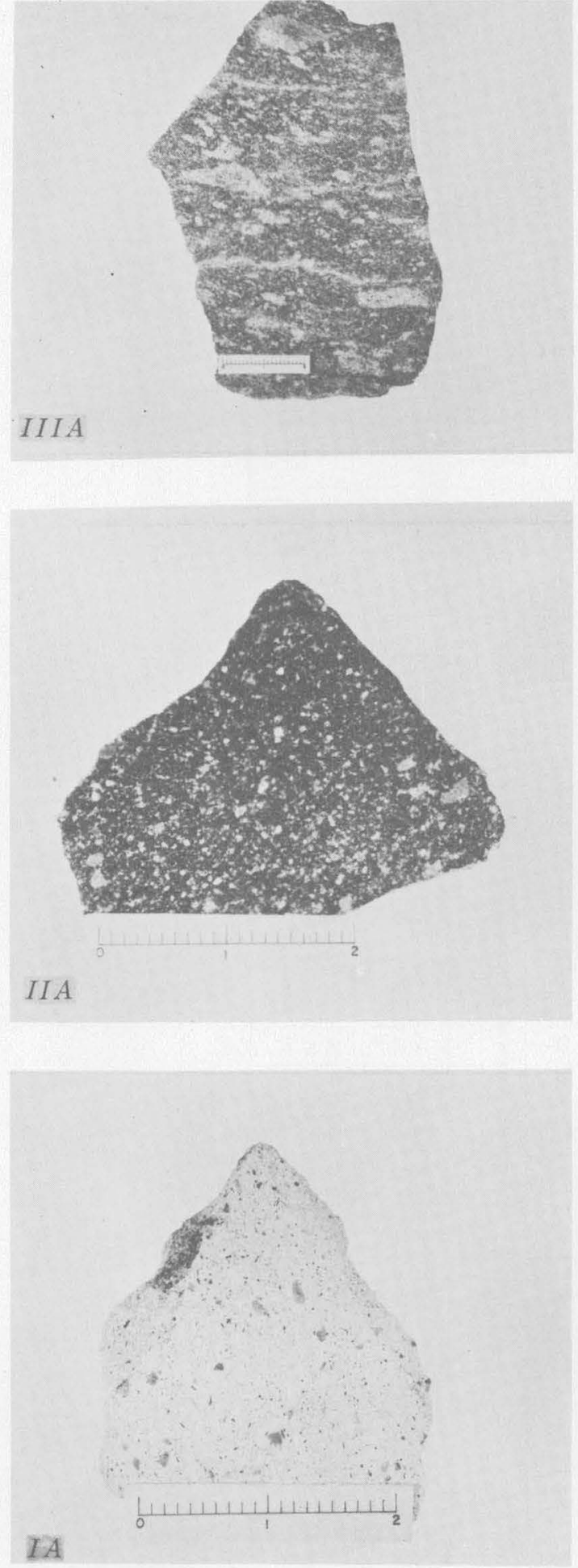
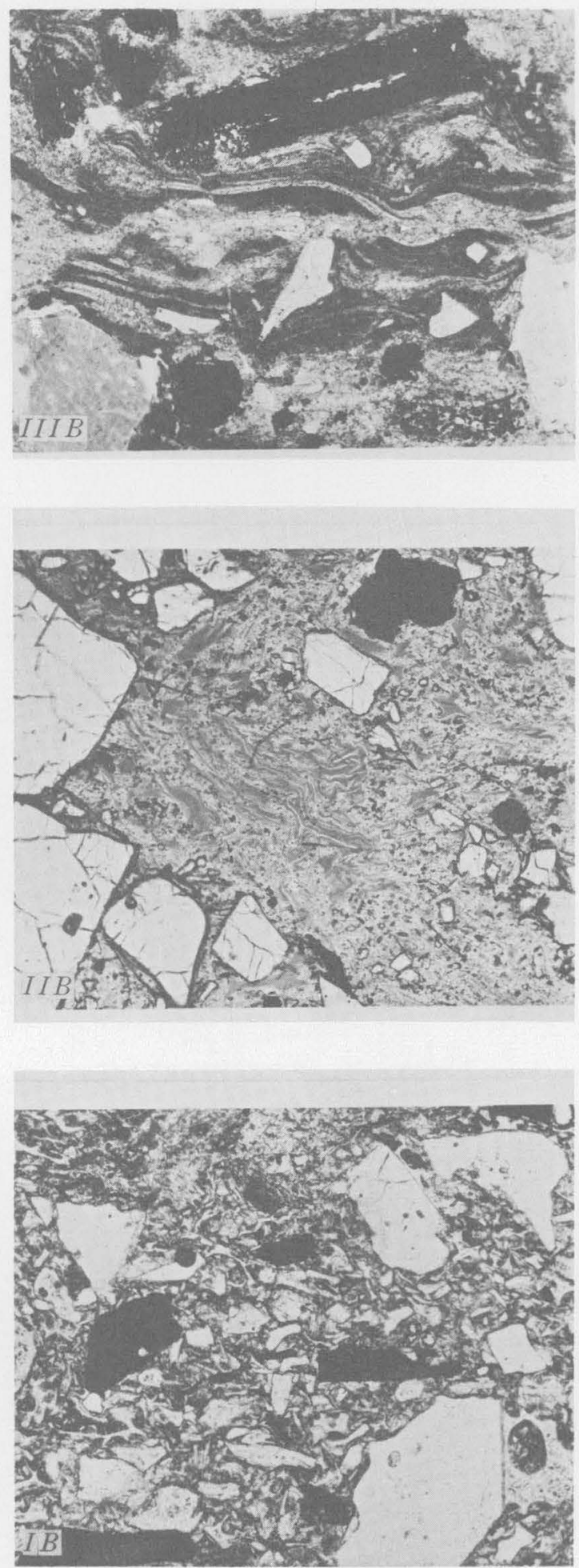

Figure 320.2.-Typical phases, dacite near Globe and Superior, Ariz.

I. Nonwelded dacitic tuff at base. Glass shards are not deformed or flattened. $A$, Hand specimen. $B$, Photomicrograph, plane light.

II. Dacitic vitrophyre from layer between nonwelded tuff and dacite. Glassy matrix shows extreme squeezing of highly welded tuff. $A$, Hand specimen. $B$, Photomicrograph, plane light.

III. Aphanitic dacite. Groundmass is cryptocrystalline, showing flow-like structures which represent relict outlines of extremely flattened and devitrified lapilli. $A$, Hand specimen. $B$, Photomicrograph, plane light. 
TABLE 320.1-Anclyses, in percent, of welded crystal tuffs and "ash" tuffs [Rock types and localities of numbered analyses listed on p. D-77]

\begin{tabular}{|c|c|c|c|c|c|c|c|c|c|c|c|c|c|c|c|c|c|c|c|c|c|c|c|c|}
\hline \multicolumn{15}{|c|}{ Welded crystal tuffs } & \multicolumn{10}{|c|}{ Welded "ash" tuffs } \\
\hline & 1 & 2 & 3 & 4 & 5 & 6 & 7 & 8 & 9 & 10 & 11 & 12 & 13 & 14 & 15 & 16 & 17 & 18 & 19 & 20 & 21 & 22 & 23 & 24 \\
\hline $\mathrm{SiO}_{2}$ & 70.2 & 71.0 & 70.7 & 71.2 & 70.8 & \begin{tabular}{|l|}
71.82 \\
\end{tabular} & 71.08 & 69.35 & 70.1 & 68.76 & 71.3 & 64.25 & 61.05 & 72.4 & 75.6 & 76.7 & 76. 38 & 74. 55 & 73.27 & \begin{tabular}{|l|l|}
75.02 \\
\end{tabular} & 74.10 & 75.6 & 73. 97 & 73. 17 \\
\hline $\mathrm{Al}_{2} \mathrm{O}_{3}$ & 14.7 & 15.1 & 14.2 & 14.6 & 13. 2 & 14.44 & 14. 43 & 15. 22 & \begin{tabular}{|l|l|}
14.2 \\
\end{tabular} & 15.48 & 14.7 & 15.01 & 16.03 & 13.9 & 13.1 & 13.0 & 12.47 & 11.16 & \begin{tabular}{|l|}
12.16 \\
\end{tabular} & $\begin{array}{l}12.56 \\
\end{array}$ & 11.59 & 12. 2 & 12.74 & 13. 34 \\
\hline $\mathrm{Fe}_{2} \mathrm{O}_{3} \ldots$ & 1.3 & 1.4 & 1.2 & 1.8 & .93 & 1.50 & .78 & 2. 50 & 2.0 & 2. 50 & 2.2 & 3. 49 & 5.42 & 1.8 & .8 & .5 & 1.56 & 1.51 & .74 & .99 & 3.36 & .58 & .94 & 1.35 \\
\hline $\mathrm{FeO} . .$. & 1:0 0 & 1.0 & .86 & .56 & .98 & .35 & .84 & .38 & .90 & .44 & .37 & 1.02 & .98 & .20 & .13 & .26 & $\operatorname{tr}$ & .00 & .23 & .00 & .03 & .11 & .27 & .76 \\
\hline $\mathrm{MgO}$. & .56 & .62 & .50 & .49 & .03 & .34 & .21 & .51 & .68 & .56 & .70 & 2. 09 & 3. 03 & .59 & .18 & .13 & .15 & .16 & .12 & .13 & .08 & .36 & .29 & .81 \\
\hline $\mathrm{CaO} .$. & 2.1 & 2.2 & 1.8 & 2.0 & 2.5 & 1.16 & 1.40 & 2. 40 & 1.8 & 2.23 & 2.3 & 4. 21 & 5.40 & 1.5 & .56 & .52 & .15 & 1.53 & .50 & .78 & .14 & .54 & 1.04 & 1. 32 \\
\hline $\mathrm{Na}_{2} \mathrm{O}_{\text {. }}$ & 3.2 & 3. 5 & 3.0 & 3. 2 & 2.1 & 3. 90 & 4.00 & 3. 25 & 3.2 & 3. 89 & 3. 0 & 2. 36 & 1.43 & 3.1 & 3.8 & 3.7 & 3.0 & 3. 11 & 3.60 & 4. 34 & 4.00 & 3.2 & 3. 08 & 1.80 \\
\hline $\mathrm{K}_{2} \mathrm{O}$ & 4.6 & 4.3 & 4.8 & 4.4 & 4.4 & 4. 88 & 5.44 & 4. 48 & 5.1 & 3.88 & 4.4 & 4.07 & 5. 58 & 4.5 & 4.8 & 4.5 & 4. 85 & 4.66 & 4.77 & 4.74 & 5. 54 & 4.4 & 4. 83 & 7. 10 \\
\hline $\mathrm{TiO}_{2 .}$ & .33 & .33 & .28 & .32 & .54 & .61 & .24 & .40 & .43 & .50 & .31 & .55 & & .28 & .11 & .06 & .12 & .11 & .14 & .15 & .22 & .10 & .18 & 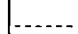 \\
\hline $\mathrm{P}_{2} \mathrm{O}_{3}$ & .14 & .14 & .11 & .12 & .07 & .26 & .09 & .15 & .18 & .06 & .01 & .15 & .30 & .01 & .01 & .00 & .01 & .02 & .01 & .02 & .02 & .00 & .03 & .07 \\
\hline MnO. & .04 & .07 & .06 & .07 & .01 & .06 & .14 & .02 & .06 & .02 & .04 & .07 & & .02 & .04 & .03 & .05 & .12 & .09 & .10 & .15 & .06 & .04 & . \\
\hline $\mathrm{H}_{3} \mathrm{O}^{+}$. & 1.6 & .49 & 1.9 & .57 & 3.0 & $\{.61$ & .22 & .67 & & $\{.57$ & & $\{.86$ & & & & & $\int .26$ & .76 & 2.95 & .36 & .22 & 29 & 2. 26 & .54 \\
\hline $\mathrm{H}_{2} \mathrm{O}^{-}$. & .19 & .05 & .24 & .44 & 3.0 & $\{.34$ & .38 & .66 & $\cdot 64$ & $\{.79$ & \} .98 & $\{1.13$ & .81 & 1.8 & .35 & .34 & R.85 & 1.15 & 1.07 & .18 & .35 & 2.9 & & 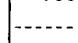 \\
\hline & & & & & & & & & & & & .01 & & & & & & & & & & & & \\
\hline $\mathrm{BaO}$ : & $\cdots$ & 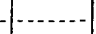 & $\cdots$ & $\ldots$ & $\cdots$ & $\cdots$ & $\cdots$ & -.. & $\ldots$ & $\cdots$ & $\cdots$ & .07 & .08 & & & & -.... & $\mathrm{SO}_{3} .54$ & & & 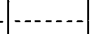 & & $\mathrm{BaO} .03$ & .10 \\
\hline & & & & & & & & & & & & & & & & & . & & & $\cdots$ & $\ldots$ & & & $\ldots$ \\
\hline $\mathrm{F}$ & & & & & & & & & & & & & & & & & & .49 & & & & & & ........... \\
\hline $\mathrm{CO}_{2 \ldots}$ & .20 & .04 & .07 & .19 & $\ldots$ & .01 & .35 & & .07 & .14 & .08 & .30 & & .05 & .16 & .08 & -...- & .04 & .01 & .43 & .02 & $\ldots$ & .01 & -..... \\
\hline Total & 100 & 100 & 100 & 100 & 99 & 99.73 & 99.60 & 99.99 & 99 & 99.82 & 100 & 99.64 & 100.11 & 100 & 100 & 100 & 99.85 & 99. 99 & 99.66 & 99.80 & 99.82 & 100 & 99.95 & 100.36 \\
\hline \multicolumn{25}{|c|}{ Normative values of $Q$, or, ab, and an recalculated to 100 percent } \\
\hline & & 26.7 & 28.1 & 30.8 & 28.7 & 27.5 & 25.0 & 29.3 & 27.4 & 27.7 & 33.2 & 27.5 & 22.8 & 35.4 & 34.8 & 36.1 & 42. 0 & 39.0 & 34.9 & 32.2 & 33.1 & 40.4 & 36.4 & 32.8 \\
\hline & 30.7 & 28.8 & 30.8 & 29.1 & 33.9 & 31.2 & 33. 9 & 28.8 & 33.7 & 24.6 & 27.8 & 28.4 & 39.0 & 28.6 & 29.3 & 28.2 & 30.5 & 29.9 & 30.2 & 28.7 & 35.6 & 27.7 & 30.2 & 44.5 \\
\hline $\mathbf{a b}_{-.}$ & 30.3 & 33.5 & 33. 2 & 30.4 & 28.0 & 35.7 & 35.8 & 29.9 & 30.3 & 35.7 & 26.9 & 23.1 & 14.1 & 28.0 & 33.0 & 33.1 & 26.6 & 28.0 & 32.2 & 38.0 & 31.3 & 28.9 & 27.8 & 16.0 \\
\hline an & 6.3 & 11.0 & 7.9 & 9.7 & 9.4 & 5.6 & 5.3 & 12.0 & 8.6 & 12.0 & 12.1 & 21.0 & 24.1 & 8.0 & 2.9 & 2.6 & .9 & 3.0 & 2.7 & 1.1 & 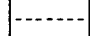 & 3.0. & 5.6 & 6.7 \\
\hline $\begin{array}{c}\text { D.I.1 } \\
\text { Total }\end{array}$ & 83.4 & $\begin{array}{l}100 \\
78.7\end{array}$ & $\begin{array}{l}100 \\
84.9\end{array}$ & $\begin{array}{l}100 \\
80.6\end{array}$ & $\begin{array}{l}100 \\
81.1\end{array}$ & $\begin{array}{l}100 \\
87.1\end{array}$ & $\begin{array}{l}100 \\
90.2\end{array}$ & $\begin{array}{l}100 \\
81.7\end{array}$ & $\begin{array}{l}100 \\
82.2\end{array}$ & $\begin{array}{l}100 \\
88.0\end{array}$ & $\begin{array}{l}100 \\
82.4\end{array}$ & $\begin{array}{l}100 \\
68.0\end{array}$ & $\begin{array}{l}100 \\
64.9\end{array}$ & $\begin{array}{l}100 \\
86.5\end{array}$ & $\begin{array}{l}100 \\
94.2\end{array}$ & $\begin{array}{l}100 \\
92.4\end{array}$ & $\begin{array}{l}100 \\
93.8\end{array}$ & $\begin{array}{l}100 \\
90.4\end{array}$ & $\begin{array}{l}100 \\
91.5\end{array}$ & $\begin{array}{l}100 \\
92.1\end{array}$ & $\begin{array}{l}100 \\
92.1\end{array}$ & $\begin{array}{l}100 \\
91.6\end{array}$ & $\begin{array}{l}100 \\
88.9\end{array}$ & $\begin{array}{l}100 \\
88.7\end{array}$ \\
\hline Crystals, percent... & 50 & $240-50 \mid$ & $\begin{array}{ll}0 & 39\end{array}$ & $230-40$ & $230-35$ & 230 & 39.1 & $\cdots . .$. & 40 & $235-45$ & $30-40$ & $320+$ & Ser & $230-41$ & 5 & 220 & $220-25$ & $220-25$ & 8.4 & 5.3 & 14.2 & 16.4 & 212 & . \\
\hline
\end{tabular}

1 Differentiation index, Thornton and Tuttle (1960).

2 Estimated.

Probably low: counted under binocular microscope. 
The relative normative values of quartz plus orthoclase, albite, and anorthite from each analysis are plotted on figure 320.3. The two types of welded tuff fall into two fields. The fields shown apply only to the Basin and Range province. Volcanic rocks of other magmatic provinces would have different differentiation trends, and the boundary between "ash" tuffs and crystal tuffs would probably be higher or lower and have a different slope.

1. Vitrophyre, Rocky Canyon, Antler Peak quadrangle, Lander County, Nev. K. E. White, H. F. Phlllips, P. W. Scott, and F. S. Borris, analysts.

2. Quartz latito, Rocky Canyon, Antler Peak quadrangle, Lander County, Nev. K. E. White, H. F. Phlllips, P. W. Scott, and F. S. Borris, analysts.

3. Vitrophyre, Elephant Head, Lander County, Nev. K. E. White, H. F. Phillips, P. W. Scott, and F. S. Borris, analysts.

4. Quarta latlte, Elephant Head, Lander County, Nev. K. E. White, H. F. Phillips, P. W. Scott, and F. S. Borris, analysts.

5. Quartz latite, near Virginia City, Nev. (collected by D. E. White). L. Shapiro, S. M. Berthold, and E. A. Nygaard, analysts.

6. Quartz latite, Toyabe quartz latite, near Unionville, Nev. (collected by C. J. Vitaliano). F. H. Neuerbert, analyst.

7. Quartz latite, Marblo Falls Canyon, Paradise Peak Range, Esmeralda County, Nov. (collected by C. J. Vitaliano), Ledoux and Co., analysts.

8. Quartz latite, Roberts Mountains, Nev. (Merriam and Anderson, 1942, p. 1720, G. Kahan, analyst).

0. Quartz latite, Humboldt County, Nev. (collected by C. R. Willden). P. L. D. Elmore, K. E. White, and S. D. Botts, analysts.

10. Daclte, near Globe, Arlz. (Ransome, 1803, p. 92-93, E. T. Allen, analyst).

11. Quartz latite, Mineral County, Nev. (collected by D. C. Ross). P. L. D. Eimore, S. D. Botts, and K. E. White, analysts.

12. Neodles Range formation, near Cedar City, Utah, J. Hoover Mackin (written communication, 1960), Robert N. Eccher, analyst.

13. Dacite from Swett Hills near Cedar City, Utah (Leith and Harder, 1908, p. 58 R. D. Hall, analyst). Probably equivalent to Harmony Hills tuff of Mackin, 1860 .

14. Rhyolite, Mineral County, Nev. (collected by D. C. Ross). P. L. D. Elmore, S. D. Botts, and K. E. White, analysts.

15. Bishop tuff, Owens River Gorge, Calif., N. edge Mt. Tom quad., sec. 22, T. 5 S., R. 31 E., white member (collected by P. C. Bateman). P. L. D. Elmore, S. D. Botts, and M. D. Mack, analysts.

16. Bishop tuff, Owons River Gorge, Calif., N. edge Mt. Tom quad., sec. 22, T. 5 S., R. 31 E., palo grayish purple member (collected by P. C. Bateman). P. L. D. Elmore, S. D. Botts, and M. D. Mack, analysts.

17. Welded rhyolite tuff, Chiricahua Natlonal Monument, Ariz. (Enlows, 1955, p. 1233, Lols D. Trumbull, analyst).

18. Welded rhyoltte tuff, Chiricahua National Monument, Ariz. (Enlows, 1955, p. 1233, Lois D. Trumbull, analyst).

19. Basal vitrophyre zono of welded tuff, Bull[rog Hills, Beatty area, Nev., H. R. Cornwall (written communlcation, 1960). Dorothy F. Powers, analyst.

20. T.itholdal welded tuff, Bullfrog Hills, Beatty area, Nev., H. R. Cornwall (written communication, 1960). Dorothy F. Powers, analyst.

21. Litholdal welded tuff, Oak Spring formation, Nevada Test Site, Nye County, Nev., H. R. Cornwall (written communication, 1960). Dorothy F. Powers, analyst.

22. Weldod tuff of the Oak Spring formation, Nevada Test Site, Nye County, Nev., H. R. Corn wall (written communication, 19R0). Frank Elmore, analyst.

23. Black glass at base of Loach Canyon tuff near Three Peaks, Iron Springs County, Utah, J. Hoover Mackin (written communication, 1960). Robert N. Eccher, analyst.

24. Trachyte from Antelope Hills, Iron Springs County, Utah (Leith and Harder, 1008 , p. 58, R. D. Hall, analyst). Probably equivalent to Bauers tuff of Mackin (1960).

\section{DIFFERENCES IN MAGMATIC HISTORY AND ERUPTIVE BEHAVIOR}

The nature of volcanic eruptions depends on composition, temperature, volatile content, rate of vesiculation, viscocity, and other factor's (Verhoogen, 1951; Williams, 1954, p. 307). Of these, volatile content and rate of vesiculation are probably the most important, for they control the violence and particle size of the eruption.
The distribution of points on figure 320.3 shows that welded "ash" tuffs are formed from magma more silicic and alkalic than magma forming welded crystal tuffs. These two kinds of magmas may either have separate origins or, alternatively, may form by differentiation of a magma of intermediate composition. In the latter alternative, following emplacement of the magma in the upper part of the crust, plagioclase and mafic minerals may crystallize and settle downward; volatiles migrating upward would carry silica and alkalis (Kennedy, 1955, p. 494-498; Tuttle and Bowen, 1958, p. 90). These two processes would tend to enrich the upper part of the magma in silica, alkalis, and volatiles; if the internal pressure finally were to exceed the confining pressure and eruption were to take place, the magma would be completely fragmented to yield typical "ash" tuff.

The magma deeper in the chamber would have lower silica, alkali, and volatile content, and lower vapor pressure. Crystallization of the magma, together with accumulation of crystals settling from the upper levels, would proceed until crystal content would be high; if an eruption were to issue from this part of the magma chamber, crystal-rich tuff would result. Lower volatile content would cause less fragmentation of the material as it erupted, forming fewer and relatively larger particles, many in the lapilli size range.

A simplified scheme of kind of eruption related to volatile content is shown in table 320.2 .

TABLE 320.2.-Effect of relative volatile content on the kind of eruption and product; siliceous and intermediate magmas

\begin{tabular}{|c|c|c|}
\hline Volatile content & Kind of eruption & Product \\
\hline I. Very high... & $\begin{array}{l}\text { Violent initial explo- } \\
\text { sion (vulcanian). } \\
\text { High degree of } \\
\text { fragmentation. }\end{array}$ & $\begin{array}{l}\text { Ash, tuff, breccia } \\
\text { (entirely non- } \\
\text { welded). }\end{array}$ \\
\hline II. High_... & $\begin{array}{l}\text { Nuée ardente or glow- } \\
\text { ing avalanche. } \\
\text { Erupted magma } \\
\text { continues to expand } \\
\text { during transport; } \\
\text { high degree of } \\
\text { fragmentation. }\end{array}$ & $\begin{array}{l}\text { Welded ash tuff } \\
\text { (large portions of } \\
\text { erupted bodies } \\
\text { are nonwelded). }\end{array}$ \\
\hline III. Moderate.-. & $\begin{array}{l}\text { Similar to II, except } \\
\text { that expansion is } \\
\text { less, and degree of } \\
\text { fragmentation is } \\
\text { moderate. }\end{array}$ & $\begin{array}{l}\text { Welded crystal tuff } \\
\text { (tops and bot- } \\
\text { toms of erupted } \\
\text { bodies are non- } \\
\text { welded). }\end{array}$ \\
\hline IV. Low $\ldots \ldots$ & $\begin{array}{l}\text { Magma erupts as } \\
\text { viscous liquid. No } \\
\text { fragmentation due } \\
\text { to gas expansion. }\end{array}$ & $\begin{array}{l}\text { Lava flows, domes, } \\
\text { and spines. }\end{array}$ \\
\hline
\end{tabular}




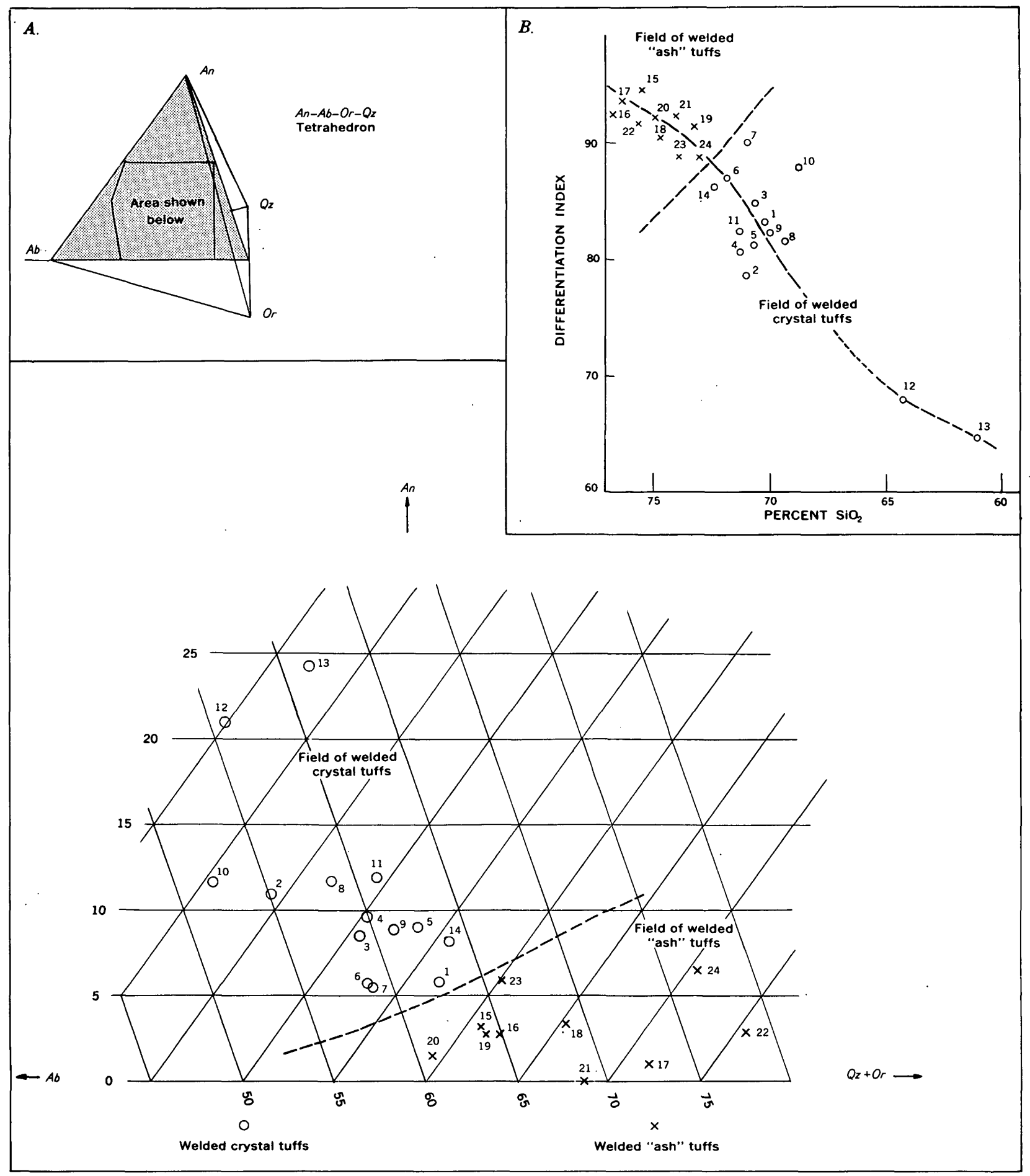

FIgURE 320.3.-Diagram showing plotted normative values of albite (Ab), anorthite (An), and orthoclase+quartz (Or+Qz) of rocks in table 320.1 plotted on expanded section through the tetrahedron (An-Ab-Or-Qz). Inset diagrams show $(A)$, plane of section, and $(B)$, differentiation index (D. I.) of Thornton and Tuttle (1960) plotted against silica. 
This table places the eruption of welded tuffs at intermediate stages in the volcanic cycle of silicic and intermediate lavas.

In several regions, both crystal-rich and crystal-poor welded tuffs are found together, such as New Zealand (Marshall, 1935) ; Sumatra (Westerveld, 1943, 1947); El Salvador (Williams and Meyer-Abich, 1955); and southwestern Utah (Cook, 1957, p. 53-69; Mackin, 1960, p. 89-105; Williams, 1960, p. 148-152). These two kinds of welded tuffs may be related in origin, and may form parts of a differentiation series. This may be tested by plotting their differentiation index (D.I. of Thornton and Tuttle, 1960) against silica. (See inset diagram on fig. 320.3.)

Additional chemical and modal analyses are needed to establish regional differentiation trends and to determine the applicability of these ideas.

\section{REFERENCES}

Cook, E. F., 1957, Geology of the Pine Valley Mountains, Utah : Utah Geol. Mineralog. Survey Bull. 58, 111 p.

Enlows, H. E., 1955, Welded tuffs of Chiricahua National Monument, Arizona : Geol. Soc. America Bull., v. 66, p. 1215-1246.

Gilbert, C. M., 1938, Welded tuff in eastern California: Geol. Soc. America Bull., v. 49, p. 1829-1862.

Kennedy, G. G., 1955, Some aspects of the role of water in rock melts: Geol. Soc. America Spec. Paper 62, p. 489-503.

Leith, C. K., and Harder, E. C., 1908, The iron ores of the Iron Springs district, southern Utah: U.S. Geol. Survey Bull. 338, $102 \mathrm{p}$.

Mackin, J. H., 1960, Structural significance of Tertiary volcanic rock in southwestern Utah: Am. Jour. Sci., n.s., v. 258, p. 81-131.
Mansfield, G. R., and Ross, C. S., 1935, Welded rhyolitic tuffs in southeastern Idaho: Am. Geophys. Union Trans., 16th Ann. Meeting, pt. 1, p. 308-321.

Marshall, P., 1935, Acid rocks of the Taupo-Rotorua volcanic district: Royal Soc. New Zealand Trans. and Proc., v. 64, p. 323-366.

Merriam, C. W., and Anderson, C. A., 1942, Reconnaissance survey of the Roberts Mountains, Nevada: Geol. Soc. America Bull., v. 53, p. 1675-1727.

Ransome, F. L., 1903, Geology of the Globe copper district, Arizona: U.S. Geol. Survey Prof. Paper 12, 168 p.

Roberts, R. J., 1951, Geology of the Antler Peak quadrangle, Nevada : U.S. Geol. Survey Quad. Map [GQ-10].

Thornton, C. P., and Tuttle, O. F., 1960, Chemistry of igneous rocks, I. differentiation index: Am. Jour. Sci., n.s., v. 258, p. 664-684.

Tuttle, O. F., and Bowen, N. L., 1958, Origin of granite in the light of experimental studies in the system $\mathrm{NaAlSi}_{3} \mathrm{O}_{5}$ $\mathrm{KAISi}_{3} \mathrm{O}_{8}-\mathrm{SiO}_{2}-\mathrm{H}_{2} \mathrm{O}$ : Geol. Soc. America Mem. 74, 153 p.

Verhoogen, Jean, 1951, Mechanics of ash formation: Am. Jour. Sci. n.s., v. 249, p. 729-739.

Westerveld, J., 1943, Welded rhyolitic tuffs or "ignimbrites" in the Pasoemah region, West Palembang, South Sumatra : Leidsche, Geol. Mededeel., v. 13, p. 202-217.

1947 , On the origin of the acidic volcanic rocks around Lake Toba, North Sumatra: Koninkl. Nederlandse Akad. Wetensch. Verh. (Tweede Sectie), DL 43, no. 1, p. 152.

Williams, Howel, 1954, Problems and progress in volcanology : Quart. Jour. Geol. Soc. London, v. 109, p. 311-332.

Williams, Howel, and Meyer-Abich, Helmut, 1955, Volcanism in the southern part of El Salvador: California Univ., Pubs. Geol. Sci., v. 32, p. 1-64.

Williams, P.L., 1960, A stained slice method for rapid determination of phenocryst composition of volcanic rocks : Am. Jour. Sci., n.s., v. 258, p. 148-152.

321. EFFECTS OF A BURIED ANTICLINE ON GROUND WATER IN NAVAJO SANDSTONE IN THE COPPER MINE-PRESTON MESA AREA, COCONINO COUNTY, ARIZONA

By N. E. McClymonds, Holbrook, Ariz.

Work done in cooperation with the Bureau of Indian Affairs and the Navajo Tribe

The Copper Mine-Preston Mesa area is in northcentral Arizona about 80 miles north of Flagstaff (fig. 321.1). This area was mapped as a part of the geologic and hydrologic investigation of the Navajo and Hopi Indian Reservations and later was studied in more detail for the purpose of locating specific water-well sites.

The rocks exposed along Echo Cliffs on the west side of the area include the Kaibab limestone of Permian age, the Moenkopi and Chinle formations of Triassic age, the Moenave formation of Triassic(?) age (Harshbarger, Repenning, and Irwin, 1957), the Kayenta formation of Triassic(?) age and the Navajo sandstone of Triassic(?) and Jurassic age (Lewis, Irwin, and Wilson, in press), and the Carmel formation of Jurassic age. Younger sedimentary rocks crop out only at Leche-e Rock and Tsai Skizzi Rock. The Wingate sandstone of Triassic age is present in the subsurface 


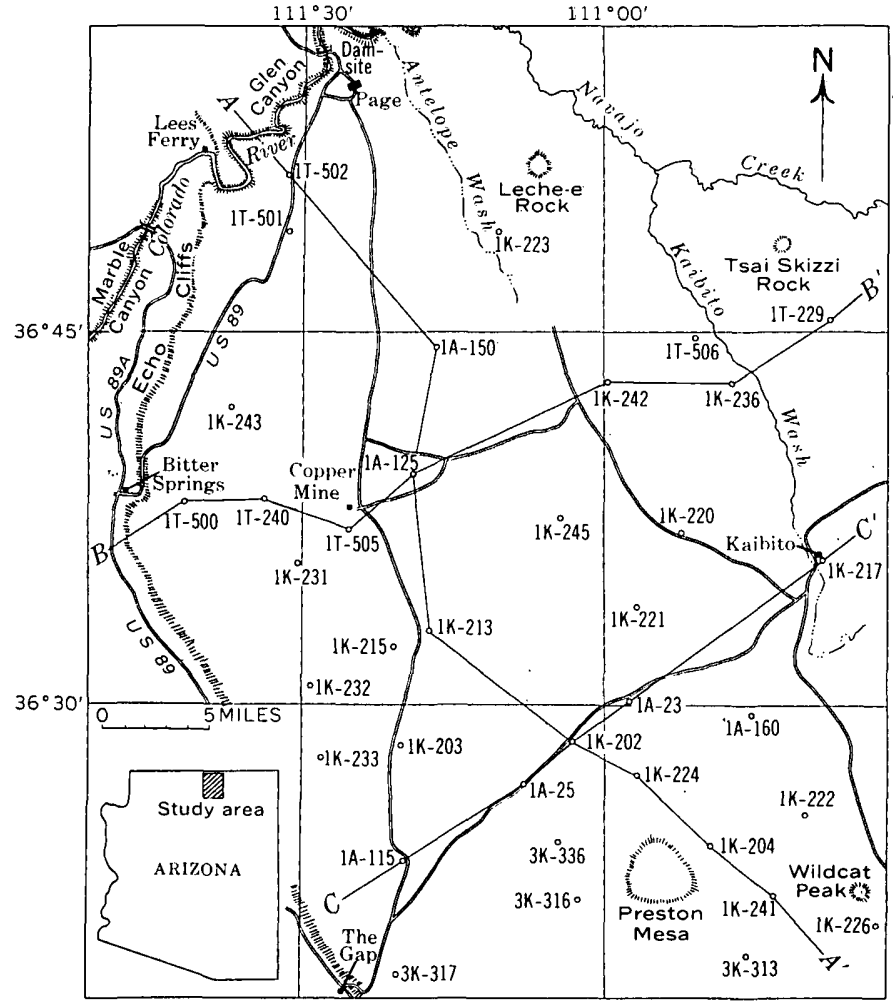

Figure 321.1.-Map of Copper Mine-Preston Mesa area, Arizona, showing wells, general physiographic features, and location of generalized sections.

between the Moenave and Chinle in the northeast part of the area but wedges out to the southwest. The Kayenta forms a barrier to the downward movement of ground water; therefore, the underlying sedimentary rocks have little bearing on the hydrology of the area and are not included on the sections (fig. 321.2). The Navajo is exposed throughout most of the area, except where it is capped by the Carmel.

The Navajo sandstone, a massive dune deposit, is composed of light-red to white fine- to medium-grained quartz sand. It is more than 1,800 feet thick northwest of the area in Zion National Park (Gregory, 1950) and thins generally in a southeasterly direction. The thinning of the Navajo is presumed to be at a uniform rate in most areas, but an anomalous thinning is apparent from well logs in the Copper Mine-Preston Mesa area (fig. 321.3). Here the sandstone is only about 800 feet thick, whereas its projected thickness would be about 1,300 feet. This anomaly occurs on the crest of an anticline in this area and indicates an increase in amplitude of the fold with depth.
A widespread tongue of the Navajo sandstone 20 to 125 feet thick occurs from 20 to 100 feet below the top of the underlying Kayenta formation. This intertonguing of the Kayenta and Navajo is important to the occurrence and development of ground water in this area.

The major structures in the Copper Mine-Preston Mesa area are the Echo Cliffs monocline, and two synclines separated by an anticline of which the buried anticline is a part. The Echo Cliffs monocline is a long sinuous feature striking northward and dipping eastward, and having about 2,000 feet of displacement. The dip is as much as $16^{\circ}$ in places. The anticlines and synclines east of Echo Cliffs have less displacement200 to 400 feet as estimated from surface expressionand more gentle dips of less than $3^{\circ}$. The surface trace of the anticline as determined by measurements on the top of the Navajo sandstone trends north-northwest-ward and extends from Preston Mesa to Page; contours on the base of the Navajo show that at depth the crest is displaced slightly to the west (fig. 321.4). Between Preston Mesa and a point about 6 miles northeast of Copper Mine the axis of this anticline is nearly flat, but beyond this point it plunges northward at about $11 / 2^{\circ}$ (figs. 321.2 and 321.4).

Grabens and horsts, not shown on figure 321.4, are prominent near the anticlinal crest east of Copper Mine and they occur elsewhere. Most faults near Copper Mine trend north-northwest ward parallel to the trend of the anticline; however, some trend northeastward. The displacement on most faults does not exceed 50 feet.

The origin of the buried anticline is not known, but presumably it was formed by differential uplift during or soon after deposition of the Navajo sandstone, inasmuch as underlying formations are conformable with the Navajo and are not thinned. An increase in the number of faults near the crest of the anticline is probably due to tension caused by the folding. Copper minerals at Copper Mine, near the crest of the anticline, may have been emplaced at a later time during Late Cretaceous or Tertiary magmatic activity.

Ground water in the Navajo sandstone occurs near the bottom of the formation and is under water-table conditions along the flanks of the buried anticline. No water is encountered on the higher parts of the anticline from about 5 miles southeast to about 15 miles north of Copper Mine.

Recharge is effective because the Navajo sandstone, and sand dunes on the surface, absorb a high percentage 

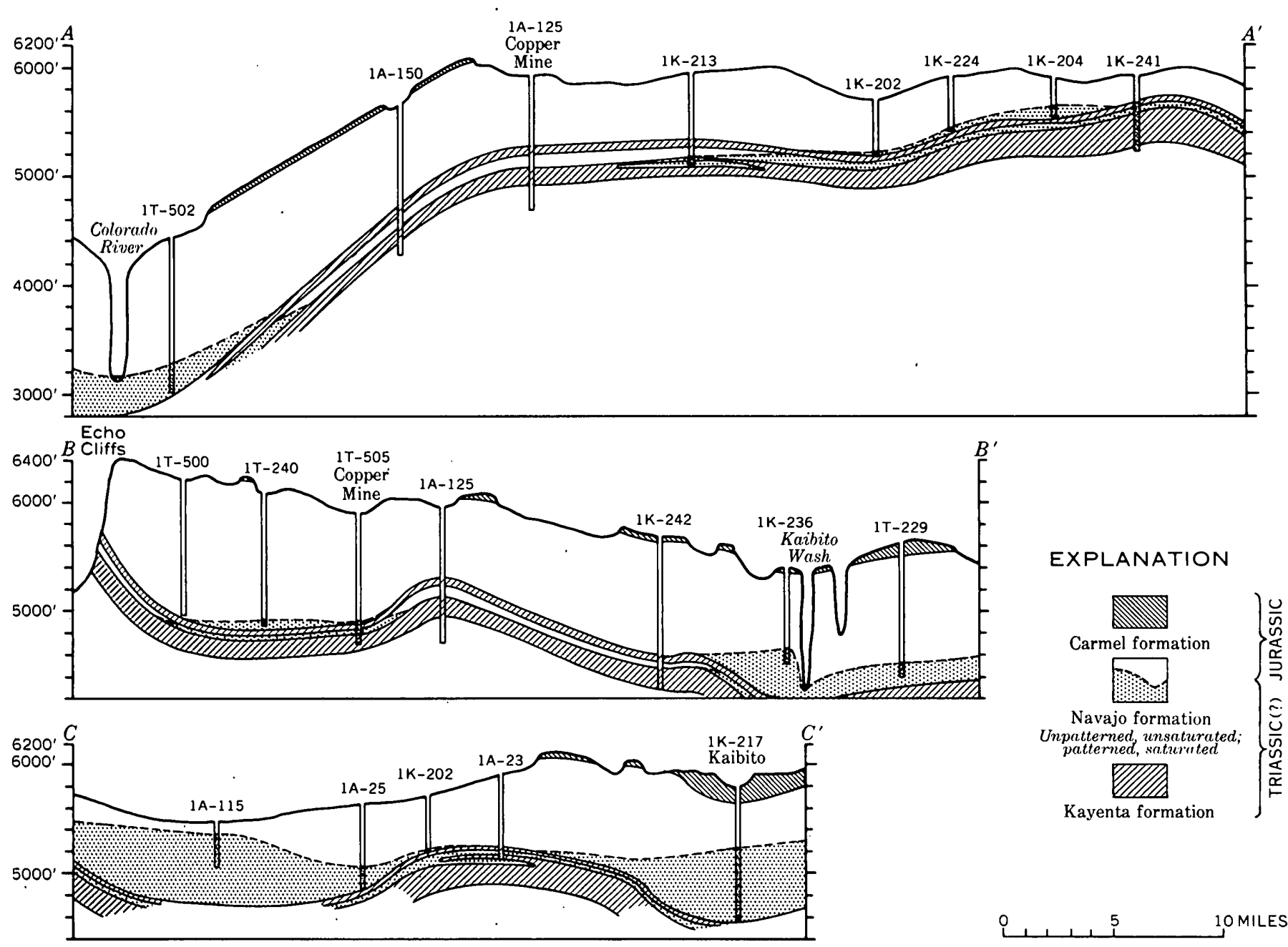

EXPLANATION

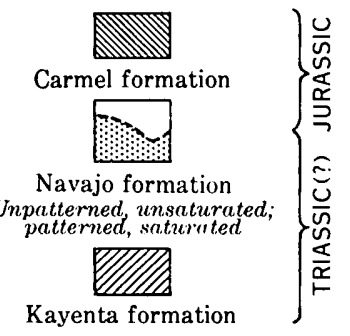

Fraure 321.2.-Generalized sections of the buried anticline. $A-A^{\prime}$, southeast along crest of anticline in the vicinity of Page, Ariz., to east side of Preston Mesa; $B-B^{\prime}$, northeast from vicinity of Bitter Springs to Tsai Skizzi Rock; and $C-C^{\prime}$, northeast from the vicinity of The Gap to Kaibito. Saturated zone in Navajo sandstone between wells is hypothetical.

of rainfall; however, the annual rate of rainfall is only 6 to 8 inches. The combination of low rainfall and the high elevation of the crest of the buried anticline relative to its flanks is unfavorable for the accumulation of ground water on the anticline. The faulting east of Copper Mine may allow water to collect in local pockets, but most of the faults probably would allow the water to escape rather than to accumulate.

The tongues of Navajo sandstone in the upper part of the Kayenta formation are important sources of ground water. Some wells, 1T-505, for example, have been drilled through the main mass of the Navajo sandstone without obtaining appreciable quantities of water, but some water was found in the tongue of the Navajo below the tongue of the Kayenta formation (figs. 321.1 and 321.2 , p. D-82).

\section{REFERENCES}

Gregory, H. E., 1950, Geology and geography of the Zion Park region, Utah and Arizona: U.S. Geol. Survey Prof. Paper $220,200 \mathrm{p}$.

Harshbarger, J. W., Repenning, C. A., and Irwin, J. H., 1957, Stratigraphy of the uppermost Triassic and the Jurassic rocks of the Navajo country : U.S. Geol. Survey Prof. Paper $291,74 \mathrm{p}$.

Lewis, G. E., Irwin, J. H., and Wilson, R. F., (in press), Changes in age assignments for the Glen Canyon group (Triassic and Jurassic) on the Colorado Plateau: Geol. Soc. America Bull. 


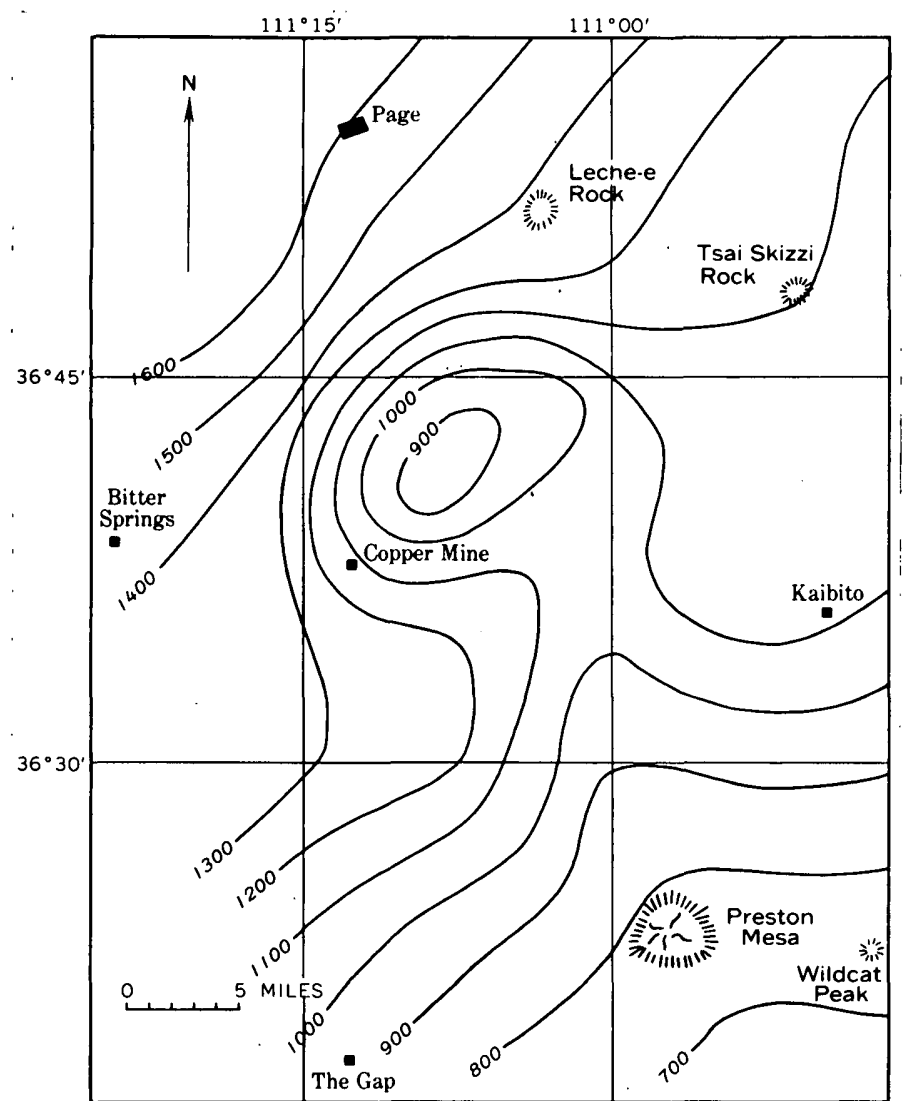

FIgURE- 321.3.-Isopach map of Navajo sandstone, showing thinning over buried anticline.

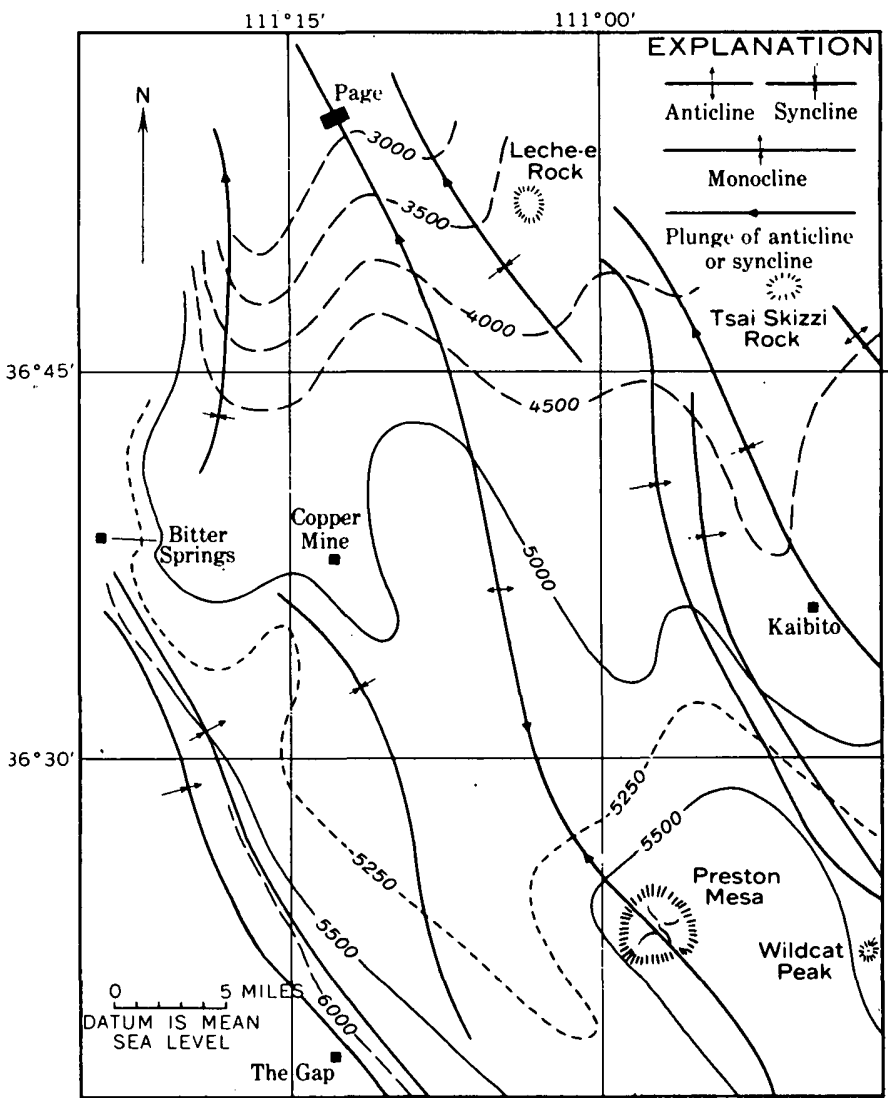

Figure 321.4.-Map showing structure contours on base of Navajo sandstone. Contour interval 500 feet (long dashes) and 250 feet (short dashes). Trend of surface structure as determined by measurements on the top of the Navajo superimposed to indicate relation with buried anticline.

322. FLATTENING RATIOS OF PUMICE FRAGMENTS IN AN ASH-FLOW SHEET NEAR SUPERIOR, ARIZONA

By Donald W. Peterson, Menlo Park, Calif.

Systematic changes in the shape of pumice fragments in a dacitic ash-flow sheet near Superior and Globe, Ariz., reflect the eruptive history and the structure of the sheet. Remnants of the sheet in this area (inset map, fig. 322.1) cover about 100 square miles; the sheet has a maximum thickness of about 2,000 feet and an average thickness of about 500 feet.

The pumice fragments are light gray to nearly white and contrast with the darker matrix, which ranges from reddish brown or reddish gray to light gray. Both the fragments and the matrix contain 35 to 45 percent phenocrysts in the approximate proportions: $3 / 4$ plagioclase, $1 / 10$ quartz, $1 / 10$ biotite, remainder sani- dine, hornblende, magnetite, and accessories. Except for their lighter color, the fragments appear to be essentially the same rock as the matrix. Recrystallization has obliterated the original pumiceous texture of the fragments, and their groundmass now consists mainly of cryptocrystalline and microcrystalline intergrowths of sanidine and cristobalite. Most of the fragments range from 1 to 4 inches in their longest dimension, but both larger and smaller sizes are common.

In the upper part of the ash-flow sheet, pumice fragments tend to be nearly equidimensional and show little preferred orientation. Lower, the fragments are some- 

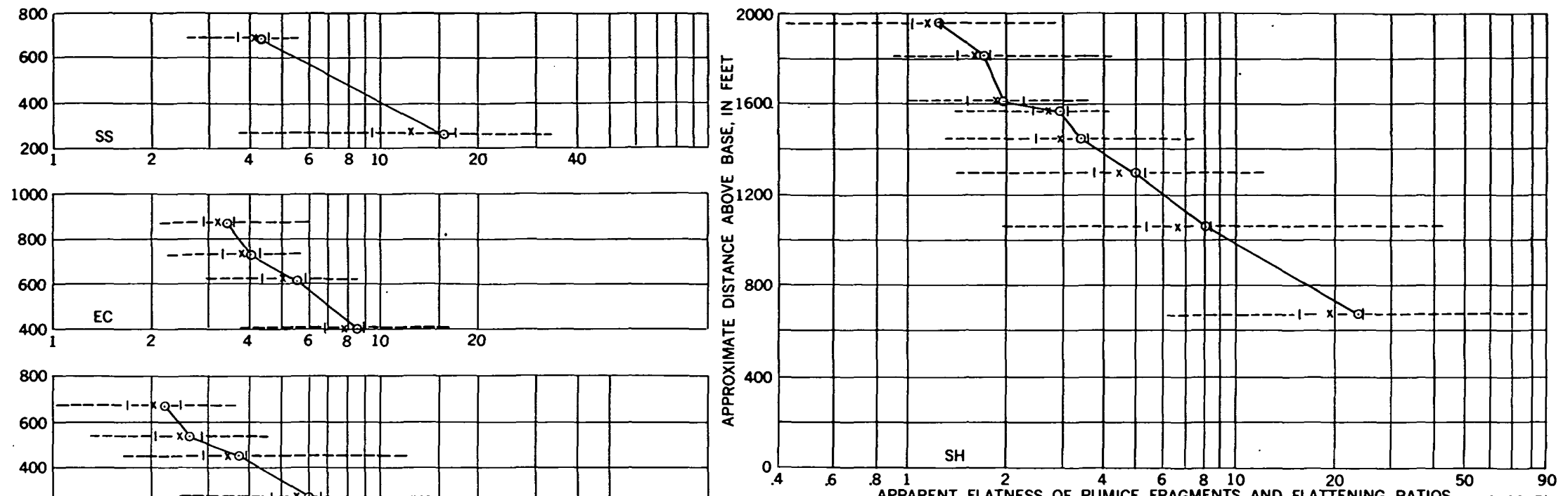

EXPLANATION
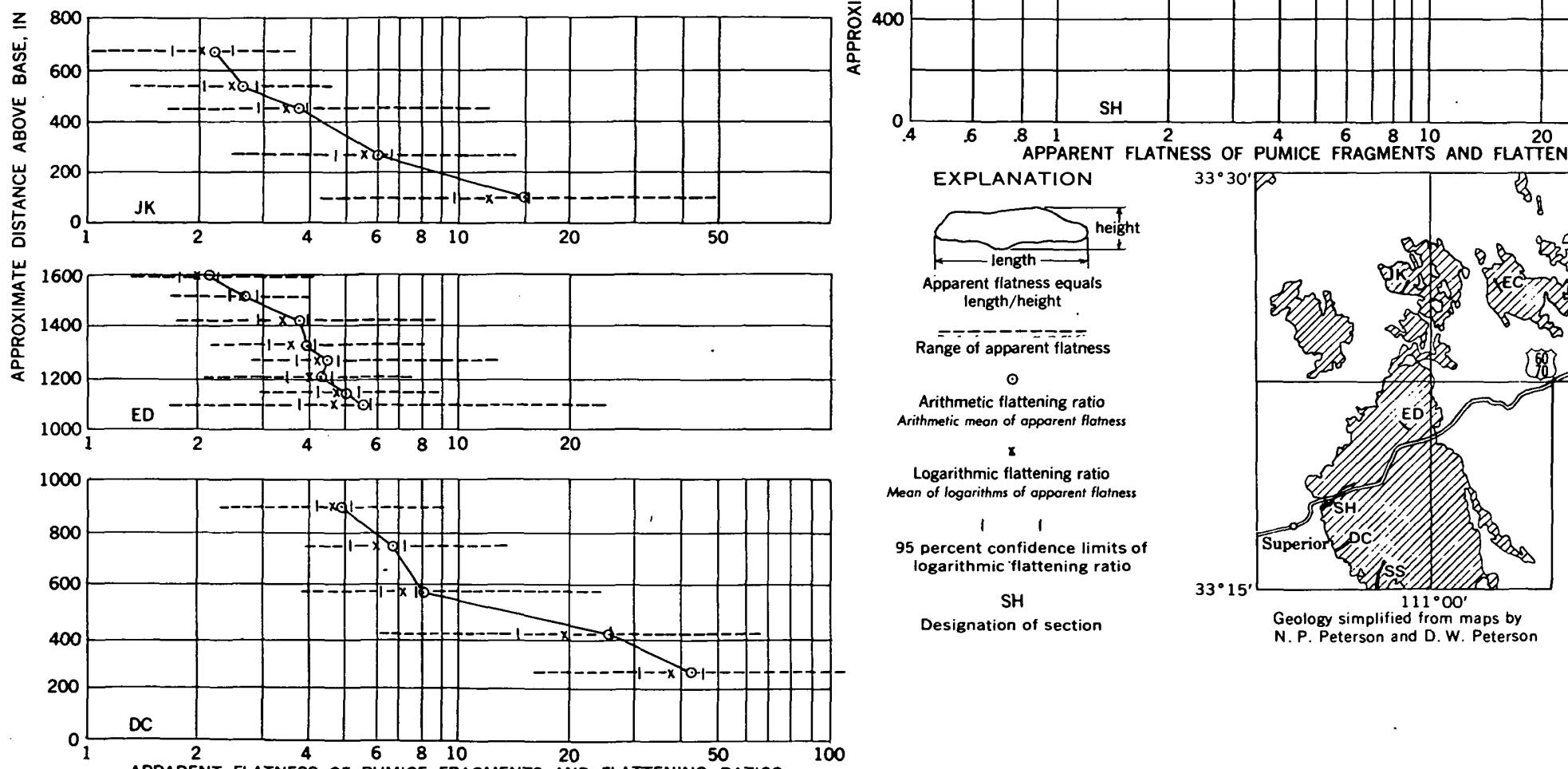

Range of apparent flatness

$\odot$

Arithmetic flattening ratio
Arithmetic mean of apporent flatnes

$x$

Logarithmic flattening ratio Mean of logarithms of apparent flotiness

11

55 percent confidence limits of

logarithmic flattening ratio

$\mathrm{SH}$

Designation of section

Geology simplified from maps by
N. P. Peterson and D. W. Peterson

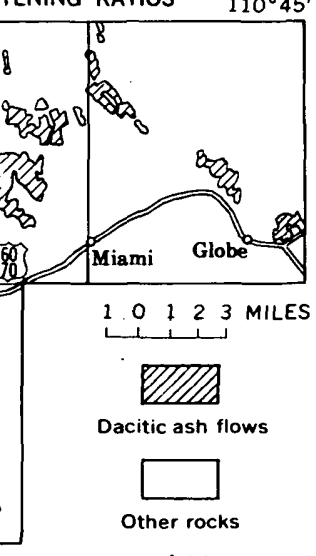

I JK

Lcation of sections where flattening

Froure 322.1.-Relation between flattening ratio of pumice fragments and distance above the base in six measured sections. Inset map shows distribution of the ash-flow sheet near Superior, Ariz., and the location of flattening-ratio studies. 
what flattened and ovoid, and are oriented with their longer dimensions in the horizontal plane. Farther downward, the flattening increases until the fragments appear in cross sections as thin streaks and stretchedout lenses. Lower still, they may be represented by mere coatings on horizontal parting surfaces, and finally they disappear. At most outcrops individual fragments show a wide variation in degree of flattening, and simple statistical tests help to indicate the trend of flattening changes. In six different areas where a considerable thickness of the ash-flow sheet is exposed, measurement of fragments showed a systematic downward increase in flattening.

At each outcrop chosen for study, the exposed vertical and horizontal dimensions of 30 or 40 fragments were measured in a plane perpendicular to the flattening. Because the plane of measurement must be perpendicular to the flattening, and because weathering tends either to obscure or destroy the pumice fragments, outcrops suitable for measurements are few and need to be carefully selected. In this sheet the two horizontal dimensions of most fragments are approximately equal, but if fragments were to show horizontal lineation, additional precautions would be required. Every clearly defined fragment within each selected area was measured in an effort to obtain a sample representative of fragments of all sizes, shapes, and orientations.

The horizontal dimension divided by the vertical dimension as measured in the outcrop is called here the "apparent flatness" of a fragment. The apparent flatness was determined for each fragment, and the arithmetic and logarithmic means were calculated for each outcrop. This mean shows the approximate amount of flattening at that level in the sheet, and is called the "flattening ratio." The arithmetic flattening ratio, which is the arithmetic mean of the individual apparent flatnesses, is the more readily determined. The logarithmic flattening ratio, however, which is the mean of the logarithms of the individual apparent flatnesses, eliminates the abnormal influence of greatly flattened fragments on the mean and is a more rigorous figure. Both the arithmetic and logarithmic flattening ratios are shown on figure 322.1 .

The curves in figure 322.1 show the relation between the flattening ratio and the stratigraphic distance of each outcrop above the base of the sheet along six measured sections. The diagram also shows the range of the apparent flatness at each locality. Most of the curves slope nearly uniformly in the same direction, indicating a progressive and nearly uniform downward increase in the flattening.
The logarithmic scale removes the skewness in the distribution of apparent flatness, and permits a test of the statistical validity of the sampling. The 95 percent confidence limits for the logarithmic flattening ratios have been calculated and are shown on the diagram. These confidence limits are the boundaries within which lie the logarithmic flattening ratios of 95 percent of randomly chosen groups of the same size sampled from this population of pumice fragments. The confidence limits are narrow enough to show that the procedure is statistically valid. During field studies the arithmetic flattening ratio is more conveniently determined, and because it falls near the logarithmic flattening ratio, within the confidence limits, errors introduced by using it are small.

The most significant application of the flatteningratio study is in its bearing on the eruptive history of the deposit. The nearly uniform slope of most of the curves in figure 322.1 shows that the down ward increase of flattening depends on the weight of the overlying material. Because the fragments must have been flattened before they cooled to rigidity, the uniform flattening trend indicates that the entire ash-flow sheet was deposited in a relatively short time. Crudely defined layered structures in the ash-flow sheet and a local reversal in flattening (fig. 322.1, curve ED) suggest that the material erupted in separate pulses, but the generally consistent flattening trend shows that the pulses followed one another closely enough for the sheet to cool as a single unit.

The flattening ratio studies have been used for several additional purposes. In any part of the sheet that has been studied statistically, the flattening ratio at an isolated outcrop indicates its approximate stratigraphic distance below the original top of the sheet. The flattening ratio changes abruptly on opposite sides of faults, hence the curves can be used to estimate the stratigraphic throw.

The slopes of the curves in figure 322.1 nearly equal one another and show that the downward increase in degree of flattening is nearly the same in different places in the deposit. The steepness of the slopes indicates that burial by several hundred feet of material was required to attain maximum flattening.

Flattening ratio curves for pumice fragments in this deposit have been particularly helpful in determining the nature of eruptions and in recognizing faults. Possible application elsewhere will depend on the nature of the flattening ratio curves of individual welded tuff sheets. 
323. LANDSLIDES EAST OF FUNERAL MOUNTAINS, NEAR DEATH VALLEY JUNCTION, CALIFORNIA

By Charles S. Denny, Washington, D.C.

At their southeast end, the Funeral Mountains are made up of a thick sequence of easterly dipping Tertiary rocks and Paleozoic dolomite and limestone (table 323.1 ), and they rise about 2,000 feet above the surrounding piedmont (fig. 323.1). Massive beds of Tertiary fanglomerate and limestone resting on shale form Bat Mountain. Large bodies of these massive rocks have slid down the precipitous mountain front and spread eastward onto the piedmont for distances of a few hundred feet to more than a mile. The slides northeast of Bat Mountain were first thought to be the much dissected remnants of an original sheet of breccia about a mile in diameter that came from the reentrant in the eastern front of the range just north of Bat Mountain. The total volume of these slides, however, represents only a very small part of the capacity of the reentrant; and detailed mapping (fig. 323.3) suggests that the form of the individual bodies of landslide breccia is largely an initial feature due in only a small way to post-slide dissection.

Uplift of the mountains along marginal faults set the stage for the erosion of cliff's on the northern and western sides of Bat Mountain. Material from these cliffs descended into gullies and moved out onto the piedmont.

The terminal lobe of the slide south of Bat Mountain (fig. 323.2) is a disordered mass of fanglomerate and limestone blocks. The internal structure of the lobe portrayed in the cross sections is largely conjectural. The western part of the lobe is predominantly fanglomerate. Near the toe, tabular masses of limestone and fanglomerate appear to overlap one another, and there is some mixture of blocks of the two rock types. In a very general way, however, the rocks of the slide remain in their original stratigraphic position of fanglomerate resting on limestone. The slide came down a narrow gully, overtopping the northeast bank, and spread out over the apex of the adjacent gravel fan. Since that time, runoff from Bat Mountain has carved the existing gully southwest of the lobe.

The three landslides northeast of Bat Mountain (fig. 323.3) consist of several digitiform plates that rest either on Quaternary gravel or on Oligocene(?) rocks stratigraphically above those comprising the plates (fig.
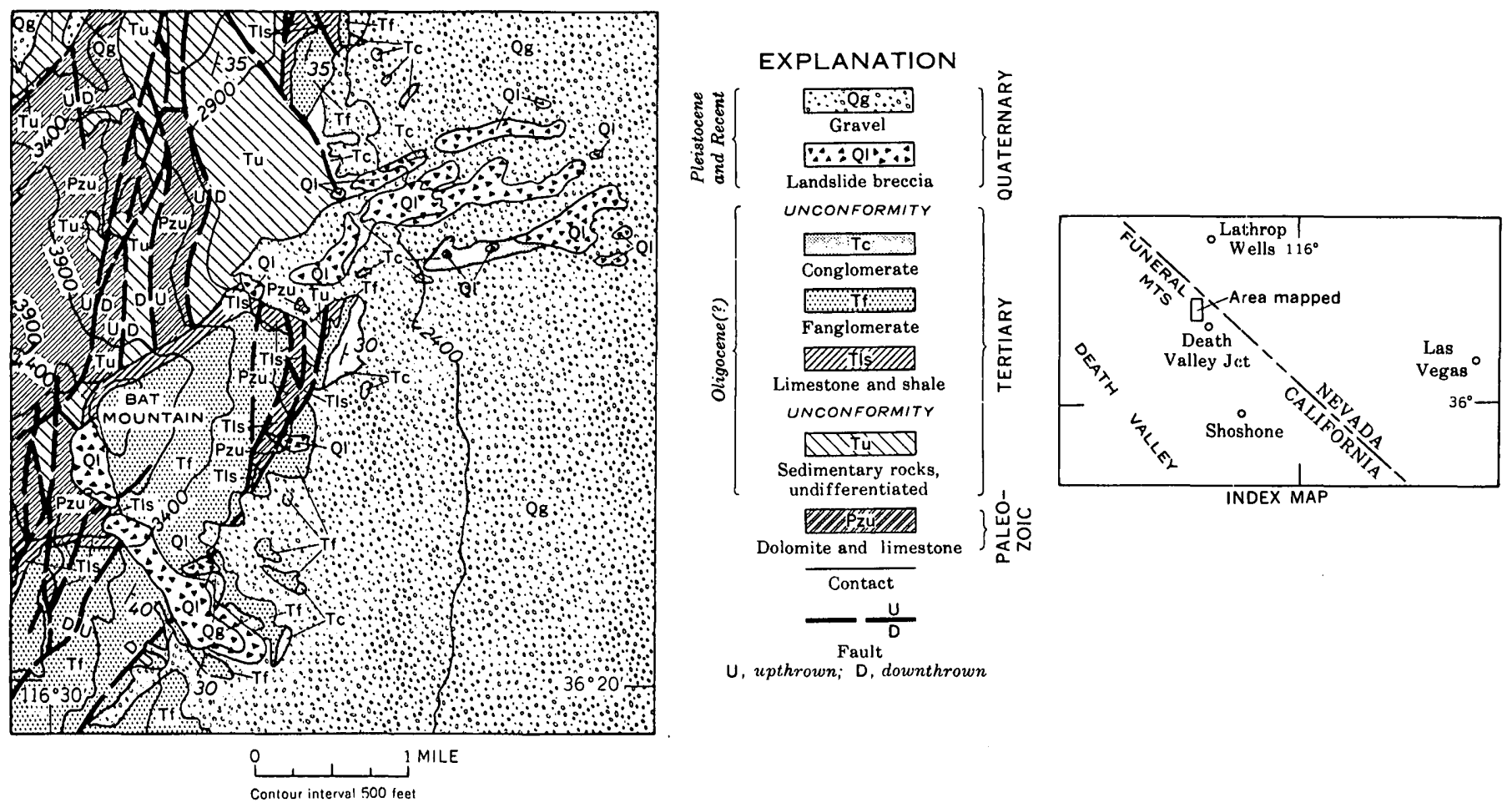

FraUre 323.1.-Generalized geologic map of eastern end of Funeral Mountains. 
TABLE 323.1.-Generalized section of rocks exposed in eastern end of Funeral Mountains. Based in part on work of Harald Drewes (written communication, 1960)

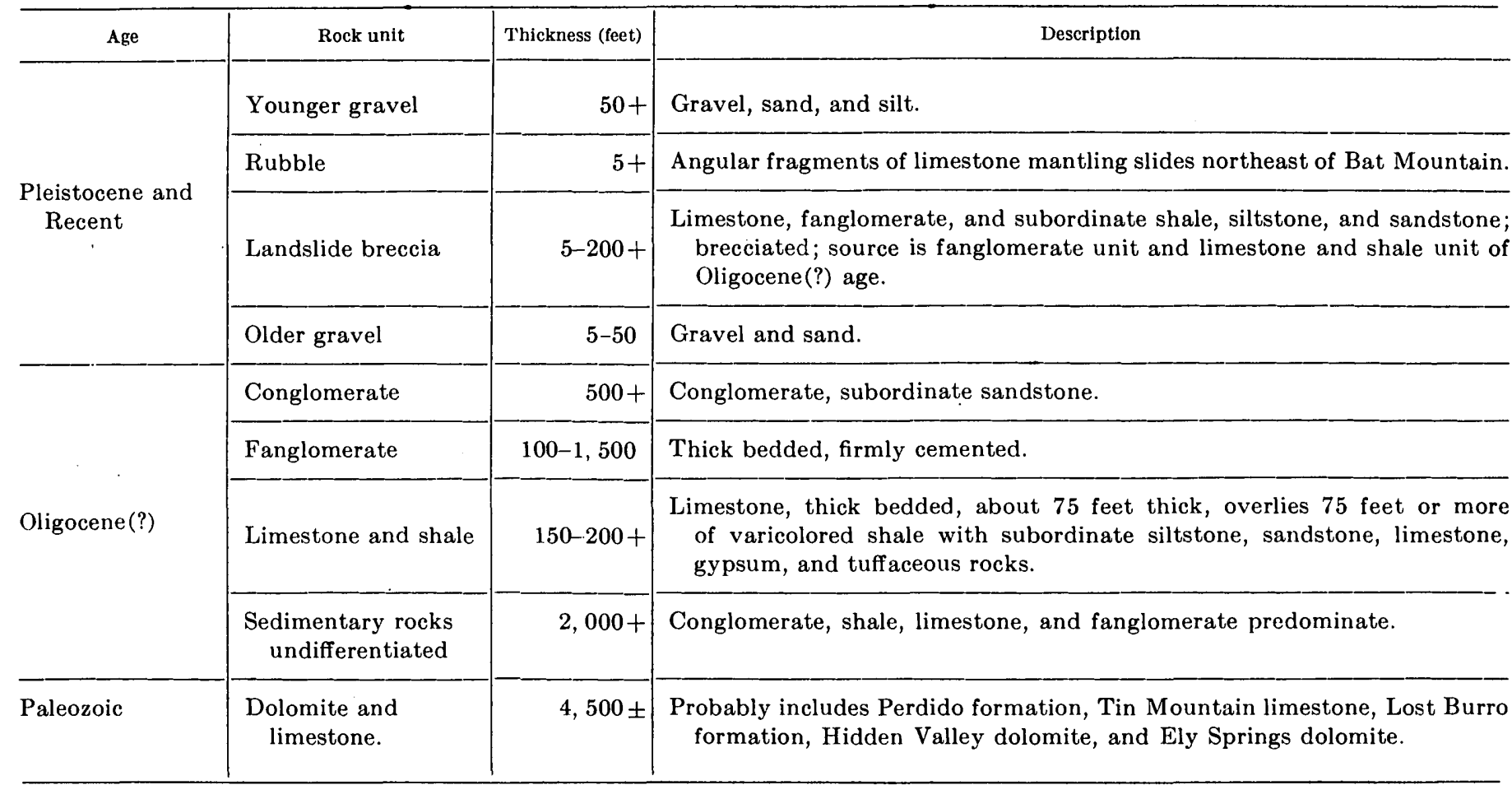

323.1). The individual slides consist of 2 or 3 unconnected segments. Brecciated limestone is the dominant rock but the western segment of the central slide consists of westward-dipping blocks of both fanglomerate and limestone. The plates of megabreccia (Longwell, 1951) rest on a breccia of limestone, sandstone, shale, and tuff, on gravel, or directly on undisturbed bedrock. The base of the slides is well exposed near their western ends, but to the east their lower slopes are mantled by rubble except at a few places where the rubble has slumped away. Contours drawn on the base of the slides define a surface that slopes eastward virtually parallel to and about 30 to 40 feet above the adjacent piedmont.

The landslides northeast of Bat Mountain came from massive limestone and fanglomerate strata that were uplifted relative to the piedmont to the east along a high-angle fault that passes beneath two of the slides. Fault movement set the stage for the erosion of steep slopes on these massive, eastward dipping beds. The individual tongues are discrete slides that moved down shallow gullies on the piedmont, carved partly in bedrock and partly in gravel. Subsequent erosion has left the slides standing considerably above their surroundings. For example, the central slide bends northward where it rests on bedrock, then eastward, presumably following a shallow gully that ended where the slide spreads out into several fingers. At this place the slide probably rests on gravel. Gravel is exposed beneath the southern slide and this gravel contains a much smaller number of pebbles of Oligocene(?) limestone than does the younger gravel on the piedmont. Contours drawn on the restored base of the slide suggest that the landslide breccia near the western end of the central slide mantles a bedrock ridge, although inaccuracies of the topographic base make this interpretation uncertain.

The estimated volumes of these slides range individually from about $1 / 2$ to 2 million cubic yards. The volumes of limestone and fanglomerate that could have been removed from two possible source areas are adequate to account for the slides; these volumes are estimated at about 3 million cubic yards for area $W$ (fig. 323.3) and at least 11 million cubic yards for area $X$.

The age of the landslides east of the Funeral Mountains is unknown. The amount of post-slide erosion indicates that some of them are at least several thousand years old. The form and location of the central slide of those northeast of Bat Mountain suggest that it is younger than its neighbors. It is presumed to have come down a gully that originated near area W (fig. 323.3). The southern slide could have come down an earlier gully that passed through the southern part of area $X$. Perhaps the landslides are Pleistocene deposits, the product of more active erosion during that epoch. On the other hand, the sporadic cloudbursts 

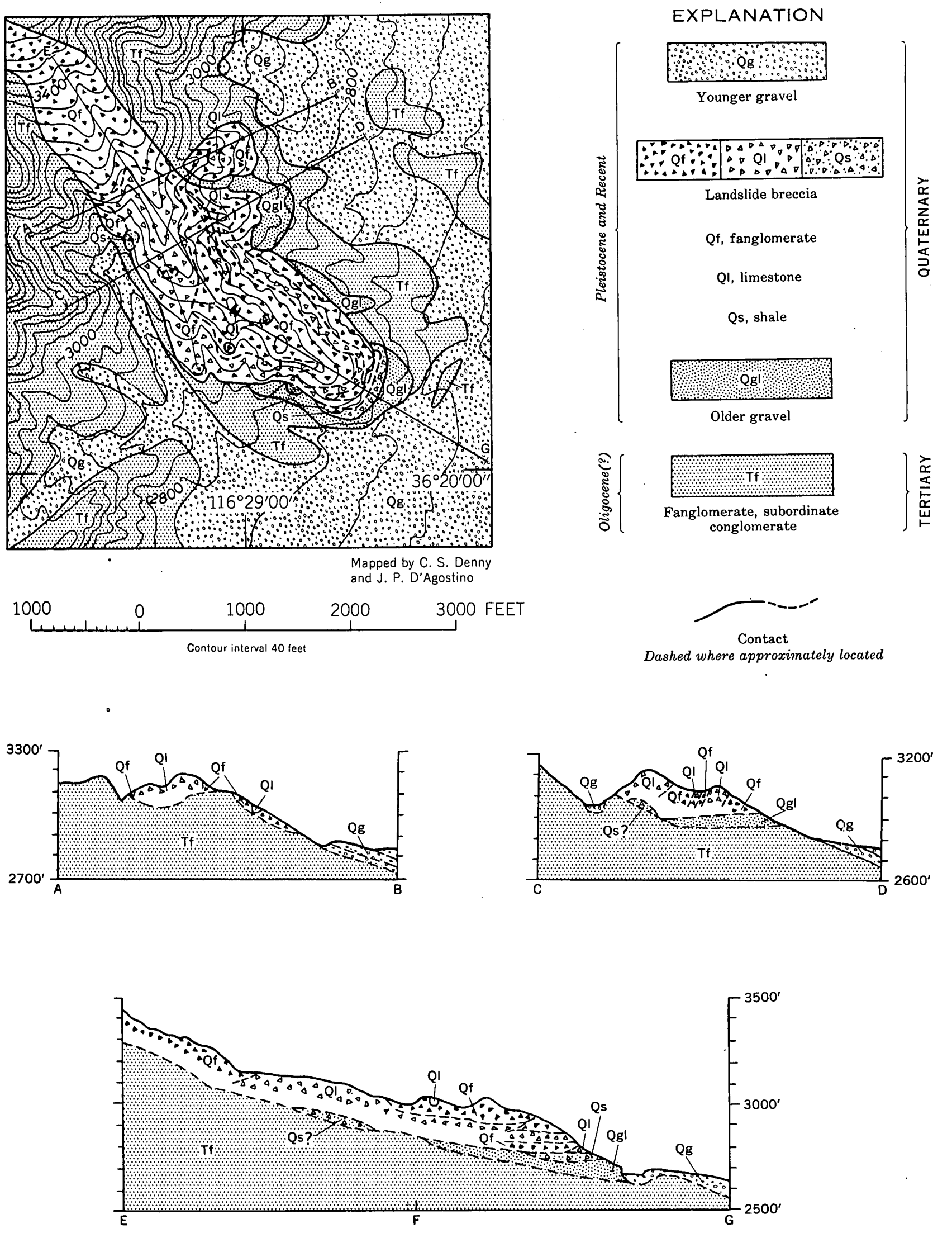

Froure 323.2.-Geologic map and sections of terminal lobe of landslide south of Bat Mountain. 


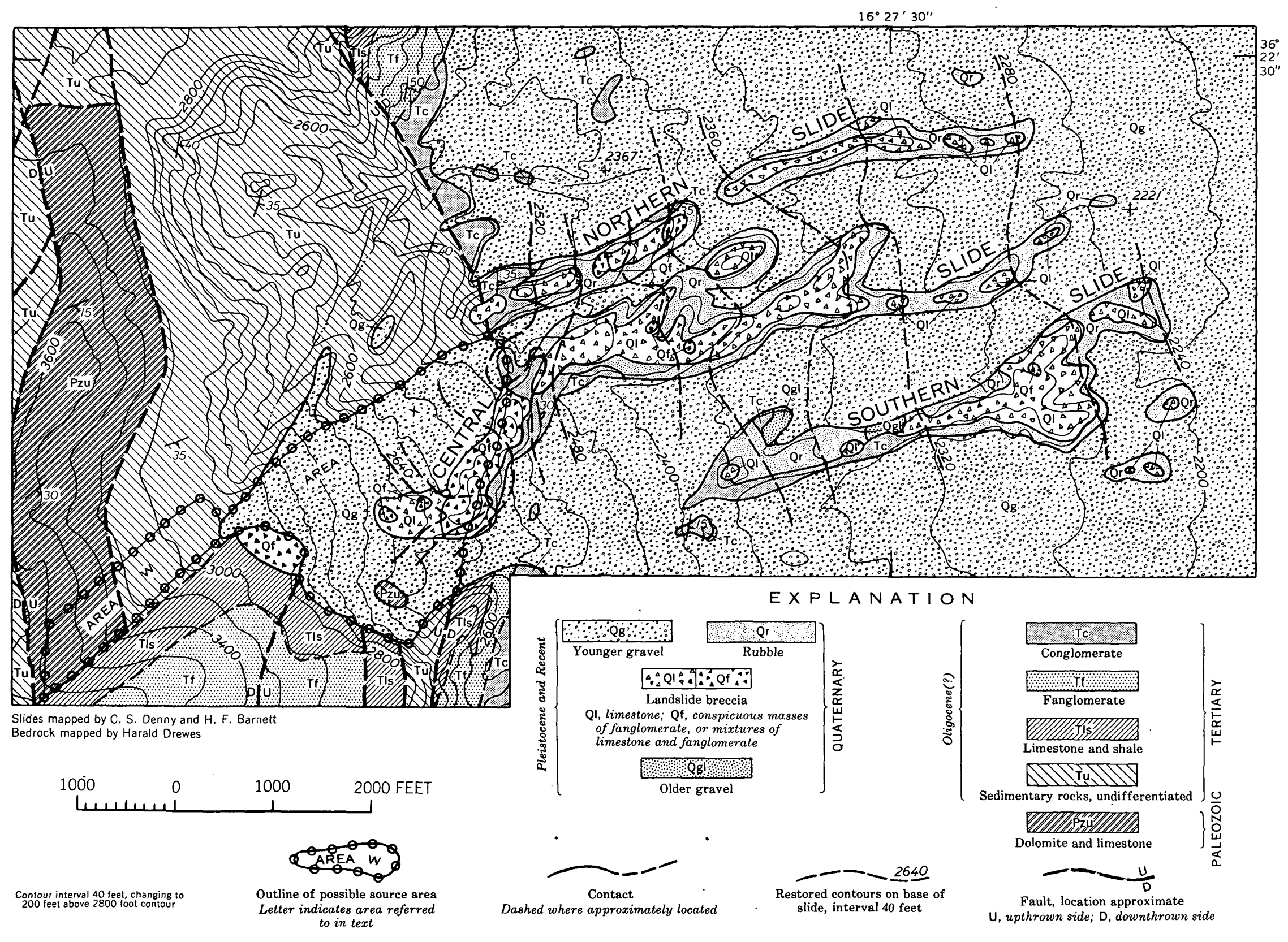

Figure 323.3.-Geologic map of landslides northeast of Bat Mountain. 
of the present day may in time so erode the Bat Mountain cliff's that some infrequent catastrophic rain or earthquake will trigger a new slide. Large bodies of rock, for example, could be dislodged from the northwest-facing cliff on the south side of area W (fig. 323.3), descend to its base, and move as a landslide northeastward down the gulch and out onto the pied- mont. Thus, the landslides may be the result of recurrent mountain uplift and sporadic erosion throughout the Quatemary period.

\section{REFERENCE}

Longwell, C. R., 1951, Megabreccia developed downslope from large faults: Am. Jour. Sci., v. 249, p. 343-355.
Several bodies of sediment are presently undergoing compaction in the San Joaquin Valley of California. This compaction is greatest in western Fresno County (fig. 324.1), where it is reflected by sinking of the land surface. The sediments here consist of unconsolidated to semiconsolidated water-bearing sand, silt, and clay that were deposited on alluvial fans, flood plains, or in fresh-water lakes during late Pliocene to Recent time. Their thickness ranges from about 1,000 feet in the northwestern part of the county to about 3,000 feet in the "southern part. More complete descriptions are given by Davis and Poland (1957, p. 420-426) and the Inter-Agency Committee (1958, p. 116-138).

The present article treats the compaction of the finest grained of these sediments, those that fall into Shepard's (1954, p. 157) size categories of clay, silty clay, and clayey silt. The fine-grained sediments are particularly rich in montmorillonite, most of them containing between 20 and 50 percent. Other clay minerals, illite, chlorite, a kaolin-type mineral, and mixed illite-montmorillonite, are present in subsidiary amounts. The principal nonclay minerals are quartz, feldspar, micaceous minerals, and hornblende.

As in previous studies of the compaction of clayey sediments (summarized and discussed by von Engelhardt, 1960, p. 35-49), progressive reduction of porosity is taken as a measure of progressive compaction. Porosities of sediments from core holes (locations shown on figure 324.1) are plotted against depth on figure 324.2. Although the change is small, the data indicate an average reduction in porosity on the order of that observed at similar depths in Germany, Italy, and Venezuela (von Engelhardt, 1960, p. 39, 41).

\section{EXPULSION OF WATER}

The principal means of compaction has been the expulsion of water-first the free pore water and later the water adsorbed by clay particles. Table 324.1 show's the variation with depth of the estimated relative amounts of pore water and adsorbed water in the

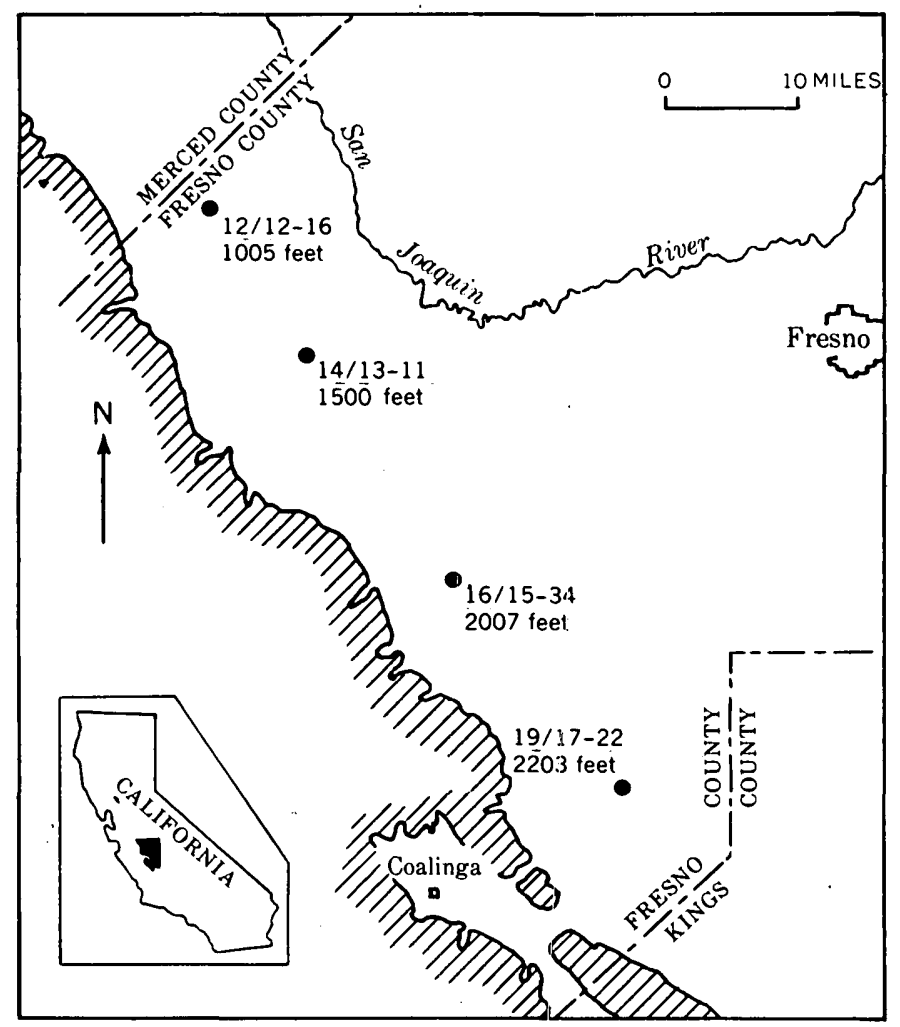

Figure 324.1.-Area of western Fresno County. Calif., in which unconsolidated to semiconsolidated late Cenozoic sediments are being compacted. Core holes from which the sediments were sampled are marked by dark circles. Holes were drilled by the Inter-Agency Committee on Land Subsidence in- the San Joaquin Valley, and are designated by township-rangesection (Mt. Diablo base line and meridian). Depths of core holes given in feet helow land surface. Shading marks northeastern edge of deforme drocks of Coast Ranges. 


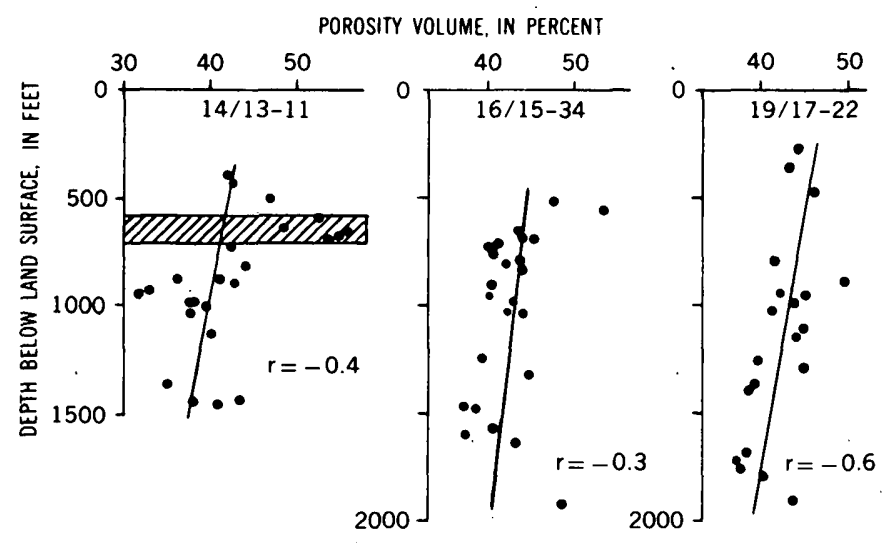

FIGURE 324.2.-Relation between porosity and depth of burial of clayey sediments from core holes 14/13-11, 16/15-34, and 19/17-22. Regression lines computed by least squares ( $r=$ correlation coefficient), assuming arithmetic correlation. Actual correlation probably is semilogarithmic, but the short segments of semilogarithmic curves represented here probably approach straight lines closely enough that the assumption has not introduced serious error. Porosities of Corcoran clay member of the Tulare formation (a freshwater lake deposit, cross hatched) not included in computation for core hole 14/13-11.

sediments in core hole 16/15-34. Above a depth of about 1,000 feet, most of the water being squeezed out of the clayey sediments is probably pore water. Below that depth, most of the water in the sediments is adsorbed by the clay particles, and its removal requires compacting pressure to overcome the physiochemical attraction between the water and the clay particles.

The greater amount of sodium adsorbed by the more deeply buried clays also contributes to the lack of pore water below depths of about 1,000 feet. With all other

TABLE 324.1.-Estimated proportions of pore water and adsorbed water in montmorillonite-rich sediments from below the uater table in core hole 16/15-94, and data from which estimates were derived

\begin{tabular}{|c|c|c|c|c|c|c|c|c|c|}
\hline \multirow{2}{*}{$\begin{array}{l}\text { Depth } \\
\text { below } \\
\text { land } \\
\text { surface } \\
\text { (feet) }\end{array}$} & \multirow{2}{*}{ 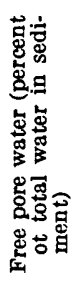 } & \multirow{2}{*}{ 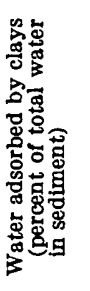 } & \multicolumn{2}{|c|}{$\begin{array}{c}\text { Thlokness, in } \\
\text { angstrom units, } \\
\text { of water layer } \\
\text { sdsorbed by } \\
\text { montmorillonite } \\
\text { on- }\end{array}$} & \multirow{2}{*}{ 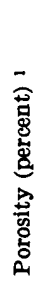 } & \multirow{2}{*}{ 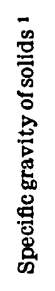 } & \multirow{2}{*}{ 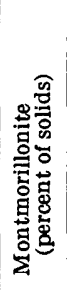 } & \multicolumn{2}{|c|}{$\begin{array}{c}\text { Ex́change } \\
\text { cations } 2 \\
\text { (percentage } \\
\text { equivalents) }\end{array}$} \\
\hline & & & $\begin{array}{c}\text { Sodi- } \\
\text { um-sat- } \\
\text { urated } \\
\text { surfaces }\end{array}$ & $\begin{array}{l}\text { Calcium- } \\
\text { and mag- } \\
\text { nesium- } \\
\text { saturated } \\
\text { surfaces }\end{array}$ & & & & $\begin{array}{c}\text { Calc- } \\
\text { ump } \\
\text { plus } \\
\text { magne } \\
\text { sium }\end{array}$ & $\underset{\text { um }}{\text { Sodi- }}$ \\
\hline 41 & 50 & 50 & 80 & 10 & 47 & 2. 66 & 25 & 95 & \\
\hline 57 & 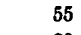 & 45 & 80 & 10 & 54 & 2.68 & 30 & 96 & \\
\hline 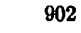 & 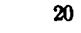 & 80 & 80 & 10 & 41 & 2. 63 & 35 & 96 & \\
\hline 1,238 & 0 & 100 & 70 & 10 & 40 & 2.75 & 20 & 81 & 18 \\
\hline 1,6 & 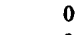 & & 25 & & 44 & 2. 69 & 35 & 64 & 36 \\
\hline 1,953 & 0 & 100 & 70 & 10 & 42 & 2. 50 & 25 & 68 & 32 \\
\hline
\end{tabular}

1 Determined in the Hydrologic Laboratory of the Geological Survey.

2 Determined in the Sedimentary Petrology Laboratory of the Geological Survey by H. C. Starkey. factors (including total water content) remaining equal, an increase in adsorbed sodium increases the amount of adsorbed water and decreases the amount of free pore water. If calcium and magnesium were the only cations adsorbed by the clays, the porosity of the sediments probably would decrease more rapidly with increasing depth (Bolt, 1956, p. 91; Warkentin and others, 1957), and pore water probably would persist to depths a few hundred feet below its present limit. Thus, a downward increase in both compacting pressure and adsorbed sodium accounts for the apparent elimination of pore water below depths of about 1,000 feet.

Although table 324.1 gives an accurate impression of the state of the water in these sediments, the figures given in columns 2,3 , and 4 are only estimates because some of the data from which they were derived are approximate. Also, several assumptions were made, the principal ones of which are listed below with references to supporting data.

1. Porosity equals total water content.

2. Montmorillonite is the important mineral in these sediments that adsorbs water. (The other clay minerals certainly adsorb water, but considerably less than montmorillonite.)

3. The specific surface of montmorillinite is $600 \mathrm{~m}^{2}$ per $\mathrm{g}$ (Bower and Goertzen, 1959 ; Diamond and Kinter, 1958; Kinter and Diamond, 1960). (This is a minimum value; other authors have assumed values as large as $800 \mathrm{~m}^{2}$ per $\mathrm{g}$.)

4. The sodium and the divalent cations are concentrated on different surfaces rather than being associated at random with each other on all surfaces (Grim, 1958, p. 20).

5. Montmorillonite, when saturated with calcium and magnesium, : will attract strongly any water within $10 \mathrm{~A}$ (angstroms) of its surface; when saturated with sodium, it will attract water (less strongly than when saturated with calcium and magnesium) within at least $80 \mathrm{~A}$ of its surface (Grim, 1958, p. 20 ; Low, 1958, p. 61; Lutz and Kemper, 1959 , p. 89 ).

6. Montmorillonite flakes are parallel to one another and no effective contact exists between solid particles. This assumption, although necessary to the computations, is untrue. Figure 324.3 shows that the montmorillonite particles are oriented at random with respect to one another. Where most of the pore water has been removed, some probably remains within "cellular" enclosures formed by the random arrangement of particles (Kemper, 1958). The error introduced by this assumption is largely compensated by the errors introduced in assumptions 2 and 3.

\section{ORIENTATION OF MONTMORILLONITE PARTICLES}

Other studies of compacted clays show that particles of illite and kaolinite tend to develop preferred orientation of their basal planes normal to compacting pressures of $2 \mathrm{~kg} / \mathrm{cm}^{2}$ or less (Buessem and Nagy, 1954; Mitchell, 1956). Under the compacting pressures existing in the first 2,000 feet below the surface in western Fresno County (up to about $60 \mathrm{~kg} / \mathrm{cm}^{2}$ ), however, 
particles of montmorillonite have not developed preferred orientation (fig. 324.3).

Ignoring for the moment the preferred orientation in the Corcoran clay member of the Tulare formation, there is no indication of a progressive orientation of montmorillonite particles normal to the compacting force as they are buried more deeply. One might draw a line through the six non-Corcoran points on the graph for core hole $12 / 12-16$ and project it downward into higher values of the orientation ratio, but these would not be confirmed by the measurements in deeper sediments from core holes 14/13-11 and 19/17-22. Most of these sediments were deposited rapidly on alluvial fans and flood plains by streams; one would not expect this kind of deposition to produce preferred orientation of clay-mineral particles. Moreover, subsequent compaction has not produced preferred orientation of the montmorillonite particles in these sediments.

In contrast to the material deposited on alluvial fans and flood plains, the material that makes up the Corcoran was deposited in the still water of a fresh-water lake. Each clay-mineral flake was allowed to settle individually, seeking a minimum energy position parallel to other flakes already deposited. The preferred orientation consequently is well developed. Similarly well-developed preferred orientation produced during the deposition of lake clays has been reported by $W u$ (1958, p. 23-29).

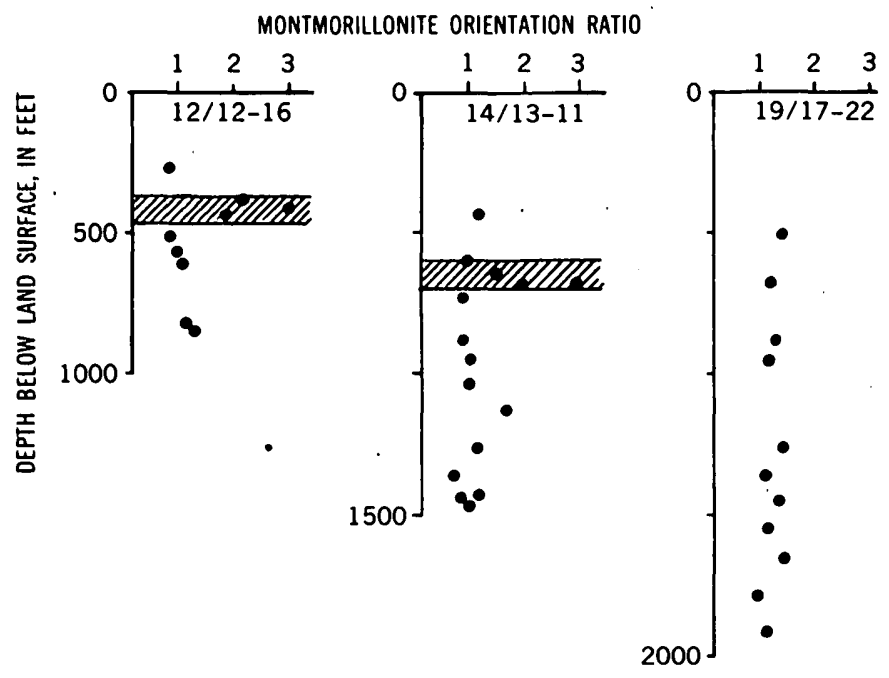

Froure 324.3.-Horizontal preferred orientation of montmorillonite in clayey sediments from core holes 12/12-16, 14/13-11, and 19/17-22. Corcoran clay member of Tulare formation cross hatched. Procedure for measuring montmorillonite orientation ratio is described by Meade (Prof. Paper 424-B, Art. 116). Orientation ratio of 1.0 indicates random orientation of montmorillonite particles with respect to bedding; ratios larger than 1.0 indicate preferred orientation in direction of bedding.

\section{CONCLUSIONS}

Two processes, the realinement of platy particles and the expulsion of water, characterize the early stages of the compaction of clayey sediments. The degree to which either of these processes affects the compaction of a given sediment depends upon the clay-mineral composition. If the principal clay mineral is illite or kaolinite-both of which occur as fairly large flakesthe compaction of the sediment involves both processes. Particles are reoriented and water is expelled concurrently. If, on the other hand, the principal clay mineral is montmorillonite-which generally occurs as much smaller flakes that have larger specific surfacesthe compaction of the sediment involves only one of these processes. Flakes of montmorillonite are not reoriented under pressure because the surface forces related to the interaction of clay particles and water are so much stronger than the gravitational force related to the particle mass. The compaction of montmorillonite-rich sediments, at least under pressures up to $60 \mathrm{~kg}$ per $\mathrm{cm}^{2}$, comes about almost entirely through the expulsion of pore water and the overcoming of surface attractions between montmorillonite particles and water.

\section{REFERENCES}

Bolt, G. H., 1956, Physico-chemical analysis of the compressibility of pure clays : Géotechnique, v. 6, p. 86-93.

Bower, C. A., and Goertzen, J. O., 1959, Surface area of soils and clays by an equilibrium ethylene glycol method: Soil Sci., v. 87 , p. 289-292.

Buessem, W. R., and Nagy, Bartholomew, 1954, The mechanism of the deformation of clay : 2d Natl. Conf. on Clays and Clay Minerals Proc., Natl. Acad. Sci.-Natl. Research Council Pub. 327, p. $480-491$.

Davis, G. H., and Poland, J. F., 1957, Ground-water conditions in the Mendota-Huron area, Fresno and Kings Counties, California: U.S. Geol. Survey Water-Supply. Paper 1360-G, p. $409-588$.

Diamond, Sidney, and Kinter, E. B., 1958, Surface areas of clay minerals as derived from measurements of glycerol retention: 5th Natl. Conf. on Clays and Clay Minerals Proc., Natl. Acad. Sci.-Natl. Research Council Pub. 566, p. 334-347.

Grim, R. E., 1958, Organization of water on clay mineral surfaces and its implications for the properties of clay-water systems, in Water and its conduction in soils: Highway Research Board Spec. Rept. 40, p. 17-23.

Inter-Agency Committee on Land Subsidence in the San Joaquin Valley, 1958, Progress report on land-subsidence investigations in the San Joaquin Valley, California, through 1957 : Sacramento, Calif., 160 p.

Kemper, W. D., 1958, Structural implications of moisture retention by clay-size soil materials: Soil Sci. Soc. America Proc., v. 22, p. 5-8.

Kinter, E. B., and Diamond, Sidney, 1960, Pretreatment of solls and clays for measurement of external surface area by glycerol retention: 7th Natl. Conf. on Clays and Clay Minerals Proc., New York, Pergamon Press, p. 125-134. 
Low, P. F., 1958, Movement and equilibrium of water in soil systems as affected by soil-water forces, in Water and its conduction in soils: Highway Research Board Spec. Rept. 40 , p. 55-64.

Lutz, J. F., and Kemper, W. D., 1959, Intrinsic permeability of clay as affected by clay-water interaction: Soil Sci., v. 88, p. $83-90$.

Mitchell, J. K., 1956, The fabric of natural clays and its relation to engineering properties: Highway Research Board Proc., v. 35 (Natl. Acad. Sci.-Natl. Research Council Pub. 426), p. $693-713$.
Shepard, F. P., 1954, Nomenclature based on sand-silt-clay ratios : Jour. Sed. Petrology, v. 24, p. 151-158.

vou Engelhardt, Wolf, 1960, Der Porenraum der Sedimente: Berlin, Springer, $207 \mathrm{p}$.

Warkentin, B. P., Bolt, G. H., and Miller, R. D., 1957, Swelling pressure of montmorillonite: Soil Sci. Soc. America Proc., v. 21 , p. $495-497$.

Wu, T. H., 1958, Geotechnical properties of glacial lake clays: Jour. Am. Soc. Civil Engineers, Soil Mech. and Found. Div. Proc., v. 84, SM 3, Paper 1732, 34 p.

325. SURFACE-WATER HYDROLOGY OF COASTAL BASINS OF NORTHERN CALIFORNIA, IN RELATION TO GEOLOGY AND TOPOGRAPHY

By S. E. Rantz, Menlo Park, Calif.

Work done in cooperation with California Department of Water Resources

The coastal drainage basins of California that are north of the southern boundary of Eel River basin comprise an area of 21,000 square miles. This area and its principal streams are shown on figure 325.1. Parts of the drainage basins of the northernmost streams lie in Oregon. Most of the region is mountainous with many peaks above 6,000 feet in altitude; the highest peak is Mount Shasta, which reaches 14,161 feet. The mountainous areas are generally well covered with timber.

Precipitation is distinctly seasonal, and is largely restricted to the months from October through May. This distribution of precipitation is controlled largely by the anti-cyclonic cell that is normally found off the California coast, particularly in summer. Precipitation in winter occurs usually when the anticyclone either is absent or is far south of its usual position.

From a consideration of major landforms, the region can be divided into three subregions, each of which is hydrologically homogeneous. These major landforms (fig. 325.1) are the Northern Coast Ranges, the Klamath Mountains, and the Southern Cascades.

The Northern Coast Ranges are underlain chiefly by a complex series of sandstone and shale, metamorphic rocks, and lavas, intruded by large masses of ultra-mafic rocks now largely altered to serpentine. Only a small part of this subregion is above 5,000 feet in altitude, so that there is little snowmelt runoff, and almost all the runoff results from the rains of late fall and winter. The soil and mantle rock are relatively impermeable and base flow is therefore poorly sus- tained, with the result that streamflow is very low in the summer and early fall. A stream typical of the subregion is Eel River; graph $A$ of figure 325.2 shows the average monthly distribution of runoff for this river at the gaging station at Scotia. The great variability of streamflow is immediately evident. During February, the month of greatest runoff, the average monthly flow is about 150 times as great as it is during September, the month of least runoff.

The Klamath Mountains include a rugged area lying between the Northern Coast Ranges on the west and the Southern Cascades on the east. The Klamath Mountains have a complex structural pattern with no apparent regional trend. The rocks are largely crystalline, consisting principally of highly metamorphosed lavas and sedimentary rocks intruded by granitic rocks. Because a large part of this subregion is above 5,000 feet in altitude, much of the winter precipitation is stored as snow, and a large amount of snowmelt runoff occurs in late spring in addition to the storm runoff in the winter. The soil and mantle rock are more permeable than that in the Northern Coast Ranges, and base flow is therefore better sustained. A stream typical of this subregion is Trinity River; graph $B$ of figure 325.2 , shows the average monthly distribution of runoff for this river at the gaging station at Lewiston. Streamflow variability is less .pronounced than in the Northern: Coast Ranges subregion; the average monthly flow for May, the month of greatest runoff, is about 30 times as great as it is for September, the month of least runoff. 


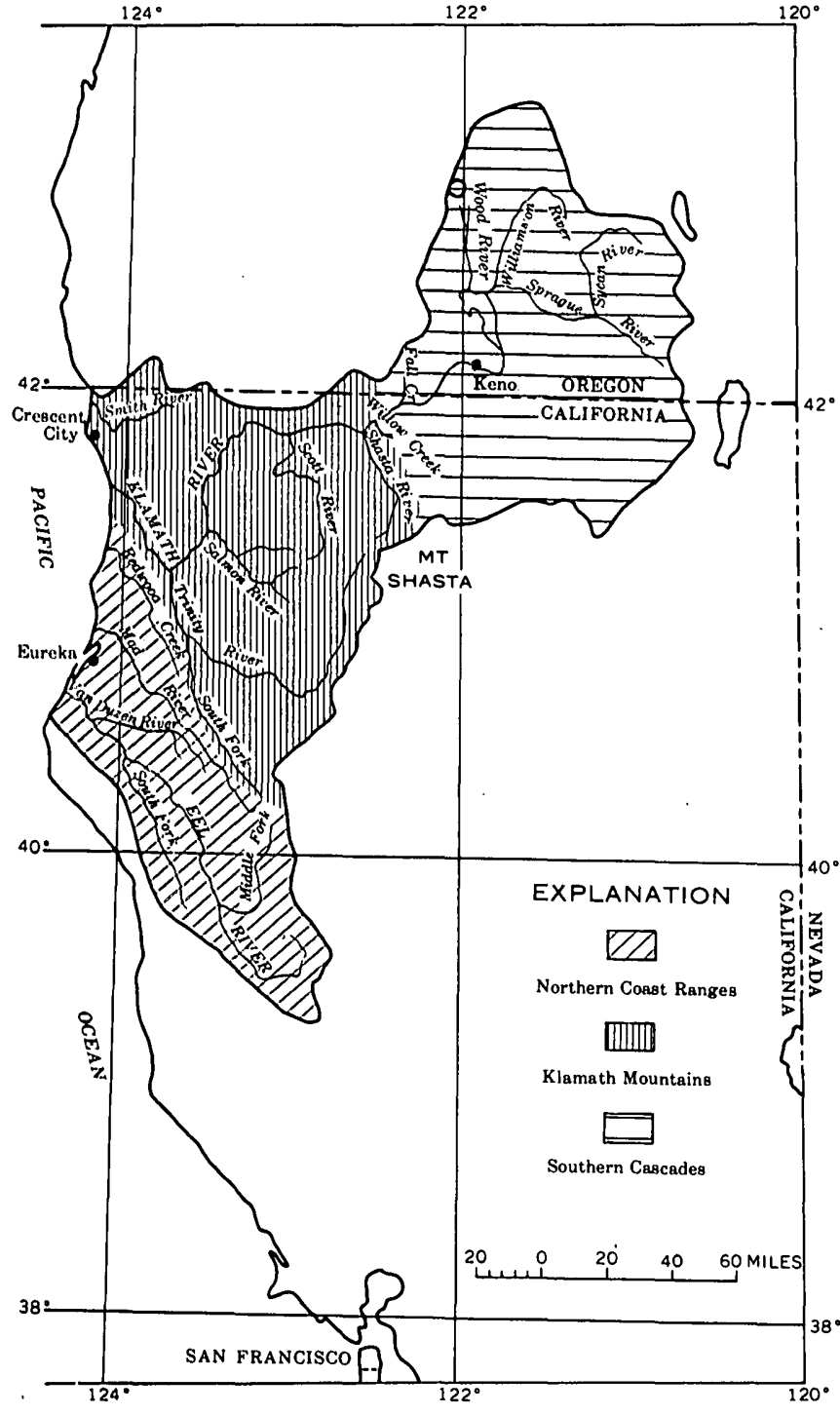

Froure 325.1.-Map showing major landforms and principal streams of northwestern California.

The Southern Cascades, eist of the Klamath Mountains and north of the Sierra Nevada, are underlain by lava and pyroclastic rocks. The upper Klamath River, from Keno, Oreg., to the mouth of Willow Creek in California, flows in a canyon cut into these rocks. The Klamath River: basin above Keno and the closed basins south and east of Klamath River lie in a plateau region likewise underlain largely by lava and pyroclastic rocks. This plateau has poorly developed surface drainage because the highly permeable and fractured lava allows ready infiltration of precipitation and snowmelt.. Seeps are common and large springs are numerous. Consequently, base flow is better sustained in this subregion than in either of the other two. In some of the headwater streams in Oregon, extensive marsh areas exert a regulating effect on the streamflow. Because of the high altitude of the subregion, the volume of snowmelt runoff is significantly large. No one stream typifies all of those of the Southern Cascade subregion, but graph $C$ of figure 325.2 shows the average monthly distribution of runoff of Fall Creek, a spring-fed tributary of the Klamath River. The equable character of the flow is apparent; no month has less than 7 percent of the annual runoff, nor more than 11 percent.

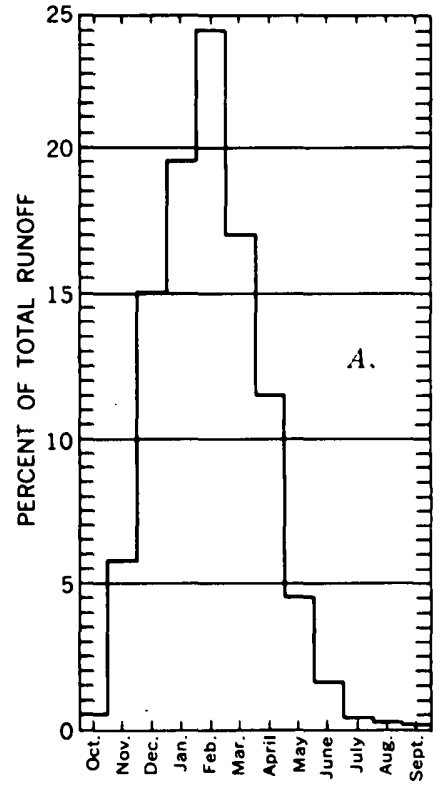

EEL RIVER AT SCOTIA, CALIF.

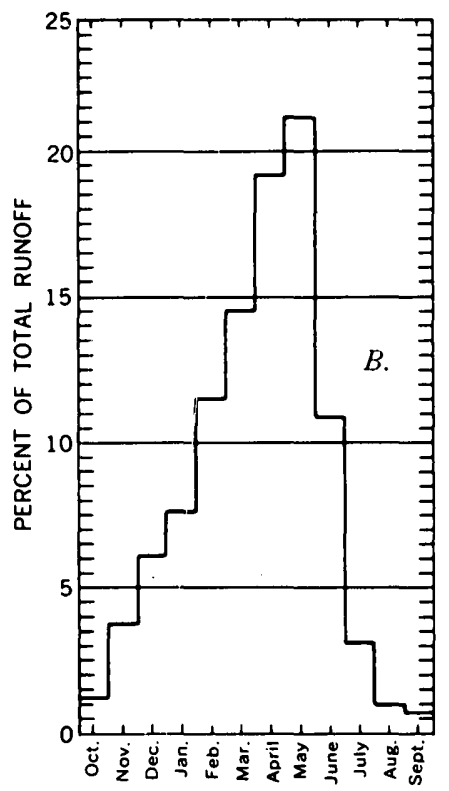

TRINITY RIVER AT LEWISTON, CALIF.

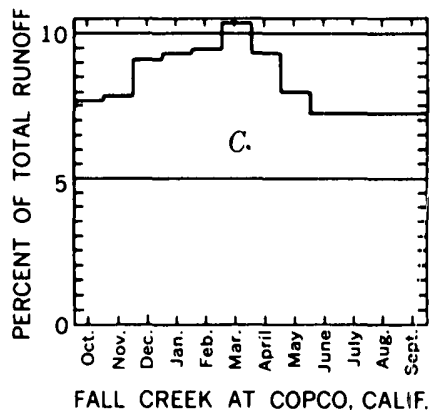

Figure 325.2.-Mean monthly distribution of runoff at selected stream-gaging stations. 


\section{CENTRAL VENT ASH-FLOW ERUPTION, WESTERN SAN JUAN MOUNTAINS, COLORADO}

By Robert G. Luedere and Wilbur S. Burbank, Washington, D.C., and Exeter, N.H.

Worls done in cooperation with the Colorado State Metal Mining Fund Board

A volcano-tectonic depression is located near the western edge of the Tertiary volcanic field in the San Juan Mountains of southwestern Colorado (fig. 326.1). The younger Silverton and Lake City calderas are within and superimposed upon this depression. Geologic mapping of the northern part of the Silverton caldera and the contiguous part of the depression has disclosed a welded ash-flow deposit of limited areal extent and the location of its vent.

The ash flow erupted from a nearly circular vent about a mile in diameter located west-northwest of Engineer Mountain (fig. 326.2). The vent lies between

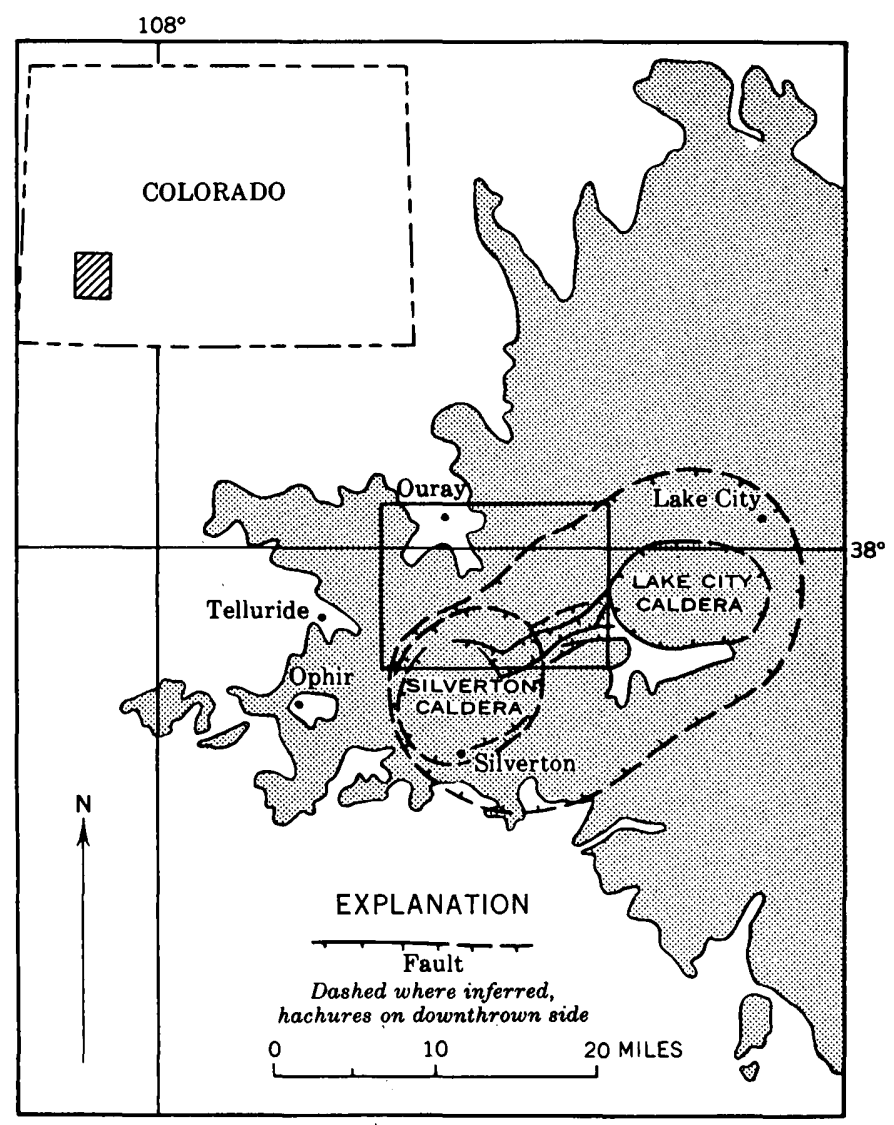

FIGURE 326.1-Generalized geologic map of the western San Juan region, Colorado, showing location of the depression and the Silverton and Lake City calderas within it. Tertiary volcanic rocks and minor intrusives, stippled; pre-Tertiary rocks, no pattern. Rectangle shows area of figure 326.2 . the peripheral ring-fault zone of the Silverton caldera and the probable ring-fault zone of the volcano-tectonic depression. The crater filling of ash-flow material is partly covered, but where exposed, it has vertical to steeply inclined and inwardly dipping flow planes.

The ash flow was erupted upon an uneven erosion surface and was confined to a northeasterly trending trough about 10 miles long and as much as $2,1 / 2$ miles wide. In the narrower and deeper part of the trough southwest of the vent, the ash flow was deposited on lava flows and related pyroclastic rocks of the San Juan tuff and the Silverton volcanic series, both of middle Tertiary age, and abutted against a volcanic dome in the depression ring-fault zone in what is now a part of Hayden Mountain. Northeast of the vent the ash flow spread as a sheet upon bedded tuff of the Silverton series in the shallower and broader part of the trough, and wedged out upon a topographic high northeast of Dolly Varden Mountain. The ash flow has a preserved thickness of about 1,000 feet at Mount Abrams southwest of the vent and only about 200 feet at Dolly Varden Mountain northeast of the vent. The volume of material erupted is estimated to have been between $11 / 2$ and 2 cubic miles.

Welded ash flows of the Potosi volcanic series of middle and late Tertiary age unconformably overlie the ash flow to the southwest and in part the vent area. Northeast of the vent the ash flow is overlain conformably by a variable thickness of bedded tuff similar to that underlying the ash flow. This position of the welded ash flow between nearly identical deposits of bedded tuff led Cross, Howe, and Irving in 1907 to interpret the welded ash flow as a sill intruding the Henson tuff of the Silverton volcanic series, and to name it the American Flat latite.

The welded ash flow is light to dark gray and weathers greenish gray to grayish brown. Locally it is altered to a rust color or bleached almost white and speckled with limonite. The outcrops have a conspicuous slabbiness parallel to the foliation, but nowhere is vertical columnar jointing well developed.

The rock contains abundant crystal fragments and sparse pumiceous fragments in a vitroclastic matrix; very few accidental rock fragments are included. The 


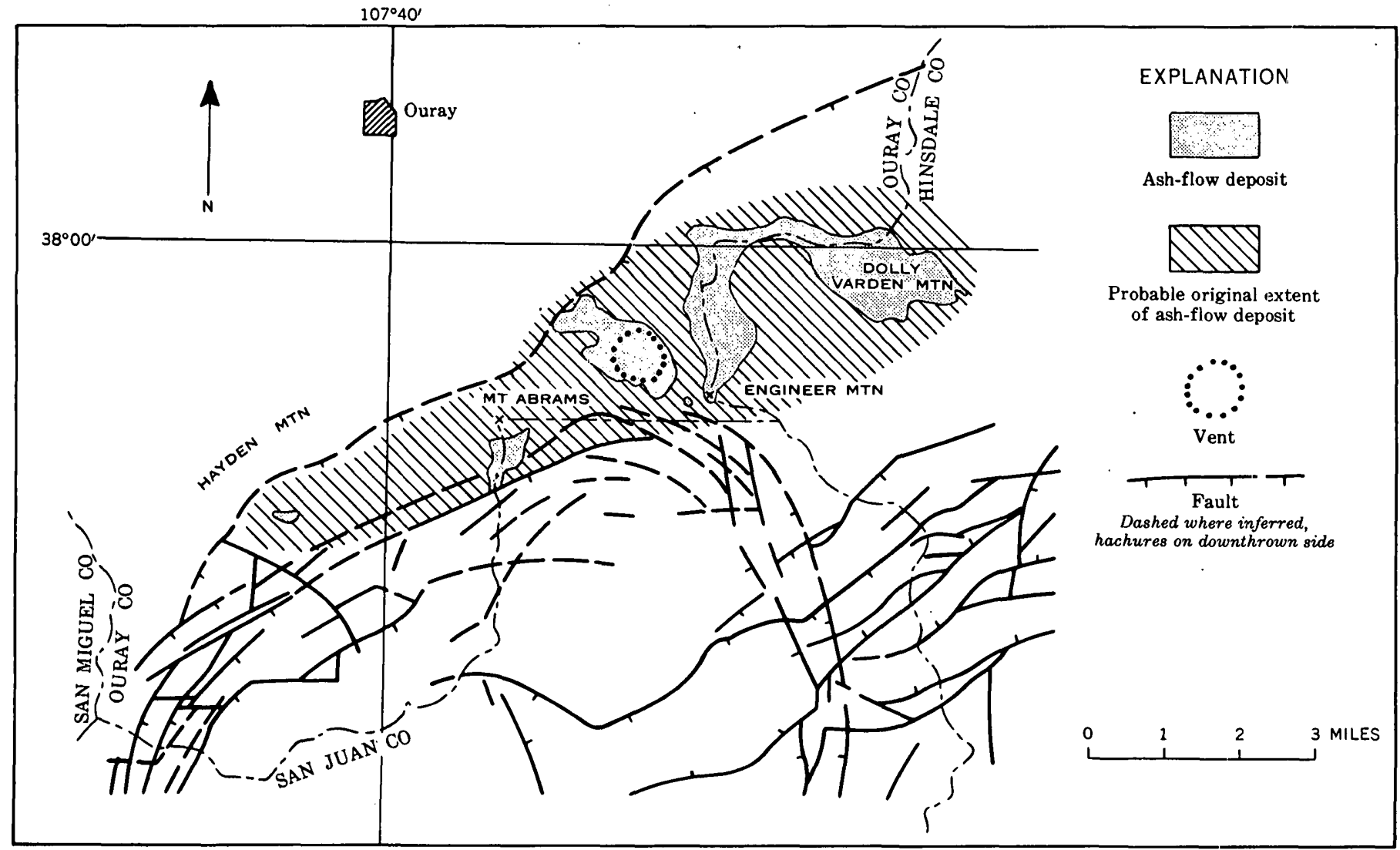

Froure 326.2.-Generalized geologic map of the north side of the Silverton caldera showing outcrops and probable extent of ash-flow deposit.

matrix is dense and characterized by eutaxitic structure but locally appears structureless. The fragmental intratelluric crystals, listed in decreasing order of abundance, are quartz, biotite, potassic feldspar, plagioclase (oligoclase-andesine), amphibole, and accessory minerals. Chlorite, carbonate minerals, sericite, iron oxides, and locally pyrite, or limonite after pyrite, are common alteration products throughout much of the rock. The vitroclastic structure of the matrix is partly to completely obliterated by crystallization to a finegrained aggregate of potassic feldspar, quartz, and accessory minerals. Axiolitic and spherulitic intergrowths of feldspar and quartz are conspicuous in the flattened pumiceous fragments. The composition of the rock is probably a quartz latite or a rhyolitic quartz latite.

The welded ash flow seems to represent the deposit of a single eruption and is a simple cooling unit (terminology of Smith, 1960). Variations in the degree and amount of welding and compaction of the tuffaceous and pumiceous material are noticeable owing to lateral thinning and to topographic irregularities on the underlying surface.
The recognition of this ash flow and its vent affords a better understanding of the petrologic and volcanic processes occurring during the evolution of the Silverton volcanic series and the volcano-tectonic depression. Preceding and succeeding volcanic activity was principally a quiet effusion of lava alternating with explosive ejection of ash; the materials erupted were andesitic to rhyodacitic in composition. In contrast, the ashflow eruption was a catastrophic hot avalanche of more silicic material. These contrasting features indicate (a) different stages of magmatic differentiation either by fractionation or contamination, and (b) different modes of eruption. This small local ash-flow eruption apparently represents an aberrant phase in the waning stages of the Silverton eruptions.

Recognition of this central vent establishes that at least one local ash-flow eruption in the San Juan region was from a conduit. In the absences of local deep erosion the position of the vent would not have been recognized from features exposed in the overlying eruptive debris. Thus it is possible that other local vents of this type and related ash-flow eruptions may be more common in the San Juan volcanic region than are readily disclosed. 
Material similar to and included as part of the American Flat latite is reported by Cross, Howe, and Irving (1907) near Uncompahgre Peak, about 6 miles northeast of Dolly Varden Mountain. This occurrence has not been examined by us, but if it is an ash-flow deposit, it may represent another local eruption from a separate vent.

\section{REFERENCES}

Cross, Whitman, Howe, Ernest, and Irving, J.D., 1907, Description of the Ouray quadrangle [Colorado]: U.S. Geol. Survey Geol. Atlas Folio 153.

Smith, R. L., 1960, Zones and zonal variations in welded ash flows: U.S. Geol. Survey Prof. Paper 354-F, p. 149-159.

327. EIGHT MEMBERS OF THE OAK SPRING FORMATION, NEVADA TEST SITE AND VICINITY, NYE AND LINCOLN COUNTIES, NEVADA

By E. N. Hinrichs and P. P. Orkild, Denver, Colo.

Work done in cooperation with the U.S. Atomic Energy Commission

Tertiary volcanic rocks that crop out extensively in the Nevada Test Site were named the Oak Spring formation by Johnson and Hibbard $(1957$, p. 367). The formation is of Miocene(?) or younger age, is at least 2,200 feet thick, and is composed of welded and nonwelded silicic tuff, tuffaceous sandstone and siltstone, rhyolite, rhyodacite, and basalt.

As the result of recent geologic mapping in five $71 / 2$-minute quadrangles and reconnaissance in about 15 other quadrangles in and around the Nevada Test Site, the Oak Spring formation is now well enough known to be divided into an informal lower member and seven formal members here named: Tub Spring, Grouse Canyon, Survey Butte, Stockade Wash, Topopah Spring, Tiva Canyon, and Rainier Mesa members. With the exception of the basal member, they are named after geographic features shown on figure 327.1 (p. D-100). Details of the lithology, the distribution, and thickness of the newly named members are given on table 327.1, and the correlation of the units in selected stratigraphic sections is given on figures 327.2-4 (p. D-101 to -103).

Hansen and Lemke (1957) informally divided the formation into eight units as a result of detailed map- . ping of about 2 square miles on the east side of Rainier Mesa in Tippipah Springs NW quadrangle (fig. 327.1). Extension of geologic mapping to the limits of the quadrangle resulted in an additional 19 map units (Gibbons and others, 1960). Correlations of these units with the eight members of this paper are given on table 327.1.

\section{REFERENCES}

Gibbons, A. B., Hinrichs, E. N., Hansen, W. R., and Lemke, R. W., 1960, Preliminary geologic map of the Tippipah Spring NW quadrangle: U.S. Geol. Survey TEI-754, openflle report.

Hansen, W. R., and Lemke, R. W., 1957, Geology of the USGS and Rainier tunnel areas, Nerada Test Site: U.S. Geol. Survey TEI-716, open-file report.

Johnson, M. S., and Hibbard, D. E., 1957, Geology of the Atomic Energy Commission Nevada Proving Grounds area, Nerada: U.S. Geol. Survey Bull. 1021-K, p. 333-384. 
TABLE 327.1-Descriptions, thicknesses, distinguishing features, and equivalent units on earlier maps of eight members of the Oak Spring formation, Nevada Test Site

\begin{tabular}{|c|c|c|c|}
\hline \multirow{2}{*}{ Distribution and thickness } & \multicolumn{2}{|l|}{ Description } & \multirow{2}{*}{ Distinguishing features } \\
\hline & Megascopic & Microscopic & \\
\hline \multicolumn{4}{|c|}{ Rainier Mesa member, equivalent to map unit Tos8 of Hansen and Lemke (1957) } \\
\hline $\begin{array}{l}\text { Thickest measured section } \\
\text { is about a mile north of } \\
\text { Survey Butte. Exposed } \\
\text { on Pahute Mesa and } \\
\text { southward to Lookout } \\
\text { Peak and eastward to } \\
\text { Nye Canyon. Unit is } \\
\text { more than } 655 \text { feet } \\
\text { thick. }\end{array}$ & $\begin{array}{l}\text { Gray and reddish-brown welded tuff marked } \\
\text { by distinct eutaxitic structure; subordinate } \\
\text { amounts of black vitrophyre; white, pink, } \\
\text { and tan nonwelded tuff at base; overlain by } \\
\text { densely welded tuff locally separated by zones } \\
\text { of partially welded or nonwelded tuff. In } \\
\text { southeastern part of test site entire mem- } \\
\text { ber is partly welded and glassy. Lower } \\
\text { contact gradational at Rainier Mesa, and } \\
\text { uncomformable southward. }\end{array}$ & $\begin{array}{l}\text { Phenocrysts of sanidine, } \\
\text { anorthoclase, quartz, } \\
\text { plagioclase, biotite, } \\
\text { and other mafic min- } \\
\text { erals make up } 10 \text { to } 30 \\
\text { percent of rock. }\end{array}$ & $\begin{array}{l}\text { Cliffs of dark welded tuff, } \\
\text { steep slopes, and conical } \\
\text { forms of nonwelded and } \\
\text { partly welded tuff; } \\
\text { conspicuous biotite. }\end{array}$ \\
\hline \multicolumn{4}{|c|}{ Tiva Canyon member, upper part; (new map unit) } \\
\hline $\begin{array}{l}\text { Shoshone Mountain north- } \\
\text { ward to Tippipah Spring } \\
\text { and eastward to Nye } \\
\text { and Lincoln County } \\
\text { line. Unit is } 0 \text { to } 550 \\
\text { feet thick. }\end{array}$ & $\begin{array}{l}\text { Gray, purple, and brown densely welded tuff, } \\
\text { much of which weathers platy; local zones } \\
\text { of lithophysae and spherulites in middle and } \\
\text { upper parts; at the top a zone of porous } \\
\text { finely crystalline partially welded tuff that } \\
\text { is thickest in vicinity. of French Peak; basal } \\
\text { part is white and pink nonwelded shards and } \\
\text { pumice, and is locally cavernous. Member } \\
\text { becomes progressively less welded and more } \\
\text { glassy from French Peak eastward. Black } \\
\text { vitrophyre near base locally in central part } \\
\text { of test site. }\end{array}$ & $\begin{array}{l}\text { Phenocrysts compose less } \\
\text { than } 5 \text { percent of basal } \\
\text { tuff; } 10 \text { to } 25 \text { percent } \\
\text { of tuff in middle and } \\
\text { upper parts. Pheno- } \\
\text { crysts chiefly of quartz } \\
\text { and potassium feldspar. } \\
\text { Mafic minerals less } \\
\text { than } 1 \text { percent. }\end{array}$ & $\begin{array}{l}\text { Steep slopes of purple } \\
\text { platy-weathering dense- } \\
\text { ly welded tuff. Caverns } \\
\text { in pink basal tuff. }\end{array}$ \\
\hline \multicolumn{4}{|c|}{ Tiva Canyon member, lower part; (new map unit) } \\
\hline $\begin{array}{l}\text { Thickest on south flank of } \\
\text { French Peak. lixtends } \\
\text { from Shoshone Mesa } \\
\text { southward to Lookout } \\
\text { Peak and eastward to } \\
\text { county line. Absent in } \\
\text { western part of test site. } \\
\text { Unit is } 0 \text { to } 250 \text { feet } \\
\text { thick. }\end{array}$ & $\begin{array}{l}\text { Gray and yellow fine to lapilli bedded tuff, } \\
\text { zeolitic near French Peak; medium to very } \\
\text { thick bedded; local thin beds contain more } \\
\text { than } 20 \text { percent rock fragments up to } 3 \mathrm{~cm} \\
\text { long; weathers to moderate ledgy slopes. } \\
\text { Lower contact locally unconformable. }\end{array}$ & $\begin{array}{l}\text { Phenocrysts of quartz } \\
\text { and feldspar, } 10 \text { to } 20 \\
\text { percent; biotite, less } \\
\text { than } 5 \text { percent, frag- } \\
\text { ments of gray welded } \\
\text { tuff, less than } 5 \text { per- } \\
\text { cent. }\end{array}$ & $\begin{array}{l}\text { Ledgy moderate slopes of } \\
\text { yellow bedded tuff. }\end{array}$ \\
\hline \multicolumn{4}{|c|}{ Topopah Spring member; equivalent to map unit $T 7_{2}$ of Gibbons and others (1960) } \\
\hline $\begin{array}{l}\text { Thickest at } 311 \text { Wash. } \\
\text { Extends from } 311 \text { Wash } \\
\text { northward to pinchout } \\
\text { on Rainier Mesa, south- } \\
\text { ward to Shoshone } \\
\text { Mountain, eastward to } \\
\text { the county line, and } \\
\text { westward to Calico Hills } \\
\text { and probably to Yucca } \\
\text { Mountain. Unit is } 0 \text { to } \\
900 \text { feet thick. }\end{array}$ & $\begin{array}{l}\text { Brown and reddish-purple densely welded } \\
\text { tuff; persistent black and brown vitrophyre } \\
\text { in upper part and local vitrophyre in lower } \\
\text { part; local zones of geodes and lithophysae; } \\
\text { strongly eutaxitic in western part of the } \\
\text { test site; basal tuff nonwelded to partly } \\
\text { welded and locally silicified; pale-red } \\
\text { crystal-poor welded tuff in the lower part of } \\
\text { member; pumice fragments are as much as } \\
18 \text { inches long at eastern edge. Member } \\
\text { forms steep slopes and cliffs. }\end{array}$ & $\begin{array}{l}\text { Phenocrysts of feldspar, } \\
\text { quartz, and biotite } \\
\text { make up about } 1 \text { per- } \\
\text { cent of the tuff at } \\
\text { base, increasing up- } \\
\text { ward to } 15 \text { percent } \\
\text { near top. Plagioclase } \\
\text { predominates in lower } \\
\text { vitrophyre; potassium } \\
\text { feldspar in upper vitro- } \\
\text { phyre. Fragments of } \\
\text { dense dark rock make } \\
\text { up less than } 5 \text { percent } \\
\text { of the rock. }\end{array}$ & $\begin{array}{l}\text { Black vitrophyre at top; } \\
\text { local geodes and litho- } \\
\text { physae; crystal-poor } \\
\text { welded tuff in lower } \\
\text { part. }\end{array}$ \\
\hline
\end{tabular}


TABLE 327.1-Descriptions, thicknesses, distinguishing features, and equivalent units on earlier maps of eight members of the Oak Spring formation, Nevada Test Site-Continued

\begin{tabular}{l|c|c|}
\hline \multirow{2}{*}{ Distribution and thickness } & Description & Distinguishing features \\
\cline { 2 - 4 } & Megascopic & Microscopic \\
\hline
\end{tabular}

Stockade Wash member; equivalent to map unit $\mathrm{T} 7_{1}$ of Gibbons and others (1960)

\begin{tabular}{|c|c|c|c|}
\hline $\begin{array}{l}\text { Extends from western and } \\
\text { southern parts of } \\
\text { Rainier Mesa south- } \\
\text { ward to Tippipah } \\
\text { Spring, and westward } \\
\text { to Fortymile Canyon. } \\
\text { Unit is } 0 \text { to } 290 \text { feet } \\
\text { thick. }\end{array}$ & $\begin{array}{l}\text { Lenticular deposit of white, pale-gray, and } \\
\text { pale-brown nonwelded to partially welded } \\
\text { tuff; most of the member contains non- } \\
\text { stratified orange and tan pumice fragments } \\
\text { as much as half an inch long; local calcite } \\
\text { cement; base is zeolitic in places. West of } \\
\text { Tippipah Spring are contorted layers and } \\
\text { closely spaced polygonal joints possibly of } \\
\text { fumarolic origin. Forms cliffs, rounded } \\
\text { knobs, and low hills. }\end{array}$ & $\begin{array}{l}\text { Phenocrysts of quartz, } \\
\text { feldspar, and biotite } \\
\text { amounting to less than } \\
5 \text { percent of the tuff. }\end{array}$ & $\begin{array}{l}\text { Rounded knobs of pale } \\
\text { nonbedded tuff having } \\
\text { contorted layers. }\end{array}$ \\
\hline
\end{tabular}

Survey Butte member; equivalent to map unit Tos7 of Hansen and Lemke (1957)

Thickest on the east side of Rainier Mesa; extends from there southward to Tippipah

Point, northward about 15 miles, westward to Pahute Mesa, and eastward to Quartzite Mountain. Unit is 60 to 750 feet thick.
Predominantly pale-gray and brown wellbedded tuff composed chiefly of glass shards and fine and coarse unaltered pumice; generally poorly cemented and friable; beds are tabular and lenticular, some crossbeds and channel fillings. The member thins southward from Rainier Mesa and interfingers with the Stockade Wash, Topopah Spring, and Tiva Canyon members. Forms steep slopes generally covered by colluvium. Lower 150 feet on east side of Rainier Mesa is zeolitic.
Fragments of dark dense. volcanic rocks and glass make up 20 percent or less of the tuff - phenocrysts of feldspar and quartz make up 5 percent or less.
Distinct parallel laminated and crossstratified gray beds alternating with nonlaminated; pale-brown beds.

Grouse Canyon member, upper part; equivalent to map unit Tos6 of Hansen and Lemke (1957)

Present from type locality at Grouse Canyon northward to Indian Spring, southward to Big Butte, eastward to Oak Spring Butte, and westward to Fortymile Canyon. Unit is 0 to $175+$ feet thick.
Reddish-brown, greenish-gray, and yellowishgray densely welded tuff; distinctly eutaxitic; black- and white-zoned lenses of flattened pumice up to 2 inches long. On the east side of Rainier Mesa the welded tuff is present only in synclines. Local conglomerate and scattered pebbles and cobbles of rhyolite and granite both are in welded tuff, and in black vitrophyre on west side of Rainier Mesa. Lower contact gradational.
Welded tuff contains 3 to 9 percent phenocrysts of sanidine, anorthoclase, and quartz. Black vitrophyre contains lenses of gray pumice and about 30 percent phenocrysts, chiefly of feldspars.
Makes cliffs; contains zoned lenses of flattened pumice having eutaxitic structure, and cobbles of rhyolite and granite.

Grouse Canyon member, lower part; equivalent to map unit Tos5 of Hansen and Lemke (1957)

About coextensive with upper part. Unit is 0 to 400 feet thick.
Medium-gray vitric tuff and greenish-yellow zeolotic tuff in beds 2 inches to 3 feet thick; thin beds composed of fine well-sorted thinly laminated pumice; local sparse pebbles and lenses of black obsidian and fragments of granitic rock as much as an inch long. Lower contact is an erosional unconformity.
Phenocrysts compose less than 5 percent of rock.
Extensive greenish-gray and yellow beds, distinctively laminated. 
TABLE 327.1-Descriptions, thicknesses, distinguishing features, and equivalent units on earlier maps of eight members of the Oak Spring formation, Nevada Test Site-Continued

\begin{tabular}{|c|c|c|c|}
\hline \multirow{2}{*}{ Distribution and thickness } & \multicolumn{2}{|l|}{ Description } & \multirow{2}{*}{ Distinguishing features } \\
\hline & Megascopic & Microscopic & \\
\hline \multicolumn{4}{|c|}{ Tub Spring member; probably equivalent to map unit Tgor of Gibbons and others (1960) } \\
\hline $\begin{array}{l}\text { Found on north and east } \\
\text { sides of Yucca Flat. } \\
\text { Unit is } 0 \text { to } 250 \text { feet } \\
\text { thick. }\end{array}$ & $\begin{array}{l}\text { Greenish-gray welded tuff, gray vitrophyre, } \\
\text { and reddish-brown partially welded pumice; } \\
\text { inclusions of rhyolite, welded tuff, and } \\
\text { Paleozoic rocks; base is nonwelded gray } \\
\text { vitric and at some places yellow zeolitic } \\
\text { tuff; the member occupies a stratigraphic } \\
\text { position between units Tos } 4 \text { and Tos5 of } \\
\text { Hansen and Lemke (1957). Forms cliffs } \\
\text { and benches. }\end{array}$ & $\begin{array}{l}\text { Phenocrysts of sanidine, } \\
\text { anorthoclase, quartz, } \\
\text { and mafic minerals } \\
\text { compose as } 30 \text { percent } \\
\text { of the rock. }\end{array}$ & $\begin{array}{l}\text { Fragments of pumice } \\
\text { and rhyolite as much } \\
\text { as } 12 \text { inches long near } \\
\text { pinchout on Paleozoic } \\
\text { rocks about } 3 \text { miles } \\
\text { west of type locality; } \\
\text { abundant phenocrysts. }\end{array}$ \\
\hline \multicolumn{4}{|c|}{ Lower member; equivalent to map units $\mathrm{Tw} 1$ to $4, \mathrm{~T} \mathrm{cj}, \mathrm{Tg}$, and $\mathrm{Tgo}$ of Gibbons and others (1960) } \\
\hline $\begin{array}{l}\text { Widespread busal unit } \\
\text { exposed on the west, } \\
\text { north, and east sides of } \\
\text { Yucca Flat, and at a } \\
\text { few places south of the } \\
\text { Flat. Unit is } 0 \text { to. } \\
1,100 \text { feet thick. }\end{array}$ & $\begin{array}{l}\text { Mostly thick lenticular nonstratified deposits } \\
\text { of gray, yellow, orange, and red zeololitic } \\
\text { tuff in basins in Paleozoic rocks; also in- } \\
\text { cludes tuffaceous sandstone and siltstone } \\
\text { that locally contain plant fossils, and minor } \\
\text { amounts of welded tuft and olivine basalt; } \\
\text { local basal breccia of Paleozoic rocks. } \\
\text { The nonstratified tuffs intertongue with } \\
\text { the Tunnel beds, which consist of gray, } \\
\text { yellow, orange, and red paralled-bedded } \\
\text { zeolitic tuff } 675 \text { to } 900 \text { feet thick at the } \\
\text { type locality on the east side of Rainier } \\
\text { Mesa. The Tunnel beds are equivalent to } \\
\text { map units Tos } 1 \text { through } 4 \text { of Hansen and } \\
\text { Lemke (1957). Member forms rounded } \\
\text { ledges and low cliffs alternating with mod- } \\
\text { erate to steep slopes. The lower member } \\
\text { is conformably overlain by the Tub } \\
\text { Spring member on the north and east sides } \\
\text { of Yucca Flat; it is unconformably overlain } \\
\text { by the Grouse Canyon member on the west } \\
\text { side. }\end{array}$ & $\begin{array}{l}\text { Phenocrysts make up } 5 \\
\text { to } 20 \text { percent (chiefly } \\
5 \text { to } 15 \text { percent) of } \\
\text { nonwelded tuff, and } \\
\text { rock fragments make } \\
\text { up } 20 \text { percent or less. } \\
\text { Welded tuffs contain } \\
\text { up to } 5 \text { percent biotite } \\
\text { and hornblende. }\end{array}$ & $\begin{array}{l}\text { Brightly colored cliff- } \\
\text { forming tuff; locally } \\
\text { thick units indicate } \\
\text { deposition in local } \\
\text { basins; plant fossils of } \\
\text { Miocene and Pliocene } \\
\text { ages. }\end{array}$ \\
\hline
\end{tabular}




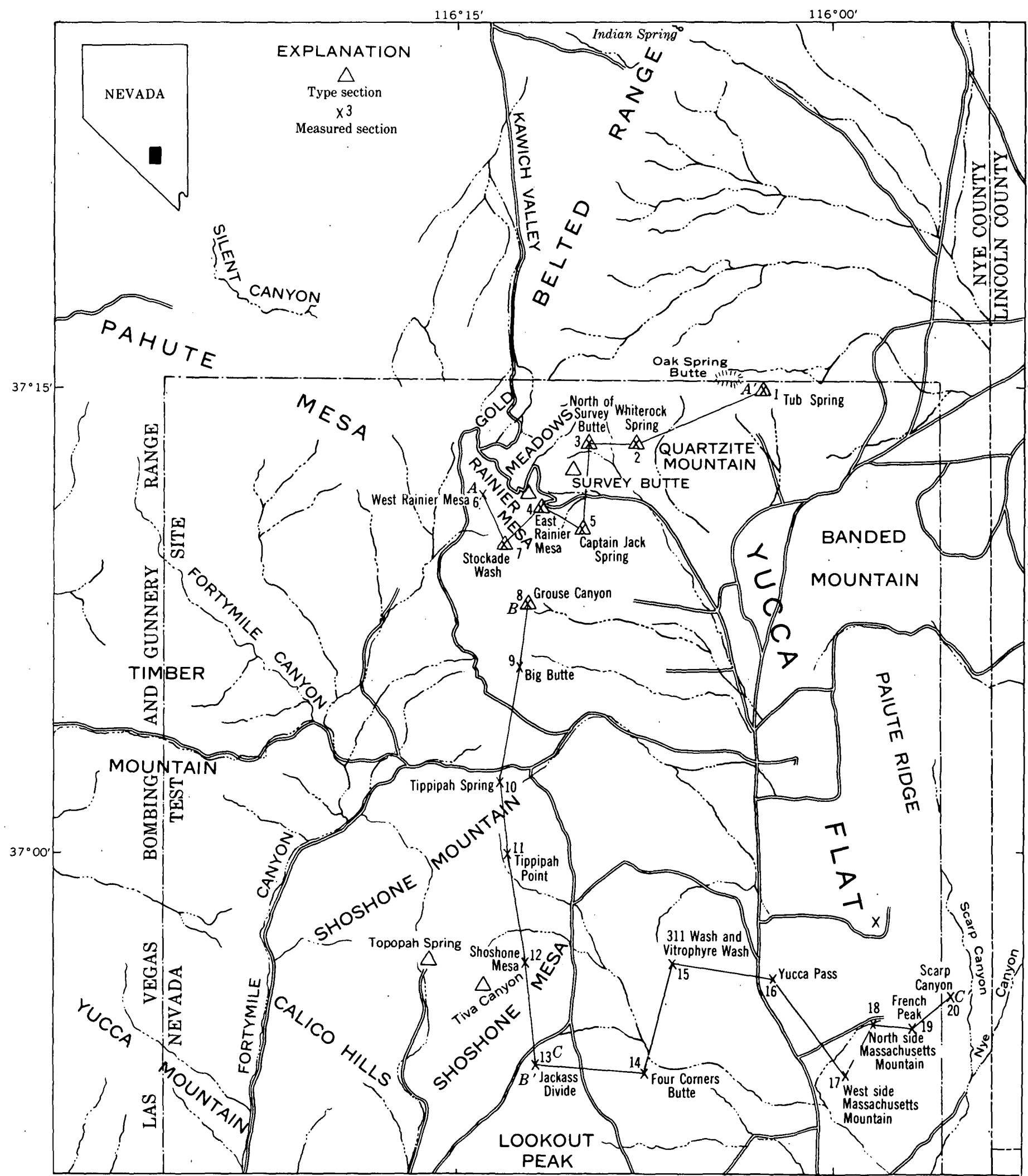

O $510 \quad 15$ MILES

Figure 327.1.-Map showing location of measured sections of eight members of the Oak Spring formation shown on figures $327.2-327.4$. 


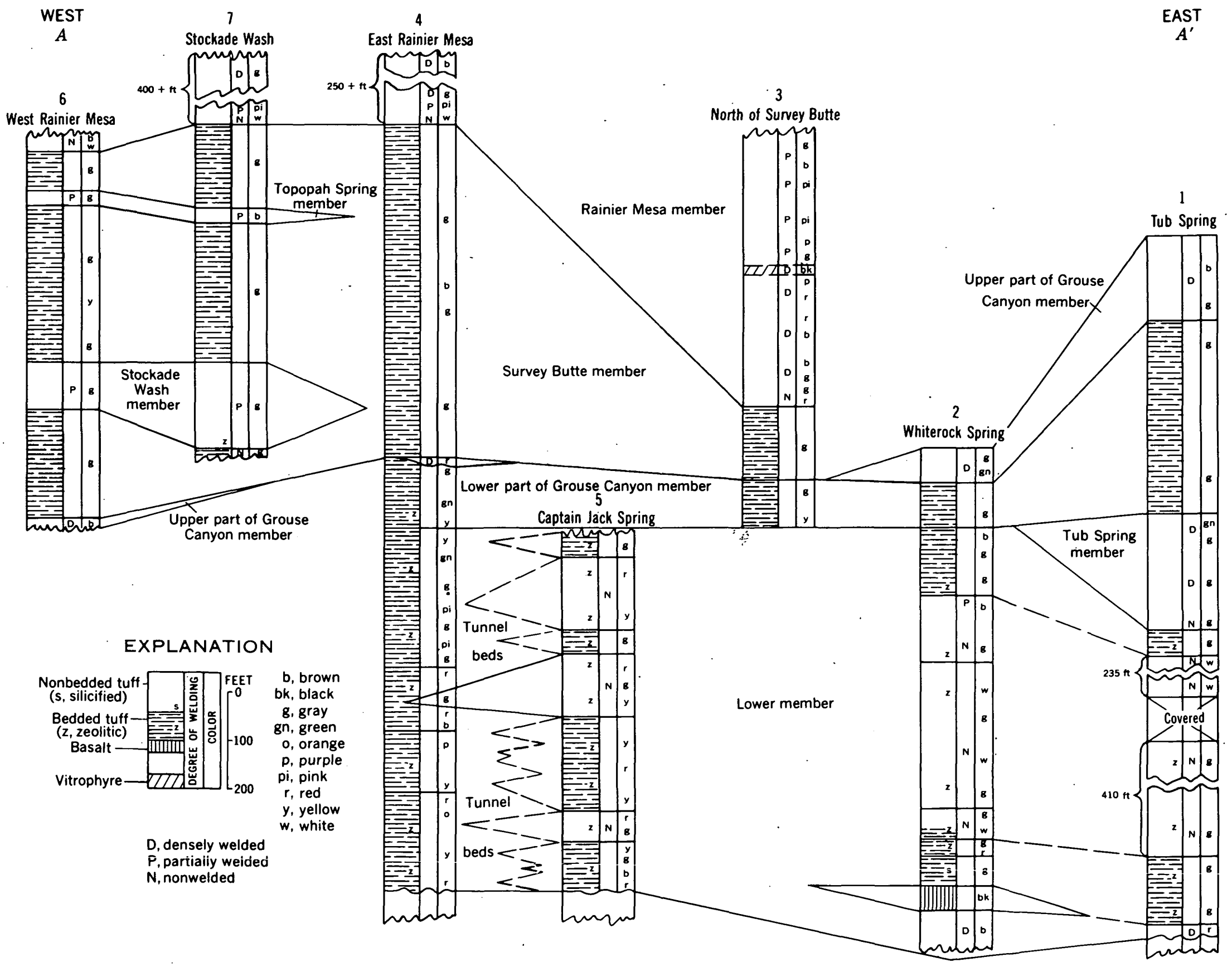


NORTH $B$
11

$\underset{B^{\prime}}{\text { SOUTH }}$

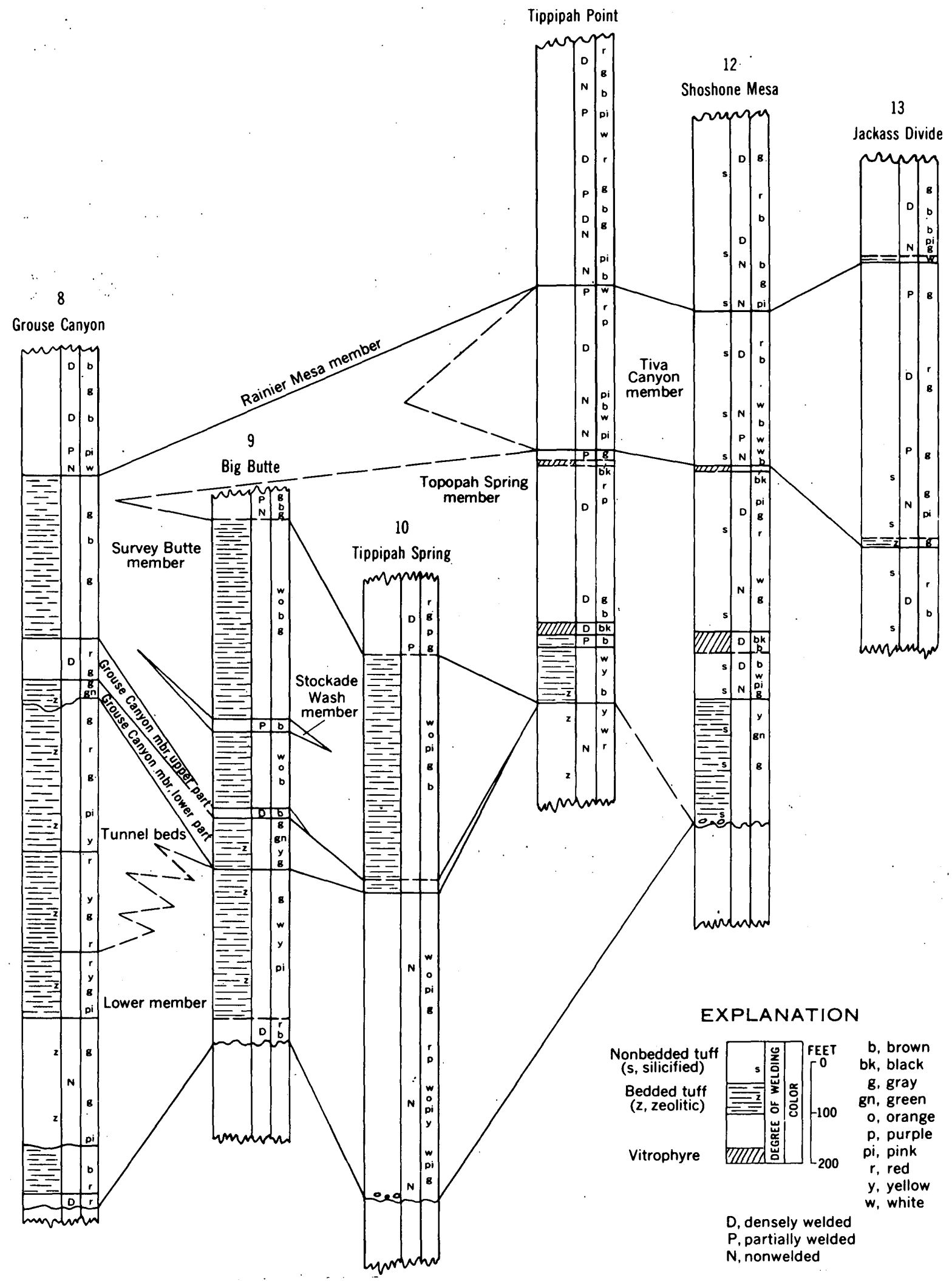

FIgurE 327.3.-Six sections of the Oak Spring formation on a north-south line, north-central Nevada Test Site. For locations see figure 327.1. 


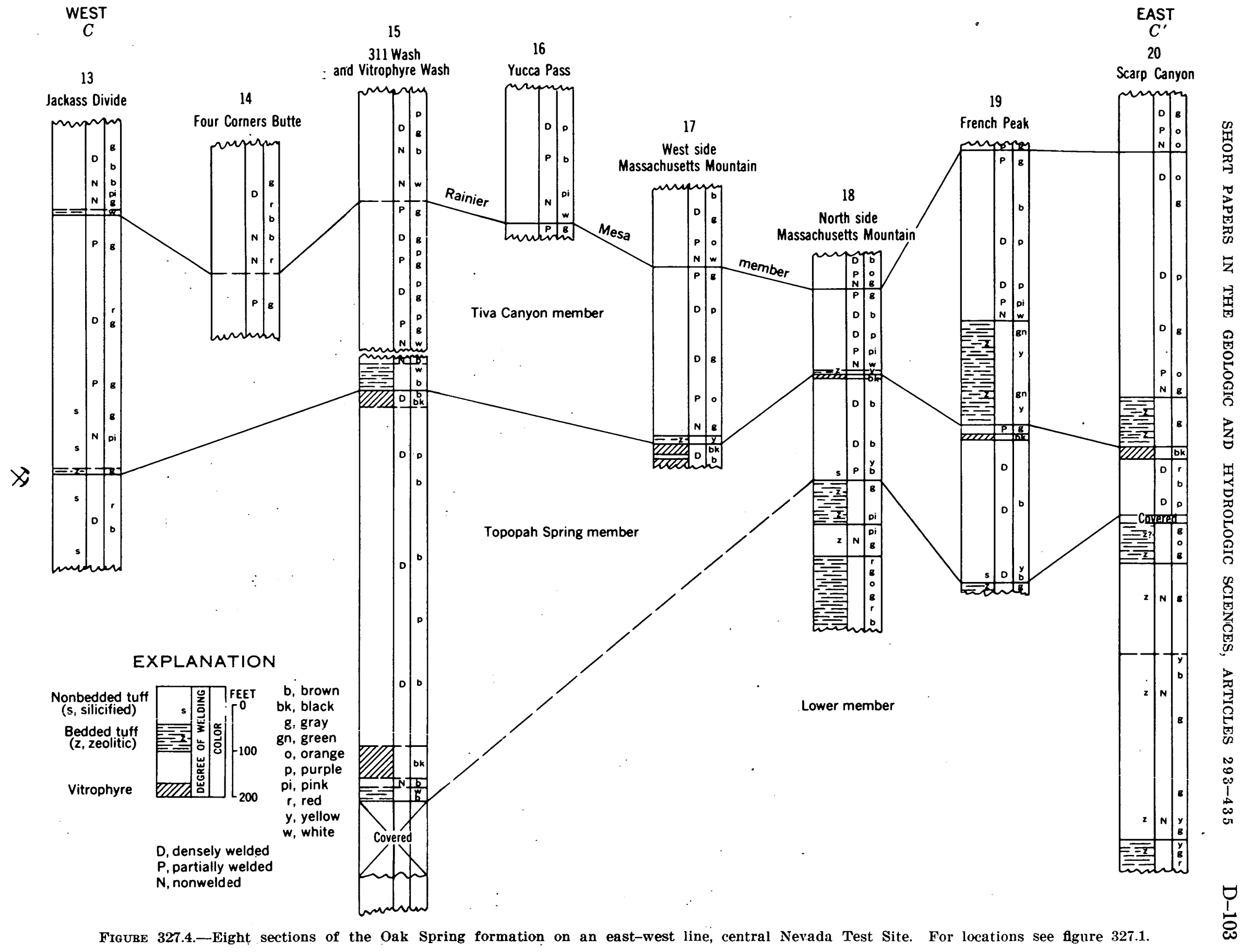




\section{8. \\ ELEANA FORMATION OF NEVADA TEST SITE AND VICINITY, NYE COUNTY, NEVADA}

By F. G. Poole, F. N. Houser, and P. P. Orkild, Denver, Colo.

Work done in cooperation with the U.S. Atomic Energy Commission

Recent stratigraphic study of nearly 8,000 feet of clastic rocks of Carboniferous age in the Nevada Test Site region (fig. 328.1) has yielded new information on late Paleozoic sedimentation and structural history in south-central Nevada. These clastic rocks were originally mapped by Ball (1907) as the Weber conglomerate of Pennsylvanian age. In the northern part of the test site, an incomplete part of this Carboniferous sequence was named Eleana formation by Johnson and Hibbard (1957), and on the basis of stratigraphic position and lithologic similarities to strata in central Nevada, they considered the formation as probable Late Mississippian in age. Southeast of the test site, the Narrow Canyon limestone of Late Devonian and Early Mississippian age and the Mercury limestone of Early Mississippian age, as defined by Johnson and Hibbard (1957), are here correlated with the lower part of the Eleana formation.

\section{IITHOLOGY}

The Eleana formation, which is at least 7,700 feet thick, is known only by means of a composite of partial sections. Correlation of these sections is difficult due to structural complexities and partial cover by younger deposits and is considered tentative.

The four major rock types that make up the Eleana formation are (a) argillite, (b) siliceous siltstone and very fine grained quartzite, (c) quartzite and conglomerite, ${ }^{1}$ and (d) limestone. The formation is divided into ten major lithologic units, in ascending order from A through $J$ (fig. 328.2). Unit $\mathbf{A}$ is limestone and limestone conglomerate; unit $\mathrm{B}$ is argillite; unit $\mathrm{C}$ is quartzite and conglomerite; unit $\mathrm{D}$ is argillite and quartzite; unit $\mathrm{E}$ is argillite; unit $\mathrm{F}$ is quartzite, argillite, and conglomerite present at Grouse Canyon; unit $\mathrm{G}$ is quartzite, conglomerite, and argillite; unit $\mathrm{H}$ is argillite; unit $I$ is limestone and argillite; and unit $J$ is argillite.

The argillite is yellowish brown to pale red, laminated, and commonly contains cubic iron oxide pseudomorphs after pyrite, plant stem imprints, and lightcolored sinuate markings on stratification planes that

1 The term "conglomerite" is used here for conglomerate with a sandstone matrix that has the induration of quartzite. are interpreted as worm trails and borings (J.T. Dutro, Jr., written communication, 1960).

The siliceous siltstone and very fine grained quartzite are brown to tan and commonly contain plant stems, convolute laminae, flow casts, current lineation, current ripple laminae, and small-scale cross-laminae.

The quartzite and conglomerite are brown and locally contain small- to medium-scale cross-laminae, current ripple laminae, and contorted strata. Much of the conglomerite has graded bedding, and locally gravels are imbricated. Pebbles, cobbles, and rare boulders in the conglomerite are composed, in order of abundance, of subangular to rounded chert, quartzite, argillite, quartz, and limestone.

Gray and brown fossiliferous coarsely crystalline limestone in unit $\mathrm{I}$ and upper part of unit $\mathrm{H}$ locally contains stringers of chert, and pebbles and cobbles of chert and subordinate argillite and limestone. Limestone in the upper part of unit $\mathbf{J}$ is ferruginous, fossiliferous, and occurs as lenses in the top 1 to 2 feet of thick quartzite beds.

The lower unit of the Eleana formation is known only at Carbonate Wash (fig. 328.2) where it is separated by an erosional unconformity from dolomite of Devonian age below. This basal unit is composed of interstratified laminae to very thin beds of gray finely crystalline limestone and limestone conglomerate, and subordinate beds of limy sandstone and rare quartzite. Most of the conglomerate contains fossiliferous limestone pebbles, cobbles, and rare boulders as large as 4 feet in maximum diameter in a limestone matrix. The beds of this unit grade upward into argillite of unit B (fig. 328.2).

The upper contact of the Eleana formation is best exposed at Red Canyon. Here gray aphanitic to finely crystalline Tippipah limestone rests with sharp contact on a brown very fine to fine-grained bed of conglomeratic quartzite assigned to the Eleana formation. The abrupt lithologic change suggests an unconformity.

The depositional environment of the Eleana formation, interpreted from lithology, sedimentary structures, fossils, and regional sedimentary facies, is believed to have been largely marine. 


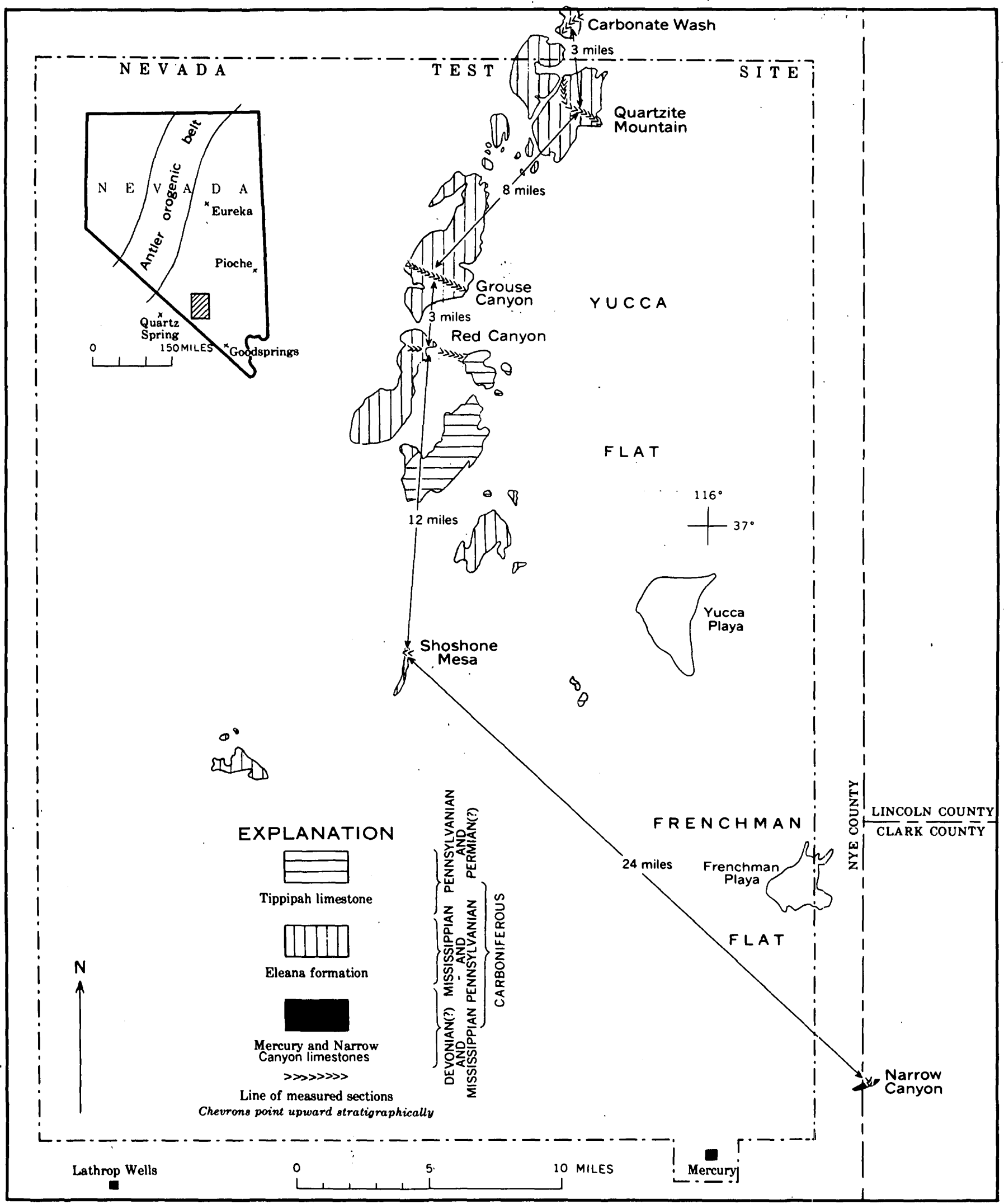

Fraure 328.1.-Map of Nevada Test Site and vicinity showing location of measured sections and outcrops of Tippipah limestone, Eleana formation, Mercury and Narrow Canyon limestones. 


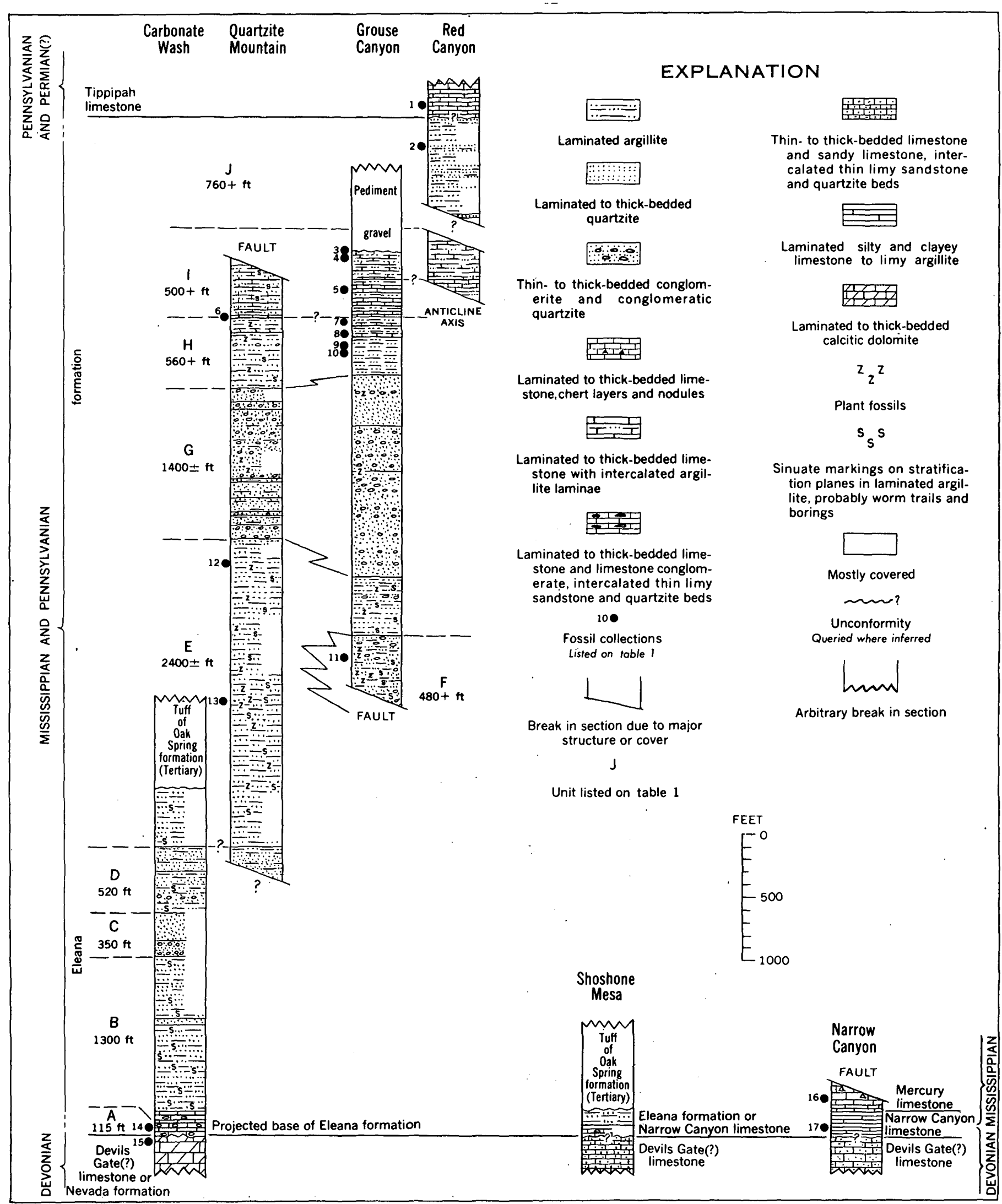

Grouse Canyon section measured by E. N. Hinrichs and A. B. Gibbons, 1959

Froure 328.2.-Composite stratigraphic section of Eleana formation and equivalent strata in Nevada Test Site and vicinity. A-J are major lithologic units. 


\section{AGE AND CORRELATION}

The age of the Eleana formation, based on stratigraphic position and fossil evidence, is considered to be Mississippian and Early Pennsylvanian (fig. 328.2, tables 328.1 and 328.2). The basal part of the Eleana may be as old as Late Devonian. The formation over- lies the Devonian Devils Gate (?) limestone ${ }^{2}$ and underlies the Pennsylvanian and Permian (?) Tippipah limestone (fig. 328.2). Fossils collected from the Eleana formation are listed in table 328.1.

${ }^{3}$ Questionably correlated by Johnson and Hibbard (1957) with the type Devils Gate limestone in the Eureka area.

TABLE 328.1.-Major lithologic units and fossil collections from Eleana formation and equivalent strata in Nevada Test Site and vicinity [Fossils collected by E. N. Hinrichs, A. B. Gibbons, F. G. Poole, F. N. Houser, and P. P. Orkild; fossils identified by Helen Duncan, J. T. Dutro, Jr., E. L. Yochelson
W. J. Sando, S. H. Mamay, Mackenzie Oordon, Jr., J. Steele Williams, C. W. Merriam, Kobert Finks, and W. A. Oliver, Jr.]

\begin{tabular}{|c|c|c|c|}
\hline $\begin{array}{l}\text { Formation and } \\
\text { lithologic unit }\end{array}$ & $\begin{array}{l}\text { Collection number } \\
\text { (see fig. 328.2) }\end{array}$ & Fossils & Age and remarks \\
\hline $\begin{array}{l}\text { Tippipah lime- } \\
\text { stone. }\end{array}$ & 1 & $\begin{array}{l}\text { Chonetes sp.; Composila?.sp.; Astartella? sp.; } \\
\text { mytilacean? pelecypod; “Mourlonia" sp.; } \\
\text { Straparollus (Euomphalus) sp.; nuculoid } \\
\text { pelecypod; gastropod, indet; paralegoce- } \\
\text { rid goniatite, genus and sp. indet. }\end{array}$ & $\begin{array}{l}\text { E. L. Yochelson reports that the brachiopods, } \\
\text { pelecypods, and gastropods could be either } \\
\text { Pennsylvanian or Permian. The cephalopod, } \\
\text { according to Mackenzie Gordon, Jr., is of a } \\
\text { type indicative of Pennsylvanian age. }\end{array}$ \\
\hline$J$ & 2 & $\begin{array}{l}\text { Schuchertella? sp., Chonetes sp., Inflatia cf. } \\
\text { I. inflata (McChesney), Schizophoria sp., } \\
\text { Spirifer sp., Myalina sp., Schizodus sp. }\end{array}$ & $\begin{array}{l}\text { Mackenzie Gordon, Jr., reports that the } \\
\text { Spirifer in this collection seems to be close to } \\
\text { or identical with an undescribed form that } \\
\text { occurs in the upper part of the Chainman } \\
\text { shale. Available evidence suggests that the } \\
\text { beds collected are of Late Mississippian age. }\end{array}$ \\
\hline \multirow[t]{4}{*}{ I } & 3 & $\begin{array}{l}\text { Echinoderm debris, indet.; bryozoan debris, } \\
\text { indet.; stenoporoids, indet; Tabulipora?; } \\
\text { rhom.boporoids, indet.; Cystodictya?; bi- } \\
\text { foliate fistuliporoids; fenestrate crypto- } \\
\text { stomes, indet. }\end{array}$ & $\begin{array}{l}\text { Helen Duncan reports the stenoporoids with } \\
\text { conspicuously moniliform walls indicate a } \\
\text { post-Devonian age, but the genera tenta- } \\
\text { tively identified and the assemblage as a } \\
\text { whole might occur throughout the Carbonif- } \\
\text { erous and into the Permian. }\end{array}$ \\
\hline & 4 & $\begin{array}{l}\text { Smooth spiriferoid like Composita or Mar- } \\
\text { tinia; productoid, possibly a Setigerites. }\end{array}$ & $\begin{array}{l}\text { Mackenzie Gordon, Jr., reports that these fos- } \\
\text { sils are Carboniferous forms, but the collec- } \\
\text { tion is too meager and poorly preserved to } \\
\text { establish the precise age. If the producto d } \\
\text { is a Setigerites, Early Mississippian age is } \\
\text { indicated. }\end{array}$ \\
\hline & 5 & $\begin{array}{l}\text { Pelmatozoan debris, indet.; corals, indet.; } \\
\text { possible zaphrentoid coral; bryozoans } \\
\text { represented by incrusting, small ramose, } \\
\text { fenestrate, and pinnate forms. }\end{array}$ & . \\
\hline & 6 & $\begin{array}{l}\text { Lophophyllidium; corals, indet.; pelmato- } \\
\text { zoan debris, indet.; bryozoan fragments, } \\
\text { indet.; gastropods, indet.; brachiopods, } \\
\text { indet.; discoidal objects, possibly algal } \\
\text { bodies. }\end{array}$ & $\begin{array}{l}\text { Helen Duncan reports that Lophophyllidium } \\
\text { ranges through the Pennsylvanian and Per- } \\
\text { mian. }\end{array}$ \\
\hline $\begin{array}{l}\text { Position in } \\
\text { IEleana forma- } \\
\text { tion unknown. }\end{array}$ & $\begin{array}{l}\text { Collected south } \\
\text { of Quartzite } \\
\text { Mountain } \\
\text { section. }\end{array}$ & $\begin{array}{l}\text { Strophomenid. brachiopod, genus indet., } \\
\text { Setigerites? sp., leiorhynchid brachiopod, } \\
\text { genus and sp. indet., Spirifer sp., Tylo- } \\
\text { thyris sp., Eumetria sp., Zaphrentites sp., }\end{array}$ & $\begin{array}{l}\text { Mackenzie Gordon, Jr., says this assemblage } \\
\text { is of Early Mississippian age and probably } \\
\text { represents the middle part of the series. }\end{array}$ \\
\hline
\end{tabular}
Amplexizaphrentis sp., pelmatozoan debris, Fenestella sp., Polypora sp., Cystodictya sp., ramose bryozoans, indet. 
TABLE 328.1.-Major lithologic units and fossil collections from Eleana formation and equivalent strata in Nevada Test Site and vicinity-Continued

\begin{tabular}{|c|c|c|c|}
\hline $\begin{array}{l}\text { Formation and } \\
\text { lithologic unit }\end{array}$ & $\begin{array}{l}\text { Collection number } \\
\text { (see fig. 328.2) }\end{array}$ & $\begin{array}{c}\text { Fossils } \\
:\end{array}$ & Age and remarks \\
\hline \multirow[t]{5}{*}{$\mathrm{H}$} & 7 & Leiorhynchid brachiopod, indet. & Possibly Mississippian in age. \\
\hline & 8 & $\begin{array}{l}\text { Penniretepora sp.; orthotetid brachiopod, } \\
\text { indet.; Spirifer sp. (molds and casts); } \\
\text { Punclospirifer? sp.; gastropod(?), indet.; } \\
\text { pelmatozoan debris, indet.; fenestrate } \\
\text { bryozoans, indet. }\end{array}$ & Do. \\
\hline & $\begin{array}{l}\text { Collected north } \\
\text { of Grouse } \\
\text { Canyon } \\
\text { section. }\end{array}$ & $\begin{array}{c}\text { Spirifer sp. (large); Spirifer sp. (small); } \\
\text { bellerophontacean gastropod, indet.; } \\
\text { Straparollus (Euomphalus) sp.; Loxonema } \\
\text { n. sp.; phillipsid trilobite; pygidium, } \\
\text { indet.; bryozoan fragments, indet.; horn } \\
\text { corals, indet.; pelmatozoan debris, indet. }\end{array}$ & $\begin{array}{l}\text { Definite Mississippian aspect. E. L. Yochelson } \\
\text { notes that the Straparollus is possibly } S .(E .) \\
\text { subplanus (Hall) and may indicate correlation } \\
\text { with the Madison and(or) upper Redwall } \\
\text { faunas. }\end{array}$ \\
\hline & 9 & $\begin{array}{l}\text { Crinoid columnals, indet.; horn corals, } \\
\text { indet.; fenestrate bryozoans, indet.; } \\
\text { euomphalacean gastropod, indet. }\end{array}$ & \\
\hline & 10 & Orthotetes? sp. & Possibly Mississippian. \\
\hline G & $\begin{array}{l}\text { Collected north } \\
\text { of Grouse } \\
\text { Canyon } \\
\text { section. }\end{array}$ & $\begin{array}{l}\text { Trilobite cast, possibly a Griffithides? } \\
\text {. }\end{array}$ & Probable Mississippian age. \\
\hline $\mathrm{F}$ & 11 & Pelmatozoan debris, indet. & \\
\hline \multirow[t]{2}{*}{ E } & 12 & $\begin{array}{l}\text { Pelmatozoan columnals and debris, indet.; } \\
\text { brachiopod fragments, indet.; pelecypod } \\
\text { fragments, indet.; branching bryozoan, } \\
\text { indet. }\end{array}$ & 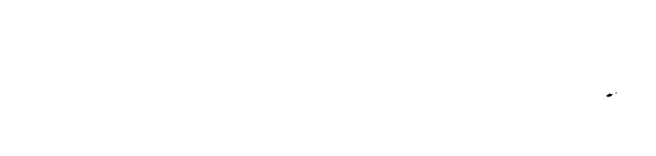 \\
\hline & 13 & $\begin{array}{l}\text { Compressed fairly stout vascular plant axis; } \\
\text { evidence of two or three branch attach- } \\
\text { ments. }\end{array}$ & $\begin{array}{l}\text { A vascular land plant, and as such, is Middle } \\
\text { Silurian or younger. }\end{array}$ \\
\hline A & 14 & $\begin{array}{l}\text { Trapezophyllum sp.; Disphyllum? sp.; } \\
\text { Acrophyllum? sp.; horn coral, indet.; } \\
\text { Favosites sp. (common); Alveolites sp.; } \\
\text { Thamnopora sp. stromatoporoids; gas- } \\
\text { tropod, indet.; Atrypa (large). }\end{array}$ & $\begin{array}{l}\text { According to W. A. Oliver, Jr., the corals are } \\
\text { definitely Devonian; most likely early Late } \\
\text { Devonian in age. J. T. Dutro, Jr., reports } \\
\text { that the large Atrypa is no younger than } \\
\text { early Late Devonian. The age could be } \\
\text { either Middle Devonian or early Late } \\
\text { Devonian. }\end{array}$ \\
\hline $\begin{array}{l}\text { Devils Gate(?) } \\
\text { limestone or } \\
\text { Nevada } \\
\text { formation. }\end{array}$ & 15 & $\begin{array}{l}\text { "Cystiphyllum" sp.; Thamnopora sp.; echi- } \\
\text { noderm debris, indet.; crinoid columnals, } \\
\text { indet.; Schizophoria? sp.; "Martinia" sp.; } \\
\text { spiriferoid brachiopod, indet. }\end{array}$ & $\begin{array}{l}\text { W. A. Oliver, Jr., reports that the corals could } \\
\text { be either Silurian or Devonian; however, the } \\
\text { structure of "Cystiphyllum" suggests Devo- } \\
\text { nian species and the fossils are probably } \\
\text { Devonian. J. T. Dutro, Jr., reports that } \\
\text { the association of the brachiopods suggests } \\
\text { a Middle Devonian age and a correlation } \\
\text { with the Nevada formation. }\end{array}$ \\
\hline
\end{tabular}


ТАвL: 328.1.-Major lithologic units and fossil collections from Eleana formation and equivalent strata in Nevada Test Site and vicinity-Continued

\begin{tabular}{|c|c|c|c|}
\hline $\begin{array}{l}\text { Formation and } \\
\text { lithologic unit }\end{array}$ & $\begin{array}{l}\text { Collection number } \\
\text { (sce flg. } 328.2)\end{array}$ & Fossils & Age and remarks \\
\hline $\begin{array}{l}\text { Mercury } \\
\text { limestone. }\end{array}$ & 16 & $\begin{array}{l}\text { Spirifer centronatus? Winchell; Productus } \\
\text { scabriculus Martin; productids, indet.; } \\
\text { spirifers, indet.; possibly Chonetes, pos- } \\
\text { sibly Rhynchopora; Syringopora cf. S. } \\
\text { aculeata Girty; Syringopora; clisiophyllid } \\
\text { fragments; caninoid horn coral fragments. }\end{array}$ & $\begin{array}{l}\text { C. W. Merriam, Helen Duncan, and J. Steele } \\
\text { Williams report that this collection is } \\
\text { probably Early Mississippian in age. }\end{array}$ \\
\hline $\begin{array}{l}\text { Narrow Canyon } \\
\text { limestone. }\end{array}$ & 17 & $\begin{array}{l}\text { Linguloid brachiopods (Barroisella); frag- } \\
\text { ments and spicules of a dictyospongid. }\end{array}$ & $\begin{array}{l}\text { According to Robert Finks dictyospongids } \\
\text { reached their peak of development in the } \\
\text { Late Devonian. J. T. Dutro, Jr., reports } \\
\text { that the brachiopod is common in Upper } \\
\text { Devonian rocks and rare in younger beds. } \\
\text { For these reasons, the age is suggested as } \\
\text { possibly Late Devonian. }\end{array}$ \\
\hline
\end{tabular}

The basal part of the Eleana may be as old as Late Devonian because it contains strata which are lithologically similar to the upper part of the Devils Gate(?) limestone elsewhere, and because it is correlated with the Narrow Canyon limestone of comparable stratigraphic position. The limy sandstone beds of unit $A$ are similar to those found in the upper part of the Devils Gate(?) limestone of Middle and Late Devonian age in exposures to the south, suggesting that erosion in the Carbonate Wash area may have begun before the end of Devils Gate(?) deposition elsewhere. Furthermore, the Narrow Canyon limestone, which is believed by the writers to be correlative with unit $A$ and lower part of unit $B$ on the basis of stratigraphic position, contains a fauna indicating a Late Devonian (?) age (table 328.1 and fig. 328.2).

Fossils from units $\mathrm{G}$ and $\mathrm{H}$ indicate a Mississippian age (table 328.1). Faunas from limestone beds of units $I$ and $J$ indicate both a Mississippian and Pennsylvanian age. The difference in age assignments for collection 6 and the collection south of Quartzite Mountain (table 328.1) is not understood. These collections are from limestone units about. 3 miles apart and preliminary correlation indicates that the faumas are from unit I; however, structural complexities may account for the inomalous position of either collection.

Marine fauna indicative of a Pennsylvanian age in the basal part of the overlying Tippipah limestone establishes an upper limit for the age of the Eleana. On the above basis, therefore, it is here proposed that the Eleana ranges in age at least from Early Mississippian to Early Pennsylvanian and it may be as old as Late Devonian.
A southeastward facies change from fine and coarse detrital strata of the Eleana formation in the northern part of the test site to an equivalent sequence of fine detrital strata and limestone at Narrow Canyon and in the northern part of the Spring Mountains (about 20 miles south of Narrow Canyon) suggests that the detrital strata represent the southeastern margin of an apron of clastic debris shed eastward from the Antler orogenic belt of Roberts and others (1.958) northwest of the test site.

In the Carbonate Wash area (figs. 328.1 and 328.2) the basal unit of the Eleana formation may reflect the beginning of the Antler orogeny in this area. Units $\mathrm{C}, \mathrm{F}$, and $\mathrm{G}$ are characterized by quartzite and conglomerite that may record a minimum of three distinct pulses or changes in base level resulting in deposition of coarse detritus eastward.

In view of the variations in thickness and lithologic character of the units in the Eleana formation in the test site area it is understandable why comparable sections have not been described in adjacent areas. Similar lithologies are known in the Eureka and Quartz Spring sections (fig. 328.1 and table 328.2), but specific units cannot be accurately correlated from one area to another. The lithic similarity of the Carboniferous sequence in these areas is probably a result of comparable proximity to the Antler orogenic belt in central Nevada (fig. 328.1). On the other hand, the Goodsprings area (table 328.2) and the Pioche district are more distant from the orogenic belt, and hence in these areas the dominantly carbonate rock of the Carboniferous section may reflect greater distance from the orogenic belt (fig. 328.1). 


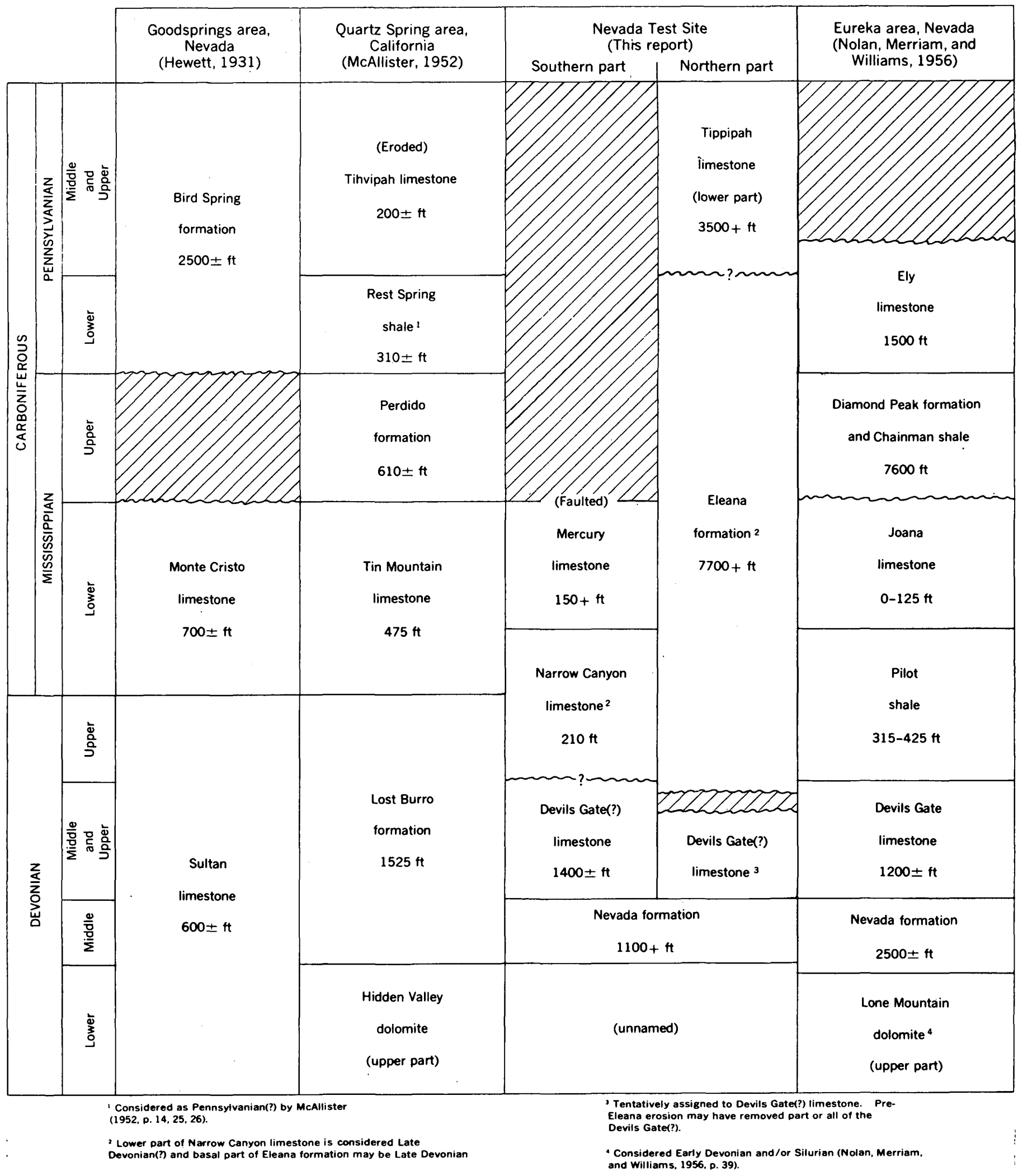

TABLE 328.2.-Tentative correlation and thickness of Devonian, Mississippian, and Pennsylvanian formations in Nevada Test site and nearby areas 


\section{REFERENCES}

Ball, S. HI., 1907, A geologic reconnaissance in southwestern Nevada and eastern California: U.S. Geol. Survey Bull. $308,218 \mathrm{p}$.

Hewett, D. F., 1931, Geology and ore deposits of the Goodsprings quadrangle, Nevada: U.S. Geol. Survey Prof. Paper $162,172 \mathrm{p}$.

Johnson, M. S., and Hibbard, D. E., 1957, Geology of the Atomic Dnergy Commission Nevada Proving Grounds area, Nevada: U.S. Geol. Survey Bull. 1021-K, p. 333-384.
McAllister, J. F., 1952, Rocks and structure of the Quartz Spring area, northern Panamint Range, California: California Div. Mines Spec. Rept. 25, 38 1.

Nolan, T. B., Merriam, C. W., and Williams, J. S., 1956, The stratigraphic section in the vicinity of Eureka, Nevada: U.S. Geol. Survey Prof. Paper 276, 77 p.

Roberts, R. J., Hotz, P. E., Gilluly, James, and Ferguson, H. G., 1958, Paleozoic rocks of north-central. Nevada: Am. Assoc. Petroleum Geologists Bull., v. 42, p. 2813-2857.

329. LAKE LAHONTAN STRATIGRAPHY AND HISTORY IN THE CARSON DESERT (FALLON) AREA, NEVADA

By R. B. Morrison, Denver, Colo.

The late Quaternary deposits of the southern Carson Desert, near Fallon, Nev., record the history of the fluctuations of Lake Lahontan and younger lakes in this intermontane basin. The Carson Desert is the sink for two of Nevada's largest rivers, the Carson and Fumboldt, and contains an unusually detailed stratigraphic record of lake rises, recessions, and desiccations in response to Quaternary climatic changes.

The late Quaternary deposits (exclusive of local volcanic units) are divided into seven formations and several soils. These units are given new stratigraphic names, which are introduced, defined, and briefly described, from oldest to youngest, below (see fig. 329.1).

\section{PAIUTE FORMATION}

This unit consists of at least 40 feet of alluvial and colluvial gravel of later Pleistocene age. It overlies andesitic and basaltic lavas of Pliocene and early Pleistocene(?) age with pronounced unconformity and underlies the pre-Lake Lahontan soil and the earliest deposits of Lake Lahontan (Eetza formation) with slight or no disconformity. It is named for Paiute Wash, and its type locality is an exposure along the middle part of this wash (stratigraphic section 56 , in Morrison, 1959). It is exposed locally, above 3,960 feet altitude, on piedmonts and in highlands.

\section{PRE-LARE LAHONTAN SOIL}

This is a very mature calcic Brown soil, developed on the Paiute formation and older rocks and overlain by the Eetza formation with slight or no disconformity. Its type locality is the same as that for the Paiute formation. This soil consists of a reddish-brown, clayey oxide (B) horizon as thick as a foot, over a white, strongly calcareous $\left(\mathrm{C}_{\mathrm{c} a}\right)$ horizon generally 4 to 8 feet thick. It is exposed locally, above 3,960 feet altitude, on piedmonts and in highlands.

\section{LAHONTAN VALLEY GROUF}

This unit, of late Pleistocene age, consists of lacustrine sediments deposited in Lake Lahontan and interfingering and immediately overlying subaerial sediments. The group is named after Lahontan Valley, its type area, which is a part of the Carson Desert. It is divided into the following five formations on the basis of lithologic differences due to two major alternations from mainly deep-lake to subaerial and shallowlake sediments:

a. Eetza formation.-This formation, the oldest in the Lahontan Valley group, consists of as much as 90 feet of lacustrine gravel to clay and tufa. It. is exposed only in highlands above 3,950 feet altitude. The Eetza overlies the pre-Lake Lahontan soil and older units with slight or no disconformity and conformably underlies the Wyemaha formation. It is named for Eetza Mountain, and the type locality is the upper part of the central gulch in this mountain. This formation is locally divisible into two tongues separated by a tongue of alluvium and colluvium of Eetza age, which bears a very weak soil. The lower tongue extends as high as the highest Lake Lahontan shoreline, 4,380 feet altitude, and the upper tongue reaches about 4,340 feet altitude; the intervening subaerial tongue has been noted as low as about 4,065 feet altitude.

b. Wyemaha formation.-This unit comprises eolian sand and alluvium, which reach the lowest parts of the basin floor and intertongue with shallowlake deposits of sand to clay. Most of the for- 

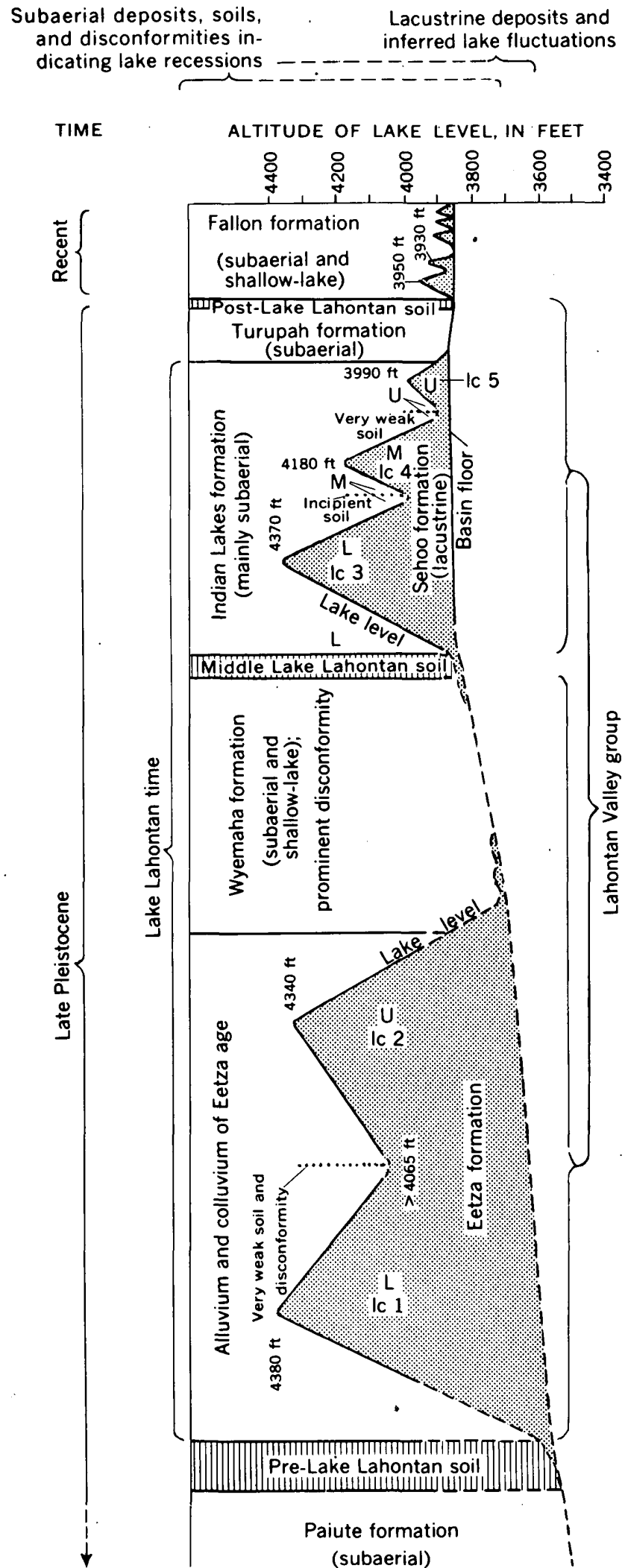

Figure 329.1.-Stratigraphic record of the fluctuations of Lake Lahontan and younger lakes in the Carson Desert. U, upper part; $M$, middle part; and $L$, lower part of a lacustrine or glacial unit; lc, lake cycles; numbers refer to lake cycles. mation lies conformably between the Eetza formation and middle Lake Lahontan soil, but some eolian sand extends higher than the highest altitudes reached by the Eetza and lies on older units. It is named for Wyemaha Valley, at the western end of which its type area (site of stratigraphic sections $42 \mathrm{~b}, 42 \mathrm{c}, 43,43 \mathrm{a}, 43 \mathrm{~b}, 44$, 44a, and 45, in Morrison, 1959) is situated. This formation, widely exposed above 3,965 feet altitude, is as much as 100 feet in exposed thickness and probably is locally more than 150 feet thick in the subsurface of the basin interior.

c. Middle Lake Lahontan soil.-This is a mature calcic Brown soil that conformably overlies the youngest subaerial beds of the Wyemaha formation and underlies the Sehoo and Indian Lakes formations with slight or no disconformity. It is intercalated with, but not a part of, the Lahontan Valley group. Its type locality is the site of stratigraphic section 34, in Morrison, 1959, in Churchill Valley. This soil has a slightly clayey, brown oxide (B) horizon 1 to $11 / 2$ feet thick, over a strongly calcareous $\left(\mathrm{C}_{\mathrm{ca}}\right)$ horizon 2 to 4 feet thick. It is exposed locally above 3,920 feet altitude.

d and e. Sehoo and Indian Lakes formations.-These are intertonguing units, both of which overlie the Wyemaha formation and the middle Lake Lahontan soil with slight or no disconformity, and underlie the Turupah formation with local disconformity. The Sehoo formation is entirely lacustrine; the Indian Lakes formation is predominantly subaerial.

The Sehoo formation consists of three tongues of lacustrine gravel to clay and tufa, separated by tongues of the Indian Lakes formation. Each tongue is locally differentiated as a member of the formation and records a separate lake cycle of Iake Lahontan. The lower tongue (lower member) extends to 4,370 feet altitude, within 10 feet of the highest Lahontan beach; the middle tongue, the dendritic member (named after a characteristic tufa), extends to as high as 4,180 feet altitude; and the upper tongue (upper member) extends to a maximum altitude of about 3,990 feet. The type area for this formation is the same as that for the Wyemaha formationthe western end of Wyemaha Valley, near Sehoo Mountain, whence the formation is named. This formation is widely exposed and is as thick as 96 feet.

The Indian Iakes formation consists of alluvium, collurium, and a little eolian sand and shallow-lake sediments, as much as 15 feet thick. 
It also has three tongues. The lower one is intercalated between the middle Lake Lahontan soil and the lower tongue of the Sehoo formation; the middle one is intercalated between the lower and middle tongues of the Sehoo, to at least as low as 3,990 feet altitude; and the upper tongue is intercalated between the middle and upper tongues of the Sehoo, to at least as low as 3,900 feet. The middle tongue bears an incipient soil, and the upper tongue a very weak soil. The type locality is the western part of the Indian Lakes area, SE1/4, T. 20 N., R. 29 E. and SW1 14 , T. 20 N., R. 30 E., where two ancient river-distributary channels are composed of alluvial sand of the formation.

f. Turupah formation.-This unit consists of as much as 30 feet of eolian sand and local alluvium overlying the Sehoo and Indian Lakes formations with local disconformity and conformably underlying the post-Lake Lahontan soil and Fallon formation. This unit and a widespread coeval disconformity recording pronounced deflation extend to lowest parts of the basin floor. The type locality is exposures of eolian sand and alluvium of the formation along the northwestern edge of Turupah Flat, secs. 29 and 33, T. 18 N., R. 30 , from which the formation is named.

\section{POST-LAKE LAFONTAN SOIL}

This is a submature Gray Desert soil, developed on the Turupah formation and older units, but overlain by the Fallon formation with slight or no disconformity. It has a top "vesicular" horizon about 3 inches thick, next, a light-brown, light brownish gray, or brown $B$ horizon about 5 inches thick, over a light-gray to light brownish gray, moderately to weakly calcareous $\mathrm{C}_{\mathrm{cn}}$ horizon 6 to 14 inches thick. Its type locality is an exposure (site of stratigraphic section 16 , in Morrison, 1959 ) about $1 / 3$ mile east of the northeast corner of the S-Line Reservoir. The upper boundary of this soil is proposed as the Pleistocene-Recent boundary in the Great Basin region (Art. 330).

\section{FALLON FORMATION}

This formation, a maximum of 36 feet thick, comprises subaerial sediments (eolian sand, alluvium; and colluvium) and intertonguing shallow-lake sediments of Recent age. It overlies the Turupah formation and post-Lake Lahontan soil with slight or no disconformity. Its type locality is the lowlands of the Carson Desert near Fallon, whence it takes its name. This formation is locally subdivided into lower and upper members at altitudes below or only slightly above the maxima of the post-Lahontan (Fallon) lakes. The lower member comprises two lacustrine tongues, separated and overlain by subaerial tongues; it bears a very weak soil. The upper member comprises three lacustrine tongues, likewise separated and overlain by subaerial tongues. The lacustrine tongues record five postLahontan lake cycles whose maxima (oldest to youngest) were at altitudes of $3,950,3,930,3,922,3,919$, and 3,919 feet. Each tongue extends to the high shoreline of the lake cycle it records. Only the first two of these shorelines are well marked by morphologic features. The intervening subaerial tongues extend, to or nearly to, the lowest parts of the lowlands, indicating complete or nearly complete desiccation.

\section{CONCLUSIONS}

The general conclusions on lake history from these deposits arę as follows:

Pre-Lake Lahontan history is fragmentary, but Lake Lahontan and post-Lake Lahontan history is fairly complete. A lake older than Lake Lahontan is suggested by a single exposure of lacustrine sediment. The Paiute formation and overlying pre-Lake Lahontan soil record an ensuing long interval of lake recession or desiccation.

The early deep-lake period of Lake Lahontan is recorded by the Eetza formation (fig. 329.1). This period consisted of two lake cycles and an intervening lake recession: Lake Lahontan first rose until it reached its maximum level of 4,380 feet altitude; it receded briefly to at least as low as 4,065 feet, and then it rose again to about 4,340 feet altitude. In middle Lake Lahontan time, recorded by the Wyemaha formation and middle Lake Lahontan soil, the basin intermittently was dry and held shallow lakes. During late Lake Lahontan time, when the Sehoo and Indian Lakes formations were deposited, the lake had 3 maxima and 2 recessions; first, it rose to 4,370 feet altitude, then dropped at least to 3,990 feet, then rose to 4,190 feet, then dropped at least as low as 3,900 feet, and then rose a last time to 3,990 feet altitude.

The Turupah formation records the stark aridity of the early part of a warm interval that is correlated with the altithermal age of Antevs $(1948,1952,1955)$ a time when the Carson Desert generally was completely dry and its lowlands were severely deflated. The postLake Lahontan soil attests to somewhat increased precipitation, plant cover, and cessation of wind erosion during the later part of this warm interval.

The Fallon formation formed during the last 3,500 or 4,000 years-the Recent epoch in the Great Basin region (Art. 330; Morrison and others, 1957). It records five intervals that were somewhat wetter than now, when small lakes with maximum depths successively (oldest to youngest) of about $90,70,57,40$, and 
30 feet occupied parts of the basin floor. The first lake maximum occurred about 3,500 years ago, the last about 100 years ago. After each lake maximum was a complete, or nearly complete, lake recession-indicating climate like that of the present or somewhat more arid. The longest, driest, and warmest recession was between the 2 nd and 3rd post-Lahontan lakes, when the basin generally was completely desiccated and a very weak soil formed.

These deductions concerning the lake history do not support J. C. Jones' (1925, 1929) interpretation that Lake Lahontan had only a single lake cycle starting a mere 2,000 or so years ago. They agree (fig. 329.2), however, with most of Russell's (1885) and Antevs' $(1945,1948,1952,1955)$ conclusions. Lake Lahontan had multiple maxima during both early and late Lake Lahontan times, supplementing both Russell's and Antevs' interpretations. The lake dried completely in mid-Lake Lahontan time, contrary to Antevs' interpretation but in line with Russell's. The lake reached its highest level in early Lake Lahontan time, as Antevs inferred, contrary to Russell's conclusion.

\section{REFERENCES}

Antevs, E. A., 1945, Correlation of Wisconsin glacial maxima, in Problems in geology and geophysics, Daly volume, 243-A : Am. Jour. Sci., p. 1-39.

1948, Climatic changes and pre-white man, in The Great Basin, with emphasis on glacial and postglacial times: Utah Univ. Bull., v. 38, no. 20, p. 168-191.

1952, Cenozoic climates of the Great Basin: Geol. Rundschau, v. 40, no. 1, p. 94-108 (in English).

- 1955, Geologic-climatic dating in the west: Am. Antiquity, v. 20, no. 4, pt. 1, p. 317-335.

Jones, J. C., 1925, The geologic history of Lake Lahontan, in Quaternary climates: Carnegie Inst. Washington Pub. 352, p. 1-50.

1929, Age of Lake Lahontan: Geol. Soc. America Bull., v. 40 , no. 3 , p. 533-540.

Morrison, R. B., 1959, Stratigraphic sections, well $\operatorname{logs}$, and soil-profile sections in the southern Carson Desert near Fallon, Nevada: U.S. Geol. Survey open-file report $\mathbf{4 7 0}$. Morrison, R. B., Gilluly, James, Richmond, G. M., and Hunt, C. B., 1957, In behalf of the Recent: Am. Jour. Sci., v. 255, no. 6 , p. $385-393$.

Russell, I. C." 1885, Geological history of Lake Lahontan, a Quaternary lake of northwestern Nevada: U.S. Geol. Survey Mon. 11, $288 \mathrm{p}$.

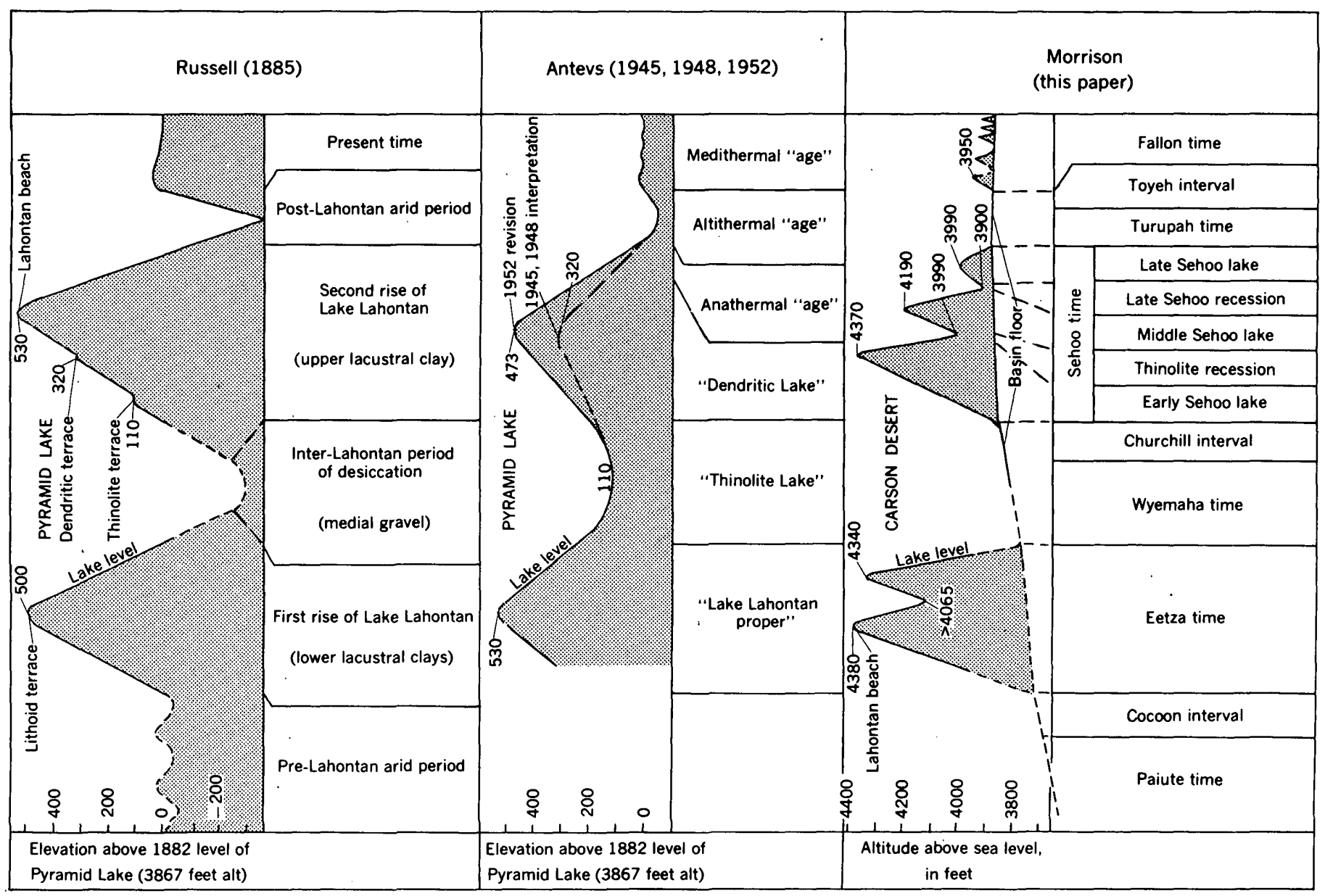

Figure 329.2.-Comparison of interpretations of Lake Lahontan by Russell, Antevs, and Morrison. 


\section{A SUGGESTED PLEISTOCENE-RECENT (HOLOCENE) BOUNDARY FOR THE GREAT BASIN REGION, NEVADA-UTAH}

By R. B. Morrison, Denver, Colo.

Establishment of a world-wide boundary between the Pleistocene and Recent (Holocene), though eventually desirable, probably still is premature. Much more stratigraphic research is needed before a boundary can be established, even on a continental basis, that will be pragmatically sound for geologists and archaeologists working in such different terrains as, for example, areas of Arctic glaciation, of midlatitude Cordilleran glaciation, margins of continental glacial drift, desert lake basins, and seacoasts. It probably will be most practical to establish this boundary independently (but within a restricted time range) in regions of unified terrain. The Great Basin of the western States is such a region.

Hunt (1953) has proposed, for the Rocky MountainGreat Basin region, that this boundary be placed at a widespread stratigraphic break that marks what is commonly known as the thermal maximum, climatic optimum, or altithermal interval. He noted that this break in the late Quaternary deposits is indicated by an unconformity, above and below which are lithologically distinct deposits. During the interval represented by the unconformity, many Pleistocene mammals, such as elephants and camels, became extinct. This proposal has merit, in spite of several drawbacks : the unconformity, although widespread, is only locally recognizable; it represents a variable timespan, probably between a few hundred and ten thousand or more years in duration; and it also is, at least locally, significantly time-transgressive. In addition, the extinction of mammals seems to have started in some areas considerably before the interval represented by the unconformity. Certain mammals became extinct during Cary time in Nebraska, for example.

Ideally, the boundary should be selected and defined to meet the following stratigraphic requirements:

1. It should be derived from a type rock-stratigraphic sequence, representative of the region, whose rock units have been well studied and classified. The boundary should not be defined wholly or mainly on inferred climatic or depositional history, or on time-stratigraphic, climastratigraphic, biostratigraphic, or geologic-time units that are not themselves defined by rock-stratigraphic or soilstratigraphic units.
2. The boundary should be marked by a prominent, widely traceable and mappable lithologic discontinuity within the sequence.

3. The boundary should be as nearly time-parallel as possible.

Fortunately, a nearly ideal marker unit for the boundary is available within the time interval that Hunt proposed-one that is applicable to all types of lithogenetic sequences (lacustrine, glacial, alluvial, colluvial, and eolian) throughout the Great Basin region. This unit is a submature soil that is distinct from other soils of late Quaternary age. This soil has been noted in the late Quaternary successions in the Lake Bonneville area (Art. 333; Bissell, 1952 and written communication, 1960), in the Lake Lahontan area (see below), in the Sierra Nevada (Art. 332), and in the Rocky Mountains (Richmond, 1.960, and in press), and reconnaissance studies indicate that it is essentially continuous throughout this region and adjoining ones (Leopold and Miller, 1954), more so than any'of the older soils.

The stratigraphic relations of this soil have been most precisely determined in a part of the area of late Pleistocene Lake Lahontan, the Carson Desert basin, Nevada, where it is called the post-Lake Lahontan soil (Art. 329). This basin is the sink for two of the largest rivers of the northwestern Great Basin; it contains an especially detailed stratigraphic record of post-Lake Lahontan time, and it also is the only area in the Great Basin where Recent (Holocerie) sediments have been intensively studied and classified into rock-stratigraphic units. The post-Lake Lahontan sequence here is as follows :

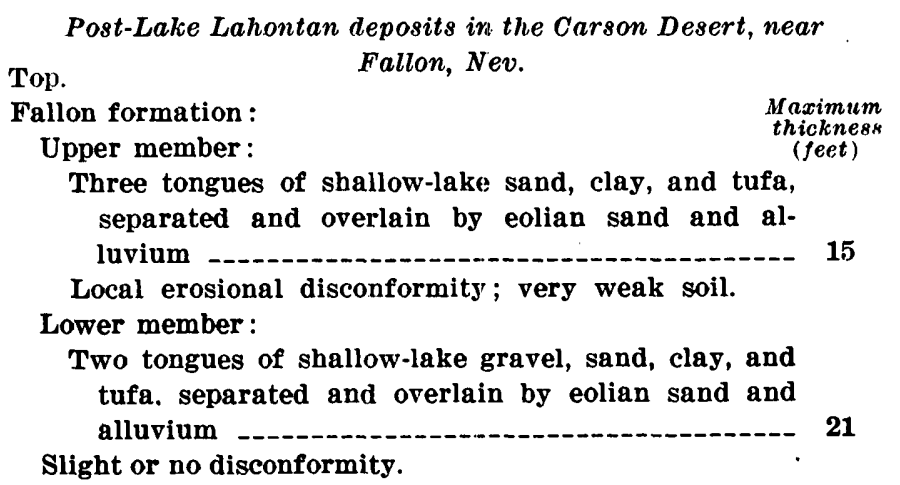


Post-Lake Lahontan deposits in the Carson Desert, near Fallon, Nev.-Continued

Post-Lake Lahontan soil :

Naximum thickness A submature Gray Desert soil

Turupah formation:

Eolian sand and local alluvium, to lowest parts of basin floor

Disconformity, recording widespread deflation, to lowest parts of basin floor.

Sehoo formation (younger sediments of Lake Lahontan) :

Lacustrine sand, clay, and tufa in basin interior; gravel, sand, and tufa in highlands; extends as high as $\mathbf{5 1 0}$ feet above lowest part of basin floor.-

The Sehoo formation is inferred to record the final lake cycles of Lake Lahontan. The overlying disconformity, Turupah formation, and post-Lake Lahontan soil record a long interval of generally complete desiccation of the Carson Desert, that is correlated with the altithermal age of Antevs $(1948,1952,1955)$. The Fallon formation records 5 post-Lahontan shallow-lake cycles, that rose successively about $90,70,57,40$, and 30 feet above the lowest part of the Carson Sink. During the intervening lake recessions the basin became nearly or entirely dry. The longest and most pronounced desiccation was between the first and second lake cycles, when the only discernible (albeit very weak) soil development in Fallon time took place.

In the author's opinion the Carson Desert should be designated as a type area for Recent (Holocene) deposits of the Great Basin, and the Pleistocene-Recent boundary (the Pleistocene-Holocene boundary of European usage) should be placed at the top of the post-Lake Lahontan soil. This soil not only is the most distinctive and widely traceable stratigraphic unit in the Recent deposits of the Lake Lahontan area, but its correlative soils in the alluvial, eolian, and glacial de- posits of the Great Basin and adjoining areas (for example, the Sierra Nevada and Wasatch-Rocky Mountains) are similarly distinctive. The post-Lake Lahontan soil and its correlatives are known, from archaeologic and radiocarbon dating, to have formed within a span of probably less than 1,000 years in later altithermal time.

This soil-forming interval was induced by a climatic change that probably was essentially synchronous over the entire Great Basin region. Thus, the post-Lake Lahontan soil is assumed to be nearly time-parallel over this region. Also, because it formed during a comparatively brief interval, it is a relatively precise timestratigraphic marker-more so than any of the younger sedimentary units or unconformities known in the region (other than a few ash beds that occur only locally).

\section{REFERENCES}

Antevs, E. V., 1948, Climatic changes and pre-white man, in The Great Basin, with emphasis on glacial and post-glacial times: Utah Univ. Bull., v. 36, no. 20 (Biol. Serv., v. 10, no. 7), p. 168-191.

1952, Cenozoic climates of the Great Basin : Geol. Rundschau, v. 40, no. 1, p. 94-108 (in English).

1955, Geologic-climatic dating in the west (U.S.) : Am. Antiquity, v. 20 , no. 4, pt. 1, p. 317-335.

Bissell, H. J.. 1952, Stratigraphy of Iake Bonneville and associated Quaternary deposits in Utah Valley, Utah [abs.] : Geol. Soc. America Bull., v. 63, no. 12, pt. 2, p. 1358.

Hunt, C. B., 1953, Pleistocene-Recent boundary in the Rocky Mountains region: U.S. Geol. Survey Bull. 996-A, p. 1-25.

Leopold, I. B., and Miller, J. P., 1954, A postglacial chronology for some alluvial valleys in Wyoming: U.S. Geol. Survey Water-Supply Paper 1261, 90 p.

Richmond, G. M., 1960. Glaciation of the east slope of Rocky Mountain National Park, Colorado: Geol. Soc. America, v. 71, p. 1371-1382.

Quaternary stratigraphy of the La Sal Mountains, Utah : U.S. Geol. Survey Prof. Paper 324 (in press).

\title{
331. HYDROTHERMAL ALTERATION OF ROCKS IN TWO DRILL HOLES AT STEAMBOAT SPRINGS, WASHOE
} COUNTY, NEVADA

\author{
By Gudmundur E. Sigvaldason and Donalp E. White, Menlo Park, Calif.
}

Steamboat Springs, in southern Washoe County, Nev., has been well known to economic geologists since the early studies on the metal-bearing spring deposits by Le Conte (1883) and Becker (1888, p. 331-351). The greology of Steamboat Springs has been reviewed by Brannock and others (1948, p. 211-216) and the thermal activity and hydrothermal alteration have been summarized by White (1955, p. 103-104, 110-113; 1957, p. 1639-1647). This report contains results of $\mathrm{X}$-ray and other mineralogical studies of hydrothermally altered rocks found in two drill holes at Steamboat Springs. 
DRILL-HOLE GS-1

Drill-hole GS-1 is on the active Low Terrace of Steamboat Springs near the southern end of the thermal aren. Some data concerning the hole are shown on figure 331.1 , and chemical compositions of fresh and altered rocks are shown by table 331.1 .

The degree of alteration in drill-hole GS-1 is determined by depth, original rock type, and relation to permeable channels. The mineral most generally altered is hornblende, followed by biotite and calcic plagioclase. Quartz remains unaffected and K-feldspar and sodic plagioclase appear to be metastable under all the conditions affecting the rocks drilled. Some nearly fresh grandodiorite occurs near the surface. Andesitic tuff breccia, originally consisting entirely of susceptible ferromagnesian minerals, calcic plagioclase, and glass, has undergone complete alteration. The most intensely altered granodiorite lies immediately below a dike of andesitic tuff breccia and near faults and flactures at depths of 270 and 364 feet.

Estimated mineralogical composition is shown graphically on figure 331.1. Straight lines connect points where the mineralogy was determined; however, nctual mineral compositions between points of obser- vation are known to differ greatly from compositions implied by these lines. Small quantities of pyrite, pyrrhotite, stibnite, and calcite are not plotted.

The dominant hydrothermal minerals are four species of clay. Montmorillonite is most abundant in the altered andesitic dike (fig. 331.1). The spacing of the basal $\mathrm{X}$-ray reflection of this material in air-dried state ranges from 12 to $15 \mathrm{~A}$. The greater spacing results from calcium and magnesium in the interchangeable positions of the montmorillonite lattice, and the lesser: spacing from sodium in the interchangeable position.

Kalolinite is the dominant mineral in the most intensely altered and leached parts of the rock penetrated in the drill hole; but is present only in small amounts where alteration is slight. Where kaolinite is a major component, it is usually accompanied by Na-K-montmorillonite; where kaolinite is a minor component, it occurs with $\mathrm{Ca}-\mathrm{Mg}$-montmorillonite.

Two types of chlorite were detected. One is a minor component, replacing biotite. The second is abundant in and near fractures at depths of 250 to 300 feet; it does not have $\mathrm{X}$-ray reflections at 14 and $4.7 \mathrm{~A}$ as do most chlorites, and its lattice collapses at relatively low temperatures. It is thus similatr in some ways to kao-

TA BLE 331.1.-Analyses of hydrothermally altered rocks of drill-hole GS-1 compared to fresh rocks

[In percent; analyzed by rapid methods by L. Shapiro, H. F. Phillips, K. White, S. M. Berthold, and E. A. Nygaard]

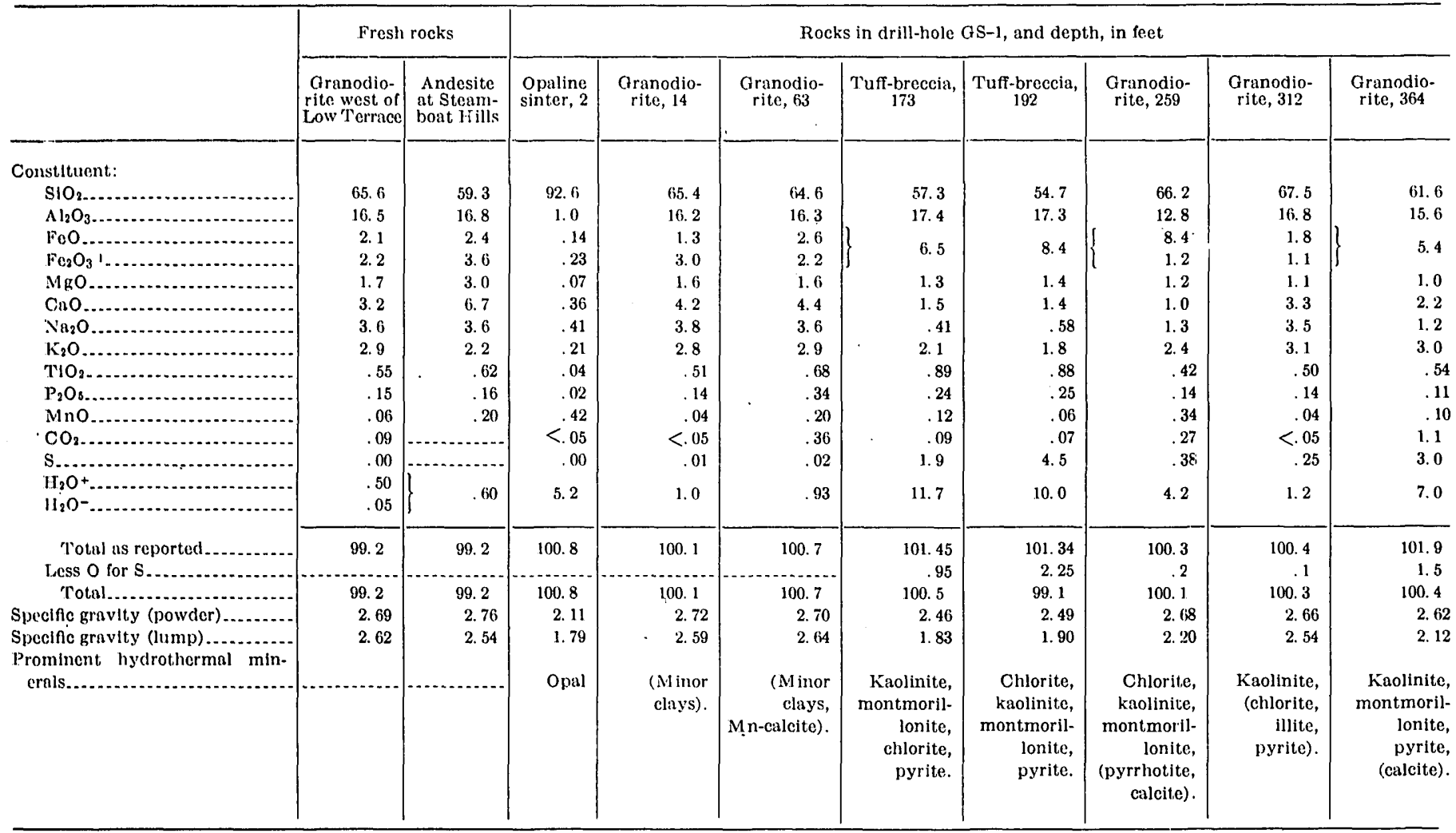

I Or total $\mathrm{Fe}$ as $\mathrm{Fe}_{2} \mathrm{O}_{3}$ 


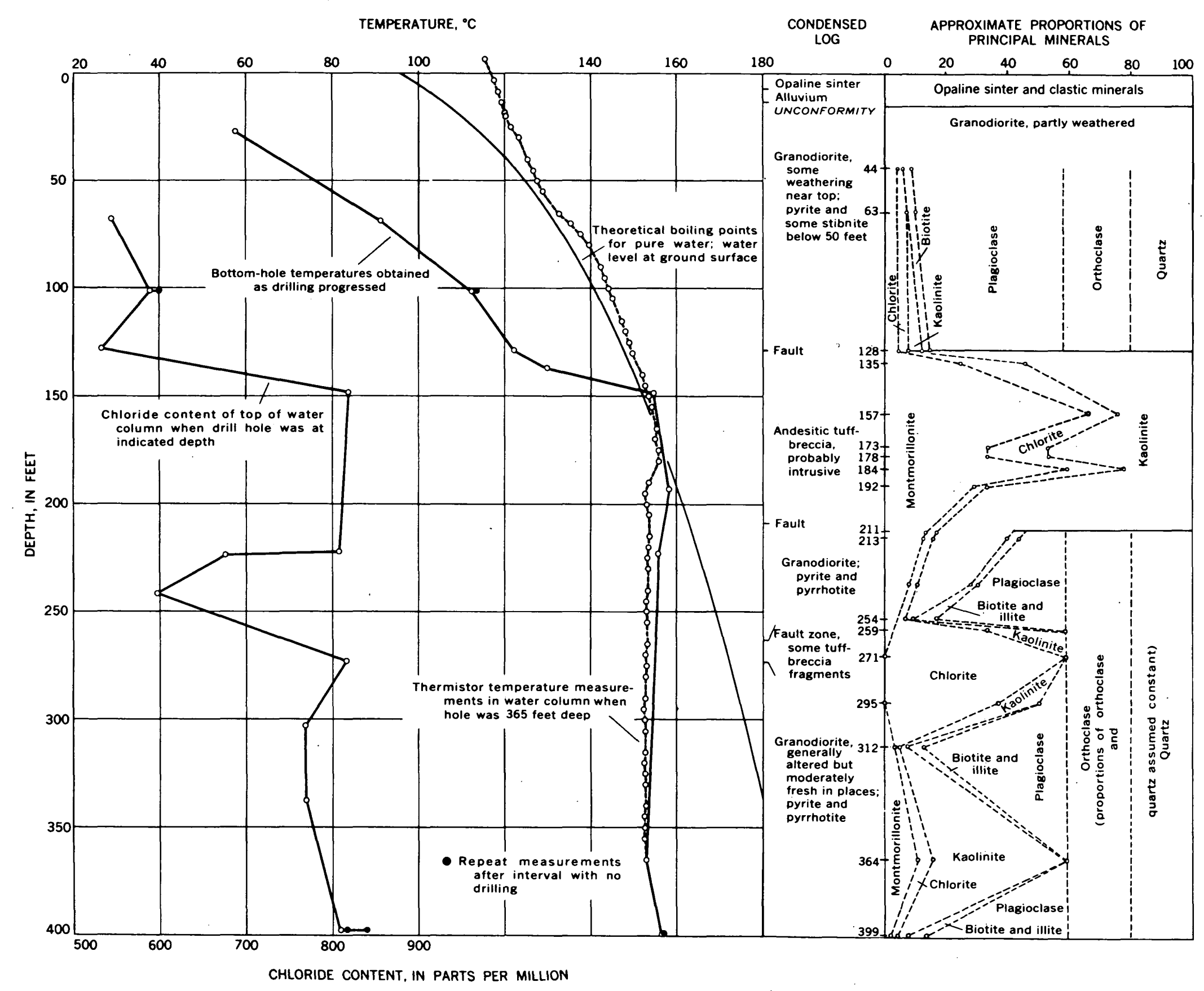

$\underset{⿱}{\boxminus}$

Figure 331.1.-Data from drill-hole GS-1, Low Terrace, Steamboat Springs, Nev. Straight lines arbitrarily drawn between points of obseivation. 
linite, but its refractive indices (1.61 to 1.62 ) and the high content of iron that must be assigned to this mineral (table 331.1, depth 259 feet) support its identification as a chlorite. This mineral is similar to some of the chamosites described by Brindley (1951).

Illite seems to be confined to slightly altered granodiorite, where the amount of illite does not exceed the original percentage of biotite in the granodiorite. Illite may be present elsewhere but obscured by other clay minerals.

\section{DRILL-HOLE GS-2}

Drill-hole GS-2 is on the High Terrace of Steamboat Springs in the northwestern part of the thermal area 6,400 feet north-northwest of drill-hole GS-1. The I-Tigh Terrace has had little or no surface discharge since the Pleistocene, but thermal water flows in the system and escapes below the surface. Descriptions of the rocks found in drilling are given on figure 331.2 and in tible 331.2.

The assemblage of hydrothermal minerals in hole GS-2 varies considerably with depth and differs from the assemblage in hole GS-1. Beginning at approxi- mately 90 feet, silicates are replaced extensively by K-feldspar. Quartz and K-feldspar are the dominant hydrothermal minerals to a depth of approximately 280 feet, where clay minerals become abundant. The clays are dominant from 288 feet to the basal contact of tuff breccia at 351 feet. From 200 to 240 feet the only identified clay mineral is chlorite-vermiculite(?) with regular mixed layering. The $\mathrm{X}$-ray pattern of the clay shows a basal reflection at approximately 28 $A$, and an integral series of 9 well-defined higher orders. Upon saturation with ethylene glycol the lattice expands to $31.5 \mathrm{~A}$; heat treatment at $550^{\circ} \mathrm{C}$ for two hours results in a poorly defined $\mathrm{X}$-ray peak at approximately $23 \mathrm{~A}$, and two higher orders at 12 and 8 A. As defined by Lippmann (1956), this mineral is a corrensite; it was not found below 277 feet.

At about 240 feet chlorite and a random mixedlayer illite-montmorillonite appear. The chlorite is an iron-rich variety, showing a low intensity $\mathrm{X}$-ray peak at $14 \mathrm{~A}$ and a strong $(002)$ reflection at $7 \mathrm{~A}$. Chlorite is dominant near 300 feet but is not present at the contact with granodiorite. Below the contact chlorite is abundant again, but as a replacement of biotite.

TA RLE 331.2.-Analyses of hydrothermally altered rocks of drill-hole GS-2

[In percent; analyzed by rapid methods by L. Shapiro, H. F. Phillips, K. White, S. M. Berthold, and E. A. Nygaard]

\begin{tabular}{|c|c|c|c|c|c|c|c|c|c|c|}
\hline & \multicolumn{10}{|c|}{ Rocks in GS-2, and depth, in feet } \\
\hline & $\begin{array}{l}\text { Chalcedonic } \\
\text { sinter, } 28\end{array}$ & $\begin{array}{c}\text { Tuff-breccia } \\
125\end{array}$ & $\begin{array}{c}\text { Tuff-breccia, } \\
\text { single pebble, } \\
138\end{array}$ & $\begin{array}{c}\text { Tuff-breccia, } \\
202\end{array}$ & \begin{tabular}{|} 
Tuff-breccia, \\
239
\end{tabular} & \begin{tabular}{|} 
Tuff-breccia, \\
297
\end{tabular} & $\begin{array}{c}\text { Tuff-breccia, } \\
317\end{array}$ & $\begin{array}{l}\text { Granodio- } \\
\text { rite, } 355\end{array}$ & $\begin{array}{l}\text { Granodio- } \\
\text { rite, } 367\end{array}$ & $\begin{array}{l}\text { Granodio- } \\
\text { rite, } 375\end{array}$ \\
\hline 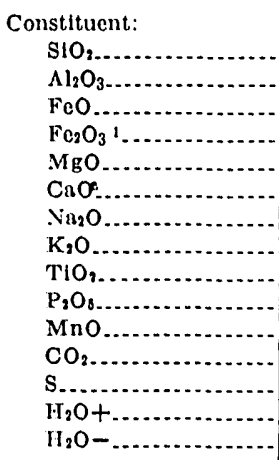 & $\begin{array}{r}98.6 \\
.58 \\
.16 \\
<.10 \\
.00 \\
.06 \\
.22 \\
.09 \\
.04 \\
.01 \\
.00 \\
<.05 \\
.03 \\
1.1\end{array}$ & $\begin{array}{c}75.0 \\
11.6 \\
2.9 \\
.15 \\
1.5 \\
.91 \\
6.0 \\
.54 \\
.04 \\
.00 \\
.20 \\
1.9 \\
2.1\end{array}$ & $\begin{array}{c}62.5 \\
18.0 \\
2.2 \\
.28 \\
1.1 \\
1.5 \\
10.8 \\
.58 \\
.08 \\
.01 \\
.10 \\
1.0 \\
2.3\end{array}$ & $\begin{array}{c}84.0 \\
7.8 \\
1.1 \\
.14 \\
.18 \\
.20 \\
5.8 \\
.22 \\
.02 \\
.00 \\
<.05 \\
.68 \\
.82\end{array}$ & $\begin{array}{c}79.0 \\
10.1 \\
.96 \\
.40 \\
.44 \\
.32 \\
8.2 \\
.30 \\
.05 \\
.01 \\
.25 \\
.37 \\
.81\end{array}$ & $\begin{array}{c}70.2 \\
12.7 \\
3.1 \\
.97 \\
1.3 \\
.28 \\
8.3 \\
.46 \\
.17 \\
.06 \\
.77 \\
.73 \\
1.7\end{array}$ & $\begin{array}{c}74.8 \\
10.0 \\
4.2 \\
1.3 \\
.34 \\
.39 \\
3.6 \\
.40 \\
.07 \\
.02 \\
<.05 \\
1.4 \\
3.8\end{array}$ & $\begin{array}{c}75.2 \\
13.9 \\
1.6 \\
.15 \\
.82 \\
1.5 \\
4.8 \\
.40 \\
.04 \\
.01 \\
<.05 \\
.88 \\
2.8\end{array}$ & $\begin{array}{c}71.2 \\
15.0 \\
1.6 \\
.30 \\
1.7 \\
2.9 \\
5.1 \\
. .86 \\
.13 \\
.01 \\
.30 \\
.53 \\
1.5\end{array}$ & $\begin{array}{c}72.2 \\
15.0 \\
.89 \\
.6 \\
.44 \\
1.3 \\
3.2 \\
4.6 \\
.32 \\
.10 \\
.01 \\
<.05 \\
.44 \\
1.2\end{array}$ \\
\hline 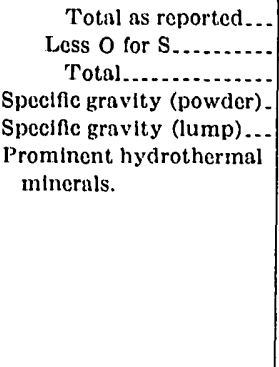 & \begin{tabular}{|r|}
100.9 \\
100.9 \\
2.60 \\
2.45 \\
Chalcedony \\
(stibnite).
\end{tabular} & $\begin{array}{r}102.8 \\
1.0 \\
101.8 \\
2.64 \\
2.44 \\
\text { K-feldspar, } \\
\text { quartz, py- } \\
\text { rite, (clays, } \\
\text { calcite). }\end{array}$ & $\begin{array}{r}100.5 \\
.5 \\
100.0 \\
2.65 \\
2.48 \\
\text { K-feldspar, } \\
\text { quartz, } \\
\text { (clays, py- } \\
\text { rite, calcite). }\end{array}$ & \begin{tabular}{|r|}
101.0 \\
.3 \\
100.7 \\
2.64 \\
2.38 \\
K-feldspar, \\
quartz (py- \\
rite).
\end{tabular} & \begin{tabular}{|r|}
101.2 \\
.2 \\
101.0 \\
2.62 \\
2.39 \\
K-feldspar, \\
quartz, cor- \\
rensite, (py- \\
rite, calcite).
\end{tabular} & $\begin{array}{r}100.7 \\
.4 \\
100.3 \\
2.61 \\
2.47 \\
\text { K-feldspar, } \\
\text { chlorite, } \\
\text { quartz, il- } \\
\text { lite, mont- } \\
\text { morillonite, } \\
\text { (calcite, py- } \\
\text { rite, apa- } \\
\text { tite(?)). }\end{array}$ & $\begin{array}{r}100.3 \\
.7 \\
99.6 \\
2.68 \\
2.41 \\
\text { Illite-mont- } \\
\text { morillonite, } \\
\text { chlorite, } \\
\text { quartz, K- } \\
\text { feldspar, } \\
\text { (pyrite). }\end{array}$ & $\begin{array}{r}102.1 \\
.4 \\
101.7 \\
2.59 \\
2.47 \\
\text { Illite-mont- } \\
\text { morillonite, } \\
\text { quartz, (py- } \\
\text { rite). }\end{array}$ & $\begin{array}{r}101.1 \\
.3 \\
100.8 \\
2.64 \\
2.47 \\
\text { Illite-mont- } \\
\text { morillonite, } \\
\text { chlorite, } \\
\text { quartz, } \\
\text { (calcite, py- } \\
\text { ritc). }\end{array}$ & $\begin{array}{r}100.3 \\
.2 \\
100.1 \\
2.66 \\
2.51 \\
\text { Illite-mont- } \\
\text { morillonite, } \\
\text { chlorite, (cal- } \\
\text { cite, quartz, } \\
\text { pyrite). }\end{array}$ \\
\hline
\end{tabular}

1 Or total $\mathrm{Fe}$ as $\mathrm{Fe}_{2} \mathrm{O}_{3}$. 


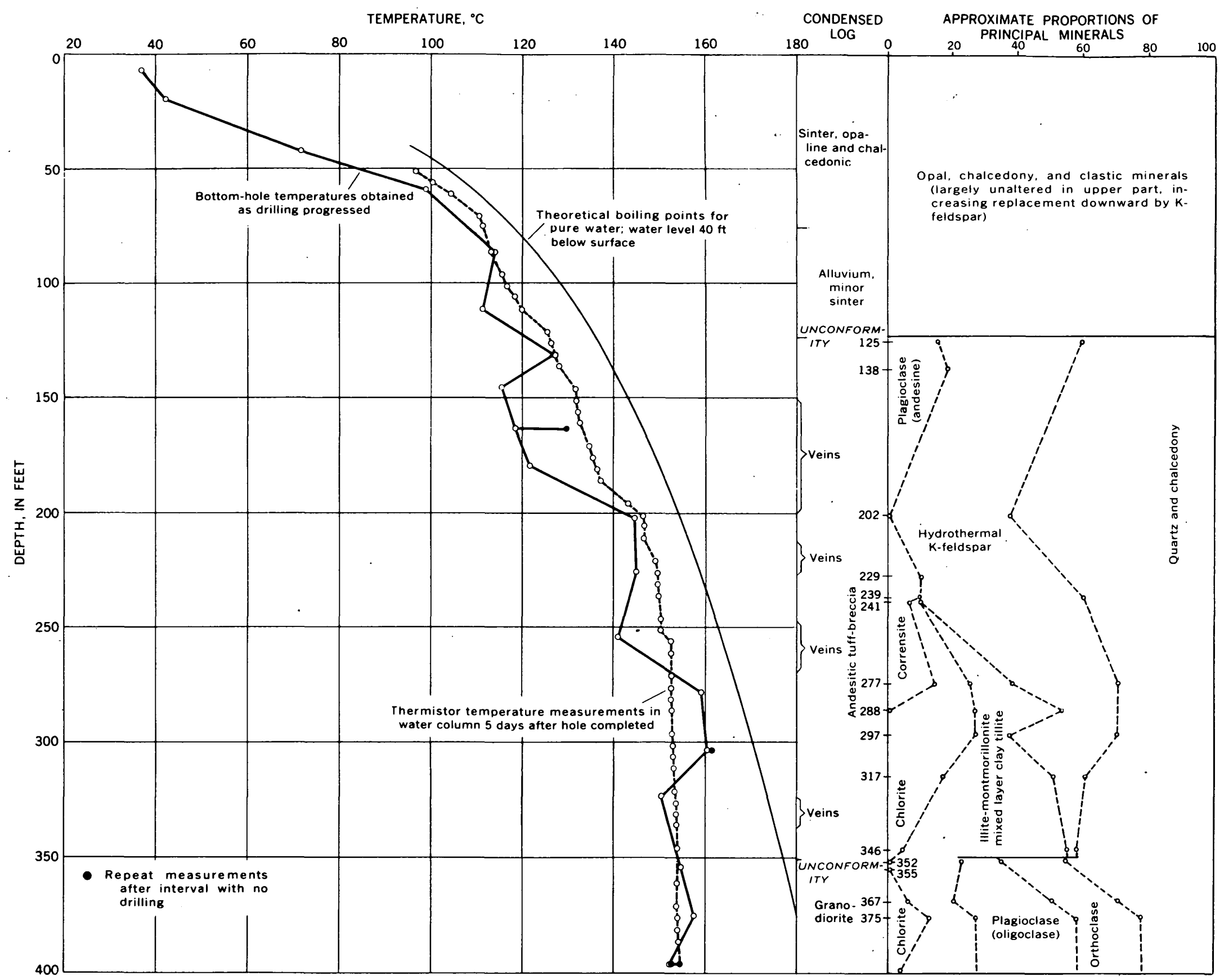


The illite-montmorillonite mixed-layer clay becomes increasingly abundant and $\mathrm{K}$-feldspar correspondingly less abundant downward; the illite-montmorillonite mixed-layer clay reaches its maximum concentration near the contact with granodiorite. The proportions of the mixed-layer components are consistent throughout rocks penetrated; the expandable montmorillonite layers make up about 25 percent of the total clay as indicated by the $(001) /(001)$ peak of the glycolated sample (Weaver, 1956, p. 206).

Small amounts of probable illite were observed microscopically in several samples below 250 feet in hole GS-2 but the occurrences could not be confirmed by $\mathbf{X}$-ray analysis, presumably because of dominance of other clay minerals.

\section{CONCLUSIONS}

The hydrothermal mineral assemblages are virtually independent of the original rock type. The extent of alteration, however, is greatly dependent upon the proportion of minerals susceptible to attack.

The Low Terrace is still undergoing active alteration by slightly acid, carbonated waters, as indicated by $\mathrm{pH}$ and by high concentrations of bicarbonate and calcium in the water (table 331.3). Kaolinite is the most stable mineral; other silicates are probably metastable or are intermediate products.

The High Terrace has probably been inactive at the surface since Pleistocene. The most stable minerals are K-feldspar nenr the surface, and probably illite at depth. These minerals are in other stability fields than kaolinite in the system $\mathrm{K}_{2} \mathrm{O}-\mathrm{Al}_{2} \mathrm{O}_{3}-\mathrm{SiO}_{2}-\mathrm{H}_{2} \mathrm{O}$ (Hemley, 1959, p. 246). Waters from both drill holes are very similar in potassium content, temperatures, and pH. The pH of both is $6.0 \pm$ if nonerupted, and 8.0 or more if erupted because of loss of $\mathrm{CO}_{2}$ (White, Sandberg, and Brannock, 1953, p. 496-498).

The mineralogy of the High Terrace is best explained by higher water temperatures in the past. Higher temperatures could have increased the extent of boiling in the upper part of the conduit system of the springs, thereby increasing $\mathrm{pH}$ by perhaps a unit or more because of the volatilization of free $\mathrm{CO}_{2}$, and also increasing potassium slightly because of loss of water as steam. These changes favor deposition of $\mathrm{K}$-feldspar over mica (illite), and presumably more than offset the effect of decrease in temperature upwards, which should favor deposition of mica (Hemley, 1959). A higher concentration of potassium than at present in the deep water also may be required to span the differences between the stability fields of kaolinite and $\mathrm{K}$-feldspar.
TARLE 331.3.-Analyses of thermal waters of Steamboat Springs. Nevada

[Analysts W. W. Brannock and H. Kramer]

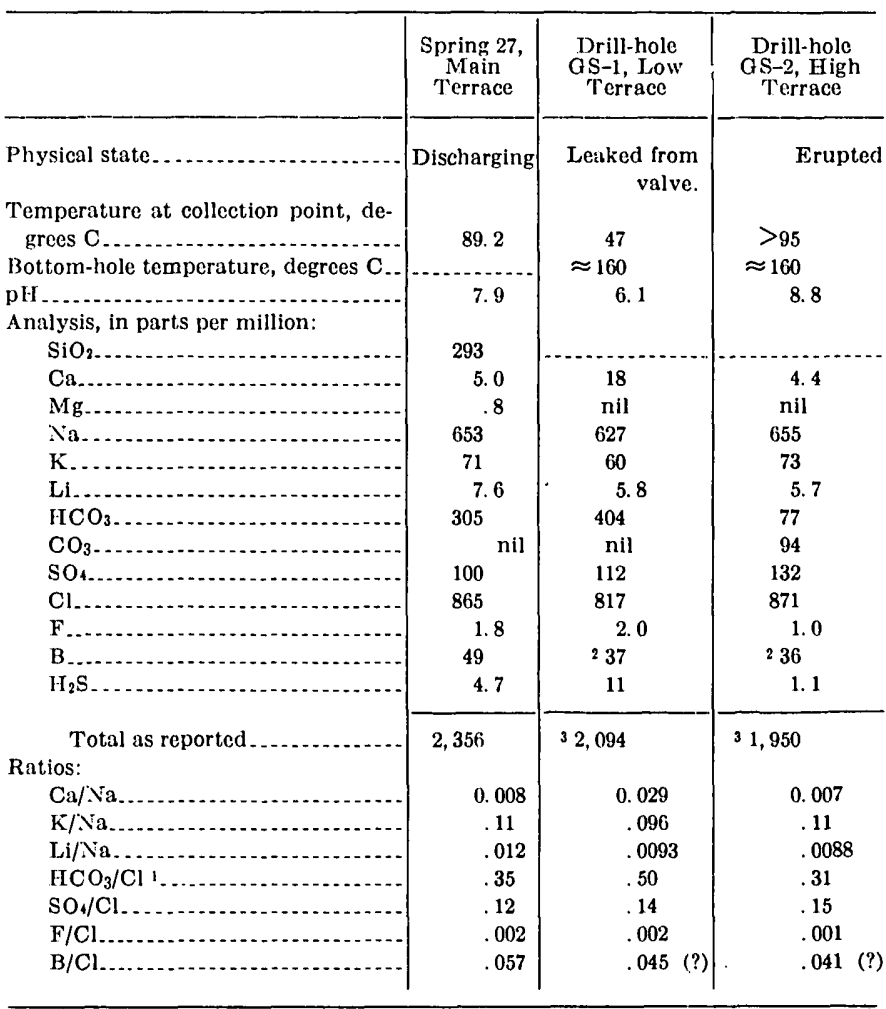

1 Total combined carbonate calculated as equivalent $\mathrm{HCO}_{3}$

2 May be low.

${ }_{3} \mathrm{SiO}_{2}$ not reported.

Hemley (Art. 408) has shown that the stability field of mica is wide in the $\mathrm{K}_{2} \mathrm{O}-\mathrm{Al}_{2} \mathrm{O}_{3}-\mathrm{SiO}_{2}-\mathrm{H}_{2} \mathrm{O}$ system, but is greatly narrowed in the $\mathrm{Na}_{2} \mathrm{O}-\mathrm{Al}_{2} \mathrm{O}_{3}-\mathrm{SiO}_{2}-\mathrm{H}_{2} \mathrm{O}$ system. His work suggests that in natural waters containing both $\mathrm{K}$ and $\mathrm{Na}$, the differences between replacement of plagioclase by $\mathrm{K}$-feldspar or by kaolinite is determined by as little as $1 / 2$ unit of $\mathrm{pH}, 50^{\circ} \mathrm{C}$ in temperature, or a variation in concentration of potassium of $1 / 2$ an order of magnitude.

\section{REFERENCES}

Becker, G. F., 1888, Geology of the quicksilver deposits of the Pacific slope: U.S. Geol. Survey Mon. 13, 4:86 p.

Brannock, W. W., Fix, P. F., Gianella, V. P., and White, D. E., 1948, Preliminary geochemical results alt Steamboat Springs, Nevada: Am. Geophys. Union Trans., v. 29, p. 211-226.

Brindley, G. W., 1951, The crystal structure of some chamosite minerals: Mineralog. Mag., v. 29, p. 502-525.

Hemley, J. J., 1959, Some mineralogical equilibria in the system $\mathrm{K}_{2} \mathrm{O}-\mathrm{Al}_{2} \mathrm{O}_{3}-\mathrm{SiO}_{2}-\mathrm{H}_{2} \mathrm{O}$ : Am. Jour. Sci., n.s., v. 257, p. 241-270. 
Le Conte, Joseph, 1883, On mineral vein formation now in progress at Steamboat Springs compared with same at Sulphur Bank: Am. Jour. Sci., ser. 3, v. 25, p. 424-428.

Lippmann, F., 1956, Clay minerals from the Röt member of the Triassic near Göttingen, Germany: Jour. Sed. Petrology, v. 26, p. 125-139.

Weaver, C. E., 1956, The distribution and identification of mixedlayer clays in sedimentary rocks: Am. Mineralogist, v. 41, p. 202-221.
White, D. E., 1955, Thermal springs and epithermal ore deposits : Econ. Geology, 50th Anniv. Volume, p. 99-154.

1957, Thermal waters of volcanic origin: Geol. Soc. America Bull., v. 68, p. 1637-1658.

White, D. E., Sandberg, C. H., and Brannock, W. W., 1953, Geochemical and geophysical approaches to the problems of utilization of hot spring water and heat: Pacific Sci. Cong., 7th, New Zealand, 1949, Proc., v. 2, p. 490-499, Wellington.

332. CORRELATION OF THE DEPOSITS OF LAKES LAHONTAN AND BONNEVILLE AND THE GLACIAL SEQUENCES OF THE SIERRA NEVADA AND WASATCH MOUNTAINS, CALIFORNIA, NEVADA, AND UTAH

By R. B. Morrison, Denver, Colo.

Modern stratigraphic studies of the deposits of Lakes Lahontan and Bonneville and of the Quaternary glacial deposits of the Sierra Nevada and Wasatch Mountains permit improved correlation of these sequences. Direct correlation is possible at only one locality: below the mouths of Little Cottonwood and Bells Canyons, south of Salt Lake City, Utah. Here, drift of one of the late Quaternary glaciations of the Wasatch Mountains intertongues and intergrades with part of the Lake Bonneville sequence (Art. 333; Richmond, Art. 334). Correlations can be made indirectly, however, between the remainder of the Lake Bonneville and Wasatch Mountain glacial sequences, and between these and the Lake Lahontan and Sierra Nevada sequences, by the use of new concepts of soil stratigraphy (Richmond, 1950; Richmond, Morrison, and Bissell, 1952).

The late Quaternary successions in all four areas have similar soil sequences, in terms of relative age and relative development of the soils. The physical record in each area indicates that the soils formed during distinct, widely separated intervals, in response to relatively infrequent combinations of climatic factors that induced erosional stability and a more rapid rate of chemical weathering than normal. The most strongly developed soils formed during the main intervals of lake desiccation or of deglaciation; weaker soils formed during the shorter recession intervals; soil profile development at other times was inappreciable. The soilforming intervals were periodically repeated parts of whole climatic cycles-mainly fluctuations in temperature and precipitation-that are manifest in the Quaternary sequences of each area. The climatic cycles, and the depositional and soil-forming cycles induced by them, probably were essentially synchronous over the entire Wasatch Mountain to Sierra Nevada region because the whole region probably acted as a climatic unit during the Quaternary as it does now. Thus, soils of similar relative age and development in the four areas are assumed to have formed contemporaneously-in other words, they are assumed to be nearly time-parallel throughout this region. Because they formed during generally shorter intervals than the inter-soil sediments, they are considered to be more precise time-stratigraphic markers. The stronger soils are readily recognizable in the successions of each area and are the most reliable and useful markers; they provide the basic framework for correlation. The sediments and weaker soils intermediate in age between the main soils are correlated by matching those units that record depositional cycles, or parts of cycles, of similar relative age and similar climatic genesis-that is, units recording early lake cycles with each other and with units recording early glacial cycles; likewise, lakerecessional units are correlated with glacial-recessional units.

Figure 332.1 diagrams the means of correlation. (The stratigraphic units and interpretations of lake and glacial history listed below and in figure 332.1 are those given in the following papers in this review, or other references: for the Lake Lahontan area, Art. 329; for the Sierra Nevada, Blackwelder, 1931; Matthes, 1942, 1945; Putnam, 1950; and for the Lake Bonneville and Wasatch Mountains areas, Morrison, Art. 333, and Richmond, Art. 334.) First, soils of similar relative development are correlated, starting with the three youngest most strongly developed soils in each sequence; then, between main soils, the deposits that record depositional cycles of similar age and magnitude are correlated, as are any weakly developed soils.

By this method, the pre-Lake Lahontan soil of the 
SHORT PAPERS IN THE GEOLOGIC AND HYDROLOGIC SCIENCES, ARTICLES 293-4\$3

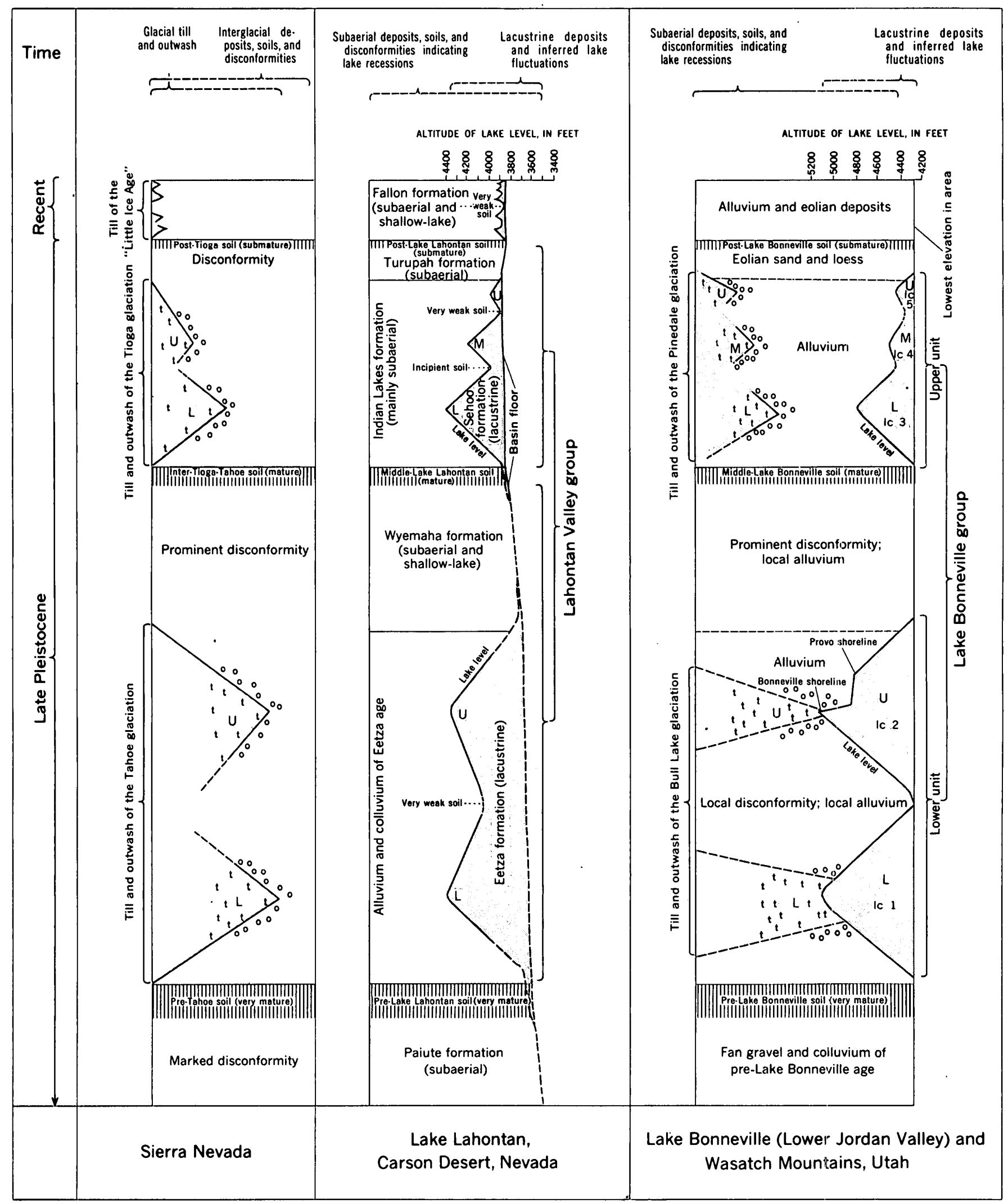

Finure 332.1.-Correlation of the late Quaternary sequences of the Sierra Nevada, Iake Lahontan (Art. 329), Lake Bommerille and Wasateh Mountains (Morrison, Art. 333, and Richmond, Art. 334t) areals, showing the age relations of deposits and soils, and inferred lake and glacial fluctuations. $U$, upper part; $M$, middle part; and $I$, lower part of a lacustrine or glacial unit; lc, lake cycle; $t$, till; o, outwash; numbers refer to lake cycles. 
Carson Desert, Nev., is correlated with the pre-Lake Bonneville soil (pre-Wisconsin soil of Hunt and Sokoloff, 1950) in the Lake Bonneville and Wasatch Mountain areas and with the soil of pre-Tahoe age in the Sierra Nevada; the mid-Lake Lahontan soil is correlated with the mid-Lake Bonneville soil, and with soils of inter-Bull Lake-Pinedale age and inter-Tahoe-Tioga age in the Wasatch Mountains and Sierra Nevada, respectively. The post-Lake Lahontan soil is correlated with soils of post-Lake Bonneville, post-Pinedale, and post-Tioga age.

The deposits intermediate in age between these main soils are correlated as follows: the Eetza formation of the Carson Desert area is correlated with the lower unit of the Lake Bonneville group (which includes the Alpine, Bonneville, and most of the Provo formations of Hunt (1953)), and with drift of the Bull Lake and Tahoe glaciations in the Wasatch Mountains and Sierra Nevada, respectively. The Wyemaha formation is correlated with subaerial deposits intercalated between the lower and upper units of the Lake Bonneville group and with disconformities of inter-Bull LakePinedale age in the Wasatch Mountains and interTahoe-Tioga age in the Sierra Nevada. The Sehoo and Indian Lakes formations are correlated with the upper unit of the Lake Bonneville group, and with drift of the Pinedale and Tioga glaciations in the Wasatch Mountains and Sierra Nevada. The Turupah formation is correlated with deposits of Antevs' "altithermal age" $(1948,1952,1955)(2,000$ to 5,500 B.C. $)$ in the Great Basin. The Fallon formation is correlated with deposits of Antevs' "medithermal age" in the Great Basin, and with drift of Matthes" "little ice age" (1942, 1945) in the Sierra Nevada.

These correlations, if valid, lead to several general deductions about regional Quaternary events:

1. The fluctuations of Lakes Lahontan and Bonneville were similar and synchronous.

2. The fluctuations of both lakes paralleled those of the glaciers in the Sierra Nevada and Wasatch Mountains; i.e., when the lakes were high the glaciers were extensive. The more complete record in the basins gives indirect evidence of glacial oscillations not yet recognized in the mountains.

3. Lake Lahontan, and probably Lake Bonneville, dried up entirely during a long period between the two major deep-lake intervals, and the Sierra Nevada and Wasatch Mountains were probably then completely deglaciated.

\section{REFERENCES}

Anters, E. V., 1948, Climatic changes and pre-white man, in The Great Basin, with emphasis on glacial and post-glacial times: Utah Univ. Bull., v. 38, no. 20, p. 168-191.

- 1952, Cenozoic climates of the Great Basin: Geol. Rundschau, v. 40, no. 1, p. 94-108 (in English).

__ 1955, Geologic-climatic dating in the west [U.S.] : Am. Antiquity, v. 20, no. 4, pt. 1, p. 317-335.

Blackwelder, Eliot, 1931, Pleistocene glaciation in the Sierra Nevada and Basin Ranges: Geol. Soc. America Bull., v. 42, no. 4, p. $865-922$.

Hunt, C. B., 1953, General geology, in Hunt, C. B., Varnes, H. D., and Thomas, H. E., Lake Bonneville-geology of northern Utah Valley, Utah: U.S. Geol. Survey Prof. Paper 257-A, p. 11-45.

Hunt, C. B., and Sokoloff, V. P., 1950, Pre-Wisconsin soil in the Rocky Mountain region, a progress report: U.S. Geol. Survey Prof. Paper 221-G, p. 109-123.

Matthes, F. E., 1942, Glaciers, in Meinzer, O. E., ed., Physics of the earth, Hydrology, pt. 9: Nèw York, McGraw-Hill Book Co., p. 149-219.

1945, Post-Pleistocene deglaciation and reglaciation [abs.] : Geol. Soc. America Bull., v. 56, no. 12, pt. 2, p. 1181.

Putnam, W. C., 1950, Moraine and shoreline relationships at Mono Lake, California: Geol. Soc. America Bull., v. 61, no. 2, p. 115-122.

Richmond, G. M., 1950, Interstadial soils as possible stratigraphic horizons in Wisconsin chronology [abs.] : Geol. Soc. America Bull., v. 61, no. 12, pt. 2, p. 1497.

Richmond, G. M., Morrison, R. B., and Bissell, H. J., 1952, Correlation of the late Quaternary deposits of the La Sal Mountains, Utah, and of Lakes Bonneville and Lahontan by means of interstadial soils [abs.] : Geol. Soc. America Bull., v. 63, no. 12, pt. 2, p. 1369. 


\section{NEW EVIDENCE ON THE HISTORY OF LAKE BONNEVILLE FROM AN AREA SOUTH OF SALT LAKE CITY, UTAH}

By R. B. Monrison, Denver, Colo.

Recent mapping of the Quaternary deposits in the eastern half of Lower Jordan Valley, south of Salt Lake City, has produced additional information on oscillations of Lake Bonneville. Fan gravel and colluvium antedating Lake Bonneville are locally exposed, mainly in faulted remnants along the edge of the Wasatch Mountains. These deposits bear a very mature soil, the "pre-Wisconsin paleosol" and "ancient soils" of Hunt and Sokoloff (1950, p. 114-115) and Hunt (1953, p. 43-44), which is directly overlain by the earliest sediments of Lake Bonneville. This soil is 5 feet or more thick where well preserved, with a strongly textured brown $B$ horizon and, a mile or more west of the mountain front, a dense $\mathrm{C}_{\mathrm{c} a}$ (caliche) horizon.

In this area the deposits of Lake Bonneville (Lake Bonneville group) are most feasibly divided into two main units (fig. 333.1). These units are separated by a mature soil, local alluvium, and a disconformity that together record subaerial exposure at least as low as , \pm 250 feet altitude-only 50 feet above the June 1951 level of Great Salt Lake. The lower unit comprises two tongues of lacustrine sediments separated by another disconformity and by local alluvium recording subaerial exposure at least as low as 4,270 feet altitude. The disconformity and alluvium are discontinuous, however, and the two tongues can be differentiated only locally. The lower tongue, which is approximately equivalent to the Alpine formation of Hunt (1953), reaches a maximum altitude of about 5,100 feet, and is inferred to record the first deep-lake cycle of Lake Bonneville. The upper tongue, which includes Hunt's Bonneville and Provo formations, extends as high as the Bonneville shoreline (about 5,135 feet altitude west of the main Wasatch fault zone) and is inferred to record the second, and highest, lake cycle. During the recession from this maximum, a long stillstand at an altitude of about 4,800 feet is recorded in the welldeveloped Provo shoreline.

The mid-Lake Bonneville soil, intermediate in age between the lower and upper units of the Lake Bonneville group, is thinner (typically 3 to 4 feet thick) than the pre-Lake Bonneville soil; its B horizon is distinctly less clayey and is generally lighter brown; and the $\mathrm{C}_{\mathrm{ca}}$ horizon, where present in the western part of the area, has less calcium carbonate.

The upper unit of the Lake Bonneville group comprises three tongues of lacustrine sediments, each locally separated by disconformities that record subaerial erosion. The lower tongue reaches a maximum altitude of about 4,770 feet, not quite as high as the Provo shoreline. The middle and upper tongues reach altitudes as high as 4,470 and 4,410 feet, respectively, but these maxima are only faintly marked by shore features and shore deposits. The disconformities between each tongue have been identified as low as 4,450 and 4,360 feet altitude, respectively, and probably extend lower. The three tongues are inferred to record the last 3 cycles of Lake Bonneville. This unit bears a submature soil that typically is 2 to $2 \frac{1}{2}$ feet thick and is somewhat less strongly cleveloped and lighter colored than the midLake Bonneville soil. Post-Lake Bonneville deposits include alluvium and local colluvium, eolian sand, and loess. The post-Lake Bonneville soil is locally intercalated between the lower and upper parts of the eolian sand.

Thus, the stratigraphic record shows that Lake Bonneville had 5 lake cycles, during which, from oldest to youngest, the lake level rose to about 5,100, 5,135, 4,770, 4,470 , and 4,410 feet altitude. During the intervening recessions, the lake level dropped at least as low as 830 , 885,320 , and 110 feet, respectively, below the preceding maximum. This is in accord with the conclusions of Gilbert (1890), Antevs (1945, 1948), Ives (1951), Hunt (1953), and Eardley, Gvosdetsky, and Marsell (1957) on the age relations and maximum height of the first two lake cycles. It is in contrast with each of these interpretations, however, in that the longest and probably most complete lake desiccation appears to have been between lake cycles 2 and 3 (not between 1 and 2). The long stillstand at the Provo level was during the recession of lake cycle 2, as Gilbert and Hunt inferred, and not mainly during lake cycle 3, as Antevs (1945, 1948, 1952, 1955), Ives (1951), and Eardley, Grosdetsky, and Marsell (1957) concluded. The 3rd lake maximum is equivalent to the "Provo 2" maximum of Jones and Marsell (1955), Bissell (1952), Anters (1952, 1955), and Eardley, Grosdetsky, and Marsell (1957). The 4th lake maximum was at the average altitude of the Stansbury shoreline of Gilbert (1890), of the "Lake Stansbury II" stillstand of Antevs (1945, $1948,1952,1955)$, and of the "Stansbury stage" of Ives (1951), and of Eardley, Gvosdetsky, and Marsell (1957). There is neither stratigraphic nor geomorphic confirmation of a comparatively long stand at and near 


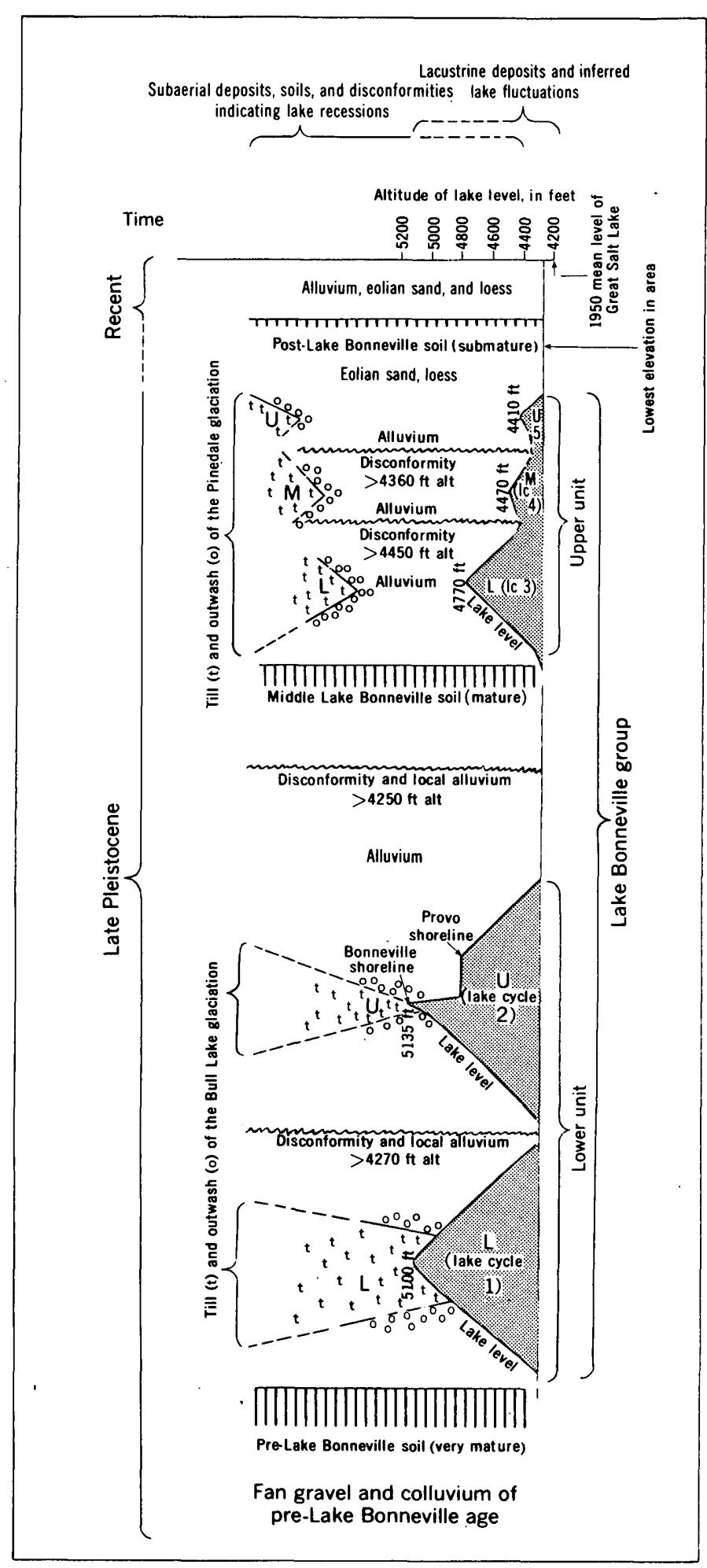

Figure 333.1.-Stratigraphic record of fluctuations of Lake Bonneville. U, upper part; $M$, middle part; and $L$, lower part of a lacustrine or glacial unit; lc, lake cycle; $>$, disconformity observed as low as the altitude given; $t$, till; $o$, outwash; numbers refer to lake cycle. the Bonneville shoreline as recently as 25,000 to 15,000 years ago nor of another even more recent rise above the Provo level (between 12,000 and 11,000 years ago), as Broecker and Orr (1958) inferred from radiocarbon dating.

Since Gilbert's (1890) study it has been known that below the mouths of Little Cottonwood and Bells Canyons bulky moraines extend somewhat below the level of the Bonneville shoreline, permitting reasonably direct correlation of parts of the glacial and lacustrine sequences, although various geologists have differed as to the correlations. The glacial geology of these canyons was recently mapped by G. M. Richmond, and he and I jointly studied the interrelations of the glacial and lacustrine deposits. Below the mouth of each canyon is a set of end moraines, representing two separate advances of glaciers from these canyons, which we correlate with the early and late stades ${ }^{1}$ of the Bull Lake glaciation of the Rocky Mountains. Around the outer margins of the moraines, till and outwash of the early stade interfinger with the lower lacustrine tongue of the lower unit of the Lake Bonneville group, and drift of the late stade interfingers with the upper tongue of this unit. The higher shorelines of the first lake cycle notch the end moraines of the early stade, and the Bonneville shoreline is carved into the end moraines of the late stade, contrary to the conclusions of Gilbert (1890) and Blackwelder (1931). The relations indicate that the two lake maxima were essentially contemporaneous with or perhaps slightly later than the corresponding glacial maxima.

End moraines of post-Bull Lake age are far above the Bonneville shoreline in both canyons, and the intervening remnants of out wash gravels and stream terraces are too discontinuous to permit reliable direct correlation between the younger glacial and lacustrine sequences. These sequences can be indirectly correlated, however, on the basis of relative stratigraphic position of soils of similar maturity in each sequence. The drift of the Bull Lake glaciation bears a mature soil, comparable in development to the soil of middle Lake Bonneville age. A submature soil, similar to the post-Lake Bonneville soil, is developed on three sets of end moraines in the middle and upper parts of the canyons that Richmond (Art. 334) correlates with the early, middle, and late stades, respectively, of the Pinedale glaciation. Consequently, the upper unit of the Lake Bonneville group is correlated with the drift of the Pinedale glaciation. The lower, middle, and upper tongues of the upper unit are matched by (and prob-

1 A stade is defined as a climatlc eplsode within a glaclation during which a secondary advance of glaciers may be Inferredi (American Commission on Stratigraphic Nomenclature, 1961). 
ably correlate with) the early, middle, and late stades of the Pinedale glaciation.

\section{REFERENCES}

American Commission on Stratigraphic Nomenclature, 1961, Code of stratigraphic nomenclature: Am. Assoc. Petroleum Geologists Bull., v. 45, no. 5, p. 645-665.

Antevs, E. V., 1945, Correlation of Wisconsin glacial maxima, in Problems in geology and geophysics (Daly volume 243-A) : Am. Jour. Sci., p. 1-39.

1948, Climatic changes and pre-white man, in The Great Basin, with emphasis on glacial and postglacial times: Utah Univ. Bull., v. 38, no. 20, p. 168-191.

1952, Cenozoic climates of the Great Basin: Geologische Rundschau, v. 40, no. 1, p. 94-108 [in English].

1955, Geologic-climatic dating in the west [U.S.]: Am. Antiquity, v. 20 , no. 4, p. 1.

Bissell, H. J., 1952, Stratigraphy of Lake Bonneville and associated Quaternary deposits in Utilh Valley, Utah [abs.]: Geol. Soc. America Bull., v. 63, no. 12, pt. 2, p. 1358.

Blnckwelder, Eliot, 1931, Pleistocene glaciation in the Sierra Nevada and Basin Ranges: Geol. Soc. America Bull., v. 42, no. 4, p. $865-922$.
Broecker, W. S., and Orr, P. C., 1958, Radiocarbon chronology of Lake Lahontan and Lake Bonneville: Geol. Soc. America Bull., v. 69 , no. 8 , p. $1009-1032$.

Eardley, A. J., Grosdetsky, Vasyl, and Marsell, R. E., 1957, Hydrology of Lake Bonneville and sediments and soils of its basin [Utah]: Geol. Soc. America Bull., v. 68, no. 9, p. 1141-1202.

Gilbert, G. K., 1890, Lake Bonneville: U.S. Geol. Survey Mon. 1, $438 \mathrm{p}$.

Hunt, C. B., 1953, General geology, in Hunt, C. B., Varnes, H. D., and Thomas, H. E., Lake Bonneville-geology of northern Utah Valley, Utah: U.S. Geol. Survey Prof. Paper 257-A, p. 11-45.

Hunt, C. B. and Sokoloff, V. P., 1950, Pre-Wisconsin soil in the Rocky Mountain region, a progress report: U.S. Geol. Survey Prof. Paper 221-G, p. 109-123.

Ives, R. L., 1951, Pleistocene valley sediments of the Dugway area, Utah: Geol. Soc. America Bull., v. 62, no. 7, p. 781797.

Jones, D. J., and Marsell, R. E., 1955, Pleistocene sediments of lower Jordan Valley, Utah, in Tertiary and Quaternary geology of eastern Bonneville Basin : Utah Geol. Soc. Guidebook No. 10, p. 85-112.

334. NEW EVIDENCE OF THE AGE OF LAKE BONNEVILLE FROM THE MORAINES IN LITTLE CO'TTONWOOD CANYON, UTAH

By G. M. Richmond, Denver, Colo.

The glacial deposits of Little Cottonwood Canyon in the Wasatch Mountains, Utah, represent three glaciations. Deposits of the oldest are probably of middle Pleistocene age and have been uplifted about 2,500 feet by normal faulting at the western margin of the mountains.

Deposits of the next younger glaciation, correlated with deposits of the Bull Lake glaciation of Wyoming, comprise two sets of end moraines at the mouth of the canyon at altitudes of 4,980 and 5,090 feet, respectively. Till and outwash of the outer moraine interfinger with and are overlapped by deposits of the first rise of the lake-the Alpine formation of Hunt, Varnes, and Thomas (1953) - and till and outwash of the inner moraine interfinger with and are overlapped by deposits of the second rise of the lake-the Bonneville formation (Hunt, Varnes, and Thomas, 1953) -or that which attained the Bonneville shoreline.

The basinward extent of a disconformity which separates the Alpine and Bonneville formations indicates a marked lowering of the lake, as concluded by Gilbert (1890), Hunt, Varnes, and Thomas (1953), and Morrison ( $\Lambda$ rt. 333 ). This in turn suggests that the ice yeceded to the cirques but did not disappear in the interval separating deposition of the two moraines.

Outwash gravels deposited during the final recession of Bull Lake graciation extend to the Provo shorelinethe upper limits of the Provo formation (Hunt, Varnes, and Thomas, 1953). Thus, the entire sequence of deposits of Lake Bonneville as recognized by Gilbert (1890) was deposited during Bull Lake glaciation.

A mature zonal soil formed on all exposed deposits during Bull Lake-Pinedale interglaciation, at which time it has been inferred that Lake Bonneville was essentially dry (Richmond, Morrison, and Bissell, 1952: Morrison, Art. 333).

The third glaciation of the mountains--correlated with the Pinedale glaciation of Wyoming-comprises three sets of moraines in the middle and upper parts of Little Cottonwood Canyon and its tributaries at average altitudes of $6,570,7,220$, and 9,195 feet. These mark a maximum advance and two minor readvances or halts during recession of the ice that are believed to have been separated by only brief interstadial intervals. No direct stratigraphic tie between these deposits and those of Lake Bonneville can be made, but probably they can 
be correlated with three post-Provo rises of the lake discovered by Morrison (1961) at successively lower altitudes below the Provo shoreline.

The glaciers probably disappeared entirely from the mountains and the lake was again dry during the "altithermal age" of Antevs (1948). Subsequently, two sets of small moraines or rock glaciers have formed in the cirques. These represent the Temple Lake and historic stades ${ }^{1}$ of neoglaciation ${ }^{2}$, both of which occurred during the "little ice age" of Matthes (1939).

Numerous workers, including Gilbert $(1890$, p. 309 310), Atwood (1909, p. 92-93), Antevs (1945, p. 74-77), Blackwelder (1931, p. 915-916), Ives (1950, p. 115), and Funt, Varnes, and Thomas (1953, p. 41), have concluded that the second rise of Lake Bonneville-that which attained the Bonneville shoreline and was lowered by erosion at its outlet to the Provo shoreline-was correlative with the last Pleistocene glaciation of the mountains. The present evidence indicates the deposits of the rise to the Bonneville shoreline and of the stillstand at the Provo shoreline are correlative with the later of two stades of Bull Lake glaciation. Only certain lower fluctuations of the lake following post-Provo dessication and preceding the "alt ithermal age" are correlative with the last or Pinedale glaciation.

The Pinedale glaciation, on the basis of a radiocarbon date of $27,000 \pm 800$ years from its outer moraine in Jackson Hole, Wyo. (Rubin and Alexander, 1958) seems to include all of the Wisconsin stage as defined by Leighton (1933), for the Farmdale loess of Illinois is probably not much older than $26,100 \pm 600$ years (Frye and Willman, 1960). The deposits of the Bull Laku glaciation are stratigraphically lower than those of the Pinedale, and are separated from them by de-

\footnotetext{
${ }^{1}$ A stade is defined as a climatic episode withln a glaciation diuring which a secondary advance of glaclers took place (American Commlssion on Stratigraphic Nomenclature, 1961, 1. 660 .

The neoglaclation is hereby defined as the last glaciation in the Rocky Mountain region. It is of post-Plelstocene (Recent) age.
}

glaciation, erosion and the development of a mature zonal soil. No such pronounced climatic break has been recognized in the classical succession of Wisconsin deposits in Illinois. Thus, it may be concluded that the deposits of the two high-level rises of Lake Bonneville is recognized by Gilbert (1890), including those of the standstill at the Provo shoreline, are older than Wisconsin.

\section{REFERENCES}

American Commission on Stratigraphic Nomenclature, 1961 , Code of stratigraphic nomenclature: Am. Assoc. Petroleum Geologists Bull., v. 45, no. 5, p. 645-665.

Antevs, Ernst, 1945, Correlation of Wisconsin glacial maxima : Am. Jour. Sci., n.s., v. 243-A, Daly volume, p. 1-39.

1948, Climatic changes and pre-white man, in The Great Basin, with emphasis on glacial and postglacial times: Utah Univ. Bull., v. 38, no. 20, p. 167-191.

Atwood, W. W., 1909, Glaciation of the Uinta and Wasatch Mountains: U.S. Geol. Survey Prof. Paper 61, 96 p.

Blackwelder, Eliot, 1931, Pleistocene glaciation in the Sierra Nevada and Basin Ranges: Geol. Soc. America Bull., v. 42, no. 4 , p. $865-922$.

Frye, J. C., and Willman, H. B., 1960, Classification of the Wisconsinian stage in the Lake Michigan glacial lobe: Illinois State Geol. Survey Circ. 285, 16 p.

Gilbert, G. K., 1890, Lake Bonneville: U.S. Geol. Survey Mon. 1, $438 \mathrm{p}$.

Hunt, C. B., Varnes, H. D., and Thomas, H. E., 1953, Lake Bonneville-geology of northern Utah Valley, Utah: U.S. Geol. Survey Prof. Paper 257-A, 99 p.

Ives, R. L., 1950, Glaciations in Little Cottonwood Canyon, Utah: Sci. Monthly, v. 71, no. 2, p. 105-117.

Leighton, M. M., 1933, The naming of the subdivisions of the Wisconsin glacial age : Science, v. 77, p. 168.

Matthes, F. E., 1939, Report of Committee on Glaciers: Am. Geophys. Union Trans., 20th Ann. Meeting, pt. 4, p. 518-523.

Richmond, G. M., Morrison, R. B., and Bissell, H. J., 1952, Correlation of the late Quaternary deposits of the La Sal Mountains, Utah and of Lake Bonneville and Iahontan by means of interstadial soils [abs.] : Geol. Soc. America Bull., v. 63 , p. 1369 .

Rubin, Meyer, and Alexander, Corrine, 1958, U.S. Geological Survey radiocarbon dates IV : Science, v. 127, p. 1476-1487.

\section{MAGNITUDE OF THRUST FAULTING IN NORTHERN UTAH}

By Max D. Crittenden, Jr., Menlo Park, Calif.

The Bannock, Willard, Charleston, and Nebo faults are part of a discontinuously exposed belt of overthrusts that extends from Montana and Idaho to southeastern Nevada. So far as known, all are rooted to the west, and all have brought thicker basin-type facies over thinner shelf-type rocks to the east. The resulting contrast in thickness or character is evident in rocks ranging in age from Precambrian to Permian.

In Utah, the northernmost segment of this thrust belt extends from a branch of the Bannock thrust near 
Bear Lake to the Willard thrust on the crest of the Wasatch Range near Ogden. Together these thrusts define an overriding structural block that is characterized by a thick basal Cambrian quartzite resting on at, least 6,000 feet of Precambrian sedimentary rocks. The block beneath the thrusts is characterized by a thin basal Cambrian quartzite, which rests directly on highly metamorphosed Precambrian rocks older than those of the upper plate. The structure within the block is that of a simple syncline; the same Cambrian formations can be traced around the fold, and serve to establish structural continuity from one thrust to the other.

The southern segment of the belt of overthrusts consists of the Charleston and Nebo thrusts, which together outline a bulging lobe of basin-type rocks that extends eastward to the edge of the Uinta Basin. The overriding block in this segment is characterized by some 30,000 feet of beds between the Humbug formation of Mississippian age and the Park City formation of Permian age, whereas in the autochthon to the east the same stratigraphic interval contains less than 2,000 feet of beds.

The structural continuity between the northern and southern segments of this belt is speculative because neither the thick unmetamorphased Precambrian sedimentary rocks of the northern block nor the thick Pennsylvanian and Permian rocks of the southern block extend unbroken from one block into the other. Nevertheless, parts of the Oquirrh formation have been identified by Olson (1956) in the Promontory Range, where they are in sequence above thick unmetamorphosed Precambrian rocks. This relation serves to establish the kinship of the two blocks, though the thrust itself is concealed. The trace shown on figure 335.1 is regarded as the likeliest of several possibilities. $\Lambda$ ntelope Island, underlain largely by highly metamorphosed Precambrian rocks, is regarded as autochthonous. The thin (288-foot) wedge of Precambrian slate, dolomite, and tillite reported there by Larsen ${ }^{1}$ may be the landward edge of a depositional basin that originally lay to the west. Overlying tan or pink conglomeratic quartzites are believed to be equivalent to the Tintic quartzite and are therefore not of Precambrian age. Deformation of these quartzites into nearly isoclinal folds in which there was sufficient axial plane shearing to produce marked stretching of quartzite pebbles, suggests that the thrust plane passes close to the northwestern tip of Antelope Island, and that the thick sequences of unmetamorphosed Precambrian rock on Fremont Island and Promontory Point are allochthonous.

\footnotetext{
I Lnrsen, W. N., 1957, Petrology and structure of Antelope Island. Daris County, Utah: Utah Univ., unpublished Ph. D. thesis.
}

Estimates of the displacement on thrusts of this belt range from as little as 12 miles (Hintze, 1960, p. 2062) to as much as 75 miles (Eardley, 1951, p. 330). The first estimate is based entirely on observations within the allochthon, and hence does not give information about the total movement with respect to the autochthon. The second, though larger than those derived below, appears to be possible from stratigraphic evidence.

The minimum displacement of the northern block is best estimated from the relations of its characteristic unmetamorphosed Precambrian sedimentary rocks. If, as suspected, Antelope Island represents the easternmost edge of the principal depositional basin, the 7,000foot sequence of these Precambrian rocks exposed east of Ogden must have come from somewhere west of the present site of the island, a distance of at; least 30 miles. Lack of information as to the rate of thickening makes it impossible to estimate how much farther west they may have originated.

Other evidence is obtained from the relative effects of the Devonian-Mississippian unconformity (fig. 335.1, p. D-130), as expressed by the thickness of beds between it and the top of the Tintic or its stratigraphic equivalent, the Brigham quartzite. The 6,000-foot isopach in the thrust block meets the Willard thrust opposite the 2,000 -foot isopach in the footwall. Projecting the isopachs eastward at the same rate as those known within the allochthon suggests about 40 miles of displacement on the thrust. A similar result is obtained from the data for rocks of Mississippian age (fig. 335.2). Isopachs representing some 4,000 to 5,000 feet of beds in the overriding block meet the Willard thrust opposite the line representing some 1,800 feet of beds in the autochthon. Here, also, a movement of some 40 miles is required to restore the continuity of the two sets of isopachs.

Displacements of the Charleston-Nebo block can best be estimated by reconstruction of the general form of the Oquirrh basin (fig. 335.3). As there is no evidence for the configuration of the now-destroyed east half, its general outline and the maximum slopes have been made approximately symmetrical with the west half. On such a basis, a displacement of about 40 miles is likely. Obviously, different assumptions regarding configuration and slope would yield values ranging from half to twice this amount.

\section{REFERENCES}

Lardley, A. J., 1951, Structural geologs of North America: New York, Harper \& Bros., 624 p.

Hintze, Lehi, 1960, Thrust-faulting limits in western Utah [abs.] : Geol. Soc. America Bull., v. 71, no. 12, p. 2062.

Olson, R. H., 1956, Geology of Promontory Range, in Utah Geol. Soc. Guidebook to the geology of Utah, no. 11: p. 41-75. 

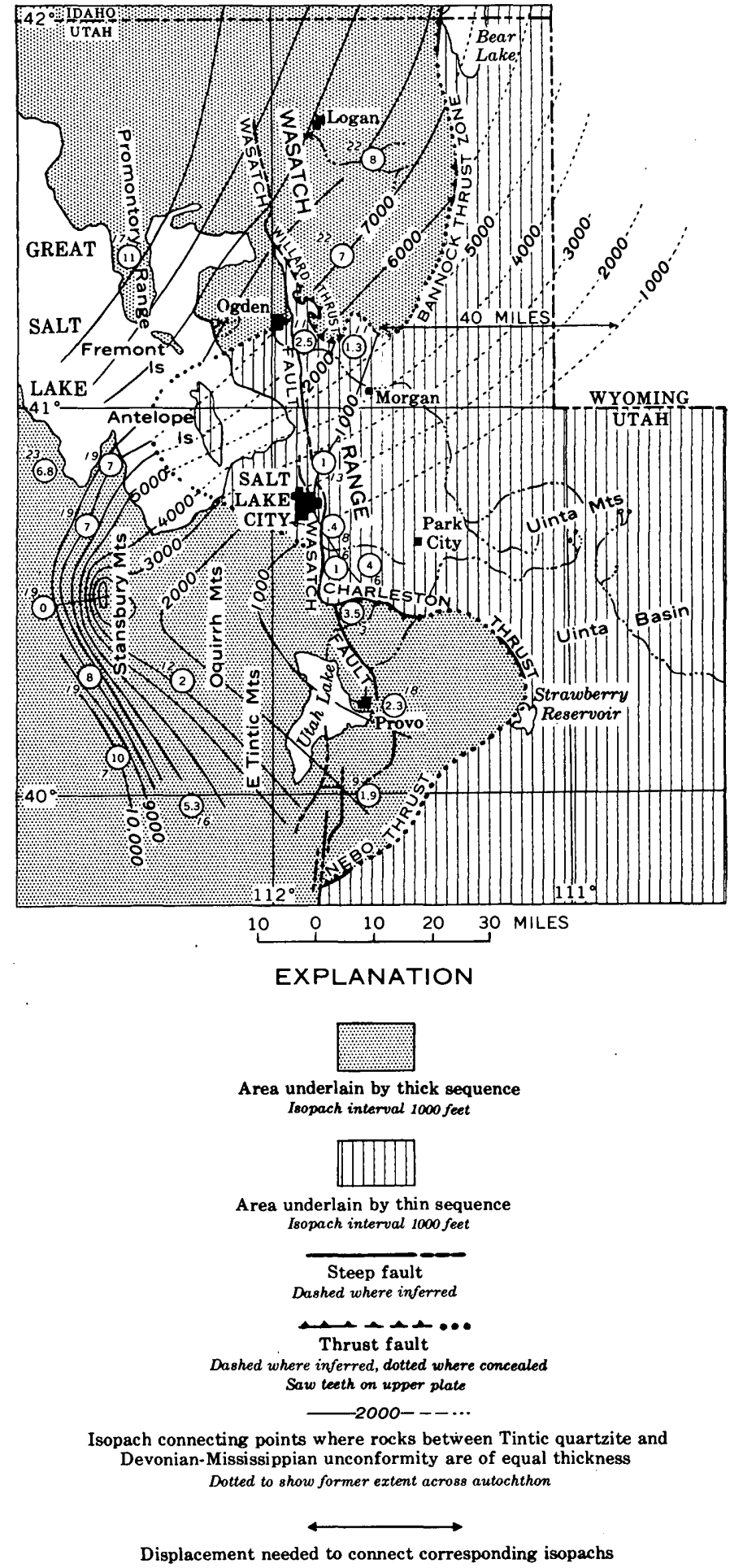

(2) $^{\prime 2}$

Location of measured section Outside number refers to reference listed in table number in circle is thickness in thousands of feet

Figure 335.1.-Displacement on Willard and Bannock thrusts based on thickness of beds between top of Tintic quartzite and the Devonian-Mississippian unconformity.
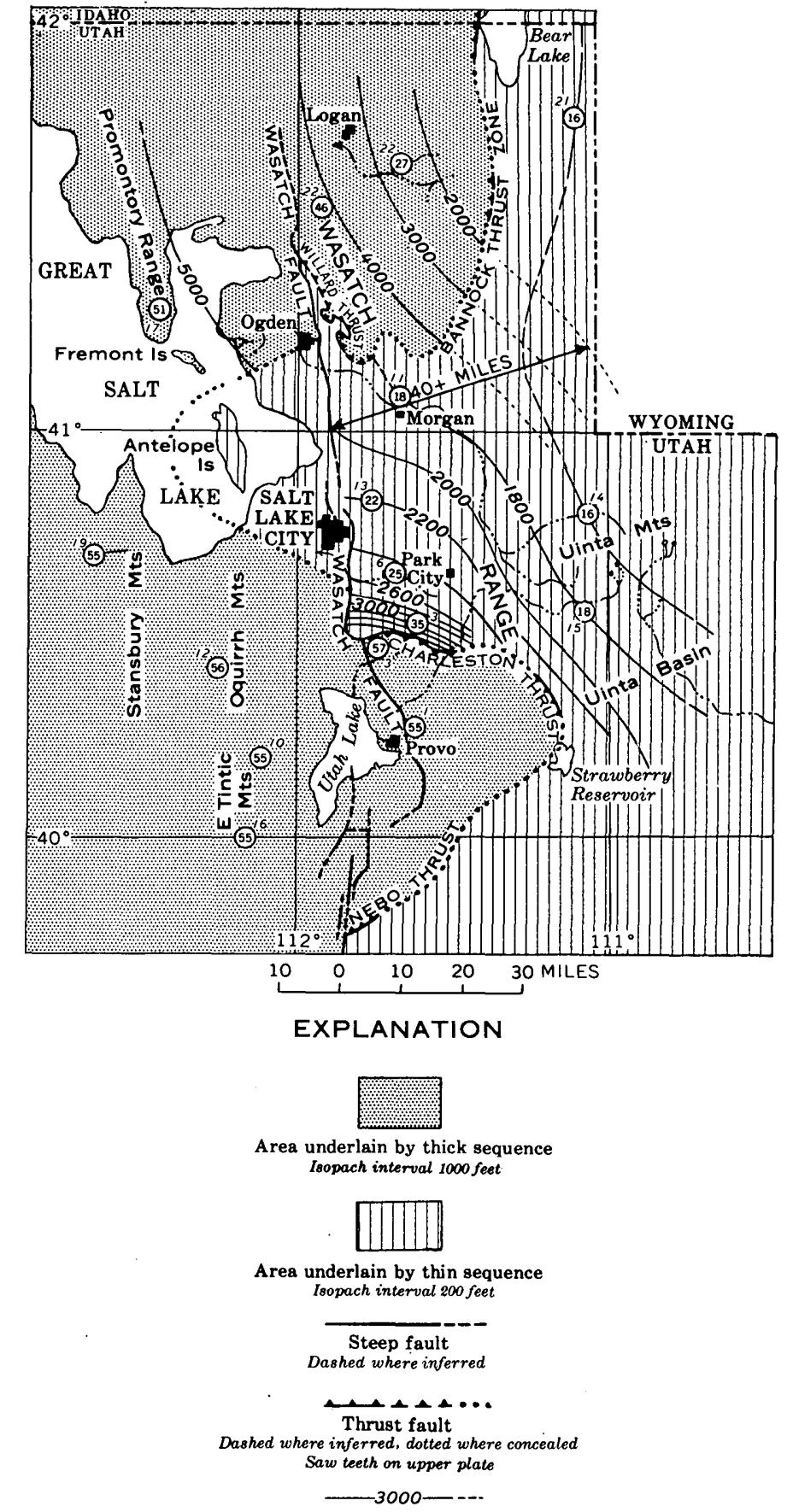

Isopach connecting points where Mississippian rocks are of equal thickness Dashed where inferred, dotted to show

Displacement needed to connect corresponding isopachs

\section{(46) 22}

Location of measured section

Outside number refers to reference listed in table, number in circle is thickness in hundreds of feet

Figure 335.2.-Displacement on Willard and Bannock thrusts based on thickness of Mississippian rocks. 

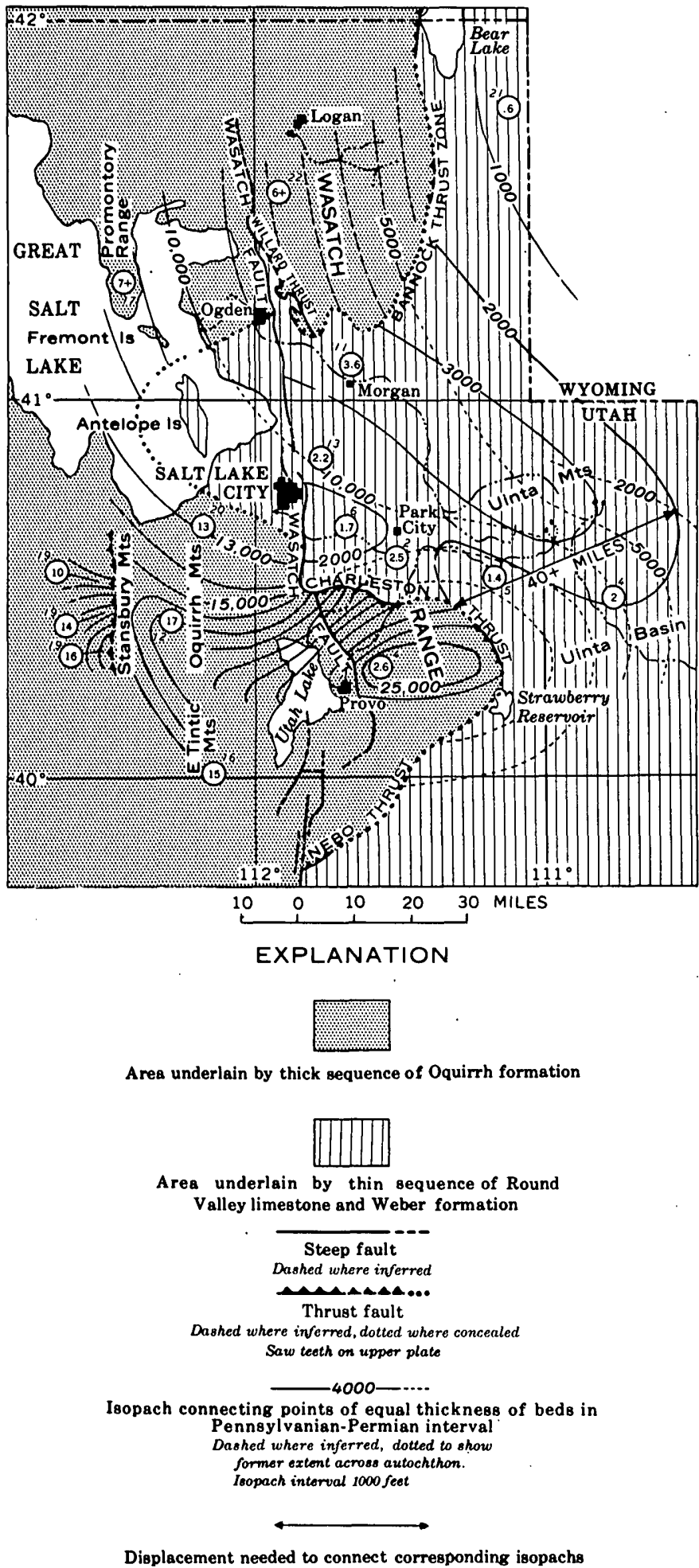

$$
\text { (15) }^{16}
$$

Location of measured section Outside number refers to localities listed in table number in circle is thickness in thousands of feet
$\mathrm{T}_{\mathrm{ABLE}}$ 335.1.-References to measured section given on figures 335.1-395.3

\begin{tabular}{l|c}
$\begin{array}{c}\text { No. on } \\
\text { map }\end{array}$ & Reference \\
\hline 1 & Baker, A. A., 1947, U.S. Geol. Survey Oil and Gas
\end{tabular}
Inv. Chart 30.

2 Unpublished data.

3 Baker, A. A., and Crittenden, M. D., 1961, U.S. Geol. Survey Geol. Quad. Map GQ-132.

4 Baker, A. A., Huddle, J. W., and Kinney, D. M., 1949, Am. Assoc. Petroleum Geologists Bull., v. 33, no. 7, p. 1161-1197.

5 Bissell, H. J., 1952, Am. Assoc. Petroleum Geologists Bull., v. 36, no. 4, p. 575-634.

6 Calkins, F. C., and Butler, B. S., 1943, U.S. Geol. Survey Prof. Paper 201, $152 \mathrm{p}$.

7 Cohenour, R. E., 1959, Utah Geol. and Mineralog. Survey Bull. 63, 200 p.

8 Crittenden, M. D., unpublished data.

9 Demars, L. C., 1956, Brigham Young Univ. Research Studies, v. 3, no. 2.

10 Disbrow, A. E., 1957, U.S. Geol. Survey Mineral Inv. Field Studies Map MF-131.

11 Eardley, A. J., 1944, Geol. Soc. America Bull., v. 55, no. 7, p. 819-894.

12 Gilluly, James, 1932, U.S. Geol. Survey Prof. Paper $173,171 \mathrm{p}$.

13 Granger, A. E., 1953, U.S. Geol. Survey Circ. 296, $14 \mathrm{p}$.

Hooper, W. G., 1951, Geology of the Smith and Morehouse-South Fork area, Utah Univ., unpublished Master's thesis.

Huddle, J. W., and McCann, F. T., 1947, U.S. Geol. Survey Circ. 16, 21 p.

Morris, H. T., 1957, Utah Geol. Soc. Guidebook to the geology of Utah, no. 12, p. 1-56.

17 Olson, R. H., 1956, Utah Geol. Soc. Guidebook to the geology of Utah, no. 11, p. 41-75.

18

Rhodes, J. A., 1955, Brigham Young Univ. Research Studies, v. 2, no. 4.

19 Rigby, J. K., 1958, Utah Geol. Soc. Guidebook to the geology of Utah, no. 13, p. 1-134.

20

21

Roberts, R. J., and Tooker, E. W., unpublished data. Sando, W. J., Dutro, J. T., and Gere, W. C., 1959, Am. Assoc. Petroleum Geologists Bull., v. 43, no. 12, p. 2741-2769.

22

Williams, J. S., 1958, Utah Geol. and Mineralog. Survey Bull. 64, 98 p.

23

Young, J. C., 1955, Utah Geol. and Mineralog. Survey Bull. 56, 110 p.

Figure 335.3.-Displacement on Charleston and Nebo thrusts based on thickness of Pennsylvanian and Lower Permian rocks. 


\title{
336. SUBDIVIDING THE JORDAN VALLEY GROUND-WATER BASIN, UTAH
}

\author{
By I. Wendell Marine, Norman, Okla.
}

Work done in cooperation with the Utah State Engineer

Jordan Valley, Utah, is a structural basin on the eastern margin of the Basin and Range physiographic province (index map on fig. 336.1). The basin has been partly filled with unconsolidated and semiconsolidated material of Tertiary and Quaternary age. This material has been deposited by streams, lake currents, mudrock flows, glaciers, and wind, and consists chicfly of mixtures of boulders, gravel, sand, silt, clay, and limestone. During both Tertiary and Quaternary times, periods of subaerial erosion and deposition have alternated with periods when lakes of different depths have occupied all or part of the valley. At many times, subaerial erosion and deposition were taking place in some parts of the valley while erosion or deposition in lakes was taking place in other parts. Stream discharge fluctuated through wide ranges caused by variations in climate, especially in Pleistocene time. At first inspection, the basin deposits appear to be a disordered array of heterogeneous rock material which resulted from the variety of the processes of sedimentation that have been active, from the number of unconformities and the varied relief on their surfaces, and from the occurrence of several faults within the valley fill. No widespread continuous aquifers were found to exist.

Despite the complex sedimentary history of the basin, it has been found possible to divide the Jordan Valley into hydrologic units on which the management and development of ground water might be based. The central problem was to determine whether bodies of material with similar hydrologic properties existed and, if so, to portray them adequately on a map. Studies of the physiography, drillers' logs, gravel percentages in well cuttings, specific capacities of wells, and water quality provided satisfactory criteria for dividing the valley into six natural ground-water districts (fig. 336.1) whose boundaries are marked on the surface by some physiographic feature. Several of these districts are divided into two or more subdistricts on the basis of less obvious differences than those that distinguish the districts. Generally the subdistrict boundaries are not distinguished by physiographic features of any sort. For the water user, the important differences in these districts are the specific capacities of the wells and the quality of water in these wells (table 336.1). The degree to which surface boundaries can be based on physiography aids in describing the districts, even though some of the subsurface boundaries are more gradational than the sharp physiographic features on the surface.

A qualitative study of drillers' logs indicated that the overall lithologic aspect of the sediments could be used to differentiate the districts and subdistricts, and a gravel-percentage map showed that coarse material generally predominated in some areas and was relatively rare in others. A map of the specific capacity of largediameter wells showed that each district or subdistrict has a characteristic range in specific capacity. The differences in specific capacity of wells between areas were great enough to render unimportant such factors as well diameter, length of pumping test, amount of drawdown, length of the perforated section, amount and nature of development, and other factors that affect the accuracy of this determination. A map of the dissolved-solids content in ground water and a comparison of the major constituents showed that, in general, the ground-water districts and some subdistricts have a distinctive range in water quality.

The differences between the districts are due to local differences in the sedimentary and tectonic events of the valley. For example, the East Lake Plain district has dropped repeatedly relative to the East Bench district along the East Bench fault which forms their common boundary. Lakes frequently covered the East Lake Plain district but only rarely extended onto the East Bench district which, for a long time, has been topographically higher. The East Lake Plain district, therefore, is underlain by thick sequences of lake sediments, whereas subaerial sediments predominate in the East Bench district. Another example is the Cottonwoods district, which has also dropped relative to the East Bench district but has had a large supply of coarse, well-sorted sediment delivered to it by the two Cottonwood Creeks. These two creeks have deposited channel and alluvial-fan deposits in times of low lake levels and have built large deltas at times of high lake levels. The coarse, well-sorted deposits in the district are highly permeable and permit the development of wells of high specific capacity. The lithology and high permeability 
SHORT PAPERS IN THE GEOLOGIC AND HYDROLOGIC SCIENCES, ARTICLES 293-435

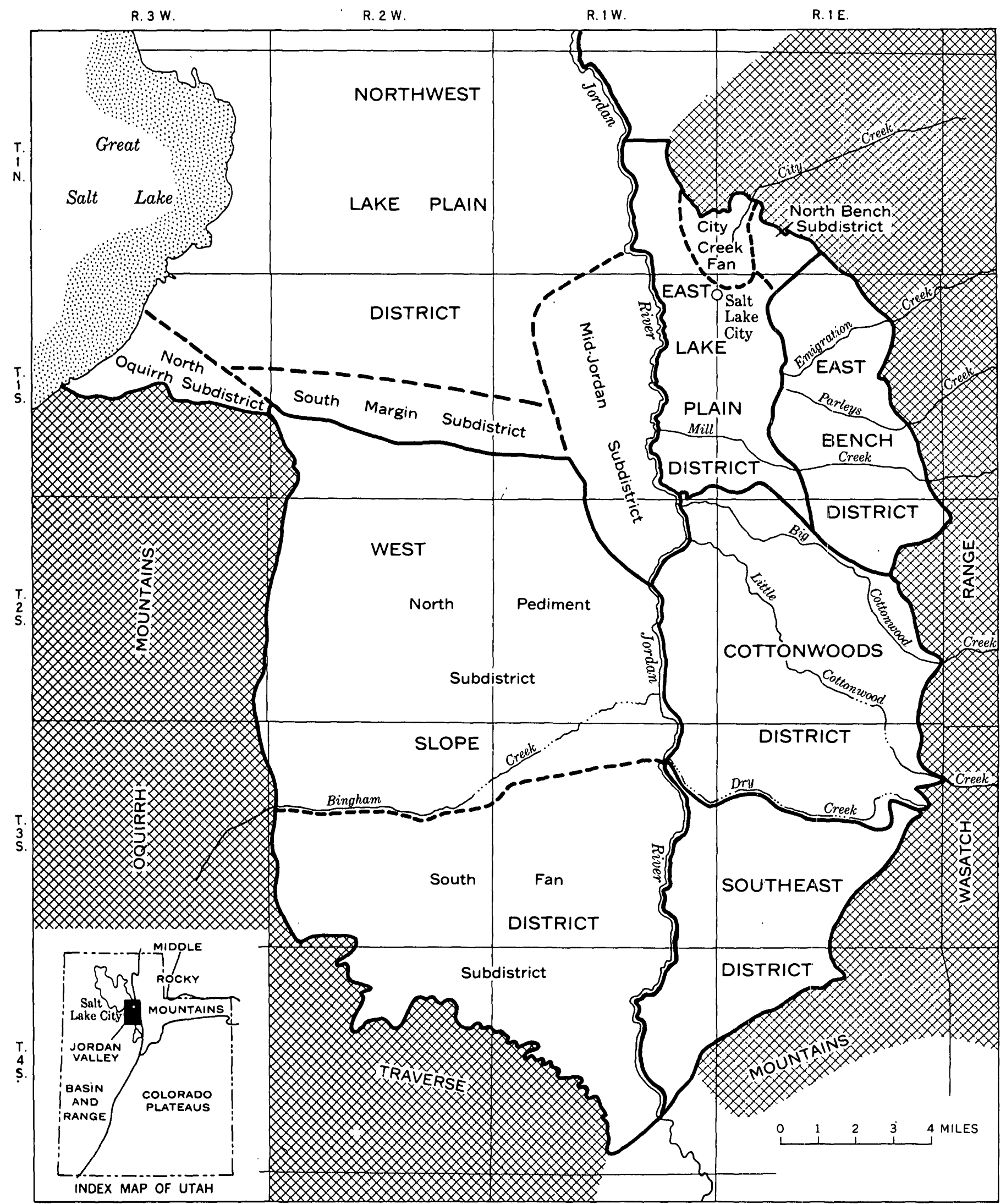

Frgure 336.1.-Map of Jordan Valley, Utah, showing ground-water districts and subdistricts. 
of the sediments probably account for the fact that the water of the Cottonwoods district contains less dissolved solids, average 250 parts per million, than the water of any other district in Jordan Valley (table 336.1 ).
The criteria used to divide the complex sedimentary basin of Jordan Valley into ground-water districts can be used to divide areas of similar complexity and thereby aid in water management of such areas, and in predicting the characteristics of future wells.

TABLE 336.1.-Occurrence of grownd uater in Jordan Valley, Utah

\begin{tabular}{|c|c|c|c|c|c|c|c|c|c|}
\hline \multirow{2}{*}{ I)istrict or subdistrict } & \multirow{2}{*}{ Physiography } & \multirow{2}{*}{ Material } & \multirow{2}{*}{ Type of deposits } & \multirow{2}{*}{$\begin{array}{l}\text { A pproximate } \\
\text { thickness } \\
\text { away from } \\
\text { boundaries } \\
\text { (fcet) }\end{array}$} & \multirow{2}{*}{$\begin{array}{l}\text { Gravel } \\
\text { gway from } \\
\text { boundaries } \\
\text { (percent) }\end{array}$} & \multirow{2}{*}{$\begin{array}{l}\text { Specific } \\
\text { capacity } \\
\text { (gallons } \\
\text { per minute } \\
\text { per foot) }\end{array}$} & \multicolumn{3}{|c|}{$\begin{array}{l}\text { Dissolved solids (parts } \\
\text { per million) }\end{array}$} \\
\hline & & & & & & & Minimum & Average & Maximum 1 \\
\hline East Bench & $\begin{array}{l}\text { Pediments and } \\
\text { alluvial fans } \\
\text { overlain in some } \\
\text { places by lake- } \\
\text { shore features. } \\
\end{array}$ & $\begin{array}{l}\text { Boulders and clay } \\
\text { with some gravel } \\
\text { and sand, mostly } \\
\text { reddish brown. } \\
\text { Sandstone, silt } \\
\text { stone, and lime- } \\
\text { stone of Mesozoic } \\
\text { age in pediment } \\
\text { areas. }\end{array}$ & $\begin{array}{l}\text { Deposits of mud- } \\
\text { rock flows and } \\
\text { ephemeral } \\
\text { streams. }\end{array}$ & $0-500 \ldots \ldots$ & $50-100$ & $20-100 \ldots$ & 320 & 600 & 685 \\
\hline $\begin{array}{l}\text { East Lake Plain: } \\
\text { Main part }\end{array}$ & $\begin{array}{l}\text { Lake plain overlain } \\
\text { in some places by } \\
\text { alluvial fans or } \\
\text { abandoned flood } \\
\text { plains. }\end{array}$ & $\begin{array}{l}\text { Blue-gray lake- } \\
\text { bottom clays and } \\
\text { silts with discon- } \\
\text { tinuous gravel } \\
\text { lenses. }\end{array}$ & $\begin{array}{l}\text { Lake-bottom sedi- } \\
\text { ments and prob- } \\
\text { ably turbidity- } \\
\text { current deposits. }\end{array}$ & $\begin{array}{l}>1,000 \text { in } \\
\text { most places. }\end{array}$ & $<25 \ldots$ & $<5 \ldots$ & 251 & 490 & 764 \\
\hline City Creek Fan... & Alluvial fan........... & $\begin{array}{l}\text { Boulders and } \\
\text { gravel. }\end{array}$ & Alluvial fan & $500 \ldots \ldots$ & $50-100 \ldots$ & $50-500$ & 253 & 530 & 761 \\
\hline . North Bench...... & $\begin{array}{l}\text { Bajada overlain by } \\
\text { lake shore } \\
\text { features. }\end{array}$ & $\begin{array}{l}\text { Boulders, gravel, } \\
\text { sand, and clay. }\end{array}$ & $\begin{array}{l}\text { Deposits of mud. } \\
\text { rock flows. }\end{array}$ & & & & & & \\
\hline Cottonwoods & $\begin{array}{l}\text { Large lake-shore } \\
\text { features cut by } \\
\text { abandoned } \\
\text { stream channels. }\end{array}$ & $\begin{array}{l}\text { Brown sand and } \\
\text { gravel inter- } \\
\text { layered with } \\
\text { blue-gray clay. }\end{array}$ & $\begin{array}{l}\text { Alluvial fans of } \\
\text { perennial streams } \\
\text { interiayered with } \\
\text { lake-bottom } \\
\text { deposits and } \\
\text { deltas. }\end{array}$ & $\begin{array}{l}\text { Unknown but } \\
>1,000 \\
\text { everywhere }\end{array}$ & $\begin{array}{l}\text { Mostly } \\
50-100 \\
\text { but in the } \\
\text { north and } \\
\text { south } \\
<25 \text {. }\end{array}$ & $\begin{array}{l}\text { Upper area } \\
50-200 ; \\
\text { lower area } \\
5-40 .\end{array}$ & 75 & 250 & 651 \\
\hline Southeast_. . . . . & $\begin{array}{l}\text { Lake-shore features. } \\
\text { In south, dis- } \\
\text { sected pediment. }\end{array}$ & $\begin{array}{l}\text { Gravel, sand, and } \\
\text { clay. }\end{array}$ & - & $\begin{array}{l}\text { Unknown but } \\
>1,200 \text { in } \\
\text { places. }\end{array}$ & $>_{50} \ldots$ & & 184 & (2) & 1,004 \\
\hline West Slope.......... & $\begin{array}{l}\text { Gentle eastward } \\
\text { slope overlain by } \\
\text { lake shore fea- } \\
\text { tures. Pedi- } \\
\text { ments near } \\
\text { mountains. }\end{array}$ & & Alluvial fans......... & & & & 365 & 640 & ${ }^{3} 1,240$ \\
\hline North Pediment.-- & do & $\begin{array}{l}\text { Bouiders, gravel, } \\
\text { sand, and clay. } \\
\text { Tertiary clay, silt, }\end{array}$ & Lake-bottom sedi- & Unknown but & $\begin{array}{l}>25,>50 \text { in } \\
\text { most } \\
\text { places. } \\
<25\end{array}$ & $<3$. & . & & \\
\hline Northwest Lake & Lake plain overlain & (n) & 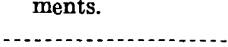 & -3 & & & & & \\
\hline Plain: & $\begin{array}{l}\text { in places by flood } \\
\text { plains. }\end{array}$ & & & & & & & & \\
\hline Main part... & .... do do........... & $\begin{array}{l}\text { Blue-gray clay with } \\
\text { thin sand lenses. }\end{array}$ & $\begin{array}{l}\text { Lake-bottom sedi- } \\
\text { ments. }\end{array}$ & & & & 492 & 1,640 & 3,600 \\
\hline Mid-Jordan_. & ......do..... & $\begin{array}{l}\text { Sand and gravel in- } \\
\text { terlayered with } \\
\text { clay. }\end{array}$ & $\begin{array}{l}\text { Channel, flood } \\
\text { plain, and lake } \\
\text { deposits. }\end{array}$ & $\begin{array}{l}\text { Unknown but } \\
>775 \text {. }\end{array}$ & $25-50$ & $<20$ & 244 & 380 & 798 \\
\hline & -....do.............. & $\begin{array}{l}\text { Sand, gravel, and } \\
\text { clay. }\end{array}$ & & & $25-50$ & $10-20 \ldots$ & 840 & 1,150 & 1,510 \\
\hline North Oquirrh.... & -.... do.... & $\begin{array}{l}\text { 0-300 feet of blue } \\
\text { lake clay under- } \\
\text { lain by coarse } \\
\text { angular gravel. }\end{array}$ & $\begin{array}{l}\text { Lake deposit under- } \\
\text { lain by talus or } \\
\text { brecciated bed- } \\
\text { rock. }\end{array}$ & $15 v-800$ & $25-50$ & $30-750$ & 2,485 & 6,860 & 10,800 \\
\hline
\end{tabular}

1 Excluded from this column are maxima caused by isolated contamination or isolated occurrences of thermal water.

2 Not meaningful.

${ }^{3}$ Exclusive of general contamination of beds less than 300 feet deep by Jordan River water in the area where this is used for irrigation. 


\title{
337. POTASH-BEARING EVAPORITE CYCLES IN THE SALT ANTIClINES OF THE PARADOX BASIN, COLORADO AND UTAH
}

\author{
By Robert J. Hite, Salt Lake City, Utah
}

\begin{abstract}
Potash was discovered in the Paradox basin of southeast Utah and southwest Colorado in 1924 (Dyer, 1945; p. 56), but the full extent and richness of the deposits were not recognized until the last decade when improved logging techniques and more closely spaced drill holes enabled a more complete investigation of the deposits.
\end{abstract}

The potash deposits occur in the "saline facies" of the Paradox member of the Hermosa formation of Pennsylvanian age. The areal extent of the "saline facies" in the Paradox basin is about 11,000 square miles and nearly two-thirds of this area is underlain by potash deposits (fig. 337.1).

The "saline facies" originally may have been about 7,000 feet thick, but locally it is now greatly thickened in intrusive salt anticlines in some of which as much as 14,000 feet of saline rocks have been drilled.

A recent detailed study of the stratigraphy of the "saline facies" resulted in an informal system of nomenclature in which the halite units of the evaporite cycles are distinguished numerically (Hite, 1960). This system is used by the writer in the correlation of potash deposits, which are widely distributed in the salt basin.

The "saline facies" consists of at least 29 evaporite cycles. Each cycle, if complete, in ascending order of deposition consists of : (1) limestone, (2) dolomite, (3) anhydrite, and (4) halite with or without potash salts. The sequence is then repeated in a reverse order of: (3) anhydrite, (2) dolomite, and (1) limestone to complete the cycle (fig. 337.2). Potash-bearing cycles generally exhibit an asymmetrical form with the potash occurring near the top of unit 4 . Units 1,2 , and 3 of each cycle include some clastic material that commonly is euxinic black shale, mudstone, and siltstone. A complete vertical succession in any one cycle is not everywhere present because of a lateral gradation from a super-saline or saline facies in the basin deep to a limestone facies on the basin shelf (fig. 337.2). Thus, in the basin deep (line $X$ of fig. 337.2) only units 3 and 4 may be present; while at some point intermediate between the basin deep and basin shelf (line $Y$ of fig. 337.2 ) all units may be present and the vertical succession is complete.

In about 18 of the 29 evaporite cycles, chemical sedimentation proceeded to the point of potash precipitation. Of these 18 cycles, 11 contain potentially valuable potash deposits. These are found in salt beds $5,6,9,13,16,18,19,20,21,24$, and 27 of Hite (1960). In several of these cycles the average content for specific intervals of some deposits may exceed 30 percent $\mathrm{K}_{2} \mathrm{O}$. Only two potash salts, sylvite $(\mathrm{KCl})$ and carnallite $\left(\mathrm{KCl} \cdot \mathrm{MgCl}_{2} \cdot 6 \mathrm{H}_{2} \mathrm{O}\right)$, are present in large quantities. Minor amounts of polyhalite $\left(2 \mathrm{CaSO}_{4}\right.$. $\left.\mathrm{MgSO}_{4} \cdot \mathrm{K}_{2} \mathrm{SO}_{4} \cdot 2 \mathrm{H}_{2} \mathrm{O}\right)$, kieserite $\left(\mathrm{MgSO}_{4} \cdot \mathrm{H}_{2} \mathrm{O}\right)$, and rinneite $\left(\mathrm{FeCl}_{2} \cdot 3 \mathrm{KCl} \cdot \mathrm{NaCl}\right)$ have been reported.

Many of the potash deposits are extensive. Perhaps the most noteworthy of these is the deposit in salt bed 19. This deposit has been traced from Crescent Junction, Grand County, Utah, in the northwestern end of the salt basin to northern Montezuma County, Colo.a distance of nearly 110 miles-and may prove to be one of the thickest in the world. In the northwestern part of Moab Valley anticline (fig. 337.1), where the salt structure is nonintrusive, the potash deposit is 420 feet thick, and consists mostly of carnallite and halite. However, the deposit shows lateral changes in mineralogy as the carnallite gives place to sylvite (fig. 337.3, p. D-138). The presence of this deposit in an area extending from Cane Creek anticline to Salt Valley anticline (fig. 337.3) solves an enigma which has discouraged prospecting in the Salt Valley anticline area for many years. The thick deposit of potash found in the Defense Plant Corporation Reeder well 1 previously was considered a secondary thickening or enrichment brought about by salt flow in the salt anticline. Such an origin can now be ruled out because the deposit shows thickness and mineralogic chbracteristics that are similar throughout a large surrounding area.

The potash deposits of the "saline facies" are found at depths ranging from 1,700 to 14,000 feet below the surface. At present they are minable only in salt anticlines. Recent exploration has been concentrated on nonintrusive folds such as the Cane Creek anticline, the northwestern part of Moab Valley anticline, and Lisbon Valley anticline (fig. 337.1). Data on these structures are fairly complete, and at the Cane Creek anticline the first shaft in the potash field is expected to be started sometime in 1961.

In the nonintrusive salt anticlines the minimum depths to the top of the salt range from 1,600 to 2,400 feet and depths to the uppermost potash deposits of economic importance may range from 1,800 to 4,000 


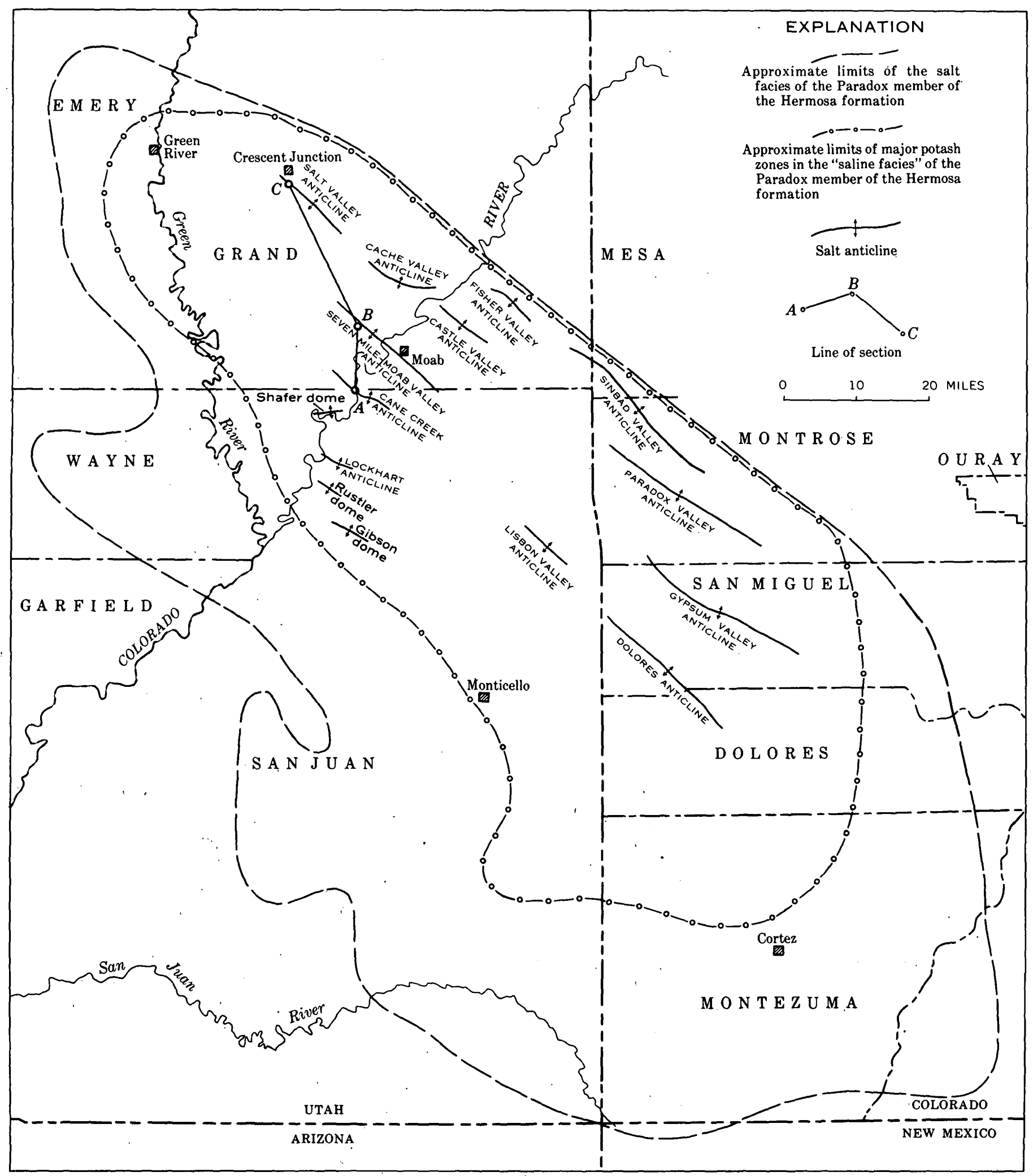

FraUre 337.1.-Distribution of halite and potash in the Paradox basin. 


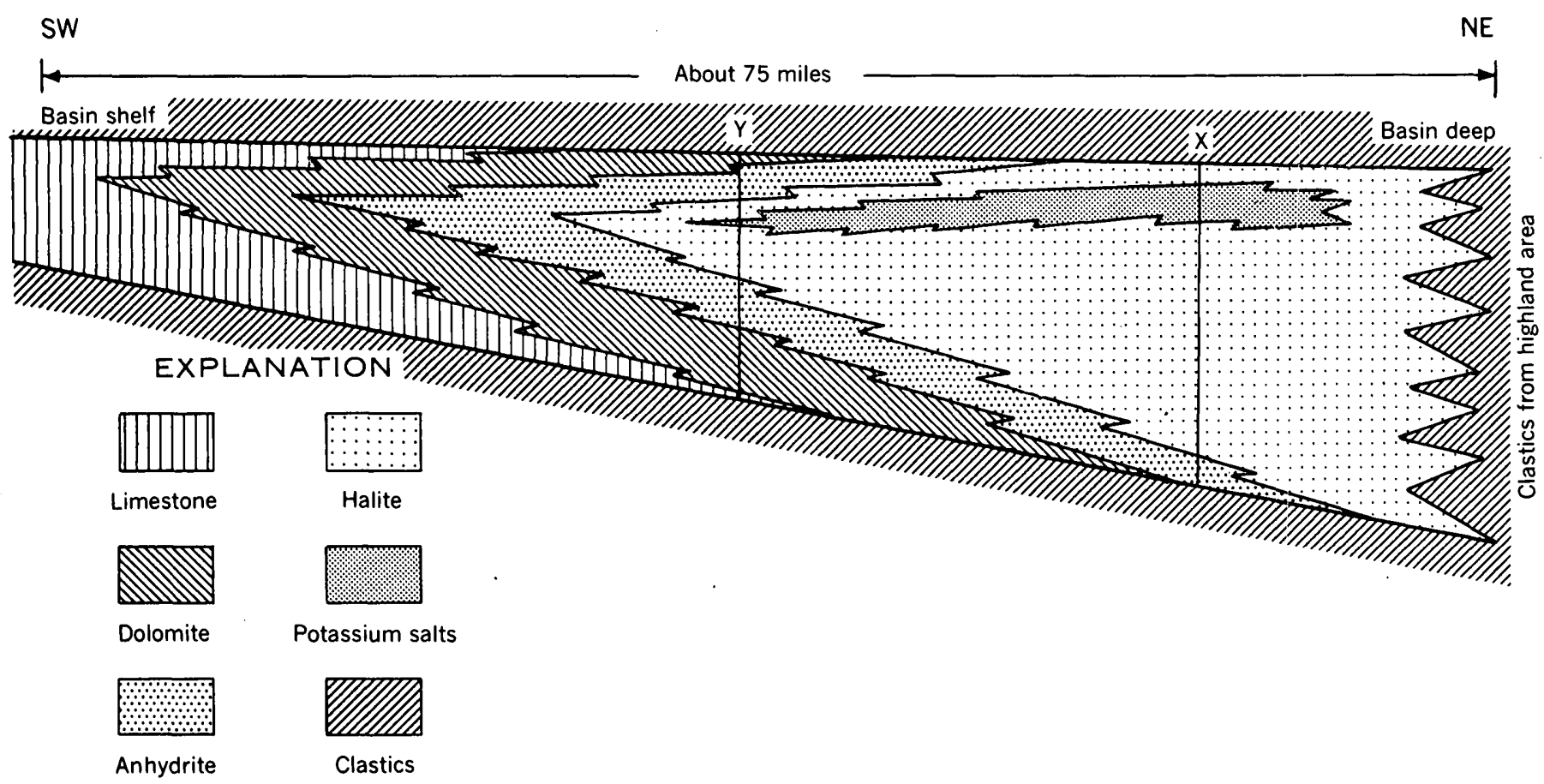

Froure 337.2.-A schematic section through an evaporite cycle of the Paradox member of the Hermosa formation.

(Lines $X$ and $Y$ are described in text.)

feet. The potash deposits of salt beds 5 and 9 appear most favorable for exploitation. On the Cane Creek anticline, mine development will probably proceed in these two deposits between the depths of 2,400 and 3,500 feet.

Drill-hole information concerning intrusive salt anticlines, however, is meager and most of it has come from oil and gas test wells. Several potash test holes were drilled on the Salt Valley anticline but unfortunately no gamma ray-neutron logs were obtained except from the Defense Plant Corporation well. Such logs are necessary to provide adequate stratigraphic control for correlation between holes.

In the intrusive salt anticlines the "saline facies" is near the surface; the uppermost salt bed may be less than 500 feet deep. The relatively thick and highgrade potash deposits in salt beds, 18, 19, 20, and 21 . although beyond the reach of present conventional mining methods in the nonintrusive structures, are upfolded within the intrusive anticlines to more favorable depths.

Variable degrees of salt dissolution and removal are evident in nearly all of the salt anticlines. In the nonintrusive structures dissolution has removed as much as 1,500 feet of salt. In the intrusive salt anticlines the effect of salt solution may be even more pronounced. Thus, by a combination of structural elevation and salt dissolution, a potash deposit low in the "saline facies" may be brought near the surface. Such deposits might well be found at depths of less than 500 feet.

Recognition of widespread units in the "saline facies" of the Salt Valley anticline indicates that the potash deposits in this and other intrusive salt anticlines probably occur as identifiable continuous bodies. These bodies would no doubt show a high degree of crenulation and faulting. In this respect the intrusive salt anticlines of the Paradox basin are probably similar to the salt stocks of Germany where stratigraphic sequences are recognizable in spite of intense tectonic deformation, and where potash salts have been successfully mined for more than a century.

\section{REFERENCES}

Dyer, B. W., 1945, Discoveries of potash in eastern Utah: Am. Inst. Mining Metall. Engineers T'ech. Pub. 1755, Mining Technology, v. 9, no. 1, p. 56-61.

Hite, R. J., 1960, Stratigraphy of the saline facies of the Paradox member of the Hermosa formation of southeastern Utah and southwestern Colorado, in. Four Corners Geol. Soc. Guidebook Field Conf. no 3 , Geology of the Paradox basin fold and fault belt, 1960 : p. 86-89. 


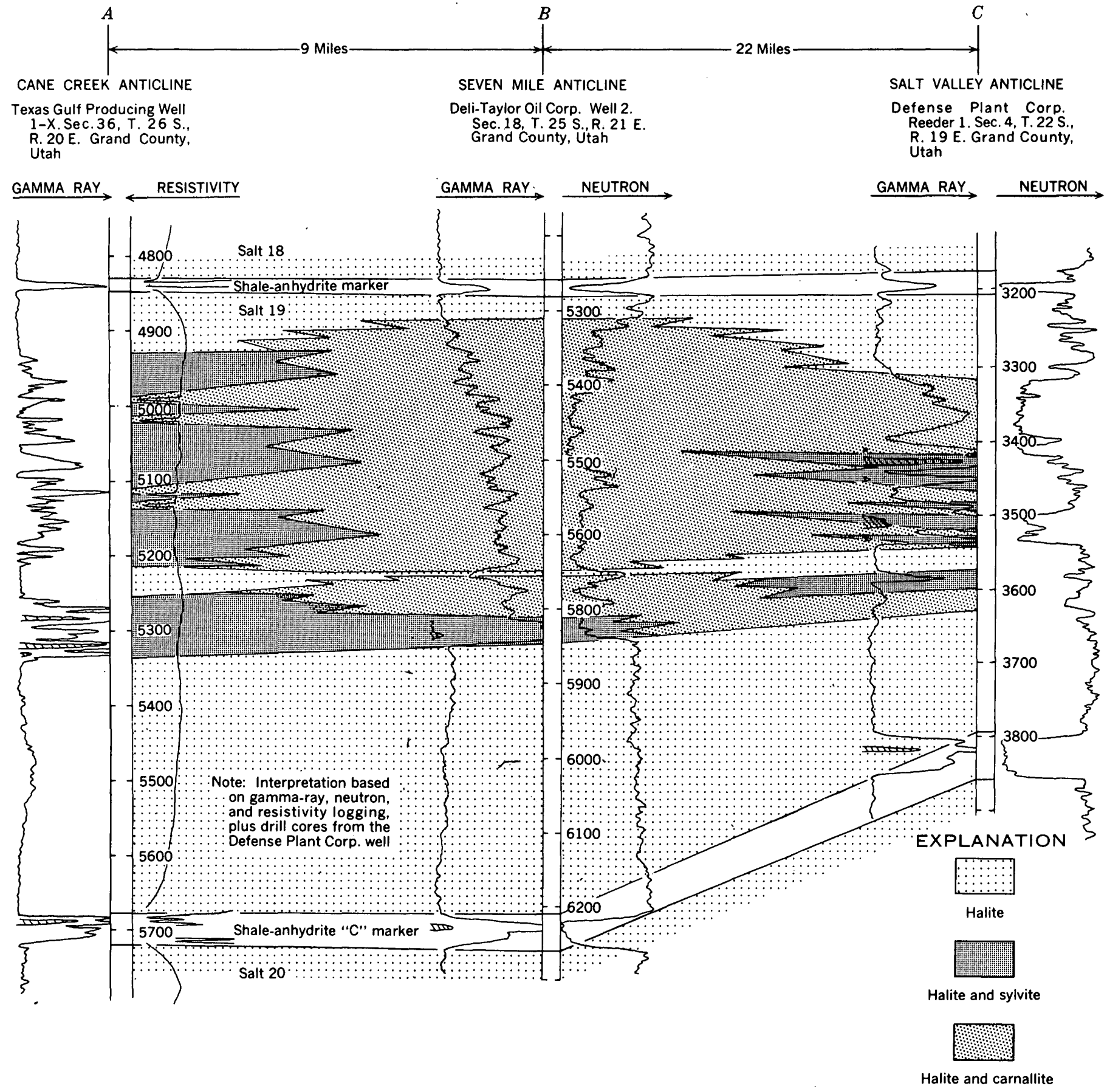

Figure 337.3.-Potash-bearing evaporite cycle of the Paradox member "saline facies". Datum is mean sea level. 


\section{CRETACEOUS ROCKS IN LEA COUNTY, NEW MEXICO}

By Sidney R. Ash and Alfred Clebserh, Jr., Albuquerque, N. Mex., and Washington, D.C.

Work: done in cooperation with the State Engineer of New Mexico and the New Mexico Institute of Mining and Technology, State Bureau of Mines and Mineral Resources Division

Rocks of Cretaceous age are exposed at only two localities in Lea County, but their subsurface distribution is extensive. The outcrop at North Lake (fig. 338.1) has been known for many years (Theis, 1934, p. $147 ; 1938$, p. 124 ; Conover and Akin, 1942, p. 285288; Lang, 1947, p. 1476; and Dane and Bachman, 1958), but it has not been related to the Cretaceous rocks in the subsurface. The Cretaceous rocks near Eunice were uncovered in the course of quarrying gravel from a pit about 3 miles east of town; apparently they have not been described previously.

\section{EXPOSURES}

The Cretaceous rocks exposed at North Lake consist of dark-gray siltstone and thin interbedded stringers of limestone (fig. 338.2). Several of the limestone stringers wedge out laterally into siltstone. In the lower part of the section that was measured the stringers are light-brown crystalline limestone; in the upper part of the section they are light gray and fine grained. Both the siltstone and limestone weather yellow.

The fossils listed below were collected from the outcrop in sec. 32, T. 10 S., R. 34 E., north of the section shown on figure 338.2 and were identified by $\mathrm{T}$. W. Stanton (written communication, 1935) :

Gryphaea corrugata Say

Exogyra texana Roemer

Plicatula cf. incongrua Conrad

Exogyra plexa Cragin

Pecten (Neithea) texanus Roemer?

Serpula(?) sp.

These fossils indicate that the enclosing rocks are of Early Cretaceous age.

Exogyra texana, Gryphaea corrugata, and Plicatula sp. have been found in the Tucumcari shale in eastcentral New Mexico (Dobrovolny and Summerson, 1946). On the basis of the similarity of the fossil assemblage and lithology, the rocks at North Lake are correlated with the Tucumcari shale.

At the other exposure, which is 3 miles east of Eunice in the SW1/4. sec. 29 , T. 21 S., R. 38 E., randomly oriented blocks of limestone 3 to 5 feet thick and as much as 20 feet long have been uncovered in a gravel pit (fig. 338.3).
The limestone is thick bedded to massive and is white, light gray, or buff; at places it weathers yellowish brown; it is fossiliferous, compact, moderately hard, and chalky. Some layers that consist mostly of fossil fragments also contain sand. The bedding planes are wavy and a few are marked by shaly partings. The upper surfaces of these blocks are smoothed and rounded, as if by sediment-laden water, and at places the abraded areas extend down into cracks along joints.

Fossils in the limestone are difficult to remove from the matrix. The fossils have not been identified, but several genera of pelecypods and one or two genera of gastropods have been observed. Some lenses consist largely of fragments apparently derived from small individuals of Gryphaea.

Brand (1953, p. 28) described similar limestones at McKenzies Lake and Cedar Lake in eastern Gaines County, Tex., about 50 to 60 miles northeast of the Eunice locality, which he correlated with the Comanche Peak limestone of the Fredericksburg group of Early Cretaceous age on the basis of fossil evidence. The lithology of some of the units of the Comanche Peak at Cedar Lake is strikingly similar to that of the limestone blocks in the gravel pit, which, therefore, are believed to be equivalent to the Comanche Peak.

Poorly cemented sandstone and conglomerate are associated with the limestone blocks and are exposed in three other pits nearby. Some of these rocks possibly are of Cretaceous age also, but they are barren of fossils and are similar to the Ogallala formation of Pliocene age, which underlies much of the surrounding area.

Stratigraphic relations are obscure; at some places the limestone blocks rest directly on the Chinle formation of Late Triassic age, but many of the blocks are covered, and apparently are underlain, by sand and gravel.

Figure 338.3 shows most of the evidence bearing on the origin of the residual blocks, and indicates that the blocks probably were preserved from pre-Ogallala erosion in a collapse or subsidence depression in the red-beds surface. However, the blocks could have slumped into a narrow pre-Ogallala valley cut through the Cretaceous rocks and into the Triassic rocks. The alluvium-filled fissure near the right side of figure 338.3 


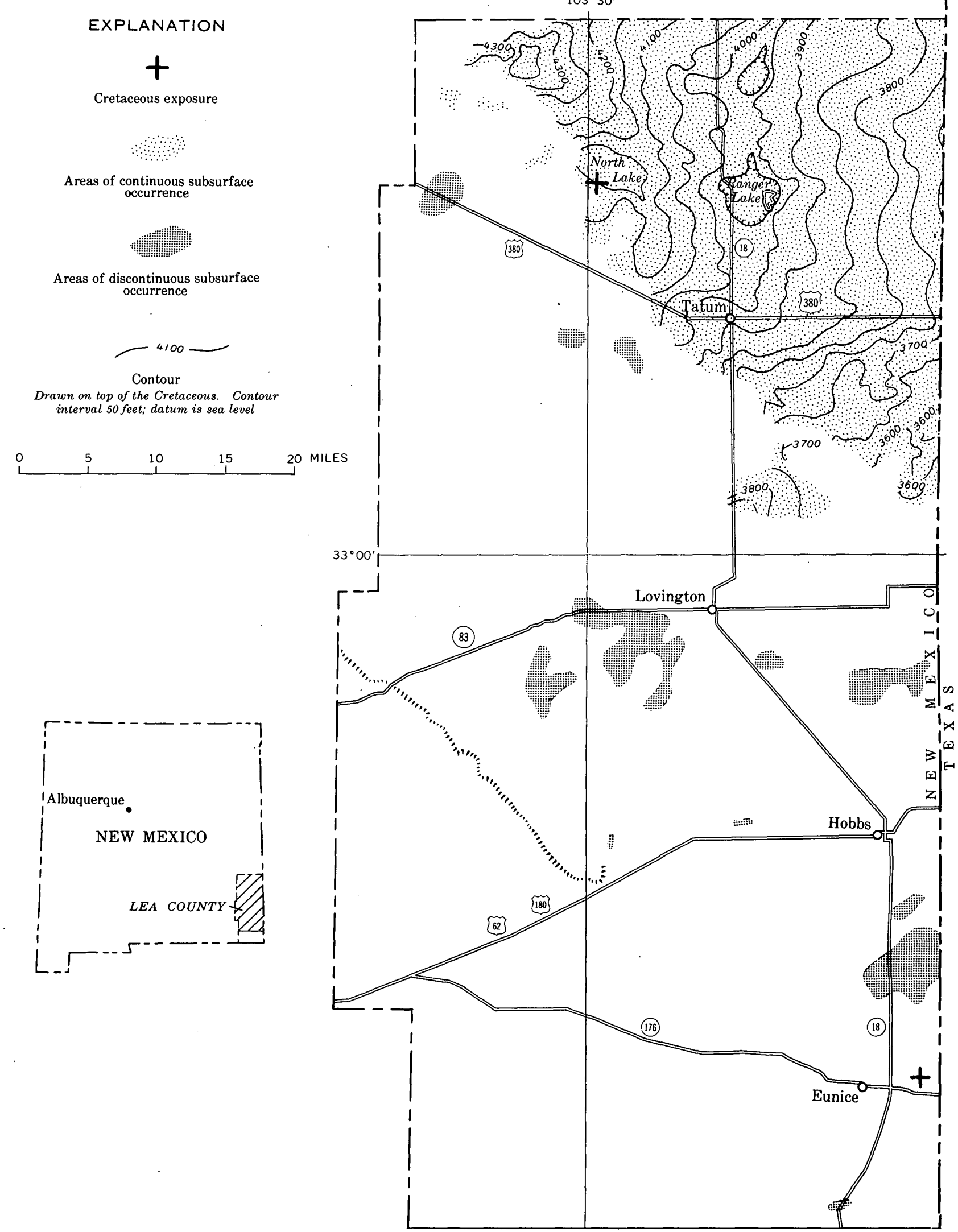

Figure 338.1.-Distribution of Cretaceous rocks in Lea County, N. Mex., based on 8,000 logs of water-wells and seismic shotholes provided by the State Engineer Office, and by oil and geophysical exploration companies. 


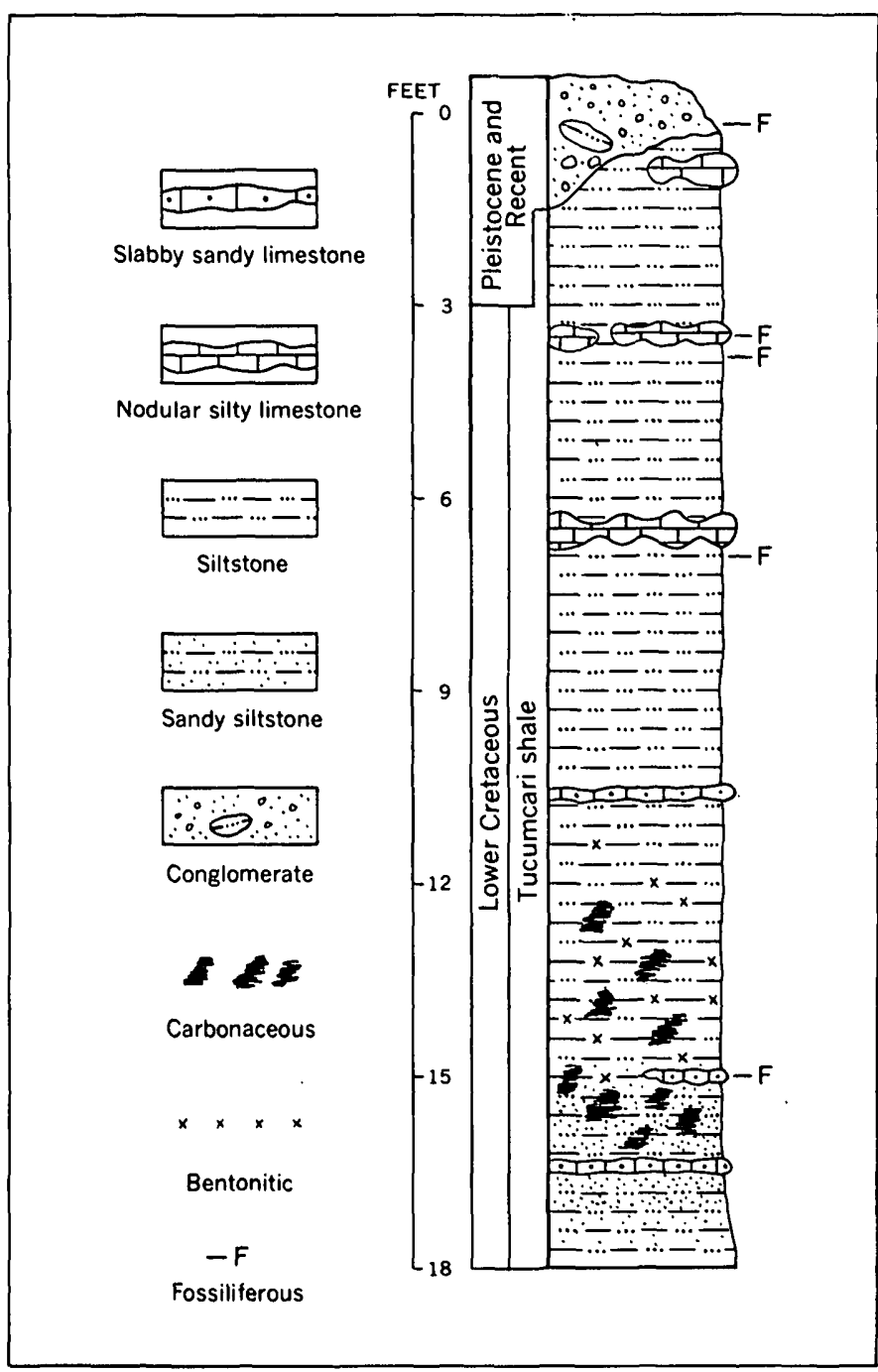

Frouke 338.2.-Composite stratigraphic section of rocks exposed on the west side of North Lake, sec. 3, T. 11. S., R. 34 E.

suggests that slumping or collapse also occurred after Ogallala deposition which strengthens the collapsedepression hypothesis.

\section{SUBSURFACE OCCURRENCE}

The principal criteria for determining the distribution of Cretaceous rocks in the subsurface (fig. 338.1) consist of references in drillers' logs to 5 feet or more of "yellow," "blue," or "gray" clay or shale, which are not descriptive of other units in the area. In some places descriptions of geologists' samples and the occurrence of fossils in drill cuttings have strengthened the interpretations. Some of the drillers' logs list limestone or sandstone with the clay or shale. Many logs indicate gravel or coarse sand between the recognizable Cretaceous rocks and the Triassic rocks. Except for the sand and gravel, the drillers' logs are consistent with the description of rocks at North Lake; therefore, the sub- surface rocks are assigned tentatively to the Tucumcari shale. Although the sand and gravel may represent Trinity or lower Fredericksburg rocks, they are assigned tentatively to the Tucumcari shale.

The main body of the Tucumcari shale lies unconformably on the eastward dipping red shales of the Chinle formation of Late Triassic age. It is nearly horizontal, and is overlain unconformably by the Ogallala formation and by sand, soil, and alluvium of Quaternary age. The erosional unconformity at the base of the Ogallala dips eastward at about 10 feet per mile, which is a little less than the slope of the land surface.

There are two large depressions in the surface of the main body of the Tucumcari shale north of Tatum, the southernmost of which is beneath the land surface depression that contains Ranger Lake. The closed depressions in the top of the Tucumcari suggest subsidence after deposition.

The main body of the Tucumcari shale ranges in thickness from 0 to nearly 200 feet but generally ranges between 50 and 100 feet. It is thickest in the northeastern part of the county and thins gradually to the west, pinching out along an irregular line from T. 9 S., R. 33 E. to T. 14 S., R. 38 E. Incumplete data suggest that the Tucumcari shale thickens beneath the depressions. The four small areas of subsurface occurrence of Tucumcari shale west and south of the main body (fig. 338.1) are relatively thin, ranging in thickness from 0 to 50 feet and averaging about 20 feet.

South of the areas in which the Tucumcari shale can be mapped as a continuous deposit are several areas of

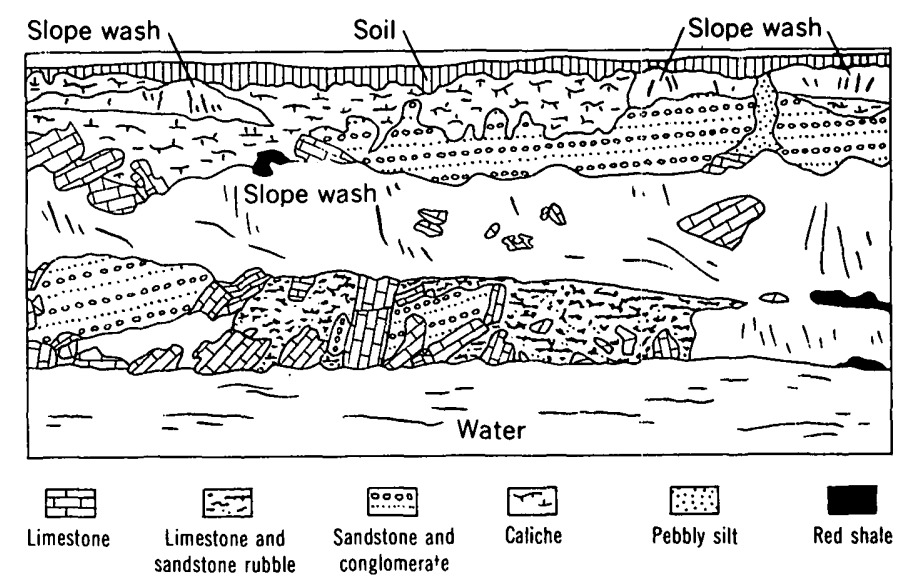

FIGURE 338.3. - Sketch of the rocks exposed in the north wall of a gravel pit in the SW $1 / 4$ sec. 29 , T. 21 S., R. 38 E., east of Eunice, N. Mex. The red shale is the upper 'Triassic Chinle formation; the limestone is the Cretaceous Comanche Peak limestone; the sandstone, conglomerate, and caliche are probably the Pliocene Ogallala formation; and the pebbly silt and soil are of Pleistocene or Recent age. From photograph by Alfred Clebsch, Jr. 
discontinuous or sporadic occurrence of Cretaceous rocks. The thicknesses reported range from about 5 feet to a little more than 100 feet. The average thickness in the large areas near Lovington and Hobbs is between 20 and 60 feet. Most of these areas contain shotholes for which the drillers did not note the diagnostic colors and rock types. However, this may reflect only the wide range in accuracy and quality of the drillers' logs. Cretaceous rocks may actually be somewhat more widespread in the subsurface than shown on figure 338.1, judging by the logs of isolated wells and shotholes, but the data are too scarce to outline additional areas.

In the southernmost subsurface outlier as shown on figure 338.1 and in a few wells 2 to 5 miles north of Hobbs, drillers have reported 5 to 20 feet of hard limestone or "hard gray rock", which might be the equivalent of the limestone exposed east of Eunice.

\section{REFERENCES}

Brand, J. P., 1953, Cretaceous of Llano Estacado of Texas: Texas Univ. Bur. of Econ. Geology Rept. Inv., 20, 55 p.

Conover, C. S., and Akin, P. D., 1942, Progress report on the ground-water supply of northern Lea County, New Mexico: New Mexico State Engineer 14th and 15th Bienn. Repts., 1938-42, p. 285-309.

Dane, C. H., and Bachman, G. O., 1958, Preliminary geologic map of the southeastern part of New Mexico: U.S. Geol. Survey Misc. Geol. Inv. Map I-256.

Dobrovolny, Ernest, and Summerson, C. H., 1946, Geology of northwestern Quay County, New Mexico: U.S. Geol. Survey Oil and Gas Inv. Prelim. Map 62.

Lang, W. B., 1947, Occurrence of Comanche rocks in Black River Valley, New Mexico: Am. Assoc. Petroleum Geologists Bull., v. 31, no. 8, p. 1472-1478.

Theis, C. V., 1934, Progress report on the ground-water supply of Lea County, New Mexico: New Mexico State Engineer 11th Bienn. Rept., 1932-34, p. 127-153.

1938, Progress report on the ground-water supply of Lea County, New Mexico: New Mexico State Engineer 12th and 13th Bienn. Repts., 1934-38, p. 121-134.

339. DISTRIBUTION OF MOISTURE IN SOIL AND NEAR-SURFACE TUFF ON THE PAJARITO PLATEAU, LOS ALAMOS COUNTY, NEW MEXICO

By John H. Abrahams, Jr., James E. Weir, Jr., and William D. Purtymun, Albuquerque, N. Mex.

Work done in cooperation with the U.S. Atomic Energy Commission

The Pajarito Plateau adjoins the steep eastern flanks of the Sierra de los Valles in north-central New Mexico. It has been dissected by eastward-flowing streams into several fingerlike mesas. The plateau is underlain by pumice deposits, ash falls, and ash flows that were ejected from a large volcanic vent to the west. Ash flows that cap the plateau are welded rhyolite tuff. Soil on the middle part of the mesas is well developed on the flat uplands and is thought to be derived largely from tuff weathered in place. Three zones are recognizable: An A zone from which most of the clay has been leached, a $\mathrm{B}$ zone containing montmorillonite, and a $\mathrm{C}$ zone (transitional from soil to tuff) with a high clay content. The zone of saturation is more than 1,000 feet beneath the surface of the plateau in the areas studied (fig. 339.1).

Measurements of the rate and amount of water movement and of moisture content of the soil and tuff, both under natural conditions and in controlled infiltration experiments, were made as an essential part of studies

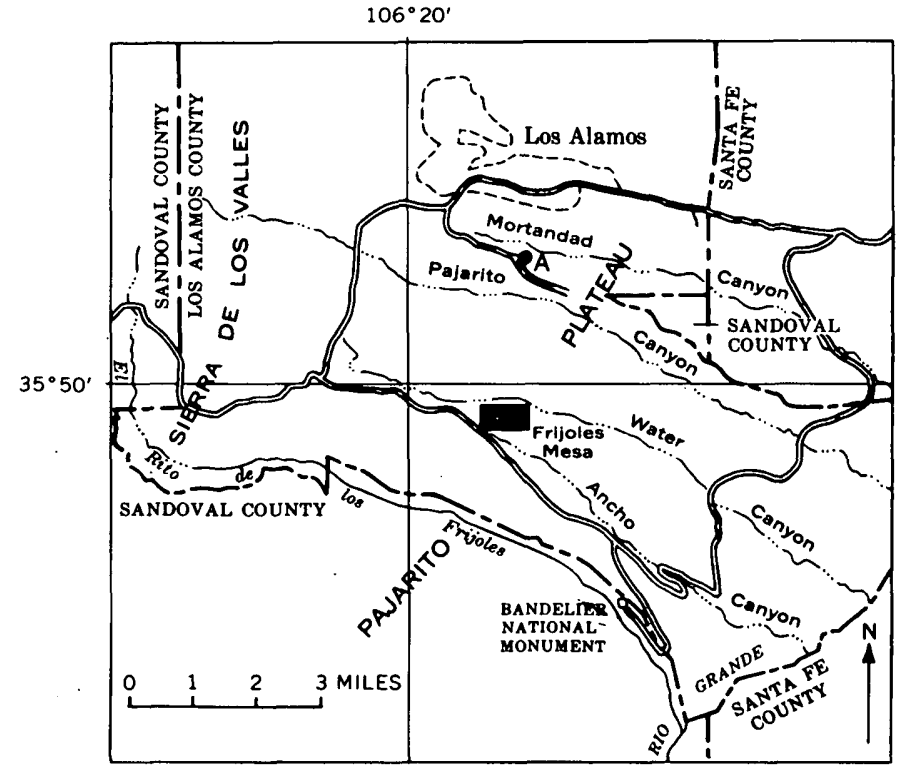

Frgure 339.1.-Pajarito Plateau, N. Mex., showing area of moisture studies (shaded). 
of aqueous movements of radioactive substances originating from liquid wastes or from leachable radioactive solids. These measurements were made as a part of the program with the Los Alamos Scientific Laboratory.

A neutron-scattering moisture probe was inserted into test holes cased with 2-inch plastic pipe to determine the moisture content of the rock and soil. The measurements were checked against laboratory determinations of moisture drill in cores. 'The moisture contents determined with the probe appeared to be about 1 to 2 percent higher than those made in the laboratory.

\section{NATURAL DISTRIBUTION OF MOISTURE}

Twenty-three test holes were drilled on Frijoles Mesa and moisture measurements were made in the spring, summer, and fall of 1960 to study natural infiltration in the soil and tuff. In general, the moisture content was found to increase from the surface to a depth of 2 to 3 feet, then decrease to a depth of 4 to 12 feet, and remain relatively constant at greater depths. There were some variations, however, that were apparently related to drainage and soil thickness. Data from the 23 test holes are summarized in the adjacent table.

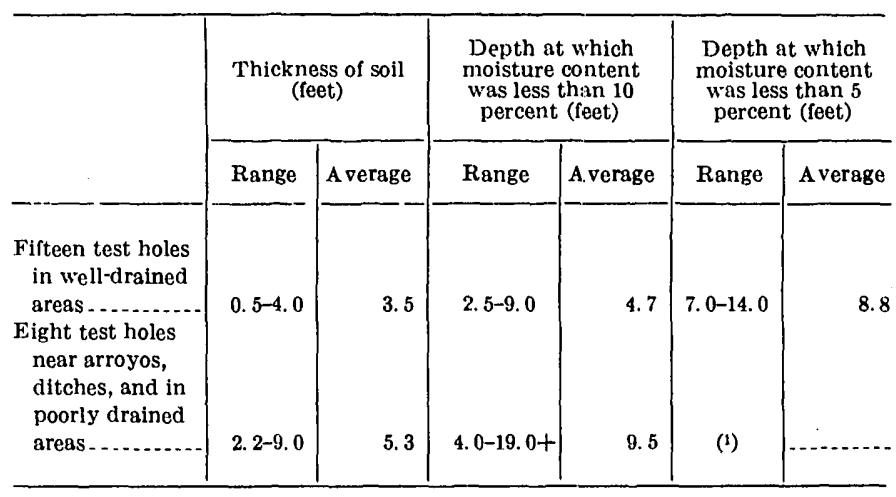

1 Moisture content does not decrease to 5 percent; the holes range in depth from 19 to 49 feet.

The moisture content in the upper 5 or 6 feet was highest in March and April, as a result of late winter snow; it decreased to a minimum in October, owing to the high evapotranspiration rate during the summer and early fall.

Test-hole $5 \mathrm{M}-2$ (fig. 339.2 ) is representative of the test holes in well-drained areas. Moisture measurements show that below a depth of 6 feet the moisture

\section{MOISTURE CONTENT, IN PERCENT BY VOLUME}
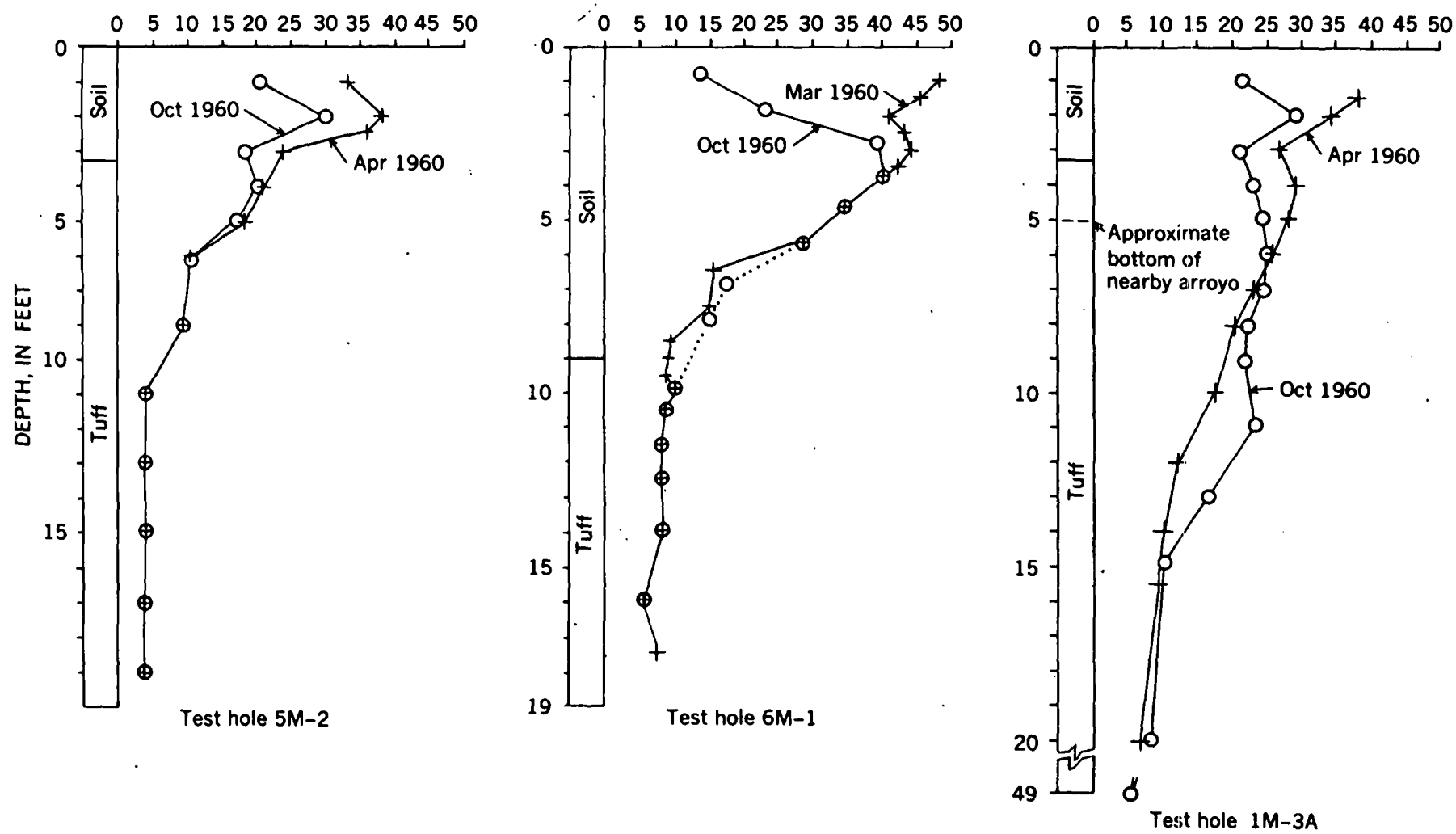

Figure 339.2.-Moisture measurements in selected test-holes on Frijoles Mesa, Los Alamos County, N. Mex. 
content of the tuff remained unchanged and below 10 feet it was less than 4 percent.

Test holes near arroyos, ditches, and in poorly drained areas that received or retained water during periods of storm runoff are represented by test-holes $6 \mathrm{M}-1$ and $1 \mathrm{M}-3 \mathrm{~A}$ (fig. 339.2). Although moisture measurements in test-hole $6 \mathrm{M}-1$ suggest a small increase in moisture content between about 6 and 10 feet in depth between March and October, they merely reflect the fact that measurements in this interval were made at slightly different depths. Thus, additional points on the October curve probably would have resulted in a curve that more nearly duplicated the March curve. In hole $6 \mathrm{M}-1$ the moisture content below a depth of about 4 feet remained nearly the same, and the moisture content in the tnff ranged from 6 to 10 percent during both periods.

Construction near test-hole $1 \mathrm{M}-3 \mathrm{~A}$, on the bank of an arroyo, caused water to pond 2 to 4 inches deep several feet from the test-hole during wet periods. The ponded water percolated through the thin soil and sand in the bed of the arroyo and moved downward and laterally into the tuff as shown by the increase of moisture from 12 percent to 17 percent at a depth of
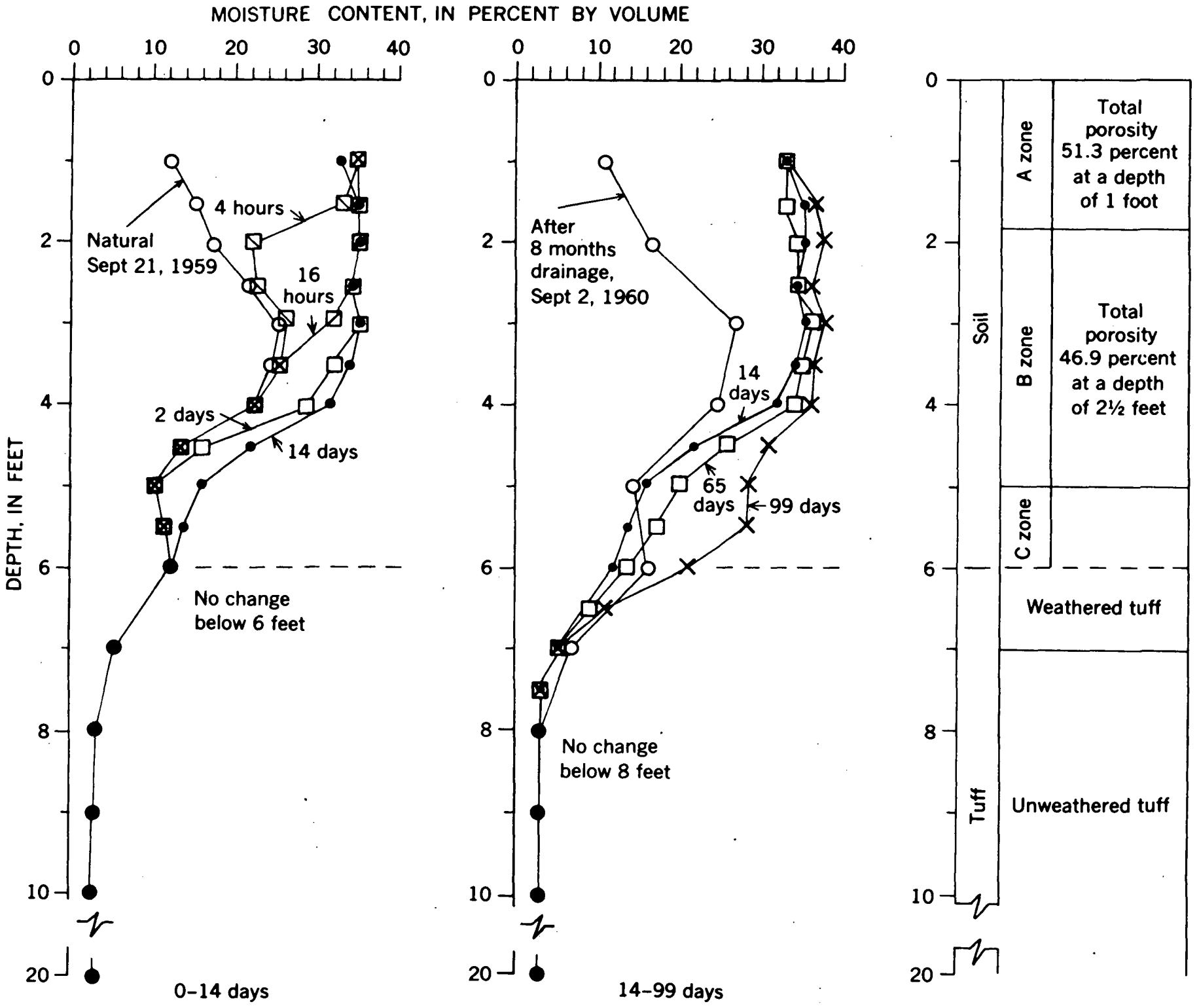

Figure 339.3.-Changes in moisture content beneath the infiltration pit at site A during 99 days of continuous infiltration, September 21 through December 29, 1959, and subsequent drainage for 8 months, Los Alamos County, N. Mex. Estimated rates of infiltration: 2nd day, 24 gallons per day per square foot; 10 th day, 10 gpd per $\mathrm{ft}^{2}$; 20 th day, 6 gpd per $\mathrm{ft}^{2}$. 
6 to 13 feet (fig. 339.2). Between 13 and 20 feet a small increase in moisture content is suggested, but between 20 and 49 feet the moisture content remained about 6 to 8 percent.

\section{INFILTRATION EXPERIMENT}

At site A (fig. 339.1) an infiltration pit 2 feet in diameter by 1 foot deep was constructed during September 1956. The soil is similar to that on Frijoles Mesal it is about 6 feet thick and is underlain by welded tuff. The area is moderately well drained. A test-hole 20 feet deep was drilled in the center of the infiltration pit and a 2 -inch plastic pipe was installed so that it projected about 1 foot above the pit. Soil and tuft were packed around the casing to prevent seepage down alongside the casing. Moisture measurements were made prior to application of water. Water was introduced into the pit and a constant head mainrained at three-quarters of a foot for 99 days.

The wetted front (fig. 339.3) moved to a depth of about $4 \frac{1}{2}$ feet during the first 2 days of infiltration and to a depth of about $61 / 2$ feet during the next 97 days, but water did not move through the transition zone into the tuff, except in the lower moisture range. The moisture content decreased with depth from a maximum of about 38 percent in the $B$ zone of the soil to less than 4 percent within a foot of the surface of the tuff.

Water: apparently was perched on the $C$ zone of the soil and the moisture content within the $B$ zone ap- proached saturation. After the first several days of infiltration, most movement of water probably was lateral, as indicated by measurements in a series of holes around another infiltration pit nearby. Some water undoubtedly was lost by evaporation and transpiration.

Although the quantity of water used during the study was equivalent to almost 50 years of precipitation on the Pajarito Plateau, the moisture content in the $A$ and $B$ zones had returned to nearly normal after 8 months of drainage; the moisture content in the $\mathrm{C}$ zone and top 2 feet of tuff was slightly higher than before the experiment, and the moisture content of the tuff between 8 and 20 feet was unchanged. However, conditions during this study cannot be considered normal because the clogging or silting of pores probably was greatly accelerated when this volume of water moved into the soil within a period of 99 days without the normal seasonal distribution which involves alternate percolation and drainage.

\section{CONCLUSIONS}

Although water not removed by surface drainage infiltrates into the soil of the Pajarito Plateau, this study indicates that the downward movement of this water is impeded or stopped by the dense transition zone between the soil and the tuff. Thus, it seems that where the normal soil cover is undisturbed, there would be little or no recharge to the zone of saturation from precipitation on the surface of the plateau.

340. STRUCTURAL EVOLUTION OF THE VALLES CALDERA, NEW MEXICO, AND ITS BEARING ON THE EMPLACEMENT OF RING DIKES

By R. L. Smith, R. A. Batley, and C. S. Ross, Washington, D.C.

The Valles caldera is located 50 miles northwest of Santa Fe, N. Mex., in the heart of the Jemez Mountains, a broad uplift composed of late Tertiary and Quaternary volcanic rocks that rest on igneous, metamorphic, and sedimentary rocks of Precambrian through Tertiary age. The volcanic rocks are of the alkali-calcic suite and range in composition from basalt, through andesite, dacite, rhyodacite, and quartz latite, to rhyolite. They cover an area of over 1,000 square miles and attain a maximum thicknes of at least 5,000 feet. Structurally, the volcanic rocks are situated on the western margin of the Rio Grande depression and are faulted progressively downward to the east by numerous northtrending faults.

In early Pleistocene time, after a period of quiescence and erosion, a series of catastrophic eruptions broke out in the center of the volcanic pile, and nearly 50 cubic miles of rhyolitic pyroclastic material in the form of ash flows poured, from vents now concealed, down canyons in the higher mountains and spread out as broad coalesced fans on the surrounding gentler slopes. The resulting deposits, now recognizable as sheets of welded tuff, attain a maximum thickness of 1,000 feet and constitute the larger part of the Bandelier rhyolite tuff 
(Smith, 1938). As a result of this tremendous outburst, the roof of the eviscerated magma chamber collapsed to form the Valles caldera (see Williams, 1941, p. 251-252).

Subsequent activity-the main concern of the present paper-was confined within the caldera. It included in succession (a) eruption of rhyolite flows and pyroclastics on the caldera floor; (b) arching of the caldera floor into a central structural dome; and (c) extrusion of a ring of volcanic domes peripheral to the structural dome.

\section{STRUCTURAI FEATURES}

The spatial relations of the intra-caldera units are shown on figure 340.1. The topographic rim of the caldera, slightly enlarged by erosion, is 12 to 15 miles in diameter. The ring faults bounding the subsided caldera block are largely covered by younger volcanics and alluvium, but existing exposures indicate that they constitute a complex fracture zone 2 to 3 miles wide. Inside this ring-fracture zone is a central, initially a fairly intact block, which now is arched into a steep-sided structural dome that is bisected by a northeast-trending graben and broken by numerous radial faults. The dome is a mosaic of blocks dipping radially as much as $25^{\circ}$, is 8 miles in diameter, and has 3,000 feet of structural and topographic relief. That this structural dome was produced by positive vertical uplift, not differential collapse, can be proved by abundant evidence, most important of which are: (a) tilted lake beds and alluvium initially deposited on the caldera floor are now exposed on the dome at elevations higher than the caldera rim; (b) prevolcanic sediments crop out 1,000 feet higher in the dome than in the caldera walls; (c) Bandelier rhyolite tuff (Smith, 1938) on the crest of the dome crops out 1,200 to 2,000 feet higher than remnants of tuff in the fault-beheaded valleys on the rim; and (d) Redondo Peak, the highest point on the dome, is 1,000 to 2,000 feet higher than peaks on the rim, yet is situated closest to the lowest segment of the rim.

Moreover, the structural pattern of the dome itself strongly supports an origin by means of vertical uplift. This pattern is a variant of one that has been mapped many times (Wisser, 1960) and has been reproduced in clay-cake experiments by $\mathrm{H}$. Cloos (1939) and others. It is considered compatible only with vertical forces, which cause radial and tangential tension over the surface of a dome owing to increase of its area. The floor of the Valles caldera was without doubt domed by such forces, either in response to hydrostatic readjustment in the partly emptied magma chamber (an explanation suggested by van Bemmelen $(1939$, p. 138) for similar features in the Toba depression) or owing to a resurgence of new magma from below which resulted in the intrusion of a stock or laccolith.

\section{POST-SUBSIDENCE VULCANISM}

The eruptive events associated with the formation of the Valles structural dome are depicted in figure 340.2. Following catastrophic eruption of the Bandelier rhyolite tuff (fig. 340.2A) and formation of the caldera by collapse, a group of early rhyolite lavas erupted along a northeast-trending zone on the caldera floor (fig. 340.2B). Shortly thereafter the center of the caldera floor began to rise, and simultaneously a group of middle rhyolite lavas erupted from the ringfracture zone northwest of the dome and also from within the graben forming along the crest of the dome (fig. 340.2C). The middle rhyolite northwest of the dome was interbedded with sediments (caldera fill) and tilted (fig. 340.1), whereas that in the graben was confined by faults and deformed as the graben deepened. Finally (fig. 340.2D), great volumes of viscous rhyolite erupted from the ring-fracture zone forming an almost complete ring of late rhyolite domes, many of which exceed 2 miles in diameter and rise 1,000 feet above the caldera floor.

The foregoing post-subsidence history, with minor modifications, appears to be common to a number of calderas, particularly those associated with large volumes of silicic welded tuffs. Van Bemmelen (1929, 1939) has described a similar sequence of structural doming and vulcanism in the Toba depression in northern Sumatra. The Rigis block, in the Gedongsoerian depression in southern Sumatra, also described by van Bemmelen $(1932,1935)$, has had a comparable history. In the San Juan Mountains, Colo., Steven and Ratté (1959) have recognized a structural dome within the Creede caldera, and Burbank and Luedke (Burbank, 1933; Burbank and Luedke, oral communication, 1960) have found evidence for a similar structure in the Silverton caldera. Cornwall and Kleinhampl (1960) postulate structural doming within a Tertiary caldera near Beatty, Nev. Of considerable importance also is the fact that B. C. King (1955) recognizes doming of the caldera floor in the Arran complex of Scotland.

\section{IGNEOUS RING COMPLEXES}

Granting that at least some igneous ring complexes are the subvolcanic equivalents of calderas as initially suggested by Clough, Maufe, and Bailey (1909), and that they are but members of a denudation series (Reynolds, 1956, Buddington, 1959), the central structural dome of the Valles caldera and its peripheral ring of volcanic domes may reasonably be considered the surficial equivalents of a central intrusion and an associated ring dike. Moreover, the close association in 


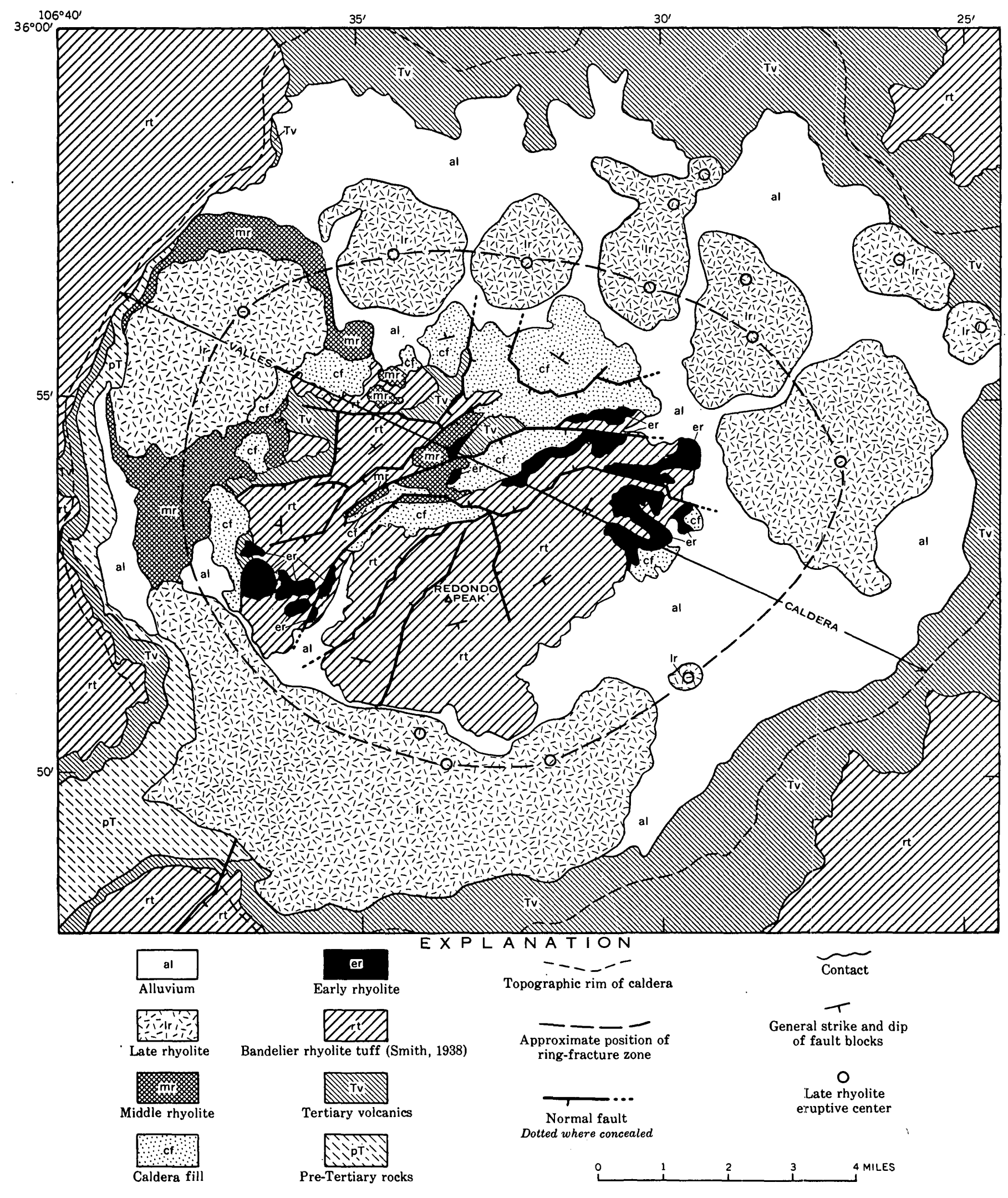

Figure 340.1.-Generalized geologic map of the Valles caldera, Jemez Mountains, N. Mex. 

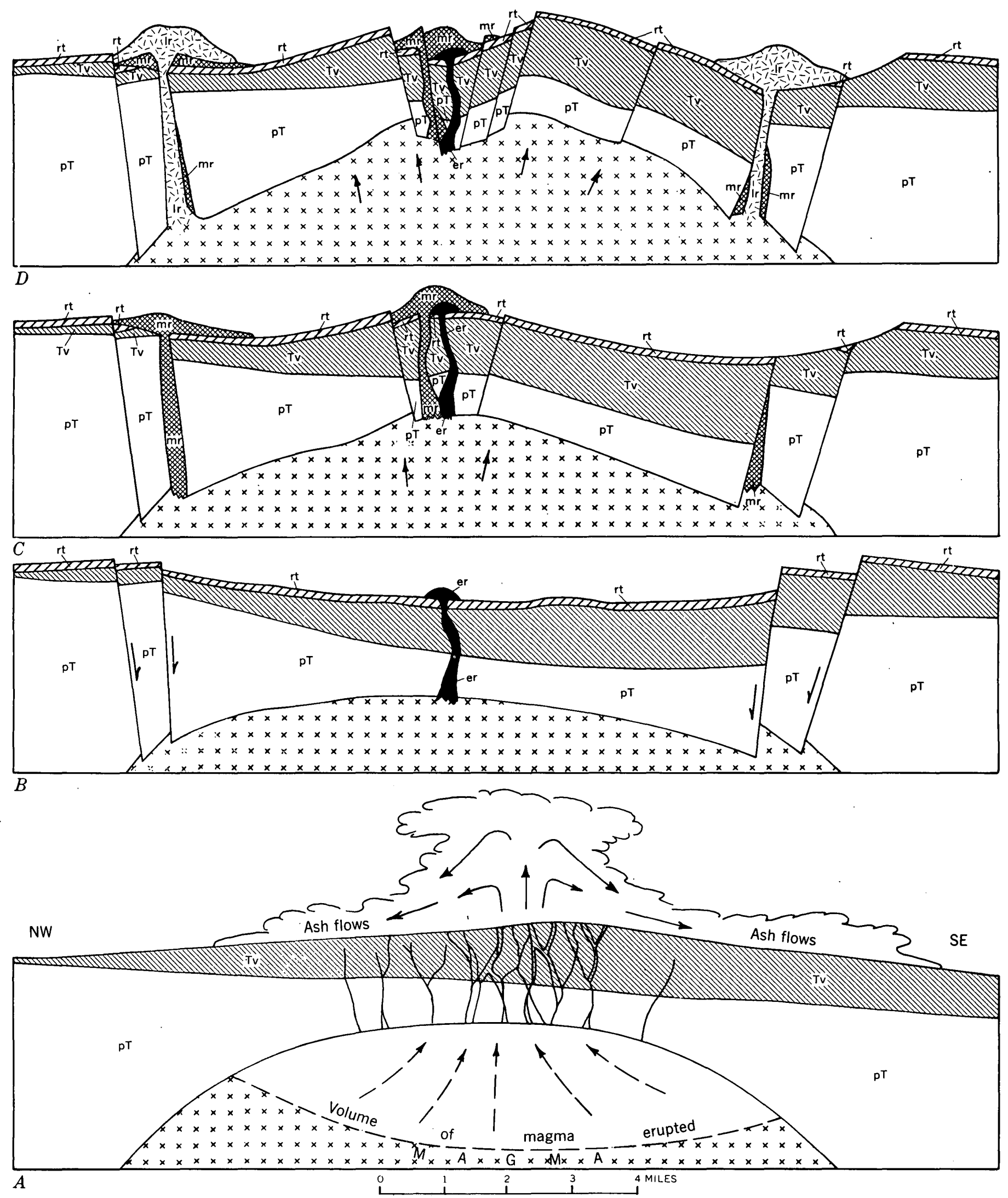

Figure 340.2.-Schematic sections showing the evolution of the Valles caldera (no vertical exaggeration). Patterns and symbols are the same as for figure 340.1 Caldera fill omitted for simplicity: 
time and space of structural doming and peripheral extrusion suggests that some ring dikes may be emplaced during uplift rather than during subsidence of the caldera floor, space for the ring dike being provided for by tensional reopening of the caldera ring fracture accompanying doming rather than by ring fracture or major stoping of the caldera block. In figure 340.3 the two contrasting mechanisms are compared schematically. The upper diagram, depicting the mechanism effective at the Glen Coe and Mull complexes in Scotland, shows cauldron subsidence and contemporaneous ring intrusion along shear fractures inclined away from the center of the complex (Anderson, 1936). The lower diagram of the Valles caldera shows ring intrusion, as inferred from vulcanism, occurring during postsubsidence doming of the caldera floor, space being provided by tensional reopening of the ring fracture. The inclination of the ring fracture in the Valles caldera is not known, but it is inferred to be vertical or to dip steeply inward.

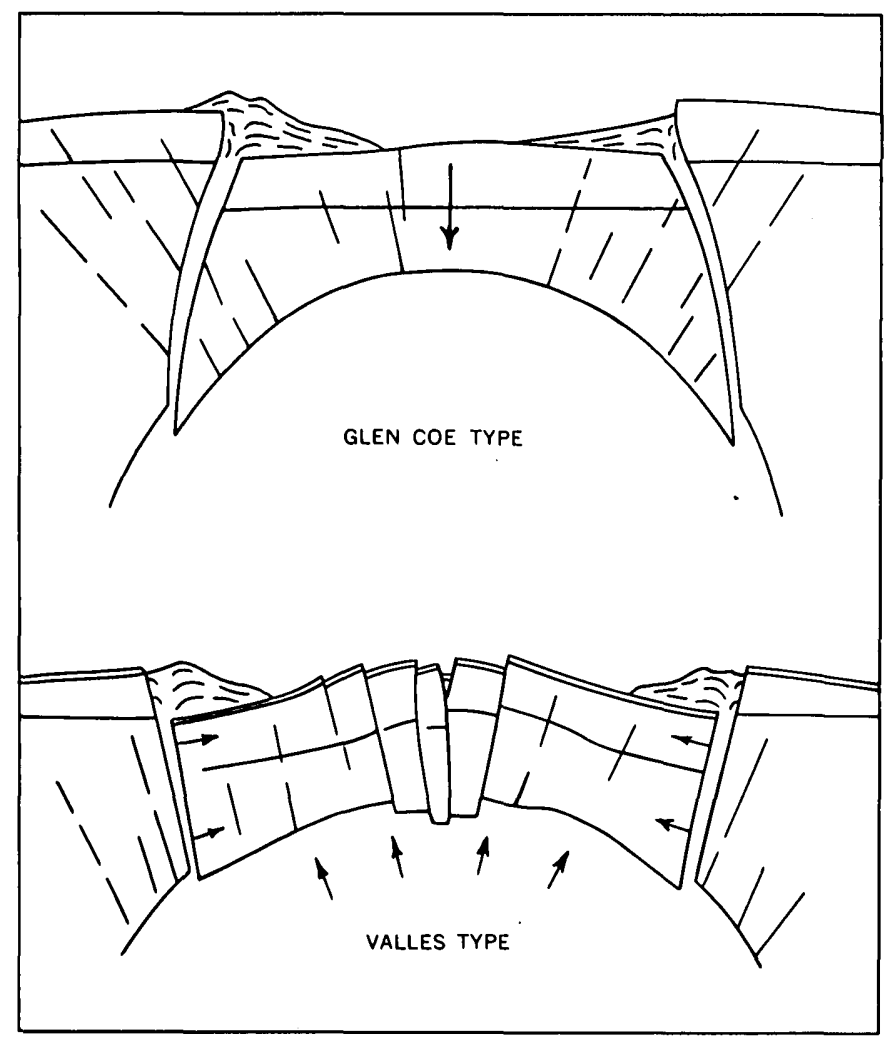

Froure 340.3.-Schematic sections contrasting the Glen Coe and Valles type calderas.
It cannot be refuted that ring-fracture stoping and major stoping are demonstrable mechanisms in many ring complexes, but it is suggested that some ring complexes, especially those with central intrusions, may have originated by the mechanism evident in the Valles caldera. A preliminary reexamination of the literature on ring complexes indicates that a number of complexes may be so interpreted.

\section{REFERENCES}

Anderson, E. M., 1936, The dynamics of the formation of cone sheets, ring dikes, and cauldron subsidences: Royal Soc. Edinburgh Proc., v. 56, p. 128-157.

Bemmelen, R. W., van, 1929, The origin of Lake Toba (North Sumatra); Pacific Sci. Congr. 4th (Bandoeng) Proc., v. 2A, p. $115-124$.

1932, De Undatietheorie: Natuurk. Tijdschr. Nederlandish-Indië, v. 92, p. 201-203.

- 1935, Vulkanotektonische depressies op Sumatra: Nederlandsch Natur. Geseek. Cong. (Leiden), hdl. 25e, p. 289-293.

__ 1939, The volcano-tectonic origin of Lake Toba (North Sumatra): De Ingenieur Nederlandsch-Indie, v. 6, p. 126-140.

Buddington, A. F., 1959, Granite emplacement, with special refer-

ence to North America: Geol. Soc. America Bull., v. 70, p. 671-748.

Burbank, W. S., 1933, Vein systems of the Arrastre Basin and regional geologic structure in the Silverton and Telluride quadrangles, Colorado: Colorado Sci. Soc. Proc., v. 13, p. 135-214.

Cloos, Hans, 1939, Hebung-Spaltung-Vulkanismus: Geol. Rundschau, v. 30 , p. $405-528$.

Clough, C. T., Maufe, H. B., and Bailey, E. B., 1909, The cauldron-subsidence of Glen Coe, and the associated igneous phenomena: Geol. Soc. Iondon Quart. Jour., v. 65, p. 611-678.

Cornwall, H. R. and Kleinhampl, F. J., 1960, structural features of the Beatty area, Nevada [abs.] : Geol. Soc. America Bull., v. 71, p. $1845-1846$.

King, B. C., 1955, The Ard Bheinn area of the central igneous complex of Arran: Geol. Soc. London Quart. Jour., v. 110, p. 323-355.

Reynolds, D. L., 1956, Calderas and ring-complexes: Koninkl. Nederlandsch Geol.-Mijnb, Genootschap, v. 16, p. 355-398.

Smith, H. T. U., 1938, Tertiary geology of the Abiquiu quadrangle, New Mexico: Jour. Geology, v. 46, no. 7, p. 933-965.

Steven, T. A., and Ratté, J. C., 1959, Caldera subsidence in the Creede area, San Juan Mountains, Colorado [abs.] : Geol. Soc. America Bull., v. 70, p. 1788-1789.

Williams, Howel, 1941, Calderas and their origin: Univ: California Publ., Dept. Geol. Sci. Bull., v. 25, no. 6, p. 239-346.

Wisser, Edward, 1960, Relation of ore deposition to doming in the North American Cordillera: Geol. Soc. America Mem. $77,117 \mathrm{p}$. 


\section{HYPOTHETICAL CIRCULATION OF GROUND WATER AROUND SALT SPRINGS IN WESTERN OKLAHOMA, TEXAS, AND KANSAS}

By Porter E. WARd and A. R. Leonard, Norman, Okla.

Work done in cooperation with the U.S. Public Health Service

Salt springs, seeps, salt plains, and marshes occur at several places in western Oklahoma and adjacent parts of Texas and Kansas. The ground water emerging from these springs and seeps is highly mineralized. The chloride concentration of water from individual springs ranges from about 20,000 to $190,000 \mathrm{ppm}$ (parts per million). Spring flow is small but the total salt load contributed to the Arkansas and Red Rivers is estimated to be 15,000 tons per day. Shallow halite deposits are concluded to be the source of the salt dissolved in these springs.

Frye and Schoff (1942) have suggested that ground water circulating to depths of 1,000 feet or more may move down fault planes in local collapse basins and then flow many miles laterally at depth to emerge ultimately as salt springs. Frye and Schoff did not describe in detail the ground-water circulation at the springs. Recent studies of other springs have indicated that some springs result from circulation of ground water in shallow relatively local hydraulic systems (fig. 341.1).

The salt springs occur in the outcrop area of red beds of Permian age, which consist principally of red and gray gypsiferous shale, siltstone, sandstone, massive gypsum, and thin dolomite. In the subsurface many of the beds contain halite as isolated crystals, discontinuous shaly lenses, and thick beds. Many of the springs

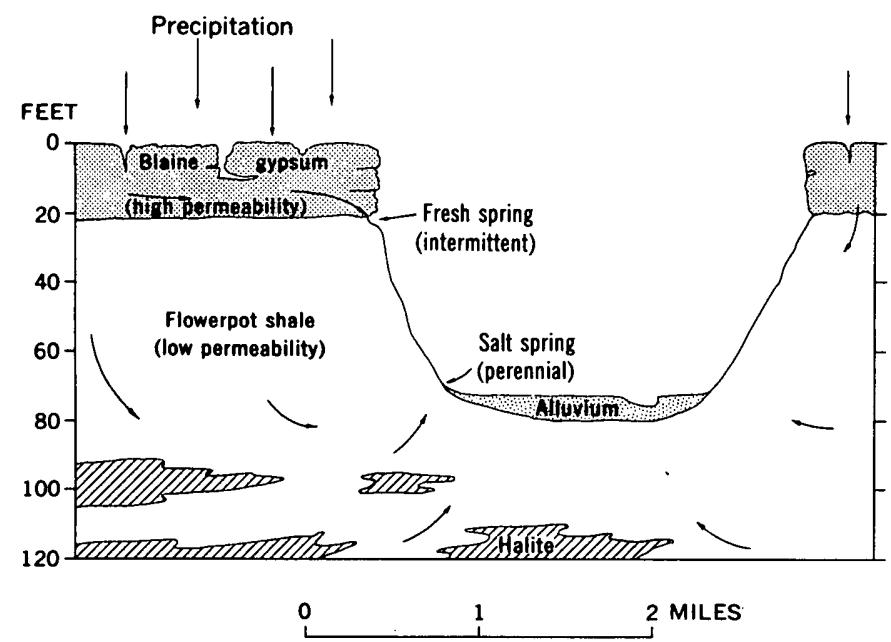

Figure 341.1.-Hypothetical circulation of ground water through halite-bearing Permian rocks near a salt spring. Arrows show the direction of water movement. in Oklahoma emerge from shale or dolomite beds in the upper part of the Flowerpot shale (or its stratigraphic equivalent), less than 50 feet below the base of the Blaine gypsum. 'Box canyons, prominent bluffs, and canyons are characteristic topographic features in most of the spring areas. The Permian red beds are relatively impermeable, but solution channels are well developed and common in the gypsum and dolomite beds. The shale and siltstone beds are fractured, jointed, and contain numerous small veins of selenite that have been deposited in the joints and along bedding planes by circulating ground water.

Salt hoppers or molds of salt crystals are common in the shale in the upper part of the Flowerpot shale, and halite has been found at depths of less than 100 feet in core holes drilled near some of the springs and plains. A core hole drilled about 1 mile from one of the salt springs in southwestern Oklahoma indicated that ground water had circulated through nearby haliterich deposits. At a depth of 200 feet the hole penetrated shale containing cubic voids which were formerly occupied by halite crystals. A few inches deeper the voids were partly filled with halite, and at still greater depth the halite cubes were unaffected by the so'vent action of ground water.

Although halite occurrences are widespread, the springs occur at relatively few places, suggesting that certain conditions are necessary for a salt spring: (a) halite deposits or halite-bearing rocks at shallow depth; (b) ground water that circulates to the halite-bearing zones; and (c) a local topographically low area where the water can emerge as a mineral spring. Joints and fractures in the shale apparently do not extend to depths of more than a few hundred feet, and most of the halite at such depths in western Oklahoma, Texas, and Kansas seems to be beyond the reach of circulating ground water. In areas of flat topography, small amounts of water may reach and dissolve the salt, but are not able to circulate to a lower point of emergence because of the topography. This salt water probably moves laterally into other formations in the subsurface. Conditions such as this occur southwest of Wichita, Kans., where brine for a chemical plant is pumped from wells about 600 feet deep although no salt springs are known in the area. The brine occurs in the Wellington formation of Permian age in a zone 
that contains halite deposits a few miles to the west (fig. 341.2).

Further evidence for the shallow circulation of ground water around the salt springs is the occurrence

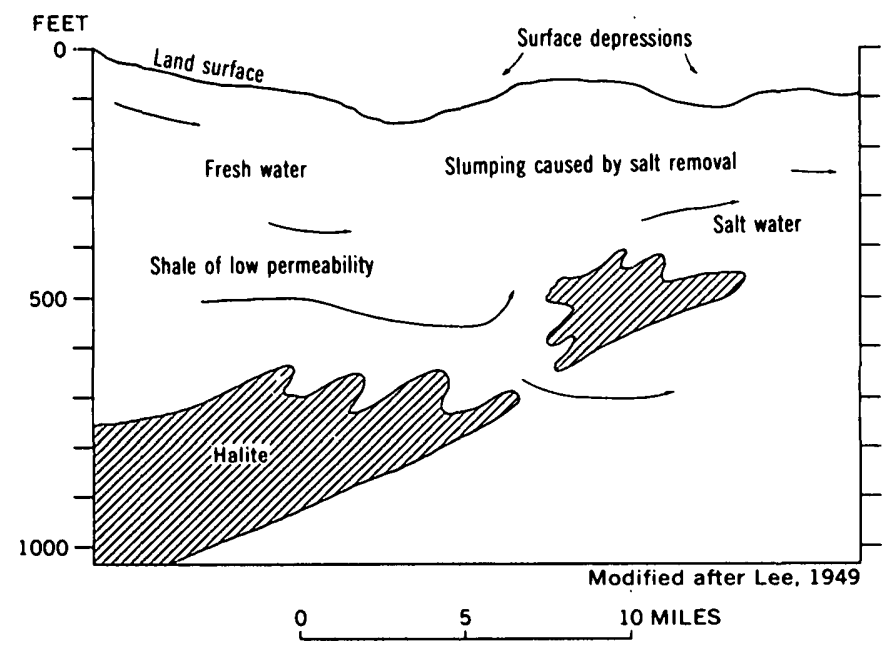

Ficure 341.2.-Generalized cross section in south-central kimsas showing the removal of salt from the Wellington formation (Permian) through solution by ground water. Arrows indicate direction of ground-water movement. of sinkholes and surface collapse features along the eastern limit of the salt deposits and in the vicinity of many salt springs. For example, the Great Salt Plain in Alfalfa County in northwestern Oklahoma is a low subcircular shallow basin that was formed, at least in part, by collapse resulting from the removal of underlying salt deposits. Salt water seeps from the underlying broken bedrock into the alluvium covering the basin and thence into the Salt Fork of the Arkansas River. Salt is brought to the surface in this manner at a rate of more than 3,000 tons per day.

Water collected from several spring areas in 1959 has been shown by tritium analyses to contain a large proportion of post-1954 water. Considering the low permeability, the rate that water moves through the rocks must be slow; consequently, the water could not have migrated more than a few miles in so short a time.

\section{REFERENCES}

Frye, J. C., and Schoff, S. L., 1942, Deep-seated solution in the Meade Basin and vicinity, Kansas and Oklahoma, in Symposium on relations of geology and the ground-water problems of the Southwest: Am. Geophys. Union Trans., 23d Ann. Mtg., pt. 1, p. 35-39.

Lee, Wallace, 1949, Subsurface geologic cross section from Barber County to Saline County, Kansas: Kansas Geol. Survey Oil and Gas Inv. no. 8, $16 \mathrm{p}$.

\section{BRECCIA AT SIERRA MADERA, TEXAS}

By R. E. Eggleton and E. M. Shommaker, Menlo Park, Calif.

Worl: done in cooperation with the National Aeronatics and Space Administration

Sierra Madera, Tex., is an isolated group of hills on the southern edge of the Edwards Plateau underlain by highly deformed Permian dolomite and limestone; the structure contrasts sharply with that of less-deformed Permian rocks in the surrounding region. King (1930), who first mapped the area in detail, interpreted the structure as a complex dome with overturned beds on the flanks, broken by radial faults, and partly encompassed by smaller concentric folds; he compared it with the similar but much larger Vredefort dome of South Africa. On the basis of King's interpretation, Boon and Albritton (1937, p. 60-62) suggested the structure was formed by meteorite impact. Data obtained from drill holes and outcrop since 1937 show that the structure of Sierra Madera is even more unusual than King supposed and tend to support the suggestion of impact origin.

In the fall of 1959 Sierra Madera was visited by Shoemaker, in company with R. S. Dietz, R. J. Hack- man, and A. C. Mason, who found that the Permian beds contained abundant conical slip surfaces termed shatter cones (Dietz, 1960). On this visit the central part of the structure was found by Shoemaker to be underlain by an immense mass of breccia, and the northwestern boundary of the breccia was located. The approximate extent of the breccia was determined by Shoemaker, Eggleton, and Roach on a second visit in January 1961 (fig. 342.1). Knowledge of the shape and character of this breccia mass, the existence of which has not been fully recognized heretofore, is critical to the interpretation of the origin of the structure.

The breccia zone consists of blocks of carbonate rocks up to several hundred feet across enclosed in a matrix of angular fragments that grade progressively downward in size to microbreccia. In the outcrops, about half of the breccia is composed of fragments small enough to permit recognition of the clastic nature of the material in hand specimens. Microbreccia, recognizable in thin 

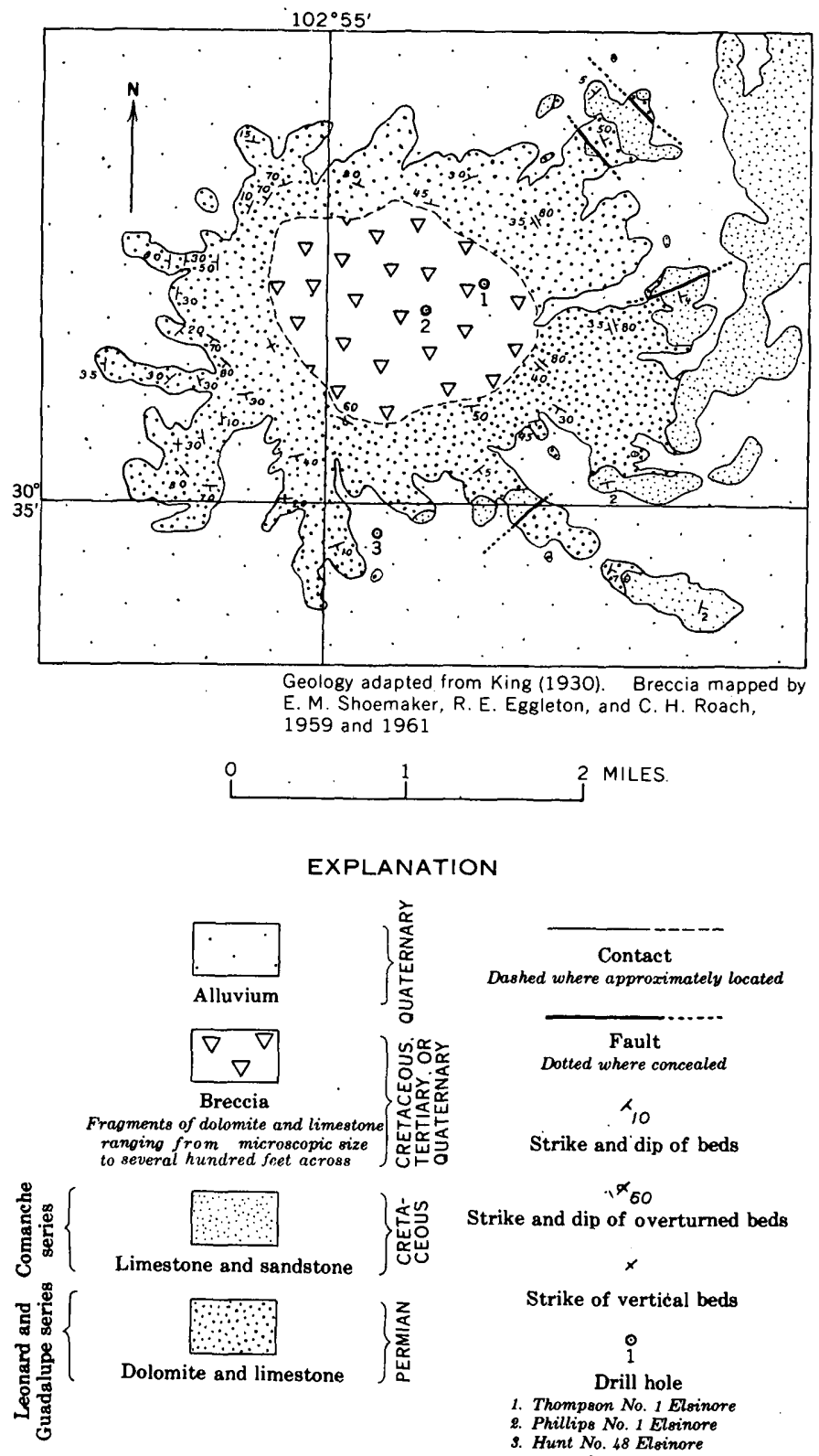

Frgure 342.1.-Geologic sketch map of Sierra Madera, Tex.

section, constitutes a smaller proportion of the body and forms the matrix between the larger fragments. Some of the microbreccia consists of mixed fragments derived from beds of diverse lithology and some is composed entirely of fragments of uniform lithology. All gradations may be found between mixed microbreccia and rock which has merely been shattered.

Three deep holes have been drilled at Sierra Madera, two of which began in the breccia. Drill cuttings of the upper 3,100 feet of Phillips No. 1 Elsinore well, which is located near the center of the breccia, were kindly given to us by Mr. Addison Young and logged by Eggleton. We are also indebted to Mr. Young for correlation of units between the three wells.
Three main lithologic phases are present in the cuttings of the Phillips No. 1 Elsinore hole: (a) microbreccia with light-colored matrix, (b) microbreccia with dark material in the matrix, and (c) unfractured dolomite and limestone. Dolomite is predominant over limestone. In most samples the cuttings are mainly chips about 1 to $5 \mathrm{~mm}$ long but some are as long as $1 \mathrm{~cm}$ and rarely $2 \mathrm{~cm}$. The microbreccia is a prominent constituent of the cuttings from the surface to a depth of about 1,600 feet and again between depths of about 2,600 feet and 2,800 feet. Microbreccia with dark material in the matrix is the predominant constituent of the cuttings between 800 feet and 1,170 feet and is rare in other samples.

A typical specimen of microbreccia with light-colored matrix consists of angular fragments of moderate yellowish-brown to light brownish-gray, yellowish-gray, and pinkish-gray to white carbonate rocks in a very pale orange carbonate matrix (fig. $342.2 A$ ). It contains 30 percent fragments ranging from $0.2 \mathrm{~mm}$ to $5 \mathrm{~mm}$ in length and about 70 percent matrix composed of grains finer than $0.2 \mathrm{~mm}$. The fragments have sharp corners and rough, commonly concave, faces.
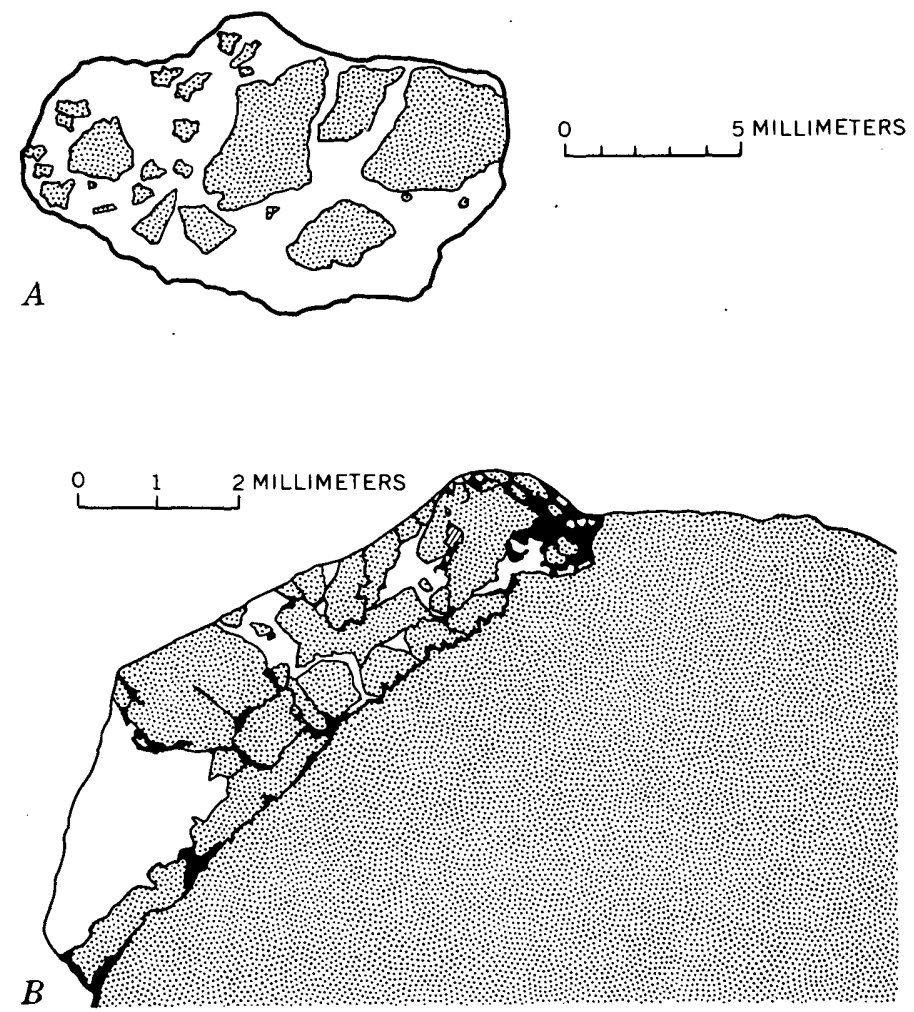

FIgURE 342.2.-Chips of breccia from cuttings from Phillips Petroleum Company's drill hole No. 1 Elsinore. $A$, Breccia with light-colored matrix ; $B$, Breccia with dark material in the matrix: Rock fragments, stippled; light-colored matrix, white; dark material in matrix, black; and pyrite, densely ruled. 
Typical microbreccia with dark material in the matrix has angular firagments of very light gray and light yellowish-brown carbonate rock in light brownish-gray matrix. The dark material, which is black megascopically but brown and slightly translucent as seen with the microscope, occurs both as partial films on the angular fragments of carbonate rock and as very small particles generally less than $1 \mathrm{~mm}$ long. Some of the films of dark material can be recognized to be stylolites but others cannot be so identified (fig. 342.2B).

The composition of the clark material in the matrix of the microbreccia has not been determined but most of it is evidently carbonaceous. Pyrite constitutes about 0.001 percent of the material in the cuttings. No meteoritic constituent has yet been identified.

Structures observed in the cuttings include slickensides and segments of shatter cones. The slickensides appear to be most common in the samples having abundant microbreccia. Shatter cones are conical surfaces in the carbonate rocks marked with fine straight ridges and grooves radiating from the apices of the cones or from subsidiary flanking conelets. The shatter cones seen at Sierra Madera are typically about $2 \mathrm{~cm}$ to $20 \mathrm{~cm}$ in basal diameter and only small parts of their surfaces can be found in cuttings. Their distribution in the drill hole appears to be relatively uniform throughout the interval studied.

Young (1952), who at first identified the cuttings from the upper part of the Phillips No. 1 Elsinore well as part of the Leonard series of Permian age, now (written communication, 1960) places the base of the Leonard at 4,100 feet. The 4,000+ foot thickness assigned to the Leonard contrasts sharply with a normal thickness for the Leonard of about 2,000 feet in the Glass Mountains to the southwest and with 2,660 feet in the Hunt
No. 48 Elsinore well (Young, written communication, 1960) on the flank of the Sierra Madera structure. The additional 1,440 feet assigned to the Leonard in the Phillips No. 1 Elsinore well can be attributed entirely to the breccia, which extends to a depth of at least 1,600 feet and possible 2,800 feet. Structural relief on the top of an anhydrite bed, which occurs at 2,910 feet in the Phillips No. 1 Elsinore well, is only about 500 feet between the three wells drilled at Sierra Madera. Dips of the beds a short distance beneath the breccia are, therefore, probably fairly gentle.

On the basis of the surface and subsurface information the breccia at Sierra Madera is here tentatively interpreted as a great lens, $11 / 2$ miles across and possibly as much as 2,800 feet thick, nested in a collar of steeply upturned and overturned beds. The structure appears to be similar to that at Meteor Crater, Ariz., and at the Teapot Ess nuclear explosion crater at the Nevada Test Site of the U.S. Atomic Energy Commission (Shoemaker, 1960, p. 422-424). By analogy, the breccia at Sierra Madera may once have underlain a crater about 2 miles in diameter.

\section{REFERENCES}

Boon, J.D., and Albritton, C. C., Jr., 1937, Meteorite scars in ancient rocks : Field and Laboratory, v. 5, no. 2, p. 53-64.

Dietz, R. S., 1960, Meteorite impact suggested by shatter cones in rock: Science, v. 131, p. 1781-1784.

King, P. B., 1930, The geology of the Glass Mountains, Texas; Part 1, Descriptive geology : Texas Univ. Bull. 3038, 167 p.

Shoemaker, E. M., 1960, Penetration mechanics of high velocity meteorites, illustrated by Meteor Crater, Arizona : Internat. Geol. Cong., 21st, Copenhagen 1960, Rept., pt. 18, p. 418-434.

Young, Addison, 1952, Geologic section in Phillips Petroleum Company's Elsinore Cattle Company No. 1, in West Texas Geol. Soc. Guidebook, 1952 spring field trip, Marathon Basin, Brewster and Pecos Counties, Trans-Pecos, Texas: p. 72-73.

\title{
343. JOHN DAY FORMATION NEAR ASHWOOD, NORTH-CENTRAL OREGON
}

\author{
By Dallas L. Peck, Menlo Park, Calif.
}

The thickness and lithology of the upper Oligocene and lower Miocene John Day formation change markedly between Ashwood, Oreg., and the type area along the John Day River between Clarno and Picture Gorge, 20 to 60 miles to the east (fig. 343.1). At the type area the formation consists of 1,000 to 2,500 feet of richly fossiliferous varicolored andesitic to rhyolitic tuff and tuffaceous claystone that were mostly deposited as ash falls (Merriam, 1901, p. 291-303; Calkins, 1902 , p. 143-159; R. G. Coleman ; Fisher and Wilcox, 1960, and Hay, R. L., 1961). West of the John Day River the formation contains increasingly abundant rhyolitic volcanic rocks (Waters, 1954). Between Ashwood and Willowdale it consists of about 4,000 feet of tuff,

${ }^{2}$ R. G. Coleman, 1949, The John Day formation In the Picture Gorge quadrangle, Oregon: Oregon State College Mtasters Thesis. 


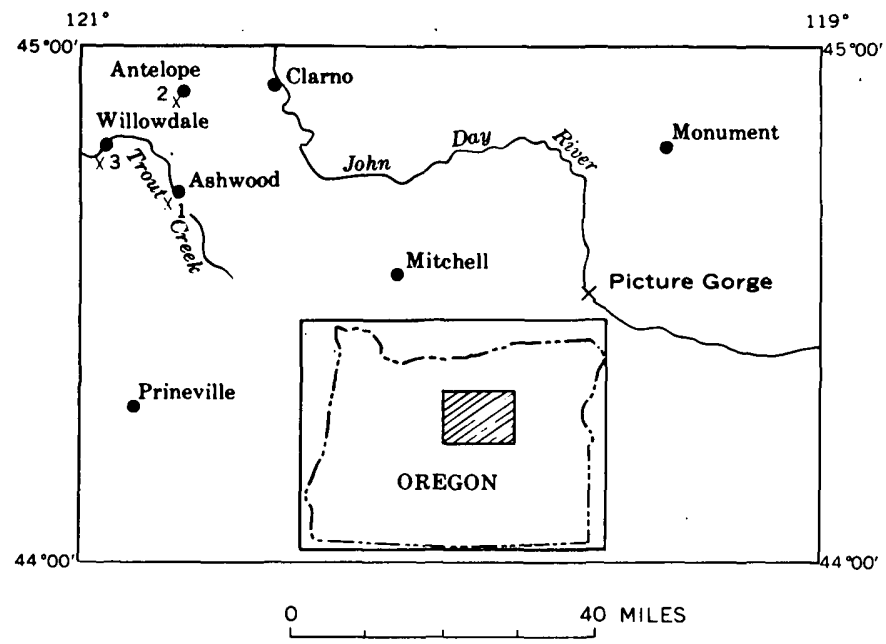

Figure 343.1.-Index map of part of north-central Oregon. $\times$, location of chemically analyzed samples listed in table 343.1.

lapilli tuff, strongly to weakly welded ash flows, and subordinate flows of trachyandesite and rhyolite (fig. 343.2). The rhyolitic flows are related to a large rhyolitic dome in the lower part of the formation, exposed along Trout Creek northwest of Ashwood.

The moderately to strongly welded ash flows range in thickness from 50 to 400 feet. Some of the thicker units, however, may be composed of several separate ash flows that comprise a single cooling unit (as defined by Smith, 1960, p. 812). Each ash flow consists of hard welded lithoidal rock, light gray to reddish, overlying a thin layer of nonwelded tuff and gray vitric welded tuff in which welded vitroclastic texture is discernible with a hand lens. From a trace to 20 percent (by volume) of each ash flow is composed of intratelluric crystals and crystal fragments, mostly of anorthoclase, oligoclase, and quartz. Sparse to abundant lithophysae, mostly concentrated in layers, occur in the upper, lithoidal part of each ash flow. In the basal portion of one thin nonwelded to weakly welded ash flow are abundant chalcedony-filled spherulites ("thunder-eggs"), described by Ross (1941). Chemical analyses of samples from three widespread ash flows are listed in table 343.1. The analyses show that the ash flows are rhyolitic, whereas analyzed silicic volcanic rocks in contemporaneous strata in the Oregon Cascade Range are dacitic and rhyodacitic (Peck, 1960a, 1960b).

The contrast in lithology of the John Day formation between Ashwood and the area along the John Day River is the result of at least two independent factors. The rhyolitic dome, lava flows, ash flows, and some of the tuff and lapilli tuff near Ashwood were derived from nearby vents. Eastward, away from the vents, the lava flows and ash flows become thinner and less abundant, and they are almost completely missing along the John Day River. The deposits of rhyolitic tuff
TABLE 343.1.-Chemical analyses, specific gravity, and norms of ash flows in the John Day formation near Ashwood, northcentral Oregon

lRapid rock analyses by P. L. D. Elmore, I. H. Barlow, and S. D. Botts; location of samples shown on map and stratigraphic position shown on columnar section]

\begin{tabular}{|c|c|c|c|}
\hline & 1 & 2 & 3 \\
\hline \multicolumn{4}{|c|}{ Chemical analysis (percent) } \\
\hline $\mathrm{SiO}_{2-}$ & 71.8 & 73. 8 & 72.2 \\
\hline$\ldots$ & 13. 0 & 11. 4 & 11. 4 \\
\hline $\mathrm{Fe}_{2} \mathrm{O}_{3} \ldots$ & 1. 3 & 1. 7 & 1.4 \\
\hline $\mathrm{FeO}$ & .26 & .85 & .66 \\
\hline $\mathrm{MgO}_{\ldots} \ldots \ldots \ldots \ldots$ & .12 & 10 & .33 \\
\hline $\mathrm{CaO}$ & .87 & .78 & .61 \\
\hline $\mathrm{Na}_{2} \mathrm{O}$ & 2. 3 & 2. 2 & 2. 9 \\
\hline $\mathrm{K}_{2} \mathrm{O}$ & 5. 0 & 4.8 & 3. 4 \\
\hline $\mathrm{H}_{2} \mathrm{O} \ldots$ & 5.4 & 4. 2 & 6. 0 \\
\hline $\mathrm{TiO}_{2} \ldots \ldots$ & .16 & .18 & .16 \\
\hline $\mathrm{P}_{2} \mathrm{O}_{5}$ & .01 & .02 & .01 \\
\hline $\mathrm{MnO}_{\ldots} \ldots$ & .03 & $\ldots 05$ & .08 \\
\hline $\mathrm{CO}_{2 \ldots} \ldots \ldots \ldots \ldots$ & .05 & .05 & .07 \\
\hline Total $\ldots . .$. & 100 & 100 & 99 \\
\hline
\end{tabular}

\begin{tabular}{l|l|l|l}
\hline Specific gravity (powder) \\
\hline \\
\hline
\end{tabular}

Norms (weight percent)

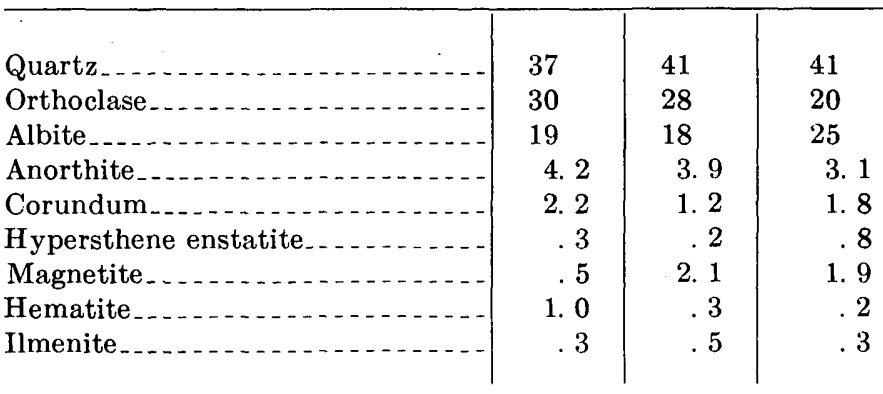

Normative feldspar (molecular percent)

\begin{tabular}{l|r|r|r|r}
\hline & & & \\
Orthoclase & & 54 & 41 \\
Albite & & 38 & 37 & 53 \\
Anorthite. & 8 & 8 & 6
\end{tabular}

1. Welded tuff (DLP-58-42); collected from vitric base of ash flow in sec. 12, T. 10 S., R. 16 E., at 3,350 feet altitude on bank of county road 1.9 miles S. $62^{\circ} \mathrm{W}$. of Ashwood. Yellowish-gray vitric rock containing 2 percent crystals and crystal fragments (avg. $1 \mathrm{~mm}$ in diameter) of sodic oligoclase in shards and ash of glass $(\mathrm{N}=1.50)$, a small part of which is devitrified to $\beta$-cristobalite and feldspar.

2. Welded tuff (DLP-58-50); collected from vitric base of ash flow in sec. 18, T. $\dot{8} \mathrm{~S}$., R. $17 \mathrm{E}$., on bank of county road 2.6 miles S. $25^{\circ} \mathrm{W}$. of Antelope. Medium gray vitric rock containing about $1 / 4$ of 1 percent crystals and crystal fragments of calcic oligoclase and a trace of altered pyroxene and amphibole in welded shards and ash of glass $(\mathrm{N}=1.50)$ that is partially devitrified to $\beta$-cristobalite and feldspar.

3. Welded tuff (DLP-58-39a); collected from vitric base of welded ash flow in sec 20, T. 9 S., R. $15 \mathrm{E}$, in roadcut on eastern side of former U.S. Highway 97 , half a mile south of Pacific States Cut Stone quarry. Medium light gray rock containing a trace of crystals and crystal fragments of sodic plagioclase and quartz in welded shards and ash of pale brown glass $(\mathrm{N}=1.50)$ that is partially devitrifted to $\beta$-cristobalite and feldspar. 


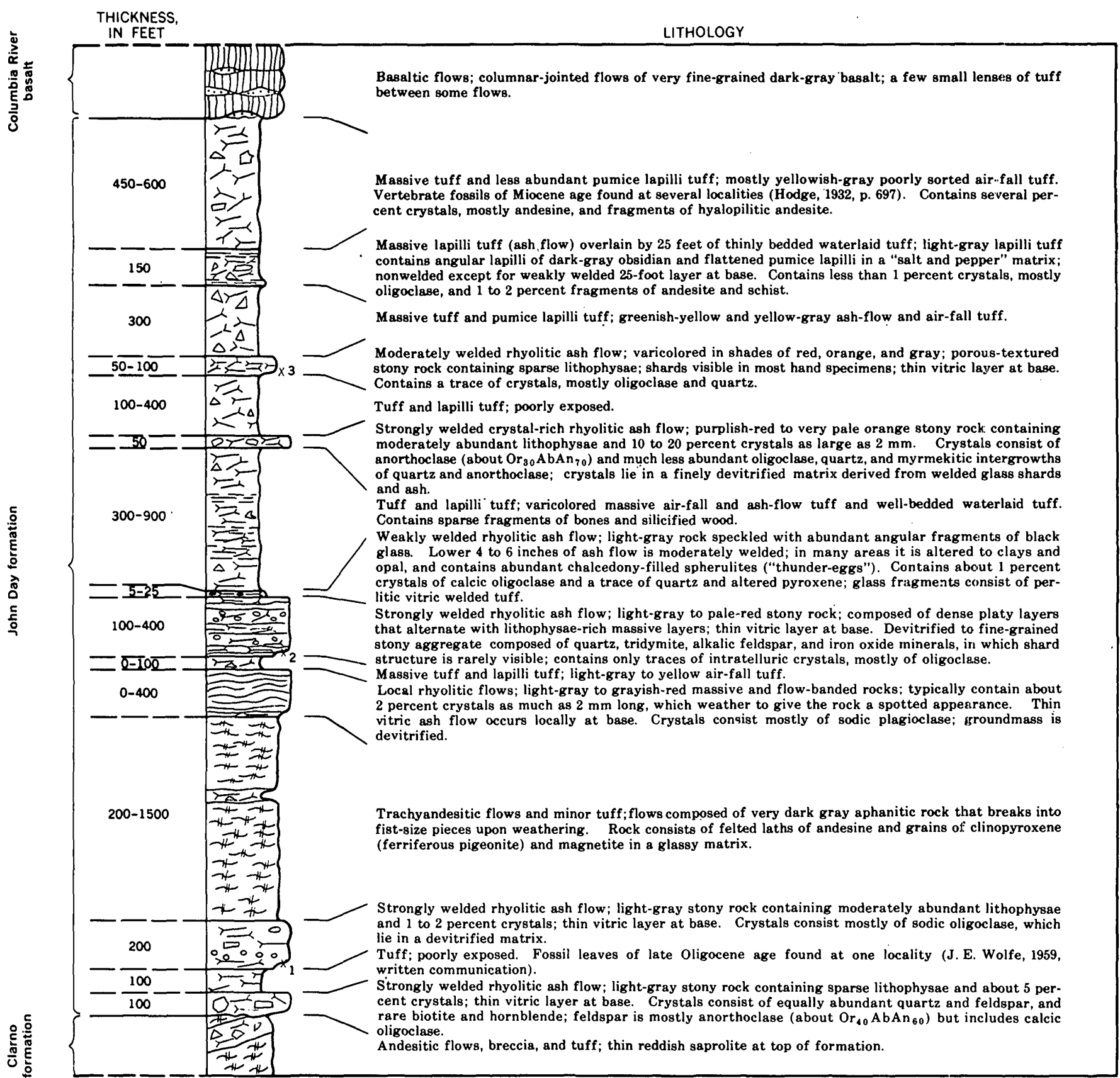

Ficure: 343.2.-Generalized columnar section of the John Day formation between Ashwood and Willowdale, north-central Oregon. $x$ and number shows stratigraphic positions of chemically analyzed samples listed in table 343.1. 
and lapilli tuff probably also thin eastward away from the vents. Some of the tuff, lapilli tuff, and tuffaceous claystone both near Ashwood and along the John Day River may have been derived from contemporaneous vents in an ancestral Cascade Range, 60 to 120 miles to the west (R. G. Coleman; ${ }^{2}$ R. L. Hay, written communication, 1961). Grain size of the tuffaceous rocks decreases eastward from Ashwood to Picture Gorge, and the rocks are similar in composition to contemporaneous andesitic, dacitic, and rhyodacitic pyroclastic rocks, flows, and intrusives in the Western Cascades (Peck, 1960a, 1960b). A decrease in thickness of these tuffaceous rocks eastward away from the vents probably accompanies the eastward decrease in grain size.

\section{REFERENCES}

Calkins, F. C., 1902, A contribution to the petrography of the John Day Basin [Oregon]: California Univ. Publ. Dept. Geol. Bull., v. 3, p. 109-172.

2 See footnote 1.
Fisher, R. V., and Wilcox, R. E., 1960, The John Day formation in the Monument quadrangle, Oregon, in Short papers in the geological sciences: U.S. Geol. Survey Prof. Paper 400-B, p. B302-B304.

Hay, R. L., 1961, Diagenetic facies in the John Day formation of Oregon: Geol. Soc. America Cordilleran Section Program, p. 41-42.

Hodge, E. T., 1932, New evidence of the age of the John Day formation: Geol. Soc. America Bull., v. 43, p. 69.5-702.

Merriam, J. C., 1901, A contribution to the geology of the John Day Basin [Oregon]: California Univ. Publ. Dept. Geol. Bull., v. 2, p. 269-314.

Peck, D. L., 1960a, Geologic reconnaissance of the Western Cascades in Oregon north of latitude 43 degrees: U.S. Geol. Survey open-file report.

—, $1960 \mathrm{~b}$, Cenozoic volcanism in the Oregon Cascades, in Short papers in the geological sciences: U.S. Geol. Survey Prof. Paper 400-B, p. B308-B310.

Ross, C. S., 1941, Origin and geometric form of chalcedony-filled spherulites from Oregon: Am. Mineralogist, จ. 26, p. $727-732$.

Smith, R. L., 1960, Ash flows: Geol. Soc. America Bull., v. 71, p. $795-842$.

Waters, A. C., 1954, John Day formation west of its type locality [abs.] : Geol. Soc. America Bull., v. 65, p. 1320.

344. DIFFERENTIATED GABbROIC SILlS AND ASSOCIATED ALKaliC ROCKS IN THE CENTRAL PART OF THE OREGON COAST RANGE, OREGON

\author{
By P. D. Snavely, Jr., and H. C. Wagner, Menlo Park, Calif.
}

Gabbroic and alkalic hypabyssal intrusive bodies ${ }^{2}$ that are closely related in space and time of development crop out throughout the central part of the Oregon Coast Range (fig. 344.1). The distribution of these bodies has been known for some time and the petrology of some of these intrusives has been briefly described by Rogers and others (1941), Baldwin (1947, 1956a, b), Snavely and Vokes (1949), and Snavely and others (1950); Roberts (1953) described in detail the petrology of the Marys Peak sill.

Studies in progress on the gabbroic and alkalic rocks in the Oregon Coast Range are concerned primarily with their magmatic evolution. The origin of the alkalic rocks is of particular interest. Considerable field and chemical data, summarized here, are available and bear on the parentage of these rocks.

\section{FIELD RELATIONS}

The gabbroic and alkalic rocks occur generally as intrusive sheets that have angles of inclination ranging

\footnotetext{
1 The term gabbrolc. as used here, Includes intrusive rocks that range In composition from gabbro to diorite, and generally have granophyric, ophitic, and subophitic textures. They are commonly referred to as dolerites by writers outside North America. The alkalle rocks discussed Include nepheline syenite and camptonite.
}

from nearly flat-lying to vertical; the thicker bodies are essentially horizontal. As the angular discordance between the thicker intrusive sheets and the enclosing strata is generally less than 20 degrees, the sheets are termed sills. The gabbroic sills commonly are thickest along the crest of the Coast Range uplift and thin toward the flanks. At most places the alkalic rocks crop out west of the gabbroic intrusives and, although in close proximity, the two types have not been found in contact. Intrusives of both rock types usually occur in beds of Eocene age and are not known to intrude strata younger than middle Oligocene. Gabbroic sills probably covered an area of more than 2,500 square miles; their thickness averages 400 to 500 feet, but locally is more than 1,000 feet. Erosional remnants of sills cap most of the prominent flat-topped mountains and concordant upland surfaces such as Mount Hebo, Mount Gauldy, Saddleback Mountain, Fanno Peak, Euchre Mountain, Marys Peak, Prairie Peak, and Roman Nose Mountain. The alkalic rocks probably comprise less than 5 percent of the intrusive suite in the Oregon Coast Range. Nepheline syenite porphyry forms the stock at Blodgett Peak in the Waldport quadrangle and the 200- to 300 -foot sills that cap Table and Cannibal Mountains in the Tidewater quadrangle; 
SHORT PAPERS IN THE GEOLOGIC AND HYDROLOGIC SCIENCES, ARTICLES 293-435

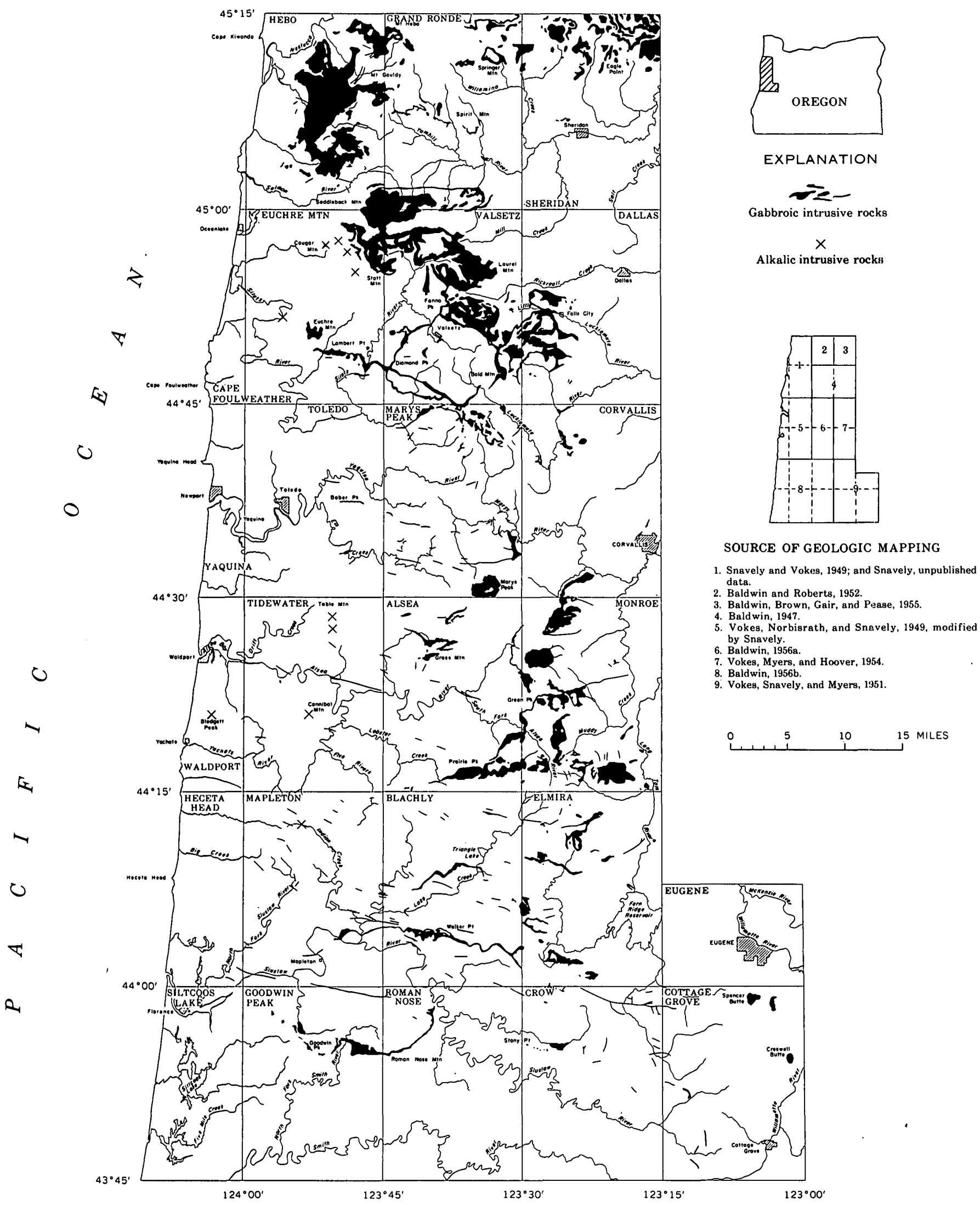

Frouke 344.1.-Distribution of upper Oligocene gabbroic and alkalic intrusive rocks in the central part of the Oregon Coast Range. 
the original extent of this sill was probably more than 200 square miles. Camptonite forms the stock at Cougar Mountain in the Euchre Mountain quadrangle and is present in sills and dikes in the same general area.

The contacts between intrusives and country rock are usually sharp; no evidence for stoping or assimilation has been found. Most commonly the sedimentary rocks are weakly metamorphosed only at (or for a few feet beyond) the contact, but above some of the thicker sills the country rock has been transformed into hornfels.

\section{GABBROIC SILLS}

The thick gabbroic sills comprise a gradational sequence of rock types that includes basalt of the chilled border facies, granophyric gabbro and granophyric diorite in the main body, and less abundant irregular masses of a pegmatitic facies and cross-cutting veins of quartz-feldspathic micropegmatite. Preliminary results of petrographic studies and analyses of samples collected from many of the larger bodies indicate that the rock types are similar to those found in other intrusives described elsewhere in the world (Wager and Deer, 1939; Walker and Poldervaart, 1949; Hotz, 1953; Walker, 1940, 1958).

The Oregon intrusive bodies range in composition from gabbro to diorite and, with few exceptions, exhibit a micropegmatitic intergrowth of quartz and feldspar in thin sections.

Plagioclase feldspar, the most abundant mineral, commonly occurs as strongly zoned tablets that range outward from cores of calcic labradorite to rims of calcic andesine in the granophyric gabbro and from calcic andesine to sodic andesine in the granophyric diorite. The abundant small plagioclase laths in the groundmass have the same composition as the rims of the larger crystals.

On the average, considering both gabbro and diorite, the rocks of the sills consist of about 50 percent plagioclase $\left(\mathrm{An}_{30-6 \mathrm{i}}\right)$, about equal amounts (10 to 20 percent each) of pyroxene (predominantly augite, pigeonite, or ferroaugite), quartz-feldspar intergrowth, and secondary minerals, and less than 5 percent of olivine, quartz, and opaque minerals. Olivine and quartz are present in some, but not in all sections studied.

The average of 21 chemical analyses of gabbroic rocks from the thicker sills of the Oregon Coast Range is given in table 344.1 , column 2. This average is nearly identical to the chemical composition of a basalt sample from the chilled margin of the Mount Hebo sill (table 344.1 , column 1). Inasmuch as the two are so similar, the average in column 2 probably represents the composition of the original magma. The Coast Range average is similar to the average tholeiitic andesite of Nockolds (1954) shown in table 344.1, column 5. Gabbroic rocks of Oregon, however, contain more $\mathrm{SiO}_{2}$ and less $\mathrm{MgO}$ and $\mathrm{CaO}$ than Nockolds' average.

The analysis of the chilled facies and the average analysis of the gabbroic rocks fall within Kuno's (1960, p. 137, fig. 10) field for tholeiite but plot near the boundary of his alkali dolerite field. The same analyses, when plotted on a diagram of Murata (1960, p. 250, fig. 2 ), fall near the differentiation trend line for the tholeiitic basalt series, but are displaced slightly toward the trend line for the alkalic basalt series. The differentiation trends of the Oregon Coast Range intrusive rocks and the Skaergaard liquids of Wager and Deer (1939) are compared in the FMA diagram, figure 344.2. Both the Oregon Coast Range and Skaergaard magmas were progressively enriched in iron during the greater part of crystallization and were enriched in alkalis (and in silica, which does not plot on the diagram) near the end of crystallization. The diagram shows that magnesia-rich rocks of the Oregon Coast Range, and presumably the magma that gave rise to them, are relatively richer in alkalis than comparable Skaergaard liquids. This relatively high alkali content seems to be typical of most Oregon Coast Range igneous rocks, for: available analyses indicate that the alkali content in the basalt flows of the widespread lower Eocene and more

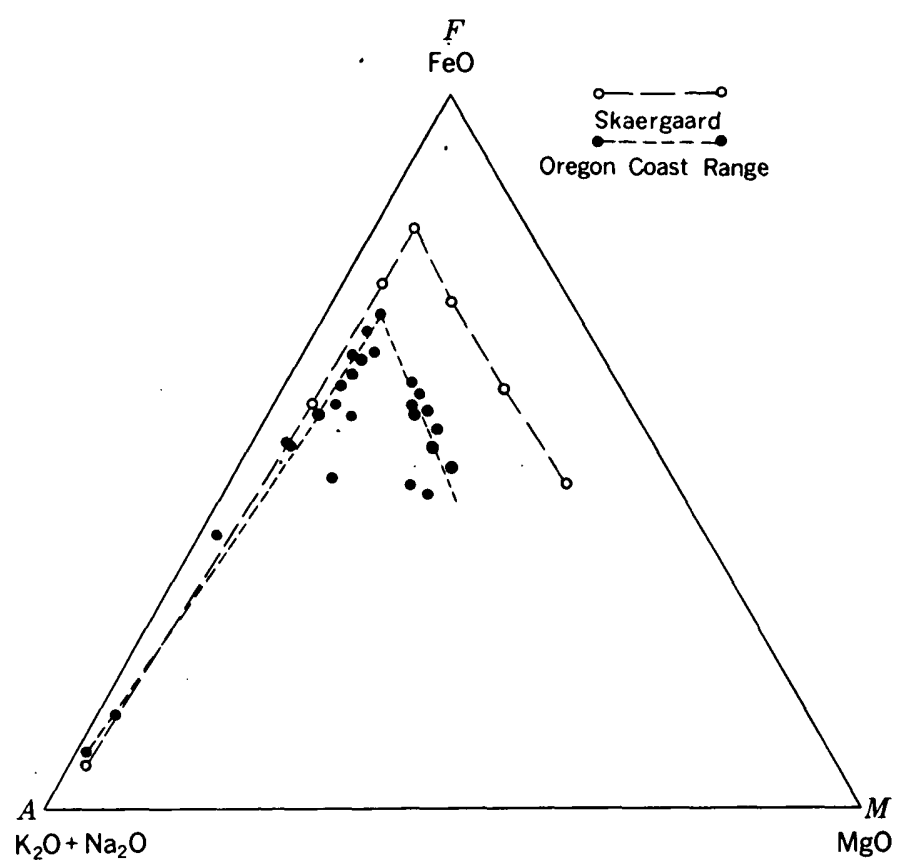

Figure 344.2-Comparison of differentiation trends of Oregon Coast Range gabbroic intrusive rocks and the Skaergaard intrusion (in weight percent). Samples include basalt and gabbro from the chilled border facies, granophyric gabbro, granophyric diorite, pegmatitic facies, and quartz-feldspathic micropegmatitic veins. 
$\mathrm{T}_{\Lambda \mathrm{BLE}}$ 344.1.-Average chemical analyses (in percent) and norms of Oregon Coast Range gabbroic and alkalic intrusive rocks and averages of similar magma types

[Annlysos in columns 1-4 by I. H. Barlow, S. D. Botts, Gillison Chloe, P. L. D. Elmore, J. W. Goldsmith, R. L. Hill, M. D. Mack, and D. F. Powers]

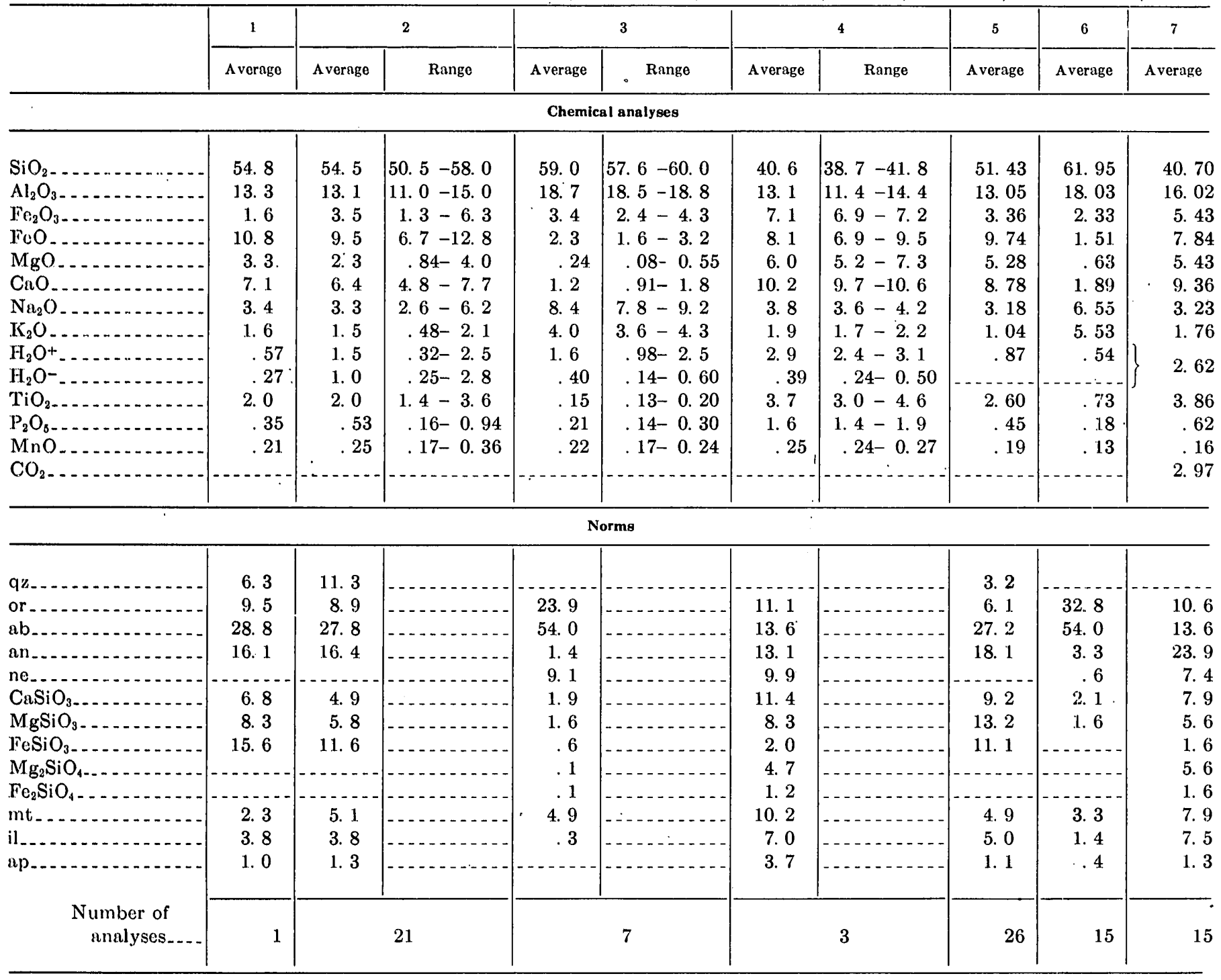

1. Basalt from upper chilled border of sill at Mt. Hebo, Oregon Coast Range.

2. A verage gabbrole intrusive rock, Oregon Coast Range.

3. Avorage nephelino syenite porphyry, Oregon Coast Range.

4. $A$ verage camptonite, Oregon Coast Range.

5. A vorago thololitic andesite, Nockolds (1954, p. 1019).

6. A verage alkali trachyte, Nockolds $(1954$, p. 1016)

7. A verage camptonite, Johannsen (1038, p. 65); norm calculated by the authors; $\mathrm{CO}_{2}$ was assumed to be secondary.

restricted upper Eocene and middle Miocene rocks is higher than that of the alkali basalts of Nockolds (1954. p. 1021).

\section{ALKAIIC ROCKS}

The nepheline syenite porphyry at Blodgett Peak has a trachytoidal texture made apparent by conspicuous euhedral and complexly twinned phenocrysts of albite (about $\left.A n_{10}\right)^{2}$ set in a medium-gray groundmass.

2Optical determination shows $\mathrm{Nx}$ as $1.532 \pm 0.003$ and $2 \mathrm{~V}$ as about $(-) \mathbf{5 5 ^ { \circ }}$.
The average mineral composition of the nepheline syenite at Blodgett Peak consists of about 50 percent albite laths in the groundmass, 10 to 15 percent each of albite phenocrysts, nepheline and analcite, and secondary minerals, 5 to 10 percent aegirine and aegirine-augite, 3 to 5 percent olivine and opaque minerals, and 1 to 2 percent riebeckite. Deuteric analcite has partially replaced both the nepheline and the albite, and also occurs as crystals in rare miarolitic cavities. At Table Mountain the albite phenocirysts have been almost completely altered to sericite and clay minerals. 
The average chemical composition of 7 samples of nepheline syenite porphyry from the Oregon Coast Range is listed in table 344.1, column 3. This average is similar to Nockolds' (1954) average alkali trachyte (table 344.1, column 6). The syenite of the Coast Range contains less $\mathrm{SiO}_{2}$ and $\mathrm{K}_{2} \mathrm{O}$ and more $\mathrm{Na}_{2} \mathrm{O}$ and total iron. These differences in silica, potash, and soda result in less orthoclase and more nepheline in the norm for the average Oregon syenite.

A lamprophyre, camptonite, forms the Cougar Mountain stock and associated dikes and sills in the northeastern part of the Euchre Mountain quadrangle (fig. 344.1). The most common facies of camptonite is a porphyritic rock composed chiefly of randomly oriented black equant crystals of hornblende in a medium-gray fine-grained groundmass. Pegmatoidal lenses and stringers are not uncommon, and contain long slender prismatic crystals of hornblende as much as $20 \mathrm{~mm}$ in length. A dike of biotite-rich camptonite intrudes the Tyee formation along the Siletz River in the west-central part of the Euchre Mountain quadrangle.

In thin sections the camptonite is characterized by phenocrysts of reddish-brown markedly pleochroic barkevikitic hornblende, which form 30 to 40 percent of the rock. Plagioclase feldspar phenocrysts $\left(\mathrm{An}_{45-55}\right)$ form 10 to 25 percent; titaniferous augite, usually with reaction rims of aegirine-augite or aegirine, as much as 25 percent; opaque minerals, 3 to 10 percent; and apatite, 1 to 2 percent. Deuteric analcite and its alteration products constitute as much as 30 percent of the rock.

Chemical analyses of camptonite from the Oregon Coast Range (table 344.1, column 4) compare closely with the average listed by Johannsen (table 344.1, column 7). Camptonite from Oregon, however, contains less $\mathrm{Al}_{2} \mathrm{O}_{3}$ and more $\mathrm{P}_{2} \mathrm{O}_{5}$ than Johannsen's average. The greater amount of alumina in Johannsen's average results in a much greater percentage of anorthite in the norm.

\section{CONCLUSIONS}

The close association in space and time of emplacement of the alkalic and gabbroic intrusives in the Oregon. Coast Range suggests that they are comagmatic. Available chemical data indicate that the parent magma was probably transitional between the tholeiitic and alkalic series. It seems reasonable to assume that a magma of intermediate composition would give rise to two divergent rock types. Therefore, the writers speculate that the alkalic rocks are an early product of differentiation of an alkali-rich tholeiite generated in a belt transitional to the continent and the Pacific Basin. It should be stressed that the results summarized here are preliminary and that additional petrographic and analytical data are needed before more than conjecture can be attempted concerning the magmatic evolution of these Oregon rocks.

\section{REFERENCES}

Baldwin, E. M., 1947, Geology of the Dallas and Valsetz quadrangles, Oregon: Oregon Dept. Geology and Mineral Industries Bull. 35, 61 p.

1956a, Geology of the Marys Peak and Alsea quadrangles, Oregon: U.S. Geol. Survey Oil and Gas Inv. Map OM-162.

1956b, Geologic map of the lower Siuslaw River area, Oregon: U.S. Geol. Survey Oil and Gas Inv. Map OM-186.

Baldwin, E. M., Brown, R. D., Jr., Gair, J. E., and Pease, M. H., Jr., 1955, Geology of the Sheridan and McMinnville quadrangles, Oregon: U.S. Geol. Survey Oil and Gas Inv. Map OM-155.

Baldwin, E. M., and Roberts, A. E., 1952, Geology of the Spirit Mountain quadrangle, northwestern Oregon: U.S. Geol. Survey Oil and Gas Inv. Map OM-129.

Hotz, P. E., 1953, Petrology of granophyre in diabase near Dillsburg, Pennsylvania: Geol. Soc. America Bull., v. 64, no. 6 , p. $675-704$.

Johannsen, Albert, 1938, A descriptive petrography of the igneous rocks, volume 4 : Chicago, Ill., Chicago Univ. Press, $523 \mathrm{p}$.

Kuno, Hisashi, 1960, High-alumina basalt: Jour. Petrology, v. 1, pt: 2, p. 121-145.

Murata, K. J., 1960, A new method of plotting chemical analyses of basaltic rocks : Am. Jour. Sci., v. 258-A, Bradley volume, p. 247-252.

Nockolds, S. R., 1954, Average chemical compositions of some igneous rocks: Geol. Soc. America Bull., v. 65, no. 10, p. $1007-1032$.

Roberts, A. E., 1953, A petrographic study of the intrusive at Marys Peak, Benton County, Oregon: Northwest Science, v. 27, no. 2, p. 43-60.

Rogers, A. F., Howe, H. V., and Staples, L. W., 1941, Trachytoid nepheline syenite from Lincoln County, Oregon [abs.]: Geol. Soc. America Bull., v. 52, no. 12, pt. 2, p. 1955.

Snavely, P. D., Jr., Baldwin, E. M., Roberts, A. E., and Isotoff, Andrei, 1950, Large intrusive bodies in the Central Coast Range of Oregon [abs.] : Geol. Soc. America Bull., v. 61, no. 12 , pt. 2 , p. $1503-1504$.

Snavely, P. D., Jr., and Vokes, H. E., 1949, Geology of the coastal area from Cape Kiwanda to Cape Foulweather, Oregon: U.S. Geol. Survey Oil and Gas Inv. Prelim. Map 97.

Vokes, H. E., Myers, D. A., and Hoover, Linn, 1954, Geology of the west-central border area of the Willamette Valley, Oregon: U.S. Geol. Survey Oil and Gas Inv. Map OM-150.

Vokes, H. E., Norbisrath, Hans, and Snavely, P. D., Jr., 1949 , Geology of the Newport-Waldport area, Lincoln County, Oregon: U.S. Geol. Survey Oil and Gas Inv. Prelim. Map 88.

Vokes, H. E., Snavely, P. D., Jr., and Myers, D. A., 1951, Geology of the southern and southwestern border areas, Willamette Valley, Oregon: U.S. Geol. Survey Oil and Gas Inv. Map OM-110. 
Wager, L. R., and Deer, W. A., 1939, The petrology of the Skaergaard intrusion, Kangerdlugssuag, East Greenland, in $\mathrm{Pt} .3$ of Geological investigations in east Greenland, Meddelelser om Grönland, v. 105, no. 4, 352 p.

Walker, Frederick, 1940, Differentiation of the Palisades diabase, New Jersey: Geol. Soc. America Bull., v. 51, p. $1.059-1.106$.
Walker, Frederick, 1958 , The causes of variation in dolerite intrusions, in Dolerite, a symposium: Tasmania Univ., Hobart [Symposia no. 1], p. 1-25.

Walker, Frederick, and Poldervaart, Arie, 1949, Karroo dolerites of the Union of South Africa: Geol. Soc. America Bull., v. 60 , no. 4 , p. $591-706$.

345. RELATION BETWEEN DEFORMATION, METAMORPHISM, METASOMATISM, AND INTRUSION ALONG THE NORTHWEST BORDER ZONE OF THE IDAHO BATHOLITH, IDAHO

\author{
By Anna Hietanen, Menlo Park, Calif.
}

The grade of metamorphism of the Belt series northwest of the Idaho batholith increases toward the batholith through a distance of about 40 miles from the greenschist facies through the epidote-amphibolite facies to the sillimanite-muscovite subfacies of the amphibolite facies (fig. 345.1).

The mineralogic changes are best exhibited in the micaceous granofelses, phyllites, and schists that are metamorphosed equivalents of parts of the Wallace formation described by Ransome and Calkins (1908) in the Coeur d'Alene district and by Umpleby and Jones (1923) and Wagner (1949) near Avery. In the micaceous rocks of the biotite-almandite subfacies of the epidote-amphibolite facies the late porphyroblasts are almandite and biotite, usually 2 to $3 \mathrm{~mm}$ in diameter; in places these minerals are partly altered to chlorite. In the schists of the staurolite-kyanite subfacies the porphyroblasts are staurolite and kyanite; the staurolite crystals are 2 to $6 \mathrm{~cm}$ long and those of kyanite are even larger. Both of these minerals contain abundant inclusions of quartz distributed along surfaces that are continuous with those of the folded beds in the enclosing schist. Many almandite grains are enclosed by later staurolite and kyanite and others have pushed the foliation aside. Some almandite crystals have a zone of inclusions of small quartz grains near their centers and another along their borders indicating two stages of synkinematic crystallization. These two stagrs (early and late phase in fig. 345.2) are also indicated by pseudomorphs consisting of kyanite, almandite, and muscovite but having the outlines of staurolite twins. A still later stage is recorded by alteration of kyanite to muscovite. In a zone next to the batholith the only stable polymorph of $\mathrm{Al}_{2} \mathrm{SiO}_{5}$ is sillimanite, which forms needles oriented parallel to the foliation. Some of the garnet, biotite, and sillimanite continued to crystalliza in a later stage.
Many outcrops show two sets of folds, one on either a northeastward- or a north westward-trending axis and another on an east-west axis. The northeastward- and northwestward-trending folds are parallel to the Nevadan (Jurassic) trends. The style of folding changes with the grade of metamorphism. In the greenschist facies large open folds are common and the foliation is parallel to bedding, to axial planes, or to nearby fault zones. The folds become increasingly tighter to the south, and in the zone next to the batholith steep isoclinal folds or overturned flow folds prevail. The axial plane foliation and cleavage folds are best developed in micaceous layers metamorphosed to the epidote-amphibolite facies; they are rare in the amphibolite facies near the batholith. Concentric folds with foliation parallel to the bedding are common in thin-bedded quartzite in all metamorphic zones. Where several sets of folds occur, the style of folding in all sets in a given metamorphic zone is similar, except as it is modified by the differences in competency of the materials folded. The northeastward- and north westward-trending folds were formed simultaneously, and east-west folding, perhaps started in Precambrian time, was renewed during the Jurassic period. Lineation is well developed in most rocks, and it is always parallel to one of the three fold axes.

In many places along the northwestern contact zone of the batholith secondary hornblende, biotite, and andesine were developed in garnet-mica schist, biotite gneiss, and diopside gneiss. Comparison of the chemical analyses of the normal metasedimentary rocks with those of the andesine and hornblende-bearing parts of the same strata indicates introduction of $\mathrm{Ca}, \mathrm{Fe}, \mathrm{Mg}$, and locally $\mathrm{Na}$, and removal of $\mathrm{K}$ and $\mathrm{Si}$ during the development of the secondary minerals. The secondary minerals show no preferred orientation and in many places obliterated the earlier structures, suggesting that 


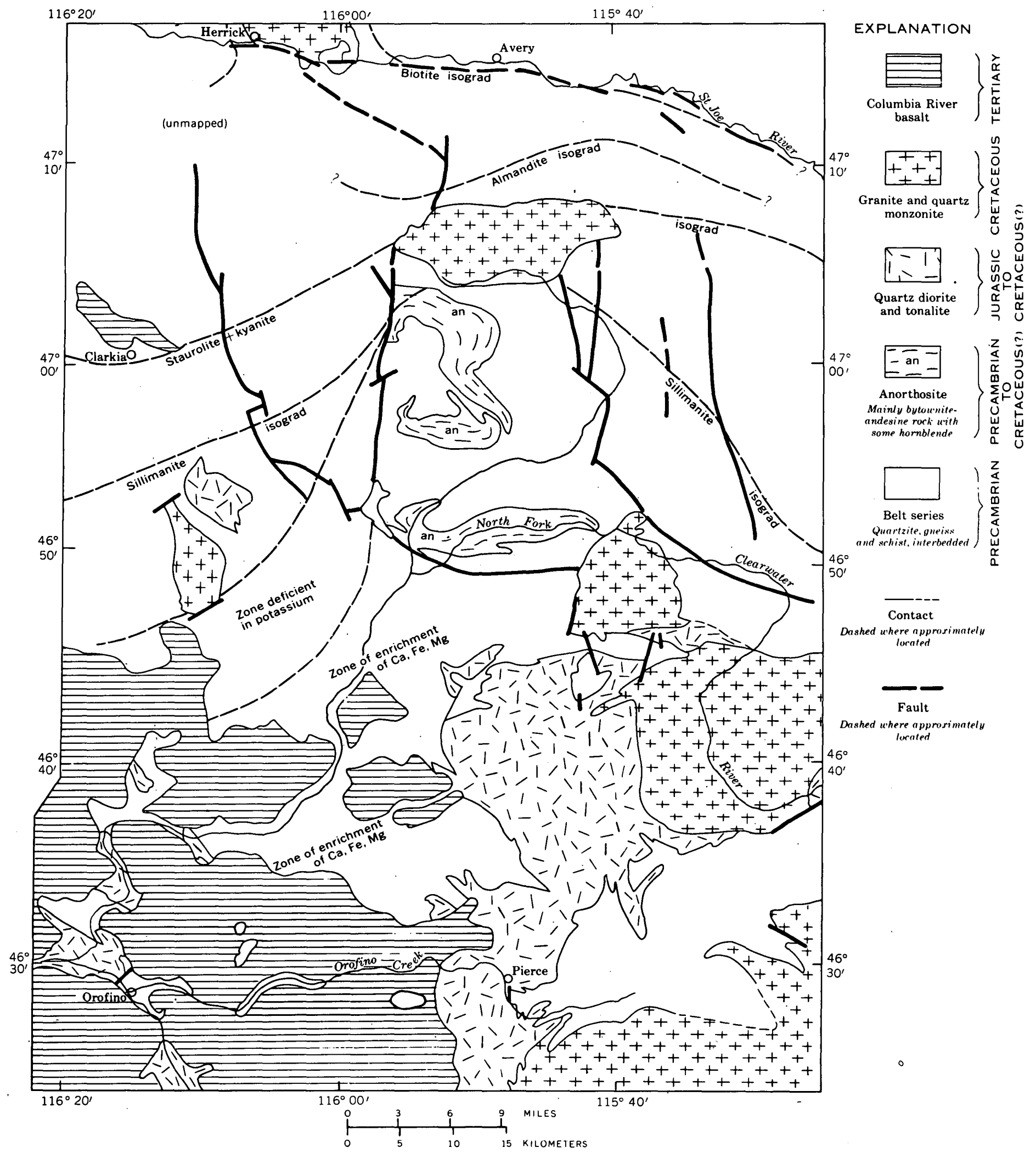

Fraure 345.1.- Sketch map showing the major rock units, distribution of some of the index minerals of metamorphic facies, and rearrangement of elements northwest of the Idaho batholith. The rocks south of the sillimanite isograd were metamorphosed to the amphibolite facies, those between the biotite and sillimanite isograds to the epidote-amphibolite facies, and the rocks north of the biotite isograd to the greenschist facies. Mainly Na was introduced into the anorthosite bodies. 


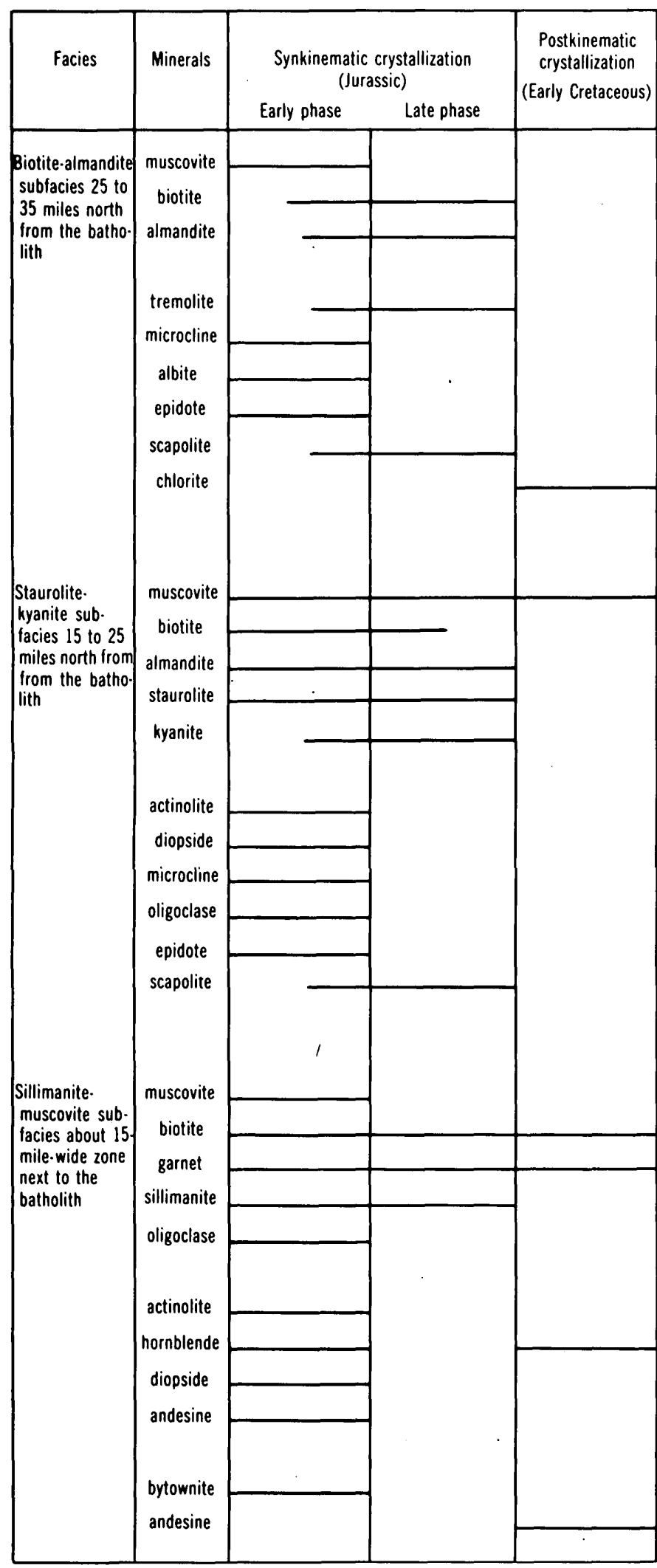

Figure 345.2.--Sequence of crystallization in various metamorphic facies northwest of the Idaho batholith. the metasomatic introduction of elements occurred after the major deformation. The basified zone is about 10 to 12 miles wide and about 15 to 20 percent of the metasedimentary rocks were affected. Potassium feldspar, which is a common metamorphic mineral in many stratigraphic units farther from the batholith, is very scarce or absent in the equivalent units in the basified aureole and also in a zone, 5 to 10 miles wide, outside it. In a zone 20 to 40 miles northwest of the batholith, the only change in chemical composition during the metamorphism was the loss of $\mathrm{H}_{2} \mathrm{O}$ and $\mathrm{CO}_{2}$ that took place at certain temperature intervals along the facies boundaries.

The largest intrusive bodies in the area are quartz diorite and quartz monzonite. The contacts of quartz diorite are in part concordant and in part discordant. Foliation is well developed in many small bodies in the western part of the area and near the contacts of the larger bodies, but the centers of the large bodies are massive. These structural relations suggest that the emplacement of small intrusive bodies began during the deformation but that the emplacement and crystallization of the largest bodies followed the deformation.

The metamorphosed and metasomatized rocks of the inner contact zone and the quartz diorite are cut by the quartz monzonite that makes up most of the present exposed batholith. The lead-alpha ages of the batholithic rocks average 108 million years, which dates the intrusion as late Early Cretaceous (Larsen and others, 1958). Because the minerals in the rocks of the sillimanite-muscovite subfacies, which were invaded, were stable in the temperature and pressure of the intrusion, new minerals formed only where elements were introduced.

These observed relations are interpreted as follows: The rearrangement of elements in the immediate vicinity of the present batholith began during the formation of the quartz monzonite magma by partial melting of a part of the crust at depth. The melting probably was an ultimate result of elevated temperatures during the deformation in the lower part of the crust. If so, the first melt would be granitic in composition (3, in fig. 345.3) and the zone around the developing magma would be relatively enriched in $\mathrm{Ca}$, $\mathrm{Fe}$, and $\mathbf{M g}$ by subtraction of granitic components (2, in fig. 345.3). When the temperature rose (or the pressure decreased) the magma would become more mafic (quartz-monzonitic) and finally the basified aureole around it would also melt partially to form a quartz diorite magma. This magma invaded its roof and gave off solutions carrying $\mathrm{Na}, \mathrm{Ca}, \mathrm{Fe}$, and $\mathrm{Mg}$, which advanced into the country rocks, reacted with their minerals, and formed local segregations of hornblende, 


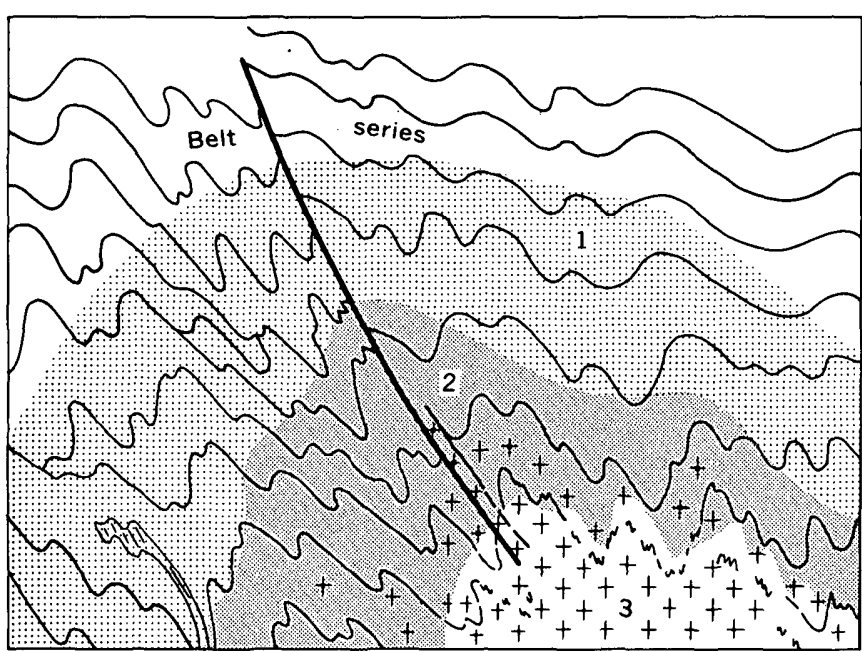

$A$

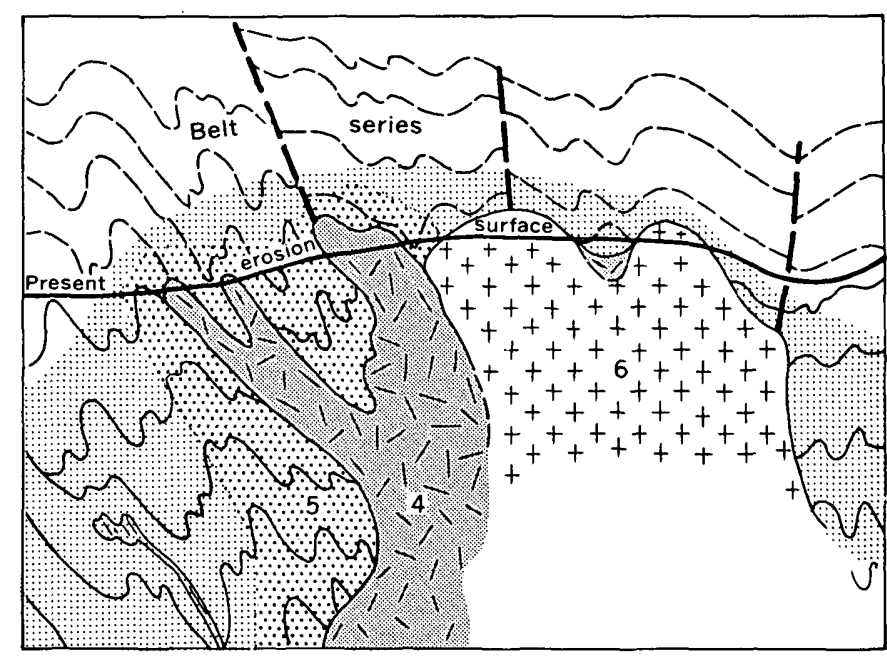

$B$

FrGURE 345.3.-Schematic cross-section showing interpretation of the relation between metamorphism and intrusion along the northwest border zone of the Idaho batholith during late Mesozoic time. Sketch $A$ shows (1) the zone of high-grade, essentially isochemical, metamorphism during Jurassic time; (2) the zone of rocks basified by depletion of granitic components; and (3) the magma produced by partial melting and aggregation. Sketch $B$ shows quartz diorite (4) which was formed from the basified rocks ( 2 of sketch $A)$, by partial melting and recrystallization. A new basified zone (basic front) (5) was formed around the quartz diorite by metasomatic introduction of $\mathrm{Na}$, $\mathrm{Ca}$, $\mathrm{Fe}$, and $\mathrm{Mg}$ from the quartz dioritic magma during Early Cretaceous time. The entire series of metamorphic, metasomatic, and early magmatic rocks was then intruded by the quartz monzonite that makes up the batholith proper (6).

biotite, and andesine (5, in fig. 345.3). During an early stage of this metasomatism the elements were carried in solutions that moved in open channels; at this stage hornblende and andesine crystallized together, forming small bodies of metasomatic quartz diorite. Later, when the pore liquids became stationary and the elements moved only by diffusion, the femic and salic constitutents crytallized in separate places, the former giving rise to segregations of hornblende and biotite and the latter to secondary andesine that replaced quartz in the schist and bytownite in the anorthosite.

Much of the potassium and silicon that have been removed from the contact aureole of the batholith probably migrated to the granitic and quartz monzonitic magmas during their formation. On the basis of the above discussion, it is concluded that the chemical differences between the quartz diorite and quartz monzonite series is due to the differentiation of elements during the formation of the magmas rather than during their crystallization. The crystallization differentiation of the quartz monzonite magma gave rise to a normal rock series ranging from olivine and pyroxene gabbros to granite, whereas the quartz diorite magma yielded hornblendite, hormblende gabbro, quartz diorite, and tonalite.

\section{REFERENCES}

Larsen, E. S., Jr., Gottfried, D., Jaffe, H. W., and Waring, C. L., 1958, Lead-alpha ages of the Mesozoic batholiths of western North America: U.S. Geol. Survey Bull. 1070-B, p. $35-62$.

Ransome, F. L., and Calkins, F. C., 1908, The geology and ore deposits of the Coeur d'Alene district, Idaho: U.S. Geol. Survey Prof. Paper 62, 203 p.

Umpleby, J. B., and Jones, E. L., 1923, Geology and ore deposits of Shoshone County, Idaho: U.S. Geol. Survey Bull. 732. $156 \mathrm{p}$.

Wagner, W. R., 1949, The geology of part of the south slope of the St. Joe Mountains, Shoshone County, Idaho : Idaho Bur. Mines and Geology, Pamph. 82, p. 1-48. 
346. DEFORMATION OF THE EPICENTRAL AREA, HEBGEN LAKE, MONTANA, EARTHQUAKE OF AUGUST 17, 1959-DUAL-BASIN CONCEPT

By Irving J. Witkind, Denver, Colo.

The geologic work completed in the Hebgen Lake area (fig. 346.1) since the earthquake of August 17, 1959 (Witkind, 1959, 1960; Niles, 1960) has yielded many detailed data on both relative and absolute ground movement in some parts of the area, but very little in other places. Two different interpretations of the nature and pattern of structural deformation stem from the available data. One interpretation (Myers and Hamilton, Art. 347), suggests subsidence of a single large basin, transverse to the major topographic elements. The other interpretation, here called the "dual-basin concept", suggests unequal subsidence of two independent basins, one on each side of the core of the Madison Range (fig. 346.2). Whichever interpretation is correct, it seems clear that the crest of the range, in a relative sense, is higher in relation to the adjacent downthrown basins than it was before the earthquake.

During the earthquake, new fault scarps appeared at several localities throughout the epicentral area. The major scarps coincide with, or are near, previously mapped normal faults which trend generally northwest and dip southwest. Two of these scarps, the Red Canyon and Hebgen fault scarps, are north of Hebgen Lake (fig. 346.1) and coincide with the northwesttrending Red Canyon and Hebgen faults respectively. Minor fault scarps, along the west front of the Madison Range (fig. 346.1), coincide with the well-established Madison Range fault. All these fault scarps clearly result from reactivation of the faults.

The Red Canyon and Hebgen faults are considered to be the fundamental faults of the earthquake, or at least surface modifications of a deep fault. This is supported by a preliminary analysis of seismograms of this earthquake which suggest "strike of the fault plane N. $80^{\circ} \pm 12^{\circ} \mathrm{W}$.; dip $55^{\circ} \pm 9^{\circ} \mathrm{SW}$.; strike of the auxiliary plane N. $62^{\circ} \pm 15^{\circ}$ W." (Ryall, 1961, p. 63).

The geologic pattern of the area indicates that each of the faults-Red Canyon, Hebgen, and Madison Range - is marginal to one or more crustal blocks which have subsided repeatedly in the past (Pardee, 1950, p. 369 ; Witkind, 1960, p. 34). Thus, the Red Canyon and

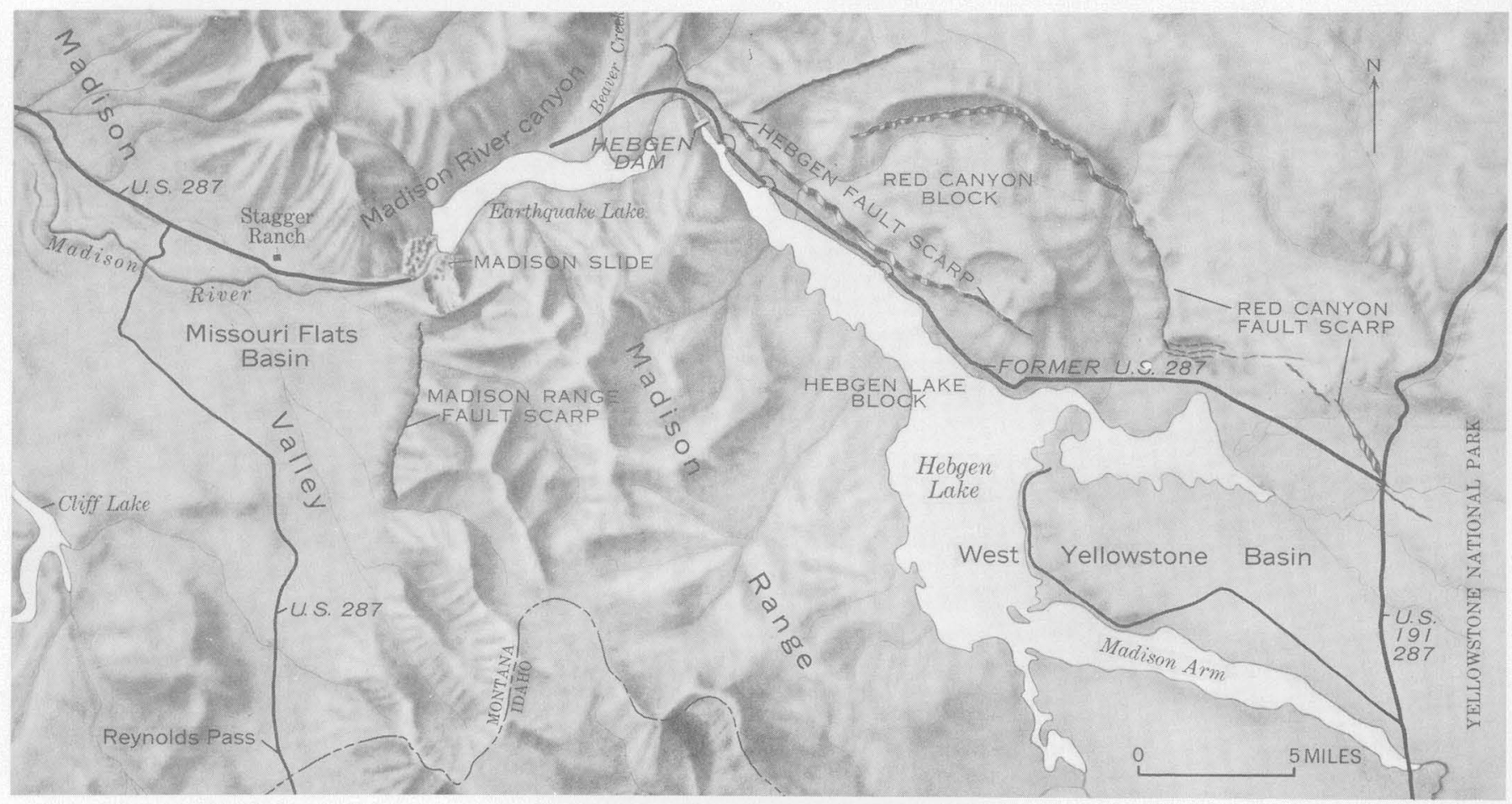

Figure 346.1.- Shaded relief map of the epicentral area, Hebgen Lake, Mont., earthquake of August 17, 1959. 


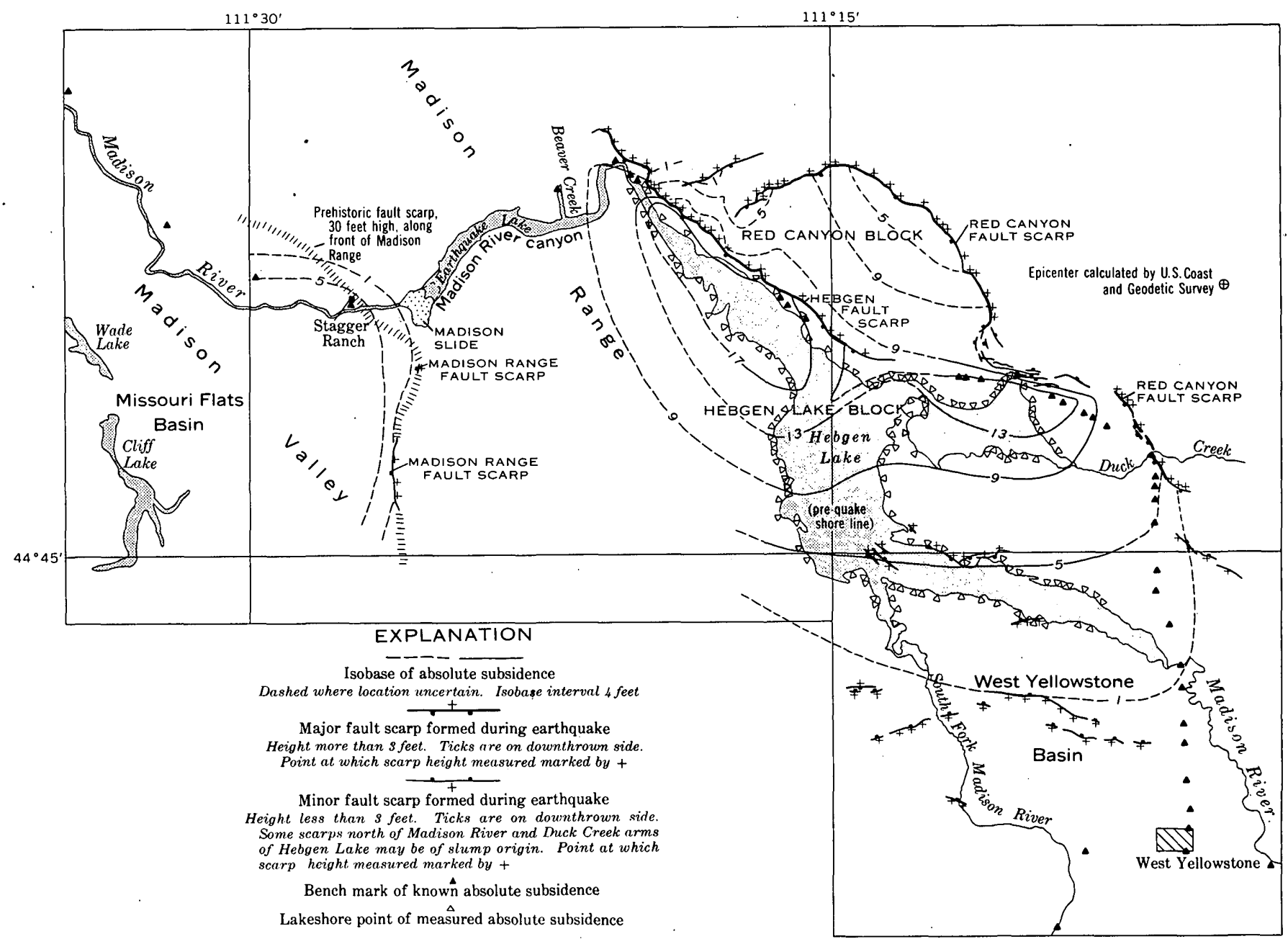

Lakeshore point of measured absolute subsidence

10 MILES

FIgure 346.2.-Absolute subsidence during Hebgen Lake earthquake-dual-basin concept. Contours based on releveling of bench marks and road profiles by the U.S. Coast and Geodetic Survey; measurements of lakeshore tilting by W. B. Myers, W. H. Hays, and Warren Hamilton; and measurements of scarp heights by I. J. Witkind, J. B. Epstein, W. B. Myers, Warren Hamilton, and W. H. Hays.

Hebgen faults flank both the Red Canyon and Hebgen Lake blocks (fig. 346.2). Similarly, the segment of the Madison Range fault that was reactivated is along the east edge of the crustal block underlying the Missouri Flats basin (fig. 346.2), part of the much larger Madison basin.

During the earthquake these blocks subsided unevenly. Their general deformational pattern is shown locally by the new shoreline of a tilted lake, by measured displacement along new fault scarps, and by pre- cise level data determined by the U.S. Coast and Geodetic Survey.

I believe that this subsidence of local crustal blocks is a direct result of the broad epeirogenic uplift and arching which this region has been undergoing since late Cenozoic (Pardee, 1950, p. 403).

The dual-basin concept, based on subsidence of local crustal blocks, holds that the West Yellowstone and Missouri Flats basins, to the east and west of the Madison Range, respectively, subsided during the earth- 
quake, but the core of the Madison Range remained fairly stable. The axes of these two basins are subparallel but not connected.

The west half of the West Yellowstone basin, and parts of the adjacent mountains to the north and west, subsided during the earthquake. This subsided area is underlain by the Red Canyon and Hebgen Lake crustal blocks (fig. 346.2). Of these, the Red Canyon block of about 20 square miles includes part of the mountains north of the lake. The Hebgen Lake block, although very much larger, is of uncertain areal extent. It includes the west half of the West Yellowstone basin and the east flank of the core of the Madison Range. The northeastern edge of this block is bounded by parts of the Hebgen and Red Canyon faults. Its southern edge may be delineated by the local faults of small displacement which break the surficial deposits south of Hebgen Lake (fig. 346.2).

Near Hebgen Lake, data on the amounts and pattern of movement are ample, for when the West Yellowstone basin, which includes Hebgen Lake, dropped and tilted northeasterly, it displaced the lake. Measurements of the old and new shorelines, made by W. B. Myers, supply many of the data used to contour this part of the basin (fig. 346.2).

The east edge of the Missouri Flats basin has subsided the most near the Madison Range fault. Precise levels completed by the U.S. Coast and Geodetic Survey indicate subsidence of about 7 feet along former U.S. Highway 287 near the east edge of the basin.

The fault scarps along the Madison Range fault are 2 to 3 feet high, but these may not accurately reflect the absolute displacement (Witkind, 1960, p. 38). It is assumed that they do, and I interpret the isobase lines to show drag of the eastern edge of the basin along the Madison Range fault, comparable to the drag along the northeast edge of the Hebgen Lake block (fig. 346.2).

Elsewhere in the Missouri Flats basin, the data are inadequate to define a pattern of displacement. Several small lakes may have been tilted, but their former shorelines are submerged, for increased surface- and ground-water discharge since the earthquake has caused the lakes to rise. This; coupled with conflicting statements by local residents, makes it uncertain which of the lakes, if any, have been tilted. The exact pattern of this deformed basin will be in doubt until it is resurveyed topographically.

The deformation pattern along the crest of the Madison Range is uncertain, for no data are presently avail- able for this critical area. One interpretation (Myers and Hamilton, Art. 347) is that it subsided as much as 13 feet at places. I suggest that maximum subsidence probably did not exceed 3 feet (fig. 346.2). The east flank of the range, within the Hebgen Lake block was flexed downward (fig. 346.2). How far to the west this downward warp extends is not established. Most of the pre-earthquake bench marks in the Madison River Canyon are concealed beneath the newly formed Earthquake Lake.

It has been proposed that deformation of the Madison Range is shown by subsidence in Madison River Canyon (Myers and Hamilton, Art. 347). A comparison of pre- and post-earthquake surveys of the U.S. Coast and Geodetic Survey and the Bureau of Public Roads suggests that the canyon floor subsided from about 8 feet at Beaver Creek to about 7 feet near Stagger's Ranch at the west mouth of the canyon (fig. 346.1 ), but these data are equivocal. In the fall of 1960 surveys by the Bureau of Public Roads showed recent changes of from 1.0 to 1.8 feet in elevation in the area between Beaver Creek and the Madison Slide (L. D. Tingey, written communication, 1961). It would seem that this part of the canyon was still not stable in 1961. The surveys show that 2,900 feet west of Beaver Creek the highway dropped about 20 feet; this compares to an 8-foot drop of the highway at Beaver Creek. This unusual and sudden change must be attributed to some factor other than absolute subsidence. I suggest that unequal compaction of the alluvial fill may be the cause; this view is supported by the many sand spouts on the broad alluvial flat near Beaver Creek. Compaction of unconsolidated materials played an important role in the subsidence elsewhere in the area, and probably was a factor in the amount of subsidence determined for former U.S. Highway 287 where it enters the west end of the canyon near Stagger's Ranch. Here the road rests on unconsolidated sand and gravel. My hesitancy to accept the subsidence data in the Madison River Canyon stems chiefly from the uncertainty as to how much of the measured subsidence is due to true bedrock movement and how much is due to compaction of the surficial cover. The true pattern of deformation for the Madison Range will be determined only by a resurvey of the bedrock crest.

Available geologic and geodetic data, and the preliminary seismic solution for the earthquake fault, suggest that the Hebgen-Red Canyon fault zone is fundamental, and that deformation everywhere in the area is most extreme near faults. On this basis, subsidence of two basins seems reasonable. 


\section{REFERENCES}

Niles, S. W., 1960, The Hebgen Lake earthquakes, in Billings Geol. Soc. Guidebook 11th Ann. Field Conf., West Yellowstone-Earthquake area, $1960:$ p. 24-30.

Pardee, J. T., 1950, Late Cenozoic block faulting in western Montana: Geol. Soc. America Bull., v. 61, no. 4, p. 359-406. Ryall, A. S., 1961, Direction of faulting in the Hebgen Lake, Montana, earthquake of August 18, 1959 [abs.] : Geol. Soc.
America, Cordilleran Section, 1961 Ann. Meeting, San Diego, Calif., Program.

Witkind, I. J., 1959, The Hebgen Lake earthquake: GeoTimes, v. 4, no. 3, p. 13-14.

1960, The Hebgen Lake, Montana, earthquake of August 17, 1959, in Billings Geol. Soc. Guidebook 11th Ann. Field Conf., West Yellowstone-Earthquake area, 1960: p. $31-44$.

347. DEFORMATION ACCOMPANYING THE HEBGEN LAKE, MONTANA, EARTHQUAKE OF AUGUST 17, 1959SINGLE-BASIN CONCEPT

\author{
By W. Bradley Myers and Warren Hamilton, Denver, Colo.
}

During the major (magnitude at least 7.1) earthquake of August 17, 1959 , in southwest Montana, an area at least 27 miles long and 14 miles wide subsided detectably. Maximum absolute subsidence was about 22 feet, and a tract of 'at least 60 square miles dropped more than 10 feet, but there was almost no known elevation of the land above previous levels.

Many details of this subsidence can be defined by the data obtained from level lines, scarp heights, and lakeshore tilting. The U.S. Coast and Geodetic Survey releveled bench marks on a line that passes through West Yellowstone, the northeast side of Hebgen Lake, Madison River Canyon, and Madison River.

By constructing a post-quake road profile from the individual Coast and Geodetic Survey level-rod readings, and comparing this with the known pre-quake profile of the highway, we obtained a continuous measure of subsidence between the bench marks. These new data show the maximum subsidence along Hebgen Lake to be 22 feet, rather than the 19 feet demonstrated by the most subsided bench mark.

The new road-profile data are critical to the structural interpretation in Madison River Canyon, which cuts directly through the Madison Range. (Bench marks in the canyon were mostly buried beneath the enormous landslide, triggered by the earthquake, and the new lake dammed behind it.) These data (fig. 347.1) show that no warping occurred across the rangefront fault at the mouth of Madison River Canyon, and that both the Madison Range and Madison Valley in that area subsided equally 6 to 8 feet. The data also show that a topographic basin in Madison River Canyon between Hebgen Lake and Earthquake Lake subsided at least 12 feet, at least 6 feet more than the

1 August 17 by local date; August 18 by Greenwich date. narrow part of the canyon between the topographic basin and Hebgen Lake. This basin has broad flats of thick alluvium and till and a gentle river gradient, whereas the Madison River Canyon is otherwise narrow and has a steep gradient, so that the increased subsidence in the basin was not unexpected.

In Article 346, Witkind states that the subsidence measured within Madison River Canyon was due partly to compaction and slumping, and, therefore, is equivocal in structural evaluations. He believes that subsidence in Madison Valley and West Yellowstone basin was due largely to structural deformation. This interpretation seems to assume that in Madison Valley, where sedimentary fill is thick, there was practically no compaction, but in Madison River Canyon, where fill was very thin, compaction unaccompanied by any noticeable slump away from nearby outcrops, produced most of the subsidence.

We examined the prehistoric fault scarp at the mouth of Madison Canyon, and found no new breaks. Further, although Madison River there runs on thin alluvium and at places reaches bedrock, there was no apparent steepening of its gradient to suggest warping at the range front.

In the upper part of Madison River Canyon (as was true also along Hebgen Lake except in obvious landslides), control points on bedrock subsided compatibly with those on surficial deposits, so slumping and compaction of unconsolidated materials at these places contributed little to the subsidence.

The contours of absolute subsidence (isobases) defined by these various data (fig. 347.1) can be drawn with confidence near Hebgen Lake and along the level line, and with less confidence near the major new fault scarps, but elsewhere their location is doubtful. Where 


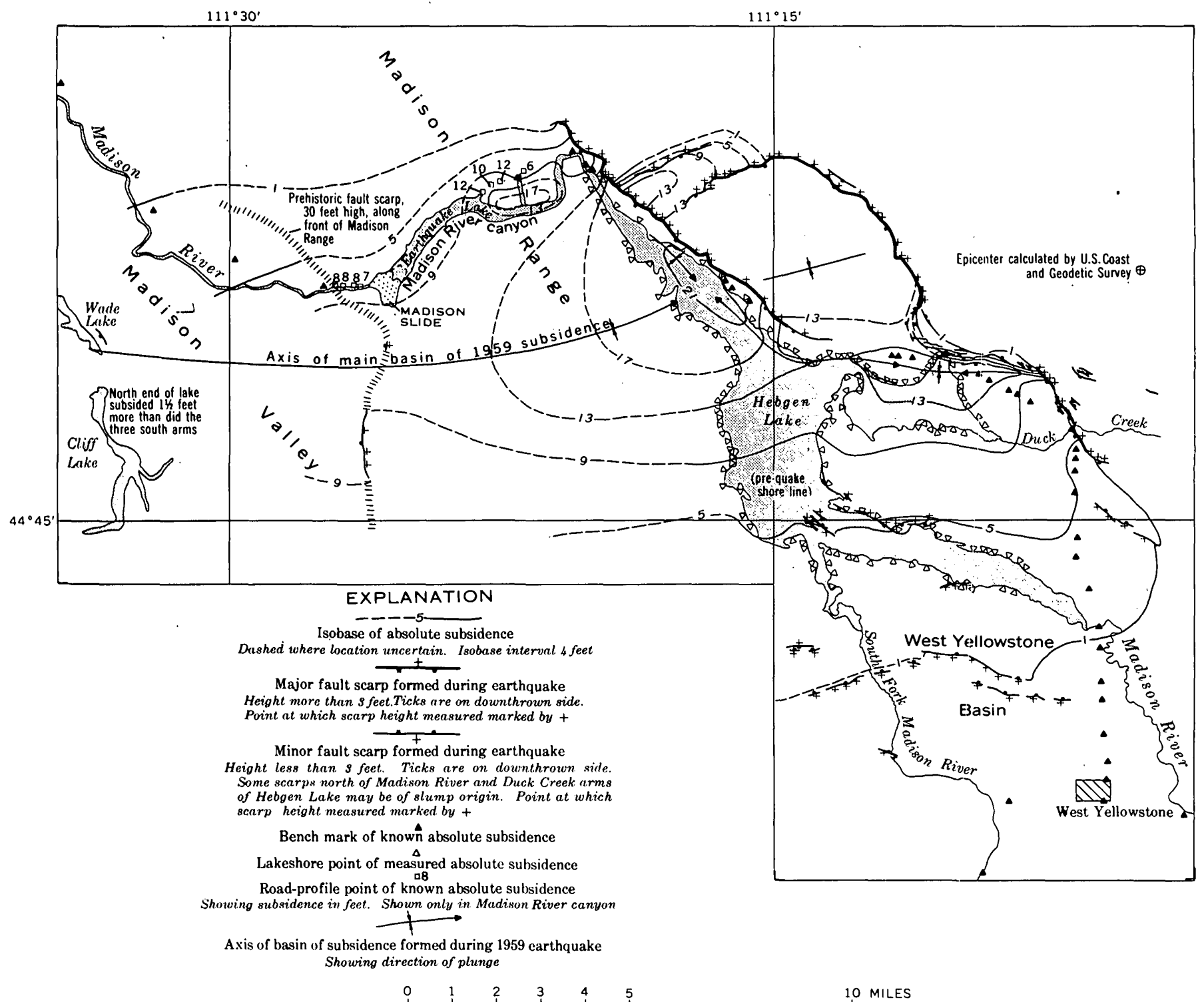

Figure 347.1.-Absolute subsidence during Hebgen Lake earthquake--single basin concept. Based on releveling of bench marks and road profiles by the U.S. Coast and Geodetic Survey; measurements of lakeshore tilting by W. B. Myers, W. H. Hays, and Warren Hamilton; and measurements of scarp heights by I. J. Witkind, J. B. Epstein, W. B. Myers, Warren Hamilton, and W. H. Hays.

the trend of the isobases is most closely controlled, near the south half of Hebgen Lake, it is westward; we assume that this trend continues into the Madison Range, whereas Witkind (Art. 346) makes a contrary assumption that the isobases define a more northerly trending basin of subsidence. Subsidence of the Madison Range seems adequately demonstrated within Madison River Canyon, and we infer that the range subsided south of the canyon also.

We thus interpret the data to indicate a broad basin of new subsidence that plunges gently eastward across Madison Valley, Madison Range, and West Yellow$6044930 \longrightarrow 61-12$ stone basin to Hebgen Lake. The basin, be it a single complex one as we suggest, or two disconnected ones as Witkind suggests, ends obliquely and abruptly against three reactivated fault scarps, 5 to 20 feet high, which trend southeastward near the northeast side of Hebgen Lake. All are dip-slip normal faults, upon which no tectonic strike-slip offset was recognized. Northeast of these scarps and their immediate disturbed zones, known elevation or subsidence in 1959 was limited to less than 1 foot. Of the three high scarps, two break Paleozoic sedimentary rocks, and the third cuts thick Pleistocene deposits which hide bedrock structure. 
The two major faults in Paleozoic rocks (mapped by I. J. Witkind, J. B. Hadley, W. H. Nelson, and others) lie for most of their lengths between bedrock bluffs and the talus below them, and probably follow previously active faults. The faults at their west ends, however, cross bedrock ridges where there is neither structural nor topographic evidence for previous faulting, and the new breaks appear here to extend beyond older faulting. The faults are nearly bedding-plane faults, and are limited to areas where the bedding dips steeply toward the subsidence basin. The trend of one of the faults swings with the bedding through a large arc in strike. Where bedding is oriented favorably to permit sliding down the dip, the measured subsidence is accounted for almost entirely by the height of new scarps. Where attitudes are less favorable for sliding, subsidence was accomplished by a combination of warping (to a maximum of $3 / 4^{\circ}$ of new tilting) and faulting.

These two major reactivated faults at the surface are thus closely controlled by fold structures, in Paleozoic rocks, which probably do not extend deeper than 1 mile. The surface scarps, therefore, cannot directly portray the pattern of deformation in deep basement rocks; rather, the surface breaks must be due to refraction or resolution of deeper faults or flexures into planes of easy near-surface slip.

The third major 1959 fault scarp extends farthest southeast and displaces early Wisconsin (late Pleistocene) deposits. It also is a reactivated fault along which had occurred at least two previous major episodes of faulting with a total pre-1959 displacement of as much as 60 feet.

The south flank of that part of the broad basin of new subsidence within the West Yellowstone basin is a gently sloping platform, broken by new low scarps (mostly less than 2 feet high) and small monoclines, along small east-trending reactivated faults. Previous displacements along these structures formed faults and abrupt monoclines with a maximum local structural relief of 50 feet in early Wisconsin surficial deposits, and progressively less in late Wisconsin and Recent materials. (The materials were studied by G. M. Richmond, and the structures by us.) Broad tilting and gentle warping also occurred during late Quaternary time.

Most 1959 fault scarps in unconsolidated materials were nearly vertical, much steeper than the probable attitudes of the underlying bedrock faults, showing that fractures were refracted into steeper orientations as they approached the surface.

Madison Valley south of the Madison River Canyon has been much deformed by Quaternary tilting and subordinate faulting along structures which are oblique at high angles to the northwest-trending and generally older basin-and-range structures of Madison Valley and Madison Range, and which are continuous with the major east-trending structures of the tectonically very active Centennial Range and Centennial Valley. The late Quaternary warps and faults of the south part of West Yellowstone basin also have a dominant eastward trend, and other modern folds strike eastward from the basin to Gibbon River in Yellowstone National Park. It appears to us that the northwest-trending Madison structures are being progressively modified and distorted as structures of the Centennial system are extended across them, and that the deformation accompanying the 1959 earthquake provided another increment in this modification.

348. STRATIGRAPHY OF THE WILKINS PEAK MEMBER OF THE GREEN RIVER FORMATION, FIREHOLE BASIN QUADRANGLE, WYOMING

By William C. Culbertson, Denver, Colo.

In the past few years the Wilkins Peak member of the lacustrine Green River formation of Eocene age has been extensively explored for trona in the southern half of the Green River basin, but very little detailed information about the member has been published. During the summer of 1960 , the author, assisted by H. W. Anderson, mapped the Wilkins Peak member in most of the Firehole Basin 15-minute quadrangle (fig. 348.1) and measured several sections. This work gives information on some prominent marker beds, their facies and color changes, and their correlation with units in the Diamond Alkali Co. No. 3 core hole, which is about 7 miles northwest of the quadrangle (fig. 348.2).

The Wilkins Peak member, which was named by Bradley (1959, p. 1072), is 875 to 1,050 feet thick in the 


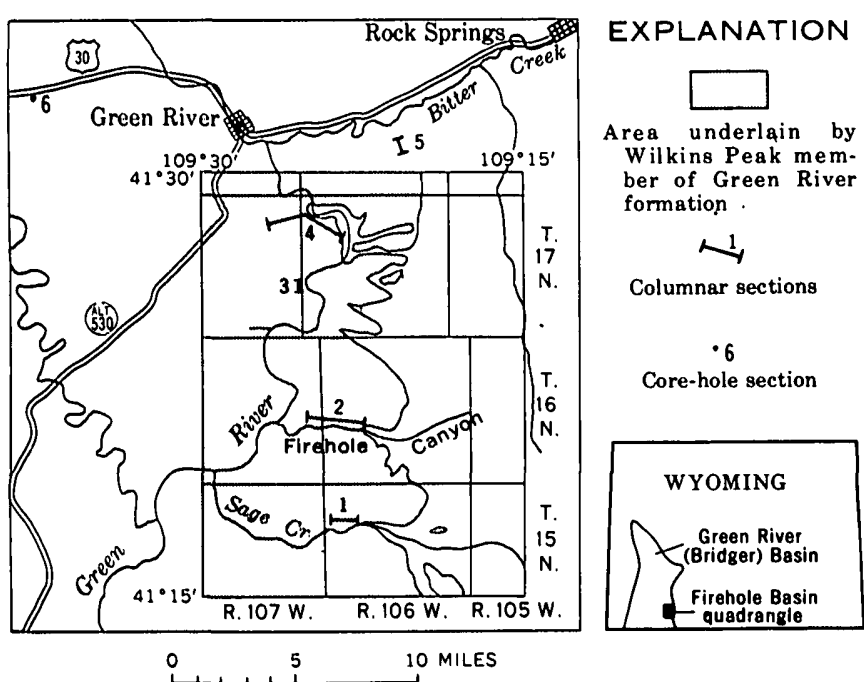

Frauke 348.1.-Index map showing Firehole Basin 15-minute quadrangle and adjacent aren, Siveetwater County, Wyo. See sections on figure 348.2 .

Firehole Basin quadrangle and consists of platy to fissile dolomitic marlstone, oil shale, claystone, limestone, and dolomite; crossbedded siltstone and sandstone; blocky mudstone; and several thin tuff beds. Calcareous algae in a few thin limestone beds and some poorly preserved plants are the only megafossils that were noted in the member. In the subsurface the member contains an unusual assemblage of saline minerals, chiefly shortite and trona (Milton and Fahey, 1960), that diminish in abundance eastward from the center of the Green River basin. On the outcrop the shortite crystals have been dissolved leaving molds, or they have been replaced to form calcite pseudomorph's. The top of the member is the base of the first brown fish-bearing oil-shale bed of the Laney shale member, and the base is placed at the top of thick laterally continuous oilshale beds of the Tipton shale member.

\section{SANDSTONE-SILTSTONE-MUDSTONE UNITS}

Nine sandstone-siltstone-mudstone units, ranging in thickness from 4 to 85 feet (fig. 348.2), are persistent in varying degrees across the quadrangle. These are designated $\mathbf{A}$ to I, from oldest to youngest. On Sage Creek the units typically consist of interbedded yellowish-gray $(5 Y 7 / 2)^{1}$ arkosic very fine to fine grained sandstone, yellowish-gray ( $5 \mathrm{Y} 7 / 2)$ arkosic siltstone, grayish-olive (10Y4/2) argillaceous siltstone, and a minor amount of silty to nonsilty grayish-olive (10Y4/2) mudstone that weathers to a blocky rubble. Some units contain a few thin beds, 1 to 4 feet thick, of limestone, oil shale, or marlstone. The sandstone and siltstone

\footnotetext{
1 Color deslgnations nccording to Rock Color Chart, National Research Councll, 1948.
}

are crossbedded in long and very short sweeps, and channeling sandstone beds are common. The arkosic sandstone and siltstone beds generally weather to moderate olive-brown (5Y4/4) ledges. Locally the units form slopes that appear dark green or olive-brown from a distance, in contrast to white-weathering beds that separate the units.

Northward the units become finer grained and thinner, and many are lighter in color. The A, B, and D units (fig. 348.2) are the most uniform and persistent of the lower eight units, and they are conspicuous ledge-formers throughout the quadrangle. The $\mathrm{C}, \mathrm{E}, \mathrm{F}, \mathrm{G}$, and $\mathrm{H}$ units are less persistent; in the vicinity of the Logan Draw and Lauder slide sections (fig. 348.2) they grade to mostly slope-forming silty and nonsilty mudstones that are pale olive $(10 \mathrm{Y} 6 / 2)$ to dusky yellow green $(5 \mathrm{GY} 5 / 2)$, and that only locally contain a thin bed of ledge-forming crossbedded siltstone or sandstone. In the Wilkins Peak section, farther northeast, the $\mathrm{C}, \mathrm{F}$, and $\mathrm{H}$ units underlie covered slopes and consist mostly of very pale-olive (10Y7/2) mudstone (fig. 348.2). Units $\mathrm{E}$ and $\mathrm{G}$ each contain a small ledge of crossbedded sandstone or siltstone interbedded with the grayish-olive to pale-olive mudstone, but the units are not conspicuous. The thinning and the change in color and ledging characteristics of the $\mathrm{E}$ through $\mathrm{H}$ units northward make this part of the section appear similar from a distance to overlying white-weathering beds.

In the upper part of the member, unit I is conspicuous everywhere as a dark-greenish band or ledge in the middle of a long white slope formed on a shortite-bearing sequence of marlstone, oil shale, and limestone.

In the core description of Diamond Alkali Co. No. 3 hole, the nine units are either silty or sandy mudstones (units $\mathrm{B}, \mathrm{D}, \mathrm{E}, \mathrm{F}$, and $\mathrm{G}$ ) or massive dark-green to gray mudstone or shale beds (units $\mathrm{A}, \mathrm{C}, \mathrm{H}$, and I), and they are easily recognized. They can also be identified on the electric log of the well by their low resistivity.

\section{TUFF, LIMESTONE, AND MUDSTONE BEDS}

At least six tuff beds in the Wilkins Peak member extend across the quadrangle (fig. 348.2). The first (oldest) tuff is an analcitized bed 3 to 6 inches thick in the lower part of the member that weathers to dark yellowish orange $(10 \mathrm{YR} 6 / 6)$ slabs and bricks. The second and next higher tuff is very irregular in thickness, ranging from 3 to 12 inches, and is everywhere present in an oil shale and limestone interbed in the lower part of unit $A$. The third and fourth tuffs in the upper part of the member are 2 to 20 inches thick and are 13 to 17 feet apart stratigraphically; they are particularly conspicuous in the northwest part of the 


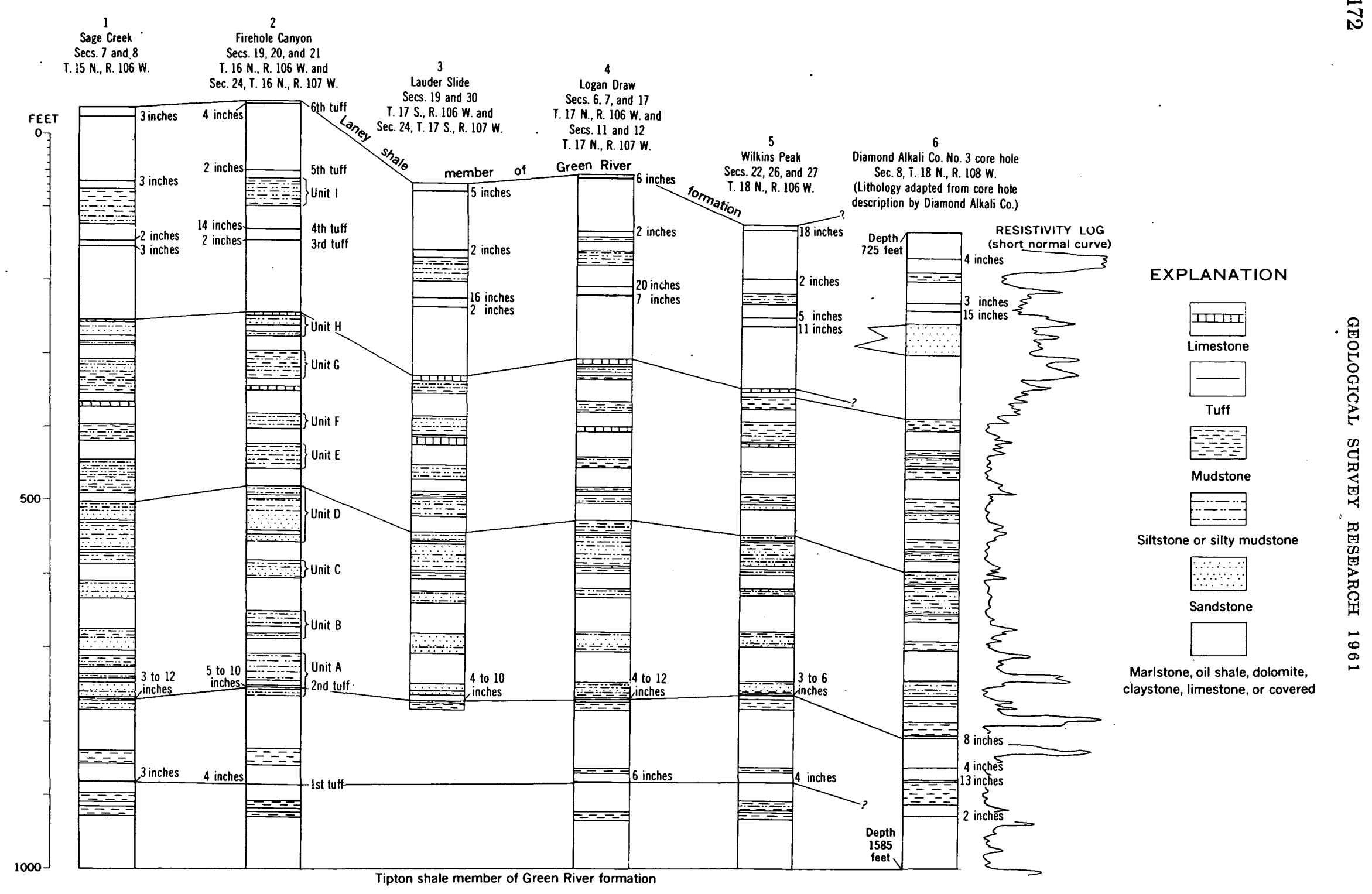

FiquRe 348.2.-Columnar sections showing lithology and correlation of marker beds in the Wilkins Peak member, Firehole Basin quadrangle, and adjacent areas, Wyoming. Location of sections shown on figure 348.1. 
quadrangle. The fifth tuff is a layered tuff 2 to 3 inches thick, and the sixth tuff is a light-gray massive tuff 3 to 18 inches thick. The second, third, fourth, and fifth tuff beds are recognized in the core description of the Diamond Alkali Co. No. 3 hole, but identification of the first tuff is uncertain.

At least two limestone beds can be easily correlated in the measured sections, but they are not recognized in the core hole (fig. 348.2). The upper is a bed 1 to 4 feet thick that forms a prominent bench at the top of unit $H$ in much of the area. The other forms a bench below unit $\mathrm{G}$ and is notable because it is 4 to 8 feet thick, contains less than 5 percent interbeds of claystune, and is slightly yellow on weathering.

Two grayish-olive (10Y4/2) mudstone beds that are about 70 and 140 feet, respectively, above the base of the Wilkins Peak member (fig. 348.2 ) are persistent marker beds throughout the quadrangle. In the core hole the lower part of the member is much thinner than in the measured sections, so that the correlation of the two mudstone beds with beds in the core hole is uncertain.

\section{THREEFOLD SUBDIVISIONS OF THE WILKINS PEAR MEMBER}

Deardorffi, Millice, and Textoris ${ }^{2}$ each subdivide the Wilkins Peak member into three parts on the basis of a middle unit composed chiefly of green or brown siltstone, sandstone, and mudstone, but each recognizes a somewhat difterent middle unit. These middle units can be correlated with the nine marker units of the Firehole Canyon section (fig. 348.2) as shown on figure 348.3.

a Deardorff, D. L., 1959, Stratigraphy and ofl shales of the Green Rlver formation southwest of the Rock surings uplift, Wyoming: Master's thesis, Univ. Wyoming, $98 \mathrm{p}$.

Millice, Roy. 1950, Strntigraphy of the Green River formation In the southeastern Brldger busin, Wyoming: Master's thesis, Univ. Wyoming, $89 \mathrm{p}$.

Jextoris, D. A., 1960, Stratigraphy of the Green River formation in the Bridger basin, Wyoming: Master's thesis, Ohlo State Univ., 107 p.

HYDROLOGIC SCIENICES, ARTICLES 293-435

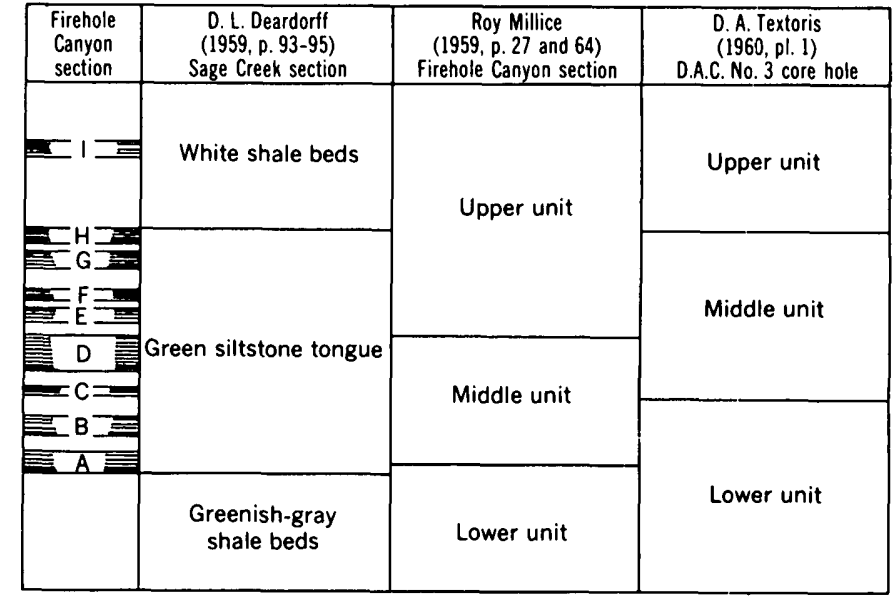

Letters $A$ to 1 refer to units shown on columnar section, figure 2 ; Theses cited in footnote in text

Figure 348.3.-Probable correlation of subdivisions of Wilkins Peak member described in three unpublished Master's theses with the Firehole Canyon section. Letters A to I refer to units shown on columnar section, figure 348.2 ; theses cited in footnote 2 .

In the southern part of the area the middle unit of Deardorff is the most distinctive, but in the northern part the middle unit of Millice is most easily recognized. The threefold subdivision of Textoris seems to be useful in the subsurface because of the distinctive electric log characteristics of each subdivision, although lateral changes such as the increase or decrease in number of trona beds may make electric log correlations locally uncertain.

\section{REFERENCES}

Bradley, W. H., 1959, Revision of stratigraphic nomenclature of Green River formation of Wyoming: Am. Assoc. Petroleum Geologists Bull., v. 43, no. 5, p. 1072-1075.

Milton, Charles, and Fahey, J. J., 1960, Green River mineralogy - a historical account; in Wyoming Geol. Assoc. Guidebook 15th Ann. Field Conf., Southwestern Wyoming overthrust, area, $1960:$ p. $159-162$.

349. CHILSON MEMBER OF THE LAKOTA FORMATION IN THE BLACK HILLS, SOUTH DAKOTA AND WYOMING

By Edwin V. Post and Henry Belu III, Denver, Colo., and Beltsville, Md.

The stratigraphic terminology of the Inyan Kara group of Early Cretaceous age in the Black Hills of South Dakota and Wyoming has recently been revised by K. M. Waagé (1959). During field work in the Black Hills in 1955 and 1956, Waagé recognized a regional transgressive disconformity that separated rocks comprising the lower and upper parts of the Inyan Kara group. This disconformable relation between the two parts of the Inyan Kara group is similar to the relation between the two principal subdivisions 
recognized by Waagé in equivalent rocks in the Colorado Front Range, in south-central Colorado, and in other parts of the western interior.

Rocks above the transgressive disconformity make up the Fall River formation; they correspond closely with the Fall River as defined by Russell $(1927,1928)$.

The rocks beneath the transgressive disconformity make up the Lakota formation, as redefined by Waagé (1959). The Lakota formation includes as members rocks that formerly were placed in Darton's (1899) original Lakota sandstone as well as the Minnewaste limestone and the Fuson formation. Much of Darton's Lakota, particularly in the southern Black Hills, has thus become merely an unnamed lower member in the revised Lakota formation, and has been referred to by Waagé $(1959$, p. 86$)$ as the "Lakota formation below [the] Minnewaste limestone member."

\section{CHILSON MEMBER}

The lower member is here named the Chilson member of the Lakota formation. The name is derived from. Chilson Canyon in the center of the Flint Hill quadrangle, where two principal subdivisions of the member are best developed coextensively.

Subsequent to Waagés work, detailed geologic mapping by members of the U.S. Geological Survey on behalf of the Division of Raw Materials of the U.S. Atomic Energy Commission in 13 71/2-minute quadrangles in the southern Black Hills has shown that the Chilson member is distinguishable beyond the limits of the Minnewaste limestone member, and that it consists of two conspicuous fluvial sandstone bodies, each of which fingers laterally into flood-plain, lacustrine, or paludal facies. Each sandstone-mudstone complex is considered a subdivision of the Chilson member. These subdivisions are here informally designated unit 1 and unit 2.

Because of the extreme lithologic variation within the Chilson member, no single type section is typical. Figure 349.1 shows representative stratigraphic sections of the Lakota formation, including the Chilson member, at three localities in the southern Black Hills. The center section shows the rock units present in Chilson Canyon in the Flint Hill quadrangle, where both units 1 and 2 of the Chilson member are well developed. The left-hand section, at Red Canyon in the Edgemont NE quadrangle, is typical of areas in the southwestern Black Hills where unit 1 forms most of the Chilson member. The right-hand section, at Flagpole Mountain in the Cascade Springs quadrangle, is representative of the Chilson member in the southeastern Black Hills where it consists entirely of unit 2.

The "Lakota formation below [the] Minnewaste limestone member" described by Waagé $(1959$, p. 85-86, sec. 11) at the reference section of the Lakota formation in Fall River Canyon in the Hot Springs quadrangle consists entirely of various facies of unit 2 in the Chilson member, none of which can be directly correlated with beds shown in the sections on figure 349.1.

Unit 1, the older, typically includes very fine grained well-sorted yellowish-gray sandstone in lenticular bodies separated by thin partings of carbonaceous siltstone. Highly carbonaceous laminated siltstone and mudstone are interbedded with, or are laterally adjacent to, the sandstone. The unit ranges in thickness from zero to a maximum of about 400 feet; the greatest thickness is estimated to be present in the southcentral part of the Edgemont NE quadrangle. Unit 1 is believed to include the coal-bearing sequence of the Lakota described by Waage $(1959$, p. 40-43) in the northern and western Black Hills.

Unit 2 is the younger of the two Chilson units. It overlaps unit 1 from the southeast, and is generally restricted to the southeastern Black Hills. Unit 2 is characterized by grayish-yellow or reddish-orange to reddish-brown very fine grained well-sorted rarely carbonaceous sandstone in lenticular bodies that are interbedded with and finger laterally into varicolored siltstone or claystone. The mudstone and sandstone are calcareous at many places. Mudstones of unit 2 are locally carbonaceous, particularly near their western boundary with unit 1 . The thickness of unit 2 ranges from zero to 437 feet, and is greatest at Flagpole Mountain in the east-central part of the Cascade Springs quadrangle.

The Chilson member of the Lakota formation rests on either the Morrison formation or the Unkpapa sandstone. Where sandstone forms the lowermost rock unit in the Lakota, the contact is clear cut. Mudstone of unit 1 can generally be distinguished by its content of carbonaceous material from the claystone in the Morrison or mudstone at the top of the Unkpapa. Locally, noncarbonaceous mudstone of unit 2 rests on mudstone of either the Morrison or Unkpapa, and at such places the contact must be chosen arbitrarily.

Because of rapid facies changes in the Chilson member and the Fuson member, there has been much diffculty in mapping the contact between them. Most of this difficulty disappears, however, when the rocks are mapped in enough detail to show the distribution of the individual facies. Such mapping has shown that a distinctive reddish-brown sandstone commonly forms the top of unit 2, both where the Minnewaste is present and for several miles beyond its limits. This sandstone has been used as a marker bed through much of the southern Black Hills. The greatest difficulty in mapping the contact between the Fuson and unit 2 of 
Stratigraphic section of the Lakota formation
Red Canyon, NW $1 / 4$ sec. 20 , T. 7 S., R. 3 E. Edgemont NE quadrangle
(Measured by G. B. Cott and E. V. Post)
Composite stratigraphic section of the Lakot a formation
Chil son Canyon, sec. 32, T. 8 S. R. 4 E. Flint Hili quadrangle
(By Henry Bell and E. V. Post)
Stratigraphic section of the Lakota formation
Flagpole Mount ain, sec. 33, T. 8 S., R. 5 E. Cascade Springs quadrangle

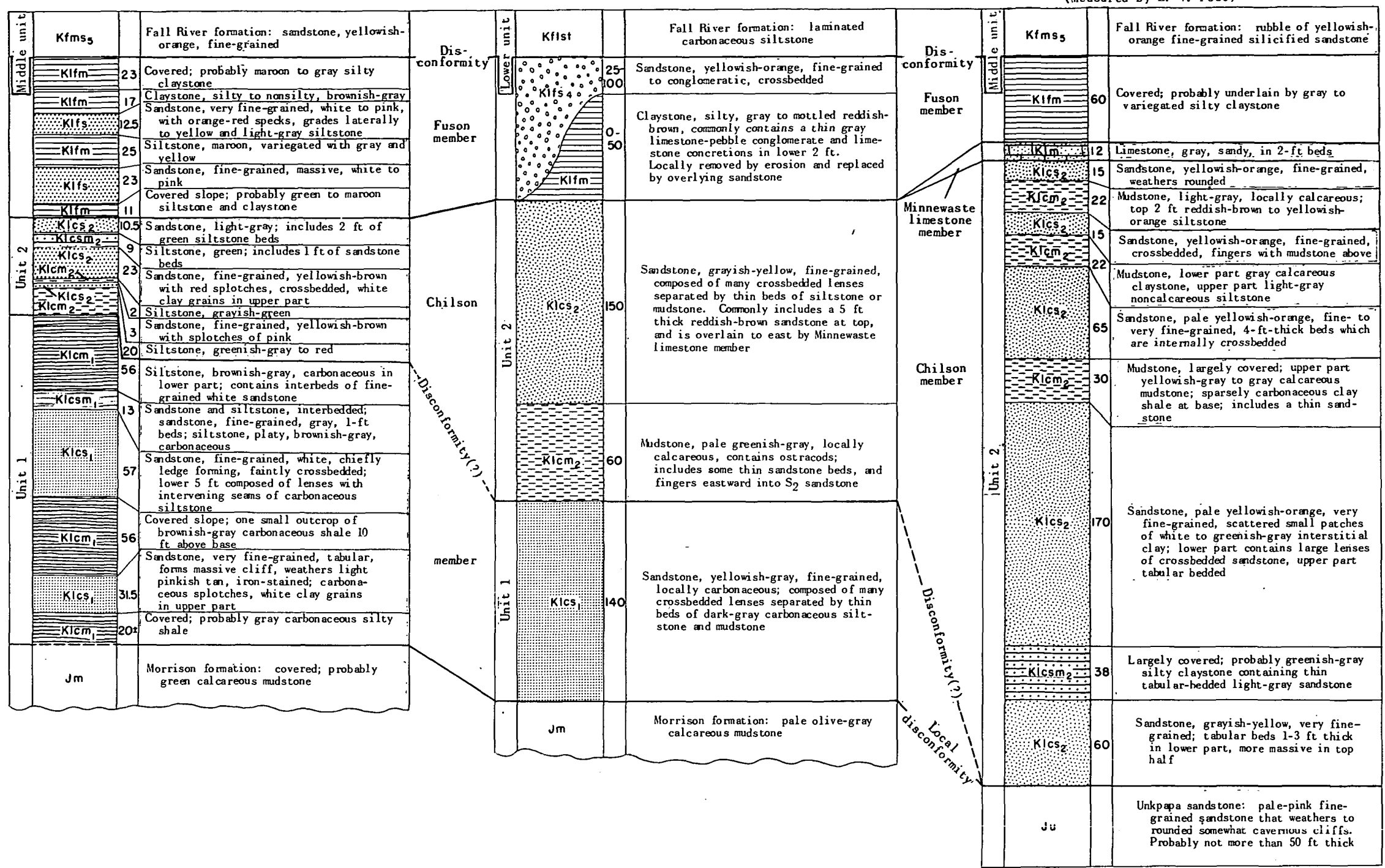


the Chilson member has been encountered beyond the limits of both the red sandstone marker bed and the Minnewaste limestone member. Detailed mapping generally allows the geologist to locate the contact between the uppermost sandstone in unit 2 and an interval of distinctive limestone concretions and calcareous conglomerate near the base of the Fuson. Rocks of unit 1 can generally be distinguished from the overly. ing Fuson rocks both by the absence of carbonaceous material and the presence of variegated mudstone and conglomeratic sandstone in the Fuson.

\section{MINNEWASTE LIMESTONE MEMBER}

The Minnewaste limestone member has been mapped with little difficulty. It ranges in composition from rather clean dense pinkish-gray limestone to calcareous sandstone; the typical rock is sandy limestone. The Minnewaste ranges in thickness from zero to a maximum of 80 feet; the greatest thickness was noted in a gully draining into the east side of Tepee Creek in the southeastern part of the Cascade Springs quadrangle. The Minnewaste described in the reference section of the redefined Lakota formation by Waagé (1959, p. 85 , sec. 11) is representative of the unit, and it is here suggested that this be taken as the reference section of the Minnewaste limestone member.

\section{FUSON MEMBER}

Waagé (1959, p. 29) has suggested that "Darton's Fuson is the key to the difficulties that have arisen in attempts to map his threefold subdivision in different parts of the Black Hills," and has stated (p. 32) that the Fuson " $* * *$ lacks definite upper and lower contacts and is too variable in rock type $* * *$ to permit consistent identification on the basis of its own lithic content." Because of this, Waagé $(1959$, p. 33) recommended discarding the name "Fuson," or at best, restricting its use to the area in the southeastern Black Hills where the Minnewaste limestone member is present.

By recognizing the regional transgressive disconformity as the contact between the Fall River and Lakota formations, Waage (1959) has in effect defined the top of the Fuson. The rocks above and below this disconformity differ from place to place; laminated carbonaceous siltstone at the base of the Fall River formation commonly rests either on Fuson mudstone or, in places, on conglomeratic channel sandstone. The contact is readily mappable where thick channel sandstone of the Fall River formation rests on Fuson mudstone, but is difficult to map where such sandstone in the Fall River rests on similar sandstone in the Fuson member.
Several characteristic lithologies have been recognized in the Fuson member. Variegated claystone and siltstone is perhaps the most widespread and characteristic Fuson rock type, particularly in the southern and northern Black Hills. White, speckled with red, massive argillaceous fine-grained sandstone commonly exists in the middle of the member, and a thin brightgreen clayey sandstone is found at many localities in the middle of the member. Channel sandstone that is locally conglomeratic ( $\mathrm{Klfs}_{3}$ on figure 349.2 ) comprises much of the lower Fuson along the western side of the Black Hills, and crossbedded conglomeratic sandstone (Klf $\mathrm{S}_{4}$ on figure 349.2 ) also fills a channel scoured from the top of the Fuson part or all the way through the mudstone and massive argillaceous sandstone facies in the southern Black Hills. Common in the lower. 15 feet of the Fuson in the southern Black Hills is a thin-bedded ripple-bedded reddish- or yellowish-orange fine-grained locally calcareous sandstone that has streaks and small lenses of clay parallel to the bedding; the clay weathers out giving the rock a characteristic pitted surface. A thin calcareous conglomerate and concretions of limestone or barite occur locally in the lower 5 feet of the member. Polished well-rounded pebbles of pink quartzite, quartz, and chert are diagnostic of the Fuson; they weather abundantly out of the mudstone beds of the member throughout the Black Hills area.

Ostracodes found in the calcareous conglomerate near the base of the Fuson member were described by I. G. Sohn (written communication, 1955) as differing from those in other collections of the Lakota formation in that they include a large smooth genus not typical of Lower Cretaceous rocks. Thus, it appears that the Fuson and Chilson members may be distinguished by paleontologic as well as lithologic evidence.

The base of the Fuson member is in contact with either the top of the Minnewaste limestone member, the top of the several facies of the Chilson member, or, in parts of the Black Hills, with the top of the Morrison formation and possibly the top of the Unkpapa sandstone. The greatest difficulty in locating the base of the Fuson member has been encountered in the relatively small area where the Fuson rests on unit 2 of the Chilson member, but detailed mapping of the various facies along this contact has resulted in satisfactory location of the contact.

The type locality of the Fuson member at Fuson Canyon in the southeastern Black Hills is not satisfactory for several reasons. The base of the member is not exposed, the Minnewaste limestone member is absent in that immediate area, and the Fuson there consists dominantly of sandstone and siltstone. The 
following stratigraphic section has the Minnewaste limestone member underlain by the red sandstone marker bed of the Chilson member as a base, and it includes more of the mudstone so typical of the Fuson in much of the Black Hills. It is presented as a reference section for the Fuson member of the Lakota formation in the southern Black Hills. The variability of the Fuson may be demonstrated by comparing this section with that at Fuson Canyon (Waagé, 1959, p. 84, sec. 10), with the Fuson member at Waagé's reference section of the Lakota formation in Fall River Canyon south of Hot Springs, S. Dak. (Waagé, 1959, p. 85, sec. 11 ), and with a section measured in Red Canyon north of Edgemont, S. Dak. (fig. 349.1).

Biseference stratigraphic section of the Fuson member of the Laliota formation on east bank of Cheyenne River, $S W 1 / 4$ NW1/4. sec. 2, T. 9 S., R. \& E., Cascade Springs quadrangle, Full River Connty, s. Dak:

[Measured by E. V. Post and D. W. Lane]

Fall River formation (in part) :

Siltstone, dark-gray, carbonaceous, laminated ; becomes sandy and more massive at top_.

Sandstone, yellowish-gray, fine-grained, locally micaceous; contains white clay grains in streaks along bedding; bedding wary; weathers cavernous.

Lakota formation :

Fuson member :

Sandstone, white to pink, splotched with red, mediumto fine-grained, friable; abundant interstitial white clay in streaks parallel to bedding; broad lowangle crossbeds; becomes clayey at top

Olaystone, variegated green to dark reddish-brown; silty alt base

Mudstone, yellow, farositic, limonitic, gypsiferous ; in part a boxwork of selenite with little mudstone...-

Claystone, dark-gray to greenish-gray; largely clean, some carbonaceous; hackly fracture ; includes limestone concretions 6 to 8 inches thick by 1 to 2 feet in diameter at base.

Conglomerate, medium-gray; limestone and white silty claystone pebbles in a calcareous sandstone matrix

Claystone, gray to olive-gray

Sandstone, light yellowish-gray, fine-grained, cal-

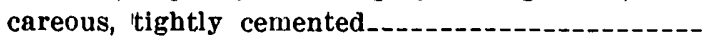

Total thickness of Fuson member

Feet

Minnewaste limestone member:

Iimestone, pinkish-gray, dense ; contains streaks of coarsely crystalline calcite.
Lakota formation-Continued

Chilson member (in part) :

Unit 2 :

Sandstone, moderate reddish-brown, fine-grained, moderately well-cemented...................... Sandstone, pinkish- to yellowish-orange, finegrained to very fine grained, moderately wellcemented; sparkles because of secondary silica overgrowths on quartz grains; color banded with red iron-oxide bands along laminae of abundant white clay grains

\section{REGIONAL CORRELATION}

The mapping and stratigraphic studies of the Inyan Kara group in the Black Hills carried out by the Geological Survey from 1952 to 1957 resulted in part in the correlation of rock units as shown by Mapel and Gott (1959). Work done during 1958 and 1959 has resulted in further definition of the relations among these various rock units in the southern Black Hills. Figure 349.2 , which is a reduced and revised version of the cross section published by Mapel and Gott (1959), shows the relations among the Fuson, Minnewaste, and Chilson members of the Lakota formation as presently under-' stood.

The most significant change in this section was made in the area between the Edgemont NE quadrangle and the Wyoming-South Dakota boundary, where it was recognized that the conglomeratic sandstone labeled $\mathrm{Klfs}_{3}$ on figure 349.2 (and $\mathrm{S}_{2}$ by Mapel and Gott, 1959) is, in fact, a sandstone in the Fuson member, and therefore younger than rocks of the Chilson member. This has resulted in assigning practically all the conglomeratic sandstone of the Inyan Kara group to the Fuson member of the Lakota formation.

The various sequences of the Lakota formation described by Waagé $(1959$, p. 35-46) can be matched very closely with the formally named members of the Lakota. His northern and eastern sequences, as well as the upper part of the southern sequence, are equivalent to the Fuson member, and his coal-bearing sequence and the lower part of the southern sequence are equivalent to the Chilson member. Waagé $(1959$, p. 48) recognized this correlation in stating,

If the correlations suggested here are correct, beds Darton called Lakota and Fuson (in part) in the northwestern Black Hills are equivalent only to beds he called Fuson in the southeastern Black Hills. To state it another way, using Darton's classification, there is no Lakota in the northwestern Black Hills-it is all Fuson. 


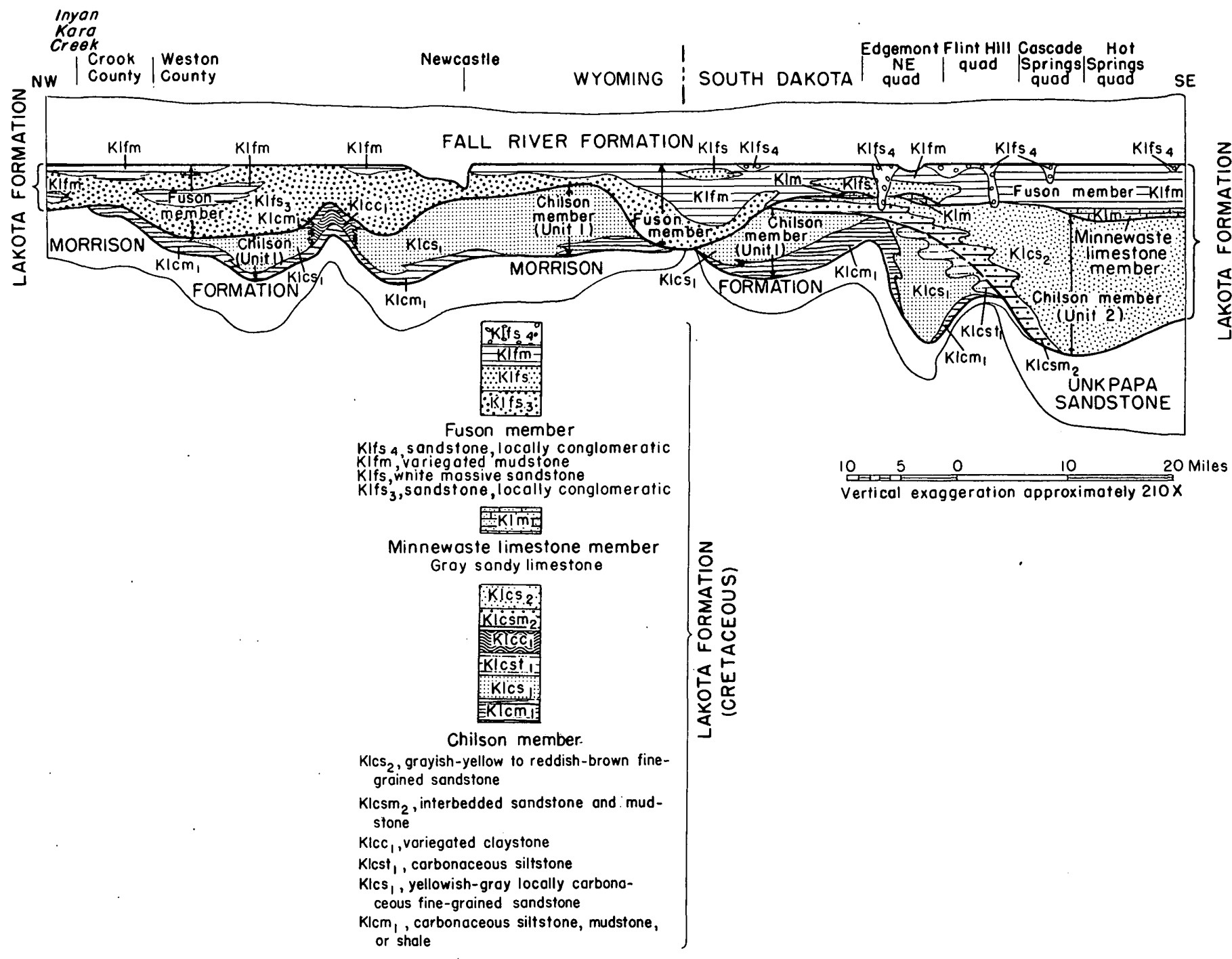

Figure 349.2.-Diagrammatic restored cross section of the Lakota and adjacent formations in the southwestern Black Hills showing the relations among the Fuson, Minnewaste limestone, and Chilson members of the Lakota formation.

The line that marks the top of the Chilson member on figure 349.2 has been emphasized. By following it northwestward, one can clearly see that the Chilson member pinches out in the vicinity of Inyan Kara Creek and that the Lakota formation northwest of that point consists entirely of the Fuson member.

\section{REFERENCES}

Darton, N. H., 1899, Jurassic formations of the Black Hills of South Dakota: Geol. Soc. America Bull., v. 10, p. 383-396.
Mapel, W. J., and Gott, G. B., 1959, Diagrammatic restored section of the Inyan Kara group, Morrison formation, and Unkpapa sandstone on the western side of the Black Hills, Wyoming and South Dakota: U.S. Geol. Survey Mineral Inv. Field Studies Map MF-218.

Russell, W. L., 1927, The origin of the sandstone dikes of the Black Hills region: Am. Jour. Sci., 5th ser., v. 14, p. 402408.

1928, The origin of artesian pressure: Econ. Geology, v. 23, no. 2, p. 132-157.

Waagé, K. M., 1959, Stratigraphy of the Inyan Kara group in the Black Hills: U.S. Geol. Survey Bull. 1081-B, p. 11-90. 
350. ARTESIAN WATER IN THE SPIRITWOOD BURIED VALLEY COMPLEX, NORTH DAKOTA

By C. J. Huxes, Jr., Grand Forks, N. Dak.

Work done in cooperation with the North Dakota State Geological Survey and the North Dakota State Water Conservation Commission

Thick bodies of saturated sand and gravel were discovered in 1958 during reconnaissance test drilling near the eastern boundary of Stutsman County, N. Dak. Subsequent drilling has indicated that these sand and gravel deposits are part of a large buried valley system cut into the Cretaceous Pierre shale. The buried valley system is referred to as the Spiritwood buried valley complex, and its location and relation to other buried valley systems are shown on figure 350.1 .

Cross sections (figs. 350.2 and 350.3) show that the Spiritwood buried valley complex consists of several distinct valleys. In section $B-B^{\prime}$ a deep trenchlike inner valley filled with clay is shown incised into a wider and more gently sloping outer valley. In section
$A-A^{\prime}$ two separate and distinct valleys are shown side by side. A similar relation is illustrated in section $D-D^{\prime}$, although the valleys are of different depths and are more widely separated than those shown in section $A-A^{\prime}$. It is inferred from existing well data that a major tributary enters the Spiritwood buried valley complex at a point about 4 miles south of section $C-C^{\prime}$ and 3 miles west of the county line (fig. 350.2).

Significant thicknesses of sand and gravel have been found only in the westernmost valley shown by section $A-A^{\prime}$, the outer and more gently sloping valley shown by section $B-B^{\prime}$, and the incompletely defined valley shown by section $C-C^{\prime}$ (fig. 350.3). Water-bearing sands and gravels in these valleys are referred to as the

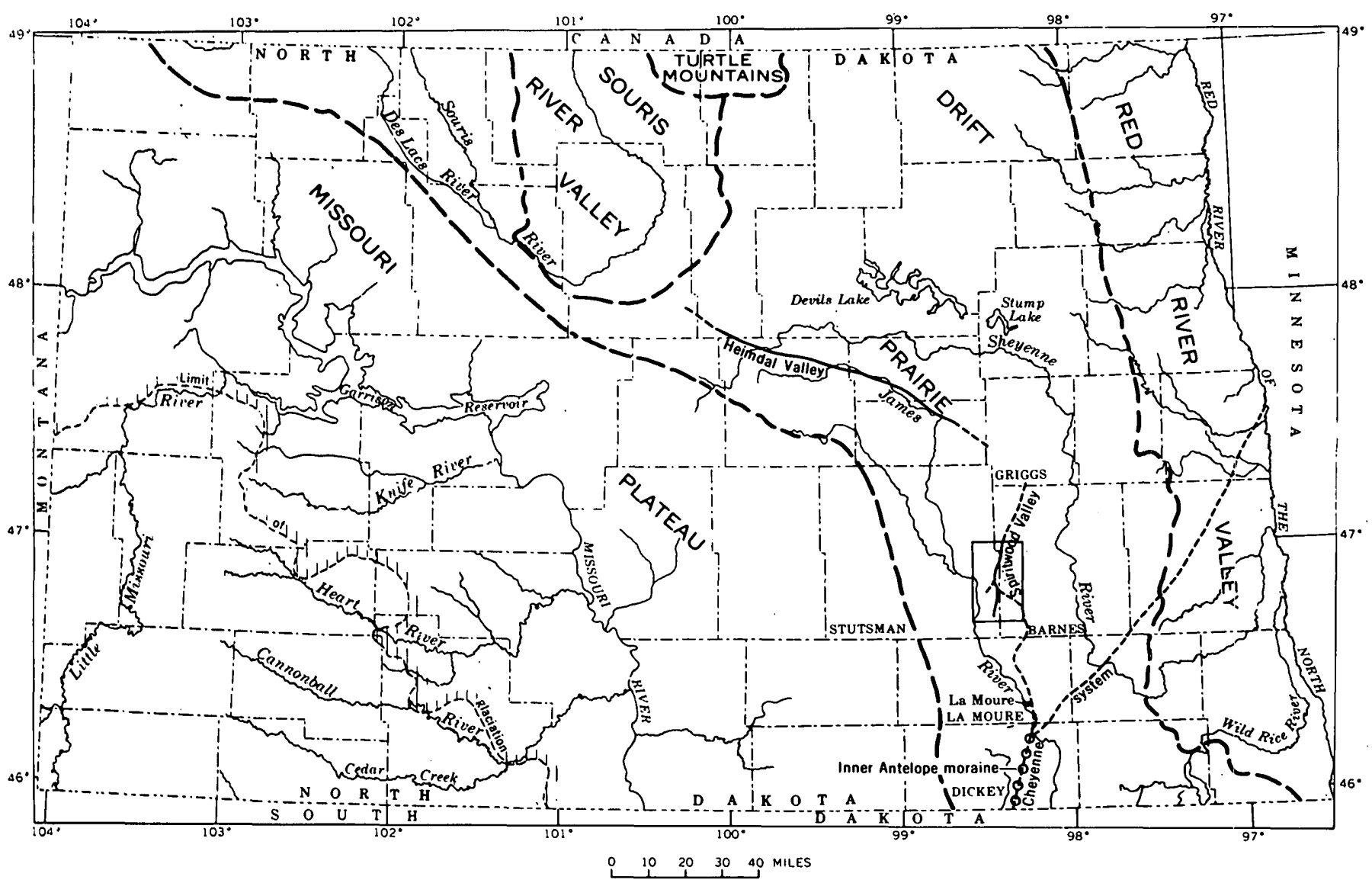

Fioure 350.1.-Map showing physiographic provinces of North Dakota (modified from Simpson, 1929) and reliation of the Spiritwood buried valley complex to other buried valley systems in the region. Rectangle indicates area shown in figure 350.2 . 
Spiritwood aquifer and are considered to be glaciofluvial in origin. The Spiritwood aquifer reaches a maximum thickness of at least 115 feet and is found between altitudes of 1,150 and 1,370 feet. Thick bodies of silt and clay in the inner valley of section $B-B^{\prime}$ (test hole 1594, fig. 350.3) and the eastern valley of section $D-D^{\prime}$ may be either preglacial or glaciofluvial in origin.

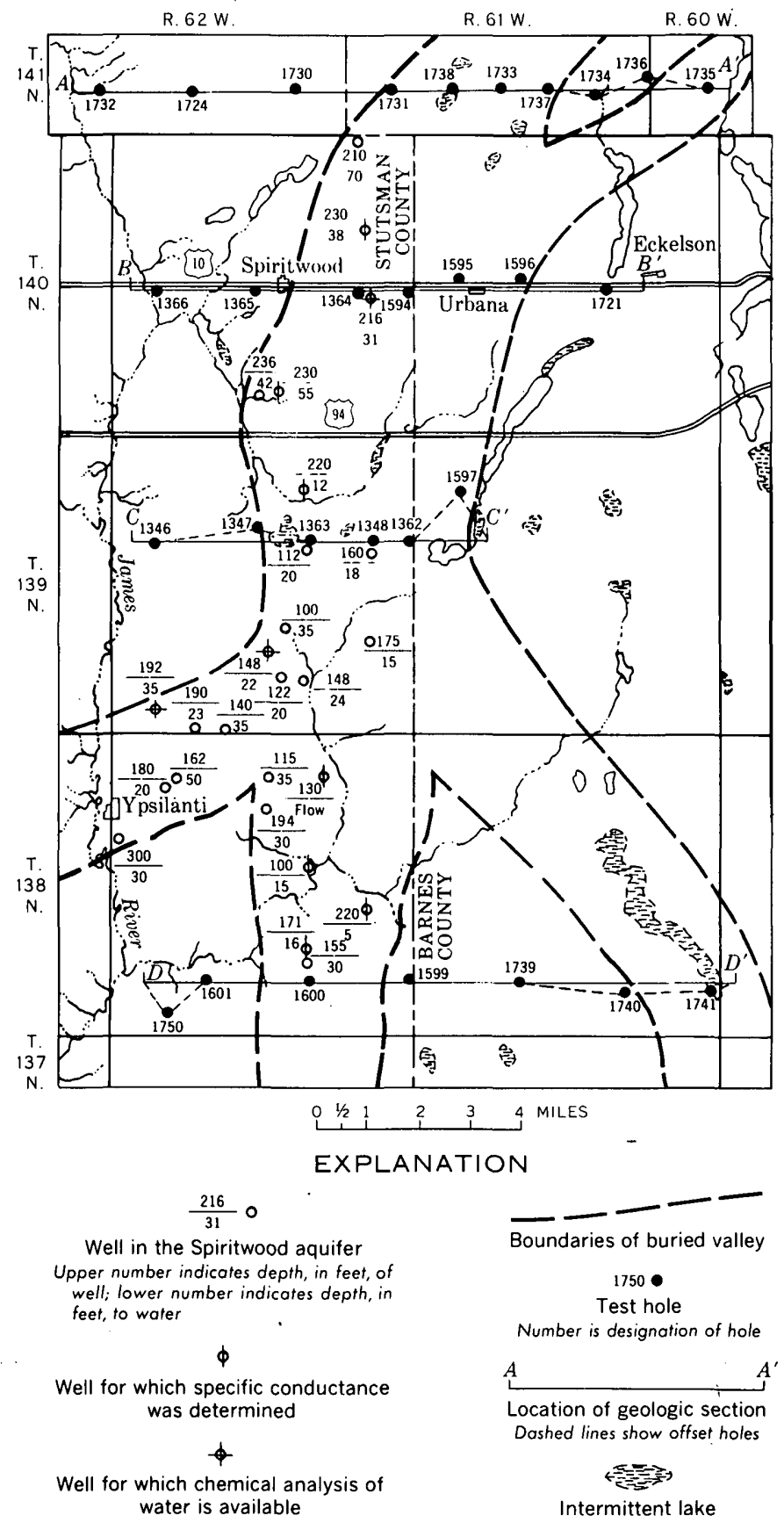

FIGURE 350.2.-Map showing location of wells and test-holes in the Spiritwood buried valley complex.
The range in depth and width of the several valleys within the Spiritwood buried valley complex is apparent in the test-hole sections. The size of the Spiritwood buried valley complex suggests that it may have been a major segment of the preglacial-drainage system in North Dakota. The ancient Cheyenne system may have flowed north into Dickey County along the trend of a moraine (Flint, 1955, p. 148) which is correlated with one of the inner members of the Antelope morainic system (fig. 350.1). According to Hard $(1929$, p. 28$)$ this moraine might mark the trend of a buried valley. Upham (1894, p. 244; 1895, p. 107) thought that the Cheyenne system extended from the end of the moraine northeastward to the present Red River channel and then northward into Hudson Bay. It is possible, however, that the ancient Cheyenne system continued straight north from the end of the inner Antelope moraine, and that the Spiritwood buried valley complex is a segment of that system. Such a course is marked by depressed areas and areas of interior drainage from LaMoure (fig. 350.1) to the line of section $D$ - $D$ ' (fig. 350.2). The Spiritwood buried valley complex can be traced on the basis of well inventory data from the line of section $A$ - $A$ ' northeastward into southern Griggs County, a distance of more than 20 miles. At this point the Spiritwood complex is only 6 miles southeast of the southeastern extension of the buried Heimdal Valley (fig. 350.1).

All existing wells in Stutsman County have been inventoried and the locations of those penetrating the Spiritwood aquifer are shown on figure 350.2. Depth to water in these wells ranges from above land surface in a flowing well in T. 138 N., R. 62 W., to 70 feet below land surface in a well in T. 140 N., R. 62 W.

Chemical analyses were made on water samples from 3 wells and specific conductance determinations in the field were made on water from 7 other wells. The total dissolved solids were calculated from the specific conductance determinations. Of the 10 wells for which data are available, 8 yielded water in which the total dissolved solids were between 500 and $800 \mathrm{ppm}$ (parts per million). The other 2 wells, in the SE1/4 T. $138 \mathrm{~N}$., R. $62 \mathrm{~W}$., are 220 and 171 feet deep and were found to have total dissolved-solid contents of $1,343 \mathrm{ppm}$ and $1,158 \mathrm{ppm}$, respectively.

Aquifer tests are needed to determine the groundwater yield of the Spiritwood aquifer; however, its large areal extent and thickness, the coarseness of its gravels, and its high degree of saturation indicate that it is potentially productive. 


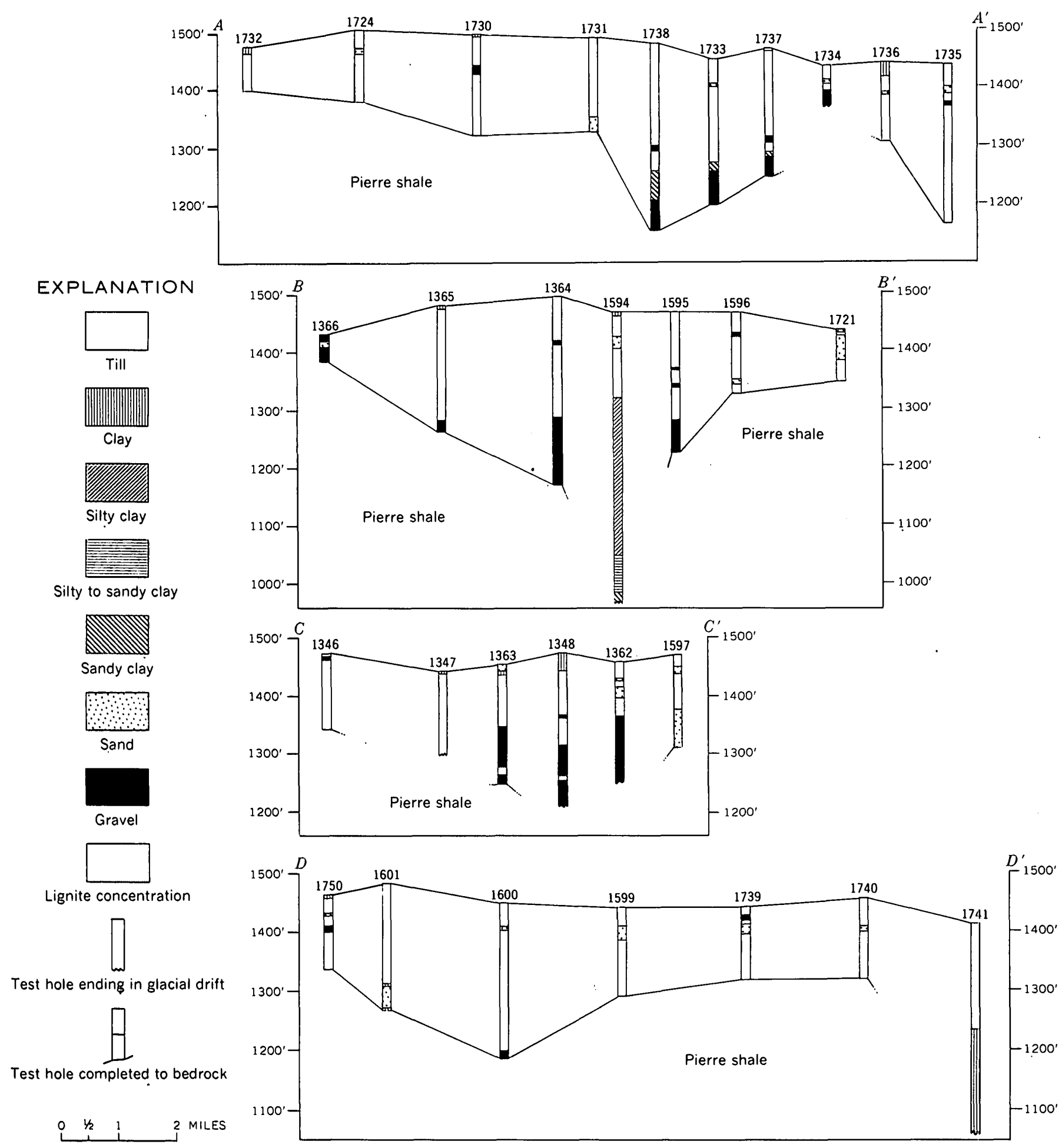

FIoURE 350.3.-Cross sections in the Spiritwood buried valley complex.

\section{REFERENCES}

Flint, R. F., 1955, Pleistocene geology of eastern South Dakota : U.S. Geol. Survey Prof. Paper 262, 173 p.

Hard, H. A., 1929, Geology and water resources of the Edgeley and LaMoure quadrangles, North Dakota: U.S. Geol. Survey Bull. $801,90 \mathrm{p}$.

Simpson, H. S., 1929, Geology and ground-water resources of
North Dakota : U.S. Geol. Survey Water-Supply Paper 598, .312 p.

Upham, Warren, 1894, Tertiary and early Quaternary base leveling in Minnesota, Manitoba, and northwestward: Am. Geologist, v. 14, p. 235-246.

1895, The glacial Lake Agassiz: U.S. Geol. Survey Mon. $25,658 \mathrm{p}$. 


\title{
351. A BURIED VALLEY NORTHWEST OF MANHATTAN, KANSAS
}

\author{
By Henry V. Beck, Manhattan, Kans.
}

Work done in cooperation with the State Geological Survey of Kansas

North and northwest of Manhattan, Kans., is a buried valley about 2 miles wide. The altitudes of the ground surface in this area ranges from about 1,040 feet in the east to about 1,180 feet in the west. The valley was reported, but not described, by Todd (1918, p. 197) and Mudge $(1955$, p. 273). The buried valley is $\mathrm{Y}$-shaped with the base of the $Y$ pointing to the northeast in the direction of former flow (fig. 351.1). The valley is widest where the two branches join and it narrows toward the northeast. Here the valley is confined between high bluffs composed of Permian rocks.

Logs of test holes indicate that the gravel deposits in the basal part of the buried valley are overlain by reddish-brown silt and clay ranging in thickness from about 7 to about 80 feet. The gravels in the southwestern tributary are composed of limestone and chert fragments of local origin. The deposits in the southeastern branch are composed principally of arkosic gravel, indicating a westerly source.

Furthermore, this area contains some gravel deposits of glacial origin. Glacial boulders in these deposits probably were derived from colluvial wash from deposits of glacial drift on Bluemont Hill.

The deposits in the buried valley are typical of those found in terraces of Kansan and Illinoian age that are east of the junction of the Kansas and Blue Rivers. Davis and Carlson (1952) applied the names Menoken to terrace deposits of Kansan age, Buck Creek to terrace deposits of Illinoian age, and Newman to terrace deposits of Wisconsin age. The principal differences in the terrace deposits of Kansan and Illinoian age are the lithologic character of the gravel and the topographic position. Generally Menoken deposits have a higher percentage of glacially derived material than the Buck Creek. In the area extending eastward from Manhattan to a point near Lawrence, the bedrock surface beneath the Menoken terrace ranges from 45 to 70 feet above the bedrock surface beneath the Buck Creek terrace. The interval between the two surfaces is less in the western part of the area. The bedrock surface beneath the Buck Creek terrace is about 15 feet below the surface of the Newman terrace.

During a part of the Pleistocene, the ancestral Kan- sas River flowed northward through the buried valley by way of the southeastern branch and the outlet to the northeast. The ancestral Wildcat Creek joined this stream at a point about 2 miles north and a little west of Manhattan. The ancestral Wildcat Creek abandoned a segment of its channel in the buried valley and established its present course no later than early Illinoian time. The evidence for dating this change in course is based on terrace deposits along the west - side of the present Wildcat Creek valley in the SW1/4 sec. 13 , T. 10 S., R. 7 E., (fig. 351.1), which have been identified as Illinoian in age. They are equivalent to the Buck Creek terrace of Davis and Carlson (1952) and Beck (1959). Gravel deposits in the basal part of this terrace are principally of local origin, but also contain some glacial gravel that probably was derived from glacial drift on the upland area west of the valley. In the buried valley the gravel deposits are an important source of ground water. The yields of wells are dependent on the thickness of gravel at any particular locality.

Bedrock in the buried valley adjacent to Blue River lies at altitudes ranging from 1,002 to 1,025 feet, and in the southeastern branch altitudes range from 1,020 to 1,050 feet (fig. 351.2). In the southwestern branch, altitudes are generally above 1,060 feet. The contours indicate that the streams flowed northward and northeastward and preclude the possibility that the ancestral Blue River flowed southward through the valley. The southwestern branch had the steepest gradient, which is typical of a tributary stream draining ${ }^{\circ}$ limestone and shale terrane. The deepest part of the southeastern branch is along the east side of the valley, which may indicate a second period of downcutting in this area. The earlier period of cutting reached base level at altitudes near 1,050 feet, and the second entrenchment reached base level near 1,020 feet.

- Glacial deposits on Bluemont Hill and on the hill south and west of Manhattan are evidence that the channel was blocked by ice during the Kansan glacial period. The cutting of the valley between Bluemont Hill and K-Hill may have begun at this time, but the southeastern branch of the buried valley was again occu- 


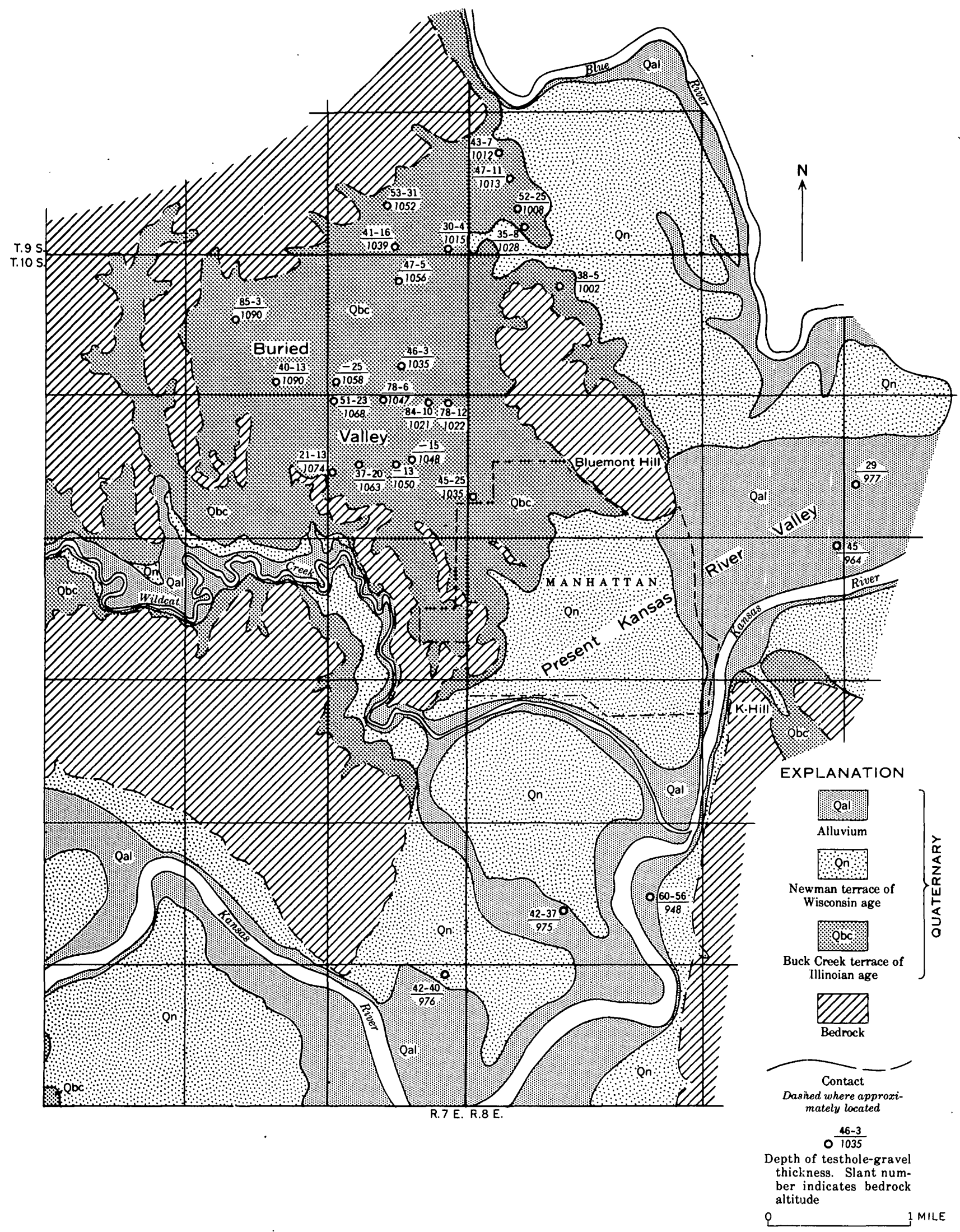

FrgURE 351.1.-Geòlogic map of Manhattan, Kans., and vicinity. 


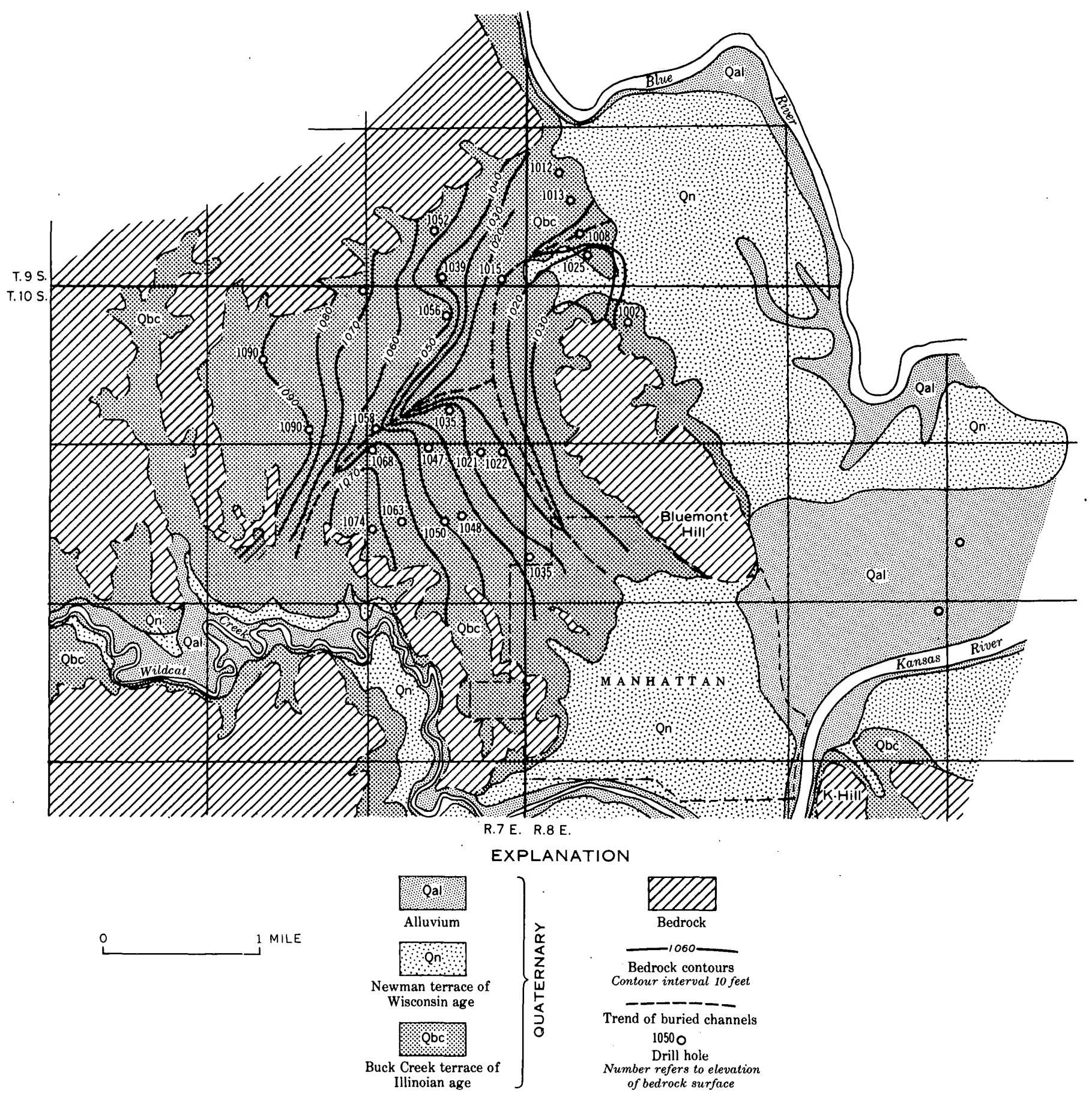

Figure 351.2.-Bedrock contour map of buried valley. 
pied and deepened by the ancestral Kansas River in late Kansan time and probably in early Illinoian time.

Illinoian terrace deposits, in the $\mathrm{SW} 1 / 4$ sec. $13, \mathrm{~T}$. 10 S., R. 7 E., are evidence that the ancestral Wildcat Creek occupied its present course no later than early Illinoian time. By early Wisconsin time, the ancestral Kansas River had abandoned the buried valley and had breached the area between Bluemont Hill and K-Hill. Illinoian deposits are absent in the valley between these hills. The valley is narrow here, however, and if such deposits were deposited it is probable that they have been removed by floods of the Kansas River.

\section{REFERENCES}

Beck, H. V., 1959, Geology and ground water, Kansas River valley between Wamego and Topeka vicinity : Kansas Geol. Survey Bull. 135, $88 \mathrm{p}$.

Davis, S. N., and Carlson, W. A., 1952, Geology and groundwater resources of the Kansas River valley between Lawrence and Topeka, Kansas: Kansas Geol. Survey Bull. 96, pt. 5, p. 201-276.

Mudge, M. R., 1955, Early Pleistocene geomorphic history of Wabaunsee, southeastern Riley, and southern Pottawatomie Counties, Kansas: Kansas Acad. Sci. Trans., v. 58, no. 2, p. 271-281.

Todd, J. E., 1918, History of Kaw Lake: Kansas Acad. Sci. Trans., v. 28, p. 187-199.

352.

\title{
STRATIGRAPHY OF LOWER AND MIDDLE PARTS OF THE PIERRE SHALE, NORTHERN GREAT PLAINS
}

\author{
By James R. Gill and Willitam A. Cobban, Denver, Colo.
}

The Pierre shale of Late Cretaceous age was deposited in a broad epicontinental sea that covered the Great Plains States and contiguous areas to the west and extended north into Canada. The eastern limit of the sea is not well known. The Pierre is being studied to determine the chemical, mineralogic, and sedimentary changes that take place in fine-grained rocks across a basin of marine deposition (Tourtelot, Schultz, and Gill, 1960). Stratigraphic investigations conducted concurrently with geochemical and mineralogic studies by H. A. Tourtelot and L. G. Schultz cover about twothirds of the basin of deposition in the northern Great Plains (fig. 352.1).

Rocks deposited along the eastern shoreline of the basin have been removed by post-Cretaceous erosion but much of the broad eastern stable shelf and eastern slope areas remain (fig. 352.1). These areas, far removed from the dominant westward source of the sediments, were the site of slow to moderate deposition and, in general, contain a distinctive suite of fine-grained shale and marlstone. The trough of the basin was the site of more rapid deposition and contains coarser grained rocks. There is a pronounced westward increase in coarser grained rocks across the trough of the basin and the western slope area, and an interfingering of marine beds with brackish-water and nonmarine deposits on a narrow western shelf.

The throe units described here (figs. $352.2 B$ and $352.3 A$ and $B$ ) represent the lower and middle parts of the Pierre shale of South Dakota and equivalent rocks described by various names in adjacent States (fig.
352.4 and table 352.1). These units reflect three distinct phases in the depositional history of the Upper Cretaceous rocks of the region. The first depositional phase is one of regression (fig. 352.1A), herein referred to as the Eagle regression ( R-2 regression of Weimer, 1960 ) ; the second phase is one of transgression (fig. $352.1 B$ ), the Claggett transgression ( $\mathrm{T}-3$ transgression of Weimer, 1960); and, the third phase is one of regression (fig. $352.1 C$ ) called the Judith River regression ( $R-3$ regression of Weimer, 1960).

\section{EAGLE REGRESSION}

Rocks between the Niobrara formation and the base of beds equivalent to the Claggett shalo-roughly equivalent to the Eagle sandstone of Montana (fig. $352.2 B$ and table 352.1) - represent the initial regressive phase of deposition of the Pierre shale (figs. $352.2 B$ and 352.4). The depositional history of the shelf area east of the zero thickness line is obscure. Some stratigraphers believe that the area was undergoing erosion at the time (Reeside, 1957; LeRoy and Schieltz, 1958), Stratigraphic and paleontologic evidence now strongly suggest that beds equivalent to the Eagle sandstone interfinger with and grade into calcareous beds of the Niobrara formation in the eastern. shelf area (fig. 352.4 ).

The western part of the stable eastern shelf and the eastern slope area contain dominantly noncalcareous deposits of gray bentonitic claystone, a few thin silty layers, and abundant red-weathering thin ferruginous layers and concretions (Gammon ferruginous member 


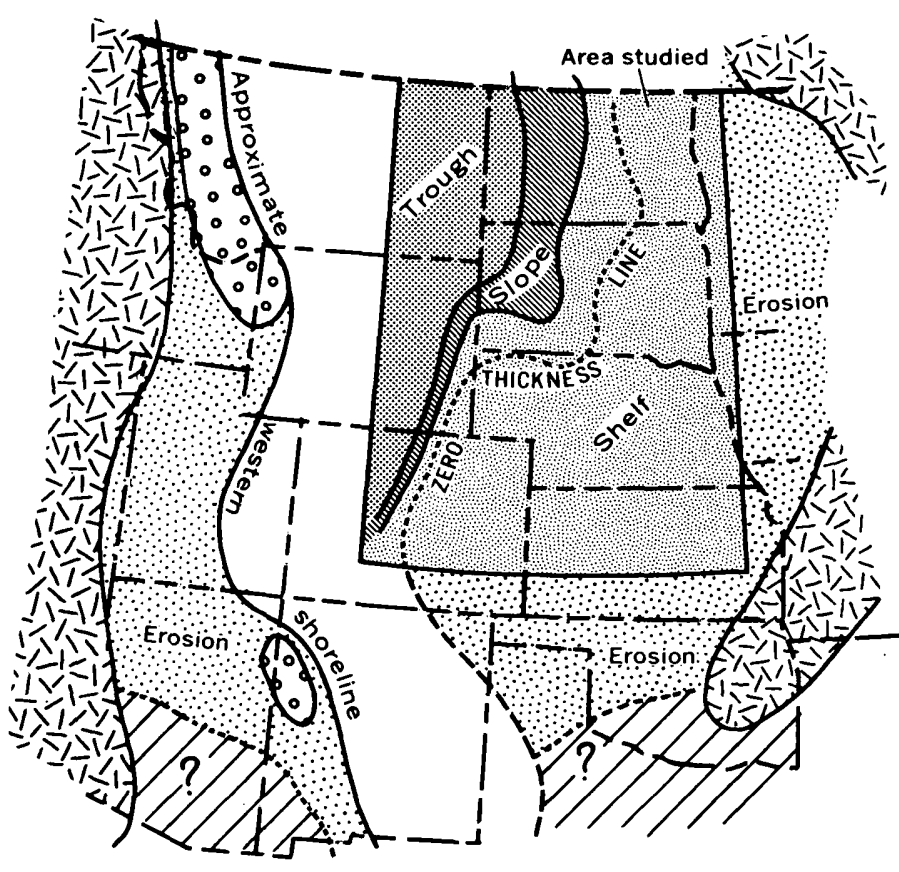

A. Eagle regression

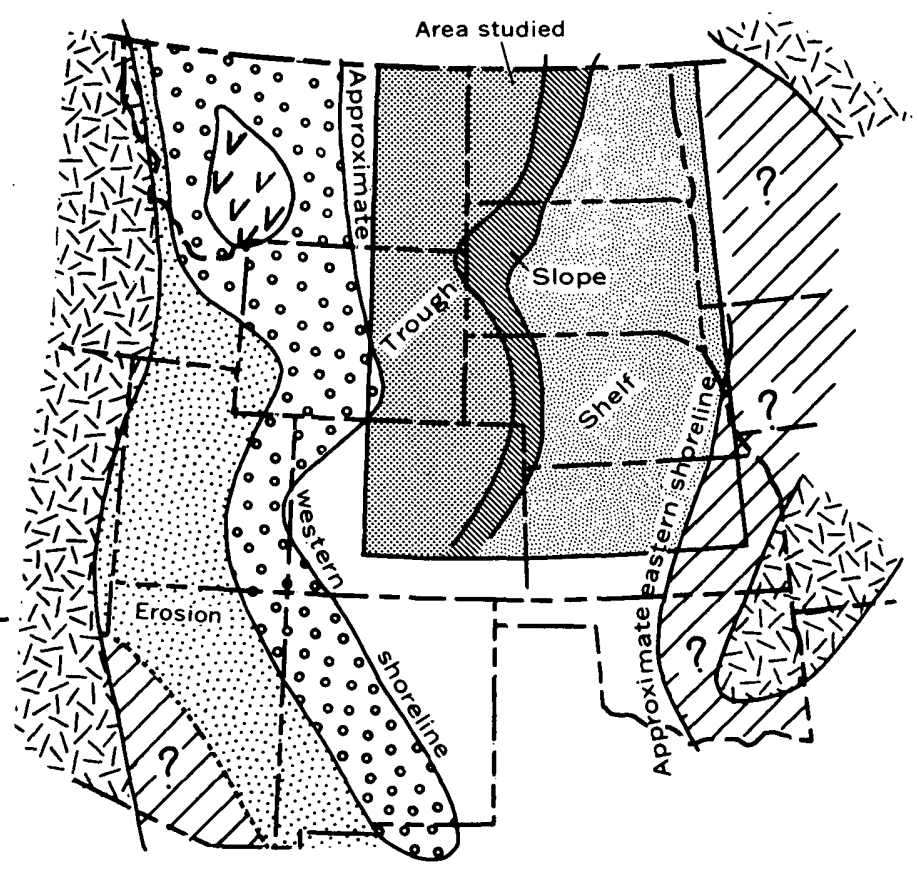

C. Judith River regression
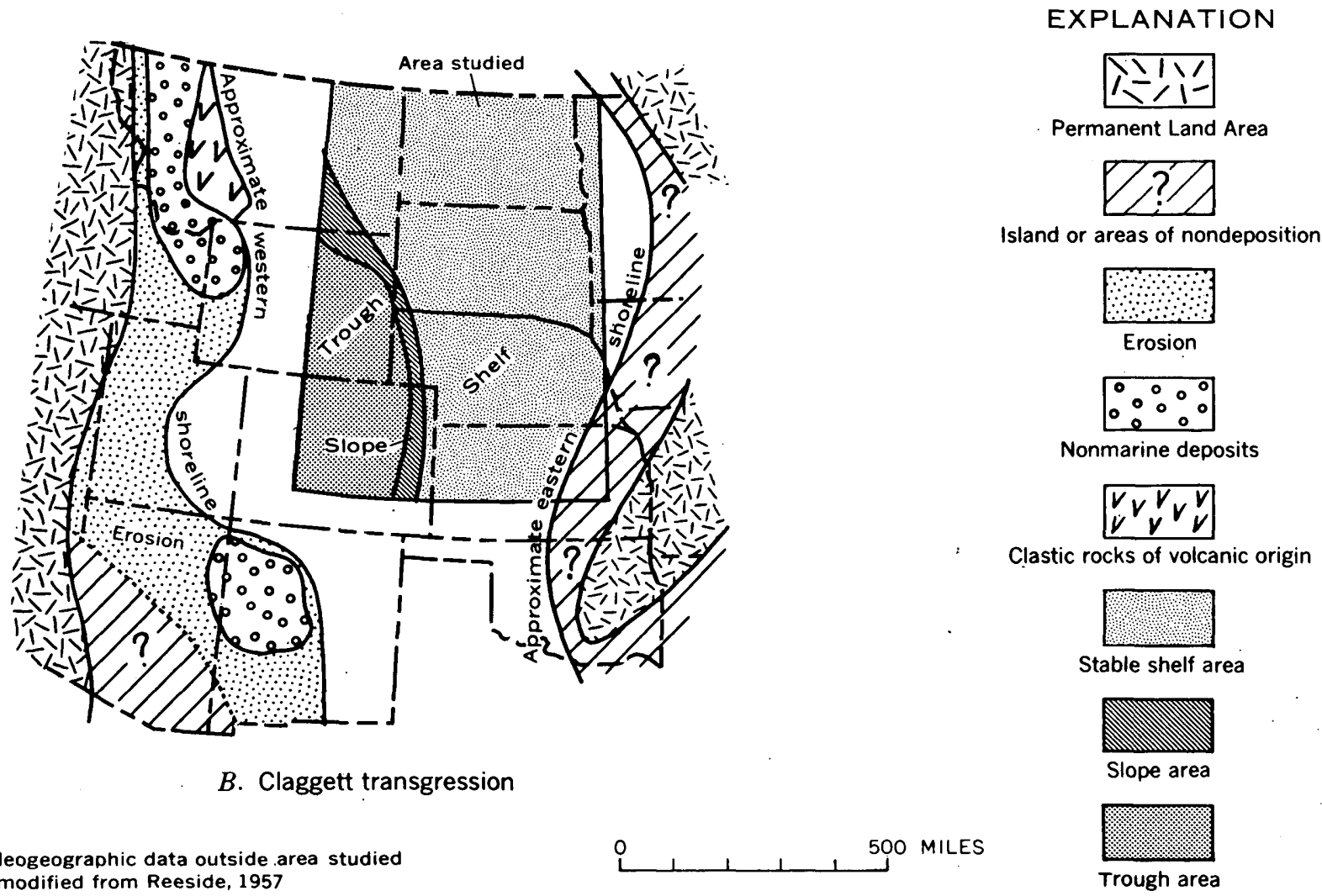

Paleogeographic data outside area studied is modified from Reeside, 1957

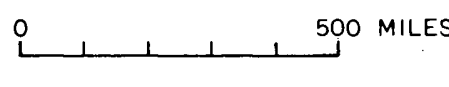

Trough area

Froure 352.1.-Paleogeographic maps for the lower and middle parts of the Pierre shale and equivalent rocks. 

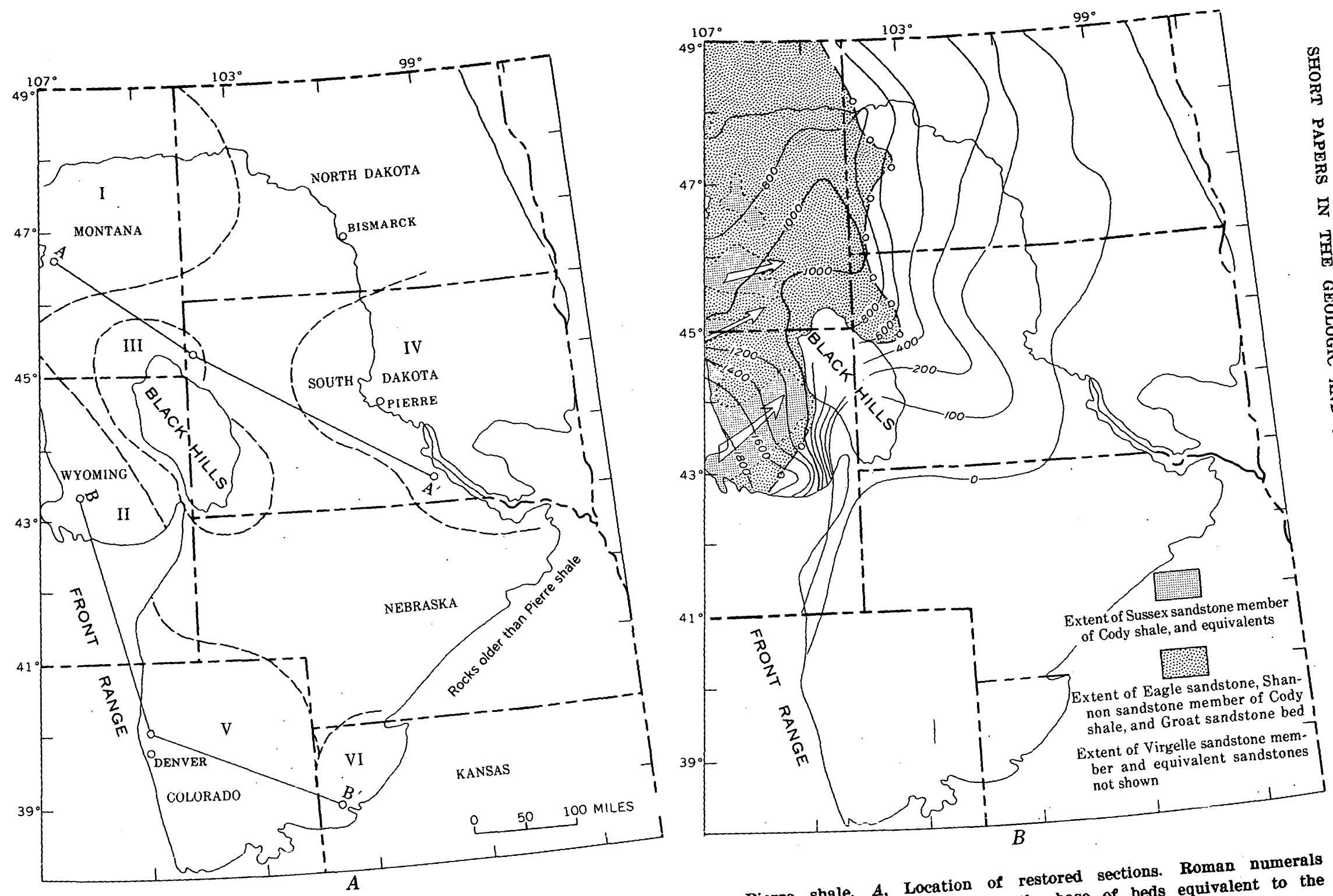

Frauke 352.2. - Index map and thickness map of $B$. Thickness map of rocks bet
refer to correlation chart (table 352.1 ).

Claggett shale. Arrows show probable directon of ged 

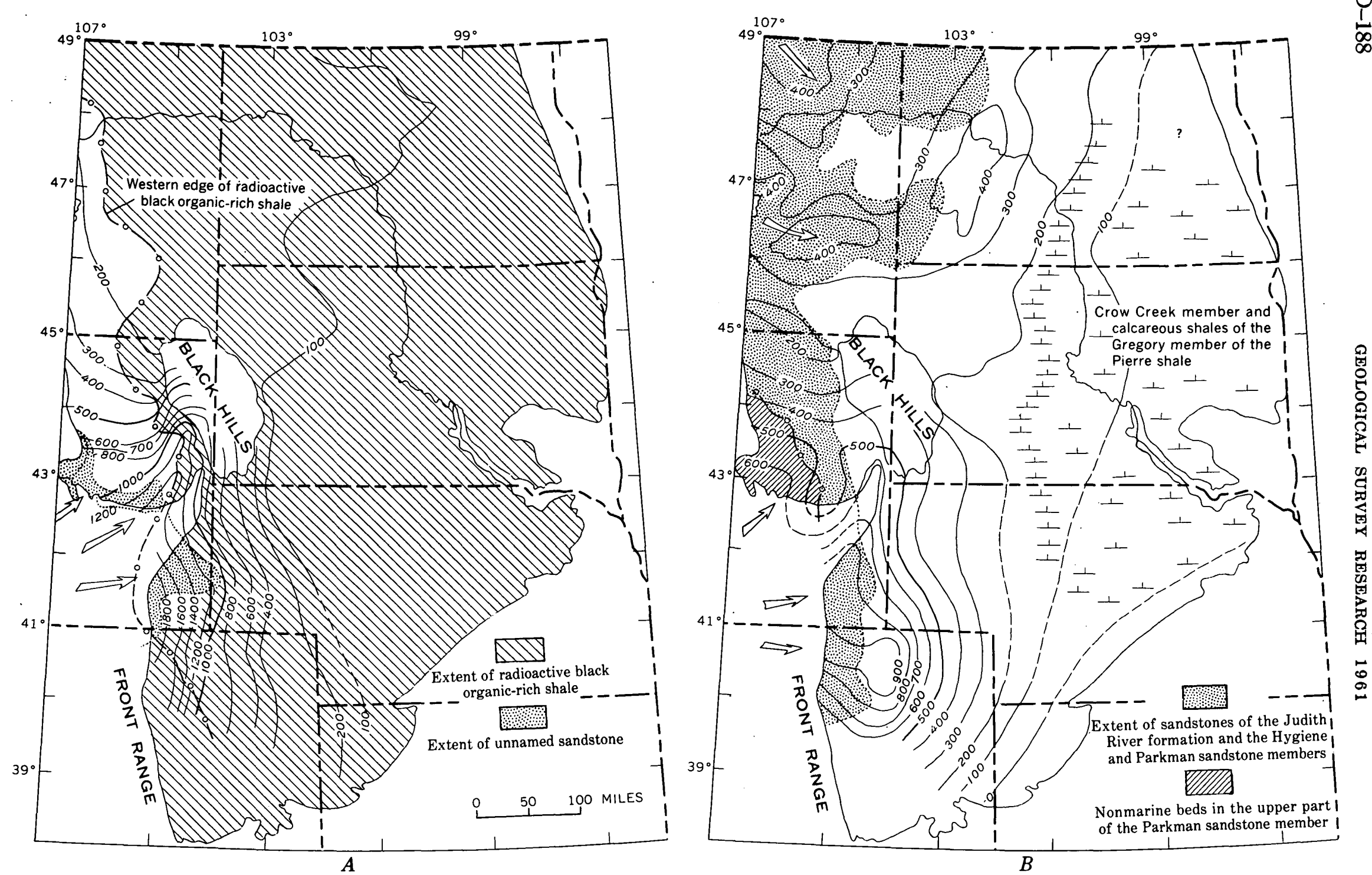

Frgure 352.3.-Thickness maps of the Claggett transgressional and the Judith River regressional phase of the Pierre shale. A, Rocks equivalent to the Claggett shale. $B$, Rocks equivalent to the Judith River formation. Arrows show probable direction of sediment transport. 


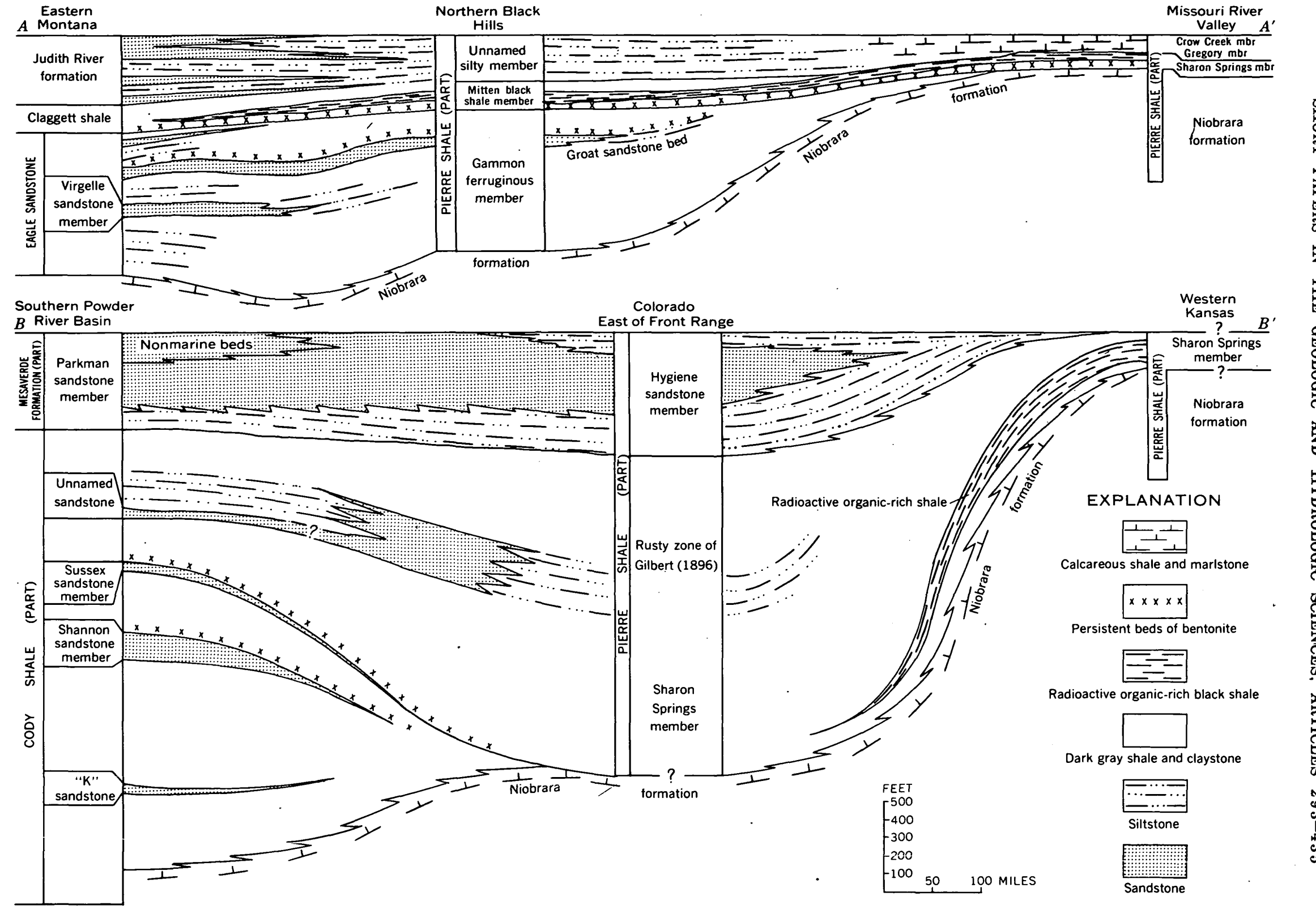

Figure 352.4.-Diagrammatic sections showing correlation of lower and middle parts of the Pierre shale and equivalent rocks in the northern Great Plains. Location of sections shown on figure $352.2 A$ 
TABLE 352.1.-Correlation of lower and middle parts of the Pierre shale and equivalent rocks, northern Great Plains [Roman numerals refer to areas shown on figure $352 . A$; dot shows index fossil collected]

\begin{tabular}{|c|c|c|c|c|c|c|c|c|c|c|c|}
\hline \multirow{2}{*}{$\begin{array}{l}\text { Index } \\
\text { fossils }\end{array}$} & I & & II & & III & & IV & & $\mathrm{V}$ & & VI \\
\hline & Eastern Montana & \multicolumn{2}{|c|}{ Powder River Basin } & \multicolumn{2}{|r|}{ Black Hills } & \multicolumn{2}{|c|}{$\begin{array}{l}\text { Missouri Valley of } \\
\text { South Dakota }\end{array}$} & & $\begin{array}{l}\text { Colorado east of } \\
\text { Front Range }\end{array}$ & \multicolumn{2}{|c|}{ Western Kansas } \\
\hline $\begin{array}{l}\text { - Baculites scotti } \\
\text { - B. gregoryensis }\end{array}$ & $\begin{array}{l}\text { Judith River formation } \\
\text { (marine in this area) }\end{array}$ & 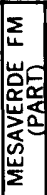 & $\begin{array}{c}\text { - Parkman sandstone } \\
\text { member }\end{array}$ & & $\begin{array}{l}\text { Unnamed silty shale } \\
\text { member }\end{array}$ & & $\begin{array}{l}\text { Crow Creek member } \\
- \\
\text { - Gregory member }\end{array}$ & & $\begin{array}{c}\text { Hygiene sandstone } \\
\text { member }\end{array}$ & & $?$ \\
\hline $\begin{array}{l}\text { - B. n. sp " } \mathrm{F} " 1 / \\
\text { - B. n. sp " } \mathrm{E} \text { " } 1 \text { - } \\
\text { - B. n. sp " } \mathrm{D} " 11 \\
\text { - B. asperiformis } \\
\text { - B. maclearni } \\
\text { - B. obtusus }\end{array}$ & Claggett shale & 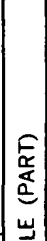 & \begin{tabular}{|r|}
$\bullet$ \\
$\bullet$ \\
$\bullet$ \\
$\bullet$ \\
\end{tabular} & 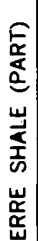 & $\begin{array}{l}\text { - } \\
\text { Mitten black shale } \\
\text { member } \\
\text { - } \\
\text { - Sharon Springs } \\
\text { member }\end{array}$ & 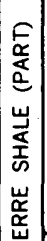 & - Sharon Springs & 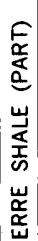 & $\begin{array}{l}\text { - } \\
\text { - Rusty zone of Gilbert } \\
\text { - } \quad \text { (1896) } \\
\text { - Sharon Springs } \\
\text { member } \\
-\end{array}$ & 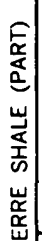 & - $\begin{array}{c}\text { Sharon Springs } \\
\text { member }\end{array}$ \\
\hline - $\underset{\text { hippocrepis }}{\text { Scaphites }}$ & Eagle sandstone & 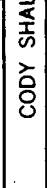 & \begin{tabular}{|l|} 
Sussex sandstone member \\
Shannon sandstone mbr \\
$-~ " K$ " sandstone \\
\end{tabular} & $\frac{\mathrm{w}}{2}$ & $\begin{array}{l}\text { Groat sandstone bed. } \\
\text { Gammon } \\
\text { ferruginous member }\end{array}$ & 容 & $?$ & $\underline{a}$ & $?$ & $\frac{\omega}{\alpha}$ & $?$ \\
\hline
\end{tabular}

of Pierre shale in the Black Hills region, fig. 352.4). The trough of the basin was the site of rapid deposition in which great thicknesses of silty and sandy beds, bentonitic claystone, and persistent beds of bentonite accumulated. The Sussex, Shannon, Groat, Virgelle, and other sandstones occur at several horizons (figs. $352.2 B$ and 352.4). These beds thicken and become coarser grained to the west. Oil has been produced commercially from some of these sandstones in the southwest part of the Powder River basin, and gas is produced from similar beds in eastern Montana.

\section{CLAGGETT TRANSGRESSION}

Rocks equivalent to the Claggett shale of Montana (fig. 352.4 and table 352.1) represent a transgression of the Pierre sea (fig. 352.3A). Volcanism at the start of this phase resulted in widespread ashfalls that are preserved as persistent beds of bentonite at the base of the black shale sequence throughout the Dakotas, Montana, Wyoming, and western Nebraska.

Deposits of the stable eastern shelf area are thin, consisting of black organic-rich radioactive shale and thin beds of bentonite characteristic of the Sharon Springs member of the Pierre shale (fig. 352.4). These rocks contain distinctive ammonite faunas (table 352.1) and have easily identified electric and gamma-ray curves that provide a reliable time-stratigraphic datum throughout the area. The distinctive black shale and bentonite sequence of the shelf area extends westward across the eastern slope area into about the center of the basin where the organic-rich black shale loses its identity because of dilution with detritus from the western source area. The bentonite beds thicken toward the source area and retain their identity over large areas.

Deposits of the stable eastern slope area accumulated more rapidly than those of the eastern shelf; in addition to bentonite and organic-rich black shale, the deposits contain black flaky shale characteristic of the Claggett shale. The thickness of these transgressive deposits increases gradually across the western Dakotas and eastern Montana (fig. 352.3A) . Western Nebraska, north-central Colorado, and southeastern Wyoming were the site of rapid deposition resulting in thick accumulations of black shale and silty and sandy beds in the bottom of the trough (figs. $352.3 \mathrm{~A}$ and 352.4). Sandy deposits in this stratigraphic interval are thought to indicate an isolated local source area in south-central Wyoming.

\section{JUDITH RIVER REGRESSION}

Rocks equivalent to the Judith River formation (fig. 352.4 and table 352.1) represent the second regressive depositional phase of the Pierre shale. Nonmarine rocks were deposited along the eastward retreating shoreline in western Montana and Wyoming (figs. $352.1 C$ and $352.3 B$ ) and are represented in the trough portion of this area by regressive beds of marine sandstone.

The restricted eastern shelf area received thin ac- 
cumulations of claystone, calcareous shale, and thin beds of silty marlstone. Noncalcareous shale and silty shale were deposited in the eastern slope area. The trough of the basin contains relatively thick deposits of silty shale, siltstone, and sandstone. In the northern part of the area, the thickness of the unit and the distribution of sandstone deposits indicate that the sediments were being transported eastward across Montana. and northeastward across North Dakota (fig. 352.3B). The arcuate pattern formed by the 300 - and 400 -foot isopach lines may have been the result of ocean currents moving in a clockwise direction.

Nonmarine deposits in the upper part of the Parkman sandstone (figs $352.3 B$ and 352.4) show that the western shoreline had moved eastward into the Powder River basin of east-central Wyoming near the close of this phase of deposition.

Natural gas is produced in eastern Montana from sandstones in the Judith River formation and oil is produced from the Parkman sandstone member of the Mesaverde formation in eastern Wyoming and from the Hygiene sandstone member of the Pierre along the Front Range in Colorado.

\section{REFERENCES}

Gilbert, G. K., 1896, The underground water of the Arkansas Valley in eastern Colorado: U.S. Geol. Survey 17th Ann. Rept., pt. 2, p. 551-601.

LeRoy, L. W., and Schieltz, N. C., 1958, Niobrara-Pierre boundary along Front Range, Colorado: Am. Assoc. Petroleum Geologists Bull., v. 42, no. 10, p. 2444-2464.

Reeside, J. B., Jr., 1957, Paleoecology of the Cretaceous seas of the Western Interior of the United States, in Treatise on marine ecology and paleoecology, v. 2 : Geol. Soc. America Mem. 67, p. 505-542.

Tourtelot, H. A., Schultz, L. G., and Gill, J. R., 1960, Stratigraphic variations in mineralogy and chemical composition of the Pierre shale in South Dakota and adjacent parts of North Dakota, Nebraska, Wyoming, and Montana, in Short papers in the geological sciences: U.S. Geol. Survey Prof. Paper 400-B, p. B447-B452.

Weimer, R. J., 1960, Upper Cretaceous stratigraphy, Rocky Mountain area : Am. Assoc. Petroleum Geologist Bull., v. 44, no. 1, p. 1-20.

Zapp, A. D., and Cobban, W. A., 1960, Some Late Cretaceous strand lines in northwestern Colorado and northeastern Utah, in Short papers in the geological sciences: U. S. Geol. Survey Prof. Paper 400-B, p. B246-B249.

GEOLOGY AND HYDROLOGY OF ALASKA AND HAWAII

353. ANALYSES OF GAS AND WATER FROM TWO MINERAL SPRINGS IN THE COPPER RIVER BASIN, ALASKA

By Donald R. Nichols and Lynn A. Yehle, Washington, D.C.

Two gas and mineralized-water springs, previously reported by the authors (1961, p. 1076), were sampled during the summer of 1960 . These springs, here termed the Copper Center and Tazlina mineral springs, issue from small mounds and thus may be classed as incipient mud volcanoes. Several other smaller springs, also presumably mineralized, have been seen from the air, but were not visited. All of the springs are in the southeastern Copper River Basin (fig. 353.1), and appear to be associated with mud volcanoes that have been divided into two general groups based on geographic distribution and chemical and physical characteristics. The Drum group (Shrub, Upper Klawasi, and Lower Klawasi mud volcanoes) lies east of the Copper River and has the largest cones, 150 to 310 feet high; its springs are characterized by carbon dioxide gas and warm sodium bicarbonate and sodium chloride waters. The Tolsona group (Nickel Creek, Shepard, Tolsona No. 1, and Tolsona No. 2 mud volcanoes) lies west of the Copper River and has cones 25 to 60 feet high; all but the inactive Shepard mud volcano have springs that discharge methane gas and cool sodium chloride and calcium chloride water.

East of the Copper River, thick glacial, lacustrine, and fluvial deposits mantle andesitic lavas of Tertiary to Recent age. West of the Copper River, marine sedimentary rocks of Cretaceous age, and semiconsolidated sandstone, conglomerate, and a few thin lignitic beds of Tertiary age, are overlain by Pleistocene deposits (Miller and others, 1959, p. 52, pl. 3).

\section{DESCRIPTION OF THE SPRINGS}

The Copper Center mineral spring is $21 / 2$ miles $\mathrm{N}$. $20^{\circ}$ E. of Copper Center (fig. 353.1). It consists of 


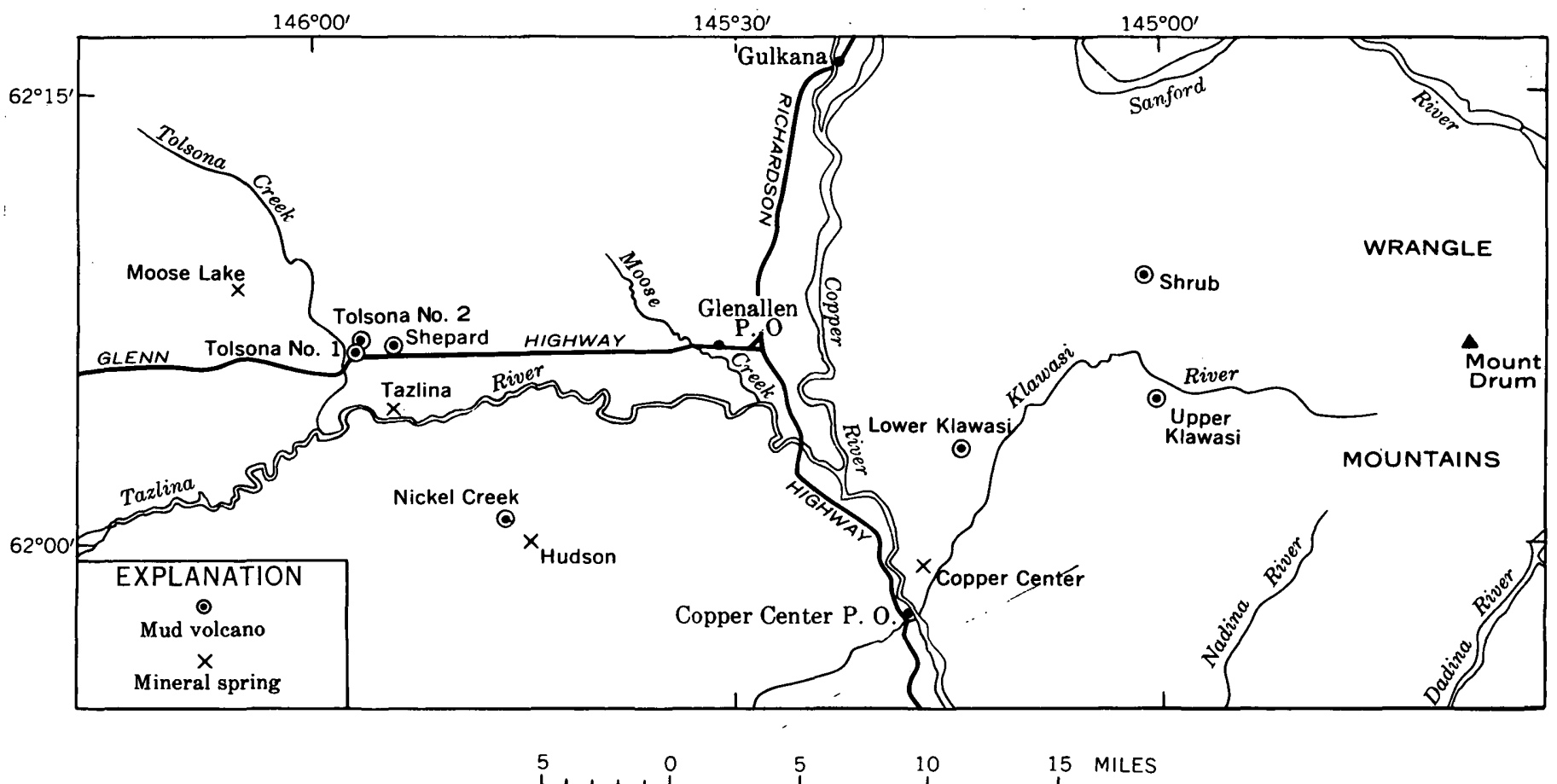

FrgURE 353.1.-Location of principal mud volcanoes and mineral springs, Copper River Basin, Alaska.

two vents, each $1 \frac{1}{2}$ inches wide, and a single pool 5 to 8 feet in diameter and 2 feet deep. The pool and vents lie on the eastern edge of a barren, almost imperceptible mound, the base of which is about 75 feet in diameter and about 1 foot below the nearby ground surface. The mound consists largely of pebbly clayey silt to a depth of at least $31 / 2$ feet. The bottom of the pool, however, is covered by medium to coarse sand. Coarse gravel, which lines the drainage channel from the spring, and twigs and sand in the pool are coated by an iridescent bluish-purple precipitate.

When observed, water in the pool was clear green and had a temperature of $63^{\circ} \mathrm{F}, 12^{\circ}$ less than the air temperature but $15^{\circ}$ to $25^{\circ}$ more than ground-water temperature. Water from the pool discharged into a small stream at a rate of about $9 \mathrm{gpm}$, but sank into the stream bed within 300 yards. Discharge from the vents. was insignificant. A dry, grass-covered drainage way, 50 to 500 feed wide, that extends southwestward from-the spring to a gully incised in the bluffs of the Copper River suggests that discharge of water from the pools was much greater in the past. Gas bubbled intermittently from several places in the pool and from the two small vents.

The Tazlina mineral spring is in a clearing on a low terrace north of the Tazlina River, about $21 / 2$ miles east of Tolsona Creek. In this approximate area, Theodore Chapin, in 1914 (unpublished data), found a "circular area 15 feet across [with] over 50 mud volcanoes *** [and with] mounds 4 to 5 feet high." The Tazlina spring, which may be the same as Chapin's mud volcanoes, presently consists of 4 pools 3 to 5 feet in diameter on a single grass-covered mound 3 to 4 feet high and 250 feet in diameter. The mound is composed of dark-gray clayey silt and fine sand. Gas bubbled intermittently from 3 of the 5 vents in the largest pool at the mound crest (fig. 353.2), but activity was very sporadic in the other 3 pools on the northeast slope of the mound. The water seeps into grass-covered marshes bordering the pools; the rate of discharge could not be measured. Gray, silt-laden water in the pools had a salty taste and a temperature of $40^{\circ} \mathrm{F}$, close to that of the ground water but $35^{\circ}$ lower than air temperature at the time measured.

\section{WATER AND GAS ANALYSES}

Waters from the Copper Center and Tazlina mineral springs (table 353.1) are similar to waters of the Tolsona group of mud volcanoes (Nichols and Yehle, 1961, table 3); the principal difference is that the average of total dissolved solids of the Tolsona group is much lower than that of the Copper Center mineral spring and much higher than that of the Tazlina mineral spring. Waters from the Tolsona group also have an appreciably higher iron content. Both the spring and mud volcano waters are relatively low in bicarbonate and high in chloride and calcium in contrast to waters of the Drum group. 


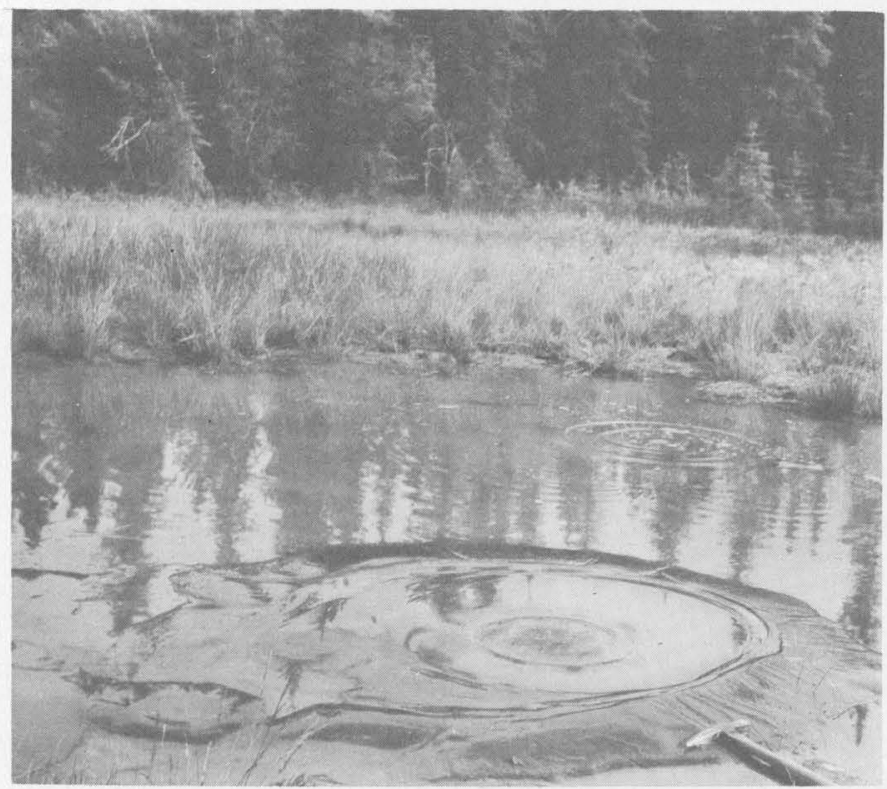

Figure 353.2.-Gas bubbling from 2 of 5 vents in pool at crest of Tazlina mineral spring.

TABLE 353.1.-Analyses of water and ratios of chemical constituents in water from Copper Center and Tazlina mineral springs

\begin{tabular}{|c|c|c|}
\hline & \multicolumn{2}{|c|}{ Mineral spring } \\
\hline & $\begin{array}{c}\text { Copper Center } \\
\text { (Sample 6129 col- } \\
\text { lected Aug. 7, 1960) }\end{array}$ & $\begin{array}{l}\text { Tazlina (Sample } \\
6131 \text { collected } \\
\text { Aug. } 8,1960 \text { ) }\end{array}$ \\
\hline 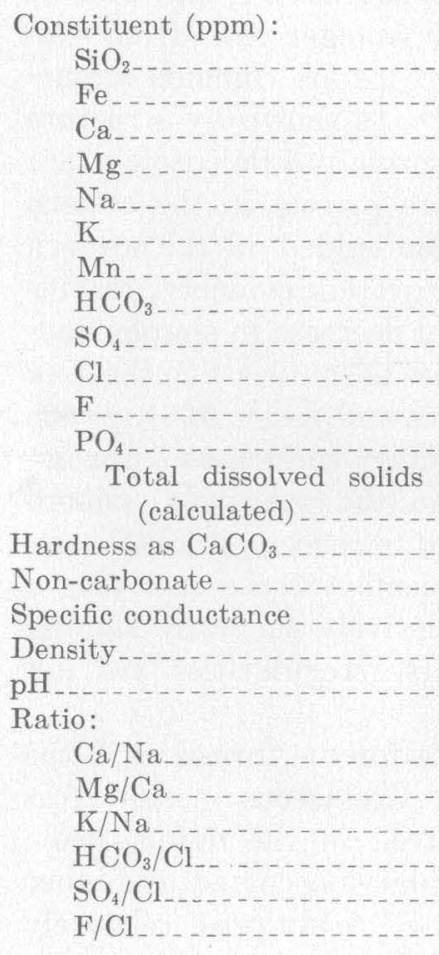 & $\begin{array}{c}3,060 \\
24 \\
5,960 \\
55 \\
.04 \\
124 \\
4.0 \\
14,400 \\
1.7 \\
.05 \\
23,600 \\
7,730 \\
7,630 \\
36,400 \\
1.017 \\
8.0 \\
.5134 \\
.0078 \\
.0092 \\
.0086 \\
.0003 \\
.0001\end{array}$ & $\begin{array}{c}{ }^{24} .03 \\
909 \\
48 \\
1,10 \\
11 \\
2^{216} .25 \\
3.5 \\
3,400 \\
.3 \\
5,670 \\
2,470 \\
2,290 \\
9,800 \\
7.3 \\
.7769 \\
.0528 \\
.0094 \\
.0635 \\
.0103 \\
.0009\end{array}$ \\
\hline
\end{tabular}

TABLE 353.2 - Analyses of gas from Copper Center and Tazlina mineral springs, and Tolsona No. 1 mud volcano

[Mass spectrometer analyses by, and used with permission of, Helium Activity Laboratory, U.S. Bureau of Mines, Amarillo, Tex.; Tr. $=$ trace, less than 0.05 percent]

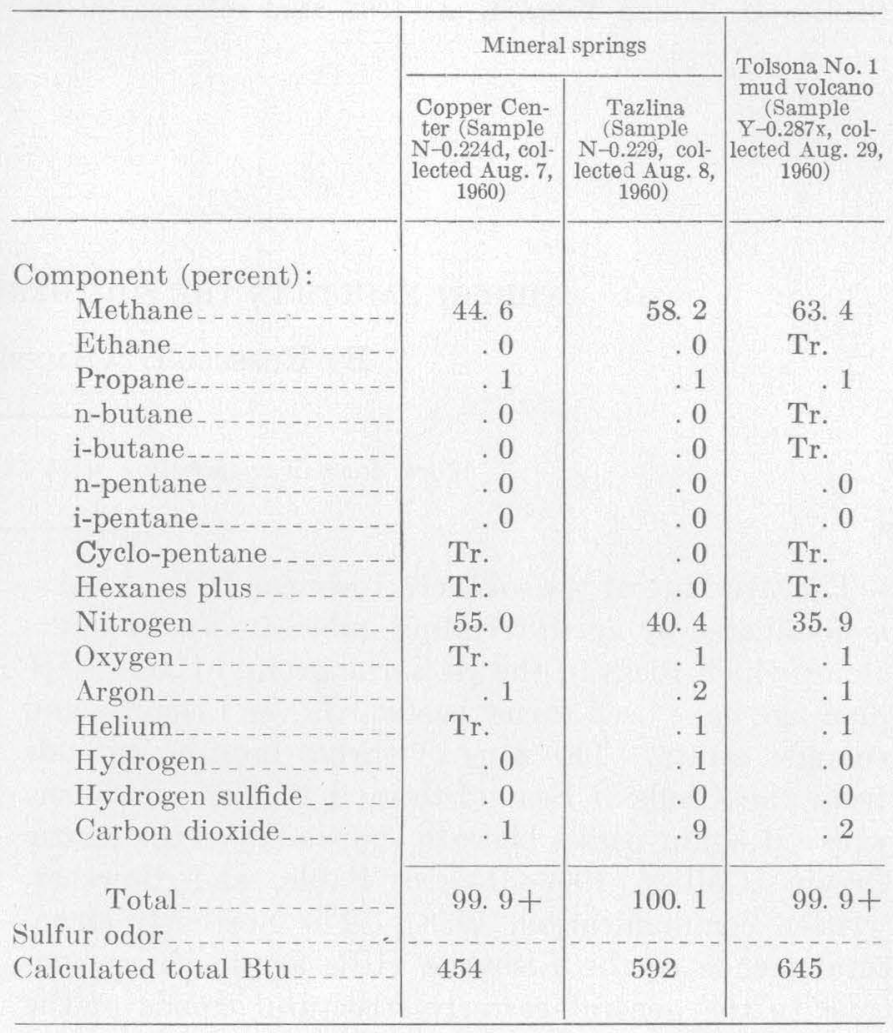

Analyses of gas emanating from the Copper Center and Tazlina mineral springs and an analysis of gas from the Tolsona No. 1 mud volcano are presented in table 353.2. These analyses show a high methane and nitrogen content and closely resemble analyses of Tolsona group gases (Nichols and Yehle, 1961, table $2)$. This contrasts with the predominantly carbon dioxide gas emanating from the Drum group.

The Copper Center and Tazlina mineral springs are included in the Tolsona group of mud volcanoes because of the composition of their water, and especially of their gas. Comparison of the ratios of chemical constituents of the spring water with median ratios of chemical constituents of other waters of different types as reported by White $(1960$, p. B452) shows no striking similarities, and the source of the water issuing from the springs and mud volcanoes remains uncertain. However, the close similarity of gas from springs and mud volcanoes of the Tolsona group suggests that all have a common source, perhaps from buried Cenozoic marsh or coal deposits, or from porous nonpetroliferous beds of pre-Tertiary (Cretaceous?) age. 


\section{REFERENCES}

Miller, D. J., Payne, T. G., and Gryc, George, 1959, Geology of possible petroleum provinces in Alaska: U.S. Geol. Survey Bull. 1094, 132 p.

Nichols, D. R., and Yehle, L. A., 1961, Mud volcanoes in the
Copper River Basin, Alaska, in Geology of the Arctic: Toronto, Canada, Univ. of Toronto Press, p. 1063-1087.

White, D. E., 1960, Summary of chemical characteristics of some waters of deep origin, in Short papers in the geological sciences: U.S. Geol. Survey Prof. Paper 400-B, p. B452B454.

\title{
354. THRUST FAULTS IN THE SOUTHERN LISBURNE HILLS, NORTHWEST ALASKA
}

\author{
By Russell H. Campbell, Menlo Park, Calif.
}

Work done in cooperation with the U.S. Atomic Energy Commission

The structure of the southern Lisburne Hills, Alaska, is dominated by north-trending imbricate thrust faults along which rocks of the Lisburne group of Mississippian age have been thrust eastward over Lisburne and younger strata. The zone of thrust faulting extends from the Chukchi Sea northward to Cape Lisburne where it again passes beneath the waters of the Arctic Ocean (Collier, 1906; Dutro, Sable, and Bowsher, written communication, 1958). The northerly structural trends of the Lisburne Hills are in sharp contrast to the general easterly structural trends of the Brooks Range and Arctic Foothills provinces.

The rocks of the area are exclusively sedimentary, probably all marine, and most are well stratified. They range in age from Devonian(?) (Collier, 1906, p. 16, 17) to Cretaceous and crop out in parallel northeast- to north-trending bands in which the rocks are generally successively younger from west to east (fig. 354.1). No angular unconformities have been observed, but a disconformity probably occurs at the top of the Lisburne group, and disconformities may separate all the younger units.

The overthrust sheets are composed principally of relatively competent limestone and dolomite beds of the Lisburne group, but they locally include infolded segments of older and younger rocks. Silty mudstone of Mississippian age underlies the Lisburne group conformably at a few places, but at most places the contact is a thrust fault, beneath which the less competent mudstone has been plastically deformed. Relatively incompetent mudstone and sandstone of Cretaceous and Cretaceous or Jurassic ages have been intensely crumpled and broken by high-angle faults chiefly along bedding planes and axial planes of folds; they give a gross impression of plastic deformation.
The combined dip slip of the thrust faults is estimated to be a minimum of 5 miles to the east. The photograph (fig. . 354.2) illustrates some details of the thrust faulting at a site of particularly good exposure. Beds of the Lisburne group that overlie the Triassic rocks along the Agate Rock thrust belong about 5,000 feet stratigraphically below the top of the Triassic strata. The basal contact of the Lisburne group is exposed in the sheet above the Eebrulikgorruk thrust. Rocks at this horizon belong about 2,000 feet below beds of the Lisburne group that immediately underlie the fault surface.

A regional dip to the east or southeast is indicated by the exposure of progressively younger units from west to east, even though westerly dips are common at surface exposures of the strata. As shown by structure section $A-A^{\prime}$ (fig. 354.1), Mesozoic and Paleozoic strata 25,000 to 30,000 feet thick are present in the eastern part of the area, but have been eroded off the western part. In addition to the stratigraphic evidence, gravity data show a generally gradual decrease in simple Bouguer anomalies from northwest to southeast in the area shown by figure 354.1 (Barnes and Allen, 1961, p. 8086). All the exposed sedimentary rocks have approximately the same density, so the relatively smooth gravity gradient is interpreted to reflect a gradual eastward thickening of the sedimentary rocks overlying a dense layer that is either relatively smoothly sloping or so deeply buried that its irregularities are not expressed.

The earliest reasonable date for the thrusting in the Lisburne Hills is late Early Cretaceous inasmuch as rocks of that age are involved in the deformation. Some folding of the thrust planes occurred as higher sheets rode over lower ones. Additional relatively 


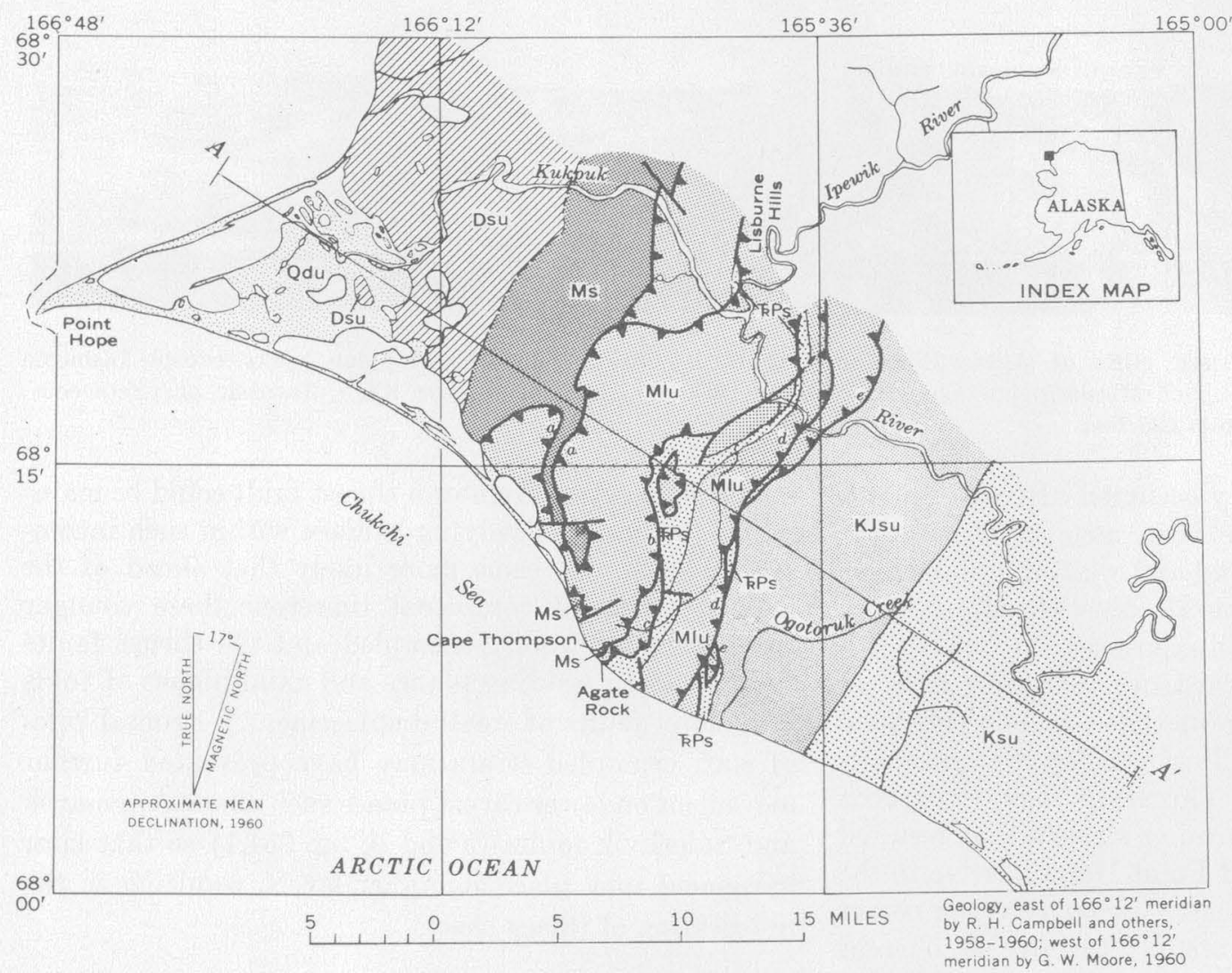

EXPLANATION Qdu
Sedimentary deposits, undivided

Ksu

Sedimentary rocks, undivided

KJsu

Sedimentary rocks, undivided

$$
\text { kPs }
$$

Shublik and Siksikpuk formations

Locally includes infolded Lower Cretaceous or Jurassic
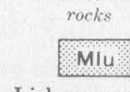

Lisburne group. undivided

\section{Ms}

Sedimentary rocks except Lisburne group

\section{Esur}

Sedimentary rocks, undivided

Contact
Dashed where approsin

located

High angle fault

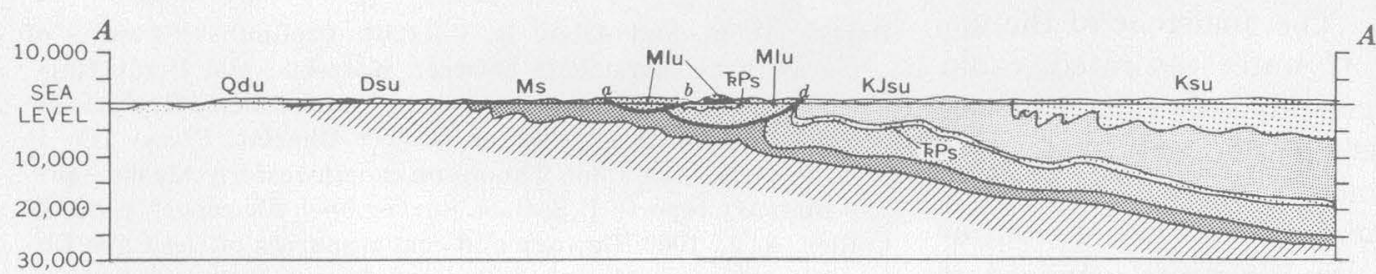

Thrust fault Sawteeth on upper plate a-Ahviknuk fault b-Eebrulikgorruk fault c-Agate Rock fault d-Saleekvik fault e-Angmarok faul

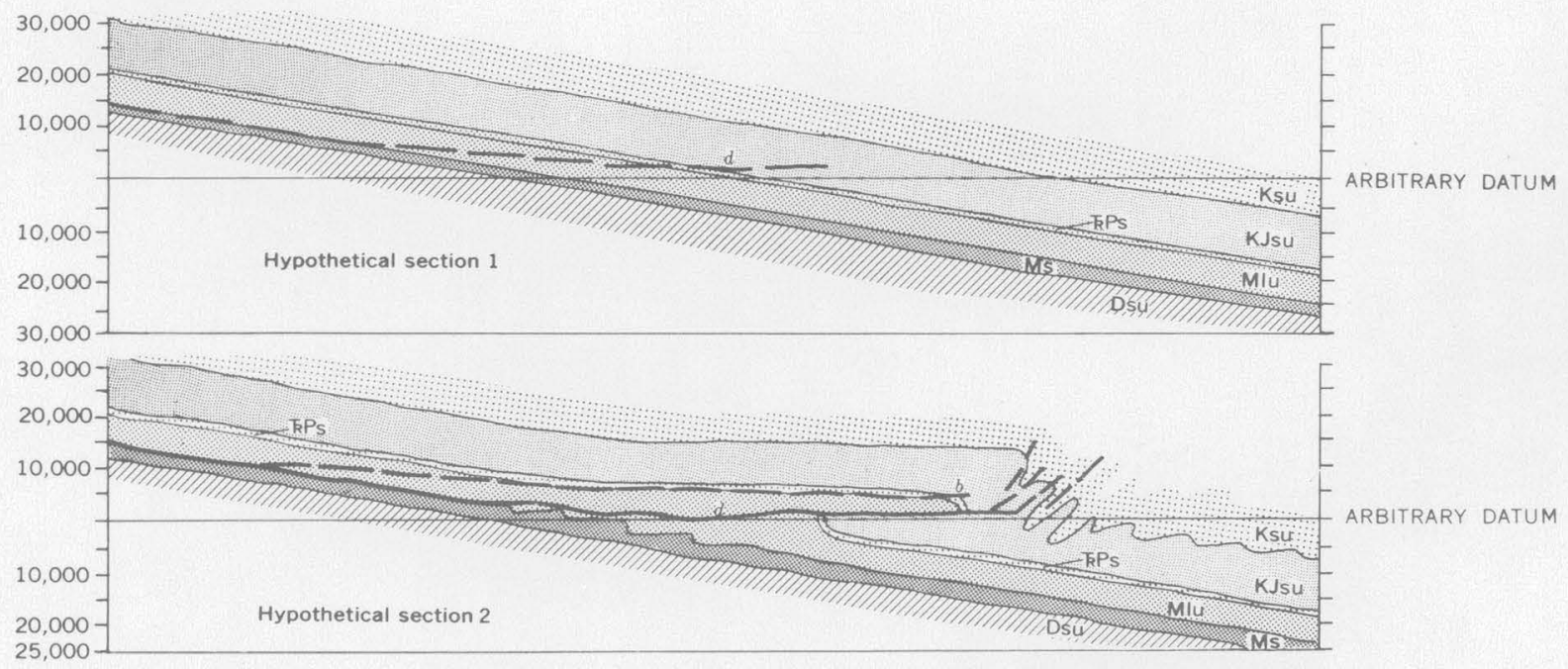

Figure 354.1.-Generalized geologic map and sections of the southern Lisburne Hills. Hypothetical sections illustrate suggested development of the thrust faults by gravity gliding. 


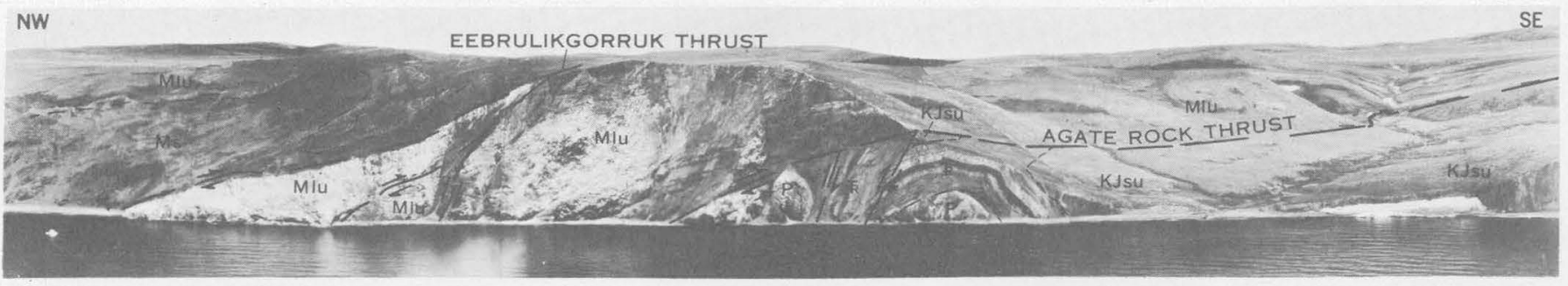

Figure 354.2.-Photograph of sea cliffs at Agate Rock showing thrust faults. Ms, Mississippian rocks except Lisburne group; Mlu, Lisburne group of Mississippian age; P, Permian rocks; 下, Triassic rocks; KJsu, Jurassic or Cretaceous rocks. Altitude of cliff top is 625 feet.

gentle folding also probably occurred after the thrusting ceased, and may have been associated with the subsidence of the area around and west of Point Hope. This may account for general westward dips of the thrust planes at their western exposures.

The association of eastward overthrusting with an eastward regional dip suggests that the thrusting took place by gravity gliding as illustrated by the hypothetical sections (fig. 354.1). Thrusting may have been triggered by the same deforming stresses that resulted in upwarp in the vicinity of Point Hope relative to the area to the east and southeast. Relatively competent rocks of the Lisburne group tended to move as coherent sheets, chiefly along numerous weakly bonded bedding planes at and near its base. The mudstone of the underlying unit, particularly if water saturated, could have served as a lubricated, possibly buoyant zone along which the overlying coherent sheets could slide. No low-angle faults have been found in the rocks of Jurassic and Cretaceous age in this area, except small discontinuous ones in locally gently dipping strata. Indeed, it is difficult to visualize how a thrust fault could be maintained as a single flat-lying surface within such incompetent beds. It seems more likely that ahead of the moving sheets of competent limestone these younger rocks were intricately crumpled and the thrust faults split up along bedding planes and axial planes of folds into many faults of small displacement. Frontal piles of such crumpled strata may have prevented further movement on lower thrust planes such as the Angmarok and Saleekvik faults ( $e$ and $d$, fig. 354.1) so that later movement took place at higher levels, resulting in the imbrication of thrust sheets.

\section{REFERENCES}

Barnes, D. F., and Allen, R. V., 1961, Preliminary results of gravity measurements between Kotzebue and Point Hope, Alaska, in Kachadoorian, Reuben, and others, Geologic investigations in support of Project Chariot, Phase III, in the vicinity of Cape Thompson, northwestern Alaska-preliminary report: U.S. Geol. Survey open-file report, p. 80-86.

Collier, A. J., 1906, Geology and coal resources of the Cape Lisburne region, Alaska: U.S. Geol. Survey Bull. 278, 54 p. 
By Hansford T. Shacklette, Georgetown, Ky.

Latouche Island is one of the outermost islands of Prince William Sound, lying about 100 miles southwest of the mainland port of Valdez. The climate here is a mild, wet coastal type; the mean annual precipitation is 184 inches, and the average snowfall is about 153 inches. The mean annual temperature is approximately $42^{\circ} \mathrm{F}$; the absolute maximum is $82^{\circ} \mathrm{F}$, and the absolute minimum is $1^{\circ} \mathrm{F}$. The bedrock is predominately hard, compact, dull-gray graywacke and interbedded medium- to dark-gray slate (Stejer, 1956, p. 110-111). Unconsolidated surficial deposits are described by Stejer ( $p .111)$ as follows:

Unconsolidated deposits of Quaternary age overlie much of the bedrock. Glacial deposits mantle large parts of the valley floor, alluvium occurs in patches along the streams, and talus forms thick blankets along the lower slopes of the high ridge that borders the valley.

The weathered upper layers of the glacial deposits contain sufficient fine silt and clay to form a zone of mineral soil almost impervious to vadose water. The area is thus without effective underground drainage, and most of the heavy rainfall and snow melt water is removed as surface runoff (George O. Gates, oral communication, 1957).

Broad terraces near the seacoast about one-half mile southwest of the village of Latouche are covered for the most part with a sedge meadow plant community (Shacklette, 1961). The principal species of sedges are Carex Kelloggii Boott, $C$. canescens L., C. macrochaeta C. A. Meyer, $C$. sitchensis Prescott and $C$. pauciflora Lightf., with which are also found cotton grass (Eriophorum gracile Koch) and bur-rced (Sparganium angustifolium Michx.). Few other plant species are present.

Small pools are conspicuous features of these sedge meadows, which are on the gently sloping terraces. Many of these pools are highly symmetrical, generally rounded to almost circular, as much as 30 feet in diameter, and raised 2 or 3 feet above the general level of the surrounding meadow (fig. 355.1). They have vertical to slightly overhanging banks or rims, formed of the roots and stems of sedges and cotton grass imbedded in reddish-brown peat. Water in the pools is open, clear, and 6 to 10 inches deep. The material on the bottoms of the pools consists of an ooze of unconsolidated dark-brown finely comminuted organic matter that extends downward an undetermined depth but grades into rather firm muck or peat at a depth of about 2 feet. There is no significant growth of mosses in the pools. The rhizomes of the yellow pond lily (Nuphar polysepalum Engelm.) are loosely imbedded

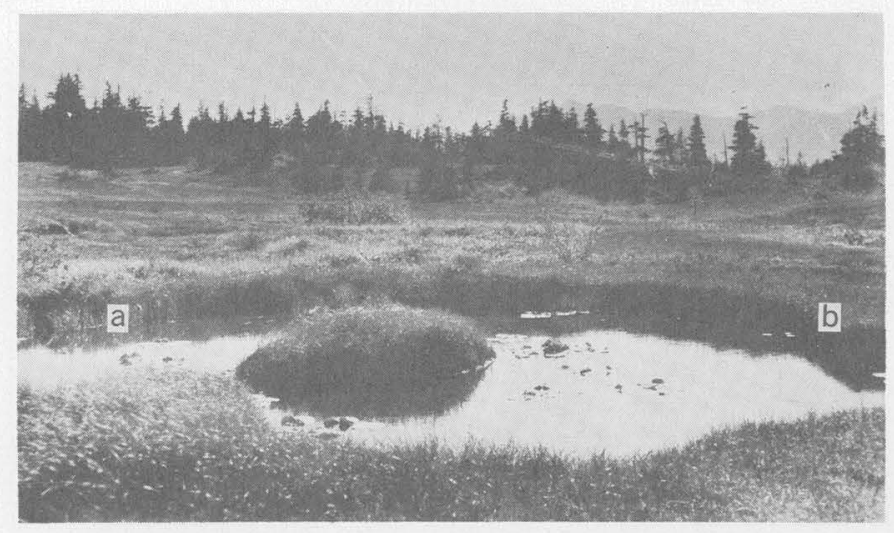

Figure 355.1.-Sedge meadow pool, Latouche Island, Alaska. Leaves of yellow pond lily are floating on the surface. The aquatic bur-reed grows in water near the margin (a). Sedges (Carex and Eriophorum spp.) form a dense, closed sod on the pool rim and island. A break in the rim is beginning to form at the right of the pool (b) ; this will eventually drain the pool. The terrace ridge in the background bears a scattered growth of mountain hemlock, Sitka spruce, and western hemlock.

in the ooze of the pool bottoms, and scattered clumps of quillwort (Isoëtes Braunii Durieu) grow completely submerged in the shallow water. A few plants of burreed also grow in the pools as emergent aquatics. These pools have no apparent surface outlets, and the water does not seem to be flowing through them.

The formation of these pools is believed to begin with the damming of a minor surface drainage channel by the growth of one or several sedge tussocks, along with leafy liverworts, principally Nardia scalaris (Schrad.) Gray, and a few mosses, principally Drepanocladus species, that grow in and around the tussocks. The pool increases in size by an increase in height of the dam through growth of the sedges, and by the thrusting aside of the banks by ice when the water freezes. The outward pressure of the ice tends to form a pressure ridge in the peat at the edge of the pool, creating an elevated rim (fig. $355.2 B$ ) as the ice of the pool pushes against the still-unfrozen sedge margin. The development of an island in the pool is a fortuitous occurrence and not a constant feature of sedge meadow pools. These islands appear to have originated from the remains of upslope rims that had reached sufficient height to escape flooding and disruptive ice action as the pool increased in size (fig. $355.2 B, C)$. The disappearance of the sedge tussocks from the flooded areas is believed to be due to the substrata becoming excessively wet for these sedge species to grow well, and to the mechanical disruption of the substrata and the sedge tussocks by ice action. Alter- 


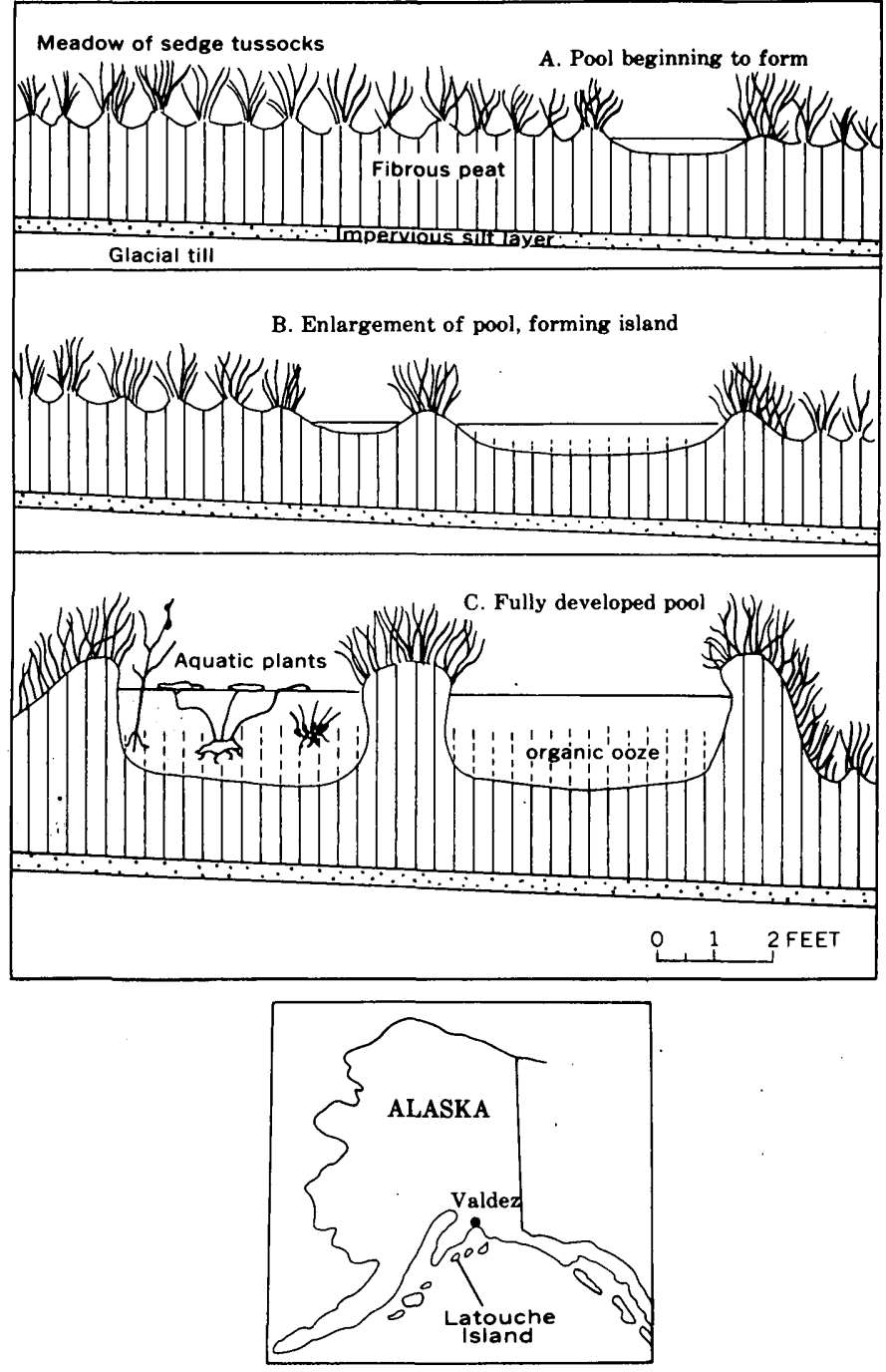

Figure 355.2.-Sketches showing evolution of a sedge meadow pool. Non-tussock forming sedges have been omitted. The tussocks are broken up as the pool rim and island form. nate freezing and thawing of the saturated fibrous peat substrata is probably the principal factor in the formation of the ooze on the pool bottom.

The continued development of sedge meadow pools leads to their eventual destruction. Field observation suggests that when the pools have attained a diameter of 20 to 30 feet a break generally occurs in the downslope rim (fig. 355.1). The pool is thus drained, and the old pool bottom is then colonized by the more hydrophytic species of sedges and cotton grass. The ridged, furrowed, and hummocky microrelief of the sedge meadow is caused by the persistence of the old pool rims, islands, and pool bottoms. Foot travel over this terrain is difficult because of the surface irregularities which are often concealed by the dense sedge growth; numerous pools and soft bottoms of old pools also must be avoided.

Other bodies of water in this vicinity range in size from that of the sedge meadow pools to small lakes (for example, Fish Lake and Lake Putnam, shown on the map of Latouche Island, the Seward A-3, 1:63,360 quadrangle). These pools or lakes lie in slight depressions, have flowing outlets, and do not have elevated margins or rims. It is believed that their origin and history are directly related to the major drainage patterns of the terrain, and that they were not derived from the unique sedge meadow pools described in this report.

\section{REFERENCES}

Shacklette, H. T., 1961, Substrate relationships of some bryophyte communities on Latouche Island, Alaska: Bryologist, v. 64, p. 1-16.

Stejer, F. A., 1956, Pyrite deposits at Horseshoe Bay, Latouche Island, Alaska : U.S. Geol. Survey Bull. 1024-E, p. 107-122.

356. REGIONALLY METAMORPHOSED METALLIFEROUS CONTACT-METASOMATIC DEPOSITS NEAR NOME, ALASKA

By C. L. Hommer, Bangkok, Thailand

Anomalously large amounts of bismuth, copper, molybdenum, and zinc in sediments from Thompson Creek (a western tributary of the Grand Central River) in the Kigluaik Mountains have been reported previously (Hummel and Chapman, 1960), but when first reported the source of the metals was unknown. These metals are now thought to have been derived from erosion of metamorphosed contact-metasomatic deposits. Four such deposits have been identified near Thompson Creek : two are west of the Thompson Creek 
drainage and two are on either side of the Grand Central River above the mouth of Thompson Creek (fig. 356.1).

In Thompson Creek, stream sediments containing heavy metals in the light fraction and scheelite in heavy-mineral concentrates are downstream from a wide belt of sulfide-bearing calc-silicate rock formed along the contact of a thick gneissic granite sill (C. L. Sainsbury, oral communication, 1960). Metamorphosed deposits lie along the contact of this same gneissic granite sill at points 4 and 7 miles west of Thompson Creek.

The contact-metasomatic deposit west of the Grand Central River lies along the contact between a body of quartz-plagioclase-biotite gneiss and interberlded marble and biotite schist. The gneiss is believed to be a metamorphosed granodiorite sill. The bedrock relations of the deposit on the east side of the river are unknown.

The contact-metasomatic deposits are difficult to recognize, for they have been recrystallized during the regional metamorphism of the enclosing sedimentary and igneous rocks, which has produced calc-silicates very similar to the contact rock developed near the intrusives. The four deposits shown on figure 356.1 contain scheelite-bearing contact silicates, and the westernmost deposit contains galena and sphalerite associated with scheelite.

The contact-metasomatic deposits associated with regionally metamorphosed intrusive masses represent a type of lode deposit hitherto unrecognized in the Nome area. Similar deposits may be associated with other meta-igneous rocks in the Kigluaik Mountains, and in high-grade metamorphic rocks in the Bendeleben and Darby Mountains on the Seward Peninsula.

\section{REFERENCE}

Hummel, C. L., and Chapman, R. M., 1960, Geologic and economic signiflcance of some geochemical results obtained from stream sediment samples near Nome, Alaska, in Short papers in the geological sciences: U.S. Geol. Survey Prof. Paper 400-B, p. B30-B33.

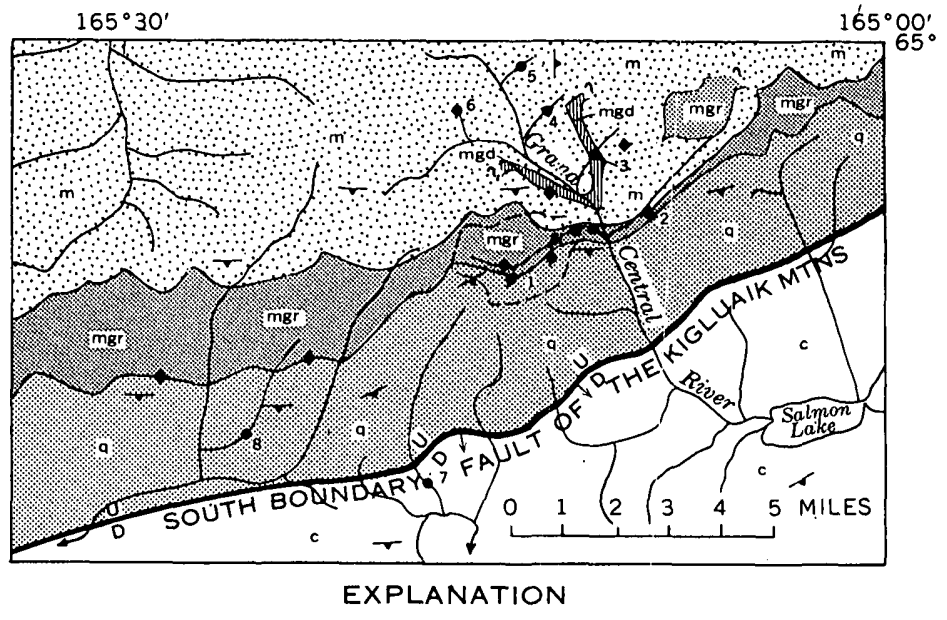

META-IGNEOUS ROCKS

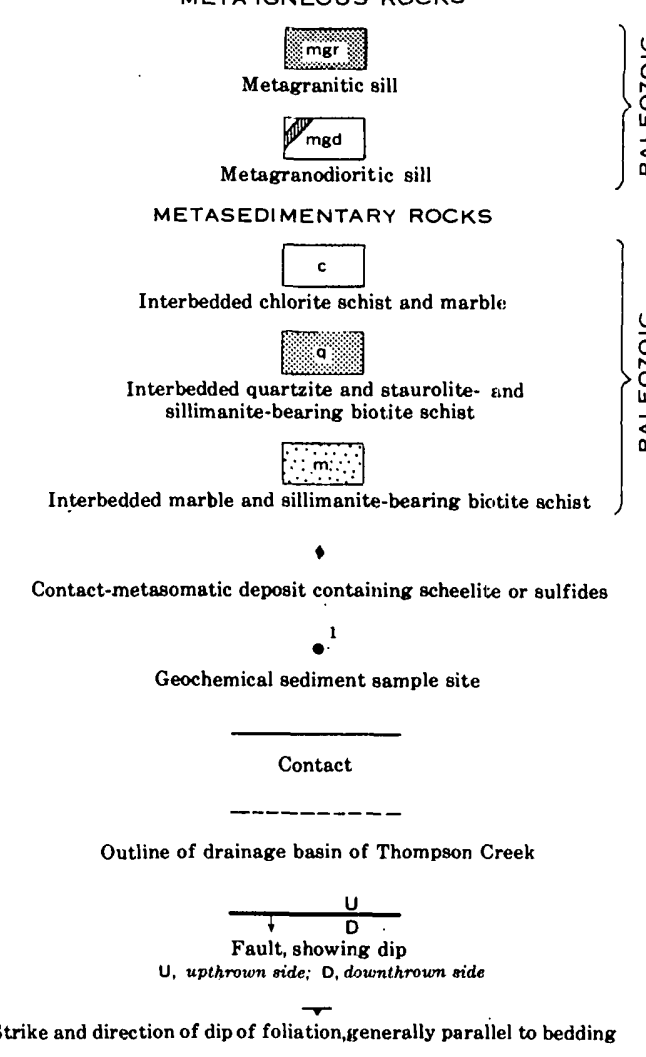

Figure 356.1.-Geologic map of part of the Kigluaik Mountains near Nome, Alaska, showing metamorphosed deposits and sediment sample sites. 


\title{
357. MULTIPLE GLACIATION IN THE HEADWATERS AREA OF THE DELTA RIVER, CENTRAL ALASKA
}

\author{
By Trox L. PÉwÉ, College, Alaska
}

At least four Quaternary glaciations, each successively less extensive than the former, are recorded on the south side of the central Alaska Range in the headwaters area of the Delta River, an area of broad valleys and low mountains. These mountains, named the Amphitheater Mountains because of small cirque glaciers on the north-facing slopes, have a relief of 2,000 to 3,000 feet (fig. 357.1). A reconnaissance study was made of the entire area, and detailed investigations were made in the vicinity of High Valley.

In the past, glaciers pushed south from the Alaska Range, and some ice was confined to the wide, deep, major river valleys, such as the Maclaren. Much of the ice, however, filtered through gaps and passes in the Amphitheater Mountains and was joined by local glaciers. A small percentage of the ice from the south side of the Alaska Range found egress to the north through the Delta River pass (Péwé and others, 1953, p. 8).

The earliest glacial advance recognized is thought to be early to middle Quaternary age. This advance covered the 6,000-foot peaks of the Amphitheater Mountains and pushed south into the Copper River Basin. No till of this advance is known, but isolated erratics up to 15 feet in diameter occur on top of Paxson Mountain and an unnamed peak in the Amphitheater Moun-

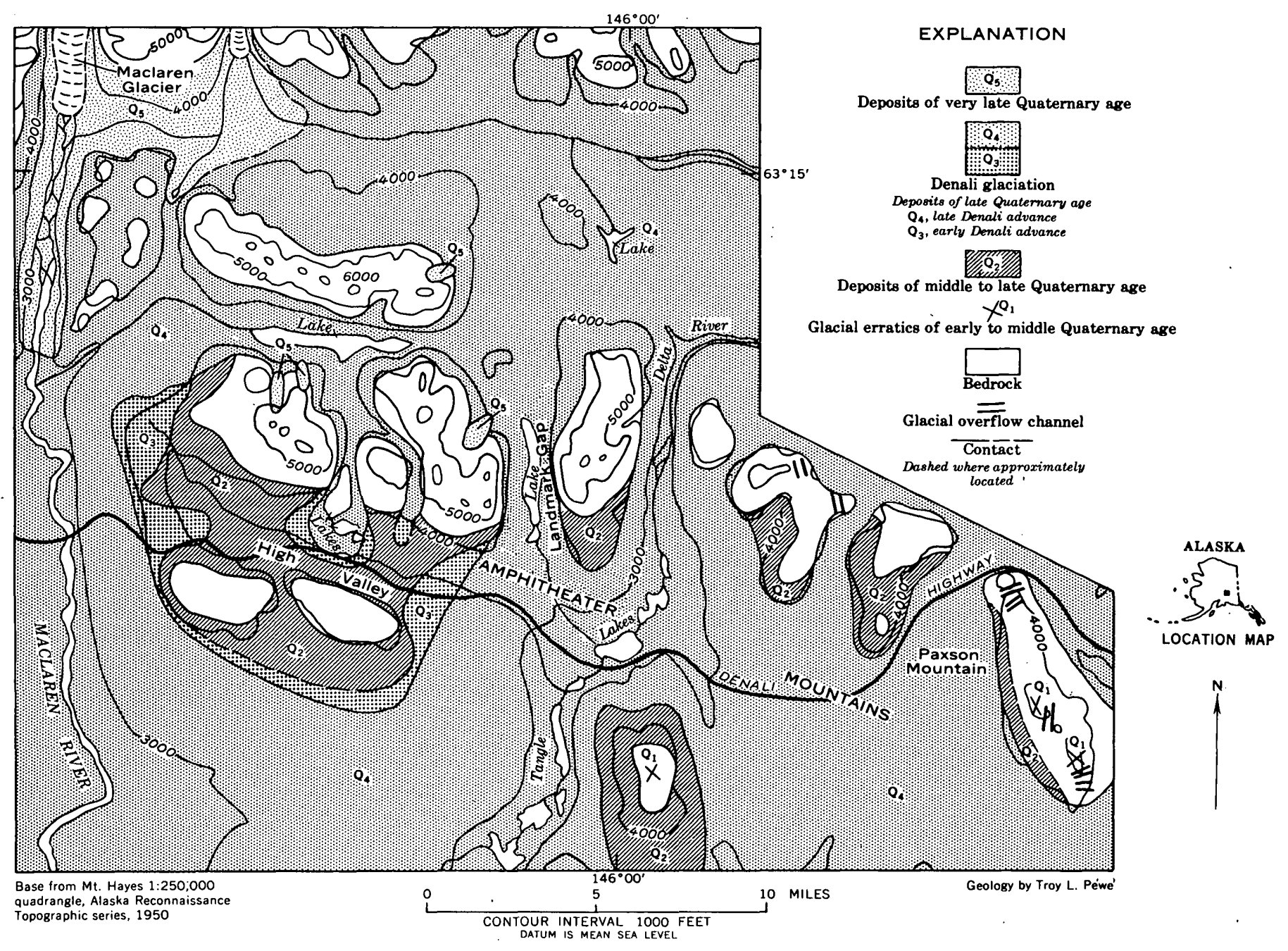

Fraure 357.1.-Glacial deposits in the headwaters area of the Delta River, Alaska. 
tains (fig. 357.1). A north-trending overflow gorge across the crest of Paxson Mountain was possibly cut during this glaciation. This advance is tentatively correlated with the Darling Creek advance recorded in the lower Delta River area (Péwé, 1952).

The second glacial advance pushed south to the Copper River Basin but did not cover the peaks of the Amphitheater Mountains. Many overflow channels were cut where drainage escaped over low places in ridges which protruded only slightly above the ice surface. These ridges now display high and dry water-cut gashes which are best exhibited just outside the southern border of the mapped area. This advance, thought to be middle to late Quaternary age, left an olivecolored silty till covering the lowlands and flanking the lower slopes of the Amphitheater Mountains. This till is now covered by later Quaternary drift or rubble sheets except above an elevation of 4,000 feet and on the floor of High Valley. No morainal forms of this glaciation are preserved in the area, probably because the drift has been covered by younger drift or rubble sheets. This glacial advance is tentatively correlated with the Delta glaciation of the lower Delta River (Péwé and others, 1953).

The next two glacial advances took place in late Quaternary time and are closely related in extent and age. They are here grouped together and named the Denali glaciation, after the Denali Highway, which traverses the deposits of these advances in the Amphitheater Mountains. The Denali glaciation is correlated with the complex Donnelly glaciation of the lower Delta River (Péwé, 1952).

These two advances did not cover the Amphitheater Mountains, but moved through gaps and were joined by local cirque ice. Ice was thick in major valleys such as the Maclaren River valley on the south side of the range, but was thinner over interfluves. Upon retreat, much of the ice in the headwaters area of the Delta River thinned and stagnated.

Well-preserved moraines, characterized by fresh knob-and-kettle topography, are typical of drift of late Denali age; moraines of early Denali age are more subdued, less effective in deflecting surface drainage, and slightly more extensive (fig. 357.1).

As the ice from the late Denali advance in the area stagnated many ice-contact features formed: eskers, kames and kettles, crevasse fillings, and pitted surfaces. The Tangle Lakes at the headwaters of the Delta River comprise a classic area for such features. They are strikingly fresh and cover an area of several hundred square miles.

Glacier-free lower slopes, especially north-facing slopes, in the Amphitheater Mountains are blanketed by a 3 - to 7 -foot thick sheet of now inactive rubble that was derived from higher slopes by frost riving during the rigorous climate of the time of the Denali glaciation. Some of the rubble sheets cover older till in High Valley.

During a readvance of the ice in very late Quaternary time (the fourth glaciation) ice streams on the south side of the central Alaska Range did not extend far enough to go through the gaps in the Amphitheater Mountains. Small glaciers in the Amphitheater Mountains deposited arcuate moraines at the mouths of short valleys at altitudes lower than the prominent lateral moraines deposited during the late Denali glaciation.

Cirque glaciers of the Amphitheater Mountains have advanced twice in historic time, each advance leaving two small sharp morainal ridges of angular rubble within a few hundred yards of the present ice fronts. These deposits are about 5,000 feet above sea level and are perhaps correlative with moraines deposited within the last two centuries by glaciers in the Delta River pass (Péwé, 1951, 1957).

\section{REFERENCES}

Péivé, T. L., 1951, Recent history of Black Rapids glacier, Alaska [abs.] : Geol. Soc. America Bull., v. 62, p. 1558.

-1952, Preliminary report of multiple glaciation in the Big Delta area, Alaska [abs.]: Geol. Soc. America Bull., v. 63, p. 1289.

1957, Recent history of Canwell and Castner glaciers, Alaska [abs.] : Geol. Soc. America Bull., v. 68, p. 1779.

Péwé, T. L., and others, 1953; Multiple glaciation in Alaska-a progress report: U.S. Geol. Survey Circ. 289, 13 p. 


\section{RECESSION OF PORTAGE GLACIER, ALASKA}

By Ruth A. M. Sснмшот, Anchorage, Alaska

Portage Glacier occupies a pass in the Kenai-Chugach Mountains between Cook Inlet and Prince William Sound at the southeastern end of Turnagain Arm, Alaska, in the Chugach National Forest. Because it is close to Anchorage and to the Seward Highway, the U.S. Forest Service has built a road to the area and provided picnic grounds and campsites. Examination of maps and photographs show that the glacier has receded 1.9 miles in 45 years; during this time a proglacial lake called Portage Lake formed behind a terminal moraine.

In 1898 Mendenhall twice crossed the glacier, and stated (Mendenhall, 1900, p. 301) -

* * the isthmus connecting Kenai Peninsula and the mainland is crossed in a portage of about 12 miles to the head of Turnagain Arm. A glacier covers 4 or 5 miles of this isthmus, and its highest point is 1,000 or 1,100 feet above the sea, with a steep approach from the east. * * This portage over the glacier is one of the oldest routes in Alaska, since more than a hundred years ago Captain George Vancouver reported that it had been long used by Russian and Indian traders as a means of communication between Cook Inlet and Chugatch Gulf [now Prince William Sound].

The route was used at that time only during the winter and spring months because of crevasses in the glacier during the summer. In 1914 it could still be crossed on a trail, but by 1939 a lake had formed in front of the glacier, and the surface had become too badly crevassed for passage.

Botanical evidence (Viereck, 1960, and oral communications, 1960) indicates that the last major advance of Portage Glacier culminated about 1893. As far as can be determined, the glacier reached about the same position then that it occupied in 1913-1914 when maps of the glacier were made in connection with studies for the Alaskan Engineering Commission. A terminal moraine that is present at this point dams the proglacial Portage Lake. No other terminal moraines have been seen in Portage Valley beyond this one.

Maps based on surveys by the Alaskan Engineering Commission in 1914 and the Alaska Railroad in 1939 (Barnes, 1943, pl. 16), and aerial photographs taken in 1950,1951 , and 1959 provide the following data on the recession of the glacier :

\begin{tabular}{|c|c|}
\hline Period: & $\begin{array}{l}\text { Approximate } \\
\text { recession of } \\
\text { ice front. in } \\
\text { feet (fig. } 558.1)\end{array}$ \\
\hline 1914 to 1939 (25 years) & 3,000 \\
\hline 1939 to 1950 (11 years) & 5,500 \\
\hline 1950 to 1959 (9 years) & 1,500 \\
\hline
\end{tabular}

In 1913 elevations above sea level were measured at points $A$ and $B$ (fig. 358.1 ) on the northeast side of the surface of the glacier (Giffen and Bagley, 1914). Elevations at these points in 1913 and in two later years are given below :

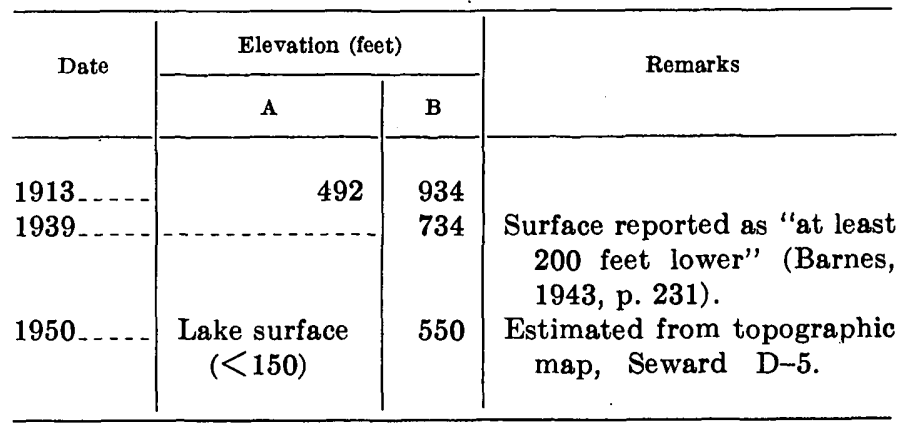

Barnes (1943, p. 232) reports that in 1939 -

Soundings in *** [Portage Lake] *** rerealed a maximum depth of 400 feet at the glacier front 2,000 feet southeast of the tip of Turnagain Shoulder, and depths of more than 200 feet at several places within 400 to 600 feet of the south and west shores.

In July 1960 soundings taken by the writer in approximately the same area as the 1939 glacier front gave depths of 250 feet to 260 feet, indicating that sediment about 150 feet thick had been deposited. The depth of the lake increased sharply from the terminal moraine to depths of more than 125 feet within 100 feet of the shore. A maximum depth of 595 feet was measured about 1,000 feet from the glacier front. Because of continual calving, no closer soundings were taken.

Measurements will continue to be made and photographs taken to provide a continuing record. Undoubtedly the recordbreaking high temperatures and low precipitation of the 1960-1961 winter will have a marked effect on the regimen of all the glaciers in Alaska. 


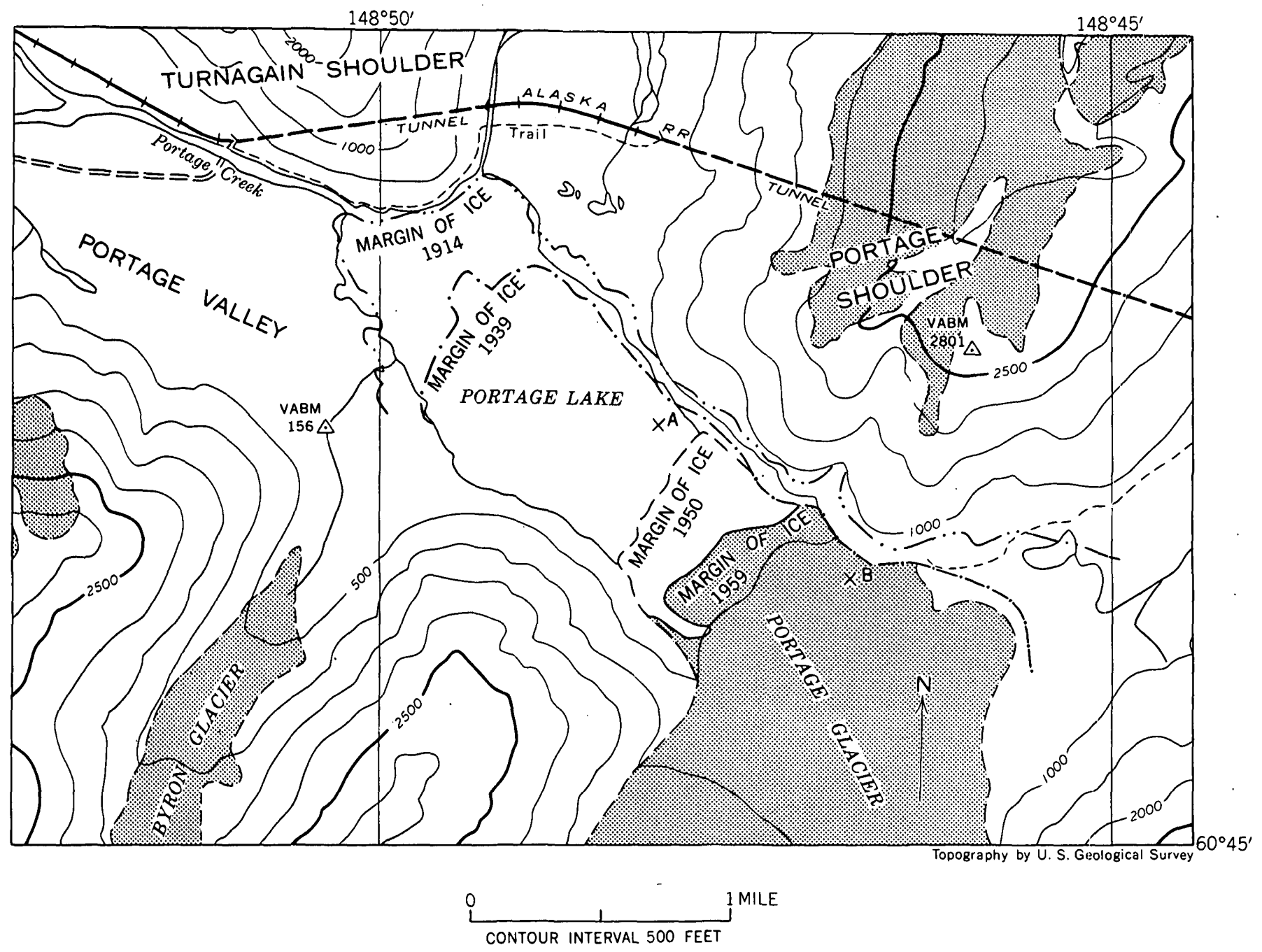

Fuaure 358.1.-Portage Glacier area, Alaska, showing glacier fronts from 1914 to 1959.

(Points $A$ and $B$ are described in text.)

\section{REFERENCES}

Barnes, F. F., 1943, Geology of the Portage Pass area, Alaska: U.S. Geol. Survey Bull. 926-D, p. 211-235.

Giftin, C. E., and Bagley, J. W., 1914, Reconnaissance map, Passage Canal to Turnagain Arm, in Brooks, A. H., and others, Mineral resources of Alaska, 1913 : U.S. Geol. Survey Bull. 592 , p. 50 .
Mendenhall, W. C., 1900, A reconnaissance from Resurrection Bay to the Tanana River, Alaska, in 1898: U.S. Geol. Survey 20th Ann. Rept., pt. 7, p. 265-340.

Viereck, L. A., 1960, Botanical dating of recent glacial activity in Alaska: Program, 11th Alaskan Science Conference, Anchorage, Aug. 31, 1960. 


\title{
359. RELATION OF DISCHARGE RATE TO DRAWDOWN IN WELLS IN OAHU, HAWAII
}

\author{
By E. R. Loвke, Honolulu, Hawaii
}

Work done in cooperation with the State of Hawaii

The relation of discharge rate to drawdown in pumping wells has been determined for wells that tap artesian and unconfined basal ground water in the basaltic lava flows in the Koolau Range of Oahu, Hawaii. This aquifer, which is generally highly permeable, supplies large quantities of water to municipal, irrigation, and industrial systems on the island. The study was made to determine whether predictions of drawdown and yield could be made from a few observations in a pumping well. Data from step-drawdown tests in 22 wells were examined in the study.
Most of the wells studied are uncased in the saturated part of the rock; a few have perforated casing. Diameters of the holes in saturated rock range from 6 to 16 inches. The area of the intake parts of the wells range from 60 square feet to about 690 square feet.

The ratio of discharge rate to drawdown (specific capacity) at variable rates of discharge in a given well generally is nonlinear, but decreases with increasing discharge. This decrease results partly from head losses due to turbulent flow in (a) that part of the aquifer adjacent to the well, (b) through the perforated

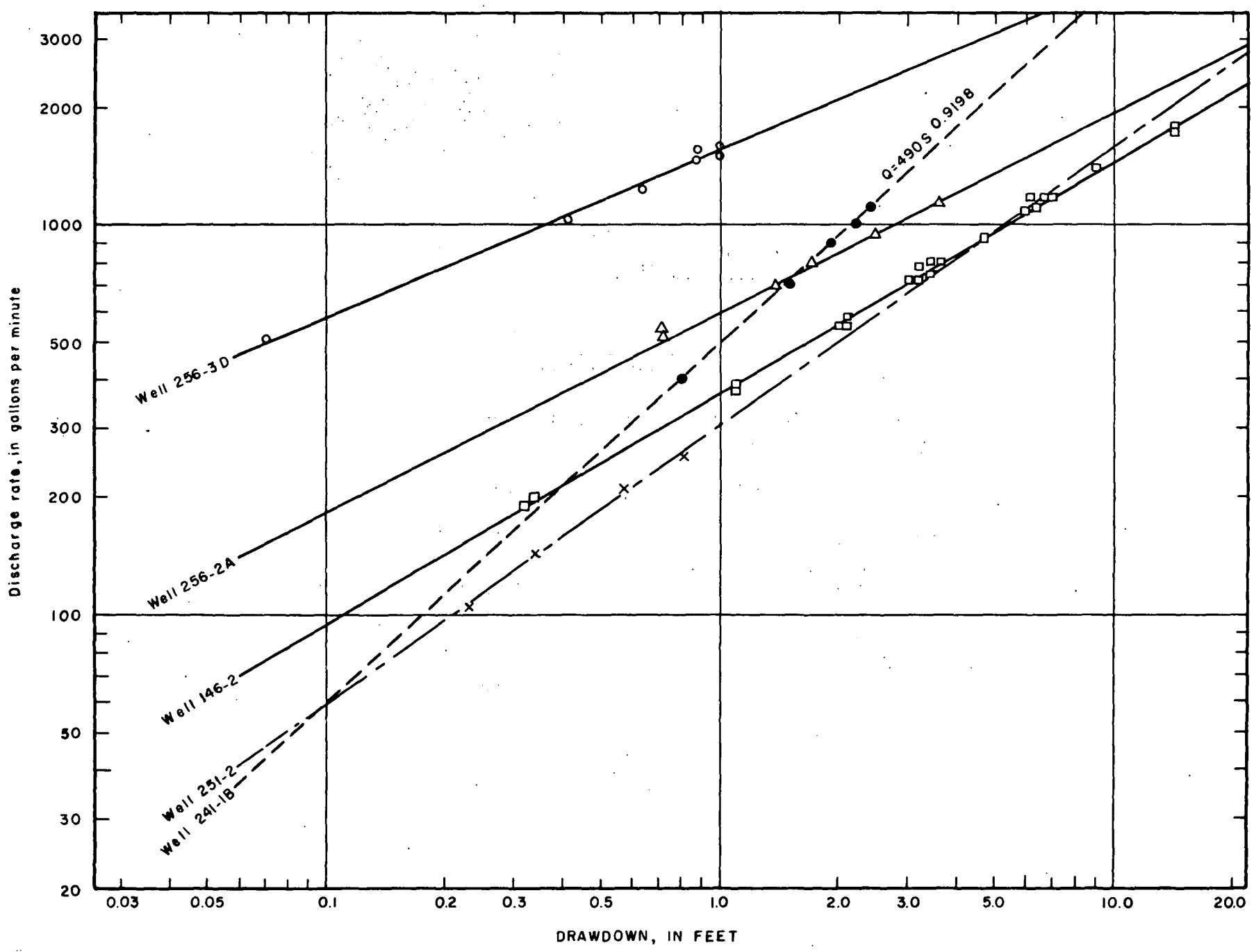

FIGURE 359.1.-Relation between discharge rate and drawdown in five wells tapping water in basaltic lava flows in Oahu, Hawaii. 
casing, and (c) inside the well casing. A nonlinear relation between discharge and drawdown could arise also in part from nonlinear boundary conditions at the water table in the vicinity of the pumping well.

For nearly all wells in which three or more drawdown measurements at different discharge rates were taken during a pumping test, the discharge and drawdown show a nonlinear relation. Examples of the relation are given on figure 359.1 , which shows the results of pumping tests on 5 wells. The relation can be expressed mathematically in the equation

$$
Q=a s^{b}
$$

in which $Q$ is the discharge rate, $a$ and $b$ are constants related to head losses, and $s$ is the drawdown within the well. The logarithmic expression for this equation is

$$
\log Q=b \log s+\log a
$$

in which $\log Q$ is expressed as a linear function of $\log s$. The constants $a$ and $b$ are determined by the method of least squares.
The observed drawdown at different discharge rates and the resulting specific capacity in well 256-2A

\begin{tabular}{|c|c|c|}
\hline Discharge rate $(Q)$ (gallons per minute) & $\underset{\text { (feet) }}{\text { Drawdown }}(s)$ & $\begin{array}{l}\text { Speciflc capacity }(Q / s) \\
\text { (gallons per minute } \\
\text { per foot) }\end{array}$ \\
\hline $520 \ldots$ & 0.8 & 650 \\
\hline $540 \ldots$ & .8 & 675 \\
\hline $700 \ldots$ & 1. 4 & 500 \\
\hline $800 \ldots$ & 1. 7 & 471 \\
\hline $950 \ldots$ & 2. 5 & 380 \\
\hline $1,130 \ldots \ldots \ldots$ & 3. 6 & 314 \\
\hline
\end{tabular}
(fig. 359.1) are as follows:

From these data the computed value of $\log a$ is 2.77 and the value of $b$ is 0.51 . The curve for this equation for well $256-2 \mathrm{~A}$ is shown on figure 359.1 .

From the given relation, drawdown can be estimated graphically or mathematically for a discharge rate that is greater or less than, or that falls within the range of measurements taken during a step-drawdown test. The specific capacity also is seen to decrease with increase in discharge rate. The method described may apply to wells drilled in other types of aquifers.

\title{
x
}

\section{PRELIMINARY GRAVITY SURVEY OF KILAUEA VOLCANO, HAWAII}

\author{
By H. L. Krivoy and J. P. EAton, Hawaiian Volcano Observatory, Hawaii
}

Kilauea is the smaller of two active shield volcanoes that form the southern half of the Island of Hawaii. The summit of Kilauea is a slight protuberance on Mauna Loa's easterly flank, and the region between the two summits contains the intercalated products of each volcano.

Eruptions of Kilauea have taken place either in the region of the summit or else along one of Kilauea's two conspicuous flank rifts. The southwest rift was last active in 1920 and is marked by an extensive pattern of linear cracks. The eruption of 1959-1960 (Eaton and Murata, 1960; Richter and Eaton, 1960) began as a summit eruption in the pit crater Kilauea Iki and continued as a flank eruption at the Kapoho graben in Puna, some 30 miles from the summit. This active region is the coastal terminus of the east rift zone, which extends from Kilauea summit as a low topographic ridge.

In 1957 and 1958, elevation loops were run in the summit and east-rift, sectors of Kilauea. Bench marks were spaced along these loops at intervals of one half and three tenths of a mile near the rifts, and at intervals of one mile in more stable regions. The elevations determined during these surveys and during re-leveling of the summit in 1960 served as the basis of the 195960 gravity survey here described.

Tilt studies and elevation surveys before and after the 1959-1960 eruption show that Kilauea summit was progressively inflated before the Kapoho flank eruption and then suddenly deflated contemporaneously with the eruption. Summit deformation decreased symmetrically from a maximum collapse of about 5 feet on the floor of the caldera to an undetectable amount about 5 miles from the summit. Wilson (1935) reports similar summit pulsations for other volcanic epochs.

A gravity survey was made in the summit region of Kilauea in December 1959 and January 1960. The survey was repeated in March and April 1960, after the major subsidence described above. Bouguer anomalies shown on figure 360.1 have been computed using the 


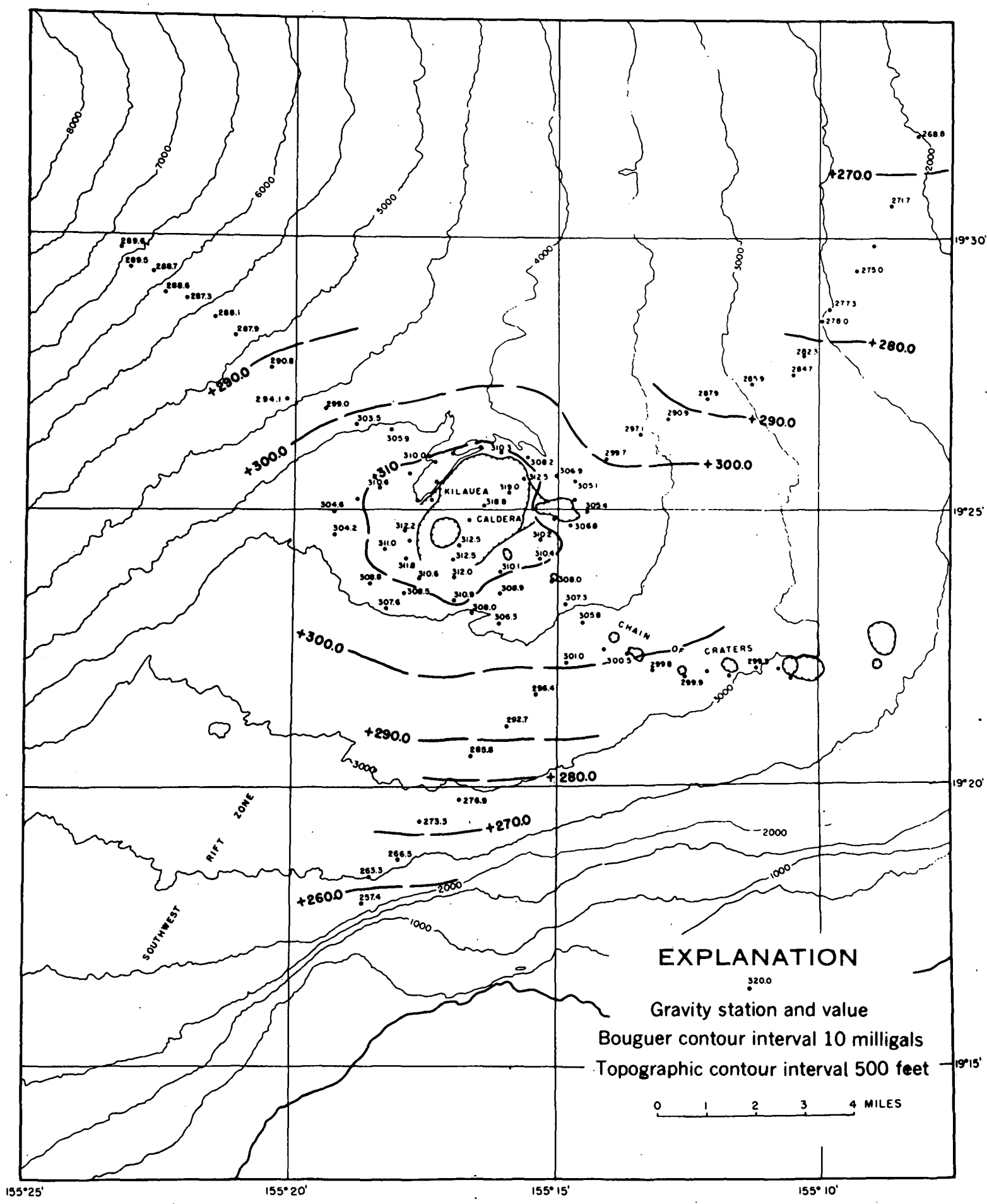

FraURE 360.1.-Positive Bouguer gravity anomalies (heavy broken lines) for the summit region of Kilauea volcano. Some gravity values have been omitted for sake of clarity.

March-April gravity data together with elevations determined in May and June 1960 for summit bench marks.

Gravity work in the Puna area (fig. 360.2) was completed in February 1960, during the east-rift eruption. Elevations used in the reduction of these data are based on the survey of 1958. Eight hours before the Kapoho eruption vertical displacements on the order of several feet were observed along the two border faults at the Kapoho graben. About a dozen bench marks in this vicinity were buried by 1960 lava. It is possible that data computed for these points, based on uncertain 


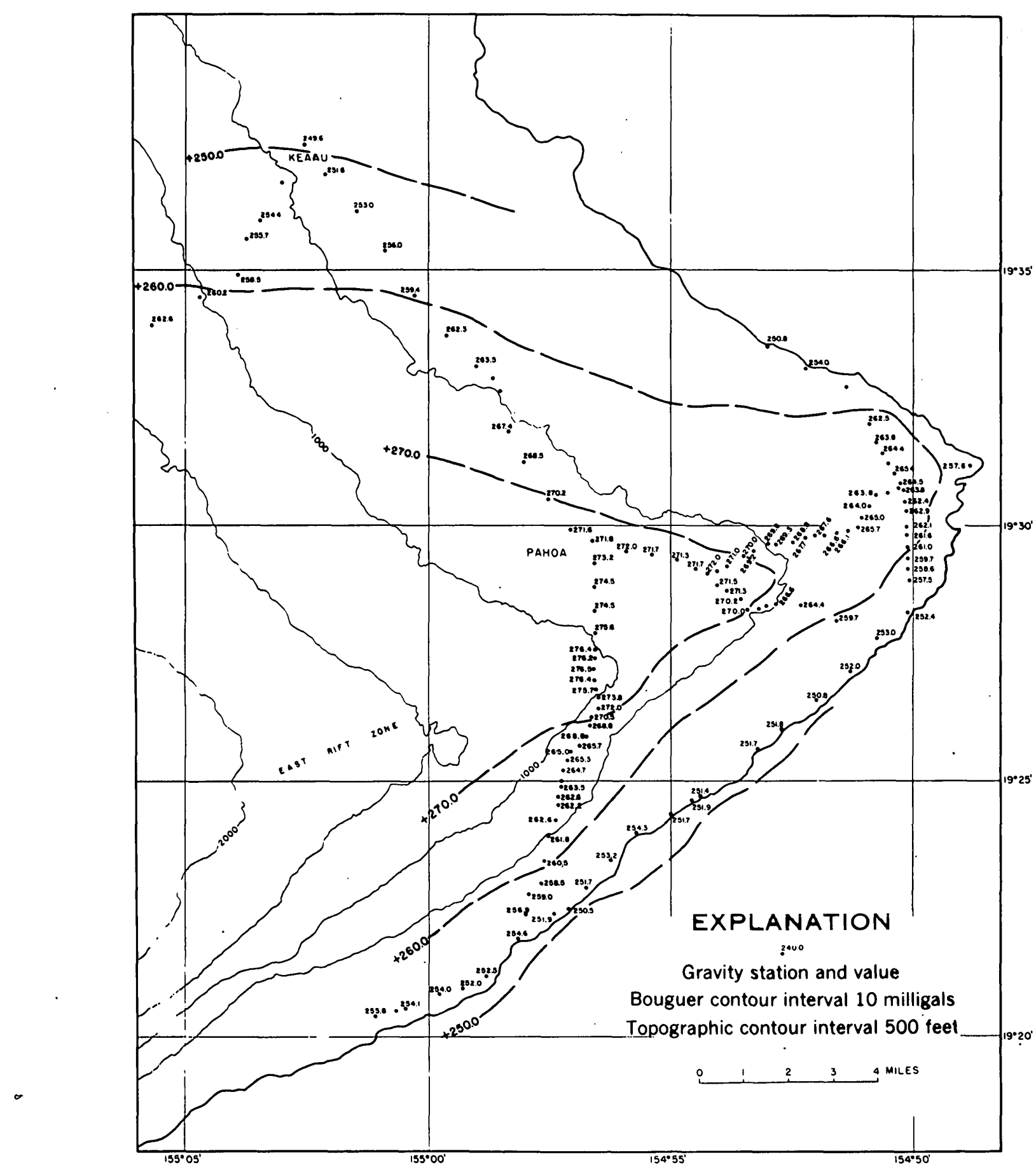

Figure 360.2.-Positive Bouguer gravity anomalies (heavy broken lines) for the east flank (Puna area) of Kilauea volcano. Some gravity values have been omitted for sake of clarity.

elevation, might be in error by three or four tenths of a milligal.

A value of $2.3 \mathrm{~g}$ per $\mathrm{cm}^{3}$ obtained by Woollard (1951) for Oahu was adopted for the average density of the island mass in computing Bouguer anomalies. Bouguer anomalies so computed for the Kilauea summit and Puna regions reflect the topography of the volcano as does Woollard's Bouguer anomaly for Waianae volcano on Oahu. Thus, the anomaly contours are parallel to the topographic contours along Kilauea's southeastern coast, where both are also parallel to the east rift zone. North of the rift zone, however, Bouguer anomaly contours cut sharply across the topography and follow the rift zone. To reduce the apparent correlation between 
Bouguer anomaly and topography, where it exists, it might seem reasonable to adopt a bulk density closer to the conventional value of $2.9 \mathrm{~g}$ per $\mathrm{cm}^{3}$ for dense basalt. This might be justified for lavas erupted beneath the sea under pressures that restrict the formation of vesicles. However, there is little reason to believe that the parts of the volcanoes above sea level, which alone are involved in the Bouguer reduction, have been so constrained. Indeed, estimates of the bulk density of basalt once covered by several thousand feet of younger lavas and later exposed by erosion are close to the value of $2.3 \mathrm{~g} \mathrm{~cm}^{3}$ found by Woollard for the entire ridge when he applied gravity-profiling theory to Vening Meinesz' submarine profile.

The Bouguer anomaly rises from about +250 milligals along Kilauea's southeastern coast to +320 milligals at the center of Kilauea caldera at an elevation of about 3,600 feet. It then drops off steadily northwestward over the southeastern flank of Mauna Loa to +290 milligals at an elevation of about 4,800 feet. Beyond this point the anomaly remains virtually constant to an elevation of 6,700 feet, where the present survey ends.
In accordance with Wollard's interpretation of the large positive Bouguer anomalies around the two main eruptive centers on Oahu, it is likely that the strong positive anomaly that is centered at Kilauea caldera and extends out along the east rift zone is largely caused by a complex of dense dikes at the core of Kilauea. It is also possible that the shallow reservoir beneath the caldera, which is revealed by the pattern of elevation changes and tilt accompanying eruptive activity, is responsible for part of the anomaly. Additional gravity measurements on Kilauea volcano may help define the physical boundaries of this dike system.

\section{REFERENCES}

Eaton, J. P., and Muralba, K. J., 1960, How volcanoes grow : Science, v. 132, n. 3432, p. 925-938.

Richter, D. H., and Eaton, J. P., 1960, The 1959-60 eruption of Kilauea Volcano: New Scientist, v. 7, p. 994-997.

Wilson, R. M., 1935, Ground surface movements at Kilauea Volcano, Hawaii: Univ. of Hawaii Research Pub., no. 10. Woollard, G. P., 1951, A gravity reconnaissance of the island of Oahu : Am. Geophys. Union Trans., v. 32, p. 358-368.

361. THICKNESS OF THE PROCELLARIAN SYSTEM, LETRONNE REGION OF THE MOON

\author{
By C. H. Marshall, Menlo Park, Calif.
}

Work done on behalf of the National Aeronautics and Space Administration

The stratigraphy of the Letronne region of the Moon is being investigated as part of a study of the lunar surface. The region lies in the general target area for a number of hard-landing lunar capsules to be launched as part of the National Aeronautics and Space Administration Ranger Program. The Procellarian system is the most extensively exposed stratigraphic unit in part of the target area.

Stratigraphic units exposed in the Letronne region include the major units thus far recognized on the Moon (Shoemaker and Hackman, 1960); these are pre-Imbrian material and the Imbrian, Procellarian, Eratosthenian and Copernican systems (Shoemaker, in press). The Imbrian system and pre-Imbrian material, the lowest stratigraphic units, cover much of the southern quarter of the Letronne region and are exposed in numerous widely scattered smaller areas (fig. 361.1). These units have a medium albedo and underlie a generally irregular surface upon which are craters ranging from less than $1 \mathrm{~km}$ to $130 \mathrm{~km}$ across. Most of the isolated exposures of the Imbrian and pre-Imbrian are the rims of large craters that have been partly buried beneath higher stratigraphic units, belonging chiefly to the Procellarian system.

The Procellarian system is characterized by low albedo and underlies extensive areas of generally low relief that occupy 82 percent of the Letronne region. Ridges of low amplitude, which have been interpreted as anticlines, and a few low domes and shallow valleys termed rilles are present on the surface of the Procellarian. The estimated thickness of the Procellarian varies from a featheredge to several thousand meters; 


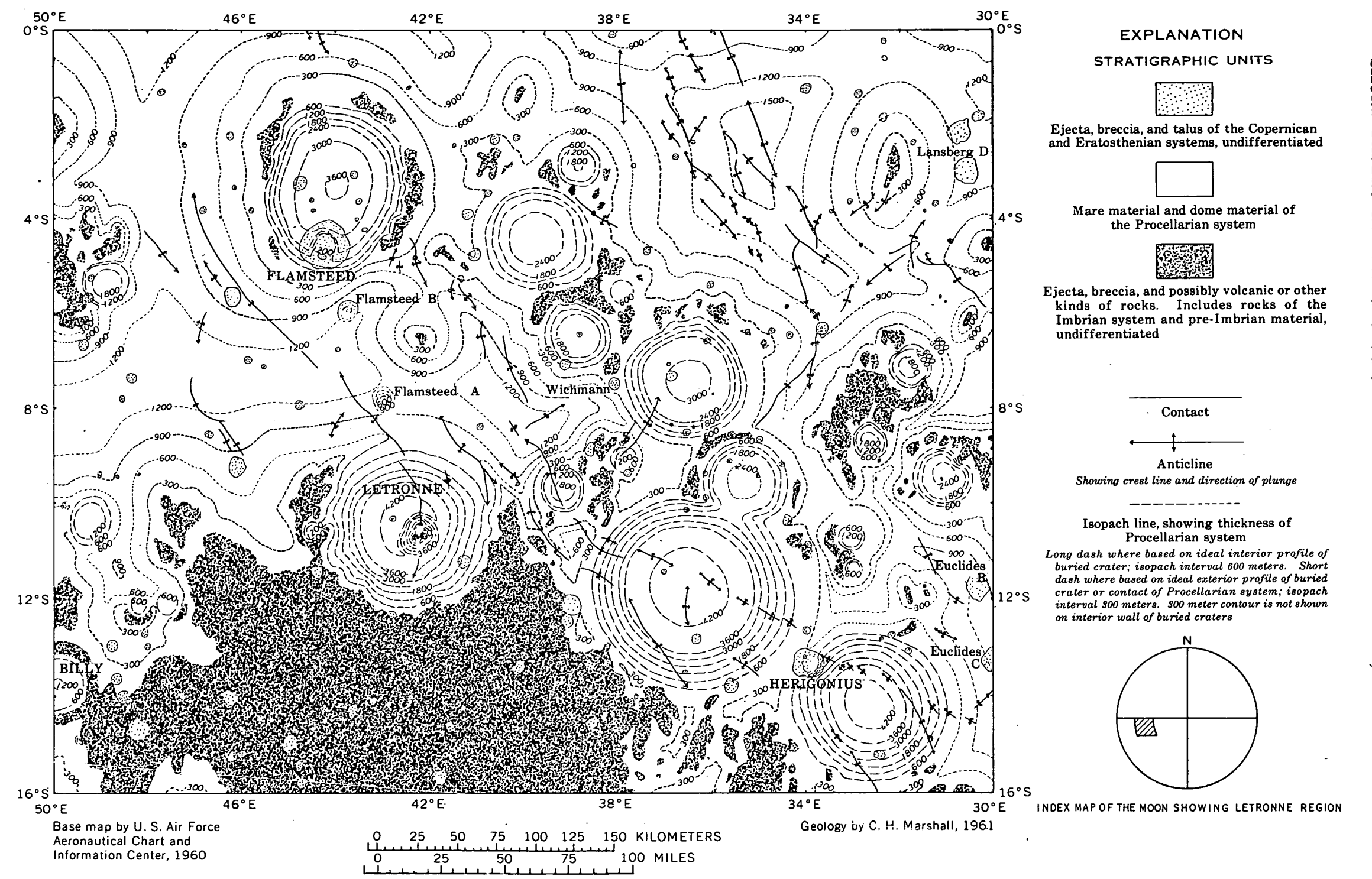

FTaURe 361.1.-Preliminary isopach map of the Procellarian system, Letronne region of the Moon. 
variations are due mainly to relief on the contact at its base.

The Eratosthenian system, characterized by low to medium albedo, and the Copernican system, characterized by relatively high albedo, are distributed in numerous isolated patches that overlie the Procellarian and lower stratigraphic units. These patches are chiefly ejecta associated with craters ranging from $1 \mathrm{~km}$ to about $20 \mathrm{~km}$ in diameter.

The thickness of the Procellarian system, the most extensively exposed unit in the Letronne region, can be estimated by reconstruction of the buried pre-Procellarian topography. Twenty partly filled or buried craters of pre-Procellarian age that are widely distributed over the Procellarian area of exposure have been identified. Examples of such craters are Letronne, Billy, and the large partly circular features near Flamstead and Wichmann (fig. 361.1). The exposed parts of the rims of these craters provide the control for this reconstruction.

Baldwin (1949, p. 128-138) has found that the depths of lunar craters and the heights of their rims above the surrounding terrain are roughly related to the crater diameters (fig. 361.2). He has expressed the depths of the craters and the heights of the crater rims as functions of the crater diameters. The scatter of observed dimensions from the fitted curves (fig. 361.2) is large, but the curves may be used to calculate average expected depths and rim heights for craters of known diameters.

No clear-cut bias or systematic departure from the curves has been found for craters whose stratigraphic position has been determined. In particular, depths and rim heights of unfilled pre-Procellarian craters appear to be as great in proportion to diameter as the depths and rim heights of Eratosthenian and Copernican craters.

The diameters of the buried craters and elevation of the crests of the crater rims above the Procellarian surface were determined from the U.S. Air Force Aeronautical Chart and Information Center Lunar Chart, Letronne sheet. Points on buried parts of the exterior slopes of pre-Procellarian craters were obtained on the assumption that rims merge with the surrounding terrain at a distance of half a crater radius. The depth of each crater center was calculated by subtracting the figure obtained from Baldwin's curve from the highest point on the rim. The possible presence of central peaks within the craters was ignored except where part of the peaks appeared to be exposed. Letronne is the only crater in which a central peak is accounted for.

Thickness of the Procellarian was determined by subtracting elevations at the calculated points on the preProcellarian surface from the elevation of the Procellarian surface. The difference between total crater
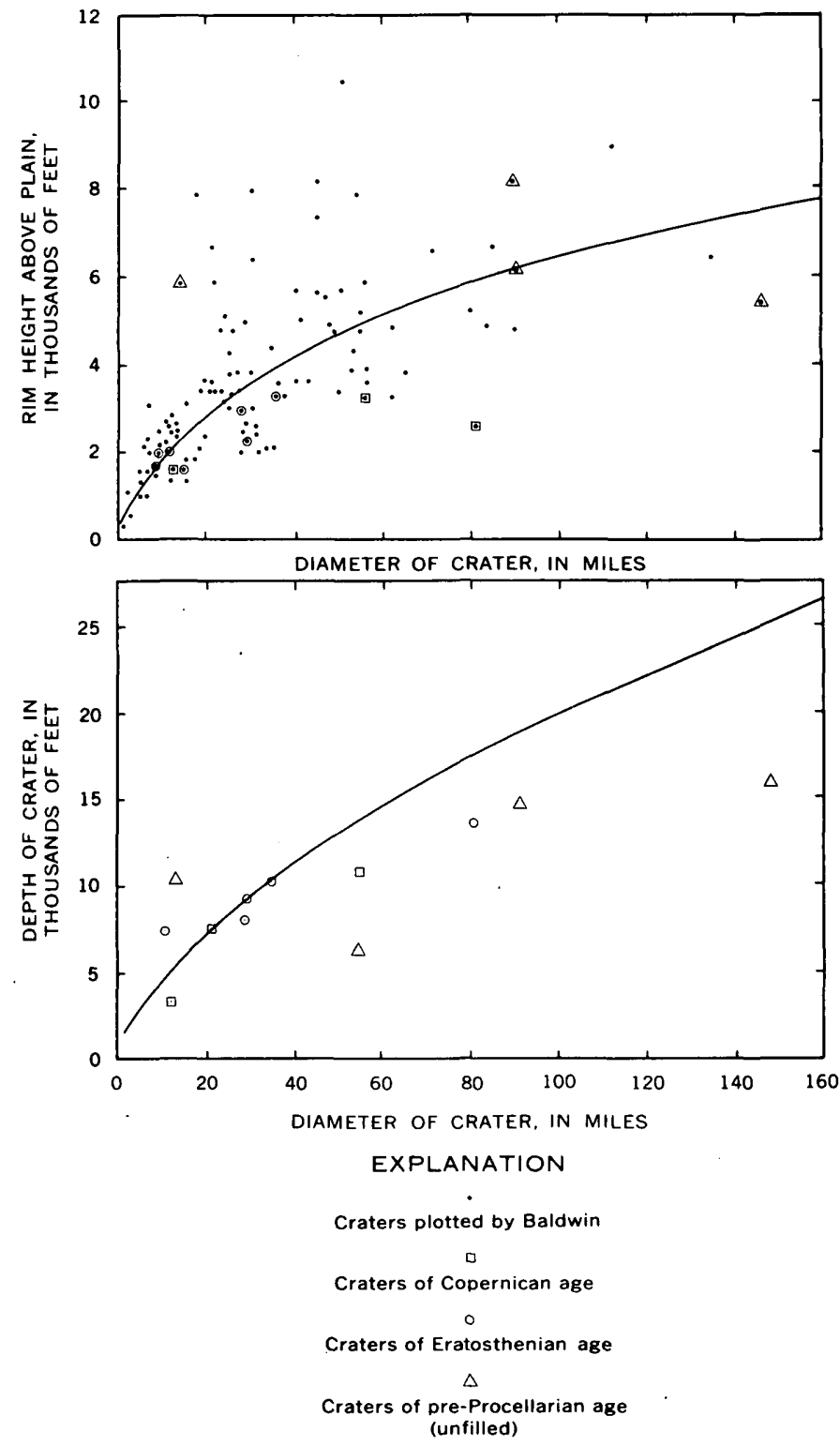

FIgURE 361.2-Curves by Baldwin (1949) showing relation between height of rim, depth of crater, and crater diameter.

depth and height of rim above the Procellarian surface yields a figure for Procellarian thickness at the buried crater centers. A total of 58 points outside and inside the craters were calculated. The contact of the Procellarian system with the pre-Procellarian, which is the line of vanishing or zero thickness, provides additional control.

Within the buried parts of the craters, isopach lines (isopleths of equal thickness) were drawn to conform with an ideal crater shape, which is steep walled from the rim inward for a distance of one-third the radius and like a nearly flat saucer in the central part. Outside the craters, the isopach lines were drawn by mechanically interpolating between the calculated points and the zero contour. 
Where Eratosthenian and Copernican craters are superimposed on the Procellarian, the depth of these younger craters was taken into account in determining the local thickness of the Procellarian. It is possible, however, and perhaps likely that a lens of breccia that intersects the entire thickness of the Procellarian underlies most of the Eratosthenian and Copernican craters shown.

Most of the partly buried craters identified in the Letromne region are easily recognized on good photographs, but the identification of a few nearly completely buried craters is uncertain. The test used for presence of a buried crater was to swing a compass centered at the supposed crater center to see if a circle would touch a sufficient number of pre-Procellarian exposures to establish an approximately circular configuration of the crater rim without enclosing isolated pre-Procellarian exposures. The only exception made to this test was for the central peak of Letronne. Many completely buried small-scale features are undoubtedly present, and a correct isopach map of the Procellarian would be more complex than the one drawn.

The scatter of observational points around Baldwin's curves (fig. 361.2) indicates the rim heights and crater depths may differ from the calculated dimensions by more than a factor of 2 in a few percent of the cases. More data are needed on the dimensions of pre-Procellarian craters before a meaningful assessment can be made of the precision of the calculated thicknesses. Partial filling of pre-Imbrian craters by the Imbrian system could introduce systematic errors in the preProcellarian crater depths calculated for the Letronne region. Areas of sparse control lie in the northwest and northeast corners and in a small east-central part of the region. These areas are the weakest parts of the map.
The isopach map represents a first attempt to estimate the thickness of the Procellarian system by a realistic method which will give reproducible results. Results obtained are a target for ultimate modification by seismic or other methods of subsurface exploration. The method employed is applicable to many other regions of Procellarian exposure on the Moon.

The Procellarian system underlies $240,000 \mathrm{sq} \mathrm{km}$ in the Letronne region and has a calculated average thickness of 1.1 kilometers and a volume of $265,000 \mathrm{cu} \mathrm{km}$. It is of interest to compare this with the dimensions of terrestrial fields of basalt. (See, for example, Hackman, 1960.) The Miocene to lower Pliocene tholeiitic basalts of the Columbia River Plateau cover an area of about $260,000 \mathrm{sq} \mathrm{km}$ and have a volume of about 150,000 cu km (Waters, 1955, p. 707-708). The Cretaceous and Eocene Deccan basalts of India cover an area of about $500,000 \mathrm{sq} \mathrm{km}$ and have an average thickness of about $0.6 \mathrm{~km}$ (Emmons and others, 1960, p. 97).

\section{REFERENCES}

Baldwin, R. B., 1949, The face of the moon: Chicago, Ill., Chicago Univ. Press, 239 p.

Emmons, W. H., Allison, J. S., Stauffer, C. R., and Thiel, G. A., 1960, Geology-Principles and Processes: New York, McGraw-Hill Book Company, Inc., 491 p.

Hackman, R. J., 1960, Generalized photogeologic map of the Moon, in Engineer special study of the surface of the moon: Washington, D.C., U.S. Army Map Service.

Shoemaker, E. M., in press, Geological interpretation of lunar craters, in Kopal, Zdenek, ed., The Moon, its astronomy and physics: New York, Academic Press.

Shoemaker, E. M., and Hackman, R. J., 1960, Stratigraphic basis for a lunar time scale [abs.]: Geol. Soc. America Bull., v. 71, p. 2112.

Waters, A. C., 1955, Volcanic rocks and the tectonic cycle: Geol. Soc. America Spec. Paper 62, p. 703-722.

GEOLOGY AND HYDROLOGY OF OTHER COUNTRIES

\title{
362. REVISION OF THE GEOLOGY OF DIAMOND DISTRICTS IN BAHIA, BRAZIL
}

\author{
By Max G. White and Charles T: Pierson, Washington, D.C.
}

The Chapada (tableland) Diamantina (fig 362.1) is a high $(900$ to $1,200 \mathrm{~m}$ ) tableland region of flat-lying rocks in the central part of the State of Bahia, Brazil. Morro do Chapéu, the principal town and commercial center of the Chapada diamond workings, is $290 \mathrm{~km}$ west of the port of Salvador. The Serra do Tombador is a northerly extension of the Chapada Diamantina. South of the Chapada Diamantina is a region of rolling hills that includes the diamond-bearing district of Lavras Diamantinas (diamantiferous workings) and the towns of Lençois and Andaraí.

Since about 1850 the diamond districts of Bahia have 


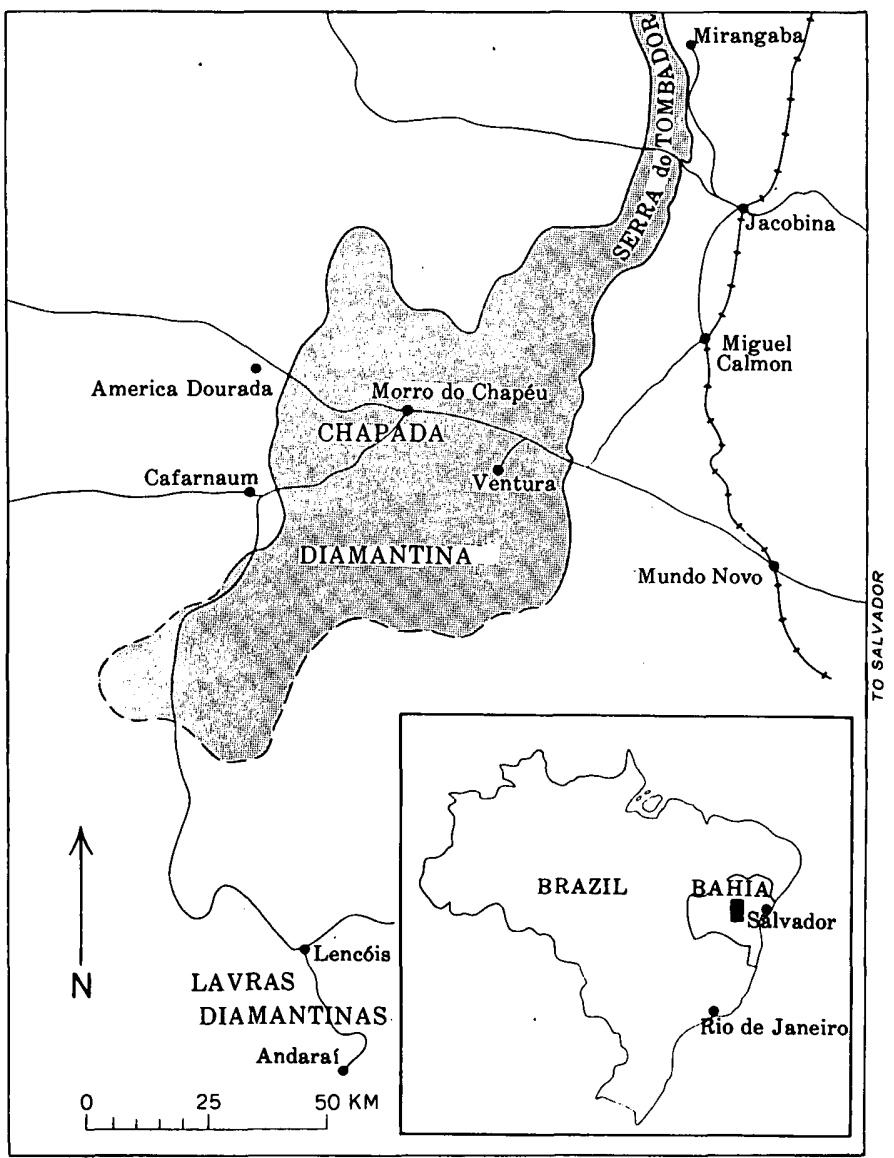

Figure 362.1.- Sketch map of the diamond districts in Bahia, Brazil.

been a source of industrial and gem-quality diamonds and of carbonados. Production declined in the years after World War I, but during the 1920's the region was the world's source of carbonados. Diamond production from the region is small and restricted to a few scattered primitive operations of individual prospectors.

The earliest geological work in the region was done in the Lavras Diamantinas by Derby (1906) and in the Serra do Tombador region by Branner (1910). Little work has been done in the Chapada Diamantina. Our field work shows that physiographically and geologically the Lavras Diamantinas region is a separate province from the Chapada Diamantina.

The sequence of rocks in the Chapada DiamantinaSerro do Tombador-Iavras Diamantinas region is shown on table 362.1 .

Kegel (1959) suggested that the geologic sequence of this large region is :

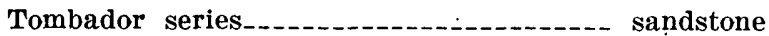

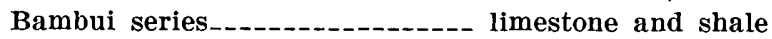

Lavras series...-. sandstone, conglomerate and shale
He dropped the name Caboclo shale or series, although apparently he included this unit in the Bambui series. $\mathrm{He}$ did not mention the Jacobina series.

A proposed revision of the nomenclature (table 362.1) is based on 6 detailed road traverses made with odometer and altimeter, and 8 detailed geologic sections measured in the region between Mirangaba and Cafarnaum.

The outline of the Chapada Diamantina tableland as shown on figure 362.1 is drawn along the 900 -m contour line. The contour represents the approximate position of the rim of the tableland escarpment, and for the most part the enclosed area is occupied by rocks of the Tombador series. The line is dashed on the southern boundary of the region where the limit of the Tombador rocks is uncertain.

South of the tableland lies rolling country containing folded arenaceous rocks that constitute the Lavras series (Kegel, 1959).

We conclude that the Tombador series occurs in both the Serrado Tombador and the Chapada Diamantina. In the region west of Jacobina this series is about 100 $\mathrm{m}$ thick and consists of thin-bedded medium-grained sandstone and some siltstone and mudstone. The series thickens to the south and in the vicinity of Morro do Chapéu it is at least $460 \mathrm{~m}$ thick, and is composed of sandstone, conglomerate, siltstone, and mudstone. The Tombador series is generally nearly flat-lying; dips greater than $8^{\circ}$ to $10^{\circ}$ were not observed. Near Jacobina the Tombador lies on the Precambrian crystalline rocks; west of Morro do Chapéu, however, it overlies the Bambui series.

Diamonds are found in the Chapada Diamantina mostly in the vicinity of Morro do Chapéu and Ventura in the alluvium of creeks and small streams and in eluvial gravels on hill slopes. The sources of the diamonds are conglomerate beds and lenses in sandstone found mostly between $900 \mathrm{~m}$ and $1,100 \mathrm{~m}$ of elevation and thus are from the Tombador series. The pebbles are mostly well-rounded and well-sorted quartz and average about $1 \mathrm{~cm}$ in width. Diamonds in the Lavras Diamantinas region are largely in alluvial gravels in the vicinity of Lençóis and Andaraí at an elevation of about $400 \mathrm{~m}$. The source of the diamonds is reported to be the conglomeratic sandstones of the area and presumably are from the Lavras series.

If the diamond-bearing horizons have been identified correctly, the diamond deposits of central Bahia are not concentrated exclusively in conglomeratic sandstone of the Lavras series as has been assumed by some previous writers. Rather it would seem that diamonds were brought in from some outside source during both Lavras and late Tombador times, or that diamonds were 
TABLE 362.1.-Nomenclature of rocks in the diamond districts, Bahia, Brazil

\begin{tabular}{|c|c|c|c|c|c|c|}
\hline \multicolumn{3}{|c|}{ Ollveira and Leonardos (1943) } & \multicolumn{4}{|c|}{ Proposed revision, this report (based partly on Kegel, 1959) } \\
\hline & ge & Nomenclature and reference & \multicolumn{2}{|c|}{ Age } & Nomenclature & Lithology \\
\hline \multirow{2}{*}{\multicolumn{2}{|c|}{$\begin{array}{l}\text { Silurian or Ordovi- } \\
\text { cian }\end{array}$}} & \multirow[t]{2}{*}{ Bambui series ${ }^{1}$} & \multirow{3}{*}{\multicolumn{2}{|c|}{$\begin{array}{l}\text { Early } \\
\text { Paleozoic }\end{array}$}} & Tombador series & $\begin{array}{l}\text { Sandstone conglomerate, } \\
\text { quartzite, siltstone, mud- } \\
\text { stone. }\end{array}$ \\
\hline & & & & & Bambui series & Varicolored limestone \\
\hline \multicolumn{2}{|c|}{ Eocambrian } & Lavras series (Derby, 1906) & & & Lavras series & Conglomeratic sandstone \\
\hline 呇 & Upper & $\begin{array}{l}\text { Paraguassu series (Derby, 1906). } \\
\text { (Caboclo series; Branner, 1911) }\end{array}$ & \multirow{3}{*}{ 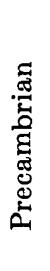 } & & \multirow[t]{2}{*}{ Jacobina series } & \multirow[t]{2}{*}{$\begin{array}{l}\text { Quartzite, sandstone; basal } \\
\text { quartzite conglomerate. }\end{array}$} \\
\hline 4 & Lower & Tombador series (Branner, 1910b) & & & & \\
\hline \multicolumn{2}{|c|}{ Archean } & Crystalline rocks & & Early & Crystalline rocks & $\begin{array}{l}\text { Granitic rocks, orthogneiss, } \\
\text { paragneiss. }\end{array}$ \\
\hline
\end{tabular}

1 Also called Sno Francisco series, Vasn Barris series, Salitre limestone, and Una formation.

first concentrated in the Lavras series and some were later reworked during erosion of the Lavras and redeposited in the Tombador.

\section{REFERENCES}

Branner, J. C., 1910a, The geology and topography of the Serra do Jacobina, State of Bahia, Brazil: Am. Jour. Sci., v. 30, p. $385-392$.

- 1910b, The Tombador escarpment in the State of Bahia, Brazil : Am. Jour. Sci., v. 30, p. 335-343.
1911, The geography of northeastern Bahia, Brazil: Royal Geog. Soc. Jour., p. 139-152 and 256-269.

Derby, O. A., 1906, The Serra do Espinhaco: Jour. Geology, v. 14, no. 3, p. 374-401.

Kegel, W., 1959, Estudos Geologicos na zona Central da Bahia : Rio de Janeiro, Div. de Geologia e Mineral do D.N.P.M. Bull. $198,35 \mathrm{p}$.

Rimann, E. T., 1917, A Serie Bambui : Anais da Escola de Minas, Ouro Preto, Minas Gerais, Brasil, Bull. 15.

Oliveira, A. I., and Leonardos, O. H., 1943, Geologia do Brasil : 2d ed., Rio de Janeiro, Ministerio da Agricultura, 813 p.

363. RESULTS OF INVESTIGATIONS FOR URANIUM IN THE TUCANO BASIN, BAHIA, BRAZIL

\author{
By D. D. Haynes and J. J. Matzko, Bowling Green, Ky., and Quetta, Pakistan
}

Work done on behalf of the U.S. Atomic Energy Commission in cooperation with the Brazilian National Atomic Energy Commission

The town of Jorro is the center for uranium exploration in the Tucano basin, Bahia, northeast Brazil. It lies about $220 \mathrm{~km}$, airline distance, north of Salvador, the capital of the State.

Exploration for uranium in the Tucano basin has been carried on since January 1957. Work in the basin was begun because of an occurrence of radioactive fossil bones reported to be from south of Jorro on the Itapicurú River (Price and Haynes, unpublished data, 1956) and because deposits of thermal springs in the basin were also radioactive.

The basin is a north-trending graben valley containing mostly clastic sedimentary rocks of Jurassic (?), Cretaceous, and Tertiary ages. It is bordered on the south by Tertiary sedimentary rocks and a few granite inliers of Precambrian age, on the east and west by crystalline rocks of Silurian age, and on the north by granite and granite-gneiss of Precambrian age. 
In a study of well logs, well cuttings, and core-chip samples, obtained by Petróleo Brasileiro, S.A. (Petrobrás) Haynes located 3 uranium-bearing samples from the 1626.1- to 1631.0-meter interval of the Petrobrás Macaco I well at Jorro, Bahia. Radiometric and chemical analyses of splits of the 3 samples showed that the equivalent-uranium $\left(\mathrm{eU}_{3} \mathrm{O}_{8}\right)$ content ranges from 0.083 to 0.096 percent, and that the uranium oxide $\left(\mathrm{U}_{3} \mathrm{O}_{8}\right)$ content ranges from 0.096 to 0.142 percent. The uranium-bearing zone occurs in the Sergí formation of Early Cretaceous age.

Near the west edge of the Tucano basin the Sergí formation is structurally higher than at Jorro because of faulting and tilting of the beds. Reconnaissance in this area led to the discovery of an outcrop of radioactive sandstone near Pôço Redondo, about 11 miles southwest of Jorro. An exploratory hole, Pôço Redondo I, drilled to a depth of 18.5 meters, penetrated several zones of radioactive sandstone. Selected samples from this hole contain as much as 0.20 percent $\mathrm{eU}_{3} \mathrm{O}_{8}$. The greatest uranium content of any of the samples analyzed chemically was 0.066 percent $\mathrm{U}_{3} \mathrm{O}_{8}$.

The uraniferous samples from the $\mathrm{P} R \mathrm{Re}-\mathrm{I}$ hole have the same general appearance and mineralogy as the samples from the Macaco I well. The P Re-I samples contain coffinite and montroseite as well as manganese oxide, pyrite, chalcopyrite, zircon, carbonized wood, and radioactive barite. The radioactive barite shows strong alpha-particle radiation, probably caused by the presence of radium in the barite structure (Stern and Stieff, 1959).

\section{REFERENCES}

Andrade, Jr., José F. de, 1926, Agua Thermo-mineraes do Valle do rio Itapicurá, Estado da Bahia, Brasil: Serv. Geol. Miner., Bull. 17.

Stern, T. W., and Stieff, L. R., 1959, Radium-uranium equilibrium and radium-uranium ages of some secondary minerals : U.S. Geol. Survey Prof. Paper 320, pt. 13, p. 154.

\title{
364. THORIUM AND RARE EARTHS IN THE POCOS DE CALDAS ZIRCONIUM DISTRICT, BRAZIL
}

\author{
By Helmuth Wedow, JR., Knoxville, Tenn.
}

Work done in cooperation with the U.S. Atomic Energy Commission

An airborne radioactivity survey of the Poços de Caldas Plateau in the States of Minas Gerais and São Paulo, Brazil, in 1953 recorded an intense anomaly at Morro do Ferro, near the geographic center of the plateau (fig. 364.1). The source of the anomalous radiation at Morro do Ferro proved to be one of the most unusual high-grade thorium and rare-earth deposits discovered in recent years. The deposit lies almost in the middle of the long-known Poços de Caldas zirconium district (Teixeira, 1936) where the ores consist of caldasite (an intimate mixture of zircon and baddeleyite) in which uranium was noted during the early 1950's and recently investigated by Tolbert (1958). Subsequent to the study of the uraniferous zirconium deposits, the U.S. Geological Survey, in collaboration with the Brazilian Conselho Nacional de Pesquisas and the Departamento Nacional da Produção Mineral, and the Cia. Geral de Minas, owner of the deposit, undertook a surface exploration program to determine the grade and tonnage of material at Morro do Ferro that might be developed by large-scale openpit mining methods.

The country rock at Morro do Ferro is deeply decom- posed and cannot be identified with certainty, but it is believed that bedrock is syenite-phonolite, typical of the alkalic igneous rock that characterizes the Poços de Caldas Plateau. At Morro do Ferro a magnetite stockwork in which the major veins trend N. $50^{\circ}$ to $60^{\circ} \mathrm{W}$. and dip $50^{\circ}$ to $85^{\circ} \mathrm{NE}$. cuts the syenite-phonolite rocks (fig. 364.1). The stockwork probably represents a late stage in the cycle of alkaline intrusion.

The mineralizing solutions containing thorium and rare-earth elements followed the emplacement of magnetite, and enriched the highly fractured rocks and the borders of some of the magnetite veins. Nothing is known of the age relations between the thorium and rare-earth and the zirconium-uranium suites of the district, as the two types are completely separated physically; the Morro do Ferro occurrence of thorium and rare earths appears to be unique for the district. Subsequent deep weathering, typical of the district as a whole and reminiscent of laterization, has altered both the thorium deposit and the surrounding country rock to a compact clayey saprolite. The depth of this weathering extends to more than 100 meters. The 


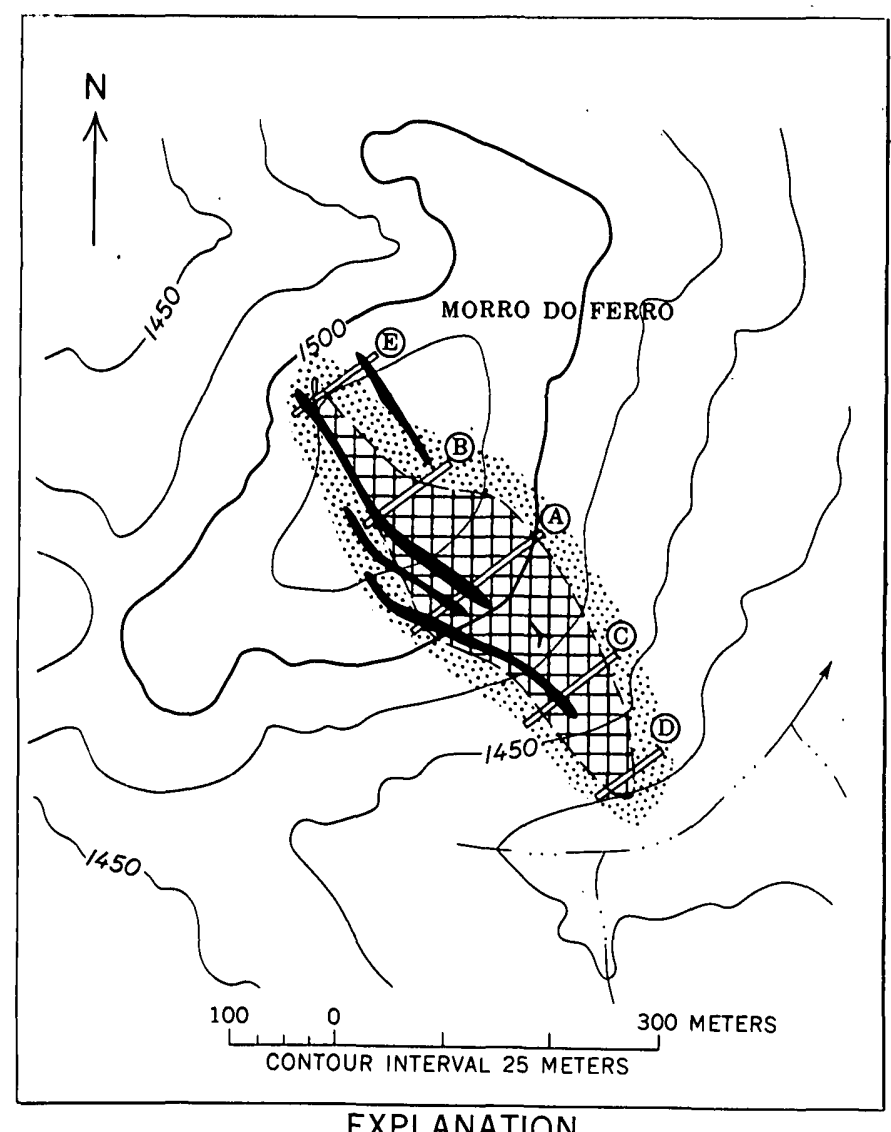

EXPLANATION

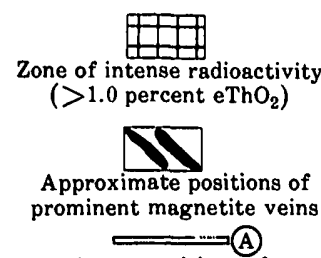

Approximate positions of trenches excavated by Cia. Geral de Minas

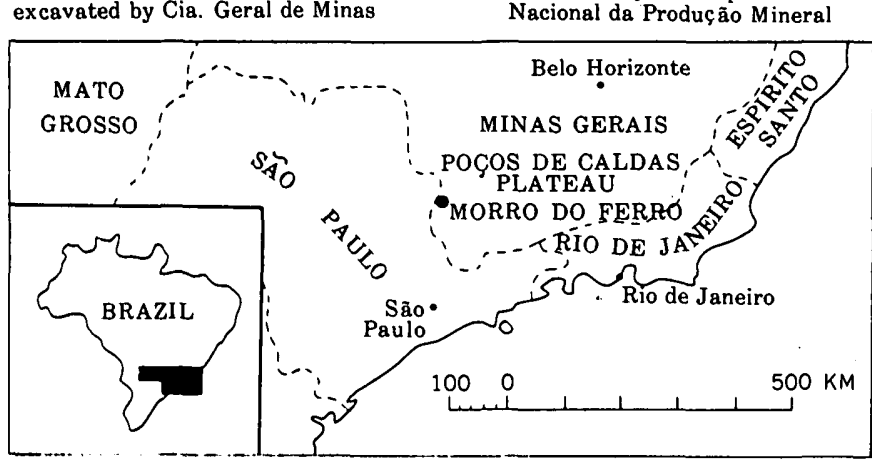

Fioure 364.1-Thorium and rare earths at Morro do Ferro, Poços de Caldas zirconium district, Brazil.

amount of eluvial or secondary chemical enrichment of the thorium and rare earths by weathering has not yet been established, although available data suggest that some such enrichment has taken place. Eluvial con- centrations of magnetite as much as 2 meters thick have locally masked parts of the deposit.

The exploration program to determine the extent of the material at Morro do Ferro that might be amenable to openpit mining consisted of preliminary scintillation-counter surveys followed by the excavation of about $600 \mathrm{~m}$ of trenches and numerous test pits and gamma-ray logging of deep auger holes drilled by the Departamento Nacional da Produção Mineral. More than 500 channel samples, taken from the trenches and test pits, were analyzed radiometrically for equivalent thoria $\left(\mathrm{eThO} \mathrm{T}_{2}\right)$; selected samples and composite samples were analyzed chemically for total rare-earth oxides and thoria $\left(\mathrm{ThO}_{2}\right)$. An example of the relation of $\mathrm{eThO}_{2}$ to total rare-earth oxides in a trench is given in figure 364.2 ; the scintillation-counter traverse over the trench line prior to excavation is also presented. Spectrographic tests and mineralogic studies were also made of selected samples. The exploration at Morro do Ferro showed a roughly lenticular zone with a length of about $500 \mathrm{~m}$ and a maximum width of about $130 \mathrm{~m}$ in which the altered alkalic rocks average about 1 percent $\mathrm{eThO} \mathrm{Th}_{2}$; this is surrounded by a halo several tens of meters broad of weaker but still significantly ( 0.1 to 1.0 percent $\mathrm{eThO}_{2}$ ) radioactive material. Radioactivity measurements in test pits and deep auger holes show that strong radioactivity extends to a depth of at least several meters. Measurements in deeper auger holes and examination of an adit driven in the center of the deposit by the Departamento Nacional da Produção Mineral (fig. 364.1) indicate that the zone of altered rock impregnated with radioactive minerals extends to depths of several tens of meters, but that at such depth the radioactivity is more spotty or pockety.

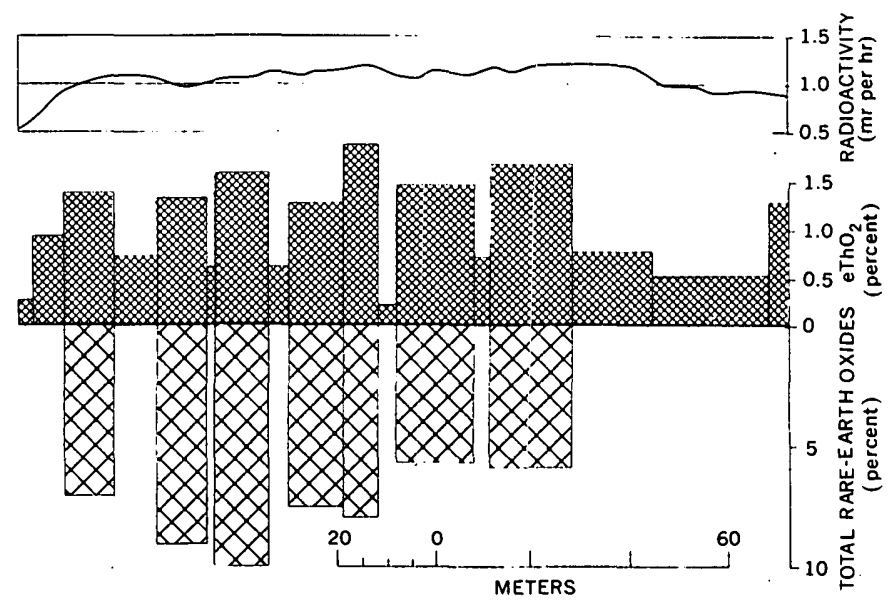

F'IGURE 364.2.- Scintillation-counter traverse and relation of equivalent thoria to total rare-earth oxides in composite samples taken along trench $A$. 
Assays on unconcentrated material show a range of 0.13 to 3.77 percent $\mathrm{e} \mathrm{ThO}_{2}$ and 1.5 to 21.13 percent total rare-earth oxides. Mineralogic study indicates that much of the thorium is present as thorogummite. Thorium also occurs in allanite, which has generally been altered by weathering to a reddish-brown claylike desilicated material similar to that described by Watson (1917) from pegmatites in the Piedmont of Virginia. The rare-earth elements occur chiefly in the allanite and its weathering products and in the rare-earth fluocarbonate, bastnaesite. The uranium content of the samples is low, generally in the $0.00 \mathrm{X}$ to $0.0 \mathrm{X}$ percent range. The uranium is believed to occur in zircon, which is present in trace amounts in the weathered rock and which probably was an accessory mineral in the original syenitic country rock.
Reserve estimates of the shallower portions of the central highgrade lenticular area indicate that 60 to 70 percent of the area contains material averaging more than 1 percent $\mathrm{ThO}_{2}$ and more than 5 percent total rare-earth oxides.

\section{REFERENCES}

Teixeira, E. A., 1936, Zirconio no planalto de Pocos de Caldas, Estados de São Paulo e Minas Geraes, Brasil: Brazil, Serviço Fomento Produção Mineral, Avulso, no. 15, 19 p.

Tolbert, G. E., 1958, The uraniferous zirconium deposits of the Pocos de Caldas Plateau, Brazil: (in English) Engenharia Mineracão e Metalurgia, v. 27, nos. 161 and 162, Rio de Janeiro.

Watson, T. L., 1917, Weathering of allanite: Geol. Soc. America Bull., v. 28, p. 463-500.

\section{VEGETATION-FREE ZONE ON DRY MANGROVE COASTS}

By F. R. Fosberg, Washington, D.C.

Aerial photographs of the mangrove swamps of southern Ecuador, especially those on Puná Island, at the mouth of the Rio Guayas, show curious, apparently bare, flat areas between the mangroves and higher ground. No vegetation is discernible on good quality photographs of these flats, which are sharply set off from the mangrove forest. There is no apparent geological explanation of this pattern.

Similar areas, even more extensive, are found on the delta of the Rio Villaneuva, at the southern end of the Gulf of Fonseca, northwest Nicaragua. They show up very well on aerial photographs and were observed from the air in 1958. Here the mangroves are found along the complex tidal channels but not on the flats between them, which have no vegetation at all but are separated from the gulf by a vegetated beach ridge. The bare areas both here and on Puná Island generally photograph white, except for some gray patches that apparently are slightly lower and possibly were wet from the tide at the time of the photographing.

Several flights along the coast of Queensland, Australia, north of Brisbane, showed what is apparently the same phenomenon as a rather consistent feature of the mangrove swamps that line estuaries and lagoons. A well-defined zone of bare flats lies between the mangrove and higher ground in most places (fig. 365.1). Tidal channels in these flats are marked by mangroves.
A short opportunity to observe this phenomenon on the ground was afforded at the port of Gladstone, Queensland. Here the bare areas consist of a fine gray sand, completely flat and dry at the time of observation, but are obviously covered by the highest tides. A wet tidal channel on one side was lined by small mangroves. In moist spots slightly lower than the flats were a few scattered plants of Suaeda, a widespread genus of halophytic herbs. Flats at a somewhat higher level than the sandy flats under consideration were covered

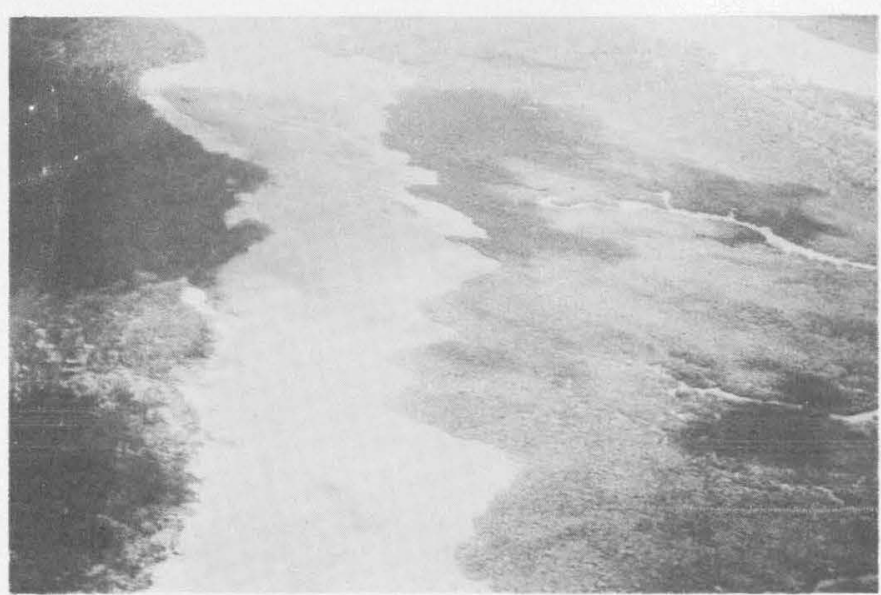

Figure 365.1.-Aerial view of mangrove swamp south of Queensland, Australia. White area is vegetation-free zone. 
by s'porobolus virginicus, a short dense grass found in sandy saline places throughout the tropics.

The phenomena described above are strikingly at variance with the pattern in mangrove swamps observed by the writer along many other tropical coasts, including Malaya, Sumatra, the Philippines, Thailand, the Ryukyu Islands, Micronesia, Fiji, New Zealand, Hawaii, New Guinea, the south coast of West Africa, Florida, and the Caribbean, and on aerial photographs of many other places. On photographs of northern Ecuador, for example, nothing of this sort was seen. The swamp forest there impinges directly on the higher ground.

The three areas where such bare flats were noted have two features in common: a very large tide range and a dry, or at least seasonally dry, climate. The general vegetation away from the coast in each area is deciduous or sclerophyllous woodland, forest or savanna, indicating a dry climate. Rainfall figures show a strongly seasonal occurrence and either less than $1,000 \mathrm{~mm}$ mean annual rainfall, or a very severe dry season, with some months having no rain at all.

Table 365.1 shows tide ranges, mean annual rainfall, number of months in wet season with total wet season rainfall, and number of months in dry season (dry months are those with less than $75 \mathrm{~mm}$ of rain, an arbitrary figure), with total rain in dry season, for a selection of localities where mangrove swamps have been observed, or for the nearest localities where tide and rainfall data are available. (For example, as no data were found for Puná Island nor for the mouth of the Rio Villanueva, Guayaquil is given for the former, and Ia Union and Nacaome for the latter.) The first four places listed in table 365.1 are those having a vegetation-free zone. It will be seen that for Gladstone and Guayaquil the climate is generally dry, as well as seasonally so, whereas the Gulf of Fonseca area (La Union and Nacaome) has a high total rainfall but an extremely severe dry season.

The last 10 stations listed in table 365.1 are known not to have a vegetation-free zone back of the mangroves. They have various combinations of tide ranges and rainfall regimes, but none has at the same time an extreme tide range and dry or seasonally very dry climate.

It is suggested that the bare zone described above is the area inundated by high spring tides, occurring only during a short period each month, and dried out, with resulting concentration of salt, between inundations. This oscillation between inundation and extreme dryness, and especially the concentration of salt during dry seasons in periods between spring tides, very prob-
TABLE 365.1.-Tide ranges and rainfall data for selected mangrove areas

\begin{tabular}{|c|c|c|c|c|c|c|c|c|}
\hline \multirow{3}{*}{ Locality } & \multicolumn{3}{|c|}{$\begin{array}{l}\text { Tide range (in } \\
\text { meters) } 1\end{array}$} & \multicolumn{5}{|c|}{$\begin{array}{l}\text { Rainfall (mean, in milli- } \\
\text { meters) }\end{array}$} \\
\hline & \multirow{2}{*}{ Mean } & \multirow{2}{*}{ Diurnal } & \multirow{2}{*}{ 总 } & \multirow{2}{*}{ Annual } & \multicolumn{4}{|c|}{$\begin{array}{c}\text { Number of months } \\
\text { and rainfall }\end{array}$} \\
\hline & & & & & & Vet & & \\
\hline Gladstone (Queensland). & 2.28 & 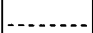 & 2. $9 \xi_{i}$ & 972 & 4 & 579 & 28 & 393 \\
\hline Guayaquil (Ecuador).... & 3. 29 & - & 3.98 & 970 & 4 & 862 & 18 & 103 \\
\hline La Union (Salvador)... & 2.46 & $\ldots$ & 3. 04: & 2111 & 6 & 2016 & ${ }^{3} 6$ & 95 \\
\hline Nacaome (Honduras) ....... & $(s)$ & & $\ldots$ & 1285 & 7 & 1240 & 15 & 47 \\
\hline Singapore. & 1.67 & & 2.25 & 2375 & 12 & 2375 & & 40 \\
\hline Buenaventura (Colombia) ...... & 3.17 & & 3.98 & 7128 & 12 & 7128 & & 10 \\
\hline Greytown (Nicaragua) & .21 & & .38 & 6588 & 12 & 6588 & & 10 \\
\hline Bluefelds (Nicaragua) & .21 & & .30 & 3200 & 11 & 3172 & 4 & 28 \\
\hline Turbo (Colombia) & .23 & $\ldots$ & .30 & 2583 & 10 & 2489 & 42 & 94 \\
\hline Manila (Philippines) .... & & 1.00 & $\ldots$ & $2 \mathrm{~L} 50$ & 7 & 1900 & 45 & 94 \\
\hline Miami (Florida) & .76 & -........ & .9 .1 & 1193 & 7 & 1165 & 45 & 305 \\
\hline Cienfuegos (Cuba) & .27 & $\ldots$ & .33 & 1055 & 6 & 873 & 46 & 183 \\
\hline Cartagena (Colombia) & .21 & $-\ldots$ & .33 & 929 & 5 & 787 & 47 & 142 \\
\hline Barranquilla (Colombia) ....... & (8) & 0.60 & (6) & 747 & 5 & 606 & 47 & 141 \\
\hline
\end{tabular}

1 Tide ranges are taken from U.S. Coast and Ceodetic Survey Tide Tables. Central and Western Paciflc Ocean and Indian 1955. 1-\$63, 1954. America, East Coast, 1958. 1-271, [1957]. America, West Coast, 1957. 1-:226, 1956.

2 Rainfall data adapted from Climatic A verages Australia.

${ }^{3}$ Rainfall data from Köppen, W. and Geiger, R., Handbuch der Klimatologle, 19301939.

4 Rainfall data supplied by U.S. Weather Bureau, Washington, D.C

$\checkmark$ Inland locality.

${ }^{B}$ Irregular.

ably exceeds the tolerance of even such halophytes as mangroves and various salt marsh plants. Some of those plants can tolerate pure sea water with no inconvenience, though their striking zonation indicates sensitivity to differences in salinity. It is probable that no available plant species have been able to develop adaptions to the augmented salt concentration brought about by evaporation over much longer periods than daily or half-daily fluctuations.

Flats perhaps comparable to these were seen from the air by the writer along certain desert coasts, such as the Caribbean coast of the Guajira Peninsula, the head of the Gulf of California, and Persian Gulf coast of Saudi Arabia. No mangroves are associated with them except for a slight development in a few places along lagoons on the Guajira Peninsula. In Saudi Arabia, near Dharan, ground examination showed that these flats are extremely saline. They represent the upper limit of wetting of sandy soil by ground water extending landward from the sea, the loose dry sand having been blown away. They have no vegetation at all. In these desert areas tide ranges from slight in the Caribbean to more than 7 meters in the Gulf of California. All have extreme evaporation in common, 
however, which would result in the concentration of salt at the surface of the ground. Thus, the underlying reason for the lack of vegetation may be the same in these desert areas and in the zones back of the mangrove swamps discussed above.
If the above interpretation is correct, it will enable the photo-interpreter to recognize a special class of vegetation-free areas resulting from the combination of an extreme tidal range and a dry climate and not from anomalies in the underlying rock.

366. POLYGONAL FEATURES ON BEDROCK, NORTH GREENLAND

By William E. Davies, Washington, D.C.

Work done in cooperation with U.S. Air Force Cambridge Research Laboratories

Polygons related to extreme freeze and thaw cycles are widespread at Brønlund Fjord in North Greenland. These features were examined during three visits to the region since 1956 .

Brønlund Fjord extends westward for about 15 miles from the north side of Independence Fjord. The fjord is bordered by gently sloping and terraced plains except on the north where cliffs over 2,200 feet high form the shore. The fjord heads in an area of broad, flatfloored interconnecting valleys. The valleys are bounded by cliffs and steep slopes that border a plateau at an altitude of 2,900 to 4,000 feet.

In the Bronlund Fjord area the rocks are mostly sedimentary and are Precambrian to Middle Ordovician in age. Some diabase sills are present (Troelson, 1949). The rocks have a regional dip of $2^{\circ}$ to $3^{\circ}$ to the northeast. A series of small, parallel, nearly vertical faults trends west along Brønlund Fjord and adjacent valleys.

Frost polygons in bedrock are prominent along the south slope of Kolen, a hill 4 miles east of the mouth of Brønlund Fjord, and on nearly level ground on the south side of the fjord near its west end. The patterned areas at these two places are about $21 / 2$ to 3 miles long and $1 / 2$ mile wide. On the south side of K $\phi$ len the polygons are in a massive gray dolomite in the middle part of the Thule group (late Precambrian). They are 30 to 60 feet long on a side and are rectangular in plan. The edges are dolomite rubble in ridges 6 to 12 inches high (fig. 366.1). The area of rubble along the edge of the polygons is about 2 feet wide. Bedrock of the central part of the polygons extends beneath the rubble, but is interrupted by fracture zones 2 to 6 inches wide bordering the polygons. The inner parts of the polygons consist of bedrock having a flat surface. In most of the area, this surface has been planed and polished by glaciers. The bedrock areas in which the polygons occur are bordered by areas of gravel from 2 to over 10 feet thick. The pattern of the polygons continues from bedrock into gravel without change. In gravel, however, the polygon boundaries are trenches 6 inches deep and 2 feet wide. Permanently frozen ground in gravel adjacent to the bedrock is 24 to 30 inches below the surface. In the fracture zone in bedrock, excavations to a depth of 3 feet did not encounter ice.

Eigil Knuth brought to the author's attention a different form of bedrock polygons in the area near the west end of Brønlund Fjord (fig. 366.2). These polygons are in slabby gray dolomite in the middle part of the Thule group. The polygons are rectangular in plan, 25 to 30 feet long on a side, and consist of slabs of rock 5 to 7 feet wide, up to 10 feet long, and a foot thick that have been heaved upwards away from the underlying rock. The slabs form ridges that are about 4 feet high and have a triangular section. Fracturing

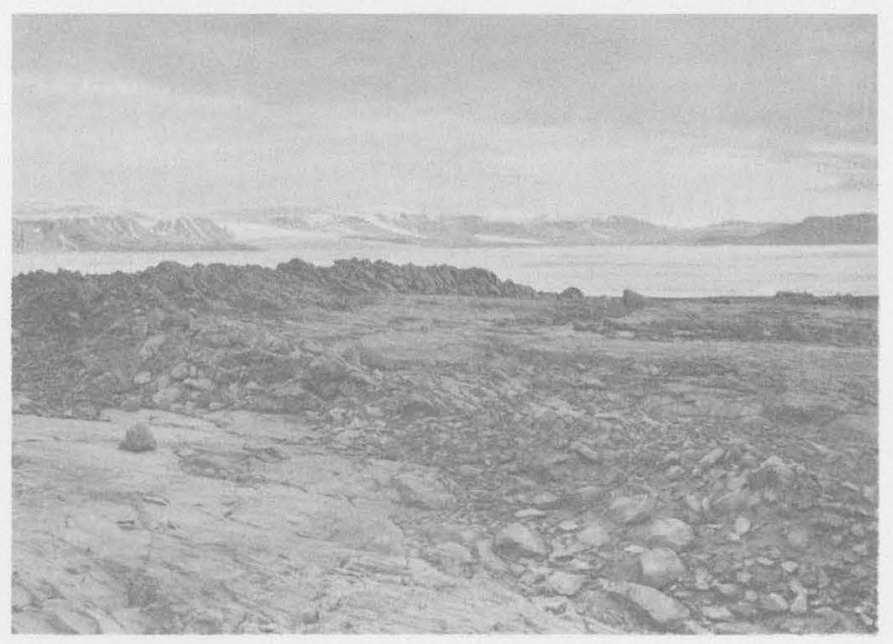

Figure 366.1.-Rubble ridge along polygon edges in bedrock, south side of Kølen, Brønlund Fjord, North Greenland. 
in bedrock along the edges of the polygons is in a zone 6 to 12 inches wide and is similar to that in the polygons at K $\phi$ len. The surface in the center of the polygons is flat and was smoothed by glacial erosion previous to the development of the polygons. Limestone in the center of the polygons has been fractured slighty, and at places the rock is broken into large slabs. In gross features the raised slabs resemble those described by Yardley (1951) in the Northwest Territories, Canada, but the separation of the slabs from the underlying rock is apparently unique in Greenland.

Jointing influences development of the polygons to some extent. In both areas of patterned ground a conspicuous set of joints trends north. The east and west sides of the polygons apparently follow fractures.

Bedrock polygons probably form as a result of frost action in a way similar to that for polygons in unconsolidated materials. Well-developed partings along bedding planes and small cavities and pores in the rock contain small quantities of water that freeze to form ice wedges along joints and fractures. The narrow width of the fracture zone along the edges of the polygons and the relatively large ridges of rubble above the joints and fractures indicate considerable working and vertical movement of material by freezing and thawing. The slab heaving along the edges of polygons at the locality near the west end of the fjord probably originated from a shallow zone of intense frost action along bedding planes.

\section{REFERENCES}

Troelsen, J. C., 1949, Contributions to the geology of the area round Jørgen Brønlunds Fjord, Peary Land: Medd. om Grønland, v. 149, no. 2, p. 9-19.

Yardley, D. H., 1951, Frost-thrusting in the Northwest Territories: Jour. Geology, v. 59, no. 1, p. 65-69.

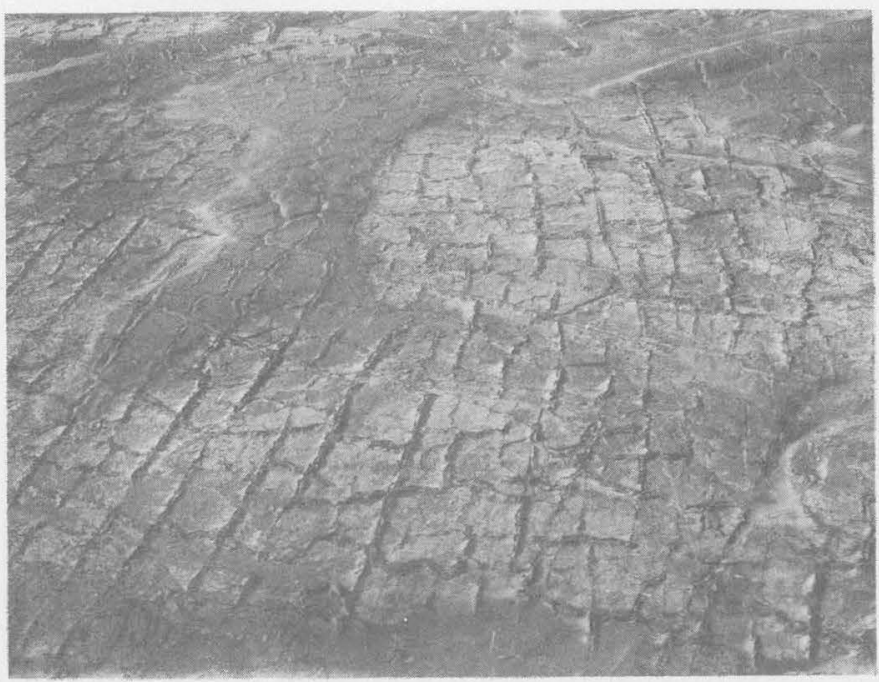

Figure 366.2.-Aerial view of bedrock polygons near west end of Brønlund Fjord, North Greenland. Darker area is gravel containing polygons having depressed edges. Other polygons have raised edges.

\section{CAVE DEPOSITS OF PHOSPHATE ROCK IN CENTRAL JAVA, INDONESIA}

By Roвert F. Johnson and Rab. Sukaмto, ${ }^{1}$ Bandung, Indonesia

An investigation of the phosphate-rock deposits of Indonesia was started in 1959 by the Djawatan Geologi in cooperation with the U.S. Geological Survey under the auspices of the International Cooperation Administration to determine the quantity and quality of phosphate rock that may be available as raw material for a superphosphate fertilizer plant.

Known deposits of phosphate rock on Java are in limestone terrane and commonly occur in caves. The phosphate rock is formed by chemical reaction between phosphoric acid, derived from the excreta of bats, and the limestone floors of the caves. Caves near Adjibarang and Sukolilo in central Java (fig. 367.1) are described in this report.

\footnotetext{
Djawatan Geologi, Indonesia
}

Steep-floored caves near Adjibarang have developed in limestone beds of late Miocene age (C.E.A. Harloff, written communication, 1932) that strike nearly east and $\operatorname{dip} 30^{\circ}$ to $60^{\circ}$ north. Cave breccia, composed of limestone fragments and soil, accumulates in the deepest part of the caves where it is covered in many caves by soil and clay as much as 4 meters deep. A vertical section through the cave filling commonly shows a barren soil layer of varying thickness underlain by 1 to 2 meters of soil containing a skeletal network of phosphate-rock veinlets that contain as much as 15 percent $\mathrm{P}_{2} \mathrm{O}_{5}$. Below this is cave breccia of limestone fragments cemented and partially replaced by phosphate rock. The grade of this material is as high as 32 percent $\mathrm{P}_{2} \mathrm{O}_{5}$. The limestone floor of the cave is also replaced by a 


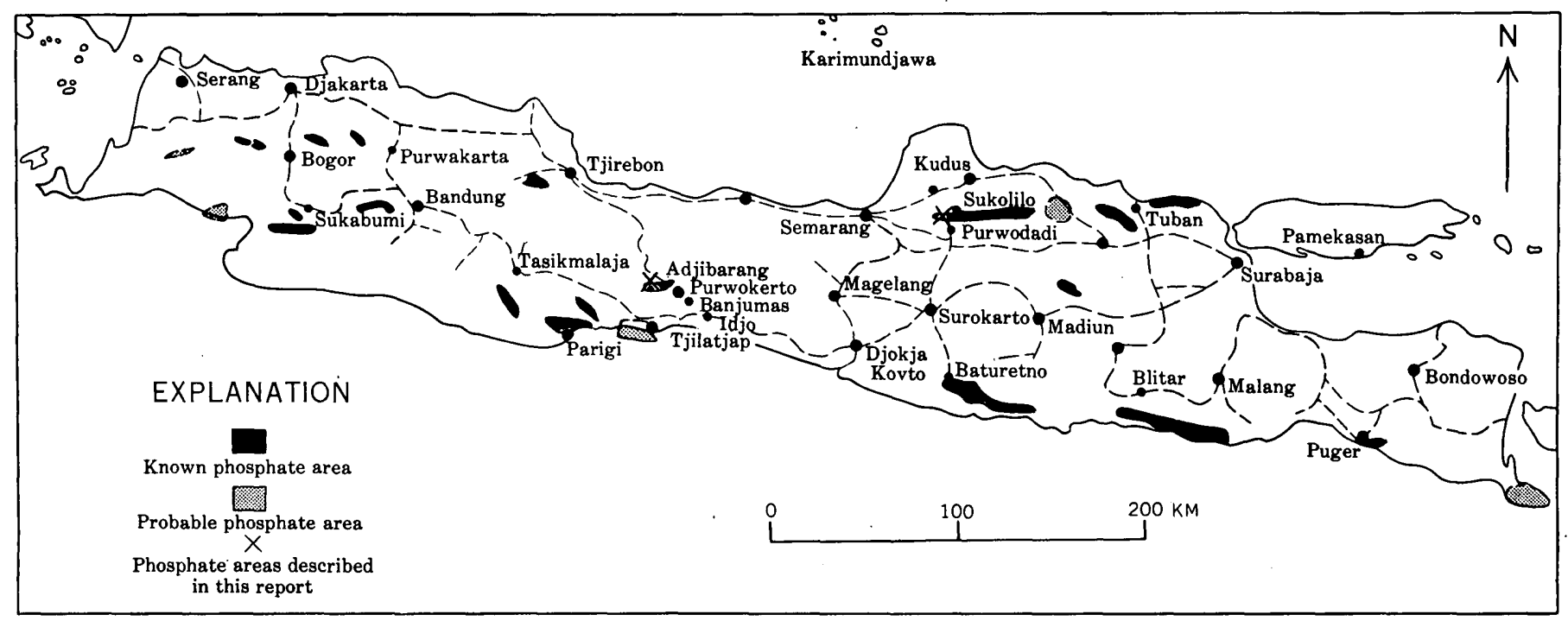

FIGURE 367.1.-Index map of Java showing the distribution of phosphate depositst.

thin layer of hard phosphate rock, generally less than $20 \mathrm{~cm}$ thick.

The phosphate rock is creamy, brown, or nearly black and has a waxy luster. It commonly shows contorted banding enclosing small limestone fragments and roughly parallel to larger limestone blocks or to the walls and floor of the cave. The rock has a high porosity owing to the leaching of unreplaced limestone fragments.

Surface deposits of phosphate rock occurring in or adjacent to the limestone beds are believed to mark the sites of former caves that have been destroyed by erosion. At these places, phosphate rock, which is less soluble than the limestone, occurs as a concentration of phosphate-rich fragments in soil. Some of the surface deposits are in slumped areas that seem to be collapsed caves and these deposits contain phosphate rock that cements breccia identical in appearance to cave breccia.

Of 21 caves and surface deposits of phosphate rock visited near Adjibarang, only 6 contained possible reserves of 100 tons or more. Three caves were nearly inaccessible and three others were blocked by soil washed in from recently deforested slopes; local residents report phosphate rock in the blocked caves. One cave, Gua Serwiti, possibly contains 20,000 tons of low-grade phosphate rock. It is estimated that about 7,000 tons of this phosphate rock would be suitable for the manufacture of superphosphate. Residents report that more than 10,000 tons of phosphate rock has been produced, largely from Gua Serwiti. The rock is mined with hand tools and is hand carried as much as 2 kilometers to the nearest road.

Sukolilo is 60 kilometers east of Semarang, on the northem edge of a range of hills that are underlain by massive limestone beds of Miocene age. The limestone is folded, but the regional dip is to the north; the maximum dip is about $20^{\circ}$. Caves develop down dip in the limestone, but in contrast to those in the Adjibarang area, they have gently sloping floors. More than 30 caves and surface deposits of phosphate rock were examined and 30 additional caves were reported in an area of about 70 square kilometers at the western end of the hills. The caves range in size from mere overhangs on limestone cliffs to caves more than 200 meters long and 4 meters wide. Rooms in some caves are as much as 20 meters in diameter.

The phosphate rock occurs as skeletal networks in soil or as cement in cave breccia similar to that at Adjibarang. About half the deposits visited contain from 70 to 2,000 tons each of phosphate rock having from 7 to 36 percent $\mathrm{P}_{2} \mathrm{O}_{5}$. Locally abundant aluminum and iron phosphate would have to be removed before the material could be used for the manufacture of superphosphate. As much as 4 meters of soil covers the phosphate rock in some caves.

I. M. Adnan (written communication, 1960) points out the following major difficulties in utilizing phosphate rock from these cave deposits: (a) The caves are small and widely scattered, and mining and transportation costs will be high; (b) most deposits are too low grade to be used directly as raw material and will have to be upgraded by hand sorting and washing; (c) impurities in the phosphate rock, such as aluminum and iron phosphates, and fluorine will require special methods of treatment and close control during mining, thus increasing costs.

It is doubtful that there are sufficient reserves of phosphate rock for sustained production of superphos- 
phate. The phosphate rock has been used as natural rock fertilizer; this may remain its most economic use. If phosphate rock were imported for the fertilizer plant, the foreign supplies of phosphate rock probably could be supplemented by the material of suitable quality that has been found locally.

\title{
父
}

\section{PACHUCA MINING DISTRICT, HIDALGO, MEXICO}

\author{
By Arturo R. Greyne, Carl Fries, Jr., Kenneth Segerstrom, Robert F. Black, and Ivan F. Wilson
}

Work done under auspices of the International Cooperation Administration in cooperation with the Compañia de Real del Monte y Pachuca and the Instituto de Geologia de la Universidad Nacional de Mexico

The Pachuca-Real del Monte mining district has been one of the prinpical silver-producing camps of the world for about 430 years. It has yielded more than 1.2 billion Troy ounces of fine silver and 6.2 million Troy ounces of fine gold, worth roughly 1.3 billion dollars at 1960 prices. This amount is about 6 percent of the silver produced in the world since the early part of the 16th century. In 1959, the district produced 6 million. Troy ounces of silver, accounting for 13.7 percent of Mexico's production and 3 percent of the world production. It is the fourth largest silverproducing district in the world, being surpassed only by the Coeur d'Alene, Cerro de Pasco, and United Keno Hill districts in the United States, Peru, and Canada, respectively.

The basement rocks in the Pachuca district are strongly folded and deeply eroded marine formations of Mesozoic age, which trend north-northwest. These are overlain unconformably by a pile of Tertiary.volcanic rocks, which form a west-northwesterly trending mountain range named the Sierra de Pachuca. During late Miocene time the Tertiary volcanic pile began to sink and was broken by several westerly trending highangle faults. In latest Miocene and early Pliocene time several groups of nearly east-west dikes were intruded, some of which are traceable for more than 10 kilometers. Following dike emplacement, norma] faulting became very active and widespread, producing a series of subparallel, rhombic blocks. The longest faults have been traced for at least 10 kilometers, and the maximum throw is about 450 meters. Late in this period of structural deformation, probably near middle Pliocene time, a group of north-south steeply dipping fractures and small faults formed in the easterm Real del Monte half of the district. These were produced either by gentle arching along a nearly northsouth axis, or by compression from the north against a convex buttress lying in the southern part of the district.

Mineralization began in middle Pliocene time very shortly after formation of the north-south fracture system. The first vein minerals deposited were mainly quartz and pyrite, with calcite and rhodonitebustamite abundant locally. In parts of the district these minerals also replaced the immediate wall rocks and inclusions in the veins to a minor degree. The quartz, pyrite, and other gangue minerals were accompanied by, and partly followed by, the deposition of sphalerite, galena, and chalcopyrite in small quantities. Silver mineralization mainly followed that of the base sulfides but in places took place simultaneously with the latest sulfides and with late.calcite and quartz. The principal silver minerals are acanthite and argentite, with smaller quantities of native silver, polybasite, miargyrite, pyrargyrite, proustite, stephanite, and sternbergite. Although some early vein minerals were locally replaced partially by the silver minerals, most of the silver is in crustiform layers of sulfide and gangue minerals filling openings along the preexisting fault and fracture systems of the region. Fault movement during mineralization locally crushed the vein fillings and formed new openings to be filled.

Within the overall areal and vertical limits of mineralization, the localization of the ore bodies appears to have been governed largely by minor structural features. Where the fractures and faults were even or regular along the strike and down the dip, the wall rocks were little shattered and few openings were produced for vein filling. Irregularities on the fracture walls on which fault movement occurred resulted in shattered zones of varied width, with many splits off the main fault, and with numerous openings available for filling. Minable ore bodies have ranged from a maximum width of about 40 meters in intensely 
shattered zones, to a minimum of about 1 meter in very narrow high-grade veinlets, but the average width has ranged mainly between 2 and 4 meters. In recent years, mining has been at the rate of nearly a million tons a year of ore averaging about 250 grams of silver and 1.4 grams of gold per metric ton, plus a few tenths of 1 percent of combined base metals.

The maximum cover over the tops of the highest ore bodies during mineralization was about 300 meters, and the deepest ore bodies were deposited about 1,000 meters below the surface. In spite of erosion after the mineralization, most of the ore bodies are still covered, although fractures, with or without barren quartz, can generally be recognized where erosion is deepest. Some ore bodies "top" as far as 600 meters below the surface.
The "roof" of the mineralized bodies is irregular, whereas the bottom is more nearly uniform. This blanketlike form of mineralized bodies suggests a temperature-pressure control.

Following mineralization, in late Pliocene or Pleistocene time, dominantly strike-slip movement occurred along or parallel to many of the east-west veins, crushing some of the vein material and displacing most of the north-south veins in the Real del Monte area where the two vein systems intersect. The deeper ore bodies have not been affected by supergene oxidation and leaching, but some of the higher ore bodies have been affected. Where alteration has occurred, the ore bodies have been impoverished in silver without any corresponding zone of secondary enrichment.

369. MARINE PHOSPHORITES OF NORTH-CENTRAL MEXICO

By Cleaves L. Rogers, Eugenio Tavera Amezcua, Jesús Ojeda Rivera, Zoltan de Cserna, and Roger van Vloten, Washington, D.C. and México, D.F.

Work done in cooperation with Consejo de Recursos Naturales No Renovables under the auspices of International Cooperation Agency, Department of State

Phosphate deposits have been mapped and sampled in an area of about 26,000 square $\mathrm{km}$, mainly in northern Zacatecas and southern Coahuila but extending eastward into the States of Nuevo León and San Luis Potosí (fig. 369.1). This area includes parts of the Sierra Madre Oriental, which is analogous physiographically to the Rocky Mountains of the United States, and the Mesa Central, which resembles the Basin and Range province. The geology and phosphate deposits of part of this area have been described by Rogers and others (1956):

The phosphorites are limited mainly to one member of the Upper Jurassic La Caja formation and its equivalent, the La Casita formation, and are in the lower part of a thick sequence of marine sedimentary rocks that were deposited in the Mexican geosyncline during Late Jurassic and Cretaceous time. The La Caja formation is the offshore facies and is predominantly calcareous siltstone, with smaller quantities of limestone, chert, phosphorite, and shale. The La Casita formation is the nearshore facies and consists mainly of gray to black carbonaceous shale, some conglomeratic sandstone, and a few layers of arenaceous coquinitic limestone. Some of the shale and limestone beds in the middle and upper parts of the La Casita formation are slightly phosphatic, and phosphatic rocks are moderately abundant where the La Casita interfingers with the La Caja formation.

The phosphatic unit has moderate to steep dips and crops out in anticlines in narrow belts flanking rather massive limestone, which forms the cores of the anticlines. In some areas the unit has been displaced by faults, and locally it is cut by intrusive rocks.

The richer phosphatic beds are mainly apatite, calcite, and chert mixed in widely varying proportions, and are designated by names such as calcareous phosphorite, phosphatic limestone, and calcareous phosphatic chert. At many places these rocks are interbedded with calcareous siltstone and smaller amounts of shale that are only slightly phosphatic.

The phosphate is a dense cryptocrystalline material with a concretionary habit. Most of the phosphate is primary, but some material has been dissolved and redeposited, probably under diagenetic conditions. Primary phosphate forms small generally structureless pellets and nodules ranging in size from $0.05 \mathrm{~mm}$ to about $3 \mathrm{~cm}$; younger phosphate replaces fossils, forms rims on primary pellets and nodules, and is disseminated through the rock matrix. The phosphatic material is light gray, pink, light to dark brown, or 


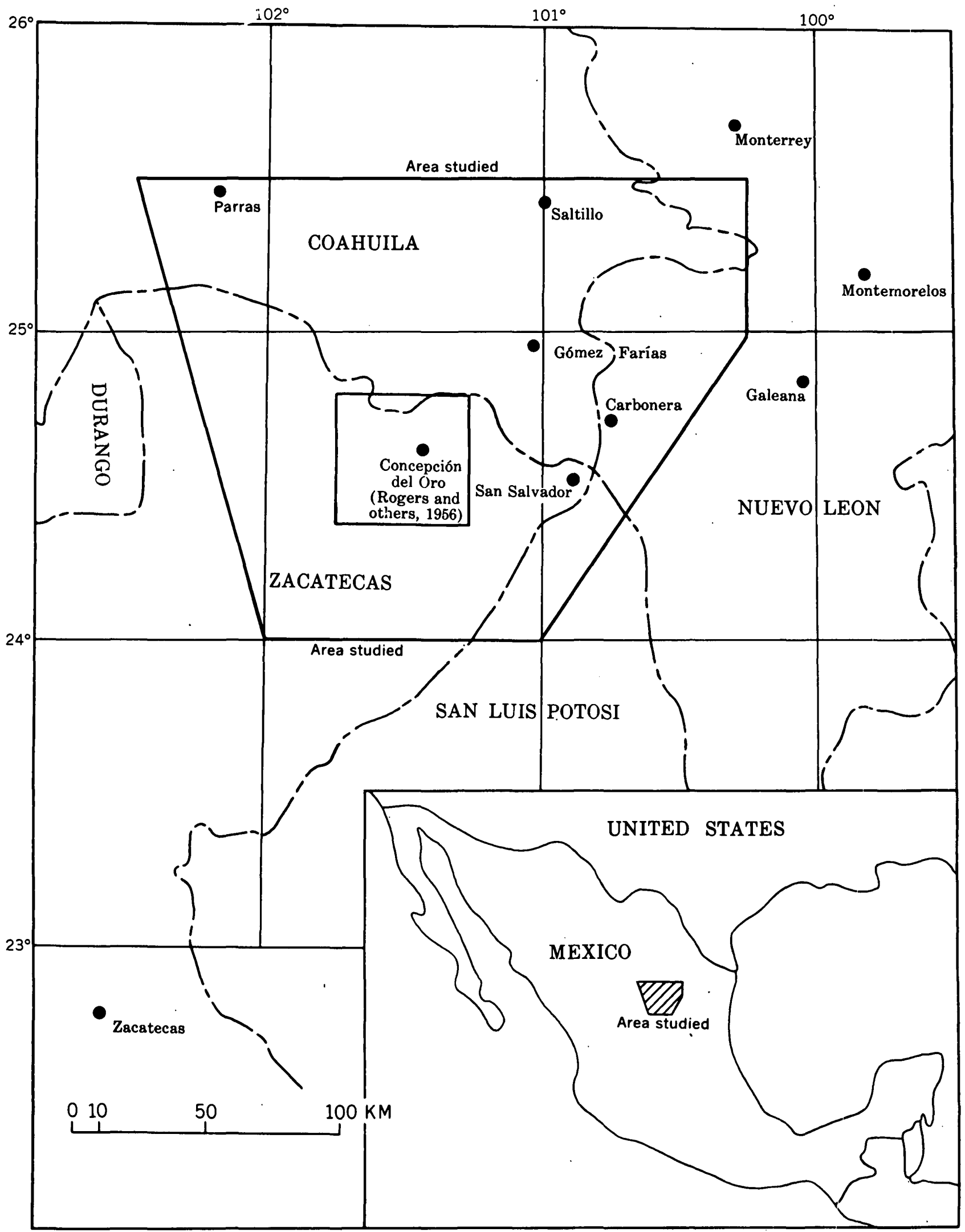

Froure 369.1.-Map of Mexico showing location of the area in which phosphate deposits were studied. 
black. 'The color, and also a fetid odor, may depend upon the amount of associated hydrocarbons and iron oxide. In thin sections the material is generally light to medium dark brown and nearly isotropic.

Microscopic study reveals that many pellets have a rounded or oval form, and a few are elongated or rodshaped; in some thin sections most of the pellets can only be described as irregular. Most pellets lack visible nomphosphatic nuclei, but where microfossils are abundant these fossils commonly appear to have been nuclei for the deposition of apatite; in some pellets the phosphate seems to have precipitated around small detrital quartz grains.

The phosphate mineral is carbonate-fluorapatite and has been shown by $\mathrm{X}$-ray analysis to be very similar to that in phosphorites of the Phosphoria formation of the western conterminous United States. Fluorine is present in a proportion equal to about 10 percent of the $\mathrm{P}_{2} \mathrm{O}_{5}$ content. The uranium content ranges from 0.001 to 0.006 percent.

The phosphorite beds were deposited as predominantly chemical or biochemical sediments, containing little detrital material. The authors favor a chemical rather than a biolithic origin for the phosphate, although the evidence is not conclusive, and both modes of origin may have played a part. Deposition of the phosphatic beds appears to have been extremely slow, if their thickness is compared with the much thicker time-equivalent beds in the Gulf region of the United States, in Cuba, or in California. Macrofossils indicate that the deposits formed in clear shallow waters, perhaps in the shallower parts of the neritic zone of a cold shallow sea. Local concentrations of phosphate apparently are due largely to nondeposition of clastic material and may have formed on low submarine ridges that received less silty material than adjacent shallow basins.

In the phosphatic unit, calcareous phosphorite contains the most phosphate and is the most abundant rock type; the $\mathrm{P}_{2} \mathrm{O}_{5}$ content of this rock ranges from 15 to 27 percent. Layers of calcareous phosphorite.range in thickness from less than $1 \mathrm{~cm}$ to $2 \mathrm{~m}$ or more, and in some areas are highly lenticular. At places, thin layers of phosphorite alternate with siltstone in sequences as much as $6 \mathrm{~m}$ thick, and the deposits would be of commercial grade if the two kinds of rock could be separated. The three columnar sections in figure 369.2 show the vertical distribution of calcareous phosphorite in the phosphatic unit and the $\mathrm{P}_{2} \mathrm{O}_{5}$ content of this unit

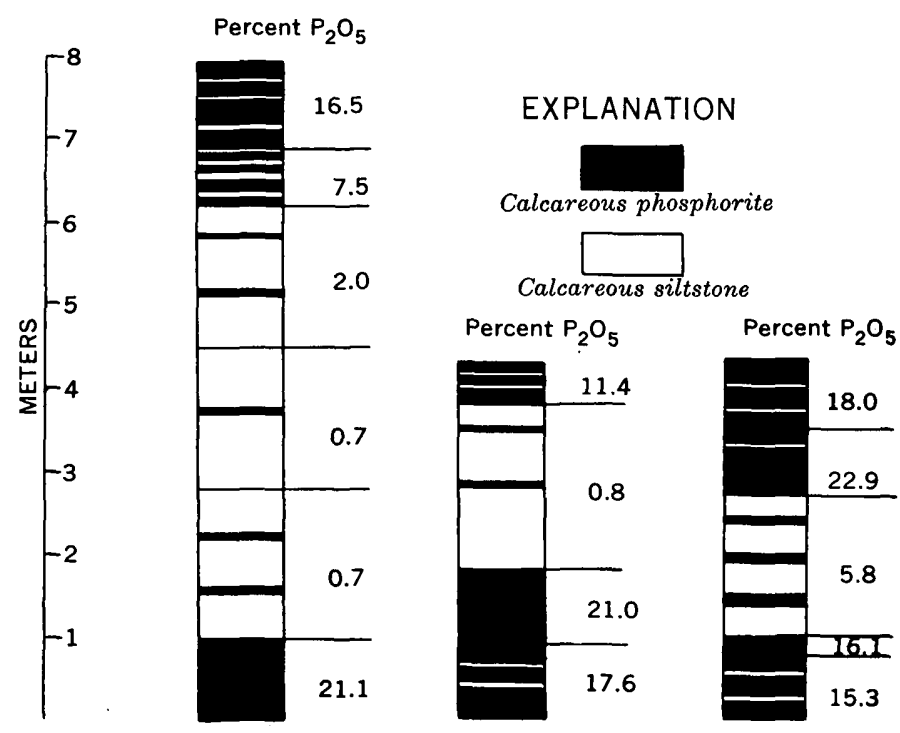

Figure 369.2-Columnar sections of phosphatic unit in the Sierra de Carbonera, Coahuila and Nuevo León, showing $\mathrm{P}_{2} \mathrm{O}_{5}$ content in percent.

in the Sierra de Carbonera, one of the areas containing potentially commercial deposits.

The reserves of phosphatic rock are estimated to total at least 77 million metric tons averaging 18 to 19 percent $\mathrm{P}_{2} \mathrm{O}_{5}$, and about 76 million metric tons averaging 13 to 14 percent $\mathrm{P}_{2} \mathrm{O}_{5}$. These figures are based on the results of sampling at 131 localities. Spacing of samples is sufficiently close to class as reasonably certain about 20 million metric tons of phosphatic rock (including about $13,500,000$ metric tons that were reported earlier by Rogers and others, 1956); the remainder is classed as inferred. Recent exploration by private companies and individuals suggests that the actual reserves may be considerably greater. Large quantities of phosphatic rock contain 10 to 12 percent $\mathrm{P}_{2} \mathrm{O}_{5}$, but these are not considered in the reserve estimates.

The Comisión de Fomento Minero constructed a pilot plant at Saltillo in 1957 to beneficiate the phosphatic rock and, using a calcination process, has been successful in raising the grade of the phosphatic material to about 30 percent $\mathrm{P}_{2} \mathrm{O}_{5}$, which is sufficient for the manufacture of superphosphates by the sulfuric acid process.

\section{REFERENCE}

Rogers, C. L., de Cserna, Zoltan, Tavera, Eugenio, and Ulloa, Salvador, 1956, General geology and phosphate deposits of Concepcíon del Oro district, Zacatecas, Mexico: U.S. Geol. Survey Bull. 1037-A, 102 p. 
370. DECELERATION OF EROSION AT PARICUTIN, MEXICO

\author{
By Kenneth Segerstrom, Santiago, Chile
}

The eruption of Parícutin volcano, which lasted from 1943 to 1952 , is one of the best documented volcanic episodes in history. A principal effect of ash fall from Parícutin was interruption of the erosion cycle, caused by the burial and destruction of vegetation and the blanketing of slopes by the easily erodable, abrasive ash (Segerstrom, 1950). Most of the ash fell during the first 2 years, and the highest rates of erosion were attained during the rainy seasons of 1943 and 1944 (fig. 370.1). Deceleration of the abnormally high erosion rate began after the 1944 rainy season, although eruption of pyroclastic material and lava continued for $71 / 2$ more years. After the ash falls ceased in 1952, the deceleration of erosion was even more evident than before (fig. 370.1). Observations were made by the author in the volcano area in February 1957, (Segerstrom, 1960), and again in December 1960.

In 1960 the depth of a conspicuous stream channel 4 $\mathrm{km}$ east of the volcano (fig. 370.2) was only $2.46 \mathrm{~m}$ below the contact between ash from Paricutin and the preexisting soil, as compared with $2.30 \mathrm{~m}$ at the same place in February 1957 (Segerstrom, 1960, p. 10, locality 8). Here in 1950 the drainage from the east side of the Parícutin lava field had breached a former watershed divide in deeply weathered soil. Similar examples of only slight channel deepening in nearly 4 years were seen at other localities. Rainfall was not measured in the volcano area during the 4-year period, but it is believed that precipitation was not below normal.

At Terúpicua on the north edge of the lava field, the surface of a fill deposit about 3 hectares in area was 6 $\mathrm{cm}$ higher in December 1960 than it was in February 1957 (fig. 370.3). Similar examples of only slight increments in stream deposits in nearly 4 years were also seen at other localities.

It may be concluded that erosion and redeposition in the Parícutin area have.slowed down for two principal reasons: the most vulnerable ash deposits have been largely stripped from the steepest slopes and from the main stream channels, and areas covered by ash or new alluvial deposits are rapidly becoming vegetated.

In December 1960, dense stands of young trees were springing up in much of the area that was forested before the eruption. In areas that were formerly cropland (fig. 370.2), scattered young trees, shrubs, and smaller plants were also growing in the ash, particularly where there was an admixture of redeposited preexisting soil or of debris from the older trees. At Chórotiro a fill deposit that partly covered the northeastern edge of the lava field supported a dense stand of vegetation,

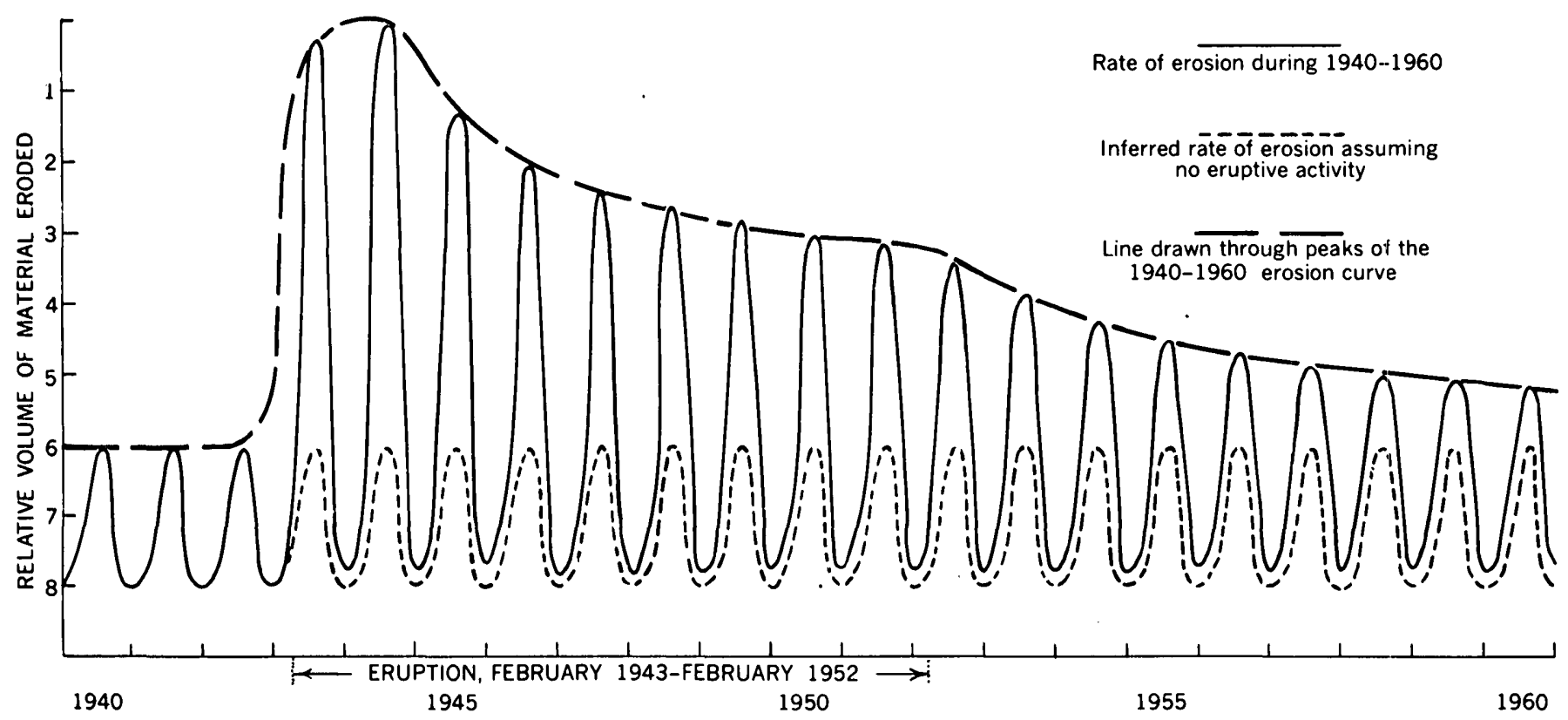

Froure 370.1.-Diagrammatic representation of erosion rates at Paricutin during the period 1940-60. 


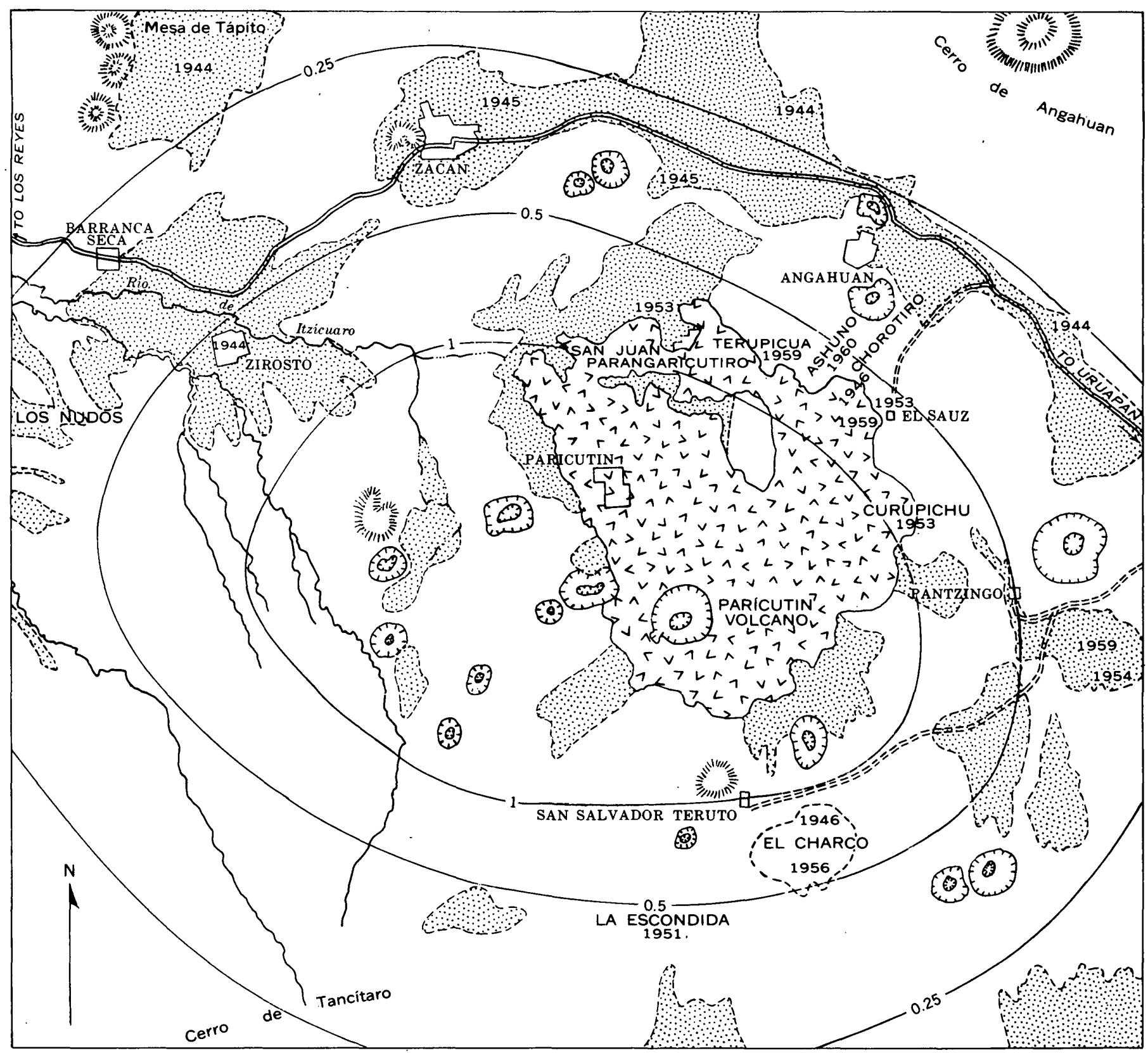

34 KILOMETERS 


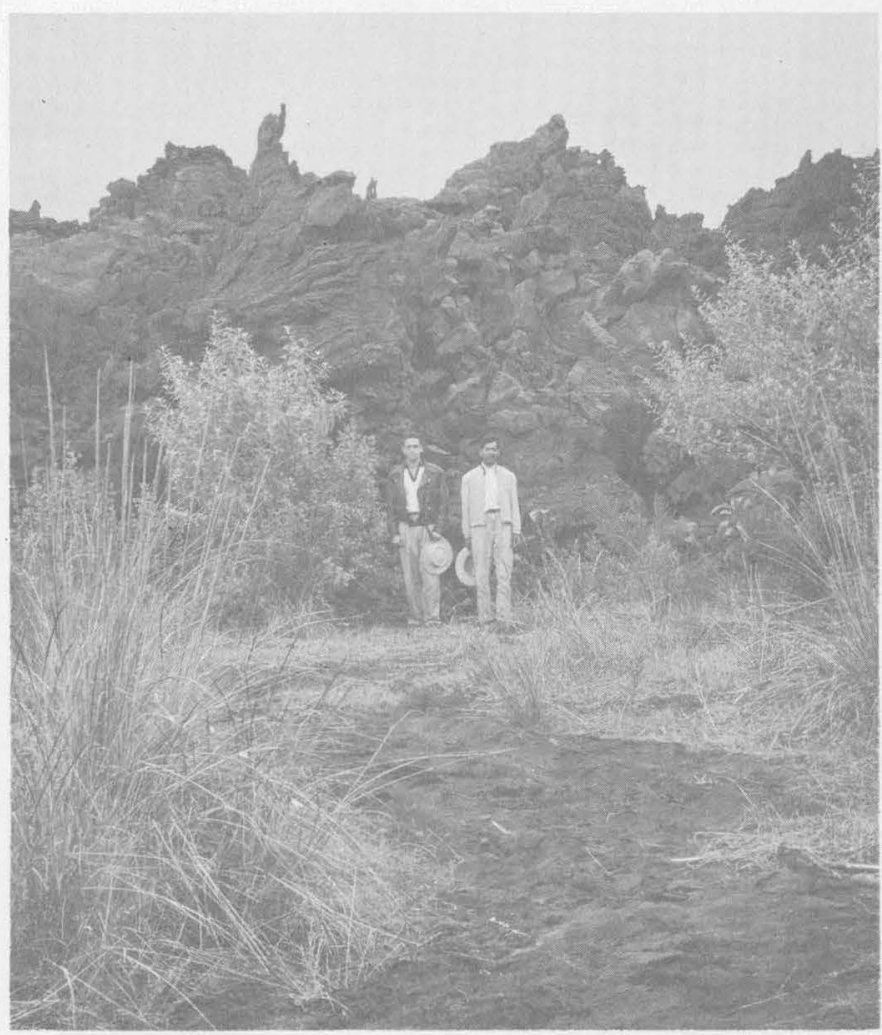

Figure 370.3.-Edge of lava field at Terúpicua showing fill deposit in foreground. This locality is the same as that of Segerstrom, 1960, figure 9 .

including several pines as much as $15 \mathrm{~cm}$ in diameter and over $3 \mathrm{~m}$ high. Pines, broadleaf trees, ferns and other plants had even taken root in narrow crevices in the lava. In December 1960, abundant lichens and scattered plants of other varieties were growing on the top of the Parícutin cone and in the crater. Beaman (1960) described 14 vascular species found on the cone in September 1958, and has reported that nearly double that number of vascular plants were found in September 1960 (written communication, January 18, 1961).

Agriculture, which was interrupted locally by the eruption, was resumed at a few places as early as 1944 . By 1960 , crops were sown and harvested at many places in the volcano area. The years when cultivation began are shown on figure 370.2 .
In the areas of renewed cultivation, corn is virtually the only crop. Cultivated areas at the east and north edges of the lava field are between the $0.5-\mathrm{m}$ and $1-\mathrm{m}$ lines of equal ash fall. All the areas are covered by redeposited ash containing admixtures of vegetal matter and preexisting soil. At the Ashuno locality, cultivation was attempted in 1960 in a wooded area in which large amounts of pine needles are mixed in the ash.

The only attempts to cultivate areas of former cropland where the ash fall was greater than $0.5 \mathrm{~m}$ were made in Zirosto, about $8.5 \mathrm{~km}$ northwest of the volcano. The townspeople at that place began shoveling ash from garden plots in 1944, and by December 1960, between one-third and one-half of Zirosto had been cleared in this manner.

In areas of less than $0.5 \mathrm{~m}$ ash fall, much of the land that had been cultivated before the eruption had been reclaimed for agriculture by 1945 . Erosion of the relatively thin ash from the sides of broad valleys and its redeposition with admixtures of preexisting soil in the valley bottoms aided in the reclamation of those areas.

Because of the deceleration of erosion and because of the rapidity of revegetation, early repopulation of the Parícutin area now seems assured, even where the total ash fall was more than $0.5 \mathrm{~m}$. The new town of San Salvador Teruto, $3 \mathrm{~km}$ south of the cone, in December 1960 had 44 families. El Sauz, $5 \mathrm{~km}$ northeast of the cone, was another new village with several families, and 9 families lived in the ruins of San Juan Parangaricutiro where only 4 had lived in 1957. Zirosto had a population of 80 families in December 1960.

\section{REFERENCES}

Beaman, J. H., 1960, Vascular plants on the cinder cone of Parícutin voleano in 1958: Rhodora, v. 62, p. 175-186.

Fries, Carl, Jr., and Gutièrrez, Celedonio, 1954, Activity of Parícutin voleano during the year 1952: Am. Geophys. Union Trans., v. 35, p. 486- 494.

Segerstrom, Kenneth, 1950, Erosion studies at Parícutin, State of Michoacan, Mexico: U.S. Geol. Survey Bull. 965-A, p. 1-164.

1960, Erosion and related phenomena at Parícutin in 1957 : U.S. Geol. Survey Bull. 1104-A, p. 1-18.

Wilcox, R. E., 1959, Some effects of recent voleanic ash falls, with especial reference to Alaska: U.S. Geol. Survey Bull. 1028-N, p. $409-476$. 


\title{
371. THE IRON FORMATION OF THE SURGHAR AND WESTERN SALT RANGES, MIANWALI DISTRICT, WEST PAKISTAN
}

\author{
By Walter DanilchiK, Quetta, Pakistan
}

Work done in cooperation with the Geological Survey of.Pakistan under the auspices of the International Cooperation Administration

Extensive efforts have been made to discover and develop a domestic source of iron ore in Pakistan in order to reduce expenditures for imported steel. Ironrich sedimentary rocks, which are widespread in West Pakistan, are now being surveyed to determine the feasibility of their use as low-grade ores of iron.

Interest in the development of iron-bearing sedimentary rocks has centered in the Surghar and western Salt Ranges in the Mianwali district of West Pakistan (fig. 371.1), where an extensive iron formation is relatively accessible. The region offers abundant labor, rail facilities, electric power, ample water from the nearby Indus River, and already supports mines producing coal, salt, limestone, dolomite, and gypsum.

In 1958, the Geological Survey of Pakistan and the U.S. Geological Survey began a comprehensive geological investigation of the Surghar Range as part of the International Cooperation Administration technical assistance program in Pakistan.

The Surghar and Salt Ranges are underlain by a thick sequence of sedimentary rocks ranging in age from Cambrian to Quaternary. The stratigraphic sequence contains many well-defined rock units, which have been defined and mapped by Wynne (1880), Gee (1945), and more recently studied by Imam and Kidwai (in press), and Kidwai (in press). Most of these. units crop out along the south and east sides of the Surghar Range and in the western Salt Range, forming steep escarpments that rise locally more than 3,000 feet above the Indus Plain. The sequence includes at least three major unconformities.

The principal structures of the Surghar and western Salt Ranges are large, generally asymmetric, faulted folds roughly paralleling the ranges (fig. 371.2). The structure of the western part of the Surghar Range is fairly simple, but is increasingly complex toward the east, particularly near Kalabagh, where the effects of at least three episodes of strong deformation during the Tertiary and Quaternary periods can be recognized.

The iron-rich beds are in the upper part of the Chichali formation (the "Belemnite beds") of Neocomian age. They consist mostly of glauconitic sandstone having a maximum thickness of 200 feet. In the high elevations of the Surghar Range, the outcrops of the beds are generally continuous. In the Salt Range, the beds are discontinuous and poorly exposed.

In the Makarwal area the iron-rich layer is mainly glauconite and ranges in thickness from 20 to 23 feet. Chemical analyses of a five-part channel sample across a 22-foot bed believed to be representative of the layer show the following percent averages: $\mathrm{Fe}_{2} \mathrm{O}_{3}, 45.88$; $\mathrm{SiO}_{2}, 26.08 ; \mathrm{Al}_{2} \mathrm{O}_{3}, 8.13 ; \mathrm{CO}_{2}, 1.9 ; \mathrm{CaO}, 0.68 ; \mathrm{Na}_{2} \mathrm{O}$, $0.10 ; \mathrm{P}_{2} \mathrm{O}_{5}, 0.52 ; \mathrm{K}_{2} \mathrm{O}, 2.97$; loss on ignition, 12.70 .

The glauconitic layer in the vicinity of Chichali Nala is believed to be stratigraphically higher than the ironrich layer at Makarwal. This suggests the possibility of two stratigraphically distinct iron-rich beds.

In the eastern part of the Chichali area the iron-bearing stratum changes from glauconitic to chamositic rock. North of Kuch it consists mostly of chamosite with some siderite and hematite. Analyese of five selected samples of this rock show the following percent averages: $\mathrm{Fe}_{2} \mathrm{O}_{3}, 52.63 ; \mathrm{SiO}_{2}, 17.00 ; \mathrm{Al}_{2} \mathrm{O}_{3}, 10.90 ; \mathrm{TiO}_{2}$, $1.10 ; \mathrm{S}, 0.35 ; \mathrm{P}_{2} \mathrm{O}_{5}, 0.46$.

Imam and Kidwai (in press) report that in the easternmost outcrops of the Kuch area the chamosite rock passes into a mixture of hematite and limonite. In the Kalabagh area and the western Salt Range the ironbearing stratum is mostly chamosite but contains discontinuous layers of limonite, hematite, and locally glauconite.

The origin of the iron-rich layer in the Chichali formation is believed to be related to the post-Neocomian unconformity. Over wide areas in the western Salt Range, much of the Chichali formation, and some of the underlying rock was removed during this period of erosion. A widespread lateritic deposit then developed on the erosion surface. In the Sakesar, Kuch, and Kalabagh areas a temporally equivalent hematitic, limonitic, and chamositic iron stratum developed on the surface of the upper part of the Chichali formation.

Southwesterly, in the Chichali and Makarwal areas, the effect of the unconformity is not noticeable, and it is evident that the glauconitic iron stratum is a marine deposit. Its enrichment in iron may be related to 


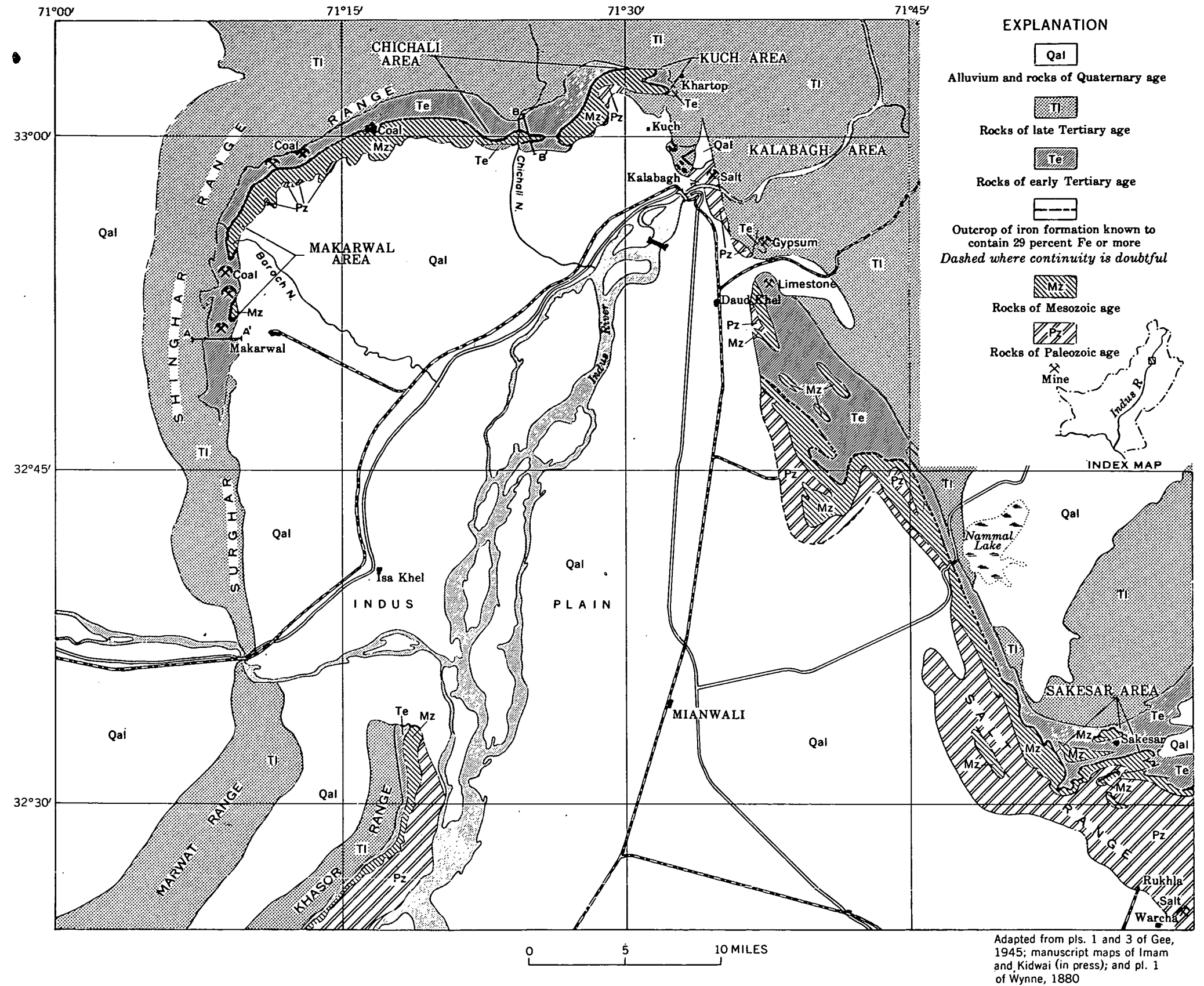



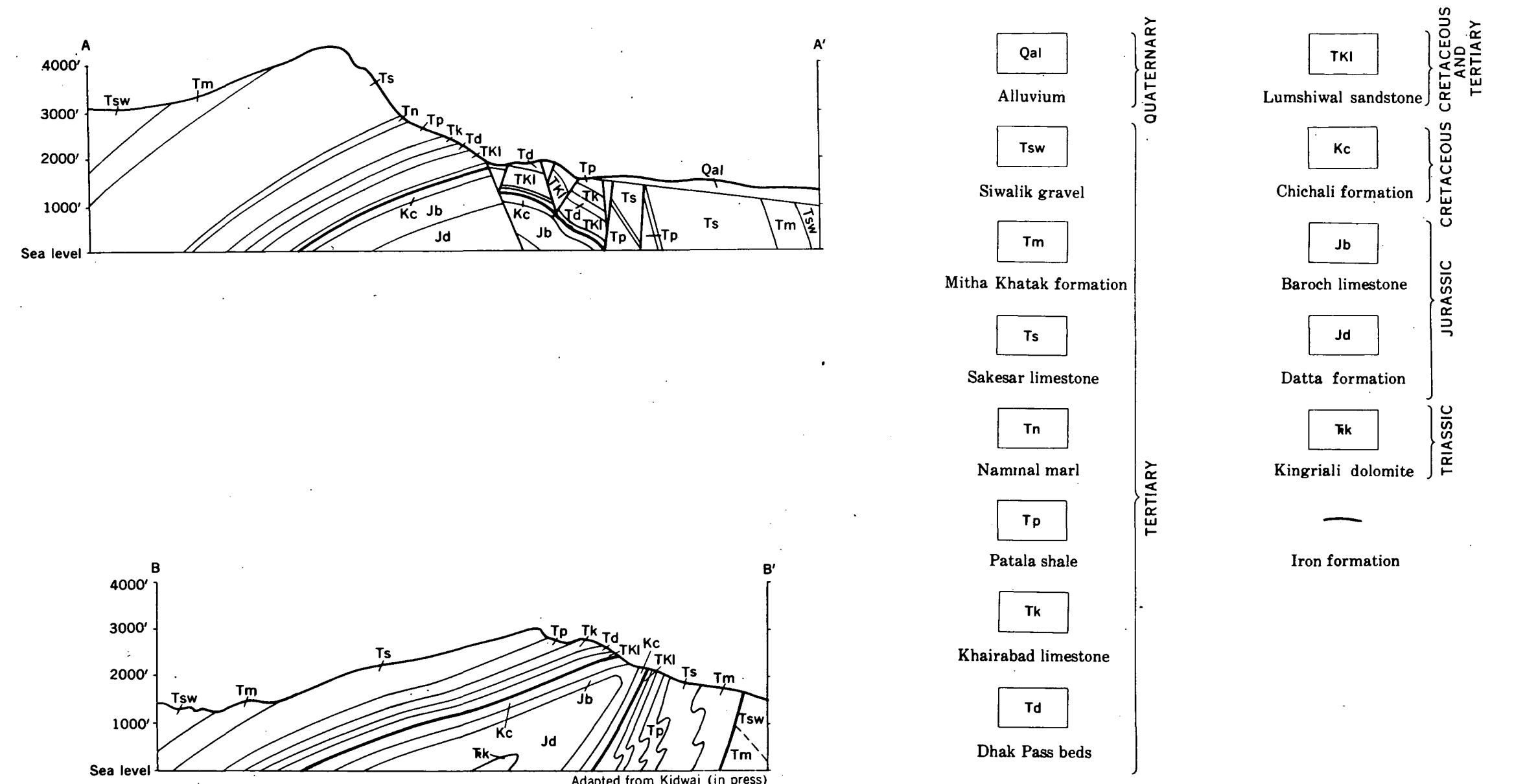

$2000, \quad, \quad 20,2000: 4000$ FEET

Figure 371.2.-Geologic cross sections of the Surghar Range, West Pakistan, along lines $A-A^{\prime}$ and $B-B^{\prime}$ on figure 371.1. 
the emergence of the terrain to the east on which lateritization was taking place.

Tschoepke (unpublished data) believes the chamosite, which has a higher ratio of ferrous iron to ferric iron than glauconite, was formed in a reducing environment in sea water deeper than that in which the glauconite originated. This interpretation precludes the emergence of the Salt Range area until after the end of deposition of the iron stratum and requires another source for the clastics that were glauconitized and enriched to form the iron formation.

Reserves of iron formation in the five areas shown on figure 371.1 are listed in table 371.1 , together with average thicknesses of the formation that have been used in the calculations for each area. Continuity of the iron formation has been traced down-dip for more than 1,000 feet in gorges in the Makarwal and Chichali areas, in the low-level adit of the Makarwal Collieries, and in exploratory adits on both sides of Chichali gorge. The reserves in these areas can be regarded as proven to a depth 1,500 feet down dip from the outcrop. The reserves listed for the Sakesar, Kalabagh, and Kuch ureas, formerly regarded as proved, probable, and possible, may now be classed as proved on the basis of new information and exploration.

\section{REFERENCES}

Gee, E. R., 1945, The age of the Saline Series of the Punjab and of Kohat: India Natl. Acad. Sci. Proc., Sec. B, v. 14, pt. 6, p. 269-311.

Imam, S. A., and Kidwai, A. H., (in press), Geology of the Kuch and Khartop blocks of the Kalabagh iron formation, Mianwali, district, West Pakistan: Pakistan Geol. Survey Inf. Release.

Kidwai, A. H., (in press), Geology of the iron formation in the Chichali Pass area, Mianwali and Kohat districts, West Pakistan: Pakistan Geol. Survey Inf. Release.

Wynne, A. B., 1880, On the Trans-Indus extension of the Punjab Salt Ranges: India Geol. Survey Mem., v. 17, pt. 2, 95 p.

TABLE 371.1-Reserves of the iron formation in the Surghar and western Salt Ranges

\begin{tabular}{|c|c|c|c|c|}
\hline Area & $\begin{array}{c}\text { Average } \\
\text { thickness, } \\
\text { in feet }\end{array}$ & Dominant mineral & $\begin{array}{c}\text { Reserves, in } \\
\text { tons of } 2,000 \\
\text { lbs. }\end{array}$ & Source of dats \\
\hline Sakesar. - & 8 & Chamosite-limonite & ${ }^{1} 2,700,000$ & $\begin{array}{l}\text { Krupp (unpublished } \\
\text { data). }\end{array}$ \\
\hline Kalabagh... & 8 & Chamosite-limonite. & ${ }^{2} 2,300,000$ & $\begin{array}{l}\text { Krupp (unpublished } \\
\text { data). }\end{array}$ \\
\hline Kuch. & 10 & Chamosite... & $322,100,000$ & $\begin{array}{l}\text { Imam and Kidwa } \\
\text { (In press). }\end{array}$ \\
\hline Chichali. & 10 & $\begin{array}{l}\text { Glauconite- } \\
\text { chamosite. }\end{array}$ & $\triangleleft 99,000,000$ & Kidwal (in press). \\
\hline Makarwal... & 20 & Glauconite - & $445,000,000$ & $\begin{array}{l}\text { Danilchik and Shah } \\
\text { (unpublished } \\
\text { data). }\end{array}$ \\
\hline
\end{tabular}

1 Total reserves to a depth of 600 feet below the outcrop.

2 Total reserves to a depth of 250 feet below the outcrop.

3 Total reserves to depths locally 1,500 feet or more below the outcrop.

4 Proved reserves to a depth 1,500 feet below the outcrop.

\section{GROUND WATER IN THE SABI VALLEY, SOUTHERN RHODESIA}

By P. Eldon Dennis, Tucson, Ariz.

Work done in cooperation with the International Cooperation Administration and the government of Southern Rhodesia

The Sabi Valley (fig. 372.1) is in the extreme southeastern part of Southern Rhodesia. It is in the low veld at an altitude of 1,300 to 2,000 feet. The alluvial plain in the valley is about 14 miles wide and 35 miles long, and the Sabi River maintains a remarkably straight course through the center of the plain in a braided channel between banks that are generally about a mile apart and about 15 feet above the stream bed. The river is the only perennial stream in the area, and its flow dwindles throughout the rainless winter season; the flow of the river ranges from a flood flow of about $600,000 \mathrm{cfs}$ (cubic feet per second) to about $130 \mathrm{cfs}$ late in the rainless season.

\section{GROUND-WATER RESOURCES}

Ground water in usable quantities was found at one or more zones in all test holes in the Sabi Valley (fig.
372.2). However, the water was saline in well 39 and test hole 41 . It seems likely that north of this saltwater area the alluvium everywhere will yield 1,000 gallons or more per hour to properly constructed wells. The records of the Southern Rhodesia Division of Irrigation and Lands show that 14 dry holes were drilled in the area prior to the investigation. Most of them were near the escarpment where the water table is nearly 150 feet below land surface, and failure to obtain water probably resulted from inability to drill deep enough through beds containing cobbles and boulders, rather than for lack of water-bearing beds. The cobbles and boulders usually can be avoided by selecting sites between the larger mountain drainage channels and valleyward from the escarpment. A little ground water moves through fractures and solution channels in the 


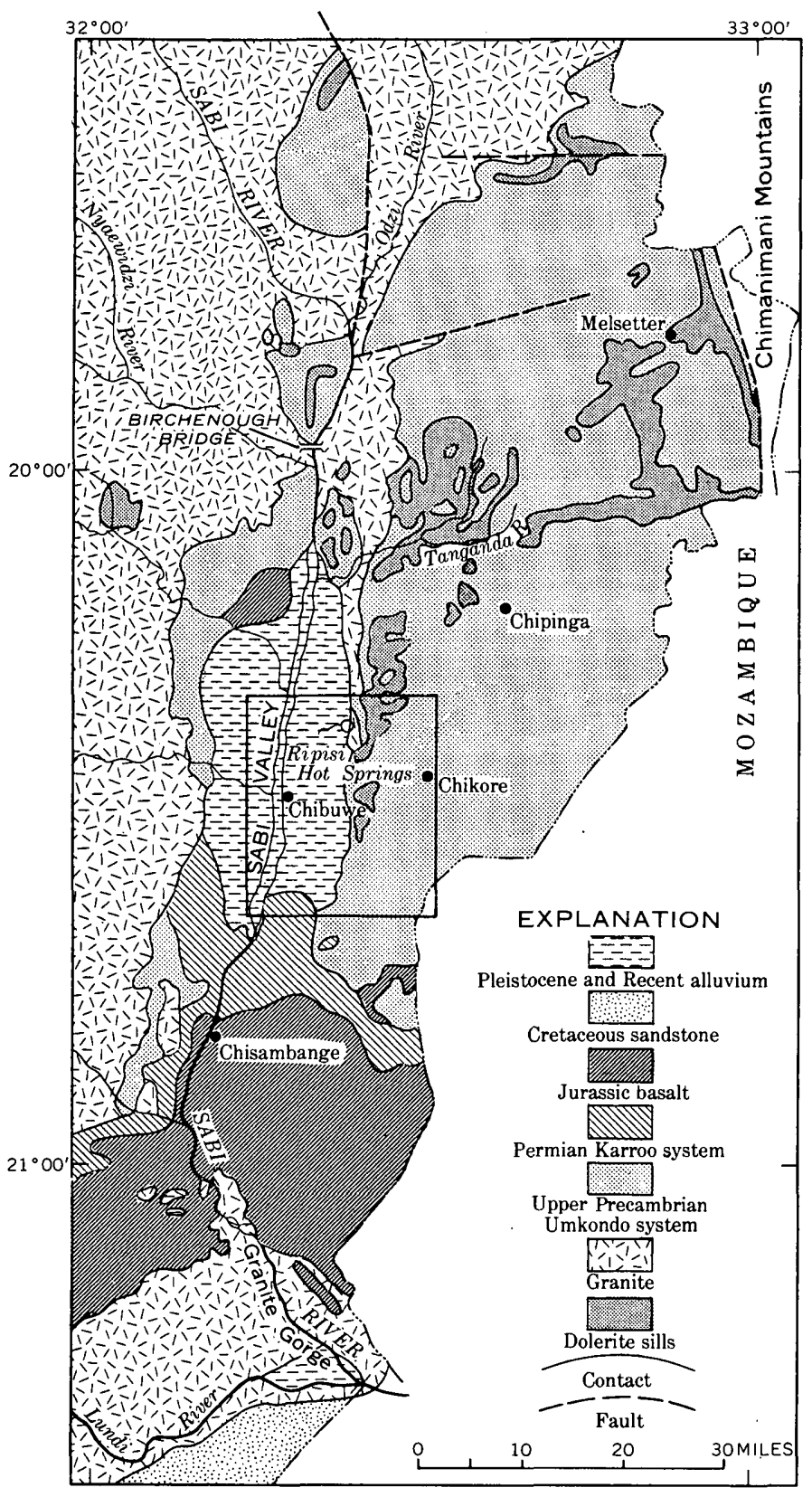

FIGURE 372.1.-Geologic map of southeastern Southern Rhodesia. Generalized from map by Southern Rhodesian Geological Survey. Rectangle in center of map shows area covered by figure 372.2.

Umkondo rocks toward the Sabi Valley, but these rocks are thought to be an effective barrier to any eastward movement of the ground water in the alluvium. The white eolian sandstone of the upper Karroo system crops out as hills near Gumira and is well cemented in surface exposures. However, the cementation may be surficial "case hardening," as some wells obtain their water from the sandstone at depths of 100 feet or less.

The altitudes of the water surfaces in the wells are given on figure 372.2 , and approximate contours on the water table have been drawn where there is sufficient control. It is evident that the water is moving generally southeastward from the Sabi River. However, a mound in the water table occurs along the mountain front in the vicinity of Ripisi Hot Springs from which water moves toward the center of the plain and then southward. The source of ground water which causes this mound is not known, but the water at Ripisi Hot Springs and in the mound may come up along a per: meable fault zone that extends for several miles along the mountain front.

Vertical movement of water in wells is caused by changes in the amount of water in storage and by changes in pressure within the aquifer. Thus far, water levels have been measured only in the dry winter season, and the fluctuation in 10 wells ranged from a few hundredths to about 2 feet. Larger fluctuations are to be expected during the rainy season.

Two areas of recharge are suggested by the watertable map-the Sabi River and the mountain front in the vicinity of Ripisi Hot Springs. Presumably, recharge occurs mostly during the summer rainy season. The surface materials appear to be very permeable every where except in the vlei areas where finer materials have been deposited by flood waters and effectively "puddled" by stock and wild game. Few of the tributary streams have made channels on the plain, presumably because their water seeps into the alluvium.

It is not entirely clear where the ground water from the alluvium is discharged. The general southeastward gradient is rather steep from the 1,350-foot contour line toward the mountain escarpment in the vicinity of "The Gap" of the Mwangazi River. There is no more use of water from wells in that area than those in the rest of the valley, nor is there a marked line of vegetation that could transpire significant amounts of water. Discharge through thick, permeable alluvium in "The Gap" seems unlikely because the Umzilizwi River discharges eastward to a larger river at an altitude as high as the altitude of the water table in the well near "The Gap." It is possible that the water discharges southward somewhere in Mozambique through a permeable fault zone bounding the western edge of the Umkondo rocks, but such a fault zone has not been detected in the rocks of the overlying Karroo system.

The Sabi River loses about 125 cfs of water between Birchenough Bridge and Granite Gorge during lowflow stages, as shown by measurements made by the Hydrological Branch of the Division of Irrigation and Lands. A part of the loss is due to evaporation, but much of it may be ground-water recharge.

More test holes will be necessary, particularly in the area between the scarp'and the Sabi River in the central 


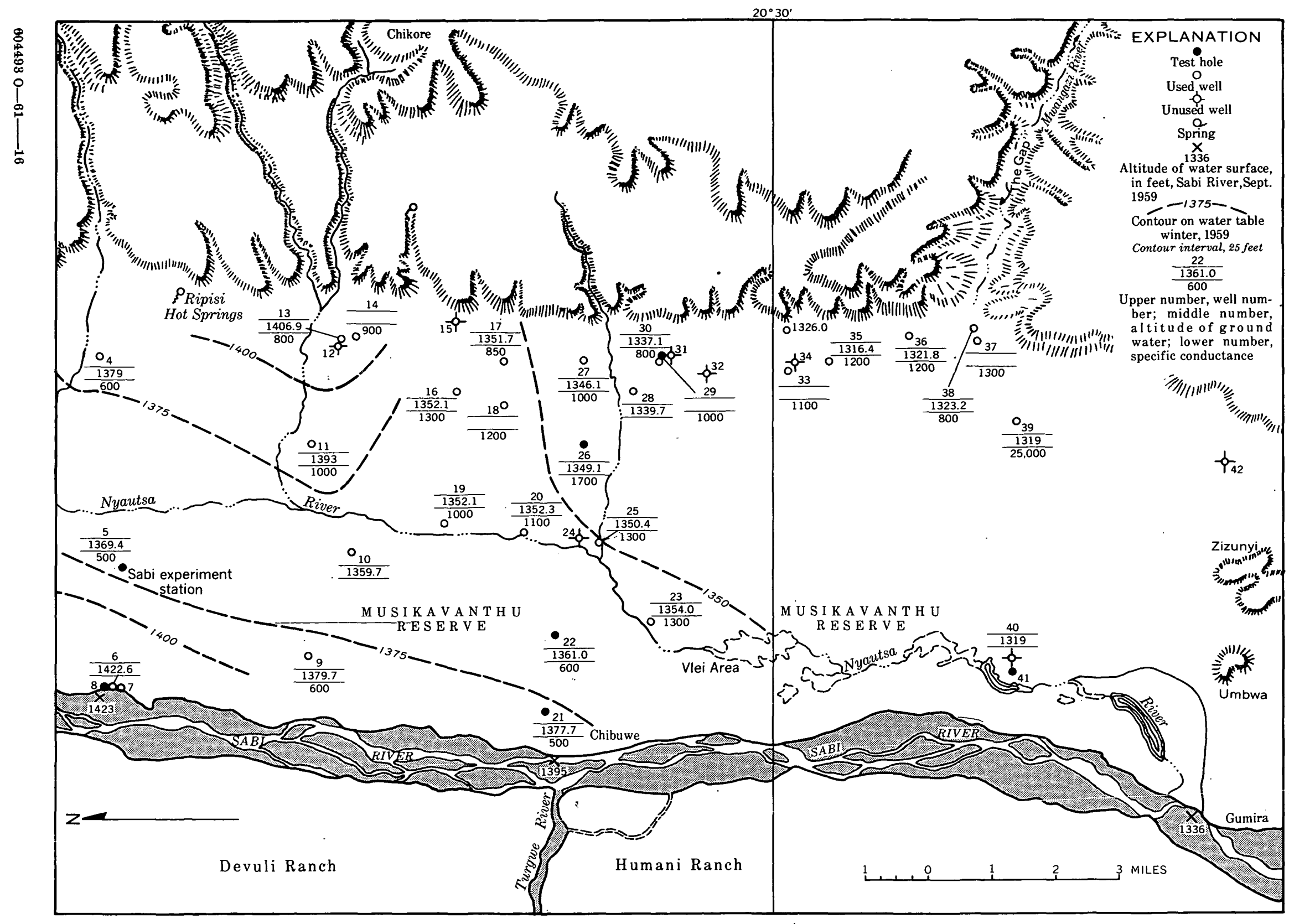

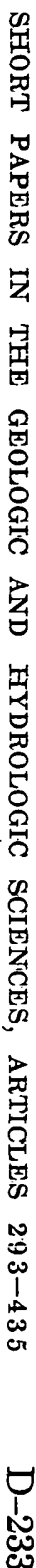

Figure 372.2.-Map of part of Sabi Valley showing ground-water data. 
and southern parts of the area shown on figure $372: 2$ before firm conclusions may be reached on the direction of ground-water movement in the area.

\section{RECOVERY OF GROUND WATER FROM WELLS}

The amount of ground water that might be obtained from wells in the river sand in the Sabi River channel could not be determined in this study, but it is possible to make rough estimates based on tests in similar sand in the bed of the Umzingwani River in western Southern Rhodesia. The coefficient of transmissibility of the sand of the Umzingwani River for a saturated thickness of about 10 feet was about 180,000 gpd (gallons per day) per foot, and the storage coefficient was 0.33 . The sand in the Sabi River channel may have coeffcients in the same order of magnitude. Assuming this and using a water-table gradient of 1 foot per 1,000 feet and a saturated thickness of 30 feet for a cross section of 3,960 feet, it is estimated that the Sabi River sand has an underflow of about $2,138,400 \mathrm{gpd}$, or about $31 / 3 \mathrm{cfs}$, and the amount of water in storage in the Sabi River sand for each mile length of channel is about $206,997,120$ cubic feet, or about 4,500 acre feet. These figures refer to water in storage only and do not take into account recharge that would occur from the Sabi River.

Although these are rough estimates based on inadequate data, they show that the river sand contains a large amount of recoverable water and that this method of calculation can be used when information from test drilling and pumping tests on the river sands are available.

Deeper sands are present not only beneath the river but throughout the valley, and these offer promise of supplying irrigation wells. Test holes drilled during the present investigation indicated good water-bearing sands to a depth of at least 340 feet at the Sabi Experiment Station and to 191 and 296 feet in a section extending from the Sabi River to the escarpment east of Chibuwe. As none of these holes reached the base of the alluvium the total thickness of the water-bearing sands is unknown.

\section{QUALITY OF WATER}

The general chemical quality of the ground water from the wells and springs was determined by 50 analyses. Samples taken from wells near the river are less mineralized than samples from wells near Ripisi Hot Springs, suggesting that infiltration from the river is taking place. Samples from wells along the eastern scarp have only a moderate mineral content, indicating accretions of fresher water from the eastern highland mass.

Water from test hole 39 is very highly mineralized. In the same area, test hole 40 was abandoned as too salty without a sample of water being taken for analysis. The reason for the highly mineralized water in the southern part of the area has not been determined.

PALEONTOLOGY, GEOMORPHOLOGY, AND PLANT ECOLOGY

\title{
373. GEOLOGIC RANGES OF CENOZOIC NONMARINE DIATOMS
}

\author{
By Kenneth E. Lohman, Washington, D.C.
}

The increasing need for making age determinations of a number of Tertiary nonmarine sediments that contain diatoms, frequently as the only available fossils, pointed up the necessity for determining the geologic ranges of the nonmarine diatoms with greater accuracy than previously known. One of the best methods of achieving this would be to collect diatomaceous sediments associated with well-authenticated vertebrate fossils. Accordingly, many vertebrate collecting localities in the Great Basin were visited and sampled for diatoms. Diatoms in adequate abundance were found in many of these localities from which the following were selected as having the best combination of abundant and well-preserved diatoms, well-dated vertebrate faunas, and simple geologic structure, so that the stratigraphic relations of the diatomaceous beds and those carrying vertebrate fossils could be established unequivocally.

1. Lower Virgin Valley beds, Humboldt County, Nev. Age determined as late middle Miocene on the basis of a definitive vertebrate fauna by Merriam (1910).

2. Upper Virgin Valley beds, Humboldt County, Nev. Age determined as late Miocene on basis of vertebrate fauna by Merriam (1910). 
3. Esmeralda formation as exposed on the east flank of Cedar Mountain, Nye County, Nev. Age determined as early Pliocene on the basis of definitive vertebrate faunas by Merriam (1916) and Stirton (1936, 1940). 4. Thousand Creek beds, Humboldt County, Nev. Age determined as middle Pliocene on the basis of extensive vertebrate fauna by Merriam (1910).

5. Hagerman lake beds, near Hagerman, Idaho. Age originally determined as late Pliocene on the basis of extensive vertebrate collections by Gidley (1930, 1931), Gazin (1933-35), and Wilson (1933), but later changed by Gazin and others to early Pleistocene as the result of additional vertebrate collections and a reevaluation of the earlier ones. The early Pleistocene age is also indicated by the nonmarine mollusks studied by Dwight W. Taylor (oral communication, 1960 ) and is in better agreement with field mapping of these sediments by Howard A. Powers (oral communication, 1960).

6. Provo formation in Goshen Valley, Utah County, Utah. Age determined as late Pleistocene $(14,000$ years B.P.) on the basis of carbon-14 measurement by Meyer Rubin (oral communication, 1960).

Collections of diatoms from measured sections at these localities were made either from the vertebratebearing beds directly or from their stratigraphic equivalents a short distance along the strike. At most localities, collections were also made from both below and above the vertebrate-bearing beds. Thus, the vertebrate collections were used as a primary standard with which to date the diatoms in association with them. Over 400 species and varieties of nonmarine diatoms were identified from these collections, of which 85 were described as new.

The results are summarized briefly on figure 373.1, where the width of the vertical columns is proportional to the number of species (indicated by the scale) found in each category. The six columns at the left indicate long-ranging species still represented in living assemblages elsewhere. Although in themselves not definitive for age determination, these long-ranging forms are very useful for paleoecological interpretations. The shorter columns on the right show the distribution of short-ranging extinct species, which are most useful for age determination.

As a result of this study, which is being augmented by the examination of additional well-dated collections, geologic age determinations of strata by means of their contained diatoms can be made more accurately than before.

\section{REFERENCES}

Gazin, C. L., 1933, A new shrew from the upper Pliocene of Idaho: Jour, Mammalogy, v. 14, p. 142-144. 1933, New felids from the upper Pliocene of Idaho: Jour. Mammalogy, v. 14, p. 251-256.

1934, Fossil hares from the late Pliocene of southern Idaho: U.S. Natl. Mus. Proc., v. 83, p. 111-121. 1934, Upper Pliocene mustelids from the Snake River Basin of Idaho: Jour. Mammalogy, v. 15, p. 137-149.

1935, Gravigrade sloth remains from the late Pliocene and Pleistocene of Idaho: Jour. Mammalogy, v. 16, p. 52-60. 1935, A new antilocaprid from the upper Pliocene of Idaho: Jour. Paleontology, v. 9, p. 390-393.

Gidley, J. W., 1930, A new Pliocene horse from Idaho: Jour. Mammalogy, v. 11, p. 300-303.

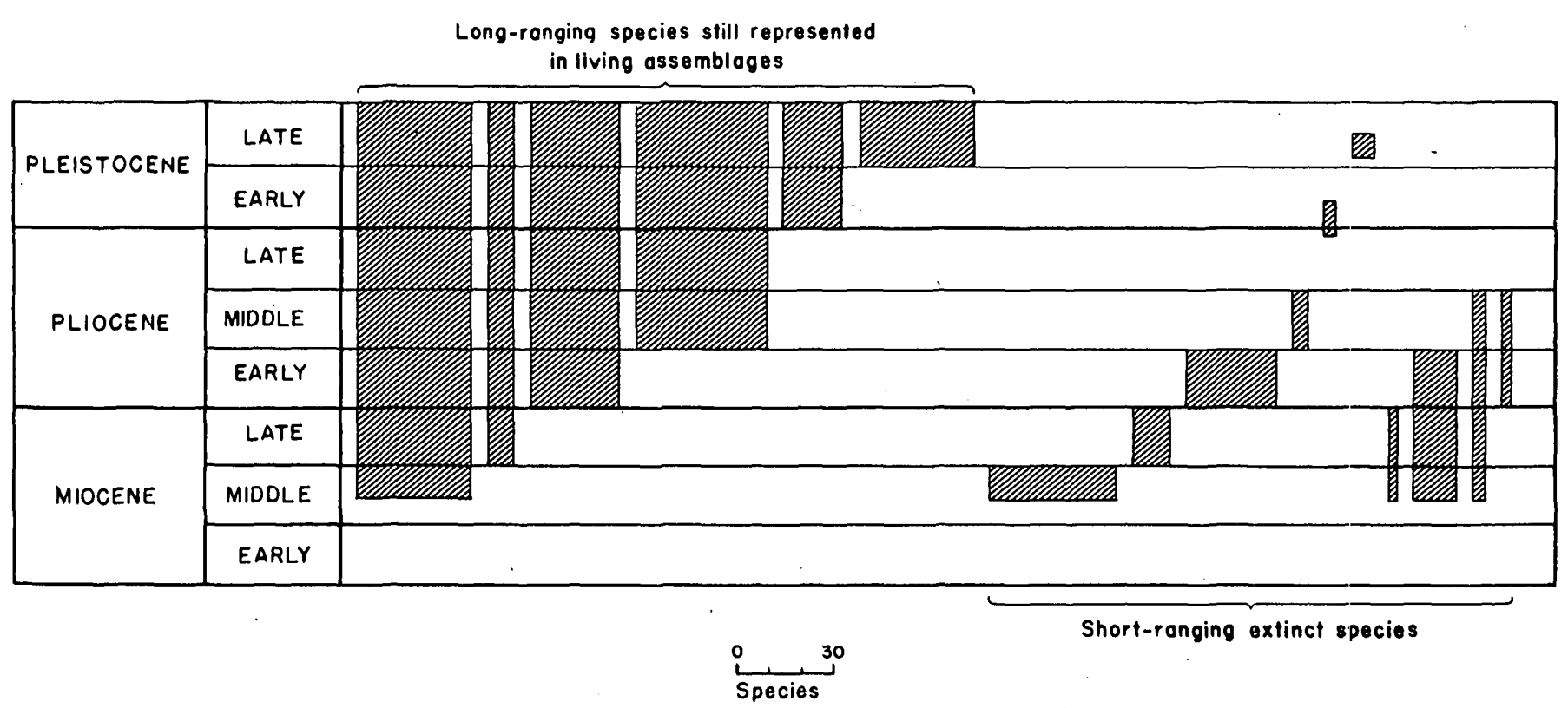

Frguke 373.1.-Geologic ranges of Cenozoic nonmarine diatoms. 
Gidley, J. W., 1931, Continuation of the fossile horse round-up on the Old Oregon Trail: Smithsonian Inst. Explor. and Field Work in 1930, p. 33-40.

Merriam, J. C., 1910, Tertiary mammal beds of Virgin Valley and Thousand Creek in northwestern Nevada: California Univ. Dept. Geol. Sci. Bull., v. 6, p. 21-53.

— 1916, Tertiary vertebrate fauna from the Cedar Mountain region of western Nevada: California Univ. Dept. Geol. Sci. Bull., v. 9, p. 161-198.
Stirton, R. A., 1936, Succession of North American continental Pliocene mammalian faunas: Am. Jour. Sci., 5th ser., v. 32, p. 161-206.

1940, The Nevada Miocene and Pliocene mammalian faunas as faunal units: Pacific Sci. Assoc., 6th Pacific Sci. Cong. Proc., v. 2, p. 627-640.

Wilson, R. W., 1933, A rodent fauna from later Cenozoic beds of southwestern Idaho: Carnegie Inst. Washington Pub. no. 440, p. 117-135.

\section{EARLY CRETACEOUS (MIDDLE NEOCOMIAN) MICROFOSSILS IN SOUTH-CENTRAL ALASKA}

By Harlan R. Bergquist, Washington, D.C.

A small microfauna of middle Neocomian age has been found in rocks associated with the Nelchina limestone in the Talkeetna Mountains, south-central Alaska. This is the second record of Foraminifera of middle Neocomian age in North America-one foraminifer has been described from rocks of Hauterivian age near Coahuila, Mexico (Loeblich and Tappan, 1952).

The microfossils were found in a few samples that were collected by Arthur Grantz and Leo Fay from silty shale beds within and below the Nelchina limestone at five localities along Tyone Creek and along tributaries to Bubb and Billy Creeks (fig. 374.1). The microfauna consists largely of calcareous Foraminifera and a few species of Radiolaria, and in addition 2 species of ostracodes were found in 2 samples. The Foraminifera consist of 17 species of lagenids, 1 rotalid species; and

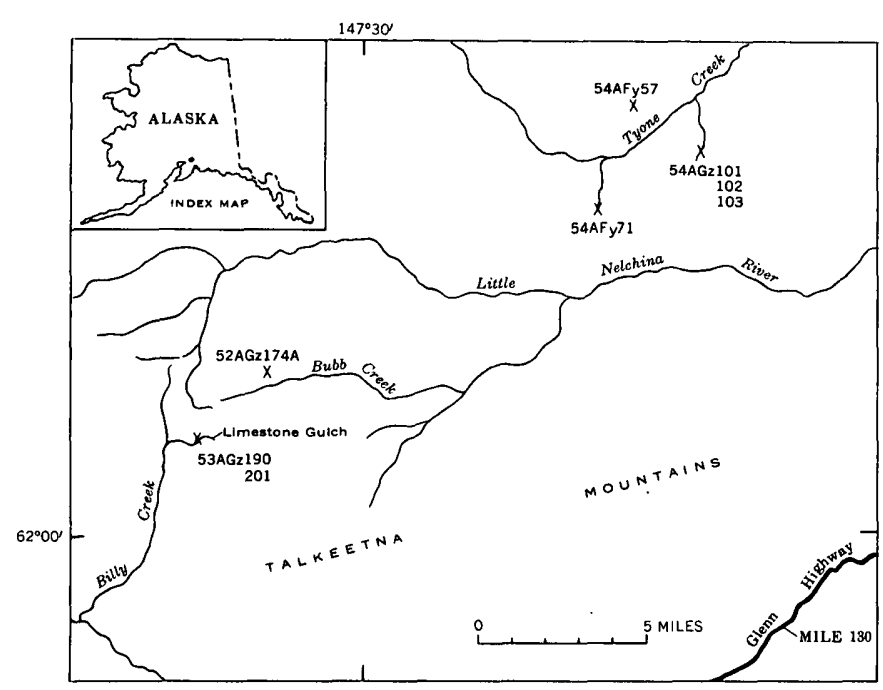

FIguRE 374.1.-Location of Lower Cretaceous microfossil collections from Nelchina limestone (Neocomian age), south-central Alaska.
1 agglutinate species. Some of the Foraminifera appear to be the same as species described from rocks of middle Neocomian (Hauterivian) age of Glanerbrug, Netherlands (ten Dam, 1946, 1948).

Three of the samples were collected from an area south of the Little Nelchina River. Collection 52AGz174A (fig. 374.1) came from silty partings in massive Nelchina limestone on a north tributary of Bubb Creek, 3.38 miles S. $21^{\circ} 30^{\prime}$ E. of the main headwater fork of the Little Nelchina River. The Nelchina limestone there overlies a sandstone unit containing Buchia crassicollis (Keyserling) of middle Valanginian age as identified by Ralph Imlay (Grantz, 1953). The sample yielded 6 species of Foraminifera, including 2 that are common to abundant. Two collections (53AGz190 and 53AGz201) were made at Limestone Gulch, a tributary of Billy Creek, about 23/4 miles southwest of the locality on Bubb Creek. Collection $53 \mathrm{AGz} 190$ from a siltstone unit immediately below the Nelchina limestone contained 14 species of Foraminifera; 4 were common to abundant. Collection 53AGz201, from a silty parting within the Nelchina limestone, yielded 15 species of Foraminifera, the most found in any of the samples. Six of the species are common to abundant.

Other collections (54AGz101, 102, 103, and 54AFy57 and 71) were made from rocks associated with the Nelchina limestone along tributaries of Tyone Creek, north of the Little Nelchina River (fig. 374.1). Foraminifera from these are similar to those in the other collections, but the samples yielded fewer species; only 2 species were common to abundant in 2 of the collections. Three of the collections (54AGz102 and 103, and 54AFy71) had abundant specimens of Radiolaria.

Because only a few microfossil samples have been obtained from these Early Cretaceous rocks associated 
with the Nelchina limestone, and additional samples could not be collected readily, only tentative identifications have been made of the fossils as shown in table

TARLE 374.1.-Distribution of microfossils in samples from Early Cretaceous (Neocomian) strata, south-central Alaska

(Numbor of specimons nro given if less then 12 were found; $C$, common (12 to 25 specimons); $A$, abundant (25 to 50 specimens); V, very abundant (more than 50 specimons found); (, fragment]

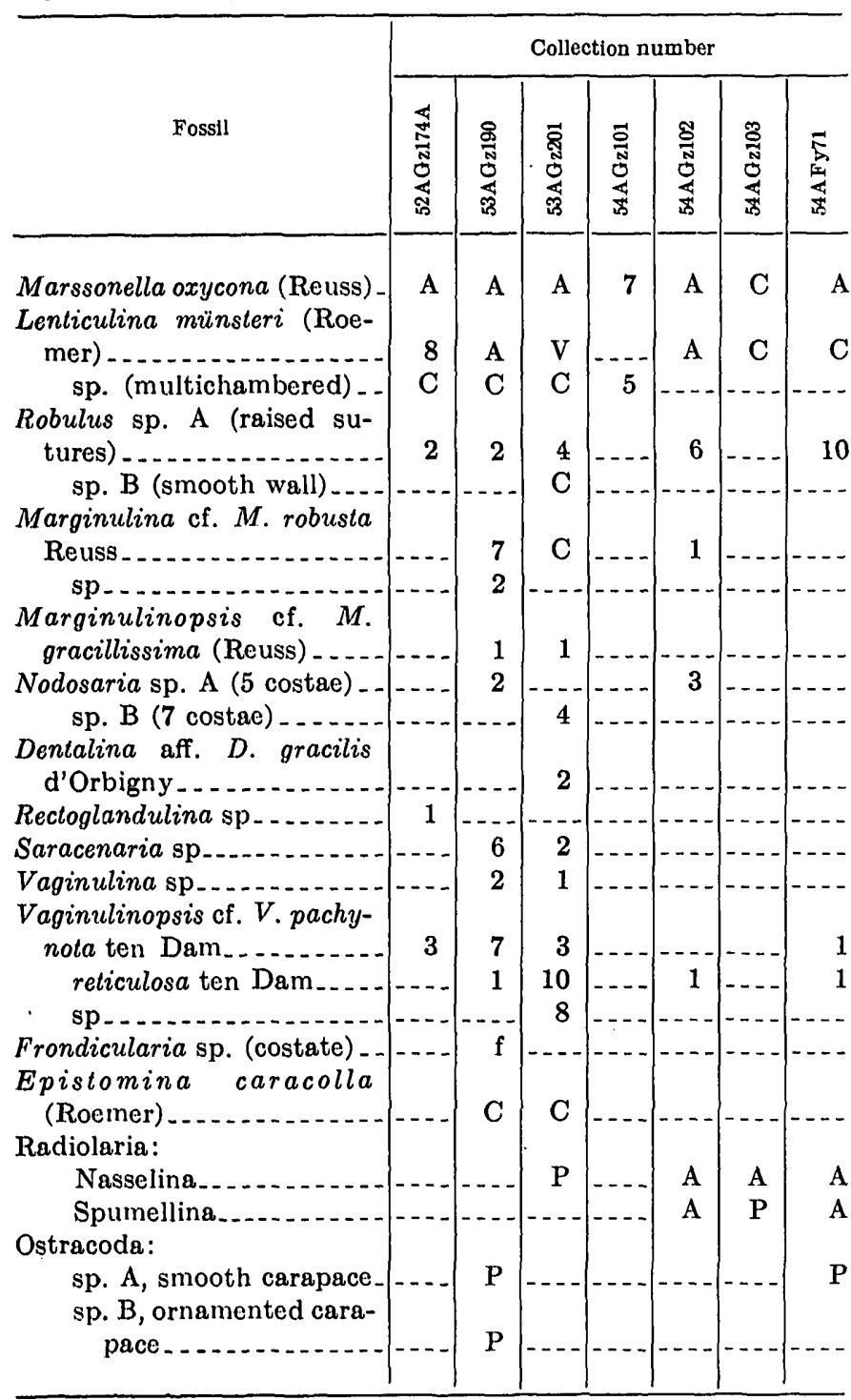

374.1. Of the Foraminifera, the following were common or abundant in one or more samples: Marssonella oxycona (Reuss), Lenticulina cf. L. münsteri (Roemer), Lenticulina sp., Robulus sp. B, Marginulina cf. $M$. robusta Reuss, and Epistonina caracolla (Roemer). Some of these are the same species that have been found in rocks of middle Neocomian age in Germany, England, and near Glanerbrug, Netherlands. Two species, Vaginulinopsis cf. V. pachynota ten Dam and Vaginulinopsis reticulosa ten Dam, though of relatively rare occurrence, appear to be the same as forms described from middle Neocomian rocks in the Glanerbrug, Netherlands area (ten Dam, 1946).

Radiolaria in these samples are nasselline and spumelline forms belonging to the Stichocorythidae, Triacartidae, and Liosphaeridae. Specimens are large, and most have been somewhat distorted by compression. Stichocorythidian forms which may be species of Dictyomitra? and Cyrtocapsa? are most abundant. Spumelline forms are represented only by Liosphaeridae, which seem to be entirely cenosphaerids and cenodiscids. The Radiolaria in collection 54AGz102 are cenosphaerids and stichocorythidian forms and are preserved as incomplete glauconitic casts. Collection 53AGz201 has a few glauconitic casts of stichocorythidian forms.

Strata of Neocomian age in south-central Alaska have not been extensively sampled for microfossils; it is intended here only to call attention to their presence in these rocks. The Foraminifera are of particular interest as little is known about this group of organisms in the earliest Cretaceous rocks of North America.

\section{REFERENCES}

Grantz, Arthur, 1953, Preliminary report on the geology of the Nelchina area, Alaska: U.S. Geol. Survey open-file report. Loeblich, A. R., Jr., and Tappan, Helen, 1952, The Foraminiferal genus Triplasia Reuss, 1854: Smithsonian Misc. Coll., v. 117 , no. 15 , p. 15 , pl. 2, figs. 21,22 .

ten Dam, Abraham, 1946, Arenaceous Foraminifera and Lagenidae from the Neocomian (Lower Cretaceous) of the Netherlands: Jour. Paleontology, v. 20, no. 6, p. 570-577.

1948, Foraminifera from the middle Neocomian of the Netherlands: Jour. Paleontology, v. 22, no. 2, p. 175-192. 


\section{LATE PERMIAN AMMONOIDS IN THE INYO RANGE, CALIFORNIA, AND THEIR SIGNIFICANCE}

By Mackenzie Gordon, Jr., and Charles W. Merriam, Washington, D.C.

Three collections from the upper part of the Owens Valley formation in the Inyo Range contain Late Permian armmonoids associated with "Punctospirifer" pulcher (Meek) and Neospirifer'pseudocameratus (Girty). The material was collected by M. W. Ellis during the mapping of the New York Butte quadrangle by W. C. Smith and C. W. Merriam. All three of the localities are high on the west slope of the range and within an area less than a mile square, 5 to 6 miles northwest of Cerro Gordo. They are reached from Swansea by the old Salt Company road, now a jeep trail, and lie within half a mile southeast of the abandoned salt tramway.

The rock matrix of these collections is a partly metamorphosed siliceous limestone, somewhat conglomeratic, containing small granules and pebbles, mostly of chert. The fossils are silicified, generally distorted or fragmental, and poorly preserved for the most part, but the principal elements of the sutures of the ammonoides can be distinguished. Stacheoceras occurs in all three collections and Xenaspis and Timorites in one of them. The fossils are listed in the table below.

\begin{tabular}{|c|c|c|c|}
\hline \multirow{2}{*}{ Species } & \multicolumn{3}{|c|}{$\begin{array}{l}\text { Late Paleozoic } \\
\text { Collection No. }\end{array}$} \\
\hline & 17706 & 17710 & 17711 \\
\hline Triticites or Schwagerina sp $_{-}$ & $x$ & & \\
\hline Schwagerina or Parafusulina sp & $x$ & 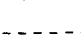 & \\
\hline Fenestrate bryozoan, genus indet & $x$ & $x$ & \\
\hline Leioclema? sp & . & $x$ & $\cdots$ \\
\hline Schuchertella? sp. & $x$ & & -- \\
\hline Productid brachiopod & $\ldots$ & $\cdots$ & $x$ \\
\hline Cancrinella cf. C. phosphatica (Girty) & . & $\cdots$ & $x$ \\
\hline Dielasmid brachiopod & $\ldots$ & $\ldots$ & $x$ \\
\hline Rhynchopora taylori Girty & $x$ & $x$ & $x$ \\
\hline Wellerella cf. W. rotunda Cooper..... & & $x$ & $x$ \\
\hline Welleralla? cf. W. hemiplicata Cooper & $x$ & & \\
\hline "Punctospirifer" pulcher (Meek) & $x$ & $x$ & $x$ \\
\hline Neospirifer pseudocameratus (Girty) . & & $x$ & $x$ \\
\hline Crinoid columnals $\ldots \ldots \ldots$ & $x$ & & $x$ \\
\hline Schizodus sp_................. & $x$ & & -. \\
\hline Bellerophontid gastropods $\ldots \ldots$ & $x$ & $x$ & $x$ \\
\hline Omphalotrochid gastropod & & & $x$ \\
\hline Mooreoceras? sp & $x$ & & \\
\hline Stearoceras aff. S. phosphoriense (Branson) & & & $x$ \\
\hline Xenaspis aff. $X$. carbonarius (Waagen) & $\ldots$ & & $x$ \\
\hline Stacheoceras aff. S. antiquum (Waagen) -. - & $?$ & $?$ & $x$ \\
\hline Timorites cf. T. uddeni Miller and Furnish & & & $x$ \\
\hline Ammonoid indet $\ldots \ldots$ & $x$ & & \\
\hline Fish $\ldots$ & $x$ & & $x$ \\
\hline
\end{tabular}

The fusulinids, which were identified by R. C. Douglass, are reworked Early Permian types. The ammonoids are mostly fragmental and certainly did not live precisely where they are now found. The more common brachiopods, however, because of their relative abundance and entirety, appear to be now buried approximately where they lived. Merriam and Hall $(1957$, p. 11) have recognized three paleontologic zones in the Owens Valley formation, in descending order as follows :

\section{Neospirifer pseudocameratus zone \\ 2. Parafusulina zone \\ 1. Pseudoschwagerina zone}

The present assemblage belongs in the uppermost of these zones.

The brachiopods are representatives of the ubiquitous "Punctospirifer" pulcher fauna which occurs also in the the Retort phosphatic shale and Tosi chert members of the Phosphoria formation in southeastern Idaho, and the Franson and Ervay carbonate rock members of the Park City formation in northeastern Utah, as well as the Gerster formation of western Utah and eastern Nevada (Williams, 1959). These beds generally have been considered in the past to correlate with the Word formation of west Texas.

The ammonoids Xenaspis and Timorites, however, are genera that first appear in Late Permian time and are characteristic of the Timorites zone (Miller and Furnish, 1940, p. 29) that is best known from the Capitan limestone of west Texas and Coahuila, Mexico, and from the Amarassi beds of Timor. The Stacheoceras is an advanced form probably of rather late Permian age.

The occurrence of these Upper Permian ammonoids in the Inyo Range is of significance in dating the upper part of the Owens Valley formation. Their association with the "Punctospirifer" pulcher fauna suggests that these brachiopods may have a higher stratigraphic range than heretofore established. But the specter of reworking of at least some of the fossils cautions against drawing too firm conclusions without further study.

\section{REFERENCES}

Merriam, C. W., and Hall, W. E., 1957, Pennsylvanian and Permian rocks of the southern Inyo Mountains, California : U.S. Geol. Survey Bull. 1061-A, 13 p. 
Miller, A. K., and Furnish, W. M., 1940, Permian ammonoids of the Guadeloupe Mountain region and adjacent areas: Geol. Soc. America Spec. Paper no. 26, 242 p.

Williams, J. S., 1959, Fauna, age, and correlation of rocks of Park City age, in McKelvey, V. E., and others, The Phosphoria, Park City, and Shedhorn formations in the western phosphate field: U.S. Geol. Survey Prof. Paper 313-A, p. 36-41.

4

\section{A STRATIGRAPHICALLY SIGNIFICANT ASSOCIATION OF SMALLER FORAMINIFERA FROM WESTERN FLORIDA}

By S. M. Herrick, Atlanta, Ga.

The Foraminifer Marginulina vacavillensis (Hanna) has been found in subsurface strata of Lisbon age in western Florida. This fossil, originally described from the United States west coast (Hanna, 1923, p. 324), was observed in wells where it occurs with Robulus inornatus (d'Orbigny) and Robulus alato-limbatus (Gümbel), and, at several localities, with Robulus pseudovortex Cole. These localities are in Santa Rosa, Escambia, and Okaloosa Counties.

Fisk $(1940$, p. 133 , pls. 3-5) reported Hemicristellaria (?) nudicostata [ = Marginulina vacavillensis] as a guide fossil for the Cane River formation in Louisiana. The writer has noted Marginulina vacavillensis together with Robulus inornatus and Robulus alatolimbatus in the middle part of the Cane River formation from two wells in Natchitoches Parish, La. Like- wise these three species, and at some places a fourth species, Robulus pserdovortex, have been used by the writer as subsurface guide fossils for the Winona sand in areas throughout the major part of the Tertiary sediments in Mississippi. The finding of these four fossils in western Florida constitutes another occurrence of this association in the United States Gulf Coast. Such an association should prove useful in identifying and correlating strata of late middle Eocene age in the Southeast.

\section{REFERENCES}

Fisk, H. N., 1940, Geology of Avoyelles and Rapides Parishes [La.]: Louisiana Dept. Conserv., Geol. Survey Bull. 18, $240 \mathrm{p}$.

Hanna, G. D., 1923, Some Eocene Foraminifera near Vacaville, California: California Univ. Dept. Geol. Sci. Bull., v. 14, no. 9, p. 319-328. 
By C. P. Zones, Honolulu, Hawaii

Work done in cooperation with the State of Hawaii

The Waianae district in western Oahu, Hawaii, is bounded on the west by the sea and on the north, east, and south by the crest of the Waianae Range, whose maximum altitude is a little more than 4,000 feet. Westward-trending spurs of the mountain range divide the area into five large valleys and several smaller ones (fig. 377.1). Rocks comprising the mountain range are mainly lava flows; terrestrial and marnue sedimentary rocks of unknown thickness underlie the valleys. The semiarid coastal areas receive less than 20 inches of rain a year, whereas the humid mountainous areas receive 70 to 100 inches a year.

Potable ground water occurs principally in a GhybenHerzberg lens, which floats on sea water in the underlying saturated rocks that occur below sea level, and also in compartments partly or entirely bounded by relatively impermeable dikes in the volcanic rocks (fig. 377.2). The water level within the dike compartments is higher than in the Ghyben-Herzberg lens and may be higher or lower than the water level in adjoining compartments. Ground water within the compartments moves slowly into adjoining compartments or down into the Ghyben-Herzberg lens. Discharge from the compartments also takes place by spring flow, by discharge into streams, probably by evapotranspiration, and by artifical withdrawal.

Ground water in the Ghyben-Herzberg lens moves seaward at a gradient that ranges from less than 2 feet to about 10 feet per mile. An unknown quantity of ground water discharges into the sea by diffusion or mixing in the transition zone between fresh water and sea water and perhaps also by discharging directly into the sea. A small part of the water is discharged from wells and a part discharges into lower reaches of stream channels, but discharge of ground water by these means accounts for only a small fraction of the estimated total annual recharge.

Water-level records in two wells indicate that a substantial quantity of ground water in the Waianae district returns to the atmosphere by evapotranspiration. These records show a daily rise and fall of the water table that is typical of areas where evapotranspiration takes place from the water table or from the capillary fringe above it. The records were obtained from Oahu dug well 1 and from test well T-76 (fig. 377.1). Evaporation from the capillary fringe occurs at a few places, but the areas are too small to account for the daily rise and fall of the ground-water level.. It is apparent that discharge of ground water must be effected by phreatophytes.

The dominant types of vegetation in the immediate areas of the two wells are koa haole (Leucaena glauca) and algaroba, or kiawe (Prosopis chilensis). Koa haole becomes dormant and dries out during periods of little or no rain, but turns green for several days after a heavy rain. Algaroba, which is a close relative of the mesquite common to the arid southwestern parts of the conterminous United States, appears to be unaffected by prolonged dry periods, except at altitudes of several hundred feet above sea level. As there are no other plants growing in sufficient profusion. in the area to affect water levels appreciably, it is concluded that algaroba is the plant principally responsible for the daily fluctuation of the water table.

In the Waianae district, the heaviest growth of algaroba is on the coastal lowlands, where the water table is less than 10 or 15 feet below the land surface. There, algaroba grows to heights of 35 to 40 feet and has an areal density of 80 to 100 percent. At increasingly higher altitudes, the algaroba becomes smaller and koa haole becomes dominant. At the highest altitudes at which algaroba grows it is stunted and has an areal density of not more than about 20 percent. Its distribution, density, and height are shown on figure 377.1. The upper limit of its growth, except for isolated trees or small groups of trees, is at about 400 feet above sea level in Makaha, Waianae, Lualualei, and Nanakuli Valleys, and about 200 feet above sea level elsewhere in the Waianae district. At the higher altitudes the depth to the permanent ground-water body may be nearly 400 feet, except where these areas are underlain by ground water in dike aompartments. The latter condition occurs in upper Waianae Valley, where the depth to water in the areas of algaroba growth is generally less than 200 feet. The condition may exist also in other areas. It is not known to what depth the roots of algaroba can penetrate. Possibly much of the algaroba growing at higher altitudes subsists on soil moisture or on small perched ground-water bodies that are depleted during periods of drought. This may account for the observed wilting of the algaroba at the higher altitudes during dry periods.

Algaroba apparently has a high salt tolerance, for 


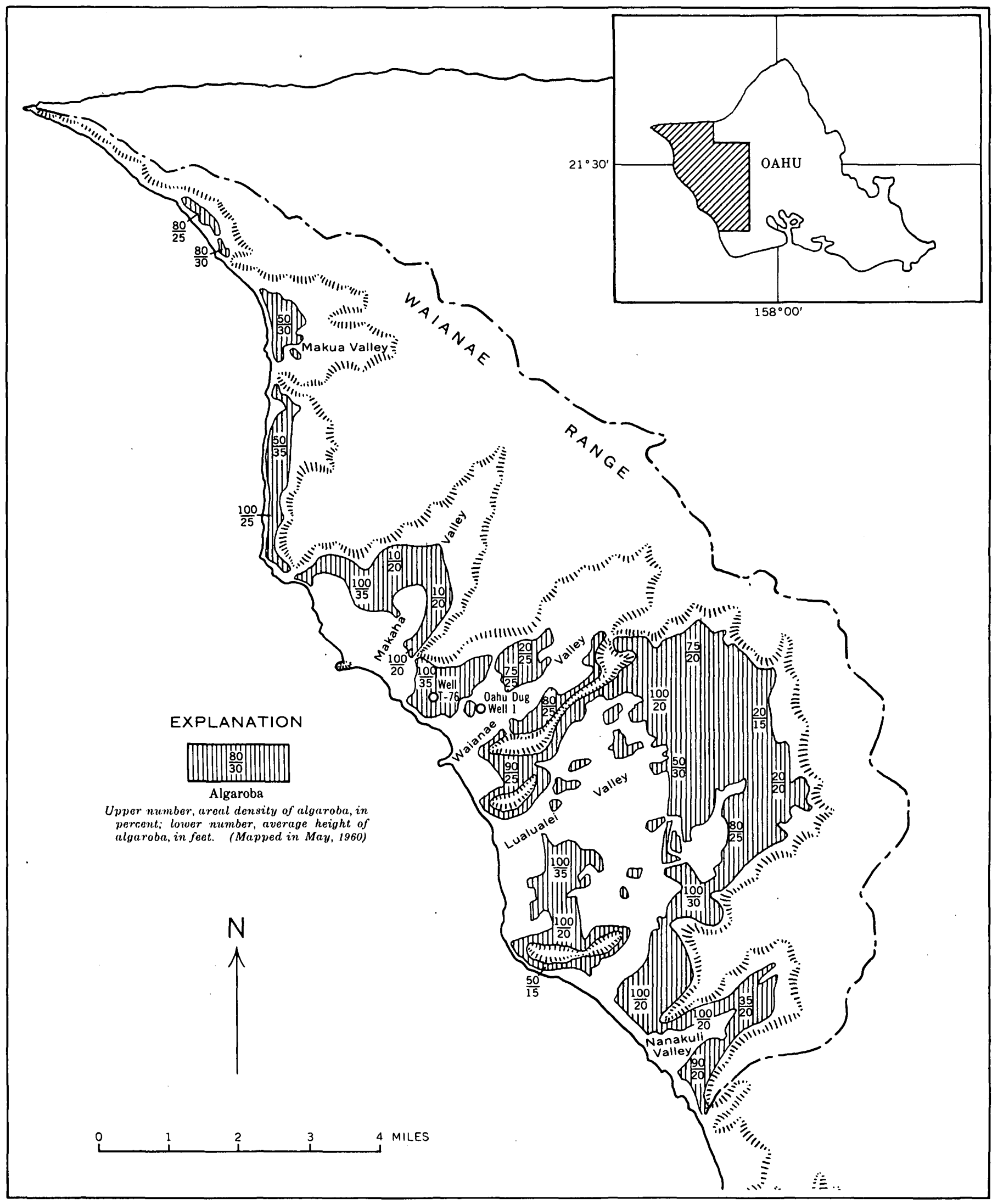

Froure 377.1.-Map of the Waianae district, Oahu, Hawaii, showing geographic features of the area and the distribution of algaroba. 


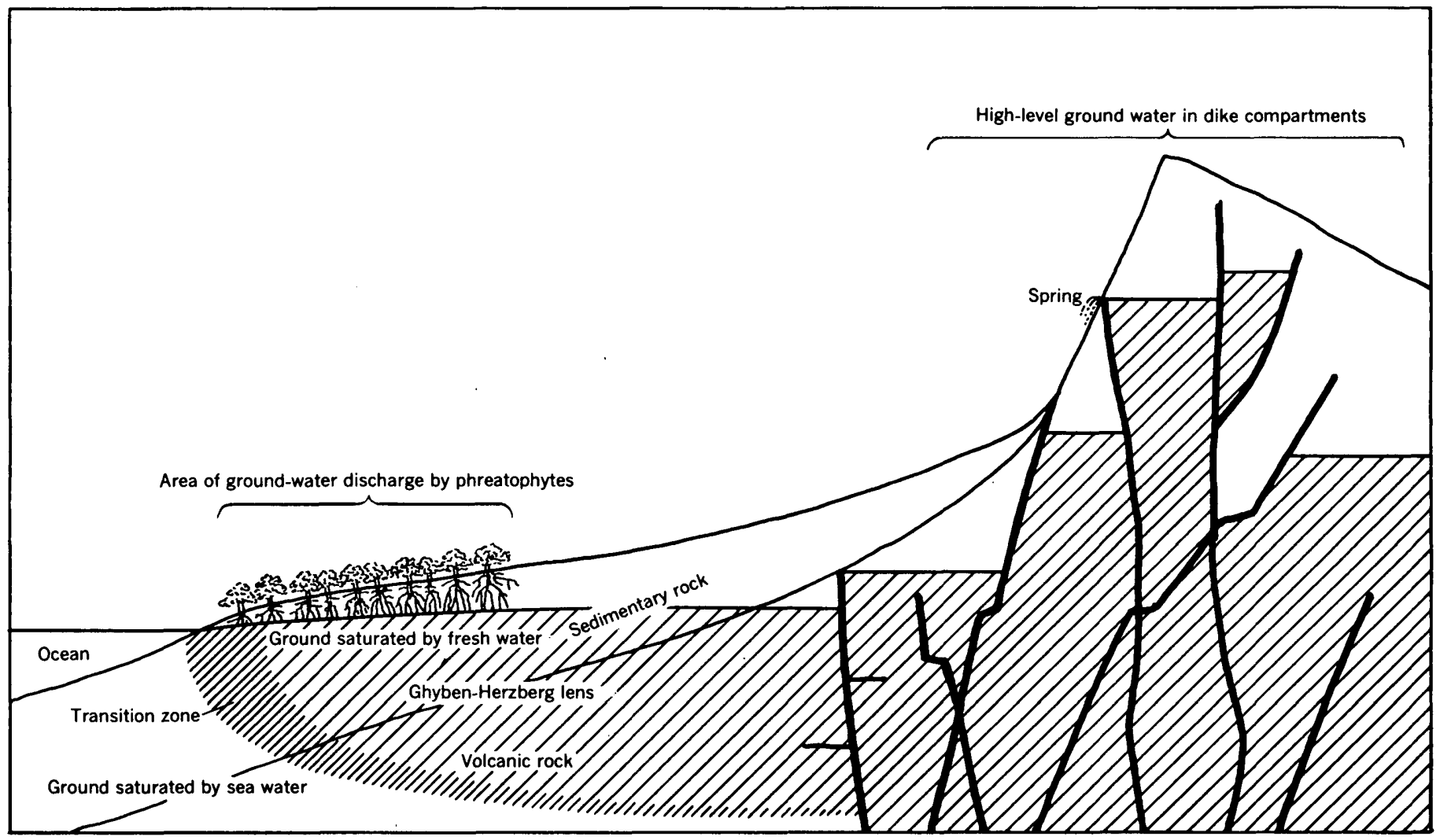

FigURE 377.2.-Diagrammatic section illustrating the occurrence of ground water in the Waianae district, Oahu, Hawail. Wide black lines represent relatively impermeable dikes.

it grows luxuriantly where the ground water contains more than $1,000 \mathrm{ppm}$ (parts per million) chloride, and there is a dense stand of algaroba even in the vicinity of well T-76, where the water at the top of the lens contains more than $5,000 \mathrm{ppm}$ chloride.

The amount of ground water used by algaroba in
Hawaii has not been determined. However, a preliminary estimate of ground-water recharge in the Waianae district as compared to known and estimated quantities discharged by means other than transpiration by phreatophytes indicates that discharge of ground water by algaroba is a major factor in the water budget.

378. DEFLATION IN BUENA VISTA VALLEY, PERSHING COUNTY, NEVADA

By Robert E. Wallace, Menlo Park, Calif.

Work done in cooperation with the Nevada Bureau of Mines

Buena Vista Valley is in central Pershing County, Nevada. Its lowest part, altitude approximately 4,035 feet, is 25 miles east of Lovelock, Nevada, and 57 miles southwest of Winnemucca. The area of the entire valley is about 400 square miles, and that of the nearly flat central valley floor is about 50 square miles.
Buena Vista Valley is one of the numerous basins in Nevada having no external drainage, and represents a graben between two horst mountains, the Humboldt and East Ranges. Unconsolidated sediments have accumulated in this graben, and gravity measurements by Don R. Mabey (oral communication) indicate that 
these sediments are at least 8,000 feet thick. Most of this material probably accumulated during Plioeene and Pleistocene time.

Lake sediments of Pleistocene Lake Lahontan are the youngest major deposits in the basin. The lake, which stood at about 4,370 feet (R. B. Morrison, written communication, 1958) in mid-Wisconsin time, dried up completely during the warm, arid Altithermal age (of Antevs), some 7,000 to 4,000 years ago; and subsequently during the somewhat moist Medithermal age (of Anters) there were only very shallow, comparatively temporary lakes (R. B. Morrison, written communication, 1961). In modern times the basin has been dry except after unusually heavy rain, when the lowest part of the basin is covered by a sheet of water, a few inches to a few feet deep.

This setting might suggest continuing accumulation of playa deposits in Buena Vista Valley, but such is not the case. The total balance appears to be one in which degradation outstrips aggradation, and the present relatively flat floor of the valley is not primarily a surface of playa deposition, but rather a surface formed by deflation down to a resistant clay bed of late Lake Lahontan age.

Especially good evidence for this interpretation can be seen in a gullied area along the southern margin of the central valley floor near lat $40^{\circ} 07.5^{\prime} \mathrm{N}$. and long $118^{\circ} 03^{\prime} \mathrm{W}$. where the upper sediments of Lake Lahontan are well exposed in sections (see figs. 378.1 and

N

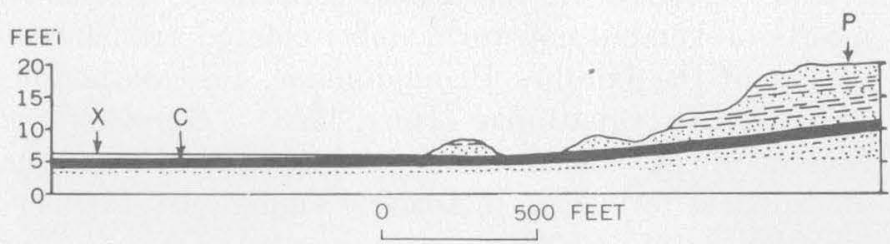

Figure 378.1.-Diagrammatic section across margin of central valley floor of Buena Vista Valley. Shows deposits dissected down to deflation-resistant clay bed (C) ; salt-expanded layer (X) over clay bed; and locality (P) of photograph (fig. 378.2 ). Scales are approximate.

378.2). Here a distinctive bed of tough greenish highly saline clay is exposed, overlain by 10 to 15 feet of other sediments that are less resistant. The latter are lacustrine, alluvial, and eolian silts and sands, mostly thin bedded and lenticular, that are progressively more eroded toward the playa, so that over the central valley floor the resistant clay bed is either at or within 10 inches of the surface.

A long low ridge, trending northeast, is situated along a medial line of the valley bottom. This ridge

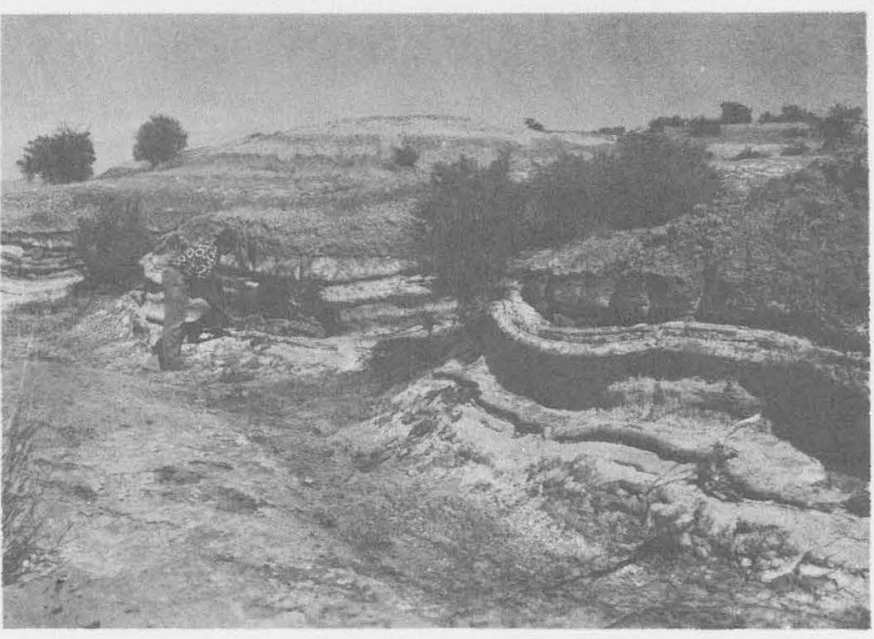

Figure 378.2.-Photograph showing exposure of deflationresistant clay bed (between about waist and shoulder height of man). This exposure is in a gulch near the southern margin of the central valley floor of Buena Vista Valley. Note the thickness of deposits overlying the clay bed, which have been deflated from most of the central valley floor.

is about 10 feet high, one-half to one mile wide, and several miles long. The lacustrine deposits within this ridge are interpreted as sediments stratigraphically higher than the resistant clay bed, and the ridge thus also represents a remnant not yet eroded from the valley bottom.

The green clay bed has great water-retention power; it was moist within 2 inches of the surface in the area of figure 378.2, even in late August of a very dry year several months after a rain. The clay has the general consistency of modeling clay, and consequently, effectively resists wind erosion.

In almost every area bordering the central valley floor, down-cutting by either stream erosion or deflation seems to dominate. Material eroded by streams from the marginal areas, of course, must be deposited in the valley bottom, but little material of this sort can be found there. On aerial photographs taken in 1952, large amoeboid-shaped patches, which represent deposition by individual floods, can be seen on the central valley floor. In 1957 some of these deposits were examined and found to be made up of clay- and silt-size material in a thin layer generally less than a quarter inch thick. In 1960 the author flew over the valley, and found that these same amoeboid-shaped patches had become very obscure, but other patches from more recent rains could be identified.

Since Lake Lahontan time, alluvial sand and gravel from the highland washes have been deposited largely in the middle and upper parts of the old pre-Lake Lahontan fans, but the younger alluvium constitutes only a fraction of one percent of the total volume of 
the fans. Alluvial deposition of sand and gravel on the central valley floor is negligible.

Material that is deposited over the resistant green clay is wetted during the rainy months of the year, and salt from underlying deposits becomes dispersed throughout. During the dry months the material dries out, and salt crystals grow and expand the material into a loose "sand" made up of salt crystals, silt, and clay-size particles. Most of the surface of the central valley floor is underlain by 6 to 12 inches of such saltexpanded silt and clay. In many places a hard crust of salt develops over the loose "sand", but where the crust does not develop, the salt-expanded silt and clay are loose and very susceptible to wind erosion.

On almost any summer day there is scarcely a moment when whirlwinds or "dust devils" can not be seen to be actively eroding the playa, and very frequently enormous dust clouds can be seen rising from it and being blown eastward.

In summary, although Buena Vista Valley contains more than 8,000 feet of late Cenozoic sediments, now more material is being carried away than is accumulating. Deflation appears to be the dominant process in the erosion.

\section{OSTRACODES AND CONODONTS FROM THE GETAWAY LIMESTONE MEMBER OF THE CHERRY CANYON FORMATION (PERMIAN), TEXAS}

By I. G. SoHs, Washington, D.C.

A limestone sample (USGS loc. 12856-PC), from Culbertson County, Tex., was digested with acetic acid and yielded abundant silicified ostracodes and some conodonts. Associated forms include fragments of larger fossils, sponge spicules, fusuline Foraminifera, biserial and coiled smaller Foraminifera, Bryozoa, fish teeth, and one fragment of a trilobite. These are the youngest Permian ostracodes and conodonts known to date in the United States. A second collection (USNM. loc. 712) from the same general locality, when treated with hydrochloric acid by G. A. Cooper, yielded the same ostracode faunule, but no conodonts.

Previous to these finds, the youngest Permian ostracodes that had been described (Hamilton, 1942; Sohn, $1950,1954)$ were reported from the uppermost limestone of Leonard age or lowermost limestone of Word age of the Glass Mountains, Tex. (USNM loc. 703c). Conodonts were not recovered from this locality, probably because hydrochloric acid was used.

A preliminary list of ostracodes from Getaway limestone member is given below.

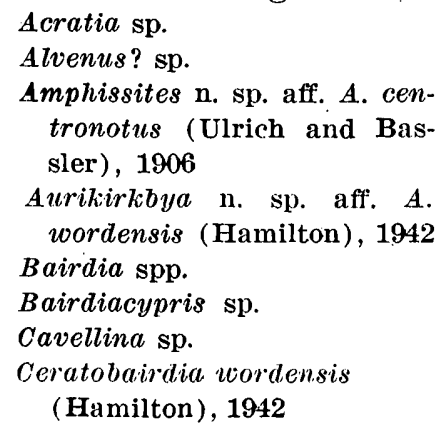

Paraparchites marathonensis Hamilton, 1942

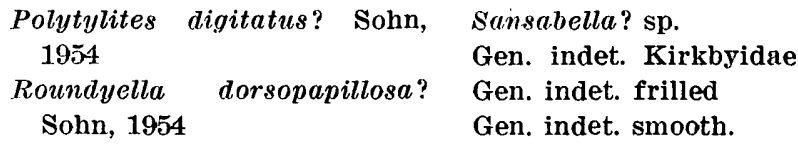

These ostracodes resemble the faunule described from the Glass Mountains. I have observed poorly preserved specimens of Ceratobairdia in shale collected from the Middle Productus limestone in the Salt Range, Pakistan.

The conodonts in the Texas collections are small, mostly broken but not worn, amber colored, translucent genera of the families Priniodonidae, Idiognathodontidae, and Polygnathidae (Hass, 1958). Gondolella is present in the collection and is also reported from the Phosphoria formation in Idaho (Youngquist, Hawley, and Miller, 195.1, p. 360).

The localities and the collectors are as follows:

USGS 12856-PC. Approximately middle of Getaway member of Cherry Canyon formation, limestone with silicified fossils. Road to Guadalupe Summit beacon, from cliff below flat place in road, just before it climbs to beacon; Culbertson County, Tex., collected by I. G. Sohn, G. O. Bachman, and D. A. Myers, May 21, 1960.

USNM 728. Getaway member, Cherry Canyon formation, on the west side of airway station road, between the road and the crest of ridge, about $21 / 2$ miles by road SSW of Pine Spring Camp; Culbertson County, Tex., collected by G. A. Cooper, July 15, 1952. Same locality as Am. Mus. Natural History no. 512.

\section{REFERENCES}

Miltonella shupei Sohn, 1950
Hamilton, 1. B., 1942, Ostracoda from the upper Permian of Texas: Jour. Paleontology, v. 16, p. 712-718. 
Huss, W. H., 1958, Classification and stratigraphic range of disjunct conodonts: Washington Acad. Sci. Jour., v. 48, no. 4, p. $141-142$.

Sohn, I. G., 1950, Growth series of ostracodes from the Permian of Texas: U.S. Geol. Survey Prof. Paper 221-C, p. 33-39.
1954, Ostracoda from the Permian of the Glass Mountains, Texas: U.S. Geol. Survey Prof. Paper 264-A, 24 p. Youngquist, Walter, Hawley, R. W., and Miller, A. K., 1951, Phosphoria conodonts from southeastern Idaho: Jour. Paleontology, v. 25, p. 356-364.

\title{
380. PHYSICAL CHARACTERISTICS OF UPPER CAMBRIAN STROMATOLITES IN WESTERN UTAH
}

\author{
By Richard K. Hose, Menlo Park, Calif.
}

Geologic mapping in Tule Valley, Utah, has disclosed abundant carbonate stromatolites in the Notch Peak limestone of Late Cambrian age (fig. 380.1). Reconnaissance in the southern House Range, which is adjacent to Tule Valley on the east, has provided additional data as to mode of occurrence and stratigraphic position of the stromatolites and has disclosed a few occurrences in the Johns Wash limestone and the Orr formation both of Late Cambrian age.

The present paper records the occurrence of the stromatolites and briefly describes those of the upper 500 feet or so of the Notch Peak limestone. It is hoped that recognition of similar forms elsewhere will facilitate correlation, genetic interpretations, and paleoecology of Upper Cambrian units of the eastern Great Basin.

Figure 380.2 shows the generalized stratigraphic section of Upper Cambrian formations exposed in Tule Valley and the House Range. The nomenclature is modified from Bentley (1958) and Drewes and Palmer (1957).

Stromatolites of the Notch Peak formation are typically cylindrical to slightly conical masses with axes perpendicular to bedding. The stromatolites range from 2 to 4 feet in height (fig. 380.3) and from 6 to 18 inches in diameter (fig. 380.4). Most of them are circular in plan, but some are irregular and polylobate. Sections cut parallel to the long axis reveal. that the laminations are convex upward; the curvature is slight near the base but increases upward and becomes parabolic (fig. 380.3) in the upper part. In plan view the laminations are concentric (fig. 380.4). The basal parts of most adjacent stromatolites are in contact but, because of their slight upward taper, the upper parts are not. The spaces between adjacent stromatolites are filled mostly with coarse-grained detrital limestone but locally the filling is homogeneous dense limestone. Generally the detrital limestone filling is lighter: colored than the stromatolites.

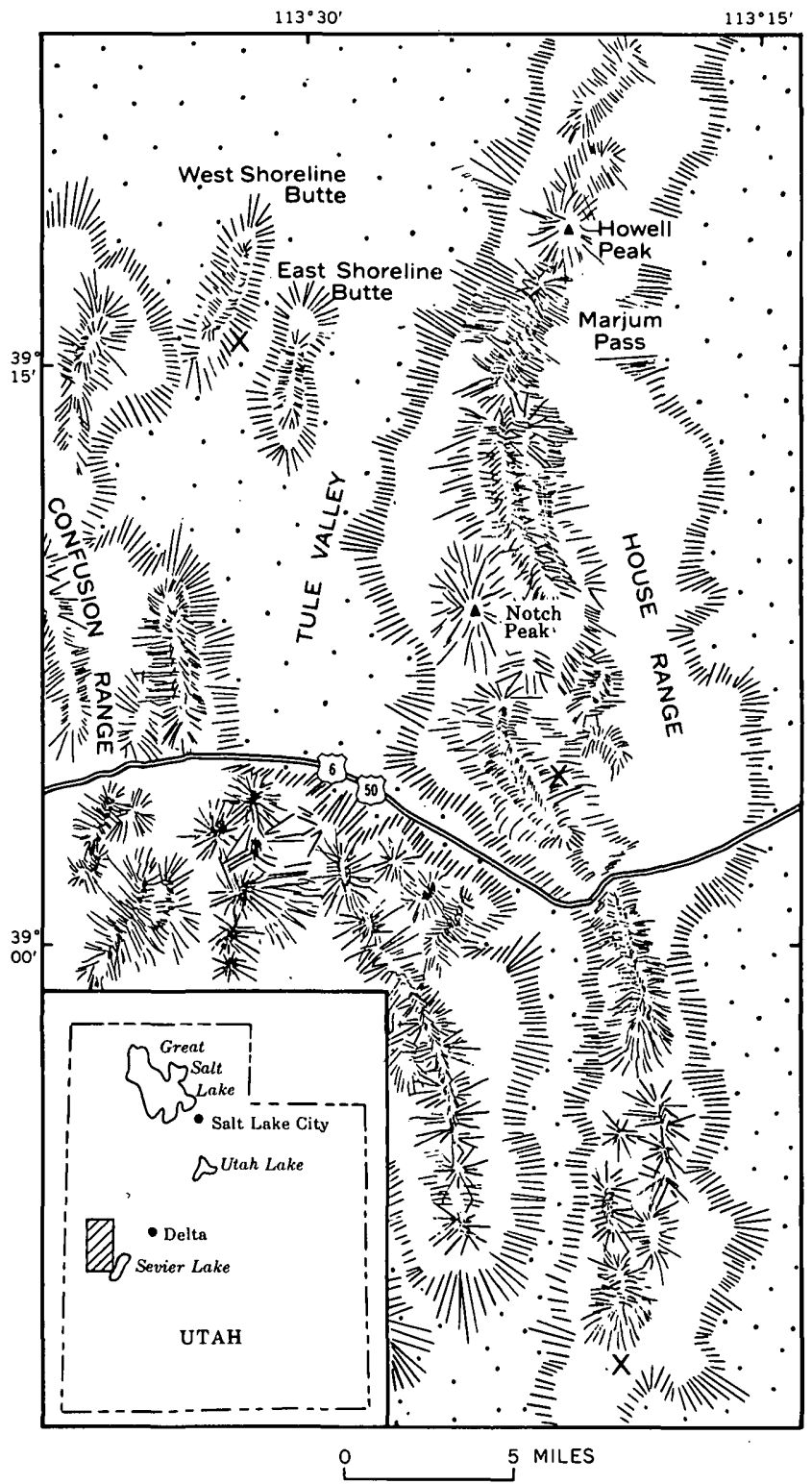

Figure 380.1.-Index map of west-central Utah showing stromatolite localities $(X)$ discussed in text. 

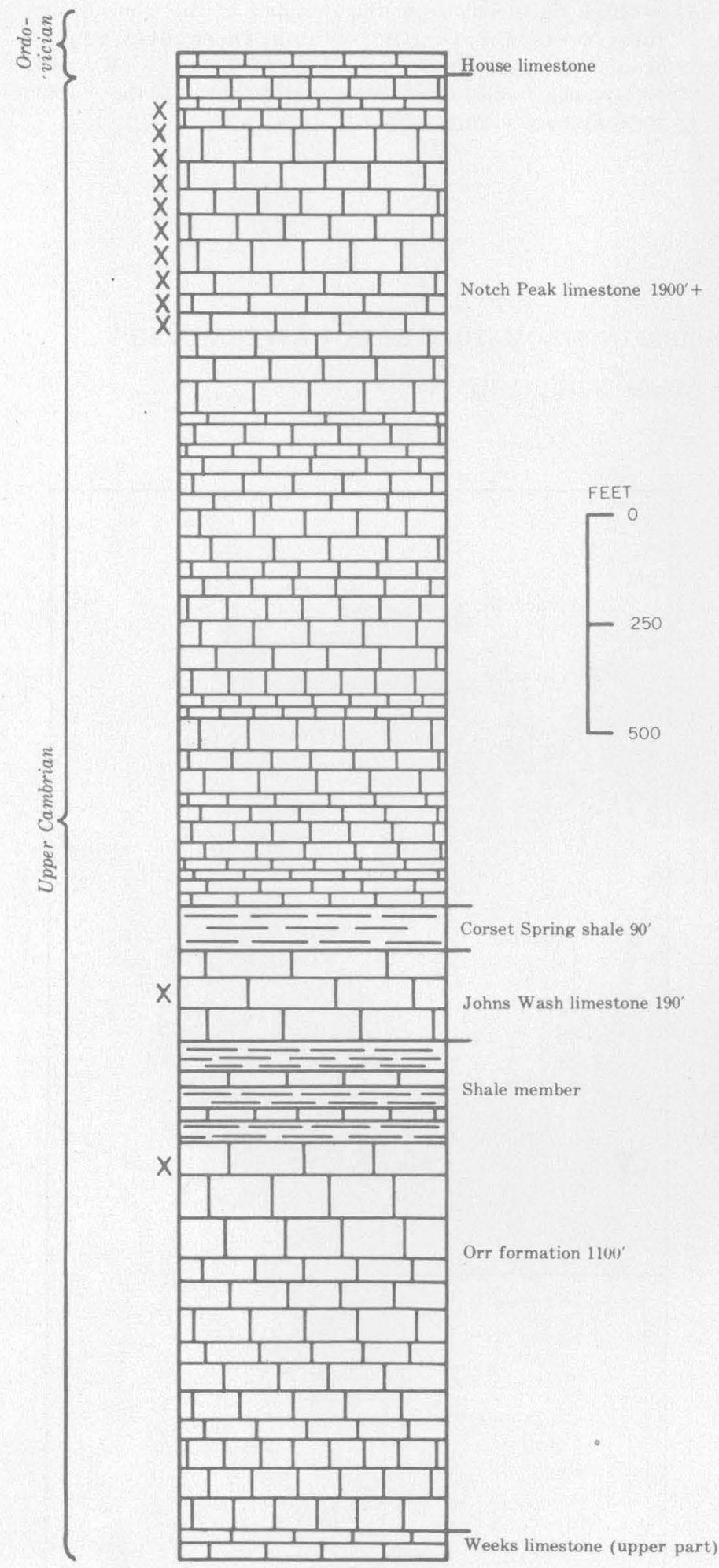

X-Stromatolites

Modified from Bentley (1958) and Drewes and Palmer(1957)

Figure 380.2.-Upper Cambrian sequence in Tule Valley and House Range, Utah, showing stromatolite occurrences.

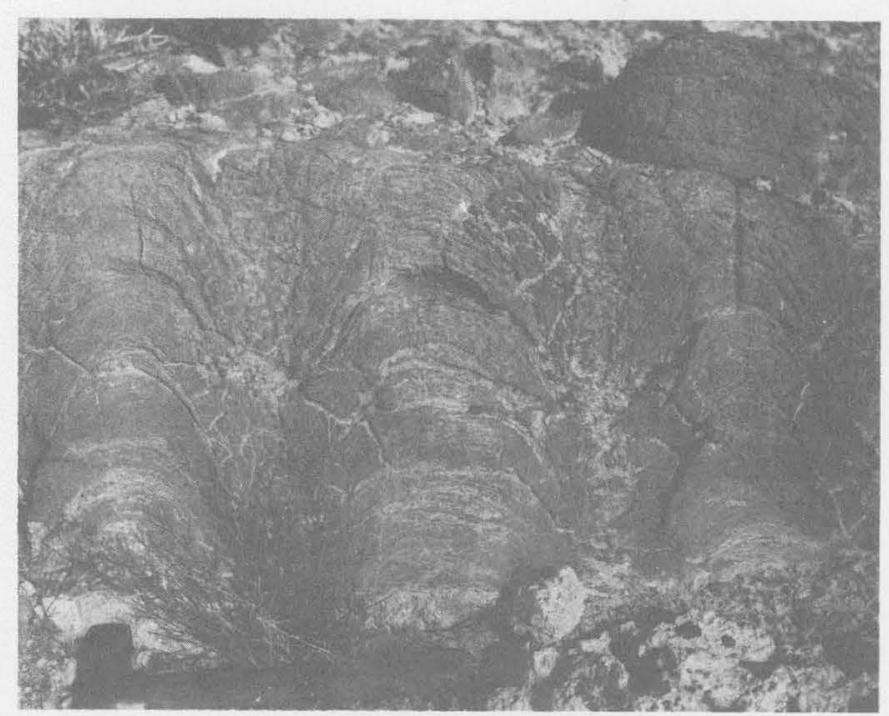

FtguRE 380.3.-Section of stromatolites showing upward convexity of laminations.

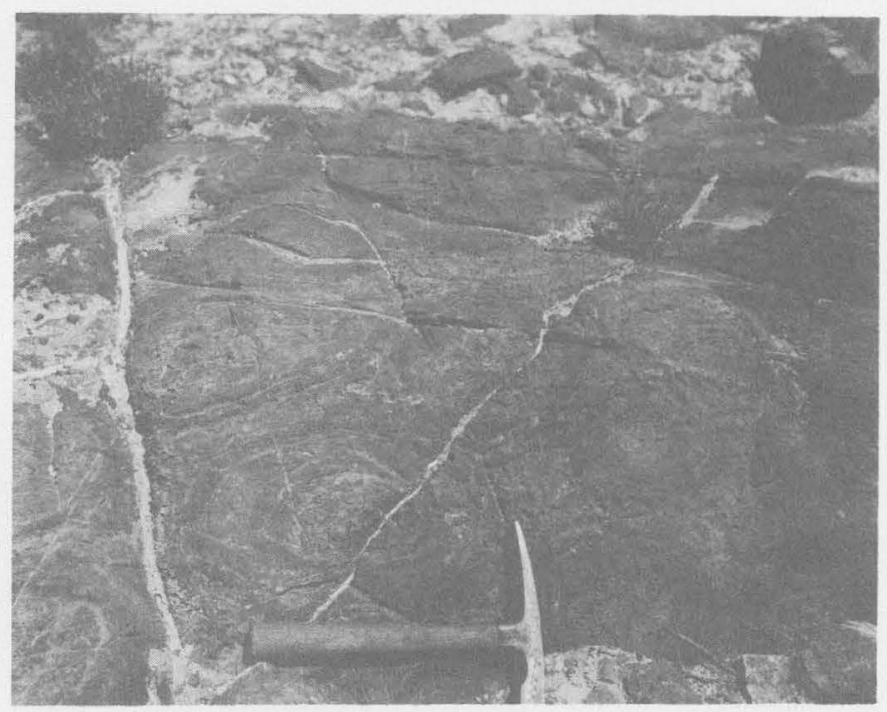

FIGURE 380.4.-Plan view of stromatolites showing concentricity of laminations.

In the southern part of West Shoreline Butte (fig. 380.1 ) the upper 500 feet of the Notch Peak limestone (fig. 380.5) consists (in ascending order) of about 100 feet of massive limestone made up almost entirely of stromatolites; 200 feet of interbedded fine-grained platy limestone, well-bedded coarse-grained detrital limestone, flat-limestone-pebble conglomerate and two stromatolitic biostromes 10 and 30 feet thick; and 200 feet of massive limestone made up almost entirely of stromatolites. The bedded limestone of this section can be traced northeastward for a few hundred yards into massive stromatolitic limestone so that the entire upper 
SHORT PAPERS IN THE GEOLOGIC AND

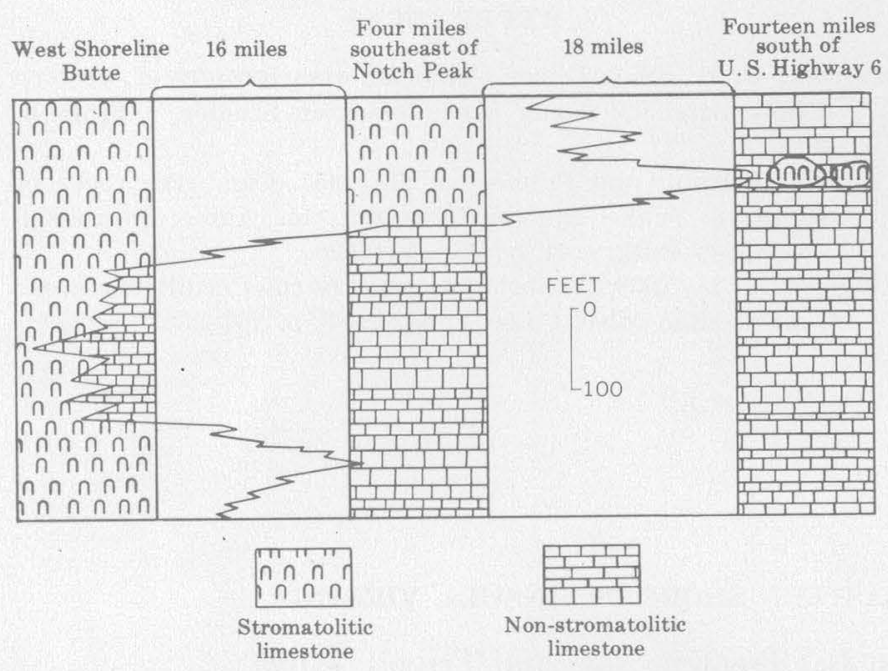

Figure 380.5.- Schematic diagram showing inferred relationship of massive stromatolitic limestone to nonstromatolitic carbonate rocks within the upper part of the Notch Peak limestone.

500 feet of the Notch Peak is made up of massive stromatolitic limestone.

Thin sections show that the stromatolites are made up of very fine grained limestone with the laminations manifested as barely perceptible increases in grain size. Sparce ( $<1$ percent) subangular silt-sized quartz grains are incorporated in the stromatolites. The detrital limestone filling the space between stromatolites consists of coarse sand to grit-sized rounded clasts of very fine texture. These clasts contain sparse fragments of brachiopods and trilobites.

Kenji Konishi of the U.S. Geological Survey has identified the stromatolites with the form genus and form species Collenia frequens Walcott. Oncolites found in association with the stromatolites were assigned to the form genus Pycnostroma by Konishi, who indicates that the Pycnostroma suggest a shallow marine environment-depths of one-third to $2 \mathrm{~m}$-and that $C$. frequens may suggest an intertidal environment close to lower tide level. Examination of thin sections of the stromatolites by Preston E. Cloud has disclosed the presence of filamentous algal material. According to Cloud (oral communication) this indicates that the stromatolites lived in shallow $(<10 \mathrm{~m})$ marine waters.

In the southern part of West Shoreline Butte parts of the stromatolitic masses are irregularly eroded and overlapped by detrital limestone. The irregular erosion surface coupled with the concept of a shallow marine origin of the stromatolites-suggests that the erosion surface was produced by wave action.

Limestone beds laterally continuous with the stromatolite masses contain zones of limestone pebble conglomerate believed to be derived in part from the stromatolites. These zones also indicate that fragmentation of the stromatolites and deposition of the nearby bedded limestone were essentially continuous. In brief, the stromatolites in the area of West Shoreline Butte formed reeflike bodies which were periodically fragmented by wave action and overlapped subsequently by detrital limestone derived from nearby areas.

In an area 4 miles southeast of Notch Peak in the House Range, the upper 500 feet of the Notch Peak is predominantly bedded limestone with only the topmost 160 feet of the formation made up of uniformly massive stromatolitic limestone (fig. 380.5). This change is due entirely to facies variation, for the thickness of the Notch Peak in the Shoreline Buttes is comparable with that in the House Range.

Still farther south in the House Range -14 miles south of U.S. Highway 6 - stromatolites are confined to a zone of reefs perhaps 40 feet thick about a hundred feet or so below the top of the Notch Peak limestone (fig. 380.6). There, bedded limestone beneath the reefs

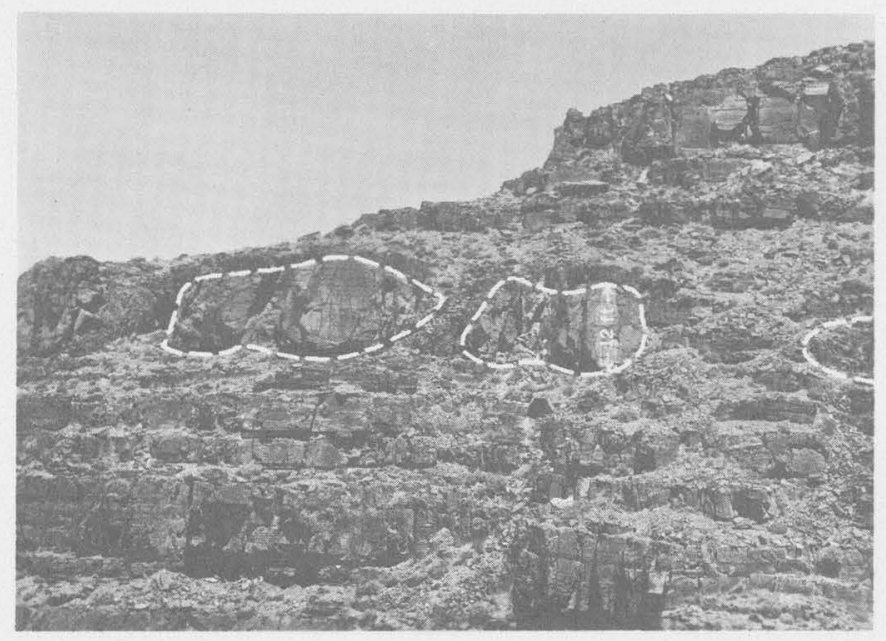

Figure 380.6.-Stromatolitic reefs in the upper part of the Notch Peak limestone, 14 miles south of U.S. Highway 6, southern House Range.

is bowed downward indicating that accumulation of carbonate was greater at the reef site than in adjacent areas. Bedded detrital limestone and carbonate-pebble conglomerate overlap the reef and are bowed upward above it, indicating that the stromatolites projected above the depositional interface of surrounding areas and were reeflike.

In detail the relationship of the main body of stromatolitic limestone to the bedded limestone between the three localities just described is obscure because of limited outcrop. The bedded limestone in the upper 
part of the Notch Peak formation of the House Range is very similar to that at West Shoreline Butte, and at the latter locality the bedded limestone passes into a reeflike body of stromatolitic limestone which is part of a still thicker stromatolitic mass (fig. 380.5). Possibly this larger body of stromatolitic limestone is also reeflike, but additional mapping in the House Range will be necessary to resolve this question.

\section{REFERENCES}

Bentley, C. B., 1958, Upper Cambrian stratigraphy of western Utah; Brigham Young Univ. Research Studies, v. 5, no. 6, $70 \mathrm{p}$.

Drewes, Harald, and Palmer, A. R., 1957, Cambrian rocks of southern Snake Range, Nevada: Am. Assoc. Petroleum Geologists Bull., v. 41, no. 1, p. 104-120.

Walcott, C. D., 1908, Cambrian sections of the Cordilleran area : - Smithsonian Misc. Colls., v. 53, no. 5, p. 167-230.

\section{PLEISTOCENE TERRACES ON THE EASTERN SHORE PENINSULA, VIRGINIA}

By Allen Sinnott and G. Chase Tibbitts, Jr., Trenton, N.J., and Tripoli, Libya

Work done in cooperation with the Commonwealth of Virginia ${ }^{1}$

Pleistocene terraces on the Eastern Shore peninsula, Virginia (fig. 381.1) can be delineated fairly well by field reconnaissance with the aid of modern topographic maps. Earlier studies of the terraces in this area (Wentworth, 1930) were made without benefit of such maps, so that the extent and correlation of terraces had to be somewhat generalized.

The Columbia group of terrace formations of Pleistocene age consists of a succession of thin very gently sloping marine and estuarine formations that overlie the Tertiary sedimentary rocks of the Virginia coastal plain (table 381.1). The terraces discussed here are considered to be the emerged upper surfaces of some of these formations.

The terraces listed in table 381.1 are well developed at many places on the mainland part of the coastal plain, but only the younger ones are represented on the Eastern Shore peninsula. From oldest to youngest these are the Chowan, Dismal Swamp, and Princess Anne terraces, as defined by Wentworth (1930).

TaBle 381.1.-Terraces of the Atlantic Coastal Plain

Terrace (youngest at top) Approximate altitude of
shoreline (feet)

Princess Anne (may include Silver Bluff) .......

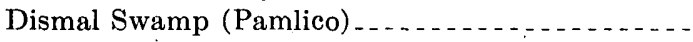

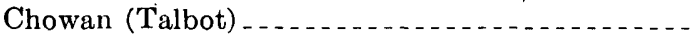

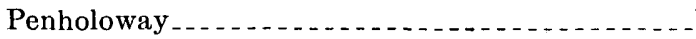

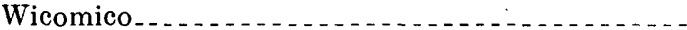

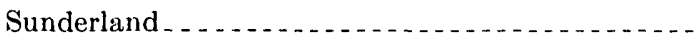

Coharie..................................

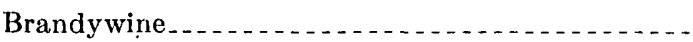

1 This paper is based on work done during a Federal-State cooperative. program that was terminated in June 1957.
Some sediments that may be pre-Chowan in age underlie several areas having altitudes above about 45 feet. These areas have altitudes of 60 to 70 feet along Butlers Bluff on the southwest shore, about 7 miles SSE. of the town of Cape Charles, and they have altitudes of 45 to 60 feet at two other places in the upper peninsula in Accomack County. Sediments at these levels probably represent Penholoway or Wicomico terrace remmants; they are shown as pre-Chowan on figure 381.1.

The shoreline of the Chowan terrace (Stephenson, 1912 ) is about 45 feet above present sea level in Virginia. It rises gently from the scarp above the 25 -foot shoreline of the Dismal Swamp terrace (Wentworth, 1930). The Chowan terrace is probably equivalent to the Talbot terrace as defined by Shattuck (1906) from the coastal plain of Maryland; Cooke (1931; 1935) retains the name "Talbot."

The Pamlico terrace in North Carolina, first described by Stephenson (1912), was later subdivided by Wentworth (1930, p. 69) into the Dismal Swamp (upper) and Princess Anne (lower) terraces. The Dismal Swamp terrace, whose shoreline is about 25 feet above present sea level, is therefore equivalent to the Pamlico as originally defined by Stephenson. In regional papers, Cooke $(1931 ; 1935)$ and most other workers prefer the name "Pamlico."

The shoreline of the Princess Anne terrace, which probably represents a late Pleistocene stand of the sea, is about 15 feet above sea level. Near the present shores of the peninsula, particularly on the bay side, the terrace descends in places to very low cliffs above the beaches (fig. 381.2). The Princess Anne terrace may 


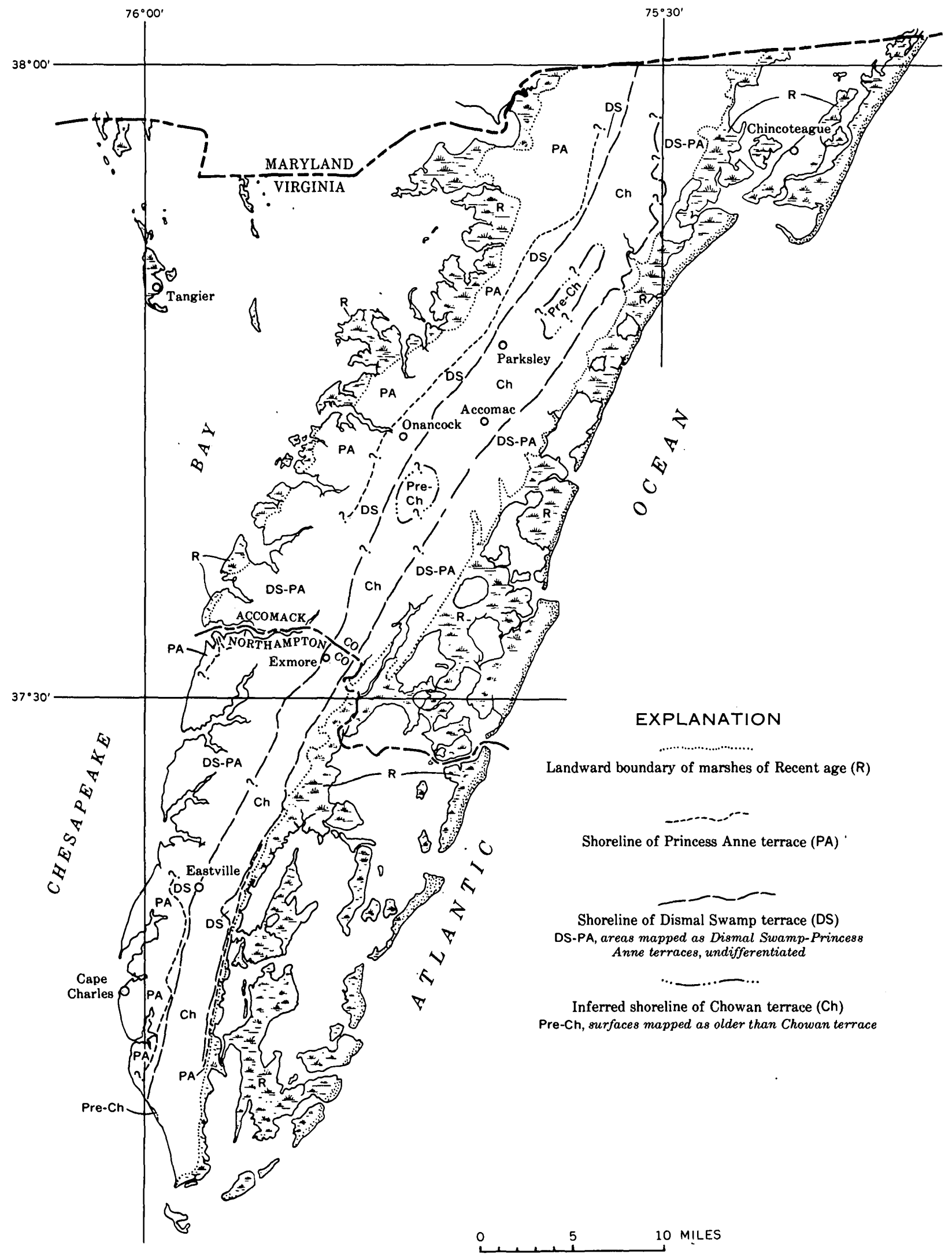

Fraure 381.1.-Map of the Eastern Shore peninsula, Accomack and Northampton Counties, Va., showing Pleistocene terraces.

$6044930-61-17$ 


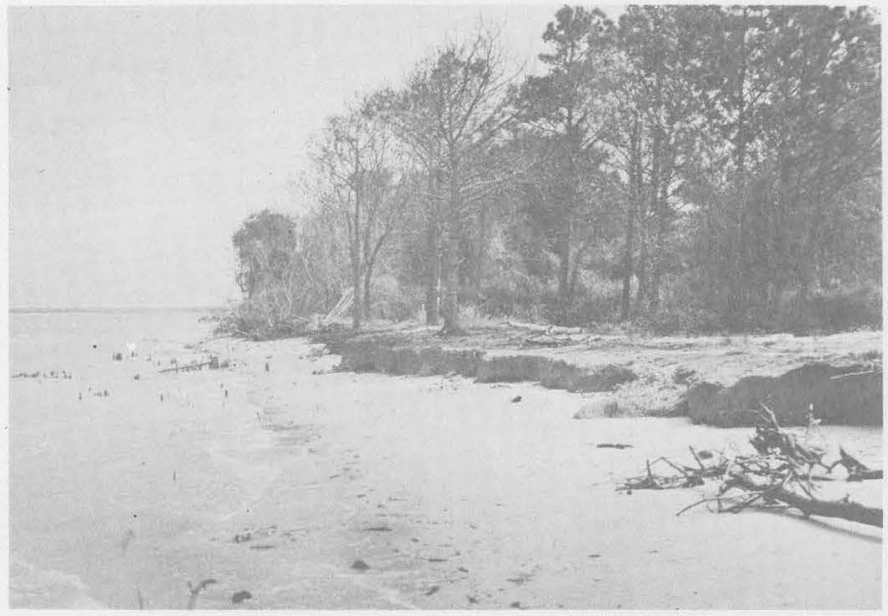

Figure 381.2.-Low wave-cut cliff truncating Princess Anne terrace on beach south of Occahannock Creek, about 6 miles west of Exmore, Northampton County, Va.

be equivalent, in part, to the Silver Bluff terrace farther south, described by several workers (Parker and Cooke, 1944; Cooke, 1945; MacNeil, 1950).

The present study indicates that the Chowan terrace extends the entire length of the peninsula and is flanked by remnants of the Dismal Swamp and Princess Anne terraces.

In the southern half of Northampton County, the Dismal Swamp terrace is generally present as a narrow remnant between the more extensive Princess Anne and Chowan terraces. There, the scarps above the Princess Anne and Dismal Swamp terraces have been considerably modified by subaerial erosion and in many places are obscure. At the extreme southeastern part of the peninsula they are absent.

Along the eastern part of Accomack County and part of northwestern Northampton County, the shoreline of the Princess Anne terrace has been greatly obscured or obliterated by erosion. At these places, the areas corresponding to the younger Pleistocene ter- races have been mapped on figure 381.1 as Dismal Swamp-Princess Anne terraces, undifferentiated.

At Assawoman Creek, in northeastern Accomack County, the writers observed what appears to be an estuarine phase of the Princess Anne terrace developed upstream at the expense of the Dismal Swamp terrace. At this locality a pronounced local scarp rises from the Princess Anne directly to the Chowan terrace level.

A scarp between the Recent shoreline and the youngest Pleistocene (Princess Anne) terrace commonly is distinct along the bay side of the peninsula (fig. 381.2). Along the ocean side, lagoons have formed behind advancing bay-mouth bars and sediment has begun to fill in many of the lagoons, resulting in salt-water marshes. The Princess Anne terrace is considered to begin along the landward edge of the marshes.

The writers agree generally with Wentworth (1930, p. 114) that relatively little of what is now the Eastern Shore peninsula was land area in pre-Chowan time. Thus, essentially all of the present land forms were developed during Chowan (Talbot) time and later.

\section{REFERENCES}

Cooke, C. W., 1931, Seven coastal terraces in the southeastern United States: Washington Acad. Sci. Jour., v. 21, p. 503513.

1935, Tentative ages of Pleistocene shore lines: Washington Acad. Sci. Jour., v. 25, no. 7, p. 331-333.

1945, Geology of Florida: Florida Geol. Survey Bull. 29, $339 \mathrm{p}$.

MacNeil, F. S., 1950, Pleistocene shore lines in Florida and Georgia : U.S. Geol. Survey Prof. Paper 221-F, p. 95-106.

Parker, G. G., and Cooke, C. W., 1944, Late Cenozoic geology of southern Florida, with a discussion of the ground water: Florida Geol. Survey Bull, 27, 119 p.

Stephenson, L. W., 1912, Quaternary formations, in The Coastal Plain of North Carolina: North Carolina Geol. and Econ. Survey, v. 3, p. 266-290.

Shattuck, G. B., 1906, Pliocene and Pleistocene deposits of Maryland: Maryland Geol. Survey, $291 \mathrm{p}$.

Wentworth, C. K., 1930, Sand and gravel resources of the coastal plain of Virginia: Virginia Geol. Survey Bull. 32, 146 p.

\title{
832. STRATIGRAPHIC SIGNIFICANCE OF THE CRETACEOUS FERN TEMPSKYA IN THE WESTERN CONTERMINOUS UNITED STATES
}

\author{
By Chartes B. Rean and Sidney R. Ash, Albuquerque N. Mex.
}

The genus Tempskya Corda (1845; Kidston and Gwynne-Vaughan, 1911) is a representative of an extinct group of leptosporangiate ferns that occur at numerous localities in the younger Mesozoic rocks of the western conterminous United States, as indicated on the index map, figure 382.1. Remains of the several known species of the genus consist of silicified masses of stems and roots organized into composite stems or 


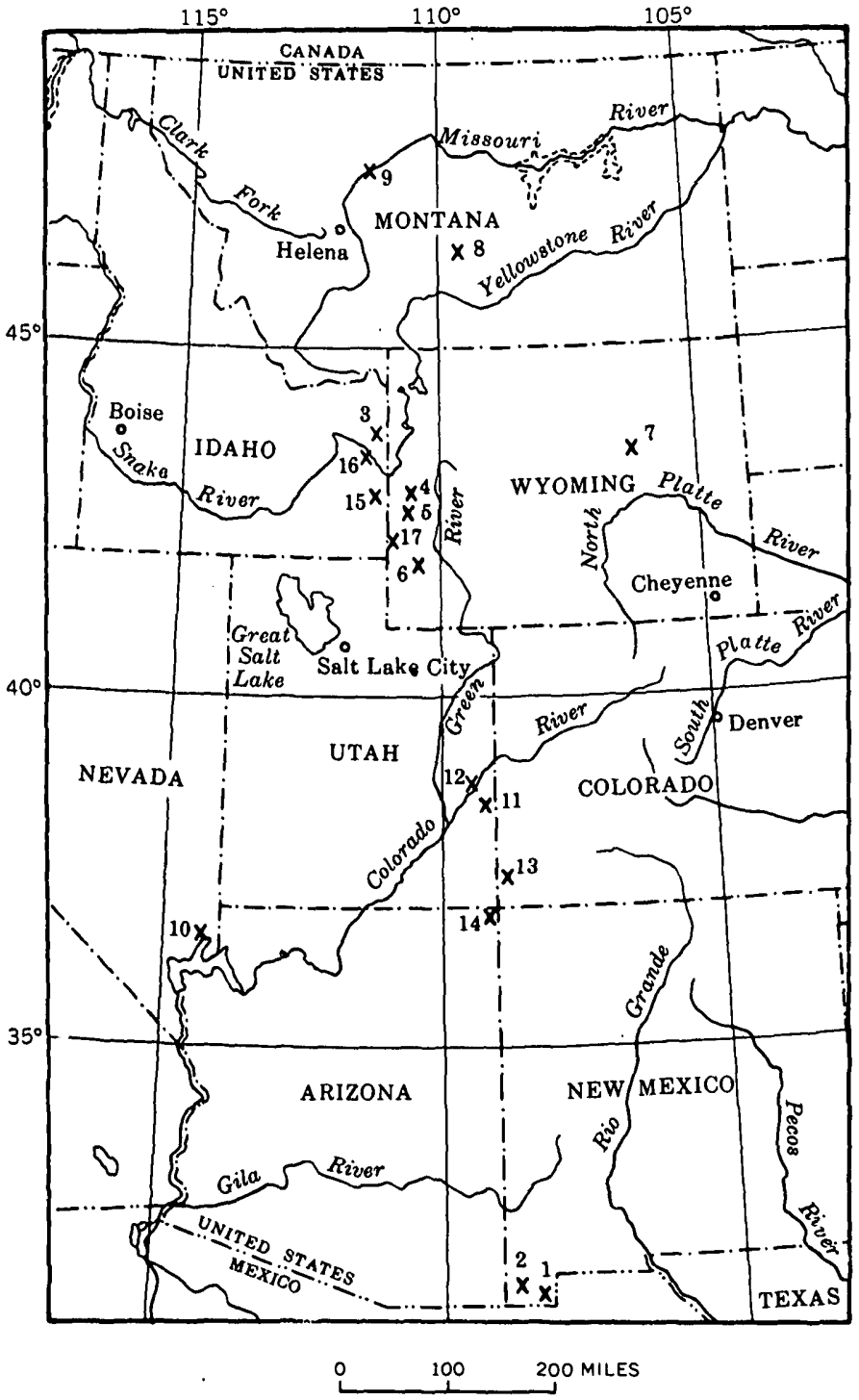

Fraure 382.1.-Index map showing general location of occurrences $(X)$ of Tempskya spp. in western conterminous United States. Localities where silicified remains have clearly been reworked from Cretaceous rocks into later gravels are not shown. Numbers refer to localities mentioned in the text and in figure 382.4 .

trunklike masses that have been called false stems or false trunks (fig. 382.2). The nature of the leaves or fronds is unknown.

The individual stems of the composite structure are dichotomous branches of a single plant. The stems are solenostelic and dorsiventral, two rows of alternate leaves being borne on the morphologically upper surfaces as shown in figure 382.3. Both upper and lower surfaces are marked by adventitious root insertions. The xylem of the solenostele is exarch and the stele is characterized by both external and internal phloem.

The roots are small and diarch. Masses of these roots appear to have constituted a feltlike matrix during the

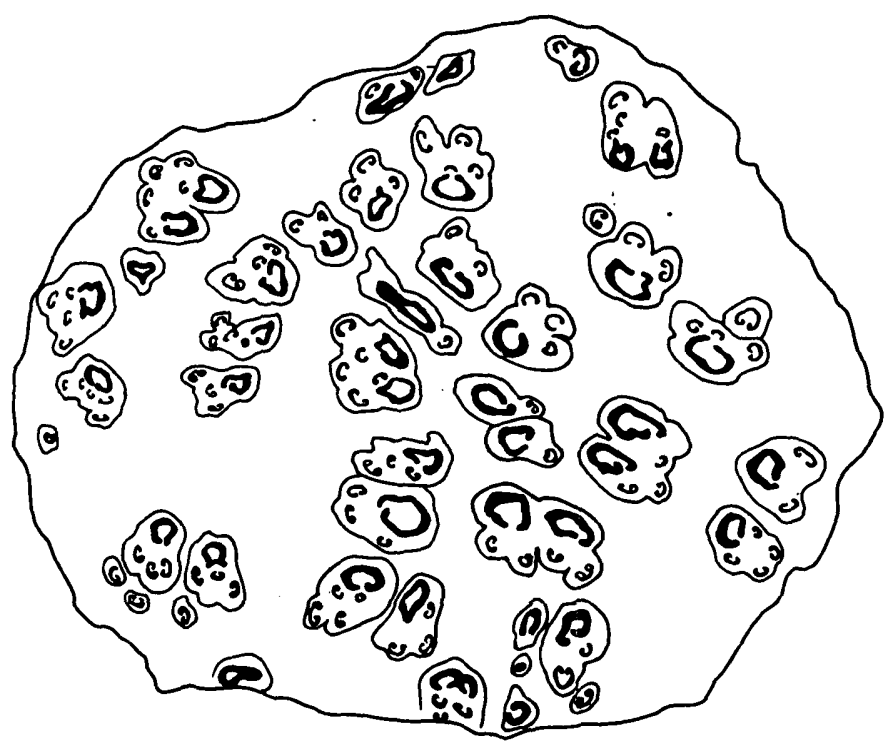

FIGURE 382.2.-Sketch of a transversely cut false stem of Tempskya grandis Read and Brown showing the radial orientation of the dorsiventral stems.

life of the plant in which the freely branching stem system was embedded. Even though both individual stems and roots are relatively small in diameter, the false stem may have had sufficient strength and rigidity so that it stood erect to a height of a few feet in some species and resembled a low tree fern in general habit (Andrews and Kern, 1947; Read and Brown, 1937). In other species it is possible that the growth form was that of a vine (Read and Brown, 1937).

The species of Tempskya that are known from the younger Mesozoic rocks of the western part of the United States are Tempskya grandis Read and Brown (1937), T. knowltoni Seward (1924), T. minor Read and Brown (1937), T. superba Arnold (1948), T. wesselii Arnold (1945), and T. wyomingensis Arnold (1945). Material that appears to represent new species has recently been discovered in rocks of Cretaceous age in the Big Hatchet and Animas Mountains of southwestern New Mexico (Zeller and Read, 1956).

Representatives of the genus Tempskya occur at several localities in New Mexico, Idaho, Wyoming, and Montana where either the containing strata or those immediately adjacent are marine. Data regarding these occurrences are presented in figure $382.4 A$, which shows the accepted age relations of the Tempskyabearing rocks. In $1957 \mathrm{~J}$. B. Reeside, Jr., made many collections of marine invertebrates associated with Tempskya in the Big Hatchet Mountains, and Zeller and others have supplemented the collections. The various groups of organisms have been examined by several paleontologists; and digests of their findings follow (written communications, 1955 to 1959 ) : 


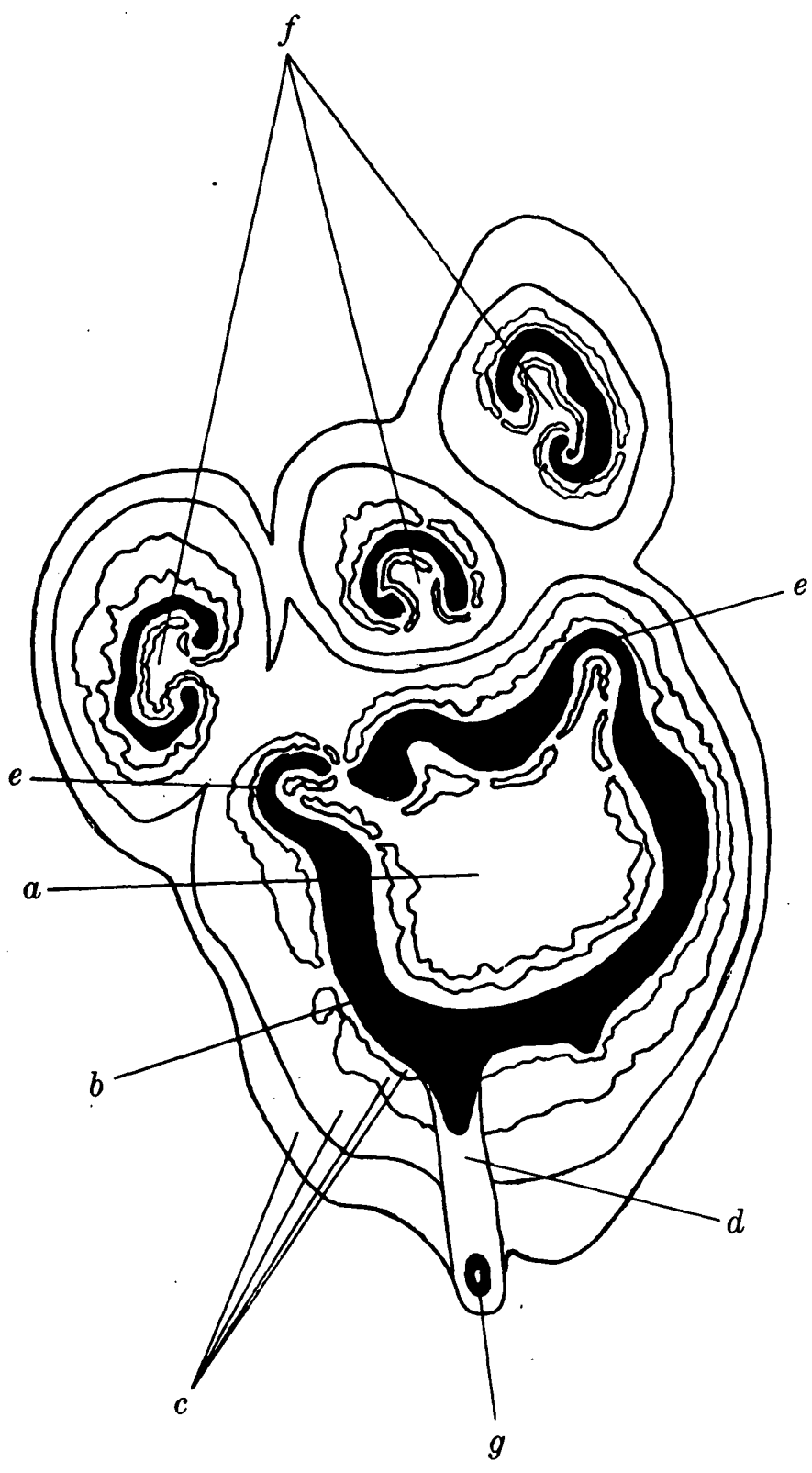

FIGURE 382.3.-Diagram of a transverse section of a stem of Tempskya grandis Read and Brown showing the general characteristics of the dorsiventral stem: $a$, pith; $b$, stele; $c$, cortex ; $d$, insertion of adventitious root; $e$, leaf traces in early stages of development; $f$, leaf traces in more advanced stages of development; $g$, adventitious root.

Collections from 30 feet above the horizon containing Tempskya in sec. 20, T. 32 S., R. 15 W.:

John B. Reeside, Jr.-Mollusks are of "middle Washita and late Albian age."

Ruth Todd-Smaller Foraminifera are of "Washita age."

N. F. Sohl-Gastropods are of "late Fredericksburg (middle Albian) age."
Collection from 10 feet below the horizon containing Tempskya in sec. 20, T. 32 S., R. 15 W.:

N. F. Sohl-Mollusks are of "late Fredericksburg to early late Washita age."

Collection from 300 feet below the horizon containing Tempskya in sec. 20, T. 32 S., R. 15 W.:

John B. Reeside, Jr.-Mollusks are of "Washita age."

Collection from strata adjacent to those containing Tempskya in sec. 13, T. 31 S., R. 18 W.:

W. A. Cobban-Foraminifera and mollusks are of "late Comanche (Washita) age (late Albian)."

The ammonite Neogastroplites, which is considered to be probably of late Albian age by Reeside and Cobban (1960, p. 30), has been collected from Tempskya-bearing formations or from overlying formations in several parts of the western United States as summarized below :

1 Neogastroplites and Tempskya spp. were reported from the Aspen shale in southwestern Wyoming near localities $3,4,5$, and 6 , and from the Thermopolis shale near locality 7, figures 382.1 and $382.4 A$ (Reeside and Cóbban, 1960, p. 30-31).

2 Neogastroplites and Tempskya knowltoni are found in the undifferentiated zone below the Big Elk sandstone member of the Colorado shale in the upper part of the Musselshell Valley at locality 8, figures 382.1 and $382.4 A$ (Reeside and Cobban, 1960, p. 1727).

3 Neogastroplites has been collected from sandy beds that directly overlie the Tempskya knowltoni-bearing Vaughn bentonitic member of Blackleaf formation (so called "red speck zone") in northwestern Montana at locality 9, figures 382.1 and $382.4 A$ (Reeside and Cobban, 1960, p. 17).

All the species of Tempsky a appear to have been land plants and at several localities the containing strata are dominantly nonmarine. Figure $382.4 B$ summarizes the known nonmarine occurrences in Mesozoic strata other than those in which it is clear that specimens have been reworked into younger strata.

In a letter dated February 14, 1956, prior to his visit to southwestern New Mexico, Reeside summed up his opinion regarding the stratigraphic significance of Tempskya in the following words-

Regarding the age of Tempskya, I think you are right about putting it in the Albian. There is no undisputed evidence of later age for the American records and much in favor of Albian.

Reeside indicated in subsequent discussions that his field observations in New Mexico confirmed his previously written opinion. 
SHORT PAPERS IN THE GEOLOGIC AND HYDROLOGIC SCIENCES, ARTICLES 293-435

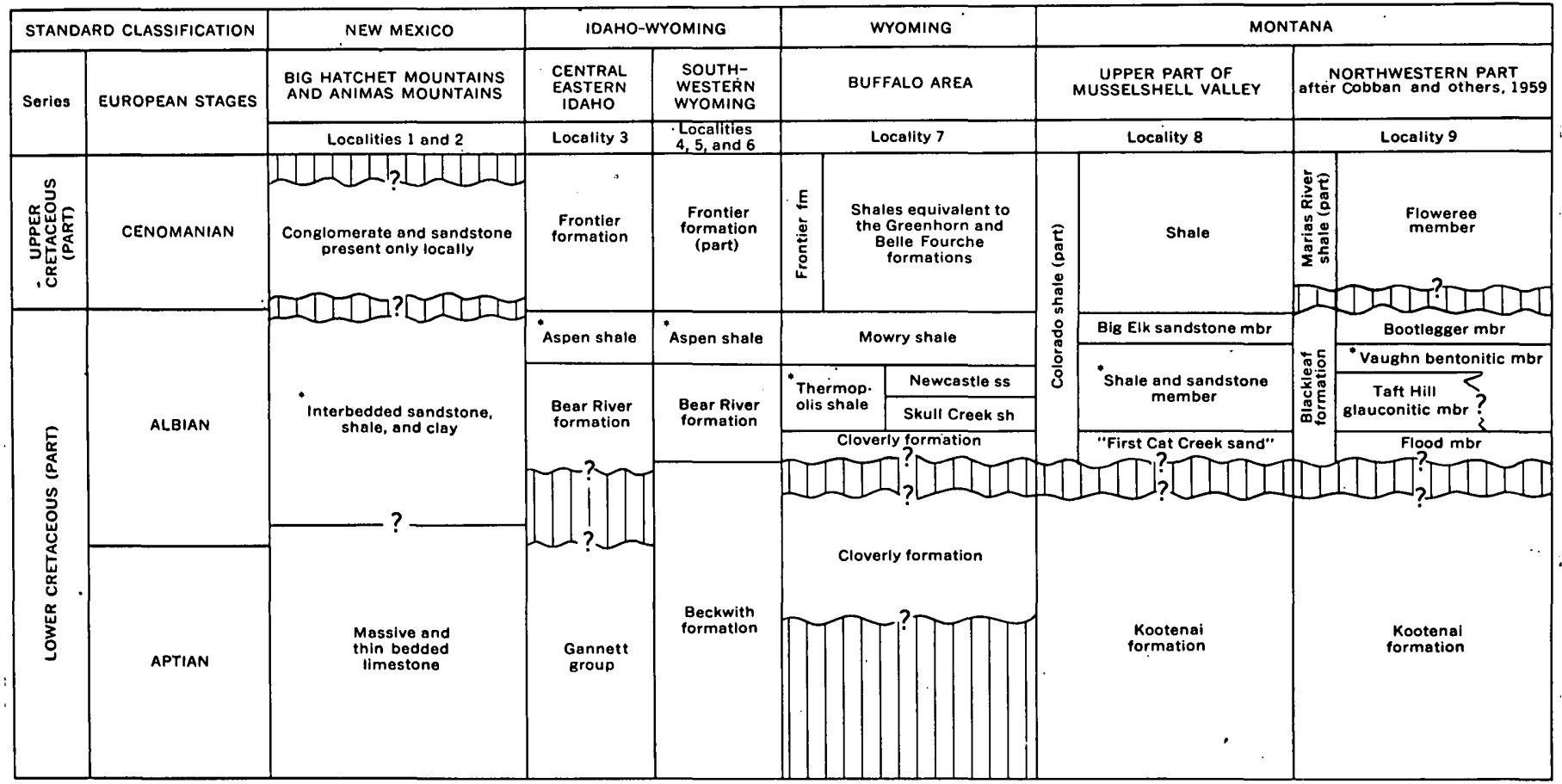

A. LOCALITIES WHERE TEMPSKYA SP. HAS BEEN REPORTED IN ASSOCIATION WITH MARINE INVERTEBRATES

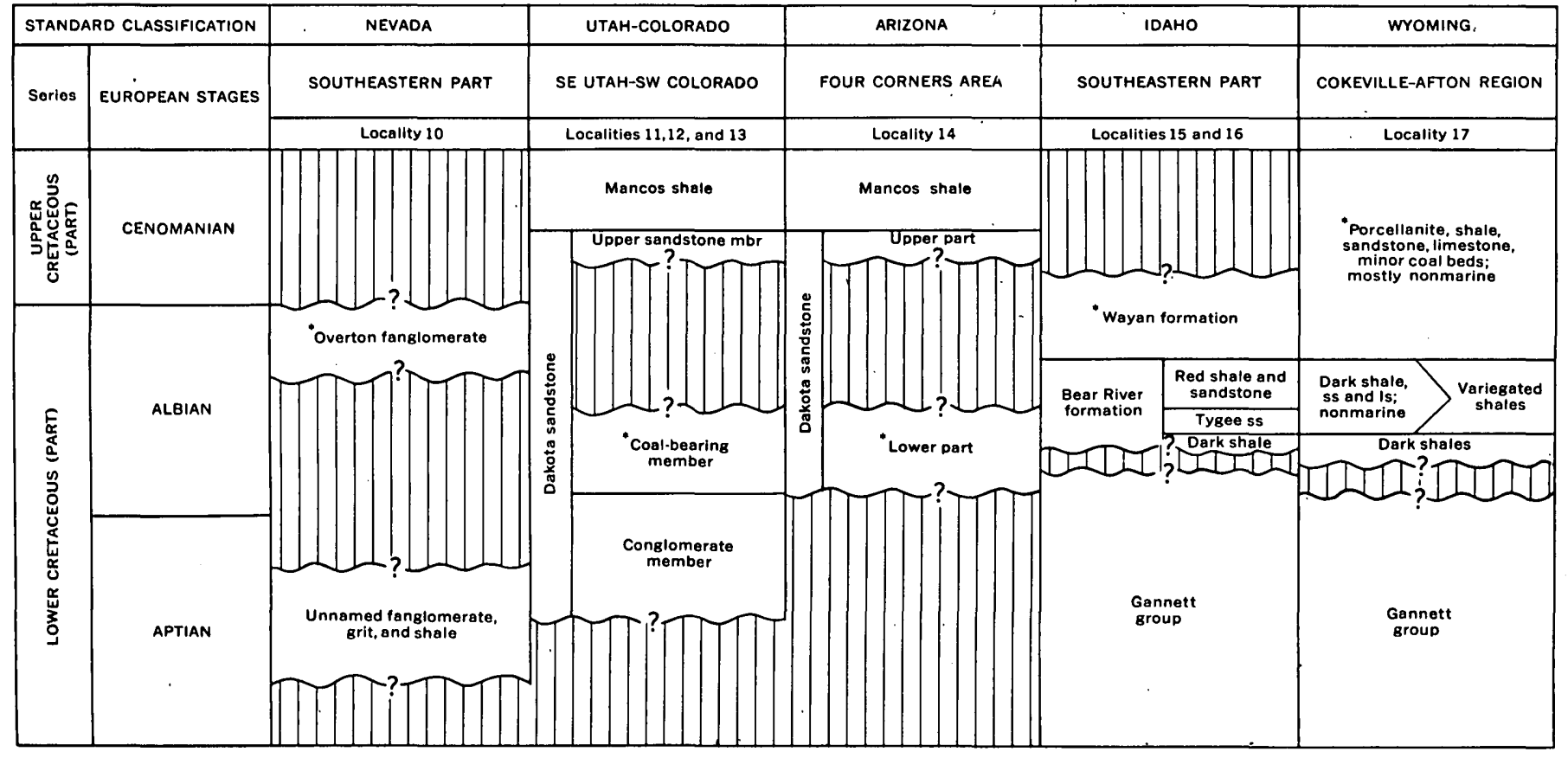

B. LOCALITIES WHERE TEMPSKYA SP. HAS BEEN REPORTED IN NONMARINE STRATA

Figure 382.4.-Correlation of parts of the Cretaceous system at selected localities in the western conterminous United States showing rock sequences at localities where Tempsliya spp. has been reported. Formations containing Tempskya are marked by an asterisk (*). Locality numbers in headings of columns are shown on figure 382.1 . Correlations after Cobban and Reeside (1952a) and Reeside and Cobban (1960). 
Re-examination of earlier information on the stratigraphic occurrences of the various species of Tempskya and consideration of new discoveries indicate that the age of the genus is more restricted than was formerly thought (Read and Brown, 1937), and that in the western part of the United States it is restricted to strata that are Albian in age.

\section{REFERENCES}

Andrews, Henry N., and Kern, Ellen M., 1947, The Idaho Tempskyas and associated fossile plants: Missouri Bot. Garden Annals, p. 119-186.

Arnold, C. A., 1944, Silicified plant remains from the Mesozoic and Tertiary of western North America. Ferns [Pt.] 1: Michigan Acad. Sci., Arts, and Letters, Papers, v. 30, p. 3-34 [1945].

- 1958, A new Tempskya: Univ. of Michigan, Mus. Paleontology, Contr., v. 14, no. 8 , p. 133-142.

Cobban, W. A., Erdman, C. E., Lempke, R. W., and Maughan, E. K., 1959, Revision of Colorado group on Sweetgrass Arch, Montana : Am. Assoc. Petroleum Geologists Bull., v. 43 , no. 12 , p. $2786-2796$.
Cobban, W. A., and Reeside, John B., Jr., 1952a, Correlation of the Cretaceous formations of the Western Interior of the United States: Geol. Soc. America Bull., v. 63, p. 1011-1044.

- 1952b, Frontier formation, Wyoming and adjacent areas: Am. Assoc. Petroleum Geologists Bull., v. 36, p. 1913-1961.

Corda, A. J., 1845, Flora protogaea ; Beiträge zur Flora der Vorwelt: Prague, p. 81-83.

Kidston, Robert, and Gwynne-Vaughan, D. T., 1911, On a new species of Tempskya from Russia : Russ.-Kaiserliche Mineralog. Gesell. St. Petersburg, Verh., v. 48, p. 1-20.

Read, C. B., and Brown, R. W., 1937, American Cretaceous ferns of the genus Tempskya: U.S. Geol. Survey Prof. Paper 186-F, p. 105-129.

Reeside, John B., Jr., and Cobban, W. A., 1960, Studies of the Mowry shale (Cretaceous) and contemporary formations in the United States and Canada: U.S. Geol. Survey Prof. Paper 355, $126 \mathrm{p}$.

Seward, A. C., 1924, On a new species of Tempskya from Montana, Tempskya knowltoni, sp. nov.: Annals of Botany, v. 38 , no. 151, p. $485-507$.

Zeller, R. A., Jr., and Read, C. B., 1956, Occurrence of Tempskya minor in strata of Albian age in southwestern New Mexico [abs.] : Geol. Soc. America Bull., v. 67, no. 12, pt. 2, p. 1804.

\title{
383. GRAVITY LOW AT MINTO FLATS, ALASKA
}

\author{
By David F. Barnes, Menlo Park, Calif.
}

Much of central Alaska consists of broad alluviumcovered topographic basins, which may also be structural basins, containing Cenozoic deposits of considerable thicknesses. One phase of the Geological Survey's petroleum investigations in this area has been the determination of the thickness of these deposits. One of the areas studied is the Middle Tanana basin (Miller, Payne, and Gryc, 1959) that extends for about 100 miles both east and west of Fairbanks. The basin is divided into two embayments by an upland promontory that extends southward to the town of Nenana. Aeromagnetic lines flown south of Fairbanks in 1955 (Zietz and Wahrhaftig, written communication, 1960) cross the center of the eastern and larger embayment, where they show that pre-Cenozoic basement rocks lie within 500 meters of the surface. Recent gravity surveys suggest that a thick section of Cenozoic deposits may be present in the western embayment. The first indication of this sedimentary section was a -40.6 Bouguer gravity anomaly recorded at the village of
Minto (Thiel and others, 1958). Recent gravity surveys by the U.S. Geological Survey have defined the form and magnitude of this gravity low (fig. 383.1) that covers all the broad swampy Minto Flats west of Nenana and extends south of them towards the Alaska Range.

Precambrian rocks of the Birch Creek schist (Mertie, 1937) crop out along the eastern edge of the Minto Flats and form the upland promontory that divides the Middle Tanana basin into two parts. The northern and western rim of the flats is formed by hills underlain by strongly folded and faulted Paleozoic and Mesozoic sedimentary rocks (Capps, 1940). The southern part of the Middle Tanana basin slopes upward into the foothills of the Alaska Range, where the Nenana gravel and the coal-bearing formation of Tertiary age crop out (Wahrhaftig, 1958). The structure of these deposits shows that folding and faulting during the middle Tertiary formed local basins in which as much as several thousand feet of sediments have accumulated 


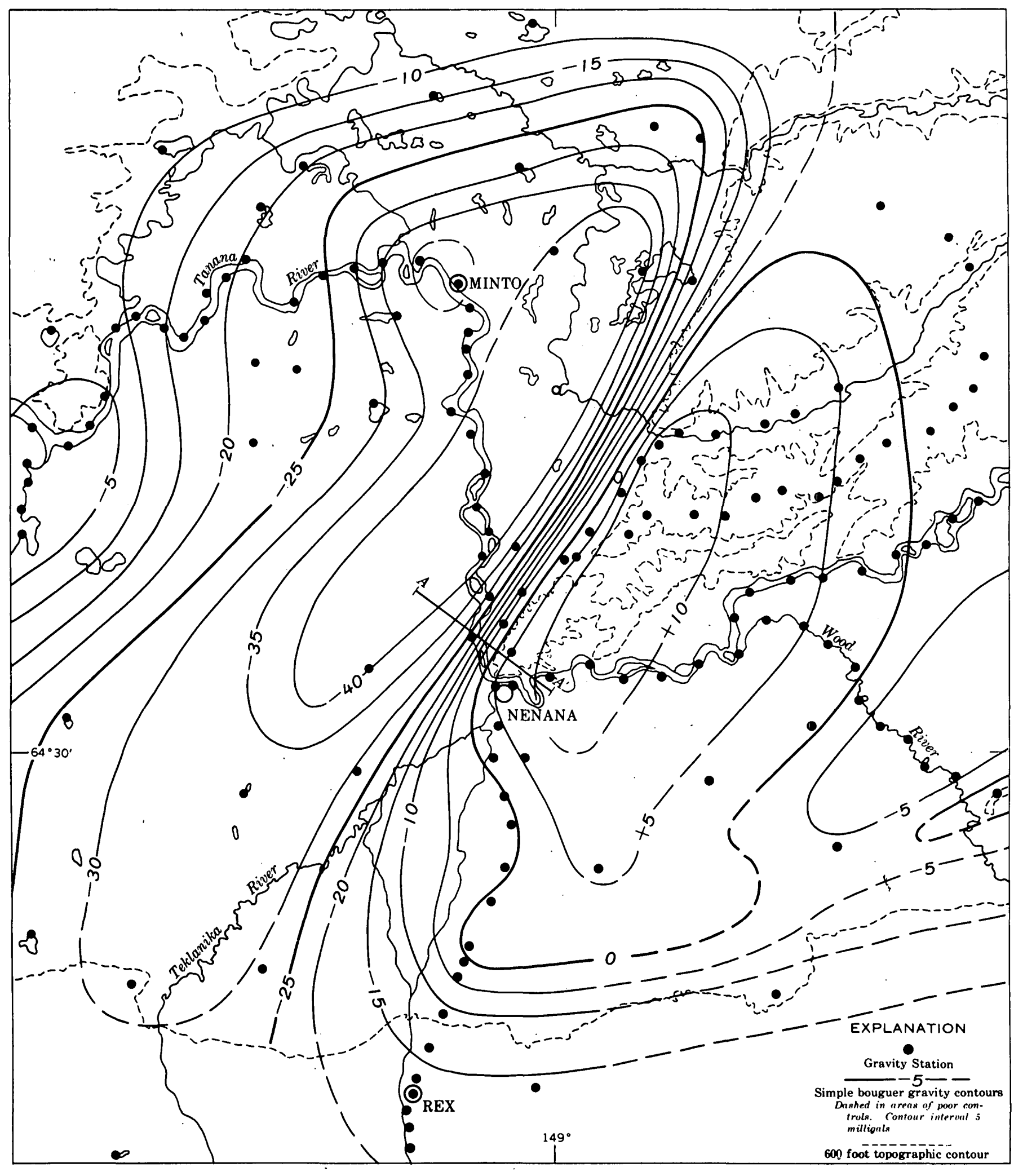

Fioure 383.1.-Contour map of simple Bouguer gravity anomaly, Minto Flats, Alaska. 
(Wahrhaftig, 1950). Physiographic evidence (D. M. Hopkins, oral communication, 1961) strongly suggests that the Minto Flats are actively subsiding, and that sediments are accumulating there at the present time.

Figure 383.1 is a map of the western part of the Middle Tanana basin. The gravity contours show simple Bouguer anomalies computed from observed gravity values at Fairbanks (Thiel and others, 1958) using a rock density of 2.67. The most important features of this map are a broad kidney-shaped low and a steep gradient along its eastern side. The $-10 \mathrm{mgal}$ contour defines the outer edge of the low and approximately coincides with the 600-foot altitude contour, which marks the edge of the hills bordering the Minto Flats. Bouguer gravity values associated with all the hills and lowlands adjacent to the flats range from -10 to +12 mgals except on the southern end of the flats where lower gravity values are associated with the Alaska Range. A gravity traverse along the road from Fox to Livengood north of the mapped area crossed contacts between Precambrian, Paleozoic, and Mesozoic rocks but did not reveal any large anomalies. Accordingly, density contrasts within the rocks forming the basement complex are probably not sufficient to explain the anomaly at Minto Flats.
The gravity low associated with the Minto Flats has a magnitude of -35 to -55 mgals in relation to the surrounding areas. The steepness of the gradient west of Nenana indicates that the anomaly has a shallow source; its maximum theoretical depth (Bott and Smith, 1958) is $3 \mathrm{~km}$. As the gradient approximately coincides with a contact at the surface between Quaternary deposits and the denser Birch Creek schist, this contact may be the source of the anomaly. The data do not completely eliminate the possibility, however, that all or part of the anomaly may be caused by another shallow basement contact such as the edge of the possible mafic rock mass postulated by Woollard and others (1960) in the vicinity of Nenana. Nearby outcrops, however, do not show such a mafic rock mass.

The thickness of the sedimentary prism required to cause the Minto Flats anomaly depends on the density contrast between the sediments and the basement rocks, but data for estimating this contrast are scarce. Specific gravities of a dozen hand specimens of Precambrian and Paleozoic basement rocks range from 2.6 to 2.8, but the densities of Cenozoic rocks of the types that may be present beneath the Minto Flats vary widely with age and character. On one extreme, Recent alluvium containing significant amounts of
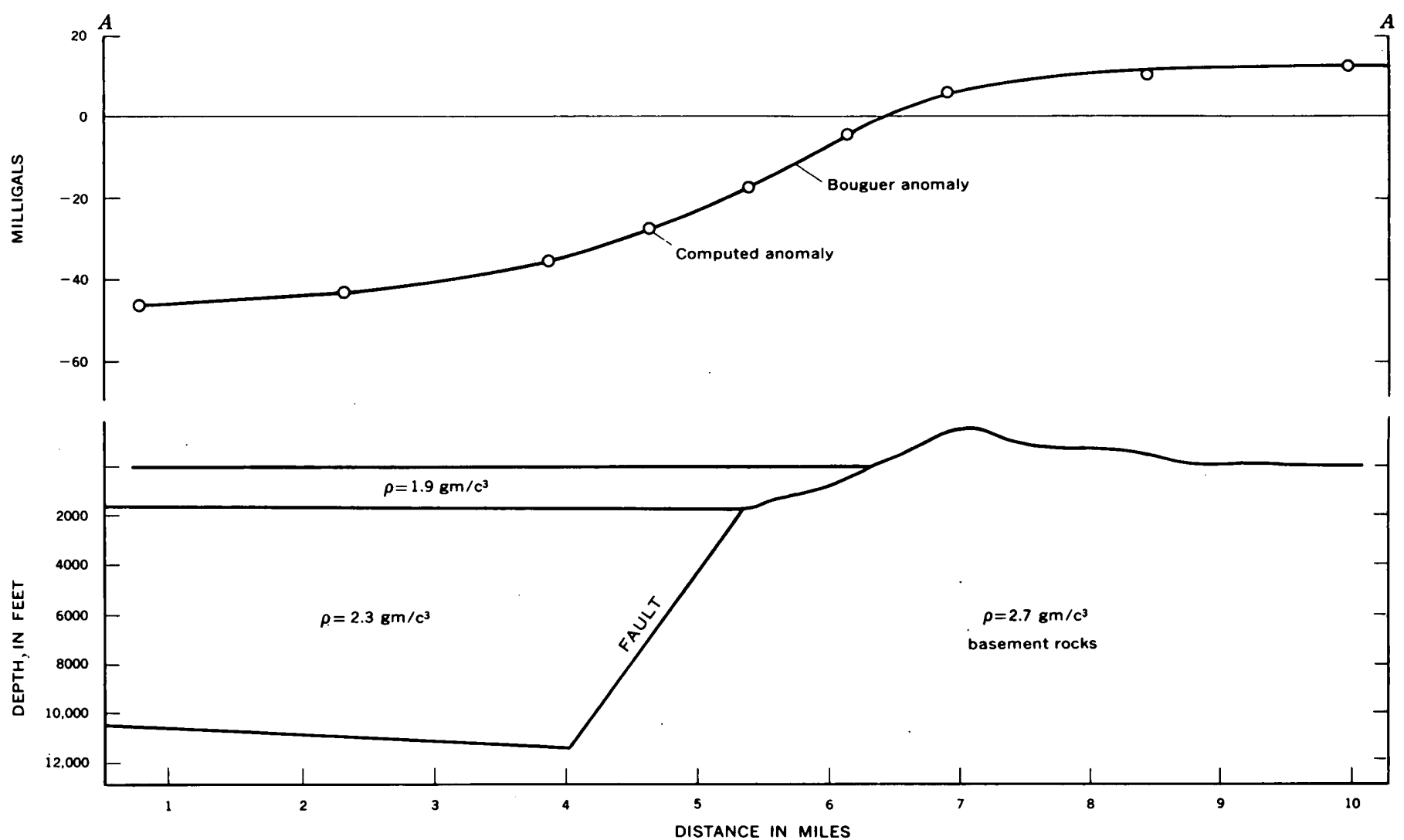

Figure 383.2.- Observed and computed gravity on profile $A-A^{\prime}$ north of Nenana and suggested subsurface configuration. 


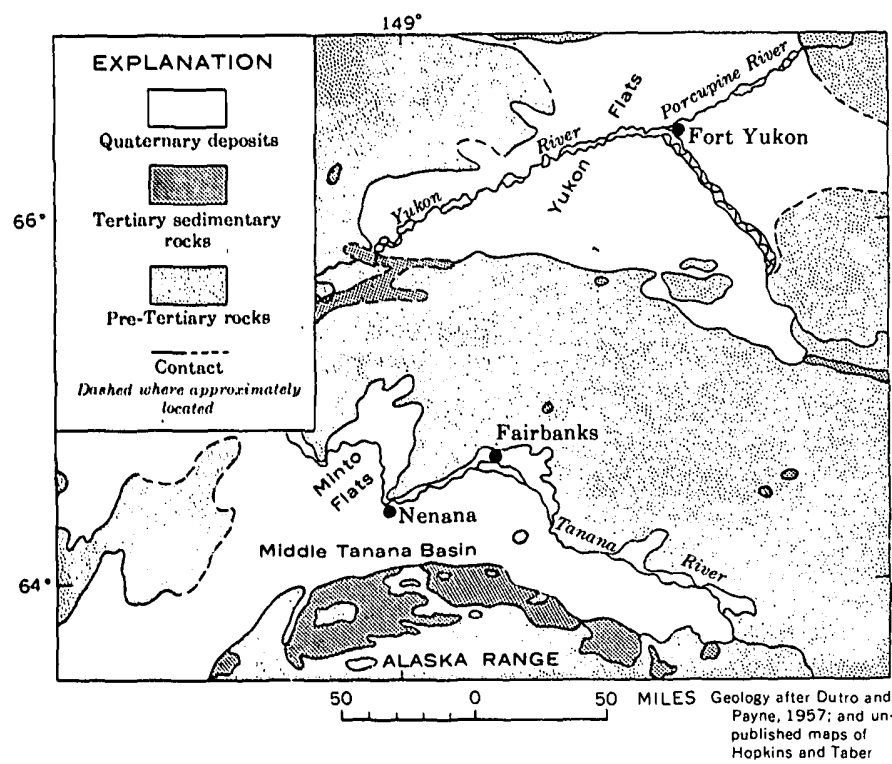

Froune 383.3.-Distribution of Tertiary and Quaternary sedimentary rocks in central Alaska.

either ice or organic matter may be lighter than 1.8 ; and at the other extreme, laboratory measurements of a few hand specimens of water-saturated sandstones of Tertiary age from the Yukon-Tanana area were as high as 2.6. Thus the thickness of the sedimentary section in Minto Flats could range from one to several kilometers. Figure 383.2 shows a plot of the anomaly along profile $A-A^{\prime}$ near Nenana and one of the several basement configurations that could produce such an anomaly. The suggested configuration assumes a layer of low-density alluvium overlying a thicker, intermedinte-density section which is separated from the basement rocks by a normal. fault. Such a fault would project very close to the oil seep reported near the mouth of the Nenana by Miller and others (1959).

Some conclusions regarding the age of the deeper deposits beneath the Minto Flats may be drawn from the rather large thickness required to explain the gravity anomaly. The maximum thickness of Quaternary alluvium that has been measured in the Tanana Valley is about 250 meter's at a seismic station 2 miles south of Fairbanks, measured by the author in 1952. Williams (1960) reports that about 120 meters of alluvium at Fort Yukon are underlain by late Tertiary deposits. Even a $1 \mathrm{~km}$ sedimentary section would thus be considembly thicker than nearby deposits of Quaternary alluvium, and even $1 \mathrm{~km}$ of subsidence during Quaternary time would represent a rather rapid crustal move- ment. Accordingly, older Tertiary deposits are probably present in the deeper part of the Minto Flats basin. These Tertiary rocks are probably denser than Quaternary alluvium so the thickness of the section required to cause the anomaly is probably greater than 1 $\mathrm{km}$. The subsidence which created the Minto Flats basin may have begun at about the same time as the subsidence and faulting that created nearby basins in which Tertiary sedimentary rocks are now exposed. Extensive Tertiary deposits (fig. 383.3) are present both north and south of the Minto Flats in the Alaska Range (Wahrhaftig, 1958) and along the Yukon River between the Yukon flats and the Palisades (Eakin, 1913). Coal-bearing rocks are present in the lower parts of both the Alaska Range and Yukon Valley Tertiary sections, and may also be present beneath the Minto Flats. Gravity values at the southern end of the Minto Flats anomaly are lower than in other bordering areas and suggest that the sedimentary prism may have a shallow connection with one of the basins containing Nenana gravel.

\section{REFERENCES}

Bott, M. H. P., and Smith, R. A., 1958, The estimation of the limiting depth of gravitating bodies: Geophys. Prosp., v. 6, no. 1, p. 1-10.

Capps, S. R., 1940, Geology of the Alaska railroad region : U.S. Geol. Survey Bull. 907, 201\%p.

Dutro, J. T. and Payne, T. G., 1957, Geologic map of Alaska: U.S. Geol. Survey, scale 1 : 2, 500,000

Eakin, H. M., 1913, A geologic reconnaissance of a part of the Rampart quadrangle, Alaska: U.S. Geol. Survey Bull. 535, $38 \mathrm{p}$.

Mertie, J. B., 1937, The Yukon-Tanana region, Alaska: U.S. Geol. Survey Bull. 872, 276 p.

Miller, D. J., Payne, T. G., and Gryc, George, 1959, Geology of possible petroleum provinces in Alaska: U.S. Geol. Survey Bull. 1094, 131 p.

Thiel, Edward, Bonini, W. E. Ostenso, N. A., and Woollard, G. P., 1958, Grávity measurements in Alaska: Woods Hole Oceanog. Inst. Ref. 58-54, 104 p.

Wahrhaftig, Clyde, 1950, Physiographic history of , southern Alaska-An hypothesis: Geol. Soc. American Bull., v. 61, no. 12, pt. 2, p. 1532 .

- 1958 , Quaternary geology of the Nenana River valley and adjacent parts of the Alaska Range: U.S. Geol. Survey Prof. Paper 293-A, 70 p.

Williams, J. R., 1960, Cenozoic sediments beneath the central Yukon flats, Alaska, in Short papers in the geological sicences: U.S. Geol. Survey Prof. Paper 400-B, p. B329.

Woollard, G. P., Ostenso, N. A., and Thiel, Edward, 1960, Gravity anomalies, crustal structure and geology in Alaska: Jour. Geophys. Res., v. 65, no. 3, p. 1021-1037. 


\section{GRAVITY SURVEY NEAR TUCSON, ARIZONA}

By Donald Plouff, Denver, Colo.

A total of 767 gravity stations were established near Tucson, Ariz. D. B. Jackson, A. J. Vaughn, and R. N. Babcock assisted in the field operations and reduction of the data. This region of the Basin and Range physiographic province is characterized by irregularly spaced mountains surrounded by desert plains.

Three major groups of rock crop out in the mountains located within the area of the gravity survey (fig. 384.1). The intrusive rocks include granite, granodiorite, and related crystalline rocks of Precambrian, Cretaceous, and Tertiary age. The Paleozoic and Mesozoic rocks mainly include a wide variety of sedimentary and volcanic rocks. The rocks of Tertiary age also include several types of sedimentary and volcanic rocks. A sampling program to determine the densities of the rock types in this area is being conducted.

The observed gravity measurements were referred to the absolute value of $979,227.2 \mathrm{mgal}$ (milligals) at the Tucson Municipal Airport (Woollard, 1958, p. 532). A standard rock density of $2.67 \mathrm{~g}$ per $\mathrm{cm}^{3}$ was assumed for calculation of the elevation and terrain corrections. Terrain corrections were carried to 18 miles, using the U.S. Coast and Geodetic Survey system (Swick, 1942).

The Bouguer gravity anomaly map (fig. 384.2) shows significant correlations between gravity highs and outcrops of Tertiary and older rocks. Many of these correlations can be attributed to the contrast in density between the rocks cropping out in the mountains and the less dense alluvium of the intervening valleys. Highs correlated with the outcrops are at localities $A$, $B, C, E$, and $F$ (figs. 384.1 and 384.2). Relative gravity lows that are associated with thick alluvium deposits are at localities $G, H, J, K$, and $L$ (figs. 384.1 and 384.2).

The gravity anomaly pattern enclosing the Tucson Mountains (loc. $A$ ) is markedly linear; this linearity suggests that the mountain area is bounded by faults. The gravity pattern in the Sierrita Mountains, (loc. $B$ ), however, does not have such striking linear boundaries, and, moreover, the gravity high is 6 miles northwest of the topographic high. The elongate gravity high is

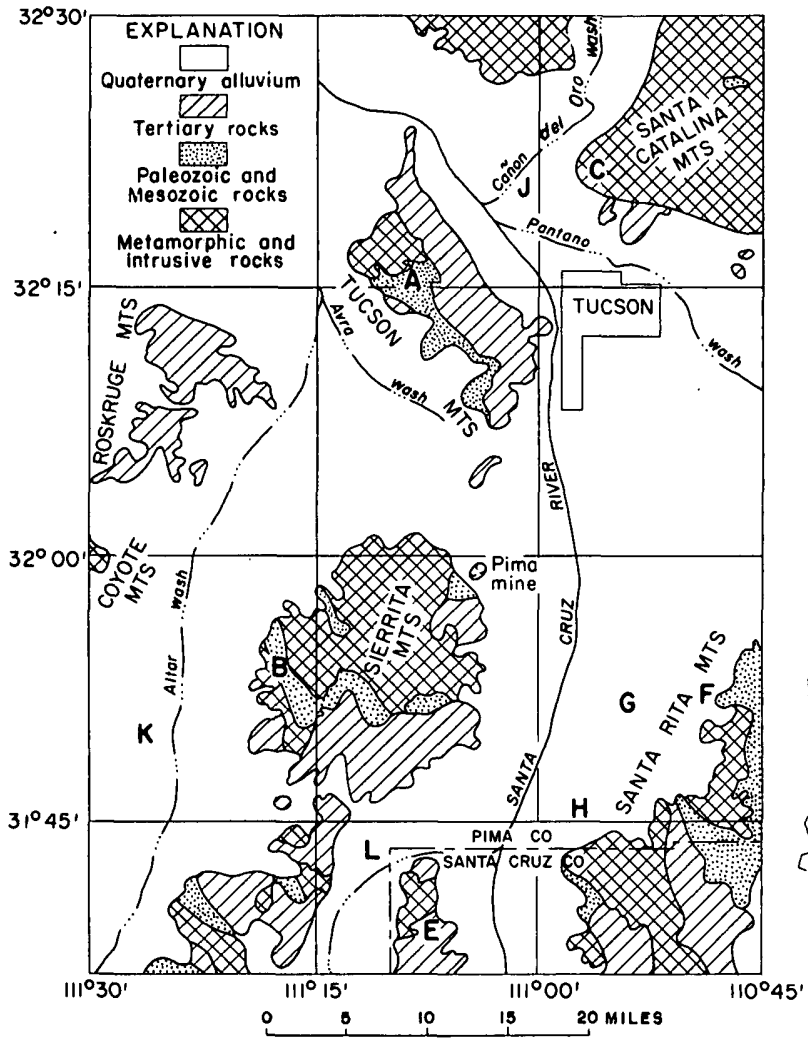

Figure 384.1.-Geologic map (generalized from Wilson and others, 1960). Localities mentioned in text indicated by capital letters.

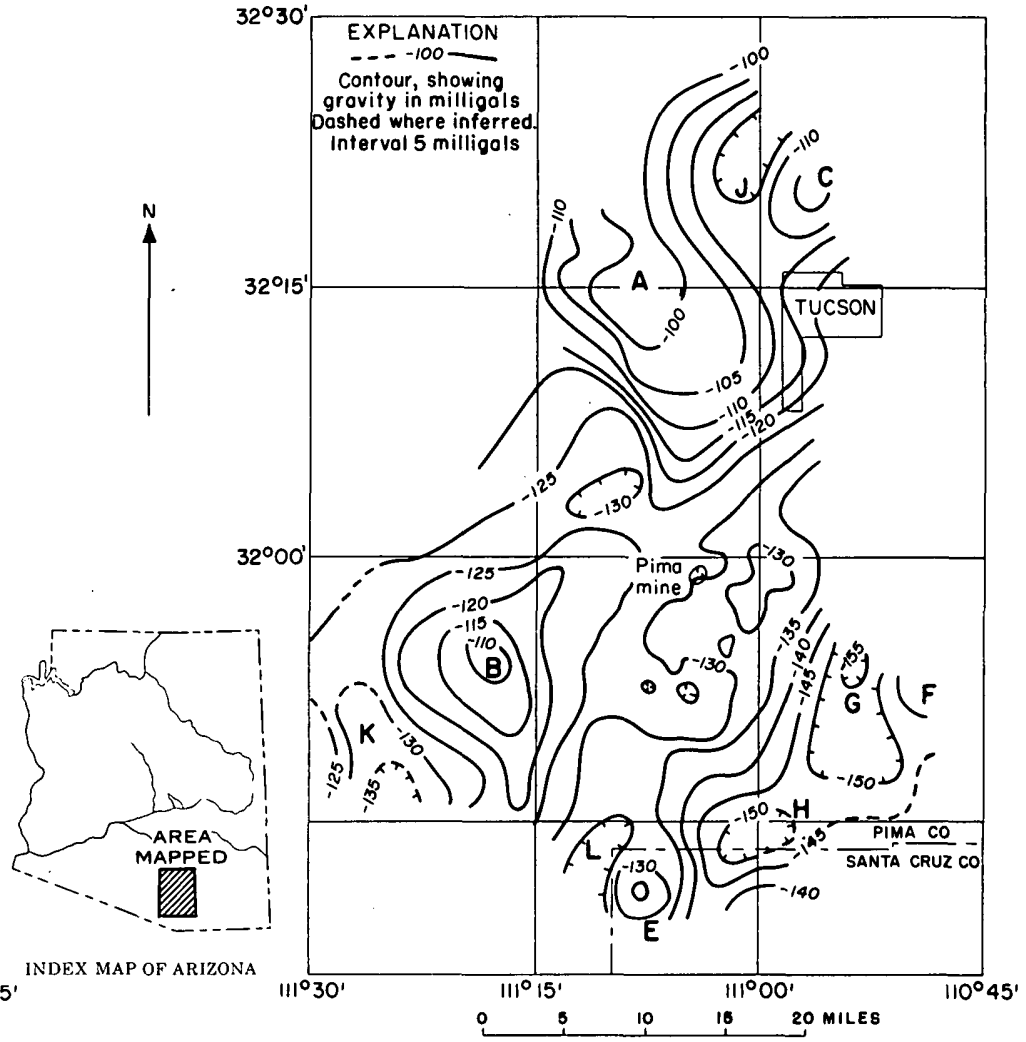

Figure 384.2.-Bouguer gravity anomaly map. Localities mentioned in text indicated by capital letters. 
along a northwestward-elongated band of Cretaceous and older sedimentary rocks.

The gravity lows at localities $G$ and $H$, are about 4 miles east of the topographic low along the Santa Cruz River. Interpretation of the thickness of alluvium in this area is complicated by the uncertain distribution beneath the alluvium; the Helmet fanglomerate, of Tertiary age, is about 10,000 feet thick in this area (Cooper, 1960). The density of the fairly to moderately well indurated conglomerate, which comprises most of the Helmet fanglomerate, is about 2.4 to 2.5 $\mathrm{g}$ per $\mathrm{cm}^{3}$, according to preliminary density measurements. This density probably is intermediate between that of the alluvium and the pre-Tertiary rocks of the area.

\section{REFERENCES}

Cooper, J. R., 1960, Some geologic features of the Pima mining district Pima County, Arizona: U.S. Geol. Survey Bull. 1112-C, p. 63-103.

Swick, C. H., 1942, Pendulum gravity measurements and isostatic reductions: U.S. Coast and Geodetic Survey Spec. Pub. 232, 82 p.

Wilson, E. D., Moore, R. T., and O'Haire, R. T., 1960, Geologic map of Pima and Santa Cruz Counties, Arizona: Arizona Bur. Mines, Tucson.

Woollard, G. P., 1958, Results for a gravity control network at airports in the United States: Geophysics, v. 23, no. 3 , p. $520-535$.

\title{
385. ELECTROMAGNETIC STUDIES IN THE TWIN BUTTES QUADRANGLE, ARIZONA
}

\author{
By F. C. Frischknecht and E. B. Ekren, Denver, Colo.
}

Electromagnetic measurements of the Helmet fanglomerate of Tertiary age (Cooper, 1960, p. 77-89) and surrounding rocks in the Twin Buttes quadrangle near Tucson, Ariz., give some information on the feasibility of prospecting for minerals in the older bedrock beneath the Helmet formation, and the usefulness of electromagnetic methods in resolving structural problems in this area.

The generalized geology of the area in which electromagnetic measurements were made is shown on figure 385.1. The Helmet fanglomerate dips steeply to the southeast in the traverse areas. According to Cooper (1960, p. 91), the fanglomerate is poorly sorted and contains pebbles, cobbles, and boulders of variegated material in a silt matrix. The most prominent structural feature in the area is the San Xivier thrust fault.

Conventional turam measurements (Hedstrom, 1940) were made along traverses normal to a long grounded wire, using a coil spacing of 100 feet and a frequency of 500 cycles per second. The turam ratios were normalized and the amplitude and phase angle of the normalized field were computed from the ratios, assuming values of 1.00 and $0^{\circ}$ for the amplitude and phase angle, respectively, at a distance of 100 feet from the cable. The results of the traverse in the northward direction are shown on figure 385.2. In general, the ratio curves are displaced considerably from their free-space values of 100 percent and 0 percent. Also, the ratio curves display discrete anomalies, which show that individual beds within the Helmet vary considerably in resistivity. Had a smaller coil spacing been used these anomalies might have been more pronounced. However, despite local lateral variations in resistivity, the turam amplitude and phase angle curves closely follow the theoretical curves for the field about an infinite wire on a conducting homogeneous half-space (Wait, 1953). The measured values of amplitude and phase angle are compared on figure 385.2 with theoretical curves chosen to fit the measured points best. The best fits for the amplitude and the phase angle curves differ, as indicated by the displacement between the points where $(\sigma \mu \omega)^{\frac{1}{2}} r=$ 2.0 on each curve. For any distance along the measured curves, there is a corresponding value of $(\sigma \mu \omega)^{\frac{1}{3}} r=$ 2.0 on the theoretical curves, making it possible to calculate an "apparent" resistivity. For example, at the point where $(\sigma \mu \omega)^{\frac{1}{2}} r^{2}=2.0$ on the theoretical amplitude curve, the distance $r$ on the measured curve is 512 feet. The apparent resistivity is then calculated to be $24 \mathrm{ohm}$ meters. Similarly, for the phase angle curve the resistivity is $16 \mathrm{ohm}$-meters.

Variable frequency measurements, or depth soundings, were made at eight different locations (fig. 385.1). 

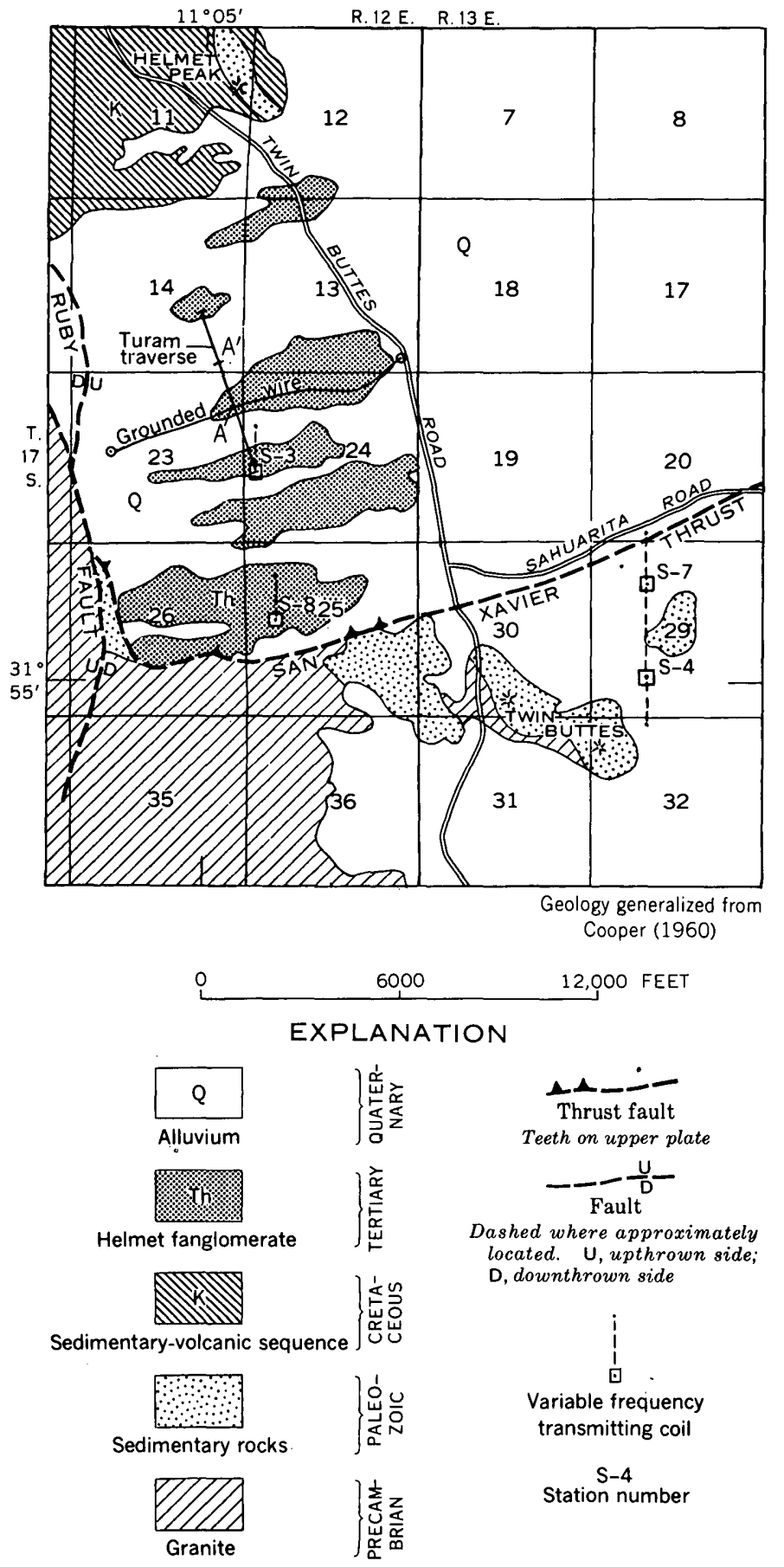

Figure 385.1.-Geologic map of part of the Twin Buttes quadrangle, Arizona, showing location of electromagnetic traverses.

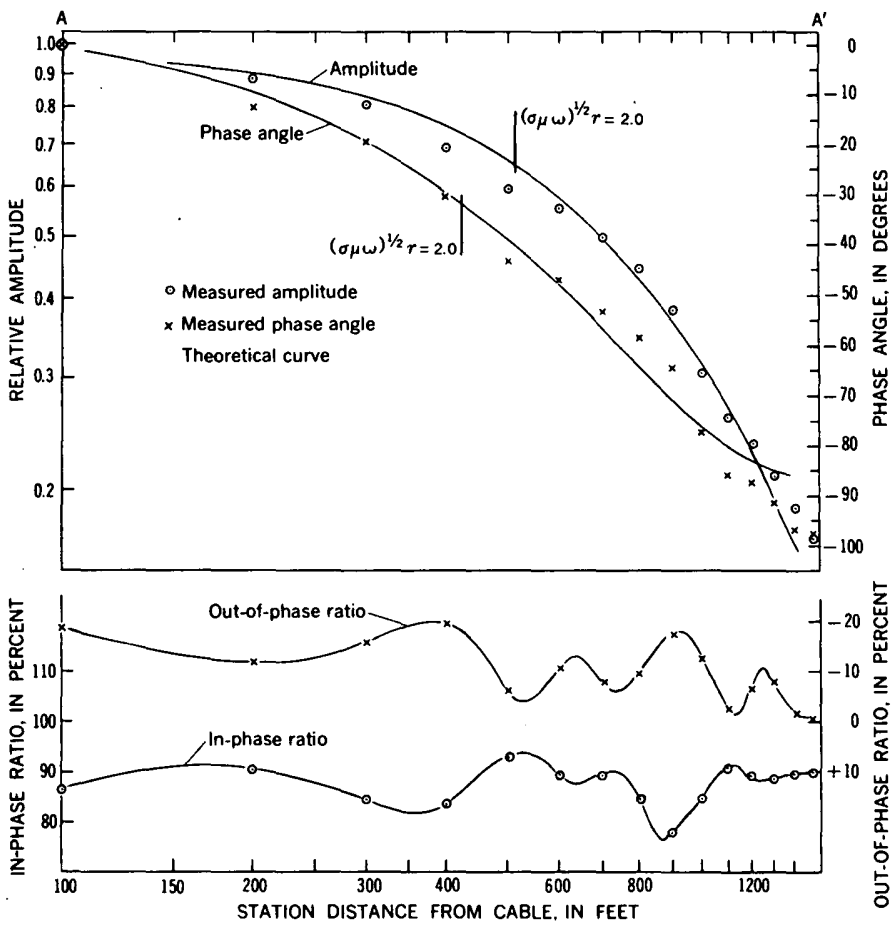

FrauRe 385.2.-Turam ratio and field curves for a traverse northward from long grounded cable. Because of attenuation of the signal beyond station distances of 1,500 feet from the cable, only results from the nearer part of the traverse are shown. The traverse in the southward direction yielded similar results.

Two large loops were placed on the ground; one was energized by a 70-watt power amplifier and the other served as a receiving coil (Keller and Frischknecht, 1960). A ratiometer was used to measure the mutual impedance between the coils over a frequency range of $35-1200$ cycles per second.

Sounding S-3 was located near the cable used for the turam measurements, and a coil spacing of $r=1,350$ feet was used. One coil for S-8 was several hundred feet north of the south edge of the San Xavier thrust; the other coil was 1,400 feet north of the first. The amplitude ratios for S-3 and S-8 were fitted on figure 385.3 to the theoretical curve (after Wait, 1955) for the mutual coupling between loops on a homogeneous half-space. The data for S-3 and S-8 closely fit the theoretical curve, indicating that in gross behavior the Helmet is an electrically homogeneous medium to a depth of at 


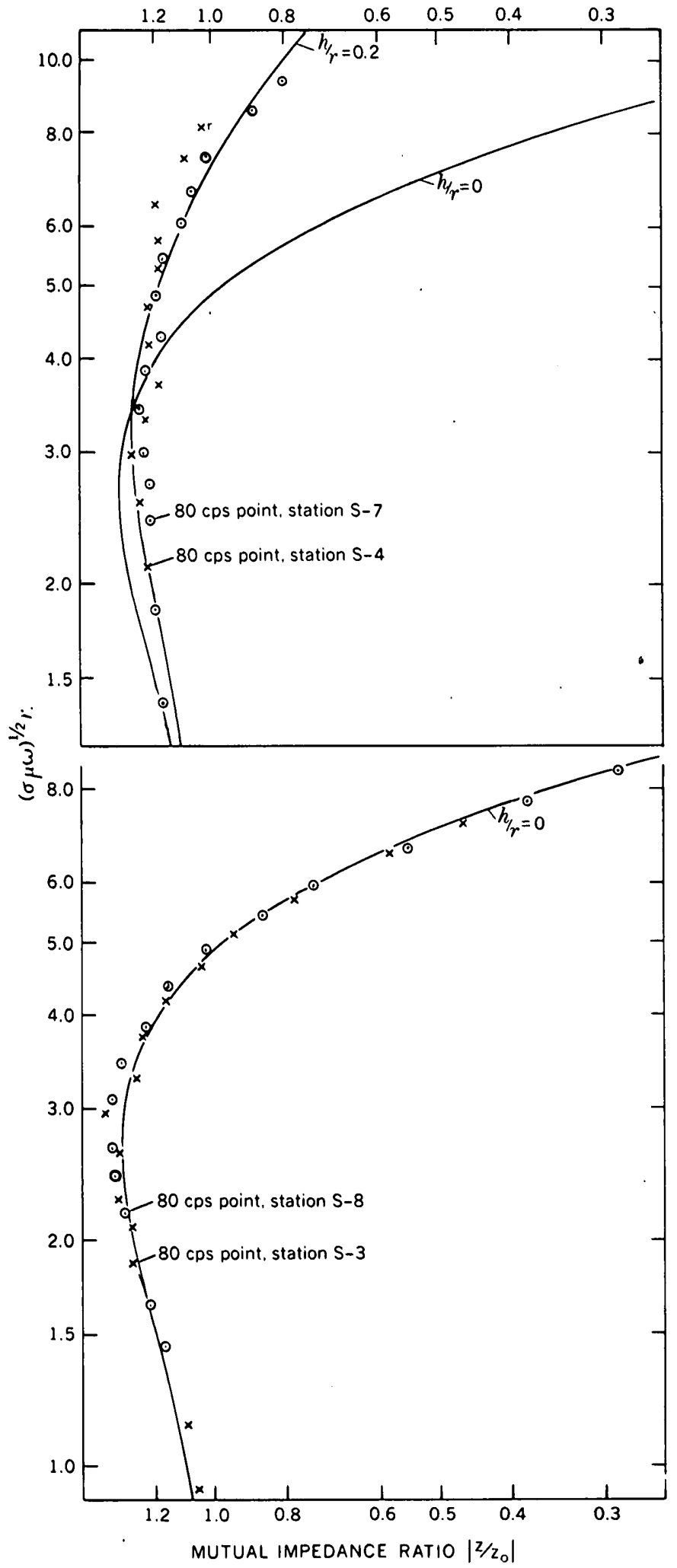

FinURE 385.3.-Variable frequency measurements and matching theoretical curve for stations $\mathrm{S}-3, \mathrm{~S}-8, \mathrm{~S}-4$, and $\mathrm{S}-7$. least several hundred feet. The scatter in the measured values represents instrumental errors.

Apparent resistivities can be determined from the variable frequency loop measurements, as from the turam measurements, by the positions at which the measured curves fit the theoretical curves (Keller and Frischknecht, 1960). For S-3 the apparent resistivity is $28 \mathrm{ohm}$-meters and for $\mathrm{S}-8$ it is $24 \mathrm{ohm}$-meters.

Four soundings were made along a north-south traverse between the easternmost of the Twin Buttes and the Sahuarita road (fig. 385.1) in order to locate the San Xavier thrust fault. Measurements from two of these soundings, $S-4$ and $S-7$, with coil spacings of 1,350 and 1,450 feet, respectively, are plotted on figure 385.3. Few theoretical curves for this type of sounding over layered earth are available, and the scatter of the data is too great to permit an accurate interpretation. The values for S-7 approximately fit the theoretical curve for loops raised above a homogeneous half-space a distance $h$, where $h=0.2 r$, implying a relatively resistant surface layer 200 or 300 feet thick, underlain by more conductive rocks. From calculations for loops raised above the surface it may be inferred that the theoretical curve for loops on the surface of a conducting layer that has an insulating half-space beneath also is probably flatter than the curve for a homogeneous half-space. The latter is the more likely, because in this area a layer of alluvium probably is underlain by granite or limestone.

Apparent resistivities of the Helmet fanglomerate, as determined by electromagnetic measurement, are somewhat lower (16 to $28 \mathrm{ohm}$-meters) than those determined from electric logs (35 to $60 \mathrm{ohm}$-meters, G. V. Keller, oral communication, 1960). Because of its low resistivity and because of local variations in resistivity the Helmet would be a formidable obstacle in trying to locate possible underlying ore bodies by electromagnetic methods.

\section{REFERENCES}

Cooper, J. R., 1960, Some geologic features of the Pima mining district, Pima County, Arizona: U.S. Geol. Survey Bull. 1112-C, p. 63-103.

Hedstrom, Helmer, 1940, Phase measurements in electrical prospecting: Am. Inst. Mining Metall. Engineers Trans., v. 138 , p. 456-472.

Keller, G. V., and Frischknecht, F. C., 1960, Electrical resistivity studies on the Athabasca Glacier, Alberta, Canada: Natl. Bur. Standards Jour. Research, v. 64D, no. 5, p. 439-448.

Wait, J. R., 1953, The fields of a line source of current over a stratified conductor: Appl. Sci. Research, sec. B, v. 3, p. 279-292.

1955, Mutual electromagnetic coupling of loops over a homogeneous ground: Geophysics, v. 20, no. 3, p. 630-637. 


\section{GEOPHYSICAL EXPLORATION OF WELLS AS AN AID IN LOCATION OF SALT-WATER LEAKAGE, ALAMEDA PLAIN, CALIFORNIA}

By R. P. Moston and A. I. Johnson, Denver, Colo.

Work done in cooperation with California Department of Water Resources

In the heavily irrigated Alameda Plain, at the southeastern edge of San Francisco Bay, Calif., there is a very high density of wells, many of which have been abandoned because of salt-water contamination. It seemed probable that saline water from an upper aquifer was contaminating the deeper and heavilypumped aquifer by moving downward through a relatively impervious clay layer along defective casings of abandoned wells. Geophysical exploration of selected wells in the area was made to determine if such leakage did occur.

Most wells in the area were constructed with a double casing, the outer pipe extending from the surface down into the clay layer. The annular space between the inner and outer casing was filled with concrete and served as a seal to prevent leakage of saline water downward from the upper aquifer. The inner casing extended into the deeper aquifer and was perforated only in this aquifer-approximately 200 feet below land surface.

Gamma radiation, temperature, fluid-resistance, and self-potential logs were made in five experimental wells near Centerville, Calif. The subsurface geology at the well sites and the construction features of these wells were known in detail and this information served as control for interpretation of the logs. Logging was later extended to wells in which the geology and construction were known in much less detail.

Logs were made under pumping, recharging, and static conditions. A portable submersible pump was used to pump the wells at rates up to a maximum of 100 gpm (gallons per minute), and a 450-gallon water-tank trailer was used to recharge wells with water of known quality and temperature. The geophysical logs, a driller's lithologic log, and a well-construction log were plotted together to assist in the interpretation of conditions in each well (fig. 386.1).

Logs of gamma radiation were used to determine lithology and well construction. These logs are especially useful in cased wells, in which electric $\operatorname{logs}_{\mathrm{s}}$ cannot be obtained. The double, concrete-filled casing in the upper part of the well shields the gamma radiation of the formation, and the depth at which this double casing was set could be determined with reasonable accuracy (fig. 386.1, depth 200 feet).

Temperature logging was done in all wells to permit conversion of fluid-resistance measurements to conductivity. The temperature $\log$ was also used to detect the positions of the leaks in the casing or flow of water from the upper aquifer to the lower aquifer. Wells outside the area of highest saline contamination in the lower aquifer had the expected geothermal gradient-the water temperature increasing $1^{\circ}$ to $2^{\circ} \mathrm{F}$ per 100 feet of depth. In the area of highest saline contamination the water temperature of some wells did not follow the expected gradient but remained constant or even decreased slightly with depth. Heat exchanges caused by interformational flow of water could cause these unexpected temperature gradients.

Changes of water salinity with depth in the well were determined by fluid-resistance logging. In wells that had not been pumped for months or years, salinity increased with depth in most wells, but decreased with depth in others. Possible interformational flow of water within the casing may have kept the lower parts of some wells flushed of saline water. The pumping equipment did not have sufficient capacity to produce significant changes in fluid resistance under prolonged pumping conditions.

To test the well casing for leaks by which saline water could move from the upper to the lower aquifer, several wells were recharged with water of known quality, and the wells were then logged several times to determine changes in fluid resistance. Figure 386.3 presents a series of fluid-resistance logs for a well where a leak was suspected by the driller. In this well, water of higher resistance than the recharge water was leaking from the aquifer into the well at a depth of 113 feet.

Self-potential logs help locate perforations and leaks in the well casings. Electrofiltration potentials in the well bore vary with the rate at which water is being pumped from the well, increasing with increasing flow through the well face. Thus, zones of leakage might be found by comparing self-potential logs obtained under static conditions with those obtained under pumping conditions. As the rate of pumping increases, the con- 
SHORT PAPERS IN THE GEOLOGIC AND HYDROLOGIC SCIENCES, ARTICLES 293-435

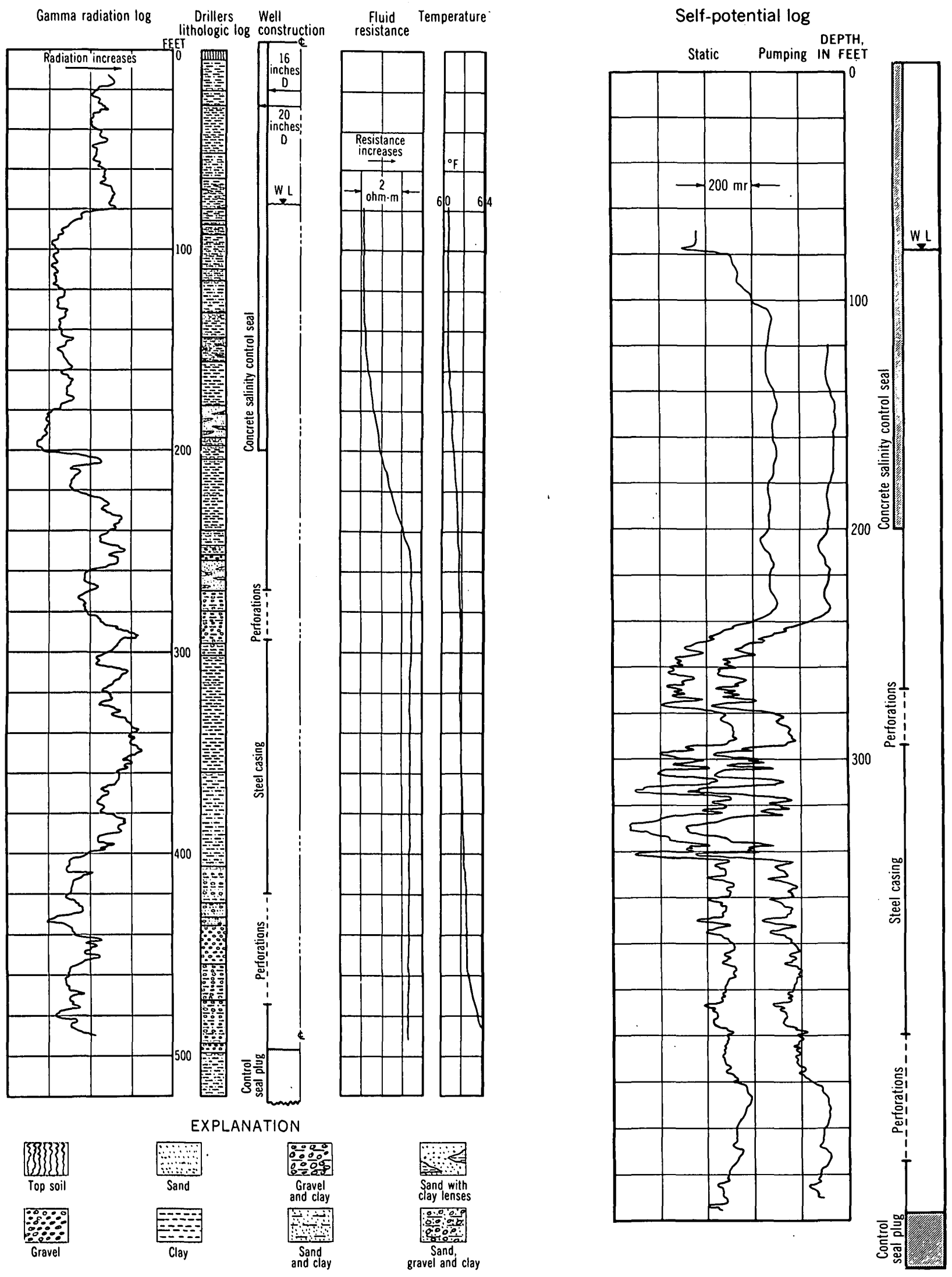

FIoURE 386.1.-Construction and geophysical logs from a well Figure 386.2.- Self-potential logs of a cased well near Alvarado, near Alvarado, Calif. Calif. 


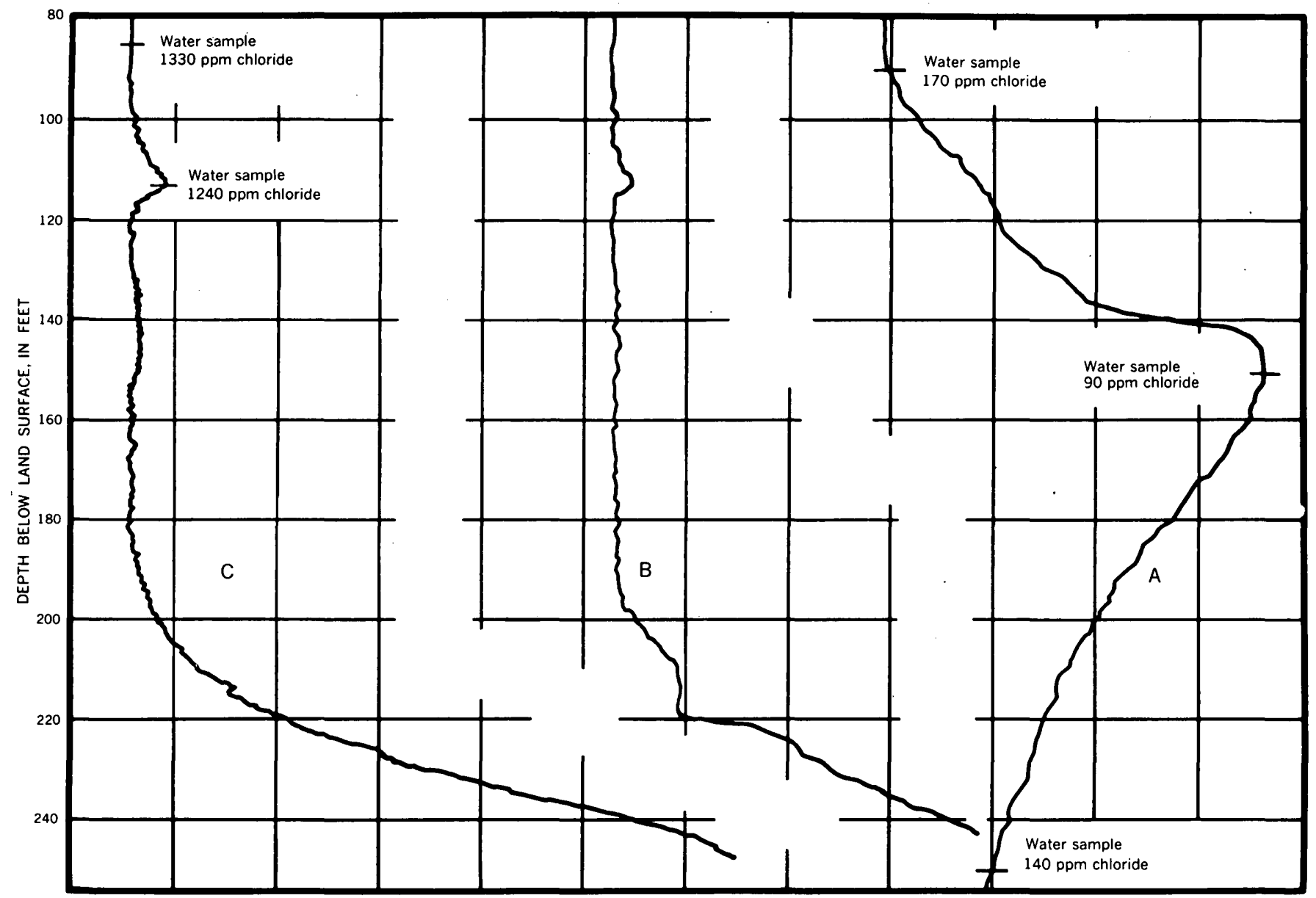

RESISTIVITY INCREASES 2 OHM-METERS PER DIVISION $\longrightarrow$

Frgure 386.3.-Logs of fluid resistance in a well near Union City, Calif. Log A, static; $\log$ B, 20 minutes after 500 gallons containing $2,000 \mathrm{ppm}$ (parts per million) of dissolved solids was recharged into the well; $\log \mathrm{C}$, $60 \mathrm{minutes}$ after recharge.

trast between the potential logs in the producing and nonproducing zones increases. This technique was described by Meyer (1958, p. 97-98) for an uncased hole. It was tried in a newly cased well perforated in two zones. A large increase in potential difference was noted at the lower perforated zone, but the increase opposite the upper zone was insignificant (fig. 386.2). If a pump of greater capacity had been available, this technique possibly would have provided data of greater sensitivity.
The in-hole logging methods outlined aided in successfully identifying a source of salt-water intrusion into deeper aquifers.

\section{REFERENCF}

Meyer, Gerald, 1958, The ground-water resources, in Meyer. Gerald, and Beall, R. M., The water resources of Carroll and Frederick Counties: Maryland Dept. Geology, Mines, and Water Resources, Bull. 22, p. 1-228. 


\section{AEROMAGNETIC INTERPRETATION OF ZONED INTRUSIONS IN NORTHERN MAINE}

By John W. Allingham, Washington, D.C.

Recent aeromagnetic surveys at two localities in northern Maine reveal several distinctive circular anomalies associated with granitic intrusions. The anomalies are believed to indicate magnetically zoned plutons. Three-dimensional analyses of aromagnetic data give the relative width of the magnetic zones and indicate the approximate attitude of their contacts.

Near Jackman, in northwesterm Maine, a small rounded pluton of quartz monzonite and a rim of metamorphic rock create a circular magnetic high over Wood Pond (fig. 387.1). The quartz monzonite intrudes relatively nonmagnetic lower Paleozoic sedimentary rocks, mainly slate and conglomerate, and older, pre-Silurian quartz monzonite (A. L. Albee and Eugene Boudette, written communication, 1961). Magnetic hornfels may comprise part of the outer zone on the west side of the intrusive. Part of the area is covered by water and glacial debris, which

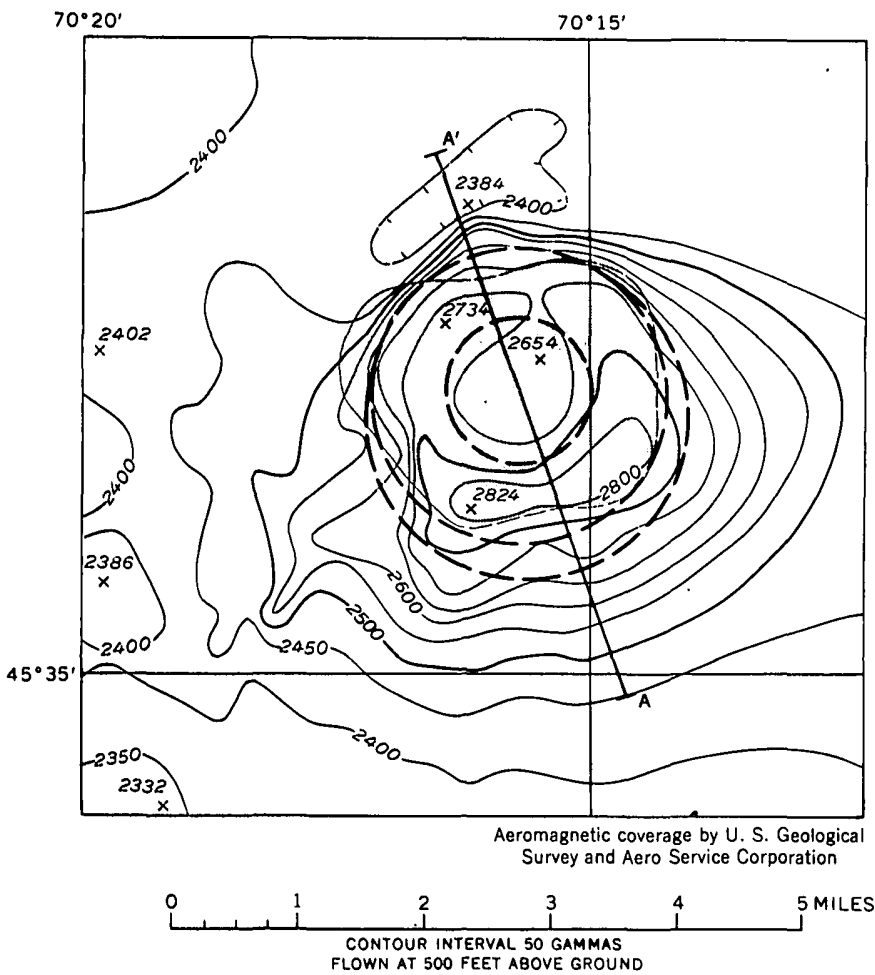

FraUre 387.1-Total-intensity aeromagnetic map of the Wood P'ond area, Maine. Magnetic profile $A-A$.' shown on figure 387.3. Quartz monzonite, shaded pattern; contact, solid where based on outcrops, dashed where inferred from aeromagnetic data; outline of cylindrical model, heavy dashed line. obscure the contact between quartz monzonite and the older rocks. Magnetic zoning is shown by a magnetic low that occurs within the area of anomalously high magnetism produced by the quartz monzonite pluton. The anomaly is elongated southwestward, which indicates a southwestward dip of the intrusive.

Lower Paleozoic slate and volcanic rocks are intruded by a circular pluton of granitic rock at Chandler Lake (T. 9 N., R. 8 E.) in northeastern Maine (Boucot and others, 1960). This intrusive, which is partly rimmed by hills of hornfels, is also magnetically zoned (fig. $387.2)$.

The magnetically zoned intrusions have been analyzed by comparing them to a model of concentric cylinders (figs. 387.3 and 387.4) for which magnetic profiles $\left(A-A^{\prime}\right)$ were computed by use of three-dimensional polar charts of Henderson (1960). Cylinders were selected because of the circular symmetry of the observed magnetic anomalies. Compensation was made for the regional northwesterly geomagnetic gradient.

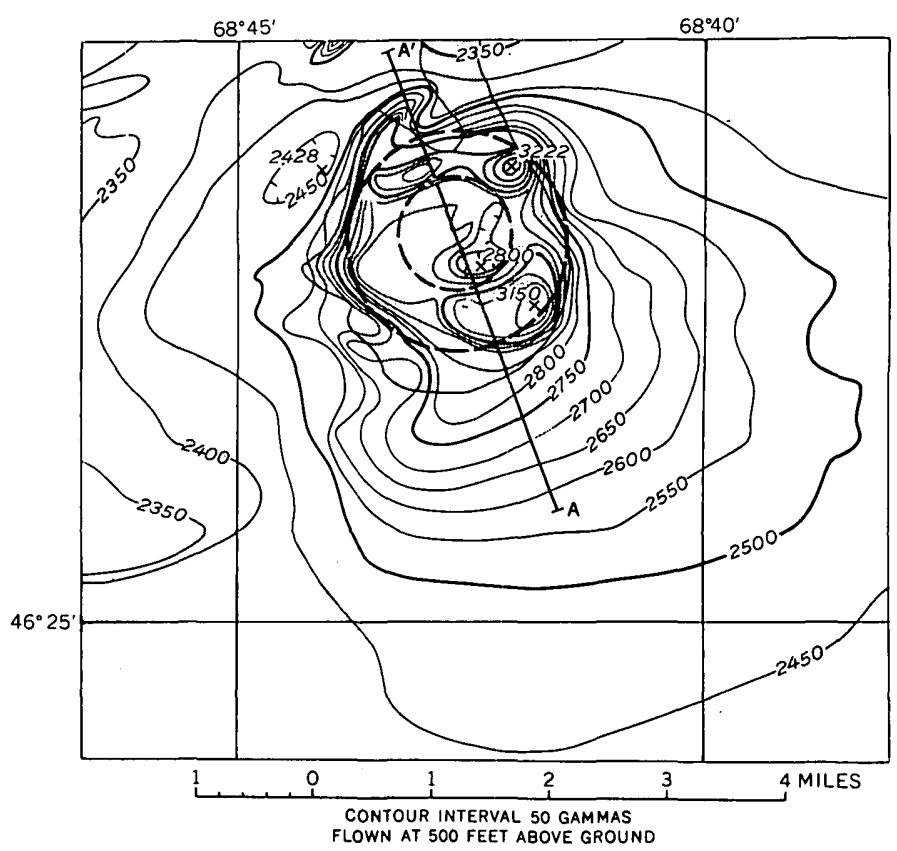

Frgure 387.2-Total-intensity aeromagnetic map of the Chandler Lake area, Maine. Magnetic profile $A-A^{\prime}$ shown on figure 387.4. Granitic intrusive, shaded pattern; contact solid where based on outcrops, dashed where inferred from aeromagnetic data; outline of cylindrical model, heavy dashed line. 


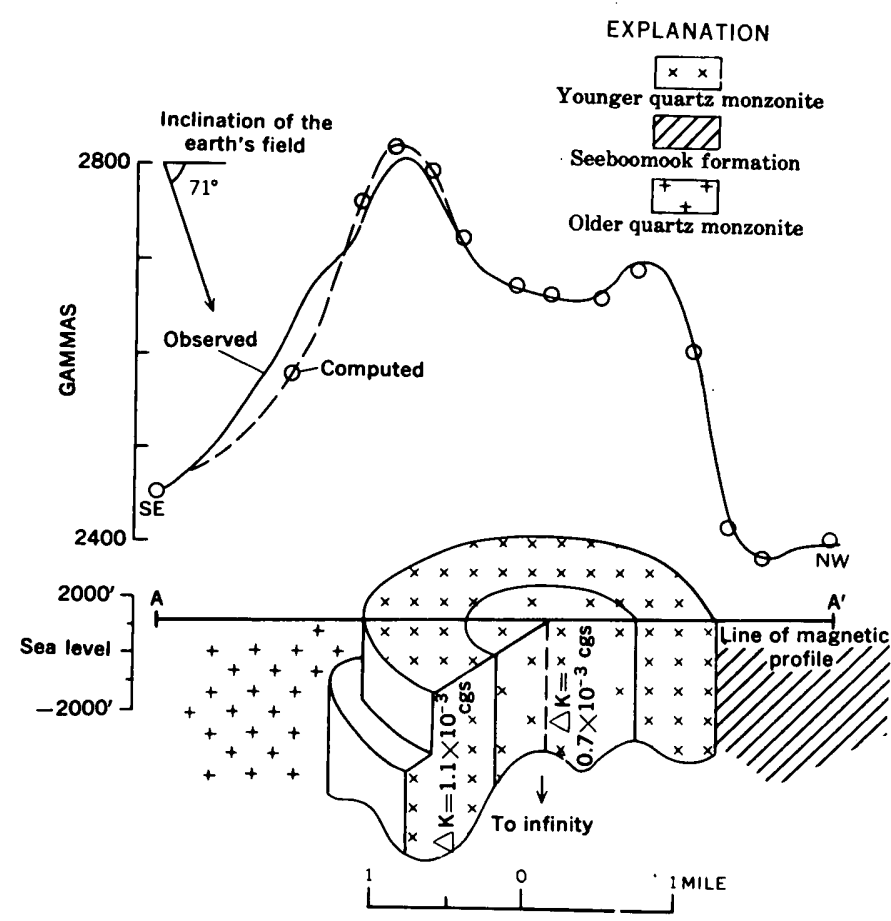

Figure 387.3.-Magnetic zoning in the younger quartz monzonite intrusive at Wood Pond, Maine.

Total-intensity profiles were computed in the direction of the earth's magnetic field. The remanent magnetization is less than the induced magnetization and is assumed to be negligible. Cylinders giving the best fit with the observed data are assumed to approximate the zoned plutons. The computed magnetic susceptibility of the outer zone of the quartz monzonite at Wood Pond, $K=1.1 \times 10^{-3} \mathrm{cgs}$ units, compares favorably with the measured susceptibility, which is $1.0 \times 10^{-3} \mathrm{cgs}$ units (average of 3 samples). For the purpose of the analysis, the susceptibility of the hornfels (less than $0.1 \times 10^{-3} \mathrm{cgs}$ units) is negligible. To match the observed profile over the Chandler Lake intrusion, two susceptibilites are needed for the outer zone. The southeast part must have a susceptibility of $2.1 \times 10^{-3}$ cgs units and the northwest part $2.6 \times 10^{-3}$ cgs units.

The fit of the observed and theoretical curves (figs. 387.3 and 387.4) indicate that the contacts of the plutons with the country rock are nearly vertical, except for the south contact of the quartz monzonite at Wood Pond which dips less steeply. The absence of small

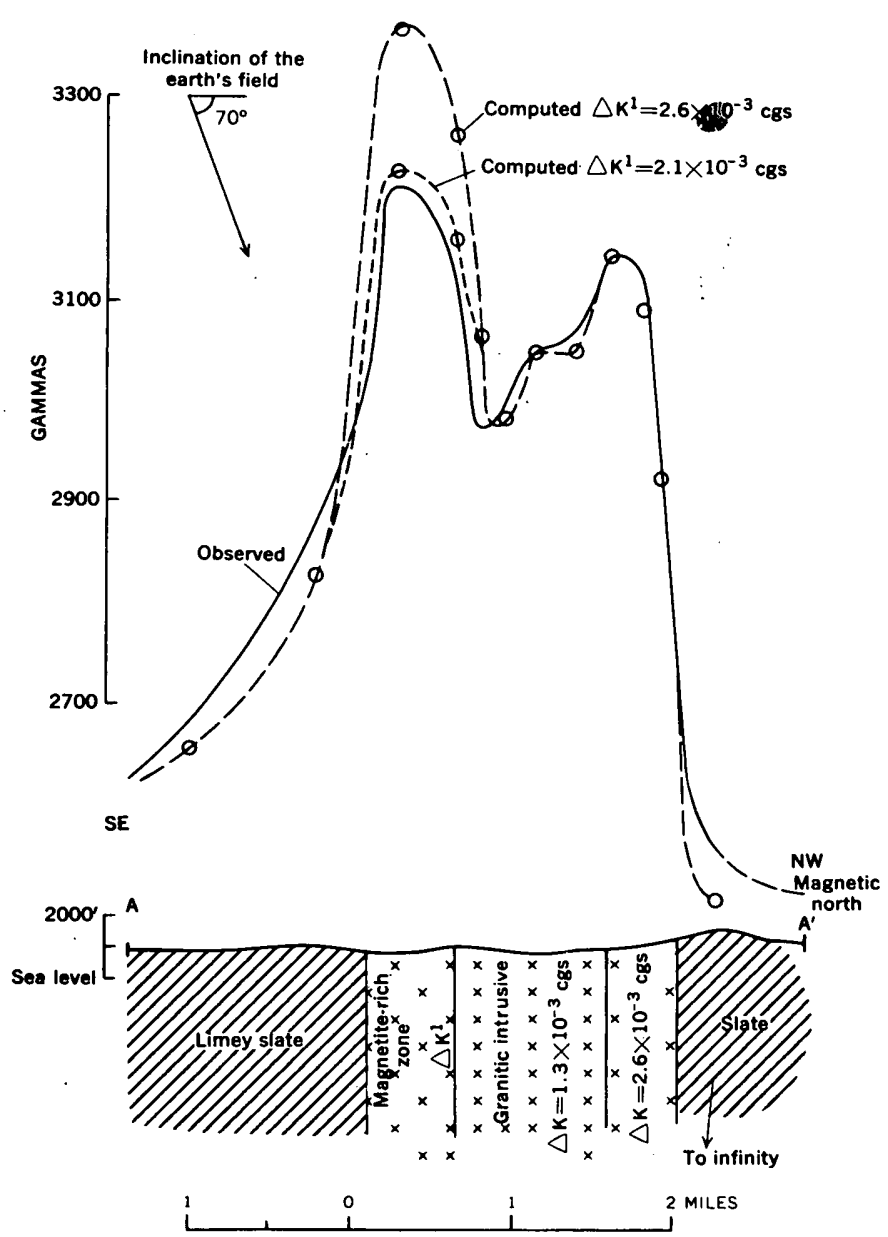

Frgure 387.4.-Magnetic zoning in the granitic intrusive at Chandler Pond, Maine.

sharp isolated anomalies over the contact zones shows that magnetite, which largely determines the magnetic susceptibility, is evenly distributed in these contact zones. The magnetic patterns over the plutons resemble those observed elsewhere over ring dikes.

\section{REFERENCES}

Boucot, A. F., Griscom, Andrew, Allingham, J. W., and Dempsey, W. J., 1960, Geologic and aeromagnetic map of northern Maine: U.S. Geol. Survey open-file report.

Henderson, R. G., 1960, Polar charts for evaluating magnetic anomalies of three-dimensional bodies, in Short papers in geological sciences: U.S. Geol. Survey Prof. Paper 400-B, p. B112-B114. 


\title{
388. AEROMAGNETIC, AERORADIOACTIVITY, AND GRAVITY INVESTIGATIONS OF PIEDMONT ROCKS IN THE ROCKVILLE QUADRANGLE, MARYLAND
}

\author{
By Andrew Griscom and Donald L. Peterson, Washington, D.C.
}

A combined aeromagnetic and aeroradioactivity survey in the Rockville area, Maryland, was made during 1958 by the U.S. Geological Survey as part of a geophysical study of the Maryland Piedmont. The aeromagnetic data were obtained and compiled by procedures previously described (Balsley, 1952). The scintillation detection equipment has been described by Davis and Reinhardt (1957) and the record is compensated for variations in flight elevation. The radiation components produced by cosmic radiation and radionuclides in the air have been removed prior to contouring by assigning a level of zero to data obtained over wide stretches of the Potomac River. East-west traverses were flown at a spacing of one-quarter of a mile and a flight elevation of 500 feet. Four north-south tie lines were flown to tie the traverses together. A gravity survey of the Rockville quadrangle was made in 1960.

The bedrock consists of the Wissahickon formation intruded by large bodies of gabbro and serpentinized periodotite. The Wissahickon formation is composed mainly of schists which resulted from the metamorphism of former shales and siltstones to quartz-albite. muscovite-chlorite-magnetito assemblages. Locally there are higher grade mineral assemblages containing biotite and garnet. The serpentines contain considerable primary magnetite and also secondary magnetite formed during serpentinization of the preexisting peridotite. In general, the gabbro contains less magnetite than the Wissahickon formation. The margins of the grabbro are metamorphosed to the green-schist facies and appear to contain more magnetite than the less-altered central portions. Geologic contacts (fig. 388.1) were determined from ground reconnaissance with the aid of aeroradioactivity and soils maps.

The aeromagnetic map (fig. 388.1) shows a linear magnetic grain associated with the structural trend of the folded Wissahickon formation. This pattern indi. cates that various subunits have differing magnetizations. Some of these subunits can be traced on the ground. The largest magnetic highs are located over serpentine. The relations between highs and associated lows show that at least locally within the larger serpentine body there must be a remanent magnetization in a direction different from that of the earth's field. Other nearby serpentine dikes (not in this quadrangle) produce negative anomalies which are probably caused by strong inverse remanent magnetizations. The gabbro bodies in general are characterized by magnetic lows which are rimmed by magnetic highs that are associated with the contacts (fig. 388.1). These marginal highs are probably associated with the metamorphosed borders of the gabbro. A two-dimensional magnetic computation was made across the central gabbro body along section $A-A^{\prime}$, using the configuration deduced from the gravity data. A reasonable fit with the observed data was obtained (fig. 388.2) by using a susceptibility contrast of $0.0014 \mathrm{cgs}$ unit for the central mass and $0.0033 \mathrm{cgs}$ unit for the lower density metamorphosed material along the contacts.

The contoured aeroradioactivity data are shown on figure 388.3 (p. D-270). The radiation recorded at 500 feet elevation is virtually the average value of radiation from within a circle 1,000 feet in diameter on the ground. The bulk of the measured radiation comes from the uranium and thorium radioactive decay series and from potassium-40. These elements tend to occur together and are relatively abundant in shales and granitic rocks but are relatively scarce in mafic and ultramafic rocks. On figure 388.3 the mafic intrusions are outlined by the radiation lows and the contacts can be located with considerable accuracy. Linear radiation trends produced by the Wissahickon formation correspond with aeromagnetic trends and the two maps have proved most useful when used in conjunction.

The simple Bouguer values shown on the gravity map (fi. 388.4, p. D-271) are all positive and range from about +37 to about +51 milligals. The measurements outline a large positive closure of +14 milligals elongated northeast, parallel to the trend of the aeromagnetic and aeroradioactivity anomalies. Local highs coincide with the gabbro outcrops showing that the anomaly is caused by high-density gabbro in contrast with lower density schist.

Theoretical gravity values were computed for a hypothetical gabbro body along section $A-A^{\prime}$. The body was assumed to be two-dimensional. The sharp peak of the measured profile could not be matched using a simple density contrast so that the body was separated into a high-density core with a lower density border zone. The best match was obtained using a core density contrast of $0.23 \mathrm{~g}$ per $\mathrm{cm}^{3}$, a border zone 


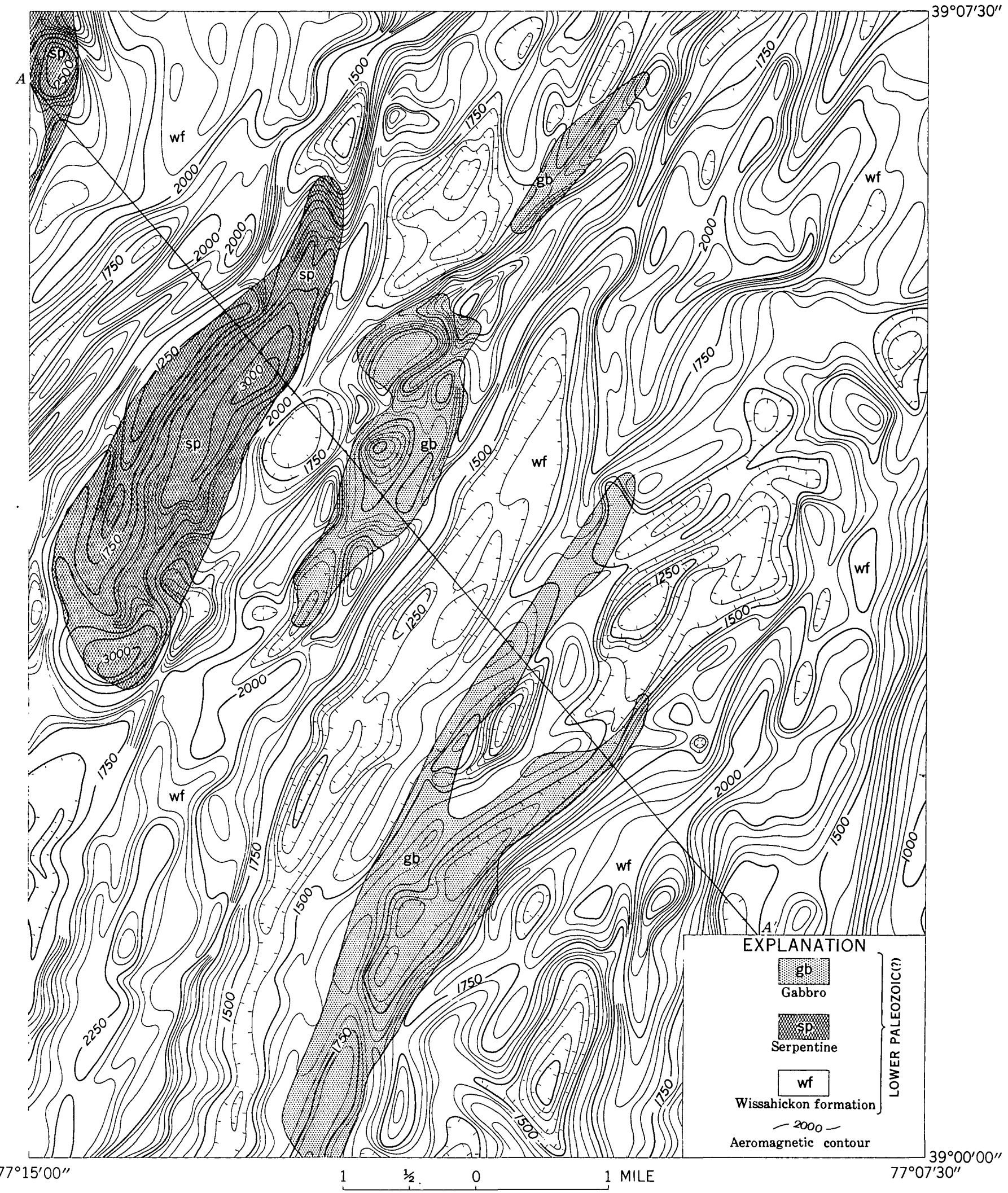

FIGURE 388.1.-Aeromagnetic and generalized geologic map of the Rockville quadrangle, Maryland. Contour interval 50 and 250 gammas. Datum arbitrary. 


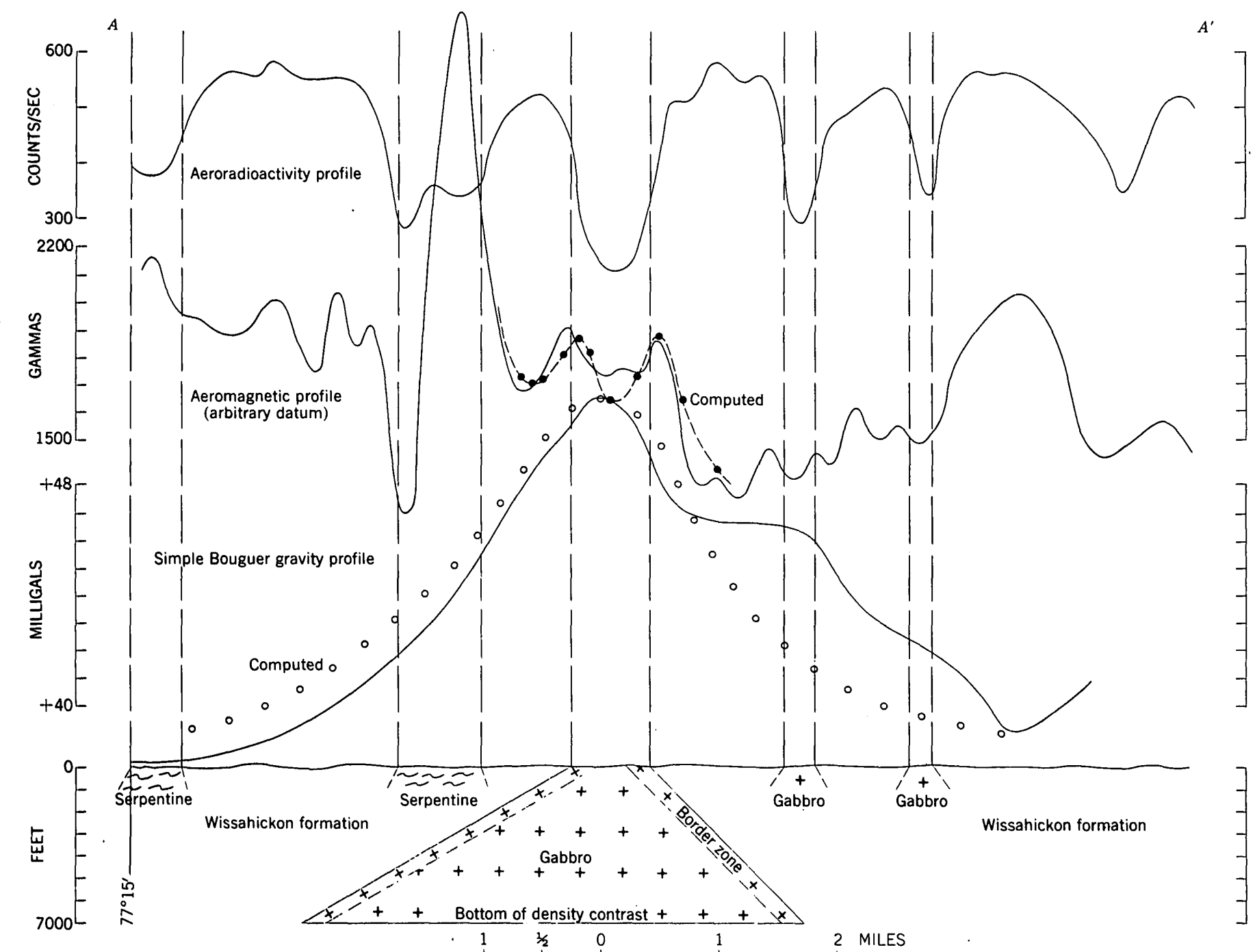

Froure 388.2.-Aeroradioactivity, aeromagnetic, simple Bouguer gravity, and geologic profiles along section $A-A^{\prime}$. The circles represent computed aeromagnetic and gravity points using the assumed shape of the gabbro body.

density contrast of $0.1 \mathrm{~g}$ per $\mathrm{cm}^{3}$, and the configuration shown on figure 388.2. Although the densities and their proportions could be changed somewhat, it seems clear that the body is more dense toward the center, has a shape similar to that which is shown, and extends at least several thousand feet in depth. Estimated residual anomalies of +6 milligals and +3 milligals are associated with the gabbro outcrops on the southeast side of the section. The high regional gravity level
(+37 milligals) indicates that there is a much larger mass of dense rock below the gabbro body.

\section{REFERENCES}

Balsley, J. R., 1952, Aeromagnetic surveying, in Landsberg, H. E., ed., Advances in geophysics: New York, Academic Press, Inc., v. 1, p. 313-349.

Davis, F. J., and Reinhardt, P. W., 1957, Instrumentation in aircraft for radiation measurements: Nuclear Sci. and Eng., v. 2, no. 6, p. 713-727. 


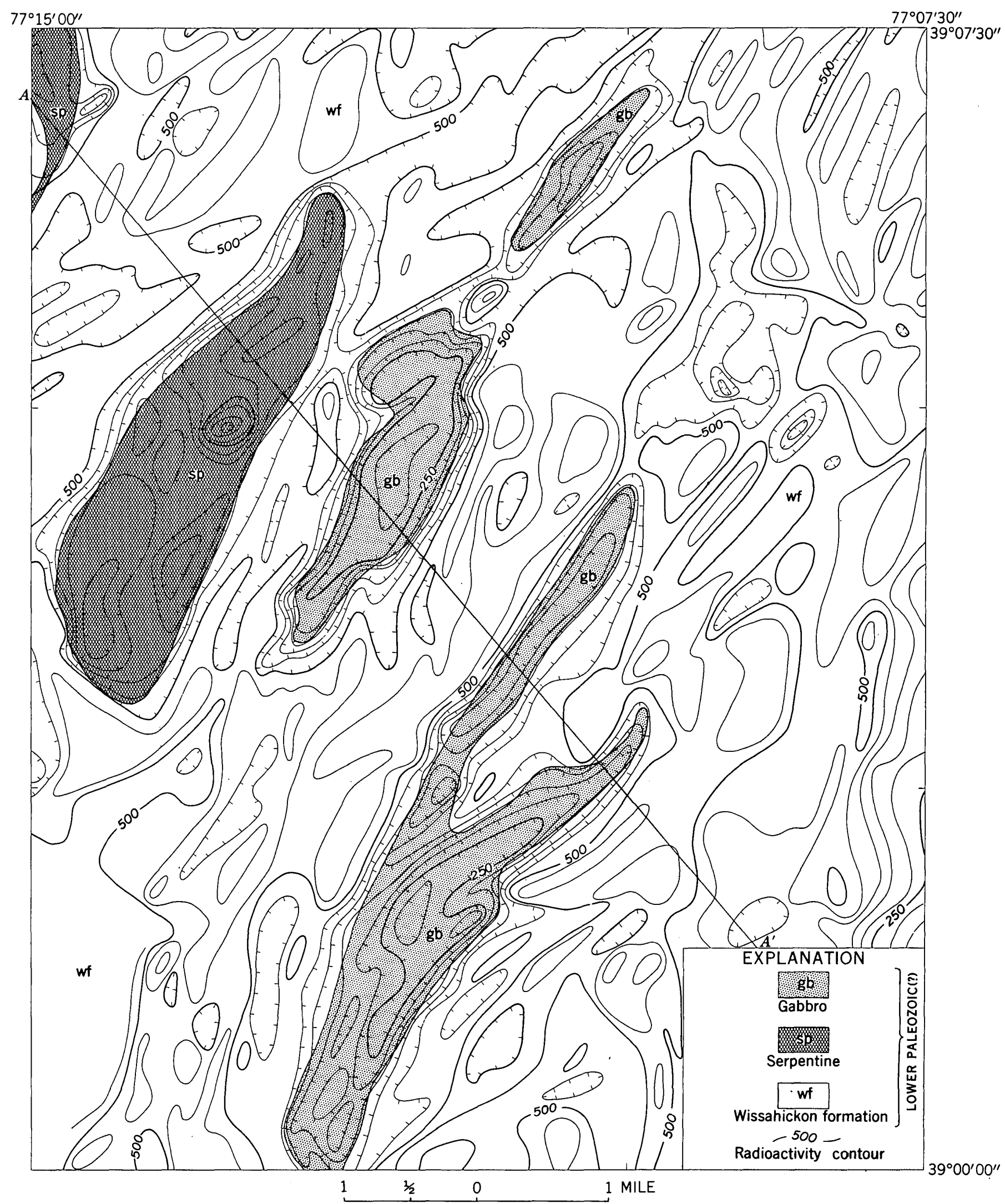

FIgURE 388.3.-Aeroradioactivity and generalized geologic map of the Rockville quadrangle, Maryland. Contour interval 50 counts per second. 


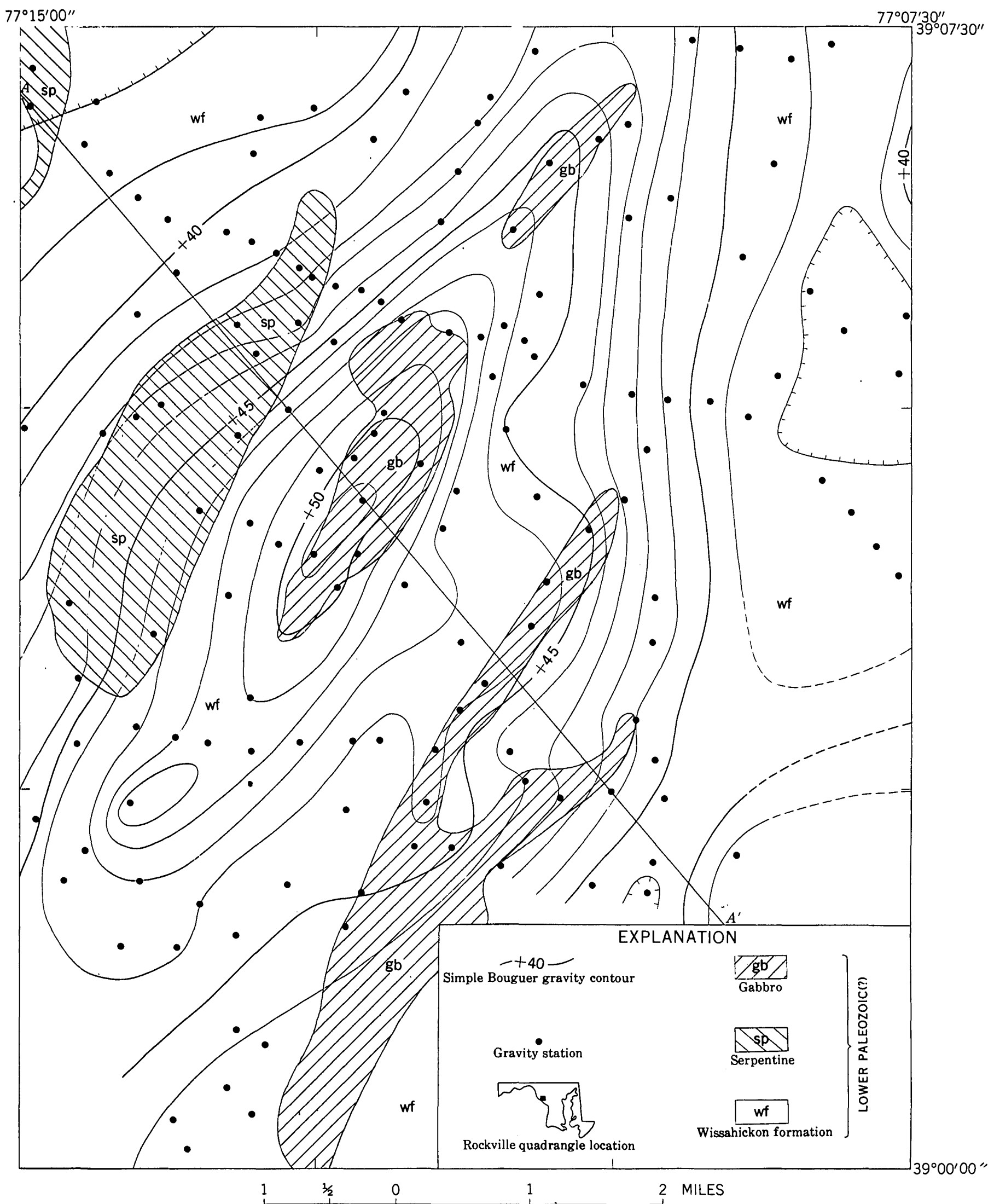

Froure 388.4.-Simple Bouguer gravity and generalized geologic map of the Rockville quadrangle, Maryland. Contour interval one milligal. 


\section{ELECTRICAL PROPERTIES OF A PART OF THE PORTAGE LAKE LAVA SERIES, HOUGHTON COUNTY, MICHIGAN}

By G. V. Keller, Denver, Colo.

The electrical properties of rocks in the Michigan copper district along the south shore of Lake Superior are being investigated to determine which of several electrical prospecting methods might be useful in the search for additional ore. Two methods of investigations are being used: measurement of the electrical properties of the rock in place using bore-hole logging, and laboratory measurement of electrical properties and determination of rock textures of drill-core samples.

In 1958 and 1959, the Calumet and Hecla Consolidated Copper Co. drilled a series of prospect holes along the strike of the Iroquois amygdaloid of the Portage Lake lava series of Keweenawan age near Calumet, Mich. These regularly spaced drill holes provided an opportunity to study the continuity of electrical properties along the strike of the beds. The continuity in electrical properties is one of the most important factors in determining whether electrical surveys can be used successfully in mapping geologic structure.

Three properties were determined in this evaluation of electrical prospecting methods: the electrical conductivity of the rock, the capacity for induced electric polarization, and the magnetic susceptibility. Borehole measurements of each of these properties were made, and measurements of the vertical component of the magnetic field and the spontaneous potential were also obtained. The logs were run in 10 drill holes along a line extending northeast through the town of Calumet. The spacing between these holes was approximately 1,000 feet.

A cross section comparing conductivity and magnetic susceptibility logs from five of these drill holes is shown on figure 389.1. The conductivity logs were run with a conventional guard electrode system. The magnetic susceptibility was measured with an induction coil operated at $400 \mathrm{cps}$, with a measuring field intensity of about 0.2 oersted.

The rock penetrated by these five holes is the Iroquois amygdaloid of the Portage Lake series. The Iroquois consists of three flows, with three oxidized amygdaloidal units, designated $\mathrm{A}, \mathrm{B}$, and $\mathrm{C}$. The electric logs are alined using the base of the Iroquois amygdaloid B as a datum plane. The logs on figure 389.1 do not extend into amygdaloid C.

The amygdaloidal units are more conductive than the rest of the flows. The conductive zones generally extend several feet above and below the zones geolog- ically described as oxidized amygdaloids, indicating that only the center parts of the porous amygdaloidal units have been oxidized. The conductive beds appear to be continuous from hole to hole, though the thickness of the conductive amygdaloidal units varies considerably. The electrical properties of the traprock between the amygdaloidal units also vary from hole to hole.

Average resistivities of the traprock and of the amygdaloidal units in three of the drill holes were computed by averaging the resistivity values appearing on the logs at 2 -foot intervals. The results are listed in table 389.1. The resistivity of the traprock is approximately twice that of the amygdaloids. Both the trap

TABLE 389.1.-Average electrical properties taken from electric logs \begin{tabular}{l|l|c|c}
\hline & $\begin{array}{c}\text { Transverse } \\
\text { resistivity } \\
\text { (ohm-meters) }\end{array}$ & $\begin{array}{c}\text { Longitudinal } \\
\text { resistivity } \\
\text { (ohm-meters) }\end{array}$ & $\begin{array}{c}\text { Coefficient } \\
\text { of macroan- } \\
\text { isotropy }\end{array}$ \\
\hline
\end{tabular}

\begin{tabular}{l|l|l|l}
\hline \multicolumn{3}{c}{ Drill hole Centennial DH-9 } \\
\hline Traprock & 279 & 236 & 1.09 \\
Amygdaloid units . & 136 & 108 & 1.12 \\
\hline
\end{tabular}

Drill hole Centennial DH-12

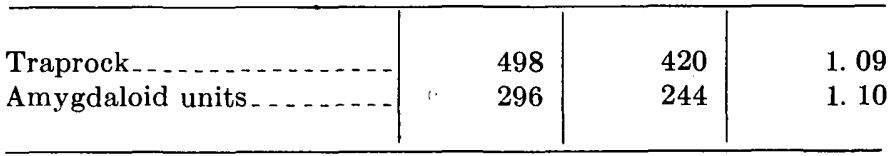

Drill hole C \& H DH-22

\begin{tabular}{|c|c|c|c|}
\hline$\ldots$ & 596 & 520 & 1. 07 \\
\hline Amygdaloid units $\ldots \ldots$ & 273 & 248 & 1. 0 \\
\hline
\end{tabular}

and the amygdaloids have moderately low coefficients of macroanistropy, which range from 1.05 to 1.12.

The magnetic susceptibility of the amygdaloidal units is uniformly low, generally less than $2 \times 10^{-6} \mathrm{cgs}$ units. The magnetic susceptibility of the traprock is considerably higher, ranging from $5 \times 10^{-4}$ to $4 \times 10^{-3} \mathrm{egs}$ units. The zones of high susceptibility cannot be traced from hole to hole, however, and probably are local concentrations of magnetite.

The induced polarization measurements were made inhole using a repeating pulse method. No logs are shown, as a relatively uniform response of from 0.75 to 1.50 percent was recorded in all drill holes. There was 


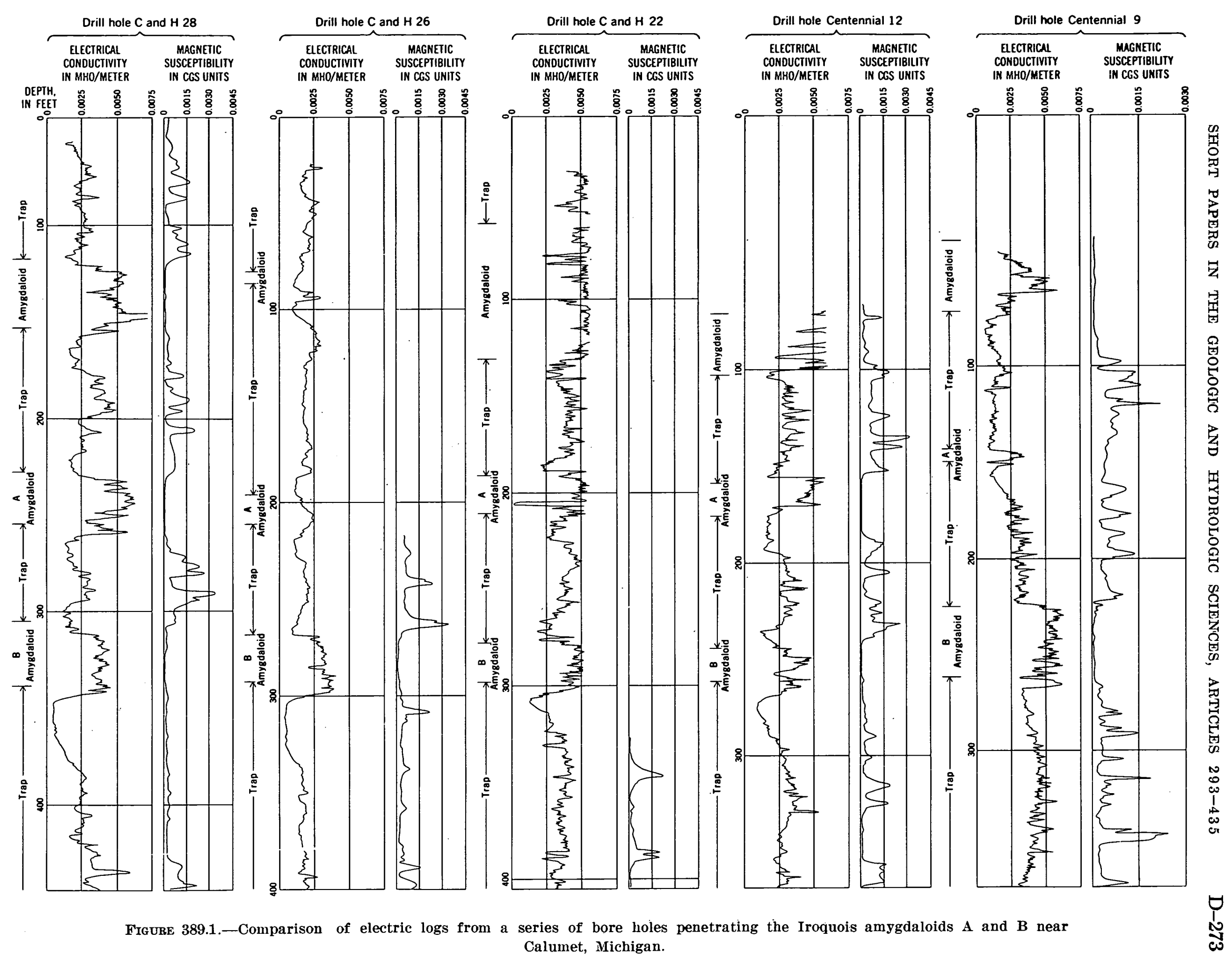


no observable difference in induced polarization of the traps and the amygdaloids.

Samples were taken at 5 -foot intervals from drill hole $\mathrm{C} \& \mathrm{H} \mathrm{DH}-22$ for laboratory measurements of electrical properties. These samples were resaturated with water, and the resistivity and induced polarization response were measured. These data (table 389.2) show that the traprock has a slightly higher polarization response, on the average, than does the amygdaloid. This difference may be caused by a greater amount of magnetite in the trap.

The amygdaloid samples are about ten times as porous as the trap samples. With such a contrast in porosity, it would be reasonable to expect a larger contrast in resistivity between these two rock types than was observed in the bore-hole measurements. The resistivity of the amygdaloids in place may be anomalously high either be cause they are not completely water saturated, or because they have been flushed by circulating surface waters.
TABLE 389.2.-Summary of induced polarization measurements determined in the laboratory

[All samples from drill hole $\mathrm{C} \& \mathrm{H}$ DH-22]

\begin{tabular}{l|r|r|r}
\hline \multicolumn{1}{c|}{ Group of samples } & $\begin{array}{c}\text { Number of } \\
\text { samples }\end{array}$ & $\begin{array}{r}\text { Porosity } \\
\text { (percent) }\end{array}$ & $\begin{array}{l}\text { I. P. response } \\
\text { (percent) }\end{array}$ \\
\cline { 1 - 2 } & 3 & 4.90 & 1.73 \\
Upper amygdaloid. & 13 & 0.87 & 2.06 \\
Traprock & 3 & 5.11 & 1.10 \\
A amygdaloid... & 3 & 0.87 & 1.95 \\
Traprock & 7 & 8.88 & 1.63 \\
B amygdaloid & 11 & 0.75 & 2.20 \\
Traprock & 3 & 7.07 & 1.90 \\
C amygdaloid. & & & \\
\hline
\end{tabular}

\section{ACKNOWLEDGMENTS}

I wish to express my thanks to the Calumet and Hecla Consolidated Copper Co. and, in particular, to Dr. James P. Pollack, Chief Geologist, for permission to conduct this study.

\section{GRAVITY ANOMALIES, ISOSTASY, AND GEOLOGIC STRUCTURE IN CLARK COUNTY, NEVADA}

By Martin F. Kane and J. E. Carlson, Washington, D.C., and Menlo Park, Calif.

In 1957 , a gravity survey of Clark County, Nev. was started to investigate the relation of the gravity field to geologic structures. Gravity stations were set in the mountain areas, as well as in valleys, in order to study variations in gravity over bedrock. However, the high cost of obtaining completely representative bedrock measurements in the dry, rugged ranges of Clark County restricted the survey to roads and paths of easy access where most points of known altitude are shown on topographic maps. Despite this limitation, the overall gravity measurements have revealed a pattern of anomalies that indicates a close relationship between isostatic adjustment and geologic structures.

Mabey (1960) has shown that over much of the Basin and Range Province regional topography and Bouguer gravity anomalies are inversely related. This correlation implies that a given mass of terrain is compensated by a mass deficiency below and near the area. One can examine this same condition by a study of the freeair gravity anomaly (fig. 390.1). If the average freeair anomaly is near zero for a large area, it indicates (as does Mabey's correlation of negative Bouguer anomalies with elevated topography) that the terrain of the area is generally compensated.
Measured free-air anomalies in Clark County range from $+132 \mathrm{mgal}$ to $-111 \mathrm{mgal}$ and average $-15 \mathrm{mgal}$. Figure 390.1 shows that the negative anomalies are over low-altitude alluviated areas and that positive anomalies are restricted to higher altitude bedrock areas; the distribution of stations shows that the negative anomalies are reasonably well defined. However, free-air anomalies are sensitive to the average altitude of a given area, and gravity stations should be distributed in a pattern representative with regard to elevation. In Clark County, bedrock stations are located in accessible areas, and they are generally below the average height of the bedrock mass. Moreover, some stations are restricted to alluviated areas between bedrock masses (mainly in the western part of the northern ranges), thereby putting all negative values in areas that should also show positive values. Adjustments for these discrepancies are both in a positive sense so that an adjusted average value would be closer to zero. Therefore, isostatic compensation within the county as a whole seems nearly complete.

The free-air-anomaly map (fig. 390.1) consists of a regular series of positive and negative anomalies which can be related to distinct geologic features. The am- 


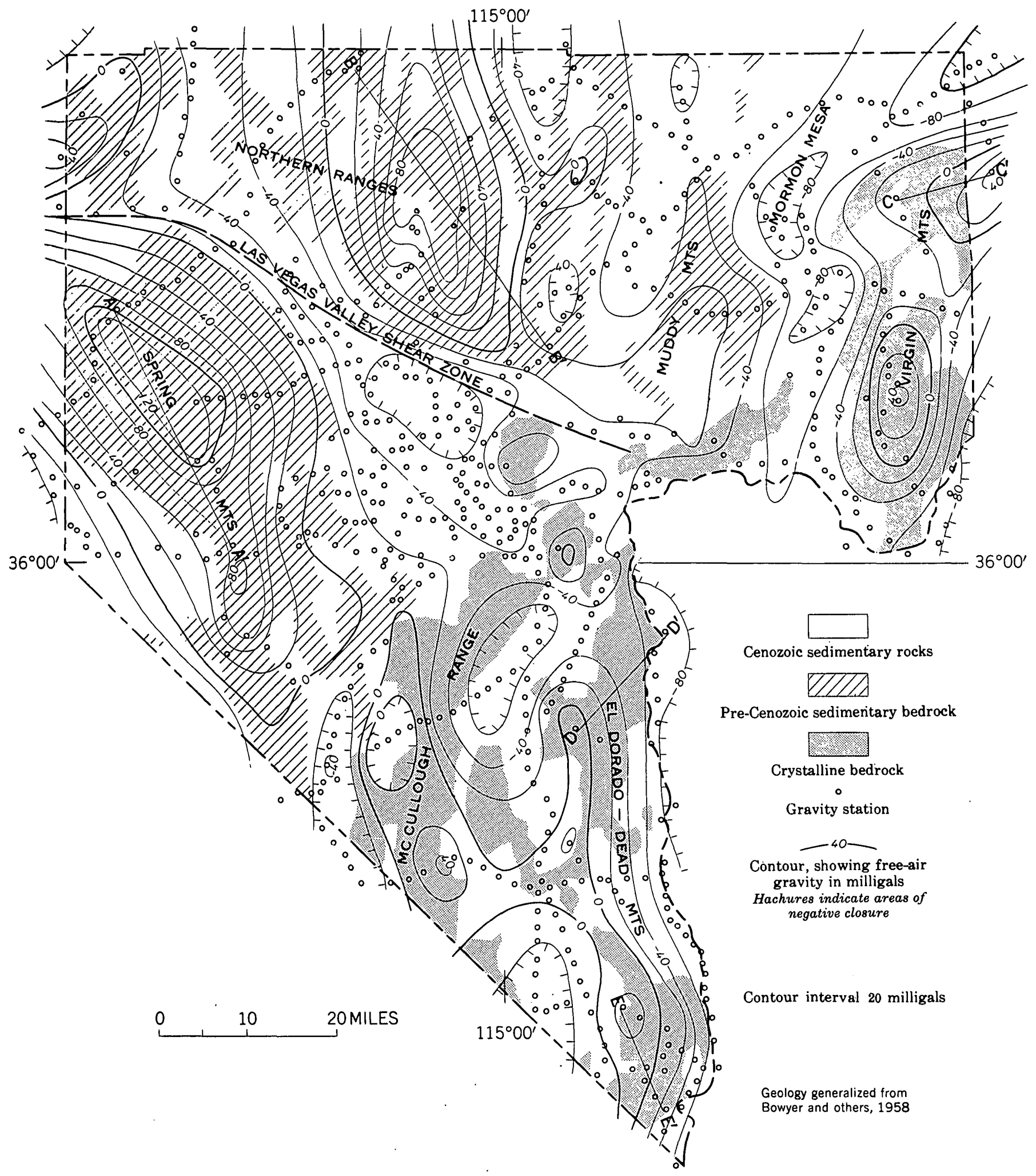

Figdre 390.1.-Free-air gravity contours and generalized geologic map of Clark County, Nev. 
plitudes in positve areas are closely proportonal to altitude, and the zero isogal is generally near the 4,000 foot contour. Anomalies are positive on the Paleozoic rocks of the northern ranges and the Spring Mountains, and the zero isogals are near the bedrock-alluvium contacts. The positive-anomaly areas include the Paleozoic mountain blocks and show that locally they are an excess crustal load. The average anomaly is closer to zero on the Precambrian rocks of the Virgin, Lucy Crey-McCullough, and El Dorado-Newberry Ranges. The coverage over Precambrian bedrock is incomplete, but the Precambrian blocks appear to be close to isostatic balance within the mountain boundaries. All of the high negative anomalies are over alluviated basins, which therefore are areas of local deficient load. In summary, the general pattern of anomalies shows positive values on Paleozic bedrock (excess load), negative values on alluviated basins (deficient loads), and near zero values on Precambrian bedrock (balanced loads).

If the Precambrian areas are excluded, it is apparent immediately that the average zero free-air anomaly for the entire area is dependent on the opposing free-air anomalies of the Paleozoic mountain blocks and the alluviated basins. Further, the mountain areas and basin areas are in juxtaposition, which suggests that they act as pairs. It is difficult to imagine an isostatic mechanism that permits separated mountain and basin blocks to balance one another; however, it seems reasonable to conclude that the basin is the depressed end and the range is the uplifted end of one tilted mountain block. Thus, the Spring Mountains represent the uplifted end and Las Vegas Valley the depressed end of a single block; the northern ranges and the Morman Mesa area are paired similarly. A cursory inspection suggests that each block is in isostatic adjustment, but this cannot be clearly determined owing to the limits of data noted above and to the unknown physical limits of the block.

\section{CAUSE OF TILTING}

The Bouguer gravity (fig. 390.2) is relatively low over the highest parts of the Spring Mountains and the the northern ranges; further, the Bouguer anomalies are too large to be attributed to inaccurate reductions (mainly terrain corrections), and too small to offset the high positive free-air values. The Bouguer values are caused by a low-density mass under the high parts of the ranges, and they can be correlated with a marked increase in thickness of the Paleozoic rocks. The computed mass effect of the Paleozoic section as compared to the higher density Precambrian rocks to the east is approximately equal to the anomalous Bouguer gravity, and it is concluded that the anomalies are caused by the Paleozoic rocks. Analogously, lower Bouguer anomalies are present over the high parts of the Precambrian ranges and can be attributed to lower density granitic rocks that are present in these areas. The presence of low-density masses on the uplifted ends of mountain blocks that are probably tilted suggests that these masses are buoyant and provide the force necessary to

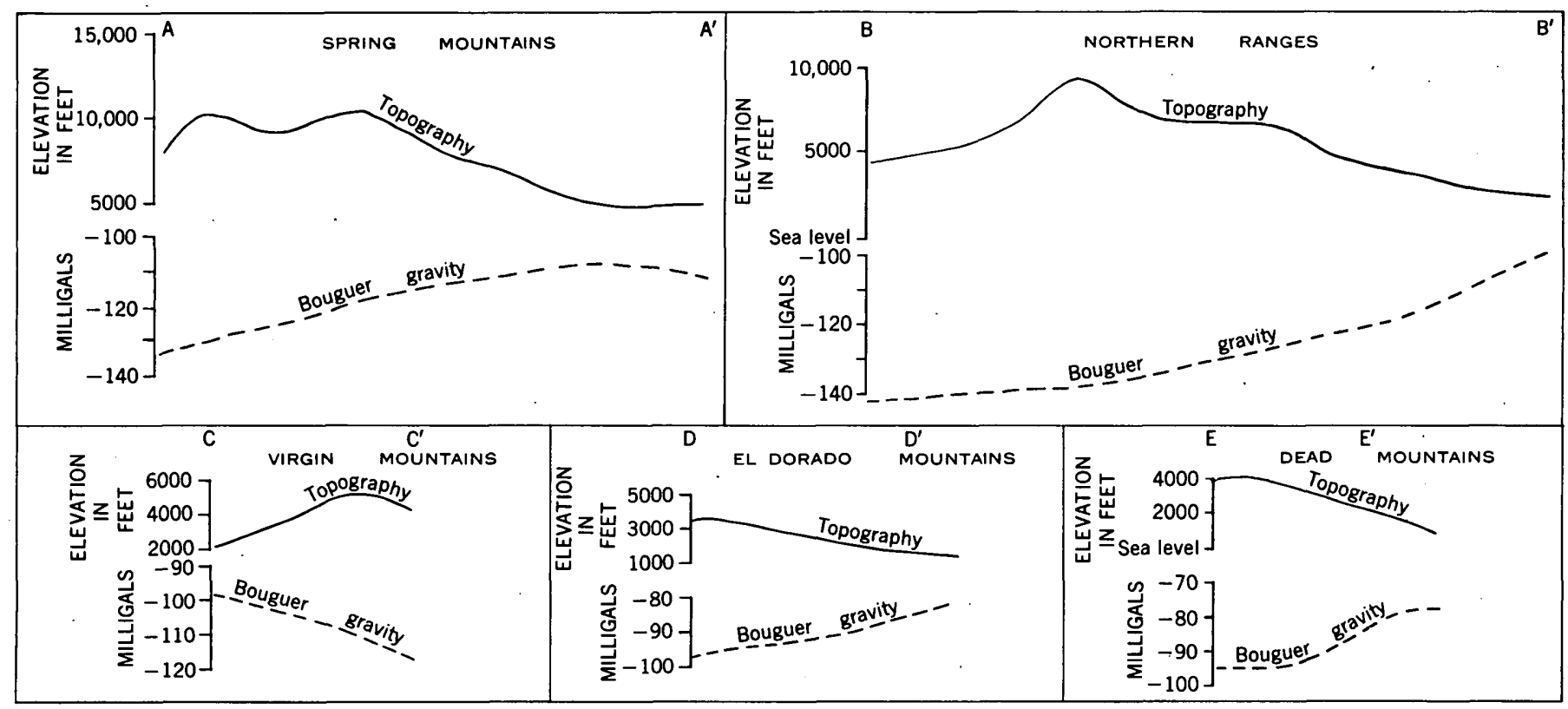

\begin{tabular}{rrrr}
0 & 5 & 10 & 15 \\
\hline
\end{tabular}

Figure 390.2.-Comparison of simple Bouguer gravity and regional elevations over bedrock areas in Clark County, Nev. 
tilt the blocks initially. Once tilting has started, sediments accumulating on the depressed end of the block serve to increase the tilt. These examples in two dissimilar geologic settings (crystalline versus sedimentary terrain) indicate that tilting may have a wide application as a mechanism of isostatic adjustment.

The buoyant tilting of segments of the earth's crust requires that the segments be outlined by deep crustal faults and have relatively free boundaries. Longwell (1960) suggests that the Las Vegas shear zone which separates the Spring Mountains and the northern ranges is a major crustal rift. The eastern boundaries of the blocks are defined by alluviated basins which imply a stratigraphic break in the crust of as much as several miles. At present, there is no evidence of the remaining boundaries, and they may lie outside the county.

\section{REFERENCES}

Bowyer, Ben, Pampeyan, E. H., and Longwell, C. R., 1958, Geologic map of Clark County, Nevada: U.S. Geol. Survey Mineral Inv. Field Studies Map MF-138.

Longwell, C. R., 1960, Possible explanation of diverse structural patterns in southern Nevada: Am. Jour. Sci., (Bradley Volume) v. 258-A, p. 192-203.

Mabey, D. R., 1960, Regional gravity survey of Nevada, in short papers in the geological sciences: U.S. Geol. Survey Prof. Paper 400-B, p. B283-B285.

\section{ISOSTATIC COMPENSATION IN THE SANGRE DE CRISTO MOUNTAINS, NEW MEXICO}

By Gordon E. Andreasen and Martin F. Kane, Washington, D.C.

The Sangre de Cristo Mountains consists of a northtrending chain of structurally complex mountains bordered on the east by the High Plains and on the west by the Rio Grande trough. Baltz and others (1956, p. 15) describe the mountains as a faulted asymmetrical synclinorium that plunges southward. In general, Paleozoic sedimentary rocks in a relatively high region that borders the Rio Grande trough dip eastward toward the axis of a syncline that extends northeastward from Cowles (fig. 391.1). East of the syncline axis the sedimentary rocks rise to a northtrending ridge located a few miles west of a line connecting Las Vegas and Cimarron. Predominantly clastic sedimentary rocks of Pennsylvanian age at least 8,000 feet thick crop out in the central part of the synclinorium (Read and Wood, 1947). A variety of plutonic and metamorphic rocks of Precambrian age also are present; these include schist, gneiss, and quartzite which, in several places, have been intruded by granite of more than one age (Baltz and Bachman, 1956$, p. 96$)$.

Figure 391.1 is a regional Bouguer anomaly and geologic map of the southern Sangre de Cristo Mountains. All gravity stations were located along accessible roads either at bench marks or at points where elevation information was available from the New Mexico State Highway Commission. The Bouguer gravity anomaly map does not include correction for terrain effects. However, sample terrain corrections computed for critical stations shows that the largest effect is about 8 milligals.
Within the surveyed area, the Bouguer gravity values decrease as the mountains are approached from the east, and are lowest over the mountain mass. Superimposed on the general gravity gradient is a local negative anomaly located approximately at the center of the map (fig. 391.1). The lowest gravity occurs over the highest topography (fig. 391.2) -an inverse relation that has been observed in other areas (Kane and Carlson, Art. 390 ), and is probably caused by a near-surface mass deficiency. If the regional gravity gradient has been properly chosen, the maximum amplitude of the anomaly is 21 milligals. A terrain correction of about 5 milligals leaves a residual anomaly of about 16 milligals. If it is assumed that the density contrast between the Precambrian rocks and the Pennsylvanian clastic rocks is about $0.2 \mathrm{~g}$ per $\mathrm{cm}^{3}$ then the anomaly indicates a thickness of clastic rocks in excess of 6,000 feet, which correlates closely with the known thickness of clastic rocks in this area and strongly suggests that they are the source of the anomaly.

In order to demonstrate better the correlation between topography and Bouguer gravity, a method suggested by Mabey (1960, p. B130) was employed in which the topography is averaged over circles 64 miles in diameter at each station location. The resulting regionalized topographic and Bouguer anomaly map is shown on figure 391.3 (p. D-280). It may be noted that the regionalized topographic contours generally parallel the Bouguer isogals. However, there is a notable decrease in the rate of change of regional topography with Bouguer gravity in the highest part of the mountains. 


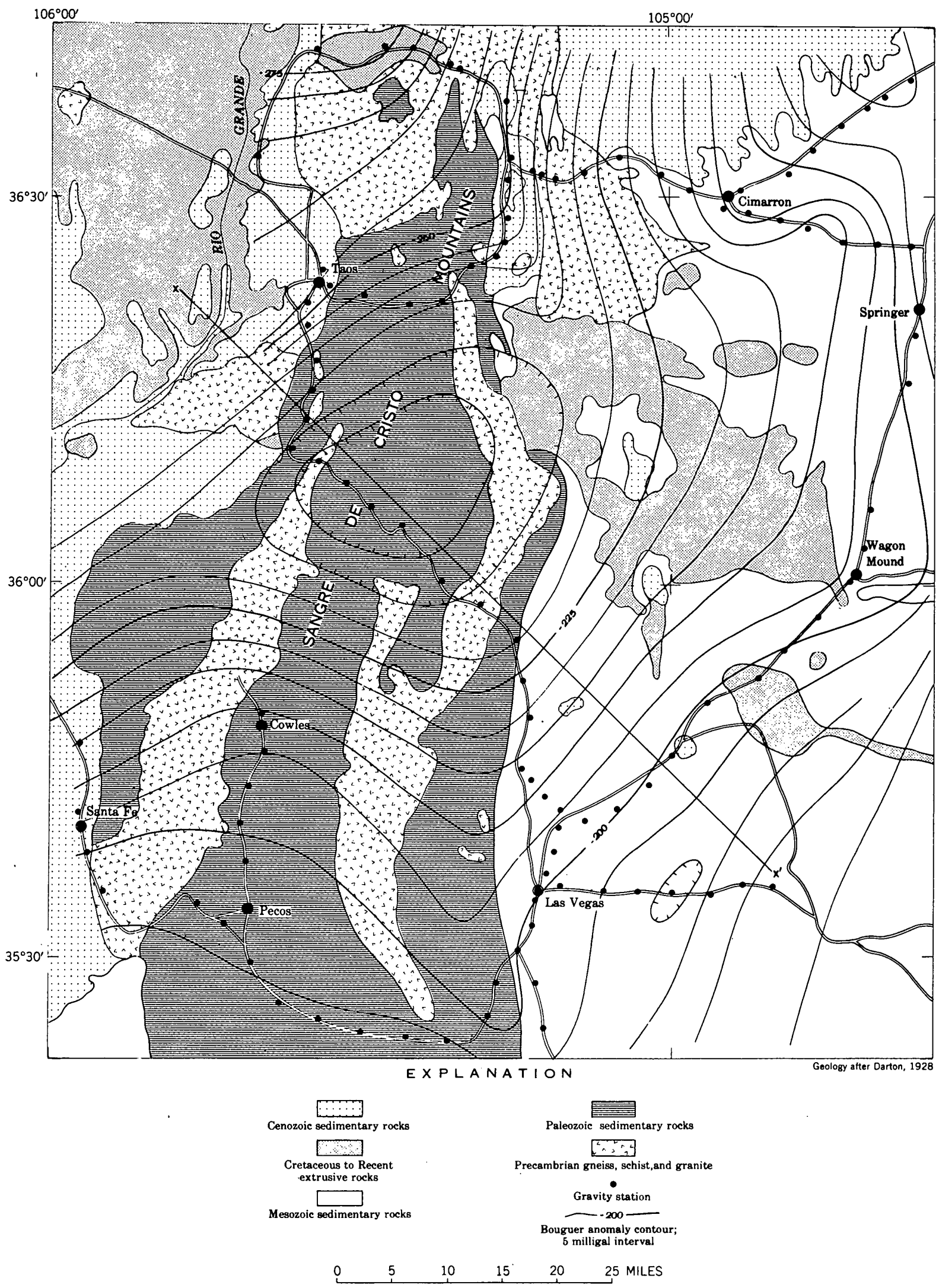

Frgure 391.1.-Regional Bouguer anomaly and geologic map of the Sangre de Cristo Mountains, N. Mex. 

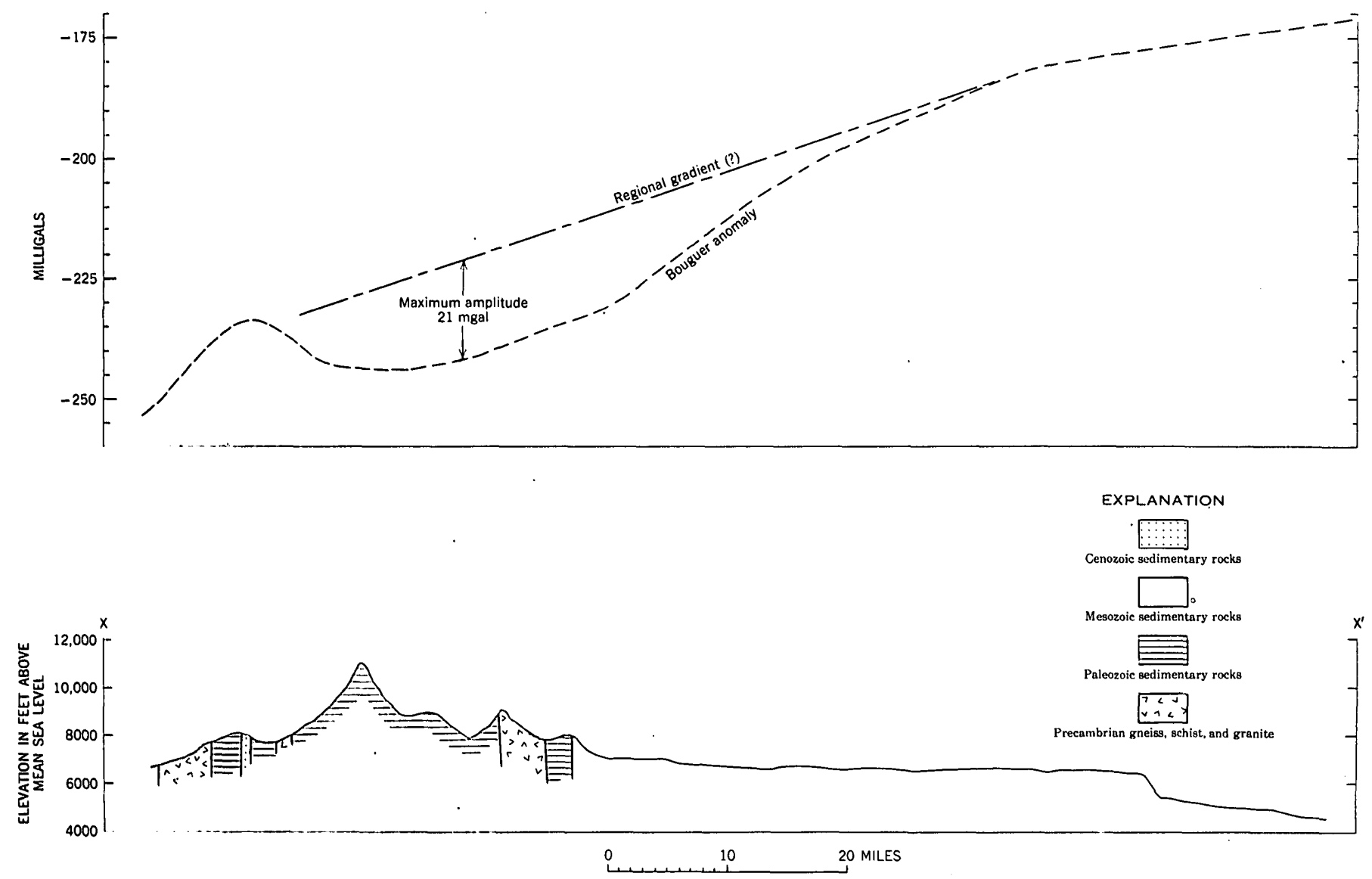

Frgure 391.2.-Topographic, geologic, and gravity profle across the Sangre de Cristo Mountains. Line of section ( $X-X^{\prime}$ ) and explanation of rock units shown on figure 391.1.

The mass-deficiency suggested by the large Bouguer anomaly (fig. 391.1) can be further analyzed by a freeair anomaly map (fig. 391.4, p. D-281). A positive free-air anomaly coincides with the crest of the mountains, and this anomaly shows that the main mountain mass is, at least locally, an excess load, and is not supported by the low-density mass outlined by the Bouguer gravity anomaly.

A Bouguer gravity high at the northwest end of the profile (figs. 391.1 and 391.2 ) is present over Precambrian rocks along the western margin of the mountains; however, the Precambrian rocks along the eastern margin of the mountains do not have an associated gravity high. Either the Precambrian rocks at the eastem margin of the mountains have insufficient volume to produce an anomaly, or crystalline and sedimentary rocks of this area have nearly the same density.

\section{REFERENCES}

Baltz, E. H., Wanek, A. A., and Read, C. B., 1956, Résumé of geology-Santa Fe to Cowles; Pecos to Las Vegas, in New Mexico Geol. Soc. Guidebook of southeastern Sangre de Cristo Mountains, New Mexico, 7th Field Conf. 1956: p. 15-23.

Baltz, E. H., Jr., and Bachman, G. O., 1956, Notes on the geology of the southeastern Sangre de Cristo Mountains, New Mexico, in New Mexico Geol. Soc. Guidebook of southeastern Sangre de Cristo Mountains, New Mexico, 7th Field Conf. 1956 : p. $96-108$.

Darton, N. H., 1928, New Mexico State geologic map: U.S. Geol. Survey.

Mabey, D. R., 1960, Regional gravity survey of part of the Basin and Range province, in Short papers in the geological sciences: U.S. Geol: Survey Prof. Paper 400-B, p. B283-B285.

Read, C. B., and Wood, G. H., Jr., 1947, Distribution and correlation of Pennsylvanian rocks in late Paleozoic sedimentary basins of northern New Mexico: Jour. Geology, v. 55, no. 3, p. 220-236. 


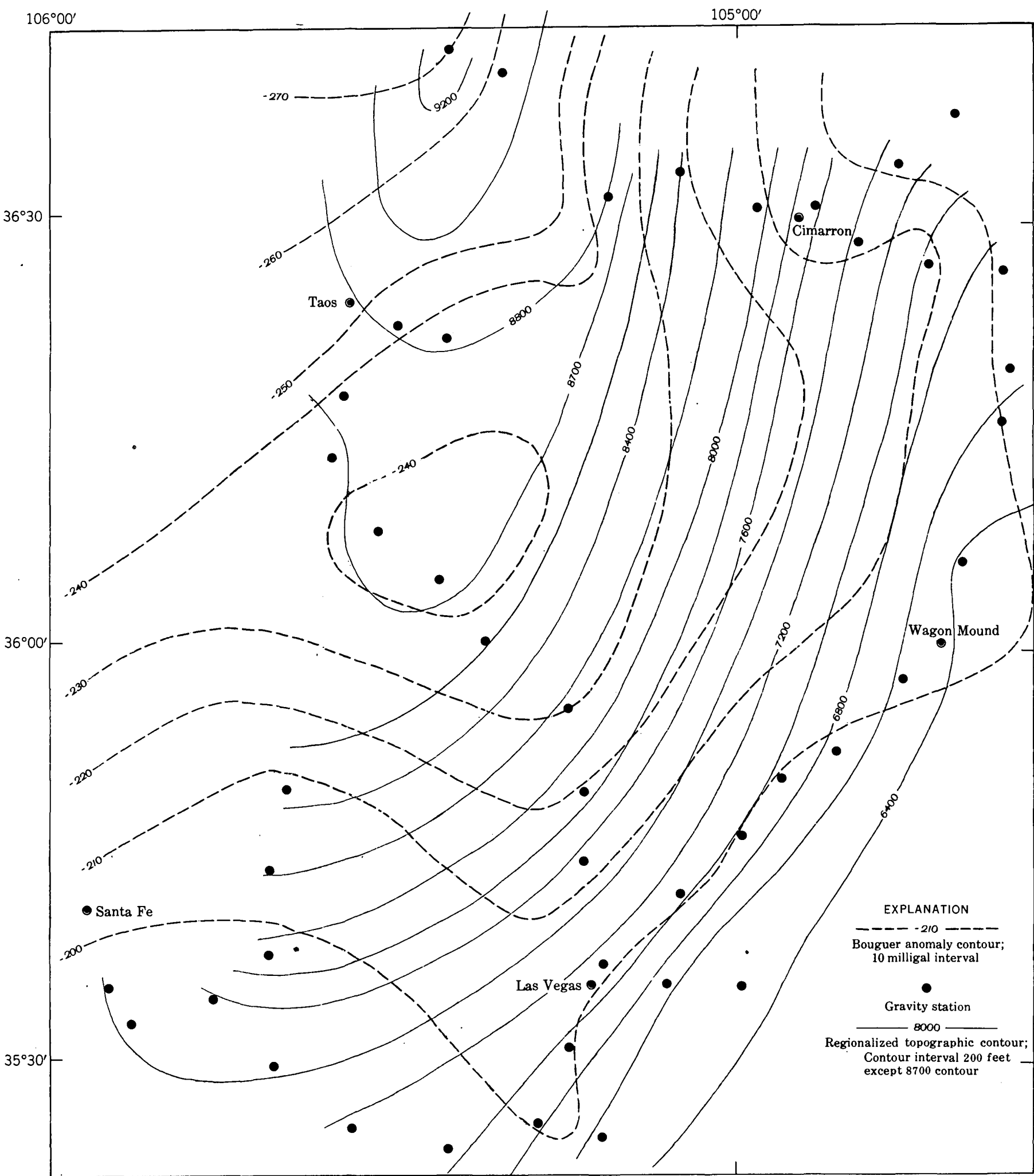

$\stackrel{5}{1} \quad 10 \quad 15 \quad 20 \quad 25$ MILES

FrgURE 391.3.-Bouguer anomaly and regionalized topographic map of the Sangre de Cristo Mountains, N. Mex. The topography is averaged over circles 64 miles in diameter. 


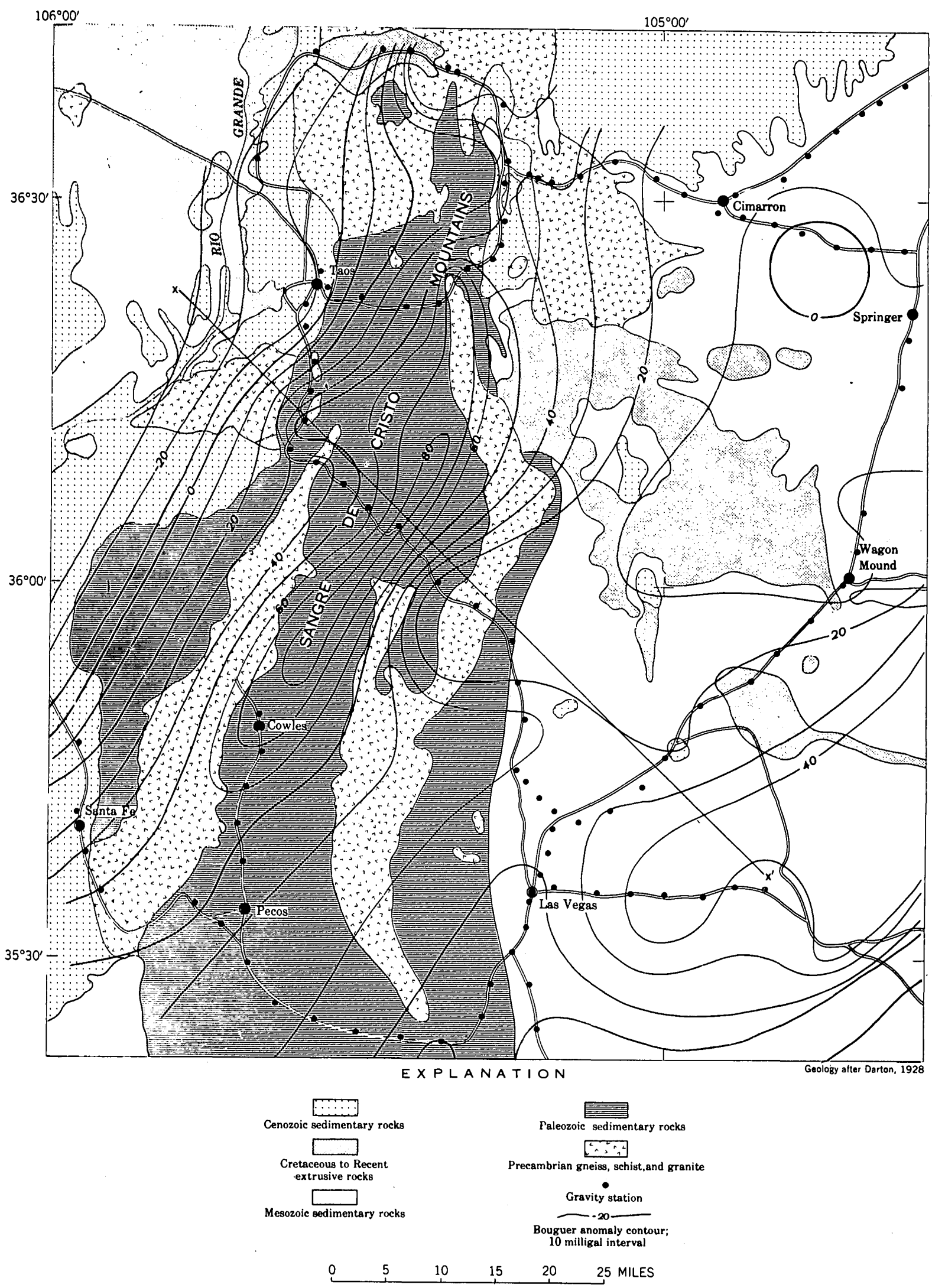

F'IGURE 391.4.-Free-air gravity anomaly and geologic map of the Sangre de Cristo Mountains, N. Mex.

$6044930-118 \longrightarrow \longrightarrow 1$ 


\section{THE RIO GRANDE TROUGH NEAR ALBUQUERQUE, NEW MEXICO}

By H. R. Joesting, J. E. Case, and L. E. Cordell, Washington, D.C., Berkeley, Calif., and Albuquerque, N. Mex.

Gravity and aeromagnetic surveys have been made of part of the Rio Grande trough and adjoining areas near Albuquerque, N. Mex., to learn more about the structural boundaries and configuration of the trough. The area covered by the gravity and aeromagnetic surveys is shown on figure 392.1.

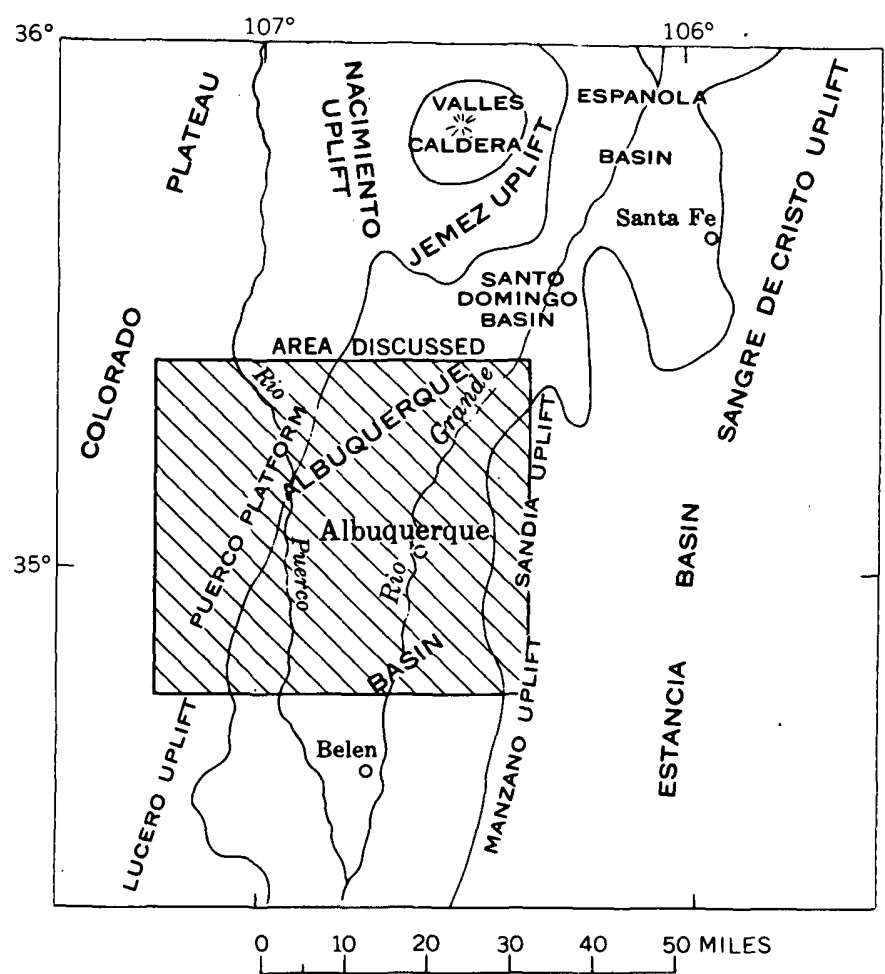

Figure 392.1.-Sketch map of part of Rio Grande trough and associated structures in north-central New Mexico. Area studied crosshatched. Structural boundaries from Kelley, 1952.

The Rio Grande trough (Kelley, 1952, 1954; Fitzsimmons, 1959) is a series of complexly faulted troughs or basins, arranged en echelon. It extends from the northern end of the San Luis valley in Colorado, southward 450 miles along the course of the Rio Grande in New Mexico, to near El Paso, Tex. The trough is bounded on the west by the Colorado Plateau and on the east by uplifts of the southern Rocky Mountains.

The Albuquerque basin, the largest basin of the Rio Grande trough, is about 90 miles long and 30 miles wide. It is bounded by the Sandia, Manzanita, and Manzano uplifts on the east, by the Lucero uplift and Puerco platform on the west, and by the southern end of the
Nacimiento uplift on the northwest. Small volcanoes and fissure flows mark the boundaries at several localities. The basin is filled with poorly consolidated Cenozoic deposits whose constituents were eroded from the uplands. Older sedimentary rocks doubtless underlie the valley fill. The thickness of sedimentary rocks is unknown, but Precambrian rocks may lie 10,000 feet below sea level in parts of the basin, whereas they are about 9,000 feet above sea level in the Sandia uplift and about sea level in the Puerco platform.

\section{BOUGUER GRAVITY MAP}

A large gravity low shown on figure 392.2 is on the valley fill (density about $2.3 \mathrm{~g}$ per $\mathrm{cm}^{3}$ ), and prominent highs are on the denser sedimentary and crystalline rocks of the bordering uplifts (densities about 2.45 to $2.7 \mathrm{~g}$ per $\mathrm{cm}^{3}$ ). Steep gradients between the low and the highs mark major bounding fault zones.

East of the trough, steep gravity gradients coincide in part with scarps along the mountain fronts, and with the projection of the Hubble Springs fault (Kelley, 1954). As some of the steeper gradients are several miles farther west, parts of the main fault zone are evidently covered by consolidated material.

A fault zone bounds the west side of the trough as shown by steepened gradients. They are less pronounced than on the east, because the comparatively dense Precambrian and Paleozoic rocks are covered by several thousand feet of less dense Mesozoic rocks; in addition, the fault zone may be wider. To the south steep gradients coincide with the faulted eastern flank of the Lucero uplift. At U.S. Highway 66 the contours bulge northeastward, indicating a buried extension of the Lucero uplift. A similar bulge on the eastern side constricts the trough. North of U.S. Highway 66 the west margin of the trough trends north, about parallel to observed and inferred faults. The Ignacio monocline is marked by a broad gravity high.

Some of the closed gravity lows within the trough may coincide with comparatively great thicknesses of low-density valley fill. If so, the ancient drainage may have been west of the present Rio Grande, except to the south near Los Lunas. Conversely, some of the prominent highs may represent uplifted blocks of the denser Paleozoic and Precambrian rocks and thinner valley fill. The most prominent high, in addition to the positive bulges already mentioned, is west of Bernalillo. 


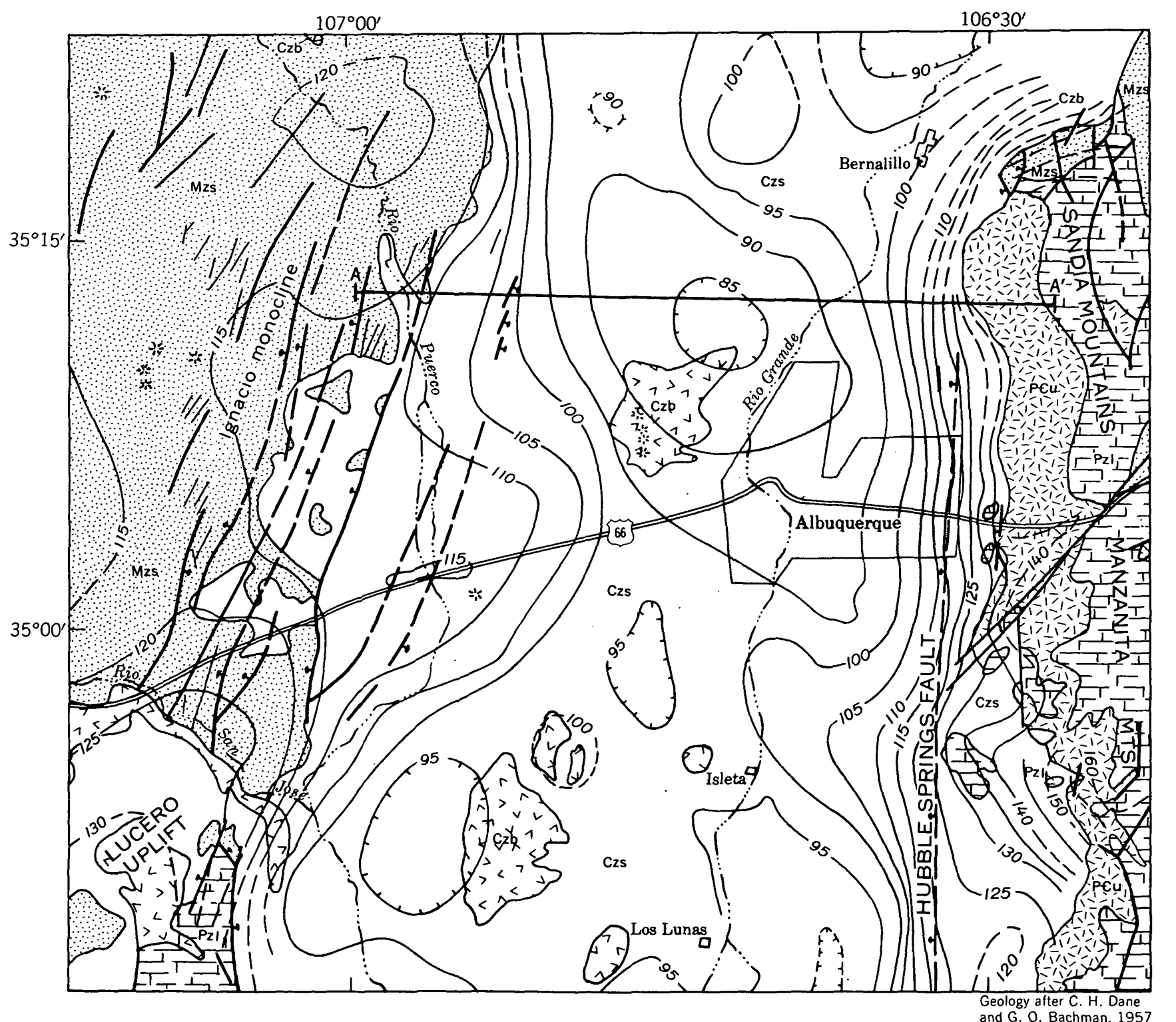

EXPLANATION

SEDIMENTARY ROCKS

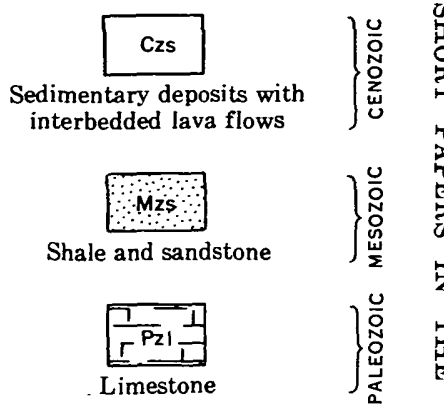

IGNEOUS AND

METAMORPHIC ROCKS Basalt flows

cones, and dikes

undivide

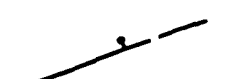

Normal fault

Ball on downthrown side,

dashed where inferred

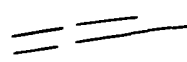

\section{Minor faults}

$100-$

Gravity contou

Dashed where uncertain. Contour

inleres ire simple Bouguer avity

oly for a reduction density of 2.45

$g$ per $\mathrm{cm}^{3}$, plus 300 milligals

5

$5 \quad 10$ MILES $\underset{\omega}{\stackrel{1}{\omega}}$

FIGURE 392.2-Preliminary gravity map and generalized geologic map of Rio Grande area near Albuquerque, N. Mex. 
An analysis of the gravity anomaly across the Rio Grande trough is shown on figure 392.3. A residual gravity low of about 45 milligals is superimposed on an assumed linear regional gradient. The density of the Cenozoic fill probably increases with depth, but the depth at which this becomes significant is unknown. The assumed density of the Mesozoic and Paleozoic

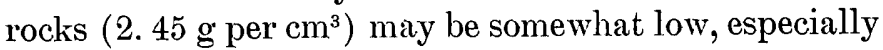
for the deeply buried rocks in the trough.

On the basis of densities shown on figure 392.3, the total thickness of sedimentary rocks in the trough is estimated to be about 15,000 feet, and the total relief of the Precambrian basement along the Sandia front about 20,000 feet. These values are approximations only as they depend in part on estimated rock densities. Single fault planes were assumed along the margins of the trough, although displacement probably occurred along many steeply dipping step faults.

\section{AEROMAGNETIC PROFILES}

Aeromagnetic profiles across the Rio Grande trough are shown on figure 392.4. The large magnetic highs are associated with the uplifted, comparatively magnetic crystalline rocks bordering the trough; smaller, local highs are associated with volcanic rocks. The sedimentary rocks are essentially nonmagnetic. In general, the profiles and gravity map are in agreement.

The magnetic anomalies are related to variations in both the magnetization and uplift of the Precambrian rocks. For example, the magnetic susceptibility of the eastern part of the exposed Precambrian rocks near Albuquerque is very low, whereas along the western edge it is moderately high (about $0.004 \mathrm{cgs}$ units). The remanent magnetization is generally low throughout. The magnetic contrast is reflected in the peak and the sharp eastward decrease of profiles 11 and 12. The profiles also show that the more magnetic rocks extend westward some 2 miles from the mountains under outwash material. The main fault zone near Albuquerque therefore coincides approximately with the Hubble Springs fault (shown on fig. 392.2).

At the north end of the Sandia uplift, the smaller amplitude of the profiles is probably related primarily to lower magnetization of the Precambrian rocks. Still farther north they reflect the apparent right lateral offset of the Rio Grande trough, which is shown more clearly by the gravity contours.

At the west ends of lines 9 to 12 there is little magnetic expression of the buried structural boundary of the trough. The small anomalies on profiles 10 and 12, southwest of the large area of volcanic rock, agree in position with the bordering gravity anomalies, but they may be caused by shallow volcanic rocks rather than displacement of the basement. Volcanoes, however, are commonly alined along the borders of the trough. North of line 9 the basement rocks are more magnetic and appear to delineate clearly the western edge of the trough. The fault zone is probably defined by the inflection points on the profiles.

Analyses of two aeromagnetic profiles using the polar chart of Pirson (1935) are shown in figures 392.5 and 392.6. The shapes and magnetic susceptibilities of the Precambrian rocks were arbitrarily chosen so that the computed and observed effects are in reasonable agree-
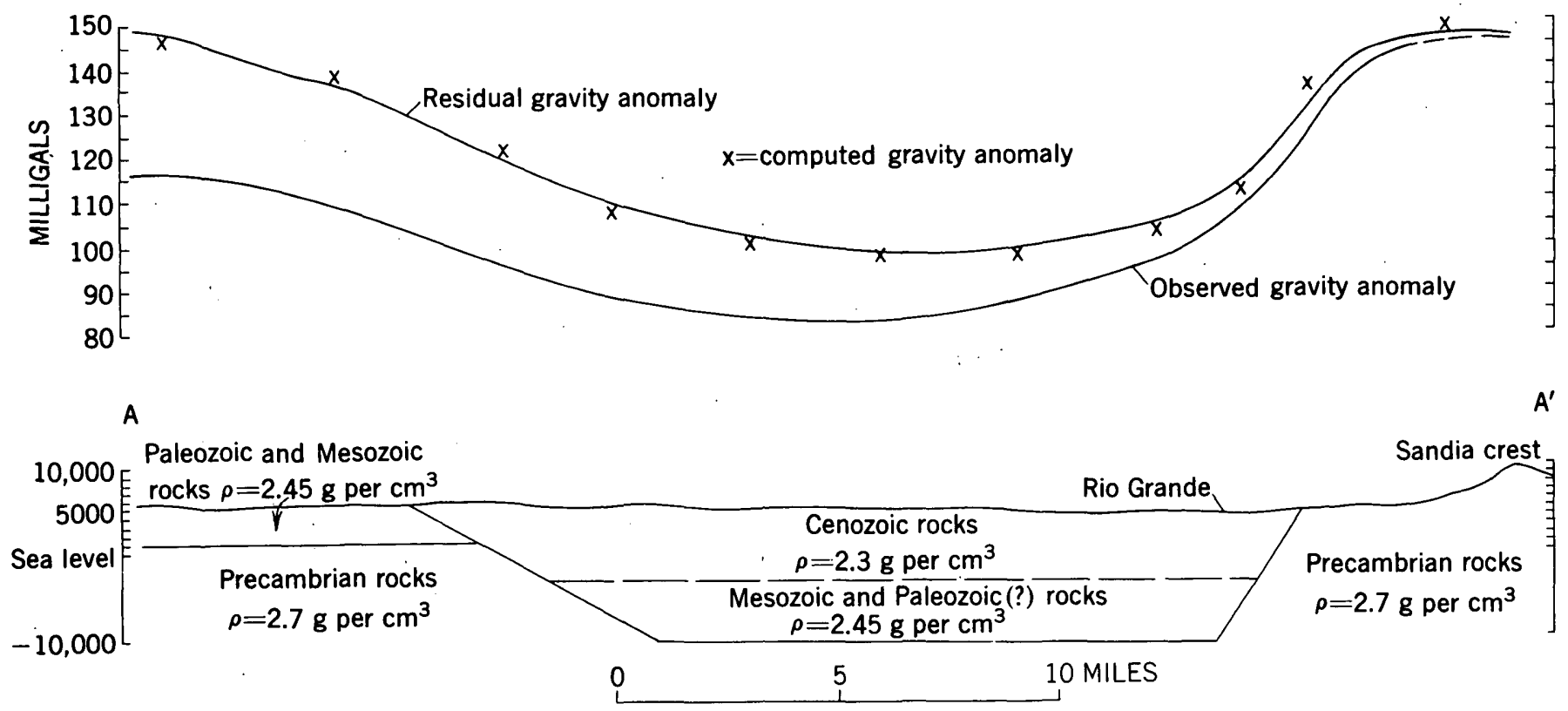

Figure 392.3.-An interpretation of the gravity anomaly across the Rio Grande trough north of Albuquerque, N. Mex. 

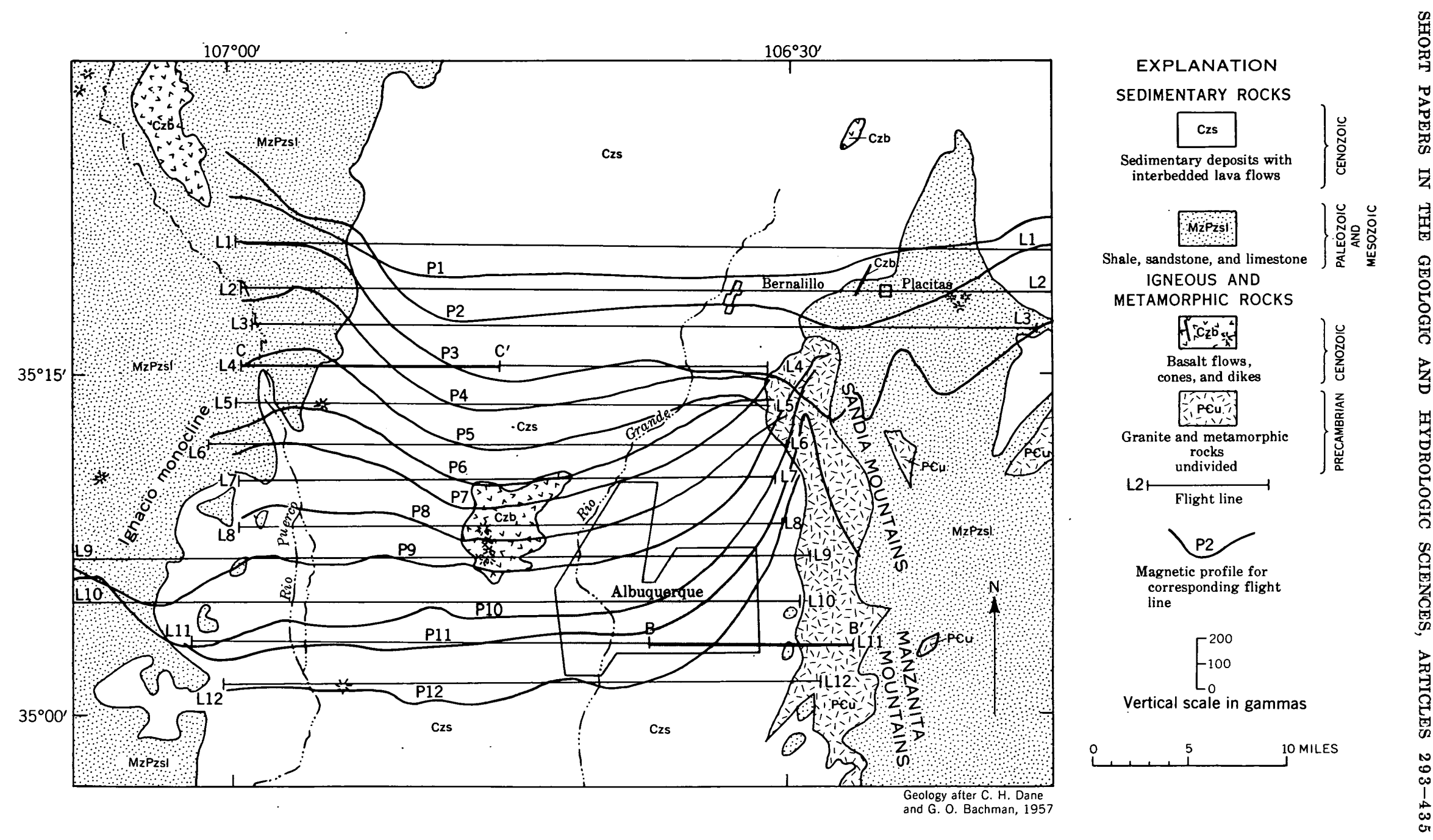

Figure 392.4.-Magnetic profiles, flight lines, and generalized geologic map of Rio Grande area near Albuquerque, N. Mex. 


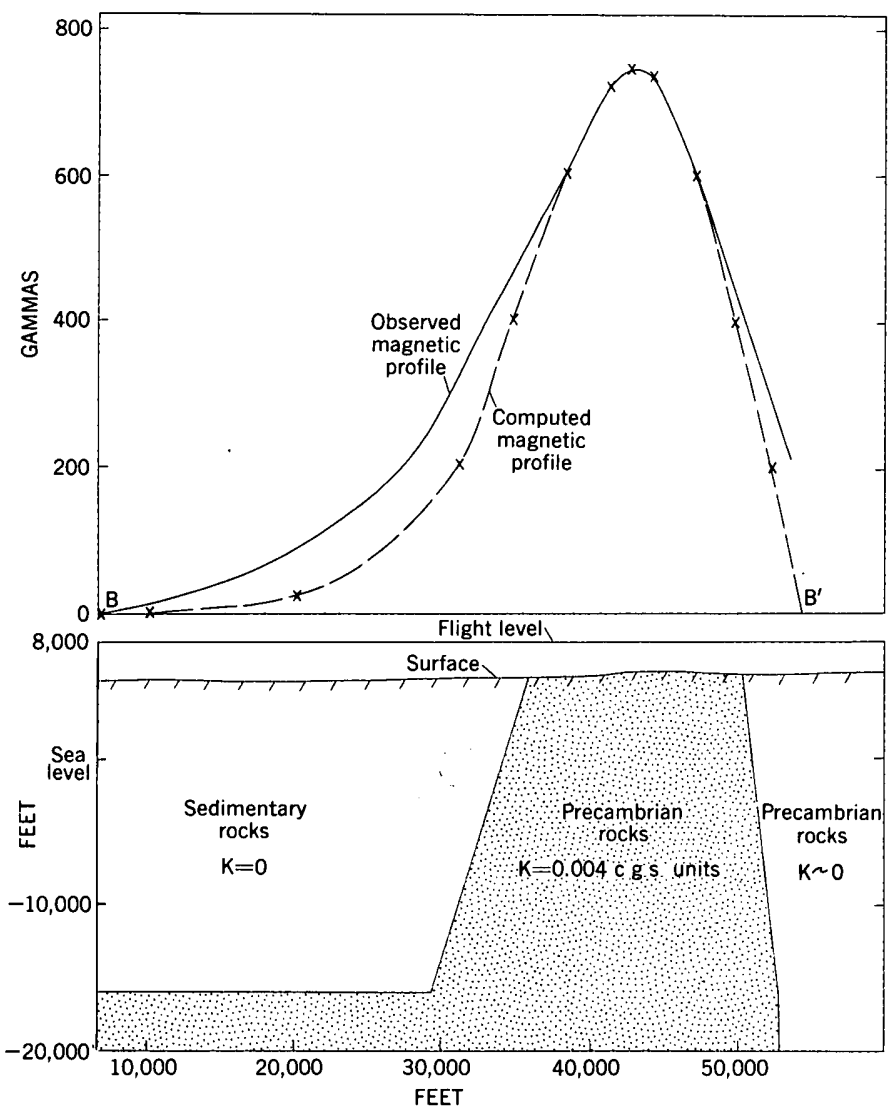

Figure 392.5.-An interpretation of the magnetic anomaly across the eastern boundary of the Rio Grande trough, southeast of Albuquerque, N. Mex.

ment. Reasonable agreement was obtained when the Precambrian rock in the trough was placed at $-16,000$ feet, sea level datum. Assuming a lesser depth would have required flattening of the fault planes, or assigning more than one susceptibility. On figure 392.5 the departure of computed and observed profiles along their west flank indicates either that the susceptibility of the down-faulted basement increases westward, or the slope of the fault decreases, perhaps step-fashion. The indicated displacement of the basement is nearly 22,000 feet

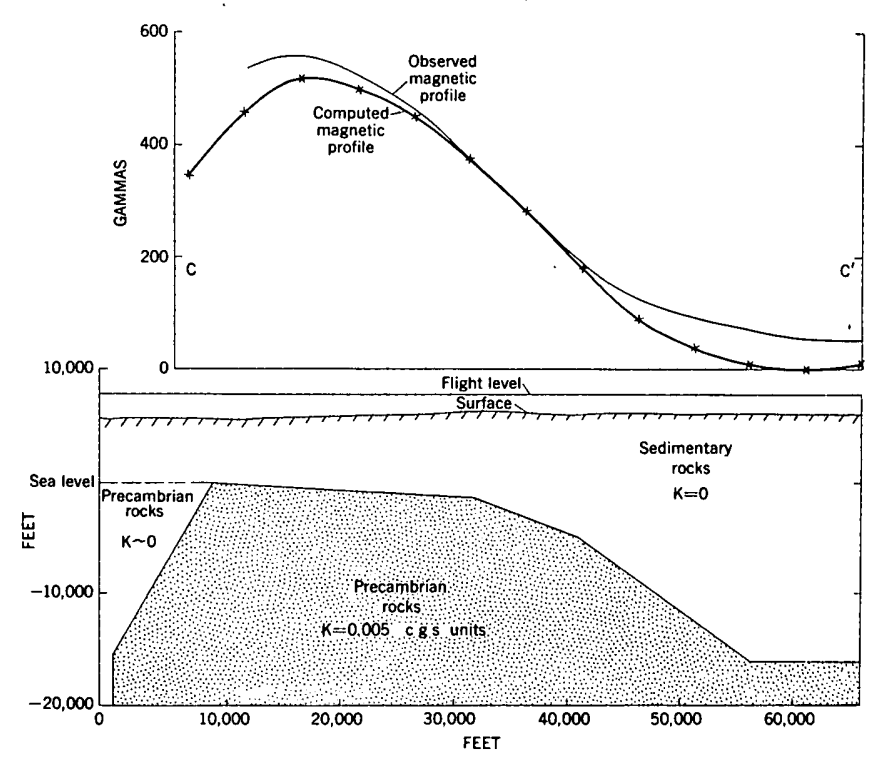

FIGURE 392.6.-An interpretation of the magnetic anomaly across the western boundary of the Rio Grande trough, northwest of Albuquerque, N. Mex.

along the Sandia front, and 16,000 feet on the west side. These estimates are in reasonable agreement with those based on gravity interpretations; but the correctness of both depends on the degree of correctness of the assigned magnetic susceptibilities and densities.

\section{REFERENCES}

Dane, C. H., and Bachman, G. O., 1957, Preliminary geologic map of the northwestern part of New Mexico: U.S. Geol. Survey Misc. Geol. Inv. Map I-224.

Fitzsimmons, J. P., 1959, The structure and geomorphology of west-central New Mexico: a regional setting, in New Mexico Geol. Soc. Guidebook of west-central New Mexico, 10th Field Conf. : p. 112-116.

Kelley, V. C., 1952, Tectonics of the Rio Grande depression of central New Mexico, in New Mexico Geol. Soc. Guidebook of the Rio Grande country, 3rd Field Conf. : p. 93-105.

1954, Tectonic map of part of the upper Rio Grande area, New Mexico: U.S. Geol. Survey Oil and Gas Inv. Map OM-157.

Pirson, S. J., 1935, Polar charts for interpreting magnetic anomalies: Am. Inst. Min. Metall. Engineers Contr. 91 . 


\title{
393. PRECAMBRIAN STRUCTURES IN THE BLANDING BASIN AND MONUMENT UPWARP, SOUTHEAST UTAH
}

\author{
By J. E. CASe and H. R. Joesting, Berkeley, Calif., and Washington, D.C.
}

Work done partly in cooperation with the U.S. Atomic Energy Commission

Prominent aeromagnetic and gravity anomalies in the Blanding basin and Monument upwarp of southeast Utah trend northeast (figs. 393.1 and 393.2) transverse to other geophysical anomalies and regional folds of Laramide (?) age. Sources of these transverse anomalies are evidently within rocks of the buried Precambrian basement. Analogous transverse trends have been detected by geophysical investigations in the northwest-trending Paradox fold and fault belt north of the Blanding basin (Joesting and Case, 1960, figs. 114.2, 114.3; Joesting and Byerly, 1958; Byerly and Joesting, 1959).

Summaries of the geology of southeast Utah, including the Blanding basin and Monument upwarp, can be found in reports by Baker (1935), Kelley (1955), Shoemaker (1954), and Lewis (1958). Briefly, the Monument upwarp is a broad asymmetric fold whose axis has a general northerly trend. The adjoining Blanding basin has no pronounced axial trend. Comb Ridge monocline is the boundary between the basin and upwarp, and has about 4,000 feet of structural relief (fig. 393.3).

The Precambrian basement lies beneath 8,000 to 9,000 feet of Paleozoic and Mesozoic rocks in the Blanding basin and beneath 2,000 to 6,000 feet on the Monument upwarp where most of the Mesozoic beds have been removed by erosion. The configuration of the Precambrian surface can be inferred from the altitude of Mississippian and older Paleozoic rocks in wells in the region (fig. 393.3). The interval between the top of the Mississippian and the Precambrian surface is about 2,000 feet at the northern end of Elk Ridge, about 1,300 feet near Bluff, and about 1,000 feet near Eastland. The form of the Precambrian surface reflects mainly Laramide folding of the region, but relief of the basement may be as much as 1,000 feet greater than relief of Triassic beds between basin and upwarp.

Because Paleozoic and Mesozoic sedimentary rocks of the region are virtually nonmagnetic (Joesting and Byerly, 1958, p. 4-5), sources of aeromagnetic anomalies shown on figure 393.1 are thought to be within the Precambrian basement, except for those associated with the laccolithic intrusions of the Abajo Mountains. The relatively simple configuration and low relief of the Precambrian surface, except at Comb Ridge monocline, can account for only a small part of the observed mag- netic anomalies; sources of the larger gravity anomalies are probably density contrasts within basement rocks. Structural relief of the basement can account for only a few milligals of the 30-milligal low in the Blanding basin or the low near Cedar Mesa (fig. 393.2). Thickening of evaporites within the Paradox evaporite member of the Hermosa formation of Pennsylvanian age can likewise account for only a few milligals of the gravity lows, as the thickness of the member changes gradually northward from 100 feet at Mexican Hat to 1,500 feet at Monticello (Wengerd and Matheny, 1958, fig. 16, p. 2090-2091).

Prominent aeromagnetic anomalies extend northeast from Cedar Mesa, across Comb Ridge, to Eastland ( $A-A^{\prime}$, fig. 393.1), and from Comb Ridge to the north edge of the map area $\left(B-B^{\prime}\right)$. Gravity lows of 20 to 30 milligals, near Cedar Mesa and in the Blanding basin, are bordered on the southeast by nearly straight contours from south of Cedar Mesa to Comb Ridge, and from north of Bluff to Eastland ( $A-A^{\prime}$, fig. 393.2). The lows are bordered on the northwest by relatively straight contours from northern Cedar Mesa to Comb Ridge, and from Blanding to the north edge of the area $\left(B-B^{\prime}\right)$. The axis of the gravity low in the Blanding basin extends northeast, and the low near Cedar Mesa is on the same trend, but the lows are interrupted by a gravity high parallel to Comb Ridge. These gravity and magnetic effects are probably caused by a deepseated block of Precambrian rocks of low density and irregular magnetization, bordered by faults, as inferred from the straightness and close-spacing of the geophysical contours along $A-A^{\prime}$ and parts of $B-B^{\prime}$. The northwestern margin of the block is not everywhere defined by magnetic data, partly because of effects of laccolithic intrusions in the Abajo Mountains and of buried magnetic masses near Blanding.

A simplified analysis of the gravity low in the Blanding basin, which neglects effects of laccoliths in the Abajo Mountains, shows that the block of low-density basement rocks extends downward about 12,000 feet, assuming a density contrast between rocks inside and outside the block of $0.3 \mathrm{~g} \mathrm{per} \mathrm{cm}^{3}$ (fig. 393.4). Such a contrast would exist, for example, between granite or quartzite (density about 2.6 to $2.7 \mathrm{~g}$ per $\mathrm{cm}^{3}$ ) and some of the denser metamorphic, mafic or ultramafic rocks (densities about 2.8 to $3.1 \mathrm{~g}$ per $\mathrm{cm}^{3}$ ). A smaller den- 


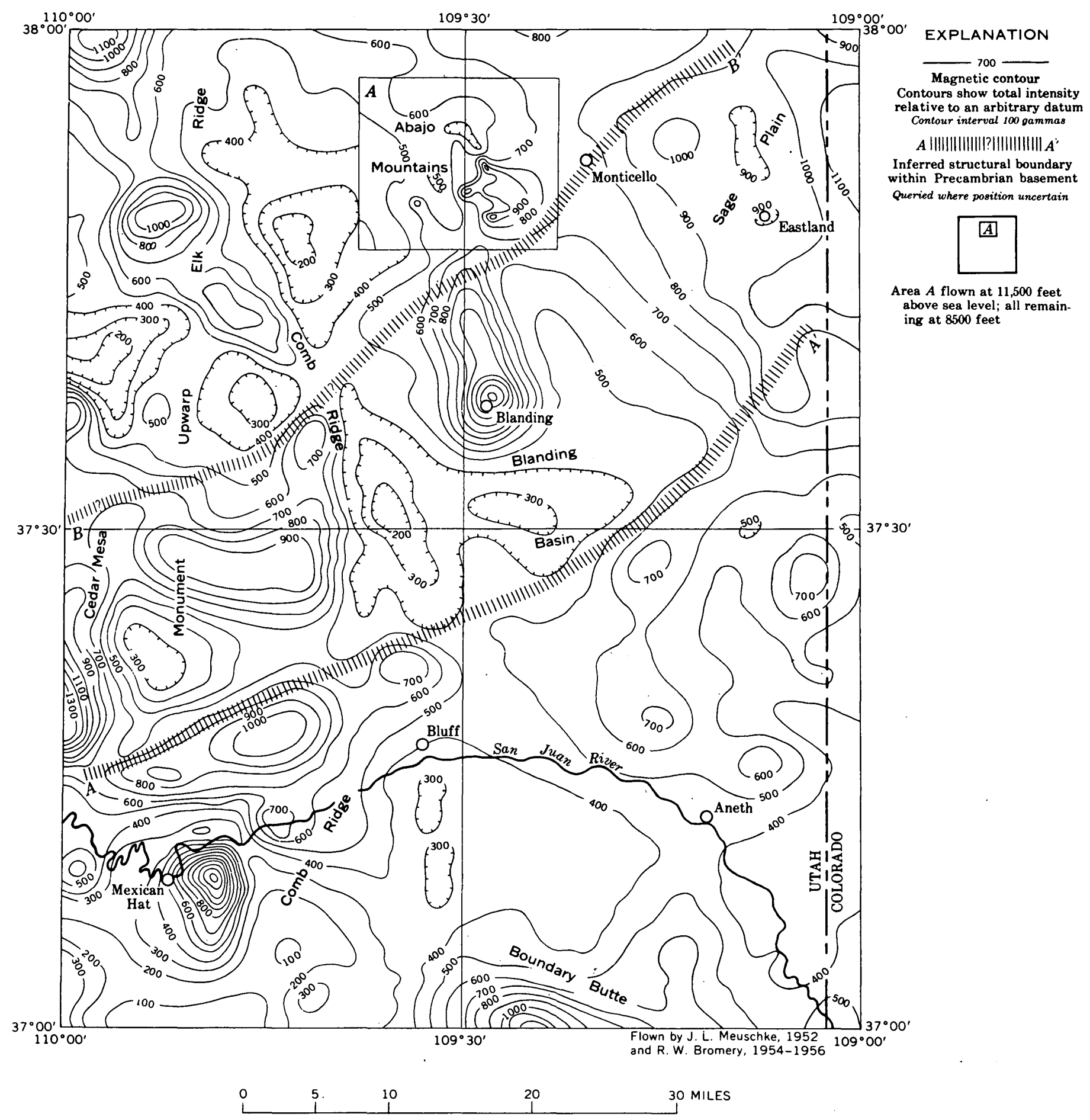

FrgURE 393.1.-Preliminary aeromagnetic map of parts of Blanding basin and Monument upwarp, Utah and Colorado. 


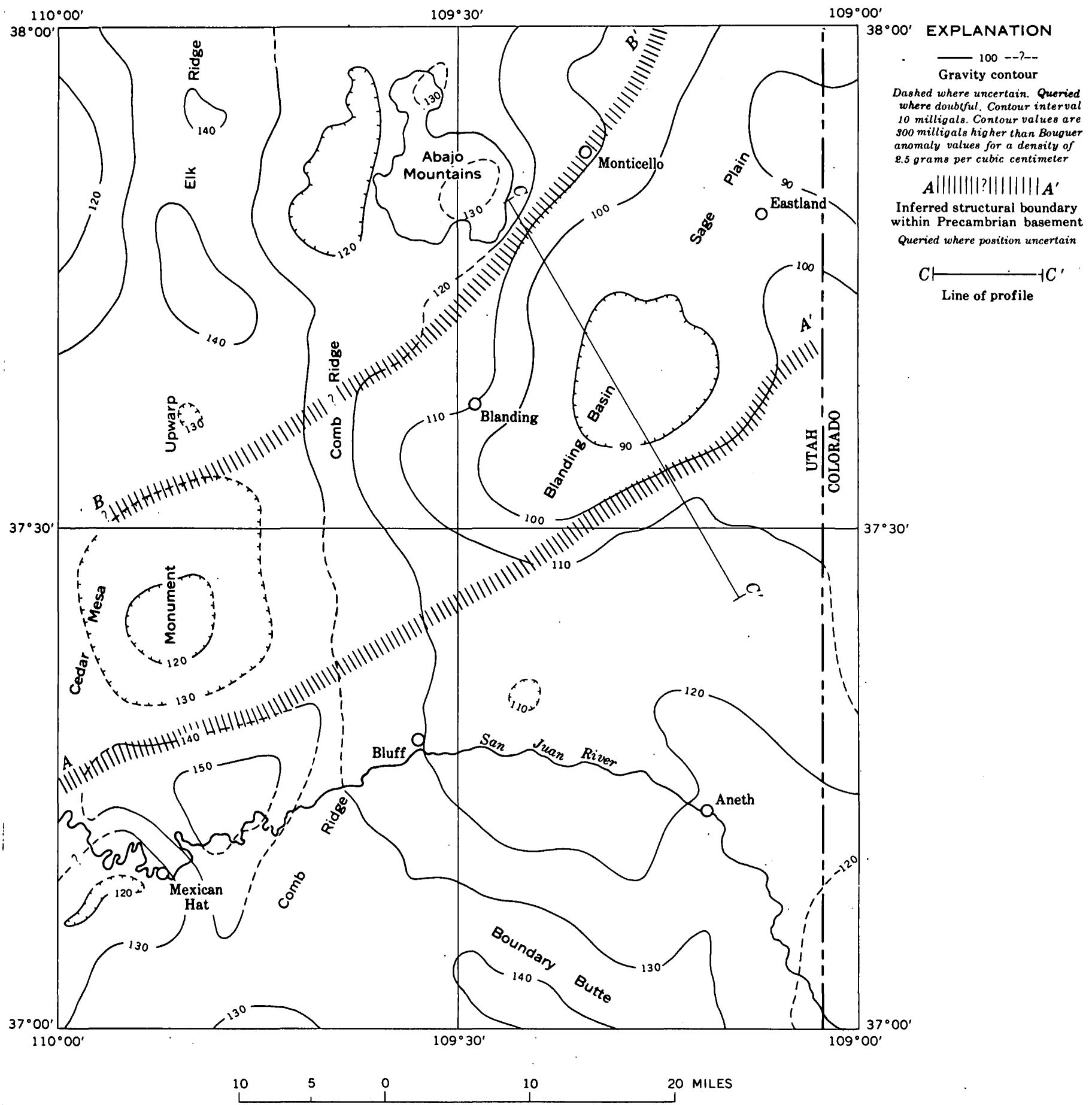

Frouke 393.2.-Preliminary gravity anomaly map of parts of Blanding basin and Monument upwarp, Utah and Colorado. See profile $C-C^{\prime}$ on figure 393.4. 


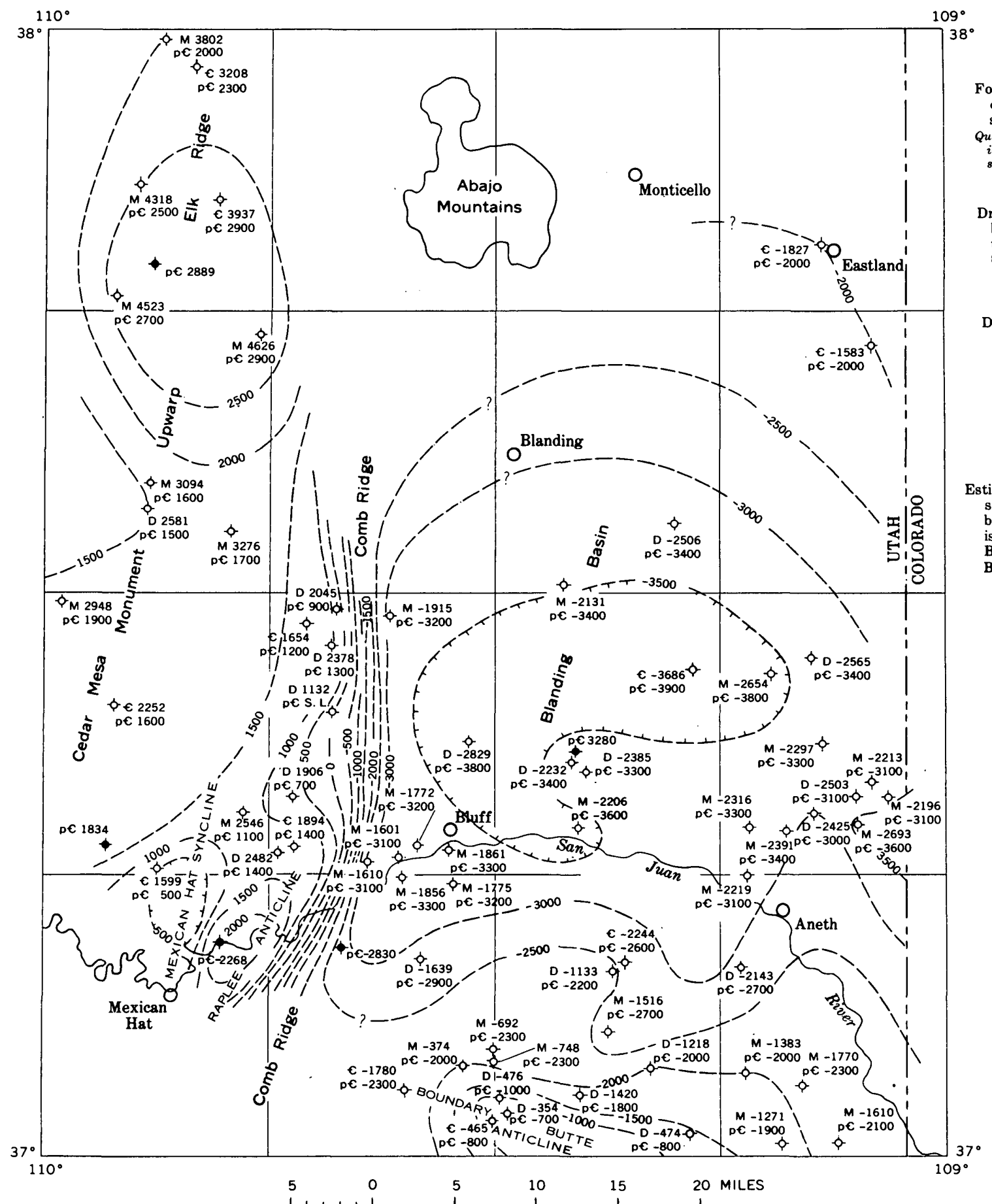

EXPLANATION

$--1500-?$

Form line showing estimated elevation of Precambrian surface

Queried where uncertain. Contour interval 500 feet: datum is mean sea level

$$
\uparrow^{p C} 1834
$$

Drill hole penetrating Precambrian rocks showing eleva. tion of top of Precambrian surface

\section{$-\alpha-M 2948$}

Drill hole penetrating Mississippian or older rocks showing estimated elevation of top of Precambrian

M, Misoissippian

D, Devonian

Estimates of thickness of Mississippian, Devonian, and Cambrian strata were guided by sopach maps of Cooper, 1955, Barrs, 1958, and Neff and Brown 1958

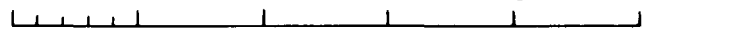

Fioure 393.3.-Inferred configuration of the Precambrian surface in parts of Blanding basin and Monument upwarp, Utah and Colorado. 


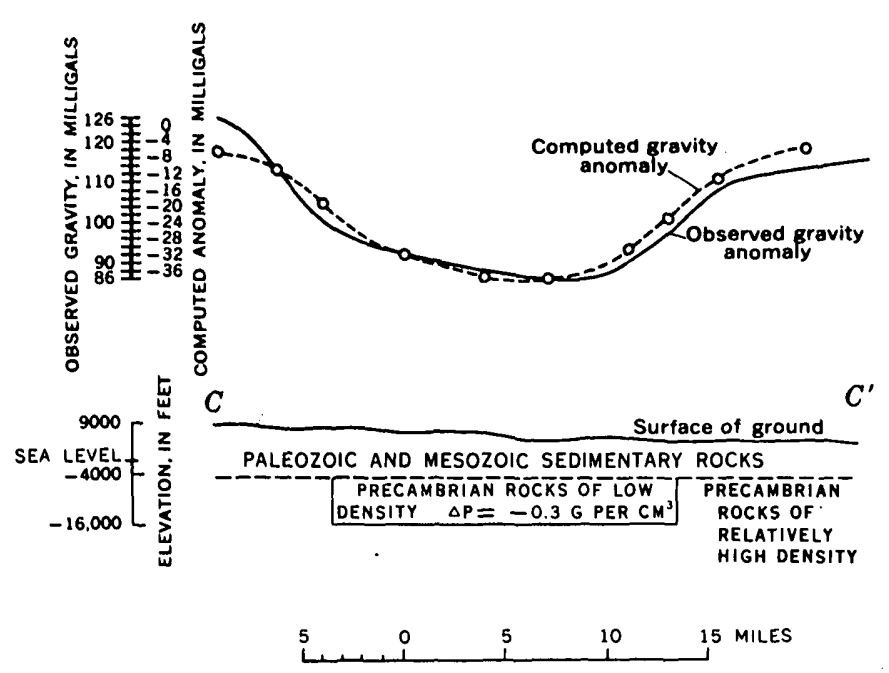

FICURE 393.4.-Interpretation of the gravity anomaly over the Blanding basin, Utah, along profile $C-C^{\prime}$ shown on figure 393.2 .

sity contrast, of course, would require a thicker block of low-density rocks to produce the gravity low.

The prominent magnetic lows in the low-density area may be caused in part by remanent magnetization of rocks in directions about opposite to magnetization induced by the earth's present field, rather than by low susceptibility. Their irregularity does not permit analysis in terms of geometry or thickness of sources. The Precambrian rocks, however, are evidently largely granitic rather than quartzitic, as the data require that they have a comparatively low density and a moderately wide range of magnetization.

The source of the large magnetic high and residual gravity high at Blanding is obviously a comparatively dense and magnetic rock. The estimated elevation of the source of the Blanding anomaly is about $-2,000$ feet (sea level datum), based on the method of Vacquier and others (1951). The basement may therefore be shallower near Blanding than estimated from stratigraphic data.

The area of low density and generally moderately magnetized basement rocks, which are probably granitic, is about 20 miles wide and 50 miles long. Other northeast-trending Precambrian structures have been inferred near Upheaval Dome, Utah; northwest of the Ia Sal Mountains, Utah; and near Cisco, Utah (Joest- ing and Case, 1960, figs. 114.2, 114.3 ; Case and Joesting, 1961). These northeast-trending structures in the central Colorado Plateau are evidently part of an ancient regional structural pattern which may include transverse zones such as the northeast-trending Colorado mineral belt of the southern Rocky Mountains.

\section{REFERENCES}

Baars, D. L., 1958, Cambrian stratigraphy of the Paradox basin region, in Intermountain.Assoc. Petroleum Geologists Guidebook 9th Ann. Field Conf., Guidebook to the geology of the Paradox basin, 1958: p. 93-101.

Baker, A. A., 1935, Geologic structure of southeastern Utah: Am. Assoc. Petroleum Geologists Bull., v. 19, no. 10, p. 1472-1507.

Byerly, P. E., and Joesting, H. R., 1959, Regional geophysical investigations of the Lisbon Valley area, Utah and Colorado: U.S. Geol. Survey Prof. Paper 316-C.

Case, J. E., and Joesting, H. R., 1961, Northeast-trending Precambrian structures in the central Colorado Plateau (abs.) : Geol. Soc. America, Program, Rocky Mountain Section Meeting, Laramie, Wyo., p. 13.

Cooper, J'. C., 1955, Cambrian, Devonian, and Mississippian rocks of the Four Corners area: Four Corners Geol. Soc. Field Conf. Guidebook, p. 59-65.

Joesting, H. R., and Byerly, P. E., 1958, Regional geophysical investigations of the Uravan area, Colorado: U.S. Geol. Survey Prof. Paper 316-A.

Joesting, H. R., and Case, J. E., 1960, Salt anticlines and deepseated structures in the Paradox basin, Colorado and Utah, in Short papers in the geological sciences: U.S. Geol. Survey Prof. Paper 400-B, p. B252-B256.

Kelley, V. C., 1955, Regional tectonics of the Colorado Plateau and relationship to the origin and distribution of uranium : New Mexico. Univ. Pub. Geology, no. 5, 120 p.

Lewis, R. Q., 1958, Structure of the Elk Ridge-Needles area, San Juan County, Utah, in Intermountain Assoc. Petroleum Geologists Guidebook 9th Ann. Field Conf., Guidebook to the geology of the Paradox basin, 1958: p. 78-85.

Neff, A. W., and Brown, S. C., 1958, Ordovician-Mississippian rocks of the Paradox basin, in Intermountain Assoc. Petroleum Geologists Guidebook 9th Ann. Field Conf., Guidebook to the geology of the Paradox basin, 1958: p. 102-108.

Shoemaker, E. M., 1954, Structural features of southeastern Utah and adjacent parts of Colorado, New Mexico, and Arizona: Utah Geol. Soc., Guidebook to the geology of Utah, no. 9 , p. $48-69$.

Vacquier, Victor, and others, 1951, Interpretation of aeromagnetic maps: Geol. Soc. America Mem. 47, 151 p.

Wengerd, S. A., and Matheny, M. L., 1958, Pennsylvanian system of Four Corners region: Am. Assoc. Petroleum Geologists Bull., v. 42, no. 9; p. 2048-2106. 


\section{USE OF GEOPHYSICAL DATA TO INTERPRET GEOLOGY IN PRECAMBRIAN ROCKS OF CENTRAL WISCONSIN}

By John W. Allingham and Robert G. Bates, Washington, D.C.

The oldest Precambrian rocks in the Driftless Area around Wausau, Wis., consist of a complex sequence of volcanic, pyroclastic, and sedimentary rocks that has been metamorphosed to greenschist and amphibolite facies. These rocks are intruded by granite and associated granophyre, and by syenite, diorite, and diabase (fig. 394.1). The area is a plain of low relief covered mostly by residual soil, with some glacial debris and loess. Hills of quartzite rise above the plain at a few places.

The rocks within the Wausau area can be divided into several groups according to their density, magnetic susceptibility and radioactivity (tables 394.1 and 394.2). Areas underlain by syenite, quartzite and various types of granite can be distinguished by well-defined radioactivity anomalies caused by different suites of accessory minerals. Areas underlain by gray granite, diorite, hormblende diorite, and diabase can be dis- tinguished by distinctive aeromagnetic patterns, which are directly related to the magnetite content of the rock units.

Figure 394.2 shows the total magnetic intensity over the area covered by the provisional geologic map (fig. 394.1). Figure 394.3 shows the geology and aeromagnetic profiles along lines 36 and 99 on figures 394.1 and 394.2. Comparison of the aeromagnetic profiles with the geology (fig. 394.3) shows many interesting relations that can be used to interpret the geology over the larger area of figure 394.2 .

On figure 394.3 , for example, line 36 crosses two inversely polarized diabase dikes (a) that appear as sharp magnetic lows in chlorite schist (b). Diorite (c) and metabasalt (d), are markedly more magnetic than granite (e), and greenstone (f). Normally polarized diabase dikes $(\mathrm{g})$ are also more magnetic than greenstone (f). The profile along line 99 of figure 394.3

TABLE 394.1.-Physical properties of rocks in Wausau area

\begin{tabular}{|c|c|c|c|c|c|c|}
\hline \multirow{2}{*}{ Rock } & \multirow{2}{*}{$\begin{array}{l}\text { Number } \\
\text { of } \\
\text { samples }\end{array}$} & \multicolumn{2}{|c|}{ Density } & \multicolumn{2}{|c|}{$\begin{array}{l}\text { Magnetic susceptibility } \\
\times 10^{-3} \mathrm{cgs}\end{array}$} & \multirow{2}{*}{$\begin{array}{c}\text { Magnetite } \\
\text { (percent } \\
\text { by volume) }\end{array}$} \\
\hline & & A verage & Range & Average & Range & \\
\hline \multicolumn{7}{|l|}{ Red granite: 1} \\
\hline Northeast of Wausau.. & 14 & 2. 67 & 2. $65-2.68$ & 0.3 & $0.1-0.4$ & 0.2 \\
\hline Southwest of Wausau & 20 & 2. 68 & .. & .05 & $.02-0.07$ & \\
\hline Syenite: & & & & & & \\
\hline Northwest of Wausau_.. & 18 & 2. 80 & & 1.4 & $0.9-2.0$ & .7 \\
\hline Skarn, & 20 & 2. 82 & $2.78-2.85$ & 4. 0 & 2. $3-48$ & 1.5 \\
\hline Basalt or greenstone & 40 & 3.0 & 2. $96-3.08$ & 5.0 & 1. 1-12 & 1. 9 \\
\hline Hornblende diorite & 22 & 3. 1 & $-\ldots \ldots \ldots$ & 6. 0 & 4. 8-7. 8 & 2. 4 \\
\hline
\end{tabular}

1 Quarry samples.

TABLE 394.2.-Total-intensity magnetic fields and radioactivity levels associated with common rock types in Wausau area

\begin{tabular}{|c|c|c|c|}
\hline \multirow{2}{*}{$\begin{array}{l}\text { Total. } \\
\text { intensity } \\
\text { anomaly in } \\
\text { gammas }\end{array}$} & \multicolumn{3}{|c|}{ Radioactivity level in counts per second } \\
\hline & $100-300$ & $300-8 \mathrm{CO}$ & $500-1000$ \\
\hline $\begin{array}{c}0-200 \\
200-500\end{array}$ & Quartzite $\ldots$ & $\begin{array}{l}\text { Syenite north- } \\
\text { west of } \\
\text { Wausau. }\end{array}$ & $\begin{array}{l}\text { Red granite } \\
\text { southwest of } \\
\text { Wausau. }\end{array}$ \\
\hline $500-3000$ & $\begin{array}{l}\text { Hornblende } \\
\text { diorite. }\end{array}$ & $\begin{array}{l}\text { Basalt or } \\
\text { greenstone. }\end{array}$ & Gray granite. \\
\hline
\end{tabular}

shows the well-defined borders of hornblende diorite (h) and some minor variations in areas mapped as schist (i) and rhyolite (j).

The arcuate high-amplitude magnetic anomalies (No. 1, fig. 394.2) are caused by skarn and associated granulite in the central area of red granite and in the adjoining area of aplitic syenite. These rocks, together with spatially related quartzite and chlorite-albite schist, outline limbs of a large fold. Dip directions of the metamorphosed sedimentary rock units, obtained by comparing computed magnetic curves with observed profiles, indicate that this fold is the keel of a south- 


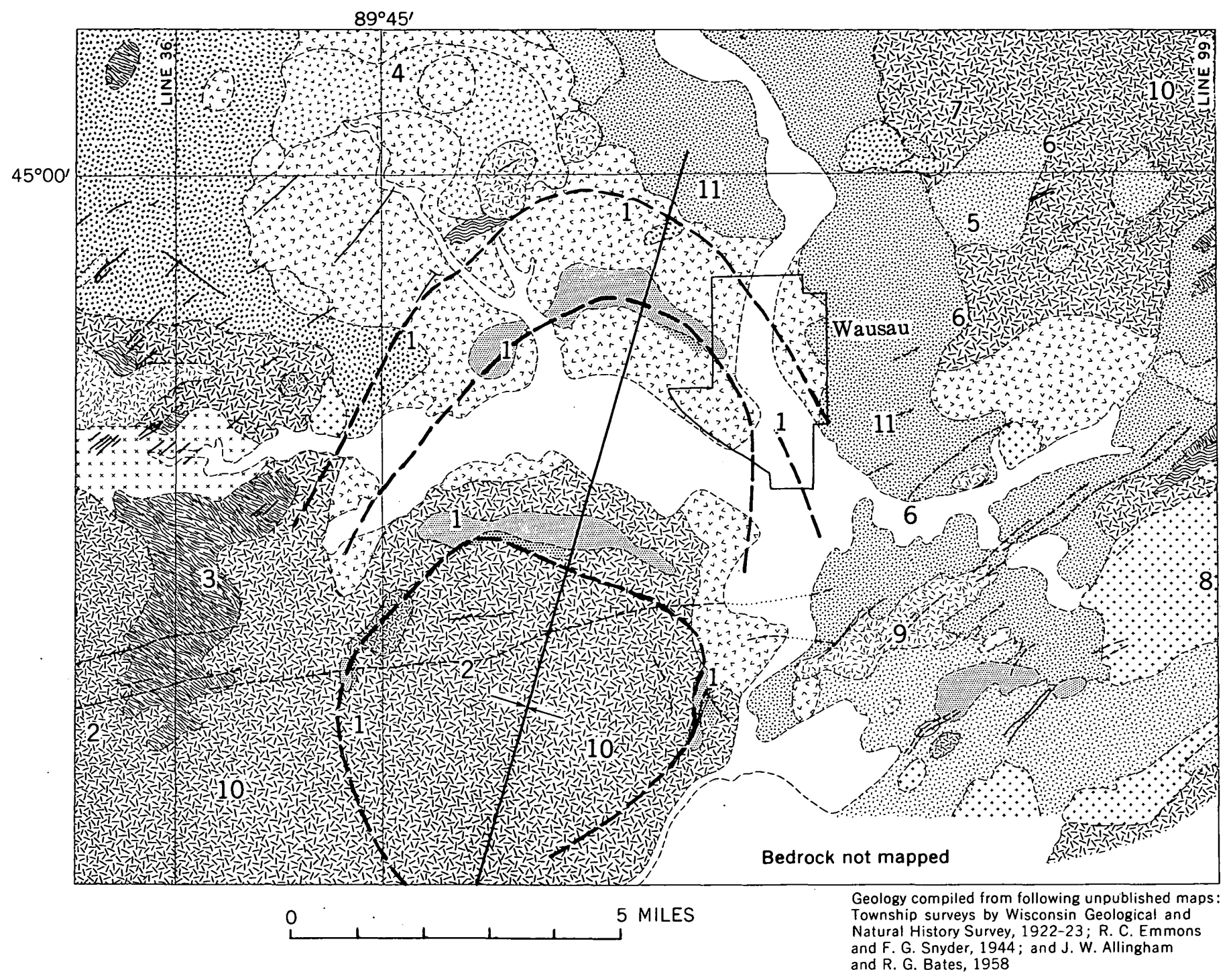

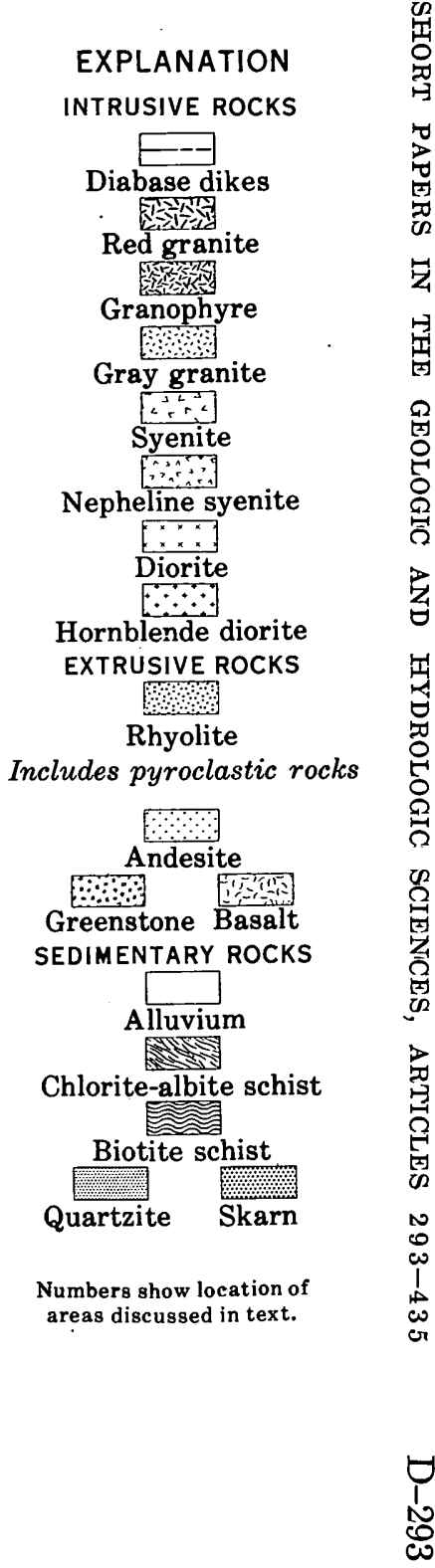

FIGURE 394.1--Provisional geologic map, Wausau area, Wisconsin. 


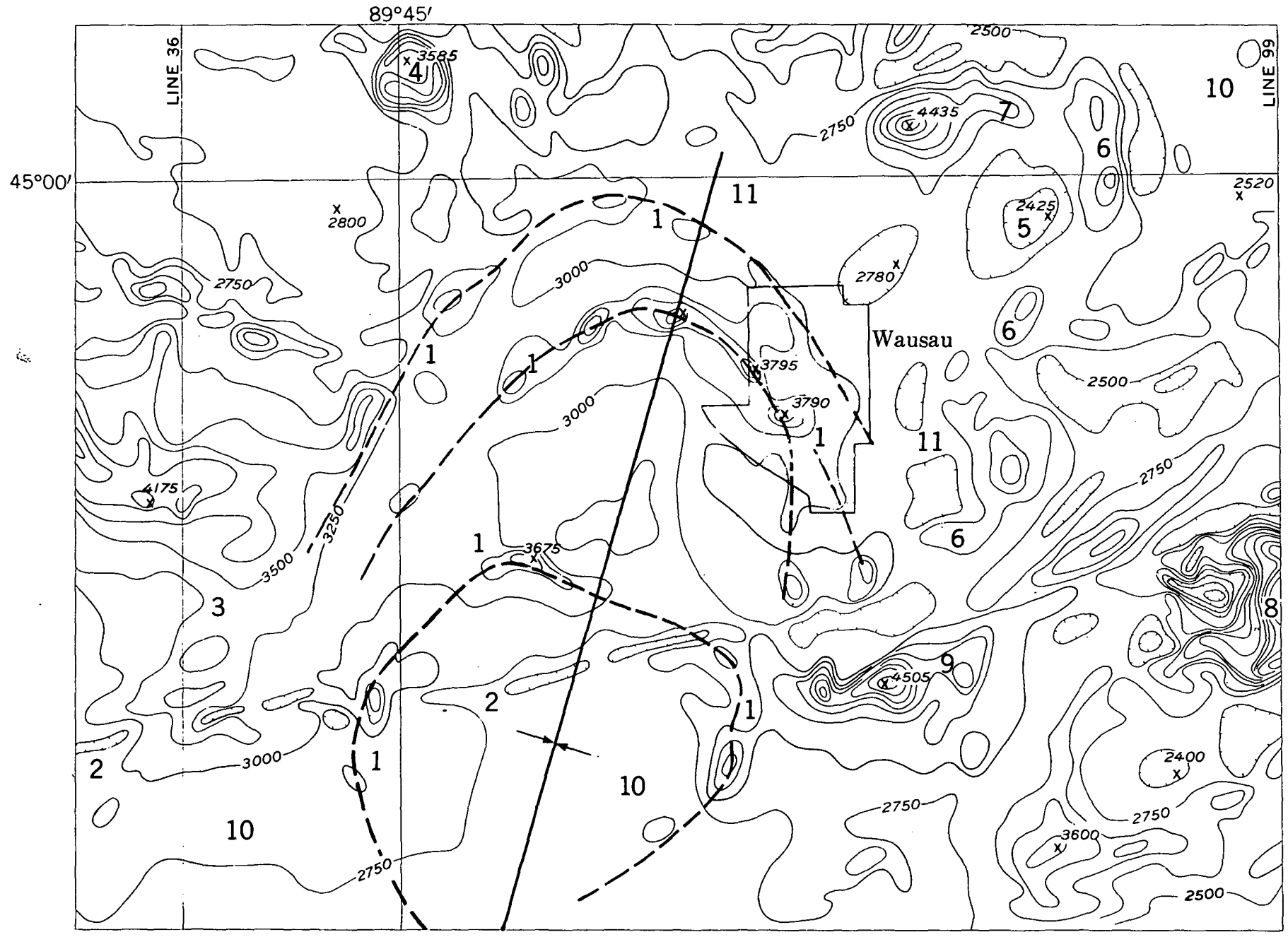

\section{EXPLANATION}

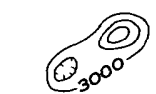

Magnetic contours, showing total
intensity magnetic field of the

intensity magnetic field of the

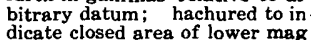

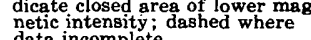
Measured maximum or minimum
intensity
hithin chinged cor magnetic
high or closed magnetic low

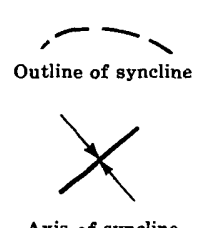

Axis of syncline

WISCONSIN

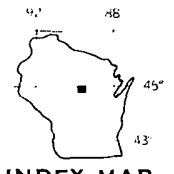

\section{Numbers show location of}

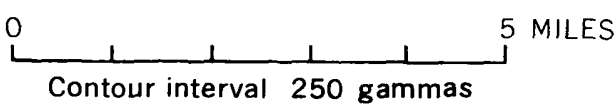

FIGURE 394.2.-Total-intensity aeromagnetic map, Wausau area, Wisconsin. 

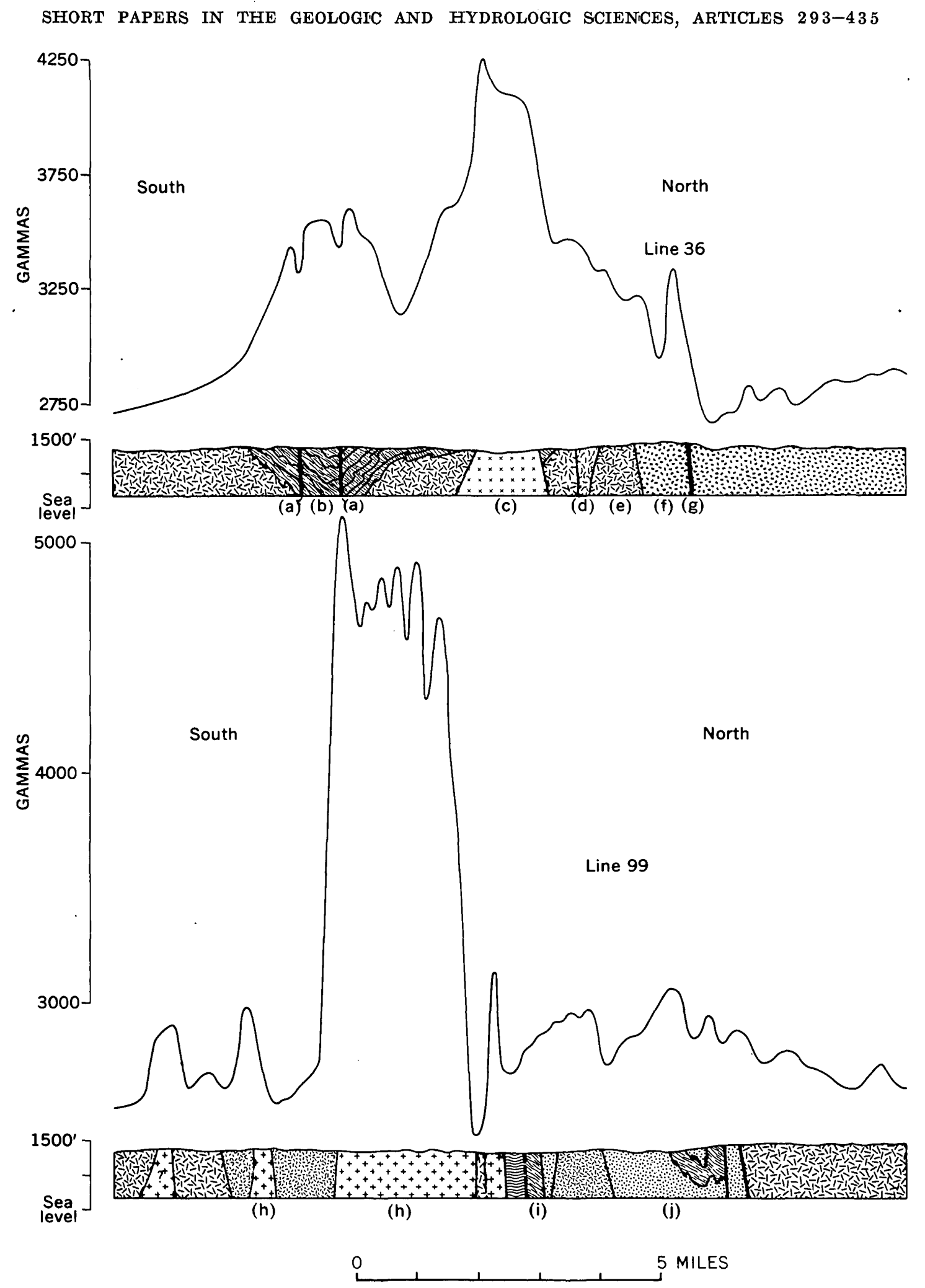

Fraure 394.3.-Aeromagnetic profiles along lines 36 and 99 on figures 394.1 and 394.2 showing correlation with geólogy, Wausau area, Wisconsin. 
west-plunging major syncline. This syncline has been partly obscured by volcanic rocks and by engulfing felsic and mafic intrusions.

Diabase dikes of reverse magnetism (No. 2), which extend for as much as 12 miles across the central part of the area (Bates and Allingham, 1958), are seen clearly on figure 394.2 as sharp, continuous magnetic lows. These dikes contain accessory titaniferous spinel, which produces the reversed remanent magnetization.

The area of chlorite-albite schist on the west edge of figure 394.2 is outlined fairly well by the 3250 gamma line (No.'3).

The circular magnetically zoned anomaly (No. 4) within the syenite complex northwest of Wausau is possibly an alkalic plug. If so, this area might be geologically favorable for exploration for niobium-bearing minerals, because this association of a circular zoned intrusion, hornblende diorite, and pyroxenitic rocks with syenite is similar to an occurrence in Ontario Province, Canada, that yields niobium (columbium)-bearing pyrochlore (Westrick and Parsons, 1957). Spectrographic analyses of samples from the syenite (Vickers, 1956) show concentrations of niobium.

The gray granite northeast of Wausau is distinguished by a large magnetic low (No. 5). This granite is surrounded by a sinuous belt of metabasalt or mafic diorite that gives magnetic highs (No.6). The pronounced and circular magnetic high (No. 7) northwest of No. 6 may represent a plug that is a possible source of these mafic rocks.

Some geologic boundaries are also sharply defined by the aeromagnetic information. The margins of the hornblende diorite east of Wausau (No. 8) and of the basalt south of Wausau (No. 9) are clearly indicated. Areas of red granite (No. 10) and rhyolite and pyroclastic rocks (No. 11) are magnetically flat, and thus are less clearly defined.

These observations show that geophyical data can add significantly to knowledge of geology in areas of complex structure and poor exposures.

\section{REFERENCES}

Bates, R. G., and Allingham, J. W., 1958, Correlations of airborne geophysical data with geology in the Wausau area, Wisconsin [abs.] : Geophysics, v. 23, no. 5, p. 1068.

Westrick, E. W., and Parsons, G. E., 1957, Integrated exploration finds columbium deposits in Chewett and Collins townships, Ontario, in Methods and case histories in mining geophysics, [Canada] Commonwealth Mining and Metall. Cong. (6th) : p. 184-195.

Vickers, R. C., 1956, Airborne and ground reconnaissance of part of the syenite complex near Wausau, Wisconsin: U.S. Geol. Survey Bull. 1042-B., p. 32-33.

\title{
395. SOME OBSERVATIONS OF THE SEISMIC-ELECTRIC EFFECT
}

\author{
By C. J. Zablocki and G. V. Keller, Denver, Colo.
}

Work done in cooperation with the U.S. Air Force and the U.S. Atomic Energy Commission

Several mechanisms have been postulated for the conversion of mechanical energy in seismic waves to electrical energy in the earth. Thompson (1939) suggested that the resistivity of a rock is increased during compression and decreased during tension, so that if a current is flowing through the rock when a seismic wave arrives, the potential gradient across the rock will vary according to Ohm's Law. Ivanov (1939) considered that differential motion between rock grains and water in pore spaces can cause electrofiltration potentials as a seismic wave passes through a rock. Other possibilities are that the motion of a conductive rock in the magnetic field of the earth may generate an electric current, and that changes in pressure at the electrodes used to measure earth voltages may change the electrode potentials.
The mechanism or mechanisms ordinarily involved in the seismic-electric effect have not been conclusively determined experimentally. Bukhnikashvili and Prangishvili (1956) were not able to substantiate the existence of the electrofiltration phenomenon, but Martner and Sparks (1959) presented experimental evidence suggesting that voltages are generated at the base of the weathered layer.

An opportunity for studying seismic-electric voltages developed by high-energy seismic waves was provided by the underground nuclear detonations included as part of the Hardtack II test site series at the U.S. Atomic Energy Commission's Nevada Test Site. Earth potentials were recorded at distances ranging from 3 to 5 miles from these underground explosions, and, more 
recently, at approximately the same distance from a large underground chemical explosion.

Earth potential differences were measured between grounded lead electrodes 2,500 feet apart. Two orientations of electrode pairs were used at each recording location, one pair of electrodes placed along a radial line from the explosion, and another pair at a constant radial distance from the explosion. The voltages between each pair of electrodes were amplified and recorded on a high speed oscillograph. The frequency response was 0 to 220 cycles per second, except that frequencies close to 60 cycles per second were rejected with a notch filter. Seismometers sensitive to ground velocity in the frequency range of 2 to 20 cycles per second were placed near each grounded electrode. The low-end response of these seismometers is down about 10 decibels at 1 cycle per second from 2 cycles per second and falls off sharply below 1 cycle per second.

Records of seismic-electric voltages from two underground explosions are shown on figure 395.1 (p. D-298). The traces on the records are identified as follows:

Scooter event:

Trace number 1, Radial electric spread, full-scale sensitivity $1.8 \mathrm{mv}$

1a, Radial electric spread, full-scale sensitivity $0.6 \mathrm{mv}$

2, Horizontal seismometer at vertex of "L" spread

3, Transverse electric spread, fullscale sensitivity $1.8 \mathrm{mv}$

3a, Transverse electric spread, fullscale sensitivity $0.6 \mathrm{mv}$

Logan event :

Trace number 1, Radial electric spread, full-scale sensitivity $12 \mathrm{mv}$

2, Transverse electric spread, fullscale sensitivity $12 \mathrm{mv}$

3 , Horizontal seismometer at vertex of "L" spread

The first group of traces were recorded during the explosion of 500 tons of chemical explosives buried approximately 80 feet in alluvium. The name of the operation was "Scooter event." The electrodes nearest the explosion point were at a radial distance of $31 / 2$ miles to the southwest. The area between the explosion point and the recording station is underlain by alluvium about 1,000 feet thick, which rests on a bedrock surface consisting of volcanic tuff, limestone, argillite, quartzite, and conglomerate.

The second group of traces shows the voltages recorded during the detonation of an underground nuclear device and the operation name was "Logan event."
The point of detonation was in volcanic tuff, approximately 800 feet below the surface of the earth. The energy released by the explosion was equivalent to that contained in approximately 5,000 tons of TNT (Griggs and Press, 1961). The recording station was 4.3 miles east of the explosion point on an outcrop of volcanic tuff. The area between the explosion point and the recording station was covered by no more than a few tens of feet of alluvium. The voltages are sufficiently large and unique in character that they cannot be interpreted as variations in the normal telluric current field. Records made at this locality during several nuclear explosions were practically identical. The characteristics of the seismic-electric signals were: (a) Seismicelectric voltages in the radial direction were always larger than the voltages in the transverse direction. (b) The frequencies of the electric signals generally correlate with the low frequencies recorded on the seismic traces. Higher frequencies that were contained in the signals from the seismometers were not apparent on the electric traces. (c) The first seismic-electric voltages at the electrode spreads appear essentially at the same time as the seismic energy. A plot of electric signal as a function of ground velocity (fig. 395.2, p. D-299) suggests that the electric signals lead the seismic signals by $45^{\circ}$ in phase. Unfortunately, the frequencies observed in the seismic records were close to the seismometer resonant frequency, and thus, all or part of this phase delay may have been in the mechanical system.

The seismic-electric signals and the seismic waves from the chemical explosion persisted at significant levels for 90 seconds, but the signals from the nuclear explosion, which was nine times larger, lasted for only 30 seconds. The alluvium in which the chemical explosive was detonated was probably a better medium in which to generate slow-moving seismic-surface waves than were the volcanic rocks in which the nuclear explosion occurred.

\section{REFERENCES}

Bukhnikashvili, A. V., and Prangishvili, G. M., 1956, Experiments on the recording of the seismoelectric effect: Akad. Nauk Gruzin. SSSR, v. 18, p. 789-795.

Griggs, D. T., and Press, F., 1961, Probing the earth with nuclear explosions: Jour. Geophys. Research, v. 66, p. 237258.

Ivanov, A. G., 1939, Effect of electrization of earth layers by elastic waves passing through them: Akad. Nauk SSSR, Doklady, v. 24, no. 1, p. 42-45.

Martner, S. T., and Sparks, N. R., 1959, The electroseismic effect: Geophysics, v. 24, no. 2, p. 297-308.

Thompson, R. R., 1939, A note on the seismic electric effect: Geophysics, v. 4, p. 102-105.

$604493-61-20$ 


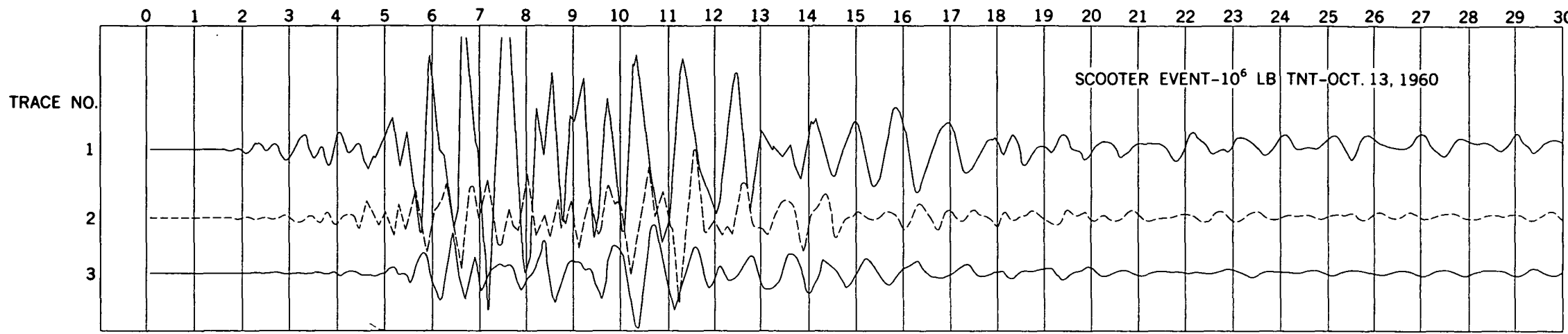

TIME IN SECONDS
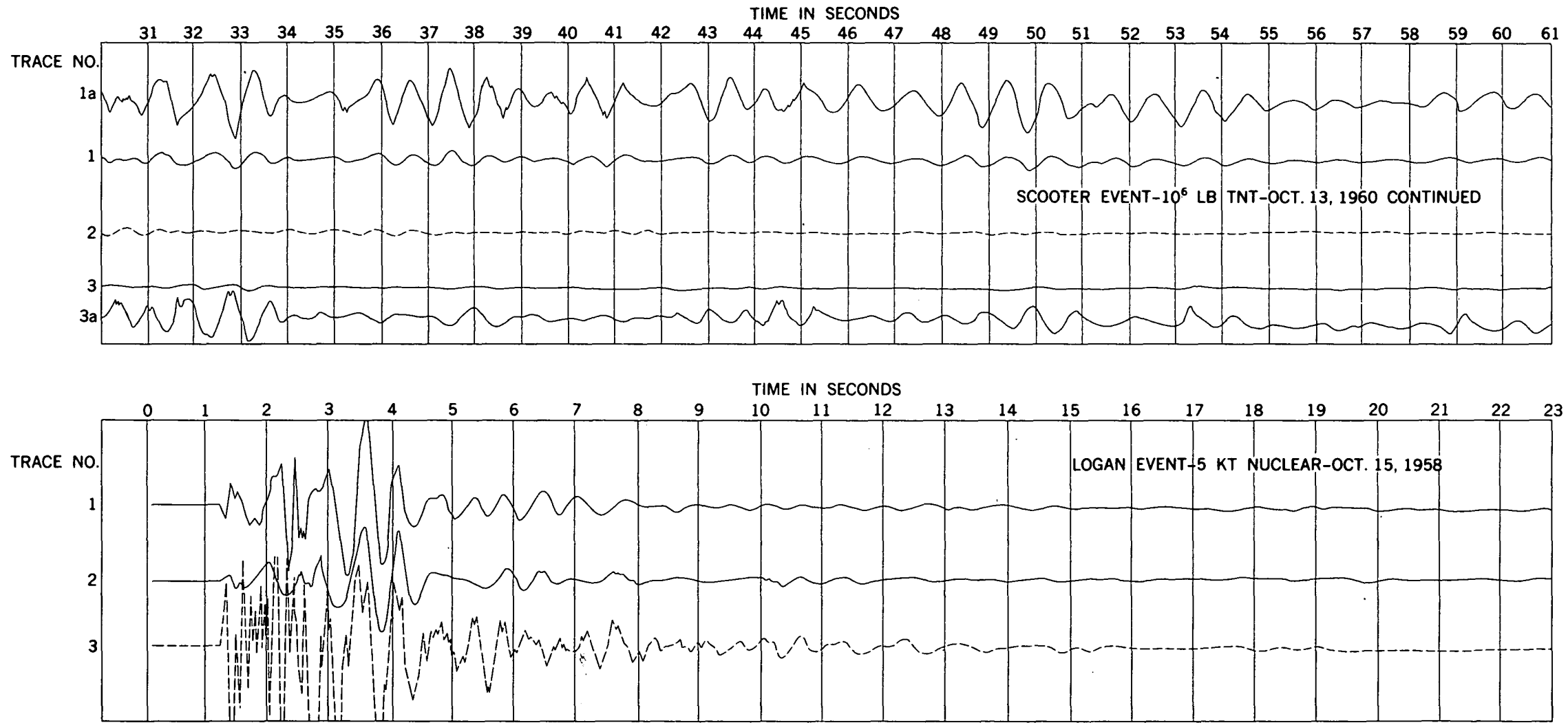

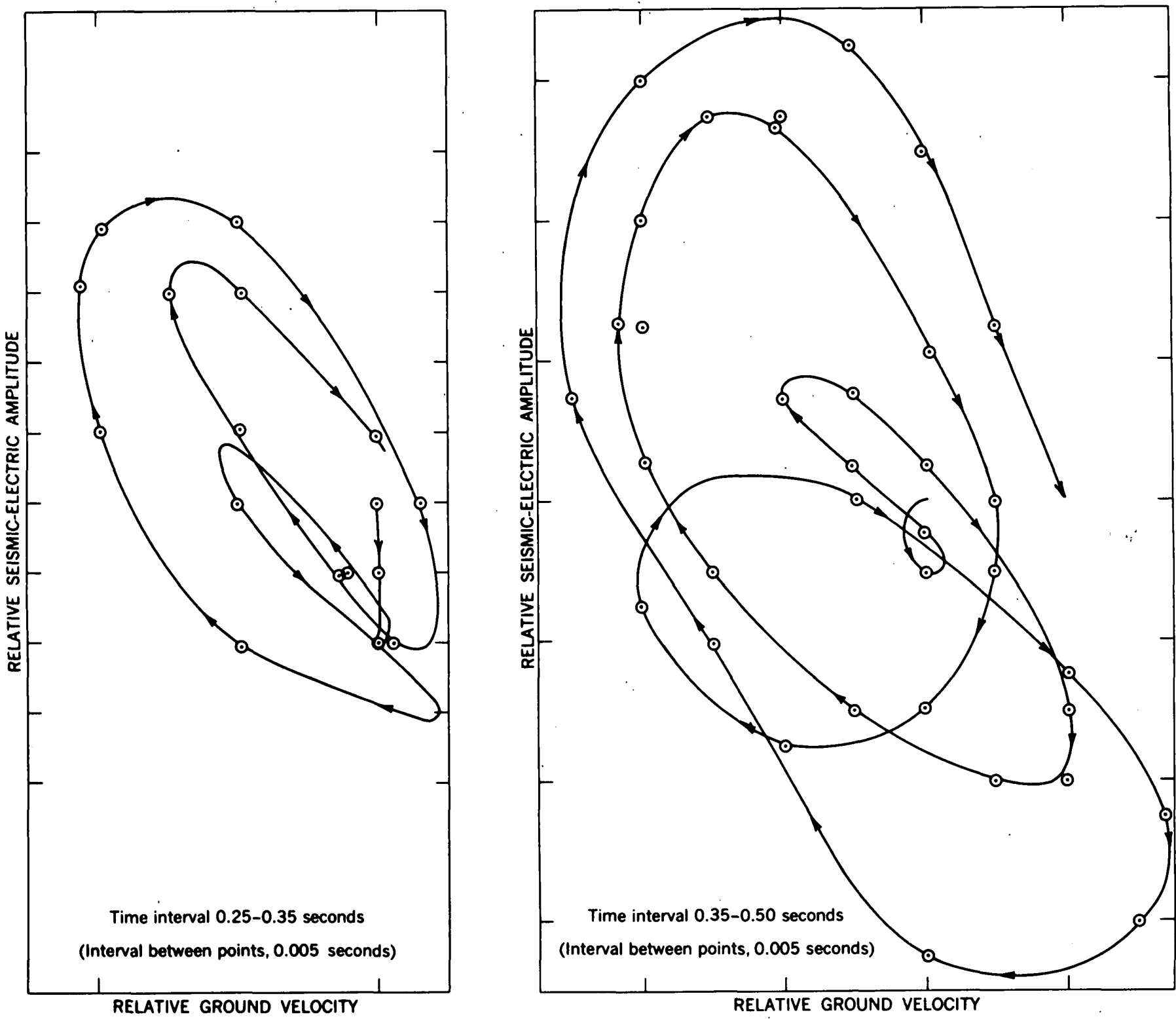

RELATIVE GROUND VELOCITY

Figure 395.2.-Plots of instantaneous seismic-electric signals versus instantaneous ground velocity for portions of record during chemical explosion.

X

396. THE SIGNIFICANCE OF A GROUP OF AEROMAGNETIC PROFILES OFF THE EASTERN COAST OF NORTH AMERICA

By Elizabeth R. King, Isidore Zietz, and William J. Dempsey, Washington, D.C.

Work done in cooperation with Office of Naval Research

The 14 aeromagnetic profiles which form the basis of this study were obtained on flights by the U.S. Geological Survey in 1948 and 1950 and make a fan-shaped pattern from the island of Bermuda (fig. 396.1). Flight elevations ranged from 500 to 6,000 feet above sea level, and averaged about 3,000 feet. Navigation 


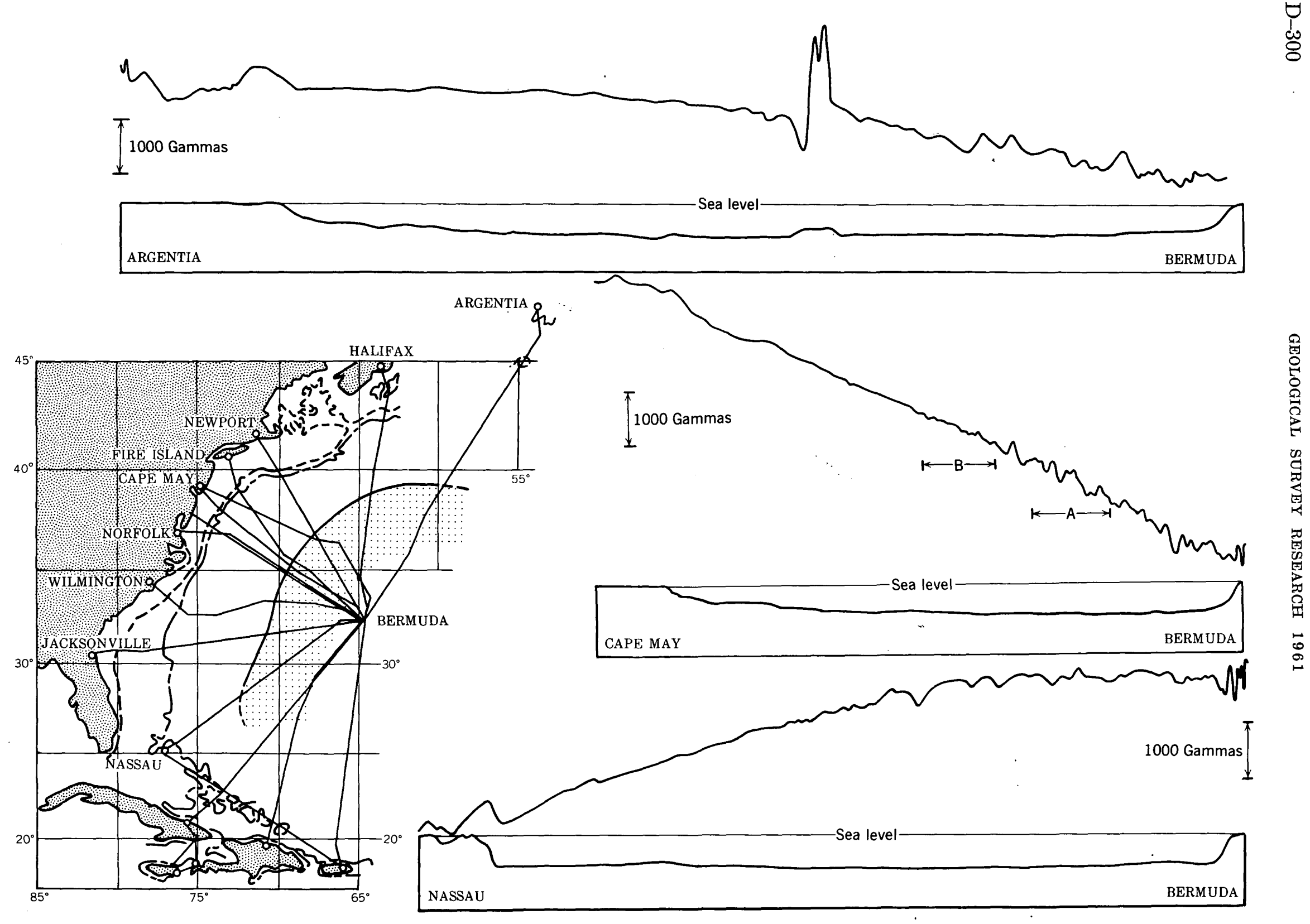

Fur 3961-Index map of region extending from Argentia, Newfoundland, to Puerto Rico, and three typical aeromagnetic profiles. Edge of continental shelf outlined by 100 and 1,000-fathom contours (broken and solid line, respectively); greatest ocean depths range from about 2,500 to 3,000 fathoms. Anomalous zone shown by shaded area around Bermuda. Profiles of total magnetic field are from an arbitrary datum. 
errors of 10 miles are not unusual in these long overwater traverses. The regional magnetic gradients of the profiles are the effect of the earth's main magnetic field. Three distinct zones of sharply contrasting magnetic pattern are apparent over most of the area surveyed. A broad zone around Bermuda is characterized by numerous closely spaced anomalies of rather uniform size and has been shown on figure 1 by the shaded area. The anomalies in a second zone over the continental shelf and slope are variable in amplitude and gradient, and this zone is bounded by a fairly continuous 300- to 500-gamma anomaly which parallels the outer edge of the continental shelf. The third zone lies between the first two zones and is characterized by relatively smooth profiles. The distinctive zoning is not clearly defined east of Nassau where the smooth magnetic pattern disappears and is replaced by a less uniform profile. The very large steep-gradient anomaly in the middle of the Bermuda-Argentia profile (fig. 396.1) is caused by one of a group of seamounts which extends to the northwest toward Cape Cod. Another of this group is crossed by the Halifax profile. Even larger anomalies are associated with the island of Bermuda, indicating that Bermuda has a core of highly magnetic volcanic rocks (Keller and others, 1954). Evidently the seamounts are also volcanic in origin.

Depth analyses were made on all possible anomalies to learn something about their source. The method used is the measurement of the horizontal extent of the steepest gradient, which assumes that the anomaly is caused by large, vertical-sided masses of magnetic rock of semi-infinite downward extent. The accuracy of the values obtained from single profiles depends on whether the anomaly is two-dimensional, that is, elongated in the direction perpendicular to the profile. If not, the values obtained may be too large. In all, 120 depth determinations were made. These fall into two groups. One group of 90 depths to magnetic rocks coincides with the Bermuda anomalous zone. The remaining 30 depth values are distributed over the continental shelf and slope, and a few are also in the region north of the West Indies where the magnetic zones were not well developed. The lack of depth determinations in the intervening flat zone is expected because of the absence of usable magnetic anomalies.

The depth values in the Bermuda zone indicate that magnetic rocks lie close to the ocean floor over the entire area. The change from the Bermuda anomalous zone to the flat magnetic zone is generally quite abrupt and well defined, but there is a short transition zone of small ripples on most of the profiles (section " $B$ " on the Cape May profile, fig. 396.1). The two most probable explanations of this transition zone are that the nearsurface magnetic rocks of the Bermuda zone have been downfaulted and buried under relatively nonmagnetic sedimentary material, or that these rocks do not extend west of the boundary except for a thin sheet or wedge. overlying rocks of low or very uniform magnetic susceptibility. The first possibility was tested by taking a section of profile (section " $A$ " on the Cape May profile) and projecting it upward mathematically to levels 2 and 4 miles above the original level of observation (fig. 396.2). Section "B" does not sufficiently resemble section " $A$ " even at the 4-mile level to support the possibility of down-faulting. A measurement of the half-widths of some of the ripples in the transition zone gives an approximate depth equal to the ocean depth,

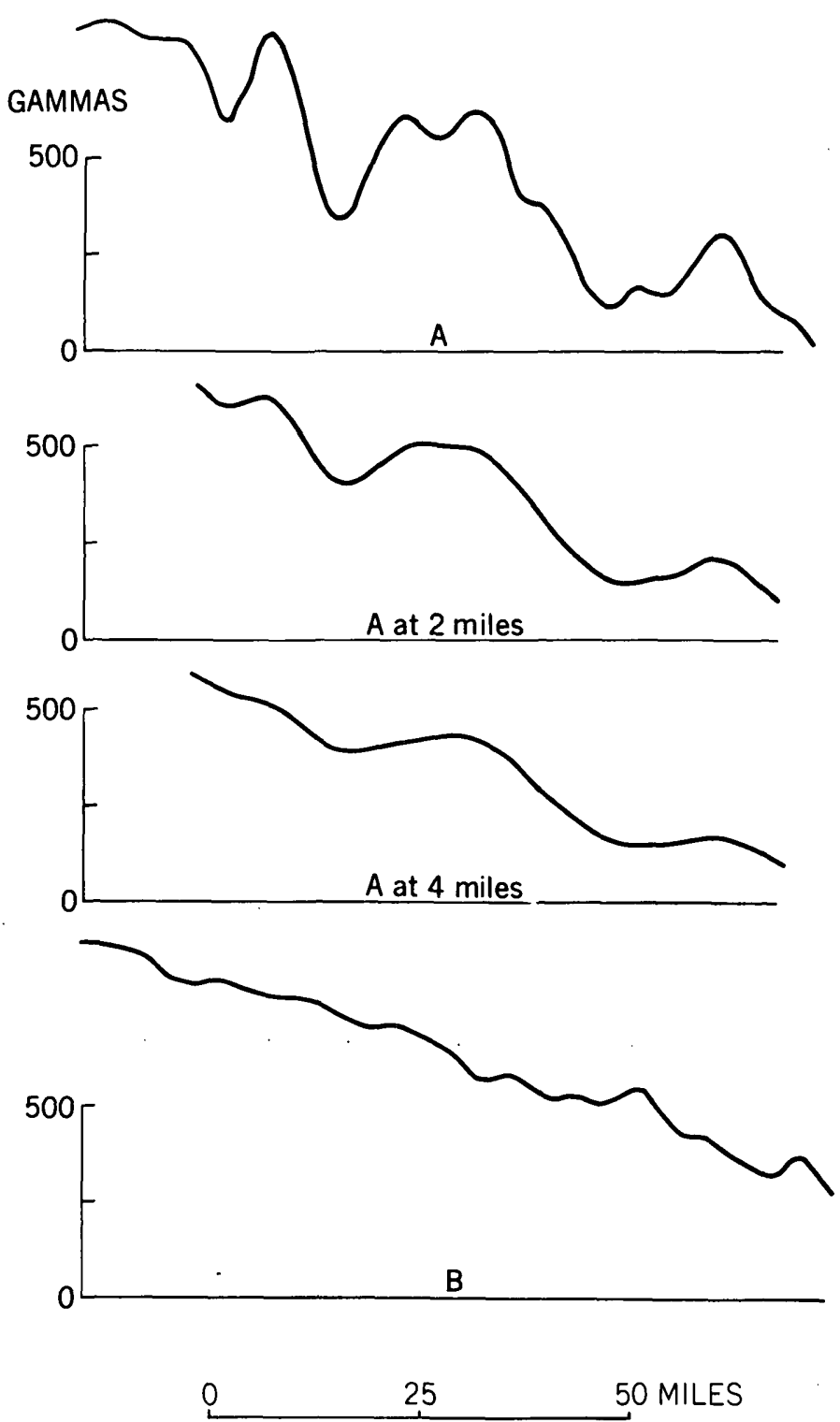

Figure 396.2.-Upward continuations of section " $A$ " of Cape May profile compared with transition zone "B." 
which supports the second possibility, that of a thin sheet of magnetic rocks on the ocean floor.

A comparison of the depths to magnetic rocks computed from anomalies over the continental shelf and slope was made with contoured values of the depth to the crystalline basement rocks determined principally from seismic profiles by Lamont Geological Observatory (Drake and others, 1959). The depths were either in good agreement with (or greater than) the seismic values, which is normal for continental areas. Figure 396.3 shows sections of each of the observed magnetic profiles across the continental shelf, and both seismic and magnetic depth values to basement rocks-the former depth values to rocks of higher seismic velocity, and the latter to rocks of higher magnetization. The fact that accurate depth analyses could be made from these basement anomalies indicates that the basic assumption of a basement composed of vertical-sided blocks of various magnetic susceptibilities is valid. The magnetic depth values which lie below the top of the crystalline rocks may indicate intrabasement magnetic rocks, departure from the necessary twodimensional conditions, or insufficient seismic information at the point of comparison.

The anomaly which parallels the outer edge of the continental shelf is the most interesting single magnetic feature revealed by these profiles. Although its width and location are similar to a gravity anomaly observed by the Lamont group (Worzel and Shurbet, $1955)$, the gravity anomaly may be accounted for by a combination of the increase in ocean depth off the edge of the shelf and a thinning of the continental crust from 20 miles to an oceanic crust of 3 miles over a very short interval at the continental margin. Neither of these factors will produce the magnetic anomaly. The correlation of the magnetic and gravity anomalies is probably only fortuitous or indicates indirect control rather than a common source. The seismic data show a buried ridge of basement rocks at the outer edge of the continental shelf (fig. 396.3). The effect of this topog-
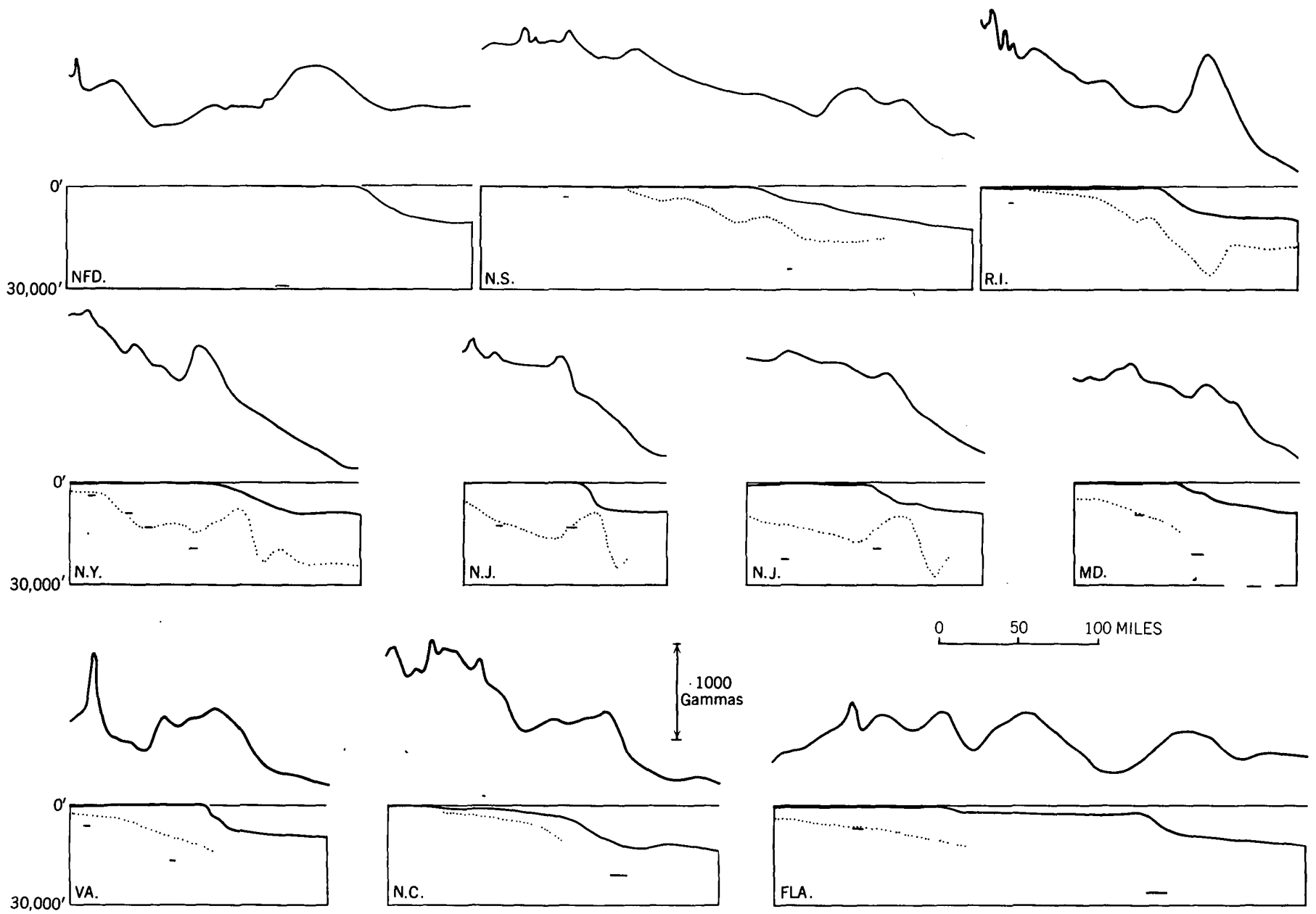

FraUre 396.3.-Sections of aeromagnetic profiles over the continental shelf and slope from Newfoundland and Nova Scotia to Florida, showing continental slope anomaly. Top of crystalline basement rocks from seismic data indicated by dots. Computed depths to magnetic rocks indicated by bars. 


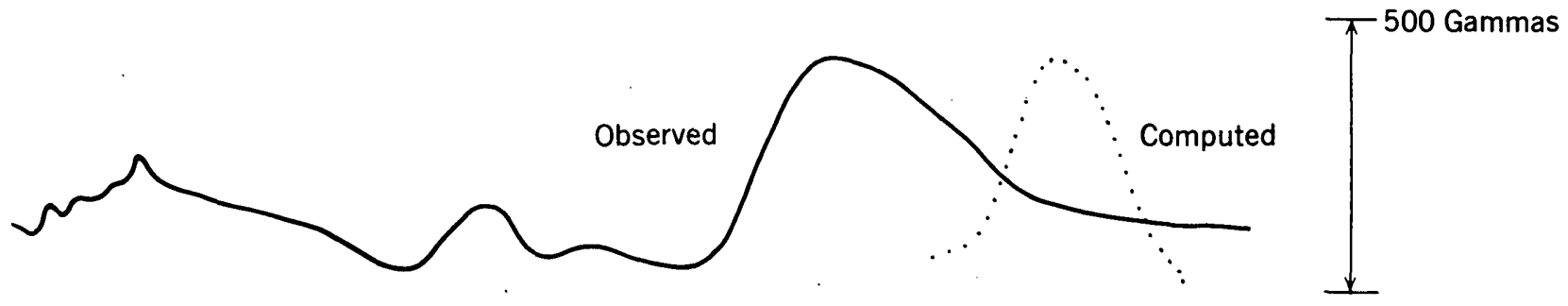

NORTH

SOUTH

\section{LONG ISLAND}

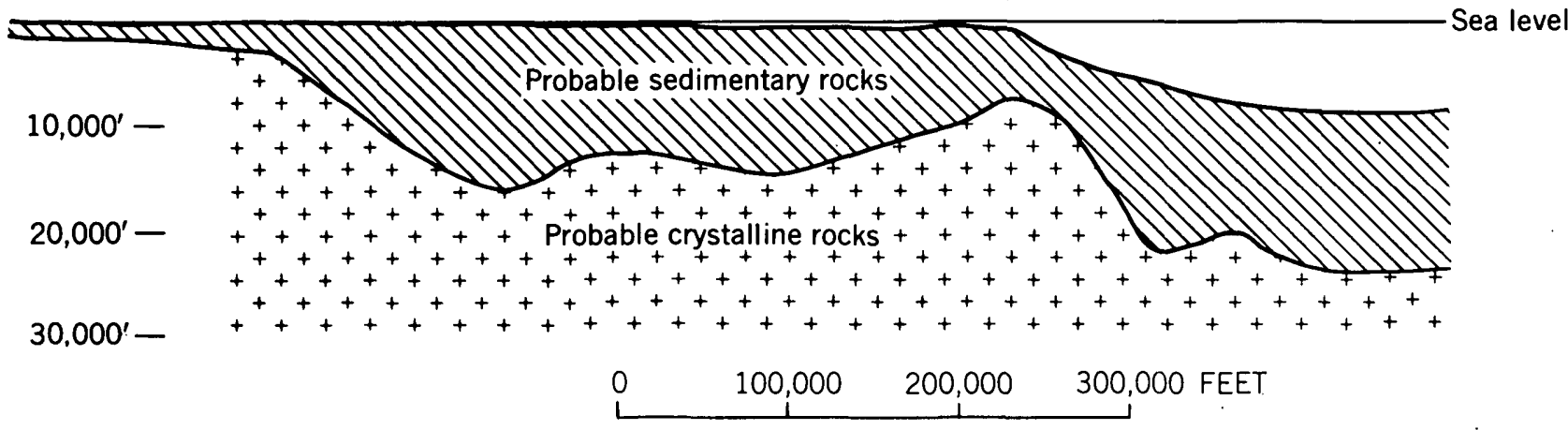

Froure 396.4.-Computed and observed magnetic anomalies over basement ridge south of Long Island, N.Y. Section compiled from seismic data.

raphy was computed for a profile south of Long Island, N.Y., where one of the Lamont seismic profiles is nearly coincident with one of the aeromagnetic profiles (fig. 396.4). An arbitrary linear gradient was removed from the observed profile to facilitate the comparison with the computed anomaly. In order to give an anomaly with the amplitude of the observed anomaly, the rock must have an apparent susceptibility of 0.006 to 0.007 cgs units, which is high for continental basement rocks. The horizontal offset in position in this and other areas may not be real because of locational errors, but in general the magnetic anomalies are not highest where the ridge is highest and not lowest where the ridge is lowest. The success of the depth calculation technique here is evidence that the anomalies are caused by susceptibility contrasts in the crystalline basement rocks. The Lamont group has not detected any marked increase in seismic velocity associated with this basement ridge, but the recorded velocities are high enough to include most types of crystalline rocks.
Therefore, we conclude that although basement topography undoubtedly contributes to the magnetic profile it is not the sole cause of this large magnetic feature. The profile may be at least partly the expression of a large mass or series of masses of more magnetic rocks within the basement-possibly intrusive bodies along a zone parallel to the continental margin at the transition from a continental to an oceanic crust.

\section{REFERENCES}

Drake, C. L., Ewing, Maurice, and Sutton, G. H., 1959, Continental margins and geosynclines: the east coast of North America north of Cape Hatteras, in Physics and chemistry of the earth: New York, Pergamon Press, v. 3, p. 110-198.

Keller, Fred, Meuschke, J. L., and Alldredge, I. R., 1954, Aeromagnetic surveys in the Alentian, Marshall, and Bermuda Islands: Am. Geophys. Union Trans., v. 35, No. 4, p. 558572 .

Worzel, J. L., and Shurbet, G. L., 1955, Gravity anomalies at continental margins: U.S. Natl. Acad. Sci. Proc., v. 41, p. $458-469$. 
MINERALOGY, GEOCHEMISTRY, AND PETROLOGY

\title{
397. COMPOSITION OF THE IRON-FORMATION OF DEV ONIAN AGE IN THE CHRISTMAS QUADRANGLE, ARIZONA
}

\author{
By Ronald Willden, Menlo Park, Calif.
}

Six standard rock analyses and six semiquantitative spectrographic analyses of samples of the iron-formation in the Devonian Martin formation (Willden, 1960) in the Christmas quadrangle have recently been completed (table 397.1). The weighted average of four of these chemical analyses of samples taken at places where the total thickness of iron-formation is: exposed shows that the bed contains 52.43 percent $\mathrm{Fe}_{2} \mathrm{O}_{3}$ and 0.23 percent $\mathrm{FeO}$. Other constituents average 8.62 percent $\mathrm{CaO}, 1.88$ percent $\mathrm{MgO}, 6.48$ percent $\mathrm{CO}_{2}, 16.90$ percent $\mathrm{SiO}_{2}, 5.49$ percent $\mathrm{Al}_{2} \mathrm{O}_{3}, 1.75$ percent $\mathrm{P}_{2} \mathrm{O}_{5}$, 0.16 percent $\mathrm{MnO}, 0.23$ percent $\mathrm{TiO}_{2}$, and 5.48 percent combined $\mathrm{Na}_{2} \mathrm{O}, \mathrm{K}_{2} \mathrm{O}, \mathrm{H}_{2} \mathrm{O}$, and $\mathrm{S}$. The chemical anal-

TABLE 397.1.-Chemical analyses and semiquantitative spectrographic analyses of iron-formation in the Devonian Martin formation, Christmas quadrangle, Ariz., and one chemical analysis of "Rockwood" iron ore from Chamberlain, Tenn., for comparison

[Chemical analyses of Christmas quadrangle samples by Paula M. Buschman and of Tennessee sample by George Steiger (Burchard, 1913, p 76). Semiquantitative spectrographic analyses of samples 59 W 38, 59 W 39, and 59 W 40 by Paul R. Barnett, and of samples $59 \mathrm{~W} 92,59 \mathrm{~W} 93$, and $59 \mathrm{~W} 94$ by Nancy M. Conklin. For location of samples sec Willden, 1960, fig. 11.1, where samples 1, 4, and 5 correspond to samples $59 \mathrm{~W} 38,59 \mathrm{~W} 39$, and $59 \mathrm{~W} 40$ respectively of this study and samples 2,6 , and 7 correspond to samples $59 \mathrm{~W} 92,59 \mathrm{~W} 94$, and $59 \mathrm{~W} 93$ respectively of this study]

\begin{tabular}{|c|c|c|c|c|c|c|}
\hline \multicolumn{6}{|c|}{$\begin{array}{l}\text { Constituents in samples, identified by laboratory and } \\
\text { field number }\end{array}$} & \multirow{2}{*}{$\begin{array}{c}\text { "Rock-; } \\
\text { wood" } \\
\text { iron } \\
\text { ore }\end{array}$} \\
\hline $\begin{array}{r}\text { F2726 } \\
59 \mathrm{~W} 38\end{array}$ & $\begin{array}{c}\text { F2727 } \\
59 \mathrm{~W} 39\end{array}$ & $\begin{array}{r}\text { F2728 } \\
59 W 40\end{array}$ & $\begin{array}{r}\text { G2892 } \\
59 \mathrm{~W} 92\end{array}$ & $\begin{array}{r}\text { G2893 } \\
59 \mathrm{~W} 93\end{array}$ & $\begin{array}{r}\text { G2894 } \\
59 \text { W94 }\end{array}$ & \\
\hline
\end{tabular}

\begin{tabular}{|c|c|c|c|c|c|c|c|}
\hline \multicolumn{8}{|c|}{ Chemical analyses } \\
\hline $\mathrm{SiO}_{2} \ldots \ldots \ldots$ & 13.60 & 19.08 & 16.54 & 30.82 & 14.73 & 19.64 & 7.92 \\
\hline $\mathrm{Al}_{2} \mathrm{O}_{3}$ & 5.17 & 4.45 & 3.58 & 10. 33 & 6.02 & 6. 30 & 3.07 \\
\hline $\mathrm{Fe}_{2} \mathrm{O}_{3} \ldots \ldots$ & 55.56 & 55.48 & 50.11 & 43.13 & 47.57 & 49.04 & 50.60 \\
\hline $\mathrm{FeO}$ & .23 & .18 & .26 & .45 & .19 & .45 & 2.44 \\
\hline $\mathrm{MgO}$ & 1.49 & 2.05 & 3.74 & 1.01 & 2. 20 & 2.40 & 1.71 \\
\hline $\mathrm{CaO}$ & 10.26 & 7.14 & 10.16 & 2. 16 & 9.96 & 7.79 & 13.77 \\
\hline $\mathrm{Na}_{2} \mathrm{O}$ & .07 & .07 & .10 & .07 & .10 & .14 & .10 \\
\hline $\mathrm{K}_{2} \mathrm{O} \ldots$ & 1.22 & 1.05 & .90 & 2. 36 & 1. 67 & 1. 69 & .25 \\
\hline $\mathrm{H}_{2} \mathrm{O}+\ldots$ & 1.88 & 1.87 & 1.93 & 4. 78 & 6.35 & 2.48 & 5.52 \\
\hline $\mathrm{H}_{2} \mathrm{O}^{-}$ & .80 & .67 & .43 & 2.05 & .60 & .95 & .59 \\
\hline $\mathrm{T}^{2} \mathrm{O}_{2} \ldots \ldots$ & .22 & .20 & .16 & .34 & .25 & .28 & .10 \\
\hline $\mathrm{P}_{2} \mathrm{O}_{5}$ & 1.80 & 1.41 & 1.21 & 1.34 & 2. 18 & 1.80 & 1.31 \\
\hline $\mathrm{MnO}$ & .14 & .15 & .17 & .21 & .20 & .16 & 1.33 \\
\hline $\mathrm{CO}_{2}$ & 7. 36 & 6.02 & 10.52 & .10 & 7. 31 & 6. 30 & 12. 29 \\
\hline $\mathrm{SO}_{3}$ & .00 & .00 & .00 & .00 & .00 & .00 & (2) \\
\hline $\mathrm{S}$ & .03 & .03 & .03 & .02 & .03 & .03 & .050 \\
\hline Subtotal. . & 99.83 & 99.85 & 99.84 & 99.17 & 99.36 & 99.45 & 100.05 \\
\hline Less $0 . .$. & .02 & .02 & .02 & .01 & .02 & .02 & \\
\hline Total. .... & 99.81 & 99.83 & 99.82 & 99.16 & 99.34 & 99.43 & \\
\hline
\end{tabular}

See footnotes at end of table.

\begin{tabular}{|c|c|c|c|c|c|c|}
\hline & \multicolumn{6}{|c|}{$\begin{array}{l}\text { Constituents in samples, identified by laboratory and } \\
\text { field number }\end{array}$} \\
\hline & $\begin{array}{l}\text { F2726 } \\
\text { 59W38 }\end{array}$ & $\begin{array}{r}\text { F2727 } \\
59 \mathrm{~W} 39\end{array}$ & $\begin{array}{r}\text { F2728 } \\
59 \text { W40 }\end{array}$ & $\begin{array}{r}\text { G2892 } \\
59 \mathrm{~W} 92\end{array}$ & $\begin{array}{r}\text { G2893 } \\
59 W 93\end{array}$ & $\begin{array}{r}\text { G2894 } \\
59 \mathrm{~W} 94\end{array}$ \\
\hline \multicolumn{7}{|c|}{ Spectrographic analyses ${ }^{3}$} \\
\hline $\mathrm{Ba}$.. & 0.007 & 0.007 & 0.003 & 0.03 & 0.015 & 0.007 \\
\hline $\mathrm{Be}_{\text {. }}$ & & & 0 & .0003 & .0003 & .00015 \\
\hline $\mathrm{Ce}_{\ldots}$ & .03 & .03 & .03 & .03 & .03 & .03 \\
\hline $\mathrm{Co}$ & .0015 & .0015 & .0015 & .003 & .003 & .003 \\
\hline Cr. . & .007 & .007 & .007 & .007 & .007 & .007 \\
\hline $\mathrm{Cu}$ & .0007 & .0003 & .0003 & .0015 & .0007 & .0015 \\
\hline $\mathrm{Ga} \ldots . . .$. & .0007 & .0007 & .0007 & .0007 & .0003 & .0007 \\
\hline La & .015 & .015 & .007 & .015 & .015 & .015 \\
\hline Mo & 0 & 0 & 0 & $<.005$ & $<.005$ & $<.005$ \\
\hline $\mathrm{Nb}$ & .0015 & .0015 & .0015 & .0015 & .0015 & .0015 \\
\hline Nd $\ldots$ & .015 & .015 & .015 & .015 & .015 & .015 \\
\hline $\mathrm{Ni}$ & .0015 & .0015 & .0015 & .003 & .003 & .003 \\
\hline $\mathrm{Pb}$ & .0015 & .0015 & .0015 & .003 & .003 & .003 \\
\hline Sc. & .0007 & .0007 & .0007 & .0015 & .0015 & .0015 \\
\hline Sr & .03 & .03 & .03 & .03 & .03 & .03 \\
\hline$v_{1} \ldots \ldots \ldots$ & .015 & .015 & .007 & .03 & .03 & .03 \\
\hline$Y_{-}$ & .003 & .003 & .003 & .007 & .007 & .007 \\
\hline $\mathrm{Yb}$ & .0007 & .0007 & .0007 & .0007 & .0007 & .0007 \\
\hline $\mathrm{Zr}_{\mathrm{n}}$ & .003 & .007 & .007 & .015 & .007 & .007 \\
\hline
\end{tabular}

\begin{abstract}
1 Reported as Mn.
2 Not reported.

3 Figures are reported to the nearest number in the series $7,3,1.5,0.7,0.3,0.15$, etc., in percent. These numbers represent midpoints of group data on a geometric scale. Comparisons of this type of semiquantitative results with data obtained by quantitative methods, either chemical or spectrographic, show that the assigned group includes the quantitative value about 60 percent of the time. Also looked for but not found: $\mathrm{Ag}, \mathrm{As}, \mathrm{Au}, \mathrm{Bi}, \mathrm{Cd}, \mathrm{Dy}, \mathrm{Er}, \mathrm{Eu}, \mathrm{Gd}, \mathrm{Ge}, \mathrm{Hf}, \mathrm{Hg}, \mathrm{Ho}, \mathrm{In}, \mathrm{Ir}$, $\mathrm{Li}$, Lu, Os, Pd, Pr, Pt, Re, Rh, Ru, Sb, Sn, Sm, Ta, Tb, Te, Th, Tl, Tm, U, W,
\end{abstract} and $\mathrm{Zn}$.

yses of the iron-formation in the Christmas quadrangle closely resemble an analysis of a semi-hard Clinton iron ore from Chamberlain, Tenn. (Burchard, 1913 , p. 76), shown in the last column of table 397.1. The Clinton hard and semi-hard ores contain less silica and alumina and more carbonates than the iron-formation in the Martin, but the total iron content of the two formations is about the same. In comparison, the oolitic iron deposits in the Bliss sandstone of Cambrian and Ordovician age in southwestern New Mexico contain 20.8 to 39.2 percent iron, 0.13 to 0.66 percent phosphorus, 0.95 to 3.3 percent lime, and 27.0 to 62.8 percent silica (Kelley, 1951, p. 2207).

The chamosite previously reported (Willden, 1960) is more probably the mineral glauconite which occurs as ooliths both with and without interlayers of hematite, 


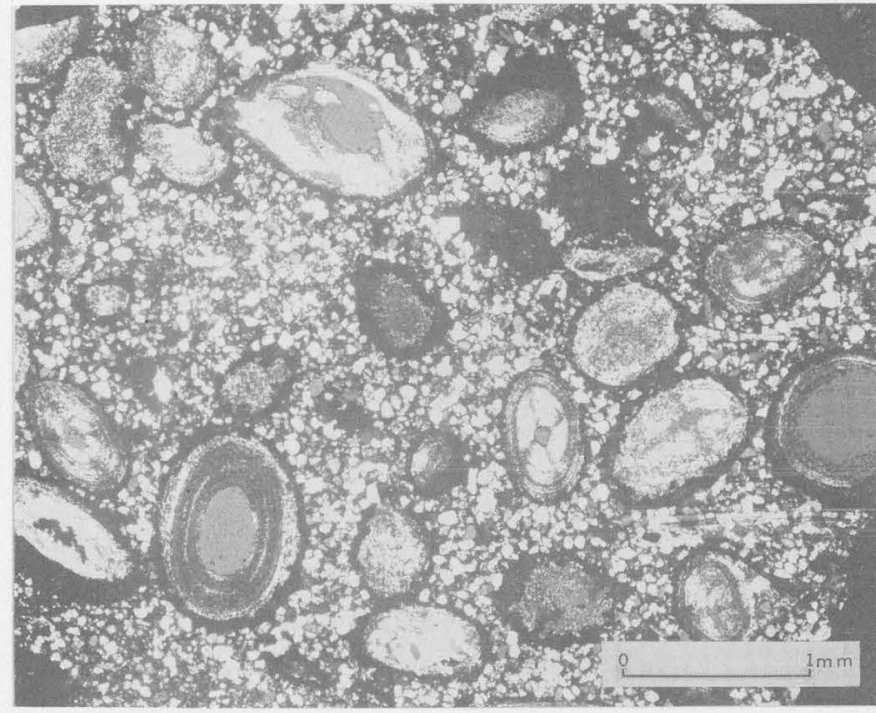

FIGURE 397.1.-Photomicrograph of glauconite-hematite ooliths in detritus-rich part of the iron-formation of the Martin formation, Christmas quadrangle, Arizona. Detrital material consists of silt-size quartz and carbonates. Cross-polarized light.

and is most abundant in parts of the bed with a high proportion of detrital material (fig. 397.1). The glauconite is believed to be a well-ordered type (Burst, 1958) because X-ray diffraction patterns of the detritusrich parts of the iron-formation show well-defined $10 \mathrm{~A}$ (angstrom) and $5 \mathrm{~A}$ lines (the $3.3 \mathrm{~A}$ line is masked by the strong quartz line at $3.35 \mathrm{~A}$ ). The relative intensities of the diffraction lines indicated the glauconite amounts to several percent of the detritus- rich rocks. No siderite has been identified in either thin sections or X-ray patterns. The shift of about $0.2^{\circ}$ toward a lower $2-\theta$ value of the characteristic dolomite lines may be due to substitution of manganese or possibly iron in the dolomite lattice.

The iron-formation contains a much greater amount of the lanthanides than normal sedimentary rocks or other common rocks of the upper lithosphere (table 397.2). However, scandium and yttrium, which are commonly associated with the lanthanides, occur in about the same amounts in the iron-formation as they do in the upper lithosphere.

The manner of occurrence of the lanthanides in the iron-formation is as yet unknown because the extremely fine grained hematite, which is intimately intergrown with the other minerals in the rocks, has greatly hampered efforts to obtain clean mineral separates for analytical work. The iron-formation in the Christmas quadrangle contains considerable apatite and it is quite possible the apatite carries the lanthanides and scandium and yttrium. This may not be the entire explanation, however, as is indicated by the average content of lanthanides in phosphorites of the Phosphoria formation (Gulbrandsen, 1960) shown in table 397.2. The phosphorites contain more than 12 times as much apatite as the iron-formation and yet the phosphorites show only a two-fold increase in the amount of lanthanum and neodymium over the ironformation, and the phosphorites contain no cerium. The phosphorites also differ in containing ten times as much yttrium as the iron-formation.

TABLE 397.2.-Distribution of scandium, yttrium, and some lanthanides in iron-formation of Devonian age, Christmas quadrangle, Ariz., in phosphorites of the Phosphoria formation (Permian), in sedimentary iron ores, in some rocks of the lithosphere, and in silicate meteorites

[Leaders indicate value not reported]

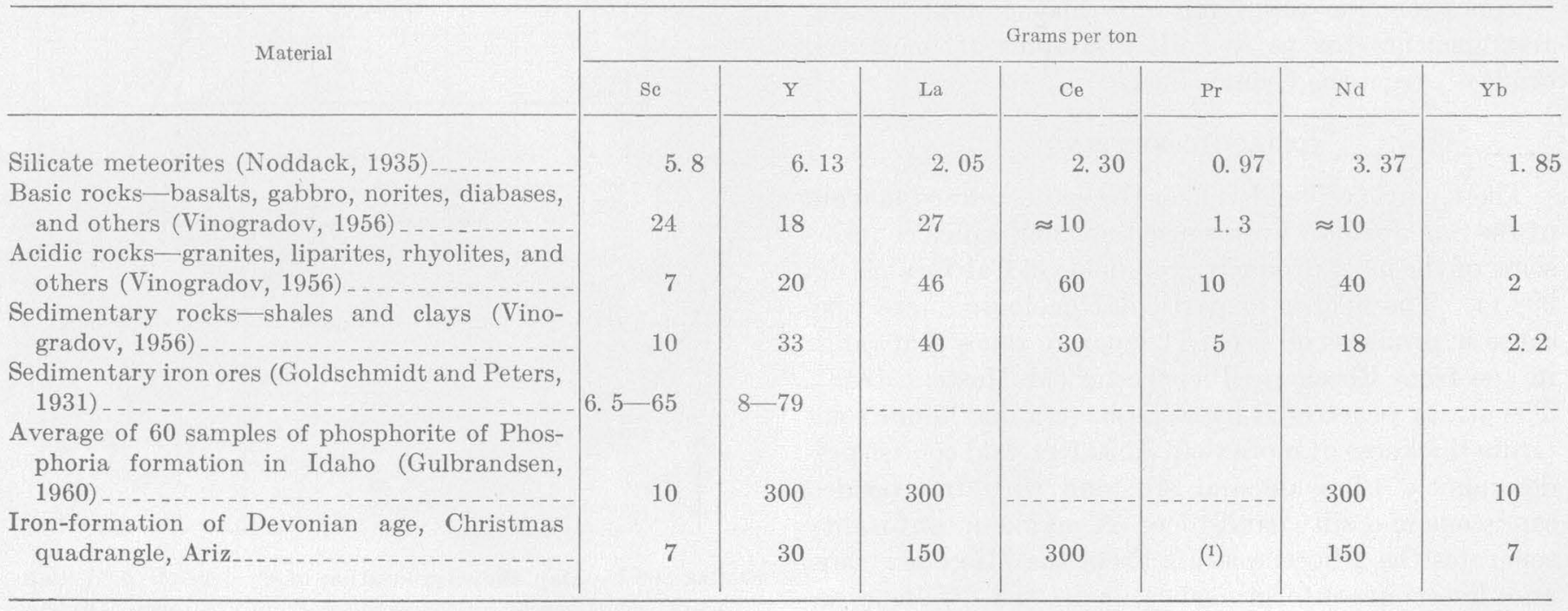

1 Looked for but not found. 


\section{REFERENCES}

Burchard, E. F., 1913, The red iron ores of east Tennessee : Tennessee Geol. Survey Bull. 16, 173 p.

Burst, J. F., 1958, Mineral heterogeneity in "glauconite" pellets : Am. Mineralogist, v. 43, p. $481-497$.

Goldschmidt, V. M., and Peters, I., 1931, Zur Geochemie des Scandiums: Nachr. Ges. Wiss. Göttingen, Math-physik. Klasse, III ; pt. iv, p. 257-279.

Gulbrandsen, R. A., 1960, Minor elements in phosphorites of the Phosphoria formation [abs.]: Geol. Soc. America Bull., v. 71, p. 1876.

Kelley, V. O., 1951, Oolitic iron deposits of New Mexico: Am. Assoc. Petroleum Geologists Bull., v. 35, p. 2199-2228.
Noddack, Ida, 1935, Die Häufigkeiten der seltenen Erden in Meteoriten: Zeitschrift anorg. allgem. Chem. 225, p. 337364.

Vinogradov, A. P., 1956, The regularity of distribution of chemical elements in the earth's crust: Akademiya Nauk SSSR, Geokhimiya. 1956, (1), p. 1-52 (translation by Mme. S. Botcharsky, in Great Britain Atomic Energy Research Est. lib. trans. 795).

Willden, Ronald, 1960, Sedimentary iron-formation in the Devonian Martin formation, Christmas equadrangle, Arizona, in Short papers in the geological sciences: U.S. Geol. Survey Prof. Paper 400-B, p. B21-B23.

398. CHEMICAL ANALYSES OF BRINES AND CRUDE OIL, CYMRIC FIELD, KERN COUNTY, CALIFORNIA

By E. H. Bailey, P. D. Snavely, Jr., and D. E. White, Menlo Park, Calif.

Connate waters and crude oil have been suspected as possible transporting agents of metals of a wide variety of mineral deposits, including lead-zinc deposits of the Mississippi Valley type (White, 1958), and possibly some quicksilver and uranium deposits (White, 1955, 1960; Erickson, Myers, and Horr, 1954, p. 2217). Chemical analyses of liquid hydrocarbons and associated brines were therefore obtained from the Cymric field, where Stockman (1947, p. 37) had reported mercury in the crude oil; particular attention was given to the minor metal contents.

We are indebted to the Honolulu Oil Corporation for permission to publish these data, and are particularly grateful to the late Mr. F. M. Cole of the Honolulu Oil Corporation for supplying information and making arrangements for us to collect samples of brine and crude oil from the Cymric field.

\section{GEOLOGIC SETTING}

The Cymric oil field is near the southwestern margin of the San Joaquin Valley synclinorium, which contains some of the most productive oil fields in California (fig. 398.1). The field is of particular geologic interest because it produces oil from 11 separate zones that range in age from Eocene to Pleistocene (McMasters, 1948). The strata penetrated by wells have a maximum composite thickness of more than 8,500 feet, and consist predominantly of shale and siltstone with interbedded sandstone and silty sandstone. A major unconformity separates the Pliocene strata from the Miocene strata, and lesser unconformities occur in the Pliocene sequence and within and at the base of the Miocene rocks.
The principal structure in the field is a narrow northwest-trending anticline which involves only Miocene and older strata; younger strata are essentially monoclinal across the fold. Along the northeast flank of the

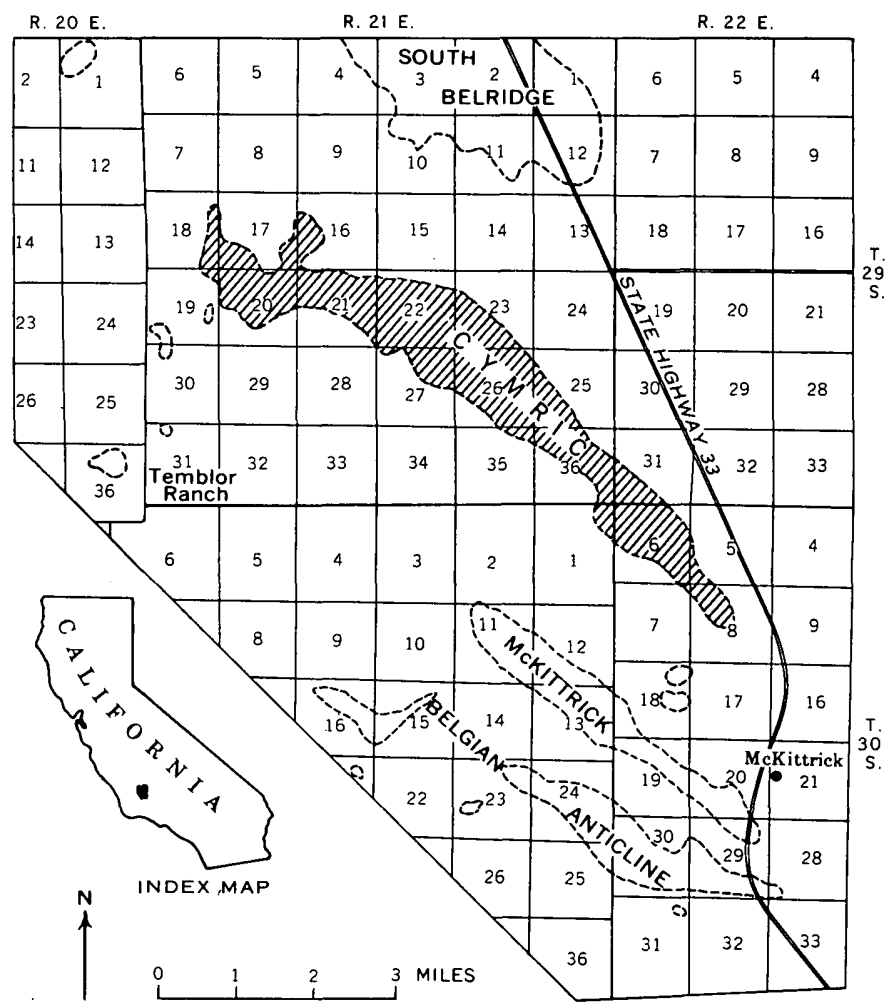

Figure 398.1.-Map showing location of Cymric oil field, California. Outlines of oil fields taken from California Division of Oil and Gas, Regional Wildcat Map 4-1, November 1955. 
anticline the pre-Pliocene beds are faulted down to the northeast, but the faults do not extend up into the Pliocene rocks (Pierce, 1947, p. 10; McMasters, 1948, p. 44). The principal controls for the accumulation of oil in the pre-Pliocene rocks are anticlinal closure and fault traps. In the monoclinal Pliocene and Pleistocene strata, favorable sites for oil accumulation result from pinch-outs and lateral changes in the permeability of sandstone beds (McMasters, 1948, p. 44).

\section{METAL CONTENTS OF CRUDE OIL}

Quantitative spectrographic analyses of metal contents were made on the ash from three samples of the Cymric field crude oil (tables 398.1 and 398.2). The crudes contain a significant quantity of mercury but lack detectable concentrations of gallium and large amounts of nickel found elsewhere in San Joaquin Valley crude oils (Hyden, 1958, p. 95-96). Other characteristics of the ash of California crude oils, outside the Cymric field, are relatively high content of cobalt, deficiency of manganese and vanadium, and zinc in quiuntities below the limits of spectographic determinations (Fyden, 1958, p. 95-96 and table 9).

The occurrence of mercury in the Cymric oil field is of unusual interest because of a possible genetic relation between mercury deposits and connate water or crude oil. Liquid and solid hydrocarbons are common in the ores of many California mercury mines (Averitt, 1945, p. 78; Bailey, 1946, p. 217; Yates and Hilpert, 1946, p. 248). In some mines, such as the Abbott mine in Lake County, methane gas is escaping in amounts large enough to require extra precautions against explosions.

TАBLD 398.1.-Quantitative spectrographic analyses of ash from petroleum of Cymric oil field, Calif.

[Analyst, Nancy Conklin; samples collected May 29, 1959.]

\begin{tabular}{|c|c|c|c|}
\hline & \multicolumn{3}{|c|}{ Well } \\
\hline & $22-255$ & $22-147^{2}$ & $22-256^{3}$ \\
\hline Producing zone........... & Phacoides & Oceanic & Point of \\
\hline Age $\ldots \ldots \ldots$ & Early & Oligo- & Late \\
\hline & Miocene. & cene. & Eocene. \\
\hline Ash, in percent. & 1.93 & 1. 70 & 1. 22 \\
\hline $\begin{array}{l}\text { Analysis of ash, in per- } \\
\text { cent: } 4\end{array}$ & & & \\
\hline $\mathrm{Cu}_{\ldots} \ldots \ldots$ & .001 & .001 & .001 \\
\hline $\mathrm{Ni}_{\ldots} \ldots \ldots . . . .$. & .012 & .012 & .009 \\
\hline $\mathrm{Fe}_{\ldots} \ldots \ldots$ & .01 & .01 & .01 \\
\hline V & .004 & .006 & .005 \\
\hline
\end{tabular}

i Well location, near center sec. 22, T. 29 S., R. 21 E.

2 Woll location, SE1/4SW1/4 sec. 22 , T. 29 S., R. 21 E.

3 Woll location, NW1/4SE $1 / 4$ soc. 22 , T. 29 S., R. $21 \mathrm{E}$

- Looked for but not found: $\mathrm{Mn}, \mathrm{Zn}, \mathrm{Mo}, \mathrm{Gr}, \mathrm{Pb}, \mathrm{U}, \mathrm{Cr}, \mathrm{Co}$. The results have an overall accuracy of \pm 15 percent of quantity reported except that they are less accurate near limits of detection, where only one digit is reported.
TABLE 398.2.-Metal contents of petroleum of Cymric oil field, Calif.

[Samples collected June 14, 1955]

\begin{tabular}{|c|c|c|c|}
\hline & \multicolumn{3}{|c|}{ Well } \\
\hline & $22-255$ & $22-147$ & $22-256$ \\
\hline Producing zone............ & Phacoides & Oceanic & $\begin{array}{l}\text { Point of } \\
\text { Rocks }\end{array}$ \\
\hline $\begin{array}{l}\text { Analysis, parts per mil- } \\
\text { lion: }\end{array}$ & & & \\
\hline $\mathrm{Cu}^{1} \ldots \ldots$ & 0.2 & 0.2 & 0.2 \\
\hline $\mathrm{Ni}^{1} \ldots \ldots \ldots$ & 2. 3 & 2. 0 & 1. 1 \\
\hline $\mathrm{Fe}^{1} \ldots \ldots$ & 2 & 2 & 2 \\
\hline$V^{1} \ldots \ldots \ldots$ & .8 & 1. 0 & .6 \\
\hline $\mathrm{Hg}^{2} \ldots \ldots \ldots$ & 2. 6 and 2.4 & $\mid-\ldots \ldots \ldots$ & 21 and 14 \\
\hline $\mathrm{Hg}^{3} \ldots \ldots$ & 1. 9 & $\mid \ldots \ldots \ldots$ & 2. 9 \\
\hline
\end{tabular}

1 Computed from quantitative spectrographic analyses of ash given in table 398.1.

2 Determined by J. D. Pera, Buckman Laboratories, Memphis, Tenn.

3 Determined by C. A. Horr, U.S. Geological Survey.

The quantity of hydrocarbons in the ores is highly variable and difficult to assess, but is considerably larger than is generally realized. In the Abbott mine, hydrocarbons are probably more abundant than cinnabar, and even in the New Almaden mine in Santa Clara County, hydrocarbons may have approached cinnabar in abundance. At the Two-forty-eight mine in the Terlingua district, Texas, oil and tar were locally so abundant that in furnacing the ore it was at times necessary to turn off the burners and exercise other precautions to prevent the self-fueled ore from damaging the furnace by overheating ( $R$. G. Yates, oral communication, 1961).

A close time relation between the deposition of mercury minerals and hydrocarbons in quicksilver deposits is generally indicated by the paragenetic sequence, and an equally close spatial relationship also generally exists. In mercury deposits of California Bailey (1959) found veins composed of many small oil-filled siliceousshelled spheres, and he interpreted the spheres as formed around oil droplets suspended in a hydrous fluid. Cinnabar occurs in the siliceous shells, indicating that either the hydrous fluid or the immiscible oil droplet was an ore-bearing fluid.

It is interesting that the Cymric field is on the southeast prolongation of the main mercury belt east of the San Andreas fault; and, further, that its distance of about 45 miles south of the Parkfield mercury district is but a little more than the average distance of about 35 miles that separates the other districts along this ore belt.

\section{CHEMICAL COMPOSITION OF THE BRINES}

The oil field brines are of particular interest because of their metal contents and because thermal waters 
TABLE 398.3.-Mercury content of petroleum and brine from Cymric oil field, Calif.

[Samples collected June 14, 1955; asterisk indicates not sufficient oil for analysis]

\begin{tabular}{|c|c|c|c|}
\hline & \multicolumn{3}{|c|}{ Well } \\
\hline & $22-255$ & 22-166 & $22-256$ \\
\hline Producing zone & Phacoides & Oceanic & $\begin{array}{r}\text { Point of } \\
\text { Rocks }\end{array}$ \\
\hline $\begin{array}{l}\mathrm{Hg} \text { content, oil layer, }{ }^{1} \\
\text { parts per million }\end{array}$ & 2. 6 & $(*)$ & 21 \\
\hline Do., duplicate 1 & 2. 4 & $(*)$ & 14 \\
\hline Do., duplicate ${ }^{2} \ldots \ldots$ & 1. 9 & $(*)$ & 2. 9 \\
\hline $\begin{array}{l}\mathrm{Hg} \text { content, water layer, }{ }^{1} \\
\text { parts per million }\end{array}$ & .098 & ${ }^{3} 0.12$ & 22 \\
\hline Do., duplicate 1 . . ... & 3.18 & .087 & 048 \\
\hline $\begin{array}{l}\text { Sediment content in } \\
\text { water, }^{1} \text { parts per mil- }\end{array}$ & & & \\
\hline $\begin{array}{l}\text { lion } \\
\text { Do., duplicate } 1\end{array}$ & 64 & 78 & 270 \\
\hline $\begin{array}{l}\text { Do., duplicate }{ }^{1}-\ldots- \\
\mathrm{Hg} \text { content of sediment, }\end{array}$ & _. . . . & 128 & 180 \\
\hline percent ${ }^{1}$ & .047 & .36 & 14 \\
\hline Do., duplicate ${ }^{1} \ldots \ldots$ & -1- & .31 & 13 \\
\hline $\begin{array}{l}\text { Additional } \mathrm{Hg} \text { in water if } \\
\text { sediment originally dis- } \\
\text { solved, }{ }^{1} \text { parts per mil- }\end{array}$ & & & \\
\hline lion & .03 & .28 & 38 \\
\hline Do., duplicate ${ }^{1} \ldots$ & & .40 & 23 \\
\hline $\begin{array}{l}\text { Average } \mathrm{Hg} \text { in water } \\
\text { when analyzed, parts } \\
\text { per million }\end{array}$ & .14 & .10 & .14 \\
\hline $\begin{array}{l}\text { Average original } \mathrm{Hg} \text { in } \\
\text { water if sediment dis- } \\
\text { solved, parts per mil- }\end{array}$ & & & \\
\hline lion & .17 & .44 & 45 \\
\hline
\end{tabular}

1 Analyst, J. D. Pera, Buckman Laboratories, Inc., Memphis, Tenn.

2 Analyst, C. A. Horr, U.S. Geological Survey.

3 Fred Ward, of the Geological Survey, searched for $\mathrm{Hg}$ in remaining parts of these same samples in February 1961, and reported less than $0.02 \mathrm{ppm}$ of $\mathrm{Hg}$ and As in each, $0.03 \mathrm{ppm}$ of $\mathrm{Sb}$ in $22-255$, and $0.01 \mathrm{ppm}$ of $\mathrm{Sb}$ in $22-166$.

chemically similar to oil field brines are associated elsewhere with quicksilver deposits (White, 1960, p. 453; and unpublished data). The analyses in tables 398.3398.5 are more detailed than others that have been published.

Of additional interest are progressive changes in composition with increasing depth and age of the probable source rocks. Although dependable generalizations cannot be drawn from three analyses, this series suggests that the following components or ratios increase downward: $\mathrm{Ca}$, I, evaporated residue, $\mathrm{Ca} / \mathrm{Na}$, and possibly $\mathrm{Ba}, \mathrm{Li}, \mathrm{NH}_{4}, \mathrm{Cl}$, and $\mathrm{Br}$. The components or ratios that decrease downward are: $\mathrm{SiO}_{2}, \mathrm{Al}, \mathrm{Mg}, \mathrm{K}$, $\mathrm{HCO}_{3}, \mathrm{~F}$, and the ratios of $\mathrm{Mg} / \mathrm{Ca}, \mathrm{HCO}_{3} / \mathrm{Cl}, \mathrm{F} / \mathrm{Cl}$, and possibly $\mathrm{Br} / \mathrm{Cl}$ and $\mathrm{B} / \mathrm{Cl}$. These changes are consistent with trends pointed out by White $(1957,1960):$ With increasing age, oil field brines are inclined to be higher in salinity and to change from $\mathrm{NaCl}$ to $\mathrm{Na}-\mathrm{Ca}-\mathrm{Cl}$ type. In line with these trends, most brines of deep Tertiary oil fields are high in $\mathrm{Na}$ and $\mathrm{Cl}$, but $\mathrm{Ca}$ is generally less than 10 percent of the $\mathrm{Na}$; deep brines of most preTertiary oil fields throughout the world, however, are of the Na-Ca-Cl type, with calcium exceeding 10 percent of the sodium, and with total salinities commonly far higher than that of sea water. We are not aware that changes in these chemical types with depth have been so clearly demonstrated in the same field. The chemical differences in the Cymric analyses almost certainly do not reflect comparable differences in composition of sea water during different parts of the Tertiary but are believed to result from diagenetic changes and reactions between sediments, organic matter, and interstitial water. Additional modifying effects probably also result from the fine-grained sediments behaving as semipermeable membranes (DeSitter, 1947 , p. 2039 ; White, 1957 , p. 1667) that permit selective diffusion of water and certain other components, and selective retention of calcium and chloride.

Concentrations of minor metals in the waters are not clearly related to metal concentrations of associated crude oils (tables 398.1 and 398.5). Reported contents of some components determined by wet methods (table 398.4) and by spectrographic methods (table 398.5) are

TABLE 398.4.-Chemical analyses of waters from Cymric oil field, Calif.

[Analyst, C. E. Roberson; sample collected June 14, 1985]

\begin{tabular}{|c|c|c|c|}
\hline & \multicolumn{3}{|c|}{ Well } \\
\hline & $22-255$ & $22-166$ & $22-256$ \\
\hline Depth of production, feet.- & $3,000 \pm$ & 4,950 & 5,320 \\
\hline Producing zone & Phacoides & Oceanic & Point of Rocks \\
\hline Temperature, degrees centigrade.- & & & 81.4 \\
\hline pH & 7.1 & 7.5 & 7.2 \\
\hline $\begin{array}{l}\text { Chemical analysis, parts per } \\
\text { million: }\end{array}$ & & & \\
\hline $\mathrm{SiO}_{2}$ & 52 & 47 & 14 \\
\hline Al & .9 & .4 & .2 \\
\hline $\mathrm{Fe}{ }^{1}$ & 6.4 & 1.2 & 61 \\
\hline Mn & .3 & .08 & 2.0 \\
\hline As....... & .00 & .0 & .00 \\
\hline $\mathrm{Cu}_{-. . .}$ & .00 & & .00 \\
\hline $\mathrm{Pb} \ldots$ & .00 & . & .02 \\
\hline $\mathrm{Zn}$ & .06 & & .40 \\
\hline $\mathrm{Ca}$ & 325 & 373 & 3,040 \\
\hline Mg... & 123 & 115 & 49 \\
\hline $\mathrm{Ba} \ldots . .$. & 7.2 & 7.1 & 8.7 \\
\hline $\mathrm{Na} . .$. & 6,150 & 5,820 & 6,710 \\
\hline $\mathrm{k} . .$. & 136 & 132 & 113 \\
\hline Li... & 4.9 & 4.3 & 9.9 \\
\hline $\mathrm{NH}_{4}$ & 45 & 51 & 51 \\
\hline $\mathrm{Hg}^{2}$ & .14 & .10 & .14 \\
\hline $\mathrm{HCO}_{3}$ & 666 & 535 & 287 \\
\hline $\mathrm{CO}_{3} \ldots$ & 0 & 0 & 0 \\
\hline $\mathrm{SO}_{4}$ & 4.1 & 1.6 & 31 \\
\hline $\mathrm{S}_{2} \mathrm{O}_{3}$ & 2.4 & Not det'd. & 3.3 \\
\hline C1 & 9,940 & 9,840 & 15,360 \\
\hline F & 3.6 & 3.4 & 2.0 \\
\hline $\mathrm{Br}$ & 35 & 30 & 46 \\
\hline I & 20 & 23 & 29 \\
\hline $\mathrm{NO}_{2}$ & .15 & .00 & .08 \\
\hline $\mathrm{NO}_{3}$. & 0 & 3 & 0 \\
\hline
\end{tabular}


TABle 398.4.-Continued

\begin{tabular}{|c|c|c|c|}
\hline & \multicolumn{3}{|c|}{ Well } \\
\hline & $22-255$ & $22-166$ & $22-256$ \\
\hline \multicolumn{4}{|l|}{$\begin{array}{l}\text { Chemical analysis, parts per } \\
\text { million-Continued }\end{array}$} \\
\hline PO4............. & 0.2 & - & 0.2 \\
\hline B.................... & 142 & 140 & 146 \\
\hline $\mathrm{H}_{2} \mathrm{~S}$ & 0 & 0 & 0 \\
\hline \multicolumn{4}{|l|}{ Total, as reported ............. } \\
\hline $\begin{array}{l}\text { Evaporated residue, at } 180^{\circ} \mathrm{C} \text {, } \\
\text { parts per million. }\end{array}$ & 17,800 & 18,600 & 28,500 \\
\hline Speclfle conductance, microhms, & 25,200 & 25,800 & 31,800 \\
\hline Specifle gravity at $20^{\circ} \mathrm{C} \ldots$ & 1.009 & 1. 009 & 1.016 \\
\hline \multicolumn{4}{|l|}{ Ratlos by wolght: } \\
\hline $\mathrm{Ca} / \mathrm{Na}$ & .053 & .064 & .45 \\
\hline $\mathrm{Mg} / \mathrm{Ca}$ & .38 & .31 & .016 \\
\hline $\mathrm{K} / \mathrm{Na}$ & .022 & .023 & .017 \\
\hline L/Na................... & .00080 & .00074 & .0015 \\
\hline NHI/Na. & .0073 & .0088 & .0076 \\
\hline $\mathrm{HCO}_{3} / \mathrm{Cl}_{2}$ & .067 & .054 & .019 \\
\hline $\mathrm{SO} / \mathrm{Cl}$ & .00041 & .00016 & .0020 \\
\hline $\mathrm{F} / \mathrm{Cl}$ & .00036 & .00034 & .00013 \\
\hline $\mathrm{Br} / \mathrm{Cl}$ & .0035 & .0030 & .0030 \\
\hline $\mathrm{J} / \mathrm{Cl}$ & .0026 & .0023 & .0019 \\
\hline $\mathrm{B} / \mathrm{Cl}$ & .014 & .014 & .0095 \\
\hline
\end{tabular}

1 In solution when analyzed.

2 Seo trable 398.3.

TABLE 398.5.-Spectrographic analyses of evaporated residues of waters from Cymric oil field, Calif.

[Analyst, N. B. Sheffey; samples collected June 14, 1955]

\begin{tabular}{|c|c|c|c|}
\hline & \multicolumn{3}{|c|}{ Well } \\
\hline & $22-255$ & $22-166$ & $22-256$ \\
\hline Producing zone.......... & Phacoides & Oceanic & $\begin{array}{r}\text { Point of } \\
\text { Rocks }\end{array}$ \\
\hline $\begin{array}{l}\text { Analysis, parts per } \\
\text { million: } 1\end{array}$ & 7. 1 & 7. 5 & 7. 2 \\
\hline $\mathrm{Cu} \ldots \ldots \ldots$ & 4. 8 & .04 & .1 \\
\hline Ag $\ldots \ldots \ldots$ & .02 & $<.02$ & .03 \\
\hline $\mathrm{Pb}_{\ldots} \ldots \ldots \ldots$ & 2. 3 & $<.2$ & <. 3 \\
\hline$M n \ldots \ldots \ldots$ & .25 & .2 & 1. 4 \\
\hline $\mathrm{Fe}_{2} \ldots \ldots$ & 29 & .15 & .14 \\
\hline $\mathrm{Cr}_{\ldots} \ldots \ldots$ & .4 & $<.04$ & $<.06$ \\
\hline $\mathrm{Al} \ldots \ldots$ & 43 & .2 & .3 \\
\hline - $\mathrm{Ti}$ & 2. 0 & $<.04$ & $<.06$ \\
\hline$Z r_{\ldots} \ldots \ldots$ & .5 & $<.2$ & $<.3$ \\
\hline$S r_{\ldots} \ldots \ldots$ & 21 & 82 & 66 \\
\hline$B \mathrm{~B}_{\ldots} \ldots \ldots \ldots$ & 2. 9 & 7 & 5. 4 \\
\hline $\mathrm{Li} \ldots \ldots$ & $-\ldots-n-\ldots$ & 2. 6 & $\ldots \ldots-\ldots$ \\
\hline $\mathrm{Rb}_{-} \ldots \ldots$ & 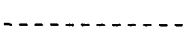 & & $\ldots \ldots$ \\
\hline
\end{tabular}

1 Looked for but not found: Mo, $<0.2 \mathrm{ppm} ; \mathrm{W},<4 ; \mathrm{Ge},<0.2 ; \mathrm{Co},<0.2 ; \mathrm{Ni},<0.2$; $\mathrm{V},<0.2 ; \mathrm{Gn},<0.06 ; \mathrm{Cs},<0.6 ; \mathrm{Be},<0.02 ; \mathrm{As},<10 ; \mathrm{Cd},<1 ; \mathrm{Sb},<2 ; \mathrm{Sn},<0.2 ; \mathrm{Y}$ $<0.2 ; \mathrm{Yb},<0.02 ; \mathrm{Zn},<4$ not in close agreement; all of the data are included without knowledge of actual quantities present when the samples were analyzed. In addition, the differences in reported mercury contents of the waters indicate that mercury is not yet certain to be in the waters; however, the reported presence of mercury in the crude oils has been confirmed definitely. Unusually high metal concentrations reported in the brine from well 22-255 are of additional interest. This brine was nearly neutral in $\mathrm{pH}$ but apparently contained very high contents of $\mathrm{Fe}, \mathrm{Cu}, \mathrm{Pb}$, and some other elements. Further careful search for minor elements in crude oils and brines is clearly needed.

\section{REFERENCES}

Averitt, Paul, 1945, Quicksilver deposits of the Knoxville district, Napa, Yolo, and Lake Counties, California : Califormia Div. Mines, 41st Rept. of State Mineralogist, chap, 2, p. 65-89.

Bailey, E. H., 1946, Quicksilver deposits of the western Mayacmas district, Sonoma County, California : California Div. Mines, 42d Rept. of State Mineralogist, chap. 3, p. 199-230. 1959, Froth veins, formed by immiscible hydrothermal fluids, in mercury deposits, California: Geol. Soc. America Bull., v. 70, p. 661-664.

DeSitter, L. U., 1947, Diagenesis of oil-field brines: Am. Assoc. Petroleum Geologists Bull., v. 31, p. 2030-2040.

Erickson, R. L., Myers, A. T., and Horr, C. A., 1954, Association of uranium and other metals with crude oil, asphalt, and petroliferous rock: Am. Assoc. Petroleum Geologists Bull., v. 28 , p. $2200-2218$.

Hyden, H. J., 1958, Uranium and other metals in crude oils: U.S. Geol. Survey open-file report, $124 \mathrm{p}$.

McMasters, J. H., 1948, Cymric oil field, Kern County, California, in Structure of typical American oil fields-a symposium: Am. Assoc. Petroleum Geologists Spec. Pub., v. 3, p. 38-57.

Pierce, G. G., 1947, Cymric oil field, Kern County, California : California Div. Oil and Gas, v. 33, no. 2, p. 7-15.

Stockman, L. P., 1947, Mercury in three wells at Cymric: Petroleum World, Feb., p. 37.

White, D. E., 1955, Thermal springs and epithermal ore deposits : Econ. Geology, 50th Anniv. vol., p. 99-154.

- 1957, Magmatic, connate, and metamorphic waters: Geol. Soc. America Bull., v. 68, p. 1659-1682.

- 1958, Liquid of inclusions in sulfides from Tri-State is probably connate in origin [abs.] : Geol. Soc. America Bull., v. 69 , p. $1660-1661$.

- 1960, Summary of chemical characteristics of some waters of deep origin, in Short papers in the geological sciences: U.S. Geol. Survey Prof. Paper 400-B, p. B452-B454.

Yates, R. G., and Hilpert, L. S., 1946, Quicksilver deposits of eastern Mayacmas district, Lake and Napa Counties, California : California Div. Mines, 42d Rept. of State Mineralogist, chap. 3, p. 231-286. 


\title{
399. SPHENE IN GRANITIC GNEISSES OF SOUTHEASTERN CONNECTICUT
}

\author{
By Richard Goldsmith, George L. Snyder, and Nancy M. Conklin, Denver, Colo.
}

Work done in cooperation with the Connecticut Geological and Natural History Survey

During mineral separations of rocks from southeastern Connecticut, it was noted that the accessory sphene from some of the rocks showed unusually high magnetic susceptibility as compared to sphene from other rocks in the area (tables 399.1, 399.2).

The formula for sphene according to Sahama (1946) is $\mathrm{CaTiSiO}^{2}(\mathrm{O}, \mathrm{OH}, \mathrm{F})$. Calcium may be replaced by $\mathrm{Na}$, rare earths, $\mathrm{Mn}, \mathrm{Sr}$, or Ba. Titanium may be replaced by $\mathrm{Al}, \mathrm{Fe}^{+3}, \mathrm{Fe}^{+2}, \mathrm{Mg}, \mathrm{Nb}, \mathrm{Ta}, \mathrm{V}$, or $\mathrm{Cr}$; and

TABLE 399.1.-Analyses, in percent, of sphene in gneisses from southeastern Connecticut

[Analyst, N. M. Conklin]

\begin{tabular}{|c|c|c|c|c|c|c|c|c|}
\hline & \multicolumn{8}{|c|}{ Sample 1} \\
\hline & 1 & 2 & 3 & 4 & 5 & 6 & 7 & 8 \\
\hline \multicolumn{5}{|c|}{ Semiquantitative spectrographic analysis ${ }^{2}$} & \multicolumn{4}{|c|}{$\begin{array}{l}\text { Analysis computed from } \\
\text { chemical analysis }\end{array}$} \\
\hline -......... & 7.0 & $>10.0$ & $>10.0$ & $>10.0$ & 14.0 & 14.2 & 14.2 & 14.6 \\
\hline ............... & .7 & 3.0 & 1.5 & 1.5 & 3.8 & .0 & 2.3 & .5 \\
\hline (n) & 3.0 & 1.5 & .7 & .3 & 4.4 & .1 & $<.1$ & 1.7 \\
\hline . & $>10.0$ & $>10.0$ & $>10.0$ & $>10.0$ & 16.0 & 20.5 & 20.2 & 18.4 \\
\hline - n-n. & $>10.0$ & $>10.0$ & $>10.0$ & $>10.0$ & 18.4 & 24.6 & 20.1 & 21.2 \\
\hline Mg..................... & .07 & .03 & .03 & .015 & $\ldots$ & $\ldots$ & $\ldots$ & $\ldots$ \\
\hline Mn & .7 & .3 & .15 & .15 & & $\ldots$ & $\ldots$ & $\ldots$ \\
\hline $\mathrm{Ba}$ & .007 & .003 & .003 & .003 & & $-\ldots$ & $\ldots$ & $\ldots$ \\
\hline $\mathrm{Be}_{\text {.. }}$ & trace & trace & .0 & .0 & - & $-\ldots$ & $\ldots$ & $-\ldots$ \\
\hline $\mathrm{Ce}$. & 1.5 & .3 & .0 & 0 & - & $\ldots$ & $\ldots$ & $\ldots$ \\
\hline Cr.. & .0 & .0015 & .007 & .007 & & $-\ldots$ & $\ldots$ & $\ldots$ \\
\hline $\mathrm{Cu}$. & .003 & .0003 & .003 & .0007 & & & & $\ldots$ \\
\hline מ... & .3 & .3 & .07 & .0 & & & & ..... \\
\hline Er.. & .15 & .07 & .03 & .0 & & & & $\ldots$ \\
\hline Eu. & .07 & .03 & .0 & .0 & & & & $\ldots$ \\
\hline 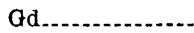 & .3 & .15 & .015 & trace & & & & \\
\hline Ho & .07 & .03 & .015 & .0 & & & & $\ldots$ \\
\hline La. & .7 & .07 & .0 & 0 & & & & $\ldots$ \\
\hline Lu................. & .015 & .007 & .007 & .0 &.- & & & $\ldots$ \\
\hline $\mathrm{Nb}$ & .3 & .15 & .15 & .015 & - & & & $\ldots$ \\
\hline Nd. & 1.5 & .7 & 0 & .0 & ............ & & $-\ldots$ & $\ldots$ \\
\hline $\mathrm{Pb}$ & .007 & .003 & 0 & 0 & - & & $-\infty$ & $-\infty$ \\
\hline 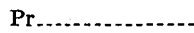 & 3 & .0 & .0 & 0 & - & $\ldots$ & -..... & $\ldots$ \\
\hline Sc..... & .0 & .0 & .007 & 0 & - & $\ldots$ & ....- & $\ldots$ \\
\hline Sn $\ldots \ldots \ldots$ & .3 & .03 & .07 & .005 & $\ldots .$. & & $\ldots$ & $\ldots$ \\
\hline $\mathrm{Sr}$ & .03 & .007 & .003 & .007 & - & & $\ldots$ & - \\
\hline Sm & .7 & .15 & .0 & .0 & - & $\ldots$ & (n..... & - \\
\hline $\mathrm{Tb}$ & .03 & .015 & .0 & .0 & $\ldots$ & $\ldots$ & $\ldots$ & ..... \\
\hline $\operatorname{Tm}$ & .03 & .015 & .007 & .0 & & & $\ldots$ & -.... \\
\hline v... & ....... & .015 & .07 & .03 & & & $\ldots$ & ..... \\
\hline $\mathbf{Y}$ & 1.5 & .7 & .7 & .03 & & ...... & $\ldots$ & $\ldots$ \\
\hline Yb. & .15 & .07 & .07 & .003 & & & 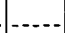 & -..... \\
\hline $\mathrm{Zr}$ & 1.5 & .7 & .07 & .0 & & & -..- & -.... \\
\hline Cerium group. & 4.8 & 1.3 & .0 & .0 & & tmo & & \\
\hline Yttrium group... & 2.5 & 1.4 & .9 & .03 & 3.1 & trace & .2 & 3.7 \\
\hline
\end{tabular}

See footnotes at end of table.
TABLE 399.1.-Continued

\begin{tabular}{|c|c|c|c|c|c|c|c|c|}
\hline & \multicolumn{8}{|c|}{ Sample 1} \\
\hline & 1 & 2 & 3 & 4 & 5 & 6 & 7 & 8 \\
\hline \multicolumn{9}{|c|}{ Optical properties } \\
\hline $\begin{array}{l}\mathrm{n}_{\mathrm{x}} \\
2 \mathrm{~V}_{2}\end{array}$ & $\begin{array}{r}1.900 \\
31^{\circ}\end{array}$ & $\begin{array}{r}1.885 \\
28^{\circ}\end{array}$ & $\begin{array}{r}1.880 \\
26^{\circ}\end{array}$ & $\begin{array}{r}1.895 \\
25^{\circ}\end{array}$ & $\begin{array}{r}1.843 \\
35^{\circ} \text { to } 40^{\circ}\end{array}$ & $\begin{array}{r}1.901 \\
23^{\circ}\end{array}$ & $\begin{array}{r}1.84 \\
38^{\circ}\end{array}$ & $\begin{array}{r}1.90 \\
33^{\circ}\end{array}$ \\
\hline
\end{tabular}

: Sample localities: 1, From aegirine-augite granitic gneiss, Flat Rock quarry, 1/4 mile west of Cohanzie school, W side Connecticut Route 82, Waterford, Conn., Montville quadrangle; Frantz isodynamic separator setting, $0.65 \mathrm{amps} ; 20^{\circ}$ forward, $15^{\circ}$ sideward tilt. 2, From hornblende-bearing granitic gneiss, road cut, Connecticut Route 163, 1/2 mile north of Connecticut Route 82, Fitch ville quadrangle; Frantz isodynamic separator setting, 0.85 amps; $20^{\circ}$ forward, $15^{\circ}$ sideward tilt. 3 , From biotite-muscovite quartz-monzonitic gneiss, Canterbury gneiss, southwest side of Hearthstone Hill, northwest corner of Norwich quadrangle; Frantz isodynamic separator setting, 1.35 amps; $20^{\circ}$ forward, $15^{\circ}$ sideward tilt. 4, From plagioclase gneiss, near junction of Cook's Hill road with Connecticut Route 87, east-central part of Columbia quadrangle; Frantz isodynamic separator setting, $1.5 \mathrm{amps} ; 20^{\circ}$ forward, $15^{\circ}$ sideward tilt. 5, Keilhauite from Rhode Island (Young, 1938, p. 151). 6 and 7, Sphene and "grothite" from Finland (Sahama, 1946, p. 96, 98). 8, Keilhauite from Abyssinia (Morgante, 1943).

2 Generally reported to nearest number in the series $7,3,1.5, .7, .3$, and so forth.

TABLE 399.2.-Percentage of sphene and rare-earth-bearing accessory minerals by modal analyses, and rare-earth content of total rock by semiquantitative spectrographic analyses, of gneisses of southeastern Connecticut

[Analysts, N. M. Conklin and Paul R. Barnett]

\begin{tabular}{|c|c|c|c|c|c|}
\hline & \multicolumn{5}{|c|}{ Sample 1} \\
\hline & 1 & 2 & 3 & 4 & 5 \\
\hline Accessory minerals: & & & & & \\
\hline Sphene............ & 0.1 & 0.2 & 0.2 & trace & 0 \\
\hline Allanite & trace & $<. i$ & 0 & trace & 0 \\
\hline Monazite........................... & $0 ?$ & 0 & 0 & & $<.1$ \\
\hline Aegirine-augite ${ }^{2}-\ldots \ldots$ & 4.3 & 0 & 0 & 0 & 0 \\
\hline Rare earth content: & & & & & \\
\hline Cerium group... & .04 & .03 & .00 & .00 & .03 \\
\hline Yttrium group........................ & .016 & .004 & .002 & .002 & .002 \\
\hline
\end{tabular}

1 Samples 1,2 and 3 , same as in table 1 , analyses by point count; 4, plagioclase gneiss, $2 / 3$ mile west-southwest of locality of sample 4 , table $1 ; 5$, biotite quartz-monzonitic gneiss, Chapel Hill road, 132 mile north of Four Corners, Montville quadrangle.

2 Contains 0.04 percent rare-earth elements by semiquantitative spectrographic analysis (N. M. Conklin, analyst).

oxygen may be replaced by $\mathrm{OH}, \mathrm{F}$, or possibly $\mathrm{Cl}$. The variety keilhauite contains appreciable amounts of rare earths (Sahama, 1946, p. 108).

The anomalously magnetic sphene, samples 1 and 2 (table 399.1) are richer in iron and minor elements than the other sphene from Connecticut, samples 3 and 4, and 
are relatively rich in rare earths. Sample 1 is particularly rich in rare earths of the cerium group. The first two samples of sphene are keilhauite. Samples 3 and 4 may be considered normal sphene. The relative rare-earth content of the sphene from Connecticut is directly proportional to the relative rare-earth content of the rocks from which they came (table 399.2). The plagioclase gneiss, sample 4 (table 399.2) is not the rock from which the sphene was taken, but is representative of the unit containing the sphene. Rare earths probably have little effect on optical properties of sphene.

The low aluminum content of the sphene (sample 1) from the aegirine-augite granitic gneiss as compared with the aluminum content of other sphene from Connecticut possibly reflects the low aluminum content of the enclosing rock. The aegirine-augite granitic gneiss is a subaluminous granitic rock in which the alumina content is insufficient to accommodate all the available alkali. Excess alkali is contained in the pyroxene. The rock has abundant quartz.

Both the aegirine-augite granitic gneiss and the hornblende-bearing granitic gneiss are phacolithic or sill-like bodies in a complex of homblende- and biotiteplagioclase gneisses and amphibolite, the complex from which the sphene (sample 4) from the plagioclase gneiss was taken. Rocks of this complex contain as much as 2 percent sphene. Other granitic gneisses in southeastern Connecticut, related in composition and field relationships to the granitic rocks mentioned above but lying in quartzite and schist rather than mafic rocks, contain little or no sphene. Many of these granitic rocks contain appreciable cerium (sample 5, table
399.2 ). In these rocks, the rare earths are probably contained in allanite, monazite, and possibly biotite. Sphene is present only in fairly biotitic quartzmonzonitic gneiss. Sphene from such rocks has not yet been analyzed. Semiquantitative spectrographic analyses of specimens of Canterbury gneiss, the source of sphene sample 3, rarely show the cerium-group rare earths, in contrast to their common presence in analyses of the group of granitic gneisses to which the aegirineaugite granitic gneiss, the hornblende-bearing granitic gneiss, and the quartz-monzonitic gneiss belong.

Young (1938) identified keilhauite in Rhode Island in rocks now called the Scituate granite gneiss (Moore, 1958) and suggested (Young, p. 152) that keilhauite might be a guide mineral to these rocks. The consanguinity of the Scituate granite gneiss with granitic gneisses in adjacent southeastern Connecticut containing keilhauite has not yet been proved, but the samples from a group of granitic gneisses in southeastern Connecticut and Rhode Island contain a greater amount of rare earths, particularly of the cerium group, than the Canterbury gneiss.

\section{REFERENCES}

Moore, G. E., 1958, Bedrock geology of the Hope Valley quadrangle, Rhode Island: U.S. Geol. Survey Geol. Quad Map GQ-105.

Morgante, S., 1943, La titanite a terre rare del granito pegmatitico di Quoscescer: Periodico di Mineralogia (Rome), v. 14, p. 13-33. [Abstract in Minerolog. Abs., v. 9, p. 216, 1946.]

Sahama, T. G., 1946, On the chemistry of the mineral titanite: Comm. geol. Finlande Bull., no. 138, p. 88-120.

Young, J. A., Jr., 1938, Keilhauite, a guide mineral to the Sterling granite gneiss of Rhode Island : Am. Mineralogist, v. 23, p. $149-152$.

400. MINERALOGY OF MICACEOUS LAMINAE IN SANDSTONES OF PALEOZOIC AGE IN FLORIDA

By Dorothy Carroll. Washington, D.C.

Work done in cooperation with the U.S. Atomic Energy Commission

Many sandstones of Paleozoic age in Florida consist of thin-bedded silty rocks containing fine, micaceous laminae. Jean M. Berdan, U.S. Geological Survey, supplied a sample of the core from 3,668 to 3,671 feet in the Hazel Langston well 1, Dixie County, Fla., in which mica is unusually abundant. In this rock, laminae of mica about one-half millimeter thick are separated by about 5 millimeters of silty sandstone: Mica from two of these laminae was examined by means of X-ray diffraction and with the petrographic microscope.

Samples of mica were obtained by scraping it off the laminae with a razor blade. The mica is rather soft and inelastic, and although compacted into large aggregates by pressure of overlying rocks, it is easily disaggregated into individual flakes. The micaceous laminae contained no quartz, so no concentration of the 
samples was required. $\mathrm{X}$-ray diffraction patterns were made using nickel filtered $\mathrm{CuK} \alpha$ radiation, $\lambda 1.54050 \mathrm{~A}$, of oriented and unoriented samples of mica treated in various ways. The $\mathrm{X}$-ray diffraction data are given in table 400.1, and tracings of the diffraction patterns are given in figures 400.1-400.4.

The X-ray spacings of an oriented sample of mica (fig. 400.1) suggest that the sample contains inter-

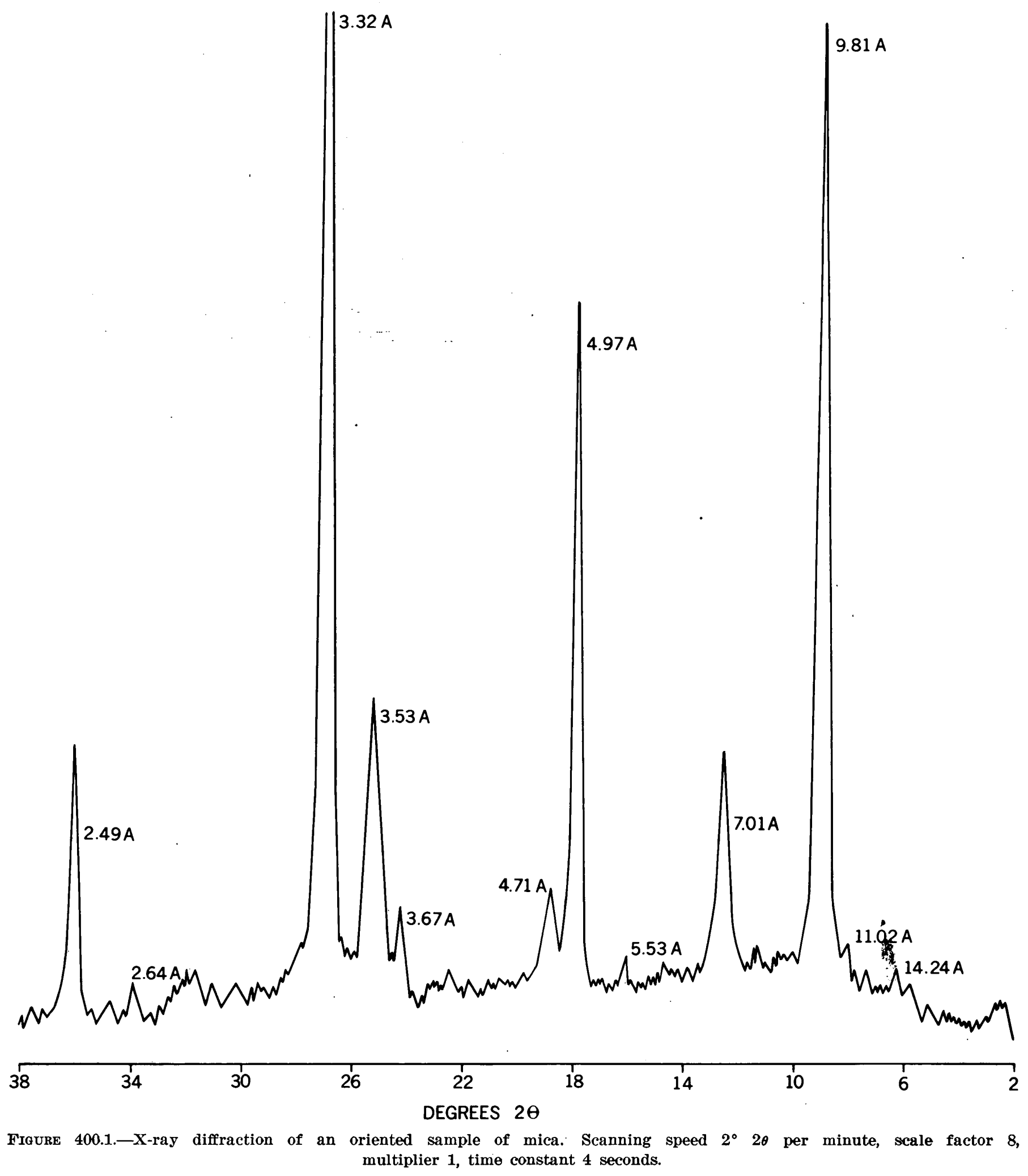




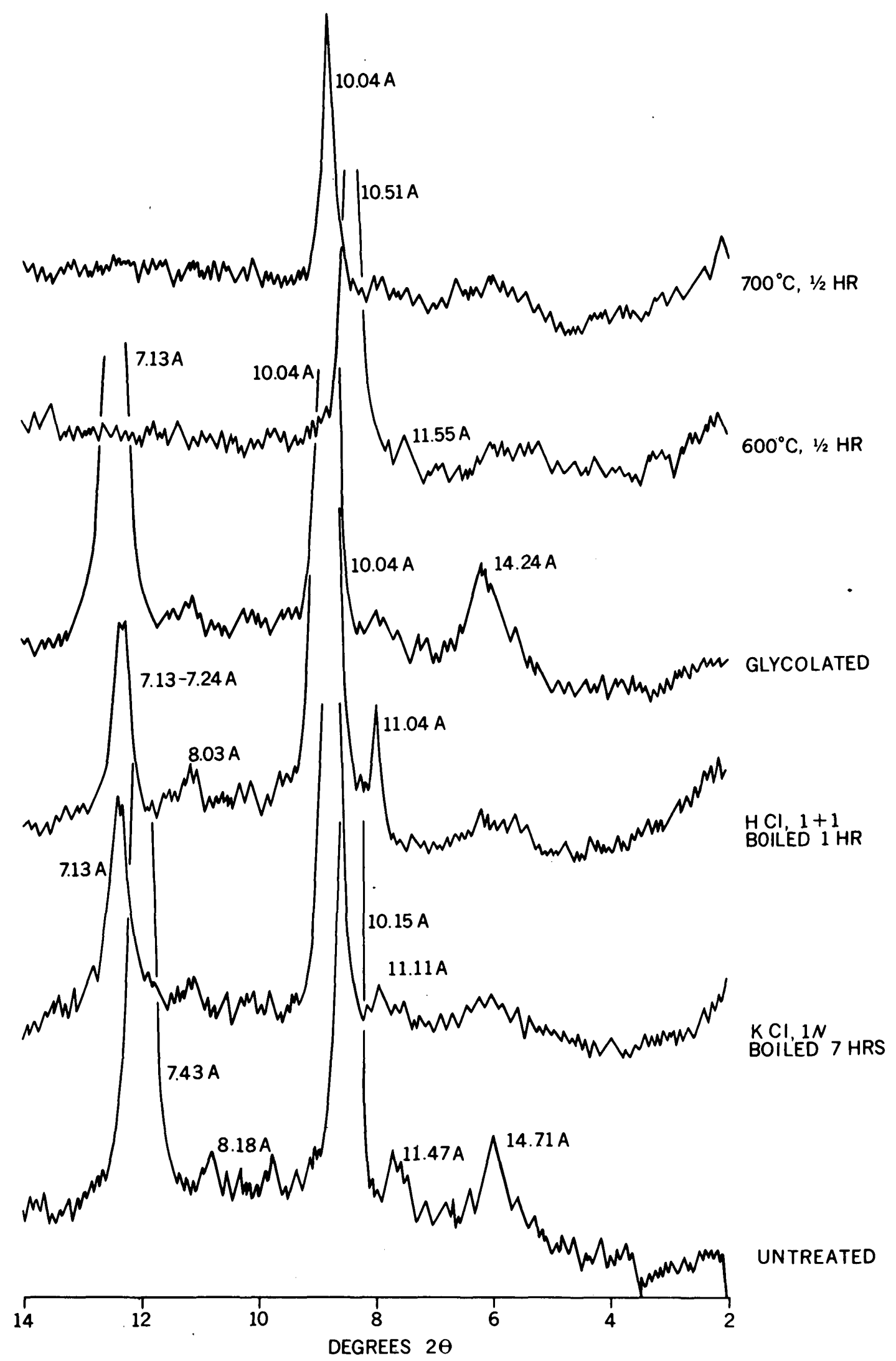

Frcure 400.2.-X-ray diffraction patterns of oriented samples of mica after the treatments indicated (nickel filtered CuKa radiation, scanning speed $1^{\circ} 2 \theta$ per minute, scale factor 8 , multiplier 1 , time constant 4 seconds). 

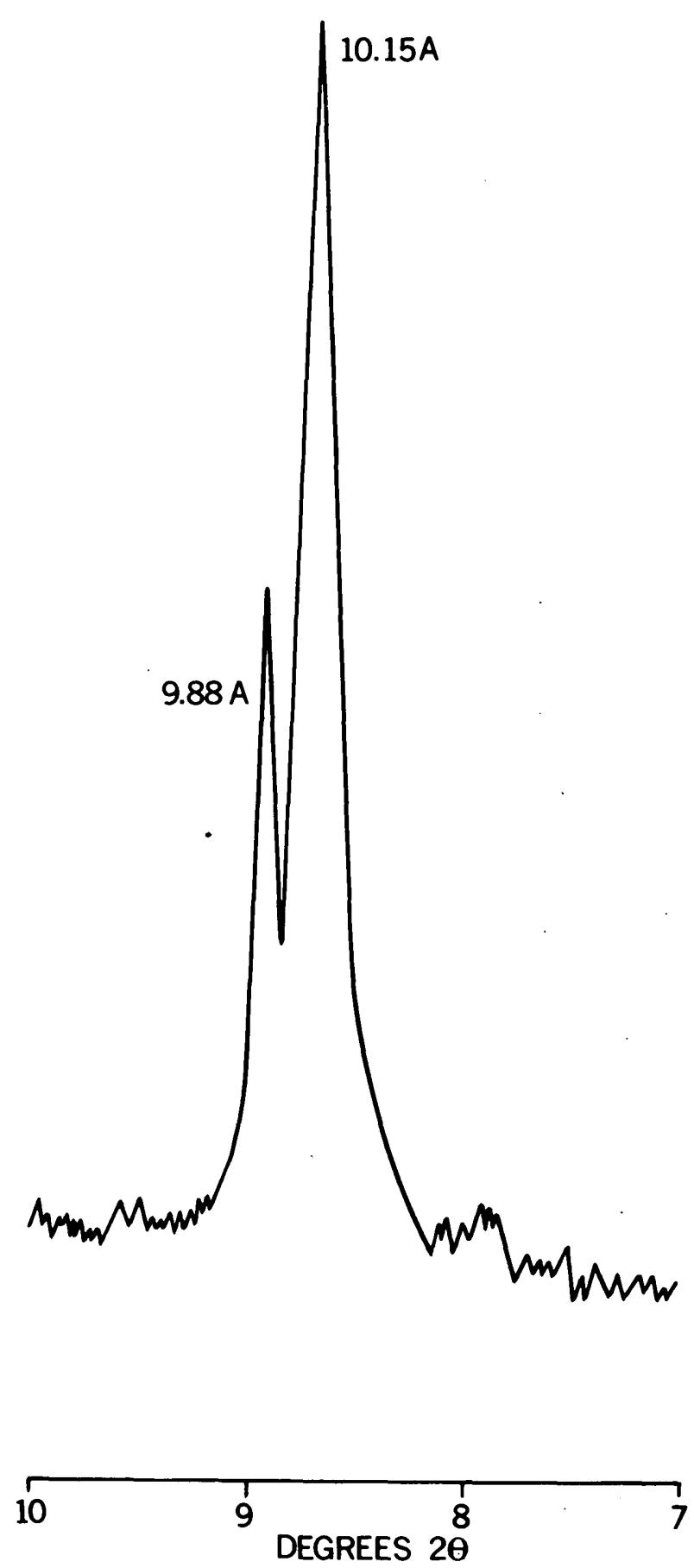

FIGURE 400.3.-X-ray diffraction pattern of mica sample heated to $300^{\circ} \mathrm{C}$ showing the resolution of the $10 \mathrm{~A}$ spacing into two distinct peaks (nickel filtered $\mathrm{CuK} a$ radiation, scanning speed $1 / 2^{\circ} 2 \theta$ per minute, scale factor 8 , multiplier 1 , time constant 4 seconds).

layered mica and hydrous mica (spacings of $10.70 \mathrm{~A}$ and $11.47 \mathrm{~A}$ ) with interlayered vermiculite $(14.7 \mathrm{~A})$ and chlorite $(7.4 \mathrm{~A})$. Table 400.1 column 2 , gives the spacings obtained from an unoriented sample prepared by spreading a thin layer of mica on the rippled surface of masking tape on an aluminum holder. There is an

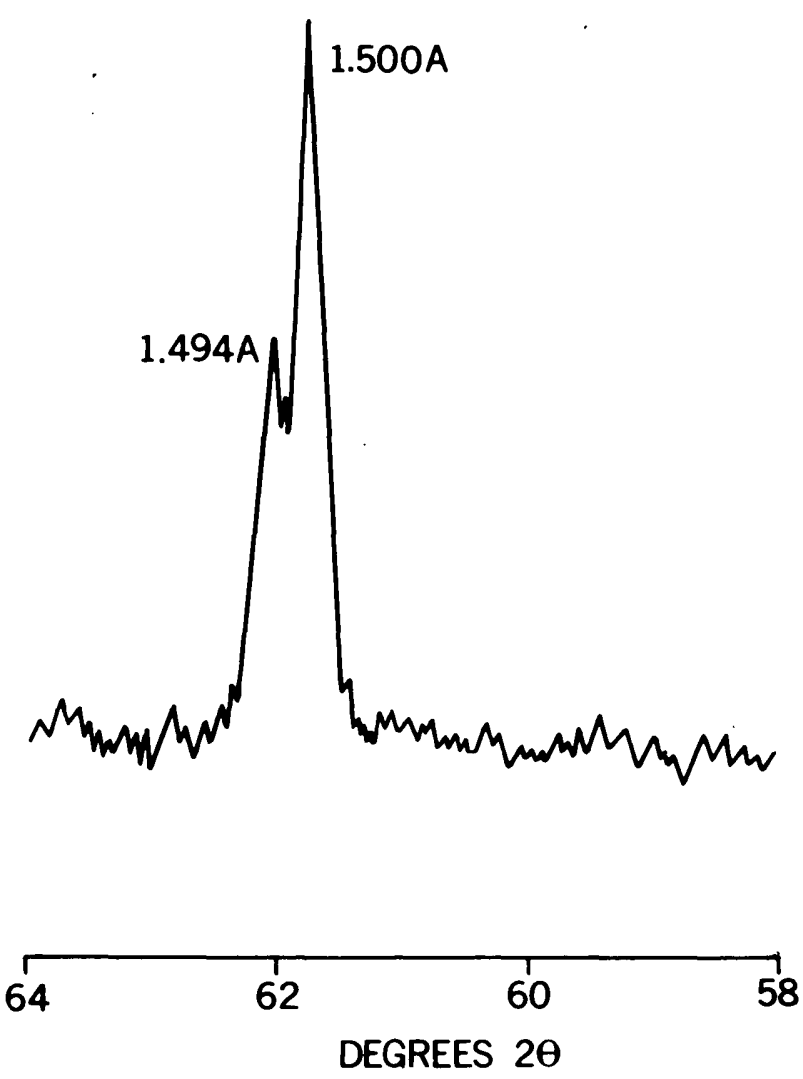

Figure 400.4.-X-ray diffraction pattern of the 060 reflection of mica obtained from a polished section of rock cut at right angles to the bedding (nickel filtered CuKa radiation, scanning speed $1^{\circ} 2 \theta$ per minute, scale factor 8 , multiplier 1 , time constant 4 seconds).

integral series of 001 spacings from 002 to 0.0 .10 for mica. The 060 spacing at $1.48 \mathrm{~A}$ indicates that the mica is dioctahedral.

Samples were glycolated, treated in $\mathrm{HCl}$, in $1 N \mathrm{KCl}$, and heated at $300^{\circ} \mathrm{C}, 600^{\circ} \mathrm{C}$, and $700^{\circ} \mathrm{C}$. The X-ray data of samples after these treatments are given in table 400.1 , columns 4 to 9 , and in figure 400.2 .

Boiling either in $\mathrm{HCl}(1+1)$ for one hour or in $1 N$ $\mathrm{KCl}$ for 7 hours shifted the $14 \mathrm{~A}$ spacing to $11 \mathrm{~A}$. Upon heating to $300^{\circ} \mathrm{C}$ two spacings centering around $10 \mathrm{~A}$ developed; one is at $10.21 \mathrm{~A}$, and the other at $9.92 \mathrm{~A}$ (fig. 400.3). The $14 \mathrm{~A}$ spacing was shifted to $11.3 \mathrm{~A}$.

Heating a sample at $600^{\circ} \mathrm{C}$ removed the $7 \mathrm{~A}$ spacing but left the $11 \mathrm{~A}$ spacing unchanged. At $700^{\circ} \mathrm{C}$ the $11 \mathrm{~A}$ spacing disappeared and only the integral series of 001 spacings of mica remained. A polished section of the rock cut at right angles to the bedding gave a number of $h k l$ mica reflections (table 400.1, column 3). The two 060 reflections at $1.49 \mathrm{~A}$ and $1.50 \mathrm{~A}$ respectively suggest that two polymorphs of muscovite are present (fig. 400.4).

All the spacings of mica identified in the X-ray patterns are assembled in table 400.1, column 10. Indices 
$\mathrm{T}_{\mathrm{ABLE}}$ 400.1.-X-ray diffraciion data ( $\mathrm{Cu} \mathrm{K} \alpha \mathrm{Ni}$ filtered radiation $\left.\lambda=1.54050 \mathrm{~A}\right)$ for micaceous samples from silty sandstone, 3,668 to \$,671 feet in the Hazel Langston well 1, Dixie County, Fla.

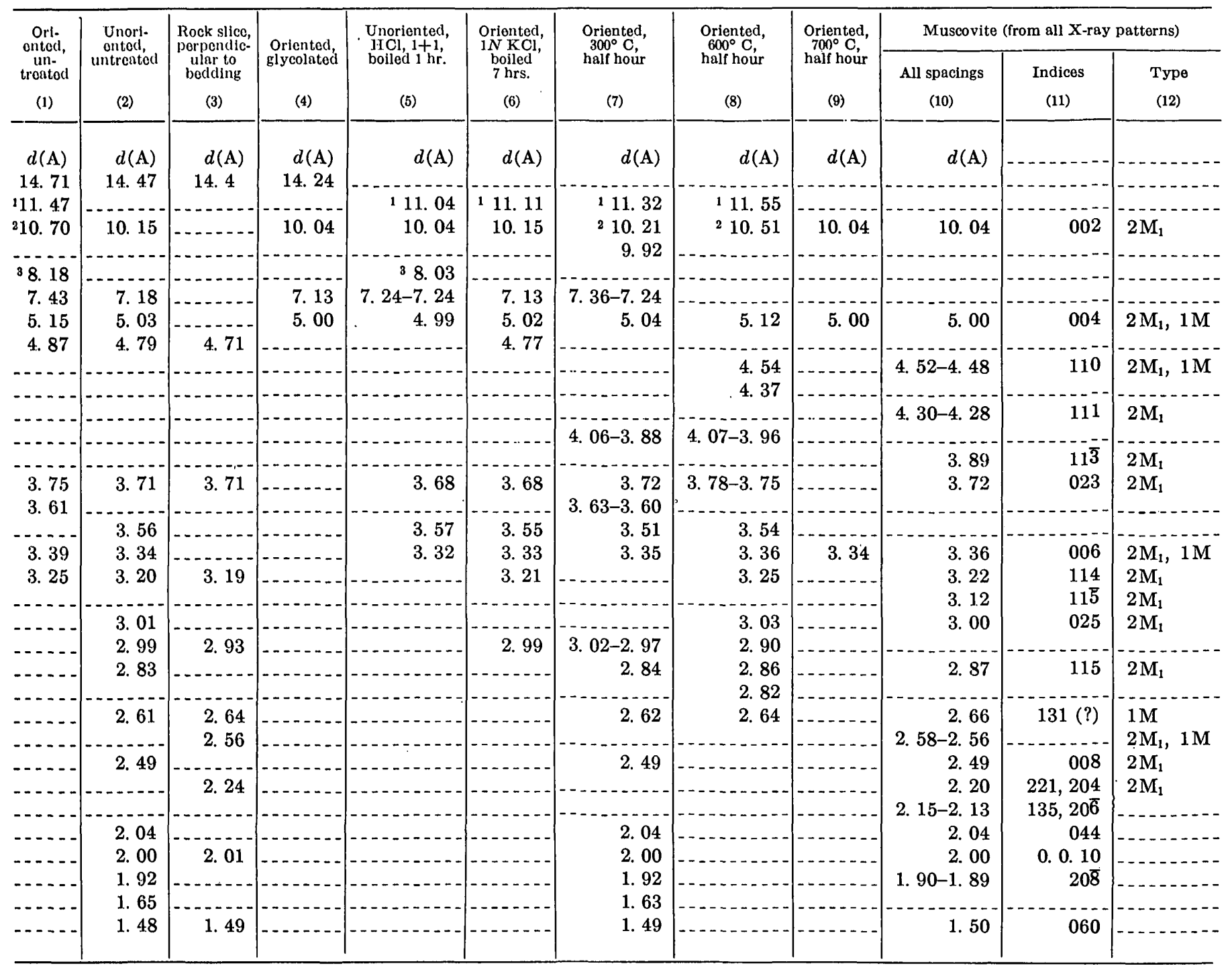

1 Hydrated muscovito. 2002 roflection of muscovite with partial collapse of hydrated layer.

- Reflection duo to interlayering of vermiculite and chlorite.

are assigned to most of these spacings (table 400.1, column 11), and the indices characteristic of the $2 \mathbf{M}_{1}$ and $1 \mathrm{M}$ muscovite polymorphs are in column 12 . The indices and polymorph identifications were obtained from Smith and Yoder (1956).

Chlorite spacings at $\sim 7 \mathrm{~A}, 4.7 \mathrm{~A}, 3.5 \mathrm{~A}, 2.28 \mathrm{~A}$, and $2.24 \mathrm{~A}$ were identified from Martin (1955). These, together with the $\sim 14 \mathrm{~A}$ spacing of chlorite plus vermiculite, are the unidentified spacings listed in table 1 . A little vermiculite is probably interlayered with the chlorite. It is apparently dioctahedral as no reflection of a trioctahedral 060 spacing was obtained. The behavior of this vermiculite with various treatments is somewhat similar to that described by Brown (1953),
Hathaway (1955), and Rich (1958). Spacings at $\sim 11 \mathrm{~A}$ and at $8-9 \mathrm{~A}$ for the Florida mica are the same as those obtained by Rich (1958) for the earlier stages of weathered muscovite in a strongly leached soil developed from muscovite schist. The 7A spacing in the Florida mica could be due to the presence of vermiculite, chlorite, or kaolinite. Various treatments (fig. 400.1) suggest that this is the 002 reflection of chlorite. A differential thermal analysis by Robert O. Fournier, U:S. Geological Survey, showed a broad low endothermic reaction at about $575^{\circ} \mathrm{C}$, but no reaction for low temperature water or for kaolinite. Furthermore, no spacings, other than that at $7 \mathrm{~A}$, characteristic of kaolinite were found. 
The mica has a cation exchange capacity of 12.3 milliequivalents (meq) $/ 100 \mathrm{~g}$, a figure indicative of hydrated mica rather than of vermiculite. Rich (1958) reported that his soil vermiculite had a cation exchange capacity of $50-65 \mathrm{meq} / 100 \mathrm{~g}$.

Microscopic examination shows that the sample consists of three minerals: colorless flakes of muscovite with indices of refraction $\alpha 1.55-1.56, \gamma 1.59-1.60$, and $2 \mathrm{~V}$ ranging from $23^{\circ}$ to $37^{\circ}$ in different flakes; a brownish, degraded mica with index of refraction $\gamma 1.62-1.63$, and interference figure very weak or absent, and almost uniaxial; and green flakes of chlorite with index of refraction $\gamma 1.61 \pm$. A grain count shows that the sample contains 58 percent muscovite, 39 percent degraded mica, and 3 percent chlorite.

In thin section at right angles to the bedding planes the micaceous laminae are seen to consist of folia of colorless mica about $0.06 \mathrm{~mm}$ across; brown pleochroic mica about $0.05 \mathrm{~mm}$ across; and green pleochroic chlorite about $0.02 \mathrm{~mm}$ across. The folia are elongated and appear to have developed schistosity through pressure. However, the presence of a $14 \mathrm{~A}$ spacing in the diffraction pattern obtained from the polished rock (table 400.1, column 3) suggests that chlorite may have developed diagenetically.

The minerals present in the Florida samples are similar to those described from the Jacksonburg forma- tion (Middle Ordovician) of Pennsylvania and New Jersey by Ray and Gault (1961).

The mica in the Florida samples is considered to be detrital. The flakes were probably floated onto the surface of the fine sandy beds by gentle current action, either some distance from a shoreline or in a quiet bay that received little coarse detritus. The mica could also have been sorted out from the silty sand after deposition but prior to the addition of further layers of silt.

\section{REFERENCES}

Brown, George, 1953, The dioctahedral analogue of vermiculite: Clay Minerals Bull., v. 2, no. 10, p. 64-70.

Hathaway, J. C., 1955, Studies of some vermiculite-type clay minerals, in Milligan, W. O., ed., Clays and clay minerals : Natl. Research Council Pub. 395, p. 74-86.

Martin, R. T., 1955, Reference chlorite characterization for chlorite identification in soil clays, in Milligan, W. O., ed., Clays and clay minerals: Natl. Research Council Pub. 395, p. 117-145.

Ray, Satyabrata, and Gault, H. R., 1961, Mineralogy of the Jacksonburg (Middle Ordovician) formation in eastern Pennsylvania and western New Jersey: Am. Assoc. Petroleum Geologists Bull., v. 45, p. 39-50.

Rich, C. I., 1958, Muscovite weathering in a soil developed in the Virginia Piedmont, in Swineford, A., ed., Clays and clay minerals: Natl. Research Council Pub. 566, p. 203-212.

Smith, J. V., and Yoder, H. S., 1956, Experimental and theoretical studies of the mica polymorphs: Mineralog. Mag., v. 31, p. 209-235.

\section{GEOCHEMICAL ANOMALIES IN THE UPPER PLATE OF THE ROBERTS THRUST NEAR CORTEZ, NEVADA}

By R. L. Erickson, Harold Masursky, A. P. Marranzino, and Uteana Oda, Denver, Colo.

Analyses of siliceous clastic rocks in the upper plate of the Roberts thrust fault near Cortez, Nev., show a wide range in metal content. The highest concentrations of metals occur along normal fault zones that cut both upper and lower plates of the thrust, and they may represent leakage halos (Hawkes, 1957, p. 241) up-rake from concealed ore deposits in the thrust zone and in the carbonate rocks below the thrust. Interest in a geochemical investigation of the area was aroused by the intense kaolinitic alteration and the copper mineralization in bedded chert at the Whitehorse Turquoise mine and at other prospect pits along the Whitehorse fault zone. The study was directed toward the development of geochemical techniques and methods that might aid in the search for ore deposits concealed by the Roberts thrust and similar thrust sheets in northcentral Nevada.
The geology of the area studied was partially remapped on a topographic base at a scale of $1: 24,000$ and recompiled from recent geologic mapping of the Cortez 15-minute quadrangle by James Gilluly and Harold Masursky.

The area is on the west side of the Cortez window (Roberts and others, 1958) in which an autochthon of Paleozoic carbonate rocks is overridden by an allochthon of Paleozoic siliceous clastic rocks along the Roberts thrust. The lower plate in the mapped area is made up of gray to black thin-bedded argillaceous Roberts Mountains formation of Silurian age, and alternating thick beds of light- to dark-gray bioclastic limestone and thin-bedded argillaceous limestone of Devonian age. The upper plate contains gray shale and black chert of the Vinini formation of Ordovician age; shale, chert, and dolomitic siltstone of Silurian age; and 
chert with limestone interbeds of probable Devonian age. Several key beds of limestone and chert in the dominantly chert section are shown on the geologic map (fig. 401.1).

In fault contact with the Paleozoic sedimentary rocks is a thick sequence of rhyolitic welded tuffs of Tertiary age (Masursky, 1960) that contains many vitrophyre beds and gravel interbeds (fig. 401.1). Tertiary dikes and sills of quartz porphyry, latite, and hornblende porphyry are lumped together on the geologic map (fig. 401.1). Much of the area is blanketed by alluvium and pediment gravels of Quaternary age.

The rocks were analyzed in the field for trace metal content by use of the mobile spectrographic laboratory of the U.S. Geological Survey. About 500 rock samples were analyzed for 27 elements, representing nearly 14,000 individual determinations. Spectrographic results were received and plotted daily, thus helping to guide the geologic mapping and sampling program. For the purpose of this report, the results are presented in generalized form showing only the areas of highest concontration of $\mathrm{Cu}, \mathrm{Pb}, \mathrm{Zn}, \mathrm{Bi}, \mathrm{Mo}, \mathrm{Ag}$, and $\mathrm{As}$.

Figure 401.2 shows that the areas of highest metal concentrations in the upper plate are alined along faults and are conspicuously zoned. The known "highs" of greatest areal extent are numbered on the geochemical map, and the maximum metal values obtained within individual "highs" are shown in table 4.01.1.

The highest copper concentrations occur in bleached, argillized, and pyritized chert breccia along the eastwest high-angle Whitehorse fault zone, which is offset by a branch of the post-mineralization frontal fault. Turquoise is mined within localities 13 and 10 ; cuprite occurs in the central part of locality 10 ; malachite and azurite stain chert breccia in locality 12 .

The highest lead, molybdenum, and silver concentrations occur at locality 15 , where a narrow galena-bearing quartz vein with as much as $1500 \mathrm{ppm}$ (parts per

TABLE 401.1.-Maximum metal values determined by semiquantitative spectrographic method within numbered localities

[Localities shown on fig. 401.2]

\begin{tabular}{|c|c|c|c|c|c|c|c|c|c|c|}
\hline \multirow{2}{*}{ Motnls } & \multicolumn{10}{|c|}{$\begin{array}{l}\text { Concentration } \\
\text { (parts per million) }\end{array}$} \\
\hline & $>10,000$ & 5,000 & 2,000 & 1,000 & 700 & 200 & 100 & 50 & 20 & 10 \\
\hline $\mathrm{Cu} .$. & 10,11 & 12,13 & & & 4,7 & & & & & \\
\hline Pb....... & 15 & $\ldots$ & 20 & 17 & 18 & $3,13,21$ & & & & $\ldots$ \\
\hline $\mathrm{Zn} . . . . . .$. & - & 11 & $5,15,16,20$ & $6,12,13,21$ & $\ldots$ & & & 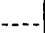 & & $\ldots$ \\
\hline As......... & $\ldots \ldots$ & 17 & $6,15,1,21$ & 14 & $\ldots$ & . & . & $\ldots$ & $\ldots$ & $\ldots$ \\
\hline Mo........ & & ... & .............. & $\ldots$ & $\ldots$ & 15,18 & 10,11 & ... & $\ldots$ & $\ldots$ \\
\hline BI........ & $\ldots$ & $\ldots$ & & & $\ldots$ & 2,4 & & 8,9 & $-x$ & $\ldots$ \\
\hline $\mathrm{Ag} \ldots . . .$. & ........ & $\ldots$ & & $\ldots$ & $\ldots$ & 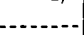 & ....... & 15 & 7 & 18 \\
\hline
\end{tabular}

million) silver is exposed in the roof of a short adit. A double salt of phosphate-sulfate was separated from soft earthy yellow-brown material in a shear zone in this adit. The mineral, tentatively identified by $\mathrm{X}$-ray methods as a member of the beudantite group by $\mathbf{F}$. $\mathbf{A}$. Hildebrand (oral communication 1961), contains more than 1 percent each of $\mathrm{Pb}, \mathrm{Mo}$, and $\mathrm{Ag}$. Two thousand $\mathrm{ppm} \mathrm{Pb}$ and $20 \mathrm{ppm} \mathrm{Ag}$ were found in gossan in locality $20 ; 1,500$ and $1,000 \mathrm{ppm} \mathrm{Pb}$ in brecciated chert at the north ends of localities 12 and 17, respectively; and 500 to $700 \mathrm{ppm} \mathrm{Pb}, 10 \mathrm{ppm} \mathrm{Ag}$, and $200 \mathrm{ppm}$ Mo in fracturefilling material at locality 18 . Molybdenum also occurs in amounts up to $150 \mathrm{ppm}$ within the copper zone.

Zinc, in concentrations greater than $1000 \mathrm{ppm}$, occurs locally in all zones but is consistently present in the $\mathrm{Pb}-\mathrm{Zn}$-Ag zone (fig. 401.2).

The highest concentrations of arsenic (up to 5,000 ppm) occur in altered chert breccia near the Roberts thrust and the Copper fault, which bound the block of siliceous clastic rocks. In the eastern part of the mapped area, the arsenic zone overlaps the $\mathrm{Pb}-\mathrm{Zn}-\mathrm{Ag}$ zone as far north as locality 5 (fig. 401.2).

The highest concentrations of bismuth occur in gossan in the eastern part of the mapped area at locality 2 $(300 \mathrm{ppm})$, and in pyritized and silicified chert breccia at locality $4(200 \mathrm{ppm})$. Soft yellow earthy material in gossan at locality 2 contained $1,500 \mathrm{ppm} \mathrm{Bi}$. The extent of the $\mathrm{Bi}$ zone is not known because of the gravel and alluvium cover to the east and the Tertiary volcanic cover to the south.

The highest concentration of manganese is at the western end of the mapped area. Lovering (1949) showed at Tintic, Utah, that manganese was commonly concentrated on the up-rake or outlet side of mineralized conduits. This suggests that the metal-bearing solutions moved from east to west with both horizontal and vertical components along the east-west fault zones. The manganese "high" area would be the cool or outlet side and the bismuth "high" would be a higher temperature zone closer to the source of the metal-bearing solutions.

This area appears favorable for the discovery of concealed ore deposits because :

1. The rock alteration and the concentration and zoning of metals along high-angle normal faults that cut both upper and lower plate rocks may be leakage halos from ore deposits in the thrust zone or in the carbonate rocks below the thrust. The intersection of the mineralized faults with the thrust plane should be favorable ground. The thickness of the upper plate rocks is not known and detailed rock-alteration studies, which might help determine the validity of the leakage halo concept, are yet to be made. 


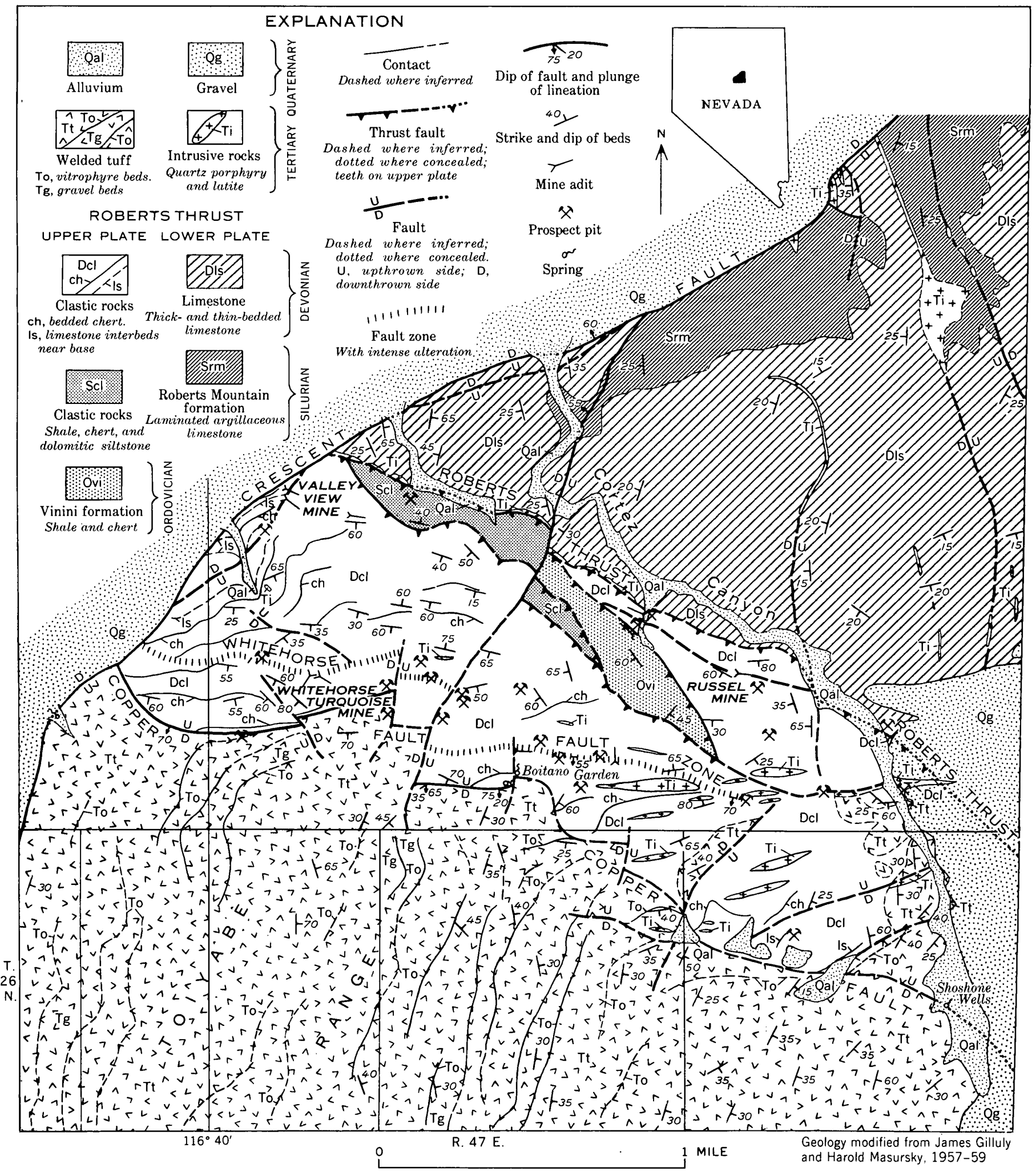

Frgure 401.1.-Preliminary geologic map of the north end of the Toiyabe Range, Cortez quadrangle, Nevada. 


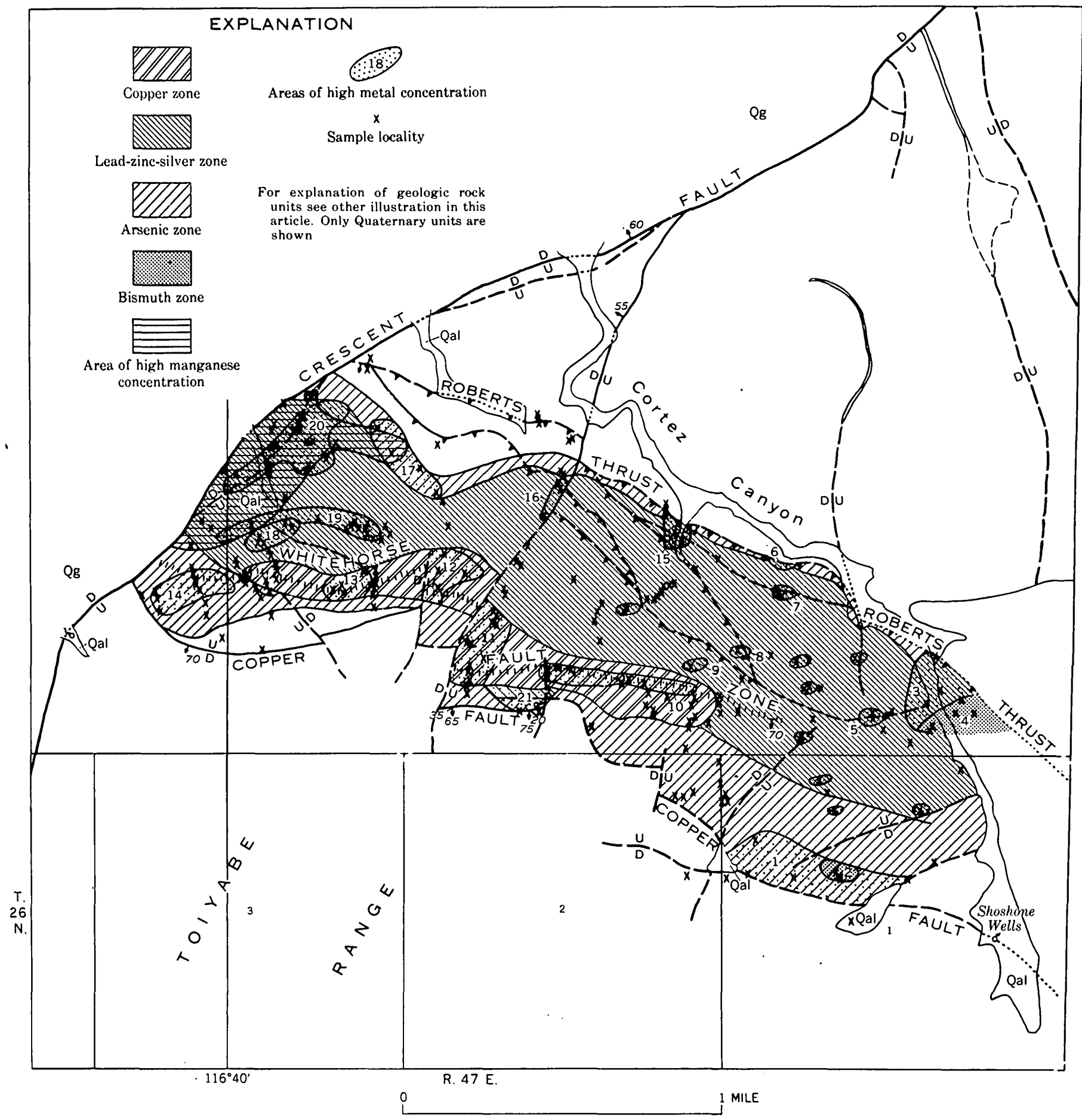

Fiqure 401.2.-Preliminary geochemical map showing distribution of copper, lead-zinc-silver, arsenic, and bismuth in the upper plate rocks of the Roberts thrust, Corteż quadrangle, Nevada. 
2. The mineralized fault zones and quartz porphyry dikes in the area of investigation can be projected on strike 2 miles southeastward across a gravel-covered pediment into the Cortez district where ore deposits in Paleozoic carbonate rocks of the lower plate have produced silver, lead, zinc, copper, and gold with a net value of more than $\$ 12,000,000$ (Emmons, 1910; Vanderburg, 1938). The pediment is favorable ground also and the depth to bedrock probably is very shallow.

Geochemical investigation of upper plate rocks near other windows that have been productive in north-central Nevada may reveal target areas similar to that described in this report.

\section{REFERENCES}

Emmons, W. H., 1910, A reconnaissance of some mining camps in Elko, Lander, and Eureka Counties, Nevada: U.S. Geol. Survey Bull. 408, p. 99-106.

Hawkes, H. E., 1957, Principles of geochemical prospecting: U.S. Geol. Survey Bull. 1000-F, p. 225-355.

Lovering, T. S., 1949, Rock alteration as a guide to ore-East Tintic District, Utah: Econ. Geology Mon. 1, p. 57.

Masursky, Harold, 1960, Welded tuffs in the northern Toiyabe Range, Nevada, in Short papers in the geological sciences: U.S. Geol. Survey Prof. Paper 400-B, p. 281-283.

Roberts, R. J., Hotz, P. E., Gilluly, James, and Ferguson, H. G., 1958, Paleozoic rocks in north-central Nevada: Am. Assoc. Petroleum Geologists Bull., v. 42, no. 12, p. 2813-2857.

Vanderburg, W. O., 1938, Reconnaissance of mining districts in Eureka County, Nevada : U.S. Bur. Mines Inf. Circ. 7022, p. $28-28$.

\section{RADIATION DAMAGE AND ISOTOPIC DISEQUILIBRIA IN SOME URANIUM-BEARING ASPHALTITE NODULES IN BACK-REEF DOLOMITES, CARLSBAD, NEW MEXICO}

By Arthor P. Pierce and John N. Rosholt, Jr., Denver, Colo., and Miami, Fla.

Uranium-bearing asphaltite nodules in marine carbonate-evaporite rocks of Late Permian age have been studied in detail in the Rocky Arroyo area near Carlsbad, N. Mex. The nodules occur in silty sandstone, shallow-marine algal dolomite, and dolomitic limestone that are part of the back-reef facies of the Capitan reef. Most of the known occurrences are in the Yates and Seven River formations.

In the Rocky Arroyo area the distribution of the uraniferous asphaltite correlates well with that of asphaltic sandstone which transgress the facies changes and which probably served as channelways for mineralizing solutions. According to Waltman (1954) these substances may be responsible for abnormally high radioactivity recorded by gamma-ray logs in hundreds of wells penetrating these formations along the flanks of the Delaware basin north of the Rocky Arroyo area.

A most striking geologic feature in the sedimentary formations of the Rocky Arroyo area is the abrupt lateral change in lithology between gypsum, red shale, and sandstone to the west, and bituminous marine dolomite to the east. The carbonate-sulfate facies changes, which are only a few miles wide, occur progressively farther eastward in the younger formations. These facies changes have been an important geochemical control on mineralization of the rocks.
Asphaltite nodules occurring in dolomite close (within tens of feet) to carbonate-sulfate contacts are encased by shells of pyrite and marcasite, whereas asphaltite nodules occurring at greater distances from the carbonate-sulfate contacts are associated with only traces of sulfide minerals.

The distribution of the asphaltite in the dolomites in the Rocky Arroyo area is locally controlled by fractures, bedding planes, stylolites, and fossil molds. Studies of sawed rock sections show that many of the nodules have been deposited within preexisting gastropod and mollusk molds. Most of the nodules both fill the molds and replace the surrounding dolomite. A part of the missing carbonate may be represented by vugs or molds in which calcite crystals are surrounded by asphaltite whose uranium content increases from several parts per million in the center to a few percent at the sharp boundaries where the asphaltite replaces the surrounding dolomite. There is a parallel increase in the sulfur content of the same samples (table 402.1). The mineralized rocks contain patches of residual oil, and the dolomite beds away from the mineralized fracture zones contain numerous fossil molds filled with petroleum that carries only 1 part per million or less of uranium. As noted above, mineralizing sulfate solutions probably migrated laterally through sandstone from the evaporite facies, and ascended through fractures into the petroliferous back-reef dolomite. 
TABLE 402.1.-Chemical properties of some uranium-bearing asphaitites

\begin{tabular}{|c|c|c|c|c|c|c|c|c|c|c|c|c|c|}
\hline \multicolumn{2}{|r|}{ Sample } & \multicolumn{6}{|c|}{ Organic analysis in weight percent 2} & \multirow[b]{2}{*}{ Fusibility } & \multirow{2}{*}{$\begin{array}{l}\text { Equiva- } \\
\text { lent } \\
\text { uranium } \\
\text { (alpha } \\
\text { count } \\
\text { percent) }\end{array}$} & \multirow{2}{*}{$\begin{array}{c}\text { Carbon: } \\
\text { hydro- } \\
\text { gen } \\
\text { weight } \\
\text { ratio } \\
\text { (per-- } \\
\text { cent) }\end{array}$} & \multicolumn{3}{|c|}{$\begin{array}{l}\text { Estimated percent dehydro- } \\
\text { genated carbon in percent } \\
\text { of carbon- }\end{array}$} \\
\hline No. & Description 1 & Ash & $\mathbf{C}$ & $\mathrm{H}$ & $\mathbf{N}$ & 0 & $\mathbf{S}$ & & & & $\begin{array}{c}\text { From } \\
\text { carbon: } \\
\text { hydrogen } \\
\text { ratios rel- } \\
\text { ative to } \\
\text { sample } 7\end{array}$ & $\begin{array}{l}\text { From } \\
\text { theory } \\
\text { (see } \\
\text { text) }\end{array}$ & $\begin{array}{l}\text { From } \\
\text { carbon: } \\
\text { hydrogen } \\
\text { ratios rel- } \\
\text { ative to } \\
\text { sample } 8\end{array}$ \\
\hline 1 & $\begin{array}{l}\text { Outermost asphaltite from vugs in dolomite Seven } \\
\text { Rlvers formation. }\end{array}$ & 5.06 & 64.44 & 4. 10 & 0.30 & 5.90 & 25. 57 & Infusible.... & 2.2 & 15.7 & 48 & 50 & 52 \\
\hline 2 & Asphaltite between samples No. 1 and No. 3....... & 4.87 & 64.97 & 4.49 & .38 & 4.98 & 23. 75 & ......do_..... & 1.4 & 14.5 & 44 & 43 & 48 \\
\hline 3 & Asphaltite botween samples No. 2 and No. $4 \ldots \ldots$. & 5.87 & 69.88 & 5.65 & .30 & ....... & 16.61 & ......do....... & .6 & 12.4 & 35 & 31 & 40 \\
\hline 4 & Asphaltite between samples No. 3 and No. $5 \ldots$ & 6.32 & 70.50 & 6. 34 & .88 & 2.45 & 13.51 & -.....do....... & .3 & 11.1 & 27 & 23 & 32 \\
\hline 5 & Asphaltito between samples No. 4 and No. 6 ...... & 3.04 & 73. 32 & 8.26 & .38 & 5.76 & 3.04 & -....do....... & .03 & 8.9 & $\theta$ & 8 & 16 \\
\hline 6 & Asphaltite next to calcite at center of vug & 1.59 & 81.45 & 9.42 & 1.33 & 2.41 & 3. 79 & Fusible $\ldots$ & .007 & 8. 6 & 6 & 4 & 13 \\
\hline 7 & Asphaltito assoclated with calcite at center of vug.- & $-\cdots$ & 82.50 & 10.13 &..---- & 3.57 & 5. 72 & $\ldots$............ & $<.003$ & 8.1 & $\mathbf{0}$ & $<2$ & 7 \\
\hline 8 & $\begin{array}{l}\text { Oil oxtract from same dolomito bed about } 20 \text { feet } \\
\text { from above samples. }\end{array}$ & $-\cdots$ & 79.31 & 10.56 & .49 & 8.46 & 2.37 & Liquid........ & ... & 7.5 & & & $\mathbf{0}$ \\
\hline
\end{tabular}

1 Samplo Nos. 1, 2, 4, and 5 were previously described in Pierce, Mytton, and Barnett (1958).

a Organte analyses by H. S. Clark, Clark Microanalytical Laboratory, Urbana, Ill. The samples were vacuum dried at room temperature before analysis. Weight losses were a fow tenths percent or less.

Deposition of the asphaltite nodules was a comparatively late event in the diagenesis of these rocks. The nodules post-date lithification, stylolitization, and at least one episode of rock fracturing. They may be contemporaneous with or postdate an episode of petroloum migration. The apparent ages of the nodules, as calculated from lead isotope, lead, and uranium analyses (table 402.2), are discordant and range from 203 to 270 million years. It was assumed in calculation that the inherited common lead (about 3 percent of the total lead) had the same composition as lead in galena from a nearby sandstone lead deposit in the Abo formation of Early Permian age (provided by R. S. Cannon, $\mathrm{Jr}$.). As most of the lead in the nodules is radiogenic, the calculated ages do not depend greatly upon this assumption. For example, a trial correction for inherited "anomalous" lead like that from lead deposits in Paleozoic limestones in the Mississippi Valley region gave apparent ages within several percent of those given below. The principal discrepancy in the age calculations of the asphaltite nodules is the difference between the ages calculated directly from uranium and actinium series decay, and that calculated from the ratio of their products $\left(\mathrm{Pb}^{207} / \mathrm{Pb}^{206}\right)$. The latter ratio gives a value of about $270 \pm 65$ million years, most of the error being due to uncertainties in physical constants (Stieff and others, 1959). The calculated $\mathrm{Pb}^{207}$ / $\mathrm{Pb}^{206}$ age does not depend on the chemical uranium and lead analyses, and when compared to the other data suggests that losses and additions of parent and daughter radioelements may have occurred during the history of the sample. Evidence regarding these possibilities is discussed below.

Studies of the effects of radiation damage in and about the nodules show several phenomena that can be correlated with their age and their overall isotopic equilibria. Data on radiation damage in the organic substance suggest that the nodules may have been fluid during a relatively long period in their early history. Data on thermoluminescence and radioisotopes in the

TABLE 402.2.-Lead isotope, lead, and uranium analyses of asphaltite nodules from the Rocky Arroyo area near Carlsbad, N. Mex.

\begin{tabular}{|c|c|c|c|c|c|c|c|c|c|c|}
\hline \multicolumn{2}{|r|}{ Samplo } & \multicolumn{3}{|c|}{ Atomic ratios 1} & \multicolumn{3}{|c|}{ Weight percent 2} & \multicolumn{3}{|c|}{$\begin{array}{c}\text { Calculated ages, in millions of } \\
\text { years }^{3}\end{array}$} \\
\hline No. & Description & $\mathrm{Pb}^{200 / \mathrm{Pb}^{209}}$ & $\mathrm{~Pb}^{207 / \mathrm{Pb}^{203}}$ & $\mathrm{~Pb}^{204 / \mathrm{Pb}^{203}}$ & $\mathrm{~Pb}$ & $\mathrm{U}$ & Th & $\underset{\mathrm{U}}{\mathrm{P} 2288}$ & $\underset{\text { U } 235}{\mathrm{~Pb}^{2077}}$ & $\begin{array}{l}\mathrm{Pb}^{2007 /} \\
\mathrm{Pb}^{200}\end{array}$ \\
\hline 2 & $\begin{array}{l}\text { Composite of sev- } \\
\text { eral asphaltite } \\
\text { nodules } \\
\text { Assumed isotopic } \\
\text { composition of } \\
\text { inherited lead }{ }^{3}\end{array}$ & $\begin{array}{l}30.338 \pm .002 \\
0.4864 \pm .0004\end{array}$ & $\begin{array}{l}1.943 \pm .002 \\
0.4057 \pm .0005\end{array}$ & $\mid \begin{array}{l}0.0342 \pm .0004 \\
0.0261 \pm .0003\end{array}$ & $0.062 ; .061$ & $2.20 ; 2.15$ & $<0.0001$ & $203 \pm 20$ & $208 \pm 20$ & $270 \pm 65$ \\
\hline
\end{tabular}

1 Load Isotope analyses by W. D. Harman, Union Carbide Nuclear Corp., Oak Ridge, Tenn., furnished by L. R. Stieff and T. W. Stern.

Analyses by Frank Cuttitta.

- Common lead correction was made with reference to $\mathrm{Pb}^{203}$. 
dolomite surrounding the nodules indicate that the asphaltite has lost uranium and daughter products during at least its recent history.

Radiation damage within the organic matrix of the nodules has caused systematic changes in their physical and chemical properties. The principal effects that correlate with increasing radiation dosage, or age and uranium content, are a progressive loss of hydrogen and destruction of original aliphatic structures (Pierce, Mytton, and Barnett, 1958). Similar effects are observed during irradiation of organic substances in nuclear piles and other radiation sources, and must occur in nature as well. Laboratory studies (Charlesby, 1954) show that the main effect of irradiation of paraffinic hydrocarbons is to break aliphatic carbonhydrogen bonds, whereupon hydrogen is released and the free carbon cross-links with carbon in other molecules. As the process continues all the molecules eventually become linked together to form an infusible, insoluble, immense polymer molecule. Charlesby (1954) has shown that infusibility corresponds to one cross-link per molecule of hydrocarbon, and occurs quite abruptly at a radiation dosage proportional to $1 / n$, where $n$ is the number of carbon atoms in the original molecule.

In a previous investigation, oil from these rocks was found to be rich in dioctylphthalate and iso-octane (Pierce, Mytton, and Barnett, 1958). Complete polymerization of the phthalate ester corresponds to crosslinking of 1 of 24 or about 4 percent of the carbon atoms, whereas complete polymerization of the isooctane corresponds to cross-linking of about 13 percent of its carbon atoms. The amount of cross-linking required for infusibility (or complete polymerization) of a mixture of the two compounds should be between these two values. Assuming that this is the case, the fraction of dehydrogenated or "cross-linked" carbon in the asphaltite samples has been estimated (table 402.1) by assuming that the initial $\mathrm{C} / \mathrm{H}$ ratio of the asphaltites was either the same as that of the least radioactive sample or the oil. These estimates indicate that infusibility corresponds to cross-linking of about 6 to 13 percent of the carbon atoms (such as sample 6 , table 402.1), which is within the range expected from the composition of the oil.

Laboratory measurements show that at low radiation intensities, reaction rates for cross-linking usually vary as the square root of the radiation intensity (Charlesby and Swallow, 1959). Similar reactions may go on in the solid asphaltites because of the intense local ionization produced by alpha particles. Trial calculations (table 402.1) indicate that a second-order reaction of this kind fits the data fairly closely; however, other explanations based on the inhibiting effect of sulfur, and on recom- bination of hydrogen with reactive carbon, may do as well. X-ray measurements indicate that the end product of cross-linking and associated reactions is "graphitic" carbon, the proportion of which increases with dehydrogenation (Pierce, Mytton, and Barnett, 1958).

If we assume that the rate at which the hydrogen atoms are lost from the asphaltite is proportional to the number remaining, we find that the samples in table 402.1 were fusible, and very probably liquid at rock temperatures during the first 10 to 20 percent of their existence. During this time the asphaltites were probably part of a continuous phase with interstitial fluids in the rock. The distribution of uranium in the asphaltite-filled vugs shows that it could have been deposited gradually from surrounding solutions. Addition of the uranium during a relatively long period of time might account for the discordant isotopic age results discussed above.

Radiation damage around the nodules is recorded as halos of intensely thermoluminescent dolomite (fig. 402.1). The halos have an average width of about 1.5

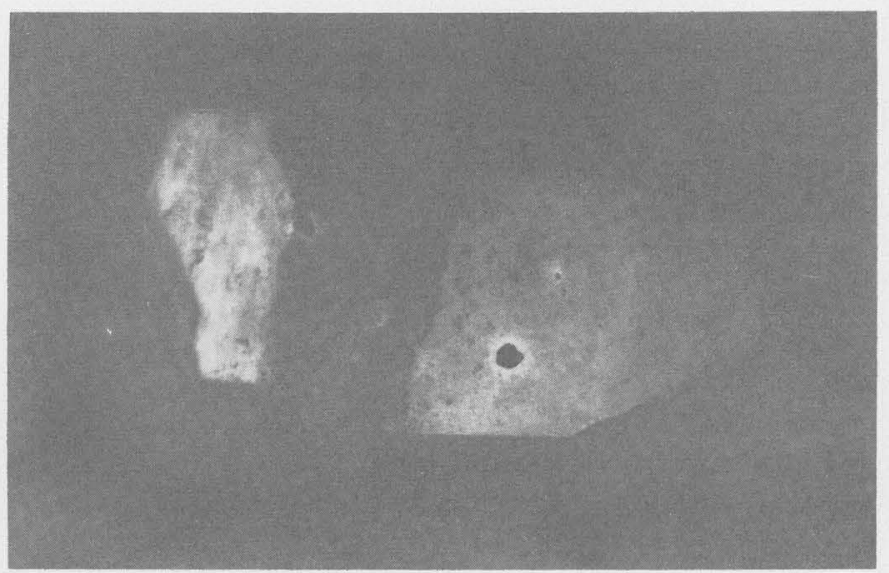

FIGURE 402.1.-Thermoluminescence photograph of a uraniumbearing asphaltite nodule in dolomite.

$\mathrm{mm}$. The luminescence intensity decreases outward and the widths of the halos tend to be independent of the sizes of the related nodules. The dimensions of these halos are greater than can be accounted for by alpha particle ranges (about 40 microns in, $\mathrm{CaCO}_{3}$ ), but are about the same as the beta particle ranges, which penetrate up to about $4 \mathrm{~mm}$ in rock (Yagoda, 1949).

Although beta radiation appears to provide a satisfactory explanation of the halos, a further investigation indicates the halos are enriched in radioisotopes. The radiochemical data (table 402.3) show that with the exception of ionium $\left(\mathrm{Th}^{230}\right)$, uranium and actinium series daughters are impoverished in the nodule but enriched in the halo. The disequilibria shown by these data can be interpreted as (a) the product of geologi- 
TAULE 402.3.-Radioisotope analyses of asphaltite nodules and associated dolomite

\begin{tabular}{|c|c|c|c|c|c|c|c|}
\hline \multicolumn{2}{|r|}{ Simplo } & $\begin{array}{l}\text { Weight } \\
\text { percent }\end{array}$ & \multicolumn{5}{|c|}{ Percent equivalent uranium } \\
\hline No. & Description & $\mathrm{U}$ & $\mathrm{Pa}^{231}$ & $\mathrm{Th}^{230}$ & $\mathrm{Ra}^{220}$ & $\mathrm{Rn}^{220}$ & $\mathrm{~Pb}^{210}$ \\
\hline 1 & $\begin{array}{l}\text { Composite of four as- } \\
\text { phaltite nodules...... }\end{array}$ & \multirow[t]{2}{*}{${ }^{2} 1.4$} & \multirow[t]{2}{*}{1.68} & \multirow[t]{2}{*}{2.13} & \multirow[t]{2}{*}{$1.9_{3}$} & \multirow[t]{2}{*}{1.67} & \multirow[t]{2}{*}{1.74} \\
\hline 2 & $\begin{array}{l}\text { Thermoluminescent } \\
\text { dolomite from halos } \\
\text { surrounding sample }\end{array}$ & & & & & & \\
\hline \multirow{2}{*}{3} & $1 . . . . . . . .$. & $.012 \cdot$ & .0074 & .0049 & $.007_{1}$ & .006 & .006 \\
\hline & sample $2 . \ldots . . . .$. & .1039 & $.004_{2}$ & $.003_{0}$ & $.003_{3}$ & .004 & .003 \\
\hline
\end{tabular}

I Fluorometric uranfum analyses by J. C. Antweiler and C. A. Horr.

a Insumcient samplo for repoat analysis.

cally recent events (several thousand years ago) in which uranium has migrated into the surrounding rock, and (b) as the result of steady migration of daughter products into the surrounding rock. For example, a recent uranium loss of 40 percent and a continual 6 percent radium migration would give three concordant ages of about 130 million years for the sample data in table 402.2. A decisive test as to the relative importance of such processes would be to analyze the lead isotopes in the thermoluminescent halos.

\section{REFERENCES}

Charlesby, A., 1954, The cross-linking and degradation of paraffin chains by high-energy radiation: Royal Soc. London Proc., ser. A; v. 222, p. 60-74.

Charlesby, A., and Swallow, A. J., 1959, Radiation chemistry, in Annual Review Phys. Chemistry, v. 10: p. 289-330.

Pierce, A. P., Mytton, J. W., and Barnett, P. R., 1958, Geochemistry of uranium in organic substances in petroliferous rocks : United Nations Second Internat. Conf. Proc. on Peaceful Uses of Atomic Energy, Geneva, Sept. 1958, v. 2, P/780: p. 192-198.

Stieff, L. R., Stern, T. W., Oshiro, Seiki, and Senftle, F. E., 1959, Tables for the calculation of lead isotope ages: U.S. Geol. Survey Prof. Paper 334-A, p. 1-40.

Waltman, R. M., 1954, Uranium in southeast New Mexico, in New Mexico Geol. Soc. Guidebook, 5th Field Conf.: p. 113-114.

Yagoda, Herman, 1949, Radioactive measurements with nuclear emulsions: New York, John Wiley and Sons, Inc., 265 p.

\section{REGULAR INTERLAYERED CHLORITE-VERMICULITE IN EVAPORITE OF THE SALADO FORMATION, NEW MEXICO}

By Robert O. Fournier, Washington, D.C.

Parts of drill core from eight clay-rich horizons in evaporite of the Permian Salado formation were made available for study through the kindness of Mr. Donald Rawson of the Lawrence Radiation Laboratory, University of California. The samples were from Gnome core, A.E.C. drill core 1, Eddy County, N. Mex. The depths at which the samples were taken are as follows:

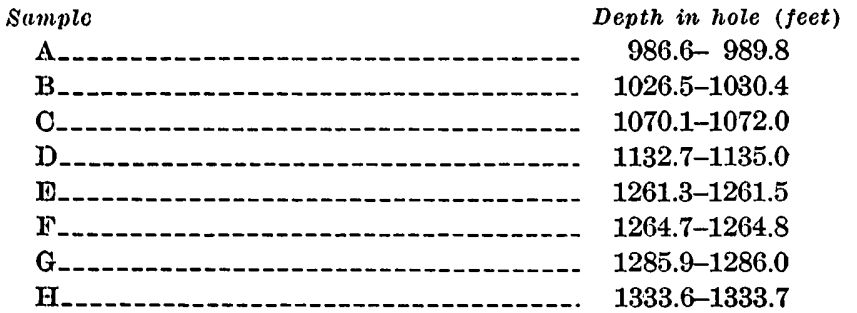

Red, brown, and gray clays are found as thin coatings on halite crystals and as dispersed flakes among sand grains in a matrix of evaporite minerals. All the samples studied contained large quantities of halite and smaller amounts of polyhalite, magnesite, anhydrite, and quartz. Elsewhere in the salt beds, sylvite, carnallite, and dolomite are present.

The predominant clay mineral in seven of the samples is an alternating one-to-one regular interlayed chlorite-vermiculite. The eighth sample (sample $\mathbf{H}$ ) contains mostly muscovite, a small amount of the interlayered chlorite-vermiculite, and a larger quantity of muscovite randomly interlayed with either vermiculite or montmorillonite. Generally both muscovite and chlorite occur, at least in part, as pure members mechanically mixed with the other clay minerals. The muscovite and chlorite are most abundant in the coarser fractions and are probably detrital in origin.

Diffractometer patterns of the interlayered chloritevermiculite are shown on figure 403.1 and the $d$ spacings of the maxima are listed in table 403.1. Superimposed reflections from muscovite and chlorite limit the accuracy of the measurements. Grim, Droste, and Bradley (1960) report almost identical results from clay in evaporite beds of the Salado formation, collected in mine workings of the U.S. Potash Co. at least 6 miles distant from the drill hole. 


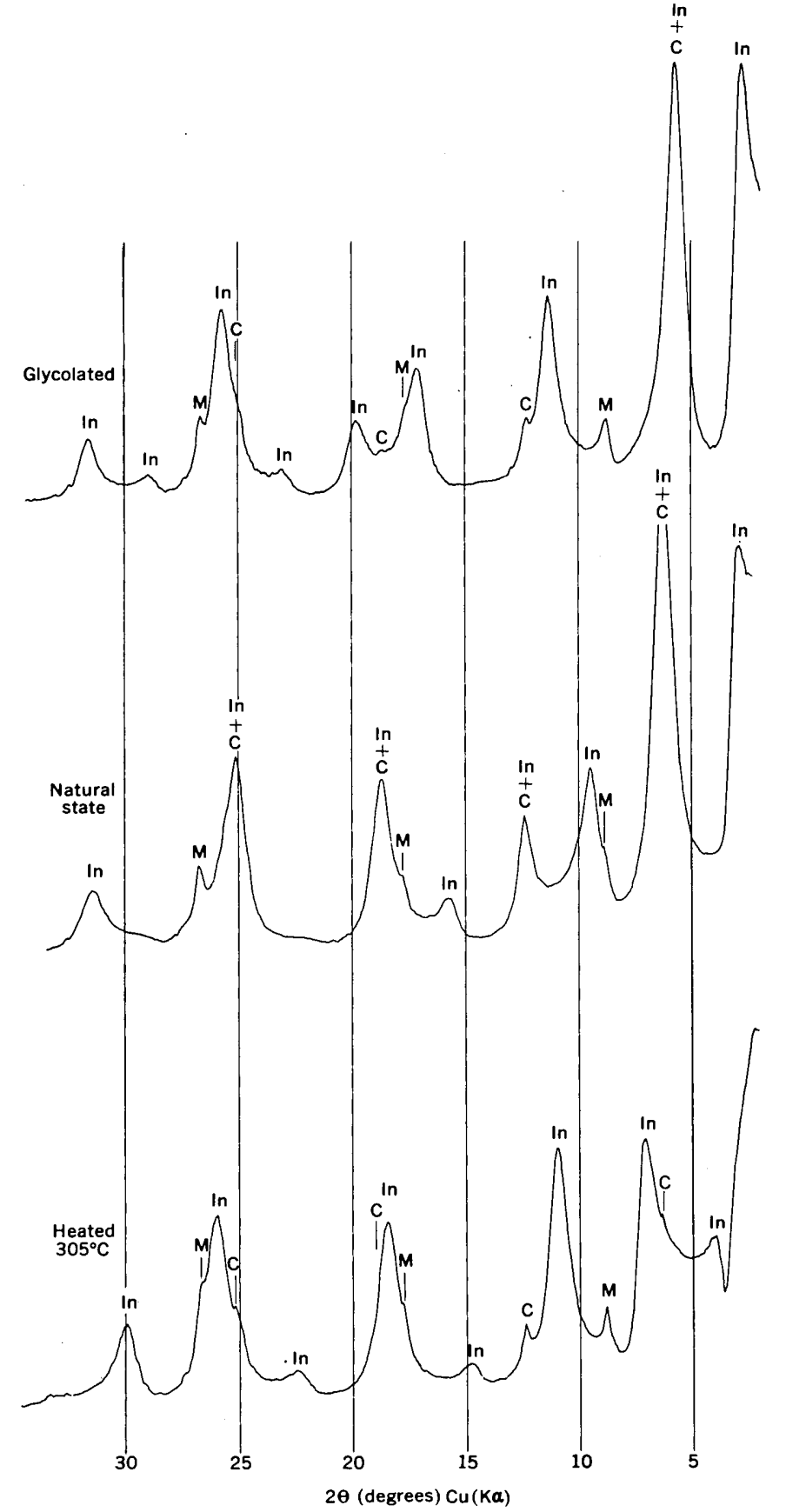

Figure 403.1.-X-ray diffractometer patterns for clay from sample $D$. In, interlayered chlorite-vermiculite; $M$, muscovite ; $\mathbf{C}$, chlorite.

Grim and others (1960) give X-ray data only for the material in the natural state and after glycolation. These data alone are more consistent with those for regularly interlayered chlorite and swelling chlorite or corrensite than with data for regular interlayered chlorite and vermiculite. Vivaldi and MacEwan (1960) point out that the original corrensite as described by Lippman (1954) will expand from 28 A to approximately $31 \mathrm{~A}$ upon glycolation, but it will not contract below $28 \mathrm{~A}$ upon heating to $500^{\circ} \mathrm{C}$. On the other hand, they point out that regular interlayered chlorite-vermiculite will collapse from $28 \mathrm{~A}$ to about $24 \mathrm{~A}$ after heating to $300^{\circ} \mathrm{C}$. However, Vivaldi and MacEwan expected that a regular mixed-layer chloritevermiculite would not expand from $28 \mathrm{~A}$ to $31 \mathrm{~A}$ upon treatment with ethylene glycol. The material reported on here does expand to $31 \mathrm{~A}$ upon treatment with ethylene glycol and it also contracts to about $24 \mathrm{~A}$ after heating to $120^{\circ} \mathrm{C}$. It is assumed that the vermiculite unit is the expanding member, going from about $14 \mathrm{~A}$ to $17 \mathrm{~A}$ whereas the chlorite unit remains at about $14 \mathrm{~A}$. Bradley (1945) had previously reported a vermiculite capable of being expanded with ethylene glycol from about $14 \mathrm{~A}$ to $17 \mathrm{~A}$.

The basal spacing of the interlayered vermiculitechlorite is not sensitive to changes in relative humidity, and once it has been partially dehydrated by heating between $100^{\circ} \mathrm{C}$ and $500^{\circ} \mathrm{C}$ it does not quickly rehydrate under normal conditions in the air. It will, however, fully rehydrate when it is placed in a water-saturated atmosphere for several minutes. Water is not readily lost from the interlayered position upon heating; 24 hours at $120^{\circ} \mathrm{C}$ were required to collapse the structure to $24.5 \mathrm{~A}$.

To make certain that no rehydration was occurring in the interval between heating the sample and X-raying it, an oriented aggregate was X-rayed in an evacuated heating chamber mounted on a diffractometer. The results at a series of temperatures are shown on figure 403.2, and tabulated in table 403.2. There are no significant differences between the $\mathrm{X}$-ray patterns obtained at temperatures from $120^{\circ} \mathrm{C}$ to $450^{\circ} \mathrm{C}$. Between $450^{\circ} \mathrm{C}$ and $510^{\circ} \mathrm{C}$ the chlorite portion of the structure collapsed from $14 \mathrm{~A}$ to $13.8 \mathrm{~A}$ and the $7 \mathrm{~A}$ and $8 \mathrm{~A}$ peaks disappeared. The $7 \mathrm{~A}$ peak was due to mechanically admixed chlorite and the $8 \mathrm{~A}$ peak to the interlayered chlorite-vermiculite. The peak occurring at about $21.5 \mathrm{~A}$ for material heated between $120^{\circ} \mathrm{C}$ and $510^{\circ} \mathrm{C}$ is anomolously low in d-spacing for a first-order basal reflection. The higher order reflections yield values of $24 \mathrm{~A}$ to $25 \mathrm{~A}$ for the basal unit. Between $510^{\circ} \mathrm{C}$ and $620^{\circ} \mathrm{C}$ the $21.5 \mathrm{~A}$ peak collapses to about $20.3 \mathrm{~A}$. Similar $20 \mathrm{~A}$ and $21 \mathrm{~A}$ reflections have been reported for regular interlayered chlorite-montmorillonite (Earley and Milne, 1956; Earley and others, 
TABLE 403.1.-X-ray data for clay from sample $D$

[In, interlayered chlorite-vermiculite; M, muscovite; C, chlorite]

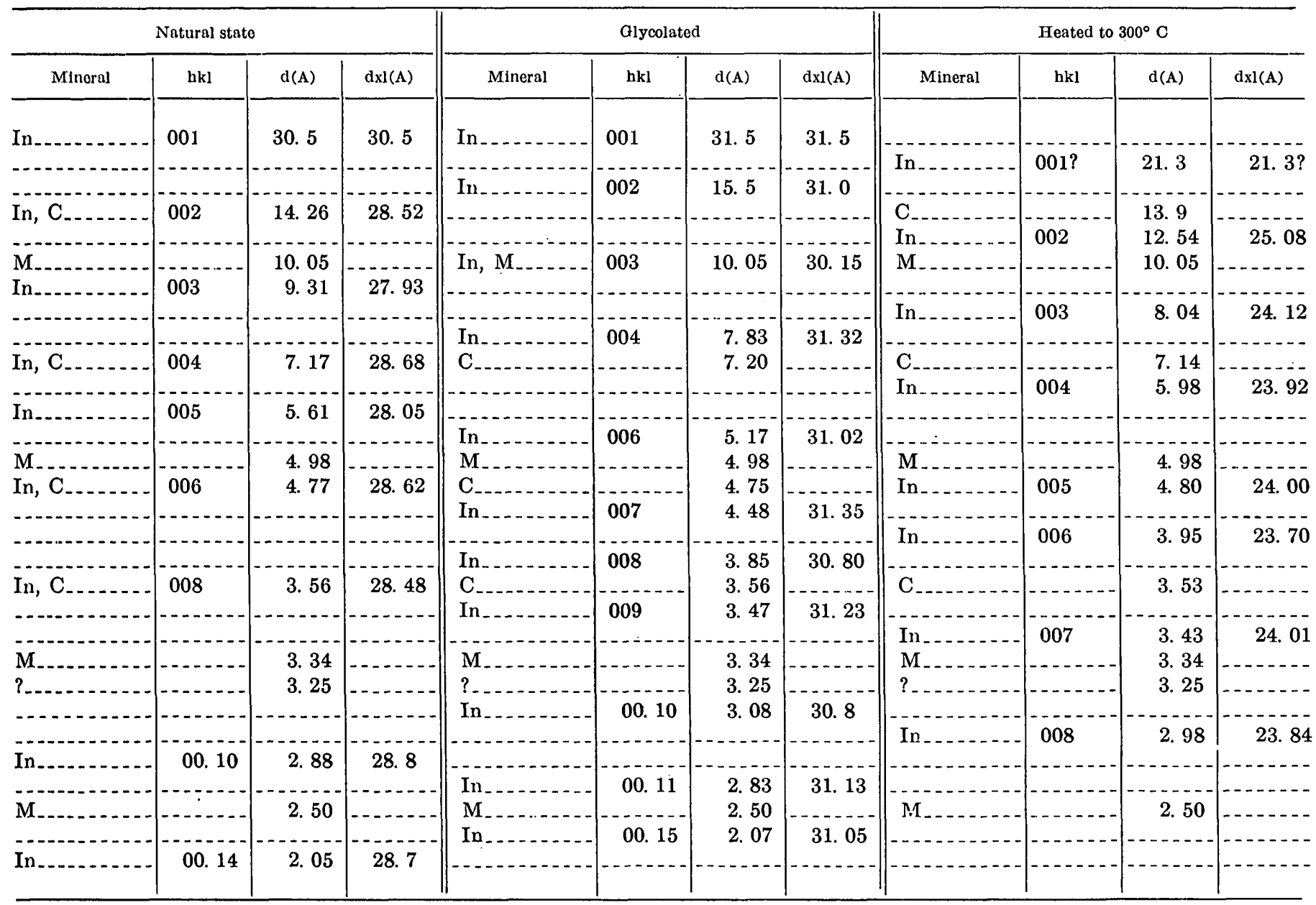

TABLE 403.2.-X-ray data for sample $D$ mounted in an evacuated chamber

[In, interlayered chlorite-vermiculite; M, muscovite; C, chlorite]

\begin{tabular}{|c|c|c|c|c|c|c|c|c|c|c|c|c|c|c|}
\hline \multicolumn{3}{|c|}{ Room temperature } & \multicolumn{3}{|c|}{$120^{\circ}$ and $410^{\circ} \mathrm{C}$} & \multicolumn{3}{|c|}{$510^{\circ} \mathrm{C}$} & \multicolumn{3}{|c|}{$620^{\circ} \mathrm{C}$} & \multicolumn{3}{|c|}{$680^{\circ} \mathrm{C}$} \\
\hline Mineral & hkl & $d(A)$ & Mineral & hkl & $d(A)$ & Mineral & hkl & $d(A)$ & Mineral & hkl & $d(A)$ & Mineral & hkl & $d(A)$ \\
\hline In _ & 001 & 30.5 & In. & $001 ?$ & 21. 55 & In. & $001 ?$ & 21.55 & In . . & $001 ?$ & 20. 3 & In. & $001 ?$ & 20. 10 \\
\hline $\ln , \mathrm{C}$. & 002 & 14. 14 & C.... & $\ldots \ldots$ & 14.03 & C... & $\ldots \ldots$ & 13. 81 & C..... & $\ldots \ldots$ & 13. 60 & C.... & - . . . & 13. 40 \\
\hline & -..... & 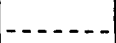 & In $\ldots$ & 002 & 12. 63 & $\mathrm{In}_{--}$ & 002 & 12. 11 & In.- & 002 & 11. 79 & In $\ldots \ldots$ & 002 & 11. 63 \\
\hline $\mathbf{M}_{-}$ & $\ldots \ldots$ & 10.00 & $\mathrm{M}_{\ldots} \ldots$ & $\ldots \ldots$ & 10. 00 & $\mathbf{M}_{-\ldots}$ & $\ldots \ldots$ & 10. 00 & $\mathrm{M}_{-\ldots}$ & $\ldots \ldots$ & 10. 00 & $M_{-\ldots \ldots}$ & $\ldots \ldots$ & 9. 94 \\
\hline $\mathrm{Tn}_{n}$ & 003 & 9. 21 & $\ldots \ldots$ & $\ldots \ldots$ & $\ldots \ldots$ & 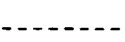 & $\ldots \ldots$ & $\ldots \ldots$ & $\ldots$ & & $\ldots \ldots$ & $\ldots \ldots$ & $\ldots \ldots$ & $\ldots$. \\
\hline $\mathrm{In}, \mathrm{C}$ & 004 & 7.17 & $\begin{array}{l}\text { In } \\
\text { C.... }\end{array}$ & 003 & $\begin{array}{l}8.15 \\
7.08\end{array}$ & $\begin{array}{l}\text { In } \ldots \ldots \\
\text { C. }\end{array}$ & 003 & $\begin{array}{cc}1 & 8.19 \\
1 & 7.14\end{array}$ & $-\ldots-\ldots$ & - & 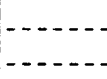 & --- & $\mid \begin{array}{c}-\cdots \\
-\cdots\end{array}$ & - \\
\hline
\end{tabular}

\footnotetext{
1 Very weak.
} 


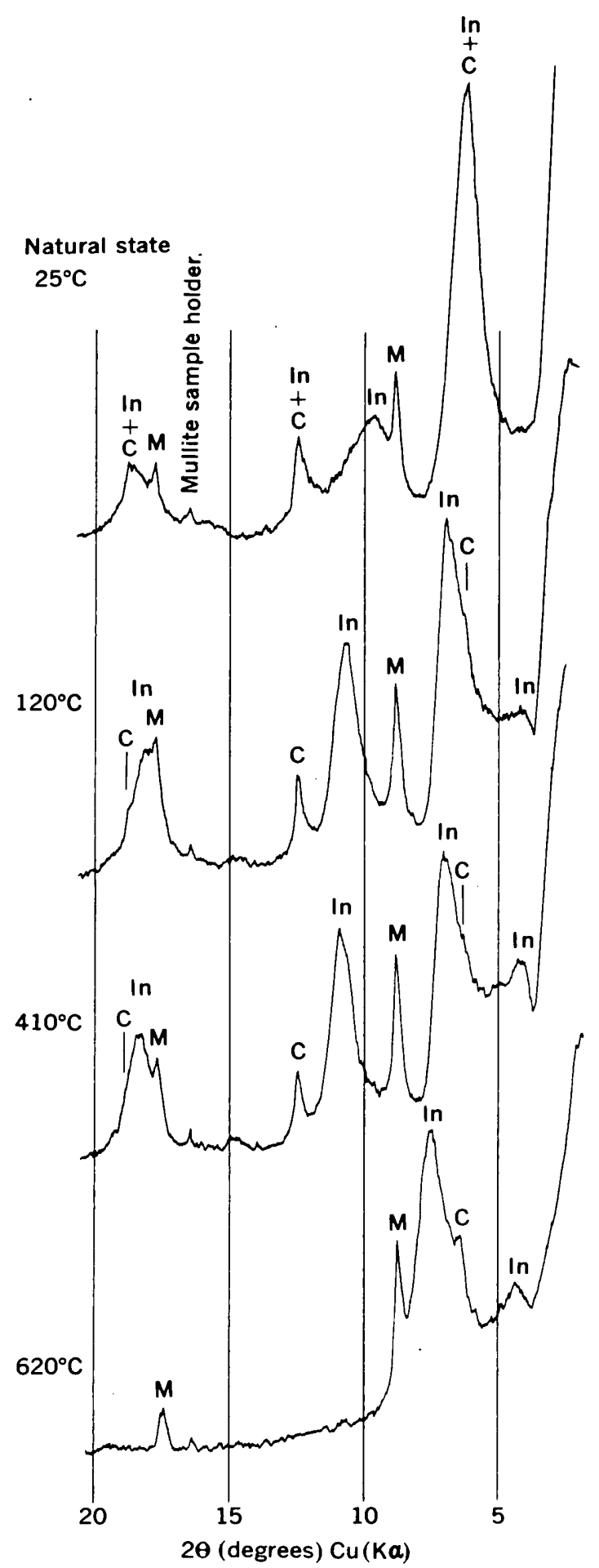

Figure 403.2.-X-ray diffractometer patterns for clay from sample $D$ heated in an evacuated chamber. In, interlayered chlorite-vermiculite; $\mathrm{M}$, muscovite; $\mathrm{C}$, chlorite.

1956). Weaver (1956, p. 218) does not specifically list such a spacing, but he shows the diffractometer pattern for a regular interlayered chlorite-vermiculite after heating to $550^{\circ} \mathrm{C}$. A peak is present at about $20 \mathrm{~A}$.

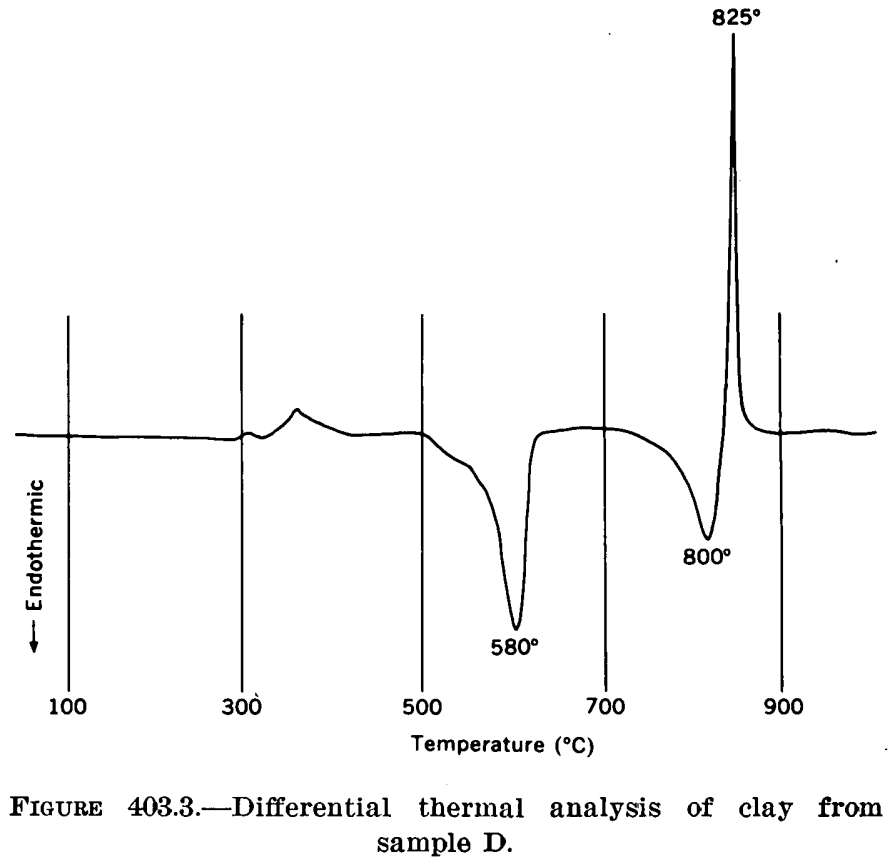

Differential thermal analyses, figure 403.3, complement the X-ray results. Water is lost so slowly above $100^{\circ} \mathrm{C}$ that low-temperature endothermic troughs do not appear between $100^{\circ} \mathrm{C}$ and $200^{\circ} \mathrm{C}$. The main endothermic reaction starts at about $500^{\circ} \mathrm{C}$ and corresponds to a slow water loss from chlorite. At about $550^{\circ} \mathrm{C}$ the slope of the peak becomes much steeper. This is probably the temperature at which the relatively strongly bonded second layer of water from the vermiculite unit is lost.

The process that formed the regular interlayered structure is unknown. The interlayered chloritevermiculite was present in every clay-bearing sample investigated through a 350 -foot section of rock. Virtually identical material has been described from mine workings more than 6 miles away. This material probably extends throughout the evaporite beds of the area and, indeed, is probably the most abundant clay mineral present.

\section{REFERENCES}

Bradley, W. F., 1945, Diagnostic criteria for clay minerals: Am. Mineralogist, v. 30, p. 704-713.

Earley, J. W., Brindley, G. W., McVeagh, W. J., and Vanden Heuvel, R. C., 1956, A regularly interstratified montmorillonite-chlorite: Am. Mineralogist, v. 41, p. 258-267.

Earley, J. W., and Milne, I. H., 1956, Regularly interstratified montmorillonite-chlorite in basalt, in Swineford, Ada, ed., Clays and clay minerals-proceedings of the 4th National Conference on Clays and Clay Minerals, University Park, Pennsylvania, Oct. 10-13, 1955: Natl. Research Council Pub. 456, p. 381-386.

Grim, R. E., Droste, J. B., and Bradley, W. F., 1960, A mixedlayer clay mineral associated with an evaporite, in Swineford, Ada, and Franks, P. C., eds., Clays and clay mineralsproceedings of the 8th National Conference on Clays and 
Clay Minerals, Norman, Oklahoma, Oct. 11-14, 1959 : [Internat.] Ser. Mons. Earth Sci., no. 9, p. 228-236.

Lippmann, Friedrich, 1954, Uber einen Keuperton von Zaisersweiher bei Maulbronn: Heidelberger Beitr. Mineralogie u. Petrographie, v. 4, p. 130-134.
Vivaldi, J. L. M., and MacEwan, D. M. C., 1960, Corrensite and swelling chlorite: Clay Minerals Bull., v. 4, p. 173-181.

Weaver, C. E., 1956, The distribution and identification of mixed-layer clays in sedimentary rocks: Am. Mineralogist, v. 41, p. 202-221.

\title{
404. WEATHERING OF PERIDOTITE, SOUTHWEST OREGON
}

\author{
By Preston E. Hotz, Menlo Park, Calif.
}

In northwest California and southwest Oregon deposits of ferruginous nickel- and cobalt-bearing lateritic residual soil formed by deep weathering of peridotite occupy terraces on steep slopes and some broad, essentially flat, summits. Most of the deposits have an area of less than 100 acres, and the largest are not much more than 400 acres in extent. Soil depths commonly are 10 to 20 feet; in some places exploration has shown thicknesses on the order of 40 to 60 feet, and in extremely localized areas drill hole. depths of 100 feet have been attained.

Samples of the residual soil, weathered bedrock, and fresh peridotite were obtained from an exploratory ex-

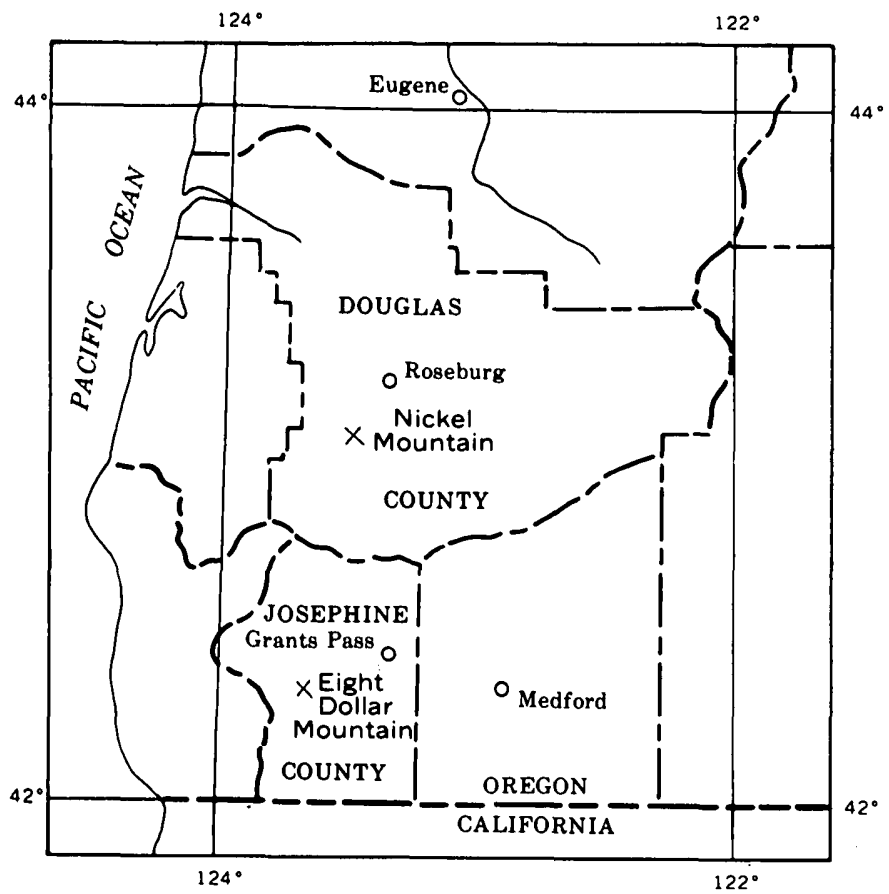

Froure 404.1.-Index map showing location of Eight Dollar Mountain, Josephine County, and Nickel Mountain, Douglas County, Oreg. cavation at Eight Dollar Mountain, Josephine County, Oreg., and from the open-pit mine of the Hanna Ore Company at Nickel Mountain, Douglas County, Oreg. (fig. 404.1). The soil sections which were sampled are summarized below.

\section{Section at Eight Dollar Mountain}

[Numbers correspond to analyzed samples in table 404.1]

Top of cut.

8. Firm red soil with iron oxide pellets and some vege- Feet tal material-_.--_-_-

7. Reddish-yellow soil with streaks of red_-_._-_-_- 1.8

6. Yellowish-orange compact soil; some fragments of thoroughly weathered peridotite.

5. Mottled reddish-brown and yellowish-orange compact soil with some black mottling.

4. Yellowish-brown soft granular saprolite with greenish and black mottlings and some paper thin quartz veinlets

3. Yellowish-brown soft granular saprolite with greenish and black mottlings and some paper thin quartz veinlets

2. Weathered peridotite; yellowish-brown soft weathered selvages as much as $2 \mathrm{in}$. thick with paper thin quartz veinlets surrounding cores of nearly fresh rock

Bottom of cut.

1. Sample of fresh peridotite from adjacent exposure.

Section at Nickel Mountain

[Numbers correspond to analyzed samples in table 404.2] Top of cut.

5. Loose red soil with iron oxide pellets and some vege- Feet tal material

4. Yellowish-orange compact soil with few fragments of quartz veinlets; some garnierite veinlets

3. Yellowish-orange compact soil ; more quartz veinlets and garnierite

2. Yellowish-brown soft saprolite, veinlets of quartz and garnierite (not in sample), grading downward into partly weathered peridotite with cores of fresh rock surrounded by weathered selvages.

Bottom of cut.

1. Composite sample of fresh peridotite from central parts of partly weathered blocks. 
The fresh rock in both areas is slightly serpentinized enstatite peridotite composed of olivine (70 to 80 percent), enstatite with microscopic lamellae of exsolved diopside (10 to 20 percent), and accessory chromite (1 to 2 percent), magnetite dust, and serpentine. The rock from Eight Dollar Mountain contains approximately 12 percent serpentine, and the sample from Nickel Mountain approximately 5 percent.

Where the peridotite is weathered, the olivine is almost completely destroyed. Pyroxene is less susceptible to weathering and crystal fragments persist throughout the soil zone, though in decreasing amounts from the base to the topmost layer. Chromite, in contrast, apparently is little affected by the weathering, for the amount increases in successively higher samples of the soil. Secondary iron minerals, including goethite and amorphous material, are the most abundant constituents of the residual zone. A member of the montmorillonite group, chlorite, and talc were identified in the clay-size fractions of the soil by X-ray spectrometer. In the red upper layer montmorillonite decreases markedly and chlorite predominates. Finegrained to microcrystalline secondary quartz films and veinlets deposited in fractures in the weathered bedrock are broken up and incorporated in higher parts of the

\section{TABLE 404.1.-Chemical analyses of peridotite and overlying residual soil at Eight Dollar Mountain, Oreg.}

[Analysts: Paul L. D. Elmore, Joseph I. Dinnin, Samuel D. Botts, and Marvin D. Mack. Samples were analyzed by rapid rock analysis methods similar to those described by Shapiro and Brannock (1956)]

\begin{tabular}{|c|c|c|c|c|c|c|c|c|}
\hline & 1 & 2 & 3 & 4 & 5 & 6 & 7 & 8 \\
\hline $\mathrm{SiO}_{2-.}$ & 43.0 & 32.5 & 31.5 & 35.1 & 21.4 & 15.6 & 18.5 & 21.4 \\
\hline $\mathrm{Al}_{2} \mathrm{O}_{3} \ldots$ & 1.6 & 3.8 & 3.9 & 3. 5 & 4.7 & 6.4 & 6.9 & 9.1 \\
\hline $\mathrm{Fe}_{2} \mathrm{O}_{3}$ & 1.4 & 29.6 & 34.5 & 38.6 & 49.1 & 56.1 & 52.2 & 47.3 \\
\hline $\mathrm{FeO}$ & 6.7 & 1.9 & .93 & .12 & .20 & .14 & .68 & .72 \\
\hline MgO. & 43.1 & 15.9 & 12.4 & 4.7 & 3.3 & 2.1 & 1.7 & 4.1 \\
\hline $\mathrm{CaO}_{-}$ & 1.4 & 1.5 & 1.4 & .72 & .42 & .30 & .05 & .32 \\
\hline $\mathrm{Na}_{2} \mathrm{O}$. & .02 & .04 & .07 & .04 & .04 & .06 & .07 & .10 \\
\hline $\mathrm{K}_{2} \mathrm{O}$ & .02 & .02 & .02 & .02 & .04 & .06 & .05 & .13 \\
\hline $\mathrm{H}_{2} \mathrm{O}_{-}$ & 2.4 & 11.3 & 12.1 & 13.6 & 15.9 & 15.9 & 16.6 & 13.4 \\
\hline $\mathrm{TiO}_{2 .-}$ & .03 & .06 & .06 & .04 & .10 & .12 & .12 & .23 \\
\hline $\mathrm{P}_{2} \mathrm{O}_{5}$ & .01 & .02 & .02 & .04 & .06 & .07 & .06 & .11 \\
\hline MnO & .14 & .24 & .30 & .46 & .44 & .25 & .25 & .28 \\
\hline $\mathrm{CO}_{2} \ldots$ & .26 & .14 & .14 & .18 & .21 & .27 & .24 & .21 \\
\hline $\mathrm{Cr}_{2} \mathrm{O}_{3} \ldots \ldots$ & .36 & 1.1 & 1.1 & 1.2 & 2.4 & 1.8 & 2.1 & 2.0 \\
\hline $\mathrm{CoO}$ & .02 & .04 & $: 04$ & .07 & .14 & .14 & .13 & .07 \\
\hline NIO & .37 & 1.9 & 2.2 & 2.0 & 2.0 & 1.8 & 2.0 & 1.4 \\
\hline Total (r & 101 & 100 & 101 & 100 & 100 & 101 & 101 & 101 \\
\hline
\end{tabular}

1. Fresh peridotite.

2. Weathored peridotite. Blocks of peridotite with soft weathered selvages as much as 2 inches thick. Few very thin seams of garnierite and quartz; 13.6 to 17.8 feet.

3. Yellowish brown soft but granular saprolite with greenish and black mottlings and some thin platy quartz veinlets; 10.8 to 13.6 feet.

5. Compact mottled reddish brown and yellowish orange lateritic soil with some black mottling; 5.5 to 8.2 feet.

6. Compact yellowish orange lateritic soil with some fragments of thoroughly weathered peridotite; 2.8 to 5.5 feet.

7. Reddish yellow lateritic soil with streaks of red; 1 to 2.8 feet.

8. Firm red lateritic soil with iron oxide pellets, and some vegetal material; 0 to 1 foot.
TABLE 404.2.-Chemical analyses of peridotite and overlying residual soil at Nickel Mountain, Oreg.

[Analysts: Paul L. D. Elmore, Joseph I. Dinnin, Samuel D. Botts, and Marvin D. Mack. Samples were analyzed by rapid rock analysis methods similar to those described by Shapiro and Brannock (1956)]

\begin{tabular}{|c|c|c|c|c|c|}
\hline & 1 & 2 & 3 & 4 & 5 \\
\hline $\mathrm{SiO}_{2 \ldots} \ldots$ & 42.8 & 71. 7 & 32. 2 & 26. 2 & 38. 4 \\
\hline $\mathrm{Al}_{2} \mathrm{O}_{3} \ldots$ & 1. 1 & 1. 4 & 4. 9 & 7. 3 & 8. 4 \\
\hline $\mathrm{Fe}_{2} \mathrm{O}_{3} \ldots$ & .8 & 14. 4 & 38. 7 & 46. 8 & 31. 3 \\
\hline $\mathrm{FeO} \ldots$ & 6. 8 & .14 & .45 & .29 & 1. 3 \\
\hline $\mathrm{MgO}$ & 45. 7 & 3. 9 & 7. 0 & 2. 1 & 6. 8 \\
\hline $\mathrm{CaO}$ & .90 & .12 & 1. 0 & .24 & .58 \\
\hline $\mathrm{Na}_{2} \mathrm{O}_{\ldots} \ldots$ & .03 & .02 & .07 & .08 & .26 \\
\hline - & .01 & .02 & .02 & .09 & .24 \\
\hline - & 1. 6 & 5. 5 & 11.9 & 13. 3 & 8. 0 \\
\hline $\mathrm{TiO}_{2} \ldots$ & .02 & .03 & .08 & .20 & .32 \\
\hline $\mathrm{P}_{2} \mathrm{O}_{6} \ldots \ldots$ & .02 & .01 & .05 & .12 & .20 \\
\hline $\mathrm{MnO}_{\ldots}$ & .12 & .20 & .48 & .43 & .49 \\
\hline $\mathrm{CO}_{2}$ & .12 & .17 & .24 & .28 & .17 \\
\hline $\mathrm{Cr}_{2} \mathrm{O}_{3} \ldots \ldots$ & .45 & .59 & 1. 1 & 1.3 & 1. 5 \\
\hline $\mathrm{CoO}$ & .02 & .03 & .06 & .08 & .06 \\
\hline $\mathrm{NiO}$ & .36 & 1. 5 & 2. 3 & 2. 2 & 1.5 \\
\hline $\begin{array}{l}\text { Total } \\
\quad \text { (rounded) }\end{array}$ & 101 & 100 & 101 & 101 & 100 \\
\hline
\end{tabular}

1. Composite sample of fresh peridotite from central parts of partly weathered blocks. 2. Soft, weathered peridotite with veinlets of quartz and garnierite; 8 to 10 feet.

3. Compact, yellowish orange lateritic soll with remnants of quartz veinlets, some garnierite-rich streaks; 5 to 8 feet.

4. Same as above, with fewer quartz veinlets; 3 to 5 feet.

5. Loose red lateritic soil with iron oxide pellets and some vegetal material; 1 to 3 feet.

soil as the weathered zone gradually descends with time, although much of the quartz is leached away in the upper zones. At Nickel Mountain garnierite commonly occurs in veinlets associated with secondary quartz, but at Eight Dollar Mountain it is only rarely seen, as paper-thin films. No other nickel minerals have been recognized, and it is assumed that nickel and cobalt are incorporated in the lattices of the secondary iron minerals and the clays.

Chemical analyses of samples from Eight Dollar Mountain and Nickel Mountain are presented in tables 404.1 and 404.2 , and the variations in composition are illustrated in figures 404.2 and 404.3.

Large quantities of $\mathrm{MgO}$ released by decomposition of olivine and enstatite are lost by removal in groundwater solutions, but $\mathrm{MgO}$ persists through the soil zones due in part to enstatite, which resists complete destruction, and in part to the formation of clay minerals. $\mathrm{CaO}$, which increases slightly in the first weathering stages, parallels the decrease of $\mathrm{MgO}$. Probably most of the $\mathrm{CaO}$ is contained in the exsolved diopside lamellae in the enstatite. $\mathrm{SiO}_{2}$ released by breakdown of the ferromagnesian minerals also is lost by removal in solution, but to a lesser extent than $\mathrm{MgO}$. Some of the $\mathrm{SiO}_{2}$ recombines with $\mathrm{MgO}, \mathrm{Fe}_{2} \mathrm{O}_{3}$, and 


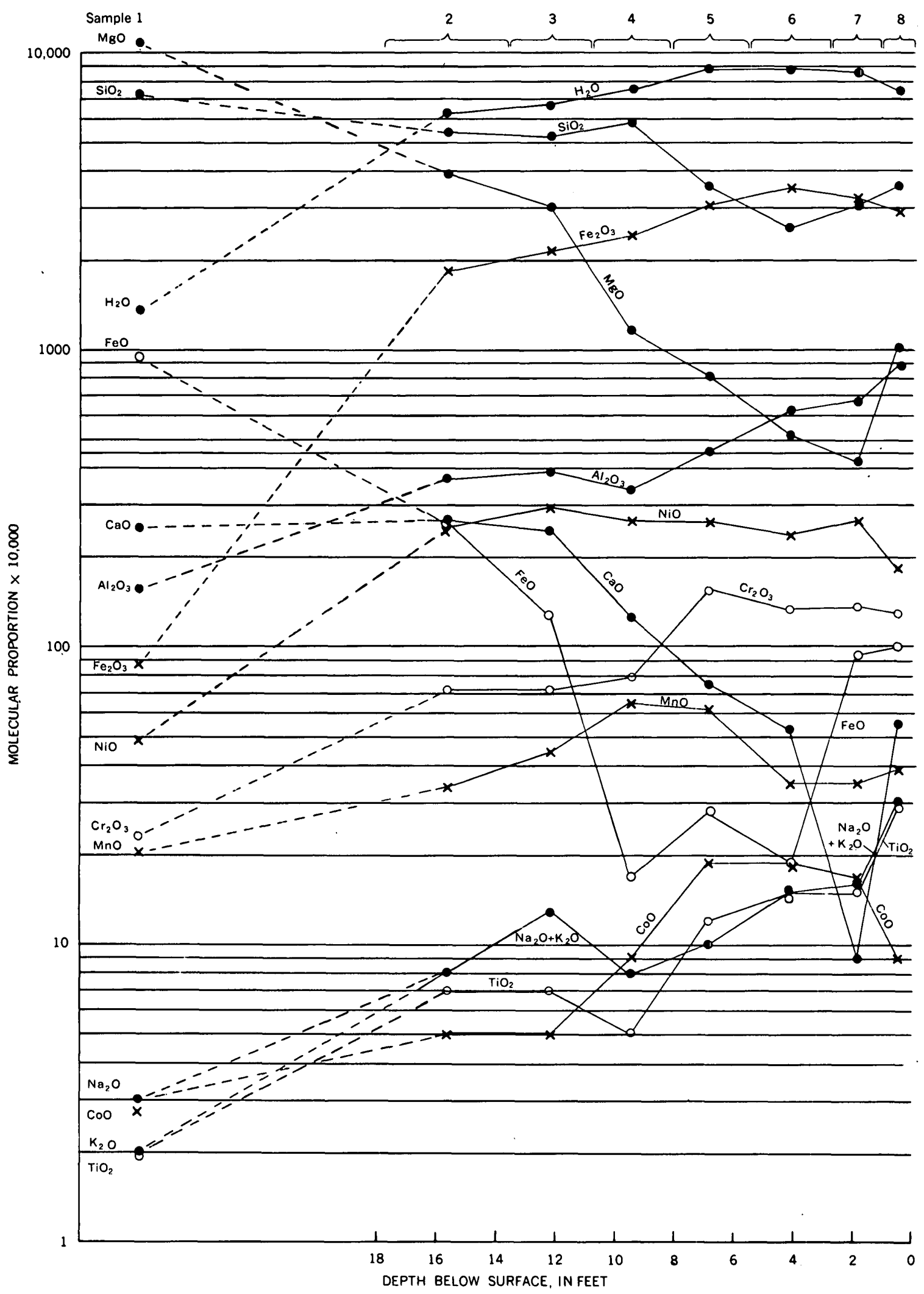

Fraure 404.2.-Molecular proportions, computed from analyses given in table 404.1, of peridotite and overlying residual soil at Eight Dollar Mountain, Oreg. 


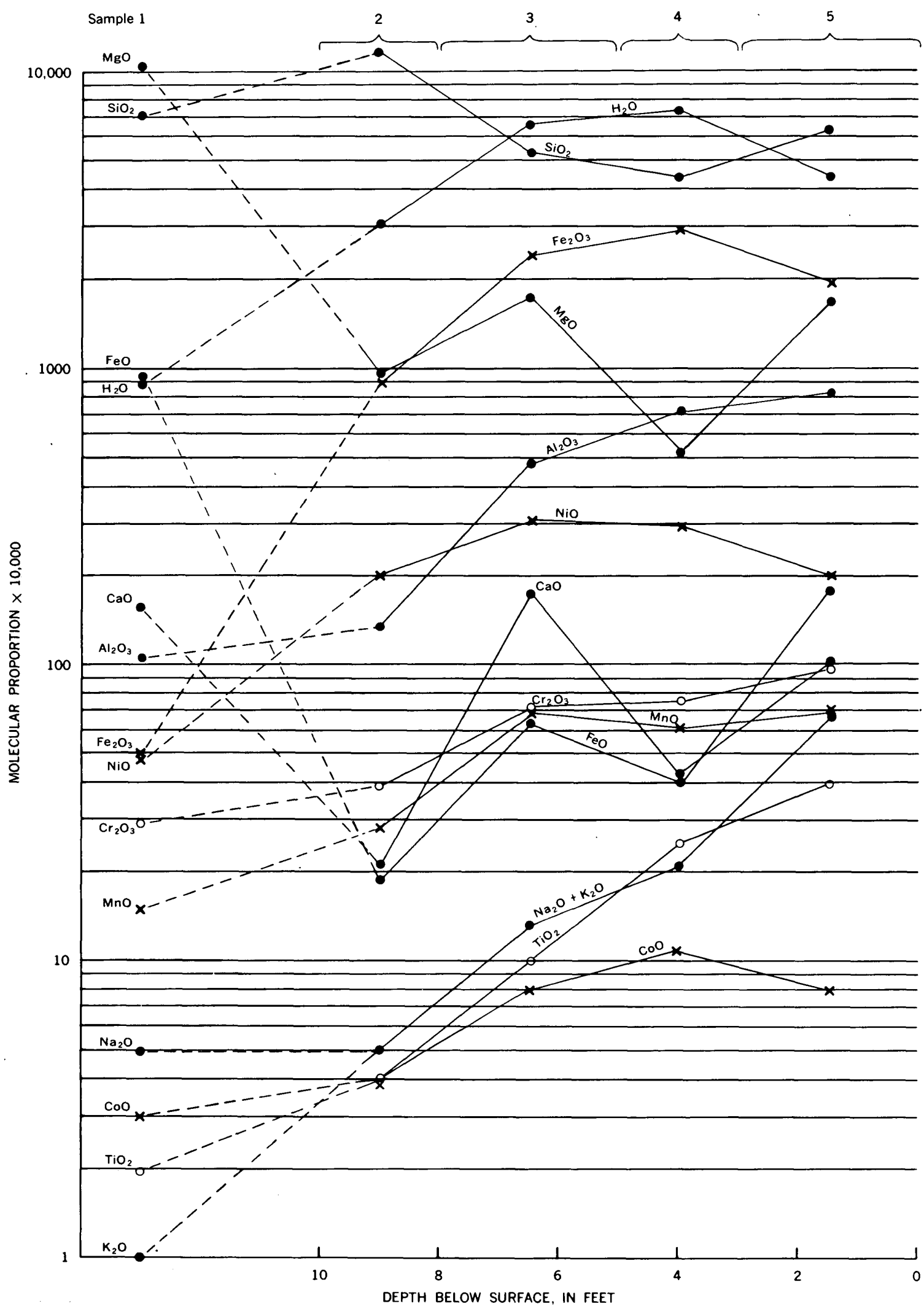

FIGURE 404.3.-Molecular proportions, computed from analyses given in table 404.2, of peridotite and overlying residual soil at Nickel Mountain, Oreg. 
$\mathrm{Al}_{2} \mathrm{O}_{3}$ to form clay minerals, and some is reprecipitated as quartz. Iron, also released by destruction of the ferromagnesian minerals, is oxidized from the ferrous to the ferric state and concentrated in the soil zone beneath the brick-red upper layer. $\mathrm{NiO}$ concentrates similarly to $\mathrm{Fe}_{2} \mathrm{O}_{3}$. The relative concentration of iron and nickel is due to the removal of $\mathrm{MgO}$ and $\mathrm{SiO}_{2}$. $\mathrm{MnO}$ and $\mathrm{CoO}$ are also concentrated in the soil zone beneath the upper layer. $\quad \mathrm{Al}_{2} \mathrm{O}_{3}$, one of the less soluble constituents, increases continuously relative to other constituents in successively higher samples of the soil. $\mathrm{Cr}_{2} \mathrm{O}_{3}$ and $\mathrm{TiO}_{2}$ show a persistent increase throughout the soil zone. $\mathrm{TiO}_{2}$, possibly the most insoluble constituent, may indicate (by its residual concentration) the absolute quantities of other components removed. It would be a more reliable indicator, however, if its content in the fresh peridotite were not so low.

In the upper 2 to 4 feet the trends are, in general, reversed except for $\mathrm{Al}_{2} \mathrm{O}_{3}, \mathrm{Na}_{2} \mathrm{O}, \mathrm{K}_{2} \mathrm{O}$, and $\mathrm{TiO}_{2}$. $\mathrm{Fe}_{2} \mathrm{O}_{3}$ decreases slightly and $\mathrm{FeO}$ increases, possibly due to reduction from $\mathrm{Fe}^{+3}$ to $\mathrm{Fe}^{+2}$ under the influence of organic matter. There is also a decrease in total iron, possibly due to removal of ferrous iron by rain water that contains dissolved $\mathrm{CO}_{2}$ in the soil zone; but presumably solution of $\mathrm{Fe}^{+2}$ is slower than the reduction

TABLE 404.3.-Quantitative spectrographic analyses (in percent) of peridotite and overlying residual soil at Eight Dollar Mountain, Oreg.

[Annlyst: Sol Berman. Sample numbers correspond to those in table 404.1]

\begin{tabular}{|c|c|c|c|c|c|c|c|c|}
\hline & 1 & 2 & 3 & 4 & 5 & 6 & 7 & 8 \\
\hline $\mathrm{Cu}$. & 0.0007 & 0.013 & 0.0098 & 0.0090 & 0.011 & 0.015 & 0.010 & 0.012 \\
\hline V. & .0051 & .011 & .012 & .010 & .020 & .016 & .020 & .023 \\
\hline Sc. & .0017 & .0042 & .0054 & .0054 & .0076 & .0076 & .0067 & .0066 \\
\hline Sr..... & $<.0002$ & $<.0002$ & $<.0002$ & $<.0002$ & $<.0002$ & $<.0002$ & $<.0002$ & .0010 \\
\hline Ba... & $<.002$ & .002 & .002 & .003 & .003 & .003 & .003 & .006 \\
\hline
\end{tabular}

Note: Results havo an overall accuracy of \pm 15 percent except where only one diglt is reported. Looked for but not found; Os, Ir, Pt, Re, Cd and Y, Rh. of $\mathrm{Fe}^{+3}$ to $\mathrm{Fe}^{+2}$. The decrease in ferric iron is accompanied by a decrease in $\mathrm{NiO}$ and $\mathrm{CoO}$. In this zone there is an increase in $\mathrm{MgO}, \mathrm{CaO}$, and $\mathrm{SiO}_{2}$, which probably is the combined effect of residual concentration due to loss of iron and dehydration at the surface, but possibly represents a real concentration caused by accumulation of litter and humus from plants growing on the soil and concentrating some elements, as recently emphasized by Lovering (1959) for silica.

Quantitative spectrographic analyses of peridotite and residual soil at Eight Dollar Mountain are given in table 404.3. $\mathrm{Cu}, \mathrm{V}$, and $\mathrm{Sc}$ increase several fold in the soil zone. $\mathrm{Sr}$ and $\mathrm{Ba}$ concentrate in the topmost zone.

In comparison with laterites formed from ultramafic rock under tropical weathering conditions in Cuba (Leith and Mead, 1915, p. 39; Mohr and Van Baren, 1954, p. 146), the Philippines (Frashe, 1941, p. 298), and French Guinea (Millot and Bonifas, 1955, p. 6), the residual soils in southwest Oregon have a notably higher content of $\mathrm{SiO}_{2}$ and $\mathrm{MgO}$, lower $\mathrm{Fe}_{2} \mathrm{O}_{3}$, and do not attain as high an $\mathrm{Al}_{2} \mathrm{O}_{3}$ concentration.

\section{REFERENCES}

Frashe, D. F., 1941, Origin of the Surigao iron ores: Econ. Geol. v. 36, p. 280-305.

Leith, C. K., and Mead, W. J., 1915, Metamorphic geology : New York, Holt and Co., $337 \mathrm{p}$.

Lovering, T. S., 1959, Significance of accumulator plants in rock weathering: Geol. Soc. America Bull., v. 70, p. 781-800.

Millot, Georges, and Bonifas, Marthe, 1955, Transformations isovolumetriques dans les phenomenes de lateritisation et bauxitisation: Alsace-Lorraine, Serv. Carte Geol., B. T. 8, f. 1, p. 3-20.

Mohr, E. C. J., and Van Baren, F. A., 1954, Tropical soils; a critical study of soil genesis as related to climate, rock and vegetation: New York, Interscience Publishers, 498 p.

Shapiro, Leonard, and Brannock, W. W., 1956, Rapid analysis of silicate rocks: U.S. Geol. Survey Bull. 1036-C, p. 19-56, (revision). 


\section{GEOCHEMICAL SURVEYING FOR GOLD VEINS IN THE ATLANTIC DISTRICT, WYOMING}

By Richard W. Bayley and Willard W. JAnes, Menlo Park, Calif., and Denver, Colo.

The ore veins in the Atlantic gold district, Wyoming, contain chiefly quartz, arsenopyrite, pyrite, and gold. A simple, though not infallible, method for finding them is to explore close to the belts of intrusive rocks that trend east-west across the district. Nearly all of the gold produced from lodes came from mines located along belts of intrusive metagabbro (fig. 405.1). But

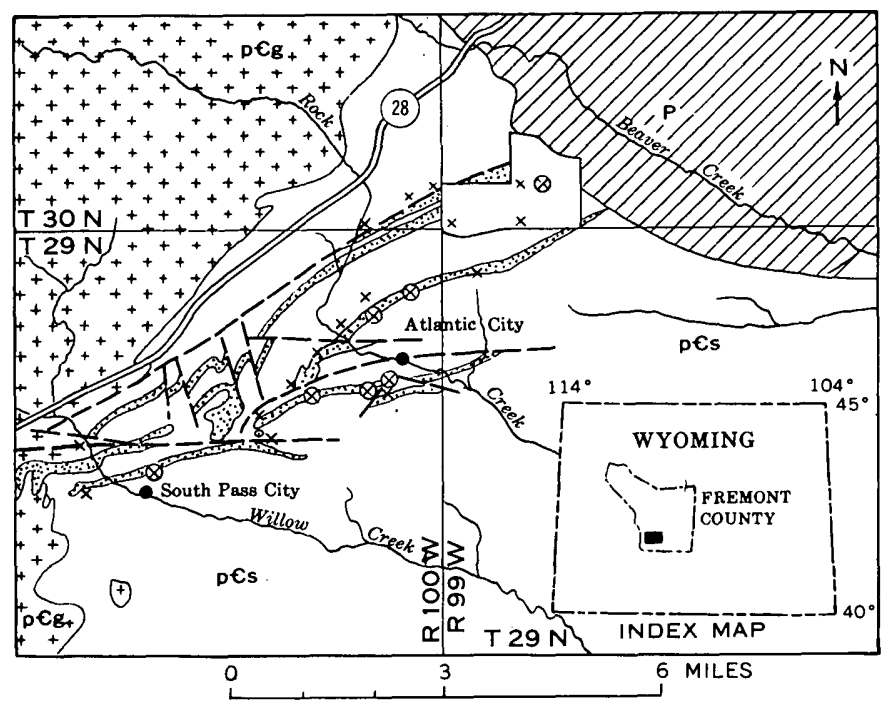

Fraure 405.1.-Generalized geologic map of the Atlantic gold district. Stippled pattern, main metagabbro belts $; \otimes$ major gold mines ; $X$, some other mines and prospects ; p€s, Precambrian metasedimentary and metavolcanic rocks, undifferentiated ; $\mathrm{p} \in \mathrm{g}$, Precambrian granite intrusive into $\mathrm{p} € \mathrm{~s} ; \mathrm{P}$, overlapping Paleozoic sedimentary rocks. Inserts indicate location of the district and area of the detailed geologic map (fig. 405.2).

much of the district underlain by the metagabbro belts is soil covered, and although the soil has been trenched to the bedrock at many places, large areas of potentially productive ground remain untouched.

Among methods tried for locating soil-covered gold veins, magnetic and self-potential electrical surveying over known veins gave very discouraging results. Soil analysis for arsenic along a few traverses, however, indicates that this method may be successful.
Figure 405.2 shows the geology of the test area, the traverse lines, and graphical representations of the varying arsenic content of the soil along the traverses. Soil samples of about 2 ounces each were taken by shovel from depths of 4 to 6 inches at intervals of 50 feet or less along each traverse. The arsenic determinations were made in the field by Janes using the Gutzeit method as modified by Almond (1953, p. 1766).

The metagabbro, andesite, and graywacke contain 9 to $22 \mathrm{ppm}$ (parts per million) arsenic; the soil over them contains 5 to $20 \mathrm{ppm}$. Samples representing a low-grade quartz vein, ore ( $1.5 \mathrm{oz}$ per ton gold), and an arsenopyrite-bearing dacite contained 600,350 , and $160 \mathrm{ppm}$ arsenic.

Traverses A, B, and C (fig. 405.2) extend uphill from soil-covered graywacke northward across part of the northern metagabbro belt. In general, the soil cover diminishes over the topographically higher areas. Arsenic anomalies of 50 to $60 \mathrm{ppm}$ occur in thin soil over areas where numerous small quartz veins cut the metagabbro. The gradients of arsenic concentration are steep on the uphill sides of the anomalies but tend to be more gentle on the down slope, suggesting that the arsenic, and probably the total anomalies as well, are slightly displaced downhill.

Traverse $D$ was made in the bottom of a valley that drains into what was rich placer ground. The arsenic profile appears to reflect the close proximity of the bedrock, which crops out on the east side of the valley. The peak concentration, about $30 \mathrm{ppm}$, is very close to bedrock exposed to the east, but no veins are exposed.

The results of this preliminary test seem very encouraging. In the test area the method has delineated a belt of rocks at least one-half mile long worthy of closer examination. No attempt was made to determine the gold content of the veins in this belt. That they are gold-bearing is almost certain inasmuch as gold is consistently associated with arsenopyrite in this district.

\section{REFERENCE}

Almond, Hy, 1953, Field method for determining of traces of arsenic in soils: Anal. Chemistry, v. 25, p. 1766-1767. 


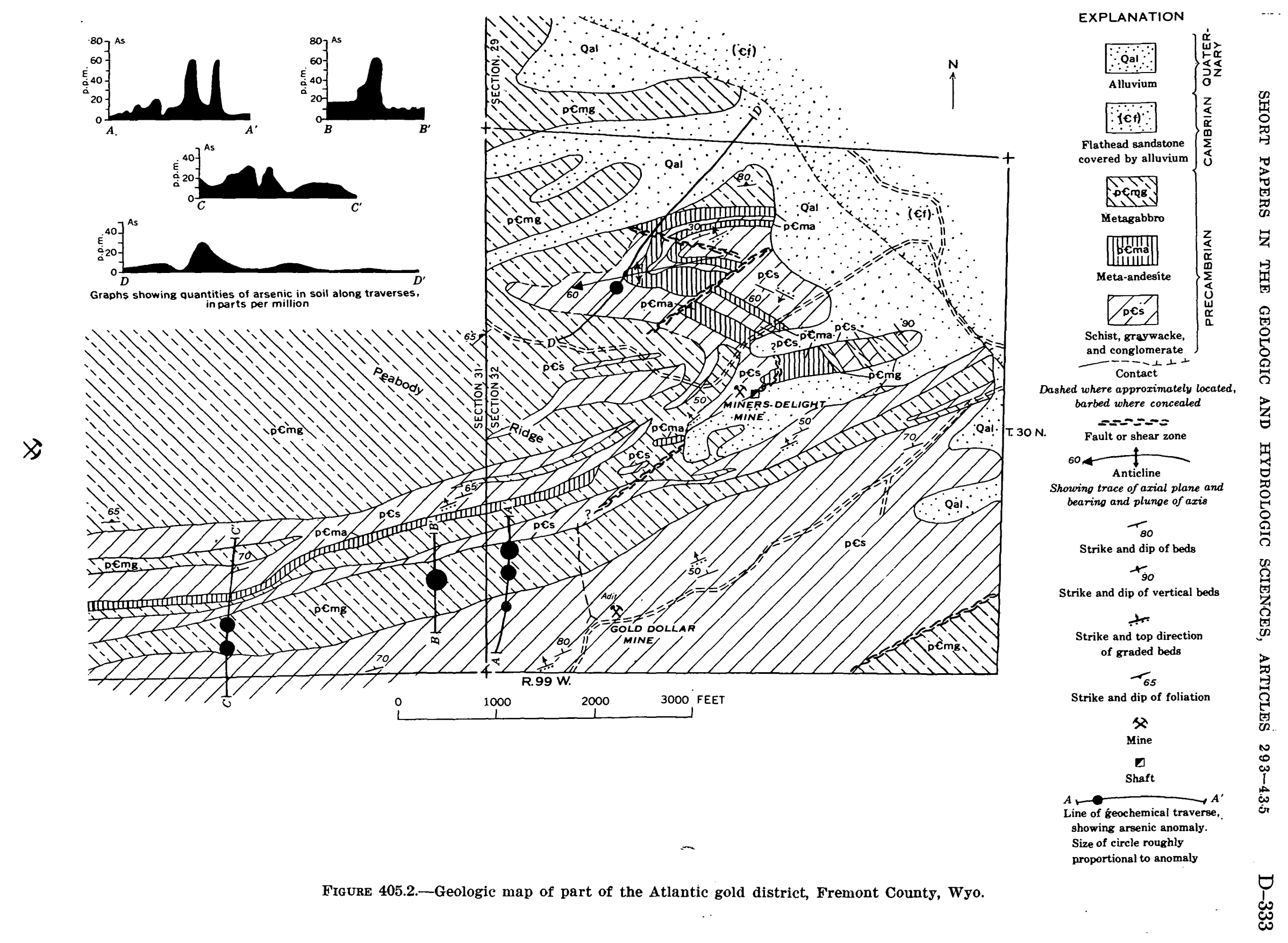




\title{
406. GEOGRAPHIC DISTRIBUTION OF MAJOR CONSTITUENTS IN STREAM WATERS OF THE WESTERN CONTERMINOUS UNITED STATES
}

\author{
By C. E. Roberson, Menlo Park, Calif.
}

Stream waters of the western conterminous United States have chemical characteristics that reflect their geologic and climatologic environments. Figure 406.1 is a graphic presentation of the chemical character of selected streams in the western States. The annual average quality at each station shown on the map is represented by two semicircles. The semicircle on the left shows the percentage composition of the principal anions (bicarbonate, sulfate, and chloride), that on the right depicts the cations (calcium, magnesium, and sodium plus potasșium). Each individual wedge represents the percentage of a particular anion or cation based on equivalents per million. The size of the circle indicates the concentration of solutes in tons per acrefoot ( $t$ per ac-ft).

The line drawn on the map labeled $\mathrm{HCO}_{3}-\mathrm{SO}_{4}$ emphasizes what is believed to be the most prominent characteristic noted in the distribution of the major elements. Generally, streams west of the line have bicarbonate as the principal anion, whereas those to the east have sulfate. Individual streams differ from the general pattern shown, but the exceptions among rivers for which detailed records are available are few. For example, parts of the Gila River in Arizona and the Pecos River in New Mexico have waters in which chloride is the major anion. Streams in mountainous areas have large percentages of bicarbonate, but become sulfate-dominant in their lower courses.

Of the sampling sites shown on figure 406.1 the Feather River in California and the Pecos River in. southeastern New Mexico illustrate extremes in percentage of bicarbonate. In the Pecos River, bicarbonate represents only about 3 percent of the total anions, but in the Feather River it makes up about 84 percent of the anions.

Calcium content is roughly equivalent to bicarbonate content in most rivers for which adequate long-term records are available. In many river waters calcium is the most abundant cation, and in several it makes up more than half of all the cations. The gypsiferous deposits in the Pecos basin are responsible for large amounts of calcium as well as of sulfate in the water of that river. There is no striking pattern in the geographic distribution of magnesium.

The highest concentrations of chloride in water of major streams studied are found in parts of the Gila and Pecos River basins. That the chloride in these waters is a result of solution of well-known halite deposits is indicated by the presence of nearly chemically equivalent amounts of sodium and of chloride. On the other hand, sodium concentrations are higher than chloride concentrations in most of the other rivers, indicating that sodium chloride is generally not the main source of sodium. Sodium and chloride are relatively more abundant in the waters of streams east of the line than in waters west of the line.

These deviations from chemical characteristics generally associated with many North American streams where bicarbonate is the principal anion (Clarke, 1924, p. 119), reflect a complex interaction of geologic and climatologic factors. The climatic factors include smaller amounts of precipitation in the eastern part of the area in figure 406.1, as well as higher rates of evaporation.

At a few places sulfate comes from bedded gypsum deposits, such as those in the basin of the Pecos River. Gypsum is doubtless a contributor of sulfate in other areas; however, minerals other than gypsum appear to be partly responsible for some high-sulfate waters such as the Powder and Bighorn Rivers in Wyoming and Montana, and some of the streams in eastern Utah and western Colorado. Here the calcium is notably deficient relative to sulfate rather than in balance as might be expected if only gypsum were being dissolved.

Waters in areas east of the line on figure 406.1 commonly have maximum sulfate concentrations ranging from 100 to more than $1,000 \mathrm{ppm}$ (parts per million). Certain exceptions in Colorado, New Mexico, Arizona, and Utah show the effects of higher elevations and greater relief which give rise to greater rainfall. Unusual geologic conditions might also affect these streams.

\section{REFERENCE}

Clarke, F. W., 1924, The data of geochemistry : U.S. Geol. Survey Bull. 770, 841 p. 


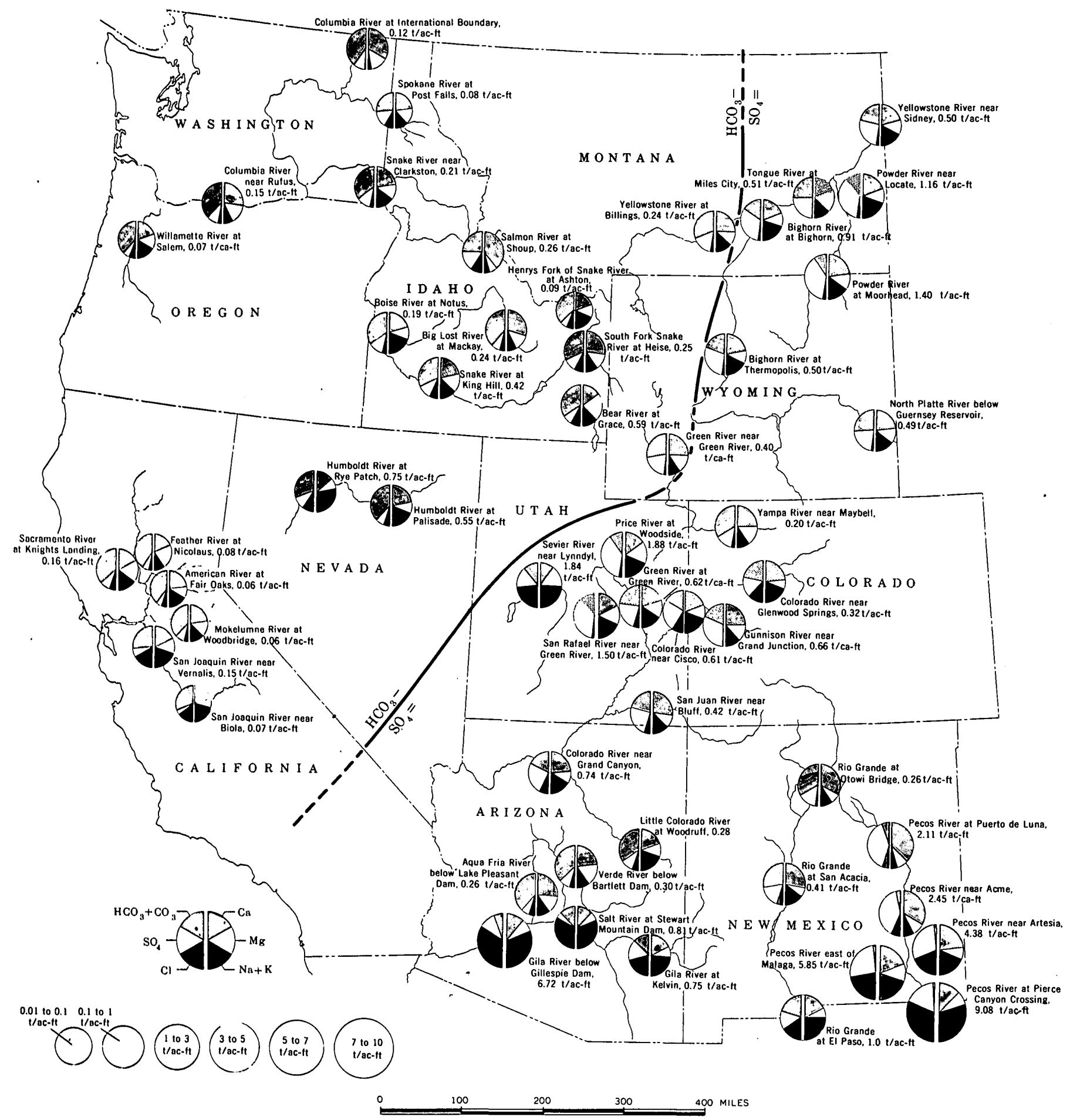

Fraure 406.1.-Map showing general chemical character of water in major rivers of the 11 western States. Concentration of solutes is given in tons per acre-foot ( $t$ per ac-ft). 


\title{
407. INTERACTION OF ANHYDRITE WITH SOLUTIONS OF STRONTIUM AND CESIUM
}

\author{
By Irving May, Marian Schnepfe, and Charles R. Naeser, Washington, D.C.
}

Storage or disposal of high-level radioactive waste solutions in cavities in salt deposits is being considered by the responsible government agencies. Strontium-90 and cesium- 137 are the most troublesome waste nuclides derived from reprocessing radioactive fuels. The interaction of these elements with anhydrite has been studied because anhydrite is commonly associated with the salt in evaporite deposits.

Anhydrite is one of the chief carriers of strontium in evaporite deposits and contains as much as 0.65 percent strontium (Noll, 1934); therefore, anhydrite might be expected to react with strontium. Celestite $\left(\mathrm{SrSO}_{4}\right)$ is appreciably less soluble in water than is anhydrite, its solubility at $20^{\circ} \mathrm{C}$ being $0.01 \mathrm{~g}$ per $100 \mathrm{ml}$ compared to $0.30 \mathrm{~g}$ per $100 \mathrm{ml}$ for anhydrite. Anhydrite would not be expected to react with cesium solutions.

\section{DESCRIPTION OF SAMPLES}

Initial experiments were conducted with natural anhydrite obtained from the U.S. Gypsum Company. An X-ray analysis by Daphne Ross of the Geological Survey showed that this anhydrite contained more than 10 percent gypsum; a Penfield water determination showed it to contain 6.24 percent water, corresponding to 30 percent gypsum. Confirmatory experiments were later conducted using a purer sample of anhydrite; this sample was from a core from Hutchinson County, Kans., obtained through the courtesy of W. B. Heroy, Geotechnical Corp., Dallas, Tex., and H. L. Parker, Oak Ridge National Laboratories, Oak Ridge, Tenn. The sample contained 0.52 percent water, corresponding to 2.5 percent gypsum.

Synthetic anhydrite samples were prepared by heating reagent grade calcium sulfate either at $900^{\circ} \mathrm{C}$ for 1 hour or at $400^{\circ} \mathrm{C}$ for 24 hours (Kelley and others, 1941). Complete conversion to anhydrite was confirmed by X-ray analysis. Most of the experimental work was done with synthetic anhydrite because of its greater purity.

\section{EXPERIMENTAL WORK}

\section{COLUMN EXPERIMENT}

A column experiment was run first to determine whether and how anhydrite takes up strontium. A sample of the U.S. Gypsum anhydrite (40 to 60 mesh) weighing $40 \mathrm{~g}$ was packed into a column with an inside diameter of $12 \mathrm{~mm}$. A solution containing $100 \mathrm{ppm}$ (parts per million) of strontium and a trace of free nitric acid as a stabilizer was passed over the anhydrite by downward flow at a rate of $5 \mathrm{ml}$ per hr. The strontium and calcium contents of the eluates, collected in four fractions, were determined with the flame photometer (table 407.1).

TABLE 407.1:-Column experiment with strontium solution and anhydrite

\begin{tabular}{|c|c|c|}
\hline Eluate fraction (ml) & $\begin{array}{l}\text { Strontium } \\
\text { (ppm) }\end{array}$ & $\underset{(p p m)}{\text { Calcium }}$ \\
\hline $0-5 \ldots$ & 37 & 450 \\
\hline $5-15^{1}$ & 18 & 430 \\
\hline $15-25 \ldots$ & 33 & 400 \\
\hline $25-35 \ldots$ & 28 & 400 \\
\hline
\end{tabular}

Column stood over weekend.

The strontium in the effluent ranged from 18 to 37 percent of the initial concentration. The strontium data do not support an exchange or absorption reaction. The calcium content of the effluent is a measure of the extent of solution of the sample.

Attempts to improve contact between solution and anhydrite by the use of finer material resulted in poor flow rates and channeling. Column studies were discontinued, therefore, in favor of batch experiments.

\section{BATCH EXPERIMENTS}

Strontium solutions were treated with anhydrite in stoppered flasks. Data for these experiments are shown in table 407.2. Most of these suspensions were stirred continuously with magnetic stirrers, which raised solution temperatures to about $40^{\circ} \mathrm{C}$. Experiments 8 and $8 \mathrm{a}$ were performed on a magnetic-stirrer hot-plate to insure a temperature exceeding the transition point of $40^{\circ} \mathrm{C}$, below which anhydrite suspended in water is converted to gypsum; these conditions thus ruled out the conversion of gypsum to anhydrite during the course of the experiment.

Three aliquots of resultant solutions were filtered and treated with fresh anhydrite to determine additional depletion of strontium from solution.

The rate of depletion of strontium from solution was also determined at room temperature. Anhydrite samples were agitated with strontium solutions on a mechanical shaker for periods ranging from 1 hour to 35 days. The results are shown on figure 407.1. 
SHORT PAPERS IN THE GEOLOGIC. AND HYDROLOGIC SCIENCES, ARTICLES 293-43:5

TABLE 407.2.-Batch experiments, strontium solutions with anhydrite

\begin{tabular}{|c|c|c|c|c|c|c|c|c|c|c|}
\hline Exporimont & $\begin{array}{c}\text { Type of } \\
\text { anhydritto }\end{array}$ & $\begin{array}{l}\text { Samplo } \\
\text { weight } \\
\text { (grams) }\end{array}$ & \multicolumn{3}{|c|}{ Contacting solution } & $\underset{\text { (hours) }}{\text { Contact time }}$ & $\begin{array}{l}\text { Approximate } \\
\text { temperature } \\
\text { (degrees } \\
\text { Centigrade) }\end{array}$ & \multicolumn{3}{|c|}{ Final solution } \\
\hline 1.. & $\mathbf{A}$ & 1 & 100 & 1. 7 & 100 & 18 & 40 & & 22 & 760 \\
\hline $2 \ldots$ & $\mathrm{B}$ & 1 & 100 & 1. 7 & 100 & 22 & 40 & 2.0 & 18 & 680 \\
\hline 4 & $\mathrm{~B}$ & 1 & 100 & $(2)$ & 100 & 23 & 40 & 10.8 & 15 & 940 \\
\hline $5 \ldots$ & $\mathrm{B}$ & 1 & 100 & $(3)$ & 100 & 23 & 40 & 1. 0 & 7 & 1,100 \\
\hline $6 \ldots \ldots$ & B & 5 & 100 & $(4)$ & 100 & 23 & 40 & 11. 2 & 34 & 1,600 \\
\hline & B & 1 & 100 & $(4)$ & 500 & 23 & 40 & 10. 7 & 33 & 2,300 \\
\hline & B & 1 & 100 & $(4)$ & 100 & 19 & 55 & $\ldots$ & 20 & 400 \\
\hline $8 a_{-}$ & B & 1 & $(5)$ & $\ldots$ & 20 & 19 & 55 & $\ldots$ & 20 & 375 \\
\hline
\end{tabular}

I A, U.S. Gypsum anhydrite (30 percent gypsum, -35 mesh); B, Synthetic anhydrite; C, Hutchinson anhydrite ( -35 mesh).

$8 \mathrm{gram} \mathrm{Na}_{2} \mathrm{SO}_{4}$, no froe acid.

81 milliliter $\mathrm{H}_{2} \mathrm{SO}_{4}$.

1 No freo ncid.

o Entiro filtrate, experiment 8 .

- Filtrate from experiment 9.

Filtrate from experiment 10.

To distinguish more conclusively between exchange and precipitation mechanisms, a final group of experiments was made in which three different weights of synthetic anhydrite were treated for 2 weeks in sealed ampoules with strontium and with cesium solutions adjusted to $\mathrm{pH} 7$. The ampoules were immersed in a constant temperature bath kept at $45^{\circ} \mathrm{C}$. Mixing was accomplished by thoroughly shaking the ampoules manually several times a day. Data for these experiments are given in table 407.3 .

\section{ANALYTICAL METHODS}

Strontium and calcium were determined with a Beckman DU flame photometer in the column experiment (table 407.1) and in batch experiments 1 to 8 a (table

TABLE 407.3.-Interaction of strontium and cesium with anhydrite

[Solution volumes $25 \mathrm{ml}, \mathrm{pH} 7,45^{\circ} \mathrm{C}$, contact timo 2 weeks]

\begin{tabular}{|c|c|c|c|c|}
\hline \multirow{2}{*}{$\begin{array}{l}\text { Woight of } \\
\text { Anhydrito } \\
\text { (g) }\end{array}$} & \multicolumn{2}{|c|}{ Strontium concontration } & \multicolumn{2}{|c|}{ Cesium concentration } \\
\hline & $\underset{(\mathrm{ppm})}{\text { Initial }}$ & $\underset{(\mathrm{ppm})}{\text { Final }}$ & $\underset{(\mathrm{ppm})}{\text { Initial }}$ & $\underset{(\mathrm{ppm})}{\text { Final }}$ \\
\hline 0.5 & 80 & 33 & & \\
\hline .5 & & & 80 & 80 \\
\hline 1. 0 & 80 & 30 & 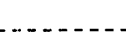 & \\
\hline 1. 0 & & & 80 & 79 \\
\hline 1. 5 & 80 & 24 & & - - \\
\hline 1. 5 & D & .... & 80 & 79 \\
\hline
\end{tabular}

407.2). A wavelength of $461 \mathrm{~m} \mu$ and the photomultiplier detector were used; under these conditions 370 ppm calcium did not interfere with the determination of $10 \mathrm{ppm}$ strontium. Calcium was determined at a wavelength of $554 \mathrm{~m} \mu$.

All other determinations of strontium were made by $\beta$-counting techniques using strontium- 89 as a tracer. Aliquots of solutions were evaporated in aluminum planchets and their activities determined with a GeigerMüller counter. The amounts of calcium dissolved during the experiments did not have a significant $a b$ sorption effect on the $\beta$-emission of strontium.

Cesium determinations were made with a scintillation counter using cesium-137 as a tracer.

\section{SUMMARY OF RESULTS}

Contact of solutions containing $100 \mathrm{ppm}$ of strontium with anhydrite resulted in final solution concentrations of about 20 to $35 \mathrm{ppm}$ strontium. Equilibrium at $40^{\circ} \mathrm{C}$ was apparently achieved in less than 1 day (table 407.2, experiments 2, 8a, 9a, and 10a).

At room temperature, two weeks were required for equilibrium to be reached in the batch experiments (fig. 407.1). However, protracted treatment at room temperature is complicated by the conversion of appreciable quantities of anhydrite to gypsum, as confirmed by $\mathrm{X}$ ray analysis (M. L. Lindberg, oral communication, $1960)$. 


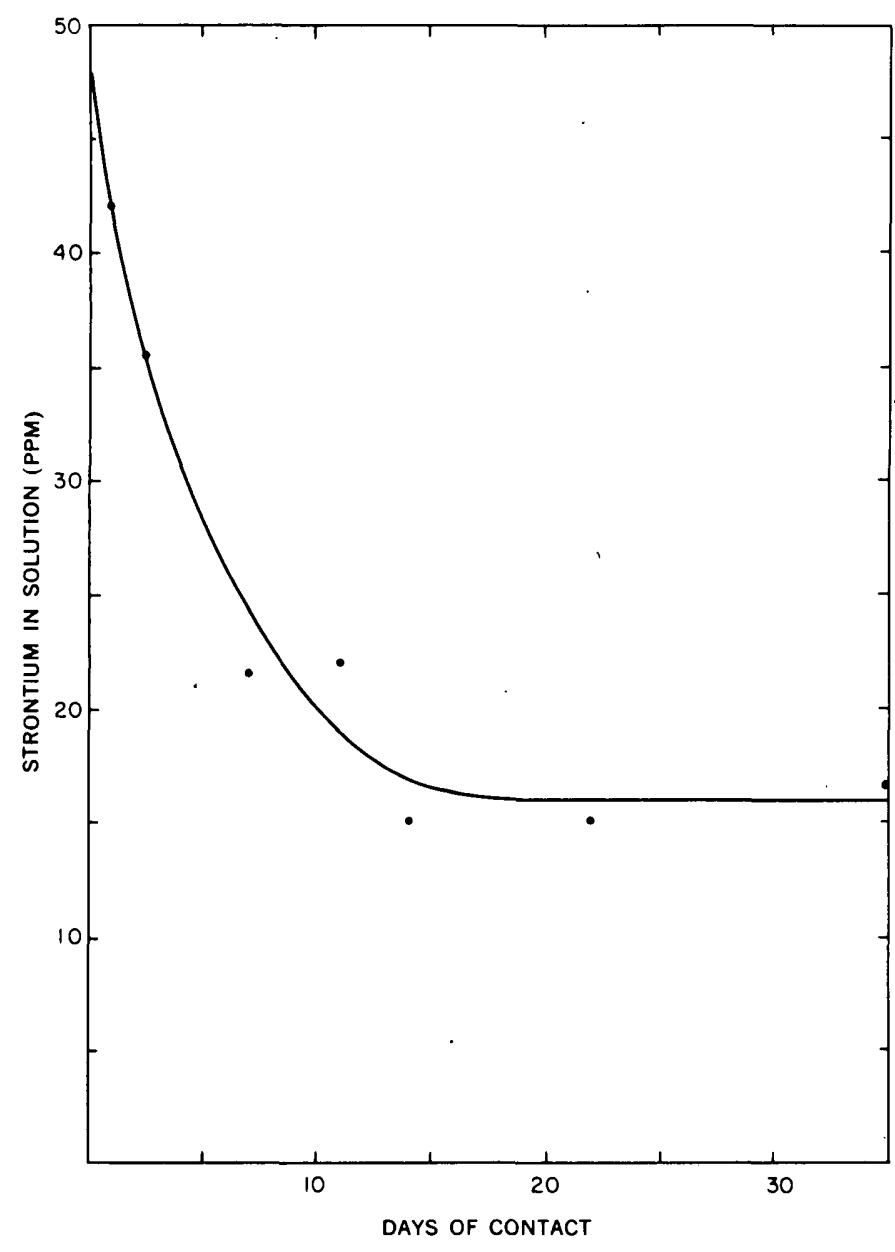

Fraure 407.1.-Rate of reaction of strontium solutions with anhydrite. Experiments conducted at room temperature using $0.7907 \mathrm{~g}$ of synthetic anhydrite in $50 \mathrm{ml}$ of solution containing $50 \mathrm{ppm}$ of strontium.
The mechanism of the reaction of strontium solutions with anhydrite appears to be mainly precipitation of strontium sulfate, the sulfate being furnished by the solution of some anhydrite. Sorption reactions are not important mechanisms, as indicated by several experiments where the reduction of strontium concentration in solution showed little dependence on increasing quantities of anhydrite. Thus, passage through a column of $40 \mathrm{~g}$ of anhydrite did not yield breakthrough data typical of sorption reactions. Experiments 8 to 10a of table 407.2 and the data for strontium in table 407.3 also support this conclusion.

As anticipated, no significant reaction takes place between cesium solutions and anhydrite.

From these experiments, strontium in excess of 35 ppm in solutions as acid as pH 1.7 could be expected to be immobilized on contact with evaporites containing anhydrite. In the absence of phosphate or carbonate ions which form extremely insoluble strontium compounds, it is unlikely that the strontium solutions would be decontaminated to a level below 10 to $20 \mathrm{ppm}$ strontium. No significant change in cesium concentrations would occur.

Anhydrite in salt deposits could cause local concentrations of strontium derived from radioactive waste solutions. These concentrations, however, would not necessarily interfere with the storage of waste solutions in salt deposits.

\section{REFERENCES}

Kelley, K. K., Southard, J. C., and Anderson, C. T., 1941, Thermodynamic properties of gypsum and its dehydration products: U.S. Bur. Mines Tech. Paper 625, p. 6 .

Noll, W., 1941, Geochemie des Strontiums mit bemerkungin zur Geochemie des Bariums: Chemie der Erde, v. 8, p. 507.

408. SOME ALTERATION REACTIONS IN THE SYSTEM $\mathrm{Na}_{2} \mathrm{O}-\mathrm{Al}_{2} \mathrm{O}_{3}-\mathrm{SiO}_{2}-\mathrm{H}_{2} \mathrm{O}$

By J. J. Hemlex, Charles Meyer, and D. H. Richter, Denver, Colo., University of California, Berkeley, Calif., and Hawaii Volcano Observatory, Hawaii

Hydrolysis equilibria involving albite and its decomposition products in an aqueous chloride environment at elevated temperatures and pressures have been investigated. Sealed platinum tubes contained in rod bombs were used in the experimental procedure. The bombs were rapidly quenched at the end of each run. At high temperatures the reactions observed are the alteration of albite to paragonite plus quartz, and the decomposition of paragonite to pyrophyllite in the presence of quartz according to the equations

$$
\begin{array}{r}
3 / 2 \mathrm{NaAlSi}_{3} \mathrm{O}_{8}+\mathrm{H}^{+} \leftrightharpoons 1 / 2 \mathrm{NaAl}_{3} \mathrm{Si}_{3} \mathrm{O}_{10}(\mathrm{OH})_{2}+3 \mathrm{SiO}_{2}+ \\
\mathrm{Na}^{+} \\
\mathrm{NaAl}_{3} \mathrm{Si}_{3} \mathrm{O}_{10}(\mathrm{OH})_{2}+\mathrm{H}^{+}+3 \mathrm{SiO}_{2} \leftrightharpoons 3 / 2 \quad \mathrm{Al}_{2} \mathrm{Si}_{4} \mathrm{O}_{10}(\mathrm{OH})_{2} \\
+\mathrm{Na}^{+}
\end{array}
$$

At lower temperatures, the corresponding reactions 
are the decomposition of albite to montmorillonite and the alteration of montmorillonite to kaolinite. The reactions may be illustrated by the following equations, although the composition of montmorillonite involved in the equilibria has not been established:

$$
\begin{array}{r}
1.17 \mathrm{NaAlSi}_{3} \mathrm{O}_{8}+\mathrm{H}+\stackrel{\leftrightarrows}{\leftrightarrows} 0.5 \mathrm{Na}_{0.33} \mathrm{Al}_{2.33} \mathrm{Si}_{3.67} \mathrm{O}_{10}(\mathrm{OH})_{2}+ \\
1.67 \mathrm{SiO}_{2}+\mathrm{Na}^{+}
\end{array}
$$

$3 \mathrm{Na}_{0.33} \mathrm{Al}_{2.33} \mathrm{Si}_{3.67} \mathrm{O}_{10}(\mathrm{OH})_{2}+\mathrm{H}^{+}+3.5 \quad \mathrm{H}_{2} \mathrm{O} \leftrightharpoons 3.5 \quad \mathrm{Al}_{2} \mathrm{Si}_{2}$

$$
\mathrm{O}_{8}(\mathrm{OH})_{4}+4 \mathrm{SiO}_{2}+\mathrm{Na}^{+}
$$

The silica phase that crystallizes spontaneously in the lower temperature reactions is generally cristobalite.

Stability relations are shown on figure 408.1 in terms of the molar $\mathrm{NaCl} / \mathrm{HCl}$ ratio or equilibrium quotient of the reaction and the temperature. The relations are similar to those found in the system $\mathrm{K}_{2} \mathrm{O}-\mathrm{Al}_{2} \mathrm{O}_{3}-\mathrm{SiO}_{2}-$ $\mathrm{H}_{2} \mathrm{O}$ (Hemley, 1959), which is indicated by dotted lines on figure 408.1. The concentrations of $\mathrm{NaCl}$ and $\mathrm{HICl}$ in the reacted solutions are the principal chemical data derived from the experiments. The concentrations of aqueous silica and alumina are not involved in the equilibrium constants for the above reactions, although they are of interest from the standpoint of min-

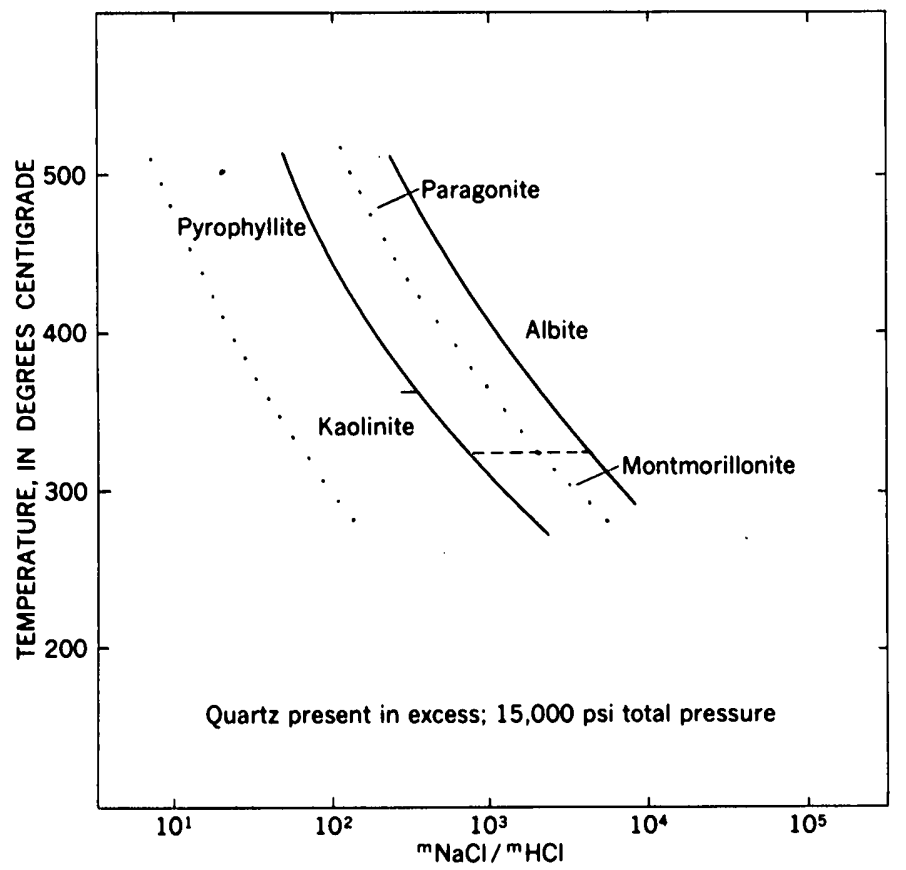

Froure 408.1.-Some stability relations in the system $\mathrm{Na}_{2} \mathrm{O}$ $\mathrm{Al}_{3} \mathrm{O}_{3}-\mathrm{SiO}_{3}-\mathrm{H}_{4} \mathrm{O}$ as a function of temperature and the $\mathrm{m} \mathrm{NaCl} / \mathrm{m} \mathrm{HCl}$ ration. Corresponding relations in the terms of $\mathrm{m} \mathrm{KCl} / \mathrm{m} \mathrm{HCl}$ are indicated by dotted lines for the system $\mathrm{K}_{2} \mathrm{O}-\mathrm{Al}_{2} \mathrm{O}_{3}-\mathrm{SiO}_{2}-\mathrm{H}_{2} \mathrm{O}$. The field of $\mathrm{K}-\mathrm{mica}$ is between the dotted curves, with $\mathrm{K}$-feldspar at higher values of $\mathrm{KCl} / \mathrm{HCl}$ and pyrophyllite and kaolinite at lower values. eral solubilities under the given conditions of temperature, pressure, and electrolyte concentration.

As indicated on figure 408.1, the fields of stability of Na-mica and montmorillonite are much narrower in terms of the $\mathrm{NaCl} / \mathrm{HCl}$ ratio than the corresponding $\mathrm{K}$-mica field in terms of the $\mathrm{KCl} / \mathrm{HCl}$ ratio in the analogous $\mathrm{K}_{2} \mathrm{O}$ system. Although slightly higher alkali/ $\mathrm{H}^{+}$ratios are needed to stabilize albite than are required for $\mathrm{K}$-feldspar, much higher alkali $/ \mathrm{H}^{+}$ratios are needed to stabilize paragonite than are required for muscovite. At $400^{\circ} \mathrm{C}$ the equilibrium quotients for the decomposition of $\mathrm{K}$-mica and $\mathrm{K}$-feldspar in the presence of excess quartz are respectively $10^{1.35}$ and $10^{2.7}$. In the soda system the values for Na-mica and Na-feldspar are respectively $10^{2.25}$ and $10^{3.0}$. The experimental uncertainty for these values is about $10^{0.2}$. Reproducible data were more difficult to obtain in this investigation than with the corresponding $\mathrm{K}_{2} \mathrm{O}$ system, especially along the albite hydrolysis curve at temperatures lower than about $400^{\circ} \mathrm{C}$. This was apparently due to poorer crystallization of phases in the reactions, as well as to experimental difficulties involved in quenching.

Experimental decomposition temperatures rather than true stability limits, which are probably somewhat lower, are shown by broken lines for the sodium montmorillonite and kaolinite (fig. 408.1). The values indicated are for $4 \mathrm{~m} \mathrm{NaCl}$ solutions. In more dilute solutions the decomposition temperatuers are higher because of the increased activity of water under these conditions. The temperatures are increased $20^{\circ}$ to $30^{\circ} \mathrm{C}$ in water completely free of electrolytes. The decomposition product of the montmorillonite obtained in the experimental work is a mixed-layer sodium montmorillonite-mica. This phase becomes increasingly rich in the mica component at higher temperatures. Also, with some paragonite present initially in the charge, montmorillonite is converted largely or completely to sodium mica. Mixtures of paragonite and mixed-layer phase show much slower conversion to mica, and results are generally inconclusive. However, from the foregoing evidence it is likely that paragonite is the thermodynamically stable phase over much, and possibly all, of the field of formation of the mixed-layer material.

The molar $\mathrm{NaCl} / \mathrm{HCl}$ ratio for the reactions is related to the equilibrium constant by the expression:

$$
\mathrm{K}=\frac{\gamma \pm_{\mathrm{NaCl}} \mathrm{m}_{\mathrm{NaCl}}}{\gamma \pm_{\mathrm{HCl}} \mathrm{m}_{\mathrm{HCl}}}=\frac{\mathrm{a}_{\mathrm{Na}}{ }^{+}}{\mathrm{a}_{\mathrm{H}^{+}}}
$$

where $\gamma$ is the activity coefficient and $a$ is the activity. For reaction (4) water also appears in the expression. The experimental data cannot be treated rigorously because of the lack of appropriate thermodynamic information at elevated temperatures and pressures; how- 
ever, by analogy with the system $\mathrm{K}_{2} \mathrm{O}-\mathrm{Al}_{2} \mathrm{O}_{3}-\mathrm{SiO}_{2}-\mathrm{H}_{2} \mathrm{O}$ (Hemley, 1959), the experimental equilibrium quotients probably approximate within a factor of 5 the true equilibrium constants of the reactions to temperatures of perhaps $350^{\circ} \mathrm{C}$ or higher. An important point is that strong electrolytes such as $\mathrm{HCl}, \mathrm{KCl}$, and $\mathrm{KOH}$ remain quite strongly ionized at moderate temperatures $\left(300^{\circ}\right.$ to $\left.400^{\circ} \mathrm{C}\right)$ and fairly high pressures $(1,000$ atmospheres). Ionization decreases gradually with increase in temperature, but the three electrolytes are affected similarly and are of comparable strength under these conditions (Franck, 1956).

Although the present study involves the use of strong acids and electrolytes, the results have general application to geologic processes. The equilibrium constants of reactions and the ratios of certain ion constituents fundamentally control mineral stability relations in alteration systems regardless of the particular composition or degree of acidity of the altering solutions. However, the amount of reaction, as distinct from the kind of reaction, depends upon absolute concentrations or the availability of reactants.

The experimental results are valuable in the interpretation of field relations in hydrothermally altered rocks. The decomposition of plagioclase results in the formation of kaolinite rather than montmorillonite at low $\mathrm{Na}^{+} / \mathrm{H}^{+}$ratios. This agrees with field alteration patterns in which argillized wall rock characteristically shows dominant kaolinite and lower $\mathrm{Na}$ content closer to the vein, and montmorillonite and higher $\mathrm{Na}$ content farther out.

The relation of argillization to processes of sericitic alteration cannot be evaluated properly until the more complex system including $\mathrm{CaO}$ has been investigated. However, the greater susceptibility of plagioclase, compared with $\mathrm{K}$-feldspar, to decomposition by hydrolysis is noteworthy. The source of potassium in rocks that have been hydrothermally altered to sericite was, in some rocks, the release of $\mathrm{K}^{+}$by the sericitization of orthoclase, whereas in other rocks $\mathrm{K}^{+}$was demonstrably added but orthoclase was not altered or was only partly altered (Meyer and Hemley, 1959). The formation of sericite during the alteration of plagioclase, without the breakdown of $\mathbf{K}$-feldspar, does not necessarily require alteration by solutions enriched in potassium. Selective decomposition of plagioclase would result in a decrease in $\mathrm{H}^{+}$and an increase in the ratio of $\mathrm{K}^{+} / \mathrm{H}^{+}$as well as $\mathrm{Na}^{+} / \mathrm{H}^{+}$in solution. A point in the muscovite field (fig. 408.1) represents a solution of a given $\mathrm{K}^{+} / \mathrm{H}^{+}$ratio which would undergo a continued diminution of the $\mathrm{H}^{+}$ activity as the solution migrates through a plagioclasebearing rock. This would tend to increase the $\mathrm{K}^{+} / \mathrm{H}^{+}$ ratio within the muscovite field and give rise to sericitization of plagioclase, with or without the destruction of orthoclase. In some rocks the $\mathrm{K}^{+} / \mathrm{H}^{+}$ratio might rise as high as the $\mathrm{K}$-feldspar stability field as a result of such a process, with possible replacement of plagioclase by K-feldspar.

On the other hand, at sufficiently low activities of $\mathrm{K}^{+}$ relative to $\mathrm{Na}^{+}$and other cations, montmorillonite rather than sericite would be produced; however, stability relations and fields of formation involving montmorillonite and $\mathrm{K}-\mathrm{Na}$ mica, both of which are of variable composition, are not yet defined.

\section{REFERENCES}

Franck, E. U., 1956, Hochverdichteter wasserdamf-I, Electrolytische leitfahigkeit in $\mathrm{KCl}-\mathrm{H}_{2} \mathrm{O}$ losungen bis $700^{\circ} \mathrm{C}$; II, Ion dissoziation von $\mathrm{KCl}$ in $\mathrm{H}_{2} \mathrm{O}$ bis $750^{\circ} \mathrm{C}$; III, Ion dissoziation von $\mathrm{HCl}, \mathrm{KOH}$, und $\mathrm{H}_{2} \mathrm{O}$ in uberkritischem wasser: Zeitschr. Physik. Chem., v. 8, p. 92-206.

Hemley, J. J., 1959, Some mineralogical equilibria in the system $\mathrm{K}_{2} \mathrm{O}-\mathrm{Al}_{2} \mathrm{O}_{3}-\mathrm{SiO}_{2}-\mathrm{H}_{2} \mathrm{O}$ : Am. Jour. Sci., v. 257, p. 241-270.

Meyer, Charles, and Hemley, J. J., 1959, Hydrothermal alteration in some granodiorites, in Swineford, Ada, ed., Clays and clay minerals-Proceedings of the 6th National Conference on Clays and Clay Minerals, Berkeley, California, Aug. 19-23, 1957 : Internat. Ser. Mons. Earth Sci., no. 2, Pergamon Press, London.

\title{
409. A PROPOSAL FOR CLARIFYING THE USE OF PLUTONIC CALC-ALKALIC ROCK NAMES
}

\author{
By Anna Hietanen, Menlo Park, Calif.
}

Because the common plutonic rock names such as granite, quartz monzonite, tonalite, and others are frequently used in the literature to represent slightly different compositional fields, each author should inform the reader in some simple effective way (for example, in graphic illustration) of the range of some of the major constituents in the rock types of his area. Because many common calc-alkalic rocks show systematic variation in their feldspar content and because some of the groups differ only in this respect, a ternary dia- 
gram with albite, orthoclase, and anorthite at the three corners seems well suited for the purpose. For example, the feldspar content of the igneous rocks from the northwestern part of the Idaho batholith was successfully used as a basis for the subdivision of large petrologic groups into smaller units. Using the new petrochemical calculations based on molecular proportions by Niggli (1936) and further developed by Barth $(1952,1959)$ and Eskola (1954), the feldspar content is expressed in terms of molecular norms. It is customary to illustrate the normative feldspar content in the OrAb-An diagram.

The molecular norms of the feldspars in 23 analyzed samples of rocks of the northwestern part of the Idaho batholith are shown as dots on figure 409.1. For a few analyzed rocks the weight norm is shown by a cross connected to the corresponding molecular norm with a short line. Weight norms plot only slightly farther

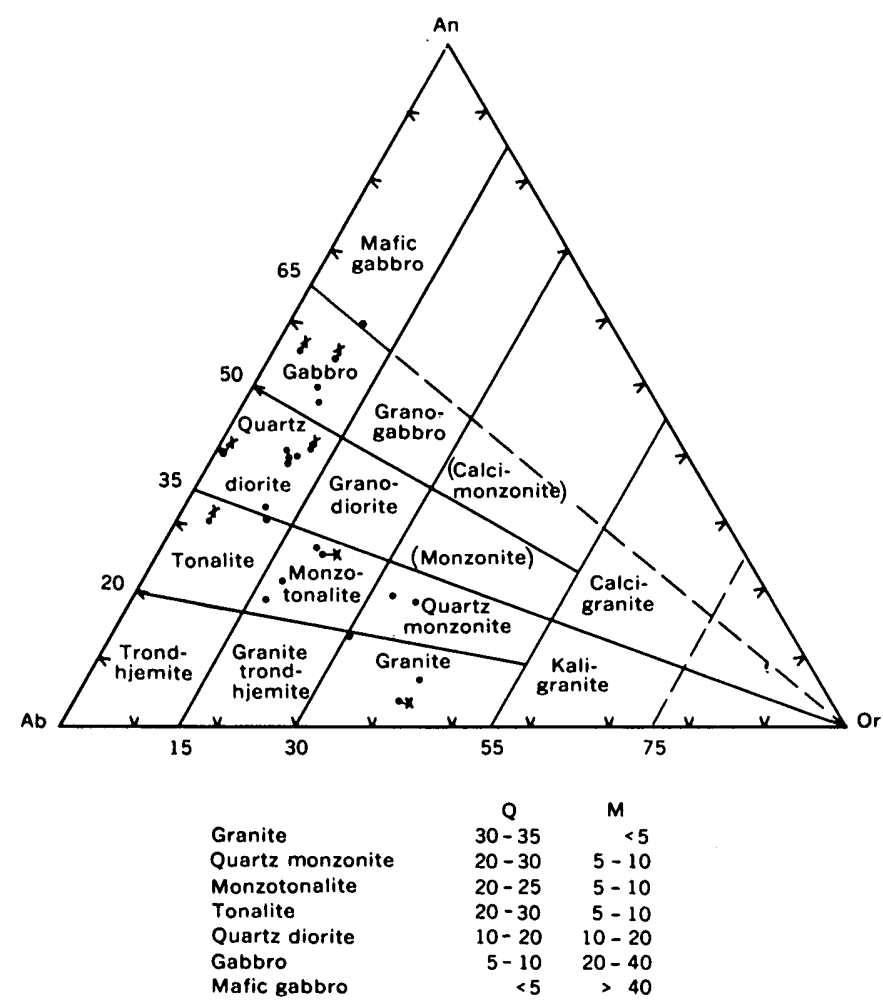

Fraure 409.1.-Ternary diagram showing the normative feldspar content of rocks from the Idaho batholith, and subdivision of some common calc-alkalic rocks. Ab, Or, and An refer to the molecular norms of albite, orthoclase, and anorthite. Dots refer to the molecular norms and crosses to the weight norms of rocks of the Idaho batholith. Ranges of $Q$ and $M$ from a ternary diagram for molecular norms of quartz (Q), feldspar (F), and femic constituents (M) of the same rocks are shown above. In most rocks $Q$ decreases and $M$ increases toward the An corner. Monzonite and calcimonzonite contain very little or no quartz. from the albite corner than the corresponding molecular norms. The ranges of quartz $(\mathrm{Q})$ and of femic constitutents (M) in several subunits such as quartz monzonite, monzotonalite, and tonalite are about equal, but the feldspar content is different. This ternary diagram (fig. 409.1) can be used successfully, therefore, to illustrate the petrologic classification. The fact that the diagram does not show an overall systematic change in the quartz and femic constituents does not destroy its usefulness because the feldspar composition can be used independently of the quartz and femic constituents to establish the subunits. For completeness the ranges of $\mathrm{Q}$ and $\mathrm{M}$ in individual rock types are tabulated below the diagram. The field occupied by the igneous rocks can be subdivided in such a manner that each subfield contains plots for only one petrologic rock type. This is done by connecting the points of suitable anorthite contents on the Ab-An line to the orthoclase corner (tielines) and drawing dividing lines parallel to the Ab-An line. The composition of plagioclase along each tieline that joins a point along the $\mathrm{Ab}$-An line to the orthoclase corner is constant. Thus, the range of the anorthite content of the plagioclase in rocks whose molecular norms plot between two tie-lines, such as trondhjemite, granite-trondhjemite, and granite stays within the same limits, but the amount of orthoclase increases from left to right. The dividing lines parallel to the Ab-An side give the range of normative orthoclase in various rock types. Because a part of the potassium enters into the biotite structure, the relative amount of modal orthoclase in the biotite-bearing rocks is smaller than the normative orthoclase shown on figure 409.1.

The tie-line drawn through $\mathbf{A n}_{35}$ divides the potassium-poor intermediate rocks that have been called synonymously quartz diorite and tonalite into two groups. The name quartz diorite is reserved, in this subdivision, for the more mafic group that contains more calcic plagioclase $\left(\mathrm{An}_{35-50}\right)$ and normally hornblende and biotite. The name tonalite is used for the more silicic group in which plagioclase is generally $\mathrm{An}_{25-35}$ and in which biotite is the only dark constituent.

The intermediate group between tonalite and quartz monzonite is called monzotonalite. In Idaho the monzotonalitic composition is common among the hypabyssal porphyritic dikes which cut the country rocks of the quartz monzonite batholith. Tonalite occurs as small intrusive bodies and as a metasomatic contact facies near many quartz diorite bodies. Granodiorite in this classification is reserved, as customary, for the potassium feldspar-bearing quartz diorite.

The position of the tie-lines and dividing lines were chosen as best suited for the rocks of the Idaho batholith and can be easily modified if necessary for other 
regions. It is also considered that some large groups without a clear break in the mineral content and texture should not be subdivided in spite of a spread of their feldspar content outside of a singular subfield on figure 409.1. Because the plotted positions of the weight norms are only slightly different from those of the molecular norms, the same diagram can be used successfully for the weight norms, or a similar diagram can be constructed for the mode.

\section{REFERENCES}

Barth, T. F. W., 1952, Theoretical petrology : New York, Wiley and Sons, $387 \mathrm{p}$.

-1959, Principles of classification and norm calculations of metamorphic rocks: Jour. Geology, v. 67, p. 135-152.

Eskola, Pentti, 1954, A proposal for the presentation of rock analyses in ionic percentage: Acad. Sci. Fennicae Annales, A. III, $38,15 \mathrm{p}$.

Niggli, Paul, 1936, Uber molecularnormen zur Gesteinsberechnung: Schweizer. Mineralog. Petrogr. Mitteilungen., v. 16, p. 295-317.

\title{
410. ORIGIN OF MOTTLED STRUCTURE IN BEDDED CALCIUM SULFATE
}

\author{
By C. F. Withington, Washington, D.C.
}

Many deposits of bedded gypsum or anhydrite have a mottled structure that has received little attention from geologists. This structure has been observed in deposits ranging in age from Silurian to Pleistocene.

The mottled structure may or may not accompany the more common laminated structure. An excellent example of typical laminated gypsum in the Fort Dodge formation (McGee, 1884) of Permian(?) age at Fort Dodge, Iowa is shown on figure 410.1. The deposit is as much as 8 feet thick and lies under a mantle of glacial drift. The gypsum is white to light gray, coarsely crystalline, in layers that range from about 1 inch to as much as 3 feet in thickness. The layers are separated from each other by very thin clay seams. The gypsum consists of thin laminae, that can be seen best in the weathered rock as alternating parallel white

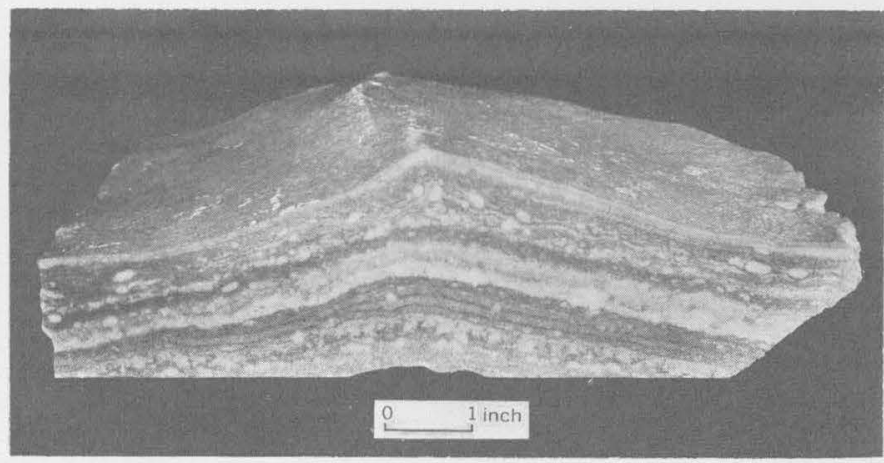

Figure 410.1.-Laminated gypsum, Fort Dodge formation (Permian(?) age), Fort Dodge, Iowa. Sedimentary structure is a ripple mark. Distortion of laminae is due to penecontemporaneous deformation, compaction of sediments and possibly to expansion of anhydrite on hydration to gypsum. and gray bands ranging from about $1 \mathrm{~mm}$ to as much as $10 \mathrm{~mm}$ in thickness, and averaging about $3 \mathrm{~mm}$. The white laminae, which generally are the thicker, consist of nearly pure gypsum. In the darker laminae the gypsum is accompanied by small amounts of silt, organic matter, calcite, and limonite. Nodules of white gypsum as much as $4 \mathrm{~mm}$ in diameter are scattered through the rock; one may infer that these were formed at the time of sedimentation because the laminae are bent by compaction below the nodules, but not above.

Laminated gypsum contrasts markedly with the mottled gypsum, an example of which, shown on figure 410.2 , is from Silurian rocks east of Port Clinton, Ottawa County, Ohio. Calcium sulfate is seattered through about 460 feet of the Tymochtee dolomite as beds and as nodules in dolomitic shale. The calcium sulfate is in the form of gypsum from the surface down to about 80 feet, where it gives way to anhydrite. The shale beds that contain the nodules are as much as 10

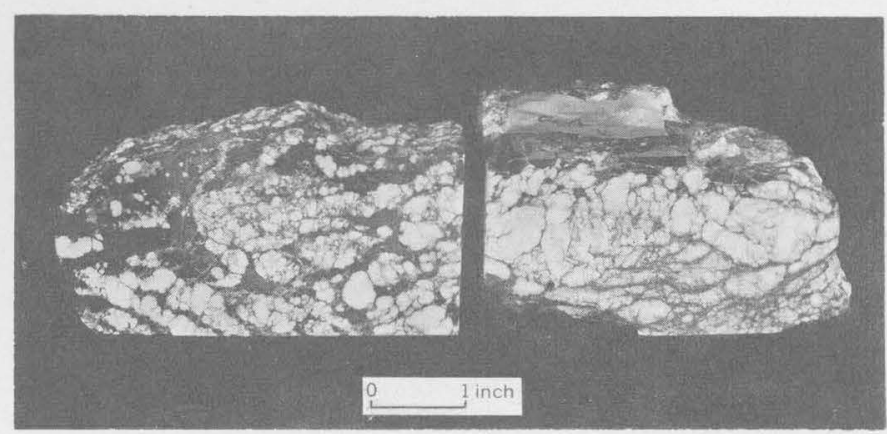

Frgure 410.2.-Mottled Silurian gypsum from Ottawa County, Ohio. Calcium sulfate appears to have grown in dolomitic mud in bottom sediments. Small veins of secondary gypsum formed during hydration of anhydrite to gypsum. 
feet thick. In thin section, a nodule of gypsum cuts across undisturbed beds of silt. In places, the beds of silt bend around both the top and bottom of the nodules. The contact between the gypsum and the silt is sharp, and little silt can be found within the individual nodules. The nodules are made up of very fine crystals of gypsum and have a feathery texture. Near the edges of some of the nodules, the crystals become coarser and may be pseudomorphic after crystals that probably were originally anhydrite. Several gypsum crystals replace each anhydrite crystal.

Another example of mottled gypsum is east of Feldman, Pinal County, Ariz., about 9 miles south of Winkelman. These beds are among the youngest in which the mottling has been observed. The gypsum is in the Gila group (middle(?) Tertiary to Pleistocene) in at least 6 beds that range in thickness from less than 2 feet to as much as 8 feet. The beds crop out for about a mile along the east side of the San Pedro River, and $\operatorname{dip} 5^{\circ}$ to $8^{\circ} \mathrm{E}$. The gypsum is aphanitic, white, and compact, and is mottled with thin siltstone seams (fig. 410.3). The gypsum beds are separated from each other by $\tan$ gypsiferous siltstone beds about 2 feet thick, which carry nodules of gypsum as much as 1 inch in diameter in a matrix of siltstone (fig. 410.4).

Dark rims of compacted mud as much as $1 \mathrm{~mm}$ thick surround the gypsum nodules. Microscopically the gypsum is in finely crystalline masses that distort the bedding of the siltstone. No anhydrite or other salts were noted in samples from this deposit.

The origin of laminated gypsum seems clear cut. Udden (1924) was the first to recognize that the laminae resulted from eyclical (probably annual) variations in the percentage of calcium sultate in the basin of deposition. These changes, which affected the rate of crys-

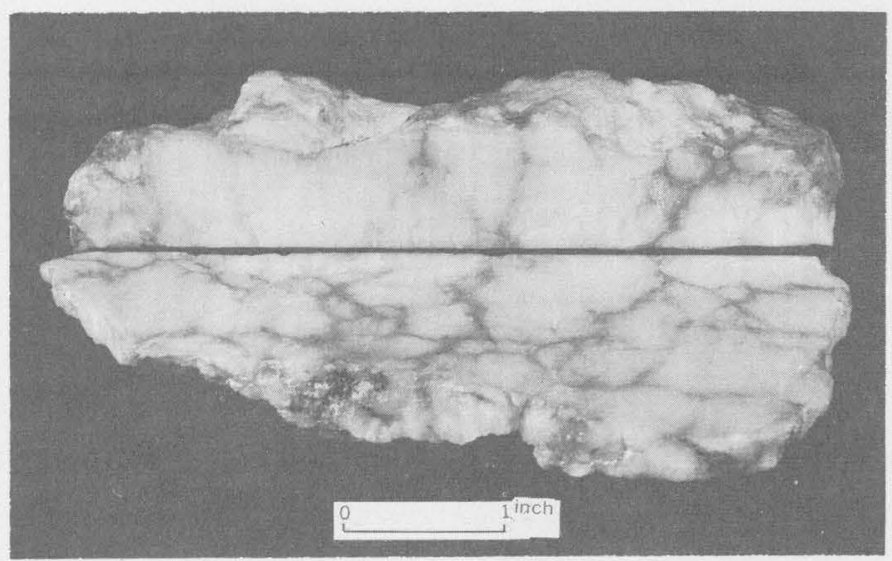

Figure 410.3.-Mottled gypsum from Pleistocene lake bed, Pinal County, Ariz. White aphanitic gypsum is mottled with thin brown siltstone seams. Picture shows two surfaces cut at right angles: bedding surface (below black line), and vertical surface (above black line).

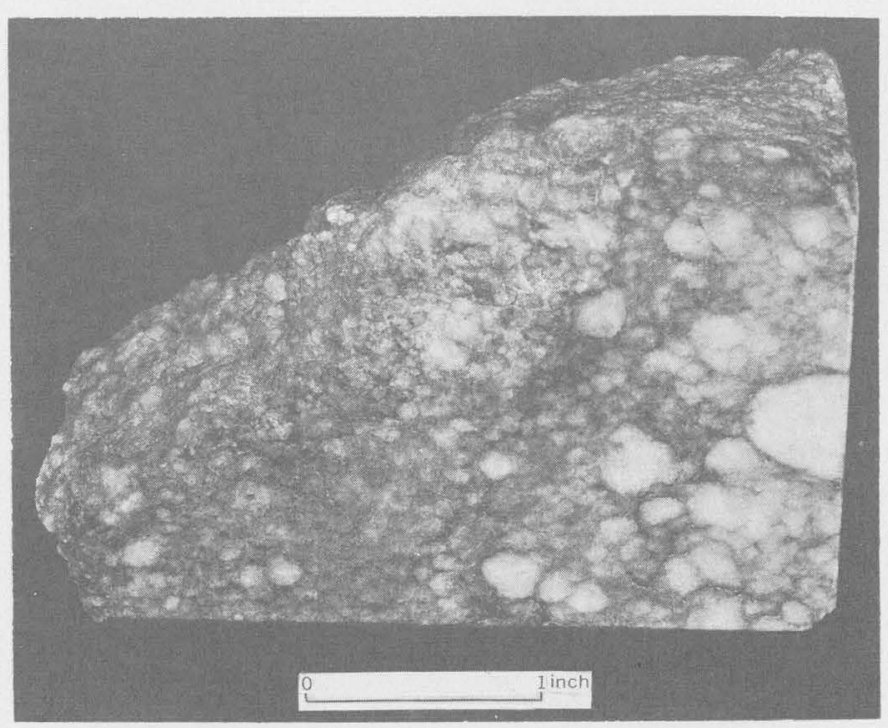

Figure 410.4.-Mottled gypsiferous siltstone from Pleistocene lake bed, Pinal County, Ariz. The gypsum has grown in a matrix of silt. Dark rims around white gypsum nodules are compacted silt.

tallization of calcium sulfate, were brought on periodically by increases in the amounts of calcium carbonate, clastic grains, and bituminous material carried into the basin by water of low salinity.

The origin of mottled gypsum is less certain. R. T. Hazzard, as quoted by Imlay (1940, p. 36), was perhaps the first to offer an interpretation. He described the mottled gypsum or the "chicken wire lattice structure" in the Cretaceous Ferry Lake anhydrite in the subsurface of southwestern Arkansas and northeastern Texas, where masses of anhydrite are separated by thin films of calcareous mud. His conclusion was that discrete, nearly gelatinous anhydrite masses settled at the same time the mud was settling. Imlay (1940, p. 36) suggests, instead, that the mottled structures were formed by wave action in shallow muddy water before the solidification of the anhydrite. Dunham (1948) expressed the opinion that some varieties of mottled anhydrite were formed by abrasion of the accumulating anhydrite masses, and that others were formed by replacement of the dolomite by anhydrite.

None of these theories of origin seems to fit the relations observed in samples described here. Wave action, which would cause abrasion of anhydrite particles, would result in such primary structures as graded bedding in the gypsum bed (Weller, 1960, p. 357), instead of the irregular arrangement in the typical mottled structure. In addition, no firm evidence for replacement of the host rock by calcium sulfate was observed.

An alternative that is in accord with the available facts is that the calcium sulfate masses grew in place 
in the bottom sediments after the sediments were deposited, but before they were lithified. The nodules of calcium sulfate may have crystallized in the bottom sediments from concentrated interstitial solutions. Some of the nodules have displaced the host rock without notable distortion of the bedding, but others appear to have pushed the host rock aside. This distortion may have taken place at the time of growth of the nodules or at the time of compaction of the sediments, but clearly it was at a time when the beds were still plastic and not yet lithified. From this, one may suppose that abundant water carrying calcium and sulfate was available to supply the ingredients of the nodules. The large nodules probably formed by the accumulation of calcium sulfate on small "seed" crystals of gypsum or anhydrite that were already present within the silt.

Most of the megascopic calcium sulfate that has been identified from Recent sediments is in the form of individual crystals or rosettes of selenite (for instance, Eardley and Stringham, 1952; Ver Planck, 1952, p. 47-48). Masson (1956) also found thin layers of gypsum and gypsiferous shale associated with the selenite crystals. Possibly some mottled gypsum originated as selenite masses, for Douglas and Goodman (1957, p. 832) have determined that selenite crystals can be altered to granular gypsum by pressures equivalent to 1,000 to 6,000 feet below the surface. However, many of the deposits in which mottled gypsum has been found were never buried to such depths, and therefore cannot have been subjected to such pressures.

Most of the calcium sulfate was probably deposited directly as rock gypsum or anhydrite. The form would depend in part on the temperatures of the unprecipitated brines contained in the sediments. In fresh water, for example, anhydrite will be precipitated at $40^{\circ} \mathrm{C}$ or above; gypsum is the stable mineral below $40^{\circ} \mathrm{C}$. In more saline water, the limiting temperatures at which anhydrite can form are lower (MacDonald, 1953, p. 890). Although it appears that much of the gypsum is pseudomorphic after anhydrite, there is no way of telling whether anhydrite was the original form deposited, or whether the calcium sulfate was altered from gypsum to anhydrite after deposition, and then subsequently was altered again to gypsum. Temperatures above $40^{\circ} \mathrm{C}$ have been reported in brines (Douglas and Goodman, 1957, p. 833) but bottom sediments are poor conductors of heat, and even if the temperature in brine is above $40^{\circ} \mathrm{C}$, the temperature in the sediment is not necessarily high enough for the precipitation of anhydrite.

When anhydrite is hydrated to gypsum by nearsurface waters, a theoretical expansion of between 30 and 50 percent (Grabau, 1920, p. 359) takes place. In no gypsum deposit has evidence been found for a swelling of this magnitude. The rims of compressed shale surrounding nodules of gypsum indicate that some of the expansion on hydration compacted the shale; additional increase in volume can be accounted for by the small veins of satinspar that have been deposited in the surrounding shales (Bundy, 1956, p. 252), presumably by the same waters that hydrated the anhydrite. The removal of the more soluble salts, which may have been deposited with the calcium sulfate by these same solutions, would compensate, in part, for lack of volume increase on hydration of anhydrite.

\section{REFERENCES}

Bundy, W. M., 1956, Petrology of gypsum-anhydrite deposits in southwestern Indiana: Jour. Sed. Petrology, v. 26, no. 3, p. 240-252.

Douglas, G. V., and Goodman, N. R., 1957, The deposition of gypsum and anhydrite: Econ. Geology, v. 52, p. 831-837.

Dunham, K. C., 1948, A contribution to the petrology of the Permian evaporite deposits of northeastern England : Yorkshire Geol. Soc. Proc., v. 27, pt. 3, p. 217-227.

Eardley, A. J., and Stringham, Bronson, 1952, Selenite crystals in the clays of Great Salt Lake [Utah] : Jour. Sed. Petrology, v. 22 , no. 4 , p. $234-238$.

Grabau, A. W., 1920, Geology of the non-metallic mineral deposits other than silicates, v. 1, Principles of salt deposition : New York, McGraw-Hill Book Co., Inc., $435 \mathrm{p}$.

Imlay; R. W., 1940, Lower Cretaceous and Jurassic formations of southern Arkansas: Arkansas Geol. Survey Inf. Circ. 12, p. 35-36.

MacDonald, G. J. F., 1953, Anhydrite-gypsum equilibrium relations: Am. Jour. Sci., v. 251, no. 12, p. 884-898.

Masson, P. H., 1956, An occurrence of gypsum in southwestern Texas : Jour. Sed. Petrology, v. 25, no. 1, p. 72-77.

McGee, W. J., 1884, Descriptions of quarries and quarry regions, chap. 6, in Report on building stones of the United States and statistics of the quarry industry: Rept. 10th Census, v. 10, p. $256-265$.

Udden, J. A., 1924, Laminated anhydrite in Texas: Geol. Soc. America Bull., v. 35, no. 2, p. 347-354.

Ver Planck, W. E., Jr., 1952, Gypsum in California : California Div. Mines Bull. 163, 151 p.

Weller, J. M., 1960, Stratigraphic principles and practice: New York, Harper Bros., 725 p. 
411. CHEMICAL BASIS OF MINOR-ELEMENT ASSOCIATIONS IN COAL AND OTHER CARBONACEOUS SEDIMENTS

By Peyer Zubovic, Taisia Stadnichenko, and Nola B. Sherfey, Washington, D.C.

In a previous paper on the relative affinity of $15 \mathrm{mi}-$ nor elements for organic matter, Zubovic and others (1960) suggested that those elements associated with organic matter in coal are held as metal-organic complexes. In this paper the relative affinities of these elements are correlated with those properties that are most likely to affect the formation and stability of such metal-organic complexes. Thus, the geochemical behavior of the elements in the coal-forming environment is further characterized. A more rigorous recalculation of the original data on 1.3 sink and float samples has produced minor changes in the order of affinity of these elements for organic matter of coal. The order reported earlier: was based on the frequency of the appearance of the elements in quartile ranges, whereas in this paper the order is based on more rigorous treatment of the data (fig. 411.1).

The 15 elements are relatively rare, whereas the amount and variety of organic matter with which they form complexes are large. This relation, coupled with the influence of certain chemical properties of the metal ions, provides optimum conditions for the formation of stable metal-organic complexes. The chemical properties are: (a) size and charge of the ion, (b) bond

TABLE 411.1.-Ionic charge, ionic radius, and bond configuration of the elements

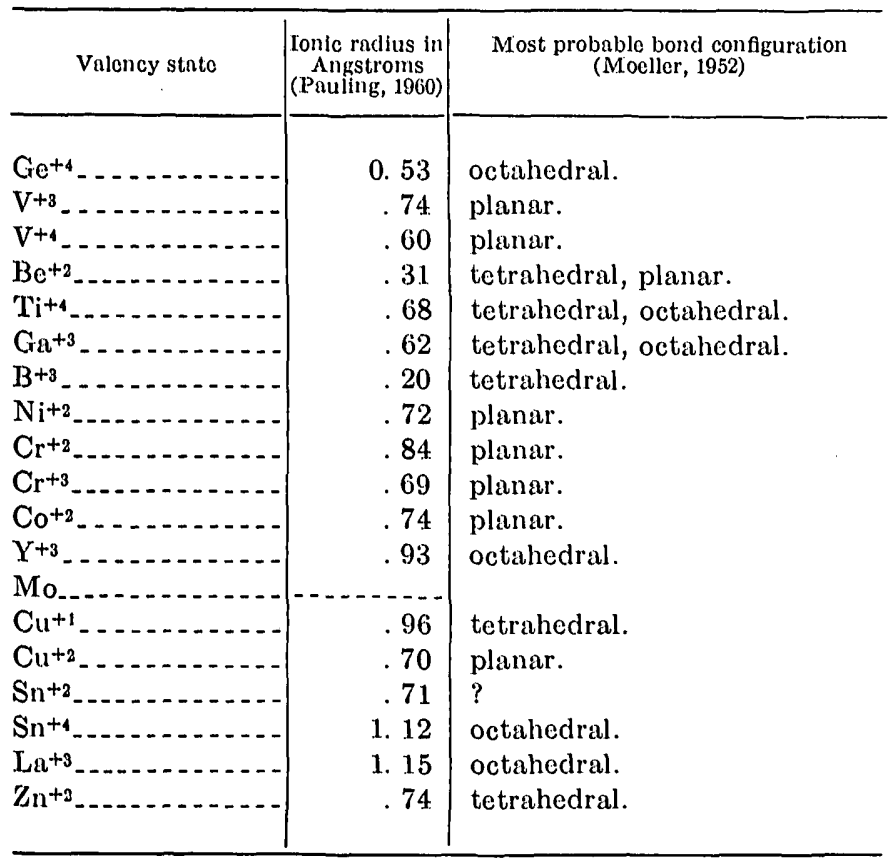

$6044930-61-23$ configuration and coordination number (table 411.1), (c) tendency toward formation of covalent rather than ionic bonds, and (d) tendency to combine with nitrogen rather than with oxygen or sulfur of the donor molecule. Generally, smaller size and higher charge increase the tendency to form more stable complexes. The stability of such complexes decreases as their bond configuration changes from octahedral (coordination no. 6) to planar (coordination no. 4) to tetrahedral (coordination no. 4). The relative strengths of such bonds (Moeller, 1952, p. 204) are 3.0, 2.7, and 2.0, respectively. Complexes in which the metal is bonded to nitrogen as the donor atom are mostly covalent and most stable, whereas those bonded to oxygen are mostly ionic and less stable. Sulfur-to-metal bonds form the least stable metal-organic complexes. The ionic radii (Pauling, 1960, p. 514, 518) and the types of bond configurations (Moeller, 1952, p. 269) of these elements are given in table 411.1.

Figure 411.2 shows that the relative stability of the bivalent metals, $\mathrm{Fe}, \mathrm{Co}, \mathrm{Ni}, \mathrm{Cu}$, and $\mathrm{Zn}$, remains unchanged for different donor molecules. In this group, the charge-size relation holds for $\mathrm{Fe}, \mathrm{Co}, \mathrm{Ni}$, and $\mathrm{Cu}$. Zinc, however, forms only tetrahedral $\mathrm{sp}^{3}$ complexes which are less stable than the planar complexes formed by the other four metals using available " $\mathrm{d}$ " orbitals. Copper, which is the most stable in this series, does not show this stability in coal.

In figure $411.1 B$, size of the metal ions is related to their affinity for organic matter of coal. Ionic radii are given for two valencies of $\mathrm{V}, \mathrm{Cr}, \mathrm{Cu}$, and $\mathrm{Sn}$. V+4, $\mathrm{Cr}^{+3}, \mathrm{Cu}^{+1}$, and $\mathrm{Sn}^{+2}$ better fit the curve shown than other valencies of these elements. Divergence from the curve for the first five elements listed (fig. $411.1 B$ ) and for zinc is the result of other factors. Figure $411.1 C$ shows the ionic potential (charge/radius) effect and again the fit is fairly good. Figure $411.1 D$ relates bond strength, charge, and radius of the ions to their affinity for organic matter.

It is apparent in figures $411.1 A$ and $C$ that the elements are arranged in four general levels (dashed lines). In figure $411.1 D$ the most stable configurations also fall into similar levels. In figures $411.1 C$ and $D$ the levels for $\mathrm{La}$ and $\mathrm{Zn}$ are different. In all of the figures the valency states $\mathrm{V}^{+4}, \mathrm{Cr}^{+3}, \mathrm{Cu}^{+1}$, and $\mathrm{Sn}^{+2}$ better fit the curves than the valency states $\mathrm{V}^{3+}, \mathrm{Cr}^{2+}, \mathrm{Cu}^{2+}$, and $\mathrm{Sn}^{4+}$. 

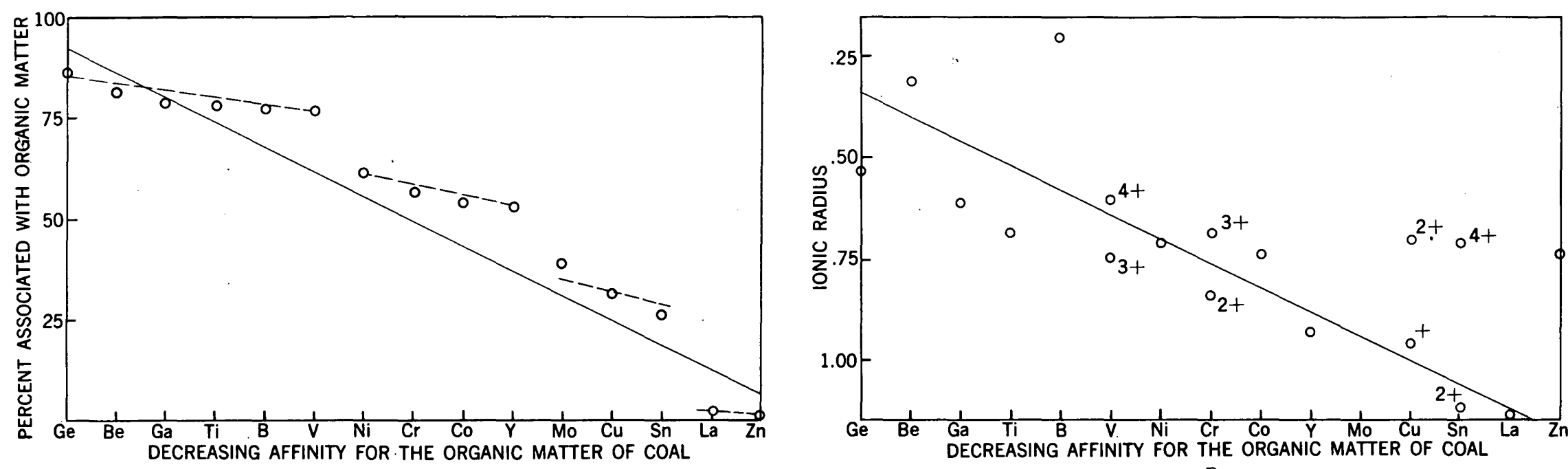

A
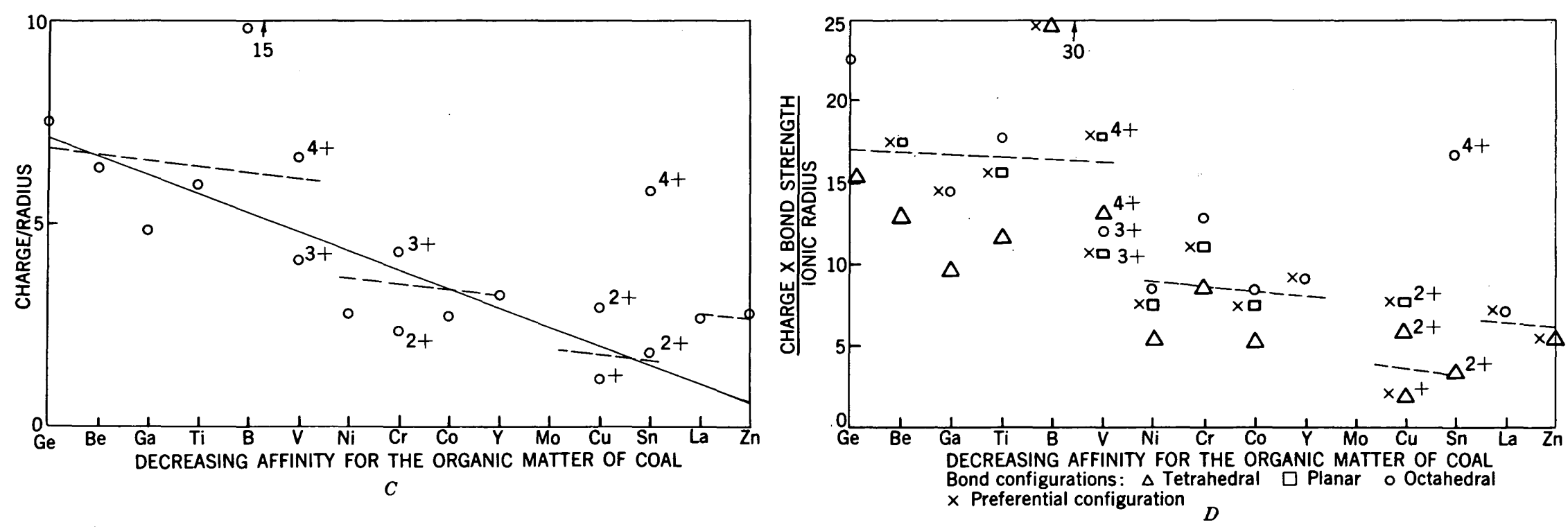

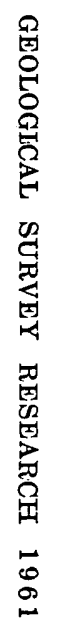

Figure 411.1.-Affinity of 15 minor elements for organic matter in coal in relation to their ionic charge, ionic radius, and bond strength. 


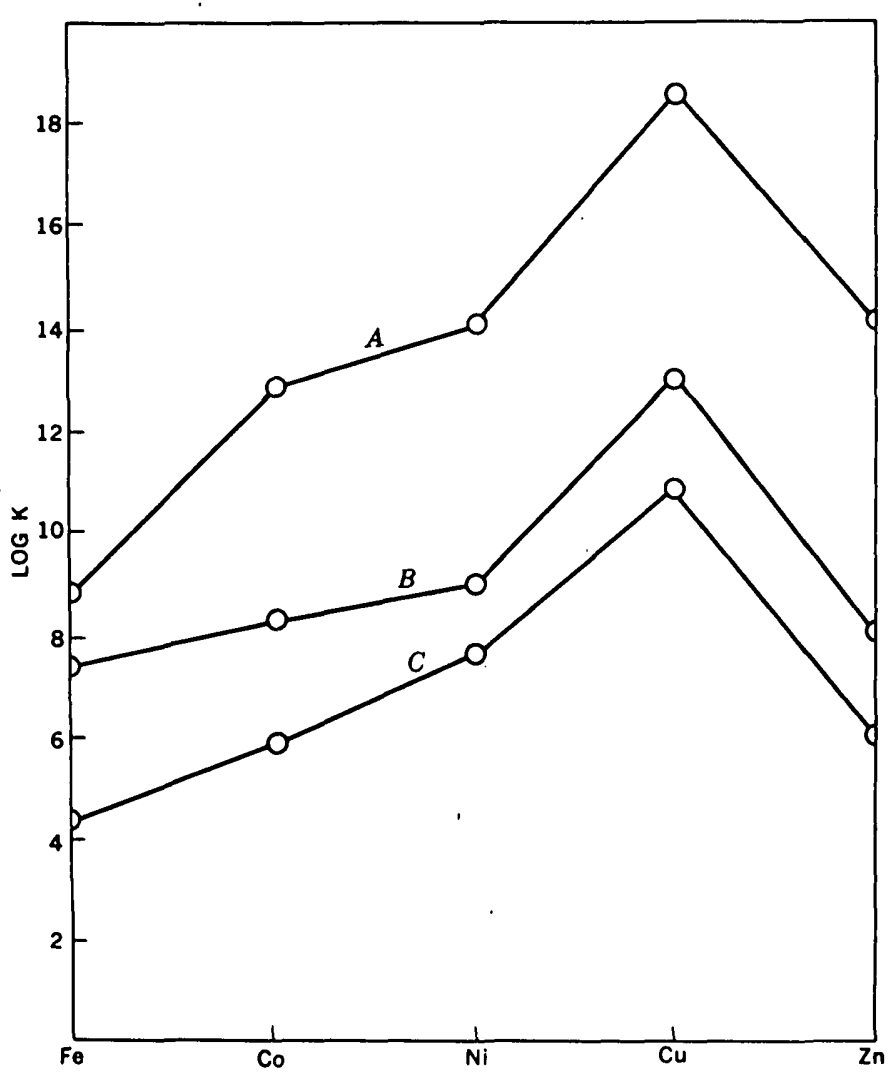

Fiqure 411.2.-Stability constants for the bivalent metals. $A$, triaminotriethylamine; $B$, salicylaldehyde; $C$, ethylenediamine.

In the environment in which coal is formed, there is a partitioning of elements between the organic and inorganic phases. Such elements as $\mathrm{Be}, \mathrm{Cr}, \mathrm{Ga}$, and $\mathrm{Sn}$ form very insoluble hydroxides at $\mathrm{pH}$ higher than 4 . Others, such as $\mathrm{Cu}, \mathrm{Zn}$, and $\mathrm{Sn}$, form insoluble sulfides. $\mathrm{H}_{2} \mathrm{~S}$ is generally available because of the activity of bacteria and because $\mathrm{H}_{2} \mathrm{~S}$ is the stable phase of sulfur in this environment. The relation between the solubility of some of the inorganic compounds that can form and the stability of organic complexes of these elements helps to reduce further the discrepancies mentioned previously. Trivalent chromium forms more stable complexes than trivalent vanadium. Quadrivalent vanadium, however, should form more stable complexes than trivalent chromium. In addition, trivalent chromium can form insoluble hydroxides, whereas most inorganic vanadium salts are quite soluble. Thus, to achieve the relation of vanadium to chromium found in coal, vanadium should be quadrivalent, or some chromium should be precipitated as hydroxide.

The general order of stability of the organic complexes of the bivalent metals is $\mathrm{Be}^{+2}>\mathrm{Cu}^{+2}>\mathrm{Ni}^{+2}>$ $\mathrm{Co}^{+2}>\mathrm{Zn}^{+2}>\mathrm{Fe}^{+2}$ (Irving and Rossotti, 1956). This same order is found in coals for $\mathrm{Be}, \mathrm{Ni}, \mathrm{Co}$, and $\mathrm{Zn}$. The position of copper in this series does not agree with the coal data. However, if copper is in the univalent state, it forms less stable tetrahedral complexes, thus explaining its lower affinity for the organic matter of coal. The stable copper minerals in bog-water environments contain copper in this univalent state (Garrels, 1960, fig. 6.25). Although copper sulfides containing bivalent copper are very insoluble, they are not stable phases in this environment. The sulfides of $\mathrm{Ni}, \mathrm{Co}$, and $\mathrm{Zn}$ have about the same equilibrium constants, but their relative affinity for organic matter in coal reflects the relative stability of the organic complexes which they form. In addition, $\mathrm{Ni}$ and $\mathrm{Co}$ cannot be precipitated by $\mathrm{H}_{2} \mathrm{~S}$ from an acid solution. It is interesting that $\mathrm{V}^{+4}, \mathrm{Cr}^{+3}, \mathrm{Co}^{+2}, \mathrm{Ni}^{+2}$, and $\mathrm{Cu}^{+1}$ can coexist in the same bog environment (Garrels, 1960, figs. 6.25, 6.29, $6.30,7.1,7.5)$.

The lack of affinity of tin for organic matter in coal is assumed to be a result of its reduction to the bivalent ion, the large size and low charge of which causes the formation of unstable organic complexes. An alternative explanation is that the highly insoluble $\mathrm{Sn}(\mathrm{OH})_{4}$ is formed before the element gets to the swamp, thus no tin is available for organic complex formation. The order of stability of the organic complexes of the following trivalent metals is $\mathrm{Ga}>\mathrm{Y}>\mathrm{La}$. This is also their order of affinity for organic matter in coal. Some of the elements, $\mathrm{Be}, \mathrm{B}$, and $\mathrm{Ti}$, are not discussed in detail because their position is obvious. There are few data available on molybdenum.

The preceding discussion of the relation of these elements in coal environments leads to generalizations as to the formation of some sulfide minerals associated with organic matter. The principal factors involved are: (a) Eh-pH of the environment, (b) availability of organic matter, and (c) availability of the metals. The first is important in producing an environment in which inorganic compounds containing metals, such as copper, tin, and zinc are more stable than metal-organic complexes. The second and third factors are important in the partitioning of these elements in that if the availability of the metals is small and the availability of organic matter is large, most of the elements would be disseminated in the organic matter as organic complexes, whereas few would form finely dispersed inorganic precipitates. Perhaps only iron, which is one of the major elements, would precipitate in discernible quantities. In fact, most coals contain some pyrite. As the ratio of metallic elements to organic matter increases, other less abundant elements that form weakly stable complexes tend to form numerous minute mineralized pockets. Thus, zinc, lead, and copper are frequently found disseminated as sulfides in coal. Where the supply of the elements is large and that of organic matter small, one would expect most of these elements 
to occur as inorganic compounds. Economic deposits of such metals as copper, zinc, iron, and perhaps the vanadium-uranium ores of the Colorado Plateau commonly form in this way. Despite the fact that vanadium has a high affinity for organic matter, it forms very labile complexes in which the exchange reactions are quite fast. The organic matter could thus act as a regulating trap in which the element is held until a suitable reaction to form an insoluble mineral comes into being.

Figure $411.1 \mathrm{~A}$ can be used as a general guide to the occurrence of elements in inorganic phases. If an element such as vanadium appear's as an inorganic phase in organic-rich sediments, then it can be assumed that the complex-forming ability of the organic matter is saturated. Unless they are extremely rare, elements with a lower affinity for organic matter should also form inorganic phases, provided suitable insoluble combinations of anions and cations come in juxtaposition. If zinc or copper minerals are absent, then minerals containing elements with a higher organic affinity should also be absent. If $\mathrm{Ni}$ and Co minerals appear, it must be assumed that the $\mathrm{pH}$ of the solutions at the time of their formation was higher than usual. Other elements which form insoluble hydroxides or sulfides should also be precipitated. Most of the processes are exceedingly complicated.

\section{REFERENCES}

Garrels, R. M., 1960, Mineral equilibria: New York, Harper and Bros., $245 \mathrm{p}$.

Irving, Harry, and Rossotti, Hazel, 1956, Some relationships among stabilities of metal complexes: Acta Chemica Scandinavica, v. 10, no. 1, p. 72-93.

Moeller, Therald, 1952, Inorganic chemistry: New York, John Wiley and Sons, Inc., $966 \mathrm{p}$.

Pauling, Linus, 1960, The nature of the chemical bond, 3d ed.: Ithaca, New York, Cornell Univ. Press, $644 \mathrm{p}$.

Zubovic, Peter, Stadnichenko, 'Taisia, and Sheffey, N. B., 1960, The association of some minor elements with organic and inorganic phases of coal, in Short papers in the geological sciences: U.S. Geol. Survey Prof. Paper 400-B, p. B84-B87.

\section{SOME MECHANISMS FOR COOLING HYDROTHERMAL FLUIDS}

By Paul B. Barton, Jr., and Priestley Toulmin 3d, Washington, D.C.

In recent years the temperatures of formation of several hypogene ore deposits have been studied in some detail by various workers, and it is expected that many more such studies will be made in the future as methods of geothermometry are perfected. Some of the studies have indicated that there are definite thermal gradients associated with the mineralization, just as had been commonly suspected for many years. A recent study of thermal gradients during mineralization in the Central City district, Colo. (P. K. Sims and P. B. Barton, Jr., unpublished data, 1961) has led us to examine the possible mechanisms by which temperature change may occur in ore-forming fluids. Many discussions of ore-forming processes attribute cooling of the ore-bearing solutions to heat loss to cooler wallrocks. However, in addition to heat exchange with wallrock, we believe that three other processes may make significant contributions to the thermal balance during ore formation. These processes are (a) heat exchanges in chemical reactions taking place in the solutions or wallrocks, (b) mixing of the solutions with ground water, and (c) adiabatic expansion of the fluid (including boiling), especially irreversible expansion through a constriction, commonly referred to as throttling.

Before the above-mentioned processes are discussed quantitatively, it should be pointed out that apparent temperature gradients can very well be due only to timing. If a mineral forms over a span of time during which the temperature in the vein changes, study of crystals formed at different times will yield different temperatures of formation. Thus, if only a few specimens are studied, the different temperatures determined may give the impression of an instantaneous spatial temperature gradient but may, in fact, represent only the change of temperature with time. Evidence that such temporal variations do occur in mineralization is furnished by zoned sphalerite crystals in which inclusion-filling temperatures (for example, Roedder, $1960)$ indicate variation in temperature during crystal growth. Kutina (1957) and Smirnov (1960) consider that some types of zoning originate through the deposition of different mineral assemblages in different places from different solutions.

Many of our colleagues, and especially P. K. Sims and E-an Zen of the Geological Survey, were very 
helpful by their comments and critical discussions of field and theoretical aspects of the problems involved.

\section{HEAT CONDUCTION INTO WALLROCK}

Quantitative evaluation of heat conduction into wallrock is extremely difficult (see discussion by Clark, 1959) because the heat-flow calculations depend on such uncertain geologic factors as rate of flow of solution and its variation with time, length of time during which the solution flows, rate of change of the solution at its source, and the like. Calculations by Lafitte (1958) led him to the conclusion that heat loss by conduction to the walls is unimportant in most veins. His calculations also show that if the temperature of the incoming solution decreases suddenly, a reversed thermal gradient along the vein may persist for a considerable time.

A serious objection to cooling by heat exchange with wallrock is illustrated by studies of thermal gradients during mineralization at Central City, Colo. (P. K. Sims and P. B. Barton, Jr., unpublished data, 1961). These studies suggest that the ore-forming solutions moved upward and outward from a central source at temperatures on the order of $600^{\circ} \mathrm{C}$ for considerable distances (at least several thousand feet) with only a small temperature drop. Then, in a narrow region perhaps only 1 or 2 thousand feet wide, the temperatures dropped rapidly and very irregularly to about $300^{\circ} \mathrm{C}$. Even in this narrow zone there is a great range of temperatures between adjacent veins and even within the same sphalerite crystals, as if each vein had its own cooling pattern that was independent of nearby veins. Farther out the temperatures drop to $150^{\circ}$ to $200^{\circ} \mathrm{C}$. The localized steep thermal gradient and the extremely erratic distribution of temperatures within the region where temperatures were dropping rapidly make it impossible to attribute the gradient to simple loss of heat to cooler wall rocks.

Thus, although heat loss by conduction to cooler wallrocks cannot be fully assessed on the basis of presently available dati, evidence from some districts raises objections to this process as the mechanism for cooling solutions from magmatic to surface temperatures. Other geologically feasible processes are considered below.

\section{HEAT EFFECTS OF REACTIONS TAKING PLACE IN THE SOLUTIONS AND WALLROCKS}

Endothermic reactions occurring within the solution or between the solution and the wallrocks could cool the solution. In fact, however, most of the predictable reactions are exothermic and therefore supply the geologic system with additional heat to be dissipated. Most minerals decrease in solubility as temperature de- creases, indicating that the precipitation reactions are exothermic and would tend to heat, rather than cool, the solution. Reactions in the fluid phase, such as the hydration, ionization, and disproportionation of $\mathrm{SO}_{2}$ proceed with falling temperature and likewise are exothermic. Many of the reactions involved in wallrock alteration (sericitization and argillization of feldspar, chloritization of ferromagnesian minerals) may be regarded as retrograde metamorphic processes and so are exothermic for the total system. Although precise calculations are again impossible, the data of Hemley (1959, p. 263-266) indicate that the effect may be significant. The heat released by complete sericitization of the alkali feldspar of a quartz monzonite according to the reaction $3 \mathrm{KAlSi}_{3} \mathrm{O}_{8}+2 \mathrm{H}^{+} \rightarrow \mathrm{KAl}_{3} \mathrm{Si}_{3} \mathrm{O}_{10}(\mathrm{OH})_{2}+$ $6 \mathrm{SiO}_{2}+2 \mathrm{~K}^{+}$should be sufficient to raise its temperature by about $20^{\circ} \mathrm{C}$, and kaolinization might produce heat sufficient to raise the temperature as much as $30^{\circ} \mathrm{C}$. If the other alteration processes have similar heat effects, the conversion of fresh quartz monzonite or granodiorite to an aggregate of quartz, sericite, clay minerals, and chlorite might conceivably release a quantity of heat capable of raising the temperature of the rock by as much as $100^{\circ} \mathrm{C}$.

This heat would, of course, be released gradually and in relatively small amounts throughout the entire alteration process. It would, however, add to the heat to be consumed by the endothermic processes described below, and would be a significant factor in reducing the amount of heat that could be lost by the solution in heating the wallrocks.

In certain cases, such as the alteration of clay-rich sediments or the development of tactites, endothermic reactions may become important mechanisms of heat consumption.

\section{MIXING WITH GROUND WATER}

There is little doubt that a hot, rising solution can be cooled by mixing with ground water, but the problem lies in demonstrating that this action takes place where mineral deposits are forming. If fractures permitting circulation are open to the surface (as is likely if the hydrothermal solutions are escaping to the surface), and if the pressure at a given point becomes less than the hydrostatic pressure of a column of meteoric water, convection should operate because the cool meteoric water will be denser than the warmer hybrid solution that results from the mixing of meteoric and hypogene solutions. The amount of cooling will of course be controlled by the proportion of meteoric water added and by the temperatures and heat capacities of the solutions. If additional hypogene solutions mix with already partially cooled hybrid solutions, actual reversals in thermal gradients might appear. Meteoric 
solutions generally have low concentrations of soluble salts, whereas hypogene solutions usually have very appreciable concentrations; hence, by the simple operation of measuring the freezing points of fluid inclusions (Roedder, 1960), which measures the relative amounts of dissolved material in the water from a series of samples, it should be possible to demonstrate whether ground water mixing has or has not taken place. Studies of the hydrogen or oxygen isotopic composition of the fluid inclusions can also provide evidence of the role of ground-water mixing.

\section{ADIABATIC EXPANSION}

"Adiabatic expansion" means expansion of the fluid without heat exchange with its surroundings. We shall discuss three variations of this process: reversible expansion, irreversible expansion or throttling, and boiling.

A fluid rising slowly through an open fracture, and exchanging a negligible amount of heat with the walls, expands reversibly and adiabatically under the decreasing pressure of the overlying fluid column. Since a reversible adiabatic process takes place at constant entropy, the cooling of the fluid can be evaluated graphically by plotting isotherms on an entropy-pressure diagram (fig. 412.1).

This process is relatively unimportant (or at least masked by other processes) in most mineralized areas, for in order to attain the large pressure change required for appreciable cooling the solutions would have to rise through an unrealistically large vertical distance.

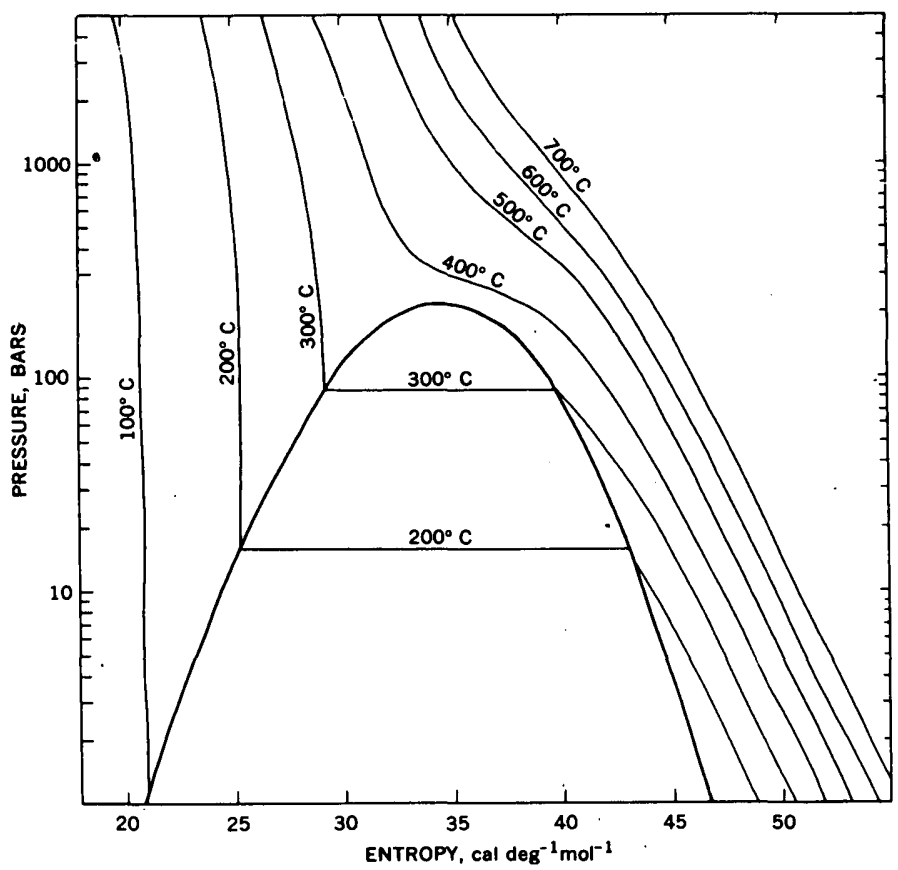

Figure 412.1.-Entropy-pressure diagram for the system $\mathrm{H}_{2} \mathrm{O}$.
Irreversible expansion of the type known as throttling or as Joule-Thomson expansion takes place when a fluid from a reservoir at constant high pressure expands through a constriction into a second reservoir at lower pressure, as undoubtedly happens in the history of some hydrothermal fluids. Such an expansion takes place at constant enthalpy (Zemansky, 1943, p. 190-192), and thus the temperature change on expansion can be estimated graphically from isotherms plotted on an enthalpy-pressure diagram such as the one constructed by Banwell (White, 1957, fig. 1). A similar diagram calculated from data recently compiled by Pistorius and Sharp is given in figure 412.2. It.is evident that appreciable cooling can result at temperatures above $350^{\circ} \mathrm{C}$ to $400^{\circ} \mathrm{C}$ by throttling: for example, a drop in pressure from 1,500 to 250 bars will cause the solution to cool from $600^{\circ} \mathrm{C}$ to $430^{\circ} \mathrm{C}$. At temperatures below about $400^{\circ} \mathrm{C}$ the isotherms are so steep that little effective cooling can result; in fact, as is shown in figure 412.2, under some conditions (on the low-temperature, highpressure side of the Joule-Thomson inversion curve) a small amount of heating, rather than cooling, results from throttling.

If the pressure on a liquid is reduced below its vapor pressure, boiling will result with consequent cooling of the solution. The temperature drop in reversible boiling, which occurs in many hot springs, can be evaluated from figure 412.1, and the case where water flashes to steam can be evaluated from figure 412.2. Most studies of fluid inclusions indicate that the depositing solution was a single fluid phase (Smith, 1953), and thus this

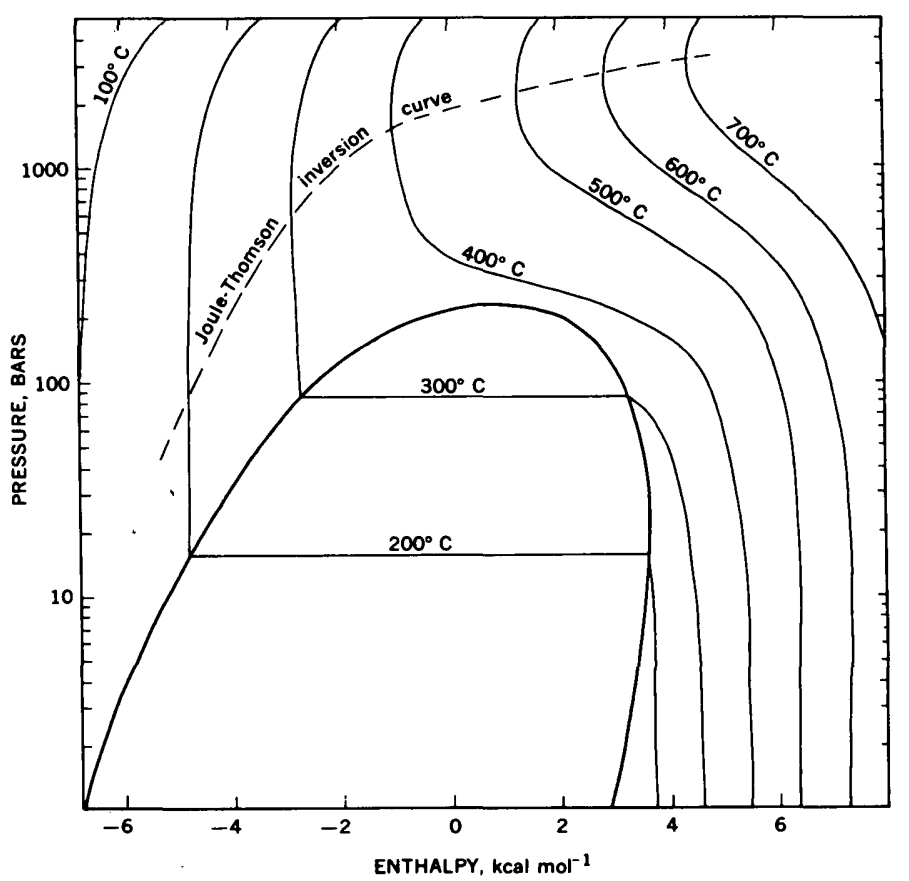

Figure 412.2.-Enthalpy-pressure diagram for the system $\mathrm{H}_{2} \mathrm{O}$. 
mechanism for heat dissipation may not be active in most deposits.

Some of the processes suggested above may seem to be somewhat improbable at first glance, but closer inspection of a typical ore-forming system as described below suggests that such processes as throttling are almost inevitable. Burbank (1950), on the basis of entirely different evidence from the Red Mountain area, Colo., concluded that throttling might be an important process; and, although he did not develop the quantitative aspects of the cooling, he did propose that steep temperature as well as steep pressure gradients might have existed.

A schematic model illustrating the behavior of an increment of solution under the influence first of adiabatic expansion and then of mixing with ground water, in agreement with the general pattern interpreted for the Central City district (P. K. Sims and P. B. Barton, Jr., unpublished data, 1961), is shown in figure 412.3. In the actual case, heat exchange with wallrock would smooth some of the sharp corners shown in figure 412.3, but it has been neglected here in order to emphasize the other processes. The six curves shown in figure 412.3 are different representations of the same increment of solution, in terms of different pairs of the variables time, temperature, pressure, and depth.
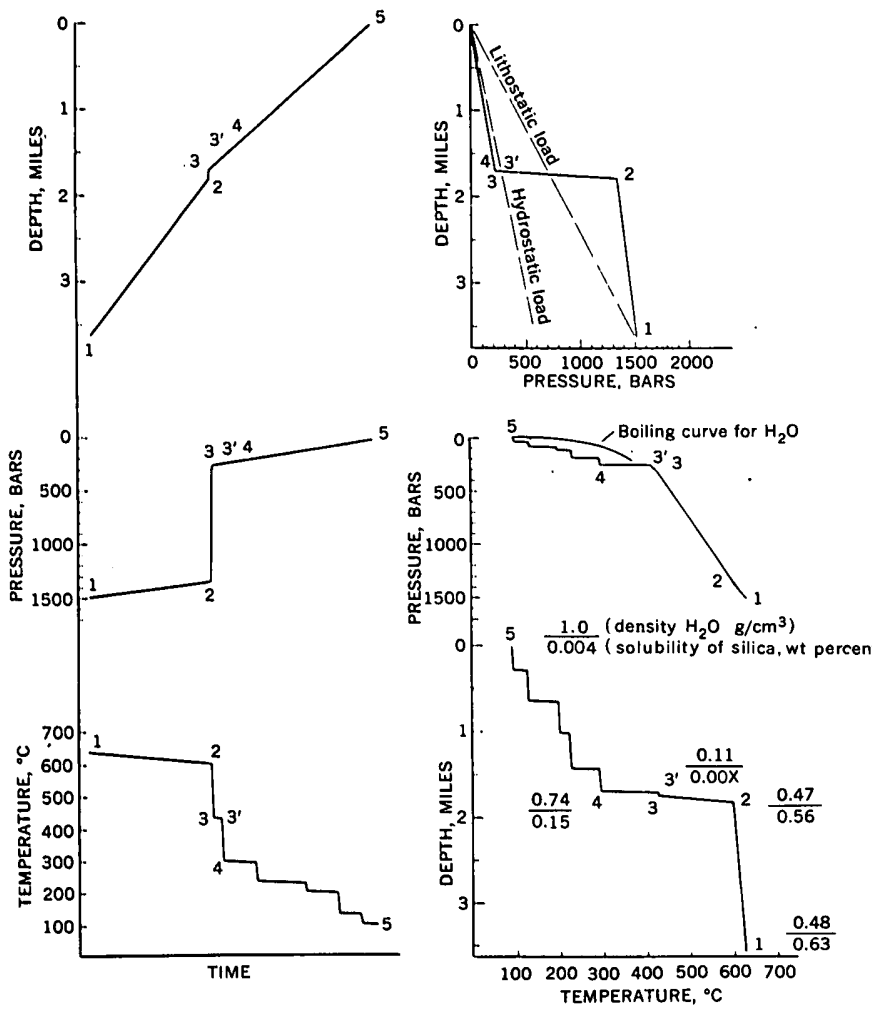

Frours 412.3.-Schematic behavior of an increment of solution en route from source to surface.
In figure 412.3, (1) represents the source of the fluids, probably the final crystallization stages of a magma. A temperature of $630^{\circ} \mathrm{C}$ and a pressure of 1,500 bars have been chosen arbitrarily. If the hydrothermal fluid constitutes a separate phase within the magma-as it must if separation is to occur-the pressure will be approximately lithostatic or greater. As the solution moves up an open fracture from (1) to (2) the pressure decreases only slightly, the decrease being equal to the hydrostatic pressure of a column of similar solution of height equal to the distance from (1) to (2). The small temperature decrease is estimated from figure 412.1. Eventually the solution will reach a constriction (2) to (3). Some sort of constriction at some position is necessary or the whole vein would become a steam vent, open to the surface. The solution expands rapidly as it proceeds through the constriction, emerging at (3) at a much lower temperature and pressure than at (2); the amount of cooling can be predicted from figure 412.2. The actual position of the constriction that causes the throttling, and the possible existence of multiple constrictions, are not critical to the discussion here-some throttling must take place somewhere on the conduit if the solutions are to move from the source (1) to the surface (5) and, unless the solutions are previously cooled to below about $400^{\circ} \mathrm{C}$ by other means, significant amounts of cooling will take place when the throttling occurs.

Because of the decrease in density and the drop in temperature of the solution during the throttling it is likely that precipitation of the various vein minerals will be concentrated in this region, as suggested by Burbank (1950). Following the throttling the solutions may move farther at very slowly diminishing pressure from $(3)$ to $\left(3^{\prime}\right)$; the temperature in this interval changes as shown in figure 412.1. However, the throttled solution in the $(3)$ to $\left(3^{\prime}\right)$ region would have a very low density- $0.11 \mathrm{gm} / \mathrm{cc}$ in the model given in figure 412.3 (Kennedy, 1950b) - and would be in a mechanicaliy unstable position relative to the cooler and denser solutions in the ground-water-mixing region above; hence there would be an opportunity for convection to eliminate the $(3)$ to $\left(3^{\prime}\right)$ interval so that throttling should take place directly into the region of ground-water mixing.

A possible consequence of the throttling is that precipitation takes place so rapidly that metastable mineral assemblages are formed. This could lead to some serious difficulties in attempts to use various mineral assemblages as geothermometers. In the study of the Central City district the sulfides from the region of presumed throttling occur as well-defined crystals, and 
many sphalerite crystals show delicate growth bands of varying iron content that are difficult to imagine as having originated from highly supersaturated solutions. Moreover, hydrothermally leached surfaces indicate that the overall process of deposition was at times reversed. Pending evidence to the contrary, we conclude that reaction rates were such that the growing surfaces of sphalerite (and presumably the other sulfides) were approximately equilibrated with the solution. Abundant data on the solubilities of vein minerals are available only for quartz, and a few of these data are noted at important points on the depthtemperature diagram in figure 412.3 (Kennedy, 1950a; Morey and Hesselgesser, 1951; and Foumier, 1960). The effects of composition of the solution on the solubilities of the various minerals can be very large and thus quantitative discussion is impossible at present.

In the region from $\left(3^{\prime}\right)$ to $(4)$ the magmatic solutions enter the region of circulating (cooler) ground waters and undergo rapid cooling at nearly constant pressure. From (4) to (5) the hybrid solutions move on toward the surface at steadily decreasing pressure with additional increments of ground water providing breaks in the cooling curve. If the path to the surface intersects the boiling curve for the solution (which would require a slight shift in the plotted curve for the solution on the temperature-pressure diagram in figure 412.3), cooling by adiabatic boiling is possible.

Because the calculations had to be based on the data for pure water even though hydrothermal fluids may contain large quantities of dissolved substances, figures 412.1 and 412.2 are to be regarded as giving only a semiquantitative measure of the temperature changes taking place during adiabatic expansion. Other factors, however, such as heat exchange with the wallrock, and uncertainties in the temperatures and pressures, most probably introduce even larger errors so that the use of the data for pure water is a sufficiently good approximation.

Several additional features of the model described above may be mentioned briefly: (a) As the magmatic source of the solutions weakens toward the end of the mineralization the locus of ground-water mixing may move inward, and high-temperature mineral assemblages may thus be "quenched" and preserved to record the former high-temperature conditions. (b) The pressures of deposition may differ very greatly from either the hydrostatic or lithostatic load, adding to the difficulty of evaluating pressure corrections for geothermometers (such as those commonly applied for fluid inclusion studies or the $25^{\circ} \mathrm{C}$ per kilobar correction for the sphalerite geothermometer). A further consequence is that pressure of formation may not be a reliable meas- ure of depth of formation, and this fact may have important implications in mineral exploration. (c) The large pressure differentials present during throttling would be especially fa vorable for the development of the breccia zones with which ore is so frequently associated. (d) Perhaps the various classes of hypogene mineral deposits are distinguished as much by the manner in which cooling and pressure drop take place as by the actual temperatures and pressures of mineralization.

Although we have discussed the cooling processes separately, several must have operated concurrently or successively in most ore deposits. The purpose of this paper is to call to the attention of geologists the possibility of these diverse processes so that field and laboratory studies may be designed to include an evaluation of their importance.

\section{REFERENCES}

Burbank, W. S., 1950, Problems of wall rock alteration in shallow volcanic environments: Colorado School Mines Quart. v. 45, no. 1B, p. 287-319.

Clark, S. P., Jr., 1959, Thermal calculations pertaining to ore deposition: Carnegie Inst. Washington Year Book 58, p. $157-160$.

Fournier, R. O., 1960, Solubility of quartz in water in the temperature interval from $25^{\circ}$ to $300^{\circ}$ C. [abs.]: Geol. Soc. America Bull., v. 71, p. 1867-1868.

Hemley, J. J., 1959, Some mineralogical equilibria in the system $\mathrm{K}_{2} \mathrm{O}-\mathrm{Al}_{2} \mathrm{O}_{3}-\mathrm{SiO}_{2}-\mathrm{H}_{2} \mathrm{O}$ : Am. Jour. Sci., v. 257, p. 241-270.

Kennedy, G. C., 1950a, A portion of the system silica-water: Écon, Geology, v. 45, p. 629-653,

1950b, Pressure-volume-temperature relations in water at elevated temperatures and pressures: Am. Jour. Sci., v. 248, p. $540-564$.

Kutina, Jan, 1957, A contribution to the classification of zoning in ore reins: Universitas Carolina, Geologica, v. 3, p. 197-225.

Lafitte, Pierre, 1958, Régime thermique au voisinage d'un filon hydrothermal: Acad. Sci. Paris Comptes rendus, v. 246, p. 2148-2151.

Morey, G. W., and Hesselgesser, J. M., 1951, The solubility of some minerals in superheated steam at high pressures: Econ. Geology; v. 46, p. 821-835.

Pistorius, C. W. F. T.; and Sharp, W. E., 1960, Properties of water. VI. Entropy and Gibbs free energy of water in the range $10-1000^{\circ} \mathrm{C}$. and $1-250,000$ bars : Am. Jour. Sci., v. 258, p. 757-768.

Roedder, Edwin, 1960, Primary fluid inclusions in sphalerite crystals from the $\mathrm{OH}$ vein, Creede, Colorado [abs.] : Geol. Soc. America Bull., v. 71, p. 1958.

Smirnov, V. I., 1960, Types of hypogene zonality of hydrothermal ore bodies: Internat. Geol. Cong., 21st, Copenhagen, 1960, Rept., pt. 16, p. 181-191.

Smith, F. G., 1953, Historical development of inclusion thermometry : Univ. Toronto Press, 149 p.

White, D. E., 1957, Thermal waters of volcanic origin: Geol. Soc. America Bull., v. 68, p. 1637-1638.

Zemansky, M. W., 1943, Heat and thermodynamics: New York, McGraw-Hill, 2d. ed., 390 p. 


\title{
413. SOME PHYSICAL PROPERTIES OF BIKITAITE AND ITS DEHYDRATION AND DECOMPOSITION PRODUCTS
}

\author{
By W. C. Phinney and D. B. Stewart, Minneapolis, Minn., and Washington, D.C.
}

Bikitaite, $\mathrm{LiAlSi}_{2} \mathrm{O}_{6} \cdot \mathrm{H}_{2} \mathrm{O}$, was described by Hurlbut $(1957,1958)$ from its only known locality at Bikita, Southern Rhodesia. As part of an investigation of the phase relations, stability, and geologic occurrence of the lithium aluminum silicates, some physical properties have been determined for bikitaite from the type locality. The material was supplied from specimen R10364, U.S. National Museum, by Dr. George Switzer. The specimen has not been analyzed chemically but its optical properties are identical to those reported by Hurlbut and the $\mathrm{H}_{2} \mathrm{O}$ content has been found to be 8.8 weight percent, in exact agreement with the theoretical $\mathrm{H}_{2} \mathrm{O}$ content.

The authors acknowledge the helpful assistance of B. J. Skinner in determining the refined cell dimensions and obtaining several high temperature $\mathrm{X}$-ray powder-diffraction patterns of bikitaite, and for making two long heating experiments at atmospheric pressure. D. E. Appleman determined the bikitaite structure and provided a summary of its special features. Our colleagues Dorothy Carroll and Harry Starkey measured the ionic exchange of bikitaite in their laboratories. Wayne Mountjoy analyzed the acetic acid leachate from bikitaite.

\section{X-RAY CRYSTALLOGRAPHY}

The unit-cell parameters of bikitaite were calcu-

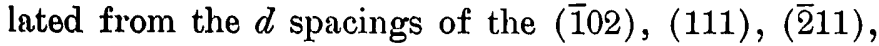
and $(\overline{3} 01)$ reflections measured relative to silicon $(a=5.43071 \mathrm{~A})$ as an internal standard with a diffractometer. Computations were made on a digital computer, using an iterative method. The refined bikitaite parameters at $26^{\circ} \mathrm{C}$ are $a=8.611 \mathrm{~A}, b=4.960 \mathrm{~A}, c=$ $7.610 \mathrm{~A}, \beta=114^{\circ} 26^{\prime}$, all measured with a precision of 0.04 percent. These dimensions were used to calculate the $d$ spacings given in table 413.1. Bikitaite $d$ spacings reported by Hurlbut $(1957$, p. 796 ) are also shown in table 413.1, however, the stilbite lines present in Hurlbut's data have been omitted.

Precise cell dimensions determined by D. E. Appleman on a quartz-calibrated precession camera using Mo $\mathrm{K} \alpha$ radiation are $a=8.616 \mathrm{~A} \pm 0.01 \mathrm{~A}, b=4.955 \mathrm{~A} \pm$ $0.005 \mathrm{~A}, c=7.611 \mathrm{~A} \pm 0.01 \mathrm{~A}, \beta=114^{\circ} 26^{\prime} \pm 05^{\prime}$, space group $P 2_{1}$, cell content $=1\left[\mathrm{LiAlSi}_{2} \mathrm{O}_{6} \cdot \mathrm{H}_{2} \mathrm{O}\right]$. Appleman also determined that bikitaite is weakly piezoelectric.

When bikitaite is dehydrated in air at temperatures below $500^{\circ} \mathrm{C}$ on a heated diffractometer stage, no ob- vious change of symmetry occurs, although the intensities of several powder-diffraction lines change notably, and several high-angle lines shift slightly. The (100), (001), (101), and (112) lines become more intense, the (112) especially so, and ( $\overline{3} 01)$ becomes less intense as the $\mathrm{H}_{2} \mathrm{O}$ content decreases. On rehydration, the line intensities return to their usual values. Similar behavior in synthetic zeolite $\mathrm{A}$ has been reported by Breck and others (1956, pp. 5969-5970). In the diffraction pattern of completely dehydrated "bikitaite" at room temperature, the (021), (121), lines are more intense and the $(201),\{(120),(\overline{3} 12)\}$, and (113) lines are less intense than in fully hydrated bikitaite.

\section{CRYSTAL STRUCTURE OF BIKITAITE}

The crystal structure of bikitaite (Appleman, 1960) is a three-dimensional network formed by laterally linked zigzag chains of silicate tetrahedra extending parallel to [010]. There are three crystallographically nonequivalent kinds of silicate chains. The structure contains one large channel and several smaller channels parallel to [010] in which lithium ions and $\mathrm{H}_{2} \mathrm{O}$ molecules are located. The distribution of $\mathrm{Al}$ and $\mathrm{Si}$ in the structure and the structural reasons for the dehydration behavior observed are being investigated. Studies to date have revealed no structural similarities to other lithium aluminum silicates or to analcime $\left(\mathrm{NaAlSi}_{2} \mathrm{O}_{6}\right.$. $\mathrm{H}_{2} \mathrm{O}$ ), wairakite $\left(\mathrm{CaAl}_{2} \mathrm{Si}_{4} \mathrm{O}_{12} \cdot 2 \mathrm{H}_{2} \mathrm{O}\right)$, or pollucite $\left(\mathrm{CsAlSi}{ }_{2} \mathrm{O}_{6} \cdot \mathrm{nH}_{2} \mathrm{O}\right)$.

\section{DEHYDRATION OF BIKITAITE}

The dehydration characteristics of bikitaite heated in air were accurately measured. Carefully purified -100 mesh samples of bikitaite were brought to constant weight at $120^{\circ} \mathrm{C}$ in glass micro-weighing bottles. The bottles were then placed in regulated furnaces, and the stoppers were removed from the bottles for from one to six days. The stopper was replaced immediately before removing each bottle from the furnace to prevent rehydration of the sample. The cooled bottles were weighed to determine the amount of $\mathrm{H}_{2} \mathrm{O}$ lost. Each weighing was corrected for the difference in density of air at room temperature and air at the temperature of the experiment. All experiments were made in an individually air-conditioned laboratory in an air-conditioned building. The temperature and humidity varied little, so that the $\mathrm{H}_{2} \mathrm{O}$ vapor pressure was 
nearly constant at $10.3 \mathrm{~mm}$ of $\mathrm{Hg}$, as measured twice daily by the sling psychrometer.

The temperature-composition isobar for the system $\mathrm{LiAlSi}{ }_{2} \mathrm{O}_{6}-\mathrm{H}_{2} \mathrm{O}$ at $10.3 \mathrm{~mm} \mathrm{H} \mathrm{H}_{2} \mathrm{O}$ pressure is shown on figure 413.1. The bikitaite dehydration curve is based on 28 experimental points at intervals of approximately $10^{\circ} \mathrm{C}$. The first loss of $\mathrm{H}_{2} \mathrm{O}$ occurs at $160^{\circ} \mathrm{C}$, and the

TABLE 413.1.-Indexed $X$-ray powder-diffraction pattern of bikitaite from Bikita, Southern Rhodesia (USNM R10364)

[Intensity (I) visually estimated from powder film. All permissible $h k l$ in space group $P 2_{1}$ calculated for unit-cell with $\left.a=8.611 \mathrm{~A}, b=4.960 \mathrm{~A}, c=7.610 \mathrm{~A}, \beta=114^{\circ} 26^{\prime}\right]$

\begin{tabular}{|c|c|c|c|c|}
\hline I & hkl & $\begin{array}{c}d_{h k l} \mathbf{A} \\
\text { calculated }\end{array}$ & $\begin{array}{l}d_{h k l} \text { A measured } \\
\text { Film No. } 13473\end{array}$ & $\begin{array}{l}d_{h k l} \text { A reported } \\
\text { Hurlbut (1957) }\end{array}$ \\
\hline 8 & 100 & 7. 840 & 7. 865 & 7. 84 \\
\hline 5 & 001 & 6. 928 & 6. 930 & 6.95 \\
\hline 3 & $\overline{1} 01$ & 6. 762 & 6. 732 & 6. 84 \\
\hline 4 & 101 & 4. 371 & 4. 374 & 4. 39 \\
\hline 1 & $\overline{2} 01$ & 4. 247 & 4. 265 & - . \\
\hline 9 & 110 & 4. 192 & 4. 195 & 4. 19 \\
\hline 2 & 011 & 4. 033 & 4. 022 & 4. 03 \\
\hline 1 & $\bar{I} 11$ & 3. 999 & 3. 991 & $-\ldots$ \\
\hline 1 & 200 & 3. 920 & 3. 926 & 3. 91 \\
\hline 3 & $\overline{1} 02$ & 3. 803 & 3. 806 & 3. 82 \\
\hline 10 & 002 & 3. 464 & 3. 462 & 3. 48 \\
\hline 10 & $\overline{2} 02$ & 3. 381 & 3. 371 & 3. 40 \\
\hline 4 & 111 & 3. 279 & 3. 284 & 3. 29 \\
\hline 4 & $\overline{2} 11$ & 3. 226 & 3. 215 & 3. 22 \\
\hline 4 & 210 & 3. 075 & 3. 076 & 3. 08 \\
\hline 1 & T12 & 3. 018 & 3. 023 & $\ldots$ \\
\hline 1 & 201 & 2. 931 & 2. 930 & 2. 93 \\
\hline \multirow[t]{2}{*}{2} & $\overline{3} 01$ & 2. 868 & 2. 870 & 2. 87 \\
\hline & 012 & 2. 840 & 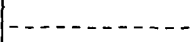 & . \\
\hline 1 & $\overline{2} 12$ & 2. 794 & 2. 794 & 2. 79 \\
\hline \multirow[t]{2}{*}{1} & 102 & 2. 773 & 2. 739 & $\ldots$ \\
\hline & $\overline{3} 02$ & 2. 688 & &.---- \\
\hline 1 & 300 & 2. 613 & 2. 629 & $\ldots$ \\
\hline \multirow[t]{4}{*}{2} & 211 & 2. 524 & 2. 523 & 2. 53 \\
\hline & 103 & 2. 515 & $\ldots$ & 2. 52 \\
\hline & $\overline{2} 03$ & 2. 491 & & - \\
\hline & $\overline{3} 11$ & 2. 483 & $\ldots$ & $\ldots$ \\
\hline 9 & 020 & 2. 480 & 2. 479 & 2. 475 \\
\hline 1 & 112 & 2. 420 & 2. 423 & $-\ldots$ \\
\hline 2 & $\left\{\begin{array}{l}120 \\
312\end{array}\right.$ & $\begin{array}{l}\text { 2. } 365 \\
2.363\end{array}$ & 2. 364 & \\
\hline & & & & \\
\hline 1 & 021 & 2. 335 & 2. 337 & $\ldots$ \\
\hline 1 & $\overline{1} 21$ & 2. 328 & 2. 323 & 2. 320 \\
\hline \multirow[t]{3}{*}{1} & 310 & 2. 312 & 2. 316 & - . - - \\
\hline & 003 & 2. 309 & . & - \\
\hline & $\overline{3} 03$ & 2. 254 & - & - \\
\hline \multirow[t]{3}{*}{1} & $\mathbf{1} 13$ & 2. 243 & 2.240 & - \\
\hline & $\overline{2} 13$ & 2. 226 & $\ldots$ & $\ldots$ \\
\hline & 202 & 2. 186 & $\cdots$ & $-\ldots-1,-\ldots$ \\
\hline \multirow[t]{2}{*}{1} & 301 & 2. 167 & 2. 167 & - \\
\hline & 121 & 2. 157 & & $\ldots$ \\
\hline
\end{tabular}

TABLE 413.1.-Indexed $X$-ray powder-diffraction pattern of bikitaite from Bikita, Southern Rhodesia (USNM R10364)-Continued

\begin{tabular}{|c|c|c|c|c|}
\hline I & hkl & $\begin{array}{c}d_{\lambda k l} \mathbf{A} \\
\text { calculated }\end{array}$ & $\begin{array}{c}d_{A k 1} \text { A measured } \\
\text { Film No. } 13473\end{array}$ & $\begin{array}{l}d_{\lambda k l} \text { A reported } \\
\text { Hurlbut (1957) }\end{array}$ \\
\hline \multirow[t]{3}{*}{1} & $\overline{2} 21$ & 2. 142 & 2. 141 & \\
\hline & 401 & 2. 131 & - & \\
\hline & $\overline{4} 02$ & 2. 123 & & \\
\hline 1 & 220 & 2. 096 & 2.097 & \\
\hline 1 & 013 & 2. 094 & 2. 094 & -150 \\
\hline \multirow[t]{2}{*}{2} & $\overline{1} 22$ & 2. 077 & 2. 077 & \multirow{3}{*}{ 2. 045} \\
\hline & $\overline{3} 13$ & 2. 052 & & \\
\hline 1 & 022 & 2. 017 & 2. 012 & \\
\hline 1 & 103 & 2. 002 & 2. 005 & \multirow{3}{*}{ 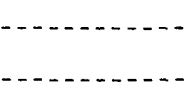 } \\
\hline \multirow{2}{*}{1} & $\{212$ & 2. 000 & \multirow{2}{*}{ 1. 996} & \\
\hline & $\{\overline{2} 22$ & 2. 000 & & \\
\hline 1 & 311 & 1. 986 & 1. 988 & \multirow{4}{*}{ 1. 96} \\
\hline \multirow{3}{*}{1} & $\left\{\begin{array}{l}400 \\
-4\end{array}\right.$ & 1. 960 & \multirow{3}{*}{ 1. 959} & \\
\hline & $\{\overline{4} 11$ & 1. 958 & & \\
\hline & 412 & 1. 952 & & \\
\hline 1 & 403 & 1. 942 & 1.947 & $\ldots$ \\
\hline \multirow[t]{2}{*}{3} & $\overline{2} 04$ & 1. 902 & 1. 900 & 1. 900 \\
\hline & 221 & 1. 893 & $\ldots$ & 1. 895 \\
\hline \multirow[t]{2}{*}{1} & $\overline{3} 21$ & 1. 876 & 1. 877 & $\ldots$ \\
\hline & $\overline{1} 04$ & 1. 861 & $\ldots$ & 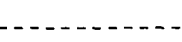 \\
\hline 2 & 113 & 1. 857 & 1. 855 & 1. 855 \\
\hline
\end{tabular}

last of the $\mathrm{H}_{2} \mathrm{O}$ is lost at $360^{\circ} \mathrm{C}$. In contrast, differential thermal analysis of bikitaite (Hurlbut, 1957, p. 795) indicated that the $\mathrm{H}_{2} \mathrm{O}$ loss began at $190^{\circ} \mathrm{C}$ and ended at $475^{\circ} \mathrm{C}$.

The dehydration curve of bikitaite shows curved segments between distinct breaks at $180^{\circ} \mathrm{C}$ and 2 weight percent $\mathrm{H}_{2} \mathrm{O}$ lost, and $280^{\circ} \mathrm{C}$ and 6.6 weight percent $\mathrm{H}_{2} \mathrm{O}$ lost. The theoretical and observed $\mathrm{H}_{2} \mathrm{O}$ content of bikitaite is 8.8 weight percent, so that these breaks correspond to one-fourth and three-fourths, respectively, of the $\mathrm{H}_{2} \mathrm{O}$ molecules lost. The bikitaite unit cell contains only a single $\mathrm{H}_{2} \mathrm{O}$ molecule, so the stepwise dehydration indicates that three energy barriers must be overcome during dehydration. It was hoped these barriers might be recognized by a precise crystal structure determination. Preliminary results of the crystal structure determination do indicate a specific structural site for about half of the $\mathrm{H}_{2} \mathrm{O}$ molecules, but the temperature interval during which this site is dehydrated is unknown. The remainder of the $\mathrm{H}_{2} \mathrm{O}$ in the structure has not yet been located.

The $\mathrm{H}_{2} \mathrm{O}$ lost in the dehydration interval from $160^{\circ} \mathrm{C}$ to $240^{\circ} \mathrm{C}$ is completely regained from the air at lower temperature, although rehydration is a slower process than dehydration. The reversible nature of the effect permits the $\mathrm{H}_{2} \mathrm{O}$ content at a given temperature to be approached from both higher and lower temperatures, 


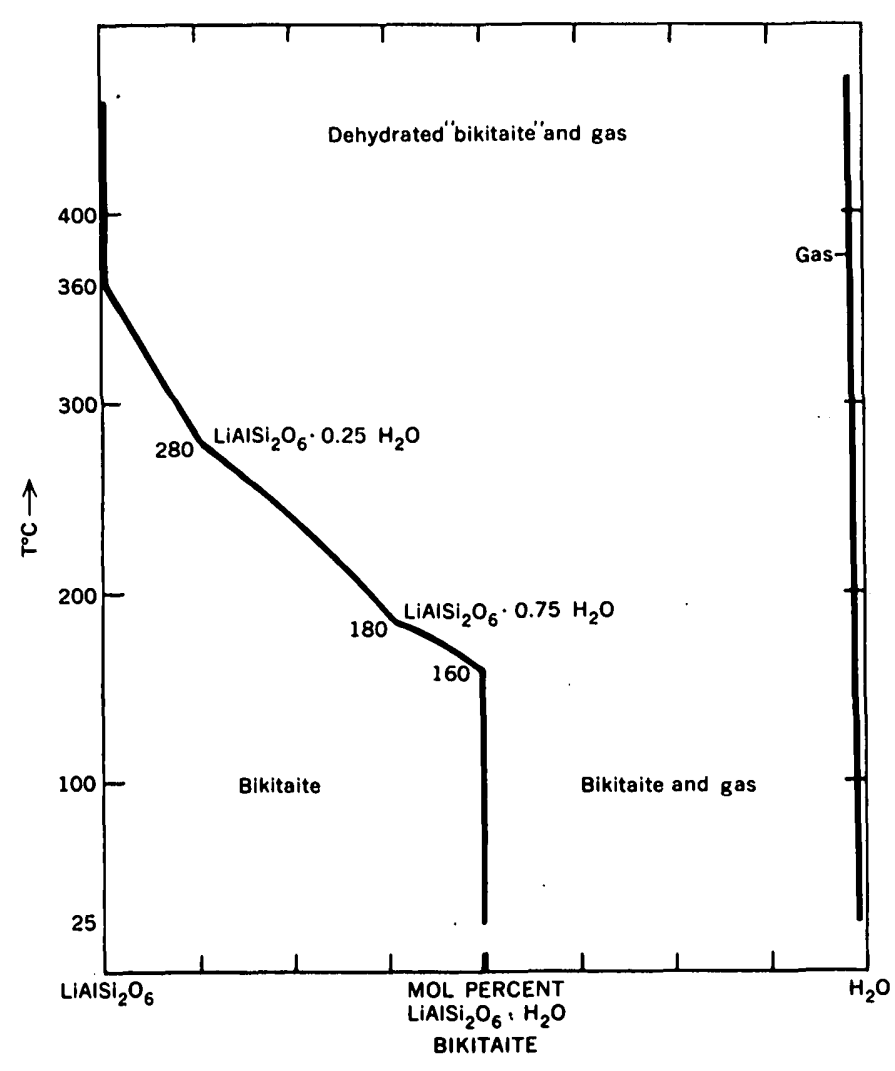

Fraure 413.1.-The temperature-composition isobar for the system $\mathrm{LiAlSi}_{2} \mathrm{O}_{0}-\mathrm{H}_{2} \mathrm{O}$ at $10.3 \mathrm{~mm} \mathrm{H}_{2} \mathrm{O}$ pressure.

so that weighing demonstrates the results to be equilibrium values in this temperature range. However, after being heated to between $240^{\circ} \mathrm{C}$ and $360^{\circ} \mathrm{C}$ and then cooled, many grains rehydrate completely, but the remainder rehydrate only partially as determined by measurement of refractive indices. The ratio of completely rehydrated to partially rehydrated grains apparently depends upon the highest temperature reached, the time at that temperature, and the grain size. After being heated to between $360^{\circ} \mathrm{C}$ and $600^{\circ} \mathrm{C}$ and then cooled, some grains do not rehydrate, while some rehydrate either partially or completely.

Ruiz-Menacho and Roy (1959) reported that bikitaite decomposed to $\beta$-spodumene at $400^{\circ} \mathrm{C}$. No $\beta$-spodumene formed in air below $600^{\circ} \mathrm{C}$ in this study.

The refractive indices of bikitaite decrease with the loss of $\mathrm{H}_{2} \mathrm{O}$, and increase during rehydration. The mineral remains biaxial negative and the birefringence is nearly the same throughout. Optical study indicates that rehydration follows a series of discontinuous steps. Rims with higher indices are visible on some grains or a mixture of two or three types of homogeneous grains is found. "Bikitaite" known to be completely dehydrated from weight-loss measurements is biaxial negative $\alpha=1.452, \beta=1.461, \gamma=1.463$. Two commonly found types of homogeneous, partially rehydrated bikitaite have $\gamma=1.473$ and $\gamma=1.486$. These substances contain approximately 1.5 and 3.4 weight percent $\mathrm{H}_{2} \mathrm{O}$, respectively, according to calculations based on the rule of Gladstone and Dale as applied to minerals by Larsen and Berman (1934, p. 30-32).

Bikitaite heated rapidly in air to temperatures above $750^{\circ} \mathrm{C}$ may decompose to $\beta$-spodumene as reported by Hurlbut (1957, p. 795), or to other phases. Several experiments yielded $\beta$-eucryptite solid solution as well as $\beta$-spodumene solid solution. One experiment at $800^{\circ} \mathrm{C}$ for 20 hours yielded 98 percent of an unidentified substance that must be close to $\mathrm{LiAlSi}_{2} \mathrm{O}_{6}$ in composition and 2 percent of partially rehydrated bikitaite. The unidentified substance is biaxial positive, $\alpha=1.520, \beta=$ 1.523, $\gamma=1.534,2 \mathrm{~V}=$ medium, and has a distinctive $\mathrm{X}$-ray powder-diffraction pattern with strong lines at $d 4.04(10), 3.48(5), 3.21(4), 2.50(3)$; and several weaker lines.

\section{IONIC EXCHANGE PROPERTIES OF BIKITAITE}

The exchange of ammonium ions for lithium ions in bikitaite at $25^{\circ} \mathrm{C}$ was studied by standard procedures with $1 \mathrm{~N}$ ammonium acetate solution by Dorothy Carroll. She found that the ammonium ion exchanged was 0.3 milliequivalents per 100 grams of bikitaite, or 0.061 percent of the lithium ions if only lithium ions were replaced. This amount is so small as to be negligible.

The exchange of hydrogen ions from $1 N$ acetic acid for lithium ions in bikitaite was studied by Harry Starkey. The experiments were made in metal containers at $122^{\circ} \mathrm{C}$ and slightly over 2 atmospheres pressure. The leachate was analyzed by Wayne Mountjoy for lithia and silica to determine if the lithium was actually replaced or released through dissolution of the sample. The analysis showed $10 \mathrm{mg} \mathrm{SiO}$ and $2.1 \mathrm{mg}$ $\mathrm{Li}_{2} \mathrm{O}$ in the leachate from a $0.25 \mathrm{~g}$ sample. The silica analysis indicates that 6.8 percent of the sample dissolved. Lithium in solution, in excess of that required to balance dissolved silica in the bikitaite ratio, amounts to 5.0 percent of the lithium theoretically present in the undissolved sample remaining, assuming that the $\mathrm{Li}: \mathrm{Si}$ atomic ratio in bikitaite is exactly $1: 2$, and that no lithium-poor aluminosilicate formed during the experiment. Therefore, hydrogen ions apparently replaced 5 percent of the lithium ions, an amount over 80 times the replacement of lithium ions by ammonium ions. A less accurate analysis of the leachate for alumina suggests that 9.6 percent of the sample dissolved, and that only 2 percent of the lithium ions were replaced by hydrogen ions. 
These two experiments suggest that limited ionic exchange of small ( $\approx 0.5 \mathrm{~A}$ radius) hydrogen ions may occur in bikitaite, but that large ( $\approx 1.5 \mathrm{~A}$ radius) ammonium ions are excluded. Apparently even the largest channel in the bikitaite structure will not accommodate the ammonium ion. Magnesium ion is almost the same size as lithium ion, and is the most abundant of the ions substituting for lithium in Hurlbut's (1957, p. 794-795) bikitaite analysis. Therefore, ionic exchange of magnesium for lithium may occur in nature.

\section{HYDROTHERMAL DECOMPOSITION OF BIKITAITE}

All attempts to synthesize bikitaite failed, and only the decomposition of natural bikitaite under hydrothermal conditions was determined. On figure 413.2 the results of holding natural bikitaite and 0 to 30 weight percent $\mathrm{H}_{2} \mathrm{O}$ in sealed metal capsules under hydrothermal conditions for from 5 to 9 days are shown. Bikitaite reacted at $390^{\circ} \mathrm{C}$ in the range 1 to 4 kilobars $\mathrm{H}_{2} \mathrm{O}$ pressure to form eucryptite and petalite by the reaction.

$$
\underset{\text { bikitaite }}{3 \mathrm{LiAlSi}_{2} \mathrm{O}_{6}} \cdot \mathrm{H}_{2} \mathrm{O} \rightarrow \underset{\text { eucryptite }}{2} \underset{\mathrm{LiAlSiO}_{4}}{\mathrm{LiAlSi}_{4} \mathrm{O}_{10}}+3 \mathrm{H}_{2} \mathrm{O}
$$

Short experiments showed that petalite and eucryptite precipitated as bikitaite dissolved. Ruiz-Menacho and Roy (1959) reported the breakdown of bikitaite to eucryptite and $\beta$-spodumene at 1013 bars and $420^{\circ} \mathrm{C}$, but observed no petalite. Petalite and bikitaite are difficult to distinguish optically, and small amounts of one mixed with the other might be overlooked.

In some hydrothermal experiments of short duration members of the $\beta$-spodumene and $\beta$-eucryptite solid solution series formed metastably from bikitaite. Larger quantities of $\beta$-spodumene and $\beta$-eucryptite formed when bikitaite was decomposed without added $\mathrm{H}_{2} \mathrm{O}$ in the capsules. However longer experiments yielded increased amounts of petalite and eucryptite, so that the direction of the reaction is clear. In several experiments conducted between $400^{\circ}$ and $450^{\circ} \mathrm{C}$ at $1 / 2$ to 2 kilobars bikitaite decomposed to a very fine grained mixture of silica-rich $\beta$-eucryptite solid solution $(\mathrm{Li}: \mathrm{Si}=1: 1.94)$ and a phase somewhat more siliceous than $\mathrm{LiAlSi}_{2} \mathrm{O}_{6}$. The mean index of the aggregate is 1.518 and individual grains of well-crystallized $\beta$-eucryptite have $\omega=1.520$ and $\epsilon=1.516$. The new phase was not recognized optically in a mixture consisting almost wholly of large amounts of the new phase and $\beta$-eucryptite as judged from X-ray powderdiffraction patterns. The optical properties must therefore be very similar to those of silica-rich $\beta$-eucryptite solid solution. The strongest lines of the

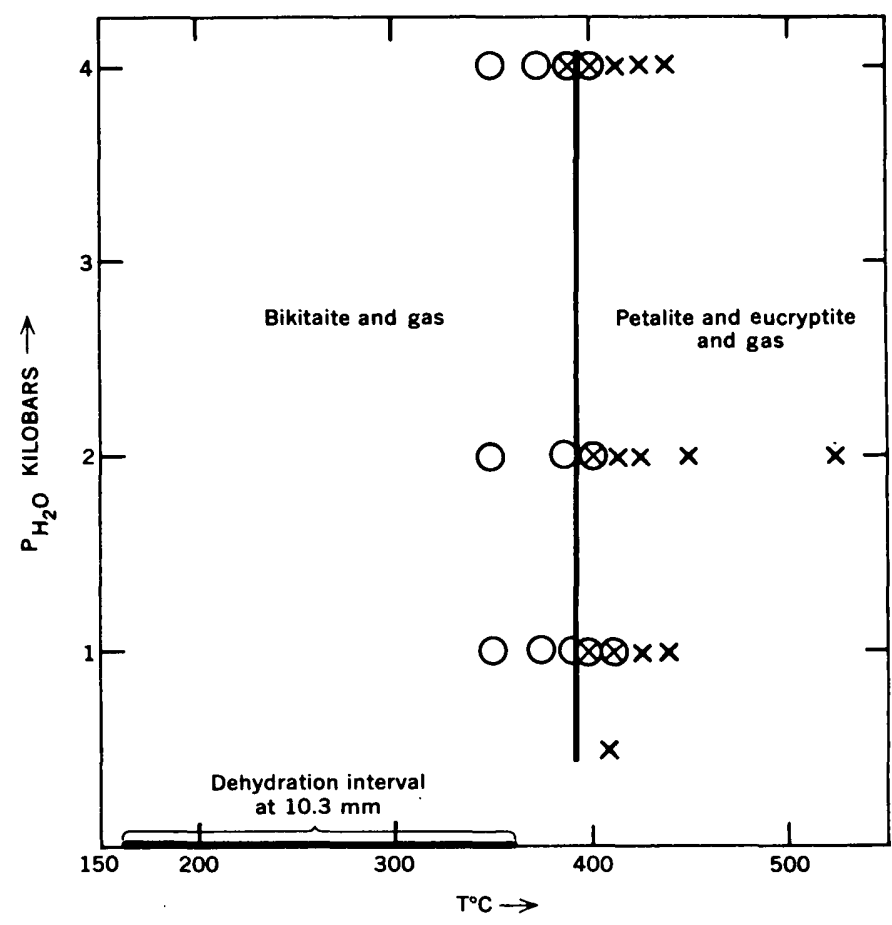

Figure 413.2.-The decomposition of bikitaite under hydrothermal conditions. Circle $=$ bikitaite unaffected, cross $=$ bikitaite completely decomposed, circle and cross=bikitaite partially decomposed.

diffraction pattern of the new phase are $4.70(10)$, $3.27(6), 2.97$ (3), 2.44 (2). Other strong lines, if coincident with the lines of silica-rich $\beta$-eucryptite solid solution, are possible.

It is not known if decomposition of bikitaite under hydrothermal conditions is preceded by dehydration. A simple projection of the decomposition curve under hydrothermal conditions suggests that dehydrated "bikitaite" should decompose in air above $390^{\circ} \mathrm{C}$ to eucryptite and petalite, but these products were not observed at any temperature from $390^{\circ}$ to $800^{\circ} \mathrm{C}$. Apparently at low $\mathrm{H}_{2} \mathrm{O}$ pressure dehydrated "bikitaite" can be superheated metastably.

At the same temperature and pressure at which bikitaite decomposes, natural spodumene remains unaffected either with or without $\mathrm{H}_{2} \mathrm{O}$ present. However, spodumene has not been synthesized under the same conditions, so that the stability of spodumene and $\mathrm{H}_{2} \mathrm{O}$ relative to bikitaite is uncertain. The geological abundance of spodumene as the only lithium mineral in pegmatites where $\mathrm{H}_{2} \mathrm{O}$ was almost certainly present suggests that bikitaite was less stable than spodumene under almost all conditions.

Experiments on many lithium aluminum silicates indicate that equilibruim is especially difficult to attain below $500^{\circ} \mathrm{C}$. Even though the equilibrium stability 
field for bikitaite, if any exists, cannot be established, the results given here show that bikitaite forms in nature only below $400^{\circ} \mathrm{C}$.

Bikitaite occurs with quartz and eucryptite (Hurlbut, 1957 , p. 793, fig. 1) and fresh contacts between quartz and eucryptite crystals are shown. Hurlbut reported that eucryptite appears to replace petalite and indeed the Bikita assemblage suggests that petalite decomposes to quartz and eucryptite under conditions at which bikitaite occurs. The quartz-eucryptite assemblage has not been synthesized, and it is not known under what conditions it forms. Further laboratory and field study of these .quartz-lithium aluminosilicate assemblages is desirable.

\section{DISCUSSION}

At a conference on zeolites at Pennsylvania State University in July 1959, a definition was proposed for zeolites-

A zeolite is a crystalline aluminosilicate with a tetrahedrally coordinated framework structure containing cavities with $\mathrm{H}_{2} \mathrm{O}$ molecules, alkali and alkaline earth ions. Consequences of these properties include reversible dehydration without destruction of the framework and ionic exchange capability.

Reversible dehydration and very limited ionic exchange are here indicated for bikitaite, even though the possible ionic exchange may be restricted to small ions by the size of the channels in bikitaite. These results together with Appleman's structure determination fulfill the requirements of the above definition and indicate that bikitaite should be classified as a zeolite.

Crystalline hydrates and zeolites differ in dehydration behavior. The crystalline hydrates dehydrate over short temperature intervals and simultaneously undergo changes in crystal structure; complex hydrates may un- dergo many dehydration steps and structural changes. Zeolites dehydrate over long temperature intervals while maintaining their structural identity. This study of bikitaite demonstrates that there is no requirement for zeolitic dehydration to follow a smooth curve, even when only one $\mathrm{H}_{2} \mathrm{O}$ molecule is present in each unit cell. This study demonstrates that measurements of the equilibrium $\mathrm{H}_{2} \mathrm{O}$ content of other zeolites during dehydration are desirable to define the role of $\mathrm{H}_{2} \mathrm{O}$ in zeolite structures.

Although an effective dessicant, partially dehydrated bikitaite has less $\mathrm{H}_{2} \mathrm{O}$ adsorptive capacity at $25^{\circ} \mathrm{C}$ and $10.3 \mathrm{~mm} \mathrm{H} \mathrm{H}_{2} \mathrm{O}$ pressure than is reported for equivalent weights of silica gel, alumina, or synthetic zeolite $\mathbf{A}$ by Breck and others $(1956$, p. 5968). This fact together with the rarity of natural bikitaite, the failure of any synthesis, the small size of the channels in the structure, and the relatively low upper limits of thermal stability argue against extensive practical use for this mineral.

\section{REFERENCES}

Appleman, D. E., 1960, The crystal structure of bikitaite, LiAlSi $\mathrm{O}_{2} \cdot \mathrm{H}_{2} \mathrm{O}$ [abs.1 : Acta Cryst., v. 13, p. 1002.

Breck, D. W., Eversole, W. G., Milton, R. M., Reed, T. B., and Thomas, T. L., 1956, Crystalline Zeolites-I, the properties of a new synthetic zeolite, type A : Am. Chem. Soc. Jour., v. 78, p. $5963-5971$.

Hurlbut, C. S., Jr., 1957, Bikitaite, $\mathrm{LiAlSi}_{2} \mathrm{O}_{0} \cdot \mathrm{H}_{2} \mathrm{O}$, a new mineral from Southern Rhodesia : Am. Mineralogist, v. 42, p. 792-797.

1958, Additional data on bikitaite: Am. Mineralogist, $\nabla$. 43 , p. 768-770.

Larsen, E. S., Jr., and Berman, Harry, 1934, The microscopic determination of the nonopaque minerals: U.S. Geol. Survey Bull. 848, 2nd ed., p. 30-32.

Ruiz-Menacho, C., and Roy, Rustum, 1959, Zeolite studies. II. Stability of the lithium zeolites [abs.]: Geol. Soc. America Bull., v. 70, p. 1666.

\title{
414. GROUND-WATER SOURCES CONTAINING HIGH CONCENTRATIONS OF RADIUM
}

\author{
By Robert C. Scott and Franklin B. Barker, Denver, Colo.
}

During the course of an investigation of the occurrence and distribution of uranium and radium in ground water of the United States (Scott and Barker, 1958) several areas were found where the concentrations of radium were unusually high. For purposes of this report, any concentration exceeding 3.3 pc per l (picocuries per liter; $1 \mathrm{pc}=10^{-12}$ curie) is considered unusually high. Concentrations of several hundred picocuries per liter have been observed in oilfield brines. Many samples containing large amounts of radium represented thermal waters, brines, or water from mineralized zones, but a few samples were from fresh-water aquifers. The locations of sources of high-radium water are shown in figure 414.1.

The aquifers that yield waters high in radium are believed to be (a) formations of Cambrian and Ordovi- 


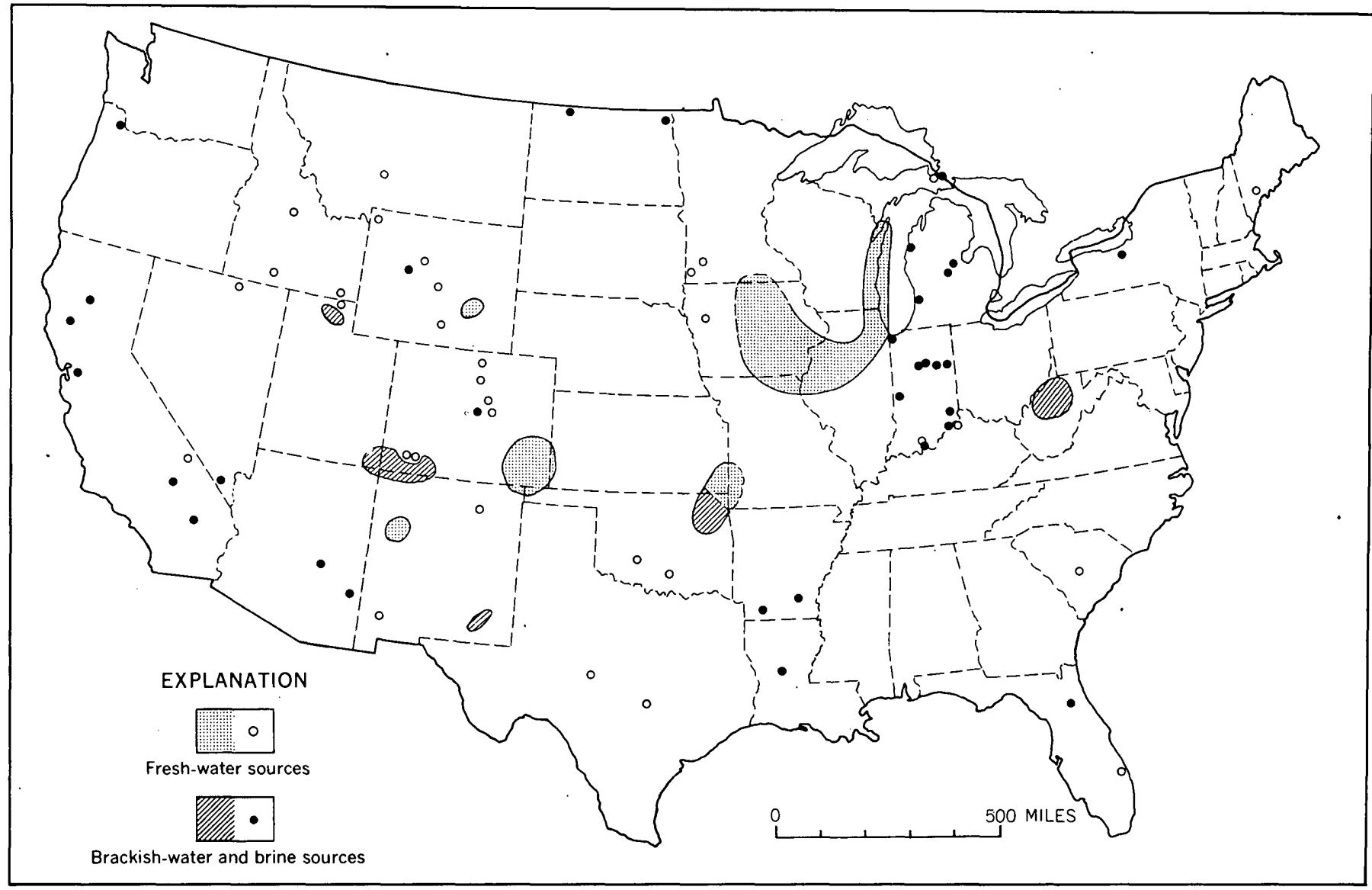

Figure 414.1.-Location of ground-water sources containing high concentrations of radium.

cian age in the north-central States, (b) the Roubidoux and Cotter formations in Kansas and Oklahoma, and (c) the Cheyenne sandstone member of the Purgatoire formation in southeastern Colorado.

Unusually high concentrations of radium in water from formations of Cambrian and Ordovician age were first discovered in Iowa, and subsequent study. has shown that the area involved covers a large part of the state. Lucas and Ilcewicz (1958) found high concentrations of radium in water from formations of Cambrian and Ordovician age in Illinois, and later work both by the present authors and by Lucas (1960) indicates an extension of the anomaly into Wisconsin. This area is the largest known in which the high concentrations of radium might be attributed to a single source. Samples from wells in the same formations in adjoining areas of northern Illinois, western Wisconsin, and central Minnesota do not show this anomaly, thus indicating a major change in the geochemical nature of these formations within a relatively short distance.

Although the study of radium concentrations in water from aquifers of Cambrian and Ordovician age in the north-central States is not complete, a consistent pat- tern seems to exist and some tentative conclusions can be drawn. Generalized contours of equal radium concentrations are shown on figure 414.2. Local anomalies in the aquifers cause a few wells in each area to yield water with a radium concentration higher or lower than the normal for the area; however, the general trend is quite pronounced and the boundaries, especially that at 3.3 pc per 1 , are fairly sharp. The concentrations of radium generally increase in the presumed direction of water movement and may represent a slow flushing of the radioactive elements from the formations. The high radium concentrations found in brines from the more extreme downgradient portions of these aquifers in Indiana might be additional evidence for such a flushing action. However, because the geochemical factors governing the occurrence of radium in brines are not well known, this evidence is not conclusive.

The deep wells in this area generally obtain water from several different formations and it is difficult to determine which of the formations of Cambrian and Ordovician age contain the high-radium water. The $3.3 \mathrm{pc}$ per 1 isogram follows approximately the northern boundary of the area underlain by the Maquoketa shale 


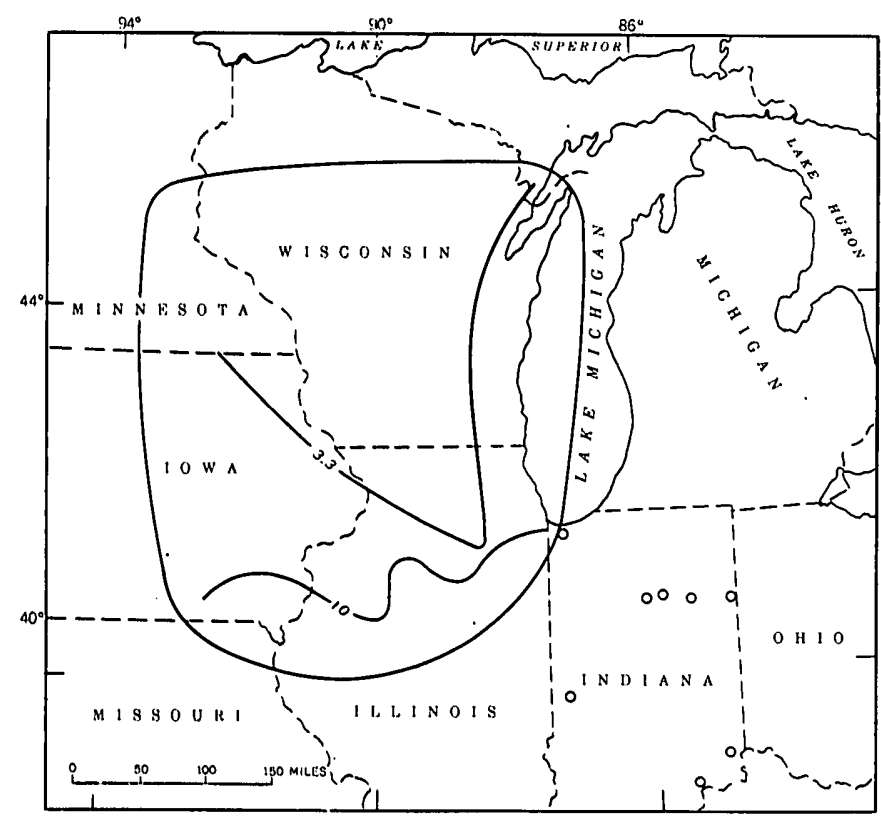

Froure 414.2.-Area of investigation in the north-central States, with generalized contours of equal concentrations of radium (in picocuries per liter).

and Orchard Creek shale (Sloss, Dapples, and Krumbein, 1960). These formations probably exercise some control over the radium concentrations eitlier by serving as the source of radium to the underlying formations or by acting as aquatards that restrict circulation of water, thus preventing efficient flushing of the aquifers. A study of the radioactivity of cores from wells in the area probably will indicate the source of the radium and help resolve the question of the role of the Maquoketa and Orchard Creek shales.

Preliminary investigation of water from the Cotter and Roubidoux formations of Ordovician age in the tri-State area of Oklahoma, Kansas, and Missouri suggest that here also the radium concentrations tend to increase in the direction of water movement. Brines from these deeply buried Ordovician formations in Oklahoma contain some of the largest concentrations of radium found in the country. The anomaly appears to extend westward and southward as far as the aquifers have been penetrated by wells.

The Cheyenne sandstone member of the Purgatoire formation of Early Cretaceous age commonly yields high-radium water throughout southeastern Colorado.
Although not all samples of water from the Cheyenne contain high concentrations of radium, these anomalies are scattered throughout the area where the Cheyenne has been developed as an aquifer. This sandstone was derived from the Ancestral Rockies and deposited under continental conditions. It is overlain by the marine Kiowa shale member of the Purgatoire formation, which is impermeable enough to confine ground water in the Cheyenne sandstone member under artesian pressure. It is not known whether the high concentrations of radium may be attributed to uranium minerals in the Cheyenne or were contributed by the Kiowa or one of the underlying formations.

Other occurrences of high-radium water are widely scattered; some of these are known to be associated with uranium deposits, but some are isolated anomalies as yet unexplained. No detailed studies have been started in the other areas where radium anomalies have been found, but several interesting problems are posed. High radium concentrations have been found in water from the Floridan aquifer of Florida, McBean formation of South Carolina, Jackson group in Arkansas, and Cockfield formation of Louisiana, all of Eocene age. These are all of the same general age; if the radium anomalies are found to persist throughout most of the areas of these formations, it will be evidence of quite similar environments and modes of deposition. Oil-field brines of the sodium-chloride type often contain radium in very high concentrations, but the geochemical aspects of this phenomenon have not been explained fully.

\section{REFERENCES}

Lucas, H. F., Jr., 1960, Study of radium-226 content of Midwest water supplies, in Radiological Physics Division semiannual report, Jan.-June, 1960: Argonne Natl. Lab. Rept. ANL-6199, p. 82-84.

Lucas, H. F., Jr., and Ilcewicz, F. H., 1958, Natural radium-226 content of Illinois water supplies: Am. Water Works Assoc. Jour., v. 50, no. 11, p. 1523-1532.

Scott, R. C., and Barker, F. B., 1958, Radium and uranium in ground water of the United States, in Survey of raw material resources, United Nations 2d Internat. Conf. on Peaceful Uses of Atomic Energy Proc., Paper P/7778; London Pergamon Press, v. 2, p. 153-157.

Sloss, L. L., Dapples, E. C., and Krumbein, W. C., 1960, Ordovician Maknoketa shale and Orchard Creek shale, in Lithofacies maps-an atlas of the United States and southern Canada: New York, John Wiley and Sons, p. 9, map 14. 


\title{
415. CHEMICAL BEHAVIOR OF BICARBONATE AND SULFATE COMPLEXES OF MANGANESE
}

\author{
By John D. Hem, Denver, Colo.
}

Manganese is normally present in natural water in the divalent state. The $\mathrm{Mn}^{+2}$ ion is capable of forming ion-pairs, or complexes with each of the three major anions present in most natural water, chloride, sulfate, and bicarbonate. A number of six-coordinated manganous chloride complexes are known; however, they do not form in appreciable quantity unless the chloride concentration is $35,000 \mathrm{ppm}$ (parts per million) or more. Chloride complexes were not studied because they are considerably weaker than the bicarbonate and sulfate complexes.

Ion pairs formed in the equilibria

and

$$
\mathrm{Mn}^{+2}+\mathrm{HCO}_{3}{ }^{-} \rightleftharpoons \mathrm{MnHCO}_{3}{ }^{+}
$$

$$
\mathrm{Mn}^{+2}+\mathrm{SO}_{4}{ }^{-2} \rightleftharpoons \mathrm{MnSO}_{4} \text { aq. (aqueous) }
$$

are fairly stable and can exist in many natural waters. The equilibrium constant for the sulfate ion-pair given by Bjerrum, Schwarzenbach and Sillén (1958) is $1.9 \times 10^{2}$. The value given by these authors for the bicarbonate ion-pair is $3.0 \times 10^{3}$. The latter value implies a very strong complexing effect from bicarbonate, and experimental work was done on the manganese bicarbonate ion pair. In this work it was assumed the simplest form of the complex, $\mathrm{MnHCO}_{3}{ }^{+}$, was present.

Systems containing an excess of powdered reagentgrade manganese carbonate, in contact with distilled water were brought to equilibrium at various partial pressures of carbon dioxide at $25^{\circ} \mathrm{C}$. The resulting data gave a value of 63 for the equilibrium constant (association constant) for the ion-pair $\mathrm{MnHCO}_{3}{ }^{+}$. This value appears reasonable when compared with constants for other metal ions of similar electronegativity (R. M. Garrels, written communication, $1960)$.

Manganese concentrations present in surface or ground water rarely exceed a few tenths of a part per million. The effect of complex formation on availability of bicarbonate or sulfate is therefore negligible.

From the relationships

and

$$
\frac{\left[\mathrm{MnHCO}_{3}{ }^{+}\right]}{\left[\mathrm{Mn}^{+2}\right]}=63\left[\mathrm{HCO}_{3}^{-}\right]
$$

$$
\frac{\left[\mathrm{MnSO}_{4} \mathrm{aq} .\right]}{\left[\mathrm{Mn}^{+2}\right]}=1.9 \times 10^{2}\left[\mathrm{SO}_{4}^{-2}\right]
$$

it is evident that half the manganese present will be in the form of the bicarbonate complex if the activity (effective concentration) of bicarbonate ions in solution is $940 \mathrm{ppm}$ or if the activity of sulfate ions is $505 \mathrm{ppm}$. In most natural water both sulfate and bicarbonate are present and both the manganese complexes are present along with uncomplexed manganese ions. From the relationships

$\mathrm{MnHCO}_{3}{ }^{+}+\mathrm{SO}_{4}{ }^{-2} \rightleftharpoons \mathrm{MnSO}_{4} \mathrm{aq} .+\mathrm{HCO}_{3}{ }^{-}$for which the equilibrium constant is 3.1 , and

$\frac{\left[\mathrm{MnHCO}_{3}{ }^{+}\right]+\left[\mathrm{MnSO}_{4}\right]}{\Sigma[\mathrm{Mn} \text { species }] \times 10^{-2}}=$ percent of $\mathrm{Mn}$ complexed,

the net effects of various activities of sulfate and bicarbonate can be calculated. Figure 415.1 is a graph. showing the proportions of manganese that would be complexed in solutions containing various activities of the two anions. It also shows which of the two complexes would be present in larger amounts.

Water used for public supplies commonly contains between 100 and $1,000 \mathrm{ppm}$ bicarbonate and between 10 and $100 \mathrm{ppm}$ sulfate, and as much as half of any manganese present could be in the complexed form in such water. Generally, however, the bicarbonate complex will predominate.

It should be noted that the activity values used in preparing the graph are not identical with the actual concentrations that are reported in water analyses. An activity is an effective concentration and generally is lower than the corresponding measured concentration because of interionic attraction in solution and other factors. The difference between concentration and activity is small at low concentrations. For divalent ions such as manganese or sulfate, however, the activity may be only half as great as the concentration if the total dissolved solids content is 3,000 to $5,000 \mathrm{ppm}$. An approximate indication of complexing action can be obtained from figure 415.1 without making activity calculations. An exact evaluation of effects of complexing requires that activity coefficients be calculated. Standard methods of chemical thermodynamics can be used for this purpose. The writer (Hem, 1961) has described some of these procedures elsewhere.

The total amount of manganese that can be retained in solution at equilibrium. is the sum of the different 
SULFATE ACTIVITY, IN PARTS PER MILLION

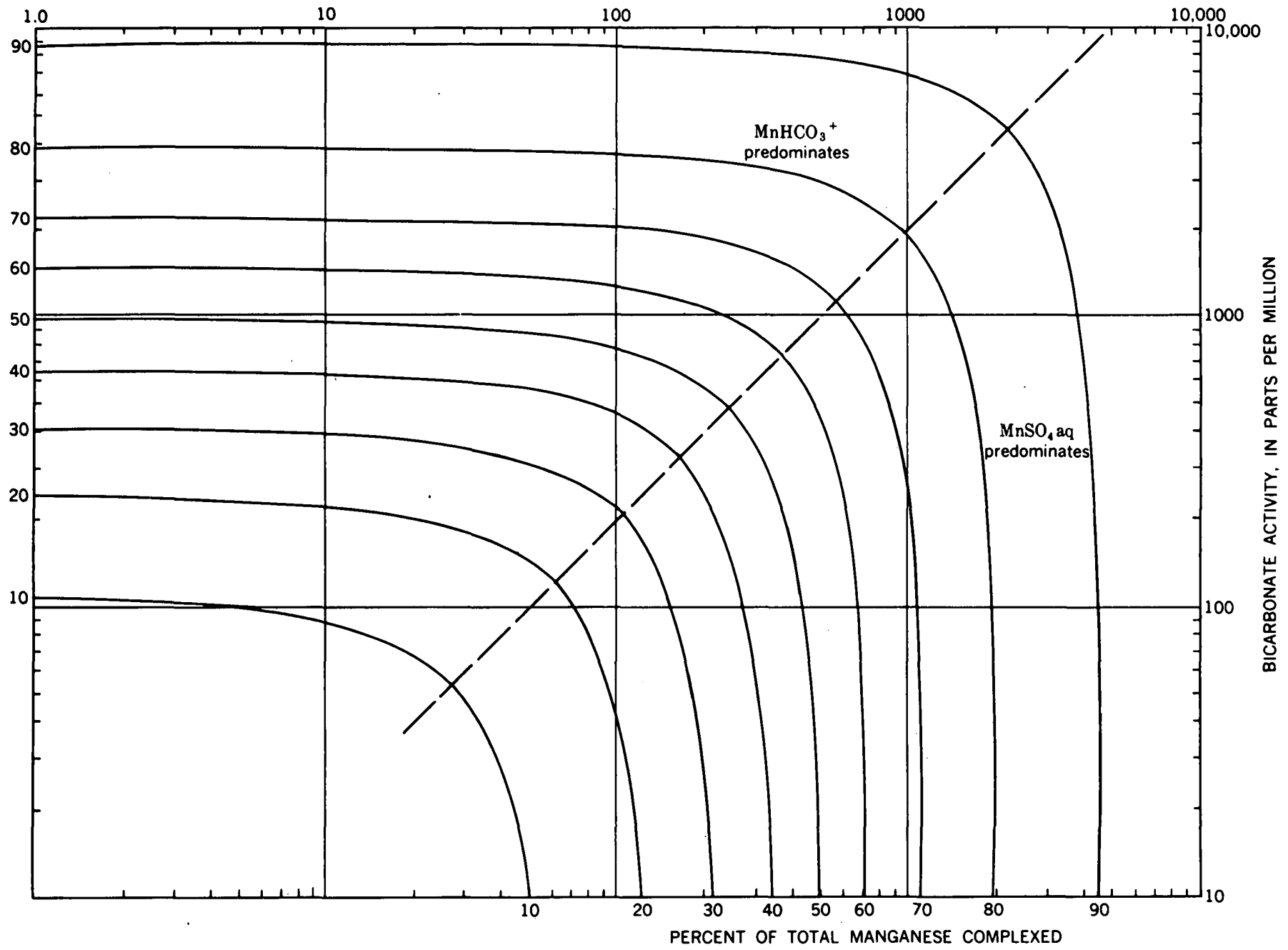

Fraure 415.1.-Percent of total dissolved manganese present as complexes, and predominant form of complex at different sulfate and bicarbonate activities.

ionic species that contain manganese. Under some conditions in nature, the amounts of dissolved manganese may be greatly increased by complexing. In a solution where half the dissolved manganese is present as a complex, for example, the amount of manganese present in solution may be double what might be expected in the absence of complexing.

Manganese complexes may influence the behavior of the element in weathering or deposition reactions in nature in other ways. The complex ions of divalent manganese may tend to protect the manganese from oxidation to the +3 or +4 state, and may influence the rates of oxidation reactions.

\section{REFERENCES}

Bjerrum, Jannik, Schwarzenbach, Gerold, and Sillén, L. G., 1958, Stability constants of metal-ion complexes; Inorganic ligands, pt. 2: London, The Chemical Society Spec. Pub., no. $7,131 \mathrm{p}$

Hem, J. D., 1961, Geochemistry of water-Calculation and use of ion activity: U.S. Geol. Survey Water-Supply Paper 1535-C, 17 p. 


\section{OVERVOLTAGE CHARACTERISTICS OF A PYRITE CRYSTAL}

By Lennart A. Anderson, Denver, Colo.

Overvoltage phenomena at the surface of a metal in contact with an electrolyte are the principal cause for the anomalous induced polarizations in disseminated sulfide deposits. This investigation deals with the overvoltage effect on a pyrite crystal and the relation of overvoltage to current density at the polarizing interface.

When a metal is placed in an electrolyte, a potential difference may be observed almost instantaneously between the metal and the electrolyte. The equilibrium potential across the metal solution interface is called the reversible electrode potential. When an external voltage is applied across the metal-electrolyte contact, the equilibrium potential will be disturbed, resulting in polarization of the electrode. A polarized electrode behaves irreversibly because some slow step in the electrochemical reaction at the electrode causes an unbalance in the electrode process. Because the energy requirements are greater in one direction than in the other, a potential is generated that differs from the the equilibrium potential by a value determined by the current density and the nature of the electrode and electrolyte. This potential is called activation overvoltage.

Another cause of overvoltage is the concentration change near the electrode as ions are either released or adsorbed by the electrode. Concentration overvoltage decreases as the concentration of the electrolyte is increased and can virtually be eliminated by agitation of the electrolyte.

A false overvoltage is sometimes caused by an ohmic drop in potential due to oxide or grease films at the surface of the electrode. The use of very small currents and careful experimental procedure tend to minimize the ohmic overvoltage (Glasstone, 1942, p. 435-440).

The apparatus used to measure overvoltages in the laboratory is shown on figure 416.1. The solution must be boiled for a long period to remove the dissolved oxygen and other reducible material. Oxygen interferes with the electrode reaction, causing overvoltages to be erratic and nonreproducible. After it is cooled in a hydrogen atmosphere, the solution is forced into the hydrogen-filled reservoirs using hydrogen as the pressure agent.

Overvoltage measurements are made with the pyrite crystal connected to the negative terminal of the current source. Current is passed from an external power supply into the solution by means of a platinum electrode, through a salt bridge connecting the reservoirs electrically, and back to the power supply by way of the pyrite crystal. The voltage drop between the pyrite and a saturated calomel electrode is measured with an electronic potentiometer having an input impedance of 100 megohms.

Overvoltages were measured with current densities at the electrode surface in the range $10^{-7}$ to $10^{-3}$ amperes per square centimeter.

Previous investigations indicate a linear relation between overvoltage and the logarithm of current density (Butler, 1951, p. 161-166). The overvoltage $(\xi)$ has been observed to satisfy the expression

$$
(\xi=a-b \log j)
$$

where $j$ is the current density in amperes per square centimeter and $a$ and $b$ are constants determined by the nature of the electrolyte and electrode. Bowden and Rideal (1928, p. 76) state that the relation holds accurately for mercury but only approximately for other metals. Butler (1951, p. 162) suggests that the value of $b$ ranges from 0.09 to 0.13 in highly purified solutions.

Bowden and Rideal (1928, p. 64) note that in pure electrolytes the overvoltage at a given current density will reach its asymptotic value within 0.2 second after the start of current flow, but if oxygen is present even in very small quantities the saturation value will not be reached in less than 30 seconds. The decay rate is also affected by oxygen. Upon shutting off the external current, the overvoltage will fall to zero in 5 seconds if oxygen is present, whereas the decay will take 20 minutes in oxygen-free solutions. Using this technique

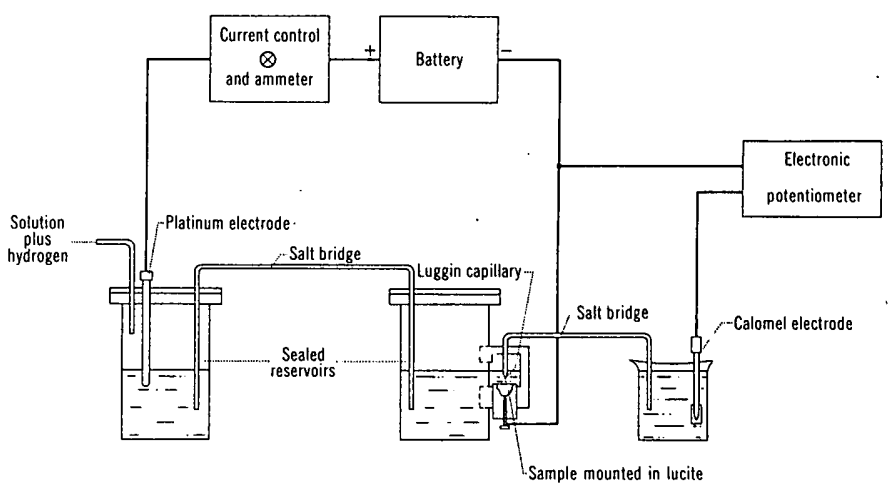

Figure 416.1.-Schematic diagram of laboratory apparatus for overvoltage measurements. 
to check the purity of the electrolyte, it was found that 1.5 seconds was required to reach the saturation level and 14.5 seconds elapsed during the return to the initial overvoltage value. Some impurities apparently are present, causing a deviation from the anticipated straight-line relation.

The results of the measurements on a pyrite sample in $0.01 \mathrm{~N}$ and $0.2 \mathrm{~N} \mathrm{H}_{2} \mathrm{SO}_{4}$ solutions and a $0.1 \mathrm{~N} \mathrm{KCL}$ solution containing dissolved hydrogen are shown on figure 416.2. The maximum current density normally applied in a field survey would be at the point indicated by the value -6.0 for $\log j$. The overvoltage behavior above this value is of interest because most laboratory measurements are made with very high current densities. At these current levels a small change in environment may cause a large variation in polarization response which may not be directly comparable to the polarization values measured in the field with low current density.

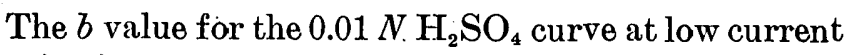
density is 0.3 , which is greater than the upper limit of the $b$ values for pure solutions as indicated by Butler. The $0.2 \mathrm{~N} \mathrm{H}_{2} \mathrm{SO}_{4}$ and $0.1 \mathrm{~N} \mathrm{KCl}$ solutions have $b$ values of 0.6 and 0.7 , respectively, at the low current densities except that the $\mathrm{KCl}$ curve has a steep slope at the very beginning of current flow, possibly because of the deposition of the potassium ions in the immediate vicinity of the electrode. Each solution was probably somewhat contaminated, but this is unavoidable due to the impurities in natural pyrite crystals. The contamination indicator or slope $b$ is not constant because a new surface is exposed by polishing the sample prior to each set of measurements. Polishing also alters the surface area in contact with the solution, which may account for the difference in the amplitude of the curves at the low current densities.

The $b$ value in each case increases when a current density of approximately $1 \times 10^{-6}$ amps per $\mathrm{cm}^{2}$ is

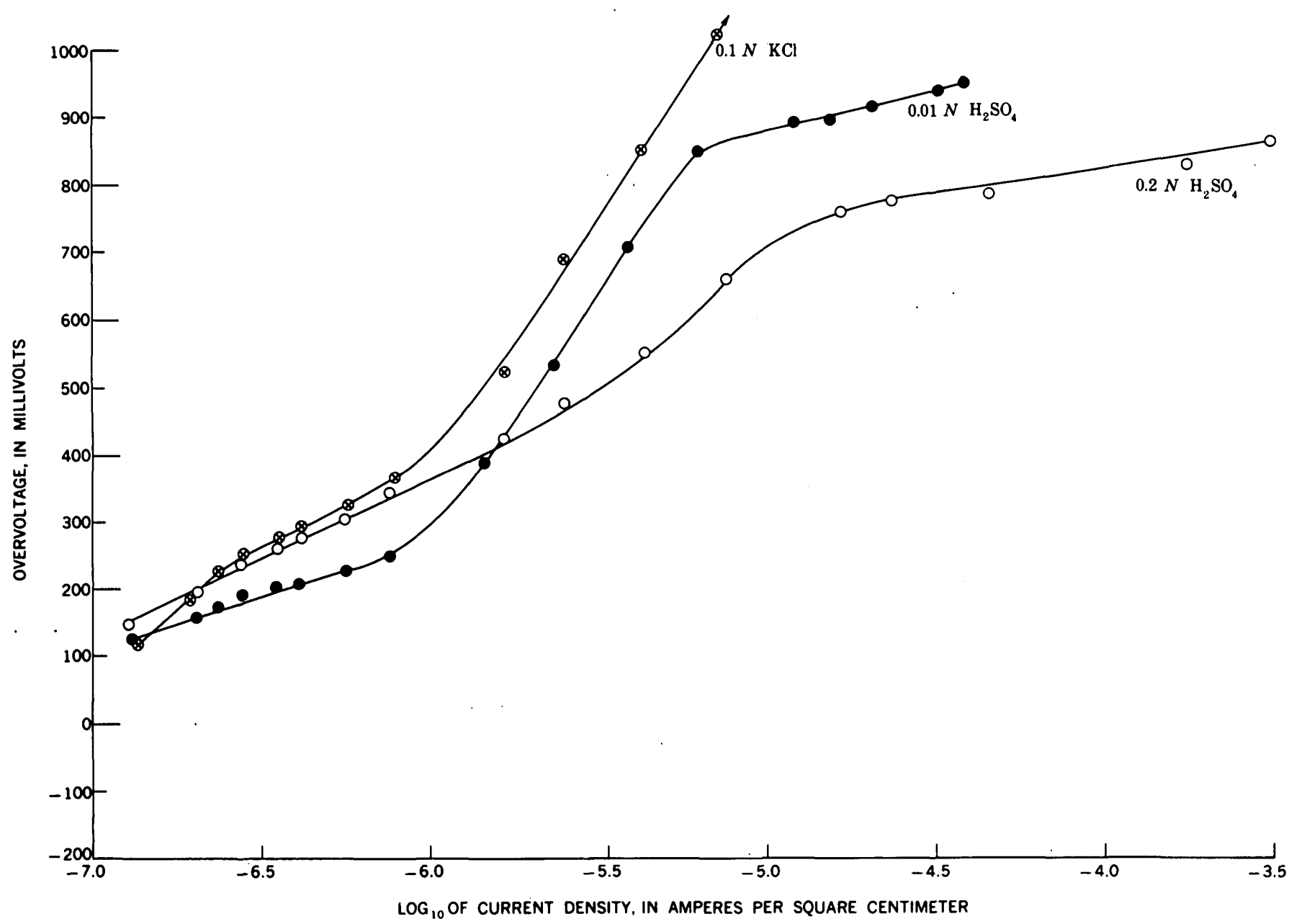

FraURE 416.2.-Overvoltages of a pyrite crystal in sulfuric acid and potassium chloride electrolytes. 


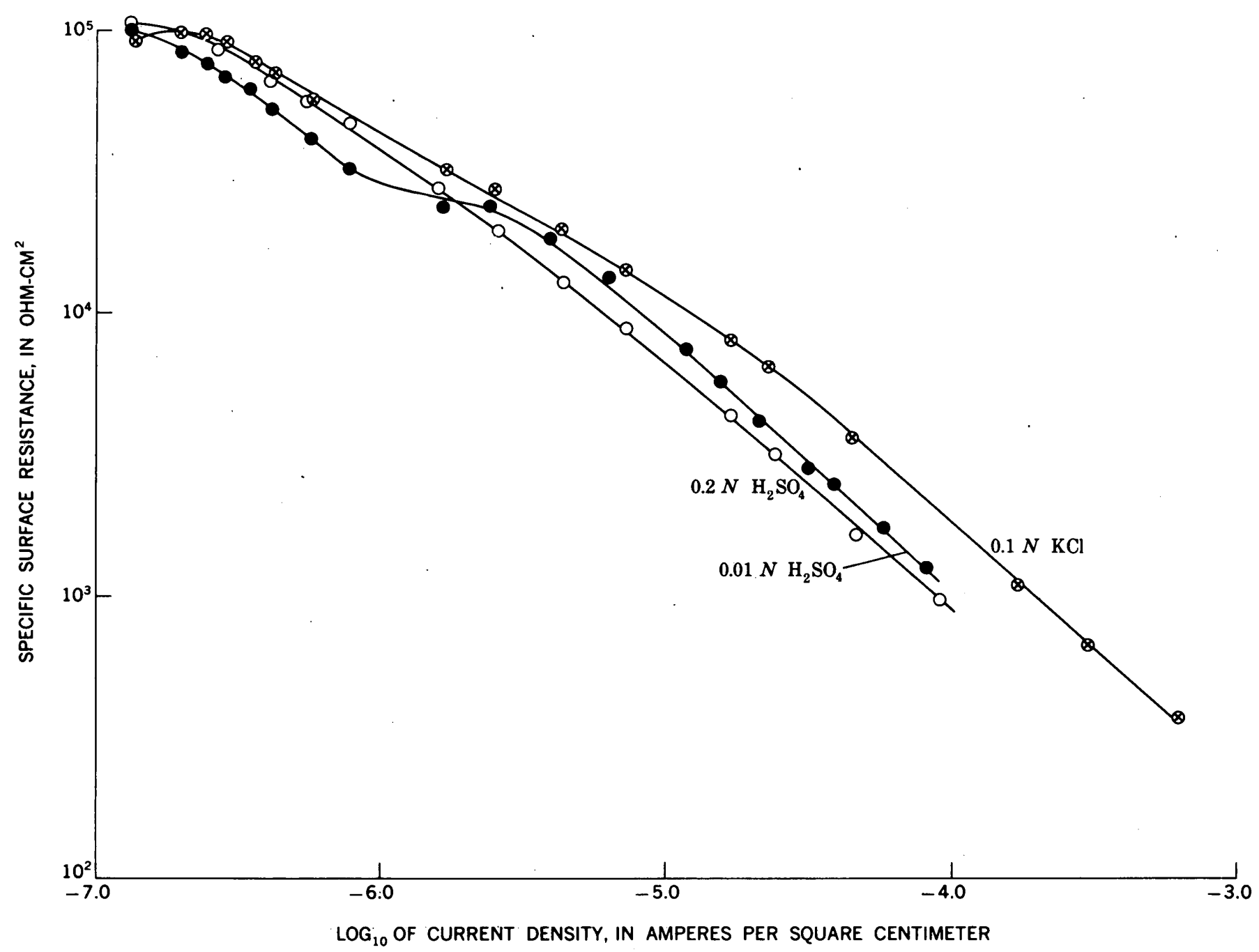

Figure 416.3.-Specific surface resistances of a pyrite crystal in sulfuric acid and potassium chloride electrolytes.

reached. At this point hydrogen gas forms at the electrode surface and causes a rapid rise in overvoltage. This continues until the surface is saturated with hydrogen atoms. As shown on figure 416.2, the electrode potential at which saturation is reached is a function of the number of hydrogen ions available for deposition.

The significance of overvoltage to geophysical applications can be better illustrated (fig. 416.3) in terms of specific surface resistance (overvoltage divided by current density). At very low current densities, the specific surface resistance is in the range of $1 \times 10^{5} \mathrm{ohm}-$ $\mathrm{cm}^{2}$. The resistance decreases as the current density is increased. Therefore, any increase in current density will cause the polarization voltage to decay through a smaller time constant, resulting in a proportionately smaller transient response.
The data demonstrate that differences in the concentrations of the electrolyte have little effect on overvoltage at very low current densities, but that impurities within the pyrite crystal make overvoltage behavior difficult to predict. In induced polarizationfield applications, small currents give maximum transient response and reasonably good reproducibility.

\section{REFERENCES}

Bowden, F. P., and Rideal, E. K., 1928, Electrolytic behavior of thin film; Part I-Hydrogen : Royal Soc. [London] Proc., ser. A, v. 120 , p. $59-80$.

Butler, J. A. V., 1951, Electrical phenomena at interfaces: New York, MacMillan Co., 318 p.

Glasstone, Samuel, 1942, Introduction to electrochemistry : New York, D. Van Nostrand Co., Inc., 557 p. 
SHORT PAPERS IN THE GEOLOGIC AND HYDROLOGIC SCIENCES, ARTICLES 293-43.5

\title{
GEOLOGY AND HYDROLOGY APPLIED TO ENGINEERING AND PUBLIC HEALTH
}

\section{SHATTER CONES FORMED BY HIGH SPEED IMPACT IN DOLOMITE}

\author{
By E. M. Shommaker, D. E. Gault ${ }^{1}$, and R. V. Lugn, Menlo Park, Calif., Moffett Field, Calif., and
} Menlo Park, Calif.

Work done in cooperation with the National Aeronautics and Space Administration

Shatter cones are striated conical slip surfaces in rock, which have been described from a number of widely scattered localities of unusual geological structuire (Branco and Fraas, 1905; Shrock and Malott, 1933; Rohleder, 1934; Dietz, 1959, 1960a, and 1960b). The cones are most commonly found in fine-grained carbonate rocks but have also been observed in shale, chert, quartzite, and granite. Dietz (1947, 1959, 1960a) has advanced the hypothesis that all natural shatter cones have been formed by shock generated by the impact of large meteorites.

Shatter cones are said to occur in strongly shocked beds of tuff around the Rainier nuclear explosion chamber in Nevada (Dietz, 1960a), but no conclusive evidence for the impact origin of natural shatter cones has been brought forward. During the course of recent work at Meteor Crater, Ariz., E.C.T. Chao found in alluvium on the rim of the crater a piece of Coconino sandstone that exhibits part of a curved slickensided surface rudely resembling part of a shatter cone. This is perhaps the closest approach to independent evidence for the impact origin of shatter cones.

Demonstration of the mechanisms and conditions under which shatter cones are formed would permit better evaluation of the confidence that may be placed in them as criteria for the recognition of ancient largescale impact structures. It was, therefore, of more than usual interest when, in a cooperative program of research on hypervelocity impact in rock between the Geological Survey and the Ames Research Center of the National Aeronautics and Space Administration, the first projectile fired produced small well-formed shatter cones in the rock target. Subsequent experiments at the Ames Research Center produced shatter cones in other targets, but none surpassed in clarity of form those produced by the first experiment.

For this experiment, a block of fine-grained sandy dolomite rock from the Alpha member of McKee (1938) of the Kaibab limestone of Permian age was collected

\footnotetext{
1 Ames Research Center, National Aeronautics and Space Administration.
}

from a fresh roadcut near Meteor Crater, Ariz. The dolomite rock is composed of about 75 percent dolomite, 20 percent quartz, and a few percent calcite, feldspar, clay minerals, hematite, goethite, and heavy minerals. According to measurements of $\mathrm{C}$. $\mathrm{H}$. Roach it has a grain density of $2.79 \mathrm{gm}$ per $\mathrm{cm}^{3}$, a dry bulk density ranging from 2.12 to $2.22 \mathrm{gm}$ per $\mathrm{cm}^{3}$, and 20.3 to 23.8 percent porosity. The acoustic velocity determined for one slab sawed from the block is $9,360 \pm 100$ feet per second $(2.86 \mathrm{~km}$ per sec), and the unconfined crushing strengths of two 1 -inch, by 1 -inch, by 2 -inch sawed samples measured with a standard testing machine were 357 and $438 \mathrm{~kg}$. per $\mathrm{cm}^{2}$. A smooth flat surface was prepared on one face of the block by a milling machine.

Under the supervision of D. E. Gault a $3 / 16^{-i n c h}$ aluminum sphere was launched at high speed from a lightgas gun (Charters, Denardo, and Rossow, 1957) at the Hypervelocity Ballistic Range of the Ames Research Center. As determined from time measurements and spark photographs at four stations along the trajectory, the sphere struck the machined surface of the rock target at perpendicular incidence with a speed of 18,400 feet per second $(5.61 \mathrm{~km}$ per sec).

The impact produced a crater in the dolomite rock $5 \mathrm{~cm}$ in diameter and $1.30 \mathrm{~cm}$ deep and a surrounding annular spall $11 \mathrm{~cm}$ across that just failed to break free (figs. 417.1 and 417.2). The color of the fresh unshocked dolomite is grayish orange (10 YR 7/4), but most of the bottom of the crater was colored very pale orange (10 YR 8/2) to white, mainly as a consequence of intergranular crushing.

Perched on the bottom of the crater were three easily recognized shatter cones and a number of striated slip surfaces of irregular or less definite form (figs. 417.3 and 417.4). The striated surfaces of the cones and other slip surfaces were colored pink evidently because of the smearing of the trace amount of hematite along them. Within a few days the cones began to break up and spall, probably owing to internal stresses induced by the impact. A rubber mold of the crater was made to provide a permanent record of the delicate features 


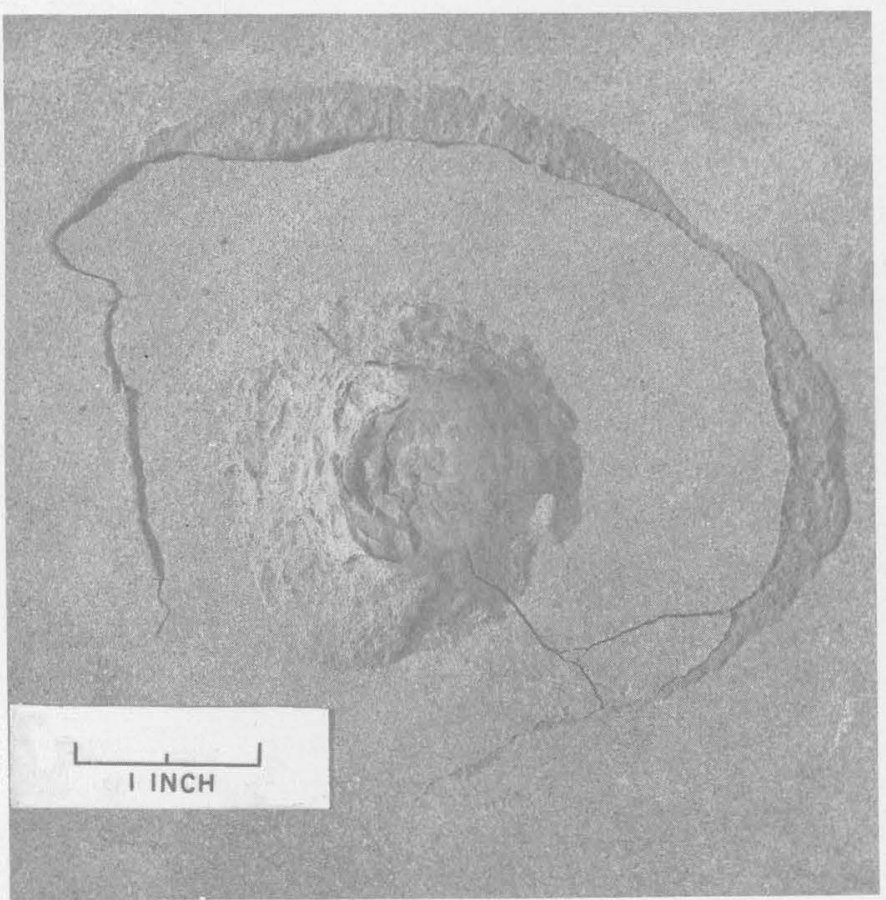

Figure 417.1.-Photograph of high speed impact erater in sandy dolomite from the Kaibab limestone.
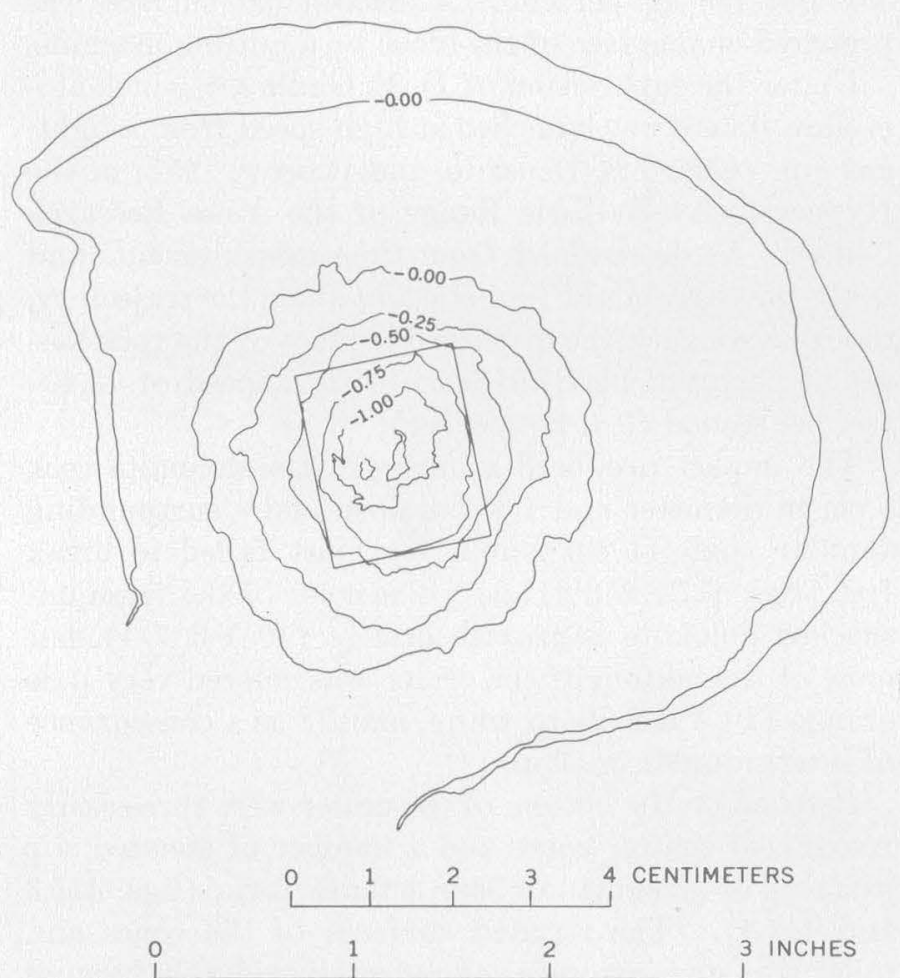

CONTOURS SHOW DEPTH BELOW SURFACE OF BLOCK IN CENTIMETERS. CONTOUR INTERVAL 0.25 CENTIMETERS

Frgure 417.2.-Map of high speed impact crater in sandy dolomite from the Kaibab limestone, by Andre Marechal and R. V. Lugn. Rectangle shows area covered by figure 417.4.

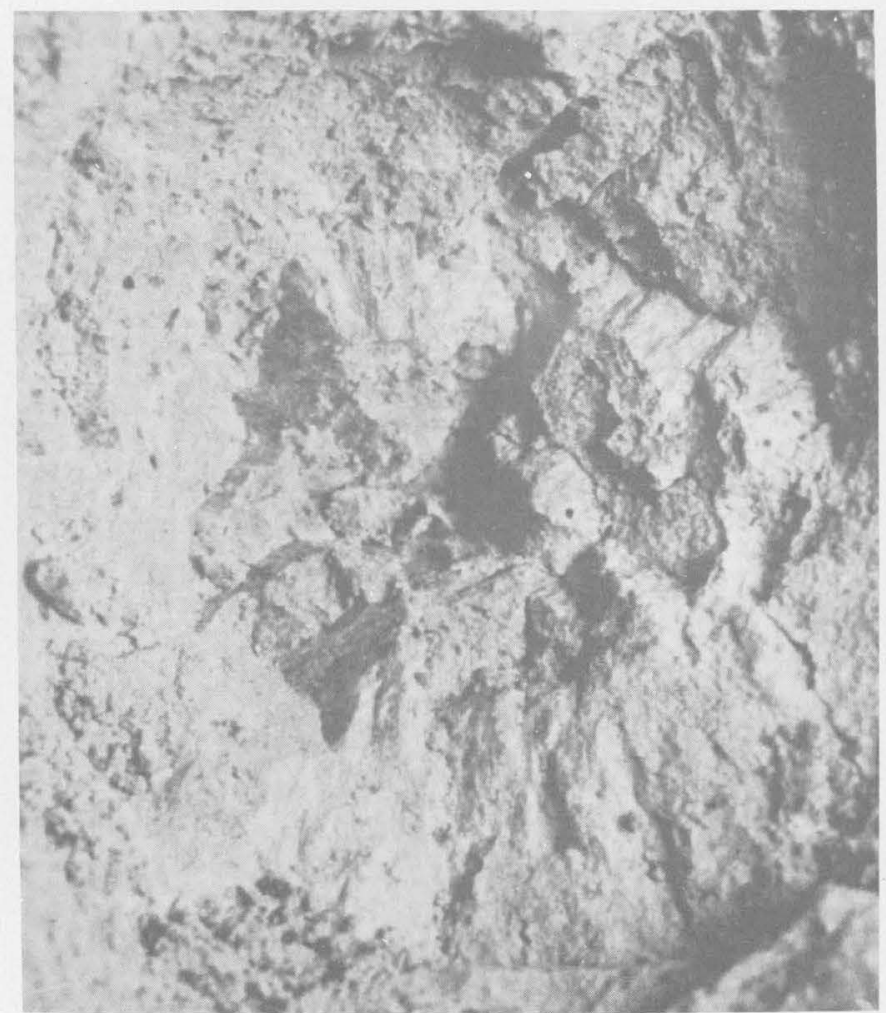

FIgURE 417.3.-Photograph of part of high speed impact erater in dolomite showing shatter cones. Photograph by National Aeronauties and Space Administration.

remaining in the crater, and the map of the shatter cones was subsequently prepared by R. V. Lugn from a plaster cast.

The shatter cones range from $2 \mathrm{~mm}$ to $7.5 \mathrm{~mm}$ in exposed basal diameter. Apices of all but the smallest cone, which is about $1 \mathrm{~mm}$ high in the direction of the axis, were lost by spalling. Like natural shatter cones, the apical angles of the three experimentally formed cones are close to $90^{\circ}$. The axes of the cones are inclined toward the path of penetration of the projectile; the cones point approximately in the direction opposite to the shock propagation as hypothesized by Dietz (1947). Striations on the cones range from 0.2 to $2.5 \mathrm{~mm}$ long, and troughs of the more conspicuous grooves are spaced about 0.1 to $0.2 \mathrm{~mm}$ apart. In general, the striations plunge more or less radially from the apices of the cones, but there is a distinct tendency for the striations to be parallel on the parts of the cones with least curvature. The trend of the striations in places changes abruptly where the curvature is sharp, a feature that is also observed on natural shatter cones. The net slip on the cone surfaces is difficult to estimate but it is probably less than $0.1 \mathrm{~mm}$. 


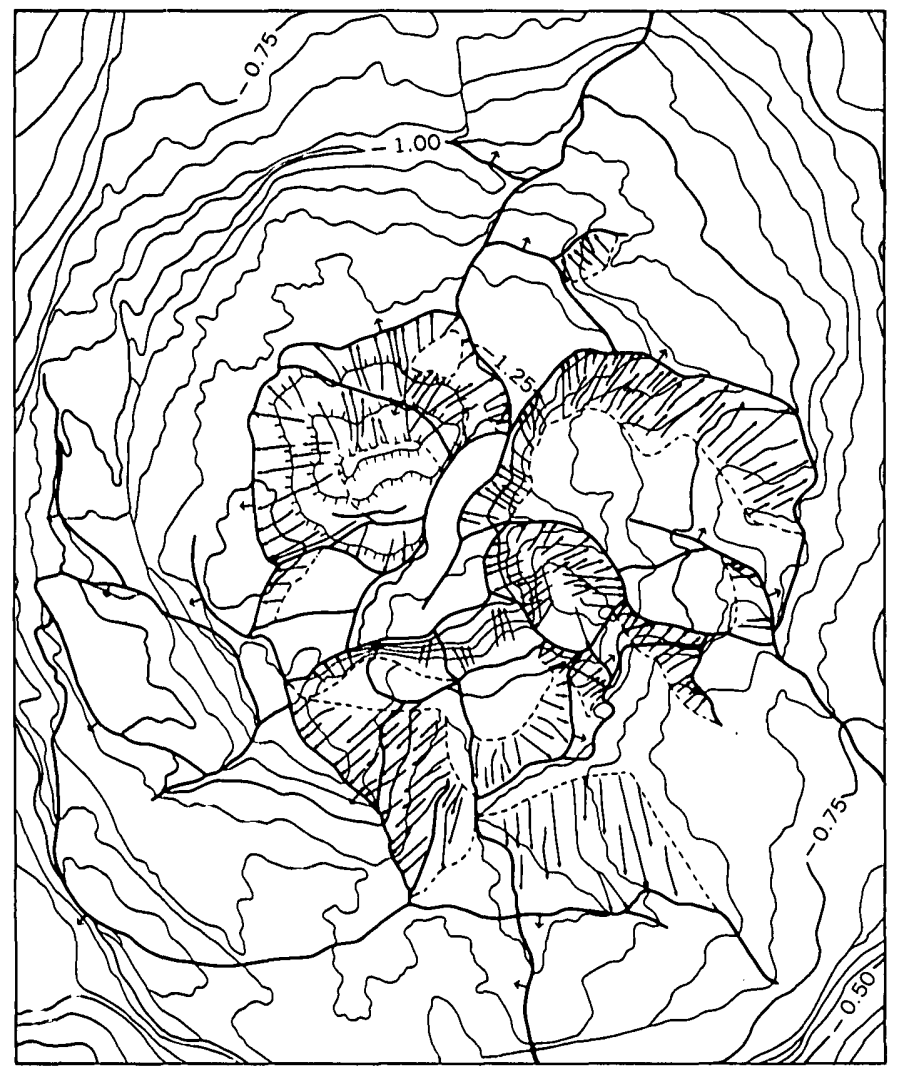

\section{0} J

EXPLANATION

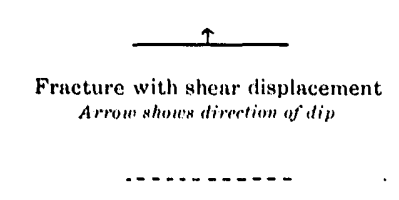

Upper limit of exposed slip surfuce

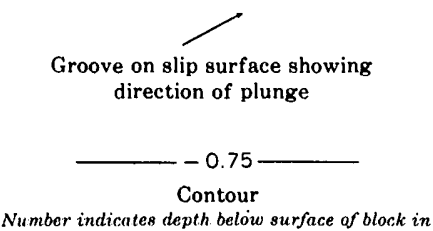

Number indicates depth below surface of block $i$
FIgưre 417.4.-Map of shatter cones and other slip surfaces in high speed impact crater in dolomite, by $R$. V. Lugn.

From the geometry of the cones, it may be seen that displacement on the slip surfaces results in a distension or stretching of the rock in planes tangential to the front of the shock generated by the impact. This stretching may be easily understood as a consequence of the divergent radial flow of material behind an approximately hemispherical shock front. The slip surfaces are evidently surfaces of maximum shear stress belind the shock front formed at about $45^{\circ}$ to the radial directions of shock compression. We suggest that the cones point toward the origin of the shock because the slip surfaces are initiated around grains or small volumes that are slightly less compressible than the sur- rounding medium and are propagated outward as the shock advances.

It is of interest to estimate the peak shock pressure at the outer radial limit of shatter cone formation in this experiment because of the possibility that shatter cones may serve as rough geological piezometers for peak shock pressures at ancient sites of meteorite impact. Initial shock pressure during the first stages of penetration of the projectile may be estimated from a one-dimensional analysis using the known impact velocity, measured densities of the target and projectile, the known hugoniot of aluminum (Altshuler and others, 1960), and a hugoniot measured by R. Schall (written communication, 1960) for a rock with a density and porosity closely similar to that of the dolomite. This calculated pressure, 475 kilobars, may be taken as the approximate peak pressure behind the shock into the rock at a moment when the shock has engulfed a mass of rock equal to that of the projectile $(0.1592 \mathrm{gm})$. The shock energy at this stage will be roughly equally spread through the rock engulfed and the projectile. If the energy remained evenly spread through the rock engulfed by the shock, the peak pressure would be inversely proportional to the mass engulfed and would have dropped to $14.8 \mathrm{~kb}$ at $1.30 \mathrm{~cm}$, the depth from the surface of the base of the most distant shatter cones. In reality, considerable energy will be trapped as heat in the region of high peak pressure and as kinetic energy of the ejecta so that the peak pressure will decay approximately as some power of the inverse of the mass engulfed exceeding 1 (pressure $\alpha\left[1 /\right.$ mass $^{\mathrm{n}}$ ), probably between $4 / 3$ and $5 / 3$. Decay of the peak pressure according to the $-4 / 3$ power of the mass gives a pressure of 4.7 kilobars at $1.30 \mathrm{~cm}$ and of 1.46 kilobars according to the $-5 / 3$ power of the mass. This may be compared with the measured unconfined static crushing strength of 0.43 . kilobars. It should be noted that Grine and Fowles (1959) have reported that apparent dynamic compressive strengths of shock loaded rocks can be an order of magnitude higher than the static strengths.

\section{REFERENCES}

Altshuler, L. V., Kormer, S. V., Bakanova, A. H., and Trunin, R. F., 1960, Equation of state for aluminum, copper, and lead in the high pressure region: Jour. Experimental Theoretical Physics, v. 38, p. 790-798 (in Russian) ; translation in Soviet Physics-JETP, v. 11, p. 573-579 (1960).

Branco, Wilhelm, and Fraas, E., 1905, Das kryptovulcanische Becken von Steinheim: Akad. Wiss. Preuss. Abh., 64 p.

Charters, A. C., Denardo, B. P., and Rossow, V. J., 1957, Development of a piston-compressor type light-gas gun for the launching of free-flight models at high velocity : Natl. Advisory Comm. Aeronautics 'Tech. Note 4143, $95 \mathrm{p}$. 
Dietz, R. S., 1947, Meteorite impact suggested by the orientation of shatter cones at the Kentland, Indiana, disturbance: Science, v. 105, no. 2715, p. 42-43.

1959, Shatter cones in cryptoexplosion structures (meteorite impact?) : Jour. Geology, v. 67, no. 5, p. 496505.

1960a, Meteorite impact suggested by shatter cones in rock : Science, v. 131, no. 3416, p. 1781-1784.

$1960 \mathrm{~b}$, Vredefort ring structure -an astrobleme meteorite impact structure [abs.] : Geol. Soc. America Bull., v. 71, p. 2093.

Grine, D. R., and Fowles, G. R., 1959, The attentuation of shock waves in solid materials with seismic applications, in
Third symposium on rock mechanics: Colorado School Mines Quart., v. 54, no. 3, p. 251-269.

McKee, E. D., 1938, The environment and history of the Toroweap and Kaibab formations of northern Arizona and southern Utah: Carnegie Inst. Washington Pub. 492, viii, $268 \mathrm{p}$.

Rohleder, H. P. T., 1934, Über den Fund von Vergriesungserscheinungen und Drucksuturen am Kesselrand des kryptovulkanischen Bosumtwi-Sees, Ashanti: Centralblatt f. Mineralogie, Geologie und Paläontologie, Abt. A, no. 10, p. 316-318.

Shrock, R. R., and Malott, C. A., 1933, The Kentland area of disturbed Ordovician rocks in northwestern Indiana: Jour. Geology, v. 41, p. 337-370.

\title{
418. GEOLOGIC RESULTS OF NOVEMBER 1960 PROJECT CHARIOT HIGH-EXPLOSIVE CRATERING EXPERIMENT, CAPE THOMPSON, ALASKA
}

\author{
By Reuben Kachadoorian, Menlo Park, Calif.
}

Work done in cooperation with the U.S. Atomio Energy Commission

In November 1960, a high-explosive cratering experiment was made at the Project Chariot site near Cape Thompson, northwestern Alaska, by the Lawrence Radiation Laboratory, Livermore, Calif., under authorization of the Atomic Energy Commission. The experiment consisted of the detonation of a 256-pound spherical charge of TNT at a depth of 8.7 feet in the Tiglukpuk(?) formation of Jurassic age. At ground zero the Tiglukpuk(?) formation consisted of mudstone in beds having an average thickness of $1 / 4$ of an inch and a maximum thickness of about 2 inches. The strike of the beds was fairly constant at N. $55^{\circ} \mathrm{E}$.; however, the dip ranged from $80^{\circ} \mathrm{SE}$ to $70^{\circ} \mathrm{NW}$ and averaged $85^{\circ}$ N.W. As shown on figure 418.1, the mudstone was frozen from the surface to a depth of 1.5 feet (frozen active zone); it was unfrozen from depths of 1.5 to 4.0 feet (thawed active zone); and it was permanently frozen from depths of 4.0 to 9.0 feet (permafrost zone). Annual freezing and thawing had distorted and highly fractured the mudstone in the active zones. Most of the fractures in the frozen active zone were healed by ice, whereas fractures and joint planes in the thawed active zone were uncemented. Mudstone in the thawed zone was more friable than the mudstone in the frozen zones. In the frozen active zone the moisture content was 3.1 percent; in the thawed active zone, it was 3.6 percent; and in the permafrost zone, it ranged from 4.4 to 12.5 percent. Ice lenses and vugs were common in the permafrost zone.
A nearly symmetrical crater 8 feet deep and 26 feet in diameter was produced by the explosion (fig. 418.1). The apparent volume of the crater was 78.5 cubic yards, and the volume of the debris on the lip of the crater was 110 cubic yards (C. Bacigalupi, written communication, 1960), which gives the swell of the debris as 40 percent. Debris was deposited in the crater, in an asymmetrical apron around the crater, and as a finegrained fallout. Throwout as used in this report consists of material that followed ballistic trajectories to the site of deposition. Fallout consists of material arrested in its ballistic flight by atmospheric drag. The subsequent deposition was controlled by free fall and by atmospheric currents. The fallout did not contain any radioactive debris because a chemical explosive was used. The spatial distribution of debris is shown on figures 418.1 and 418.2. Only minor intermingling of debris of the different zones occurred in the crater.

The average diameter of the area covered by the throwout debris was between 800 and 900 feet (figs. 418.1 and 418.2). The minimum radius of the apron of throwout debris was about 350 feet in a northwest direction, which is the direction of the average dip of the beds. The maximum radius was 550 feet in a southeast direction, opposite the direction of dip.

Three zones of debris were recognized in the apron (fig. 418.2) : an inner zone extending from the crater lip to about 45 feet from ground zero; an intermediate zone extending from about 45 to about 250 feet from 


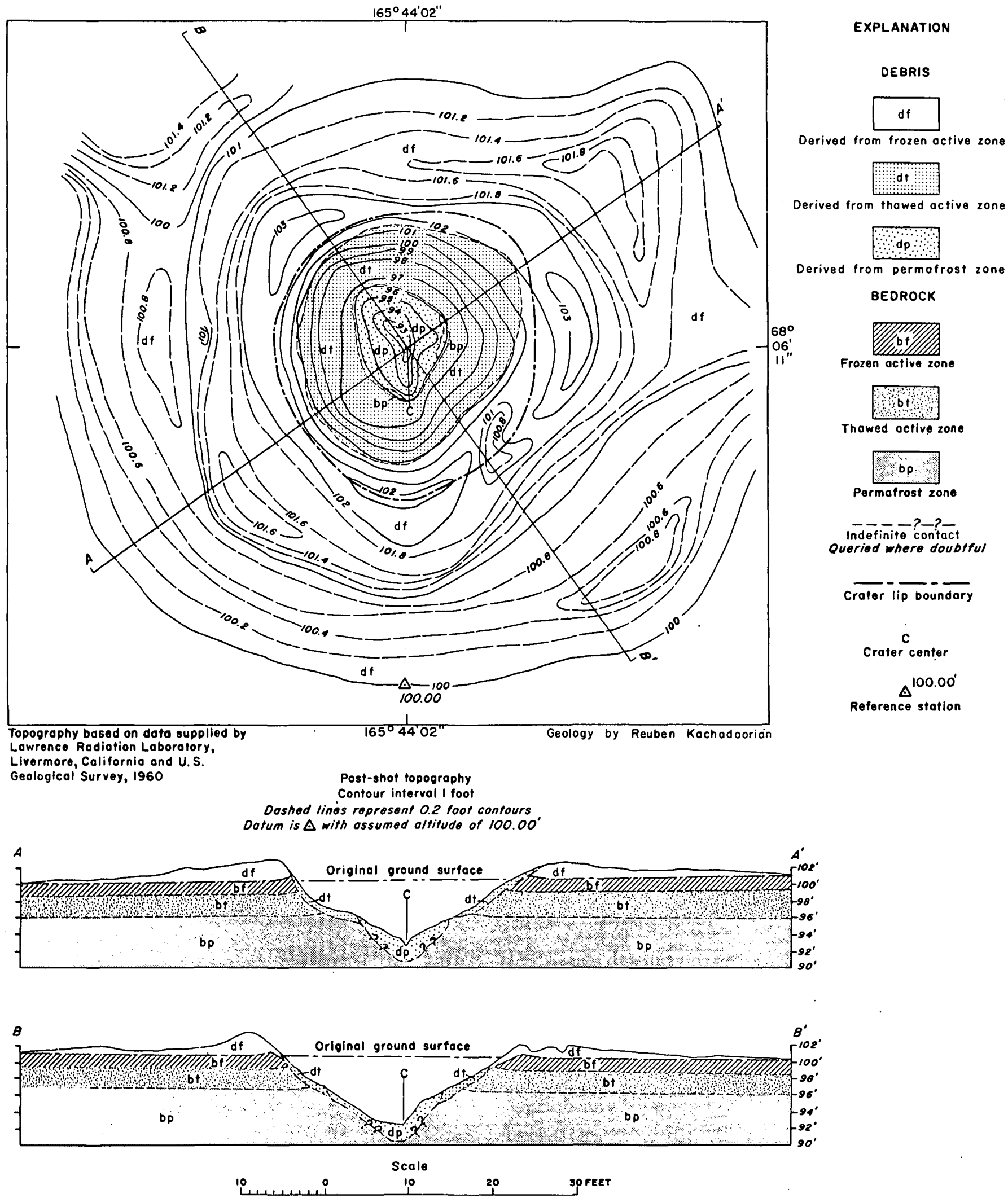

Frgure 418.1.-Geologic map and sections of November 1960 Project Chariot high-explosive test. 


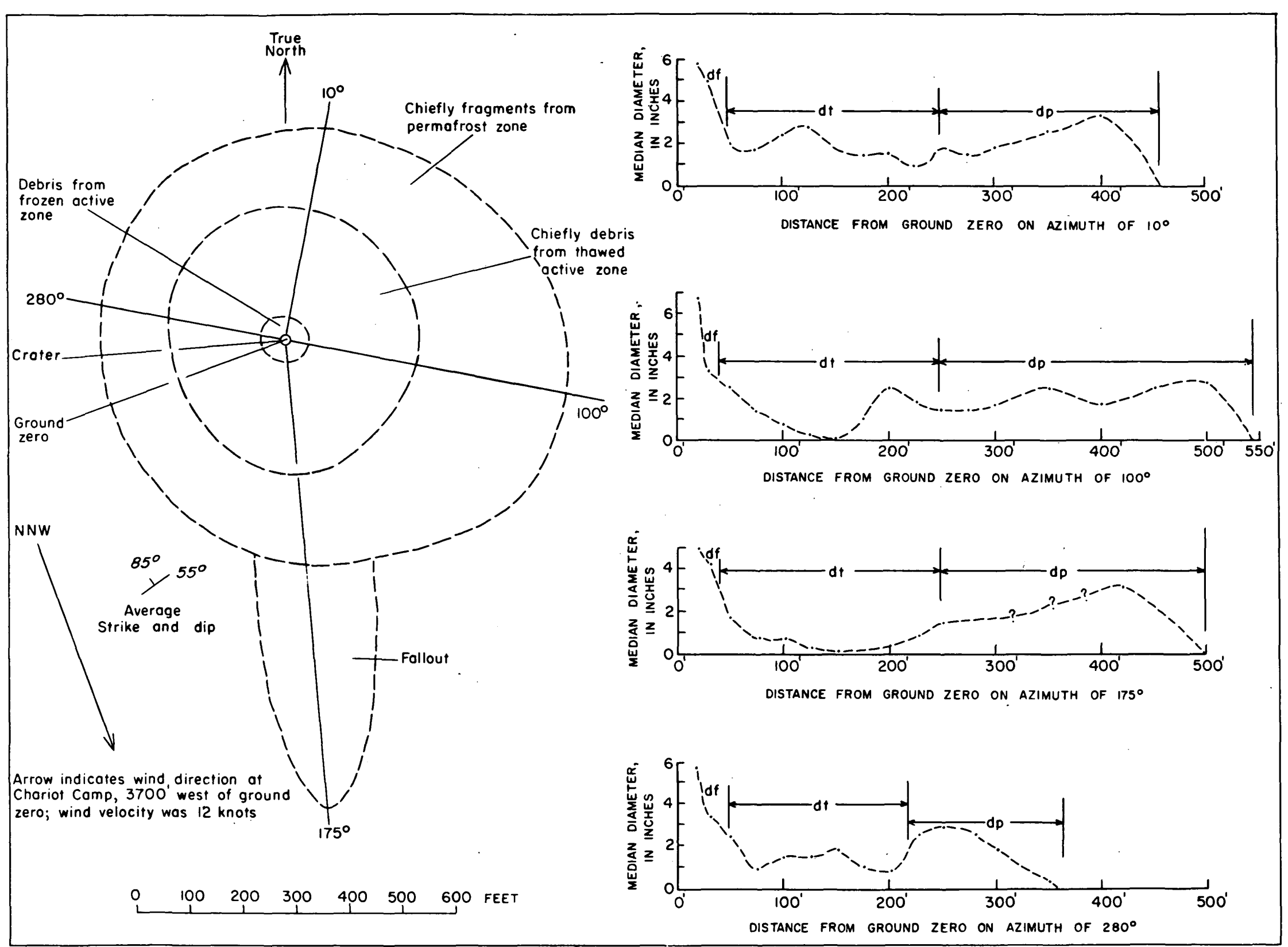

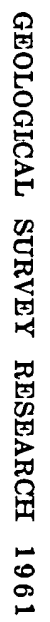

FIGURE 418.2.-Map showing distribution of throwout and fallout debris and graphic depiction of size distribution of throwout debris. 
ground zero; and an outer zone extending from about 250 feet from ground zero to the maximum distance of throwout (550 feet).

The rocks in the inner zone were derived from the frozen active zone and consisted of debris that was mostly overturned and had traveled only short distances. The largest boulder noted was in this zone and had the dimensions $5 \times 41 / 2 \times 1 \frac{1}{2}$ feet. The frozenunfrozen interface, 1.5 feet below the surface, controlled one dimension of the fragments derived from the frozen active zone. No fragment with a minimum dimension larger than 1.5 feet was noted. Although most of the large fragments were overturned and had moved short distances, the top 2 to 3 feet of concrete used to plug the hole in which the explosive was placed landed 335 feet from ground zero on an azimuth of $185^{\circ}$.

Throwout debris in the intermediate zone consisted chiefly of material derived from the thawed active zone. The thickness of debris was much less than that of the debris derived from the frozen active zone, and the median diameter of the fragments was much less than that of fragments obtained from the overlying and underlying frozen rock zones. This was to be expected because the rocks of the thawed active zone were not cemented by ice and were somewhat more friable than the frozen rocks.

Rock fragments in the outer throwout zone were derived chiefly from the more massive mudstone beds of the permafrost zone. The median diameter of the fragments was larger than that of the debris in the intermediate zone, but smaller than that of debris in the inner zone. However, the number of fragments was much lower. Beyond 300 feet from ground zero, only sporadic fragments were noted.

The pattern of deposition of the fine-grained fallout, consisting of nonradioactive particles less than 2,000 microns in diameter as determined by $\mathbf{K}$. H. Larson (written communication, 1961), was controlled by the direction of wind, which at the time of detonation was from the north-northwest $\left(340^{\circ}\right)$ and had a velocity of 12 knots. Fallout debris was seen only south of ground zero (fig. 418.2). The fallout debris was noted as far as 875 feet from ground zero on an azimuth of $175^{\circ}$; the fallout belt was about 215 feet wide, 550 feet from ground zero. The material comprising the fallout consisted chiefly of mudstone from the thinner beds. The zone or zones (frozen active, thawed active, and permafrost) from which the debris was derived is unknown.

The average height of the cloud due to the detonation was about 190 to 200 feet and the width was approximately 175 feet. However, in the center of the cloud a streamer about 30 feet wide rose to a height of approximately 250 feet. This streamer probably marked the trajectory of the concrete plug that landed 335 feet south of ground zero.

419. ENGINEERING GEOLOGY PROBLEMS IN THE YUKON-KOYUKUK LOWLAND, ALASKA

By Florence Robinson Weber and Troy L. Péwé, College, Alaska

Engineering geology problems in the YukonKoyukuk lowland, west-central Alaska (fig. 419.1) are concerned mainly with flooding, source of aggregate, and poor foundation conditions caused by seasonally and perennially frozen ground. The low land is approximately 100 miles long and 40 miles wide, and is bounded by rounded hills 1,000 to 2,000 feet above the flood plains of the major rivers. The area was not glaciated in Pleistocene time but was subject to alternating periods of great deposition and erosion. Unconsolidated deposits of Quaternary age are more than 300 feet thick in places, although locally a few bedrock knobs project above the alluvium.

Two large rivers, the Yukon and Koyukuk, meander across the lowland. The flood plains are covered by a mosaic of tundra and forest interspersed with a complex of sloughs, meander scars, oxbow lakes, swamps, and creeks. For mapping purposes the surficial deposits have been subdivided into 6 map units -2 terrace units, and 4 flood plain units-which may- be distinguished largely on the basis of ice and organic content, topographic expression, vegetation, and to some extent lithology. Engineering geology problems differ in degree or kind in the various units.

The two terraces range in height above the flood plains from 30 to 250 feet. They are formed of perennially frozen gray silt and sand with variable amounts of organic matter and include masses of ground icevertical and inclined ice dikes or wedges $1 / 4$-inch to 3 feet wide and 3 to 15 feet high (Péwê, unpublished 


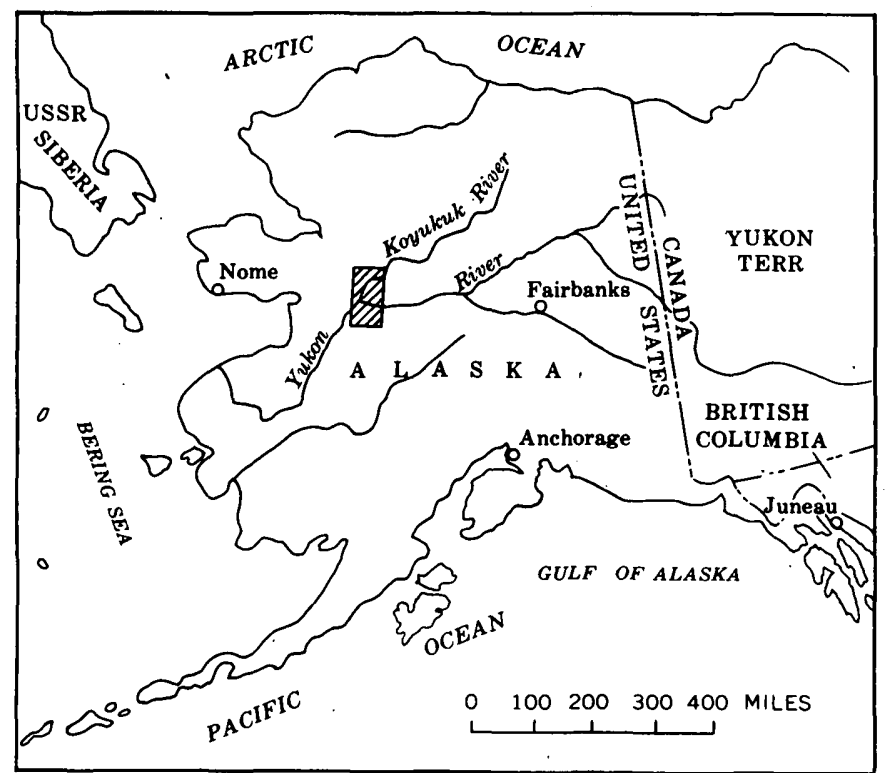

Figure 419.1.- Index map of a part of Alaska showing the location of the Yukon-Koyukuk lowland.

data). The terraces, which differ from each other only in relative height, are poorly drained and are covered with a myriad of steepsided thaw lakes, ponds, and swamps. Polygonal ground and braided streams are common. Mosses, sedges, low brush, stunted black spruce, and (rarely) birch grow on these frozen silts. Foundation conditions on both of the terraces are poor. Breaking of the insulating tundra can result in a summer quagmire and the ground will subside because of the thawing of ice masses. The poorly drained finegrained sediments are also susceptible to intense seasonal frost heaving.

In the northern part of the lowland the terraces are commonly covered by alluvial sand, which in many places forms dunes. The sandy areas are well drained, free of large ground-ice masses and thaw lakes. The dunes are largely inactive and support an open forest of aspen, birch, and spruce. Foundation construction conditions on the ice-free sandy zones are fair although slopes in dry sand are unstable.

The flood-plain map units_-"linear," "advanced linear," "coalescent," and "scalloped"-represent four arbitrary phases in the development of the flood plain (fig. 419.2). This area has been cited as a classic example of the development of a flood plain by meandering rivers under subarctic conditions (Péwé, 1947), and the classification of these flood plain units has been extended successfully to the flood plain of the Kuskokwim River (Drury, 1956). The linear phase is the first formed and the scalloped is the last. The four units can be distinguished on the basis of the shape of the lakes, vegetation, and the amount of ice and organic material they contain. The foundation qualities of the units vary largely with the amount of ground ice present. The first phase of development, the linear unit, is made up of gray micaceous silt and sand forming slipoff slopes, islands, and other low areas most recently occupied by rivers. Linear, "point bar" lakes are present and an integrated drainage is lacking. Permafrost is absent or discontinuous; no large ground ice masses are present. Vegetation is made up mostly of grasses, Equisetum, alder, willow, and some large cottonwood and spruce trees. This unit is fairly good for foundation purposes but is subject to flooding, river cutting, and icing. The only gravel suitable for aggregate that is present at the surface in the lowland is found sparingly in this unit.

The second flood-plain map unit, marking the advanced linear phase, is lithologically similar to the first. Elongate lakes, partially broken into segments by encroaching vegetation, and discontinuous permafrost (with no large ice masses) are characteristic of this phase. Relatively large birch and spruce with a brushy understory grow on the unit. Although the unit is fairly good for foundation purposes, it is also subject to seasonal flooding.

Broad swampy areas adjacent to the large rivers which are marked by coalescing linear lakes form the third unit or coalescent phase of the flood plain. Large ground-ice masses are present in the organic silt, and melting of these masses results in the partial coalescence of the linear lakes. Mosses, cottongrass tussocks, cranberry, alder, stunted spruce, and birch grow here. The unit is poor for construction as it is very wet and subject to intense frost heaving and to subsidence upon thawing of permafrost. Areas underlain by this unit may be inundated in flood stage.

The last unit of flood plain development is the scalloped phase. Lakes have lost their linear shape, are rounded, and have scalloped edges. Ice wedges and many large masses of ground ice are characteristic of this stage. In general, drainage, ground ice, and vegetation characteristics are similar to those of the adjoining terraces but the unit lies near enough to river level to be flooded occasionally. Because of poor drainage, susceptibility to intense frost heaving, and the presence of large ground-ice masses, the unit is very poor for foundations or construction of any sort.

Precise dating of the units in the area is not yet possible. However, bones of extinct Pleistocene mammals (Mammoth) have been found in deposits of the oldest terrace. A carbon-14 date of $8,140 \pm 300$ years 


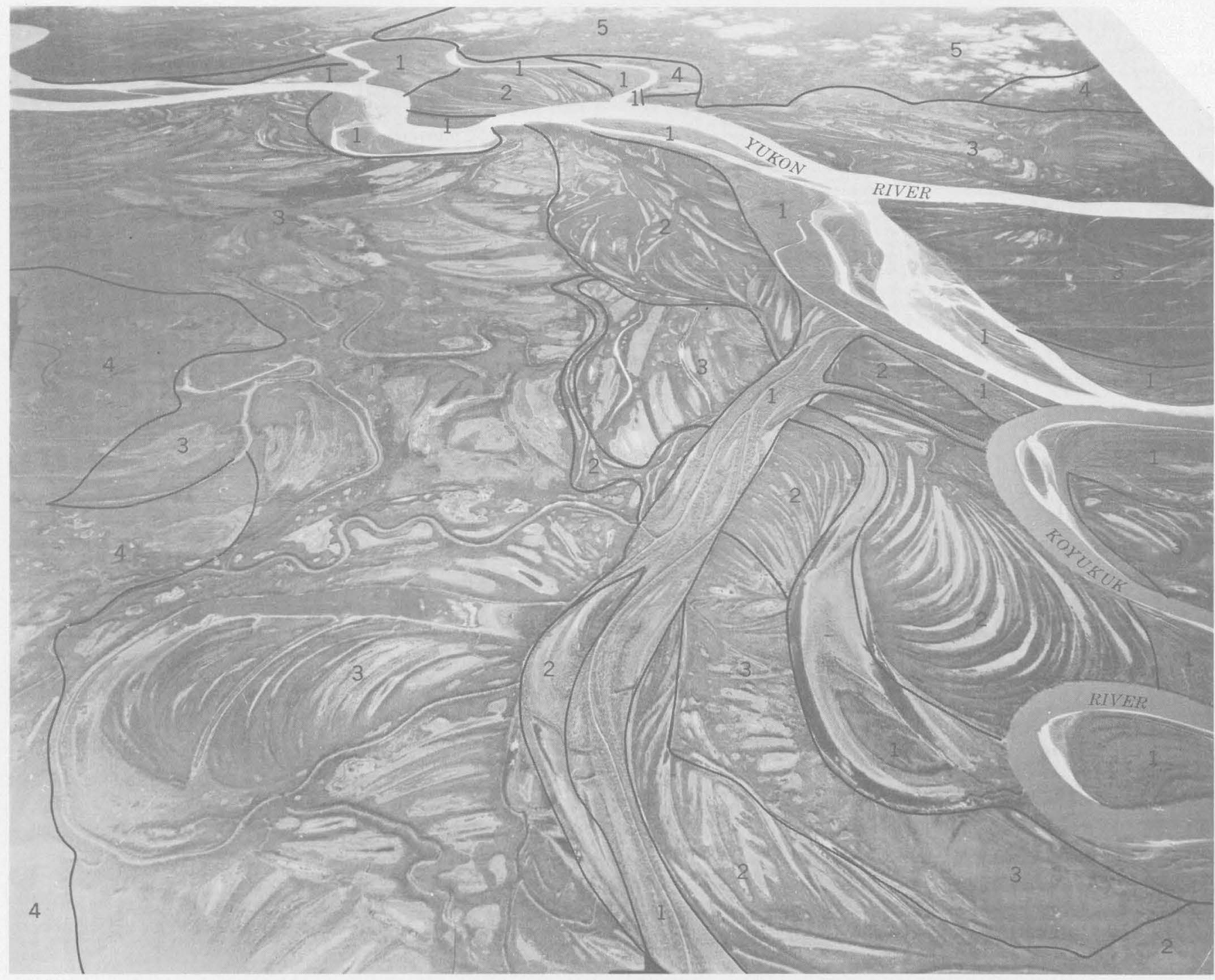

Figure 419.2.-High-altitude oblique aerial photograph looking south toward the junction of the Yukon and Koyukuk Rivers. The Koyukuk River (dark color) joins the silt-laden Yukon River (light color) at the right. Flood-plain units indicated by number are the (1) linear phase, (2) advanced linear phase, (3) coalescent phase, and (4) scalloped phase. Unit (5) is the high terrace. Photograph by U.S. Army Air Corps, August 24, 1941.

(W-472) (Rubin and Alexander, 1958, p. 1479) was obtained from organic material taken from the scalloped phase of the flood plain. Therefore, the formation of much of the modern flood plain postdates this time; cutting of the terraces took place prior to this date. Eolian reworking of the sand on the terraces has persisted until the present, as indicated by a small area of active dunes north of the Koyukuk River.

\section{REFERENCES}

Drury, W. H., Jr., 1956, Bog flats and physiographic processes in the upper Kuskokwim River region, Alaska: Harvard Univ. Gray Herbarium Contr., no. 178, 130 p.

Péwé, T. L., 1947, Permafrost and geomorphology in the lower Yukon River valley [Alaska] [abs.]: Geol. Soc. America Bull., v. 58, no. 12, pt. 2, p. 1256 .

Rubin, Meyer, and Alexander, Corrinne, 1958, U.S. Geological Survey radiocarbon dates IV: Science, v. 127, p. 1476-1487. 
420. HYDROLOGY OF RADIOACTIVE-WASTE DISPOSAL AT THE IDAHO CHEMICAL PROCESSING PLANT, NATIONAL REACTOR TESTING STATION, IDAHO

By Paul H. Jones, Idaho Falls, Idaho

Work done in cooperation with the Idaho Operations Office, U.S. Atomic Energy Commission

Low-level aqueous radioactive waste (less than $10^{-4}$ microcuries per milliliter, gross beta-gamma) is pumped directly into the ground-water reservoir at the Idaho Chemical Processing Plant (ICPP) through a drilled, cased, gravel-packed well 598 feet deep. This well penetrates several thin basalt flows and a single thin bed of silt, sand, and gravel below the water table, which occurs at a depth of about 460 feet. Radioactive waste is diluted with warm nonradioactive water from plant wastes, including large amounts of sodiumchloride brine from water-softening units. Since 1952,757 curies of activity have been disposed to this well in 2,495,450,000 gallons of water. The annual rate of disposal is summarized in table 420.1. The hydrology of basalt aquifers is difficult to interpret because of the sheet-conduit nature of the aquifers, the very low gradients in head, and the difficulty of establishing local stratigraphic and hydraulic continuity, but geophysical logging has resulted in identification, description, and correlation of aquifers. Well-packing equipment has enabled isolation and testing of aquifers.

During the period 1953 through 1959,15 intercept wells 6 inches in diameter were drilled by percussion methods to depths ranging from 570 to 730 feet. Of these, 9 are uncased below the water table. Several persons made detailed studies of the lithology of beds penetrated and of the chemical and physical quality of water from selected depths in the wells. Water-level

TABLE 420.1.-Volume and curies of liquid waste discharged to ICPP disposal well

\begin{tabular}{|c|c|c|c|}
\hline \multirow{2}{*}{ Year } & \multirow{2}{*}{$\begin{array}{c}\text { Thousands of } \\
\text { gallons }\end{array}$} & \multicolumn{2}{|c|}{ Curies } \\
\hline & & $\beta-\gamma$ & $\alpha$ \\
\hline $1953 \ldots \ldots \ldots$ & 396,000 & 15 & 0.15 \\
\hline 1954 & 229,838 & 8 & .03 \\
\hline 1955 & 396,175 & 15 & .04 \\
\hline 1956 & 351,314 & 16 & .04 \\
\hline 1957 & 230,747 & 285 & .01 \\
\hline 1958 & 373,151 & 339 & .02 \\
\hline 1959 & 328,225 & 47 & .38 \\
\hline 1960 & 190,000 & 32 & .00 \\
\hline Total_ & $2,495,450$ & 757 & 0.67 \\
\hline
\end{tabular}

measurements were made in intercept wells, and hydraulic tests were conducted in the ICPP supply wells. Gamma-ray logs were made for wells 34 to 44 , and flow-meter logs for wells 40 to 48 (fig. 420.1). Results of aquifer tests have been described by Walton and Stewart (1959) ; results of other tests are not published.

In 1960 the network of intercept wells was broadened by drilling wells 51, 52, 57, 59, and 67 (fig. 420.1). Borehole geophysical logging has provided data that serve to identify the aquifers tapped and to describe some of their characteristics. Hole-diameter (caliper) logs indicate that the boreholes are enlarged where interbeds of scoria, cinders, flow breccia, and sedimentary rocks occur between dense basalt flows. Such interbeds are the principal aquifers. Sedimentary interbeds are identified by gamma-ray logs, the radioactivity intensity of the sedimentary rocks being markedly greater than that of basalt. Gamma-ray intensity logged in enlarged sections of the hole below the water table is reduced by the shielding effect of the water. The cross

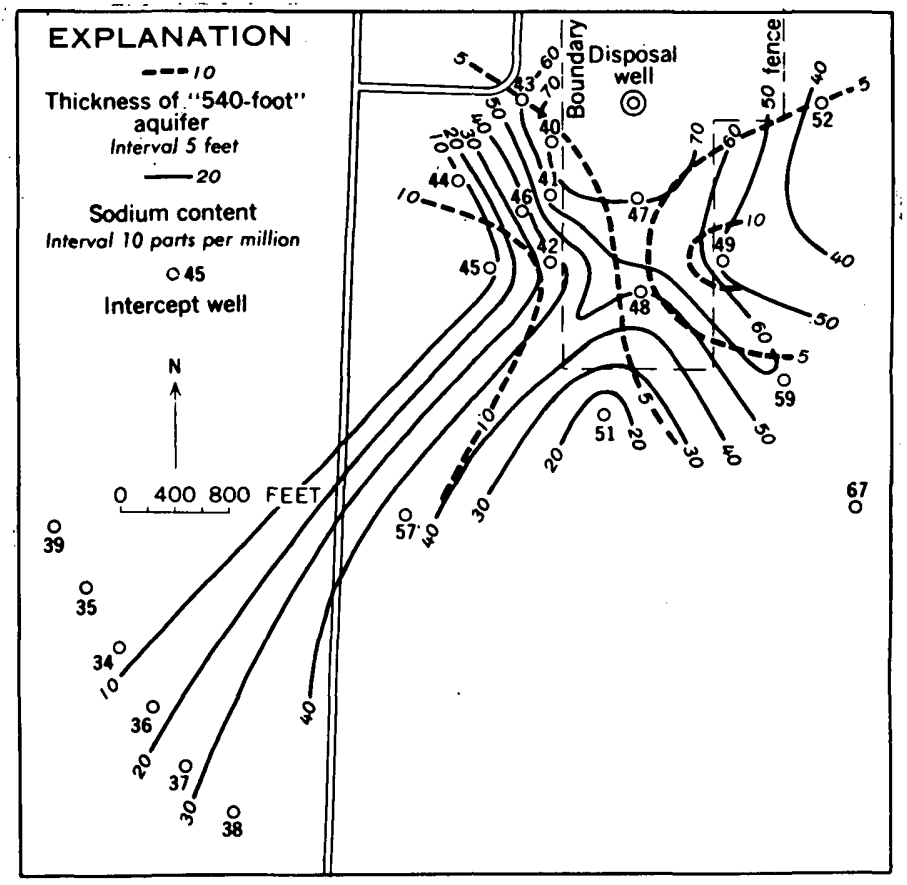

FraURE 420.1.-Thickness of the "540-foot" aquifer and sodium content of water from wells in the vicinity of the Idaho Chemical Processing Plant, 1960. 
section, figure 420.2 , shows the correlation and lithology of the significant aquifers. The " 540 -foot" aquifer has been mapped throughout the ICPP area and is believed to be the most important aquifer above a depth of 700 feet in this area.
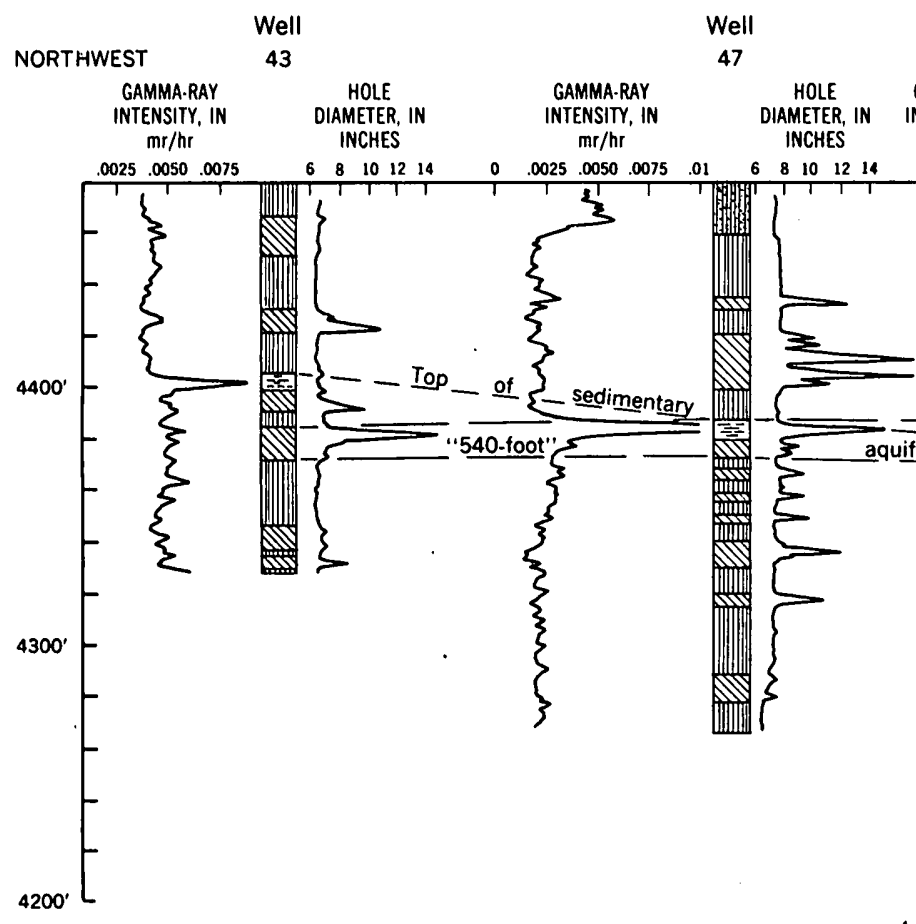

Logs of water resistivity and temperature show the depths at which saline waste water from the disposal well enters and leaves the intercept wells. Figure $420.2 B$ illustrates the vertical spread of waste water with distance from the disposal well, and the decrease in Well Well

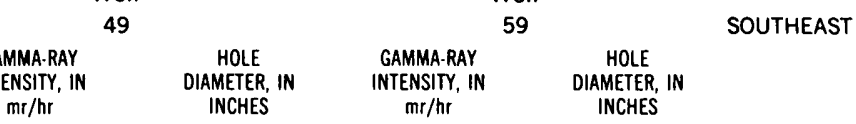

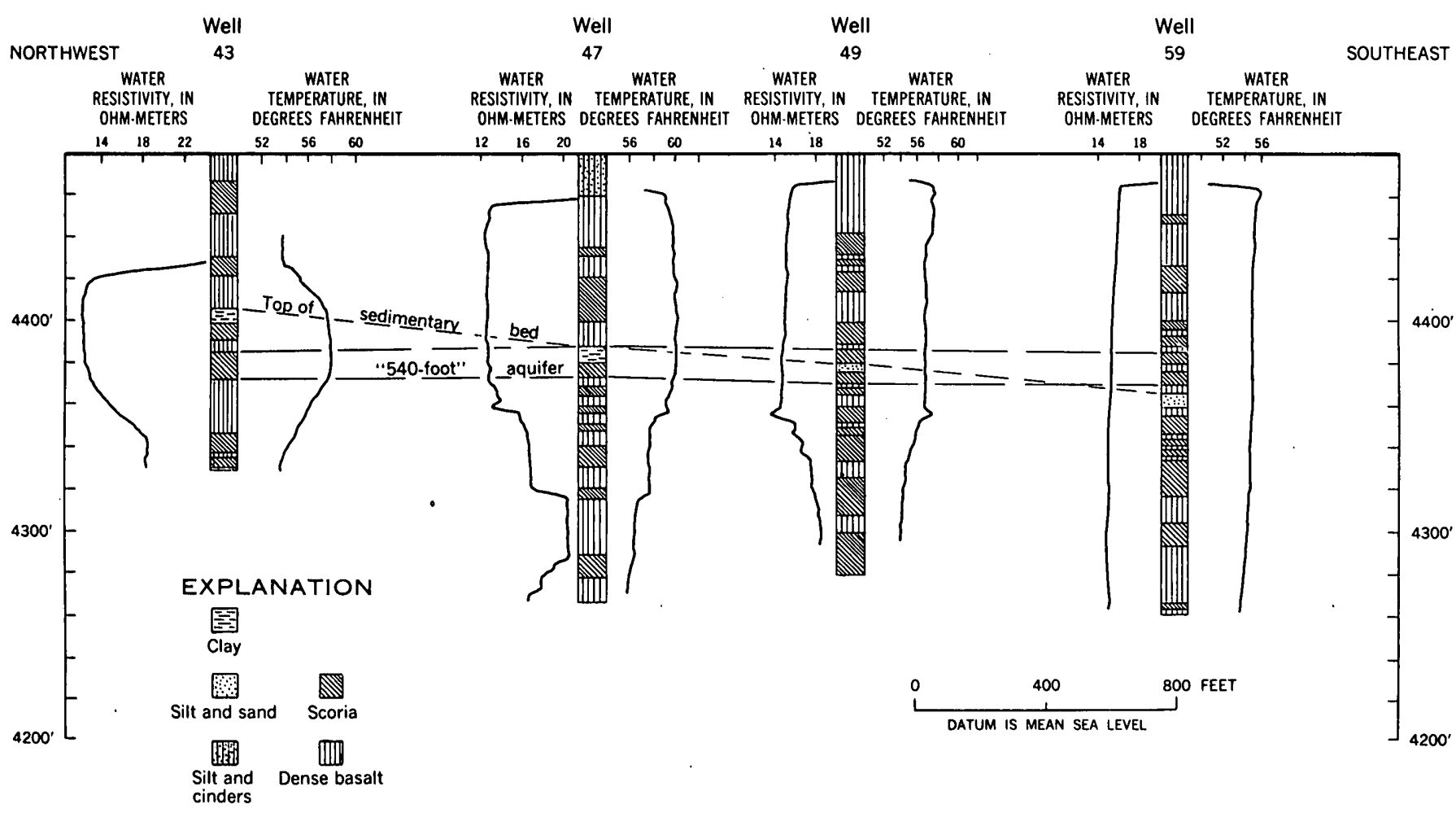

$B$

Ficure 420.2.-Cross section through wells in the vicinity of Idaho Chemical Processing Plant. $A$, gamma-ray intensity and hole diameter; $B$, temperature and electrical resistivity of water. Location of wells shown on figure 420.1 . Vertical scale is in feet above sea level. 
temperature and salinity away from the disposal well.

The thickness of the "540-foot"-aquifer in the ICPP area is shown on figure 420.1. The thickness indicated by the contours is that thickness in which the diameter of the drill hole is more than 2 inches larger than the diameter of the bit used in drilling. Waste water from the disposal well tends to move from thin to thicker. parts of the aquifer. One preferred direction of movement is southwest, toward well 45 , and another is southeast, toward well 49 . Flow southward tends to veer to the east or west, and no appreciable flow reaches the vicinity of well 51 .

The average sodium content of water from intercept wells in the ICPP area in 1960 is shown on figure 420.1. Two "lobes" of higher salinity occur, corresponding to the areas where the aquifer is thickest; one trends southwestward past well 47 toward well 57 , and the other trends southeastward past well 49. Minimum salinity occurs at well 51. A sharp decrease in salinity westward from well 42 may be the result of channeled through-flow of ground water, and the gradual decrease in salinity eastward may indicate that the aquifer pinches out in that direction.

Vertical flow between aquifers tapped by intercept wells results in an erratic distribution of waste water in the ground-water reservoir and makes measurements of water level in the well useless for quantitative purposes. Effective study of vertical flow requires reconstruction of intercept wells so that they tap but one aquifer. Where this has been done using modified oilwell packers, head differences between aquifers generally are less than 1 foot, but differences of 70 to 80 parts per million of chloride occur in waters from different aquifers tapped by the same well.

\section{REFERENCE}

Walton, W. C., and Stewart, J. W., 1959, Aquifer tests in the Snake River basalt: Jour. Irrig. and Drainage Div., Proc. Am. Soc. Civil Engineers, v. 85, no. IR3, paper no. 2156, Sept., 1959.

\section{DISPOSAL OF URANIUM-MILL EFFLUENT NEAR GRANTS, NEW MEXICO}

By S. W. West, Albuquerque, N. Mex.

Work done in cooperation with the New Mexico State Engineer

Disposal of uranium-mill effluent at The Anaconda Co. Bluewater Mill; 9 miles northwest of Grants, N. Mex., became a problem in a relatively short time after the mill was built in 1952. A typical chemical analysis of effluent is shown in table 421.1.

The use of an evaporation pond in a natural depression and much research by The Anaconda Co. on impervious pond linings and on other methods of surface disposal indicated that surface methods of disposal might contaminate the potable ground water. The company then investigated the possibility of injecting the waste fluids into an unused aquifer that contains non-potable water and is below, and isolated from, the principal sources of ground water in the area. Early in 1959 a deep test well for underground disposal was drilled in the NE1/4 SW1/4 sec. 8, T. 12 N., R. 10 W. The Geological Survey and the New Mexico State Engineer cooperatively observed the drilling, logged cores, observed drill-stem tests and well completion work, and observed initial withdrawal and injection tests.
The general geology in the vicinity of the mill and disposal well is shown on figure 421.1, and the stratigraphic units that were penetrated are shown on a diagram of the well, figure 421.2 .

The San Andres limestone (Permian) is the principal aquifer, and water from it is used for domestic, municipal, industrial, and irrigation supplies. Wells that tap the San Andres yield as much as 2,800 gpm (gallons per minute), and the specific capacity of wells ranges from 10 to $1,100 \mathrm{gpm}$ per foot of drawdown. Although few wells are completed in the Glorieta sandstone (Permian), it is a source of potable water that leaks upward into the San Andres in areas of large withdrawal. The gradient of the water table in the San Andres and Glorieta is to the east and southeast. Dissolved solids in the water from the San Andres range from 350 to $2,200 \mathrm{ppm}$ (parts per million). The most critical chemical constitutent is sulfate, which ranges in concentration from 120 to $830 \mathrm{ppm}$.

Alluvium and basalt along the Rio San Jose form an aquifer of secondary importance. Most of the water 

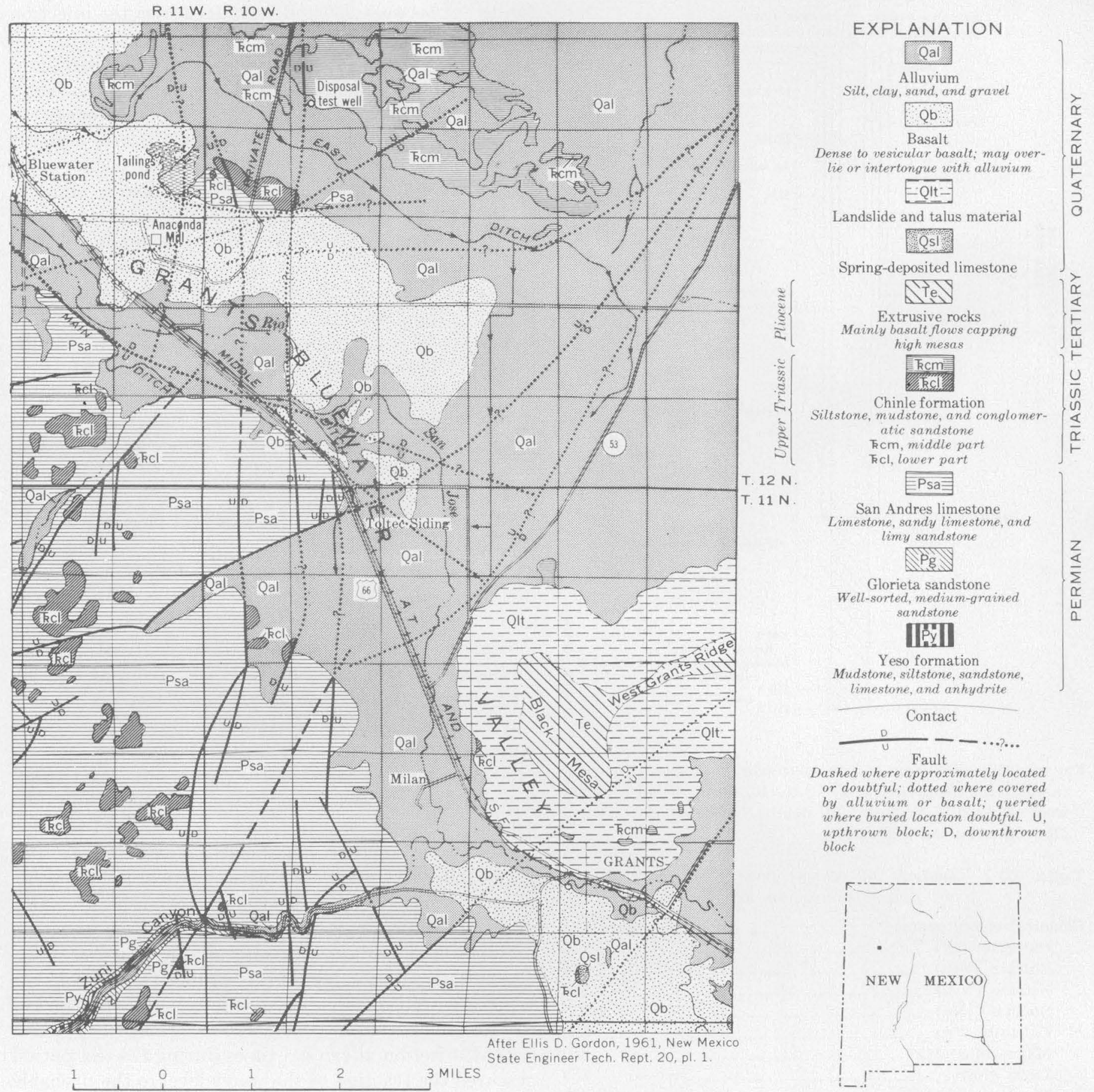

Figure 421.1.-Geologic map of the Grants-Bluewater valley, Valencia County, N. Mex.

from the alluvium and basalt is used for domestic and municipal supplies. The water in the alluvium and basalt moves down the valleys approximately parallel to the Rio San Jose and its principal tributaries.

Other aquifers are utilized for only small supplies of water, mainly for stock. The only wells that tap the Yeso formation (Permian) are near its outerops several miles upgradient from the disposal well.
The disposal well was drilled to a depth of 2,511 feet and was cored continuously below 445 feet. Many drill-stem pressure tests and swabbing tests were made as the hole was cored. A sample of water collected from the Meseta Blanca sandstone member of the Yeso formation in the interval from 1,305 to 1,450 feet in the test well contained 4,130 ppm of dissolved solids and $2,170 \mathrm{ppm}$ of sulfate. This zone and thin zones of 


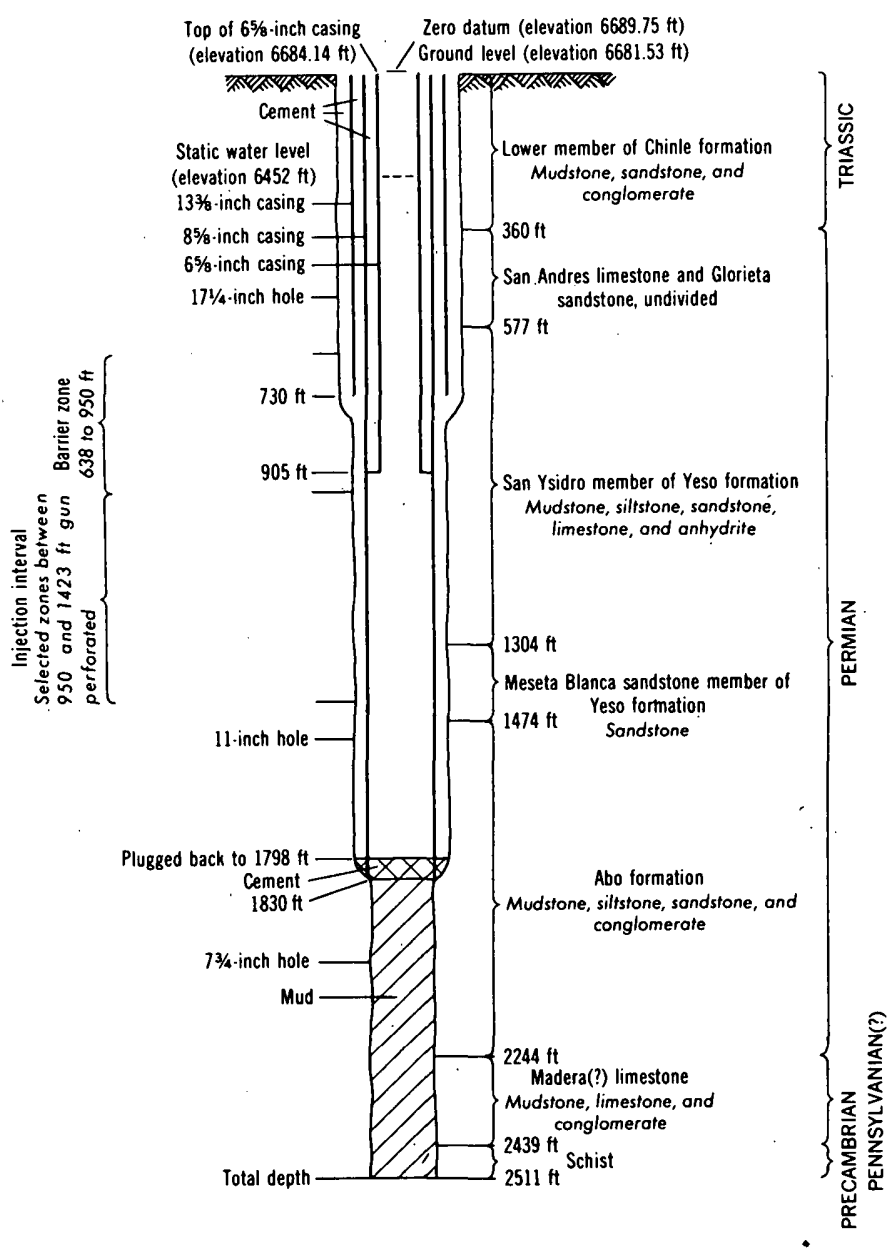

Figure 421.2.-Diagram of The Anaconda Co. disposal test well in the $\mathrm{NE} 1 / 4 \mathrm{SW} 1 / 4$ sec. 8 , T. $12 \mathrm{~N}$., R. $10 \mathrm{~W}$., 9 miles northwest of Grants, N. Mex. All depths are below zero datum. Hole diameter not to scale.

TABle 421.1.-Analysis of effuent from The Anaconda Co. Bluewater iranium mill

Chemical constituents : ${ }^{2}$ Parts per million Chloride (Cl) 1,350

Sulfate $\left(\mathrm{SO}_{4}\right)$

6,450

Nitrate $\left(\mathrm{NO}_{3}\right)$

Sodium ( $\mathrm{Na})$

Calcium (Ca)

Magnesium ( $\mathrm{Mg})$

Manganese (Mn)

Total dissolved solids

Radiological constituents: ${ }^{2}$

Gross alpha

Uranium-natural

Thorium-230

Radium-226

100

1,050

550

550

350

450

11,000

Average of four samples of filtered influent to disposal well, $\mathrm{pH} 2.7$. samples collected between December 1, 1959, and March 30, 1960; analyses by. The Anaconda New. Mexico Operations Chemical Laboratory.

2 Composite of samples collected dally from January 20 to 31,1960 ; analysis by Tracerlab, Inc. sandstone between 950 and 1,423 feet form the injection interval.

Beds of dense mudstone, limestone, anhydrite, and gypsum between the base of the Glorieta sandstone and the highest injection zone were expected to prevent the movement of water upward into the Glorieta and the San Andres limestone. Many fractures in the cores from this interval were observed, but nearly all were sealed tightly with gypsum. The annular spaces between the casing and the wall of the hole and between the strings of casing (fig. 421.2) were cemented and tested by using air pressure. The pressure tests indicated a tight seal.

The casing was gun-perforated adjacent to permeable zones in the interval from 950 to 1,423 feet. The perforations are $1 / 2$-inch and $\% / 16^{-i n c h}$ in diameter, and 261 shots were fired in the injection interval. Several zones below 1,423 feet also were perforated and tested, but none took water.

The altitude of water level was 6,452 feet in the disposal well after the San Andres and Glorieta formations were cased off and before injection of fluids into the Yeso formation was started. A drill-stem pressure test of the San Andres and the Glorieta indicated the same altitude of water level for these units. A. monitoring well was drilled to the base of the Glorieta sandstone 300 feet southeast of the disposal well, and the altitude of water level in it was 6,452 feet. The same water level in the two aquifers was first interpreted as an indication of vertical hydrologic continuity.

There are many faults in the region (fig. 421.1), and it was feared that fractures in the fault zones might be conduits through which water could move from one formation to another. It seemed possible, also, that permeable beds might be offset against impermeable beds forming barriers to lateral movement of water away from the injection well and causing excessive buildup of hydraulic pressure in the disposal zone. The initial injection test.indicated that vertical leakage was negligible and that one or more faults are barriers to lateral movement of the water. Temporary cessation of injection at critical times during the test period obscured the reaction of the water level to the probable barrier. Thus, the future pressure buildup cannot be forecast until more is learned about the effects of the barrier.

Various rates of injection were tried, ranging from 380 to $1,400 \mathrm{gpm}$. Projection of the pressure buildup curves indicated that the well would not take as much as $1,000 \mathrm{gpm}$ by gravity injection, but that it would take more than $380 \mathrm{gpm}$. The apparent coefficient of transmissibility of the sandstone in the Yeso formation is about 10,000 gpd (gallons per day) per foot. 
The results of the injection tests indicate that the mill eflluent can be disposed of feasibly by injection into the lower part of the Yeso formation and that vertical leakage in significant amounts into the potable water aquifers is unlikely. Routine disposal of effluent by injection was started in December 1960.

\section{SOME USES OF THE SODIUM-ADSORPTION-RATIO DIAGRAM}

By D. J. Cederstrom, Washington, D.C.

By far the greatest amount of ground water used in the Tripoli quadrangle, Tripolitania, Libya, is for agricultural purposes. The water used varies widely in chemical character. As a part of exploration for and development of additional ground water supplies in an investigation on behalf of the International Cooperation Administration, it was necessary to determine the agricultural usefulness of the water.

Classification of water according to a single dissolved constituent did not appear to offer a sufficient answer nor did specific conductance seem to be more than a rough rule-of-thumb guide. The sodium-adsorptionratio (U.S. Salinity Laboratory Staff, 1954, p. 72), by itself was only moderately helpful because many highly mineralized waters of doubtful value had a favorable calcium-sodium ratio. Early consideration, therefore, was given to the sodium-adsorption ratio (SAR) diagram developed by the U.S. Salinity Laboratory Staff $(1954$, p. 80$)$ on which total dissolved salts are plotted against the sodium-adșorption ratio. As might be expected this proved to be an excellent method of classifying irrigation waters. However, when it was applied to waters actually used in Tripolitania, several interesting anomalies were observed.

Effort was made to determine what use might be made of waters plotting in the various classes of the SAR diagram. Published tables (U.S. Salinity Laboratory Staff, 1954, p. 67 ) giving the relative tolerance of various crops were helpful, but did not furnish as complete an answer as desired. In the first place, no data are given for certain crops such as tobacco and peanuts, which are important to Tripolitania. Further, there seemed to be no way to establish how low "low tolerance" (oranges) might be nor how high "high tolerance" (alfalfa) might be. In addition, a statement by Hem $(1959$, p. 250$)$ was found to be particularly applicable:

"It is very difficult to predict on the basis of water analyses what may take place in the complex mineral assemblage of most soils, where physical adsorption, base exchange and the formation of complex salts may all occur as irrigation water is added. Those who use water analyses to evaluate irrigation supplies should not depend exclusively upon any classification system that takes only the composition of the water into account."

Accordingly, an "SAR crop diagram" (If that designation may be introduced here) was prepared. The crop irrigated by a specific water was indicated at the point on the SAR diagram where the SAR and salinity of the water plotted (fig. 422.1).

The SAR crop diagram shows at a glance the range of usefulness of irrigation waters. As evident on figure 422.1, waters having a medium to high salinity hazard can be used successfully to grow oranges if the sodium hazard is low. Two reports of oranges grown where the irrigation water has a medium sodium hazard are suspect; these are not grown for commercial use and yields may be poor.

Peanuts and potatoes have a greater tolerance than oranges and are raised successfully where sodium hazard of irrigation water is high and salinity hazard is very high. It may be noted that this class of water has two notations, one indicating that these crops can be raised successfully, the other indicating they cannot. Equally or even more interesting is the notation for water classified as medium in sodium hazard and very high in salinity hazard that peanuts and potatoes cannot be raised. Such apparent contradictions emphasize the fact that the chemical character of the water may not be the only limiting factor-in this instance, the farm where the better water is said to be unsuitable for peanuts and potatoes is in a lower rainfall area than the farm where the poorer water is used successfully. Other factors such as drainage characteristics and gypsum content of the soil may influence the usefulness of the water. In any event, the diagram suggests that in this area some "unsuitable" waters might be used for irrigation of low- or medium-tolerance crops by proper husbandry. 


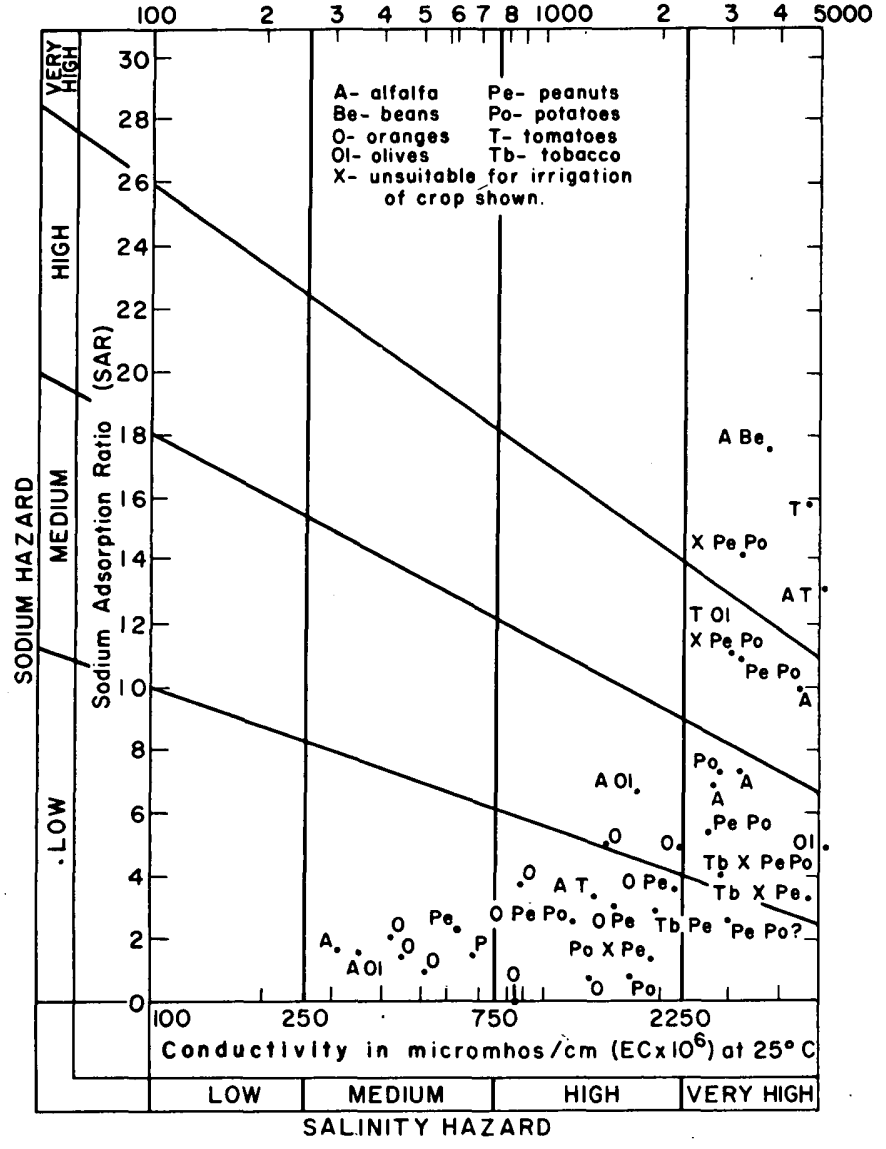

Figure 422.1.-U.S. Salinity Laboratory diagram for classification of irrigation waters showing crops irrigated by waters of various chemical characteristics in the Tripoli area, Libya.
Alfalfa has an extremely high tolerance-in fact, the SAR diagram shown would have to be expanded upward and to the right to show the complete range of tolerance. On the other hand, inspection of the SAR crop diagram suggests that at some places valuable water on which citrus would flourish is being put to a less productive use in raising alfalfa.

The SAR crop diagram affords a convenient means of indicating to persons who have little or no acquaintance with chemistry some important aspects of water quality and how those aspects are related to agricultural suitability. A series of diagrams, each showing where plotted points for analyses pertinent to a particular crop are grouped might be prepared as a visual aid in explaining the suitability of any water. Such diagrams also might prove useful in public presentations of papers dealing with irrigation water.

The SAR diagram proved helpful in still another way not directly pertaining to crop use. An SAR diagram of water from a leaky artesian well and of shallow ground waters in the immediate area shows at a glance the degree of contamination that has occurred. In this respect the SAR diagram performs the function served by the more elaborate tri-linear diagram and is more easily understood by the general public.

\section{REFERENCES}

Hem, J. D., 1959, Study and interpretation of the chemical characteristics of natural water: U.S. Geol. Survey WaterSupply Paper 1473, 269 p.

U.S. Salinity Laboratory Staff, 1954, Diagnosis and improvement of saline anù alkali soils: U.S. Dept. of Agriculture, Agriculture Handbook 60.

\section{TECHNIQUES FOR MAPPING OF HYDROCHEMICAL FACIES}

By William BaCk, Washington, D.C.

The concept of hydrochemical facies is a means of describing the diagnostic chemical character of water solutions in aquifers. These facies reflect the effects of chemical processes in the lithologic environment and the contained ground-water flow patterns. The techniques and procedures used in mapping hydrochemical facies were developed during the course of work on the Atlantic Coastal Plain as a means of deriving and presenting a coherent generalization from thousands of discrete facts. Significant characteristics of hydrochemical facies can be illustrated by methods similar to those used in lithofacies studies-trilinear diagrams that. show the types of facies present in an area or in formations, fence diagrams that show the overall facies distribution, and maps that show isopleths of chemical constituents within certain formations.

The classification of hydrochemical facies is shown in table 1. For simplification of terminology, mag- 
nesium and potassium are not mentioned in some of the cation-facies terms because of their relatively minor importance in the Atlantic Coastal Plain. For other areas, these constituents could be added to the terminology. The numerical values (table 423.1) are percentages of the particular constituent indicative of the total cations or total anions computed on the basis of equivalents per million. The positions of these facies are shown on the parallelogram diagrams on figure 423.1. Although two parallelograms are shown here for clarification of the nomenclature, analyses commonly are plotted on only one parallelogram, including both the anions and cations.

Parallelograms and other similar diagrams are useful primarily for screening and sorting large numbers of chemical analyses. The percentage of the equivalents per million of the various constituents are plotted according to the stratigraphic unit and geographic location. The grouping of the analyses thus plotted may be used to identify or group those stratigraphic units that contain water of similar chemical character, which may be treated as a hydrologic unit. Plotting of the analyses provides, further, a basis for determining the degree of detail required in delineating hydrologic units for the construction of maps and fence diagrams.

The next phase of hydrochemical facies mapping may be the preparation of maps showing the significant chemical aspects of the water in selected hydrologic units. Unless the study is restricted to one stratigraphic unit, fence diagrams are believed to be one of the most effective means of illustrating hydrochemical
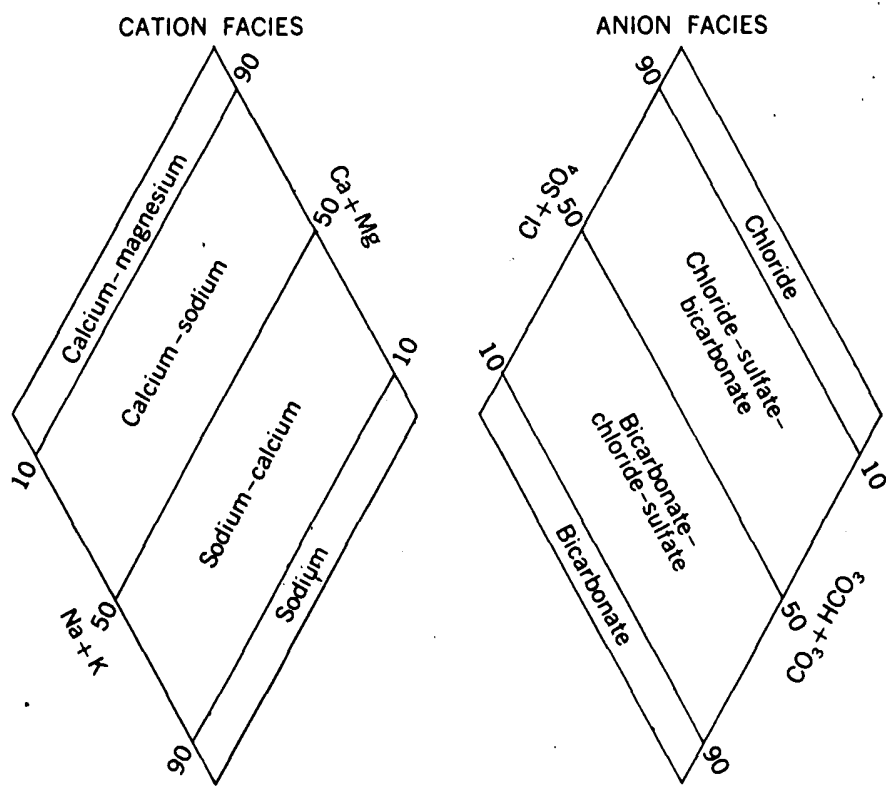

PERCENTAGE OF CONSTITUENTS

Froure 423.1.-Nomenclature for hydrochemical facies.
TABLE 423.1.-Classification of hydrochemical facies

\begin{tabular}{|c|c|c|c|c|}
\hline & \multicolumn{4}{|c|}{ Constituent (percent) } \\
\hline & $\mathrm{Ca}+\mathrm{Mg}$ & $\mathrm{Na}+\mathrm{K}$ & $\mathrm{HCO}_{3}+\mathrm{CO}_{3}$ & $\mathrm{SO}_{4}+\mathrm{Ol}$ \\
\hline \multicolumn{5}{|l|}{ Cation facies: } \\
\hline Calcium-magnesium_ & $90-100$ & $0<10$ & & \\
\hline Calcium-sodium__._- & $50-90$ & $10<50$ & & \\
\hline Sodium-calcium _... & $10-50$ & $50<90$ & & \\
\hline Sodium $\ldots$ & $0-10$ & $90-100$ & & \\
\hline \multicolumn{5}{|l|}{ Anion facies: } \\
\hline Bịcarbonate_ & & & $90-100$ & $0<10$ \\
\hline \multicolumn{5}{|l|}{ Bicarbonate-chlor- } \\
\hline \multicolumn{5}{|l|}{$\begin{array}{l}\text { Chloride-sulfate- } \\
\text { bicarbonate }\end{array}$} \\
\hline Chloride-sulfate.... & $\ldots \ldots$ & $\ldots$ & $0-10$ & $90-100$ \\
\hline
\end{tabular}

facies. They are believed superior to maps for several reasons: (a) a large number of maps would be required to show the various chemical constituents within the several hydrologic units of an area; (b) correlation of available data can be done with more confidence on the hydrochemical panel diagrams, in much the same manner that geologic block diagrams and cross-sections are used to interpret and extrapolate available stratigraphic and structural data; (c) the chemical effect of water moving across stratigraphic or lithologic boundaries can be more readily depicted on fence diagrams than on maps restricted to one stratigraphic unit.

A typical fence diagram for part of the northern Atlantic Coastal Plain is shown on figure 423.2. The fence diagram shows the major stratigraphic or lithologic units in the area and the vertical direction of ground-water flow.

Values for selected chemical constituents are plotted on the fence diagram according to location and depth. The constituents plotted are those most diagnostic of the water for the particular area under study. For the Atlantic Coastal Plain, which was used as the model for this study, the concentration of total dissolved solids, bicarbonate ion, chloride ion, and the summary fence diagrams showing the cation facies and anion facies were judged to be the most informative. However, for some areas the sulfate ion might be more significant than the bicarbonate or chloride ions. After the values of the particular constituents have been plotted, the boundaries between the distinctive facies are drawn. Diagrams for minor elements, such as fluoride or iron, can be prepared in the same way.

In summary, application of the concept of facies to the chemical aspects of ground water indicates that the nature and concentration of ions in solution are determined by the lithologic character and the ground-water 


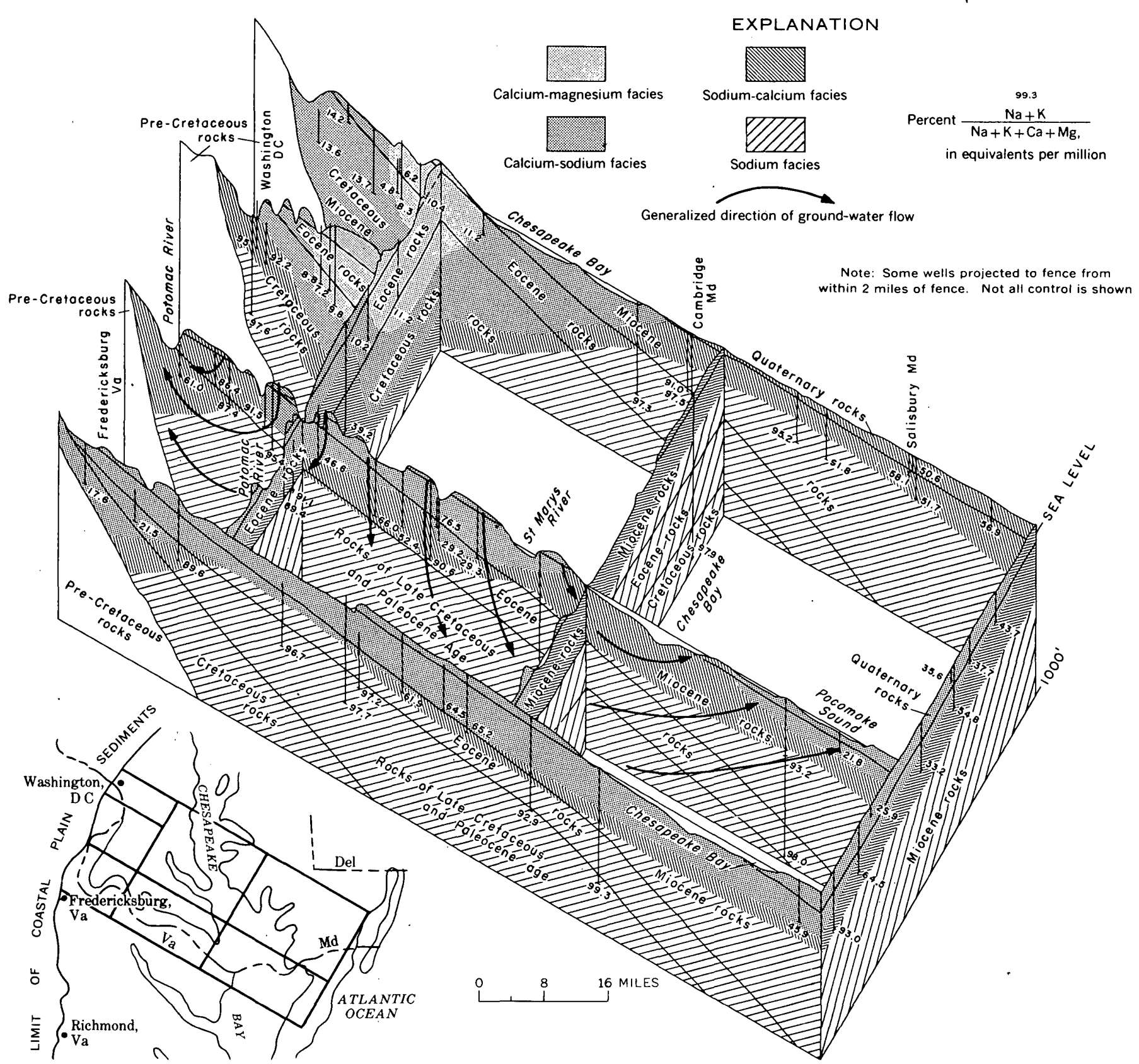

Figure 423.2.-Fence diagram of part of the northern Atlantic Coastal Plain showing hydrochemical facies.

flow pattern of a particular region (Back, 1960). Development of mapping techniques provides the means to present in two dimensions the three-dimensional nature of ground-water flow and the spatial distribution of chemical and mineral assemblages. The chemical character of ground water within a hydrologic system, as depicted in a facies diagram, shows the relation of the chemical character of the ground water to the flow patterns and to the geologic environment.

\section{REFERENCE}

Back, William, 1960, Origin of hydrochemical facies of ground water in the Atlantic Coastal Plain : Internat. Geol. Cong., 21st, Copenhagen 1960 , pt. 1, p. 87-95. 
424. OPTICAL CURRENT METER

By Winchell Sмith, Menlo Park, Calif.

Work done in cooperation with the California Department of Water Resources

Velocity measurements in open channels are normally made with a rotating meter suspended on a rod or sounding line. Infrequently, measurements are made by other methods such as timing of drift or floats in the stream, or use of impact rods which convert kinetic energy into a static head. None of these methods is well suited to measurement of velocities greater than 20 feet per second. In closed conduits, high velocities are routinely measured by Pitot tubes inserted in the stream, by timing the rate of transfer of a slug of salt solution or other material injected under pressure, by computation of dilution of chemicals injected at a known rate, or by measurement of energy dissipated when flow rate is decreased to zero. Most of these methods could be applied to open channel velocity measurement, but in each case the instrumentation becomes involved and much too complicated for routine field use. Difficulties arise in each case from the necessity for placing the equipment in the stream; this suggests an alternate approach, based on optical principles, which requires no physical contact with the flowing water.

The optical device, described in this paper, gives an instantaneous measure of the surface velocity by direct observation from a point above the stream. No equipment is inserted into the stream.

The optical meter, now being developed, is a stroboscopic device whereby the motion of the water surface is apparently stopped by adjusting the angular speed of a set of rotating mirrors. Principal components of the meter are shown on figure 424.1. The drive motor is powered by a 15 -volt battery.

Velocity measurements are made by looking down at the water surface through the meter while gradually increasing the angular speed of the rotating mirrors. As synchronization is approached, the apparent motion of the water surface, seen in the eyepiece as a succession of images or frames, gradually slows down until it is stopped. If the mirror speed is increased beyond this point, the apparent motion is reversed and the water appears to move upstream. Angular speed of the mirror wheel, indicated by the tachometer, and the vertical distance from the meter to the water surface, which is measured with a weighted tape, are the measurements needed to compute velocity. The observation distance may be varied depending upon the velocity regimen and physical features of the site, so long as it is measured to the same degree of accuracy that is required for the velocity under observation.

Sensitivity of reading is very precise. The pilot model was tested on an irrigation canal near San Jose, Calif., where a velocity of 15 feet per second was attained. Consecutive readings made from a fixed point by nine observers checked within 5 percent. None of the observers had any previous experience with the

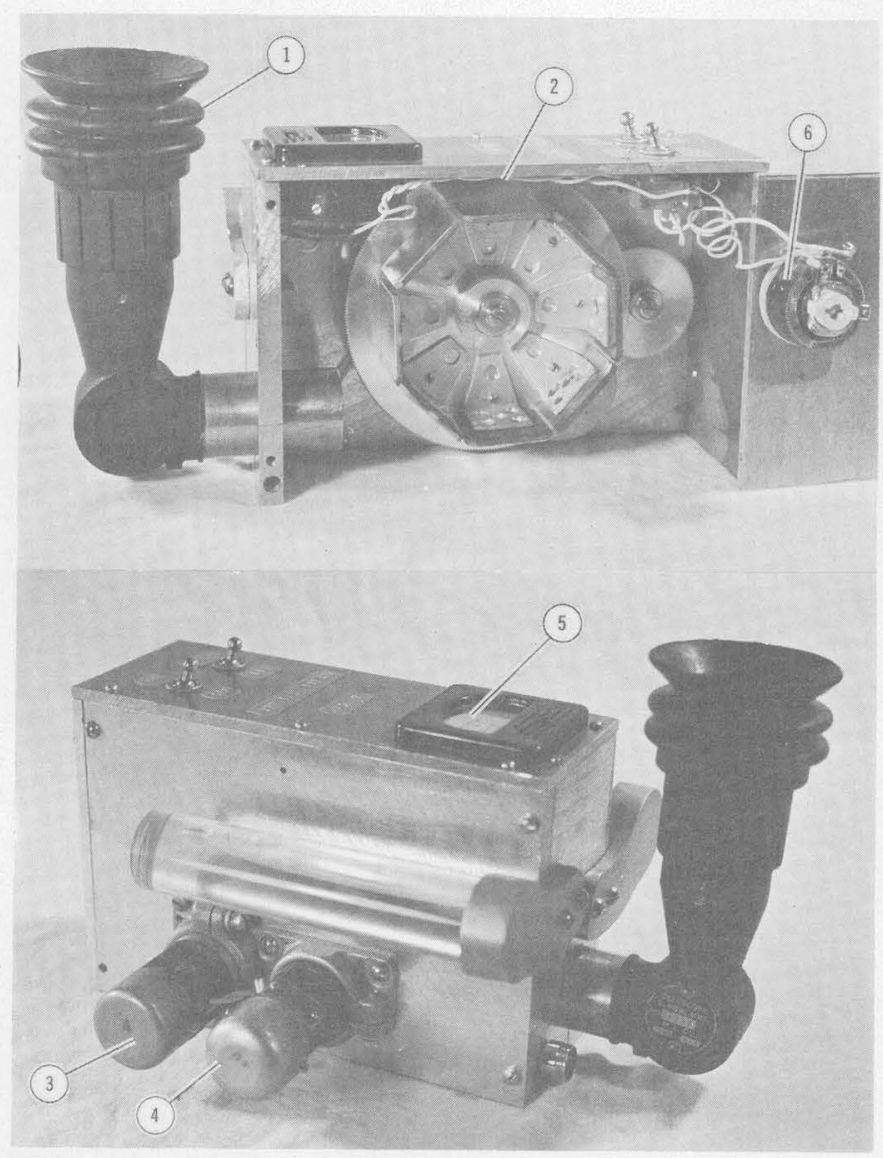

Figure 424.1.-Optical current meter. 1, telescope; 2 rotating mirror ; 3 , drive motor; 4 , tachometer generator; 5 , tachometer microammeter; 6, drive-motor rheostat. 
meter; the results therefore indicate that training in the use of the instrument is not necessary.

The small area of the water surface that is seen in a given frame actually travels along the surface on the chord of the vertical angle through which it is followed (fig. 424.2). This vertical angle (referred to hereafter as the viewing angle) ranged from $+30^{\circ}$ to $-30^{\circ}$ for the pilot model. To synchronize perfectly, the rotational speed of the mirror wheel must be modulated in proportion to the square of the cosine of the instantaneous angle of view. When the mirror wheel is rotated at constant speed, as was the case with the pilot model, close synchronization can be obtained only within the central portion of the viewing angle. Asynchronization of the image at the extremes is believed responsible, in large part, for the divergence of the readings made by the different observers.

To correct this difficulty, a second model has been built using a set of function gears between the drive motor and the mirror wheel. Gearing could not be obtained which exactly fitted the required $\cos ^{2}$ function, so an approximation using eccentrically mounted circular gears was employed. Preliminary field tests with this instrument indicate improvement over the first model, but additional calibration work is needed before this improvement can be accurately assessed.

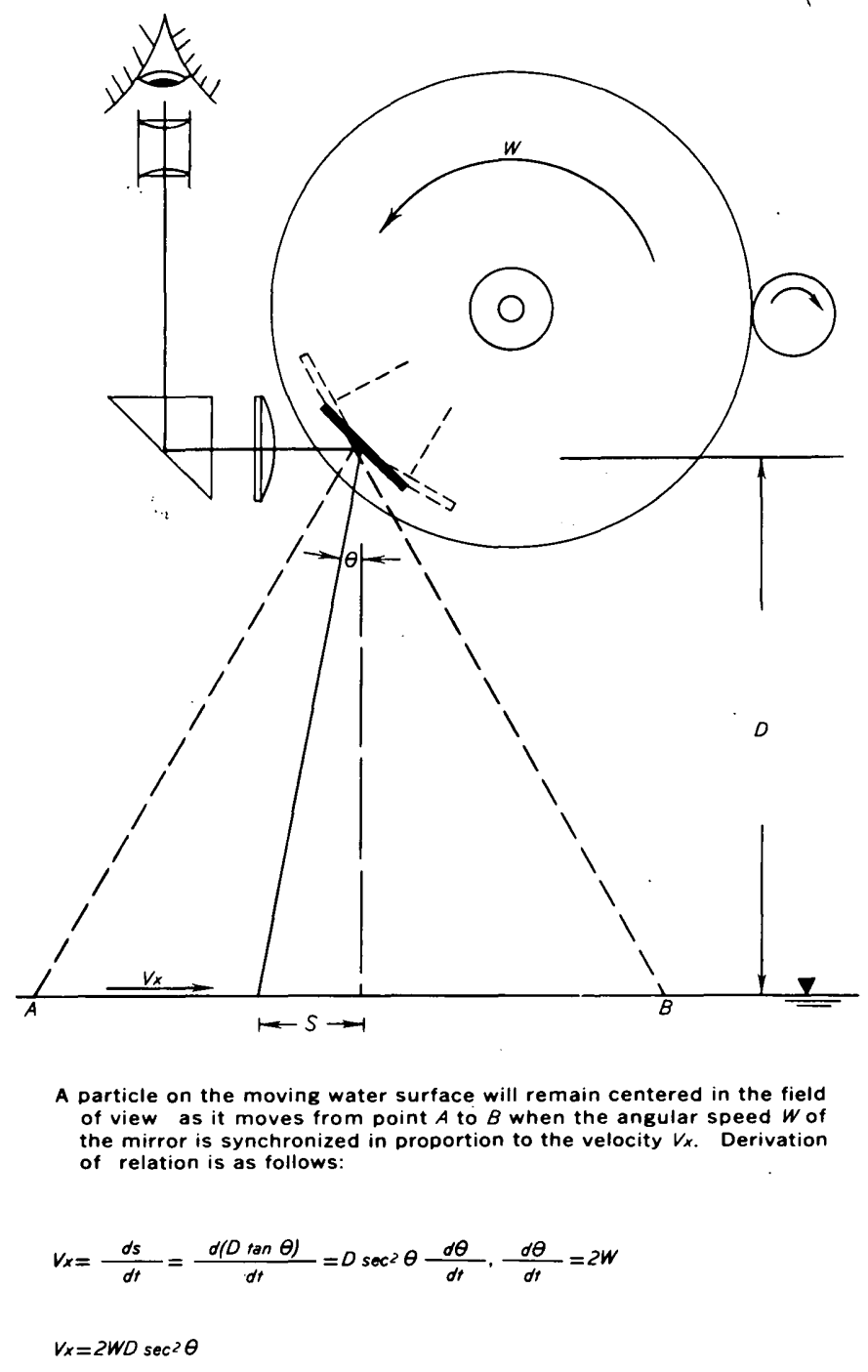

As $V_{x}$ is constant, $W$ must be modulated by $\cos ^{2} \theta$ if synchronization is to be maintained

FIGURE 424.2.-Schematic diagram showing relation between velocity of stream and rotational speed of the mirror. 


\section{THE EFFECT OF FINITE BOUNDARIES ON MEASUREMENT OF GOLD-198 WITH A SCINTILLATION DETECTOR}

By Bernard J. Frederick and Richard G. Godfrey, Oak Ridge, Tenn., and Washington, D.C.

Work done in cooperation with the U.S. Atomic Energy Commission

Measurement in situ of radioactive tracers in openchannel flow studies appears to have great potential as an aid in understanding the micromechanics of flow. However, in the calibration of equipment for absolute measurement of the concentration of activity, the boundary conditions of isotope containment must be considered.

Experiments have been made that define the effect of boundary conditions on measurements of isotope concentration in cylindrical tanks. In these tests gold198 in the form of $\mathrm{AuCl}_{3}$ is used as the tracer. A known amount of the isotope is added to a known amount of water in the tank. The detection system used has a $1 \mathrm{in}$. by $1 \mathrm{in}$. sodium iodide crystal (thallium activated). The crystal, photo-multiplier tube, and transitorized preamplifier are encased in a waterproof plexiglas housing. The counting system is a portable batteryoperated decade scaler. The resolving time for the entire system is 50 microseconds.

In the first test, a tank 4 feet in diameter was filled with water to a depth of 5 feet. The isotope was added and the mixture was stirred continuously. The probe containing the scintillation crystal was suspended at 164 locations in a vertical plane through the center of the tank. The count rate was observed for each location and corrected for radioactive decay. Figure 425.1 is a scale drawing showing the isograms of the ratio of the count rate at various locations to that at the center of the tank. The isograms are symmetrical about the vertical axis and asymmetrical about a horizontal plane at mid-depth. The asymmetry is attributed to a noncontributing volume containing the photo-multiplier tube and preamplifier which is located directly behind the crystal. Because the probe was suspended with the crystal downwards, the volume of mixture affecting the crystal was less at the bottom of the tank than near the water surface. The isograms (fig. 425.1) indicate that the effect of the proximity to boundaries is minor when the minimum distance is 12 inches. Thus, the count rate in the center of a tank 2 feet in diameter would be only slightly less than that in a tank 4 feet in diameter.

The test was repeated in tanks having diameters of 1 and 2 feet and filled with a mixture of water and gold198 such that the concentration of the activity was the same as in the tank. 4 feet in diameter. Figure 425.2 shows the count rate along the vertical axis of each tank. The maximum observed count rate in the 2-foot diameter tank is 75 percent of that in the large tank. As in the larger tank, the count rate varies only slightly once the crystal is more than a foot away from the top or bottom. Thus, it appears that tank diameter plays a larger role than proximity to the top or bottom.

To investigate the depth-diameter effect, water was drained out of each tank in successive increments of 4 inches, and count-rate observations were made with the crystal at 2 locations on the vertical axis of the tank(a) $4 \mathrm{in}$. below the water surface and (b) at the center of depth after each increment was removed. The re-

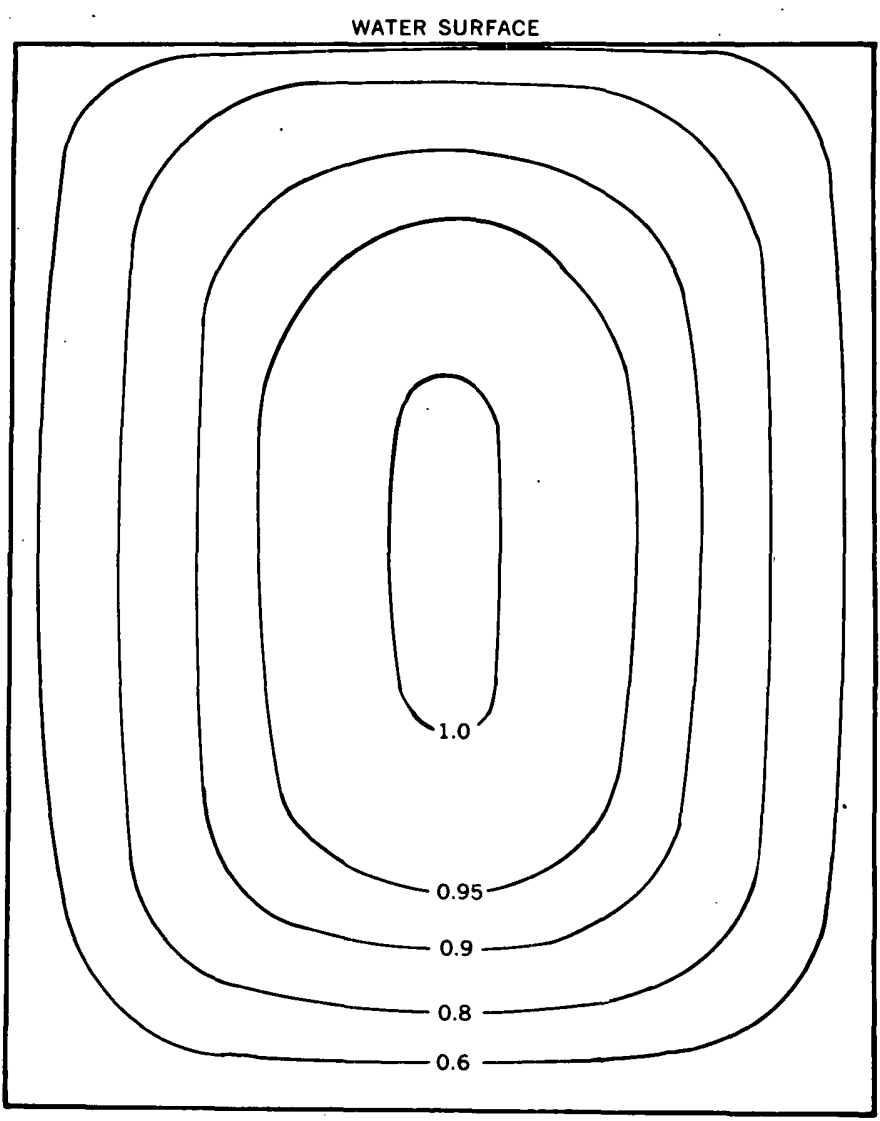

FIoure 425.1.-Vertical section of a tank 4 feet in diameter showing ratio of count rate at various crystal locations to count rate at center of tank. 


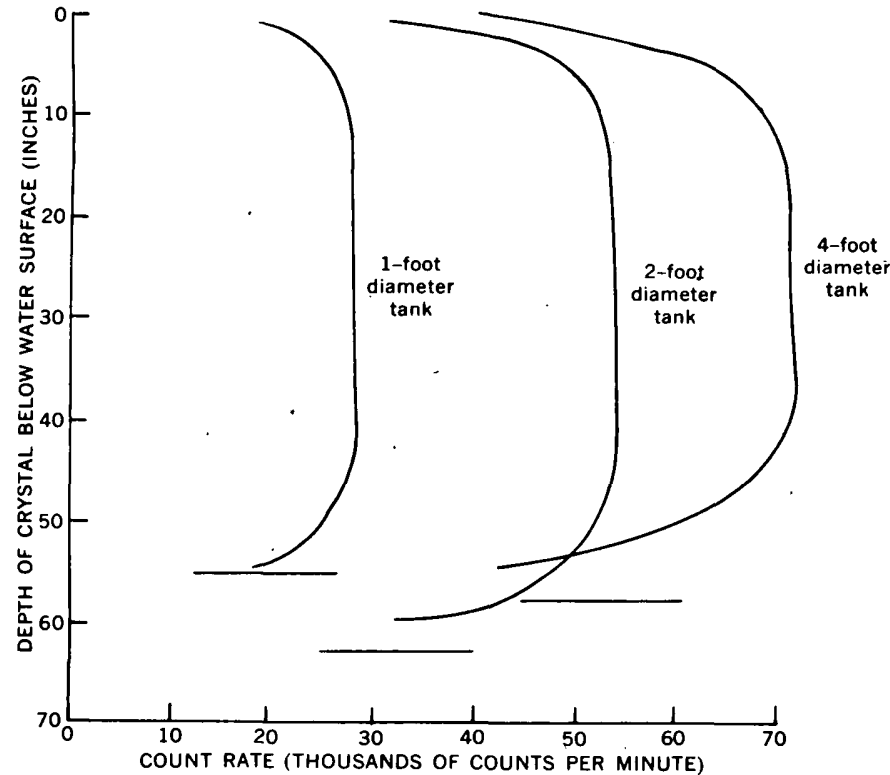

Frgure 425.2.-Relation between count rate and depth of scintillation crystal below water surface.

sults are plotted on figure 425.3. The graph shows that regardless of the tank diameter, the rate of change of count rate decreases considerably when the minimum vertical distance from the crystal to the nearest boundary is greater than 15 to 20 inches. In the larger diameter tank, the count rate constantly increases with an increase in depth, whereas the count rate in the smallest tank remains steady for depths greater than about 34 inches (the crystal being 17 inches from the nearest horizontal boundary).

In both studies where tanks of different size were used, regardless of location of the crystal the rate of increase in count rate was not as great as the rate of increase in tank diameter. This would indicate that there is a practical "infinite volume," where observed count

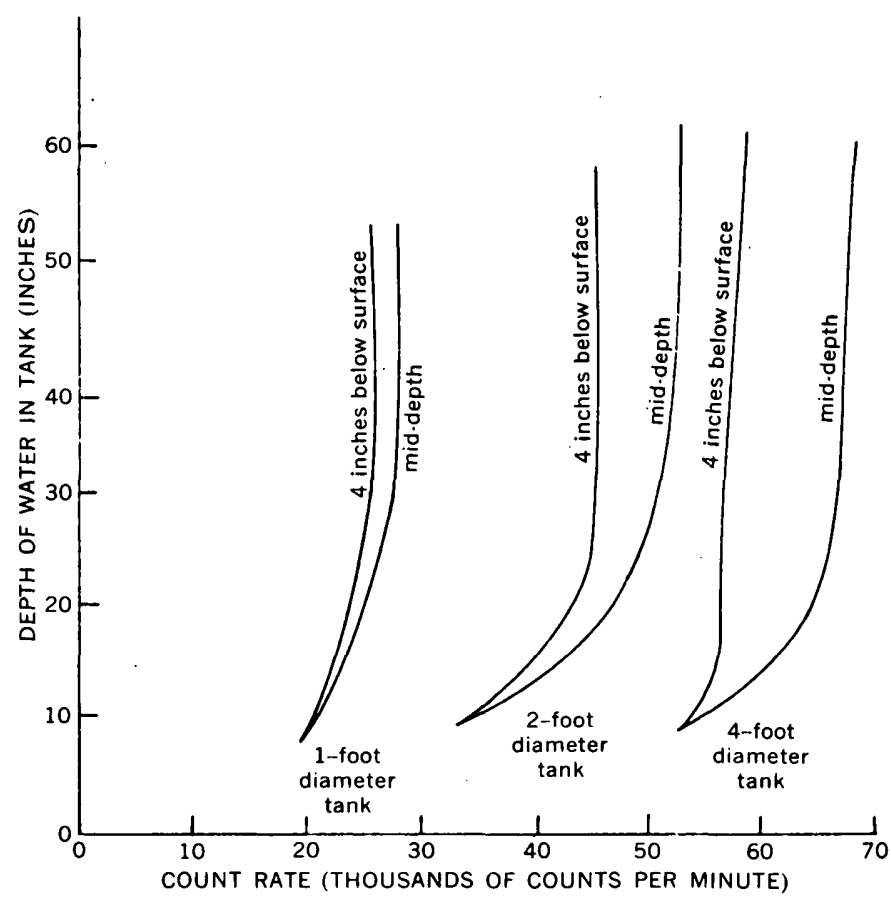

Figure 425.3.-Relation between count rate and depth of water in tank for two positions of the scintillation crystal.

rate would not change appreciably as volume increases. Theoretical considerations indicate that this "infinite volume" for a $1 \mathrm{in}$. by $1 \mathrm{in}$. cylindrical crystal-would be an oblate spheroid whose major axis would be horizontal and about 1.3 times as great as the minor axis. Extrapolation of the data presented here suggests that the major (horizontal) axis might be twice as great as the minor (vertical) axis and that these axes might be about 70 in. and 35 in., respectively. It is possible, however, that the predicted shape of the "infinite volume" is considerably influenced by the shape of the tank used in the experiments.

426. THE MAGNIFYING SINGLE-PRISM STEREOSCOPE, VIRTUALLY A NEW FIELD INSTRUMENT

By T. P. ThaYer, Washington, D.C.

The magnifying single-prism stereoscope is virtually a new instrument for stereoscopic viewing of aerial photographs in the field. Although designed for and by geologists, it should be equally useful for engineers, foresters, and others who use aerial photographs outdoors. Basically, the new magnifying model (figs. 426.1 and 426.2 ) consists of the single-prism stereoscope designed several years ago by W. G. Pierce and J. L. Buckmaster of the Geological Survey, with the following additions designed by the author: a magnifying system, a traverse bar, and means for holding the photographs in register. The present model when closed is 13 inches long, 121/4 inches wide (measured along the hinge), and $11 / 2$ inches thick; it weighs $31 / 4$ pounds. 


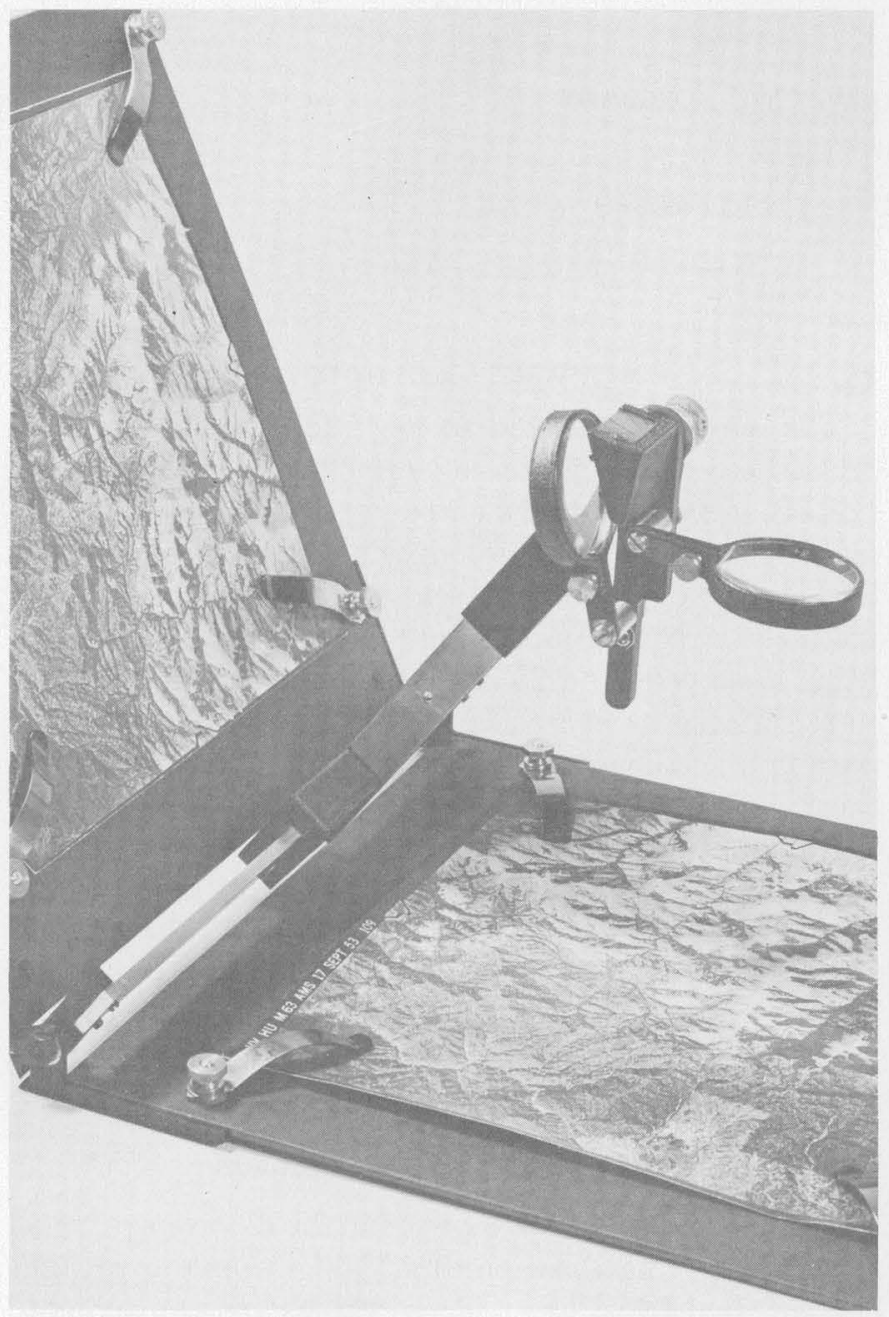

FrguRe 426.1.- Stereoscope open, showing magnifying lenses in position for use, traverse bar, and adjustable clips for holding photographs.

Substitution of aluminum for brass in the hinges and of plastics or other materials in the small parts would reduce the weight by several ounces. The model illustrated was made by the Geological Survey with suggestions from J. L. Buckmaster.

As shown on figure 426.1, the optical system consists of two magnifying lenses through which the photographs are viewed, one directly, the other through the prism. The vertical support provides for focusing, and allows a range in magnification from about $1 \frac{1}{2}$ to 2 diameters. The lens mounts are interchangeable for

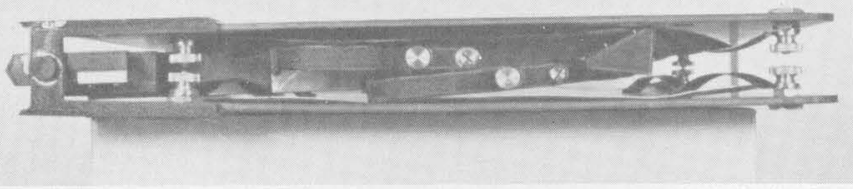

Figure 426.2.-Stereoscope closed, showing hinge mechanism and support by clips at outer corners of covers.

easy replacement in case of damage, and the lenses themselves can be changed by releasing tension screws on the retaining rims. The optical system and traverse bar are positioned midway between the covers automatically by the hinge mechanism when the stereoscope is opened. All parts of the stereoscopic model may be examined by moving the lens system from front to back on the traverse bar, and by rotating the lenses to the left or right on a pivot through the top of the vertical support. The size of the lenses, $13 / 4$ inches in diameter, provides a field 4 to 6 inches across. The low magnifications allow considerable latitude in focusing, while providing good definition. The lenses are folded down for viewing the model without magnification and when the stereoscope is closed for carrying (fig. 426.2).

The photographs are mounted with the flight line normal to the hinge and are held by adjustable-tension spring clips that may be rotated to provide clear fields in the corners. The clips at the corners away from the hinge serve also as stops to protect the optical system when the stereoscope is closed (fig. 426.2). The covers are of tempered hardboard one-eighth of an inch thick and can be replaced easily if broken.

The principal advantages of the new model stereoscope are: (a) complete coverage of the stereo model with a choice of magnification as high as 2 diameters or with the prism alone; (b) simplicity of operation; (c) easy insertion or adjustment of photographs, but positive retention in stereo position; (d) provision of a clear working area and firm support for annotating photographs; (e) protection of the photographs when not in use; (f) compactness, lightweight, and convenience; $(\mathrm{g})$ suitability for use in the office as a substitute for more expensive stereoscopes. The stereoscope could be adapted for enlargements more than 9 inches square by substituting a longer traverse bar and larger covers. 


\section{ANALYTICAL AND PETROGRAPHIC METHODS}

\section{TRACE ELEMENT SENSITIVITIES}

By Frank S. Grimaldi and Armin W. Helz, Washington, D.C.

There is an urgent need for more and better data on the distribution, mode of occurrence, and behavior under changing geologic conditions of many elements, especially those that are becoming increasingly important in our expanding technology. Inquiry should be made into the present status of analytical methods, especially to determine whether they are sufficiently sensitive to enable detection of the elements in concentrations as given by their average abundance in the crust.

Compilations comparing trace-element sensitivities of different methods are given by Meinke (1955) and Winchester (1960). Winchester also examined the question of analytical sensitivity versus concentration of occurrence of an element. The purpose of this report is to bring these data, and some based on present Survey practices, to the attention of the geologist. Such data can supply an initial estimate of the lowest measurable concentrations in a sample and may suggest the best analytical method.

The comparative data are much simplified in regard to any specific analytical problem. Complexities that increase with the number of components of the sample, the size and nature of the sample, and the required accuracy must be considered before making the final choice of an analytical method. For example, high sensitivities are listed for the photometric methods for $\mathrm{Ba}$ and $\mathrm{Sr}$ based on o-cresolphthalein complexone (table 427.1), but calcium interferes seriously and the separation of these elements from calcium and from one another is so complex that the o-cresolphthalein complexone method may be worthless.

The sensitivities of the elements by "wet," spectrographic, and radioactivation methods are compared in table 427.1. Values for the X-ray spectrochemical technique are not included because this method is generally not suitable for trace analysis, the detection limits ranging from about 5 to 100 micrograms in a 0.1 -gram sample. However, it should be pointed out that the electron probe may have great utility in samples where the local concentration of an element is relatively high (for example, in a particular mineral phase), yet very low when the total sample is considered.

\section{"WET" METHODS}

The sensitivities listed in table 427.1 were computed from those given by Sandell (1959), Boltz (1958), and Gilbert (1959) supplemented by those derived from original papers and the present authors' experience. The limit of detection for the spectrophotometric methods is based on a minimum absorbance of 0.01 , using $1-\mathrm{cm}$ cells and $25-\mathrm{ml}$ volume. There is a reserve in sensitivity by at least a factor of 10 if a longer light path and smaller volumes are used. The sensitivity of the fluorimetric methods is based on obtaining a reading amounting to at least five scale deflections above a blank for the limiting amounts shown in a $25-\mathrm{ml}$ volume. The values given for the flame photometric methods were obtained by multiplying the limits given by Gilbert by a factor of 35 . The sensitivities listed for "wet" methods are realistic and result in less than a 20 percent relative error at the limits of detection.

\section{SPECTROGRAPHIC METHODS}

$D$-c arc.-The values shown for the d-c arc are based on complete volatilization of a 10 -mg sample in a highcurrent $d$-c carbon arc. These values are approximate detection limits obtained with the d-c arc on mineral and rock samples routinely analyzed in the Survey. There are too many variables of equipment, type of material being analyzed, and spectral region employed to consider the values other than approximate. Some combinations of elements may be very unfavorable for as low a figure as shown for the detection limit while in some specific examples improvement may be expected if special emphasis is given in the procedure to detecting low concentrations.

Copper spark.-The values shown for the copper spark method are from Fred, Nachtrieb, and Tomkins (1947). This method is noted for its high sensitivity for a limited kind and size of sample, for example, a dilute solution that can be handled by drying a measured drop of a solution on the tip of an electrode. These data serve to emphasize the small amount of material that can, under favorable conditions, give measurable spectra. Although the absolute sensitivity is very high, the concentration limits are comparable 
TABLE 427.1.-Sensitivities of various methods

\begin{tabular}{|c|c|c|c|c|c|c|c|c|c|c|c|c|}
\hline \multirow[b]{2}{*}{ Element } & \multirow[b]{2}{*}{$\begin{array}{c}\text { Approxi- } \\
\text { mate } \\
\text { averago } \\
\text { abundance } \\
\text { (percent) }\end{array}$} & \multicolumn{3}{|l|}{ Wet methods } & \multicolumn{3}{|c|}{ Spectrographic } & \multicolumn{5}{|c|}{ Radioactivation } \\
\hline & & Method 1 & $\begin{array}{c}\text { Detection } \\
\text { limit } \\
\text { (micro- } \\
\text { grams) }\end{array}$ & $\begin{array}{c}\text { Minimum } \\
\text { sample } \\
\text { to detect } \\
\text { average } \\
\text { abundance } \\
\text { (grams) }\end{array}$ & $\begin{array}{l}\text { D-c arc } \\
\text { detection } \\
\text { limit } \\
\text { (micro- } \\
\text { grams) }\end{array}$ & $\begin{array}{c}\text { Minimum } \\
\text { sample } \\
\text { to detect } \\
\text { average } \\
\text { abundance } \\
\text { (grams) }\end{array}$ & $\begin{array}{c}\text { Cu-spark } \\
\text { detection } \\
\text { limit } \\
\text { (micro- } \\
\text { grams) }\end{array}$ & Half-life & $\begin{array}{c}\text { Activity } \\
\text { measured }\end{array}$ & $\begin{array}{c}\text { Detection } \\
\text { limit, } \\
\text { flux 10 } \\
\text { (micro- } \\
\text { grams) }\end{array}$ & $\begin{array}{l}\text { Detection } \\
\text { limit, } \\
\text { flux 1019 } \\
\text { (micro- } \\
\text { grams) }\end{array}$ & $\begin{array}{c}\text { Minjmum } \\
\text { sample } \\
\text { to detect } \\
\text { average } \\
\text { abundance, } \\
\text { flux 1012 } \\
\text { (grams) }\end{array}$ \\
\hline l.. & $5 \times 10^{-3}$ & $\begin{array}{l}\text { Flame photometry } \\
\text { Thoron }(\mathrm{S})\end{array}$ & $\begin{array}{l}0.5 \\
.25\end{array}$ & $\begin{array}{l}0.01 \\
.005\end{array}$ & 0.007 & $2 \times 10^{-4}$ & 0.0002 & & & & & \\
\hline Na. & 2.5 & Flame photometry & .15 & $6 \times 10^{-0}$ & .03 & $1 \times 10^{-0}$ & .01 & $14.8 \mathrm{~h}$ & $\mathrm{Na24}$ & 16 & 0.016 & $6 \times 10^{-7}$ \\
\hline K.. & 2.5 & 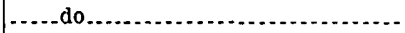 & 8 & $3 \times 10^{-4}$ & .3 & $1 \times 10^{-5}$ & .01 & $12.4 \mathrm{~h}$ & $\mathrm{~K}^{12}$ & 190 & .19 & $7.5 \times 10^{-0}$ \\
\hline Rb.. & $2.8 \times 10^{-2}$ & .....do....... & 25 & .09 & .1 & $4 \times 10^{-4}$ & .02 & $17.8 \mathrm{~m}$ & $\mathbf{R b}^{88}$ & 48 & .05 & $2 \times 10^{-6}$ \\
\hline Os.. & $\left(1 \times 10^{-3}\right)$ & ....do. & 85 & $(8.5)$ & 3 & .03 & .05 & 3. $2 \mathrm{~h}$ & Csi34m & 700 & .7 & .07 \\
\hline Bo.. & $4 \times 10^{-4}$ & Morin (F) & .001 & $2.5 \times 10^{-4}$ & .01 & $2.5 \times 10^{-3}$ & .0002 & & & & $\ldots$ & \\
\hline $\mathrm{Mg}$ - & 1.7 & OxIne butylamine (S) ......... & & $6 \times 10^{-5}$ & .01 & $6 \times 10^{-8}$ & .001 & $10.2 \mathrm{~m}$ & $\mathrm{Mg}^{27}$ & 80 & .08 & $5 \times 10^{-0}$ \\
\hline $\mathrm{Ca}$. & 3.3 & Flame photometry & 2 & $7 \times 10^{-5}$ & $\cdots$ & & $-\cdots$ & & & & & \\
\hline $\mathbf{r}$ & $3.5 \times 10^{-2}$ & $\begin{array}{l}\text { Murexide (S) } \\
\text { Flame photometry }\end{array}$ & $9^{.75}$ & $\begin{array}{l}2 \times 10^{-6} \\
.03\end{array}$ & .01 & $3 \times 10^{-7}$ & .01 & $8.8 \mathrm{~m}$ & $\mathrm{Ca}^{49}$ & 300 & .3 & $1 \times 10^{-8}$ \\
\hline & 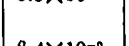 & o-cresolph thalein complexone (S) & .8 & .003 & .01 & $3 \times 10^{-5}$ & .05 & $2.8 \mathrm{~h}$ & $\mathrm{Sr}^{85 \mathrm{~m}}$ & 48 & .048 & $1.4 \times 10^{-4}$ \\
\hline Ba. & $6.4 \times 10^{-2}$ & Flame photometry & $\begin{array}{r}250 \\
1\end{array}$ & $\begin{array}{l}.4 \\
.002\end{array}$ & .01 & $1 \times 10^{-5}$ & & $85 \mathrm{~m}$ & $\mathrm{Ba}^{180}$ & 16 & .016 & $3 \times 10^{-5}$ \\
\hline Sc... & $1.3 \times 10^{-3}$ & $\begin{array}{l}\text { Oxine (S) } \\
\text { Morln (F) } \ldots\end{array}$ & $(15)^{2}$ &.$^{2}$ & & & -....... & & & & & \\
\hline Y.. & $2 \times 10^{-3}$ & Alizarin red $\mathrm{S}(\mathrm{S}) . . . . . .$. & 2.5 & .15 & $\begin{array}{l}.01 \\
.05\end{array}$ & $2.5 \times 10^{-3}$ & $\begin{array}{l}.0005 \\
.001\end{array}$ & $\begin{array}{l}85 \mathrm{~d} \\
62 \mathrm{~h}\end{array}$ & $\begin{array}{l}\mathrm{Sc}^{10} \\
\mathrm{Y}^{\text {p0 }}\end{array}$ & $\begin{array}{l}100 \\
110\end{array}$ & $\begin{array}{l}.1 \\
.1\end{array}$ & $\begin{array}{l}8 \times 10^{-3} \\
5 \times 10^{-3}\end{array}$ \\
\hline La.. & $4 \times 10^{-3}$ & -.... do do _ n & 5 & .15 & .2 & $5 \times 10^{-3}$ & .005 & $40 \mathrm{~h}$ & $\mathrm{La}^{140}$ & 15 & .02 & $5 \times 10^{-4}$ \\
\hline Co.. & $\left(4 \times 10^{-3}\right)$ & As Ce$\left(\mathrm{SO}_{4}\right)_{2}(\mathrm{~S}) \ldots$ & 5 & .15 & 1 & .025 & .05 & $33 \mathrm{~h}$ & $\mathrm{Ce}^{143}$ & $1 \times 10^{3}$ & 1 & .025 \\
\hline Pr.. & $7 \times 10^{-1}$ & Alizarin red $S(S)$ & 5 & .7 & 2 & .3 & .02 & $19 \mathrm{~h}$ & $\operatorname{Pr} 162$ & 6 & .006 & $1 \times 10^{-3}$ \\
\hline $\mathrm{Na}$. & $3 \times 10^{-3}$ & -.... do do........... & $\mathbf{5}$ & .15 & .5 & .02 & .02 & 1.7h & $\mathrm{Nd} 10$ & 55 & .06 & $2 \times 10^{-3}$ \\
\hline $8 \mathrm{~m}$. & $4 \times 10^{-1}$ & ......do... & 5 & 1 & .5 & .1 & .02 & $47 \mathrm{~h}$ & Sm 153 & 2.3 & .002 & $5 \times 10^{-4}$ \\
\hline Eu. & $\left(10^{-4}\right)$ & ......do... & 5 & $(5)$ & .2 & .2 & .002 & $9.2 \mathrm{~b}$ & Eu132 & .05 & $5 \times 10^{-5}$ & $5 \times 10^{-5}$ \\
\hline ad. & $\left(7 \times 10^{-1}\right)$ & ......do.... & 5 & .7 & .3 & .04 & .01 & $18 \mathrm{~h}$ & $\operatorname{Gd}^{159}$ & 60 & .06 & .01 \\
\hline Tb. & $\left(10^{-1}\right)$ & .....do........ & 5 & $(5)$ & .5 & .5 & $\cdots$ & $71 d$ & Tb 100 & 300 & .3 & .3 \\
\hline Dy. & $\left(4 \times 10^{-1}\right)$ & .....do do & 5 & (1) & .3 & .08 & .05 & $2.4 \mathrm{~h}$ & Dy 188 & .15 & $1.5 \times 10^{-5}$ & $4 \times 10^{-0}$ \\
\hline Ho. & $\left(10^{-1 ?}\right)$ & .....do. . . . & 5 & $(5)$ & .2 & .2 & .02 & $27 \mathrm{~h}$ & Ho100 & 1.6 & .002 & $2 \times 10^{-3}$ \\
\hline Er. & $\left(2 \times 10^{-4}\right)$ & 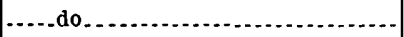 & 5 & $(2.5)$ & .2 & .1 & .05 & $7.5 \mathrm{~h}$ & $\mathrm{Er}^{171}$ & 30 & .03 & .015 \\
\hline $\mathrm{Tm}$. & $\left(1 \times 10^{-4}\right)$ & do. & 5 & $(5)$ & .2 & .2 & .005 & $127 \mathrm{~d}$ & Tmino & 100 & .1 & .1 \\
\hline Yb.. & $\left(2 \times 10^{-0}\right)$ & ....do do & 5 & $(2.5)$ & .01 & $5 \times 10^{-3}$ & .01 & $2 \mathrm{~h}$ & $\mathrm{Yb}^{177}$ & 16 & .016 & $8 \times 10^{-3}$ \\
\hline Lu. & $\left(1 \times 10^{-1}\right)$ & (1....do do & 5 & $(5)$ & .2 & .2 & .2 & 3. $7 \mathrm{~h}$ & $\mathrm{Lu}^{176 m}$ & .6 & $6 \times 10^{-4}$ & $6 \times 10^{-4}$ \\
\hline TI... & $4 \times 10^{-1}$ & Tiron $(\mathrm{S})$ - & 1 & $2.5 \times 10^{-6}$ & .02 & $5 \times 10^{-0}$ & .01 & $6 \mathrm{~m}$ & $T^{151}$ & 110 & .1 & $2.5 \times 10^{-5}$ \\
\hline Zr... & $2 \times 10^{-2}$ & Morln (F) & .2 & $1 \times 10^{-8}$ & $\ldots$ & (n......... & & $\cdots$ & & & & - n \\
\hline & & Quercetin (S) .................... & .6 & $4.5 \times 10^{-3}$ & .05 & $2.5 \times 10^{-4}$ & .01 & $17 \mathrm{~h}$ & $\mathrm{Zr}^{07}$ & $5 \times 10^{3}$ & 5 & .025 \\
\hline Hf. & $3 \times 10^{-4}$ & Morin $(F)$ & .4 & .13 & $\ldots$ & (n............ & & & & …..... & $\ldots$ & $\cdots$ \\
\hline & & (S) & 1.2 & 6 & .3 & .1 & .05 & $46 \mathrm{~d}$ & H/181 & $1.4 \times 10^{3}$ & 1.4 & .5 \\
\hline Th. & $1 \times 10^{-3}$ & Thoron (S) & 5 & .5 & 2 & .2 & .02 & $22 \mathrm{~m}$ & $T^{233}$ & .6 & $6 \times 10^{-4}$ & $6 \times 10^{-3}$ \\
\hline V.. & $1 \times 10^{-2}$ & Phosphotungstic acld (S) ........... & 5 & .05 & .02 & $2 \times 10^{-4}$ & .005 & $3.7 \mathrm{~m}$ & Vs2 & .26 & $2.6 \times 10^{-4}$ & $2.6 \times 10^{-\infty}$ \\
\hline Nb. & $2 \times 10^{-3}$ & Thiocyanate (S) & 1 & .05 & .05 & $2.5 \times 10^{-3}$ & .02 & $6.6 \mathrm{~m}$ & $\mathrm{Nb}^{04 \mathrm{~m}}$ & 1.3 & $1 \times 10^{-8}$ & $5 \times 10^{-6}$ \\
\hline Ta.. & $2 \times 10^{-1}$ & Pyrogallol (S) ............ & 10 & 5 & & & & & & & . & - \\
\hline & $1 \times 10-3$ & Phenylfluorone (S) & .8 & .4 & 1 & .5 & .1 & $16 \mathrm{~m}$ & TA $^{182 \mathrm{~m}}$ & 100 & .1 & .05 \\
\hline Cr. & $1 \times 10^{-2}$ & $\begin{array}{l}\text { Diphenylcarbazide (S) } \\
\text { As chromate (S) }\end{array}$ & $3^{.3}$ & $\begin{array}{l}3 \times 10^{-3} \\
.03\end{array}$ & .02 & $2 \times 10^{-1}$ & .005 & $3.5 \mathrm{~m}$ & $\mathrm{Cr}^{53}$ & 100 & .1 & $1 \times 10^{-3}$ \\
\hline Mo & $2 \times 10^{-4}$ & Thlocyanate (S) & 2.5 & 1.2 & & & & & & & & \\
\hline & & Dithiol (S) & 1.2 & .6 & .02 & .01 & .005 & $14.6 \mathrm{~m}$ & $\mathrm{Mo}^{101}$ & 36 & .036 & .018 \\
\hline W. & $\left(10^{-4} ?\right)$ & Thlocyanate (S) & 2.5 & 2.5 & $\cdots$ & $\cdots$ & $\cdots$ & & & & & \\
\hline & $3 \times 10^{-1}$ & $\begin{array}{l}\text { Dithiol (S) } \\
\text { NaF (F) }\end{array}$ & $\begin{array}{l}2.2 \\
.001\end{array}$ & $\begin{array}{l}2.2 \\
3 \times 10^{-4}\end{array}$ & .5 & .5 & .05 & $24 \mathrm{~h}$ & W: $: 87$ & 10 & $\begin{array}{l}.01 \\
\cdots\end{array}$ & 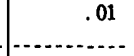 \\
\hline & & Thlocyanate (S) $\ldots$ & 17 & 6 & 4 & . 1.3 & .1 & $24 \mathrm{~m}$ & U230 & 2 & .002 & $1 \times 10^{-3}$ \\
\hline Mn & 0.1 & As $\mathrm{MnO}_{4}-(\mathrm{S})$ & 7 & $7 \times 10^{-3}$ & & .............. & $\cdots$ & ...... & & $\therefore-.$. & $\therefore \ldots \ldots+n$ & \\
\hline Re. & $\left(10^{-7} ?\right)$ & $\begin{array}{l}\text { 4, 4'Tetramethyldiaminotriphenyl } \\
\text { Methane (S). } \\
\text { Catalysis } \mathrm{Te} \mathrm{SnCl}_{2} \text { (S).............. }\end{array}$ & .025 & $2.5 \times 10^{-5}$ & .01 & $1 \times 10^{-5}$ & .002 & $2.6 \mathrm{~h}$ & $\mathrm{Mn}^{56}$ & .32 & $3.2 \times 10^{-1}$ & $3 \times 10^{-1}$ \\
\hline & & (S) & 1.3 & 1300 & .2 & 200 & .2 & $17 \mathrm{~h}$ & $\mathrm{Re}^{183}$ & 1.8 & $1.8 \times 10^{-3}$ & 1.8 \\
\hline Fo.. & 4.7 & o-phenanthroline (S) & 1.3 & $3 \times 10^{-5}$ & .1 & $2 \times 10^{-0}$ & .05 & $46 d$ & $\mathrm{Fe}^{30}$ & $1.6 \times 10^{6}$ & $1.6 \times 10^{3}$ & .03 \\
\hline Ru.. & $\left(10^{-8} ?\right)$ & Catalysis Co (IV), As(III) (S) ...... & 0.001 & $(10 ?)$ & & & & & & $\cdots$ & . & \\
\hline Os. & $\left(10^{-8 ?)}\right.$ & $\begin{array}{l}\text { o-phenanthroline (S) } \\
\text { Catalysis } \mathrm{Ce}(\mathrm{IV}), \mathrm{As} \text { (III) (S) }\end{array}$ & $\begin{array}{c}1.3 \\
.01\end{array}$ & $\begin{array}{l}1.3 \times 10^{4} \\
(100)\end{array}$ & .2 & $2 \times 10^{-3}$ & - & $4.5 \mathrm{~h}$ & Ru10s & 110 & 0.1 & $\begin{array}{l}1 \times 10^{8} \\
-1\end{array}$ \\
\hline & & Tetraphenylarsonium chloride (S) ... & 5 & $5 \times 10^{4}$ & .4 & $4 \times 10^{3}$ & ..... & $32 \mathrm{~h}$ & Os ${ }^{103}$ & 180 & .2 & $2 \times 10^{3}$ \\
\hline Co. & $2 \times 10^{-3}$ & Nitroso-R salt (S) ........... & .5 & .025 & & (n......... & (-.......... & & & & & (2.......... \\
\hline & & 2-nitroso-1-naphthol (S) -. & 1.0 & .05 & .01 & $5 \times 10^{-4}$ & .05 & $10.7 \mathrm{~m}$ & $\mathrm{Co}^{00 \mathrm{~m}}$ & 1.4 & $1.4 \times 10^{-3}$ & $7 \times 10^{-5}$ \\
\hline Rh. & $\left(10^{-1} ?\right)$ & $\mathrm{SnCl}_{2}(\mathrm{~S}) \ldots$ & 6.5 & $\left(6.5 \times 10^{3}\right)$ & & & & ....... & & $-\cdots$ & & (n) \\
\hline & & 2 mercapto-4, 5 dimethyl thiazole (S) & 1.7 & $\left(1.7 \times 10^{3}\right)$ & .03 & 30 & $\cdots \cdot$ & $4.4 \mathrm{~m}$ & $\mathrm{Rh}^{104 \mathrm{~m}}$ & .15 & $1.5 \times 10^{4}$ & .15 \\
\hline & $\left(10^{-7} ?\right)$ & $\mathrm{SnCl}_{2}-\mathrm{HBr}(\mathrm{S})$ & 1 & $\left(1 \times 10^{3}\right)$ & .5 & 500 & .5 & $19 \mathrm{~h}$ & Ir.194 $^{104}$ & 1.1 & $1 \times 10^{-3}$ & 1 \\
\hline Ni.. & $1 \times 10^{-2}$ & Dimethylglyoximefoxidant $(\mathbb{S})$ & 1 & .01 & .02 & $2 \times 10^{-4}$ & .01 & $2.5 \mathrm{~h}$ & Nibs & 100 & .2 & $2 \times 10^{-3}$ \\
\hline Pd. & $2 \times 10^{-0}$ & 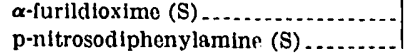 & $\begin{array}{r}1.3 \\
.3\end{array}$ & $\begin{array}{r}70 \\
15\end{array}$ & 02 & 1 & .05 & $13 \mathrm{~h}$ & $P d^{100}$ & 11 & 01 & 5 \\
\hline
\end{tabular}


TABLE 427.1.-Sensitivities of various methods-Continued

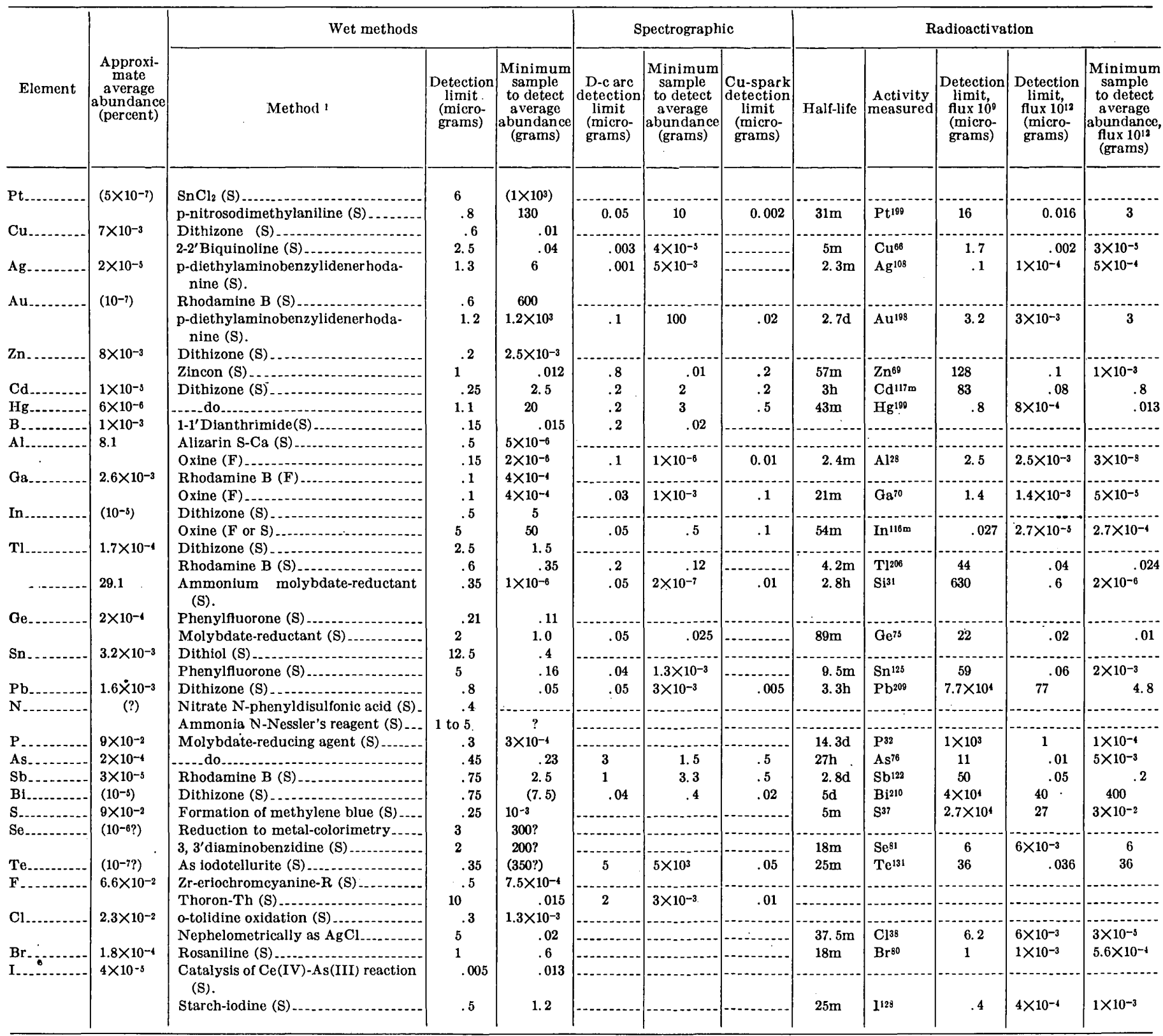

1 (S), spectrophotometry; (F), fluorimetry.

with the d-c arc (which can use a much larger sample) if it is assumed that the copper spark sample size is limited to no more than 250 micrograms. In general, the copper spark is applied to 50 micrograms or less in which one element predominates. The method holds promise for the analysis of small samples, especially if pre-enriched, or for natural materials such as liquid inclusions.

\section{ACTIVATION METHODS}

Data for activation analysis were largely taken from a bulletin by Burrill and Gale (1960) available from the High Voltage Engineering Corporation. The detection limits are based on a counting-rate of 1 disintegration per second above background, assuming a 10-percent counting efficiency; the bombarding period is 1 hour, with thermal fluxes of $10^{9}$ and $10^{12} \mathrm{n} / \mathrm{sec}-\mathrm{cm}^{2}$. It is immediately apparent that for fluxes of the order: of $10^{9}$, activation analysis is not competitive with wet chemical methods. The method, however, shows promise for determining some of the rare-earth elements. With the higher fluxes available from reactors, activation analysis represents the ultimate in sensitivity. 


\section{CONCLUSIONS}

Using sensitivity as the only criterion, it can be seen that wet methods can be used to detect many elements in concentrations represented by their average abundance as given by Vinogradov (1956) based on 2 parts of "average acidic rock" and 1 part of "average basic rock." If it is assumed that the sample size suitable for wet chemical methods. is limited to several grams, the following elements cannot readily be determined by wet chemical methods: $\mathrm{Ru}, \mathrm{Os}, \mathrm{Rh}, \mathrm{Ir}, \mathrm{Pd}, \mathrm{Pt}, \mathrm{Ag}, \mathrm{Au}$, $\mathrm{Hg}, \mathrm{Cs}$, most of the rare earth elements, In, Se, and Te. Without pre-enrichment, the $d-c$ arc method fails for the following elements based on a 10-mg sample: Hf, Th, Ta, W, U, Re, Ru, Os, Rh, Ir, Pd, Pt, Au, Cd, Hg, $\mathrm{B}, \mathrm{Cs}$, most of the rare earth metals, In, Tl, Ge, As, Sb, $\mathrm{Bi}, \mathrm{Se}, \mathrm{Te}$, and F. Assuming a 0.5 -g sample and a flux of $10^{12} \mathrm{n} / \mathrm{sec}-\mathrm{cm}^{2}$, the radioactivation method fails for the following elements: $\mathrm{Re}, \mathrm{Ru}, \mathrm{Os}, \mathrm{Ir}, \mathrm{Pt}, \mathrm{Au}, \mathrm{Cd}, \mathrm{Pb}$, $\mathrm{Bi}, \mathrm{Se}$, and Te.

\section{REFERENCES}

Boltz, D. F., 1958, Colorimetric determination of nonmetals : New York, Interscience Publishers, 372 p.

Burrill, E. A., and Gale, A. J., 1960, Activation analysis with Vande Graff neutron sources : Burlington, Mass., High Voltage Engineering Corp., Bull. AA, 12 p.

Fred, M., Nachtrieb, N. H., and Tomkins, F. S., 1947, Spectrochemical analysis by the copper spark method: Optical Soc. America Jour., v. 37, p. 279.

Gilbert, Paul T., Jr., 1959, Flame spectra of the elements: Fullerton, Calif., Beckman Instruments Div., Bull. 753, 35 p.

Meinke, W. W., 1955, Trace element sensitivity, Comparison of activation analysis with other methods: Science, v. 121, p. $177-184$.

Sandell, E. B., 1959, Colorimetric determination of traces of metals, 3d ed.: New York, Interscience Publishers, 1032 p.

Vinogradov, A. P., 1956, The regularity of distribution of chemical elements in the earth's crust: Geokhimiya, p. 1-52.

Winchester, J. W., 1960, Radioactivation analysis in inorganic geochemistry, in Cotton, F. A., ed., Progress in inorganic chemistry, v. 2 : New York, Interscience Publishers, p. 1-32.

\section{USE OF RELEASING AGENTS IN THE FLAME PHOTOMETRIC DETERMINATION OF MAGNESIUM AND BARIUM}

By Joseph I. Dinnin, Washington, D.C.

The flame spectra of magnesium and barium, like those of calcium and strontium, are seriously affected by the presence of aluminum and numerous other elements in the solution aspirated into the flame. Because the elimination of the interferences usually necessitates a time-consuming separation, not always completely successful, the usefulness of the flame photometric of these elements is seriously impaired.

Silica, phosphate, and sulfate are among the most serious depressants of the magnesium emission (Dean, $1960)$; sulfate and phosphate can reduce the weak flame emission of barium by approximately half of its original value. Releasing agents eliminate depressive interferences in the determination of calcium and strontium (Dinnin, 1960; Art. 429). The present investigation shows that the releasing effect also applies in the determination of magnesium and barium.

The methods, reagents, and instruments used in this study were the same as those described earlier (Dinnin, 1960). The resonance line at $285.2 \mathrm{~m} \mu$ was the primary wavelength used for the study of magnesium; background was measured at $286.0 \mathrm{~m} \mu$. Supplementary data were obtained at the band heads $371 \mathrm{~m} \mu$ and $383 \mathrm{~m} \mu$ with background corrections made at $376 \mathrm{~m} \mu$ and 420 $\mathrm{m} \mu$, respectively. The band head at $488 \mathrm{~m} \mu$ and the resonance line at $553.6 \mathrm{~m} \mu$ were used for the study of barium; background measurements were made at 470 $\mathrm{m} \mu$ and $560 \mathrm{~m} \mu$, respectively.

Acetone, like many other organic solvents, enhances the spectral emission of magnesium and barium many fold. Although studies with organic solvents have been made with magnesium, they have not as yet been made with barium. The results presented here for the effect of releasing agents on magnesium include studies made in perchloric acid and 80 percent acetone media.

\section{MAGNESIUM}

\section{PERCHLORIC ACID MEDIA}

The depressive effects of aluminum and phosphate were found to be less severe at $285.2 \mathrm{~m} \mu$ than at $371 \mathrm{~m} \mu$ and $383 \mathrm{~m} \mu$. At $285.2 \mathrm{~m} \mu, 100 \mathrm{ppm}$ (parts per million) aluminum depresses the emission of $30 \mathrm{ppm}$ magnesium approximately 20 percent; at $371 \mathrm{~m} \mu$ and $383 \mathrm{~m} \mu$, the magnesium is depressed more than 4.0 percent. Phosphate $(100 \mathrm{ppm})$, at $285 \mathrm{~m} \mu$ reduces the magnesium emission 35 percent; at $371 \mathrm{~m} \mu$ and $383 \mathrm{~m} \mu$ the magnesium emission is reduced more than 60 percent. The explanation for this differential depressant effect is 
probably based on the fact that emission at $285.2 \mathrm{~m} \mu$ is due to the resonance of the neutral atom and those at $371 \mathrm{~m} \mu$ and $383 \mathrm{~m} \mu$ are thought to be due to the $\mathrm{MgOH}$ molecule.

At $285.2 \mathrm{~m} \mu$, calcium, strontium, or barium in concentrations greater than $500 \mathrm{ppm}$ releases the full emission of $30 \mathrm{ppm}$ magnesium from the depressive effect of 100 ppm phosphate. Each of the three elements, in their effective concentrations, contributes a lower background emission than the emission of $30 \mathrm{ppm}$ magnesium.

At $371 \mathrm{~m} \mu$ and $383 \mathrm{~m} \mu$, the background contributions of strontium and barium are too high to warrant further study. However, calcium at these wavelengths contributes a lower background emission than magnesium and releases magnesium from the depressive effects of $100 \mathrm{ppm}$ phosphate. The reagents act similarly in the presence of $100 \mathrm{ppm}$ aluminum.

\section{EIGHTY PFRCENT ACETONE MEDIA}

In addition to enhancing the flame emissions of many elements, acetone and many other organic solvents are known to eliminate partially or completely the depressant effects of many anions. This was verified when it was found that the depressive effects of both aluminum and phosphate on magnesium in 80 percent acetone is less than half of their effect in 2 percent perchloric acid. Both calcium (200 ppm) and strontium (800 ppm) in 80 percent acetone release the full emission of magnesium from the depressive effects of either $100 \mathrm{ppm}$ aluminum or phosphate, while contributing less background emission than magnesium. High concentrations of barium precipitate with phosphate and bar- ium can not be studied in high concentrations; however, barium does not precipitate in 60 percent acetone and can be used in this medium.

Lanthanum and many rare-earth elements give a low background emission in the lower wavelength region and their use as releasing agents should be attractive. Lanthanum has been used in this laboratory for the determination of magnesium in chromite; it effectively releases magnesium from the depressive effect of relatively high concentrations of aluminum.

\section{BARIUM}

The use of releasing agents for the elmination of interferences in the determination of barium has been studied less extensively. However, data thus far obtained indicate that releasing agents are also effective with this element. Strontium ( $800 \mathrm{ppm})$ and calcium $(500 \mathrm{ppm})$ completely release the emission of $20 \mathrm{ppm}$ barium from the depressive effect of $100 \mathrm{ppm}$ aluminum or phosphate. However, both strontium and calcium, in their effective concentrations, contribute a higher background emission than the net emission of barium. Magnesium, although contributing a lower background emission than barium, releases a maximum of 85 to 90 percent of the full emission of barium in the presence of $100 \mathrm{ppm}$ aluminum or phosphate.

\section{REFERENCES}

Dean, J. A., 1960, Flame photometry: New York, McGraw-Hill Book Co., $354 \mathrm{p}$

Dinnin, J. I., 1960, Releasing effects in flame photometry; determination of calcium : Anal. Chemistry, v. 32, p. 1475-1480.

\title{
429. FLAME PHOTOMETRIC DETERMINATION OF STRONTIUM WITH THE USE OF RELEASING AGENTS
}

\author{
By Joseph I. Dinnin, Washington, D.C.
}

The flame photometric determination of strontium is seriously affected by several depressive interferences. Although the presence of calcium no longer presents a problem, as it does in classical gravimetric analysis, difficulty does arise from the presence of silicates, aluminum, phosphate, and sulfate, all of which are commonly associated with strontium. These elements and compounds, along with less commonly associated boron, beryllium, chromium, iron, manganese, tungsten, and zirconium, seriously depress the flame emission of strontium. Silica, in high concentration, has been reported to depress 99 percent of the emission.
It has been known for some time that high concentrations of calcium salts would eliminate the depressive effects of aluminum. It is only recently, however, that the nature of the depressive effects has been elucidated and that general means have been found for the elimination of other depressive interferences.

Dean (1960) has reviewed the general flame photometric determination of strontium and Dinnin (1960) has reviewed the use of releasing agents to eliminate the effects of depressive interferences. It was the purpose of the present investigation to determine whether releasing agents could be applied to eliminate 
depressive intereferences in the flame photometric determination of strontium.

The methods, reagents, and instruments used in this investigntion were the same as those described earlier (Dinnin, 1960). Studies were made at 2 wavelength combinations: the resonance line at $460.7 \mathrm{~m} \mu$ (millimicrons) was used with background measurements at 454 and $466 \mathrm{~m} \mu$; the band head at $683 \mathrm{~m} \mu$ was used with background measurements at $695 \mathrm{~m} \mu$.

Calcium has been the releasing agent most frequently used for the elimination of interferences in the determination of strontium. However, as most commercial salts of calcium contain appreciable amounts of strontium it is critical that corrections be made for the strontium impurity, especially in the determination of low strontium concentrations. Also, with high concentrations of calcium it may be impossible to correct completely for the continuous radiation exhibited by calcium.

The effect of increasing concentrations of calcium, magnesium, barium, and praseodymium on the flame emission of strontium in the presence of $100 \mathrm{ppm}$ (parts per million) aluminum is shown on figure 429.1. Although corrected for background emission and strontium impurity, calcium appears to enhance the emission of strontium. This is in pitrt due to the continuous emission of calcium which is not completely corrected by background measurements. Magnesium and barium do not completely release strontium from the depressive effect of aluminum. Their releising action approaches a maximum of approximately 70 percent and decreases with increasing concentration. Praseodymium, in the concentrations indicated, completely releases strontium from the depressing effects of aluminum.

Lanthanum and neodymium give results similar to those shown for praseodymium. All three elements release $20 \mathrm{ppm}$ strontium from the depressing effects of $100 \mathrm{ppm}$ aluminum, phosphate, or sulfate. Although the background emissions of lanthanum, praseodymium, and neodymium at 681 and $695 \mathrm{~m} \mu$ are too intense or unequal to be useful, their backgrounds at $461 \mathrm{~m}_{\mu}$ are low and uniform on each side of the strontium line.

Praseodymium and neodymium are the only rare earth elements studied thus far for use as releasing agents for strontium. Other rare earths may also be useful for this purpose. Pure oxides are now commercially available and their use is no longer economically prohibitive.

Praseodymium has been most frequently used as releasing agent in this laboratory. It has been used for the determination of strontium in silicate and phosphate rocks and in a wide assortment of minerals.

$6044930-61-26$

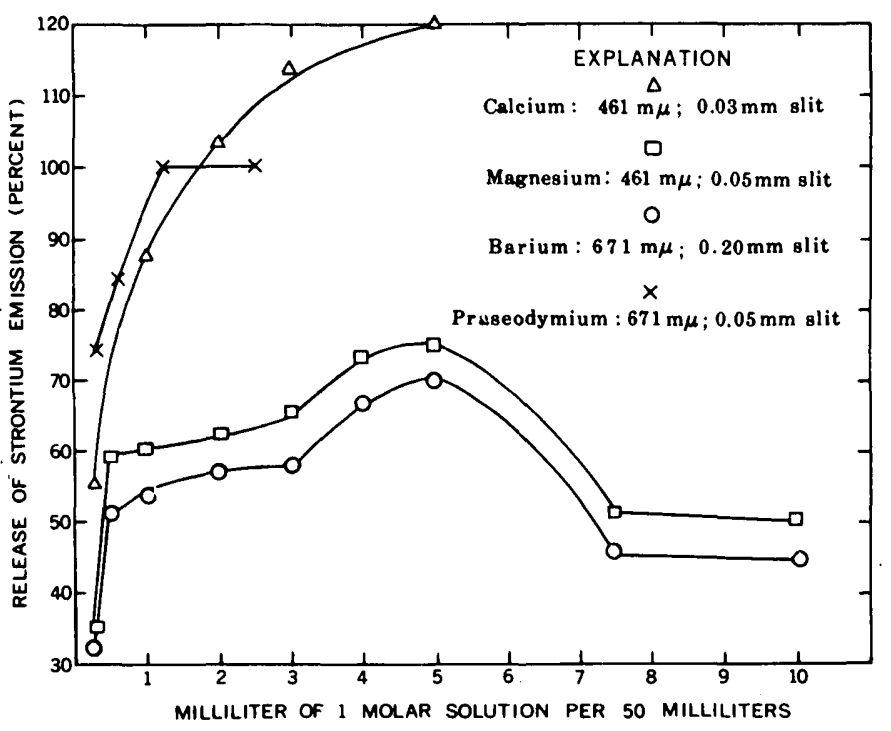

Figure 429.1.-Effect of calcium, magnesium, barium, and praseodymium on the flame emission of strontium in the presence of aluminum. Strontium concentration, $20 \mathrm{ppm}$; aluminum, $100 \mathrm{ppm}$; perchloric acid, 5 percent.

As most rocks and minerals are decomposed by a procedure which includes the use of hydrofluoric acid, no interference is normally encountered from the presence in solution of high concentrations of silica. However, in the direct analysis of natural water, the presence of silica would be of concern. If strontium is to be determined in natural water, it is advisable that silica be volatilized by evaporation with hydrofluoric acid prior to analysis.

In rocks and minerals, strontium is usually determined in an aliquot of a solution prepared for the determination of several elements. The preparation of this solution has been described elsewhere (Dinnin, 1960). Before taking an aliquot for the determination of strontium, an estimate is made of the amount of releasing agent required to provide a mole ratio of releasing agent to depressant of approximately 25 to 1 . This ratio has been determined empirically and varies with the concentration of strontium and the nature of the materials being analyzed. The ratio, 25 to 1 , is a maximum that has normally been required in the analysis of many types of materials; a lower ratio suffices for the determination of extremely low concentrations of strontium. The following procedure is normally used for the flame photometric determination :

Take an aliquot such that the final solution aspirated into the flame contains a maximum of 10-20 ppm strontium. Add the required amount of releasing agent to the sample and standard solutions and add additional perchloric acid as required to form a 5 -percent solution $(\mathrm{v} / \mathrm{v})$. Dilute 
samples and standards with water to the same specified volume. Aspirate the solutions into the flame.

Measure the gross emission at $461 \mathrm{~m} \mu$ and the background emissions at 454 and $466 \mathrm{~m} \mu$. Subtract the average background from the gross emission. Compare the net emissions of the samples to the net emissions of the standards by interpolation or by plotting a standard curve.

The concentrations of depressants in a given rock or mineral species are usually of the same order of magnitude and the estimated amount of releasing agent is normally sufficient to counteract the effects of the range of interferences normally encountered. In carbonate rocks, the high concentrations of calcium or magnesium are normally sufficient to eliminate the depressive effects of aluminum or other depressants present. Additional reagent may have to be added to phosphate rocks to overcome the high concentrations of phosphate.

\section{REFERENCES}

Dean, J. A., 1960, Flame photometry : New York, McGraw-Hill Book Co., 354 p.

Dinnin, J. I., 1960, Releasing effects in flame photometry; determination of calcium: Anal. Chemistry, v. 32, p. 1475-1480.

430. CHEMICAL AID FOR DISTINGUISHING CHROMITE, ILMENITE, AND MAGNETITE

By Joseph I. Dinnin and E. G. Williams, Washington, D.C.

Chromite, ilmenite, and magnetite frequently occur in heavy mineral fractions of ultramafic rocks and laterites. Except for the magnetic properties of magnetite, all three minerals have similar physical properties, and they may be difficult to distinguish. All three have a metallic luster, hardness of 6 , specific gravity greater than 4.5, and are usually black. The following chemical technique has been found to be useful as an aid in distinguishing them:

Reagent: Mix equal volumes of concentrated phosphoric and sulfuric acids.

Procedure: Add approximately $10 \mathrm{mg}$ of the finely pulverized mineral to a beaker containing $10 \mathrm{ml}$ of reagent. Swirl to disperse completely. Heat gradually until the mineral is completely disintegrated or dissolved. Cool. Dilute with water to approximately $40 \mathrm{ml}$.

Characteristic reactions of each of the three minerals in both the concentrated and diluted solutions are listed below. Portions of the diluted solution can be used for more specific tests for characteristic elements in the minerals.

\begin{tabular}{|c|c|c|c|}
\hline Mineral & $\begin{array}{l}\text { Rate of dissolu- } \\
\text { tion }\end{array}$ & $\begin{array}{l}\text { Color of concen- } \\
\text { trated solution }\end{array}$ & Color of diluted solution \\
\hline Chromite. . & Slow_- & $\begin{array}{c}\text { Emerald } \\
\text { green }\end{array}$ & Emerald green \\
\hline Ilmenite__._. & Rapid & $\begin{array}{l}\text { Murky } \\
\text { white }\end{array}$ & $\begin{array}{l}\text { Colorless (white } \\
\text { precipitate) }\end{array}$ \\
\hline . & Very & Pale green_ & Pale green \\
\hline
\end{tabular}

\title{
431. COMPLETENESS OF PRECIPITATION OF SELENIUM AS THE ELEMENT
}

\author{
By Irving May and Frank Cutritta, Washington, D.C.
}

As part of a more comprehensive study of analytical methods for determining selenium, tests were made of the completeness of precipitation of elemental selenium. The method tested is a modification of the commonly used method of Noyes and Bray (1948). In this procedure, after distilling selenium as the tetrabromide, excess bromine is reduced by sulfur dioxide, and selenium is then precipitated from $6 \mathrm{~N}$ hydrobromic acid with hydroxylamine hydrochloride.

The completeness of precipitation was tested using as a tracer selenium-75 (High Specific Activity) obtained from the Oak Ridge National Laboratory. The counts of filtrates from the precipitation procedure were compared with those of reference solutions. Counting 
was done in a scintillation counter using as the detector a well-t,ype 2-inch thallium-activated sodium-iodide crystal.

Precipitations were made in 25-ml volumetric flasks. Each solution had a volume of $20 \mathrm{ml}$, was $6 \mathrm{~N}$ in hydrobromic acid, and contained $0.5 \mathrm{ml}$ of free bromine. Precipitations were made by bubbling sulfur dioxide into the solutions to reduce the bromine, adding $1 \mathrm{ml}$ of 10 percent hydroxylamine hydrachloride, and then heating on the steam bath for two hours. After the solution stood overnight, the volumes were adjusted to the mark with water.

The quantities of selenium taken ranged from 0.19 to $519 \mu \mathrm{g}$, corresponding to a concentration range of 0.009 to $25 \mathrm{ppm}$ (parts per million) at the time of precipitation. The two lowest levels of selenium tested were prepared by diluting the ORNL solution of selenium-75. The selenium content of these solutions was calculated from the specific activity of the isotope solution. 'The higher selenium samples were prepared by enriching inactive selenium solutions with selenium-75.

Prior to counting, parts of all the precipitated solutions were filtered through Selas No. 01 porous porcelain crucibles. The solutions with the two lowest levels were also filtered through dry Millipore type HA filters.

Five-milliliter aliquots of each of the filtered solutions were counted in glass vial containers for five minutes. For comparison, counts were also made of appropriately diluted control solutions. The data are summarized in table 431.1.

The experiments show that selenium, in concentrations as low as $0.9 \mathrm{ppm}$; is quantitatively precipitated with hydroxylamine hydrochloride and may be quantitatively filtered with a porcelain or Millipore filter. There is a decrease in the percentage of selenium precipitated at lower initial concentrations, but precipitation is nevertheless 99.0 percent complete in solutions containing $0.09 \mathrm{ppm}$ selenium and 80 to 90 percent complete in solutions containing $0.009 \mathrm{ppm}$ selenium.

TABLE 431.1.-Precipitation of selenium

\begin{tabular}{|c|c|c|c|c|c|}
\hline \multirow{2}{*}{$\begin{array}{l}\text { Selenium } \\
\text { taken } \\
\text { (micro- } \\
\text { grams) }\end{array}$} & \multirow{2}{*}{$\begin{array}{c}\text { Initial } \\
\text { activity } 1\end{array}$} & \multicolumn{2}{|c|}{ Activity of filtrate } & \multirow{2}{*}{$\begin{array}{c}\text { Selenium } \\
\text { unprecipi- } \\
\text { tated } \\
\text { (micrograms) }\end{array}$} & \multirow{2}{*}{$\begin{array}{c}\text { Completeness of } \\
\text { precipitation } \\
\text { (average percent) }\end{array}$} \\
\hline & & $\begin{array}{l}\text { Porcelain } \\
\text { filter }\end{array}$ & $\begin{array}{c}\text { Millipore } \\
\text { filter }\end{array}$ & & \\
\hline 0.19 & 197 & 42 & 24 & 0. 032 & 83 \\
\hline .19 & 197 & 22 & 17 & .019 & 90 \\
\hline 1. 9 & 2062 & 19 & 16 & .017 & 99. \\
\hline 1. 9 & 2062 & 27 & 19 & 021 & 98. \\
\hline 19 & 220620 & 95 & $\ldots \ldots$ & .087 & 99.5 \\
\hline 19 & 20620 & 80 & $\ldots \ldots$ & .074 & $99 . t$ \\
\hline 69 & 20620 & 17 & $\ldots \ldots \ldots$ & .056 & 99.8 \\
\hline 69 & 20620 & 13 & $\ldots \ldots$ & .043 & 99. \\
\hline 119 & 20620 & 14 & $\ldots \ldots$ & .080 & $99 . \mathrm{s}$ \\
\hline 219 & 20620 & 7 & $\ldots \ldots$ & .074 & 99.8 \\
\hline 219 & 20620 & 7 & $\ldots$ & .074 & 99. \\
\hline 519 & 20620 & 3 & $\ldots$ & 078 & 100. \\
\hline 519 & 20620 & 3 & $\ldots \ldots$ & .078 & 100. \\
\hline
\end{tabular}

1 Register counts $(512$ scale) for 5 minutes given by $5-\mathrm{ml}$ aliquots (corrected for a background of 7 counts).

2 Calculated from counts of diluted spiking solution.

\section{REFERENCE}

Noyes, A. A., and Bray, W. C., 1948, A system of qualitative analysis for the rare elements: New York, Macmillan Co. 


\title{
432. EVALUATION OF HYDROLOGIC TRACERS
}

\author{
By L. L. Thatcher, Washington, D.C.
}

Several types of tracer substances with different characteristics are available for the study of the movement of water in nature. Although no single tracer is completely applicable to the diverse problems of hydrologic movement, one group of tracer substances presents a broader spectrum of applicability than the others. This is the group of isotopic tracers made up of the stable isotopes of oxygen and hydrogen and the single radioactive isotope of hydrogen with mass 3 , tritium. The superiority of these tracers is due to the fact that they are physically incorporated into the water molecule; therefore, they exhibit essentially the same physical and chemical properties as the normal water molecule with mass 18.

While it is generally desirable to use an isotope of oxygen or hydrogen for tracer purposes in the hydrosphere, the situation sometimes arises that some other tracer must be used because of cost, public reaction against radioisotopes, or other practical consideration. It is then desirable to use a tracer substance that has a minimum of adsorption loss or other adverse environmental reaction; in other words, one that behaves like tritium. Some studies have been undertaken to develop a suitable test method whereby satisfactory conventional tracers for a particular environment might be identified. Studies were made in a montmorillonite environment using an equilibration method. It was known from previous research that the degree of adsorption of the tracer substance by montmorillonite could be related on a semiquantitative basis to the relative rates of movement between the tracer substance and the parcel of water originally associated with the tracer. As the adsorption effect on a particular tracer increases, the retardation of the tracer with respect to its labeled water front increases. Conversely a tracer that shows no adsorption in equilibrium tests generally shows little or no retardation in rate of movement tests with columns. Actually these are empirical relations which cannot be formulated precisely in mathematical terms at the present status of exchange and sorption studies. However, a useful empirical tool is provided here to permit the rapid laboratory evaluation of substances for their potential utility as hydrologic tracers.

A series of substances selected for their overall potential as tracers because of their intense color or fluorescence, water solubility, and chemical stability was compared against tritium in an equilibrium experiment. Each tracer was equilibrated with 1 gram of
A. P. I. montmorillonite (No. 23) suspended in $10 \mathrm{ml}$ of distilled water. The concentration of tracer substance was measured before $\left(C_{0}\right)$ and after $\left(C_{1}\right)$ equilibration and the absorbance ratio, $A$, was evaluated:

$$
A=\frac{C_{1}}{C_{0}}
$$

Geiger counting was used for the tritium measurement and spectrophotometry was used for the dye tracer measurements. The results are summarized in the following tabulation:

\begin{tabular}{|c|c|c|c|}
\hline Tracer & $C_{0}$ & $C_{1}$ & $A$ \\
\hline Tritiated water & 87 & 83 & .95 \\
\hline Thiazol yellow & .49 & .32 & .65 \\
\hline Fast crimson & .81 & 83 & 1. 02 \\
\hline Rhodamine $\mathrm{B}_{\ldots} \ldots$ & 1. 076 & 016 & .015 \\
\hline Fuchsin $\ldots \ldots \ldots$ & .312 & 219 & .7 \\
\hline Methyl green $\ldots \ldots \ldots$ & .260 & 028 & .11 \\
\hline Aurin tricarboxylic acid & .491 & 200 & .41 \\
\hline Potassium permanganate & 1. 51 & 84 & .57 \\
\hline Potassium dichromate $_{\ldots} \ldots \ldots$ & .90 & 34 & .38 \\
\hline Methyl blue & 1. 22 & 05 & .4 \\
\hline Fluorescein & 1. 05 & 1. 05 & 1. 0 \\
\hline
\end{tabular}

On the basis of the above tests it was indicated that Fast crimson and fluorescein possessed the best tracer characteristics of the dye group. In similar tests with other media, however, fluorescein gave relatively high adsorption loss. Several tests with Fast crimson indicated that it generally exhibited less adsorption reactivity than other dyes and tended to move with a minimum of retardation in columns tested with porous media. In short, its overall hydrologic behavior is similar to that of tritium. Thus, Fast crimson appeared to present considerable potential as a tool for laboratory tracer studies. In particular, it might be added to tritium-labeled water to provide an approximate visual indication of the movement of the tritium front, which would be of. considerable value in laboratory studies inasmuch as it would minimize the collection and analysis of unnecessary eluates and other fractional samples in laboratory model tests.

The effectiveness of the experimental approach outlined above, whereby the potential value of tracer substances as accurate indicators for the rate of movement of water may be screened by equilibrium experiments, was further tested by column experiments with Fast 
crimson and tritium. A column was filled with a mixture of 20 percent montmorillonite and 80 percent Ottawa sand, and then saturated with water. The top inch of the column was charged with a mixed tracer of tritium and Fast crimson and the mixture was eluted through the column. Ninety percent of the tritium and dye elution was found in the first $20 \mathrm{ml}$ of eluate, and the concentrations of successive 5 to $6 \mathrm{ml}$ portions of eluate were used to determine the time-concentration relation. Maximum concentrations were found in the first 5- to 6-ml part; the tritium peak was $0.4 \mathrm{ml}$ behind the Fast crimson peak. The tritium peak was more sharply defined and exhibited less tailing. It was concluded that the two peaks were practically coincident within experimental error and that Fast crimson provides a useful visual indicator for tritium movement in laboratory studies with montmorillonite. This conclusion has been confirmed by further tests.

433. GRAVIMETRIC DETERMINATION OF SILICA IN CHROMITE AND CHROME ORE

\author{
By Joseph I. Dinnin, Washington, D.C.
}

Results obtained by the colorimetric determination of silica in chromite and chrome ore have been found to be several tenths of a percent (absolute) higher than the results obtained by the usual gravimetric procedures. Although the uncertainty this produces in the analysis of a highly siliceous ore may be relatively unimportant, it may be significant in the analysis of a purified chromite.

A purified chromite usually contains less than 1 percent silica. An error of several tenths of a percent (absolute) may represent as much as 50 percent of the silica present. Besides affecting the calculation of the impurities in the mineral this may seriously affect the mineralogical and geological interpretations that are based upon the analysis.

If the lower gravimetric result is caused by incomplete recovery of the silica, this may also cause a positive error in the determination of alumina; silica that has not been completely dehydrated is usually recovered and reported as alumina in the gravimetric determination of alumina.

Most of the gravimetric methods that have been described for the determination of silica in chrome ore rely upon a single dehydration for the recovery of the silica (Hartford, 1953). In order to determine whether appreciable quantities of silica were unrecovered after a single dehydration, a series of chrome ores and standard samples was subjected to a double dehydration, and the quantity of silica recovered after each dehydration was separately recorded. Slight variations of the conventional procedures were used for the determinations. In an attempt to conform to common practice, glass beakers rather than platinum dishes were used for the dehydrations so as not to prejudice the results towards low recovery of silica. Reagent and apparatus blanks were determined with each method of analysis used. In spite of the fact that no effort was made to limit contamination, blanks containing no greater than $0.2 \mathrm{mg}$ $\mathrm{SiO}_{2}$ were found after a double dehydration.

The methods used for the gravimetric determination of silica were variations of those that have been described for the determination of silica in chromite and chrome ore. Where fusions were made, they were performed with sodium peroxide in zirconium crucibles. The alkaline melts were acidified in polypropylene beakers and then transferred to Pyrex beakers for evaporation and dehydration. Silica precipitate washing techniques were standardized so as to limit the solubility effects of the wash solution; all precipitates were washed 10 times alternately with hot water and hot 5-percent hydrochloric acid. All ignitions of the precipitated silica and all volatilizations with hydrofluoric acid were performed in platinum crucibles. A semimicro-balance was used for all weighings; weights were recorded to the nearest $0.01 \mathrm{mg}$.

The results of the gravimetric determination of silica by the various methods used are compared on figure 433.1 to the results obtained by spectrophotometric analysis and by independent analysis. In almost every instance, significant amounts of silica were recovered after a second dehydration. In general the greatest amount of silica was recovered after a second dehydration with perchloric acid; the least amount was recovered after a second dehydration with hydrochloric acid.

The lowest total amount of silica was recovered after decomposition of the sample with perchloric acid. The amounts recovered could, however, be increased by pro- 


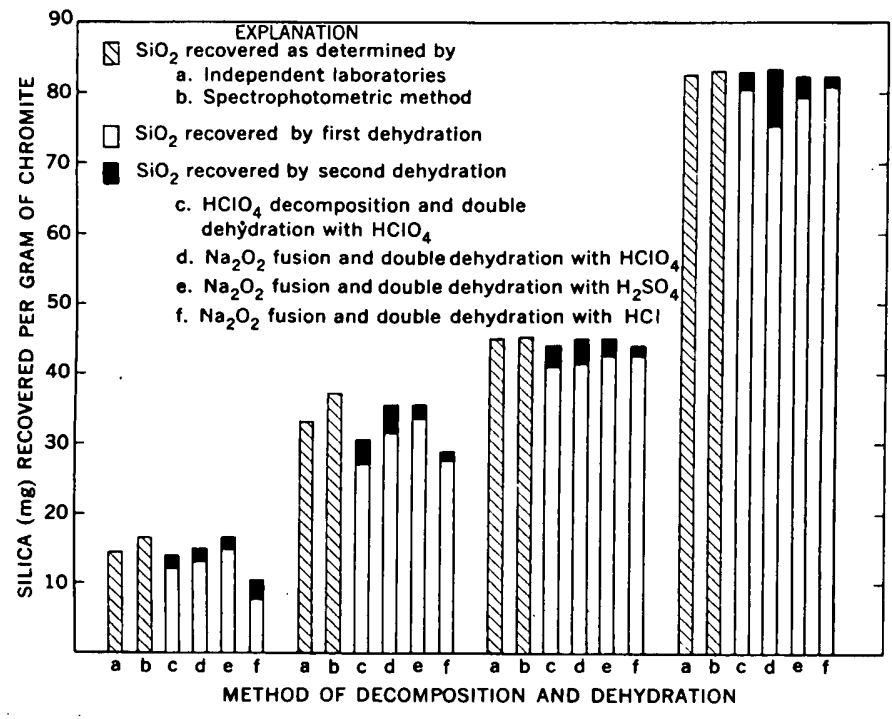

Figure 433.1.-Recovery of silica from 4 samples of chromite by various methods of decomposition and dehydration.

longed treatment of the ignited silica with hydrofluoric acid in a covered crucible. Presumably, attack of the sample with perchloric acid had not completely decomposed the quartz or refractory silicates; silica in the refractories was not completely volatilized by the brief treatment with hydrofluoric acid.

Dehydration of the silica with hydrochloric acid also resulted in lower total recoveries of silica. Although no additional amount could be recovered by a third dehydration with hydrochloric acid, additional amounts could be recovered by dehydration of the same solution with sulfuric acid.

The dehydration action of hydrochloric acid was further tested in the following manner: 41 -g portions of a purified chromite, estimated by colorimetric analysis to contain $5 \mathrm{mg} \mathrm{SiO}_{2}$ per $\mathrm{g}$, were enriched with additional amounts of pure quartz. The recovery of silica after each of 2 dehydrations with hydrochloric acid and an additional dehydration with sulfuric acid is shown on figure 433.2. Although little additional silica was recovered after a second dehydration with hydrochloric acid, significant amounts of silica were recovered after an additional dehydration with sulfuric acid. Failure of the sulfuric acid dehydration line to go through the origin of the graph (fig. 433.2) is due to either an incomplete recovery of the silica or an error of 0.2 percent (absolute) in the colorimetric analysis. To test which of these two alternatives was the more likely, the following procedure was followed:

Various amounts of a purified chromite, estimated by colorimetric analysis to contain 1.03 percent $\mathrm{SiO}_{2}$, were fused with sodium peroxide; silica was dehydrated with hydrochloric acid in a polypropylene beaker;

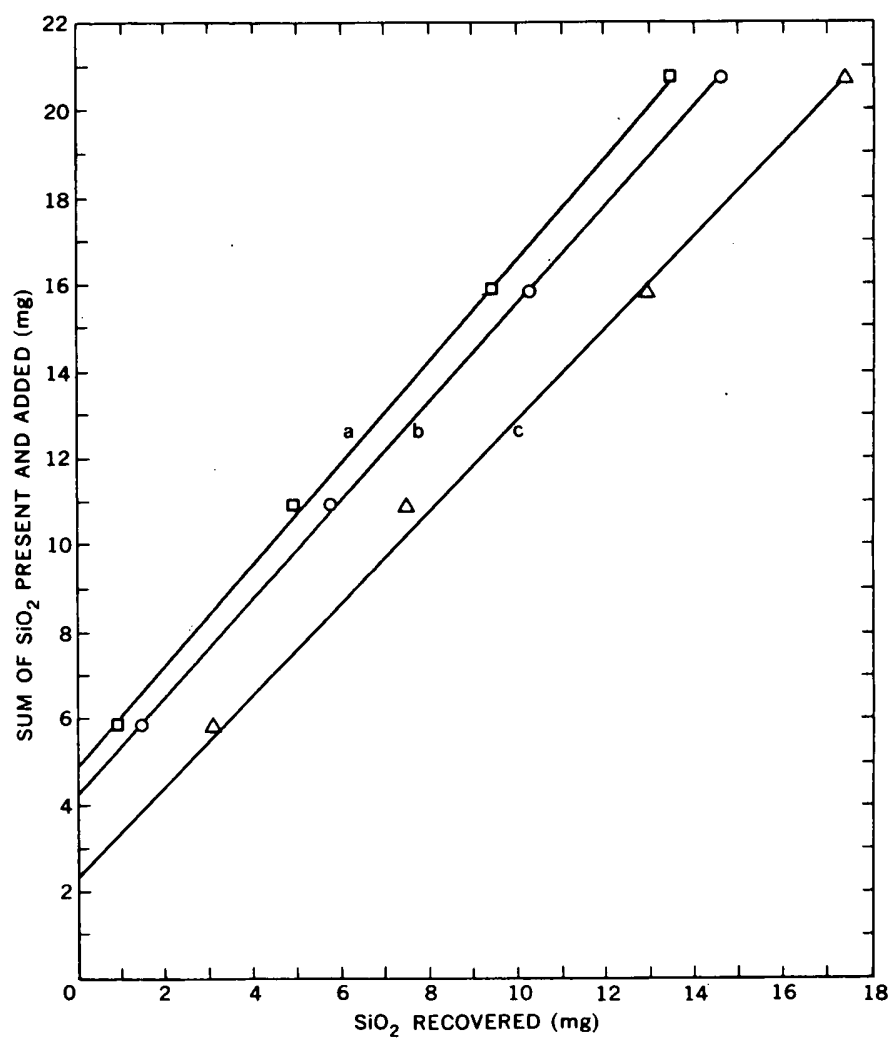

FIGURE 433.2.-Recovery of silica in chromite after enrichment with varying amounts of quartz. a, single dehydration with hydrochloric acid; b, double dehydration with hydrochloric acid; and c, double dehydration with hydrochloric acid followed by dehydration with sulfuric acid.

and the filtrate was dehydrated with sulfuric acid in a Pyrex beaker. The silica recovered after each dehydration was weighed separately. The silica recovered by each method of dehydration was then plotted against the sumple weight taken as shown. on figure 433.3. Extrapolation of the plotted lines indicates that approximately $4 \mathrm{mg}$ of silica remains in solution after dehydration with hydrochloric acid; an additional $2 \mathrm{mg}$ of silica is recovered after a second dehydration with sulfuric acid. However, approximately $2 \mathrm{mg}$ of silica remains in solution and is not recovered.

The gravimetric determination of silica on a $1-\mathrm{g}$ portion of this sample would normally be reported as 0.8 percent; repeated colorimetric analysis reported 1.03 percent $\mathrm{SiO}_{2}$. The difference, 0.2 percent $(2 \mathrm{mg}$ per $\mathrm{g}$ ), is almost completely accounted for by the $2 \mathrm{mg}$ of silica estimated to remain unrecovered in the solution.

\section{REFERENCE}

Hartford, W. H., 19533, Industrial chrome ore analysis: Anal. Chemistry, v. 25, p. 290-295. 


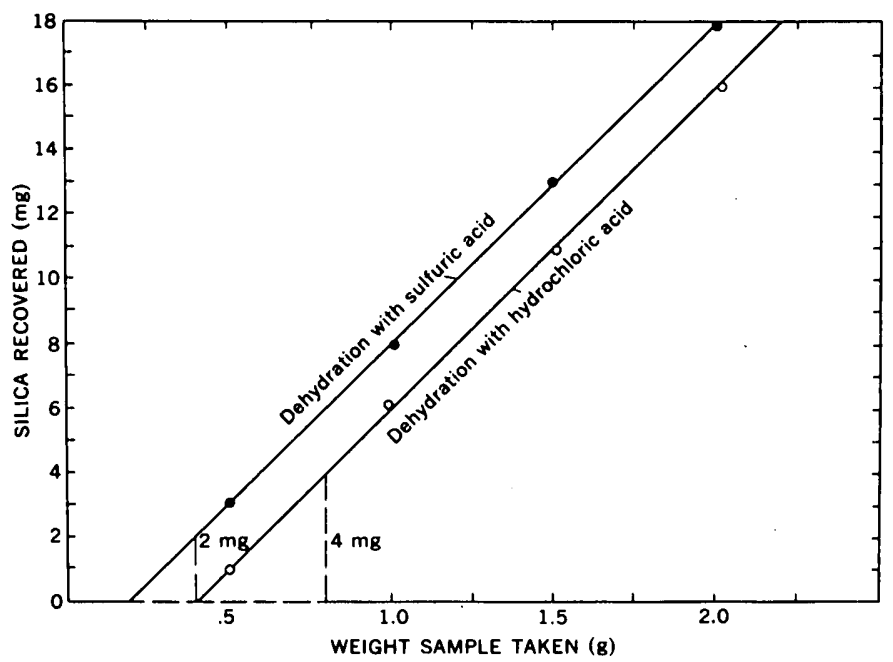

Fraure 433.3.-Recovery of silica from various amounts of chromite.

\section{父}

\section{COMPARISON OF DRAINAGE DATA OBTAINED BY THE CENTRIFUGE AND COLUMN DRAINAGE METHODS}

By R. C. Prill, Denver, Colo.

Work done in cooperation with the California Department of Water Resources

In studies of specific yield of water-bearing materials, a knowledge of the moisture distribution during drainage is important. However, procedures for estimating the moisture distribution pattern are still in the development stage. Numerical procedures (Klute, 1952; Childs, 1960) that require moisture-tension and unsaturated-permeability measurements have been the principal approach to this problem but as yet are very expensive and provide only approximate solutions. Use of the centrifiuge has been considered for some time to be a promising method of estimating moisture distribution after different periods of drainage (Miller and Miller, 1955). Because there has been only limited research on this method (Slobod and others, 1951; Marx, 1956) the Hydrologic Laboratory, Denver, Colo., has been evaluating use of the centrifuge for this purpose. In the present paper, a comparison is made of moisture contents of samples after centrifuging and after drainage by gravity.

Three sizes of glass beads, $0.47 \mathrm{~mm}$ (medium sand size), $0.120 \mathrm{~mm}$. (very fine sand size), and $0.036 \mathrm{~mm}$ (coarse silt size) (fig. 434.1) were packed in columns and were saturated. The columns of beads were drained at $20^{\circ} \mathrm{C}$ until drainage had virtually ceased, which was 1 day for the $0.47-\mathrm{mm}$ beads, 2 days for the $0.120-\mathrm{mm}$

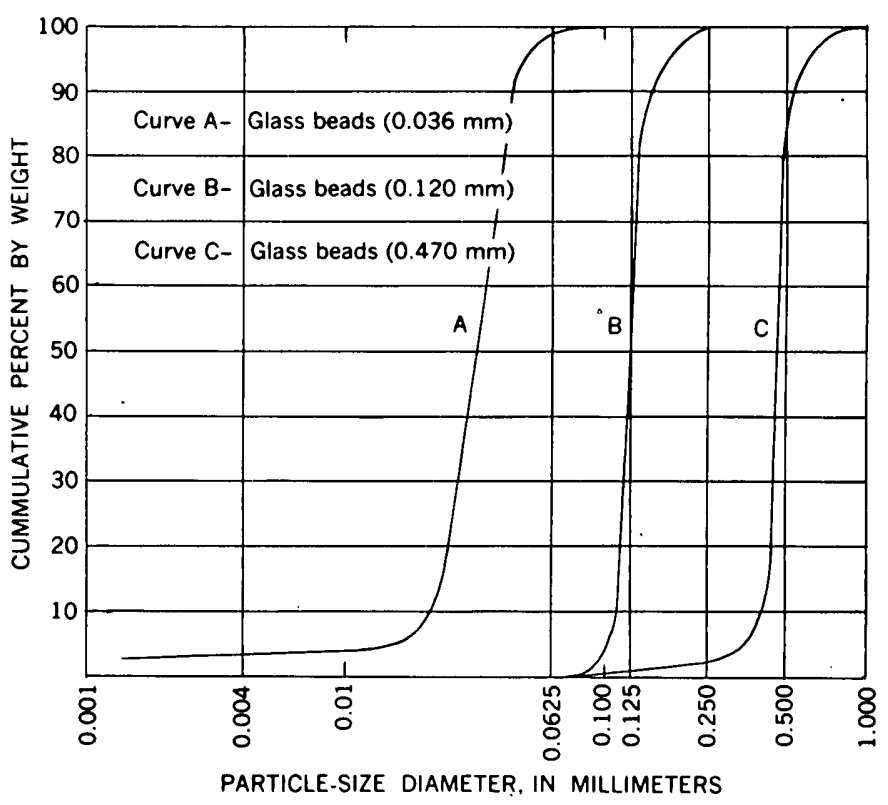

Figure 434.1.-Particle-size distribution of glass beads. 
beads, and 3 days for the 0.036 -mm beads. After drainage, the columns were separated and the moisture content determined gravimetrically for each segment (fig. 434.2).

In the centrifuge test, 5-gram samples of the three sizes of glass beads $(0.8 \mathrm{~cm}$ thick) were placed in Gooch crucibles, and after saturation the samples were centrifuged for 1 hour at a temperature of $20^{\circ} \mathrm{C}$ and accelerations between 1 and 1,000 times the acceleration due to earth's gravity $(g)$. The observed moisture content versus applied acceleration is shown on figure 434.3.

Assuming that the columns were drained long enough so that equilibrium prevailed in them, the moisture tension at any point in the drained media would be equivalent to the height above the water table. Thus, for the data shown on figure 434.2 , the tension at the top of the zone that is at or near capillary saturation would be approximately 72,24 , and 6 inches of water

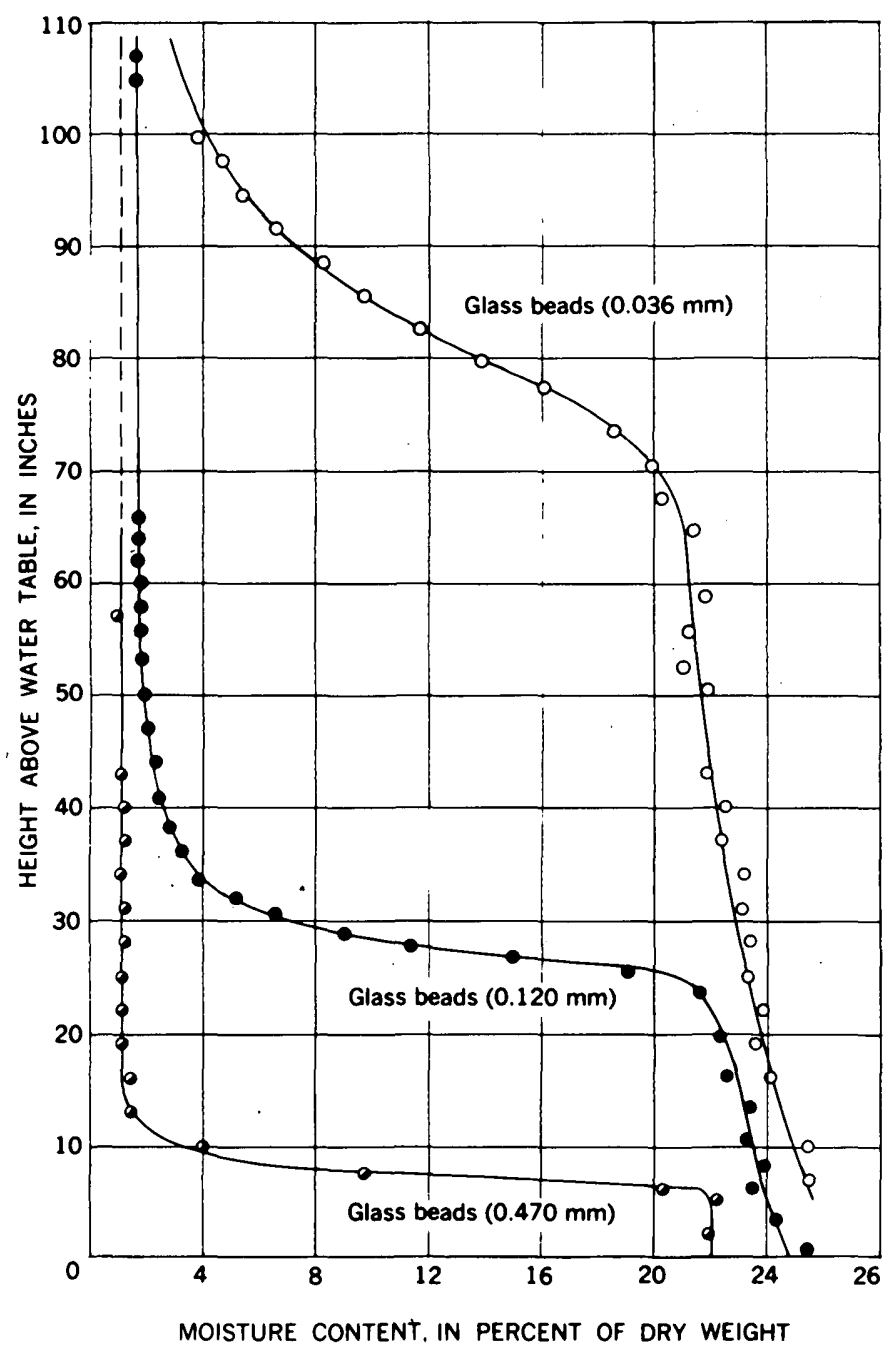

Figure 434.2.-Moisture retained after gravity drainage. for the $0.036-, 0.120-$, and $0.47-\mathrm{mm}$ beads, respectively.

The relationship between length of drainage time to acceleration for the two tests on identical media and fluids is expressed by the formula:

$$
t_{1}=t_{2}\left(\frac{a_{2}}{a_{1}}\right)^{2}
$$

in which $t_{1}$ and $t_{2}$ are the times under accelerative fields 1 or 2; and $a_{1}$ and $a_{2}$ are rates of acceleration due to force fields applied to sample.

According to equation 1, 100 hours of drainage from a stationary column, for which $a_{1}=g$, would be simulated by 1 hour of centrifuging at an acceleration of $10 \mathrm{~g}$ 's; and 10,000 hours of drainage from a stationary column would be simulated by 1 hour of centrifuge drainage at an acceleration of $100 \mathrm{~g}$ 's.

Provided the centrifuged sample has been accelerated for a long enough time, the moisture tension at any distance from the bottom of the sample can be calculated from the formula.

$$
T=\frac{\omega^{2}}{2 g} \cdot\left(r_{1}^{2}-r_{2}^{2}\right)
$$

in which $T$ is tension, in centimeters of water; $\omega$ is angular velocity, in radians per second; $g$ is acceleration of gravity, in centimeters per second per second; $r_{1}$ is distance from bottom of sample from center of rotation, in centimeters; and $r_{2}$ is distance of specified point in sample from center of rotation, in centimeters.

On figure 434.3, the flat parts of the curves at the higher moisture contents represent near-capillary saturation. As acceleration is increased, the moisture tension at the top of the sample increases according to equation 2. As the moisture tension at the top of the sample exceeds the height of capillary saturation, the moisture content decreases rapidly with increasing acceleration. Thus, the lowermost moisture content of the flat segments of the curves originating along the left side of figure 434.3 may be viewed as the moisture content corresponding with the maximum height of capillary saturation, and the accelerations at which the curves break may be substituted in equation 2 to determine that height. The curve breaks at an acceleration of about $235 \mathrm{~g}$ 's for the $0.036-\mathrm{mm}, 74 \mathrm{~g}$ 's for the 0.120 $\mathrm{mm}$, and $15 \mathrm{~g}$ 's for the $0.47-\mathrm{mm}$ glass beads. Tensions of 75,24 , and 5 inches of water are obtained for these points from equation 1 . These tensions may be compared with similar breaks in the moisture content profiles of figure 2 at 72,24 , and 6 inches of water.

The data presented above are evidence of the applicability of formula 2 in centrifuge drainage. This suggests the possibility of using the same basic procedure 


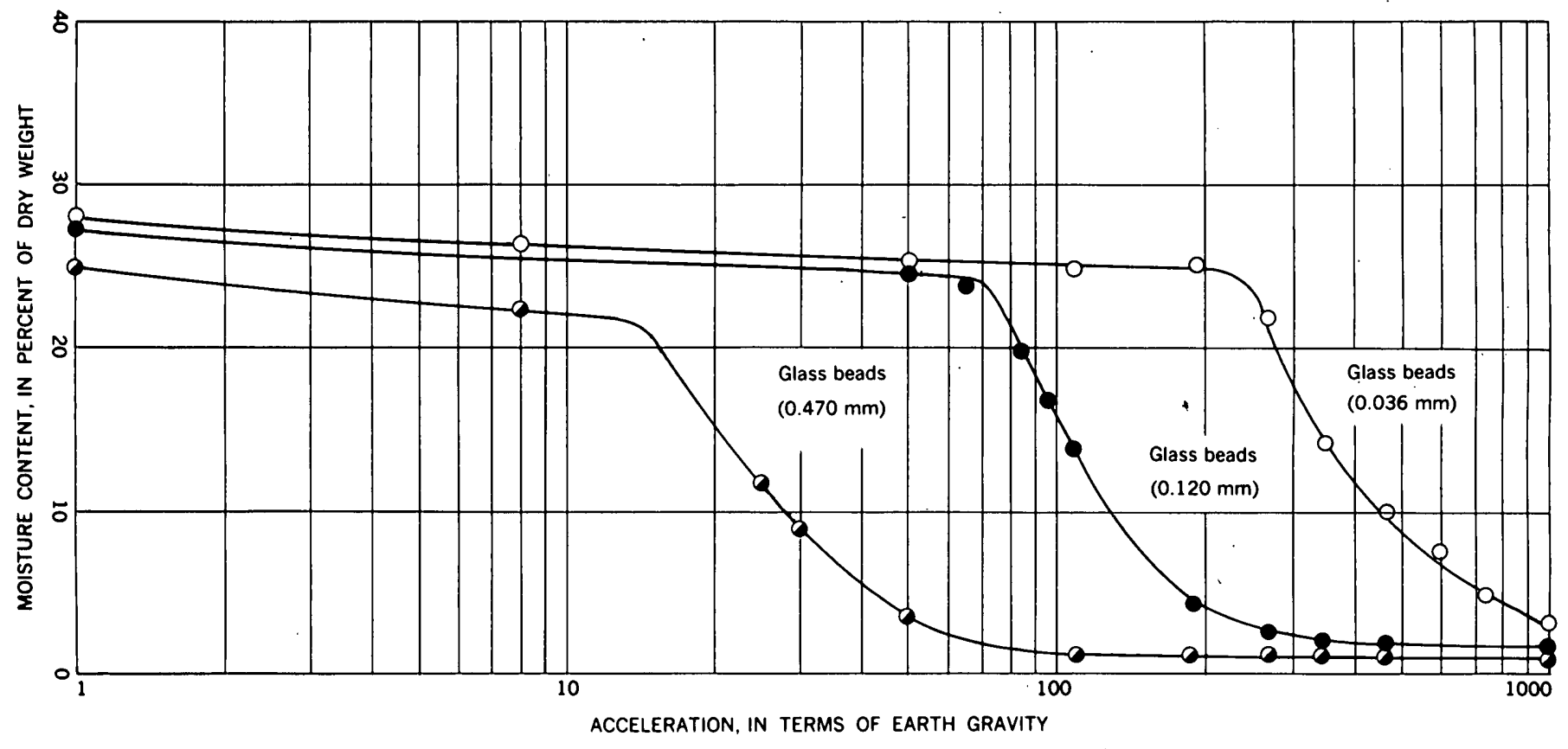

Figure 434.3.-Effect of acceleration on centrifuge moisture content.

for centrifuge scale modeling of drainage by gravity, and such experiments are presently being made. A modification of formula 2 is used for relating the cen-. trifuge sample thickness to the thickness of the material being drained by gravity, and formula 1 is used for relating time of drainage by the two methods.

\section{REFERENCES}

Childs, E. C., 1960, The nonsteady state of the water table in drained land: Jour. Geophys. Research, v. 65 , no. 2, p. 780782.
Klute, Arnold, 1952, A numerical method for solving the flow equation for water in unsaturated materials: Soil Sci., v. 73, no. 2 , p. $105-116$.

Marx, J. W., 1956, Determining gravity drainage characteristics on the centrifuge: Am. Inst. Mining Metall. Petroleum Engineers Trans., v. 207, p. 88-91.

Miller, E. E., and Miller, R. D., 1955, Theory of capillary flowI. Practical implications: Soil Sci. Soc. America Proc., v. 19, no. 3, p. 267-271.

Slobod, R. L., Chambers, Adele, and Prehn, W. L., Jr., 1951, Use of centrifuge for determining connate water, residual oil, and capillary pressure curves of small core samples: Am. Inst. Mining Metall. Engineers Trans., v. 192, p. 127-134.

435. REMOVAL OF MANGANESE FROM SOLUTIONS PRIOR TO DETERMINATION OF CALCIUM AND MAGNESIUM

By Lee C. Peck and Vertie C. Smith, Denver, Colo.

The colloidal hydrated manganese dioxide precipitate formed by heating a manganese solution containing ammonium persulfate is readily filterable if zirconium hydroxide is used as a gathering agent.

In silicate analysis, after solution of the sample and after separation of silica and the ammonium hydroxide group, a solution is obtained that contains manganese, calcium, and magnesium (Kolthoff and Sandell, 1952, p. 702-704). Although a prior separation of manganese simplifies determinations of calcium and magnesium, such a separation is seldom made because no rapid reliable method is known. Usually these elements are precipitated in the presence of manganese and suitable corrections are made for the amounts of manganese coprecipitated.

It is well known that ammonium persulfate quantitatively precipitates manganese as hydrated manganese dioxide from ammoniacal solutions containing large amounts of ammonium salts, but the colloidal character of the precipitate makes this method unsatisfactory. 
The filtration is tedious and the precipitate tends to pass the finest paper. If zirconium hydroxide is used to gather the precipitate, filtration is rapid through a coarse-textured paper and the removal of manganese is complete. Paper pulp added to the solution before filtration prevents channeling of the precipitate.

Sulfate ions do not cause interference in subsequent operations. If calcium is separated by a double precipitation with ammonium oxalate, no calcium sulfate is present in the final precipitate. Barium and strontium behave much as they do if manganese is not removed. In amounts of $10 \mathrm{mg}$ or less, barium oxide does not coprecipitate with either calcium or magnesium. Much of the strontium present coprecipitates with calcium and most of the remainder with magnesium.

Calcium does not coprecipitate appreciably with hydrated manganese dioxide but magnesium does. Coprecipitation of magnesium is minimized if the manganese is precipitated from acid solution, but the precipitation is incomplete. The best separation is obtained if the solution is acidified, heated, then made ammoniacal and heated for a short additional period. Where the manganese oxide content of a silicate is 2 percent or less, the error in the magnesium determination caused by the coprecipitation of magnesium with manganese can be tolerated (table 435.1); but where the manganese oxide content is greater, the error is large and a double precipitation should be made. If a double precipitation is necessary, each precipitation is made as described in the following procedure except that a larger initial volume of solution is used. The first pre-
TABLE 435.1.- Average amounts of magnesium coprecipitated with manganese

[In milligrams]

\begin{tabular}{|c|c|c|c|c|}
\hline \multirow{2}{*}{$\begin{array}{l}\text { Amount manganese } \\
\text { oxide taken }\end{array}$} & \multicolumn{4}{|c|}{$\begin{array}{l}\text { A mount magnesium oxide coprecipitated for indicated } \\
\text { amounts magnesium oxide taken- }\end{array}$} \\
\hline & 400 & 100 & 50 & 10 \\
\hline $\begin{array}{l}20 \\
5 \\
5\end{array}$ & $\begin{array}{r}0.30 \\
.10\end{array}$ & $\begin{array}{r}0.20 \\
.06\end{array}$ & $\begin{array}{r}0.15 \\
.05\end{array}$ & $\begin{array}{r}0.10 \\
.05\end{array}$ \\
\hline
\end{tabular}

cipitate is dissolved in a dilute hydrochloric acid solution containing sodium sulfite.

Evaporate to a volume of $100 \mathrm{ml}$ the combined acidified filtrates from the ammonium hydroxide group determination. Add $1 \mathrm{ml}$ of an acidified 5 percent zirconyl chloride octahydrate solution and about 0.1 gram of dry-dispersed paper pulp.

Make the solution ammoniacal to brom cresol purple; then make it just barely acid with 1 to 1 hydrochloric acid. Add 1 gram of ammonium persulfate; stir the solution and heat it on the water bath for 20 minutes. Add $1 \mathrm{ml}$ of ammonium hydroxide; then heat the solution 5 minutes more.

Filter the solution at once through a $7-\mathrm{cm}$ coarse-textured paper. Wash the inside of the beaker three times with hot 2-percent ammonium nitrate solution and transfer the washings to the paper. Finally, wash the precipitate on the paper 10 times with the same wash solution.

Discard the precipitate and reserve the filtrate for the determinations of calcium and magnesium.

\section{REFERENCE}

Kolthoff, I. M., and Sandell, E. B., 1952, Textbook of quantitative inorganic analysis, 3d ed.: New York, Macmillan. 


\section{SUBJECT INDEX}

[Numbers refer to articles; finding list of articles page numbers follows author index]

A rrial photographs, new stereoscope for viewing in fleld ..........-

Alaska, Cape Thompson engInecring geology gcologic mup...

Copper River basin, hydrology ............

Delta River aren, glacintion................

Kiglualk Mountains, economic geology... geologic map....

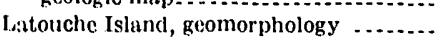

Lisburne Hills, geologic map.............. structurul geology

Minto Flats, geophysics.

Portage Alacler, recesslon

Talkcetna Mountains, palcontology

Yukon-koyukuk lowland, engineering geology...

geomorphology

Algac, Cambrian, Utah.

Algaroba, offect of on ground water

Alkalic rocks, associated with gabbrolc silts...

Alluvium, ground water in ...................

Alterntion, hydrothermal, association of hot springs with. mechunisms of temperature change... system $\mathrm{Na}_{2} \mathrm{O}-\mathrm{Al}_{2} \mathrm{O}_{3}-\mathrm{SiO}_{2}-\mathrm{H}_{2} \mathrm{O} \ldots \ldots .$. thorlum deposition.

A mmonolds, Permian, Californin................

Anhydrite, interaction with solutions of strontlum and cesium............

Origin of mottled structure...............

Arizona, Christmas quadrangle, economic geoingy ............................... geochemistry ..........................

Copper Minc-Preston Mesa area, hydrology .....................................

Feldman, economic geology ...............

Four Corners area, palcobotany...........

Globe, petrolngy...

Superlor, petrology... geophysics

Twin Buttes quadrangle, geologic map... geophysics.

Arsunic, in gold ore velns, wyoming

Ash flows, flattening ratios of pumice frag ments. ...........................

See also Tuff, welded.

Asphaltite, uranium-bearing nodules in dolomitc.............................

Atluntic Occan, western, magnetic profles.... Austrullu, mangrove coasts....................

$$
\text { B }
$$

Bambul series, Buhla, Brazil................ 362 Barlum, flame photometric determination of.. Basalt, ground water in ....................... Beckmantown dolomite, St. Lawrence County, N.Y.

Belt scries, Idaho batholith area................ Bermuda, magnetic profles..................... Blcarbonate, in surface water ................... Bikitaite, dehydration and decomposition.... Bismuth, contact-metasomatlc deposits, Alaska............................. 356

Bonneville, glacial Lake, age................... 334 stratigraphy ......................... 332, 333 Brachlopods, Permian, California......... 375
Article

Brazil, Bahia, Chapada Diamantina, economic geölogy

Tucano basin, economic geology-- 362

Minas Gerais and São Paulo, Poços de Caldas Plateau, economic geology. Breccia, associated with impact craters....... Brines, oil-field, metals in . ...................

Buried valleys, ground water in ............ 350, 351

Butte Spring member. See Oak Spring formation.

C

Calcalkalic rocks, proposal for clarification of use of names

Calcium, in surface water

Calcium and magnesium, removal of manganese from solutions of.

California, Alameda Plain, hydrology .........

Cymric oil field, geochemistry....

Funeral Mountains, geologic map........

geomorphology

Inyo Range, paleontology

Klamath Mountains, hydrology

Menlo Park, precipitation, chemical char. acter of

Northern Coast Ranges, hydrology ........-

San Joaquin Valley, sedimentary petrology...

Sierra Nevada, glacial geology Southern Cascades, hydrology Cambrian, Utah, Tule Valley .................. Capillarity, comparison of centrifuge and gravity determinations.............

Carboniferous, Nevada, Nevada Test Site.... See also Mississippian, Pennsylvanian. Caves, deposits of phosphate rock.. ground water in

Centrifuge, in est meting moisture distribution

Cesium, reaction with anhydrite..............

Cherry Canyon formation, Getaway limestone member, Culbertson County, Tex.

Chichalt formation, Surghar and Salt Ranges, Pakistan...

Chilson member. See Lakota formation.

Chloride, in surface water.....................

Chlorite, association with hot springs..........

interlayered in evaporite.................

Chrome ore, gravimetric determination of silica in ........................

Chromite, chemical method of distinguishin from ilmenite and magnetite....

gravimetric determination of silica in.....

Clatborne group, Jadkson dome area, Mississippi

Clay, effective fall diameter and fall velocity.

in evaporite...................................

Clay minerals, effect on compaction processes.

in hot springs.

Coal, minor-element associations.

Cockficld formation, Jackson dome area Mississippi.

Cohansey sand, Wharton Tract, N.J...........

Colorado, eastern, paleontology and stratigraphy.

Paradox basin, economic geology ............ San Juan Mountains, geologic map....... volcanism.

southeastern, geochemistry

southwestern, paleobotany

Wet Mountains, petrology
Article

Column drainage, in estimating moisture distribution. ................... 434

Comanche Peak limestone, Lea County, N. Mex

Connecticut, southeastern, mineralogy ........

Conodonts, Permian, Texas. ................ 379

Continental shelf, magnetic profiles............ 396

Cook Mountiln formation, Jackson dome area, Mississippi.................. 312

Copper, contact-metasomatic deposits, Alaska . 356

electrical prospecting for, Michigan........ 389

Cotter formation, Kansas-Missouri-Oklahoma............................. 414

Craters, Alaska, Project Chariot high-explosive test.

Colorado, Lake City caldera

Silverton caldera.

impact.

Moon

New Mexico, Valles caldera

retaceous, A laska, Lisbourne Hills......

Talkeetna Mountains....

Great Plains, northern.

New Mexico, Lea County.....

South Dakota, Black Hills

western United States.

Wyoming, Black Hills

Current meter, optical

D

Deflation, as a cause of erosion

Deformation, associated with impact craters.. $\quad 342$ caused by earthquakes................. 346,347 relation to intrusion, metamorphism, and metasomatism

Devils Gate limestone, Nevada Test Site, Nev_ $\quad 328$

Devonian, Arlzona, Christmas quadrangle.... 397

Nevada, Nevada Test Site.................. 328

Utah, northern ......................... 335

Diamond districts, revised geology of, Brazil_.. $\quad 362$

Diatoms, Tertiary, Nevada................... 373

Diorite, associated with alkalic rocks.......... 344

Dolomite, back-reef shatter cones formed by high-speed impact. $\quad 417$ Drainage, comparison of centrifuge and gravity methods.

$\mathbf{E}$

Earthquakes, deformation by, Montana.... 346, 347

Economic geology. See particular mineral name and under State names.

Ecuador, mangrove coasts

Eleana formation, Nevada Test Site, Nev....

Electrical prospecting, copper, Michigan .....-

Electromagnetic surveys, Arizona, Twin Buttes quadrangle........

Engineering geology. See under State names.

Erosion, deceleration by ash falls.............. deflation as cause.

Eskers, Alaska, Delta River area............

Etza formation, Carson Desert, Nev...........

Evaporites, in salt anticlines................. interlayed chlorite-vermiculite in........

$$
\text { F }
$$

Fall diameter of particles, definition.......... 30 significance............................... 300

\section{5}

385

370

378

357 328 337 403

00




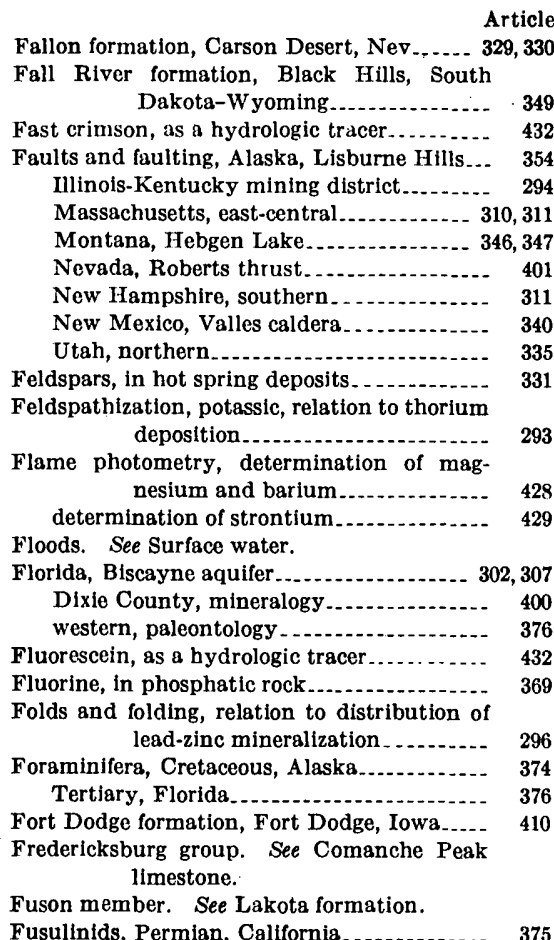

G

Gabbro, associated with alkalic rocks in relation to uranium deposits.... ....... 295 Geochemical, in vestigations, alteration reaction in system $\mathrm{Na}_{2} \mathrm{O}-\mathrm{Al}_{2} \mathrm{O}_{3}-\mathrm{SiO}_{2}-\mathrm{H}_{2} \mathrm{O}$ evaluation of hydrologic tracers........... ground-water sources of radium concentrations. . .

precipitation, influence on chemical composition of surface water

surface water, western United States..... See also under State names.

Geochemical prospecting, copper deposits beneath thrusts, Michigan

gold veins, wyoming

Geomorphology. Spe particular type of feature and under State names.

Geophysical investigations, borehole methods. 386 ,

overvoltage characteristics of pyrite crystal. well-logging methods

See also particular method and under State names.

Geothermometry..................................

Getaway limestone. See Cherry Canyon formation.

Gila group, Feldman, Ariz.

Glacial lakes. See Bonneville and Lahontan.

recession of, Alaska .................. 358

Glaciofluvial deposits, ground water in . .... 350, 351

Glorieta sandstone, Grants, N. Mex

Gnelss, granitic, sphene content

Gold, geochemical surveying for, Wyoming.-. 405

Grav̀imetic methods, determination of silica in chrome ore and chromite....

Gravity surveys, Alaska, Minto Flats..........

Arizona, Tucson.

Hawail, Kilauea Volcano..................

Maryland, Rockville quadrangle

Nevada, Clark County ....................

New Mexico, Rio Grande trough.........

Sangre de Cristo Mountains

Utah, soutbeast.
Greenland, Brønlund Fjord, geomorphology Green River formation, Wilk ins Peak member, Firehole Basin quadrangle, Wyoming -

Ground water, Alaska, Copper River Basin

Arizona, Coconino County

buried ridge, influence on aquifers.......

California, Alameda Plain

connate, oil-field brine

cooling of hydrothermal fluids

discharge, by ph:eatophytes

relation to drawdown.

domal structure influence on aquifers

Flo:ida, Dade County .................. 302, 307

Hawaii, Oahu .......................... 359, 377

hydrochemical facies, mapping of ......... 423

Idaho, Snake River Plain . . . ............. 420

in alluvium................................ 372

in basalt............................... 420

in buried valleys $\ldots \ldots \ldots \ldots \ldots \ldots$

in caves. 308

in glaciofluvial deposits................ 350; 351

Kansas, Manhattan..................... 351

south-central _... 341

Kentucky, Mammoth Cave 308

levee seepage

levels, dispersion-motivated fluctuations. 302

Mississippi, Jackson dome

moisture studies.

New Jersey, Wharton Tract.............. 313

New Mexico, Los Alamos County ........ 339

New York, St. Lawrence County......... $\quad 315$

North Dakota, Stutsman County........ 350

Oklahoma, western..................... 341

porous media, mechanical vibratory packer-. 305

mechanics of flow ................... 303,386

pressure-volume relation in clayey sediments............................

quality, complexes of manganese

irrigation use. ..................... 422

radioactive waste, disposal of ......... 420,421

radium concentrations in ................ 41

relation to mineral springs................. 353

salt springs, circulation around ........... 341

salt-water encroachment............. 302, 303, 386

sea water, residual in basement complex rocks.............................

Southern Rhodesia, Sabi Valley........

subdivisions of a ground-water basin......

Texas, northern

Utah, Jordan Valley

Virginia, Fredericksburg. .............. 319

water-level contours, relation to streamflow ...................................

wells, relation of discharge to drawdown in. ................... 359

Grouse Canyon member. See Oak Spring formation.

Gypsum, origin of mottled structure..........

\section{H}

Halite deposits, removal through solution ... 341

Hawaii, Kilauea Volcano, geophysics......... 360

Oahu, hydrology . $\ldots . . .359,377$

Helmet fanglomerate, Twin Buttes quadrangle, Arizona ........ 384, 385

Hermosa formation, Paradox basin, ColoradoUtah . . . . . . . . . . . . . . .

Hicks dome, nlinois-Kentucky ............... 294

Hot springs. See Thermal waters.

Hydrochemical facies, techniques for mapping_ 423

Hydrology. See Ground water, Surface water, and under State names.

Hydrothermal fluids, mechanisms for cooling_ $\quad 412$
I

Article

Idaho, central eastern, paleobotany ........... 382

Snake River Plain, geophysics.............. bydrology ......................... 420

southeastern, paleobotany ................ 382

Idaho batholith, relation between deformation, intrusion, metamorphism, metasomatism....................

Igneous rocks, post-Cambrian, Appalachian Mountains and Gulf Coastal Plain -

post-Carboniferous deformation, Mas sachusetts..............................

proposal for clarification of use of names. . See also particular rock type.

Illinois-Kentucky mining district, economic geology

geologic map.

structural geology

Illite, association with hot springs.

llmenite, chemical method of distinguishing from chromite and magnetite

Indian Lakes formation, Carson Desert, Nev Indonesia, central Java, economic geology .... Intrusions, relation to deformation, metamorphism, and metasomatism....

relation to ring dikes. ....................

zoned, magnetic interpretation........... Inyan Kara group, Black Hills, South DakotaWyoming . . . . . . . . . . .

Iowa, Fort Dodge, economic geology .......... Iron deposits, iron-formation, Pakistan....... Iron-formation, analyses of . . . . . . Isostasy, Nevada, Clark County . ............ 390

NewMexico. Sangre de Cristo Mountains. Isotopic disequilibrium, asphaltite nodules... . 391 402

Jackson group, Jackson dome area, Mississippi.......................... 312 Jacobina series, Bahia, Brazil ............... 362 John Day formation, north-central Oregon.... 343 Jurassic, Arizona, Conconino County ......... 321

$\mathbf{K}$

Kansas, Manhattan, geologic map............ 351

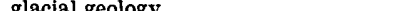
south-central, hydrology ..................... 341 western, paleontology and stratigraphy ..- $\quad 352$ Kaolinite, association with hot springs........ 331 Kentucky, Echo River, hydrology ............ 308 Mammoth Cave, hydrology ............... $\quad 308$ Styx River, hydrology Kentucky-Illinois mining district, economic geology geologic map................................. structural geology $\mathbf{L}$

La Caja formation, north-central Mexico..... $\quad 369$ La Casita formation, north-central Mexico...- $\quad 369$ Lahontan, glacial Lake, stratigraphy ......... 329 , $330,332,378$

Lahontan Valley group, Carson Desert, Nev_ 329 Lake St. Lawrence, effect of flooding, on ground water

Lakota formation, new and old members, Black Hills, South Dakota-Wyoming...

Landslides, origin, California................. 323 Lavras series, Bahia, Brazil................... 362 Lead ores, origin, Wisconsin Leonard series, Sierra Madera, Tex........... 342 Libya, Tripolitania, hydrology ............... 422 Lisburne group, Lisburne Hills, Alaska. . . . . 354 
$\mathbf{M}$

Article

Magnesium, flame photometric determina-

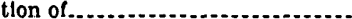
Magnesium and calclum, removal of manganese from solutions of..

Magnetlc survoys, Malne, Chandler Lake area.

Wood Pond area. Maryland, Rockville quadrangle........... New Mexico, Rio Grande trough.......... North Amorice, off east coast

Utnh, southeast.

Wisconsin, Driftless Area..................

Magnetite, chemical method of distinguishing from chromite and llmenite.......

Maine, Chandler Lake area, geophysics...... Island Falls quadrangle, geologlc map....

Mount Chase, petrology ....................

Wood Pond area, geophysics. ..............

Manganese, bicarbonate and sulfate complexes In water.

separation from calclum and magnesium.

Mengroves, ecology of .-.

Martin formation, Christmas quadrangle, Arizona.

Maryland, Rockville quadrangle, geologic map....................................

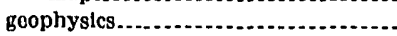

Massachusott's, Boston Basin, structural geology.......................................

enst-central, geologlc map................... structural geology.

Morcury, in crude oll...

Mercury limestone, Nevada Test Site, Nev

Metamorphlc rocks, post-Carboniferous deformation, Massachusetts.........

Motamorphlsm, relation to deformation, in. trusion, and metasomatism.......

Motasomatism, contact, in deposition of metalliferous deposits. ....................

relation to deformation; intrusion, and metamorphism......................

Moxico, Hidalgo, economic geology............

north-central, economlc geology .............

Pachuca mining district, economic geology...

Paricutín, geomorphology

Mica, mineralogy of laminae in sandstone...

MichIgßn, Houghton County, geophysics......

Middle Lako Lahontan soll, Carson Desert, Nev.........................

Minoral springs, analyses of gas and water from................................

origin and movement of water..............

Mineralogy. See particular mineral name and under State names.

Minnewaste limestone member. See Lakota formation.

Mississippi, Jackson dome area, hydrology...

Mississipplan, Alaska, Lisburne Hills........

Nevada, Nevada Test Site................

Utah, northern.

Molybdenum, contact-metasomatlc deposits, Alaska. ..........................

Montana, eastern, paleontology and stratig. raphy. .

428

387

387

388

392

386

393

430

387

415

397

388

388

310

311

311

398

328

310

345

356

345

368

369

368

370

400

329

353

341

312 354 328

Hebgen Lake, structural geology

Musselshell Valiey, paleobotany.......... 382

northwestern, paleobotany............... 382

Montmorlllonito, assoclation with hot springs. $\quad 331$

effect on compaction of sediments.......... 324

Moon, Letronne reglon, Isopach maps......... 361 stratlgraphy......................... 361

Moralnes, Rhode Island, southern............. 318

Utah, Little Cottonwood Canyon....... $\quad 334$

Mottled structure, in calclum sulfate......... $\quad 410$
Article

$P$

Narrow Canyon limestone, Nevada Test Site, Nev ..........Navajo sandstone, Copper Mine-Preston Mesa area, Arizona.................... 32

Nebraska, paleontology and stratigraphy .... 352

Nelchina limestone, Talkeetna Mountains, Alaska........................... 374

Neoglaciation, definition..................... 334

Nevada, Antler Peak quandrangle, petrology - 320

Buena Vista Valley, genmorphology ...... 378

Carson Desert, glacial geology ....... 329, 330, 332

Clark County, geologic map............... 390 geophysics........................... 390 structural geology $\ldots 390$

Cortez, economic geology

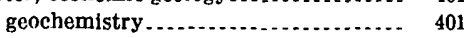

Fallon area, glacial geology ............ 329, 330

Great Basin, glacial geology ............. 330

Lake Lahontan, glacial geology ......... . 330, 332

Nevada Test Site, paleontology and stratigraphy ..................... 327, 328

southeastern, paleobotany............... 382

Steamboat Springs, geochemistry

Tolyabe Range, geologic map............. 401

Nevada formation, Nevada Test Site, Nev... 328

New Hampshire, southern, structural geology _ $\quad 311$

New Jersey, Wharton Tract, hydrology ...... 313

New .Mexico, Anlmas Mountains, paleo botany.

Big Hatchet Mountains, paleobotany

Carlsbad area, geochemistry

Eddy County, mineralogy ...

Grants, radioactive-waste disposal........

Grants-Bluewater valley, geologic map. .

Isea County, paleontology and stratigraphy ......................

Pajarito Plateau, hydrology ...............

Rio Grande trough, geologic map......... geophysics.............................

Sangre de Cristo Mountains, geologic map. geophysics.......................... structural geology .....

Valles caldera, Jemez Mountains, geologic map............................... structural geology ...................

New York, Long Island, hydrology

St. Lawrence County, hydrology ........

Nicaragua, mangrove coasts...................

Nickel, in soll formed by weathering of peri dotite

North Carolina, northwestern, geologic map.

Stokes and Surry Counties, structural geology

North Dakota, paleontology and stratigraphy

Stutsman County, glacial geology........ hydrology...

Notch Peak formation, western Utah

$$
\mathrm{O}
$$

Oak Spring formation, Nevada Test Site, Nev. Oakdale quartzite, east-central Massachusetts

Ohio, Ottawa County, economic geology.....

Oll, crude, metals in ...............................

in relation to uranium deposits.......... Oklahoma, western, hyclrology ....................

Open channels. See Surface water.

Ordiovician, Maine, Mount Chase............

Wisconsin, Lafayette...

Oregon, Ashwood, petrology stratigraphy

Coast Ranges, petrology

Eight Dollar Mountain, economic geology

Nickel Mountain, economic geology

Ostracodes, Permian, Texas

Overvoltage characteristics, pyrite crystals..

Owens Valley formation, Inyo Range, Calif..

28

Pate formation, Carson Desert, Nev........

Pakistan, Salt Range, economic geology ...... geologic map. .................

Surghar Range, economic gcology ......... geologic map . ...........................

Paleobotany. See particular plant name and under State names.

Paleontology. See particular fossil name and under State names.

Paleozolc, Brazil, Bahia.......................

Florida, Dixic County.....................

See also particular system.

Pennsylvania, Swatara Creek basin, hydrology ......................

Pennsylvanian, Nevada, Nevada Test Site...

Utah, northern. ............................

Peridotite, weathering of ......................

Permafrost, Alaska, Yukon-Koyukuk lowland..........................

Greenland, northern.........................

Permian, California, Inyo Range ..........

Kansas, south-central .........................

New Mexico, Eddy County...............

Texas, Culbertson County . ................. Sierra Madera

Utah, northern

Petrofabrics, clay-mineral orientation, sedi-

ments undergoing compaction....
Petrologic classiflcation, proposal for clarification of use of igneous rock names.

Phosphate deposits, in caves, Indonesia...... marine, Mexico.

Phreatophytes, discharge of ground water by.-

Pierre shale, Great Plains, northern...........

Plefstocene, Kansas, Manhattan...............

New Mexico, Valles caldera...............

Virginia, Eastern Shore peninsula.........

See also Quaternary.

Polygons, in bedrock........................ 366

Portage Lake lava series, Houghton County, Mich..............................

Post-Lake Lahontan soil, Carson Desert, Nev .......................... 329, 330

Potash deposits, in salt anticlines, ColoradoUtah................................

Precambrian, Brazil, Bahia.................

Utah, Blanding Basin ..................... Monumer

Wisconsin, Driftless Area

Procellarian system, Letronne region, Moon.-

Pumice, flattening ratios of fragments in ash flows...

Purgatoire formation, Cheyenne sandstone member, southeastern Colorado. -

Pyrite, overvoltage characteristics of crystals.. $\quad 416$

$$
\text { Q }
$$

Quaternary, Alaska, Delta River area....... 357 Minto Flats ........................ 383 Yukon-Koyukuk lowland . ............ 419

California, Sierra Nevada................ 332

Kansas, Manhattan..................... 351

Montana, Hebgen Lake............... 346, 347

Nevada, Carson Desert.............. 329, 330, 332

Rhode Island, southern.................. 318

Utah, Jordan Valley ..................... 336 l,ake Bonneville area................ 332,333

Wasatch Mountains................. 332

Wyoming, Firehole Basin quadrangle.... 348

\section{R}

Radiation damage, uranium-bearing usphaltite nodules...................... 40 71 362 317 335 04 419
366 375 0 
Radioactive tracers, in measurement of openchannel flow.....................

Radioactive-waste disposal, in salt deposits... 407

in wells

Radioactivation method, determination of sensitivities of trace elements .....

Radioactivity, association with petroleum $\ldots . .295$

Radioactivity surveys, Rockville quadrangle, Maryland...................... 388

Rainier Mesa member. See Oak Spring formation.

Radium, in ground water.

Rare earths, associated with zirconium deposits, Brazil ....................

in iron-formation, Arizona................

Reefs, Cambrian, Utah.........................

Releasing agents, in flame photometric determinations......................

Reservoir storage. See Surface water.

Rhode Island, southern, glacial geology .......

Ring dikes, associated with calderas related to doming

Ripples, regressive, origin . .

Roberts Mountains formation, Cortez, Nev .

Roubidoux formation, Kansas-Missouri-Oklahoma

Salado formation, Eddy County, N. Mex .... Salt, origin in ground water............ Salt anticlines, potash evaporite cycles in .... Salt deposits, removal through solution....... Salt-water encroachment, dispersion with oscillating flow. ..................

effect on water levels in wells. ............

leakage through well casings...............

San Andres limestone, Grants, N. Mex .....

Sand, effective fall diameter and fall velocity

Sandstone, mineralogy of micaceous laminae. Scintillation detector, in measurement of openchannel fiow.

Seamounts, magnetic profiles................

Sedge, in meadow-pool formation.............

Sedimentary facies, influence of domal structure on

Sedimentation, effect of temperature.......... significance of effective fall diameter and fall velocity 300

Sehoo formation, Carson Desert, Nev ........ 329, 330

Seismology, seismic-electric effect.............. 395

Seleniun, completeness of precipitation as the eloment ...............................

Sensitivities, trace elements . ............... 427

Shatter cones, formed by high-speed impact _ 342,417

Shorelines, Pleistocene, Virginia........... 381

Silica, gravimetric determination in chromite and chrome ore

Sills, gabbroic, associated with alkalic rocks.- 34

Silurian, Nevada, Cortez ................. 40

Silver deposits, Pachuca mining district, Hidalgo, Mexico

Sodium, in surface water. ................ 406

Sodium-adsorption-ratio diagram, uses of ... . 422

Soils, formed by weathering of peridotite ... . 404

moisture distribution .................... 339

Qunternary, California. . . . .

Nevada . . ..................... 329, 330, 332

Utah. . . . . . .

South Dakota, Black Hills, stratigraphy...... $\quad 349$ paleontology and stratigraphy ............ 352

Southern Rhodesia, Bikita, geochemistry..... 413

Sabi Valley, geologic map ............... 372

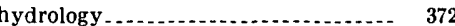

Sparta sand, Jackson dome area, Mississippi._. 312

Specific yield, determination of moisture distribution during drainage.........

Spectrographic methods, determination of sensitivities of trace elements....

\begin{tabular}{l|}
\hline 25 \\
407 \\
421 \\
427 \\
295 \\
388 \\
\\
414 \\
364 \\
397 \\
380 \\
428 \\
318 \\
340 \\
294 \\
299 \\
401 \\
414 \\
\end{tabular}

Sphene, in granitic gneisses $\ldots \ldots \ldots \ldots \ldots . . . \quad 399$ Spiritwood buried valley complex, North Dakota

Springs. See Mineral springs, Thermal waters.

Stade, definition........................... 333, 334

Stereoscope, magnifying single-prism, new instrument for field use

Stockade Wash member. See Oak spring formation.

Stratigraphy. See particular formation name, system name, and under State names.

Streambed materials, significance of eflective fall diameter......................

Streams, western United States, major chemical constituents...................

See also Surface water.

Stromatolites, Cambrian, Utah ............... trontium, flame photometric determination

of reaction with anhydrite. ..............

Structural geology. See Deformation, Faults and Faulting. Folds and Folding, Subsidence, and under State names.

Subsidence, caldera

caused by earthquakes. . . ............ 346, 347

Surface water, acid streams, natural processes that dilute and neutralize.........

California, northern......................

chemical constituents, geographic distribution.

current meter, optical . .

floods, levee control

Florida, Dade County. plexes of
ple com

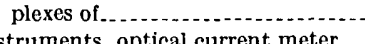

new instruments, optical current meter-.

New York, Long Island..................

open channels, scintillation detector in measurement of flow . . ...........

velocity measurements, method of -.--

Pennsylvania, Swatara Creek basin..... regressive ripples, origin .................. relation to geology and topography...... reservoir storage, for short-period stream flow regulation.....................

general solution of a queue model.....

temperature variation . .................. 314 survey Butte member. See Oak Spring formation.

Systems, $\quad \mathrm{Na}_{2} \mathrm{O}-\mathrm{Al}_{2} \mathrm{O}_{3}-\mathrm{SiO}_{2}-\mathrm{H}_{2} \mathrm{O} \ldots \ldots \ldots \ldots . .408$

Tallahatta formation, Jackson dome area, Mississippi -

Temperature, water. See Surface water.

Tempskya, western United States . . . . . . .
Terraces, Pleistocene, Kansas

Virginia

Tertiary, Alaska, Minto Flats...............

California, Funeral Mountains.

Colorado, San Juan Mountains

Idaho, Hagerman

Mississippi, Jackson dom

Nevada, Humboldt County

Nevada Test Site.

Nye County....

Oregon, north-central

Utah, Jordan Valley

Utah County...

Texas, Culbertson County, paleontology

Karnes County, economic geology .........

northern, hydrology ........................

Sierra Madera, geologic map..............

structural geology ....................

Thermal waters, hydrothermal alteration associated with.....................

Thorium deposits, associated with zirconium deposits, Brazil ....................

relation to feldspathization, Colorado.... Thule group, Brønlund Fjord, Greenland...

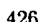

300

406

380

429

07 40
Tiglukpuk formation, Cape Thompson, Alaska. . . . . .

Tippipah limestone, Nevada Test Site, Nev .. 328 Tiva Canyon member. See Oak Spring formation.

Tombador series, Bahia, Brazil.

Topopah Spring member. See Oak Spring formation.

Trace elements, sensitivities.................. $\quad 427$

Tracers, hychologic......... 43?

Triassic, Arizona, Coconino County ........... 321

Tritium, as a hydrologic tracer......... 43'

Tucumcari shale, Lea County, N. Mex...... 338

Tuff, welded, ash, Arizona-Nevada........... 320 crystal, Arizona-Nevada............... 320 moisture distribution, New Mexico... 339 petrology, Colorado ................. 326 New Mexico. . . . Oregon stratigraphy, Nevada................. 327 Turupah formation, Carson Desert, Nev... 329, 330 Tymochtee dolomite, Port Clinton, Ohio..... 410

U

United States, central and southern, petrology_ $\quad 306$ north-central, geochemistry and hydrology western, paleobotany ..................... streams, geochemistry See also State names.

Uranium, in asphaltite nodules............... 402 in phosphatic rock ......................... 369 relation to hydrogen sulfide-bearing hydrocarbons.....................

Uranium deposits, in oil fields, Texas......... 295 Tucano basin, Bahia, Brazil............ 363

Utah, Blanding basin, geophysics . ........... 393 House Range, paleontology and stratigraphy . . Jordan Valley, glacial geology . . ......... 333 hydrology . . . . . Lake Bonneville area, glacial geology ... 332, 333 Little Cotton wood area, glacial geology . 333, 334 Monument upwarp, geophysics . . ........ 393 northern, structural geology .............. 335

Paradox basin, economic geology ......... 337 southeastern, paleobotany ................ 382 Tule Valley, paleontology and stratigraphy . ....................... 380

W asatch Mountains, glacial geology .... 332, 333

Vegetation, influence of seasonal flooding on .. tropical coastal.

$$
\mathrm{V}
$$

Vermiculite, interlayered in evaporite.............. Vibratory packer, mechanical method of packing porous media.............

Vinini formation, Cortez, Nev ...............

Virginia, Eastern Shore peninsula, geomorphology

Fredericksburg, hydrology

Volcanic rocks, flattening ratios of pumico fragments........................... magmatic differences in tuff . . ............ Ordovician, Maine........................ Quaternary, New Mexico . ................. Tertiary, Colorado ........................

Nevada... . . . .

Oregon ............................. 343 See also particular rock type.

Volcanism, Jemez Mountains, N. M.ex.....- 340 San Juan Mountains, Colo ….......... 326 Volcanoes, Kilauea; Hawaii .. . .............. 360 mud, mineral springs associated with ..... 353 Parícutin, Mexico...................... $\quad 320$

365 403 305 401 


\section{W Article}

Wellington formation, south-central Kansas.- $\quad 341$ "Wet" methods, determination of sensitivity of trace elements . . . . . . Wilcox group, Jackson dome area, Mississippi_ $\quad 312$ Wilkins Peak member. See Green River formation.

Windows, quartzite area, North Carolina.... 316 Winona sand, Jackson dome area, Mississippi_ $\quad 312$ Wisconsin, Lafayette County, economic geology ......................... 296

Wausau area, geologic map.............. 394 geophysics......................... 394 structural geology : . . . . . ......... 296, 394
Wissahickon formation, Rockville quadrangle, Maryland ........................ 388 Wood, silicified.......... setts............................... Wyemaha formation, Carson Desert, Nev ...- 329 Wyoming, Atlantic gold district, economic geology

geochemistry

geologic map.

Black Hills, stratigraphy

Buffalo area, paleobotany

Cokeville-Afton region, paleobotany ......

Firehole Basin quadrangle, stratigraphy .-

Powder River Basin, paleontology and stratigraphy $\mathrm{x}$

Article

X-ray diffraction, bikitaite $\ldots \ldots \ldots \ldots \ldots$ clay minerals. . ......................... 403

mica.............................. 400

$\mathrm{Y}$

Yeso formation, Grants, N. M.ex

421

Z

Zilpha clay, Jackson dome area, Mississippi_- $\quad 312$ Zinc, contact-metasomatic deposits, Alaska... 356 Zinc ores, origin, Wisconsin ................. 2

\section{AUTHOR INDEX}

Abrahams, J. H., Jr...
Ali, K. A-S. Articl
Allingham, J. W
Amezcua, E. T
Anderson, L. A
Andreasen, G. E.
Ash, S. R.

Back, William

Bailey, E. H

Bailey, R. A

Barker, F. B

Barnes, D. F

Barton, P. B., Jr

Bates, R. G.

Bayley, R. W

Beck, H. V......... 351

Bell, Henry, III.

Bergquist, H. R........................ 374

Black, R. F . . . .

Brock, M. R.

Bryant, Bruce............................... 316

Burbank, W. S

Campbell, R. H....... 354

Carlson, J. E

Carroll, Dorothy . . . . .

Case, J. E...... 392, 393

Cederstrom, D. J

Clebsch, Alfred, Jr . .

Cobban, W. A

Conklin, N. M

Cordell, L, E

Crittenden; M. D., Jr........ 335

Cserna, Zoltan de.

Culbertson, W. C........................... 348

Cuppels, N. P........... 310

Cuttitta, Frank. 431

Danilchik, Walter.......................... 371

Davies, W. E. .

Dempsey, w. J............ 396

Dennis, P. E................. 372

Denny, C. S.......... 323

Dinnin, J. I. . . .

Eargle, D. H.

Eaton, J. P ........... 360

Eggleton, R. E. .

Ekren, E. B

Erickson, R. L
Article

Feth, J. H

Fisher, F. G

Foserg,

Fournier, R. O.

Frederick, B. J........................... 425

Fries, Carl, Jr. . .

Frischknecht, F. C.

Gault, D, E

George, J. R.................... 317

Geyne, A. R .

Gill, J. R

Godfrey, R. G.

Goldsmith, Richard..... 399

Gordon, Mackenzie, Jr.

Grimaldi, F. S

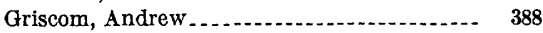

Hamilton, Warren

347

Haushild, W. L.

Haynes, D. D.

Heath, R. C............................ 315

Helz, A. W

Hem,

Hemley, J. J

Hendrickson, G. E

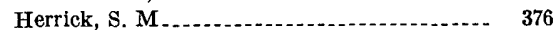

Heyl, A. V., Jr

Hietanen, Anna

Hinrichs, E. N.

Hite, R. J....... 337

Hose, R. K.......... 380

Hotz, P. E . . . .

Houser, F. N ........ 328

Hubbell, D. W

Hummel, C. L. . . . .

Huxel, C. J., Jr $\ldots \ldots$

Janes, W. W . . . .

Joesting, H. R

Johnson, A. I........ 386

Johnson, R. F

Jones, P. H........... 420

Jopling, A. V.................... 299

Kachadoorian, Reuben

Kane, M. F

Keller, G. V.

King, E. R

Klein, Howard............. 307

Klemic, Harry . . . . .
Article

Kohout, F. A . . . .

Kulp, W. K... 303, 305

Lang, J. W ............. 312

Lang, S. M......... 313

Langbein, W. B

Leonard, A. R . . . . . . . . 341

Lohman, K. E. . 373

Lubke, E. R

Luedke, R. G........................... 326

Lugn, R. V

McCarren, E. F............... 317

McClymonds, N. E. .................... 321

Marine, I. W

Marranzino, A. P. . . .

Marshall, C. H........... 361

Masursky, Harold

Matzko, J. J . . . . . . . . . . . . . . . . . . 363

May, Irving ... . . . . . . . . . . .

Meade, R. H

Merriam, C. W

Mesnier, G. N.............................. 297

Meyer, Charles.

Morris, D. A

Morrison, R. B... $\ldots \ldots \ldots . . . . . . .329,330,332,333$

Moston, R. P. .

Myers, W. B .......... 347

Naeser, C. R $\ldots \ldots 7$

Nichols, D. R .

Novotny, R. F . .

Oda, Uteana........................... 401

Oltman, R. E. . . .

Orkild, P. P............ 327, 328

Peck, D. L. .

Peck, L.C

Peterson, D. L $\ldots$

Peterson, D. W . . . . 320, 322

Péwé, T. L 357,419

Phair, George...

Phinney, W. C................... 413

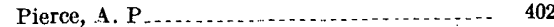

Pierson, C. T.............. 362

Plouff, Donald

Pluhowski, E. J

Poole, F. G. . . . . .

Post, E. V

Prill, R. C............ 434

Purtymun, W. D............. 339 


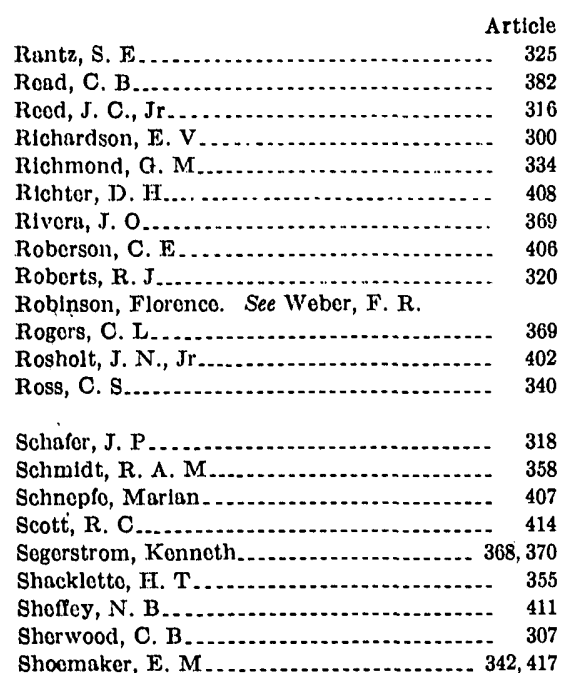

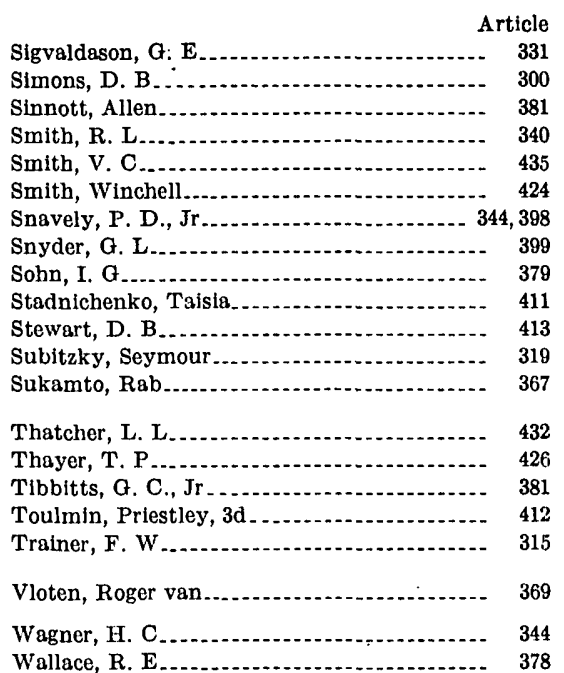

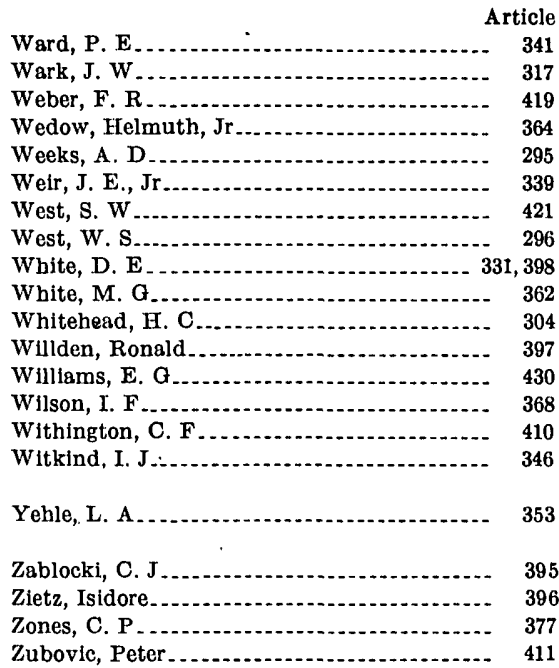

FINDING LIST OF ARTICLE PAGE NUMBERS

\begin{tabular}{|c|c|c|c|c|c|c|c|c|c|c|c|}
\hline Article & Page & Article & Page & Article & Page & Article & Page & Article & Page & Article & Page $^{3}$ \\
\hline 293. & 1 & $317 \ldots \ldots$ & 64 & $341 \ldots \ldots \ldots$ & 150 & 365 & 216 & $389 \ldots \ldots \ldots$ & 272 & $413 \ldots \ldots$ & 357 \\
\hline . & 3 & . & 68 & 342 & 151 & 366 & 218 & 390 & 274 & 414 & $35^{\mathrm{C}}$ \\
\hline $295 \ldots \ldots \ldots \ldots$ & 7 & ............ & 71 & 343:- & 153 & 367. & 219 & $391 \ldots \ldots$ & 277 & 415 & $36^{2}$ \\
\hline ............ & $\theta$ & . & 73 & $344 \ldots \ldots$ & 156 & 368 & 221 & $392 \ldots \ldots \ldots$ & 282 & 416 & $36^{5}$ \\
\hline - & 12 & . & 79 & 345 & 161 & 369 & 222 & $393 \ldots \ldots$ & 287 & 417 & $36^{8}$ \\
\hline ....... & 13 & $322 \ldots$ & 82 & $346 \ldots \ldots \ldots$ & 165 & 370 & 225 & $394 \ldots \ldots \ldots \ldots$ & 292 & 418 & $36^{1}$ \\
\hline 200. & 15 & 323. & 85 & 347. & 168 & $371 \ldots \ldots$ & 228 & $395 \ldots \ldots \ldots$ & 296 & 419 & $37^{4}$ \\
\hline 300. & 17 & 324 & 89 & 348 & 170 & $372 \ldots \ldots \ldots$ & 231 & $396 \ldots \ldots \ldots$ & 299 & 420 & $37^{6}$ \\
\hline ......... & 21 & $325 \ldots$ & 92 & $349 \ldots$ & 173 & 373. & 234 & 397. & 304 & 421 & $37^{9}$ \\
\hline 302. & 24 & 326 & 94 & 350. & 179 & $374 \ldots$ & 236 & 398. & 306 & 422 & 370 \\
\hline 303. & 26 & 327. & 96 & 351 & 182 & 375 & 238 & 399. & 310 & 423. & 383 \\
\hline -........... & 29 & 328 & 104 & 352 & 185 & 376 & 239 & 400 & 311 & 424 & 385 \\
\hline (............... & 31 & $329 \ldots$ & 111 & 353 & 191 & 377 & 240 & $401 \ldots$ & 316 & 425 & 38 \\
\hline .......... & 33 & $330 \ldots \ldots$ & 115 & $354 \ldots$ & 194 & 378 & 242 & 402 & 320 & 426. & $38^{\circ}$ \\
\hline .......... & 36 & $331 \ldots \ldots$ & 116 & $355 \ldots$ & 197 & 379 & 244 & 403. & 323 & 427 & 388 \\
\hline .......... & 41 & $332 \ldots \ldots$ & 122 & $356 \ldots \ldots \ldots$ & 198 & 380 & 245 & $404 \ldots$ & 327 & 428 & 391 \\
\hline $309 \ldots \ldots$ & 43 & $333 \ldots \ldots$ & 125 & $357 \ldots \ldots$ & 200 & (n....... & 248 & 405. & 332 & $\ldots$ & 392 \\
\hline $310 \ldots \ldots \ldots$ & 46 & $334 \ldots \ldots \ldots \ldots$ & 127 & $358 \ldots \ldots$ & 202 & $382 \ldots \ldots \ldots$ & 250 & 406 & 334 & 430 & 394 \\
\hline $311 \ldots \ldots \ldots \ldots$ & 48 & $335 \ldots \ldots$ & 128 & $359 \ldots \ldots$ & 204 & $383 \ldots \ldots$ & 254 & $407 \ldots$ & 336 & $431 \ldots \ldots \ldots$ & 394 \\
\hline $312 \ldots \ldots$ & 50 & $336 \ldots$ & 132 & $360 \ldots \ldots$ & 205 & 384 & 258 & 408 & 338 & 432 & 396 \\
\hline 313............... & 52 & $337 \ldots \ldots$ & 135 & $361 \ldots \ldots \ldots$ & 208 & $385 \ldots \ldots$ & 259 & $409 \ldots \ldots$ & 340 & $433 \ldots \ldots$ & 397 \\
\hline $4 \ldots \ldots \ldots \ldots \ldots$ & 55 & $338 \ldots$ & 139 & $362 \ldots$ & 211 & $386 \ldots \ldots$ & 262 & $410 \ldots$ & 342 & $434 \ldots$ & 399 \\
\hline$\ldots$ & 58 & $339 \ldots \ldots \ldots$ & 142 & $363 \ldots \ldots$ & 213 & (n........ & 265 & $411 \ldots \ldots$ & 345 & $435 \ldots \ldots$ & 401 \\
\hline & 61 & 340 & 145 & 364 & 214 & 388. & 267 & 412 & 348 & & \\
\hline
\end{tabular}

